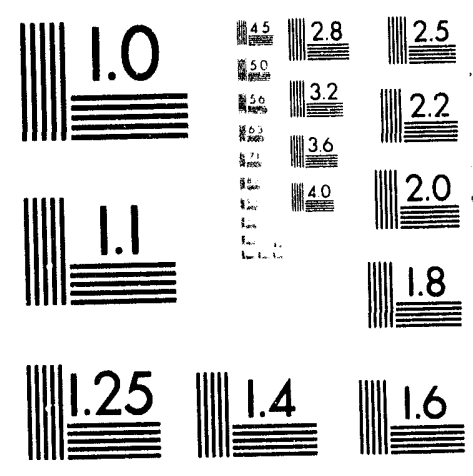



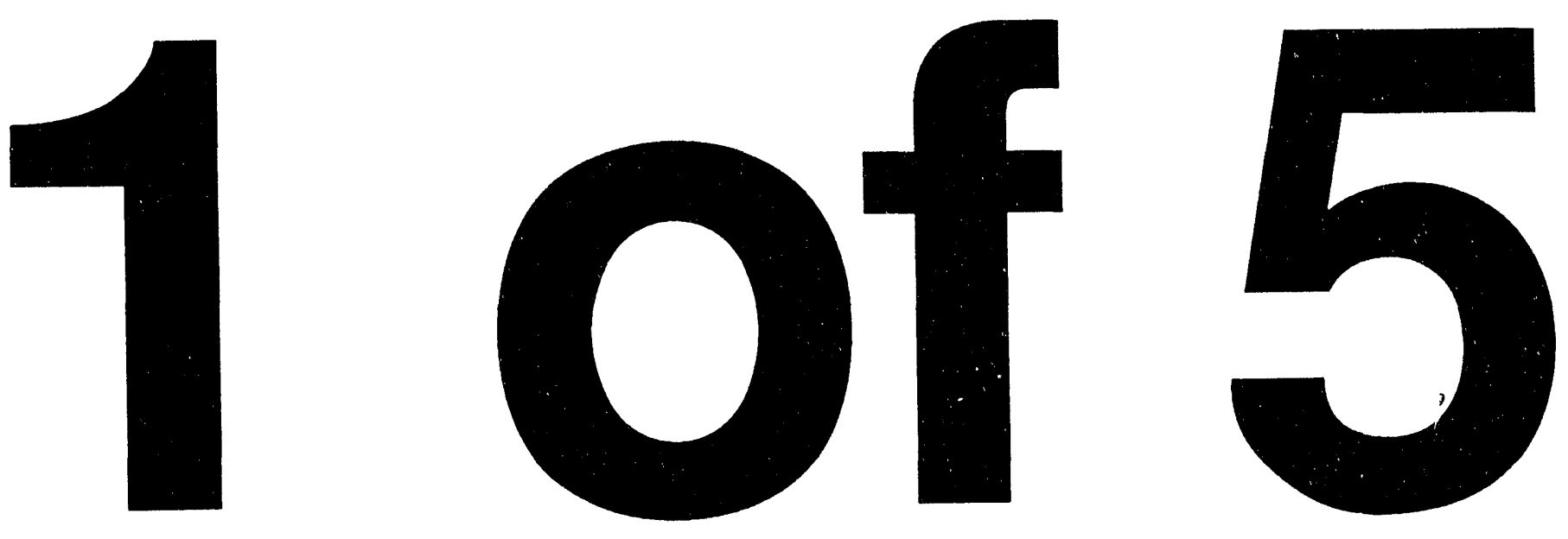


\title{
Remedial action Plan and Site DESIGN FOR STABILIZATION OF THE INACTIVE URANIUM MILL TAILINGS Sites at Slick Rock, Colorado
}

\section{Appendix A to Attachment 3, TABles}

\author{
Preliminary Final
}

March 1994

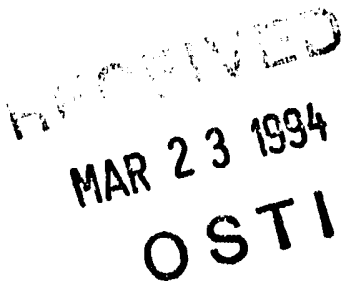

\section{Appendix B of the Cooperative Agreement}

No. DE-FC04-81AL16257

\section{DISCLAIMER}

This report was prepared as an account of work sponsored by an agency of the United States Government. Neither the United States Government nor any agency thereof, nor any of their employees, makes any warranty, express or implied, or assumes any legal liability or responsibility for the accuracy, completeness, or usefulness of any information, apparatus, product, or process disclosed, or represents that its use would not infringe privately owned rights. Reference herein to any specific commercial product, process, or service by trade name, trademark, manufacturer, or otherwise does not necessarily constitute or imply its endorsement, recommendation, or favoring by the United States Government or any agency thereof. The views and opinions of authors expressed herein do not necessarily state or reflect those of the United States Government or any agency thereof. 


\section{INTENDED FOR PUBLIC RELEASE}

This report has been reproduced from the best available copy. Available in paper copy and microfiche.

Number of pages in this report: 469

DOE and DOE contractors can obtain copies of this report from:

Office of Scientific and Technical Information

P.O. Box 62

Oak Ridge, TN 37831

(615) 576-8401

This report is publicly available from:

National Technical Information Service

Department of Commerce

5285 Port Royal Road

Springfield, VA 22161

(703) $487-4650$ 
LIST OF TABLES

\section{$\underline{T A B L E}$}

1.1 Maximum concentration of constituents for groundwater protection

3.1 Monitoring well information for the NC processing site, slick Rock, Colorado

3.2 Monitoring well information for the UC processing site, Slick Rock, Colorado

3.3 Static groundwater levels for the NC and UC processing sites, Slick Rock, Colorado

3.4 Hydraulic parameters for the NC and UC processing sites, Slick Rock, Colorado

3.5 Background groundwater quality data by parameter for the alluvium, NC and UC processing sites, slick Rock, Colorado

3.6 Background groundwater quality statistics by parameter for the alluvium, NC processing site, Slick Rock, Colorado

3.7 Summary of regulated constituents in alluvial background groundwater, NC processing site, Slick Rock, Colorado

3.8 Groundwater quality measurements exceeding maximum concentration limits in alluvial background groundwater, NC and UC processing sites, Slick Rock, Colorado

3.9 Background groundwater quality statistics by parameter for the alluvium, UC processing site, Slick Rock, Colorado

3.10 Summary of regulated constituents in alluvial background groundwater, UC processing site, Slick Rock, Colorado

3.11 Background groundwater quality data by parameter for the Entrada Formation, UC processing site, Slick Rock, Colorado

3.12 Background groundwater quality statistics by parameter for the Entrada Formation, UC processing site, Slick Rock, Colorado

3.13 Summary of regulated constituents in the Entrada Formation background groundwater, UC processing site, slick Rock, Colorado

3.14 Groundwater quality measurements exceeding maximum concentration limits in Entrada Formation background groundwater, UC processing site, Slick Rock, Colorado

3.15 Background groundwater quality data by parameter for the Navajo Sandstone, NC and UC processing sites, Slick Rock, 


\section{Colorado}

3.16 Background groundwater quality statistics by parameter for the Navajo Sandstone, NC processing site, Slick Rock, Colorado

3.17 Summary of regulated constituents in the Navajo Sandstone background groundwater, NC processing site, Slick Rock, Colorado

3.18 Groundwater quality measurements exceeding maximum concentration limits in Navajo sandstone background groundwater, NC and UC processing sites, Slick Rock, Colorado

3.19 Background groundwater quality statistics by parameter for the Navajo Sandstone, UC processing site, Slick Rock, Colorado

3.20 Summary of regulated constituents in the Navajo sandstone background groundwater, UC proçessing site, slick Rock, Colorado

3.21 Tailings pore fluid water quality data by parameter, NC and UC processing sites, slick Rock, Colorado

3.22 Tailings pore fluid water quality statistics by parameter, NC processing site, slick Rock, Colorado

3.23 Summary of regulated constituents in tailings pore fluid samples, NC processing site, Slick Rock, Colorado

3.24 Tailings pore fluid measurements exceeding maximum concentration limits, NC and UC processing sites, Slick Rock, Colorado

3.25 Tailings pore fluid water quality statistics by parameter, UC processing site, Slick Rock, Colorado

3.26 Summary of regulated constituents in tailings pore fluid samples, UC processing site, Slick Rock, Colorado

3.27 Baseline groundwater quality data by parameter for the alluvium, NC and UC processing sites, Slick Rock, Colorado

3.28 Baseline groundwater quality statistics by parameter for the alluvium, NC processing site, Slick Rock, Colorado

3.29 Summary of regulated constituents in alluvial baseline groundwater, NC processing site, Slick Rock, Colorado

3.30 Groundwater quality measurements exceeding maximum concentration limits in alluvial baseline groundwater, NC and UC processing sites, Slick Rock, Colorado

3.31 Baseline groundwater quality statistics by parameter for the alluvium, UC processing site, Slick Rock, Colorado 
3.32 Summary of regulated constituents in alluvial baseline groundwater, UC processing site, Slick Rock, Colorado

3.33 Baseline groundwater quality data by parameter for the Entrada Formation, UC processing site, Slick Rock, Colorado

3.34 Baseline groundwater quality statistics by parameter for the Entrada Formation, UC processing site, Slick Rock, Colorado

3.35 Summary of regulated constituents in the Entrada Formation baseline groundwater, UC processing site, Slick Rock, Colorado

3.36 Groundwater quality measurements exceeding maximum concentration limits in Entrada Formation baseline groundwater, UC processing site, Slick Rock, Colorad's

3.37 Baseline groundwater quality data by parameter for the Navajo Sandstone, UC processing site, Slick Rock, Colorado

3.38 Baseline groundwater quality statistics by parameter for the Navajo Sandstone, UC processing site, Slick Rock, Colorado

3.39 Summary of regulated constituents in the Navajo sandstone baseline groundwater, UC processing site, Slick Rock, Colorado

3.40 Groundwater quality measurements exceeding maximum concentration limits in Navajo Sandstone baseline groundwater, UC processing site, Slick Rock, Colorado

3.41 Information for private wells located in the vicinity of the Slick Rock processing sites

3.42 Monitoring well information for the Burrro Canyon disposal site, Slick Rock, Colorado

3.43 Static groundwater levels for the Burro Canyon disposal site, Slick Rock, Colorado

3.44 Hydraulic parameters for the Burro Canyon disposal site, Slick Rock, Colorado

3.45 Background groundwater quality data by parameter for the upper sandstone unit, Burro Canyon disposal site, slick Rock, Colorado

3.46 Background groundwater quality statistics by parameter for the upper sandstone unit, Burro Canyon disposal site, Slick Rock, Colorado

3.47 Summary of regulated constituents in the upper sandstone unit, Burro Canyon disposal site, Slick Rock, Colorado

3.48 Groundwater quality measurements exceeding maximum concentration limits in the upper sandstone unit, Burro Canyon 
disposal site, Slick Rock, Colorado

3.49 Background groundwater quality data by parameter for the middle sandstone unit, Burro Canyon disposal site, slick Rock, Colorado

3.50 Background groundwater quality statistics by parameter for the middle sandstone unit, Burro Canyon disposal site, Slick Rock, Colorado

3.51 Groundwater quality measurements exceeding maximum concentration limits in the middle sandstone unit, Burro Canyon disposal site, Slick Rock, Colorado

3.52 Background groundwater quality data by parameter for the lower sandstone unit, Burro Canyon disposal site, Slick Rock, Colorado

3.53 Background groundwater quality statistics by parameter for the lower sandstone unit, Burro Canyon disposal site, Slick Rock, Colorado 
Table 1.1 Maximum concentration of constituents for groundwater protection"

\begin{tabular}{|c|c|c|c|}
\hline $\begin{array}{c}\text { Constituents with } \\
\text { MCLs }\end{array}$ & $\mathrm{mg} / \mathrm{I}$ & $\begin{array}{c}\text { Constituents with } \\
\text { MCLs }^{b}\end{array}$ & $\mathrm{mg} / \mathrm{l}$ \\
\hline Arsenic (As) & 0.05 & $\begin{array}{l}\text { Carbon } \\
\text { tetrachloride }\end{array}$ & 0.005 \\
\hline Barium (Ba) & 1.0 & $\begin{array}{l}\text { p-Dichlorobenzene } \\
\text { (benzene, } 1,4 \text { di-) }\end{array}$ & 0.075 \\
\hline Cadmium (Ca) & 0.01 & $\begin{array}{l}1,1- \\
\text { Dichloroethylene } \\
\text { (ethene, } 1,1 \mathrm{di}-\text { ) }\end{array}$ & 0.007 \\
\hline Chromium (Cr) & 0.05 & Endrin & 0.0002 \\
\hline Lead $(\mathrm{Pb})$ & 0.05 & $\begin{array}{l}\text { Ethylene } \\
\text { dichloride }\end{array}$ & 0.005 \\
\hline Mercury (Hg) & 0.002 & Lindane & 0.004 \\
\hline Molybdenum (MO) & 0.1 & Methoxychlor & 0.1 \\
\hline Nitrate $\left(\mathrm{NO}_{3}\right)$ & 44.0 & Methylchloroform & 0.2 \\
\hline Selenium (Se) & 0.01 & Toxaphene & 0.005 \\
\hline Silver (Ag) & 0.05 & $2,4-D$ & 0.1 \\
\hline $\begin{array}{l}\text { Combined radium } \\
\text { ( } \mathrm{Ra}-226 \text { and - } \\
228)\end{array}$ & $5.0^{c}$ & $2,4,5-\mathrm{TP}$ & 0.01 \\
\hline $\begin{array}{l}\text { Combined uranium } \\
(U-234 \text { and }-238)\end{array}$ & $30.0^{c}$ & Trichlorethylene & 0.005 \\
\hline $\begin{array}{l}\text { Net gross alpha } \\
\text { (excluding radon } \\
\text { and uranium) }\end{array}$ & $15.0^{\mathrm{c}}$ & Vinyl chloride & 0.002 \\
\hline
\end{tabular}


Table 1.1 Maximum concentration of constituents for groundwater protection" (Concluded)

Constituents without MCLS
Constituents without MCLs

\begin{tabular}{|c|c|}
\hline $\begin{array}{l}\text { Antimony (Sb) and compounds, } \\
\text { NOS }^{d}\end{array}$ & $\begin{array}{l}\text { Nickel (Ni) and compounds, } \\
\text { NOS }^{d}\end{array}$ \\
\hline Aluminum phosphide & Strontium sulfide \\
\hline $\begin{array}{l}\text { Beryllium (Be) and compounds, } \\
\text { NOS }^{d}\end{array}$ & Sulfide (S) \\
\hline Calcium chromate & $\begin{array}{l}\text { Thallium (Th) and } \\
\text { compounds, Nos }\end{array}$ \\
\hline Carbon disulfide & $\operatorname{Tin}(\mathrm{Sn})$ \\
\hline Carbon oxyfluoride & Vanadium (V) \\
\hline Copper (Cu) & $\begin{array}{l}\text { Vanadic acid, ammonium } \\
\text { saltc }\end{array}$ \\
\hline Cobalt (Co) & Vanadium pentoxide \\
\hline Cyanides $(\mathrm{CN}), \mathrm{NOS}^{\mathrm{d}, \mathrm{e}, \mathrm{f}}$ & Zinc $(\mathrm{Zn})$ \\
\hline & Zinc phosphide ${ }^{e}$ \\
\hline
\end{tabular}

Nickel (Ni) and compounds,

Strontium sulfide

Sulfide (S)

Thallium (Th) and

Vanadium (V)

Vanadic acid, ammonium salt

Zinc $(\mathrm{Zn})$

Zinc phosphide

'Summarized from EPA Proposed groundwater standards, April 1989, 40 CFR 192.02.

Maximum concentration limits. Concentrations of these constituents shall not exceed background or the MCL limits, whichever is higher.

'Units are $\mathrm{pCi} / 1$.

dNot otherwise specified. Members of compounds not specified in Appendix I.

'Added when Appendix I replaced Appendix IX of 40 CFR 264 . Soluble salts and complexes. 
TABLE 3.1 MONITORING YELL INFORMATION FOR THE NC PROCESSING SITE, SLICK ROCK, COLORADO

SITE: SRKO1 SLICK ROCK (BOTH SITES)

REPORT DATE: 06/17/93

\begin{tabular}{|c|c|c|c|c|c|c|c|c|c|c|c|c|}
\hline $\begin{array}{c}\text { LOCATION } \\
10\end{array}$ & $\begin{array}{c}\text { NORTH } \\
\text { COORDINATE } \\
\text { (FT) }\end{array}$ & $\begin{array}{c}\text { EAST } \\
\text { COORDINATE } \\
\text { (FT) }\end{array}$ & $\begin{array}{c}\text { GROUND } \\
\text { ELEVAYION } \\
\text { (FT MSL) }\end{array}$ & $\begin{array}{l}\text { BOREHOLE } \\
\text { DEPTH } \\
\text { (FT) }\end{array}$ & $\begin{array}{l}\text { BOREHOLE } \\
\text { DIAMETER } \\
\text { (INCHES) }\end{array}$ & $\begin{array}{l}\text { CASING } \\
\text { ELEVATION } \\
\text { (FT MSL) }\end{array}$ & $\begin{array}{c}\text { CASING } \\
\text { DEPTH } \\
\text { (FT) }\end{array}$ & $\begin{array}{l}\text { CASING } \\
\text { DIAMETER } \\
\text { (INCHES) }\end{array}$ & $\begin{array}{c}\text { SCREEN } \\
\text { BEGINNING } \\
\text { DEPTH (FT) }\end{array}$ & $\begin{array}{l}\text { SCREEN } \\
\text { LENGTH } \\
\text { (FT) }\end{array}$ & $\begin{array}{l}\text { FLOW } \\
\text { CODE }\end{array}$ & $\begin{array}{c}\text { FORMATION } \\
\text { OF } \\
\text { COMPLETION }\end{array}$ \\
\hline $\begin{array}{l}0501 \\
0503 \\
0504 \\
0512 \\
0686 \\
0687 \\
0690\end{array}$ & $\begin{array}{l}58537.7 \\
58246.7 \\
58094.9 \\
58394.2 \\
58619.9 \\
57223.2 \\
57927.8\end{array}$ & $\begin{array}{l}63677.8 \\
63269.3 \\
63088.4 \\
63267.2 \\
63769.6 \\
62932.9 \\
61902.3\end{array}$ & $\begin{array}{l}5454.80 \\
5457.90 \\
5448.50 \\
5450.40 \\
5455.10 \\
5492.80 \\
5506.90\end{array}$ & $\begin{array}{r}22.00 \\
27.00 \\
19.00 \\
20.00 \\
22.00 \\
195.00 \\
182.00\end{array}$ & $\begin{array}{l}8.000 \\
8.000 \\
8.000 \\
8.000 \\
6.000 \\
6.000 \\
6.000\end{array}$ & $\begin{array}{l}5456.48 \\
5459.39 \\
5450.81 \\
5452.67 \\
5457.29 \\
5494.14 \\
5509.41\end{array}$ & $\begin{array}{c}22.00 \\
27.00 \\
19.00 \\
20.00 \\
22.00 \\
195.0 \\
182.00\end{array}$ & $\begin{array}{l}4.000 \\
4.000 \\
4.000 \\
4.000 \\
2.000 \\
2.000 \\
2.000\end{array}$ & $\begin{array}{l}12.00 \\
20.00 \\
14.00 \\
12.00 \\
15 . \\
173 . \\
160 .\end{array}$ & $\begin{array}{r}9.0 \\
6.0 \\
4.0 \\
8.0 \\
5.0 \\
20.0 \\
20.0\end{array}$ & $\begin{array}{l}0 \\
0 \\
0 \\
0 \\
0 \\
U \\
U\end{array}$ & $\begin{array}{l}A L \\
A L \\
A L \\
A L \\
A L \\
\text { NA } \\
\text { NA }\end{array}$ \\
\hline
\end{tabular}

FORMATION OF COMPLETION COOE:

AL - ALLUVIUM

NA - NAVAJO SANDSTONE

DATA FILE: M: IDARTISRK01\MHI10001.DAT
FLON RELATIONSHIP CODE:

O - OW-SITE

D. DON GRADIENT

$U$ - UPGRADIENT 
TABLE 3.2 MONITORING WELL INFORMATION FOR THE UC PROCESSING SITE, SLICK ROCK, COLORADO

SITE: SRKOI SLICK ROCK (BOTH SITES)

REPORT DATE: $06 / 17 / 93$

\begin{tabular}{|c|c|c|c|c|c|c|c|c|c|c|c|c|c|}
\hline & $\underset{10}{\text { LOCATION }}$ & $\begin{array}{c}\text { NORTH } \\
\text { COORDINATE } \\
\text { (FT) }\end{array}$ & $\begin{array}{c}\text { EAST } \\
\text { COORDINATE } \\
\text { (FT) }\end{array}$ & $\begin{array}{c}\text { GROUND } \\
\text { ELEVATION } \\
\text { (FT MSL) }\end{array}$ & $\begin{array}{l}\text { BOREHOLE } \\
\text { DEPTH } \\
\text { (FT) }\end{array}$ & $\mid \begin{array}{l}\text { BOREHOLE } \\
\text { DI IAMETER } \\
\text { (INCHES) }\end{array}$ & $\begin{array}{l}\text { CASING } \\
\text { ELEVATION } \\
\text { (FT MSL) }\end{array}$ & $\begin{array}{l}\text { CASING } \\
\text { DEPTH } \\
\text { (FT) }\end{array}$ & $\begin{array}{l}\text { CASING } \\
\text { DIAMETER } \\
\text { (INCHES) }\end{array}$ & $\begin{array}{c}\text { SCREEN } \\
\text { BEGINNING } \\
\text { DEPTH (FT) }\end{array}$ & $\begin{array}{l}\text { SCREEN } \\
\text { LENGTH } \\
\text { (FT) }\end{array}$ & $\begin{array}{l}\text { FLOW } \\
\text { CODE }\end{array}$ & $\begin{array}{l}\text { FORMATION } \\
\text { OF } \\
\text { COMPLETION }\end{array}$ \\
\hline & $\begin{array}{l}0505 \\
0506 \\
0507 \\
0508 \\
0509 \\
0510 \\
0551 \\
0552 \\
0553 \\
0554 \\
0555 \\
0556 \\
0557 \\
0558 \\
0559 \\
0560 \\
0668 \\
0669 \\
0670 \\
0684 \\
0685 \\
0688 \\
0702 \\
0703 \\
0704\end{array}$ & $\begin{array}{l}58621.3 \\
59877.7 \\
60019.9 \\
59547.6 \\
59201.7 \\
59726.1 \\
58464.81 \\
58480.06 \\
58498.13 \\
59171.94 \\
59128.84 \\
58533.37 \\
58559.45 \\
58131.86 \\
58410.30 \\
59348.92 \\
58670.83 \\
59555.2 \\
59797.4 \\
60988.0 \\
62187.5 \\
60020.8 \\
58881.87 \\
58719.29 \\
59173.01\end{array}$ & $\begin{array}{l}60065.9 \\
58895.7 \\
58704.2 \\
59575.2 \\
60131.0 \\
59228.0 \\
58510.72 \\
58476.35 \\
58539.82 \\
58549.51 \\
58569.09 \\
58255.91 \\
58270.92 \\
58863.79 \\
59120.23 \\
58463.56 \\
58711.47 \\
59550.5 \\
59171.8 \\
58964.8 \\
58927.9 \\
57956.9 \\
59277.12 \\
58732.28 \\
58879.14\end{array}$ & $\begin{array}{l}5436.40 \\
5431.10 \\
5431.50 \\
5437.30 \\
5434.80 \\
5436.40 \\
5524.49 \\
5524.82 \\
5524.47 \\
5500.87 \\
5502.45 \\
5528.27 \\
5527.06 \\
5524.79 \\
5515.27 \\
5492.83 \\
5522.93 \\
5438.80 \\
5435.89 \\
5430.20 \\
5426.30 \\
5453.60 \\
5489.55 \\
5522.34 \\
5489.25\end{array}$ & $\begin{array}{r}19.00 \\
21.00 \\
20.00 \\
20.00 \\
22.00 \\
26.00 \\
80.00 \\
80.00 \\
25.00 \\
50.00 \\
35.00 \\
95.00 \\
45.00 \\
82.00 \\
52.00 \\
25.00 \\
249.00 \\
107.00 \\
96.00 \\
23.00 \\
27.00 \\
70.00 \\
70.00 \\
55.00 \\
61.50\end{array}$ & $\begin{array}{l}8.000 \\
8.000 \\
8.000 \\
8.000 \\
8.000 \\
8.000 \\
8.000 \\
8.000 \\
8.000 \\
8.000 \\
8.000 \\
8.000 \\
8.000 \\
8.000 \\
8.000 \\
8.000 \\
6.000 \\
6.000 \\
6.000 \\
6.000 \\
6.000 \\
6.000 \\
8.000 \\
8.000 \\
8.000\end{array}$ & $\begin{array}{l}5441.05 \\
5431.37 \\
5433.06 \\
5439.77 \\
5436.80 \\
5438.59 \\
5524.00 \\
5525.00 \\
5525.00 \\
5500.50 \\
5502.00 \\
5529.00 \\
5527.00 \\
5526.00 \\
5515.00 \\
5492.00 \\
5524.91 \\
5440.50 \\
5437.76 \\
5432.51 \\
5428.34 \\
5455.46 \\
5486.50 \\
5526.50 \\
5491.67\end{array}$ & $\begin{array}{l}19.00 \\
19 . \\
20.00 \\
19 . \\
22.00 \\
24 . \\
58 . \\
80 . \\
24 . \\
49.5 \\
33.00 \\
90 . \\
42 . \\
80 . \\
52 . \\
24.00 \\
153.0 \\
107.00 \\
96.00 \\
23.00 \\
27.00 \\
70.00 \\
68 . \\
55 . \\
60 .\end{array}$ & $\begin{array}{l}4.000 \\
4.000 \\
4.000 \\
4.000 \\
4.000 \\
4.000 \\
4.000 \\
4.000 \\
4.000 \\
4.000 \\
4.000 \\
4.000 \\
4.000 \\
4.000 \\
4.000 \\
4.000 \\
2.000 \\
2.000 \\
2.000 \\
2.000 \\
2.000 \\
2.000 \\
4.000 \\
4.000 \\
4.000\end{array}$ & $\begin{array}{c}11.00 \\
12.00 \\
10.00 \\
12.00 \\
12.00 \\
15.00 \\
46 . \\
68 . \\
12 . \\
37.5 \\
21.00 \\
78.0 \\
30.0 \\
68.0 \\
38.0 \\
12.00 \\
111 . \\
100 . \\
84 . \\
11.0 \\
15 . \\
53 . \\
55 . \\
41.8 \\
46.00\end{array}$ & $\begin{array}{r}8.0 \\
7.0 \\
10.0 \\
7.0 \\
10.0 \\
9.0 \\
10.0 \\
10.0 \\
10.0 \\
10.0 \\
10.0 \\
10.0 \\
10.0 \\
10.0 \\
10.0 \\
10.0 \\
40.0 \\
5.0 \\
10.0 \\
10.0 \\
10.0 \\
15.0 \\
10.0 \\
10.0 \\
10.0\end{array}$ & $\begin{array}{l}0 \\
0 \\
0 \\
0 \\
0 \\
0 \\
U \\
U \\
0 \\
U \\
0 \\
U \\
0 \\
U \\
0 \\
0 \\
U \\
U \\
U \\
0 \\
0 \\
U \\
0 \\
0 \\
0\end{array}$ & $\begin{array}{l}A L \\
A L \\
A L \\
A L \\
A L \\
A L \\
J E \\
N A \\
A L \\
J E \\
A L \\
N A \\
A L \\
N A \\
J E \\
A L \\
N A \\
N A \\
N A \\
A L \\
A L \\
N A \\
J E \\
J E \\
J E\end{array}$ \\
\hline
\end{tabular}

FORMATION OF COMPLETION CODE:

AL - ALLUVIUM

JE - JURASSIC ENTRADA SANDSTONE FORMATION

FLOW RELATIONSHIP COOE:

NA - NAVAJO SANDSTONE

O - ON-SITE

D - DOWN GRADIENT

DATA FILE: M: IDARTISRK01 MMHI 10002.DAT 
TABLE 3.3 STATIC GROUNDWATER LEVELS FOR THE NC AND UC PROCESSING SITES,

SLICK ROCK, COLORADO

SITE: SRKO1 SLICK ROCK (BOTH SITES)

REPORT DATE: 06/17/93

\begin{tabular}{|c|c|c|c|c|c|c|c|c|c|c|c|}
\hline $\begin{array}{c}\text { LOCATION } \\
10\end{array}$ & $\begin{array}{l}\text { NORTH } \\
\text { COORDINATE } \\
\text { (FT) }\end{array}$ & $\begin{array}{l}\text { EAST } \\
\text { COORDINATE } \\
\text { (FT) }\end{array}$ & $\begin{array}{l}\text { FORMATION } \\
\text { OF } \\
\text { COMPLETION }\end{array}$ & $\begin{array}{l}\text { FLON } \\
\text { CODE }\end{array}$ & $\begin{array}{l}\text { CASING } \\
\text { ELEVATION } \\
\text { (FT MSL) }\end{array}$ & $\begin{array}{l}\text { GROUND } \\
\text { ELEVATION } \\
\text { (FT MSL) }\end{array}$ & LOG DATE & $\begin{array}{l}\text { LOG } \\
\text { TIME }\end{array}$ & $\begin{array}{l}\text { DEPIH FROM } \\
\text { TOP OF } \\
\text { CASING (FT) }\end{array}$ & $\begin{array}{l}\text { DEPTH FROM } \\
\text { GROUND } \\
\text { (FT) }\end{array}$ & $\begin{array}{l}\text { GROUNDWATER } \\
\text { ELEVATION } \\
\text { (FT MSL) }\end{array}$ \\
\hline 0501 & 58537.7 & 63677.8 & AL & 0 & 5456.48 & 5454.80 & $\begin{array}{l}02 / 04 / 86 \\
03 / 31 / 86 \\
06 / 27 / 86 \\
06 / 30 / 86 \\
10 / 11 / 87 \\
02 / 20 / 88 \\
05 / 15 / 90 \\
12 / 02 / 90 \\
03 / 29 / 91 \\
08 / 27 / 91 \\
12 / 09 / 91 \\
10 / 09 / 92\end{array}$ & $\begin{array}{l}13: 45 \\
11: 00 \\
15: 40 \\
10: 30 \\
15: 05 \\
13: 10 \\
13: 15 \\
13: 10 \\
11: 24 \\
14: 15 \\
10: 55 \\
15: 32\end{array}$ & $\begin{array}{l}17.03 \\
15.48 \\
15.55 \\
15.91 \\
17.00 \\
16.72 \\
17.53 \\
17.47 \\
17.25 \\
17.55 \\
17.37 \\
17.08\end{array}$ & $\begin{array}{l}15.35 \\
13.80 \\
13.87 \\
14.23 \\
15.32 \\
15.04 \\
15.85 \\
15.79 \\
15.57 \\
15.87 \\
15.69 \\
15.40\end{array}$ & $\begin{array}{l}5439.45 \\
5441.00 \\
5440.93 \\
5440.57 \\
5439.48 \\
5439.76 \\
5438.95 \\
5439.01 \\
5439.23 \\
5438.93 \\
5439.11 \\
5439.40\end{array}$ \\
\hline 0503 & 58246.7 & 63269.3 & AL & 0 & 5459.39 & 5457.90 & $\begin{array}{l}02 / 04 / 86 \\
03 / 31 / 86 \\
06 / 27 / 86 \\
06 / 28 / 86 \\
10 / 11 / 87 \\
02 / 20 / 88 \\
05 / 15 / 90 \\
12 / 02 / 90 \\
03 / 29 / 91 \\
08 / 08 / 91 \\
12 / 09 / 91 \\
10 / 0 y / 92\end{array}$ & $\begin{array}{l}15: 45 \\
11: 15 \\
16: 16 \\
10: 00 \\
11: 30 \\
15: 00 \\
10: 20 \\
13: 16 \\
15: 25 \\
16: 15 \\
12: 07 \\
11: 43\end{array}$ & $\begin{array}{l}20.55 \\
19.82 \\
18.88 \\
18.91 \\
20.33 \\
20.85 \\
21.11 \\
21.13 \\
21.85 \\
21.00 \\
21.12 \\
20.74\end{array}$ & $\begin{array}{l}19.06 \\
18.33 \\
17.39 \\
17.42 \\
18.84 \\
19.36 \\
19.62 \\
19.64 \\
20.36 \\
19.51 \\
19.63 \\
19.25\end{array}$ & $\begin{array}{l}5438.84 \\
5439.57 \\
5440.51 \\
5440.48 \\
5439.06 \\
5438.54 \\
5438.28 \\
5438.26 \\
5437.54 \\
5438.39 \\
5438.27 \\
5438.65\end{array}$ \\
\hline 0504 & 58094.9 & 63088.4 & $A L$ & D & 5450.81 & 5448.50 & $\begin{array}{l}02 / 04 / 86 \\
03 / 31 / 86 \\
06 / 30 / 86 \\
10 / 11 / 87 \\
02 / 21 / 88 \\
05 / 15 / 90 \\
12 / 02 / 90 \\
04 / 03 / 91 \\
08 / 27 / 91 \\
12 / 09 / 91 \\
10 / 09 / 92\end{array}$ & $\begin{array}{l}17: 35 \\
11: 45 \\
13: 45 \\
09: 41 \\
08: 45 \\
15: 00 \\
13: 19 \\
11: 50 \\
13: 00 \\
13: 38 \\
12: 00\end{array}$ & $\begin{array}{l}11.28 \\
10.90 \\
10.00 \\
10.20 \\
11.04 \\
11.95 \\
12.30 \\
11.68 \\
12.94 \\
13.75 \\
13.45\end{array}$ & $\begin{array}{r}8.97 \\
8.59 \\
7.69 \\
7.89 \\
8.73 \\
9.64 \\
9.99 \\
9.37 \\
10.63 \\
11.44 \\
11.14\end{array}$ & $\begin{array}{l}5439.53 \\
5439.91 \\
5440.81 \\
5440.61 \\
5439.77 \\
5438.86 \\
5438.51 \\
5439.13 \\
5437.87 \\
5437.06 \\
5437.36\end{array}$ \\
\hline 0505 & 58621.3 & 60065.9 & $A L$ & 0 & 5441.05 & 5436.40 & $\begin{array}{l}02 / 18 / 86 \\
03 / 31 / 86 \\
06 / 28 / 86\end{array}$ & $\begin{array}{l}16: 45 \\
12: 30 \\
10: 20\end{array}$ & $\begin{array}{r}10.41 \\
9.91 \\
9.09\end{array}$ & $\begin{array}{l}5.76 \\
5.26 \\
4.44\end{array}$ & $\begin{array}{l}5430.64 \\
5431.14 \\
5431.96\end{array}$ \\
\hline $\begin{array}{l}\text { FORMATION } \\
\text { AL - ALLL }\end{array}$ & COMPLET & $D E$ & & & & & \multicolumn{5}{|c|}{$\begin{array}{l}\text { FLOW RELATIONSHIP COOE: } \\
\text { O - ON-SITE } \\
\text { D - DOWN GRADIENT }\end{array}$} \\
\hline
\end{tabular}


TABLE 3.3 STATIC GROUNDWATER LEVELS FOR THE NC AND UC PROCESSING SITES,

SLICK ROCK, COLORADO

SITE: SRKOI SLICK ROCK (BOTH SITES)

REPORT DATE : 06/17/93

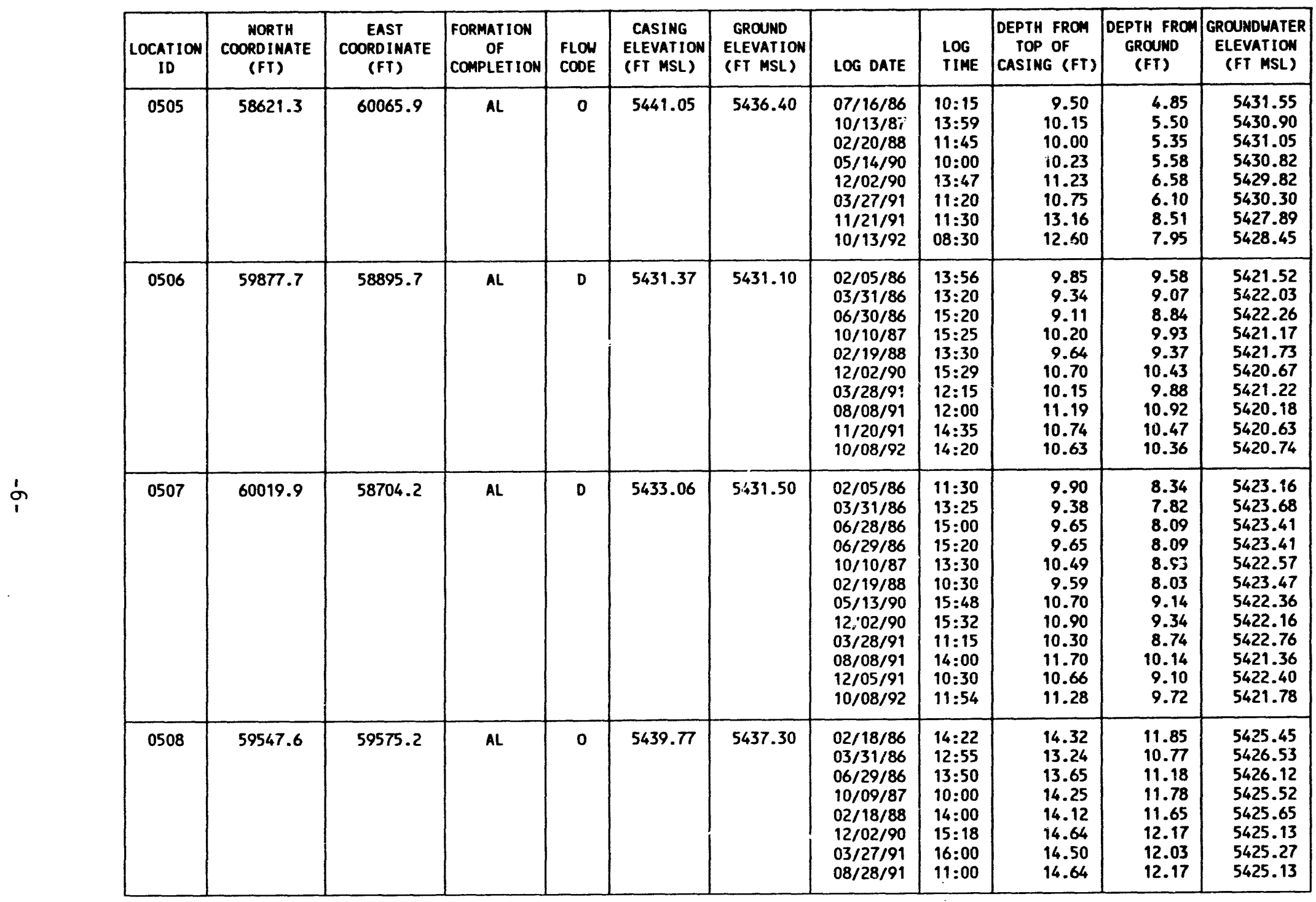

FORMATION OF COMPLETION CODE:

AL - ALLUVIUM
FLON RELATIONSHIP CODE:

D - DOWN GRADIENT 
TABLE 3.3 STATIC GROUNDWATER LEVELS FOR THE NC AND UC PROCESSING SITES,

SLICK ROCK, COLORADO

SITE: SRKO1 SLICK ROCK (BOTH SITES)

SIE: SRTE DATE: O6/17/93

\begin{tabular}{|c|c|c|c|c|c|c|c|c|c|c|c|}
\hline $\begin{array}{c}\text { LOCATION } \\
\text { ID }\end{array}$ & $\begin{array}{l}\text { NORTH } \\
\text { COORDINATE } \\
\text { (FT) }\end{array}$ & $\begin{array}{c}\text { EAST } \\
\text { COORDINATE } \\
\text { (FT) }\end{array}$ & $\begin{array}{l}\text { FORMATION } \\
\text { OF } \\
\text { COMPLETION }\end{array}$ & $\begin{array}{l}\text { FLOW } \\
\text { COOE }\end{array}$ & $\begin{array}{l}\text { CAS!NG } \\
\text { ELEVATION } \\
\text { (FT MSL) }\end{array}$ & $\begin{array}{l}\text { GROUND } \\
\text { ELEVATION } \\
\text { (FT MSL) }\end{array}$ & LOG DATE & $\begin{array}{l}\text { LOG } \\
\text { TIME }\end{array}$ & $\begin{array}{l}\text { DEPTH FROM } \\
\text { TOP OF } \\
\text { CASING (FT) }\end{array}$ & $\begin{array}{c}\text { DEPTH FROM } \\
\text { GROUND } \\
\text { (FT) }\end{array}$ & $\begin{array}{l}\text { GROUNDWATER } \\
\text { ELEVATION } \\
\text { (FT MSL) }\end{array}$ \\
\hline 0508 & 59547.6 & 59575.2 & AL & 0 & 5439.77 & 5437.30 & $\begin{array}{l}12 / 05 / 91 \\
10 / 10 / 92\end{array}$ & $\begin{array}{l}13: 52 \\
15: 55\end{array}$ & $\begin{array}{l}16.00 \\
15.87\end{array}$ & $\begin{array}{l}13.53 \\
13.40\end{array}$ & $\begin{array}{l}5423.77 \\
5423.90\end{array}$ \\
\hline 0509 & 59201.7 & 60131.0 & AL & 0 & 5436.80 & 5434.80 & $\begin{array}{l}02 / 18 / 86 \\
03 / 31 / 86 \\
06 / 28 / 86 \\
07 / 15 / 86 \\
10 / 10 / 87 \\
02 / 20 / 88 \\
12 / 02 / 90 \\
03 / 27 / 91 \\
08 / 28 / 91 \\
11 / 21 / 91 \\
10 / 13 / 92\end{array}$ & $\begin{array}{l}15: 20 \\
12: 35 \\
15: 15 \\
10: 00 \\
10: 15 \\
10: 30 \\
15: 09 \\
14: 09 \\
13: 40 \\
09: 25 \\
09: 50\end{array}$ & $\begin{array}{r}11.14 \\
10.51 \\
9.42 \\
9.20 \\
10.98 \\
10.71 \\
11.93 \\
11.45 \\
12.20 \\
11.96 \\
11.60\end{array}$ & $\begin{array}{r}9.14 \\
8.51 \\
7.42 \\
7.20 \\
8.98 \\
8.71 \\
9.93 \\
9.45 \\
10.20 \\
9.96 \\
9.60\end{array}$ & $\begin{array}{l}5425.66 \\
5426.29 \\
5427.38 \\
5427.60 \\
5425.82 \\
5426.09 \\
5424.87 \\
5425.35 \\
5424.60 \\
5424.84 \\
5425.20\end{array}$ \\
\hline 0510 & 59726.1 & 59228.0 & AL & 0 & 5438.59 & 5436.40 & $\begin{array}{l}02 / 18 / 86 \\
03 / 31 / 86 \\
06 / 28 / 86 \\
10 / 09 / 87 \\
02 / 20 / 88 \\
05 / 14 / 90 \\
12 / 02 / 90 \\
03 / 28 / 91 \\
08 / 28 / 91 \\
12 / 05 / 91 \\
10 / 08 / 92\end{array}$ & $\begin{array}{l}13: 00 \\
13: 05 \\
13: 50 \\
13: 30 \\
09: 10 \\
13: 49 \\
15: 22 \\
09: 45 \\
12: 15 \\
15: 12 \\
16: 47\end{array}$ & $\begin{array}{l}15.93 \\
15.09 \\
14.84 \\
15.87 \\
15.82 \\
16.21 \\
16.21 \\
16.10 \\
16.22 \\
16.13 \\
15.90\end{array}$ & $\begin{array}{l}13.74 \\
12.90 \\
12.65 \\
13.68 \\
13.63 \\
14.02 \\
14.02 \\
13.91 \\
14.03 \\
13.94 \\
13.71\end{array}$ & $\begin{array}{l}5422.66 \\
5423.50 \\
5423.75 \\
5422.72 \\
5422.77 \\
5422.38 \\
5422.38 \\
5422.49 \\
5422.37 \\
5422.46 \\
5422.69\end{array}$ \\
\hline 0512 & 58394.2 & 63267.2 & $A L$ & 0 & 5452.67 & 5450.40 & $\begin{array}{l}02 / 04 / 86 \\
03 / 31 / 86 \\
06 / 30 / 86 \\
10 / 11 / 87 \\
02 / 20 / 88 \\
12 / 02 / 90 \\
04 / 05 / 91 \\
08 / 08 / 91 \\
12 / 10 / 91 \\
10 / 09 / 92\end{array}$ & $\begin{array}{l}16: 10 \\
11: 10 \\
11: 50 \\
13: 33 \\
13: 00 \\
13: 14 \\
08: 30 \\
16: 05 \\
14: 32 \\
14: 22\end{array}$ & $\begin{array}{l}12.48 \\
11.05 \\
11.74 \\
12.42 \\
12.19 \\
12.95 \\
12.70 \\
12.71 \\
14.16 \\
14.10\end{array}$ & $\begin{array}{r}10.21 \\
8.78 \\
9.47 \\
10.15 \\
9.92 \\
10.68 \\
10.43 \\
10.44 \\
11.89 \\
11.83\end{array}$ & $\begin{array}{l}5440.19 \\
5441.62 \\
5440.93 \\
5440.25 \\
5440.48 \\
5439.72 \\
5439.97 \\
5439.96 \\
5438.51 \\
5438.57\end{array}$ \\
\hline 0551 & 58464.81 & 58510.72 & JE & $u$ & 5524.00 & 5524.49 & $\begin{array}{l}12 / 02 / 90 \\
12 / 09 / 90 \\
03 / 28 / 91\end{array}$ & $\begin{array}{l}14: 24 \\
09: 25 \\
15: 47\end{array}$ & $\begin{array}{l}46.75 \\
46.93 \\
46.21\end{array}$ & $\begin{array}{l}47.24 \\
47.42 \\
46.70\end{array}$ & $\begin{array}{l}5477.25 \\
5477.07 \\
5477.79\end{array}$ \\
\hline
\end{tabular}

FORMATION OF COMPLETION COOE:

AL - ALLUVIUM

JE - JURASSIC ENTRADA SANDSTONE FORMATION
FLOW RELATIONSHIP CODE:

O- ON-SITE 
TABLE 3.3 STATIC GROUNDHATER LEVELS FOR THE NC AND UC PROCESSING SITES,

SLICK ROCK COLORADO

SITE: SRKOI SLICK ROCK (BOTH SITES)

PEPOPT DATE: $06 / 17 / 93$

\begin{tabular}{|c|c|c|c|c|c|c|c|c|c|c|c|}
\hline${ }_{10}^{\text {LOCATION }}$ & $\begin{array}{l}\text { NORTH } \\
\text { COORDINATE } \\
\text { (FT) }\end{array}$ & $\begin{array}{c}\text { EAST } \\
\text { COORDINATE } \\
\text { (FT) }\end{array}$ & $\begin{array}{c}\text { FORMATION } \\
\text { OF } \\
\text { COMPLETION }\end{array}$ & $\begin{array}{l}\text { FLOW } \\
\text { CODE }\end{array}$ & $\begin{array}{l}\text { CASING } \\
\text { ELEVATION } \\
\text { (FT MSL) }\end{array}$ & $\begin{array}{l}\text { GROUND } \\
\text { ELEVATION } \\
\text { (FT MSL) }\end{array}$ & LCG DATE & $\begin{array}{l}\text { LOG } \\
\text { TIME }\end{array}$ & $\begin{array}{l}\text { DEPTH FROM } \\
\text { TOP OF } \\
\text { CASING (FT) }\end{array}$ & \begin{tabular}{|} 
DEPTH FROM \\
GROWND \\
(FT)
\end{tabular} & $\begin{array}{l}\text { GROUNDWATER } \\
\text { ELEVATION } \\
\text { (FT MSL) }\end{array}$ \\
\hline 0551 & 58464.81 & 58510.72 & JE & u & 5524.00 & 5524.49 & $\begin{array}{l}08 / 05 / 91 \\
12 / 11 / 91 \\
10 / 10 / 92\end{array}$ & $\begin{array}{l}12: 48 \\
15: 21 \\
13: 52\end{array}$ & $\begin{array}{l}45.90 \\
46.02 \\
45.40\end{array}$ & $\begin{array}{l}46.39 \\
46.51 \\
45.89\end{array}$ & $\begin{array}{l}5478.10 \\
5477.98 \\
5478.60\end{array}$ \\
\hline 0552 & 58480.06 & 58476.35 & NA & U & 5525.00 & 5524.82 & $\begin{array}{l}12 / 02 / 90 \\
12 / 11 / 90 \\
03 / 27 / 91 \\
08 / 24 / 91 \\
12 / 12 / 91 \\
10 / 10 / 92\end{array}$ & $\begin{array}{l}14: 21 \\
12: 20 \\
10: 25 \\
09: 50 \\
10: 10 \\
15: 15\end{array}$ & $\begin{array}{l}49.95 \\
67.86 \\
49.20 \\
49.17 \\
49.05 \\
48.57\end{array}$ & $\begin{array}{l}49.77 \\
67.68 \\
49.02 \\
48.99 \\
48.37 \\
48.39\end{array}$ & $\begin{array}{l}5475.05 \\
5457.14 \\
5475.80 \\
5475.83 \\
5475.95 \\
5476.43\end{array}$ \\
\hline 0553 & 58498.13 & 58539.82 & AL & 0 & 5525.00 & 5524.47 & $\begin{array}{l}12 / 02 / 90 \\
03 / 29 / 91\end{array}$ & $\begin{array}{l}14: 28 \\
10: 15\end{array}$ & $\begin{array}{l}\text { DRY } \\
\text { DRY }\end{array}$ & $\begin{array}{l}\text { DRY } \\
\text { DRY }\end{array}$ & - \\
\hline 0554 & 59171.94 & 58549.51 & JE & u & 5500.50 & 5500.87 & $\begin{array}{l}12 / 02 / 90 \\
12 / 11 / 90 \\
03 / 28 / 91 \\
08 / 05 / 91 \\
12 / 06 / 91 \\
10 / 15 / 92\end{array}$ & $\begin{array}{l}14: 52 \\
08: 45 \\
09: 50 \\
15: 58 \\
14: 20 \\
08: 35\end{array}$ & $\begin{array}{l}34.97 \\
34.58 \\
34.90 \\
34.71 \\
34.71 \\
34.28\end{array}$ & $\begin{array}{l}35.34 \\
34.95 \\
35.27 \\
35.08 \\
35.08 \\
34.65\end{array}$ & $\begin{array}{l}5465.53 \\
5465.92 \\
5465.60 \\
5465.79 \\
5465.79 \\
5466.22\end{array}$ \\
\hline 0555 & 59128.84 & 58569.09 & AL & 0 & 5502.00 & 5502.45 & $\begin{array}{l}12 / 02 / 90 \\
03 / 29 / 91\end{array}$ & $\begin{array}{l}14: 48 \\
10: 40\end{array}$ & $\begin{array}{l}\text { DRY } \\
\text { DRY }\end{array}$ & $\begin{array}{l}\text { DRY } \\
\text { DRY }\end{array}$ & - \\
\hline 0556 & 58533.37 & 58255.91 & NA & u & 5529.00 & 5528.27 & $\begin{array}{l}12 / 02 / 90 \\
12 / 13 / 90 \\
03 / 29 / 91 \\
08 / 05 / 91 \\
12 / 12 / 91 \\
10 / 15 / 92\end{array}$ & $\begin{array}{l}14: 16 \\
13: 33 \\
13: 24 \\
14: 20 \\
11: 39 \\
10: 41\end{array}$ & $\begin{array}{l}54.15 \\
54.0 \\
52.95 \\
52.61 \\
53.29 \\
53.70\end{array}$ & $\begin{array}{l}53.42 \\
53.27 \\
52.22 \\
51.88 \\
52.56 \\
52.97\end{array}$ & $\begin{array}{l}5474.85 \\
5475.00 \\
5476.05 \\
5476.39 \\
5475.71 \\
5475.30\end{array}$ \\
\hline 0557 & 58559.45 & 58270.92 & $A L$ & 0 & 5527.00 & 5527.06 & $\begin{array}{l}12 / 02 / 90 \\
03 / 29 / 91\end{array}$ & $\begin{array}{l}14: 14 \\
10: 30\end{array}$ & $\begin{array}{l}\text { DRY } \\
\text { DRY }\end{array}$ & $\begin{array}{l}\text { DRY } \\
\text { DRY }\end{array}$ & - \\
\hline 0558 & 58131.86 & 58863.79 & NA & $u$ & 5526.00 & 5524.79 & $\begin{array}{l}12 / 02 / 90 \\
12 / 14 / 90 \\
03 / 29 / 91 \\
08 / 07 / 91 \\
12 / 11 / 91 \\
10 / 12 / 92\end{array}$ & $\begin{array}{l}14: 01 \\
09: 08 \\
10: 56 \\
10: 18 \\
13: 15 \\
15: 10\end{array}$ & $\begin{array}{l}53.16 \\
53.5 \\
52.61 \\
52.55 \\
52.16 \\
52.30\end{array}$ & $\begin{array}{l}51.95 \\
52.29 \\
51.40 \\
51.34 \\
50.95 \\
51.09\end{array}$ & $\begin{array}{l}5472.84 \\
5472.50 \\
5473.39 \\
5473.45 \\
5473.84 \\
5473.70\end{array}$ \\
\hline
\end{tabular}

FORMATION OF COMPLETION COOE:

JE - JURASSIC ENTRADA SANDSTONE FORMATION

NA - NAVAJO SANDSTONE

AL - ALLUVIUM
FLOW RELATIONSHIP COOE:

$U$ - UPGRADIENT

O - ON-SITE 
TABLE 3.3 STATIC GROUNDWATER LEVELS FOR THE NC AND UC PROCESSING SITES,

SLICK ROCK, COLORADO

SITE: SRKO1 SLICK ROCK (BOTH SITES)

REPORT DATE : $06 / 17 / 93$

\begin{tabular}{|c|c|c|c|c|c|c|c|c|c|c|c|c|}
\hline & $\underset{\text { LOCATION }}{\text { ID }}$ & $\begin{array}{l}\text { MORTH } \\
\text { COORDINATE } \\
\text { (FT) }\end{array}$ & $\begin{array}{c}\text { EAST } \\
\text { COORDINATE } \\
\text { (FT) }\end{array}$ & $\begin{array}{c}\text { FORMATION } \\
\text { OF } \\
\text { COMPLETION }\end{array}$ & $\begin{array}{l}\text { FLOW } \\
\text { CODE }\end{array}$ & $\begin{array}{l}\text { CASING } \\
\text { ELEVATION } \\
\text { (FT MSL) }\end{array}$ & $\begin{array}{l}\text { GROUND } \\
\text { ELEVATION } \\
\text { (FT MSL) }\end{array}$ & LOG DATE & $\begin{array}{l}\text { LOG } \\
\text { TIME }\end{array}$ & $\begin{array}{l}\text { DEPTH FROM } \\
\text { TOP OF } \\
\text { CASING (FT) }\end{array}$ & $\begin{array}{l}\text { DEPTH FROM } \\
\text { GROUND } \\
\text { (FT) }\end{array}$ & $\begin{array}{l}\text { GROUNDWATER } \\
\text { ELEVATION } \\
\text { (FT MSL) }\end{array}$ \\
\hline & 0559 & 58410.30 & 59120.23 & JE & 0 & 5515.00 & 5515.27 & $\begin{array}{l}12 / 02 / 90 \\
12 / 11 / 90\end{array}$ & $\begin{array}{l}14: 08 \\
08: 30\end{array}$ & $\begin{array}{l}\text { DRY } \\
\text { DRY }\end{array}$ & $\begin{array}{l}\text { DRY } \\
\text { DRY }\end{array}$ & - \\
\hline & 0560 & 59348.92 & 58463.56 & $A L$ & 0 & 5492.00 & 5492.83 & $\begin{array}{l}12 / 02 / 90 \\
03 / 29 / 91\end{array}$ & $\begin{array}{l}14: 56 \\
10: 42\end{array}$ & $\begin{array}{l}\text { DRY } \\
\text { DRY }\end{array}$ & $\begin{array}{l}\text { DRY } \\
\text { DRY }\end{array}$ & - \\
\hline & 0634 & - & - & NA & $u$ & - & 5433.40 & $\begin{array}{l}02 / 01 / 86 \\
06 / 27 / 86\end{array}$ & $\begin{array}{l}12: 30 \\
15: 00\end{array}$ & 16.00 & $\dot{-}$ & - \\
\hline & 0635 & - & - & ss & N & - & 5450.00 & $\begin{array}{l}02 / 01 / 86 \\
06 / 28 / 86\end{array}$ & $\begin{array}{l}10: 15 \\
10: 45\end{array}$ & $\begin{array}{l}12.90 \\
12.27\end{array}$ & - & - \\
\hline & 0668 & 58670.83 & 58711.47 & NA & $u$ & 5524.91 & 5522.93 & $\begin{array}{l}02 / 02 / 86 \\
03 / 31 / 86 \\
06 / 29 / 86 \\
10 / 11 / 87 \\
02 / 17 / 88 \\
12 / 02 / 90 \\
12 / 13 / 90 \\
03 / 27 / 91 \\
11 / 18 / 91 \\
10 / 11 / 92\end{array}$ & $\begin{array}{l}15: 40 \\
14: 10 \\
14: 00 \\
13: 35 \\
09: 00 \\
14: 39 \\
11: 10 \\
15: 15 \\
08: 40 \\
13: 40\end{array}$ & $\begin{array}{l}59.20 \\
59.27 \\
59.08 \\
58.82 \\
88.51 \\
58.91 \\
58.8 \\
58.05 \\
57.99 \\
57.67\end{array}$ & $\begin{array}{l}57.22 \\
57.29 \\
57.10 \\
56.84 \\
86.53 \\
56.93 \\
56.82 \\
56.07 \\
56.01 \\
55.69\end{array}$ & $\begin{array}{l}5465.71 \\
5465.64 \\
5465.83 \\
5466.09 \\
5436.40 \\
5466.00 \\
5466.11 \\
5466.86 \\
5466.92 \\
5467.24\end{array}$ \\
\hline & 0669 & 59555.2 & 59550.5 & NA & $u$ & 5440.50 & 5438.80 & $\begin{array}{l}02 / 04 / 86 \\
03 / 31 / 86 \\
06 / 29 / 86 \\
10 / 09 / 87 \\
02 / 18 / 88 \\
12 / 02 / 90 \\
12 / 13 / 90 \\
04 / 01 / 91 \\
08 / 24 / 91 \\
11 / 19 / 91 \\
10 / 12 / 92\end{array}$ & $\begin{array}{l}11: 45 \\
12: 50 \\
10: 04 \\
15: 00 \\
12: 05 \\
15: 16 \\
07: 15 \\
10: 45 \\
13: 45 \\
09: 30 \\
11: 03\end{array}$ & $\begin{array}{c}0.75 \\
0.33 \\
0.09 \\
0.78 \\
\text { FLOWING } \\
1.07 \\
0.75 \\
0.95 \\
.95 \\
0.65 \\
1.0\end{array}$ & $\begin{array}{r}-0.95 \\
-1.37 \\
-1.61 \\
-0.92 \\
\text { FLOWING } \\
-0.63 \\
-0.95 \\
-0.75 \\
-0.75 \\
-1.05 \\
-0.70\end{array}$ & $\begin{array}{c}5439.75 \\
5440.17 \\
5440.41 \\
5439.72 \\
-- \\
5439.43 \\
5439.75 \\
5439.55 \\
5439.55 \\
5439.85 \\
5439.50\end{array}$ \\
\hline & 0670 & 59797.4 & 59171.8 & NA & $u$ & 5437.76 & 5435.89 & $\begin{array}{l}02 / 03 / 86 \\
03 / 31 / 86 \\
06 / 18 / 86 \\
10 / 11 / 87\end{array}$ & $\begin{array}{l}14: 55 \\
13: 00 \\
09: 55 \\
10: 00\end{array}$ & $\begin{array}{l}2.85 \\
2.34 \\
2.72 \\
3.68\end{array}$ & $\begin{array}{l}0.98 \\
0.47 \\
0.85 \\
1.81\end{array}$ & $\begin{array}{l}5434.91 \\
5435.42 \\
5435.04 \\
5434.08\end{array}$ \\
\hline
\end{tabular}

FORMATION OF COMPLETION COOE:

JE - JURASSIC ENTRADA SANDSTONE FORMATION

AL - ALLUVIUM

FLOW RELATIONSHIP COOE:

Ma - NAVAJO SANDSTONE

O- ON-SITE

$U$ - UPGRADIENT

SS - SANDSTONE 
TABLE 3.3 STATIC GROUNDWATER LEVELS FOR THE NC AND UC PROCESSING SITES,

SLICK ROCK, COLORADO

SITE: SRKO1 SLICK ROCK (BOTH SITES)

PEPORT DATE: $06 / 17 / 93$

\begin{tabular}{|c|c|c|c|c|c|c|c|c|c|c|c|}
\hline$\underset{\text { LOCATION }}{\text { ID }}$ & $\begin{array}{l}\text { NORTH } \\
\text { COORDINATE } \\
\text { (FT) }\end{array}$ & $\begin{array}{l}\text { EAST } \\
\text { COORDINATE } \\
\text { (FT) }\end{array}$ & $\begin{array}{l}\text { FORMATION } \\
\text { OF } \\
\text { COMPLETION }\end{array}$ & $\begin{array}{l}\text { FLOW } \\
\text { COOE }\end{array}$ & $\begin{array}{l}\text { CASING } \\
\text { ELEVATION } \\
\text { (FT MSL) }\end{array}$ & $\begin{array}{l}\text { GROUND } \\
\text { ELEVATION } \\
\text { (FT MSL) }\end{array}$ & LOG DATE & $\begin{array}{l}\text { LOG } \\
\text { TIME }\end{array}$ & $\begin{array}{l}\text { DEPTH FROM } \\
\text { TOP OF } \\
\text { CASING (FT) }\end{array}$ & $\begin{array}{l}\text { DEPTH FROM } \\
\text { GROUND } \\
\text { (FT) }\end{array}$ & $\begin{array}{l}\text { GROUNDWATER } \\
\text { ELEVATION } \\
\text { (FT MSL) }\end{array}$ \\
\hline 0670 & 59797.4 & 59171.8 & NA & u & 5437.76 & 5435.89 & $\begin{array}{l}02 / 18 / 88 \\
12 / 02 / 90 \\
12 / 12 / 90 \\
03 / 31 / 91 \\
08 / 24 / 91 \\
11 / 20 / 91 \\
10 / 13 / 92\end{array}$ & $\begin{array}{l}09: 00 \\
15: 25 \\
11: 30 \\
13: 05 \\
15: 00 \\
08: 20 \\
13: 50\end{array}$ & $\begin{array}{l}1.78 \\
3.25 \\
3.20 \\
2.88 \\
3.50 \\
3.13 \\
2.89\end{array}$ & $\begin{array}{r}-0.09 \\
1.38 \\
1.33 \\
1.01 \\
1.63 \\
1.26 \\
1.02\end{array}$ & $\begin{array}{l}5435.98 \\
5434.51 \\
5434.56 \\
5434.88 \\
5434.26 \\
5434.63 \\
5434.87\end{array}$ \\
\hline 0675 & 57457.6 & 60088.4 & AL & N & 5443.17 & 5443.20 & $\begin{array}{l}03 / 31 / 86 \\
06 / 28 / 86\end{array}$ & $\begin{array}{l}14: 50 \\
13: 00\end{array}$ & $\begin{array}{l}12.40 \\
11.45\end{array}$ & $\begin{array}{l}12.43 \\
11.48\end{array}$ & $\begin{array}{l}5430.77 \\
5431.72\end{array}$ \\
\hline 0684 & 60988.0 & 58964.8 & AL & 0 & 5432.51 & 5430.20 & $\begin{array}{l}06 / 20 / 86 \\
06 / 29 / 86 \\
04 / 06 / 87 \\
10 / 13 / 87 \\
02 / 19 / 88 \\
12 / 02 / 90 \\
03 / 28 / 91 \\
08 / 06 / 9 \\
11 / 19 / 91 \\
10 / 15 / 92\end{array}$ & $\begin{array}{l}15: 20 \\
12: 25 \\
15: 30 \\
08: 50 \\
14: 50 \\
15: 51 \\
15: 30 \\
14: 05 \\
14: 12 \\
10: 50\end{array}$ & $\begin{array}{r}12.94 \\
13.73 \\
13.83 \\
15.21 \\
15.08 \\
16.11 \\
5.90 \\
16.30 \\
16.28 \\
16.20\end{array}$ & $\begin{array}{r}10.63 \\
11.42 \\
11.52 \\
12.90 \\
12.77 \\
13.80 \\
3.59 \\
13.99 \\
13.97 \\
13.89\end{array}$ & $\begin{array}{l}5419.57 \\
5418.78 \\
5418.68 \\
5417.30 \\
5417.43 \\
5416.40 \\
5426.61 \\
5416.21 \\
5416.23 \\
5416.31\end{array}$ \\
\hline 0685 & 62187.5 & 58927.9 & AL & 0 & 5428.34 & 5426.30 & $\begin{array}{l}06 / 20 / 86 \\
07 / 15 / 86 \\
04 / 07 / 87 \\
10 / 13 / 87 \\
02 / 19 / 88 \\
12 / 02 / 90 \\
03 / 28 / 91 \\
08 / 06 / 91 \\
11 / 20 / 91 \\
10 / 08 / 92\end{array}$ & $\begin{array}{l}14: 00 \\
13: 00 \\
15: 00 \\
09: 10 \\
15: 50 \\
16: 02 \\
16: 25 \\
15: 38 \\
13: 15 \\
09: 50\end{array}$ & $\begin{array}{l}11.26 \\
11.53 \\
11.55 \\
12.95 \\
12.72 \\
13.45 \\
13.20 \\
14.10 \\
13.71 \\
13.43\end{array}$ & $\begin{array}{r}9.22 \\
9.49 \\
9.51 \\
10.91 \\
10.68 \\
11.41 \\
11.16 \\
12.06 \\
11.67 \\
11.39\end{array}$ & $\begin{array}{l}5417.08 \\
5416.81 \\
5416.79 \\
5415.39 \\
5415.62 \\
5414.89 \\
5415.14 \\
5414.24 \\
5414.63 \\
5414.91\end{array}$ \\
\hline 0686 & 58619.9 & 63769.6 & AL & 0 & 5457.29 & 5455.10 & $\begin{array}{l}06 / 26 / 86 \\
07 / 15 / 86 \\
04 / 07 / 87 \\
10 / 13 / 87 \\
02 / 21 / 88 \\
12 / 02 / 90 \\
03 / 29 / 91\end{array}$ & $\begin{array}{l}09: 00 \\
14: 50 \\
09: 35 \\
12: 15 \\
11: 10 \\
13: 06 \\
14: 30\end{array}$ & $\begin{array}{l}13.78 \\
16.55 \\
15.00 \\
17.54 \\
17.18 \\
18.90 \\
17.75\end{array}$ & $\begin{array}{l}11.59 \\
14.36 \\
12.81 \\
15.35 \\
14.99 \\
16.71 \\
15.56\end{array}$ & $\begin{array}{l}5443.51 \\
5440.74 \\
5442.29 \\
5439.75 \\
5440.11 \\
5438.39 \\
5439.54\end{array}$ \\
\hline
\end{tabular}

FORMATION OF COMPLETION CODE:

NA - NAVAJO SANDSTONE

AL - ALLUVIUUM
FLON RELATIONSHIP COOE:

$U$ - UPGRADIENT

N - UNKNOWN 
TABLE 3.3 STATIC GROUNDWATER LEVELS FOR THE NC AND UC PROCESSING SITES,

SLICK ROCK, COLORADO

SITE: SRKO1 SLICK ROCK (BOTH SITES)

REPORT DATE: $06 / 17 / 93$

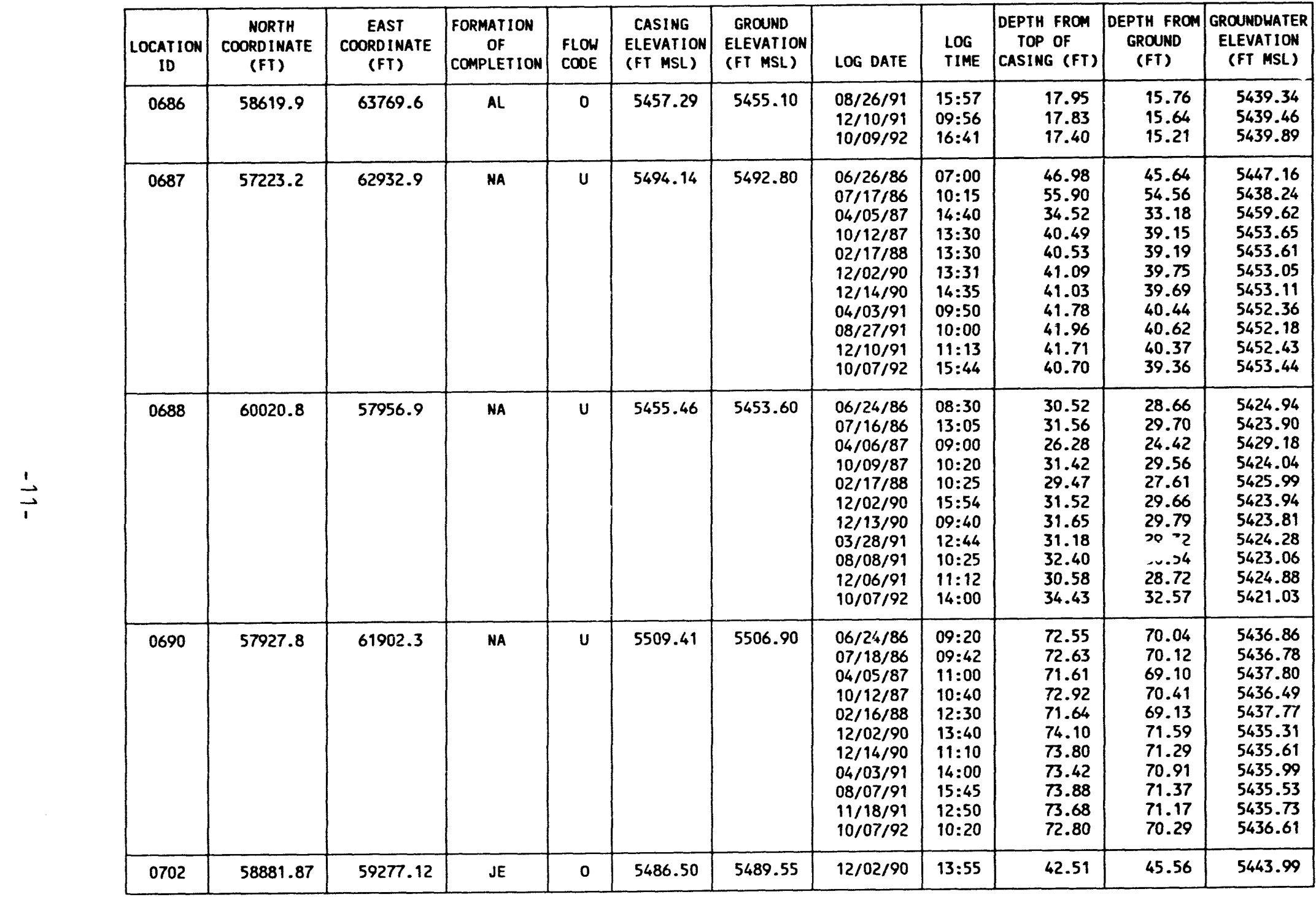

FORMATION OF COMPLETION COOE:

AL - ALLUVIUM

MA - NAVAJO SANDSTONE

FLOW RELATISNSHIP CODE:

JE - JURASSIC ENTRADA SANDSTONE FORMATION

O - ON-SITE

U - UPGRADIENT 
TABLE 3.3 STATIC GROUNDWATER LEVELS FOR THE NC AND UC PROCESSING SITES,

SLICK ROCK, COLORADO

SITE: SRKO1 SLICK ROCK (BOTH SITES)

REPORT DATE: $06 / 17 / 93$

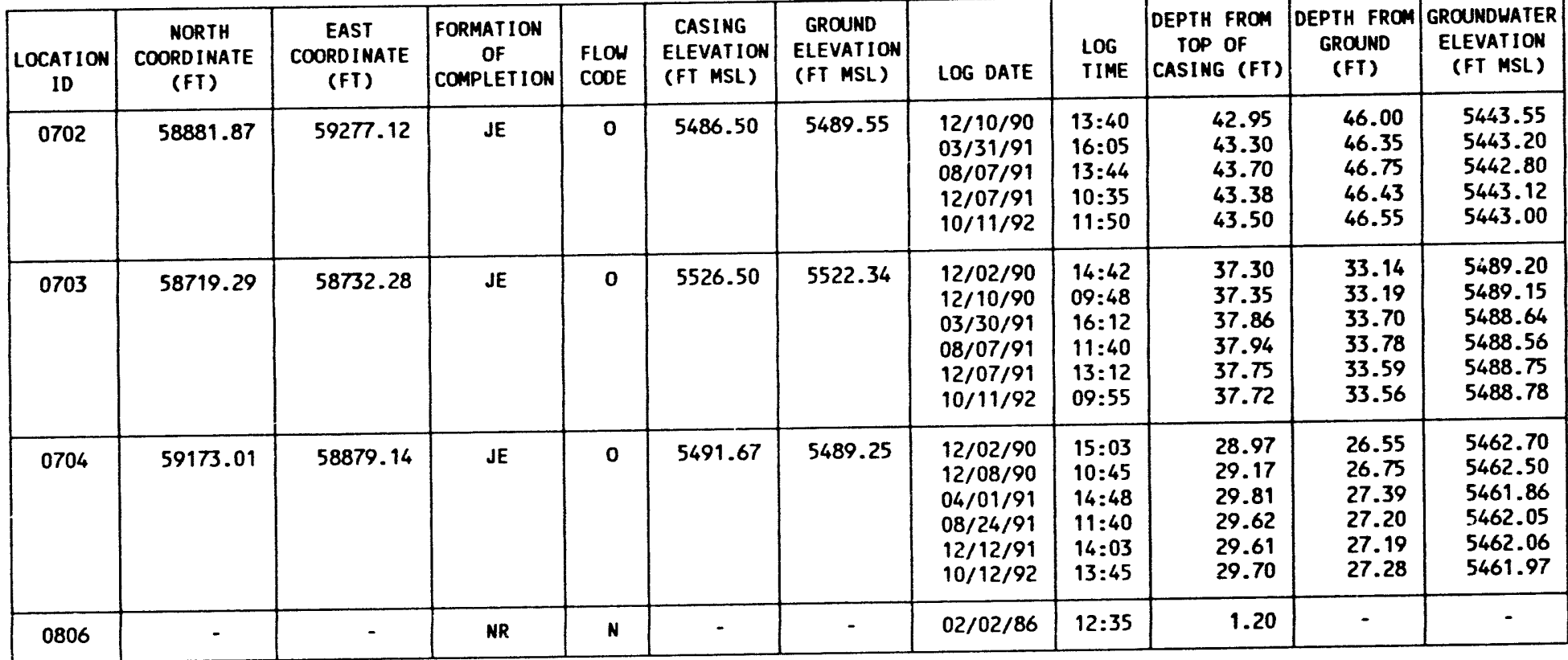

FORMATION OF COMPLETION CODE:

JE - JURASSIC ENTRADA SANDSTONE FORMATION

FLOW RELATIONSHIP COOE:

O- ON-SITE

NR - NO RECOVERY OF DATA FOR CLASSIFYING

N - UNKNONN

DATA FILE: M: IDARTISRK01\GWL10005.DAT

FIELDS DISPLAYED WITH A DASH INDICATE THE DATA IS UNAVAILABLE 
Table 3.4 Hydraulic parameters for the NC and UC processing sites, slick Rock, Colorado

\begin{tabular}{|c|c|c|c|}
\hline $\begin{array}{l}\text { Hydraulic } \\
\text { property }\end{array}$ & $\begin{array}{c}\text { Dolores River } \\
\text { Alluvium }\end{array}$ & $\begin{array}{l}\text { Entrada } \\
\text { Formation }\end{array}$ & Navajo Sandstone \\
\hline $\begin{array}{c}\text { Average } \\
\text { hydraulic } \\
\text { conductivity } \\
\text { (NC site) }\end{array}$ & $\begin{array}{c}23 \mathrm{ft} / \text { day } \\
8.1 \times 10^{-3} \mathrm{~cm} / \mathrm{s}\end{array}$ & Not determined & Not determined \\
\hline $\begin{array}{c}\text { Average } \\
\text { hydraulic } \\
\text { conductivity } \\
\text { (UC site) }\end{array}$ & $\begin{array}{c}14 \mathrm{ft} / \text { day } \\
4.9 \times 10^{-3} \mathrm{~cm} / \mathrm{s}\end{array}$ & Not determined & $\begin{array}{c}2.4 \times 10^{-2} \mathrm{ft} / \mathrm{day} \\
8.5 \times 10^{-6} \mathrm{~cm} / \mathrm{s}\end{array}$ \\
\hline $\begin{array}{l}\text { Average } \\
\text { hydraulic } \\
\text { gradient } \\
\text { (NC site) }\end{array}$ & 0.003 & Not determined & Not determined \\
\hline $\begin{array}{l}\text { Average } \\
\text { hydraulic } \\
\text { gradient } \\
\text { (UC site) }\end{array}$ & 0.008 & Not determined & 0.02 \\
\hline $\begin{array}{l}\text { Average } \\
\text { linear } \\
\text { groundwater } \\
\text { velocity } \\
\text { (NC site) }\end{array}$ & $\begin{array}{c}100 \mathrm{ft} / \mathrm{yr} \\
1.5 \times 10^{4} \mathrm{~cm} / \mathrm{s}\end{array}$ & Not determined & Not determined \\
\hline $\begin{array}{l}\text { Aver gge } \\
\text { linear } \\
\text { groundwater } \\
\text { velocity } \\
\text { (UC site) }\end{array}$ & $\begin{array}{c}150 \mathrm{ft} / \mathrm{yr} \\
2.4 \times 10^{-4} \mathrm{~cm} / \mathrm{s}\end{array}$ & Not determined & $\begin{array}{cc}1 \mathrm{ft} / \mathrm{yr} \\
1 \times 10^{-6} \mathrm{~cm} / \mathrm{s}\end{array}$ \\
\hline
\end{tabular}


TABLE 3.5 BACKGROUND GROUNDHATER QUALITY DATA BY PARAMETER FOR THE ALLUVIUM NC AND UC PROCESSING SITES, SLICK ROCK, COLORADO

SITE: SRKO1 SLICK ROCK (BOTH SITES)

SITE: SRKO1 SLICK ROCK

REPORT DATE: $06 / 17 / 93$

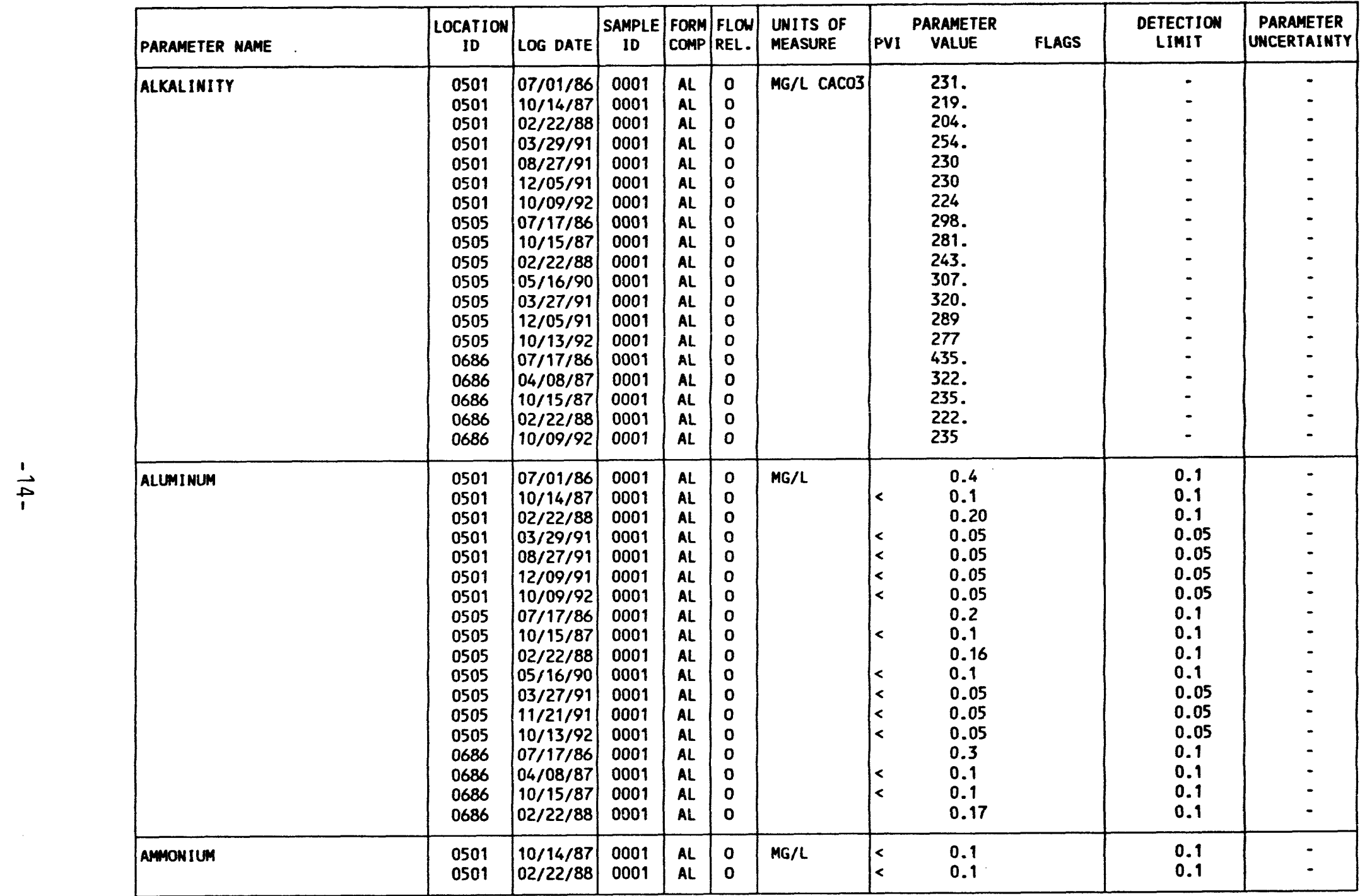

FORMATION OF COMPLETION CODE:

AL - ALLUVIUM

PARAMETER VALUE INDICATOR (PVI): < - LESS THAN DETECTION LIMIT
FLOW RELATIONSHIP CODE:

O- ON-SITE

SAMPLE ID COOES:

0001 - FILTERED SAMPLE (.45 MICRONS) 
TABLE 3.5 BACKGROUND GROUNDHATER OUALITY DATA BY PARAMETER FOR THE ALLUVIUM WC AND UC PROCESSING SITES, SLICK ROCK, COLORADO

SITE: SRKOI SLICK ROCK (BOTH SITES)

07/01/86 TO $10 / 13 / 92$

REPORT DATE: 06/17/93

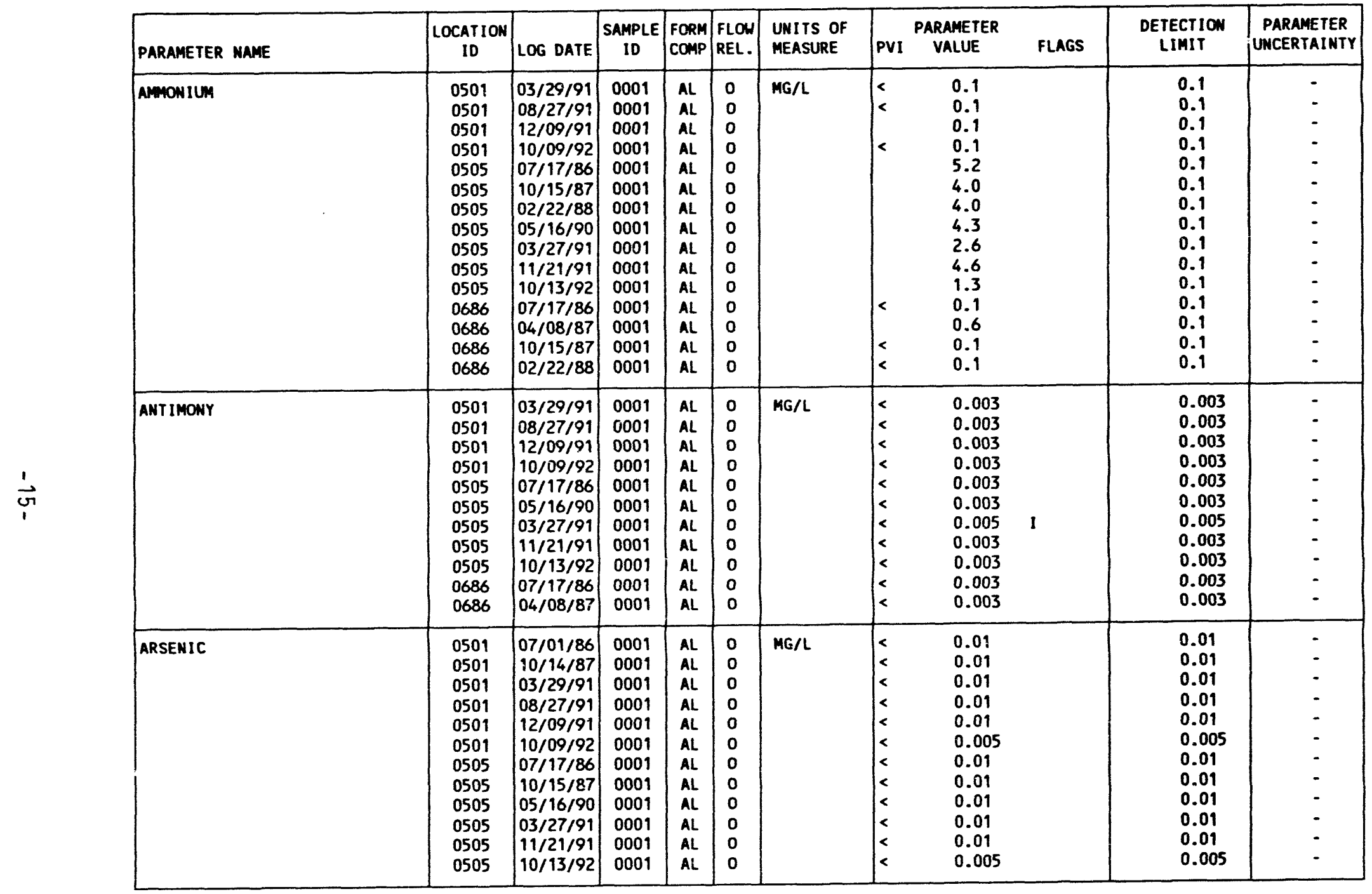

FORMATION OF COMPLETION COOE:

AL - ALLUVIUH

PARAMETER VALUE INDICATOR (PVI): < - LeSS than DETECTION LIMIT
FLOW RELATIONSHIP CODE:

O - ON-SITE

SAMPIE ID CODES:

0001 - FILTERED SAMPLE (.45 MICRONS)

OTHER PARAMETER VALUE FLAGS:

I - INCREASED DETECTION LIMIT DUE TO REQUIRED DILUTION 
TABLE 3.5 BACKGROUND GROUMDYATER OUALITY DATA BY PARAMETER FOR THE ALLUVIUM

NC AND UC PROCESSING SITES, SLICK ROCK, COLORADO

SITE: SRKO1 SLICK ROCK (BOTH SITES)

SLICK ROCK
86 TO 10/13/92

REPORT DATE: $06 / 17 / 93$

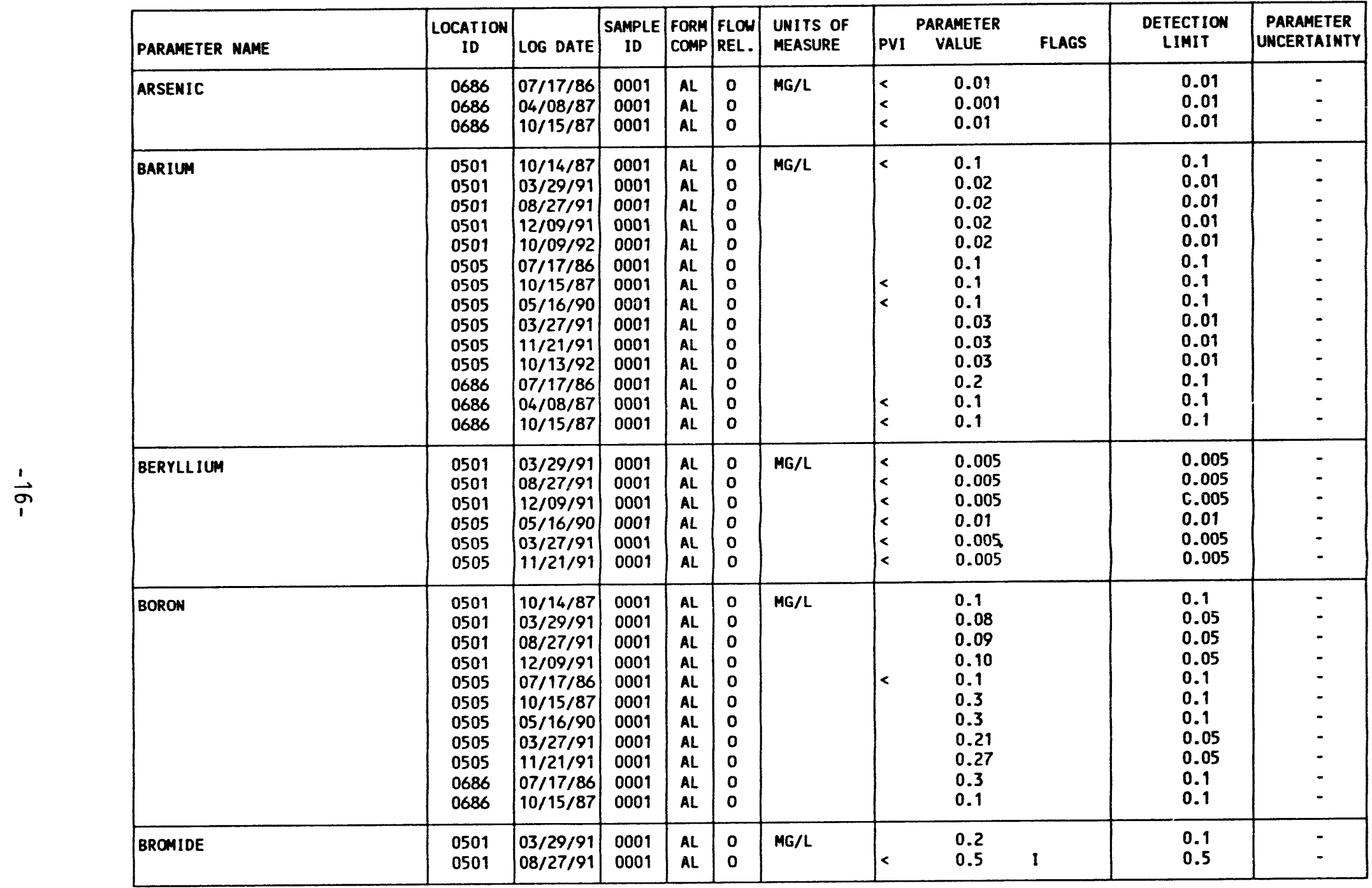

FORMATION OF COMPLETION CODE:

AL - ALLUVIUM

PARAMETER VALUE INDICATOR (PVI): < - LESS THAN DETECTION LIMIT
FLOW RELATIONSHIP COOE:

0001 - FILTERED SAMPLE (.45 MICRONS)

OTHER PARAMETER VALUE fLAGS:

I - INCREASED DETECTION LIMIT DUE TO REQUIRED DILUTION 
TABLE 3.5 BACKGROUND GROUNDWATER QUALITY DATA BY PARAMETER FOR THE ALLUVIU:

NC AND UC PROCESSING SITES, SLICK ROCK, COLORADO

SITE: SRKO1 SLICK ROCK (BOTH SITES)

07/01/86 TO $10 / 13 / 92$

REPORT DATE: $06 / 17 / 93$

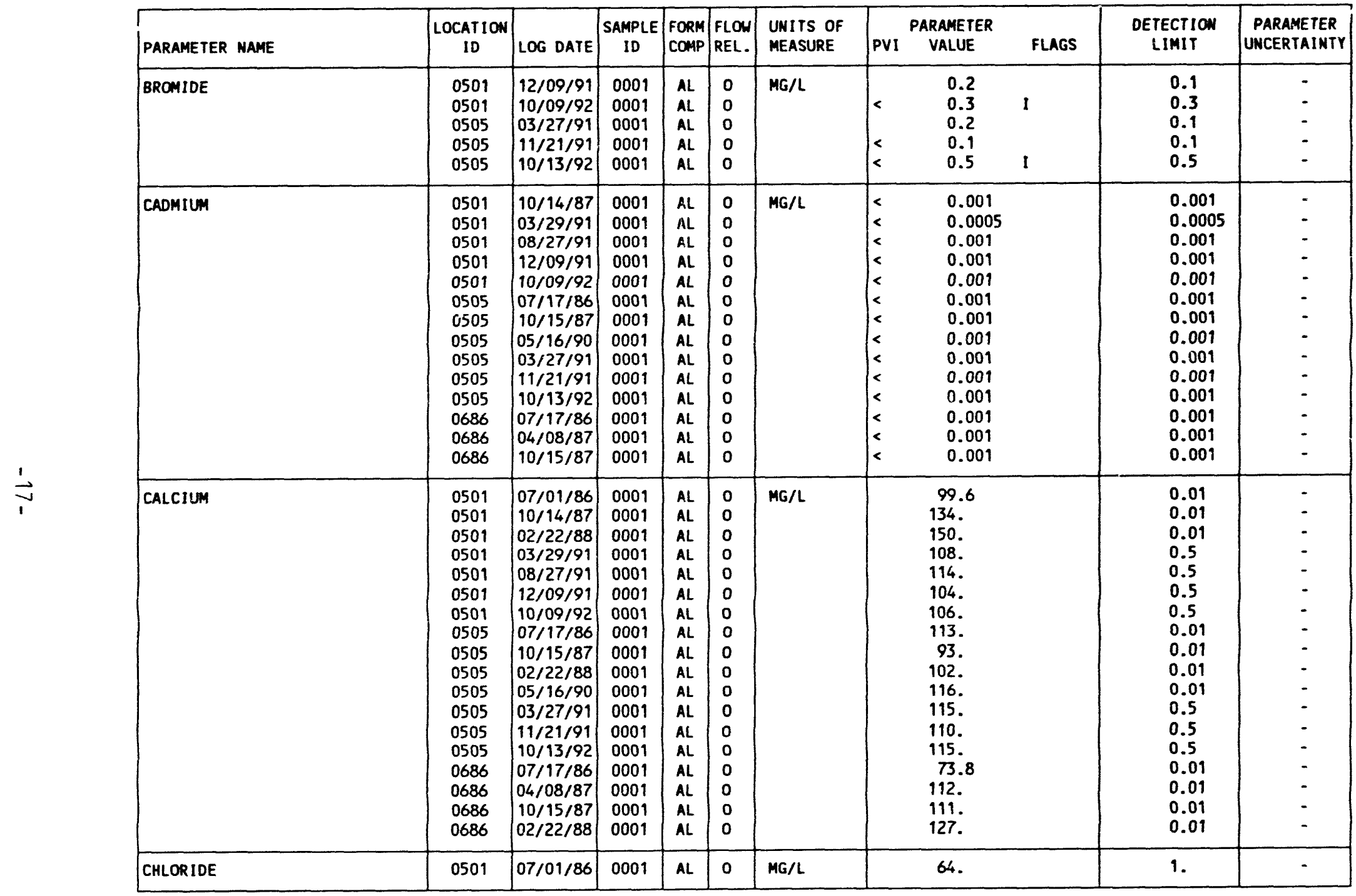

FORMATION OF COMPLETION COOE:

FLOW RELATIONSHIP CODE:

AL - ALLUVIUM

O - ON-SITE

PARAMETER VALUE INDICATOR (PVI): < - LESS THAN DETECTION LIMIT

SAMPLE ID COOES:

0001 - FILTERED SAMPLE (. 45 MICRONS)

OTHER PARAMETER VALUE FLAGS:

1 - INCREASED DETECTION LIMIT DUE TO REQUIRED DILUTION 
TABLE 3.5 BACKGROUND GROUNDWATER OUALITY DATA BY PARAMETER FOR THE ALLUVIUM MC AND UC PROCESSING SITES, SLICK ROCK, COLORADO

SITE: SRKO1 SLICK ROCK (BOTH SITES)

$07 / 01 / 86$ TO $10 / 13 / 92$

REPORT DATE: $06,17 / 93$

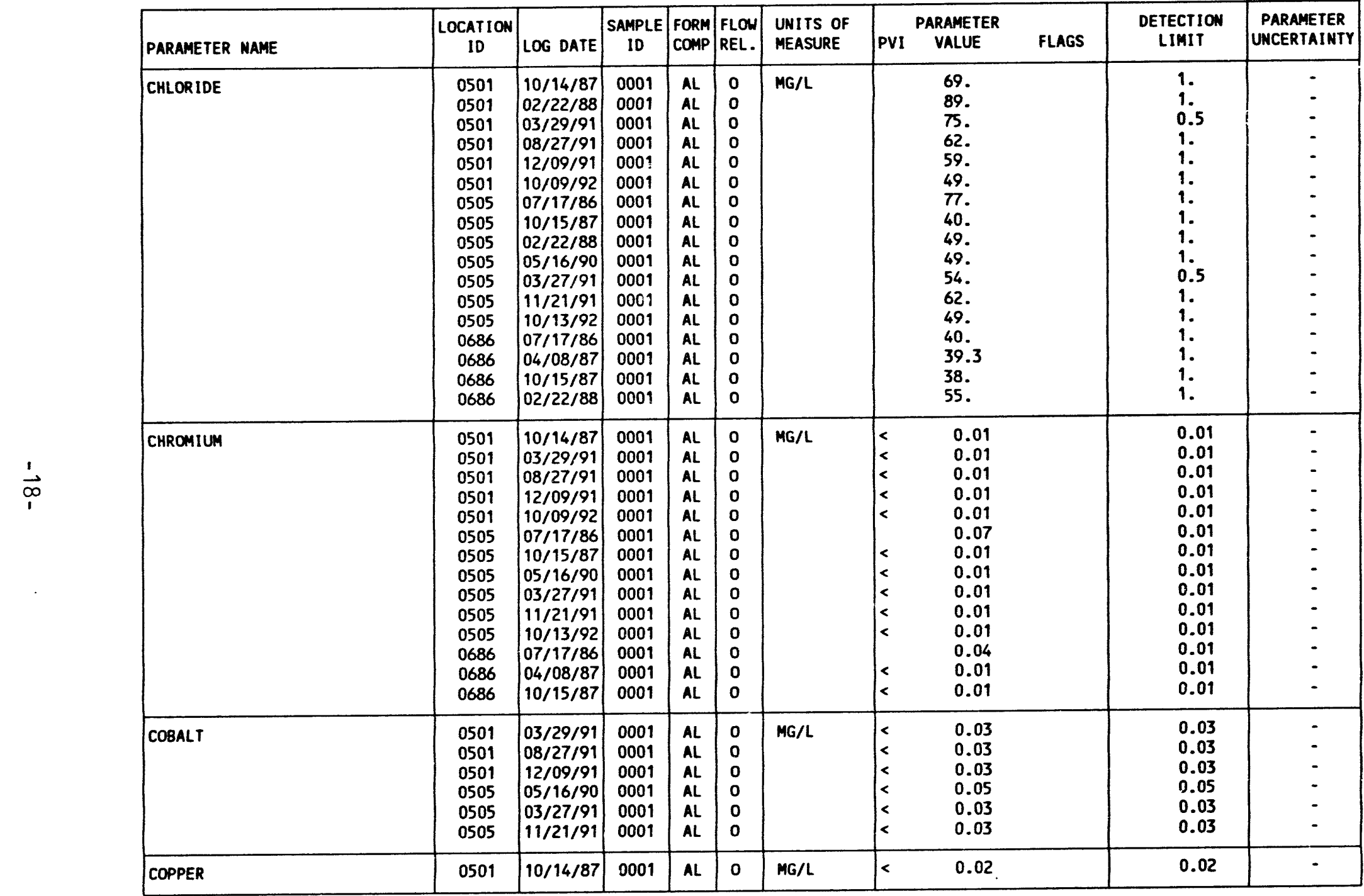

FORMATION OF COMPLETION COOE:

FLOW RELATIONSHIP COOE:

AL - ALLUUVIUM

O - ON-SITE

PARAMETER VALUE INDICATOR (PVI): < - LESS THAN DETECTION LIMIT

SAMPLE ID COOES:

0001 - FILTERED SAMPLE (.45 MICRONS) 
TABLE 3.5 BACKGROUND GROUNDHATER QUALITY DATA BY PARAMETER FOR THE ALLUVIUM NC AND UC PROCESSING SITES, SLICK ROCK, COLORADO

SITE: SRKO1 SLICK ROCK (BOTH S

07/01/86 TO $10 / 13 / 92$

REPORT DATE: $06 / 17 / 93$

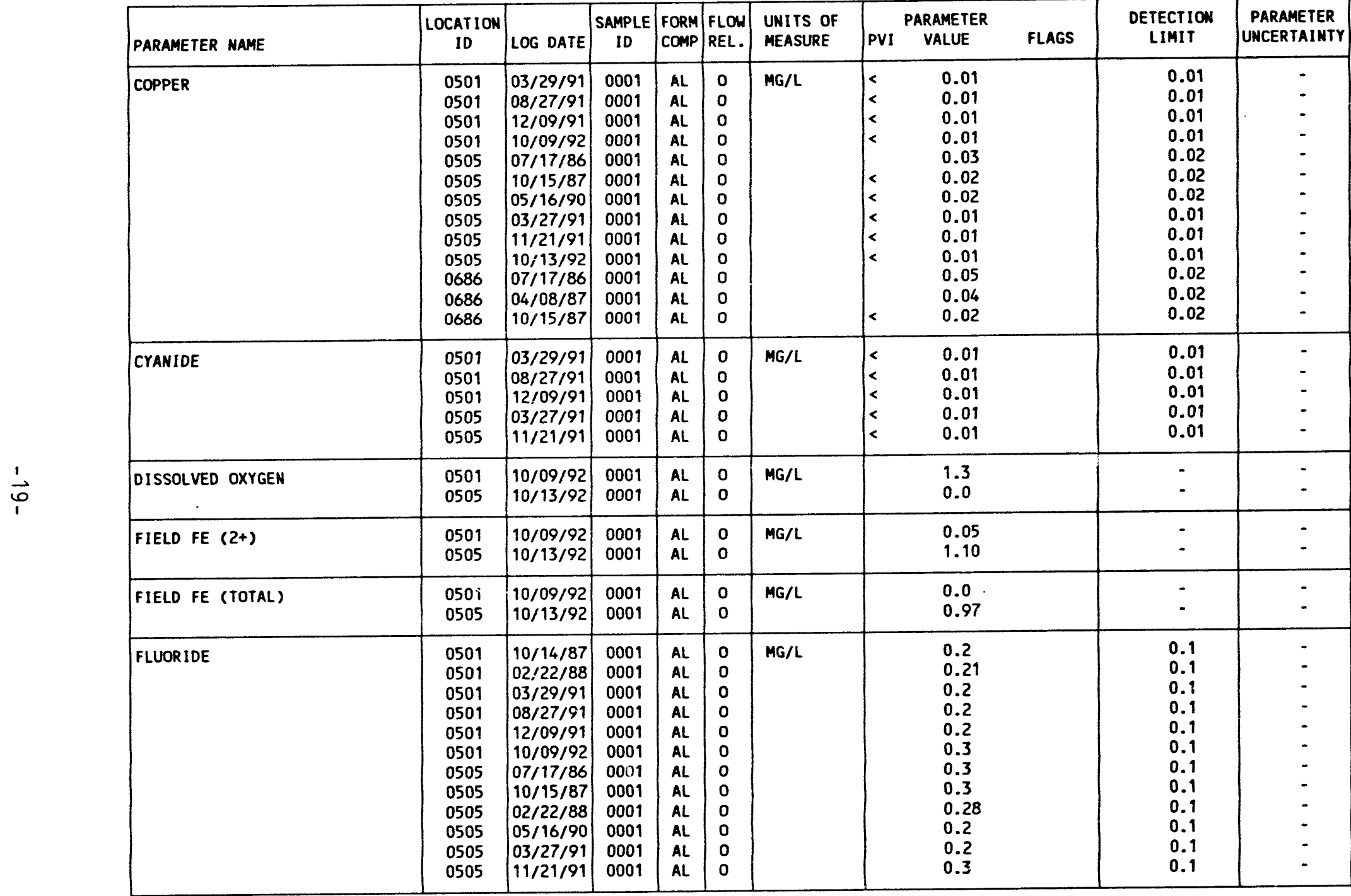

FORMATION OF COMPLETION COOE:

AL - ALLUVIUNH

PARAMETER VALUE INDICATOR (PVI): < - LESS THAN DETECTION LIMIT
FLOW RELATIONSHIP CODE:

O - ON-SITE

0001 - FILIERED SAMPLE (.45 MICRONS) 
TABLE 3.5 BACKGROUND GROUNDWATER QUALITY DATA BY PARAMETER FOR THE ALLUVIUM MC AND UC PROCESSING SITES, SLICX ROCK, COLORADO

SITE: SRKO1 SLICK ROCK (BOTH SITES)

07/01/86 TO 10/13/92

REPORT DATE: $06 / 17 / 93$

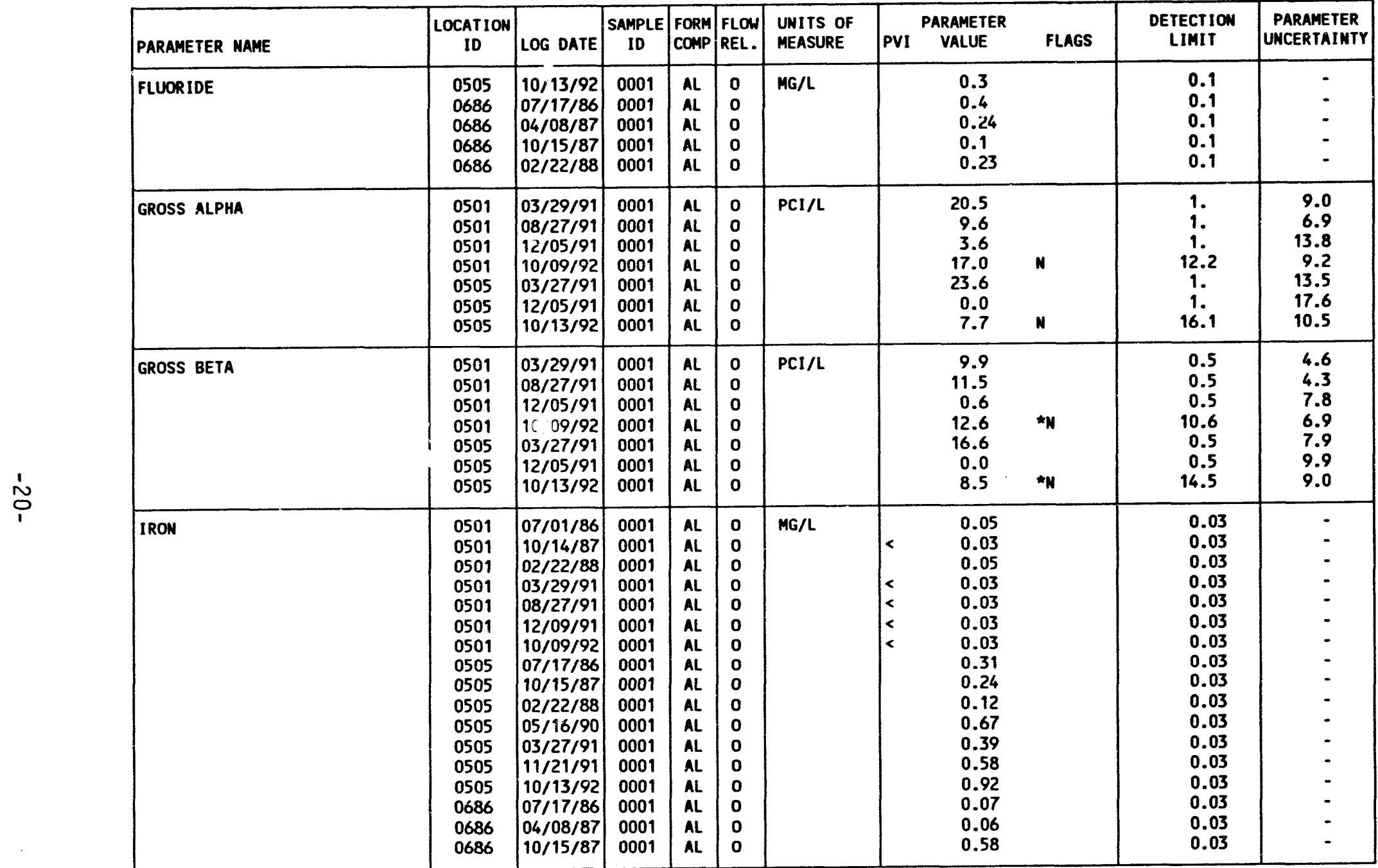

FORMATION OF COMPLETION COOE:

AL - ALLUYIUM

PARAMETER VALUE Indicator (PVI): < - LESS than DeteCtion LIMIT
FLOW RELATIONSHIP CODE:

0001 - FILTERED SAMPLE (.45 MICRONS)

OTHER PARAMETER VALUE FLAGS:

- DUPLicate analysis not hithin control limits

N - SPIKE SAMPLE RECOVERY NOT WITHIN CONTROL LIMITS 


\begin{tabular}{|c|c|c|c|c|c|c|c|c|c|c|c|}
\hline \multicolumn{12}{|c|}{$\begin{array}{l}\text { TABLE } 3.5 \text { BACKGROUND GROUNDWATER QUALITY DATA BY } \\
\text { NC AND UC PROCESSING SITES, SLICK ROCK, COLORADO } \\
\text { SITE: SRKO1 SLICK ROCK (BOTH SITES) } \\
\text { OT/01/86 TO } 10 / 13 / 92 \\
\text { REPORT DATE: } 06 / 17 / 93\end{array}$} \\
\hline PARAMETER MAME & $\begin{array}{c}\text { LOCATION } \\
\text { ID }\end{array}$ & LOG DATE & $\underset{10}{\text { SAMPLE }}$ & $\begin{array}{l}\text { FORM } \\
\text { COMP }\end{array}$ & $\begin{array}{l}\text { FLOW } \\
\text { REL. }\end{array}$ & $\begin{array}{l}\text { UNITS OF } \\
\text { MEASURE }\end{array}$ & PVI & $\begin{array}{l}\text { PARAMETER } \\
\text { VALUE }\end{array}$ & FLAGS & $\begin{array}{l}\text { DETECTION } \\
\text { LIMIT }\end{array}$ & $\begin{array}{l}\text { PARAMETER } \\
\text { UNCERTAINTY }\end{array}$ \\
\hline IRON & 0686 & $02 / 22 / 88$ & 0001 & AL & 0 & $M G / L$ & & 0.65 & & 0.03 & $\cdot$ \\
\hline LEAD & $\begin{array}{l}0501 \\
0501 \\
0501 \\
0501 \\
0501 \\
0505 \\
0505 \\
0505 \\
0505 \\
0505 \\
0505 \\
0686 \\
0686 \\
0686\end{array}$ & $\begin{array}{l}10 / 14 / 87 \\
03 / 29 / 91 \\
08 / 27 / 91 \\
12 / 09 / 91 \\
10 / 09 / 92 \\
07 / 17 / 86 \\
10 / 15 / 87 \\
05 / 16 / 90 \\
03 / 27 / 91 \\
11 / 21 / 91 \\
10 / 13 / 92 \\
07 / 17 / 86 \\
04 / 08 / 87 \\
10 / 15 / 87\end{array}$ & $\begin{array}{l}0001 \\
0001 \\
0001 \\
0001 \\
0001 \\
0001 \\
0001 \\
0001 \\
0001 \\
0001 \\
0001 \\
0001 \\
0001 \\
0001\end{array}$ & $\begin{array}{l}A L \\
A L \\
A L \\
A L \\
A L \\
A L \\
A L \\
A L \\
A L \\
A L \\
A L \\
A L \\
A L \\
A L\end{array}$ & $\begin{array}{l}0 \\
0 \\
0 \\
0 \\
0 \\
0 \\
0 \\
0 \\
0 \\
0 \\
0 \\
0 \\
0 \\
0\end{array}$ & $M G / L$ & $\begin{array}{l}< \\
< \\
< \\
< \\
< \\
< \\
< \\
< \\
< \\
k \\
< \\
k \\
k \\
< \\
k\end{array}$ & $\begin{array}{l}0.01 \\
0.005 \\
0.005 \\
0.005 \\
0.02 \\
0.01 \\
0.01 \\
0.01 \\
0.005 \\
0.005 \\
0.02 \\
0.01 \\
0.001 \\
0.01\end{array}$ & $\begin{array}{l}1 \\
1\end{array}$ & $\begin{array}{l}0.01 \\
0.005 \\
0.005 \\
0.005 \\
0.02 \\
0.01 \\
0.01 \\
0.01 \\
0.005 \\
0.005 \\
0.02 \\
0.01 \\
0.01 \\
0.01\end{array}$ & $\begin{array}{l}- \\
- \\
- \\
: \\
- \\
- \\
- \\
- \\
-\end{array}$ \\
\hline LEAD-210 & $\begin{array}{l}0501 \\
0501 \\
0505 \\
0505\end{array}$ & $\begin{array}{l}08 / 27 / 91 \\
12 / 05 / 91 \\
07 / 17 / 86 \\
12 / 05 / 91\end{array}$ & $\begin{array}{l}0001 \\
0001 \\
0001 \\
0001\end{array}$ & $\begin{array}{l}\text { AL } \\
A L \\
A L\end{array}$ & $\begin{array}{l}0 \\
0 \\
0 \\
0\end{array}$ & $\mathrm{PCl} / \mathrm{L}$ & & $\begin{array}{l}1.1 \\
1.5 \\
0.7 \\
2.9\end{array}$ & & $\begin{array}{l}1.5 \\
1.5 \\
1.5 \\
1.5\end{array}$ & $\begin{array}{l}1.0 \\
1.4 \\
1.3 \\
1.0\end{array}$ \\
\hline MAGNESIUM & $\begin{array}{l}0501 \\
0501 \\
0501 \\
0501 \\
0501 \\
0501 \\
0501 \\
0505 \\
0505 \\
0505 \\
0505 \\
0505 \\
0505 \\
0505 \\
0686 \\
0686 \\
0686 \\
0686\end{array}$ & $\begin{array}{l}07 / 01 / 86 \\
10 / 14 / 87 \\
02 / 22 / 88 \\
03 / 29 / 91 \\
08 / 27 / 91 \\
12 / 09 / 91 \\
10 / 09 / 92 \\
07 / 17 / 86 \\
10 / 15 / 87 \\
02 / 22 / 88 \\
05 / 16 / 90 \\
03 / 27 / 91 \\
11 / 21 / 91 \\
10 / 13 / 92 \\
07 / 17 / 86 \\
04 / 08 / 87 \\
10 / 15 / 87 \\
02 / 22 / 88\end{array}$ & $\begin{array}{l}0001 \\
0001 \\
0001 \\
0001 \\
0001 \\
0001 \\
0001 \\
0001 \\
0001 \\
0001 \\
0001 \\
0001 \\
0001 \\
0001 \\
0001 \\
0001 \\
0001 \\
0001\end{array}$ & $\begin{array}{l}A L \\
A L \\
A L \\
A L \\
A L \\
A L \\
A L \\
A L \\
A L \\
A L \\
A L \\
A L \\
A L \\
A L \\
A L \\
A L \\
A L \\
A L\end{array}$ & $\begin{array}{l}0 \\
0 \\
0 \\
0 \\
0 \\
0 \\
0 \\
0 \\
0 \\
0 \\
0 \\
0 \\
0 \\
0 \\
0 \\
0 \\
0 \\
0\end{array}$ & $M G / L$ & & $\begin{array}{l}29 . \\
36 . \\
41.9 \\
28.7 \\
30.3 \\
28.3 \\
27.5 \\
52.2 \\
41 . \\
45.5 \\
50.4 \\
48.9 \\
48.7 \\
55.0 \\
20.9 \\
30.3 \\
26 . \\
30.9\end{array}$ & & $\begin{array}{l}0.001 \\
0.001 \\
0.001 \\
0.1 \\
0.1 \\
0.1 \\
0.1 \\
0.001 \\
0.001 \\
0.001 \\
0.001 \\
0.1 \\
0.1 \\
0.5 \\
0.001 \\
0.001 \\
0.001 \\
0.001\end{array}$ & $\begin{array}{l}- \\
- \\
- \\
- \\
- \\
- \\
- \\
- \\
- \\
- \\
- \\
- \\
-\end{array}$ \\
\hline
\end{tabular}

FORMATION OF COMPLETION COOE:

AL - AlLuviUm
O- ON-SITE

SAMPLE ID COOES:

0001 - FILTERED SAMPLE (.45 MICRONS)

OTHER PARAMETER VALUE FLAGS:

I - INCREASED DETECTION LIMIT DUE TO REQUIRED DILUTION 
TABLE 3.5 BACKGROUND GROUNDHATER QUALITY DATA BY PARAMETER FOR THE ALLUVIUM NC AND UC PROCESSING SITES, SLICK ROCK, COLORADO

SITE: SRKO1 SLICK ROCK (BOTH SITES)

DT/01/86 TO $10 / 13 / 92$

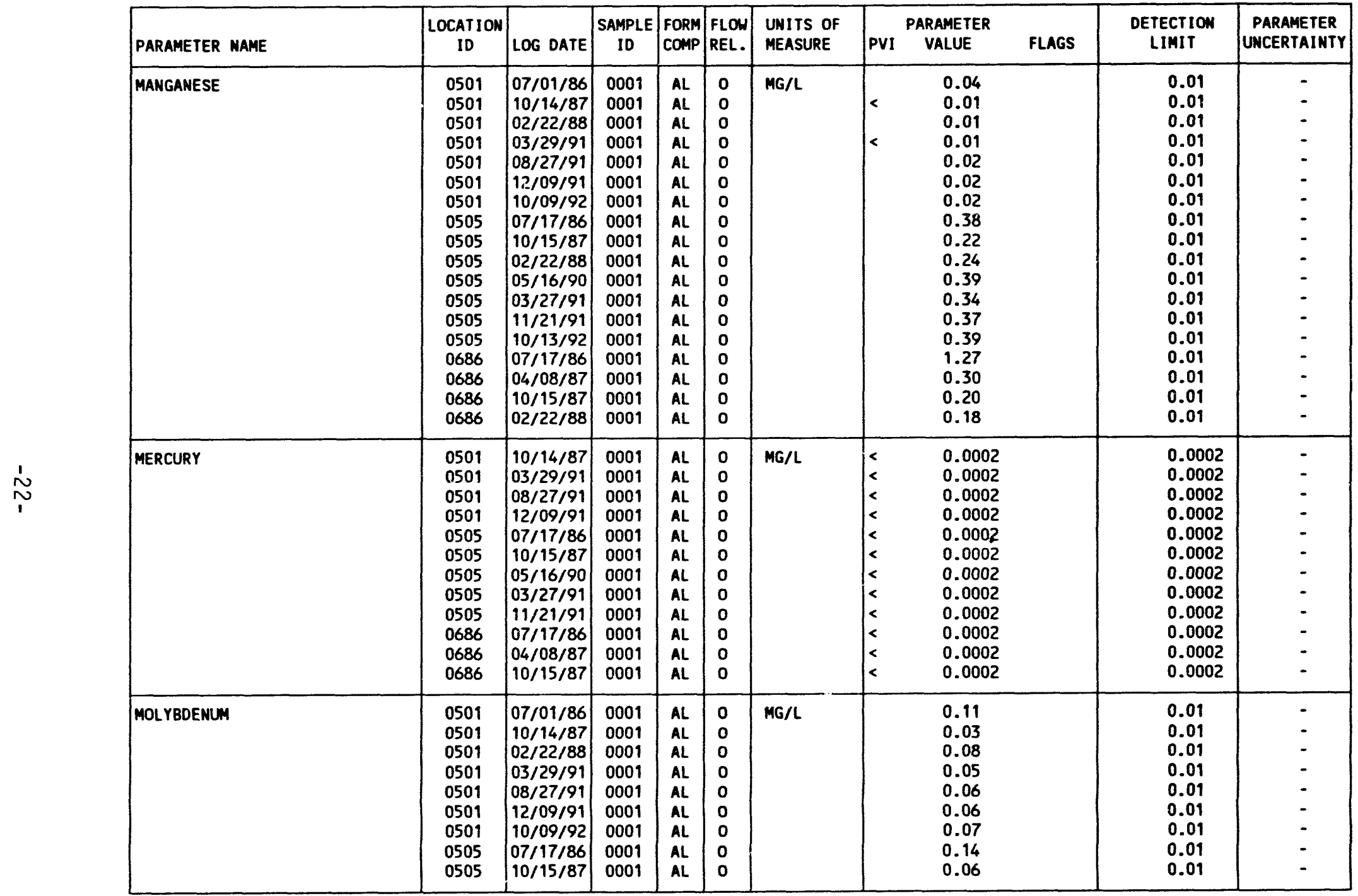

FORMATION OF COMPLETION CODE:

FLOW RELATIONSHIP COOE:

AL - ALLUVIUM

O- ON-SITE

PARAMETER VALUE INDICATOR (PVI): < - LESS than DETECTION LIMIT

SAMPLE ID COOES:

0001 - FILTERED SAMPLE (.45 MICRONS) 
TABLE 35 BACKGROUND GROUNDHATER QUALITY DATA BY PARAMETER FOR THE ALLUVIUM NC AND UC PROCESSING SITES, SLICK ROCK, COLORADO

SITE: SRKO1 SLICK ROCK (BOTH SITES)

SITE: SRKO1 SLICK ROCK

REPORT DATE: $06 / 17 / 93$

\begin{tabular}{|c|c|c|c|c|c|c|c|c|c|c|c|c|}
\hline & PARAMETER NAME & $\underset{\text { ID }}{\text { LOCATION }}$ & LOG DATE & $\underset{\text { SAMPLE }}{\text { ID }}$ & $\begin{array}{l}\text { FORM } \\
\text { COMP }\end{array}$ & $\begin{array}{l}\text { FLOW } \\
\text { REL. }\end{array}$ & $\begin{array}{l}\text { UNITS OF } \\
\text { MEASURE }\end{array}$ & PVI & $\begin{array}{l}\text { PARAMETER } \\
\text { VALUE }\end{array}$ & FLAGS & $\begin{array}{l}\text { DETECTION } \\
\text { LIMIT }\end{array}$ & \begin{tabular}{|l} 
PARAMETER \\
UNCERTAINTY
\end{tabular} \\
\hline & MOL YBDENUM & $\begin{array}{l}0505 \\
0505 \\
0505 \\
0505 \\
0505 \\
0686 \\
0686 \\
0686 \\
0686\end{array}$ & \begin{tabular}{|l|}
$02 / 22 / 88$ \\
$05 / 16 / 90$ \\
$03 / 27 / 91$ \\
$11 / 21 / 91$ \\
$10 / 13 / 92$ \\
$07 / 17 / 86$ \\
$04 / 08 / 87$ \\
$10 / 15 / 87$ \\
$02 / 22 / 88$
\end{tabular} & $\begin{array}{l}0001 \\
0001 \\
0001 \\
0001 \\
0001 \\
0001 \\
0001 \\
0001 \\
0001\end{array}$ & $\begin{array}{l}A L \\
A L \\
A L \\
A L \\
A L \\
A L \\
A L \\
A L \\
A L\end{array}$ & $\begin{array}{l}0 \\
0 \\
0 \\
0 \\
0 \\
0 \\
0 \\
0 \\
0\end{array}$ & $M G / L$ & |< & $\begin{array}{l}0.1 \\
0.05 \\
0.04 \\
0.05 \\
0.06 \\
0.24 \\
0.1 \\
0.08 \\
0.11\end{array}$ & c & $\begin{array}{l}0.01 \\
0.01 \\
0.01 \\
0.01 \\
0.01 \\
0.01 \\
0.1 \\
0.01 \\
0.01\end{array}$ & $\begin{array}{l}- \\
- \\
- \\
- \\
- \\
- \\
-\end{array}$ \\
\hline & NET GROSS ALPHA * & $\begin{array}{l}0501 \\
0501 \\
0501 \\
0501 \\
0505 \\
0505 \\
0505\end{array}$ & $\begin{array}{l}03 / 29 / 91 \\
08 / 27 / 91 \\
12 / 05 / 91 \\
10 / 09 / 92 \\
03 / 27 / 91 \\
12 / 05 / 91 \\
10 / 13 / 92\end{array}$ & $\begin{array}{l}0001 \\
0001 \\
0001 \\
0001 \\
0001 \\
0001 \\
0001\end{array}$ & $\begin{array}{l}A L \\
A L \\
A L \\
A L \\
A L \\
A L \\
A L\end{array}$ & $\begin{array}{l}0 \\
0 \\
0 \\
0 \\
0 \\
0 \\
0\end{array}$ & $\mathrm{PCI} / \mathrm{L}$ & & $\begin{array}{r}4.72 \\
-2.75 \\
-9.43 \\
1.91 \\
5.08 \\
-17.15 \\
-9.45\end{array}$ & & $\begin{array}{l}- \\
- \\
- \\
-\end{array}$ & $\begin{array}{l}- \\
- \\
- \\
- \\
-\end{array}$ \\
\hline$\stackrel{\text { N }}{\omega}$ & NICKEL & $\begin{array}{l}0501 \\
0501 \\
0501 \\
0501 \\
0501 \\
0501 \\
0505 \\
0505 \\
0505 \\
0505 \\
0505 \\
0505 \\
0505 \\
0686 \\
0686 \\
0686 \\
0686\end{array}$ & $\begin{array}{l}10 / 14 / 87 \\
02 / 22 / 88 \\
03 / 29 / 91 \\
08 / 27 / 91 \\
12 / 09 / 91 \\
10 / 09 / 92 \\
07 / 17 / 86 \\
10 / 15 / 87 \\
02 / 22 / 88 \\
05 / 16 / 90 \\
03 / 27 / 91 \\
11 / 21 / 91 \\
10 / 13 / 92 \\
07 / 17 / 86 \\
04 / 08 / 87 \\
10 / 15 / 87 \\
02 / 22 / 88\end{array}$ & $\begin{array}{l}0001 \\
0001 \\
0001 \\
0001 \\
0001 \\
0001 \\
0001 \\
0001 \\
0001 \\
0001 \\
0001 \\
0001 \\
0001 \\
0001 \\
0001 \\
0001 \\
0001\end{array}$ & $\begin{array}{l}A L \\
A L \\
A L \\
A L \\
A L \\
A L \\
A L \\
A L \\
A L \\
A L \\
A L \\
A L \\
A L \\
A L \\
A L \\
A L \\
A L\end{array}$ & $\begin{array}{l}0 \\
0 \\
0 \\
0 \\
0 \\
0 \\
0 \\
0 \\
0 \\
0 \\
0 \\
0 \\
0 \\
0 \\
0 \\
0 \\
0\end{array}$ & MG/L & $\mid \begin{array}{l}< \\
< \\
< \\
< \\
< \\
< \\
< \\
< \\
< \\
< \\
< \\
< \\
< \\
< \\
<\end{array}$ & $\begin{array}{l}0.04 \\
0.02 \\
0.04 \\
0.04 \\
0.04 \\
0.04 \\
0.04 \\
0.04 \\
0.02 \\
0.04 \\
0.04 \\
0.04 \\
0.04 \\
0.04 \\
0.04 \\
0.04 \\
0.01\end{array}$ & c & $\begin{array}{l}0.04 \\
0.02 \\
0.04 \\
0.04 \\
0.04 \\
0.04 \\
0.04 \\
0.04 \\
0.02 \\
0.04 \\
0.04 \\
0.04 \\
0.04 \\
0.04 \\
0.04 \\
0.04 \\
0.01\end{array}$ & $\begin{array}{l}- \\
- \\
- \\
- \\
- \\
- \\
- \\
- \\
- \\
- \\
- \\
- \\
-\end{array}$ \\
\hline & NITRATE & $\begin{array}{l}0501 \\
0501\end{array}$ & $\begin{array}{l}07 / 01 / 86 \\
10 / 14 / 87\end{array}$ & $\begin{array}{l}0001 \\
0001\end{array}$ & $\begin{array}{l}A L \\
A L\end{array}$ & $\begin{array}{l}0 \\
0\end{array}$ & $M G / L$ & $<$ & $\begin{array}{l}1 . \\
1.4\end{array}$ & & $\begin{array}{l}1 . \\
1 .\end{array}$ & - \\
\hline
\end{tabular}

* NET GROSS ALPHA (GROSS ALPHA - URANIUM) WITH 1 MG URANIUM = 686 PCI

FORMATION OF COMPLETION CODE:

AL - ALLUVIUN

PARAMETER VALUE INDICATOR (PVI): < - LESS THAN DETECTION LIMIT
FLOW RELATIONSHIP CODE:

O - ON-SITE

SAMPLE ID CODES:

0001 - FILTERED SAMPLE (.45 MICRONS)

OTHER PARAMETER VALUE FLAGS:

C - CHANGED DETECTION LIMIT 
TABLE 3.5 BACKGROUND GROUNDWATER OUALITY DATA BY PARAMETER FOR THE ALLUVIUM NC AND UC PROCESSING SITES, SLICK ROCK, COLORADO

SITE: SRKO1 SLICK

07/01/86 TO $10 / 13 / 92$

REPORT DATE: 06/17/93

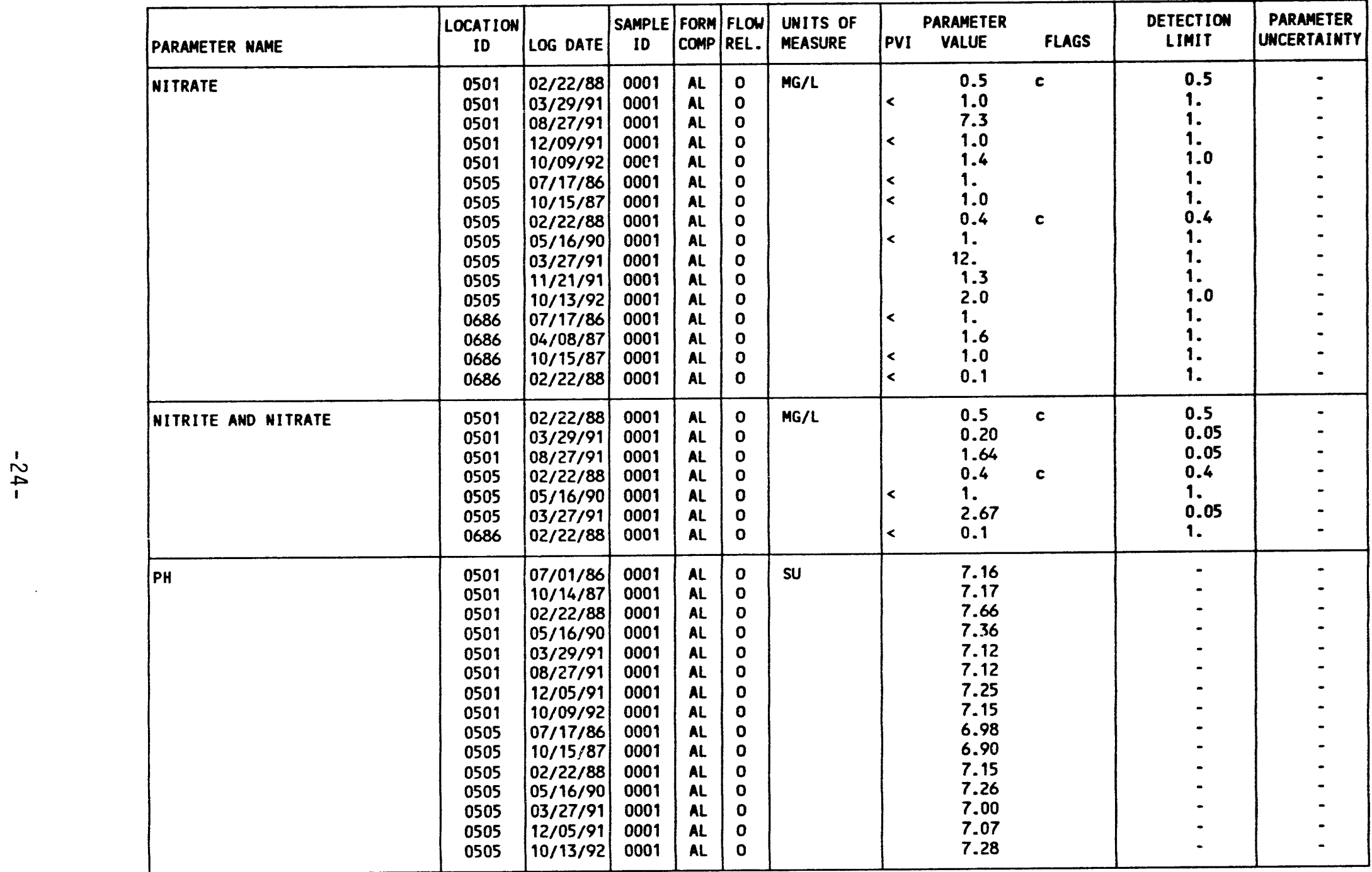

FORMATION OF COMPLETION COOE:

AL - ALLUVIUM

PARAMETER VALUE INDICATOR (PVI): < - LESS THAN DETECTION LIMIT
FLOW RELATIONSHIP COOE:

O - ON-SITE

SAMPLE ID CODES:

0001 - FILTERED SAMPLE (.45 MICRONS)

OTHER PARAMETER VALUE fLAGS:

c - CHANGED DETECTION LIMIT 
TABLE 3.5 BACKGROUND GROUNDWATER QUALITY DATA BY PARAMETER FOR THE ALLUVIUM NC AND UC PROCESSING SITES, SLICK ROCK, COLORADO

SITE: SRKO1 SLICK ROCK (BOTH SITES)

07/01/86 TO $10 / 13 / 92$

REPORT DATE: 06/17/93

\begin{tabular}{|c|c|c|c|c|c|c|c|c|c|c|c|c|}
\hline & PARAMETER NAME & $\underset{\text { ID }}{\text { LOCATION }}$ & LOG DATE & $\begin{array}{c}\text { SAMPLE } \\
\text { ID }\end{array}$ & $\begin{array}{l}\text { FORM } \\
\text { COMP }\end{array}$ & $\begin{array}{l}\text { FLOW } \\
\text { REL. }\end{array}$ & $\begin{array}{l}\text { UNITS OF } \\
\text { MEASURE }\end{array}$ & PVI & $\begin{array}{l}\text { DARAMETE } \\
\text { VALUE }\end{array}$ & FLAGS & $\begin{array}{l}\text { DETECTION } \\
\text { LIMIT }\end{array}$ & $\begin{array}{l}\text { PARAMETER } \\
\text { UNCERTAINTY }\end{array}$ \\
\hline & PH & $\begin{array}{l}0686 \\
0686 \\
0686 \\
0686 \\
0686 \\
0686\end{array}$ & \begin{tabular}{l|}
$07 / 17 / 86$ \\
$04 / 08 / 87$ \\
$10 / 15 / 87$ \\
$02 / 22 / 88$ \\
$08 / 06 / 91$ \\
$10 / 09 / 92$
\end{tabular} & $\begin{array}{l}0001 \\
0001 \\
0001 \\
0001 \\
0001 \\
0001\end{array}$ & $\begin{array}{l}A L \\
A L \\
A L \\
A L \\
A L \\
A L\end{array}$ & $\begin{array}{l}0 \\
0 \\
0 \\
0 \\
0 \\
0\end{array}$ & su & & $\begin{array}{l}7.55 \\
6.98 \\
6.93 \\
7.24 \\
7.50 \\
6.89\end{array}$ & & $\begin{array}{l}- \\
- \\
- \\
- \\
-\end{array}$ & $\begin{array}{l}- \\
\vdots \\
-\end{array}$ \\
\hline & PHOSPHATE & $\begin{array}{l}0501 \\
0501 \\
0501 \\
0501 \\
0501 \\
0505 \\
0505 \\
0505 \\
0505 \\
0505 \\
0505 \\
0686 \\
0686 \\
0686\end{array}$ & \begin{tabular}{|l|}
$10 / 14 / 87$ \\
$03 / 29 / 91$ \\
$08 / 27 / 91$ \\
$12 / 09 / 91$ \\
$10 / 09 / 92$ \\
$07 / 17 / 86$ \\
$10 / 15 / 87$ \\
$05 / 16 / 90$ \\
$03 / 27 / 91$ \\
$11 / 21 / 91$ \\
$10 / 13 / 92$ \\
$07 / 17 / 86$ \\
$04 / 08 / 87$ \\
$10 / 15 / 87$
\end{tabular} & $\begin{array}{l}0001 \\
0001 \\
0001 \\
0001 \\
0001 \\
0001 \\
0001 \\
0001 \\
0001 \\
0001 \\
0001 \\
0001 \\
0001 \\
0001\end{array}$ & $\begin{array}{l}A L \\
A L \\
A L \\
A L \\
A L \\
A L \\
A L \\
A L \\
A L \\
A L \\
A L \\
A L \\
A L \\
A L\end{array}$ & $\begin{array}{l}0 \\
0 \\
0 \\
0 \\
0 \\
0 \\
0 \\
0 \\
0 \\
0 \\
0 \\
0 \\
0 \\
0\end{array}$ & MG/L & $\begin{array}{l}< \\
< \\
< \\
< \\
< \\
< \\
< \\
< \\
< \\
<\end{array}$ & $\begin{array}{l}0.1 \\
0.1 \\
0.1 \\
0.1 \\
0.1 \\
0.1 \\
0.1 \\
0.1 \\
0.1 \\
0.1 \\
0.1 \\
0.1 \\
0.1 \\
0.1\end{array}$ & $\begin{array}{l}\text { J } \\
\text { J }\end{array}$ & $\begin{array}{l}0.1 \\
0.1 \\
0.1 \\
0.1 \\
0.1 \\
0.1 \\
0.1 \\
0.1 \\
0.1 \\
0.1 \\
0.1 \\
0.1 \\
0.1 \\
0.1\end{array}$ & $\begin{array}{l}- \\
: \\
: \\
- \\
- \\
- \\
- \\
- \\
-\end{array}$ \\
\hline & POLONIUA-210 & $\begin{array}{l}0501 \\
0501 \\
0505 \\
0505\end{array}$ & $\begin{array}{l}08 / 27 / 91 \\
12 / 05 / 91 \\
07 / 17 / 86 \\
12 / 05 / 91\end{array}$ & $\begin{array}{l}0001 \\
0001 \\
0001 \\
0001\end{array}$ & $\begin{array}{l}A L \\
A L \\
A L \\
A L\end{array}$ & $\begin{array}{l}0 \\
0 \\
0 \\
0\end{array}$ & $\mathrm{PCI} / \mathrm{L}$ & $k$ & $\begin{array}{l}0.1 \\
0.0 \\
0.5 \\
0.2\end{array}$ & b & $\begin{array}{l}1 . \\
1 . \\
1 .\end{array}$ & $\begin{array}{l}0.5 \\
0.3 \\
0.5 \\
1.0\end{array}$ \\
\hline & POTASSIUN & $\begin{array}{l}0501 \\
0501 \\
0501 \\
0501 \\
0501 \\
0501 \\
0501 \\
0505 \\
0505 \\
0505 \\
0505 \\
0505\end{array}$ & $\begin{array}{l}07 / 01 / 86 \\
10 / 14 / 87 \\
02 / 22 / 88 \\
03 / 29 / 91 \\
08 / 27 / 91 \\
12 / 09 / 91 \\
10 / 09 / 92 \\
07 / 17 / 86 \\
10 / 15 / 87 \\
02 / 22 / 88 \\
05 / 16 / 90 \\
03 / 27 / 91\end{array}$ & $\begin{array}{l}0001 \\
0001 \\
0001 \\
0001 \\
0001 \\
0001 \\
0001 \\
0001 \\
0001 \\
0001 \\
0001 \\
0001\end{array}$ & $\begin{array}{l}A L \\
A L \\
A L \\
A L \\
A L \\
A L \\
A L \\
A L \\
A L \\
A L \\
A L \\
A L\end{array}$ & $\begin{array}{l}0 \\
0 \\
0 \\
0 \\
0 \\
0 \\
0 \\
0 \\
0 \\
0 \\
0 \\
0\end{array}$ & $M G / L$ & & $\begin{array}{l}4.75 \\
3.8 \\
4.42 \\
3.9 \\
4.9 \\
3.82 \\
3.96 \\
6.64 \\
5.1 \\
5.19 \\
5.7 \\
5.0\end{array}$ & & $\begin{array}{l}0.01 \\
0.01 \\
0.01 \\
0.01 \\
0.01 \\
0.01 \\
0.01 \\
0.01 \\
0.01 \\
0.01 \\
0.01 \\
0.01\end{array}$ & $\begin{array}{l}- \\
: \\
- \\
- \\
- \\
- \\
-\end{array}$ \\
\hline
\end{tabular}

FORMATION CF COMPLETION COOE:

AL - ALLUVIUM

PARAMETER VALUE INDICATOR (PVI): < - LESS than DETECTION LIMIT
FLOW RELATIONSHIP COOE:

0001 - FILTERED SAMPLE (.45 MICRONS)

Other PARAMETER VALUe fLAGS:

$J$ - ESTIBATED VALUE

b - CHANGED PARAMETER VALUE 
TABLE 3.5 BACKGROUND GROUNDWATER QUALITY DATA BY PARAMETER FOR THE ALLUVIUM NC AND UC PROCESSING SITES, SLICK ROCK, COLORADO

SITE: SRKO1 SLICK ROCK (BOTH SITES)

07/01/86 TO $10 / 13 / 92$

REPORT DATE: $06 / 17 / 93$

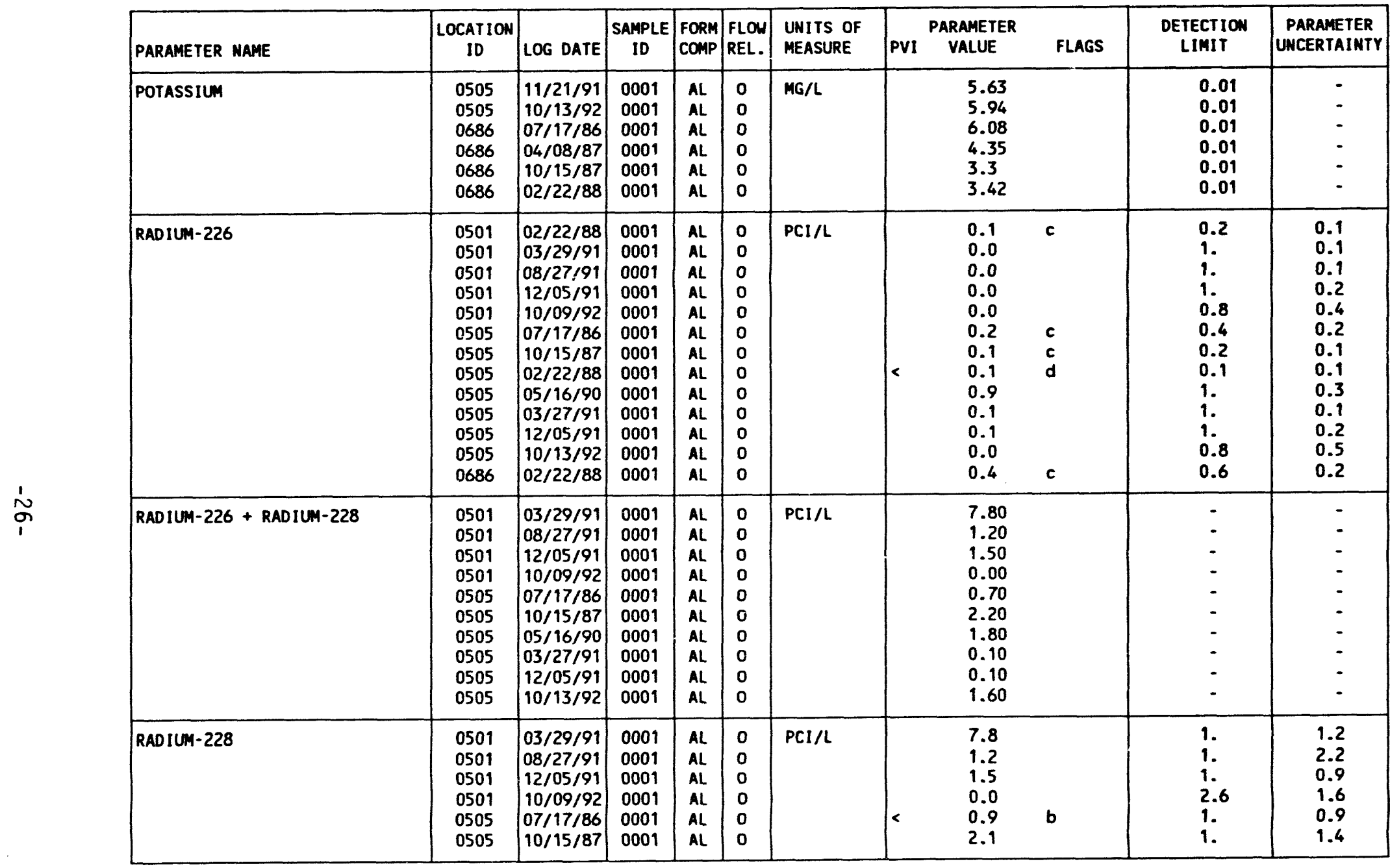

FORMATION OF COMPLETION COOE:

AL - ALLUVIUM

PARAMETER VALUE INDICATOR (PVI): < - LESS THAN DETECTION LIMIT
FLON RELATIONSHIP CODE:

O- ON-SITE

SAMPLE ID COOES:

0001 - FILTERED SAMPLE (.45 MICRONS)

OTHER PARAMETER VALUE FLAGS:

b - CHANGED PARAMETER VALUE

c - CHANGED DETECTION LIMIT

d - CHANGED DETECTION LIMIT AND PARAMETER VALUE 
TABLE 3.5 BACKGROUND GROUMDUATER QUALITY DATA BY PARAMETER FOR THE ALLUVIUM TABLE 3.5 BACKGROUND GROUNDWATER OUALITY DATA BY PA

NC AND UC PROCESSING SITES, SLICK ROCK,

SITE: SRK01 SLICK ROCK

REPORT DATE: 06/17/93

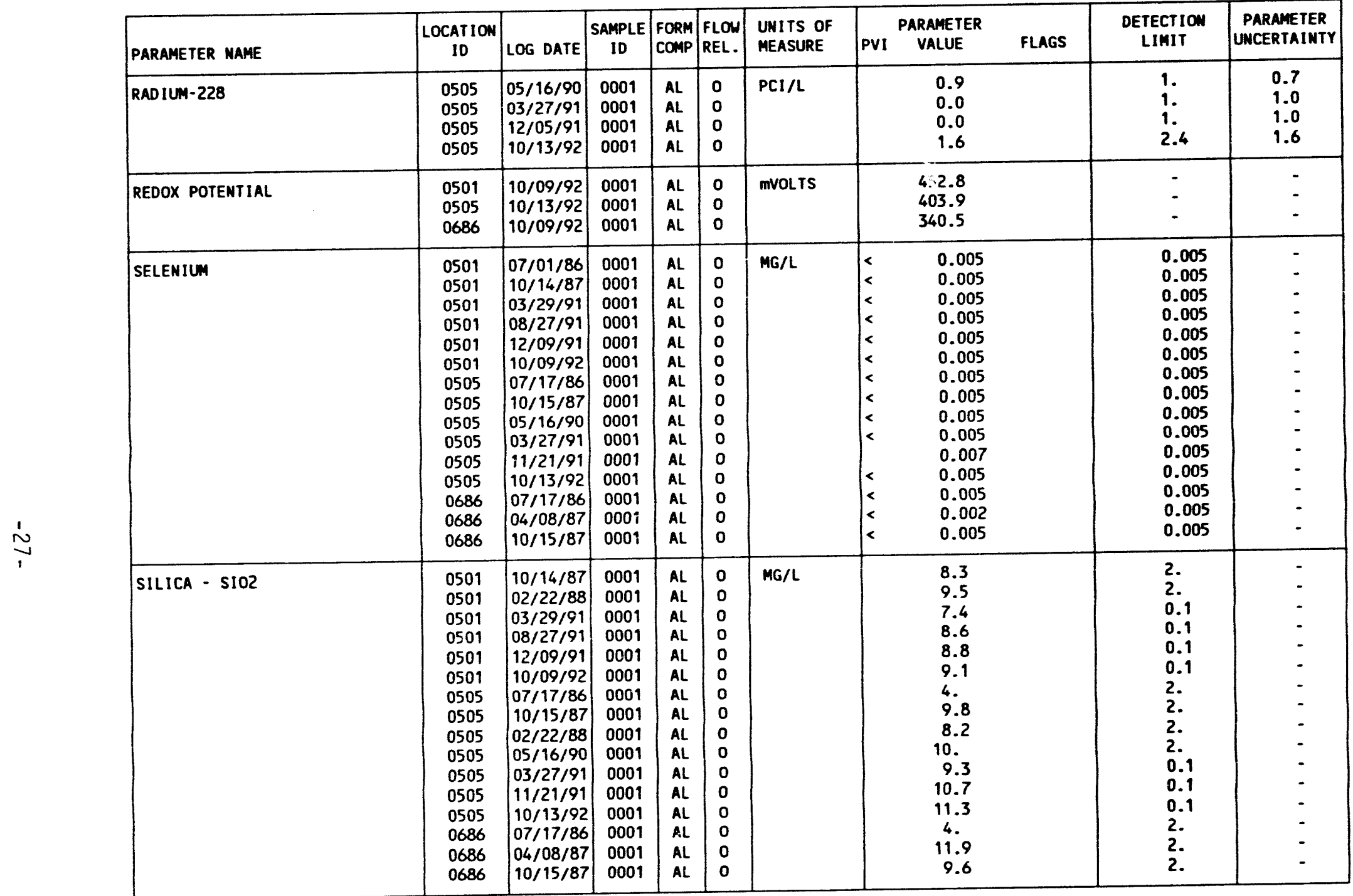

FORMATION OF COMPLETION CODE:

AL - ALLUVIU⿴囗十

PARAMETER VALUE INDICATOR (PVI): < - LESS THAN DETECTION LIMIT
FLOW RELATIONSHIP COOE:

O - ON-SITE

SAMPLE ID COOES:

OOO1 - FILTERED SAMPLE (.45 MICRONS) 
TABLE 3.5 BACKGROUND GROUNDWATER OUALITY DATA BY PARAMETER FOR THE ALLUVIUM NC AND UC PROCESSING SITES, SLICK ROCK, COLORADO

SITE: SRKO1 SLICK ROCK (BOTH SITES)

07/01/86 TO 10/13/92

REPORT DATE: $06 / 17 / 93$

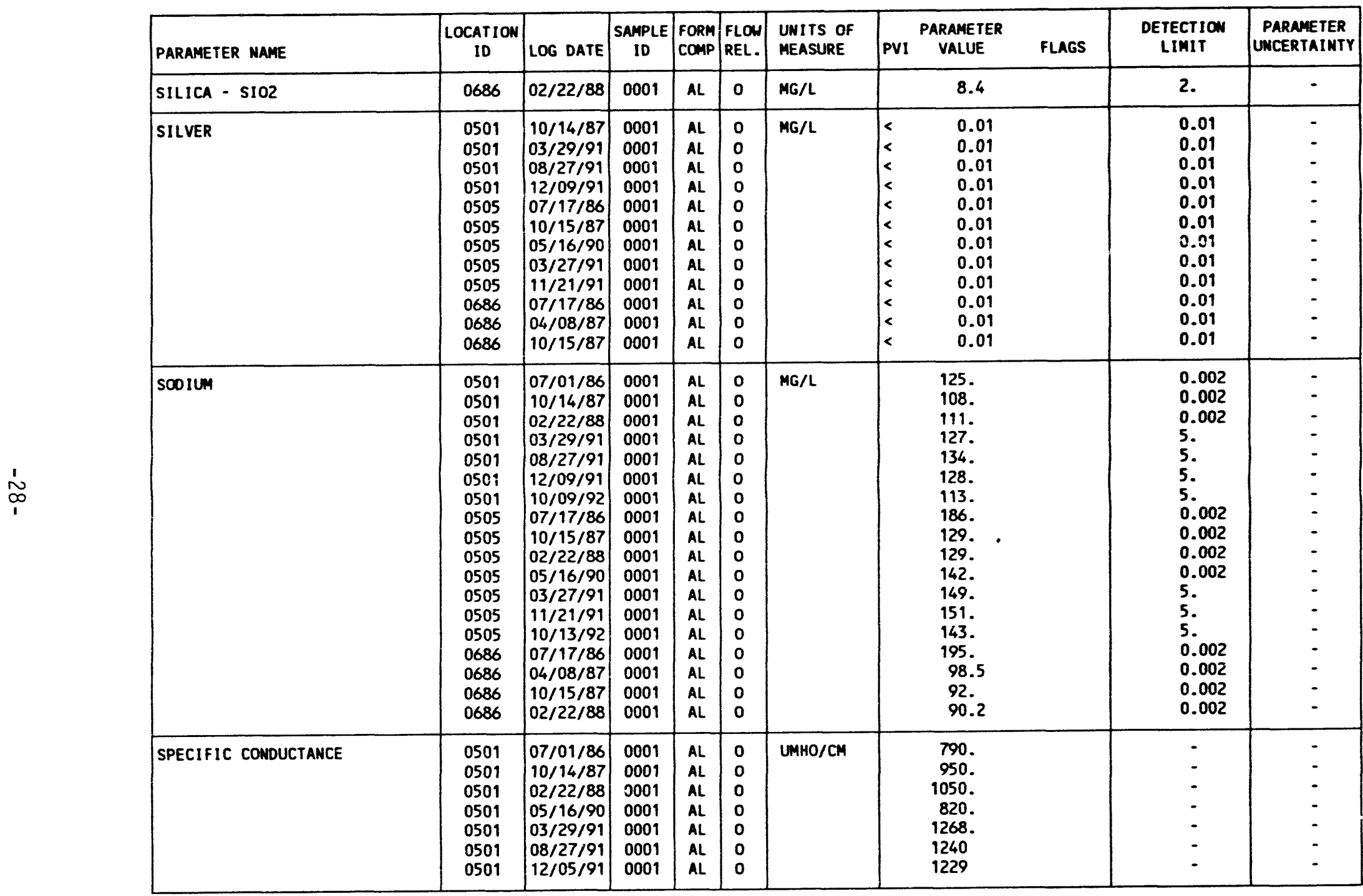

FORMATION OF COMPLETION CODE: AL - ALLUVIUM

PARAMETER VALUE INDICATOR (PVI): < - LESS THAN DETECTION LIMIT
FLON RELATIONSHIP COOE:

O- ON-SITE

SAMPLE ID CODES:

0001 - FILTERED SAMPLE (.45 MICRONS) 


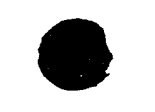

TABLE 3.5 BACKGROUND GROUNDHATER QUALITY DATA BY PARAMETER FOR THE ALLUVIUM NC AND UC PROCESSING SITES, SLICK ROCK, COLORADO

SITE: SRK01 SLICK ROCK (BOTH SITES)

07/01/86 TO $10 / 13 / 92$

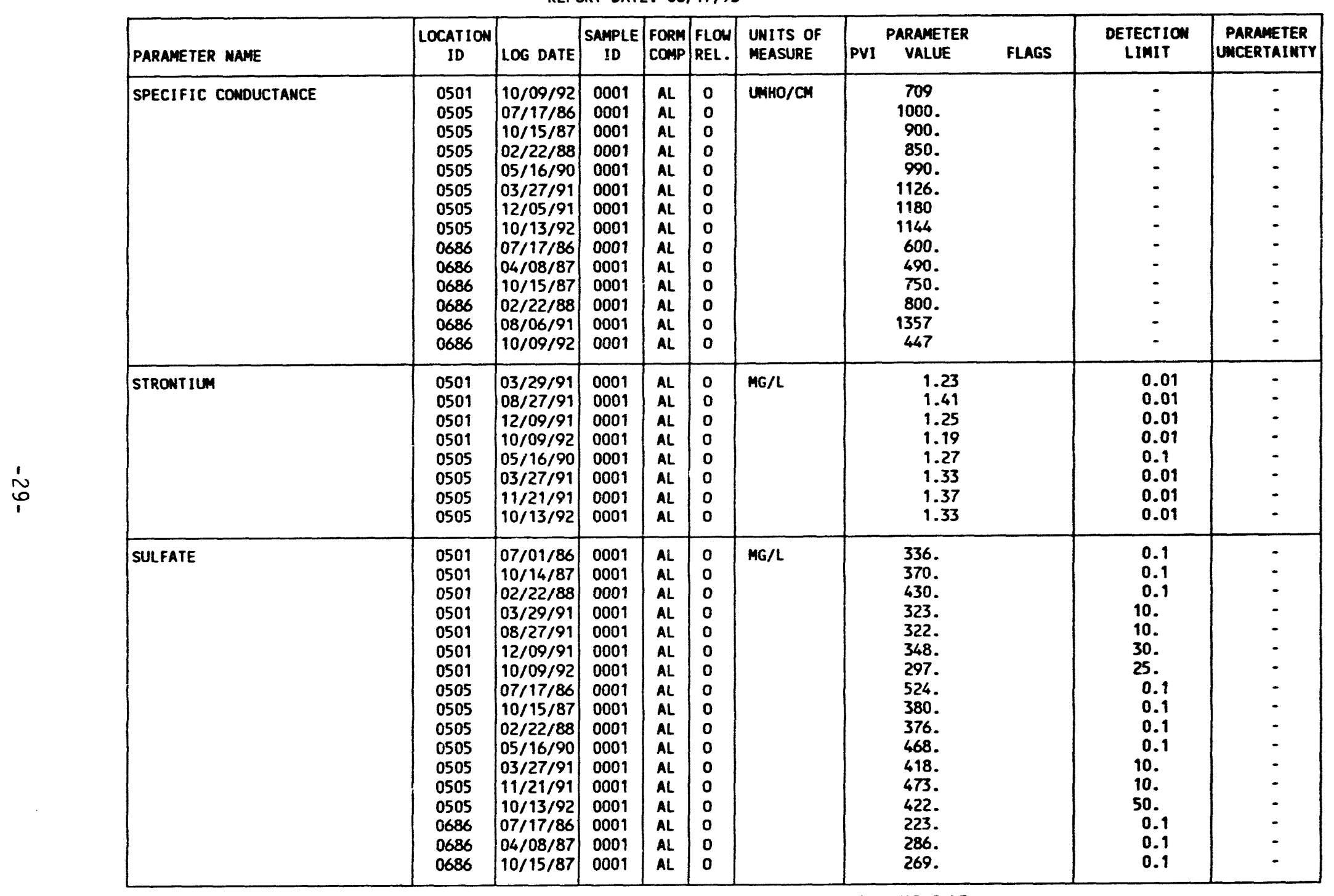

FORMATION OF COMPLETION CODE:

AL - ALLUVIUM

PARAMETER VALUE INDICATOR (PVI): < - LESS thaN DETECTION LIMIT
FLOW RELATIONSHIP COOE:

O- ON-SITE

SAMPLE ID COOES:

0001 - FILTERED SAMPLE (.45 MICRONS) 
TABLE 3.5 BACKGROUND GROUMDUATER QUALITY DATA BY PARAMETER FOR THE ALLUVIU: NC AND UC PROCESSING SITES, SLICK ROCK, COLORADO

SITE: SRKO1 SLICK ROCK (BOTH SITES)

07/01/86 TO $10 / 13 / 92$

REPORT DATE: 06/17/93

\begin{tabular}{|c|c|c|c|c|c|c|c|c|c|c|}
\hline PARAMETER MAME & $\underset{10}{\text { LOCATION }}$ & LOG DATE & $\begin{array}{c}\text { SAMPLE } \\
\text { ID }\end{array}$ & $\begin{array}{l}\text { FORM } \\
\text { COMP }\end{array}$ & $\begin{array}{l}\text { FLOW } \\
\text { REL. }\end{array}$ & $\begin{array}{l}\text { UNITS OF } \\
\text { MEASURE }\end{array}$ & PVI & $\begin{array}{l}\text { PARAMETER } \\
\text { VALUE }\end{array}$ & $\begin{array}{l}\text { DETECTION } \\
\text { LIMIT }\end{array}$ & $\begin{array}{l}\text { PARAMETER } \\
\text { UNCERTAIMTY }\end{array}$ \\
\hline SULFATE & 0686 & $02 / 22 / 88$ & 0001 & AL & 0 & $M G / L$ & & 316. & 0.1 & - \\
\hline SULFIDE & $\begin{array}{l}0501 \\
0501 \\
0501 \\
0501 \\
0501 \\
0505 \\
0505 \\
0505 \\
0505 \\
0686\end{array}$ & $\begin{array}{l}07 / 01 / 86 \\
03 / 29 / 91 \\
08 / 27 / 91 \\
12 / 09 / 91 \\
10 / 09 / 92 \\
07 / 17 / 86 \\
03 / 27 / 91 \\
11 / 21 / 91 \\
10 / 13 / 92 \\
07 / 17 / 86\end{array}$ & $\begin{array}{l}0001 \\
0001 \\
0001 \\
0001 \\
0001 \\
0001 \\
0001 \\
0001 \\
0001 \\
0001\end{array}$ & $\begin{array}{l}A L \\
A L \\
A L \\
A L \\
A L \\
A L \\
A L \\
A L \\
A L \\
A L\end{array}$ & $\begin{array}{l}0 \\
0 \\
0 \\
0 \\
0 \\
0 \\
0 \\
0 \\
0 \\
0\end{array}$ & $M G / L$ & $\begin{array}{l}< \\
< \\
< \\
<\end{array}$ & $\begin{array}{l}0.1 \\
0.3 \\
0.1 \\
1.0 \\
0.8 \\
0.1 \\
0.3 \\
0.3 \\
0.1 \\
0.1\end{array}$ & $\begin{array}{l}0.1 \\
0.1 \\
0.1 \\
0.1 \\
0.1 \\
0.1 \\
0.1 \\
0.1 \\
0.1 \\
0.1\end{array}$ & $\begin{array}{l}- \\
- \\
- \\
- \\
- \\
-\end{array}$ \\
\hline TEMPERATURE & $\begin{array}{l}0501 \\
0501 \\
0501 \\
0501 \\
0501 \\
0501 \\
0501 \\
0501 \\
0505 \\
0505 \\
0505 \\
0505 \\
0505 \\
0505 \\
0505 \\
0686 \\
0686 \\
0686 \\
0686 \\
0686 \\
0686\end{array}$ & $\begin{array}{l}07 / 01 / 86 \\
10 / 14 / 87 \\
02 / 22 / 88 \\
05 / 16 / 90 \\
03 / 29 / 91 \\
08 / 27 / 91 \\
12 / 05 / 91 \\
10 / 09 / 92 \\
07 / 17 / 86 \\
10 / 15 / 87 \\
02 / 22 / 88 \\
05 / 16 / 90 \\
03 / 27 / 91 \\
12 / 05 / 91 \\
10 / 13 / 92 \\
07 / 17 / 86 \\
04 / 08 / 87 \\
10 / 15 / 87 \\
02 / 22 / 88 \\
08 / 06 / 91 \\
10 / 09 / 92\end{array}$ & $\begin{array}{l}0001 \\
0001 \\
0001 \\
0001 \\
0001 \\
0001 \\
0001 \\
0001 \\
0001 \\
0001 \\
0001 \\
0001 \\
0001 \\
0001 \\
0001 \\
0001 \\
0001 \\
0001 \\
0001 \\
0001 \\
0001\end{array}$ & $\begin{array}{l}A L \\
A L \\
A L \\
A L \\
A L \\
A L \\
A L \\
A L \\
A L \\
A L \\
A L \\
A L \\
A L \\
A L \\
A L \\
A L \\
A L \\
A L \\
A L \\
A L \\
A L\end{array}$ & $\begin{array}{l}0 \\
0 \\
0 \\
0 \\
0 \\
0 \\
0 \\
0 \\
0 \\
0 \\
0 \\
0 \\
0 \\
0 \\
0 \\
0 \\
0 \\
0 \\
0 \\
0 \\
0\end{array}$ & C - DEGREE & & $\begin{array}{r}12.5 \\
15.0 \\
12.5 \\
12.0 \\
11.1 \\
14.4 \\
13.4 \\
14.6 \\
11.5 \\
13.0 \\
9.5 \\
10.5 \\
9.0 \\
12.7 \\
12.7 \\
13.5 \\
9.0 \\
14.5 \\
11.0 \\
18.2 \\
17.2\end{array}$ & $\begin{array}{l}- \\
- \\
- \\
- \\
- \\
- \\
- \\
- \\
- \\
- \\
- \\
- \\
- \\
- \\
- \\
- \\
-\end{array}$ & $\begin{array}{l}- \\
- \\
- \\
- \\
- \\
- \\
- \\
- \\
- \\
- \\
- \\
- \\
- \\
- \\
-\end{array}$ \\
\hline THALLIUM & $\begin{array}{l}0501 \\
0501 \\
0501 \\
0501 \\
0505 \\
0505\end{array}$ & $\begin{array}{l}03 / 29 / 91 \\
08 / 27 / 91 \\
12 / 09 / 91 \\
10 / 09 / 92 \\
05 / 16 / 90 \\
03 / 27 / 91\end{array}$ & $\begin{array}{l}0001 \\
0001 \\
0001 \\
0001 \\
0001 \\
0001\end{array}$ & $\begin{array}{l}A L \\
A L \\
A L \\
A L \\
A L \\
A L\end{array}$ & $\begin{array}{l}0 \\
0 \\
0 \\
0 \\
0 \\
0\end{array}$ & $M G / L$ & & $\begin{array}{l}0.01 \\
0.01 \\
0.01 \\
0.005 \\
0.01 \\
0.01\end{array}$ & $\begin{array}{l}0.01 \\
0.01 \\
0.01 \\
0.005 \\
0.01 \\
0.01\end{array}$ & $\begin{array}{l}- \\
: \\
:\end{array}$ \\
\hline
\end{tabular}

FORMATION OF COMPLETION CODE:

AL - ALLUYIUM

PARAMETER VALUE INDICATOR (PVI): < - LESS THAN DETECTION LIMIT
FLOW RELATIONSHIP COOE:

ID COOES:

0001 - FILTERED SAMPLE (.45 MICRONS) 
TABLE 3.5 BACKGROUND GROUNDHATER OUALITY DATA BY PARAMETER FOR THE ALLUVIUM NC AND UC PROCESSING SITES, SLICK ROCK, COLORADO

SITE: SRKO1 SLICK ROCK (BOTH SITES)

07/01/86 TO 10/13/92

REPORT DATE: 06/17/93

\begin{tabular}{|c|c|c|c|c|c|c|c|c|c|c|c|c|}
\hline & PARAMETER NAME & $\underset{\text { ID }}{\text { LOCATION }}$ & LOG DATE & $\begin{array}{c}\text { SAMPLE } \\
\text { ID }\end{array}$ & $\begin{array}{l}\text { FORM } \\
\text { COMP }\end{array}$ & $\begin{array}{l}\text { FLON } \\
\text { REL. }\end{array}$ & $\begin{array}{l}\text { UNITS OF } \\
\text { MEASURE }\end{array}$ & PVI & $\begin{array}{l}\text { PARAMETER } \\
\text { VALUE }\end{array}$ & FLAGS & $\begin{array}{l}\text { DETECTION } \\
\text { LIMIT }\end{array}$ & $\begin{array}{l}\text { PARAMETER } \\
\text { UNCERTAINTY }\end{array}$ \\
\hline & THALLIUM & $\begin{array}{l}0505 \\
0505\end{array}$ & $\begin{array}{l}11 / 21 / 91 \\
10 / 13 / 92\end{array}$ & $\begin{array}{l}0001 \\
0001\end{array}$ & $\begin{array}{l}A L \\
A L\end{array}$ & $\begin{array}{l}0 \\
0\end{array}$ & $M G / L$ & $<$ & $\begin{array}{l}0.01 \\
0.005\end{array}$ & & $\begin{array}{l}0.01 \\
0.005\end{array}$ & - \\
\hline & THORIUM-230 & $\begin{array}{l}0501 \\
0501 \\
0505 \\
0505\end{array}$ & $\begin{array}{l}08 / 27 / 91 \\
12 / 05 / 91 \\
07 / 17 / 86 \\
12 / 05 / 91\end{array}$ & $\begin{array}{l}0001 \\
0001 \\
0001 \\
0001\end{array}$ & $\begin{array}{l}A L \\
A L \\
A L \\
A L\end{array}$ & $\begin{array}{l}0 \\
0 \\
0 \\
0\end{array}$ & PCI/L & & $\begin{array}{l}0.5 \\
0.5 \\
0.5 \\
1.5\end{array}$ & c & $\begin{array}{l}1 . \\
1.9 \\
0.9 \\
1 .\end{array}$ & $\begin{array}{l}0.6 \\
0.7 \\
0.4 \\
0.7\end{array}$ \\
\hline & TIN & $\begin{array}{l}0501 \\
0501 \\
0501 \\
0501 \\
0505 \\
0505 \\
0505 \\
0505 \\
0505 \\
0686\end{array}$ & $\begin{array}{l}03 / 29 / 91 \\
08 / 27 / 91 \\
12 / 09 / 91 \\
10 / 09 / 92 \\
07 / 17 / 86 \\
05 / 16 / 90 \\
03 / 27 / 91 \\
11 / 21 / 91 \\
10 / 13 / 92 \\
07 / 17 / 86\end{array}$ & $\begin{array}{l}0001 \\
0001 \\
0001 \\
0001 \\
0001 \\
0001 \\
0001 \\
0001 \\
0001 \\
0001\end{array}$ & $\begin{array}{l}A L \\
A L \\
A L \\
A L \\
A L \\
A L \\
A L \\
A L \\
A L \\
A L\end{array}$ & $\begin{array}{l}0 \\
0 \\
0 \\
0 \\
0 \\
0 \\
0 \\
0 \\
0 \\
0\end{array}$ & $M G / L$ & $\begin{array}{l}< \\
< \\
< \\
< \\
< \\
< \\
< \\
<\end{array}$ & $\begin{array}{l}0.005 \\
0.005 \\
0.005 \\
0.005 \\
0.005 \\
0.005 \\
0.005 \\
0.005 \\
0.05 \\
0.005\end{array}$ & 1 & $\begin{array}{l}0.005 \\
0.005 \\
0.005 \\
0.005 \\
0.005 \\
0.005 \\
0.005 \\
0.005 \\
0.05 \\
0.005\end{array}$ & $\begin{array}{l}- \\
- \\
- \\
- \\
- \\
-\end{array}$ \\
\hline 1 & TOTAL DISSOLVED SOLIDS & $\begin{array}{l}0501 \\
0501 \\
0501 \\
0501 \\
0501 \\
0501 \\
0501 \\
0505 \\
0505 \\
0505 \\
0505 \\
0505 \\
0505 \\
0505 \\
0686 \\
0686 \\
0686 \\
0686\end{array}$ & $\begin{array}{l}07 / 01 / 86 \\
10 / 14 / 87 \\
02 / 22 / 88 \\
03 / 29 / 91 \\
08 / 27 / 91 \\
12 / 09 / 91 \\
10 / 09 / 92 \\
07 / 17 / 86 \\
10 / 15 / 87 \\
02 / 22 / 88 \\
05 / 16 / 90 \\
03 / 27 / 91 \\
11 / 21 / 91 \\
10 / 13 / 92 \\
07 / 17 / 86 \\
04 / 08 / 87 \\
10 / 15 / 87 \\
02 / 22 / 88\end{array}$ & $\begin{array}{l}0001 \\
0001 \\
0001 \\
0001 \\
0001 \\
0001 \\
0001 \\
0001 \\
0001 \\
0001 \\
0001 \\
0001 \\
0001 \\
0001 \\
0001 \\
0001 \\
0001 \\
0001\end{array}$ & $\begin{array}{l}A L \\
A L \\
A L \\
A L \\
A L \\
A L \\
A L \\
A L \\
A L \\
A L \\
A L \\
A L \\
A L \\
A L \\
A L \\
A L \\
A L \\
A L\end{array}$ & $\begin{array}{l}0 \\
0 \\
0 \\
0 \\
0 \\
0 \\
0 \\
0 \\
0 \\
0 \\
0 \\
0 \\
0 \\
0 \\
0 \\
0 \\
0 \\
0\end{array}$ & $M G / L$ & & $\begin{array}{c}819 . \\
879 . \\
991 . \\
846 . \\
840 . \\
822 . \\
744 . \\
1180 . \\
880 . \\
875 . \\
914 . \\
993 . \\
1010 . \\
1050 . \\
622 . \\
813 . \\
672 . \\
777 .\end{array}$ & & $\begin{array}{l}10 . \\
10 . \\
10 . \\
10 . \\
10 . \\
10 . \\
10 . \\
10 . \\
10 . \\
10 . \\
10 . \\
10 . \\
10 . \\
10 . \\
10 . \\
10 . \\
10 . \\
10 .\end{array}$ & $\begin{array}{l}- \\
: \\
- \\
- \\
- \\
- \\
- \\
- \\
- \\
- \\
- \\
- \\
-\end{array}$ \\
\hline & TOTAL KJELDAHL NITROGEN & 0501 & 03/29/91 & 0001 & AL & 0 & $M G / L$ & $<$ & 1. & & 1. & - \\
\hline
\end{tabular}

FORMATION OF COMPLETION COOE:

AL - ALLUVIUM

PARAMETER VALUE INDICATOR (PVI): < - LESS THAN DETECTION LIMIT
FLOW RELATIONSHIP COOE:

O - ON-SITE

OTHER PARAMETER VALUE FLAGS:

SAMPLE ID CODES:
0001 - FILTERED SAMPLE (.45 MICRONS)

1 - INCREASED DETECTION LIMIT DUE to REQUIRED DILUTION

c - CHANGED DETECTION LIMIT 
TABLE 3.5 BACKGROUND GROUNDHATER QUALITY DATA BY PARAMETER FOR THE ALLUVIU: NC AND UC PROCESSIMG SITES, SLICK ROCK, COLORADO

SITE: SRKO1 SLICK ROCK (BOTH SITES)

$07 / 01 / 86$ TO $10 / 13 / 92$

REPORT DATE: 06/17/93

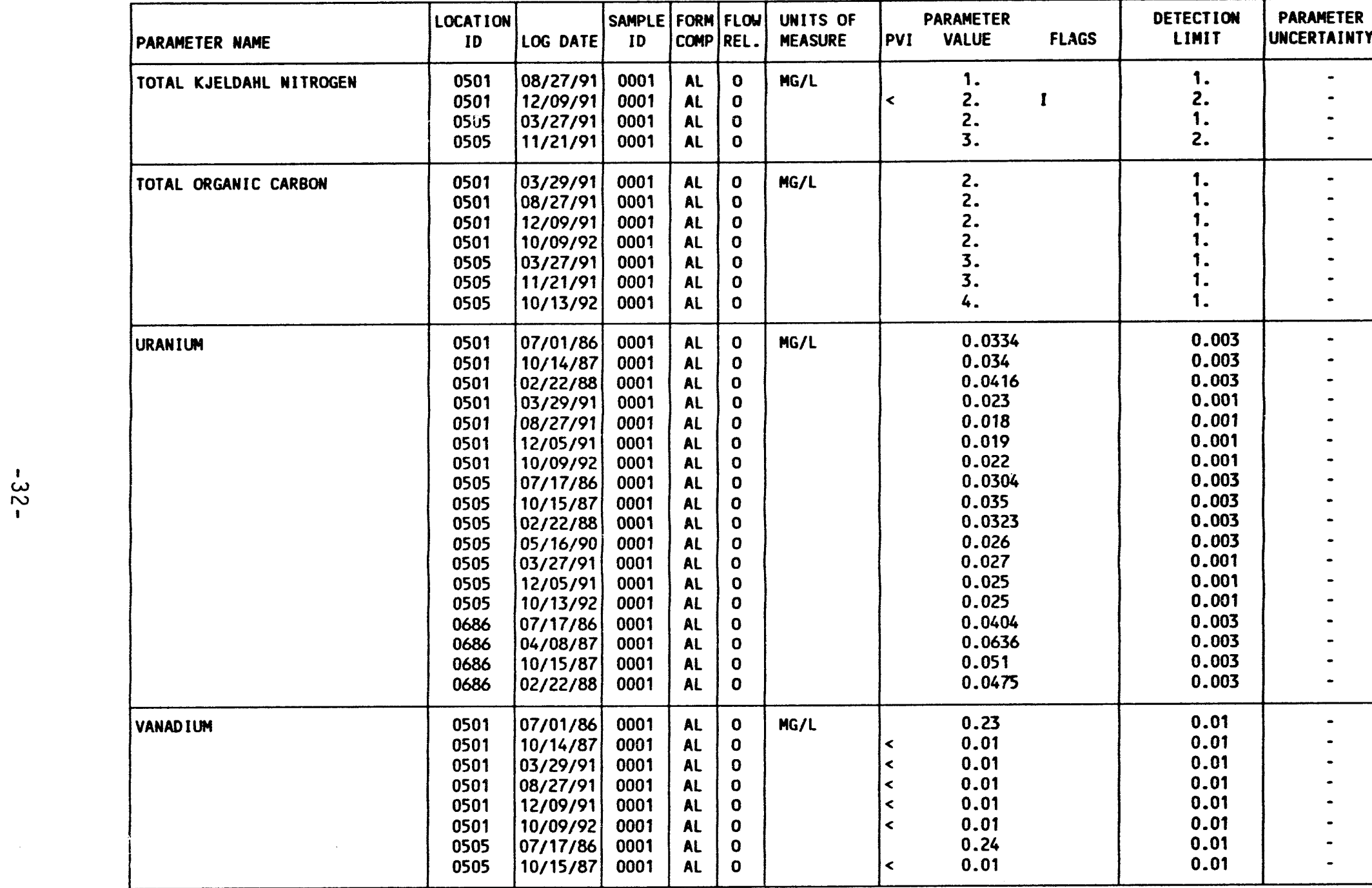

FORMATION OF COMPLETION COOE:

AL - ALLUVIUM

FLOW RELATIONSHIP CODE:

O - ON-SITE

PARAMETER VALUE INDICATOR (PVI): < - LESS THAN DETECTION LIMIT

DOMP - FILTERED SAMPLE. (.45 MICRONS)

OTHER PARAMETER VALUE FLAGS

I - INCREASED DETECTION LIMIT DUE TO REQUIRED DILUTION 


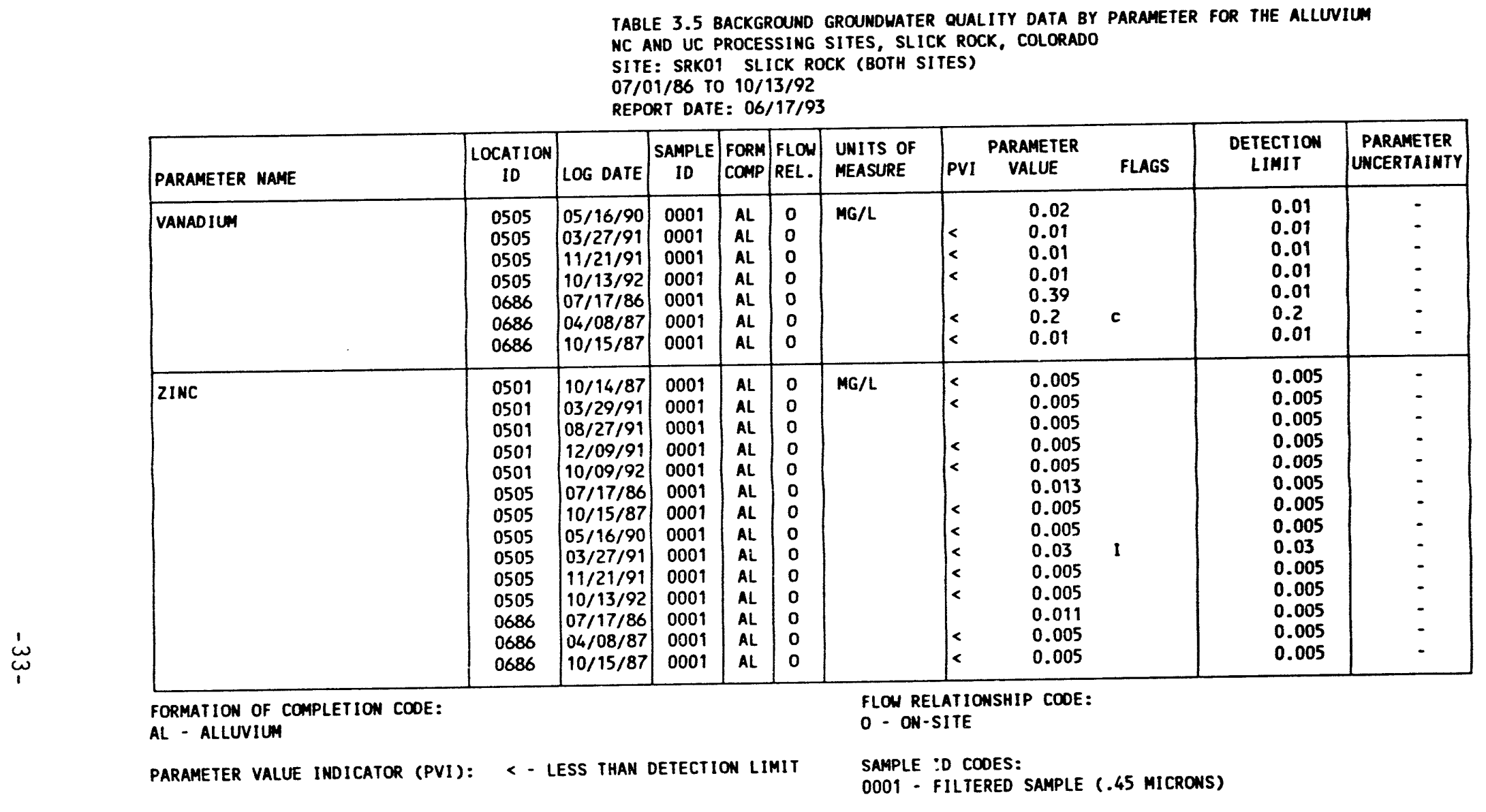

Other PARAMETER VALUE fLAGS:

I - INCREASED DETECTION LIMIT DUE TO REQUIRED DILUTION

c - CHANGED DETECTION LIMIT

DATA FILE MAME: M: IDARTISRKO1IGWOI0023.DAT 
TABLE 3.6 BACKGROUND GROUNDHATER OUALITY STATISTICS BY PARAMETER

FOR THE ALLUVIUM, NC PROCESSING SITE, SLICK ROCK, COLORADO

SITE: SRKO1 SLICK ROCK (BOTH SITES)

$07 / 01 / 86$ TC $10 / 09 / 92$

REPORT DATE: $07 / 26 / 93$

\begin{tabular}{|c|c|c|c|c|c|c|c|c|c|c|c|}
\hline \multicolumn{3}{|c|}{ PARAMETER NAME } & UNITS & \multirow[b]{2}{*}{ MEAN } & \multirow{2}{*}{$\begin{array}{l}\text { STANDARD } \\
\text { DEVIATION }\end{array}$} & \multirow{2}{*}{$\begin{array}{c}\text { COEFF. } \\
\text { OF } \\
\text { VARIATION }\end{array}$} & \multirow{2}{*}{$\begin{array}{c}\% \text { OF } \\
\text { NON } \\
\text { DETECTS }\end{array}$} & \multirow{2}{*}{\multicolumn{2}{|c|}{$\begin{array}{l}\text { CTATISTICAL RANGE } \\
\text { 98\% CONFIDENCE INTERVAL } \\
\text { MINIMUM MAXIMUM * }\end{array}$}} & \multirow{2}{*}{$\begin{array}{l}\text { OISTRIBUTION } \\
\text { TYPE }\end{array}$} & \multirow{2}{*}{$\begin{array}{l}\text { FOOT } \\
\text { NOTE }\end{array}$} \\
\hline \# OF SAMP & MINIMUM & MAXIMUM & MEDIAN & & & & & & & & \\
\hline \multicolumn{3}{|l|}{ ALKALINITY } & \multicolumn{2}{|c|}{$\mathrm{MG} / \mathrm{L} \mathrm{CACO} 3$} & \multirow[b]{2}{*}{64.2671} & \multirow[b]{2}{*}{0.2536} & \multirow[b]{2}{*}{0.0} & \multirow[b]{2}{*}{202.9914} & \multirow[b]{2}{*}{303.8419} & \multirow[b]{2}{*}{ MORMAL } & \\
\hline 12 & 204.0000 & 435.0000 & +230.5000 & 253.4167 & & & & & & & \\
\hline \multicolumn{3}{|l|}{ ALUMINUM } & $M G / L$ & \multirow[b]{2}{*}{ NA } & \multirow[b]{2}{*}{ NA } & \multirow[b]{2}{*}{ NA } & \multirow[b]{2}{*}{63.6} & \multirow[b]{2}{*}{0.0500} & \multirow[b]{2}{*}{0.3000} & \multirow[b]{2}{*}{ NONPARAMETRIC } & \multirow[b]{2}{*}{2} \\
\hline 11 & ** $\quad 0.0500$ & 0.4000 & 0.0500 & & & & & & & & \\
\hline \multicolumn{3}{|l|}{ AMMONIUM } & $\mathrm{MG} / \mathrm{L}$ & \multirow[b]{2}{*}{ NA } & \multirow[b]{2}{*}{ NA } & \multirow[b]{2}{*}{ NA } & \multirow[b]{2}{*}{80.0} & \multirow[b]{2}{*}{0.1000} & & & \\
\hline 10 & $\star \quad 0.1000$ & 0.6000 & ** $\quad 0.1000$ & & & & & & 0.1000 & NONPARAMETRIC & 2 \\
\hline ANT IMONY & & & $M G / L$ & & & & & & & & \\
\hline 6 & $\star \star \quad 0.0030$ & 0.0030 & 0.0030 & NA & NA & NA & 100.0 & 0.0030 & $\star * 0.0030$ & MONPARAMETRIC & 2,6 \\
\hline ARSENIC & & & $M G / L$ & & & & & & & & \\
\hline 9 & $\star \star \quad 0.0050$ & 0.0050 & 0.0050 & NA & NA & NA & 100.0 & 0.0050 & 0.0050 & NONPARAMETRIC & 2 \\
\hline BARIUM & & & $M G / L$ & & & & & & & & \\
\hline 8 & 0.0200 & 0.2000 & 0.0350 & NA & NA & NA & 37.5 & .0 .0200 & 0.2000 & NONPARAMETRIC & 2 \\
\hline BERYLLIUM & & & $M G / L$ & & & & & & & & \\
\hline 3 & ** $\quad 0.0050$ & $\star \quad * \quad 0.0050$ & 0.0050 & NA & NA & NA & 100.0 & MA & NA & UNKNOWN & 1 \\
\hline BORON & & & MG/L & & & & & & & & \\
\hline 6 & 0.0800 & 0.3000 & 0.1000 & 0.1283 & 0.0845 & 0.6583 & 0.0 & 0.0500 & 0.2444 & MORMAL & \\
\hline BROMIDE & & & $\mathrm{MG} / \mathrm{L}$ & & & & & & & & \\
\hline 4 & 0.1500 & 0.2500 & 0.2000 & NA & NA & NA & 50.0 & 0.1500 & 0.2500 & NONPARAMETRIC & 2,4 \\
\hline
\end{tabular}

** The reported value is the minimum detection limit of the data set

+ The sample size is even, so the median value is the arithmetic average of the two middle values

* The statistical maximm is the 99 percent one sided confidence interval, $a=0.01$

1) A minimum of 4 samples must be available for the statistical analysis.

2) The nonparametric distribution was used because the nondetected values comprise more than $15 \%$ of the samples.

4) The stat. range is the $87.5 \%$ confidence interval che to a sample size of 4 . The maximum is the $93.8 \%$ one sided confidence int.

6) The stat. range is the $96.9 \%$ confidence interval due to a sample size of 6 . The maximum is the $98.5 \%$ one sided confidence int. 
TABLE 3.6 BACKGROUND GROUNDUATER QUALITY STATISTICS BY PARAMETER

FOR THE ALLUVIUM MC PROCESSING SITE, SLICK ROCK, COLORADO

SITE: SRKO1 SLICK ROCK (BOTH SITES)

$07 / 01 / 86$ TO $10 / 09 / 92$

REPORT DATE: $07 / 26 / 93$

\begin{tabular}{|c|c|c|c|c|c|c|c|c|c|c|c|}
\hline \multicolumn{3}{|c|}{ PARAMETER NAME } & UNITS & \multirow[b]{2}{*}{ MEAN } & \multirow{2}{*}{$\begin{array}{r}\text { STANDARD } \\
\text { DEVIATION }\end{array}$} & \multirow{2}{*}{$\begin{array}{c}\text { COEFF. } \\
\text { OF } \\
\text { VARIATION }\end{array}$} & \multirow{2}{*}{$\begin{array}{l}\% \text { OF } \\
\text { NON } \\
\text { DETECTS }\end{array}$} & \multirow{2}{*}{\multicolumn{2}{|c|}{$\begin{array}{l}\text { STATISTICAL RANGE } \\
\text { 98\% CONFIDENCE INTERVAL } \\
\text { MINIMUM MAXIMUM * }\end{array}$}} & \multirow{2}{*}{$\begin{array}{c}\text { DISTRIBUTION } \\
\text { TYPE }\end{array}$} & \multirow{2}{*}{$\begin{array}{l}\text { FOOT } \\
\text { NOTE }\end{array}$} \\
\hline \# OF SAMP & MINIMMM & MaXIMUM & MEDIAN & & & & & & & & \\
\hline \multicolumn{3}{|l|}{ CADMIUM } & MG/L & \multirow[b]{2}{*}{ NA } & \multirow[b]{2}{*}{ NA } & \multirow[b]{2}{*}{ NA } & \multirow[b]{2}{*}{100.0} & \multirow[b]{2}{*}{0.0005} & \multirow[b]{2}{*}{0.0005} & \multirow[b]{2}{*}{ NONPARAMETRIC } & \multirow[b]{2}{*}{2} \\
\hline 8 & $\star \quad 0.0005$ & 0.0005 & 0.0005 & & & & & & & & \\
\hline \multicolumn{3}{|l|}{ CALCIUM } & $M G / L$ & \multirow[b]{2}{*}{112.6727} & \multirow[b]{2}{*}{19.7028} & \multirow[b]{2}{*}{0.1749} & \multirow[b]{2}{*}{0.0} & \multirow[b]{2}{*}{96.2528} & \multirow[b]{2}{*}{129.0926} & \multirow[b]{2}{*}{ NORMAL } & \\
\hline 11 & 73.8000 & 150.0000 & 111.0000 & & & & & & & & \\
\hline \multicolumn{3}{|l|}{ CHLORIDE } & MG/L & \multirow[b]{2}{*}{58.1182} & \multirow[b]{2}{*}{16.0858} & \multirow[b]{2}{*}{0.2768} & \multirow[b]{2}{*}{0.0} & \multirow[b]{2}{*}{44.7126} & & & \\
\hline 11 & 38.0000 & 89.0000 & 59.0000 & & & & & & 71.5237 & NORMAL & \\
\hline CHROMIUM & & & MG/L & & & & & & & & \\
\hline 8 & $\star \star \quad 0.0100$ & 0.0400 & 0.0100 & NA & NA & NA & 87.5 & 0.0100 & 0.0400 & NONPARAMETRIC & 2 \\
\hline COBALT & & & $M G / L$ & & & & & & & & \\
\hline 3 & $\star \quad * \quad 0.0300$ & $\star \quad 0.0300$ & $\star * \quad 0.0300$ & NA & NA & NA & 100.0 & NA & MA & UNKNOWN & 1 \\
\hline COPPER & & & $M G / L$ & & & & & & & & \\
\hline 8 & $\approx * \quad 0.0100$ & 0.0500 & ** $\quad 0.0100$ & NA & MA & NA & $\pi .0$ & 0.0100 & 0.0500 & NONPARAMETRIC & 2 \\
\hline CYANIDE & & & $M G / L$ & & & & & & & & \\
\hline 3 & $\star \quad 0.0100$ & $\approx \quad 0.0100$ & $\star \quad 0.0100$ & NA & NA & NA & 100.0 & NA & MA & UNKNOWN & 1 \\
\hline DISSOLVED & OXYGEN & & MG/L & & & & & & & & \\
\hline 1 & 1.3000 & 1.3000 & 1.3000 & NA & NA & NA & 0.0 & NA & Ma & UNKNOWN & 1 \\
\hline FIELD FE & $(2+)$ & & $M G / L$ & & & & & & & & \\
\hline 1 & 0.0500 & 0.0500 & 0.0500 & NA & NA & NA & 0.0 & MA & MA & UNKNOWN & 1 \\
\hline FIELD FE & (TOTAL) & & $M G / L$ & & & & & & & & \\
\hline 1 & 0.0000 & 0.0000 & 0.0000 & NA & NA & NA & 0.0 & NA & MA & UNKNOWN & 1 \\
\hline
\end{tabular}

** The reported value is the minimm detection limit of the data set

+ The sample size is

- The statistical maximm is the 99 percent one sided confidence interval $a=0.01$

1) A minimum of 4 samples must be available for the statistical analysis.

2) The nonparametric distribution was used because the nondetected values comprise more than $15 \%$ of the samples. 
TABLE 3.6 BACKGROUND GROUNDWATER QUALITY STATISTICS BY PARAMETER FOR THE ALLUVIUM, NC PROCESSING SITE, SLICK ROCK, COLORADO

SOR THE ALLUVIUH,

$07 / 01 / 86$ TO $10 / 09 / 92$

REPORT DATE: $07 / 26 / 93$

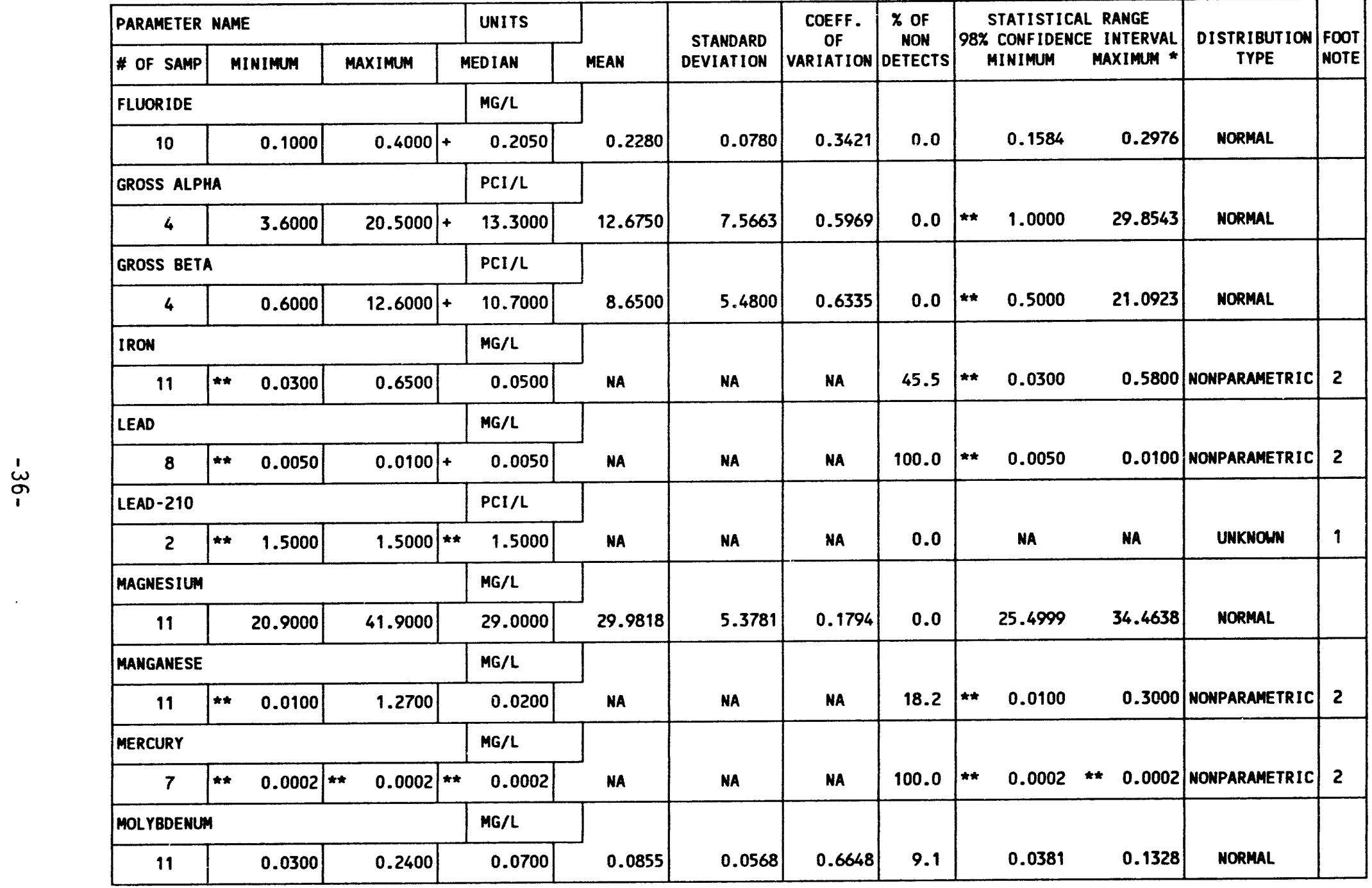

** The reported value is the minimum detection limit of the data set

+ The sample size is even, so the median value is the arithmetic average of the two middle values

* The statistical maximum is the 99 percent one sided confidence interval, $\alpha=0.01$

1) A minimum of 4 samples must be available for the statistical analysis.

2) The nonparametric distribution was used because the nondetected values comprise more than $15 \%$ of the samples. 
TABLE 3.6 BACKGROUND GROUNDWATER QUALITY STATISTICS BY PARAMETER

FOR THE ALLUVIUM, NC PROCESSING SITE, SLICK ROCK, COLORADO

SITE: SRKO1 SLICK ROCK (BOTH SITES)

$07 / 01 / 86$ TO $10 / 09 / 92$

REPORT DATE: $07 / 26 / 93$

\begin{tabular}{|c|c|c|c|c|c|c|c|c|c|c|c|}
\hline \multicolumn{3}{|c|}{ PARAMETER MAME } & UNITS & \multirow[b]{2}{*}{ MEAN } & \multirow{2}{*}{$\begin{array}{l}\text { STANDARD } \\
\text { DEVIATION }\end{array}$} & \multirow{2}{*}{$\begin{array}{c}\text { COEFF. } \\
\text { OF } \\
\text { VARIATION }\end{array}$} & \multirow{2}{*}{$\begin{array}{c}\text { X OF } \\
\text { HON } \\
\text { DETECTS }\end{array}$} & \multirow{2}{*}{\multicolumn{2}{|c|}{$\begin{array}{c}\text { STATISTICAL RANGE } \\
\text { 98\% CONFIDENCE INTERVAL } \\
\text { MINIMUM MAXIMUM }\end{array}$}} & \multirow{2}{*}{$\begin{array}{c}\text { DISTRIBUTION } \\
\text { TYPE }\end{array}$} & \multirow{2}{*}{$\begin{array}{l}\text { FOOT } \\
\text { NOTE }\end{array}$} \\
\hline \# OF SAMP & MINIMUM & MAXIMUM & MEDIAN & & & & & & & & \\
\hline \multicolumn{3}{|c|}{ 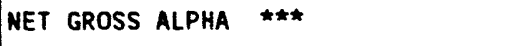 } & $\mathrm{PCI} / \mathrm{L}$ & \multirow[b]{2}{*}{ NA } & \multirow[b]{2}{*}{ MA } & \multirow[b]{2}{*}{ NA } & \multirow[b]{2}{*}{0.0} & \multirow[b]{2}{*}{-9.4300} & \multirow[b]{2}{*}{4.7200} & \multirow[b]{2}{*}{ MONPARAMETRIC } & \multirow[b]{2}{*}{9,4} \\
\hline 4 & -9.4300 & 4.7200 & $+\quad-0.4200$ & & & & & & & & \\
\hline \multicolumn{3}{|l|}{ NICKEL } & $M G / L$ & \multirow[b]{2}{*}{ NA } & \multirow[b]{2}{*}{ NA } & \multirow[b]{2}{*}{ NA } & \multirow[b]{2}{*}{70.0} & \multirow[b]{2}{*}{0.0200} & \multirow[b]{2}{*}{0.0200} & \multirow[b]{2}{*}{ MONPARAMETRIC } & \multirow[b]{2}{*}{2} \\
\hline 10 & 0.0100 & 0.0400 & 0.0200 & & & & & & & & \\
\hline \multicolumn{3}{|l|}{ NITRATE } & $M G / L$ & \multirow[b]{2}{*}{ NA } & \multirow[b]{2}{*}{ NA } & \multirow[b]{2}{*}{ NA } & \multirow[b]{2}{*}{54.5} & \multirow[b]{2}{*}{0.5000} & \multirow[b]{2}{*}{1.6000} & & \\
\hline 11 & 0.5000 & 7.3000 & 0.5000 & & & & & & & NONPARAMETRIC & 2 \\
\hline NITRITE A & ND NITRATE & & $M G / L$ & & & & & & & & \\
\hline 4 & 0.2000 & 1.6400 & 0.5000 & NA & NA & NA & 25.0 & 0.2000 & 1.6400 & NONPARAMETRIC & 2,4 \\
\hline PH & & & su & & & & & & & & \\
\hline 14 & 6.8900 & 7.6600 & 7.1650 & NA & NA & NA & 0.0 & NA & MA & UNKNOWN & \\
\hline PHOSPHATE & & & $M G / L$ & & & & & & & & \\
\hline 8 & $\star \star \quad 0.1000$ & 0.1000 & 0.1000 & NA & NA & NA & 87.5 & 0.1000 & 0.1000 & NONPARAMETRIC & 2 \\
\hline POLONIUA- & 210 & & $\mathrm{PCI} / \mathrm{L}$ & & & & & & & & \\
\hline 2 & $\star \star \quad 1.0000$ & 1.0000 & $\star \quad \quad 1.0000$ & NA & NA & NA & 0.0 & NA & MA & UNKNOWN & 1 \\
\hline POTASSIUM & & & $M G / L$ & & & & & & & & \\
\hline 11 & 3.3000 & 6.0800 & 3.9600 & 4.1727 & 0.7603 & 0.1822 & 0.0 & 3.5391 & 4.8063 & NORMAL & \\
\hline RADIUA-22 & & & $\mathrm{PCI} / \mathrm{L}$ & & & & & & & & \\
\hline 6 & $\neq \quad 0.2000$ & 0.4000 & $\star \quad 0.2000$ & NA & MA & NA & 0.0 & 0.2000 & 0.4000 & MONPARAMETRIC & 9,6 \\
\hline
\end{tabular}

*** NET GROSS ALPHA (GROSS ALPHA - URANIUM) WITH 1 MG URANIUM = 686 PCI

* The reported value is the minimum detection limit of the data set

+ The sample size is even, so the median value is the arithmetic average of the two middle values

* The statistical maximm is the 99 percent one sided confidence interval, $a=0.01$

1) A minimum of 4 samples must be available for the statistical analysis.

2) The nonparametric distribution was used because the nondetected values comprise more than $15 \%$ of the samples.

4) The stat. range is the $87.5 \%$ confidence interval due to a sample size of 4 . The maximm is the $93.8 \%$ one sided confidence int.

6) The stat. range is the $96.9 \%$ confidence interval due to a sample size of 6 . The maximm is the $98.5 \%$ one sided confidence int.

9) The nonparametic distribution was used because the data failed the normal distribution test and includes values $\leq 0$. 
TABLE 3.6 BACKGROUND GROUNDWATER QUALITY STATISTICS BY PARAMETER

FOR THE ALLUVIUM, NC PROCESSING SITE, SLICK ROCK, COLORADO

SITE: SRKO1 SLICK ROCK (BOTH SITES)

$07 / 01 / 86$ TO $10 / 09 / 92$

REPORT DATE : $07 / 26 / 93$

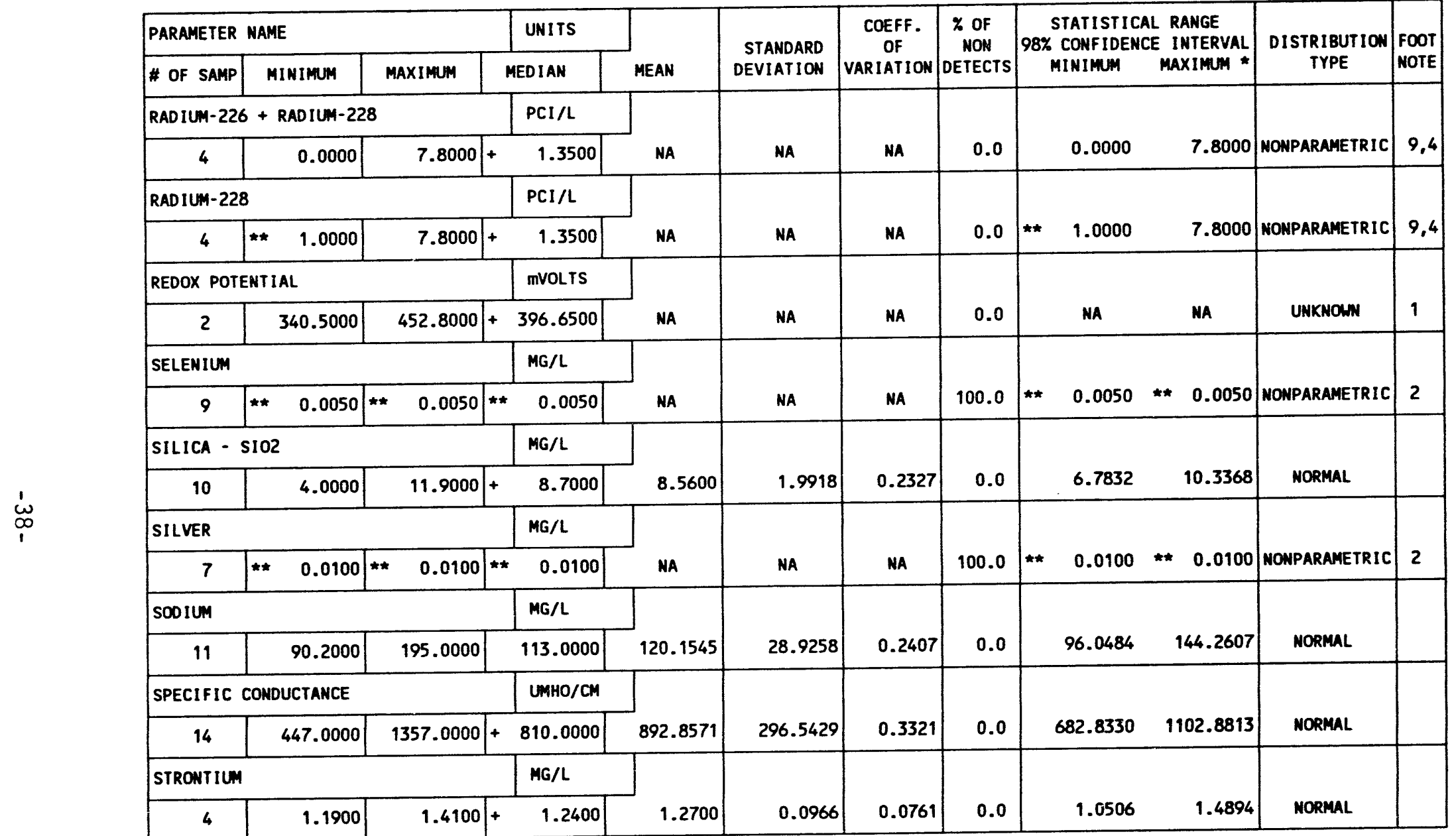

** The reported value is the minimum detection limit of the data set

- The sample size is even, so the median value is the arithmetic average of the two middle values

* The statistical maximm is the 99 percent one sided confidence interval, $a=0.01$

1) A minimum of 4 samples must be available for the statistical analysis.

2) The nonparametric distribution was used because the nondetected values comprise more than $15 \%$ of the samples.

4) The stat. range is the $87.5 \%$ confidence interval due to a sample size of 4 . The maximum is the $93.8 \%$ one sided confidence int.

9) The nonparametic distribution was used because the data failed the normal distribution test and includes values $\leq 0$. 
TABLE 3.6 BACKGROUND GROUNDWATER QUALITY STATISTICS BY PARAMETER FOR THE ALLUVIUM, NC PROCESSING SITE, SLICK ROCK, COLORADO

SITE: SRKO1 SLICK ROCK (BOTH

07/01/86 TO 10/09/92

REPORT DATE: $07 / 26 / 93$

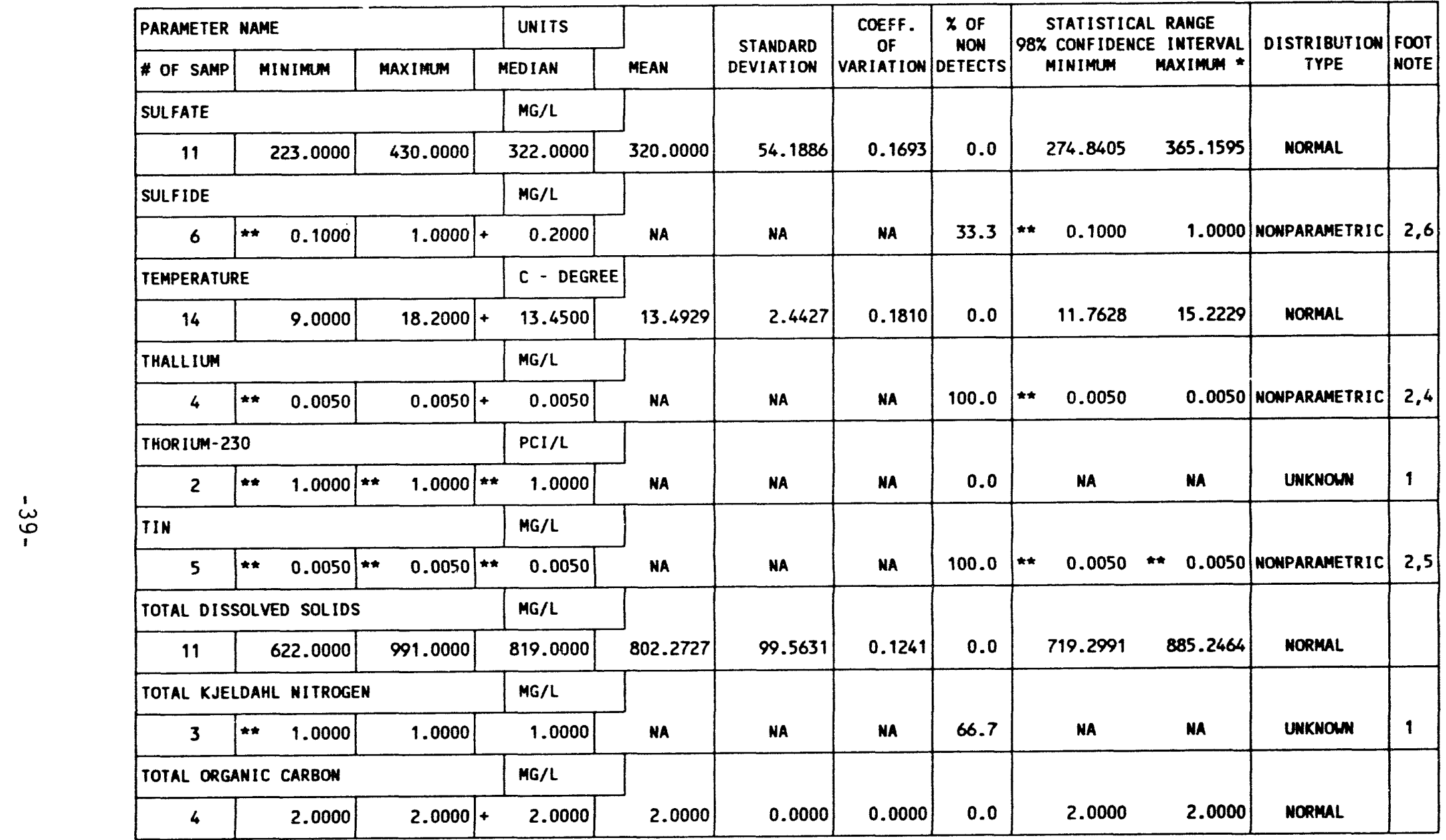

** The reported value is the minimum detection limit of the data set

- The sample size is even, so the median value is the arithmetic average of the two middle values

- The statistical maximm is the 99 percent one sided confidence interval, $a=0.01$

1) A minimum of 4 samples must be available for the statistical analysis.

2) The nonparametric distribution was used because the nondetected values comprise more thar $15 \%$ of the samples.

4) The stat. range is the $87.5 \%$ confidence interval due to a sample size of 4 . The maximum is the $93.8 \%$ ore sided confidence int.

5) The stat. range is the $93.8 \%$ confidence interval due to a sample size of 5 . The maximm is the 96.97 one sided confidence int.

6) The stat. range is the $96.9 \%$ confidence interval due to a sample size of 6 . The maximum is the $98.5 \%$ one sided confidence int. 
TABLE 3.6 BACKGROUND GROUNDWATER QUALITY STATISTICS BY PARAMETER

FOR THE ALLUVIUM, NC PROCESSING SITE, SLICK ROCK, COLORADO

SITE: SRKO1 SLICK ROCK (BOTH SITES)

$07 / 01 / 86$ TO $10 / 09 / 92$

REPORT DATE: $07 / 26 / 93$

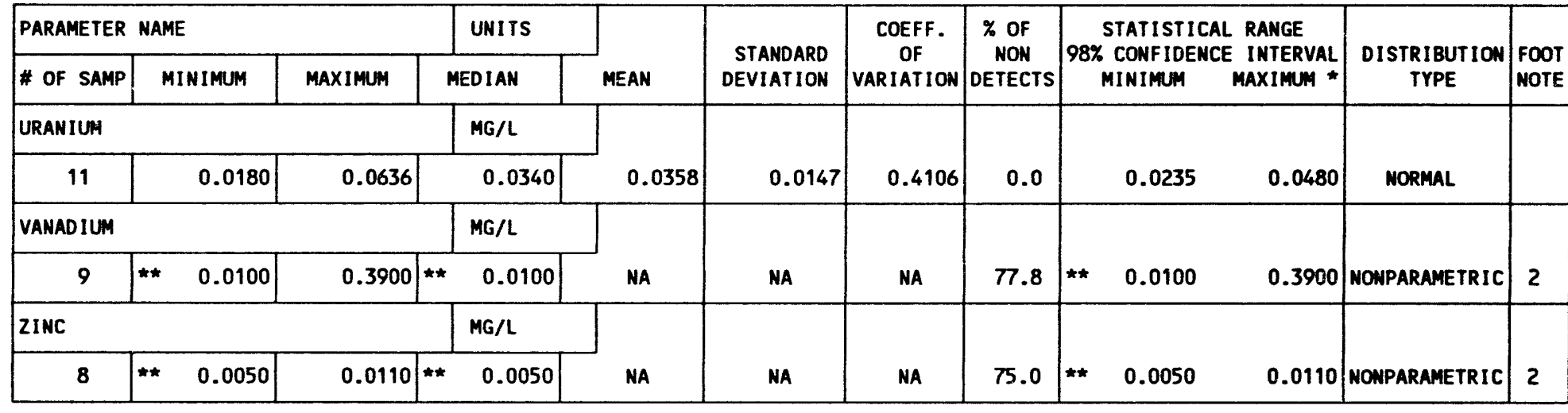

** The reported value is the minimum detection limit of the data set

* The statistical maximm is the 99 percent one sided confidence interval, $a=0.01$

2) The nonparametric distribution was used because the nondetected values comprise more than $15 \%$ of the samples.

INPUT DATA FILENAME: M: IDARTISRKO1IGWQ10031.DAT 
Table 3.7 Summary of regulated constituents in alluvial background groundwater, NC processing site, Slick Rock, Colorado

\begin{tabular}{|c|c|c|c|}
\hline \multicolumn{4}{|c|}{ Constituents with MCLsa } \\
\hline Parameter & MCLs & $\begin{array}{l}\text { Mean or } \\
\text { Median }\end{array}$ & $\begin{array}{c}\text { statistical } \\
\text { maximum }\end{array}$ \\
\hline Arsenic & 0.05 & $0.01^{\mathrm{c}}$ & $0.01^{\mathrm{e}}$ \\
\hline Barium & 1.00 & $0.1^{e}$ & 0.2 \\
\hline Cadmium & 0.01 & $0.001^{\mathrm{e}}$ & $0.001^{e}$ \\
\hline Chromium & 0.05 & $0.01^{\mathrm{e}}$ & 0.04 \\
\hline Net gross alphab & 15.0 & -0.42 & 4.72 \\
\hline Lead & 0.05 & $0.01^{\circ}$ & $0.01^{e}$ \\
\hline Mercury & 0.002 & $0.0002^{e}$ & $0.0002^{e}$ \\
\hline Molybdenum & 0.10 & $0.0855^{d}$ & 0.133 \\
\hline Nitrate & 44.0 & 0.50 & 1.6 \\
\hline Radium-226 and $-228^{b}$ & 5.00 & 1.35 & 7.80 \\
\hline Selenium & 0.01 & $0.005^{\mathrm{e}}$ & $0.005^{\mathrm{c}}$ \\
\hline Silver & 0.05 & $0.01^{\mathrm{e}}$ & $0.01^{c}$ \\
\hline Uranium & 0.044 & $0.036^{\mathrm{d}}$ & 0.048 \\
\hline
\end{tabular}


Table 3.7 Summary of regulated constituents in alluvial background groundwater, NC processing site, Slick Rock, Colorado (concluded)

Constituents without MCLs"

\begin{tabular}{|c|c|c|}
\hline Parameter & $\begin{array}{l}\text { Mean or } \\
\text { Median }\end{array}$ & $\begin{array}{l}\text { Statistical } \\
\text { maximum }\end{array}$ \\
\hline Antimony & $0.003^{\mathrm{e}}$ & $0.003^{e}$ \\
\hline Beryllium & $0.01^{\mathrm{e}}$ & $0.01^{e, f}$ \\
\hline Cobalt & $0.05^{\circ}$ & $0.05^{\mathrm{e}, \mathrm{f}}$ \\
\hline Copper & $0.02^{\mathrm{e}}$ & 0.05 \\
\hline Cyanide & $0.01^{\mathrm{c}}$ & $0.01^{e, f}$ \\
\hline Nickel & $0.04^{\mathrm{c}}$ & $0.04^{e}$ \\
\hline Sulfide & 0.20 & 1.00 \\
\hline Thallium & $0.01^{e}$ & $0.01^{e}$ \\
\hline Tin & $0.005^{\mathrm{e}}$ & $0.005^{\mathrm{e}}$ \\
\hline Vanadium & $0.01^{\mathrm{e}}$ & 0.39 \\
\hline Zinc & $0.005^{\mathrm{e}}$ & 0.011 \\
\hline
\end{tabular}

"All units are $\mathrm{mg} / \mathrm{l}$ unless otherwise noted.

buits are $\mathrm{pCi} / \mathrm{l}$.

'Mean value, Lognormal distribution, mean is geometric.

Mean value, Normal distribution, mean is arithmetic.

'Statistical values are below laboratory detection limits in

Table 8.1 of the Technical Approach Document (DOE, 1989).

$f$ Value is an observed maximum, rather than a statistical maximum, because less than four samples were available for statistical analysis. 
TABLE 3.8 GROUNDUATER OUALITY MEASUREMENTS EXCEEDING MAXIMM CONCENTRATION IMITS IN ALLUVIAL BACKGROUND GROUMDHATER, NC\&UC PROCESSIMG SITE SLICK ROCK SITE: SRKOI SLICK ROCK (BOTH SITES)

$07 / 01 / 86$ TO $10 / 13 / 92$

REPORT DATE: 06/17/93

\begin{tabular}{|c|c|c|c|c|c|c|c|c|c|c|c|}
\hline PARAMETER NAME & $\begin{array}{l}\text { TOTAL } \\
\text { \# OF } \\
\text { SAMP. }\end{array}$ & $\begin{array}{l}\text { UNITS } \\
\text { OF } \\
\text { MEASURE }\end{array}$ & $\begin{array}{l}\text { MAXIMUM } \\
\text { CONC. } \\
\text { LIMIT }\end{array}$ & LOC. & LOG DATE & $\begin{array}{c}\text { SAMP } \\
\text { ID }\end{array}$ & $\begin{array}{l}\text { FORM } \\
\text { OF } \\
\text { COMP }\end{array}$ & $\begin{array}{l}\text { HYOR } \\
\text { FLOW } \\
\text { REL. }\end{array}$ & $\begin{array}{c}\text { RESULT EXCEEDING MaX. } \\
\text { CONCENTRATION LIMIT } \\
\text { VALUE } \\
\text { FLAGS }\end{array}$ & $\begin{array}{l}\text { DETECTIOH } \\
\text { LIMIT }\end{array}$ & $\begin{array}{l}\text { PARAMETER } \\
\text { UMCERT. }\end{array}$ \\
\hline ARSENIC & 15 & $M G / L$ & 0.0500 & - & - & $\cdot$ & - & - & $\cdot$ & $\cdot$ & $\cdot$ \\
\hline ARSENIC (TOTAL) & 0 & MG/L & 0.0500 & - & - & - & - & - & - & $\cdot$ & - \\
\hline BARIUM & 14 & $M G / L$ & 1.0000 & $\cdot$ & - & - & - & - & - & - & - \\
\hline BARIUM (TOTAL) & 0 & $M G / L$ & 1.0000 & - & - & $\cdot$ & - & - & - & - & - \\
\hline CADMIUM & 14 & $M G / L$ & 0.0100 & - & - & - & - & - & - & - & - \\
\hline CADMIUM (TOTAL) & 0 & $M G / L$ & 0.0100 & - & - & $\cdot$ & $\cdot$ & - & - & - & - \\
\hline CHRONIUM & 14 & $\mathrm{MG} / \mathrm{L}$ & 0.0500 & 0505 & $07 / 17 / 86$ & 0001 & AL & 0 & 0.07 & 0.01 & - \\
\hline CHROMIUM (TOTAL) & 0 & $M G / L$ & 0.0500 & - & - & - & - & - & - & - & - \\
\hline GROSS ALPHA & 7 & $\mathrm{PCI} / \mathrm{L}$ & 15.0000 & $\begin{array}{l}0501 \\
0501 \\
0505\end{array}$ & $\begin{array}{l}03 / 29 / 91 \\
10 / 09 / 92 \\
03 / 27 / 91\end{array}$ & {$\left[\begin{array}{l}0001 \\
0001 \\
0001\end{array}\right]$} & $\begin{array}{l}\text { AL } \\
\text { AL } \\
\text { AL }\end{array}$ & $\begin{array}{l}0 \\
0 \\
0\end{array}$ & $\begin{array}{l}20.5 \\
17.0 \\
23.6\end{array}$ & $\begin{array}{c}1 . \\
12.2 \\
1 .\end{array}$ & $\begin{array}{r}9.0 \\
9.2 \\
13.5\end{array}$ \\
\hline GROSS ALPHA (TOTAL) & 0 & $\mathrm{PCI} / \mathrm{L}$ & 15.0000 & - & - & $\cdot$ & - & - & - & - & - \\
\hline LEAD & 14 & $M G / L$ & 0.0500 & - & - & $\cdot$ & - & - & - & - & - \\
\hline LEAD (TOTAL) & 0 & $M G / L$ & 0.0500 & - & - & - & - & - & - & - & - \\
\hline MERCURY & 12 & $M G / L$ & 0.0020 & - & - & - & - & $\cdot$ & - & - & - \\
\hline MERCURY (TOTAL) & 0 & $M G / L$ & 0.0020 & - & - & - & - & - & - & - & - \\
\hline MOL YBDENUM & 18 & $M G / L$ & 0.1000 & $\mid \begin{array}{l}0501 \\
0505 \\
0505 \\
0686 \\
0686 \\
0686\end{array}$ & $\begin{array}{l}07 / 01 / 86 \\
07 / 17 / 86 \\
02 / 22 / 88 \\
07 / 17 / 86 \\
04 / 08 / 87 \\
02 / 22 / 88\end{array}$ & $\left|\begin{array}{l}0001 \\
0001 \\
0001 \\
0001 \\
0001 \\
0001\end{array}\right|$ & $\begin{array}{l}A L \\
A L \\
A L \\
A L \\
A L \\
A L\end{array}$ & $\begin{array}{l}0 \\
0 \\
0 \\
0 \\
0 \\
0\end{array}$ & $\begin{array}{l}0.11 \\
0.14 \\
0.1 \\
0.24 \\
0.1 \\
0.11\end{array}$ & $\begin{array}{l}0.01 \\
0.01 \\
0.01 \\
0.01 \\
0.1 \\
0.01\end{array}$ & $\begin{array}{l}- \\
- \\
- \\
-\end{array}$ \\
\hline
\end{tabular}

< - the data is flagged as a non-detect, so the result is an estimated value or the detection limit

FORMATION OF COMPLETION COOE:

AL - ALLUVIUU

OTHER PARAMETER VALUE FLAGS:

- SPIKE SAMPLE RECOVERY NOT WITHIN CONTROL LIMITS

c - CHANGED DETECTION LIMIT
FLOH RELATIONSHIP COOE:

$$
\text { O - ON-SITE. }
$$

SAMPLE ID CODES:

0001 - FILTERED SAMPLE (.45 MICROWS) 
TABLE 3.8 GROUNDWATER QUALITY MEASUREKENTS EXCEEDING MAXIMUM CONCENTRATION LIMITS IN ALLUVIAL BACKGROUND GROUMDUATER, NC\&UC PROCESSING SITE SLICK ROCK

SITE: SRKO1 SLICK ROCK (BOTH SITES)

07/01/86 TO $10 / 13 / 92$

REPORT DATE: 06/17/93

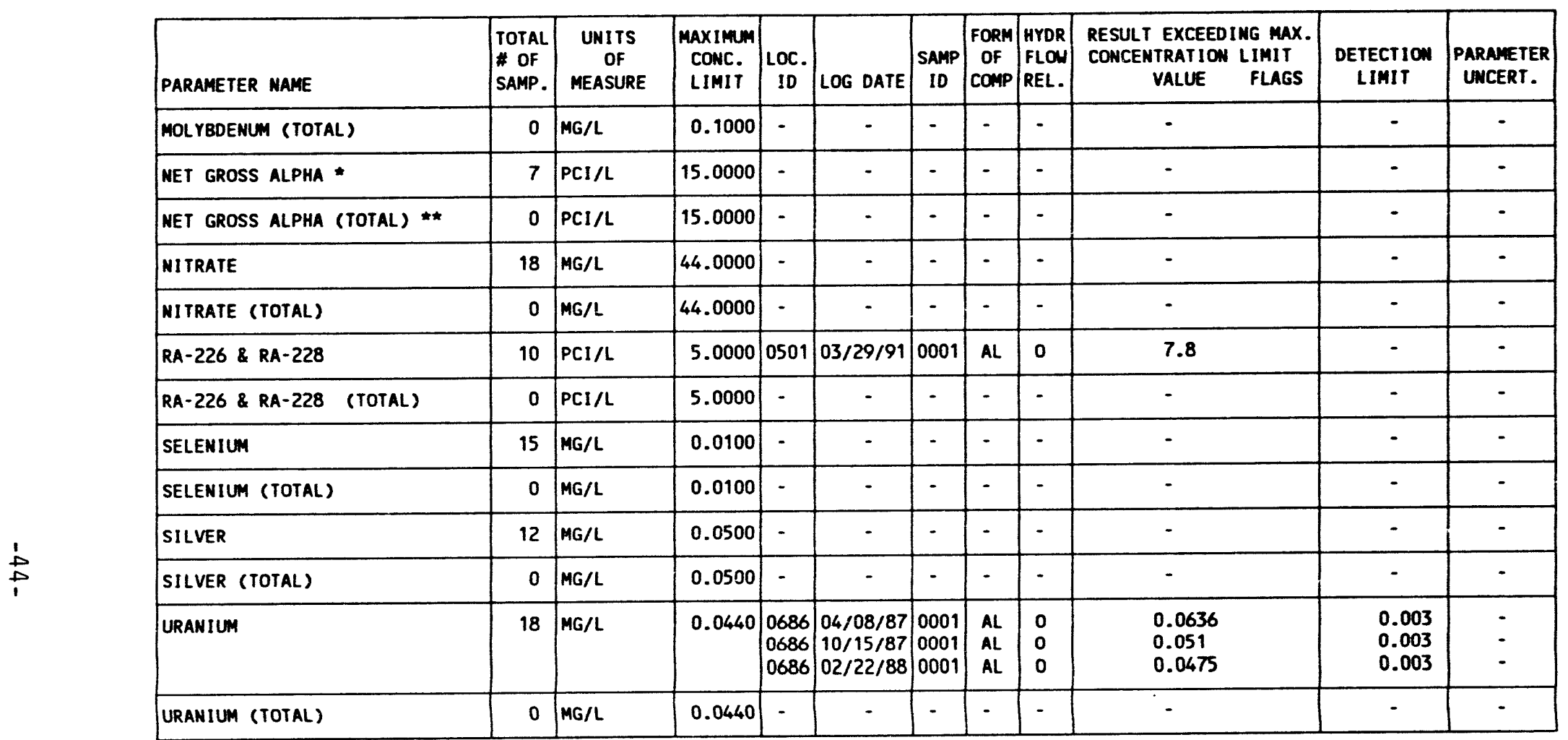

* NET GROSS ALPHA (GROSS ALPHA - URANIUM) WITH 1 MG URANIUM $=686 \mathrm{PCI}$

* total net gross alPHa (TOTAL GROSS ALPHA - tOTAL URANIUM)

FORMATION OF COMPLETION COOE:

AL - ALLUVIUA

DATA FILE NAME: M: IDARTISRK01\GWQ10023.DAT
FLOW RELATIONSHIP COOE:

O- ON-SITE

SAMPLE ID CODES:

0001 - FILTERED SAMPLE (.45 MICRONS) 
TABLE 3.9 BACKGROUND GROUNDHATER OUALITY STATISTICS BY PARAMETER

FOR THE ALLUVIUM, UC PROCESSING SITE, SLICK ROCK, COLORADO

SITE: SRKO1 SLICK ROCK (BOTH SITES)

$07 / 17 / 86$ TO $10 / 13 / 92$

REPORT DATE: $07 / 26 / 93$

\begin{tabular}{|c|c|c|c|c|c|c|c|c|c|c|c|}
\hline \multicolumn{3}{|c|}{ PARAMETER NAME } & UNITS & \multirow[b]{2}{*}{ MEAN } & \multirow{2}{*}{$\begin{array}{r}\text { STANDARD } \\
\text { DEVIATION }\end{array}$} & \multirow{2}{*}{$\begin{array}{c}\text { COEFF. } \\
\text { OF } \\
\text { VARIATION }\end{array}$} & \multirow{2}{*}{$\begin{array}{c}\% \text { OF } \\
\text { NON } \\
\text { DETECTS }\end{array}$} & \multirow{2}{*}{\multicolumn{2}{|c|}{$\begin{array}{c}\text { STATISTICAL RANGE } \\
\text { 98\% CONFIDENCE INTERVAL } \\
\text { MINIMU MAXIMUM * }\end{array}$}} & \multirow{2}{*}{$\begin{array}{c}\text { DISTRIBUTION } \\
\text { TYPE }\end{array}$} & \multirow{2}{*}{$\begin{array}{l}\text { FOOT } \\
\text { MOTE }\end{array}$} \\
\hline \# OF SAMP & MINIMUM & MAXIMUM & MEDIAN & & & & & & & & \\
\hline \multicolumn{3}{|c|}{ ALKALINITY } & MG/L CACO & \multirow[b]{2}{*}{287.8571} & \multirow[b]{2}{*}{24.7685} & \multirow[b]{2}{*}{0.0860} & \multirow[b]{2}{*}{0.0} & \multirow[b]{2}{*}{258.4336} & \multirow[b]{2}{*}{317.2806} & \multirow[b]{2}{*}{ NORMAL } & \\
\hline 7 & 243.0000 & 320.0000 & 289.0000 & & & & & & & & \\
\hline \multicolumn{3}{|l|}{ ALUMINUM } & $\mathrm{MG} / \mathrm{L}$ & \multirow[b]{2}{*}{ NA } & \multirow[b]{2}{*}{ NA } & \multirow[b]{2}{*}{ NA } & \multirow[b]{2}{*}{71.4} & \multirow[b]{2}{*}{$0.050 \overline{\mathrm{u}}$} & \multirow[b]{2}{*}{0.2000} & \multirow[b]{2}{*}{ NONPARAMETRIC } & \multirow[b]{2}{*}{2} \\
\hline 7 & $\star \quad 0.0500$ & 0.2000 & 0.0500 & & & & & & & & \\
\hline \multicolumn{3}{|l|}{ ArminONIUM } & $M G / L$ & \multirow[b]{2}{*}{3.7143} & \multirow[b]{2}{*}{1.3272} & \multirow[b]{2}{*}{0.3573} & \multirow[b]{2}{*}{0.0} & \multirow[b]{2}{*}{2.1377} & & & \\
\hline 7 & 1.3000 & 5.2000 & 4.0000 & & & & & & 5.2909 & NORMAL & \\
\hline ANTIMONY & & & $\mathrm{MG} / \mathrm{L}$ & & & & & & & & \\
\hline 5 & $\star \star \quad 0.0030$ & \#* $\quad 0.0030$ & 0.0030 & NA & NA & NA & 100.0 & 0.0030 & $\Rightarrow 0.0030$ & MONPARAMETRIC & 2,5 \\
\hline ARSENIC & & & MG/L & & & & & & & & \\
\hline 6 & ** $\quad 0.0050$ & 0.0050 & 0.0050 & NA & NA & MA & 100.0 & 0.0050 & 0.0050 & NONPARAMETRIC & 2,6 \\
\hline BARIUM & & & $M G / L$ & & & & & & & & \\
\hline 6 & 0.0300 & 0.1000 & 0.0400 & NA & NA & NA & 33.3 & 0.0300 & 0.1000 & MONPARAMETRIC & 2,6 \\
\hline BERYLLIUM & & & $M G / L$ & & & & & & & & \\
\hline 3 & $\begin{array}{ll}* & 0.0050\end{array}$ & 0.0050 & 0.0050 & NA & MA & NA & 100.0 & MA & NA & UNKNOWN & 1 \\
\hline BORON & & & $M G / L$ & & & & & & & & \\
\hline 5 & 0.0500 & 0.3000 & 0.2700 & NA & NA & NA & 20.0 & 0.0500 & 0.3000 & NONPARAMETRIC & 2,5 \\
\hline BROMIDE & & & $M G / L$ & & & & & & & & \\
\hline 3 & $\star * \quad 0.1000$ & 0.2500 & 0.2000 & NA & NA & NA & 66.7 & MA & NA & UNKNOWN & 1 \\
\hline
\end{tabular}

** The reported value is the minimum detection limit of the data set

+ The sample size is even, so the median value is the arithmetic average of the two middle values

the sample size is even, so the median value is the arithmete interval, $a=0.01$

1) A minimum of 4 samples must be available for the statistical analysis.

2) The nomparametric distribution was used because the nondetected values comprise more than 15\% of the samples.

5) The stat. range is the $93.8 \%$ confidence interval due to a sample size of 5 . The maximm is the $96.9 \%$ one sided confidence int.

6) The stat. range is the $96.9 \%$ confidence interval due to a sample size of 6 . The maximm is the $98.5 \%$ one sided confidence int. 
TABLE 3.9 BACKGROUND GROUMDHATER OUALITY STATISTICS BY PARAMETER

FOR THE ALLUVIUM, UC PROCESSING SITE, SLICK ROCK, COLORADO

SITE: SRKO1 SLICK ROCK (BOTH SITES)

$07 / 17 / 86$ TO $10 / 13 / 92$

REPORT DATE : 07/26/93

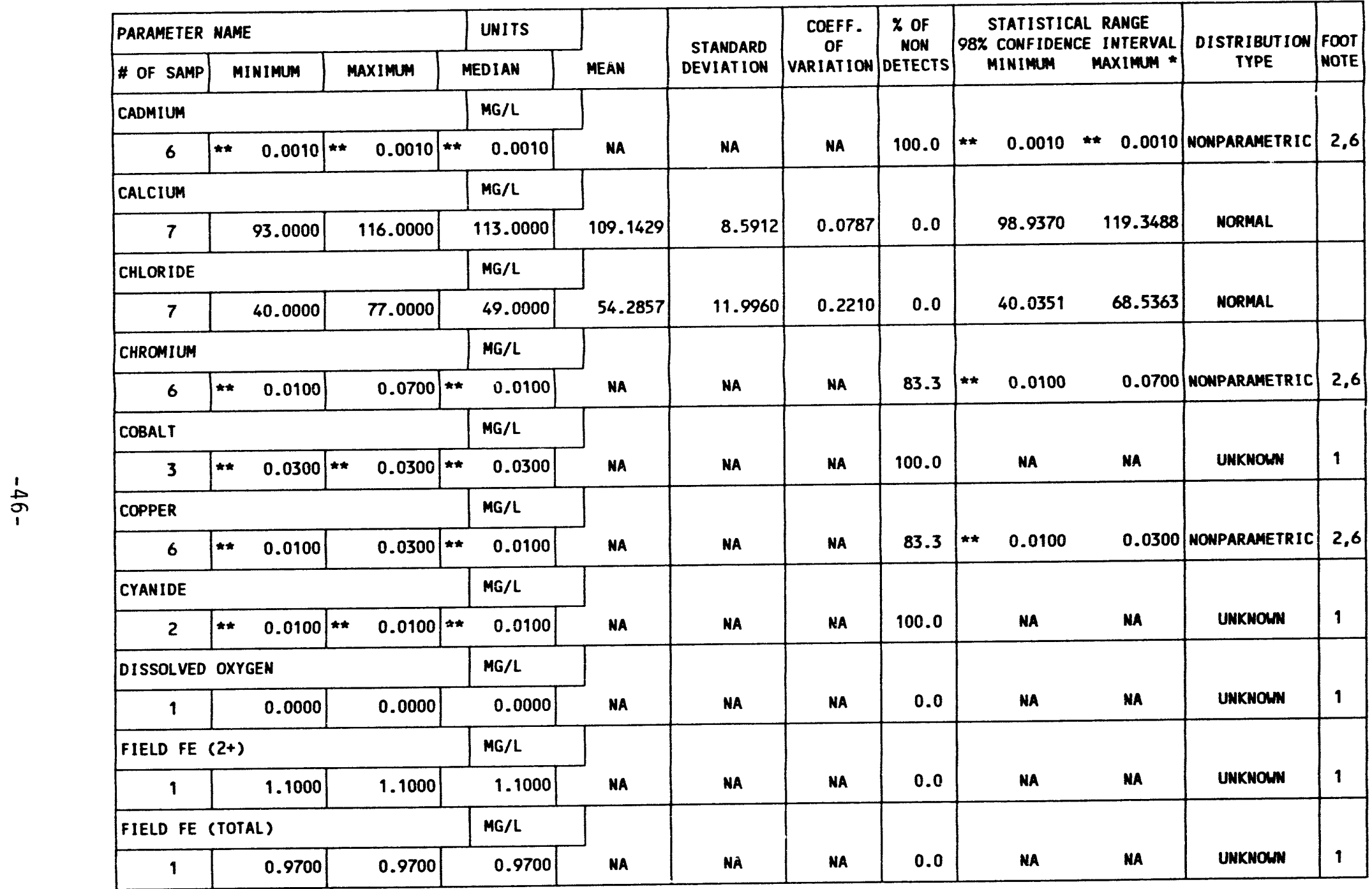

** The reported value is the minimum detection limit of the data set

* The statistical maximm is the 99 percent one sided confidence interval, $a=0.01$

1) A minimum of 4 samples must be available for the statistical analysis.

1) A minimum of 4 samples must be available for

2) The nonparametric distribution was used because the nondetected values comprise more than is\% of the samples. 
TABLE 3.9 BACKGROUND GROUNDWATER QUALITY STATISTICS BY PARAMETER

FOR THE ALLUVIUM, UC PROCESSING SITE, SLICK ROCK, COLORADO

SITE: SRKO1 SLICK ROCK (BOTH SITES)

$07 / 17 / 86$ TO $10 / 13 / 92$

REPORT DATE: $07 / 26 / 93$

\begin{tabular}{|c|c|c|c|c|c|c|c|c|c|c|c|}
\hline \multicolumn{3}{|c|}{ PARAMETER NAME } & UNITS & \multirow[b]{2}{*}{ MEAN } & \multirow{2}{*}{$\begin{array}{l}\text { STANDARD } \\
\text { DEVIATION }\end{array}$} & \multirow{2}{*}{$\begin{array}{c}\text { COEFF. } \\
\text { OF } \\
\text { VARIATION }\end{array}$} & \multirow{2}{*}{$\mid \begin{array}{c}x \text { OF } \\
\text { NON } \\
\text { DETECTS }\end{array}$} & \multirow{2}{*}{\multicolumn{2}{|c|}{$\begin{array}{c}\text { STATISTICAL RANGE } \\
\text { 98\% CONFIDENCE INTERVAL } \\
\text { MINIMUM MAXIMUM }\end{array}$}} & \multirow{2}{*}{$\begin{array}{c}\text { DISTRIBUTIOH } \\
\text { TYPE }\end{array}$} & \multirow{2}{*}{$\begin{array}{l}\text { FOOT } \\
\text { MOTE }\end{array}$} \\
\hline \# OF SAMP & MINIMUM & MAXIMUM & MEDIAN & & & & & & & & \\
\hline \multicolumn{3}{|l|}{ FLUORIDE } & MG/L & \multirow[b]{2}{*}{0.2686} & \multirow[b]{2}{*}{0.0474} & \multirow[b]{2}{*}{0.1765} & \multirow[b]{2}{*}{0.0} & \multirow[b]{2}{*}{0.2123} & \multirow[b]{2}{*}{0.3249} & \multirow[b]{2}{*}{ NORMAL } & \\
\hline 7 & 0.2000 & 0.3000 & 0.3000 & & & & & & & & \\
\hline \multicolumn{3}{|c|}{ GROSS ALPHA } & $\mathrm{PCI} / \mathrm{L}$ & \multirow[b]{2}{*}{ NA } & \multirow[b]{2}{*}{ NA } & \multirow[b]{2}{*}{ NA } & \multirow[b]{2}{*}{0.0} & \multirow[b]{2}{*}{ MA } & \multirow[b]{2}{*}{ MA } & \multirow[b]{2}{*}{ UNKNOWN } & \multirow[b]{2}{*}{1} \\
\hline 3 & $\star \quad 1.0000$ & 23.6000 & 7.7000 & & & & & & & & \\
\hline \multicolumn{3}{|l|}{ GROSS BETA } & $\mathrm{PCI} / \mathrm{L}$ & \multirow[b]{2}{*}{ NA } & \multirow[b]{2}{*}{ NA } & \multirow[b]{2}{*}{ NA } & \multirow[b]{2}{*}{0.0} & \multirow[b]{2}{*}{ MA } & \multirow[b]{2}{*}{ NA } & \multirow[b]{2}{*}{ UNKNOWH } & \\
\hline 3 & $\star \quad 0.5000$ & 16.6000 & 8.5000 & & & & & & & & 1 \\
\hline IRON & & & MG/L & & & & & & & & \\
\hline 7 & 0.1200 & 0.9200 & 0.3900 & 0.4614 & 0.2773 & 0.6010 & 0.0 & 0.1320 & 0.7909 & NORMAL & \\
\hline LEAD & & & $M G / L$ & & & & & & & & \\
\hline 6 & $\approx \quad 0.0050$ & 0.0100 & 0.0050 & Nâ & NA & NA & 100.0 & 0.0050 & 0.0100 & MOMPARAMETRIC & 2,6 \\
\hline LEAD - 210 & & & $\mathrm{PCI} / \mathrm{L}$ & & & & & & & & \\
\hline 2 & $\star \quad 1.5000$ & 2.9000 & 1.8000 & NA & NA & NA & 0.0 & . MA & NA & UNKNOWN & 1 \\
\hline MAGNESIUM & & & $M G / L$ & & & & & & & & \\
\hline 7 & 41.0000 & 55.0000 & 48.9000 & 48.8143 & 4.5517 & 0.0932 & 0.0 & 43.4071 & 54.2215 & NORMAL & \\
\hline MANGANESE & & & $M G / L$ & & & & & & & & \\
\hline 7 & 0.2200 & 0.3900 & 0.3700 & 0.3329 & 0.0725 & 0.2178 & 0.0 & 0.2467 & 0.4190 & NORMAL & \\
\hline MERCURY & & & MG/L & & & & & & & & \\
\hline 5 & $\star \quad * \quad 0.0002$ & $\star \quad 0.0002$ & 0.0002 & MA & NA & MA & 100.0 & 0.0002 & $\star 0.0002$ & NONPARAMETRIC & 2,5 \\
\hline
\end{tabular}

* The reported value is the minimum detection limit of the data set

+ The sample size is even, so the median value is the arithmetic average of the two middle values

* The statistical maximm is the 99 percent one sided confidence interval, $a=0.01$

1) A minimm of 4 samples must be available for the statistical analysis.

2) The nomparametric distribution was used because the nondetected values comprise more than $15 \%$ of the samples.

5) The stat. range is the $93.8 \%$ confidence interval due to a sample size of 5 . The maximm is the $96.9 \%$ one sided confidence int.

6 ) The stat. range is the $96.9 \%$ confidence interval due to a sample size of 6 . The maximm is the $98.5 \%$ one sided confidence int.

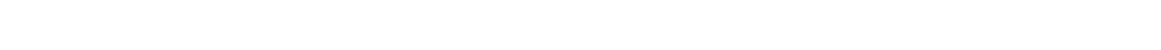


TABLE 3.9 BACKGROUND GROUNDWATER QUALITY STATISTICS BY PARAMETER

FOR THE ALLUVIUM, UC PROCESSING SITE, SLICK ROCK, COLORADO

SITE: SRKO1 SLICK ROCK (BOTH SITES

$07 / 17 / 86$ TO $10 / 13 / 92$

REPORT DATE: $07 / 26 / 93$

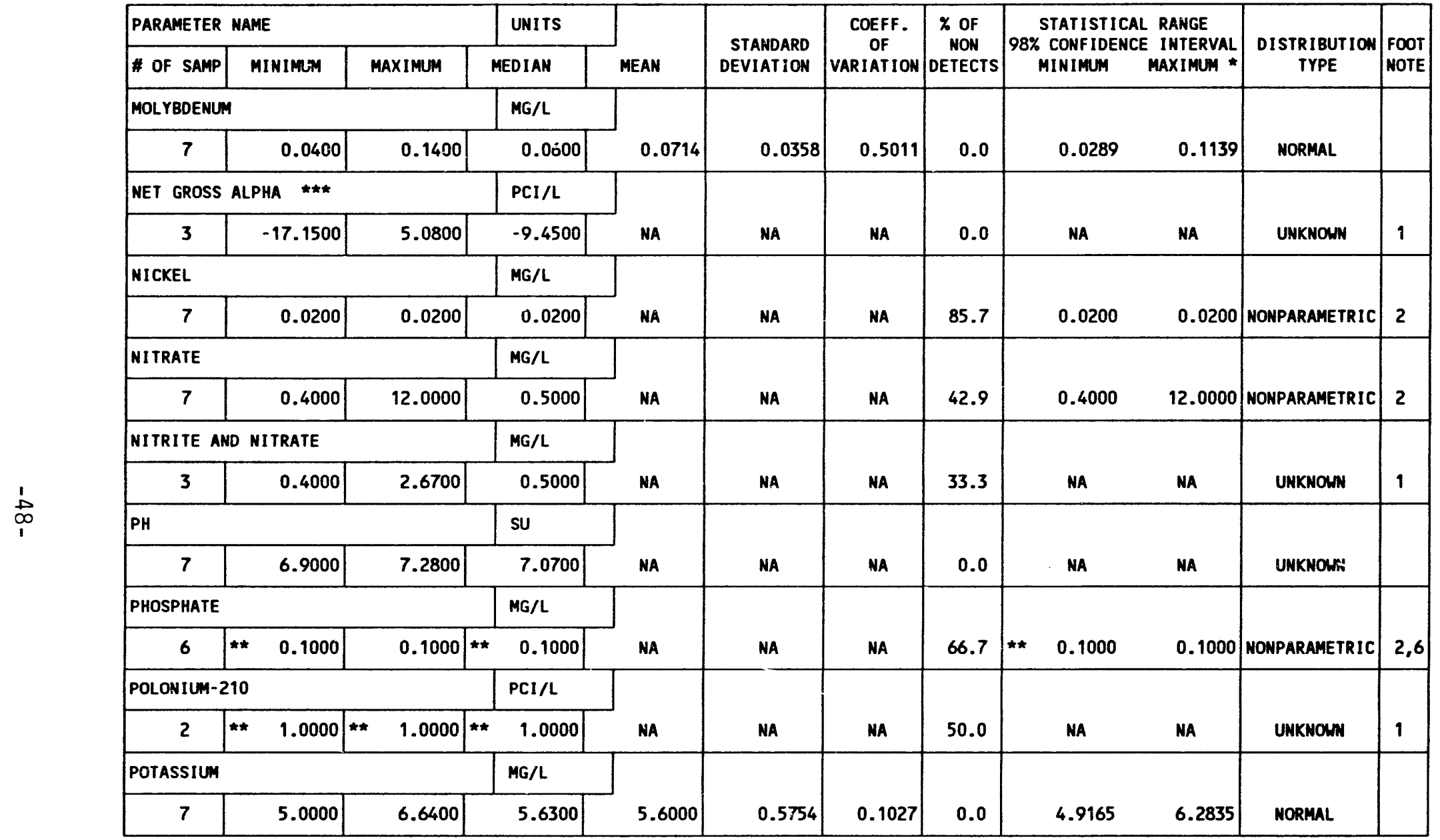

*** NET GROSS ALPHA (GROSS ALPHA - URANIUM) WITH 1 MG URANIUM $=686 \mathrm{PCI}$

* The reported value is the minimum detection limit of the data set

* The statistical maximum is the 99 percent one sided confidence interval, $\alpha=0.01$

1) A minimum of 4 samples must be available for the statistica! analysis.

2) The nonparametric distribution was used because the nondetected values comprise more than $15 \%$ of the samples.

6) The stat. range is the $96.9 \%$ confidence interval due to a sample size of 6 . The maximu is the $98.5 \%$ one sided confidenze int. 
TABLE 3.9 BACKGROUND GROUNOWATER QUALITY STATISTICS BY PARAMETER

FOR THE ALLUVIUM, UC PROCESSING SITE, SLICK ROCK, COLORADO

SITE SRKO1 SLICK ROCK (BOTH SITES)

$07 / 17 / 86$ TO $10 / 13 / 92$

REPORT DATE : $07 / 26 / 93$

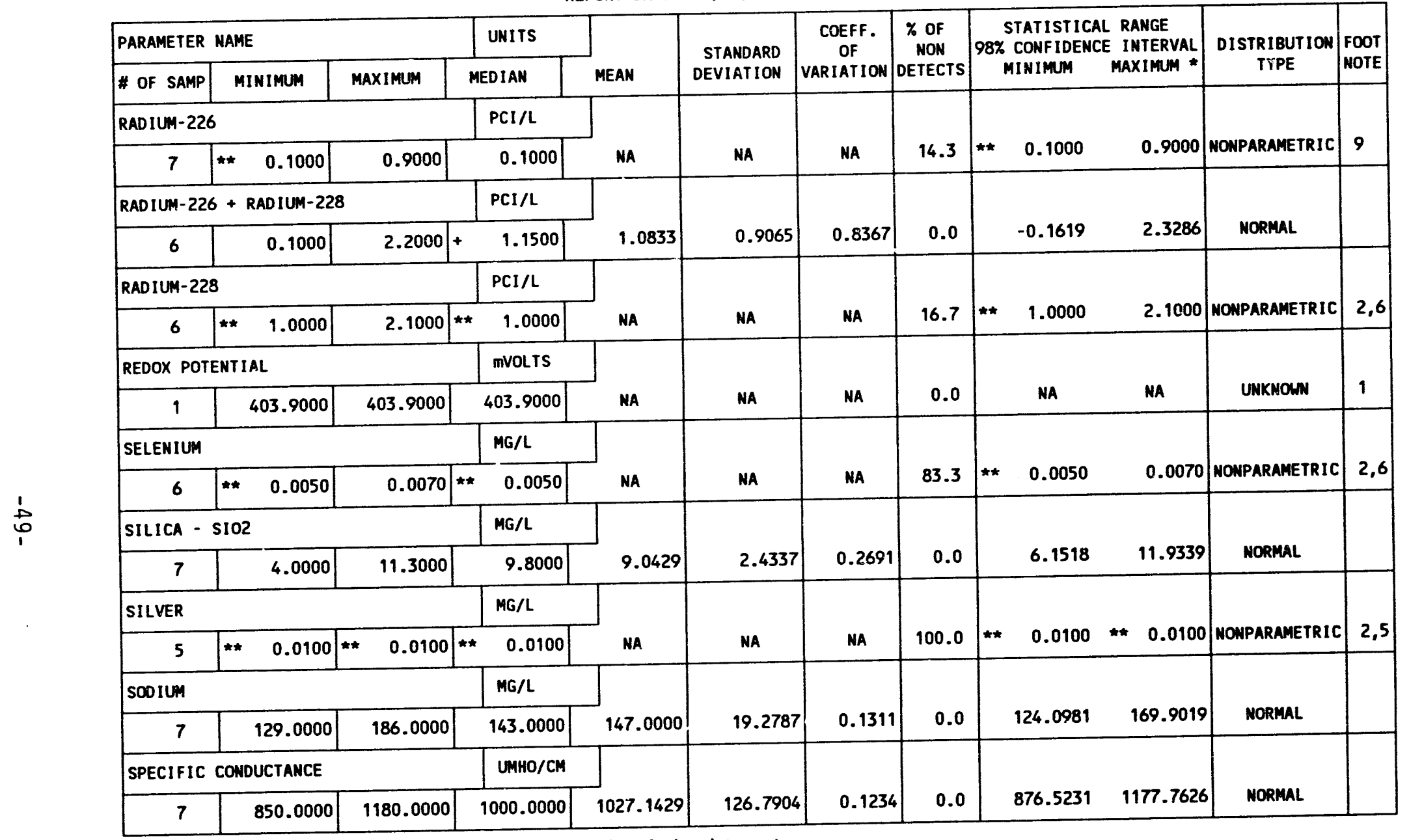

* The reported value is the minimm detection limit of the data set

The reported value is the minimun detection limit of the two middle values

+ The sample size is even, so the median value is the arithidence interval, $\alpha=0.01$

1) The atistical maximm is the 99 percent one sided confidence intysis.

2) A

The

作

6) The stat. range is the $96.9 \%$ confidence because the data failed the normal distribution test and includes values $\leq 0$. 
TABLE 3.9 BACKGROUND GROUNDWATER QUALITY STATISTICS BY PARAMETER

FOR THE ALLUVIUM, UC PROCESSING SITE, SLICK ROCK, COLORADO

SITE: SRKO1 SLICK ROCK (BOTH

$07 / 17 / 86$ TO $10 / 13 / 92$

REPORT DATE: $07 / 26 / 93$

\begin{tabular}{|c|c|c|c|c|c|c|c|c|c|c|c|}
\hline \multicolumn{3}{|c|}{ PARAMETER NAME } & UNITS & \multirow[b]{2}{*}{ MEAN } & \multirow{2}{*}{$\begin{array}{l}\text { STANDARD } \\
\text { DEVIATIION }\end{array}$} & \multirow{2}{*}{$\begin{array}{c}\text { COEFF. } \\
\text { OF } \\
\text { VARIATION }\end{array}$} & \multirow{2}{*}{$\begin{array}{c}\% \text { OF } \\
\text { NON } \\
\text { DETECTS }\end{array}$} & \multirow{2}{*}{\multicolumn{2}{|c|}{$\begin{array}{l}\text { STATISTICAL RANGE } \\
\text { 98\% CONF IDENCE INTERVAL } \\
\text { MINIMUM MAXIMUN * }\end{array}$}} & \multirow{2}{*}{$\begin{array}{c}\text { DISTRIBUTION } \\
\text { TYPE }\end{array}$} & \multirow{2}{*}{$\begin{array}{l}\text { FOOT } \\
\text { NOTE }\end{array}$} \\
\hline \# OF SAMP & MINIMUM & MAXIMUM & MEDIAN & & & & & & & & \\
\hline \multicolumn{3}{|l|}{ STRONTIUM } & $M G / L$ & \multirow[b]{2}{*}{1.3250} & \multirow[b]{2}{*}{0.0412} & \multirow[b]{2}{*}{0.0311} & \multirow[b]{2}{*}{0.0} & \multirow[b]{2}{*}{1.2314} & \multirow[b]{2}{*}{1.4186} & \multirow[b]{2}{*}{ NORMAL } & \\
\hline 4 & 1.2700 & 1.3700 & 1.3300 & & & & & & & & \\
\hline \multicolumn{3}{|l|}{ SULFATE } & $M G / L$ & \multirow[b]{2}{*}{437.2857} & \multirow[b]{2}{*}{53.8229} & \multirow[b]{2}{*}{0.1231} & \multirow[b]{2}{*}{0.0} & \multirow[b]{2}{*}{373.3472} & \multirow[b]{2}{*}{501.2242} & \multirow[b]{2}{*}{ NORMAL } & \\
\hline 7 & 375.0000 & 524.0000 & 422.0000 & & & & & & & & \\
\hline \multicolumn{3}{|l|}{ SULFIDE } & $M G / L$ & \multirow[b]{2}{*}{ NA } & \multirow[b]{2}{*}{ NA } & \multirow[b]{2}{*}{ NA } & \multirow[b]{2}{*}{50.0} & \multirow[b]{2}{*}{0.1000} & \multirow[b]{2}{*}{0.3000} & \multirow[b]{2}{*}{ NONPARAMETRIC } & \\
\hline 4 & $\star \star \quad 0.1000$ & 0.3000 & 0.1750 & & & & & & & & 2,4 \\
\hline TEMPERATU & & & $C-D E G I$ & & & & & & & & \\
\hline 7 & 9.0000 & 13.0000 & 11.5000 & 11.2714 & 1.6337 & 0.1449 & 0.0 & 9.3307 & 13.2122 & NORMAL & \\
\hline THALLIUM & & & $M G / L$ & & & & & & & & \\
\hline 4 & $\star \quad 0.0050$ & 0.0050 & 0.0050 & NA & NA & NA & 100.0 & 0.0050 & 0.0050 & NONPARAMETRIC & 2,4 \\
\hline THORIUM-2? & & & PCI/L & & & & & & & & \\
\hline 2 & $\begin{array}{ll}* & 0.9000\end{array}$ & 1.5000 & 1.0000 & NA & NA & NA & 0.0 & NA & NA & UNKNOWN & 1 \\
\hline TIN & & & $M G / L$ & & & & & & & & \\
\hline 5 & $\star \quad * \quad 0.0050$ & 0.0250 & $\star \star \quad 0.0050$ & NA & NA & NA & 100.0 & 0.0050 & 0.0250 & NONPARAMETRIC & 2,5 \\
\hline TOTAL DISS & SOLVED SOLIDS & & $M G / L$ & & & & & & & & \\
\hline 7 & 875.0000 & 1180.0000 & 993.0000 & 986.0000 & 108.8562 & 0.1104 & 0.0 & 856.6851 & 1115.3149 & NORMAL & \\
\hline TOTAL KJEL & LDAHL NITROGE & & $M G / L$ & & & & & & & & \\
\hline 2 & 2.0000 & 3.0000 & 2.5000 & NA & NA & NA & 0.0 & Ma & MA & UNKNOWN & 1 \\
\hline
\end{tabular}

** The reported value is the minimum detection limit of the data set

+ The sample size is even, so the median value is the arithmetic average of the two middle values

* The statistical maximm is the 99 percent one sided confidence interval, $a=0.01$

1) A minimm of 4 samples must be available for the statistical analysis.

2) The nonparametric distribution was used because the nondetected values comprise more than $15 \%$ of the samples.

4) The stat. range is the $87.5 \%$ confidence interval due to a sample size of 4 . The maximm is the $93.8 \%$ one sided confidence int.

5) The stat. range is the $93.8 \%$ confidence interval due to a sample size of 5 . The maximu is the $96.9 \%$ one sided confidence int. 
TABLE 3.9 BACKGROUMD GROUNDWATER QUALITY STATISTICS BY PARAMETER

FOR THE ALLUVIUM, UC PROCESSING SITE, SLICK ROCK, COLORADO

SITE: SRKOI SLICK ROCK (BOTH SI

$07 / 17 / 86$ TO $10 / 13 / 92$

REPORT DATE: $07 / 26 / 93$

\begin{tabular}{|c|c|c|c|c|c|c|c|c|c|c|c|c|}
\hline \multicolumn{3}{|c|}{ PARAMETER NAME } & UNITS & \multirow[b]{2}{*}{ MEAN } & \multirow{2}{*}{$\begin{array}{r}\text { STANDARD } \\
\text { DEVIATION }\end{array}$} & \multirow{2}{*}{$\begin{array}{c}\text { COEFF. } \\
\text { OF } \\
\text { VARIATION }\end{array}$} & \multirow{2}{*}{$\begin{array}{c}\% \text { of } \\
\text { NON } \\
\text { DETECTS }\end{array}$} & \multirow{2}{*}{\multicolumn{3}{|c|}{$\begin{array}{l}\text { STATISTICAL RANGE } \\
\text { 98\% CONFIDENCE INTERVAL } \\
\text { MINIMUM MAXIMUM }\end{array}$}} & \multirow{2}{*}{$\begin{array}{c}\text { DISTRIBUTION } \\
\text { TYPE }\end{array}$} & \multirow{2}{*}{$\begin{array}{l}\text { FOOT } \\
\text { NOTE }\end{array}$} \\
\hline \# OF SAMP & MINIMUM & MAXIMUM & MEDIAN & & & & & & & & & \\
\hline \multicolumn{3}{|c|}{ TOTAL ORGANIC CARBON } & $M G / L$ & \multirow[b]{2}{*}{ NA } & \multirow[b]{2}{*}{ NA } & \multirow[b]{2}{*}{ NA } & \multirow[b]{2}{*}{0.0} & \multirow{2}{*}{\multicolumn{2}{|c|}{ NA }} & \multirow[b]{2}{*}{ NA } & \multirow[b]{2}{*}{ UNKNOWN } & \multirow[b]{2}{*}{1} \\
\hline 3 & 3.0000 & 4.0000 & 3.0000 & & & & & & & & & \\
\hline \multicolumn{3}{|l|}{ URANIUM } & $M G / L$ & \multirow[b]{2}{*}{0.0287} & \multirow[b]{2}{*}{0.0039} & \multirow[b]{2}{*}{0.1374} & \multirow[b]{2}{*}{0.0} & \multirow{2}{*}{\multicolumn{2}{|c|}{0.0240}} & \multirow[b]{2}{*}{0.0334} & \multirow[b]{2}{*}{ NORMAL } & \\
\hline 7 & 0.0250 & 0.0350 & 0.0270 & & & & & & & & & \\
\hline \multicolumn{3}{|l|}{ VANADIUM } & $M G / L$ & \multirow[b]{2}{*}{ NA } & \multirow[b]{2}{*}{ NA } & \multirow[b]{2}{*}{ NA } & \multirow[b]{2}{*}{66.7} & \multirow[b]{2}{*}{$\star \star$} & \multirow[b]{2}{*}{0.0100} & \multirow[b]{2}{*}{0.2400} & \multirow[b]{2}{*}{ NONPARAMETRIC } & \multirow[b]{2}{*}{2,6} \\
\hline 6 & $\star \quad 0.0100$ & 0.2400 & ** $\quad 0.0100$ & & & & & & & & & \\
\hline \multicolumn{3}{|l|}{ ZINC } & $M G / L$ & \multirow[b]{2}{*}{ NA } & \multirow[b]{2}{*}{ NA } & & & & & & & \\
\hline 6 & ** $\quad 0.0050$ & 0.0150 & 0.0050 & & & NA & 83.3 & $\star \star$ & 0.0050 & 0.0150 & NONPARAMETRIC & 2,6 \\
\hline
\end{tabular}

* The reported value is the minimum detection limit of the data set

- The statistical maximm is the 99 percent one sided confidence interval, $\alpha=0.01$

1) A minimm of 4 samples must be available for the statistical analysis.

列

A

6) The stat. range is the $96.9 \%$ confidence interv 
Table 3.10 Summary of regulated constituents in alluvial background groundwater,

UC processing site, Slick Rock, Colorado

Constituents with MCLs"

\begin{tabular}{llll}
\hline \multicolumn{1}{c}{ Parameter } & \multicolumn{1}{c}{ MCLs } & $\begin{array}{c}\text { Mean or } \\
\text { Median }\end{array}$ & $\begin{array}{c}\text { Statistical } \\
\text { maximum }\end{array}$ \\
\hline Arsenic & 0.05 & $0.01^{\mathrm{e}}$ & $0.01^{\mathrm{e}}$ \\
Barium & 1.00 & $0.1^{\mathrm{e}}$ & $0.1^{\mathrm{e}}$ \\
Cadmium & 0.01 & $0.001^{\mathrm{e}}$ & $0.001^{\mathrm{e}}$ \\
Chromium & 0.05 & $0.01^{\mathrm{e}}$ & $0.07^{\mathrm{e}}$ \\
Net gross alphab & 15.0 & -9.45 & $5.08^{\mathrm{f}}$ \\
Lead & 0.05 & $0.01^{\mathrm{e}}$ & $0.01^{\mathrm{e}}$ \\
Mercury & 0.002 & $0.0002^{\mathrm{e}}$ & $0.0002^{\mathrm{e}}$ \\
Molybdenum & 0.10 & $0.07^{\mathrm{d}}$ & $0.11^{\mathrm{c}}$ \\
Nitrate & 44.0 & 0.50 & 12.0 \\
Radium-226 and $-228^{\mathrm{b}}$ & 5.00 & $1.08^{\mathrm{d}}$ & 2.33 \\
Selenium & 0.01 & $0.005^{\mathrm{e}}$ & 0.007 \\
Silver & 0.05 & $0.01^{\mathrm{e}}$ & $0.01^{\mathrm{e}}$ \\
Uranium & 0.044 & $0.029^{\mathrm{d}}$ & 0.033 \\
\hline
\end{tabular}


Table 3.10 summary of regulated constituents in alluvial background groundwater, UC processing site, slick Rock, Colorado (concluded)

\begin{tabular}{lcc}
\hline \multicolumn{3}{c}{ Constituents } \\
\multicolumn{1}{c}{ without MCLs $^{\mathrm{a}}$} \\
\hline Antimony & $\begin{array}{c}\text { Mean or } \\
\text { Median }\end{array}$ & $\begin{array}{c}\text { Statistical } \\
\text { maximum }\end{array}$ \\
Beryllium & $0.003^{\mathrm{e}}$ & $0.003^{\mathrm{e}}$ \\
Cobalt & $0.01^{\mathrm{e}}$ & $0.01^{\mathrm{e}, \mathrm{f}}$ \\
Copper & $0.05^{\mathrm{e}}$ & $0.05^{\mathrm{e}, \mathrm{f}}$ \\
Cyanide & $0.02^{\mathrm{e}}$ & 0.03 \\
Nickel & $0.01^{\mathrm{e}}$ & $0.01^{\mathrm{e}, \mathrm{f}}$ \\
Sulfide & $0.04^{\mathrm{e}}$ & $0.04^{\mathrm{e}}$ \\
Thallium & 0.18 & 0.30 \\
Tin & $0.01^{\mathrm{e}}$ & $0.01^{\mathrm{e}}$ \\
Vanadium & $0.005^{\mathrm{e}}$ & 0.025 \\
Zinc & $0.01^{\mathrm{e}}$ & 0.24 \\
\hline
\end{tabular}

"All units are $\mathrm{mg} / \mathrm{l}$ unless otherwise noted.

bunits are $\mathrm{pCi} / \mathrm{l}$.

Mean value, Lognormal distribution, mean is geometric.

Mean value, Normal distribution, mean is arithmetic.

'statistical values are below laboratory detection limits in

Table 8.1 of the Technical Approach Document (DOE, 1989).

fValue is an observed maximum, rather than a statistical maximum, because less than four samples were avaiable for statistical analysis. 
TABLE 3.11 BACKGROUND GROUNDHATER QUALITY DATA BY PARAMETER FOR THE ENTRADA

FORMATION, UC PROCESSING SITE, SLICK ROCK, COLORADO

SITE: SRKO1 SLICK ROCK (BOTH SITES)

03/29/89 TO $10 / 11 / 92$

REPORT DATE: $06 / 17 / 93$

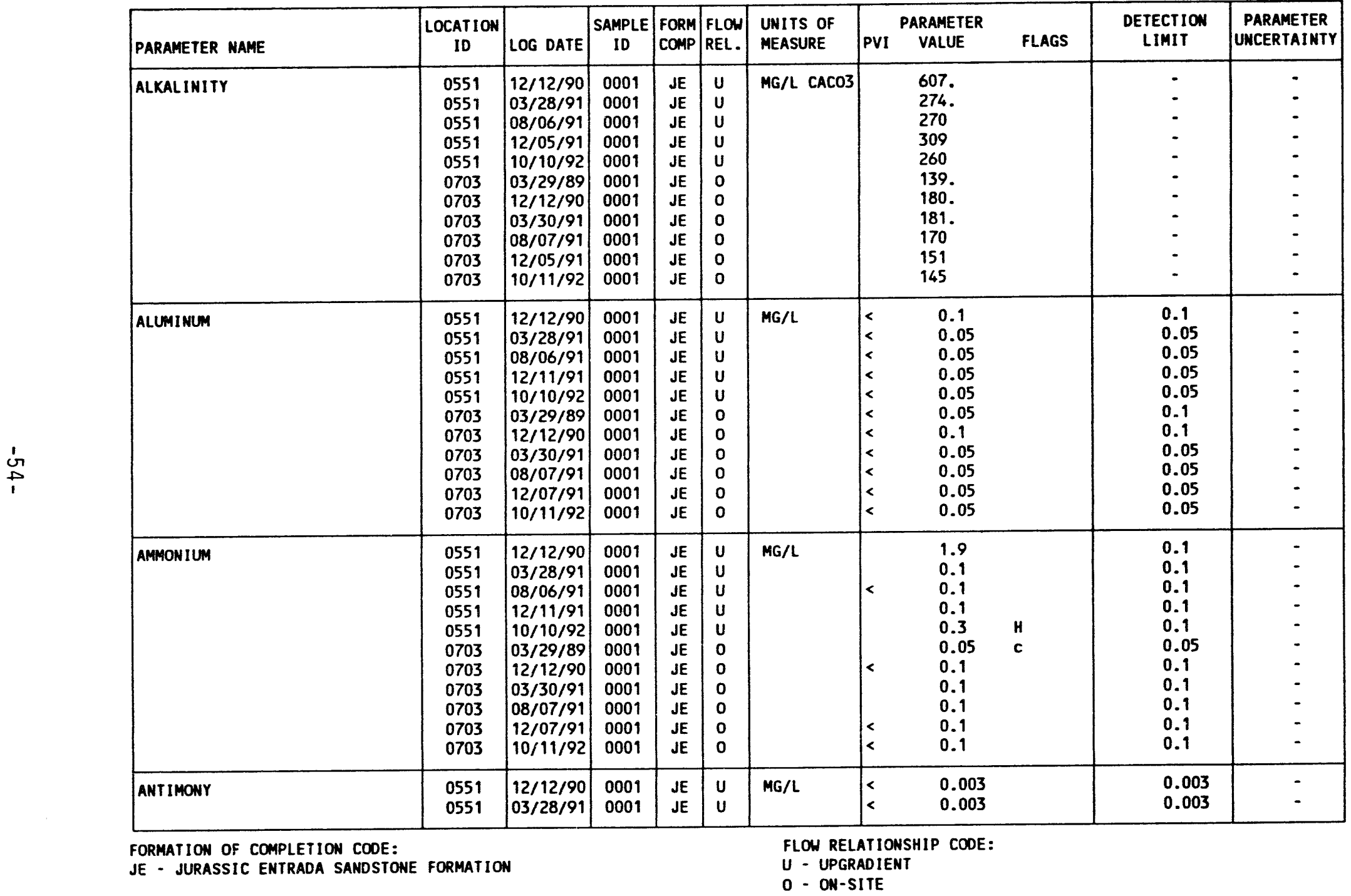

PARAMETER VALUE INDICATOR (PVI): < - LESS THAN DETECTION LIMIT

0001 - FILTERED SAMPLE (.45 MICRONS)

OTHER PARAMETER VALUE FLAGS:

H - HOLD TIME EXPIRED, VALUE SUSPECT

H - CHANGED DETECTION LIMIT 
TABLE 3.11 BACKGROUND GROUNDWATER QUALITY DATA BY PARAMETER FOR THE ENTRADA

FORMATION, UC PROCESSING SITE, SLICK ROCK, COLORADO

SITE: SRKOI SLICK ROCK (BOTH SITES)

03/29/89 TO $10 / 11 / 92$

REPORT DATE: $06 / 17 / 93$

\begin{tabular}{|c|c|c|c|c|c|c|c|c|c|c|}
\hline PARAMETER NAME & $\begin{array}{l}\text { LOCATION } \\
\text { ID }\end{array}$ & LOG DATE & $\begin{array}{c}\text { SAMPLE } \\
\text { ID }\end{array}$ & $\begin{array}{l}\text { FORM } \\
\text { COMP }\end{array}$ & $\begin{array}{l}\text { FLOW } \\
\text { REL. }\end{array}$ & $\begin{array}{l}\text { UNITS OF } \\
\text { MEASURE }\end{array}$ & PVI & $\begin{array}{l}\text { PARAMETER } \\
\text { VALUE }\end{array}$ & $\begin{array}{l}\text { DETECTION } \\
\text { LIMIT }\end{array}$ & $\begin{array}{l}\text { PARAMETER } \\
\text { UNCERTAINTY }\end{array}$ \\
\hline ANTIMONY & $\begin{array}{l}0551 \\
0551 \\
0551 \\
0703 \\
0703 \\
0703 \\
0703 \\
0703 \\
0703\end{array}$ & $\begin{array}{l}08 / 06 / 91 \\
12 / 11 / 91 \\
10 / 10 / 92 \\
03 / 29 / 89 \\
12 / 12 / 90 \\
03 / 30 / 91 \\
08 / 07 / 91 \\
12 / 07 / 91 \\
10 / 11 / 92\end{array}$ & $\begin{array}{l}0001 \\
0001 \\
0001 \\
0001 \\
0001 \\
0001 \\
0001 \\
0001 \\
0001\end{array}$ & $\begin{array}{l}J E \\
J E \\
J E \\
J E \\
J E \\
J E \\
J E \\
J E \\
J E\end{array}$ & $\begin{array}{l}U \\
U \\
U \\
0 \\
0 \\
0 \\
0 \\
0 \\
0\end{array}$ & $M G / L$ & $\begin{array}{l}< \\
< \\
< \\
< \\
< \\
< \\
< \\
< \\
<\end{array}$ & $\begin{array}{l}0.003 \\
0.003 \\
0.003 \\
0.001 \\
0.003 \\
0.003 \\
0.003 \\
0.003 \\
0.003\end{array}$ & $\begin{array}{l}0.003 \\
0.003 \\
0.003 \\
0.003 \\
0.003 \\
0.003 \\
0.003 \\
0.003 \\
0.003\end{array}$ & $\begin{array}{l}- \\
- \\
- \\
: \\
-\end{array}$ \\
\hline ARSENIC & $\begin{array}{l}0551 \\
0551 \\
0551 \\
0551 \\
0551 \\
0703 \\
0703 \\
0703 \\
0703 \\
0703 \\
0703\end{array}$ & $\begin{array}{l}12 / 12 / 90 \\
03 / 28 / 91 \\
08 / 06 / 91 \\
12 / 11 / 91 \\
10 / 10 / 92 \\
03 / 29 / 89 \\
12 / 12 / 90 \\
03 / 30 / 91 \\
08 / 07 / 91 \\
12 / 07 / 91 \\
10 / 11 / 92\end{array}$ & $\begin{array}{l}0001 \\
0001 \\
0001 \\
0001 \\
0001 \\
0001 \\
0001 \\
0001 \\
0001 \\
0001 \\
0001\end{array}$ & $\begin{array}{l}\mathrm{JE} \\
\mathrm{JE} \\
\mathrm{JE} \\
\mathrm{JE} \\
\mathrm{JE} \\
\mathrm{JE} \\
\mathrm{JE} \\
\mathrm{JE} \\
\mathrm{JE} \\
\mathrm{JE} \\
\mathrm{JE}\end{array}$ & $\begin{array}{l}U \\
U \\
U \\
U \\
U \\
0 \\
0 \\
0 \\
0 \\
0 \\
0\end{array}$ & $M G / L$ & $\begin{array}{l}< \\
< \\
< \\
< \\
< \\
< \\
< \\
< \\
< \\
< \\
<\end{array}$ & $\begin{array}{l}0.01 \\
0.01 \\
0.01 \\
0.01 \\
0.005 \\
0.001 \\
0.01 \\
0.01 \\
0.01 \\
0.01 \\
0.005\end{array}$ & $\begin{array}{l}0.01 \\
0.01 \\
0.01 \\
0.01 \\
0.005 \\
0.01 \\
0.01 \\
0.01 \\
0.01 \\
0.01 \\
0.005\end{array}$ & $\begin{array}{l}- \\
- \\
- \\
- \\
- \\
- \\
-\end{array}$ \\
\hline BARIUM & $\begin{array}{l}0551 \\
0551 \\
0551 \\
0551 \\
0551 \\
0703 \\
0703 \\
0703 \\
0703 \\
0703 \\
0703\end{array}$ & $\begin{array}{l}12 / 12 / 90 \\
03 / 28 / 91 \\
08 / 06 / 91 \\
12 / 11 / 91 \\
10 / 10 / 92 \\
03 / 29 / 89 \\
12 / 12 / 90 \\
03 / 30 / 91 \\
08 / 07 / 91 \\
12 / 07 / 91 \\
10 / 11 / 92\end{array}$ & $\begin{array}{l}0001 \\
0001 \\
0001 \\
0001 \\
0001 \\
0001 \\
0001 \\
0001 \\
0001 \\
0001 \\
0001\end{array}$ & $\begin{array}{l}J E \\
J E \\
J E \\
J E \\
J E \\
J E \\
J E \\
J E \\
J E \\
J E \\
J E\end{array}$ & $\begin{array}{l}U \\
U \\
U \\
U \\
U \\
0 \\
0 \\
0 \\
0 \\
0 \\
0\end{array}$ & $M G / L$ & $<$ & $\begin{array}{l}0.1 \\
0.05 \\
0.06 \\
0.07 \\
0.07 \\
0.12 \\
0.2 \\
0.13 \\
0.14 \\
0.31 \\
0.16\end{array}$ & $\begin{array}{l}0.1 \\
0.01 \\
0.01 \\
0.01 \\
0.01 \\
0.1 \\
0.1 \\
0.01 \\
0.01 \\
0.01 \\
0.01\end{array}$ & $\begin{array}{l}- \\
- \\
- \\
- \\
- \\
- \\
-\end{array}$ \\
\hline BERYLLIUM & $\begin{array}{l}0551 \\
0551 \\
0551 \\
0551 \\
0703 \\
0703\end{array}$ & $\begin{array}{l}12 / 12 / 90 \\
03 / 28 / 91 \\
08 / 06 / 91 \\
12 / 11 / 91 \\
03 / 29 / 89 \\
12 / 12 / 90\end{array}$ & $\begin{array}{l}0001 \\
0001 \\
0001 \\
0001 \\
0001 \\
0001\end{array}$ & $\begin{array}{l}\mathrm{JE} \\
\mathrm{JE} \\
\mathrm{JE} \\
\mathrm{JE} \\
\mathrm{JE} \\
\mathrm{JE}\end{array}$ & $\begin{array}{l}u \\
U \\
U \\
U \\
0 \\
0\end{array}$ & $M G / L$ & $\begin{array}{l}< \\
< \\
< \\
< \\
<\end{array}$ & $\begin{array}{l}0.01 \\
0.005 \\
0.005 \\
0.005 \\
0.005 \\
0.01\end{array}$ & $\begin{array}{l}0.01 \\
0.005 \\
0.005 \\
0.005 \\
0.005 \\
0.01\end{array}$ & $\begin{array}{l}- \\
- \\
- \\
-\end{array}$ \\
\hline
\end{tabular}

FORMATION OF COMPLETION CODE:

JE - JURASSIC ENTRADA SANDSTONE FORMATION
FLOW RELATIONSHIP COOE:

$U$ - UPGRADIENT

O - ON-SITE

PARAMETER VALUE INDICATOR (PVI): < - LESS THAN DETECTION LIMIT SAMPLE ID CODES:

0001 - FILTERED SAMPLE (.45 MICRONS) 
TABLE 3.11 BACKGROUND GROUNDUATER OUALITY DATA BY PARAMETER FOR THE ENTRADA FORMATION, UC PROCESSING SITE, SLICK ROCK, COLORADO

SITE: SRKO1 SLICK ROCK (BOTH SITES)

03/29/89 TO $10 / 11 / 92$

REPORT DATE: $06 / 17 / 93$

\begin{tabular}{|c|c|c|c|c|c|c|c|c|c|c|c|}
\hline PARAMETER NAME & $\begin{array}{c}\text { LOCATION } \\
\text { ID }\end{array}$ & LOG DATE & $\begin{array}{c}\text { SAMPLE } \\
\text { ID }\end{array}$ & $\begin{array}{l}\text { FORM } \\
\text { COMP }\end{array}$ & $\begin{array}{l}\text { FLON } \\
\text { REL. }\end{array}$ & $\begin{array}{l}\text { UNITS OF } \\
\text { MEASURE }\end{array}$ & PVI & $\begin{array}{l}\text { ARAMETER } \\
\text { VALUE }\end{array}$ & FLAGS & $\begin{array}{l}\text { DETECTION } \\
\text { LIMIT }\end{array}$ & $\begin{array}{l}\text { PARAMETER } \\
\text { UNCERTAINTY }\end{array}$ \\
\hline BERYLLIUM & $\begin{array}{l}0703 \\
0703 \\
0703\end{array}$ & $\begin{array}{l}03 / 30 / 91 \\
08 / 07 / 91 \\
12 / 07 / 91\end{array}$ & $\begin{array}{l}0001 \\
0001 \\
0001\end{array}$ & $\begin{array}{l}\mathrm{JE} \\
\mathrm{JE} \\
\mathrm{JE}\end{array}$ & $\begin{array}{l}0 \\
0 \\
0\end{array}$ & $M G / L$ & $\begin{array}{l}< \\
<\end{array}$ & $\begin{array}{l}0.005 \\
0.005 \\
0.005\end{array}$ & & $\begin{array}{l}0.005 \\
0.005 \\
0.005\end{array}$ & : \\
\hline BORON & $\begin{array}{l}0551 \\
0551 \\
0551 \\
0551 \\
0703 \\
0703 \\
0703 \\
0703\end{array}$ & $\begin{array}{l}12 / 12 / 90 \\
03 / 28 / 91 \\
08 / 06 / 91 \\
12 / 11 / 91 \\
12 / 12 / 90 \\
03 / 30 / 91 \\
08 / 07 / 91 \\
12 / 07 / 91\end{array}$ & $\begin{array}{l}0001 \\
0001 \\
0001 \\
0001 \\
0001 \\
0001 \\
0001 \\
0001\end{array}$ & $\begin{array}{l}\mathrm{JE} \\
\mathrm{JE} \\
\mathrm{JE} \\
\mathrm{JE} \\
\mathrm{JE} \\
\mathrm{JE} \\
\mathrm{JE} \\
\mathrm{JE}\end{array}$ & $\begin{array}{l}U \\
U \\
U \\
U \\
0 \\
0 \\
0 \\
0\end{array}$ & $\mathrm{MG} / \mathrm{L}$ & & $\begin{array}{l}0.2 \\
0.14 \\
0.14 \\
0.14 \\
0.3 \\
0.48 \\
0.08 \\
0.07\end{array}$ & & $\begin{array}{l}0.1 \\
0.05 \\
0.05 \\
0.05 \\
0.1 \\
0.05 \\
0.05 \\
0.05\end{array}$ & $\begin{array}{l}- \\
: \\
- \\
: \\
-\end{array}$ \\
\hline BROMIDE & $\begin{array}{l}0551 \\
0551 \\
0551 \\
0551 \\
0551 \\
0703 \\
0703 \\
0703 \\
0703 \\
0703\end{array}$ & $\begin{array}{l}12 / 12 / 90 \\
03 / 28 / 91 \\
08 / 06 / 91 \\
12 / 11 / 91 \\
10 / 10 / 92 \\
12 / 12 / 90 \\
03 / 30 / 91 \\
08 / 07 / 91 \\
12 / 07 / 91 \\
10 / 11 / 92\end{array}$ & $\begin{array}{l}0001 \\
0001 \\
0001 \\
0001 \\
0001 \\
0001 \\
0001 \\
0001 \\
0001 \\
0001\end{array}$ & $\begin{array}{l}\text { JE } \\
\text { JE } \\
\text { JE } \\
\text { JE } \\
\text { JE } \\
\text { JE } \\
\text { JE } \\
\text { JE } \\
\text { JE } \\
\text { JE }\end{array}$ & $\begin{array}{l}U \\
U \\
U \\
U \\
U \\
0 \\
0 \\
0 \\
0 \\
0\end{array}$ & $M G / L$ & $\begin{array}{l}< \\
< \\
< \\
< \\
< \\
< \\
< \\
<\end{array}$ & $\begin{array}{l}0.8 \\
0.1 \\
0.1 \\
0.1 \\
0.5 \\
0.1 \\
0.1 \\
0.1 \\
0.1 \\
0.1\end{array}$ & $\begin{array}{l}\text { I } \\
\text { C }\end{array}$ & $\begin{array}{l}0.01 \\
0.1 \\
0.1 \\
0.1 \\
0.5 \\
0.1 \\
0.1 \\
0.1 \\
0.1 \\
0.1\end{array}$ & $\begin{array}{l}- \\
- \\
- \\
- \\
- \\
-\end{array}$ \\
\hline CADMIUM & $\begin{array}{l}0551 \\
0551 \\
0551 \\
0551 \\
0551 \\
0703 \\
0703 \\
0703 \\
0703 \\
0703 \\
0703\end{array}$ & $\begin{array}{l}12 / 12 / 90 \\
03 / 28 / 91 \\
08 / 06 / 91 \\
12 / 11 / 91 \\
10 / 10 / 92 \\
03 / 29 / 89 \\
12 / 12 / 90 \\
03 / 30 / 91 \\
08 / 07 / 91 \\
12 / 07 / 91 \\
10 / 11 / 92\end{array}$ & $\begin{array}{l}0001 \\
0001 \\
0001 \\
0001 \\
0001 \\
0001 \\
0001 \\
0001 \\
0001 \\
0001 \\
0001\end{array}$ & $\begin{array}{l}\text { JE } \\
\text { JE } \\
\text { JE } \\
\text { JE } \\
\text { JE } \\
\text { JE } \\
\text { JE } \\
\text { JE } \\
\text { JE } \\
\text { JE } \\
\text { JE }\end{array}$ & $\begin{array}{l}U \\
U \\
U \\
U \\
U \\
0 \\
0 \\
0 \\
0 \\
0 \\
0\end{array}$ & $M G / L$ & $\begin{array}{l}< \\
< \\
< \\
< \\
< \\
< \\
< \\
< \\
<\end{array}$ & $\begin{array}{l}0.001 \\
0.001 \\
0.001 \\
0.001 \\
0.001 \\
0.0001 \\
0.001 \\
0.001 \\
0.001 \\
0.005 \\
0.005\end{array}$ & $\begin{array}{l}\text { I } \\
\text { I }\end{array}$ & $\begin{array}{l}0.001 \\
0.001 \\
0.001 \\
0.001 \\
0.001 \\
0.001 \\
0.001 \\
0.001 \\
0.001 \\
0.005 \\
0.005\end{array}$ & $\begin{array}{l}- \\
- \\
- \\
: \\
- \\
-\end{array}$ \\
\hline CALCIUM & $\begin{array}{l}0551 \\
0551\end{array}$ & $\begin{array}{l}12 / 12 / 90 \\
03 / 28 / 91\end{array}$ & $\begin{array}{l}0001 \\
0001\end{array}$ & $\begin{array}{l}\text { JE } \\
\text { JE }\end{array}$ & $\begin{array}{l}u \\
u\end{array}$ & $M G / L$ & & $\begin{array}{l}54.2 \\
28.3\end{array}$ & & $\begin{array}{l}0.01 \\
0.5\end{array}$ & - \\
\hline
\end{tabular}

FORMATION OF COMPLETION CODE:

JE - JURASSIC ENTRADA SANDSTONE FORMATION

FLON RELATIONSHIP COOE:

U - UPGRADIENT

PARAMETER VALUE INDICATOR (PVI): < - LESS THAN DETECTION LIMIT

SAMPLE ID CODES:

0001 - FILTERED SAMPLE (.45 MICRONS)

OTHER PARAMETER VALUE FLAGS:

1 - INCREASED DETECTION LIMIT DUE TO REQUIRED DILUTION

c - CHANGED DETECTION LIMIT 
TABLE 3.11 BACKGROUND GROUMDHATER QUALITY DATA BY PARAMETER FOR THE ENTRADA FORMATION UC PROCESSING SITE, SLICK ROCK, COLORADO

SITE SRKO1 SLICK ROCK (BOTH SITES)

$03 / 29 / 89$ TO $10 / 11 / 92$

REPORT DATE: 06/17/93

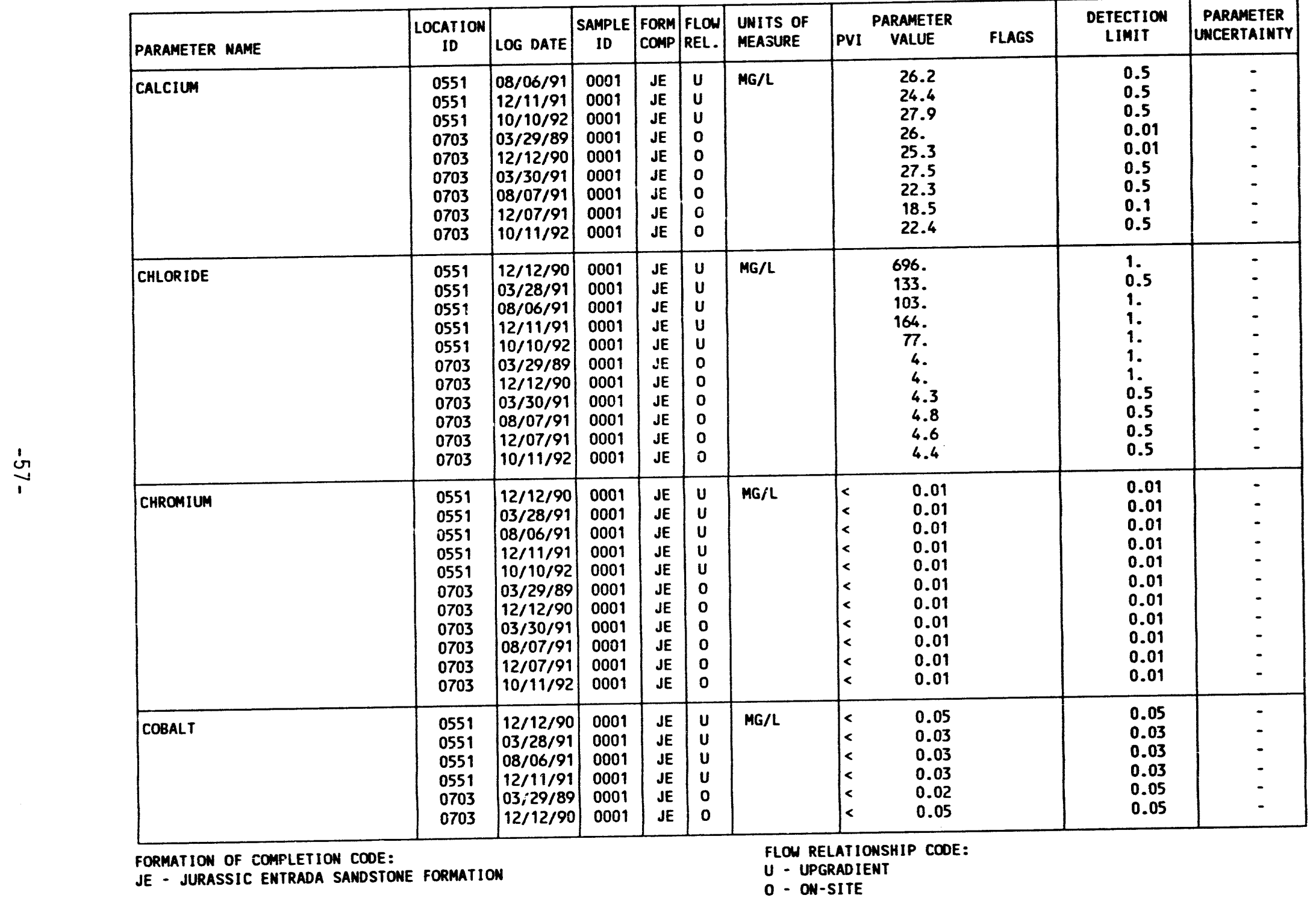

$\begin{array}{ll}\text { PARAMETER VALUE INDICATOR (PVI): - LESS THAN DETECTION LIMIT SAMPLE ID CODES: } & 0001 \text { - FILTERED SAMPLE (.45 MICRONS) }\end{array}$ 
TABLE 3.11 BACKGROUND GROUNDHATER QUALITY DATA BY PARAMETER FOR THE EMTRADA FORMATION, UC PROCESSING SITE, SLICK ROCK, COLORADO

SITE: SRKO1 SLICK ROCK (BOTH SITES)

SITE: SRKOT SLICK ROCK

REPORT DATE: $06 / 17 / 93$

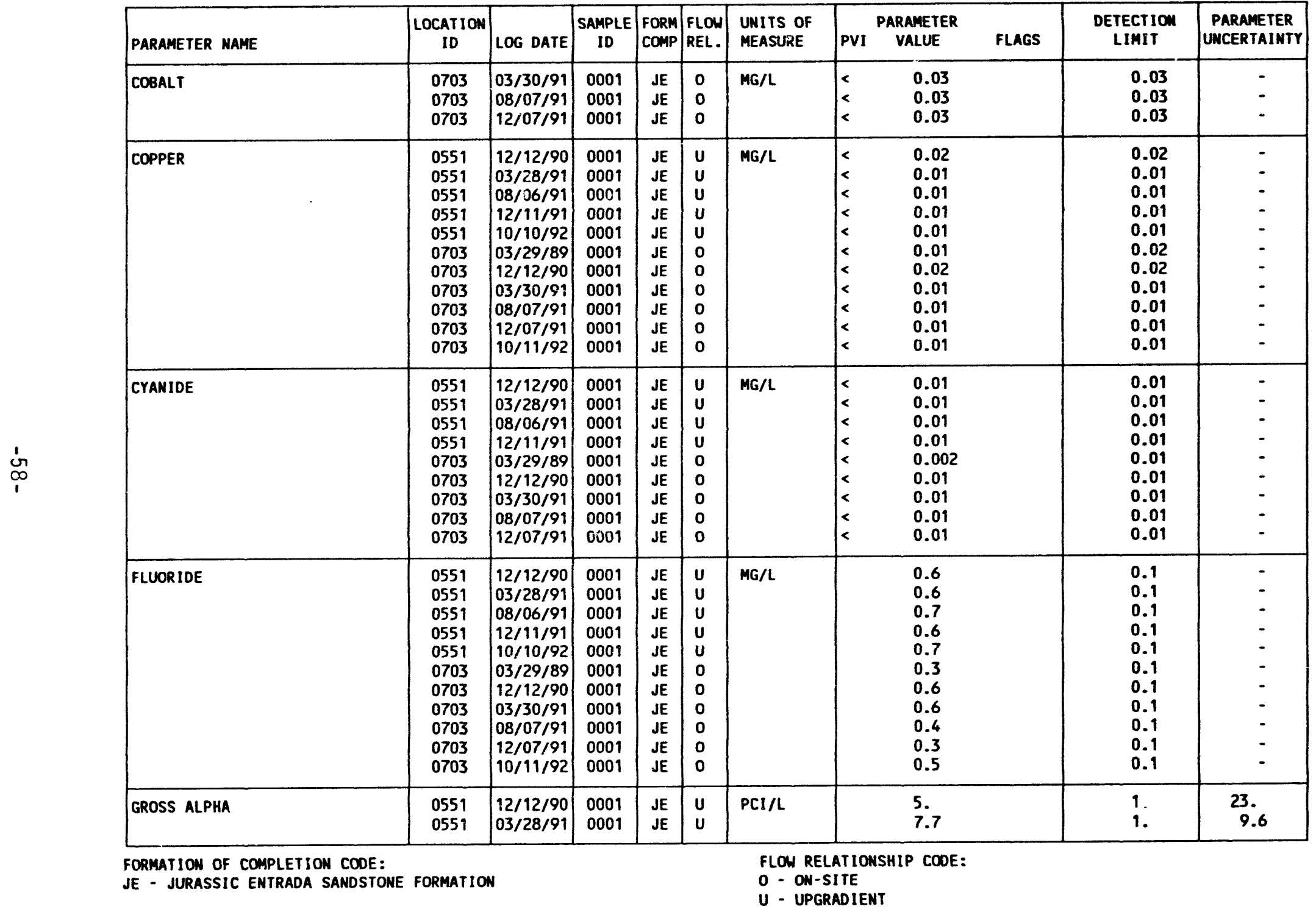

PARAMETER VALUe INDICATOR (PVI): - - LESS than DETECTION LIMIT SAMPLE ID COOES:

0001 - FILTERED SAMPLE (.45 MICRONS) 
TABLE 3.11 BACKGROUND GROUNDWATER QUALITY DATA BY PARAMETER FOR THE EMTRADA

FORMATION, UC PROCESSING SITE, SLICK ROCK, COLORADO

SITE: SRKO1 SLICK ROCK (BOTH SITES)

03/29/89 TO 10/11/92

REPORT DATE: $06 / 17 / 93$

\begin{tabular}{|c|c|c|c|c|c|c|c|c|c|c|c|c|}
\hline & PARAMETER NAME & $\underset{\text { LOCATION }}{\text { ID }}$ & LOG DATE & $\begin{array}{c}\text { SAMPLE } \\
\text { ID }\end{array}$ & $\begin{array}{l}\text { FORM } \\
\text { COMP }\end{array}$ & $\begin{array}{l}\text { FLON } \\
\text { REL. }\end{array}$ & $\begin{array}{l}\text { UNITS OF } \\
\text { MEASURE }\end{array}$ & PVI & $\begin{array}{l}\text { ARAMETER } \\
\text { VALUE }\end{array}$ & FLAGS & $\begin{array}{l}\text { DETECTION } \\
\text { LIMIT }\end{array}$ & $\begin{array}{l}\text { PARAMETER } \\
\text { UMCERTAINTY }\end{array}$ \\
\hline & GROSS ALPHA & $\begin{array}{l}0551 \\
0551 \\
0551 \\
0703 \\
0703 \\
0703 \\
0703 \\
0703\end{array}$ & $\begin{array}{l}08 / 06 / 91 \\
12 / 05 / 91 \\
10 / 10 / 92 \\
12 / 12 / 90 \\
03 / 30 / 91 \\
08 / 07 / 91 \\
12 / 05 / 91 \\
10 / 11 / 92\end{array}$ & $\begin{array}{l}0001 \\
0001 \\
0001 \\
0001 \\
0001 \\
0001 \\
0001 \\
0001\end{array}$ & $\begin{array}{l}\text { JE } \\
\text { JE } \\
\text { JE } \\
\text { JE } \\
\text { JE } \\
\text { JE } \\
\text { JE } \\
\text { JE }\end{array}$ & $\begin{array}{l}U \\
U \\
U \\
0 \\
0 \\
0 \\
0 \\
0\end{array}$ & PCI/L & & $\begin{array}{l}0.0 \\
0.0 \\
0.0 \\
6.3 \\
4.5 \\
3.0 \\
0.0 \\
0.9\end{array}$ & N & $\begin{array}{l}1 . \\
1 . \\
7.6 \\
1 . \\
1 . \\
1 . \\
1 . \\
4.5\end{array}$ & $\begin{array}{l}5.1 \\
9.1 \\
4.2 \\
3.0 \\
3.3 \\
2.8 \\
4.2 \\
2.8\end{array}$ \\
\hline & GROSS BETA & $\begin{array}{l}0551 \\
0551 \\
0551 \\
0551 \\
0551 \\
0703 \\
0703 \\
0703 \\
0703 \\
0703 \\
0703\end{array}$ & $\begin{array}{l}12 / 12 / 90 \\
03 / 28 / 91 \\
08 / 06 / 91 \\
12 / 05 / 91 \\
10 / 10 / 92 \\
03 / 29 / 89 \\
12 / 12 / 90 \\
03 / 30 / 91 \\
08 / 07 / 91 \\
12 / 05 / 91 \\
10 / 11 / 92\end{array}$ & $\begin{array}{l}0001 \\
0001 \\
0001 \\
0001 \\
0001 \\
0001 \\
0001 \\
0001 \\
0001 \\
0001 \\
0001\end{array}$ & $\begin{array}{l}\mathrm{JE} \\
\mathrm{JE} \\
\mathrm{JE} \\
\mathrm{JE} \\
\mathrm{JE} \\
\mathrm{JE} \\
\mathrm{JE} \\
\mathrm{JE} \\
\mathrm{JE} \\
\mathrm{JE} \\
\mathrm{JE}\end{array}$ & $\begin{array}{l}U \\
U \\
U \\
U \\
U \\
0 \\
0 \\
0 \\
0 \\
0 \\
0\end{array}$ & $\mathrm{PCI} / \mathrm{L}$ & & $\begin{array}{r}24 . \\
10.8 \\
4.4 \\
0.0 \\
4.5 \\
11.0 \\
5.9 \\
7.4 \\
6.0 \\
0.0 \\
7.5\end{array}$ & $\begin{array}{l}\star_{N} \\
\star_{N}\end{array}$ & $\begin{array}{l}0.5 \\
0.5 \\
0.5 \\
0.5 \\
7.1 \\
0.5 \\
0.5 \\
0.5 \\
0.5 \\
0.5 \\
4.5\end{array}$ & $\begin{array}{l}18 . \\
6.7 \\
3.3 \\
5.3 \\
4.4 \\
4.80 \\
1.8 \\
2.1 \\
2.0 \\
3.6 \\
3.0\end{array}$ \\
\hline & IRON & $\begin{array}{l}0551 \\
0551 \\
0551 \\
0551 \\
0551 \\
0703 \\
0703 \\
0703 \\
0703 \\
0703 \\
0703\end{array}$ & $\begin{array}{l}12 / 12 / 90 \\
03 / 28 / 91 \\
08 / 06 / 91 \\
12 / 11 / 91 \\
10 / 10 / 92 \\
03 / 29 / 89 \\
12 / 12 / 90 \\
03 / 30 / 91 \\
08 / 07 / 91 \\
12 / 07 / 91 \\
10 / 11 / 92\end{array}$ & $\begin{array}{l}0001 \\
0001 \\
0001 \\
0001 \\
0001 \\
0001 \\
0001 \\
0001 \\
0001 \\
0001 \\
0001\end{array}$ & $\begin{array}{l}J E \\
J E \\
J E \\
J E \\
J E \\
J E \\
J E \\
J E \\
J E \\
J E \\
J E\end{array}$ & $\begin{array}{l}U \\
U \\
U \\
U \\
U \\
0 \\
0 \\
0 \\
0 \\
0 \\
0\end{array}$ & $M G / L$ & $\begin{array}{l}< \\
< \\
< \\
< \\
< \\
< \\
< \\
< \\
< \\
< \\
<\end{array}$ & $\begin{array}{l}0.03 \\
0.03 \\
0.03 \\
0.03 \\
0.03 \\
0.02 \\
0.03 \\
0.03 \\
0.03 \\
0.03 \\
0.03\end{array}$ & & $\begin{array}{l}0.03 \\
0.03 \\
0.03 \\
0.03 \\
0.03 \\
0.03 \\
0.03 \\
0.03 \\
0.03 \\
0.03 \\
0.03\end{array}$ & $\begin{array}{l}- \\
- \\
- \\
- \\
- \\
- \\
- \\
-\end{array}$ \\
\hline & LEAD & $\begin{array}{l}0551 \\
0551 \\
0551 \\
0551 \\
0551\end{array}$ & $\begin{array}{l}12 / 12 / 90 \\
03 / 28 / 91 \\
08 / 06 / 91 \\
12 / 11 / 91 \\
10 / 10 / 92\end{array}$ & $\begin{array}{l}0001 \\
0001 \\
0001 \\
0001 \\
0001\end{array}$ & $\begin{array}{l}\mathrm{JE} \\
\mathrm{JE} \\
\mathrm{JE} \\
\mathrm{JE} \\
\mathrm{JE}\end{array}$ & $\begin{array}{l}u \\
u \\
u \\
u \\
u\end{array}$ & $M G / L$ & $\mid \begin{array}{l}< \\
< \\
< \\
< \\
<\end{array}$ & $\begin{array}{l}0.01 \\
0.005 \\
0.005 \\
0.005 \\
0.003\end{array}$ & & $\begin{array}{l}0.01 \\
0.005 \\
0.005 \\
0.005 \\
0.003\end{array}$ & $\begin{array}{l}- \\
- \\
-\end{array}$ \\
\hline
\end{tabular}

FORMATION OF COMPLETION COOE:

JE - JURASSIC ENTRADA SANDSTONE FORMATION

PARAMETER VALUE INDICATOR (PVI): < - LESS THAN DETECTION LIMIT
FLOW RELATIONSHIP CODE:

U - UPGRADIENT

O - ON-SITE

SAMPLE ID CODES:

0001 - FILTERED SAMPLE (.45 MICRONS)

OTHER PARAMETER VALUE FLAGS:

* - DUPLICATE ANALYSIS NOT WITHIN CONTROL LIMITS

N - SPIKE SAMPLE RECOVERY NOT WITHIN CONTROL LIMITS 


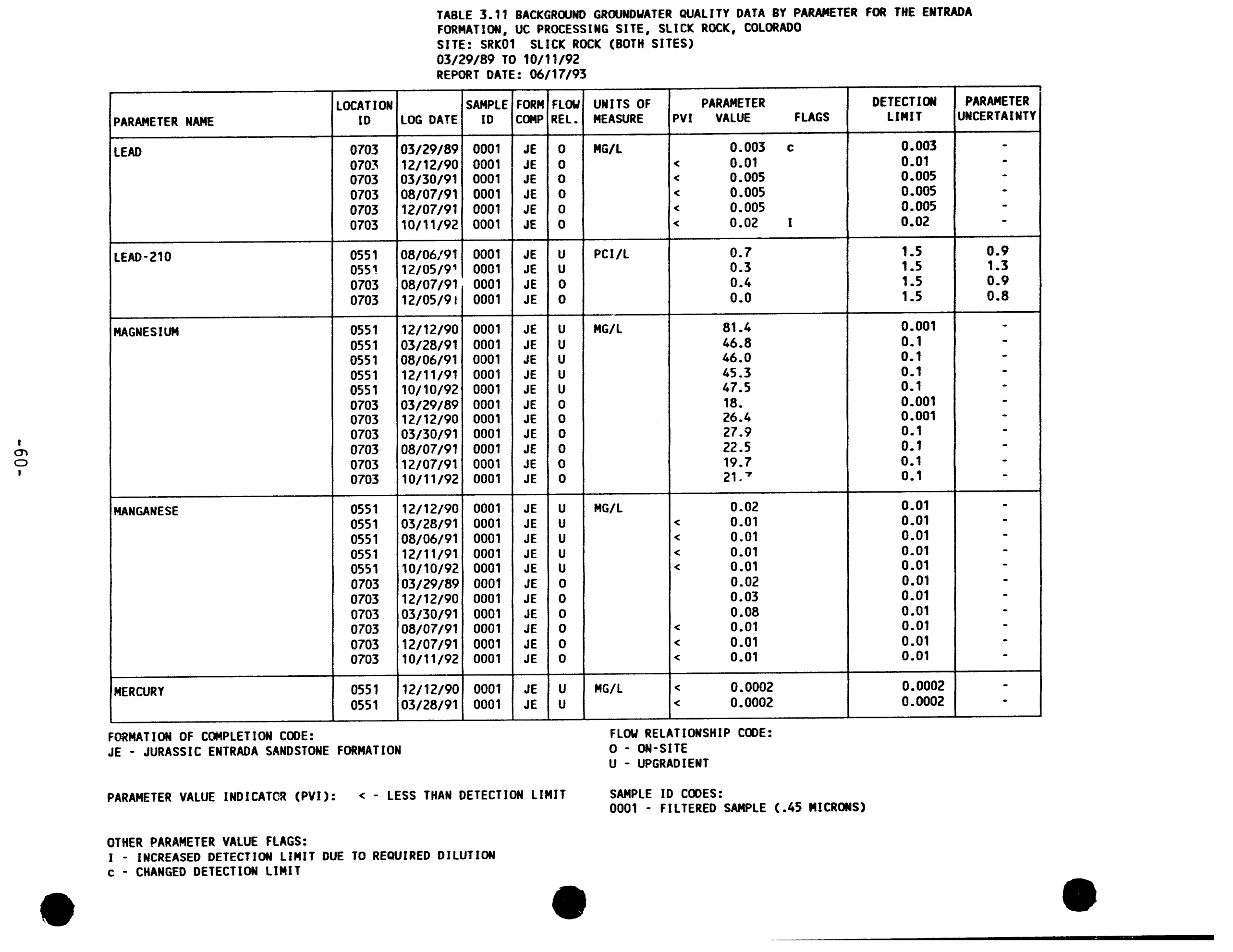


TABLE 3.11 BACKGROUMD GROUNDHATER QUALIIYY DATA BY PARAMETER FOR THE EMTRADA

FOPMATION UC PROCESSING SITE, SLICK ROCK, COLORADO

SITE: SRKO1 SLICK ROCK (BOTH SITES)

$03 / 29 / 89$ TO $10 / 11 / 92$

REPORT DATE: $06 / 17 / 93$

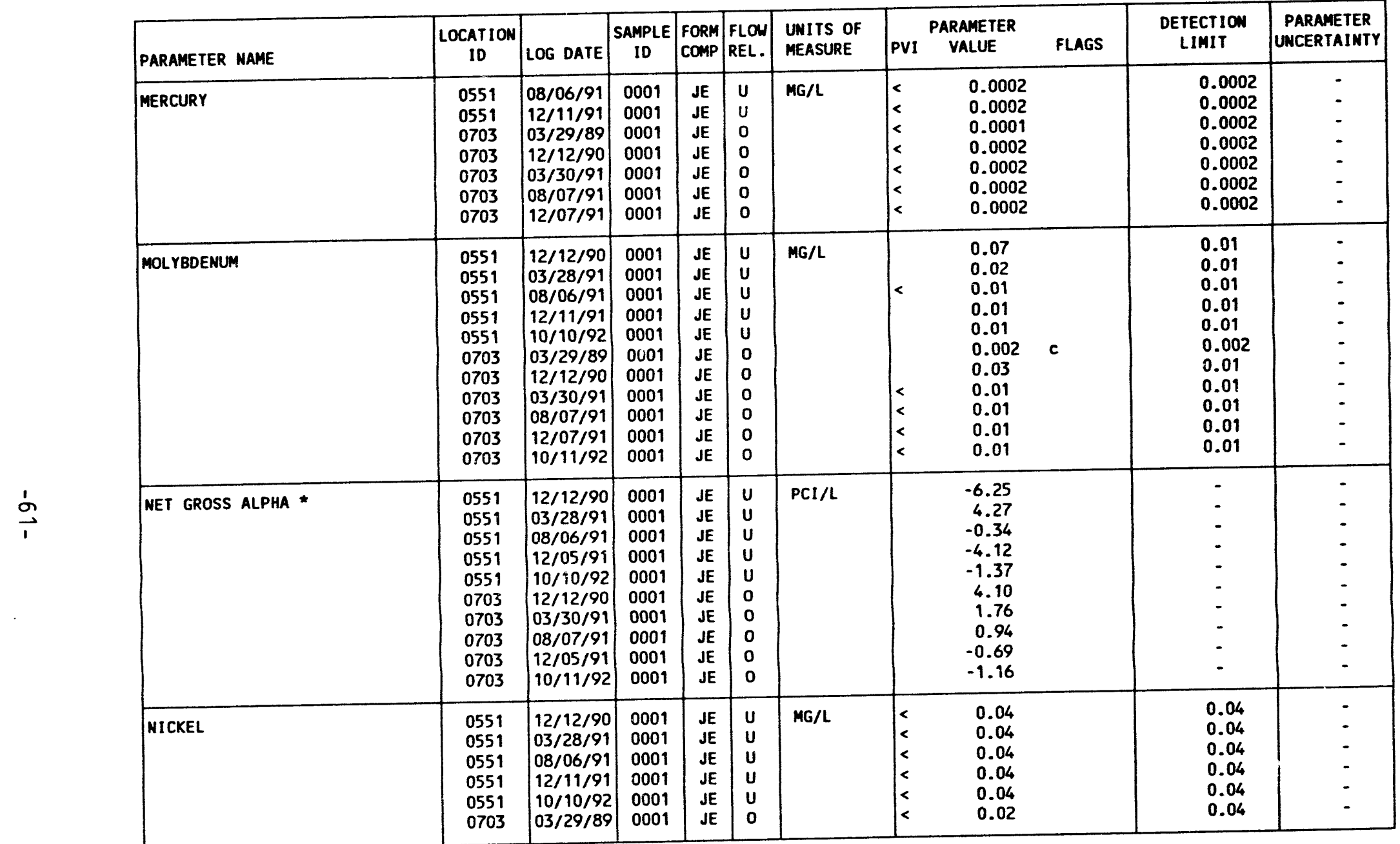

- NET GROSS ALPHA (GROSS ALPHA - URANIUM) WITH 1 MG URANIUM = 686 PCI

FORMATION OF COMPLETION CODE:

JE - JURASSIC ENTRADA SANDSTONE FORMATION
FLOW RELATIONSHIP COOE:

U - UPGRADIENT

O - ON-SITE

SAMPLE ID COOES:

0001 - FILTERED SAMPLE (.45 MICRONS)

PARAMETER VALUE INDICATOR (PVI): < - LESS THAN DETECTION LIMIT

OTHER PARAMETER VALUE FLAGS:

c - CHAMGED DETECTION LIMIT 
TABLE 3.11 BACKGROUND GROUNOWATER QUAi ITY DATA BY PARAMETER FOR THE ENTRADA FORMATION, UC PROCESSING SITE, SLICK ROCK, COLORADO

SITE: SRKO1 SLICK ROCK (BOTH SITES)

03/29/89 TO $10 / 11 / 92$

REPORT DATE: 06/17/93

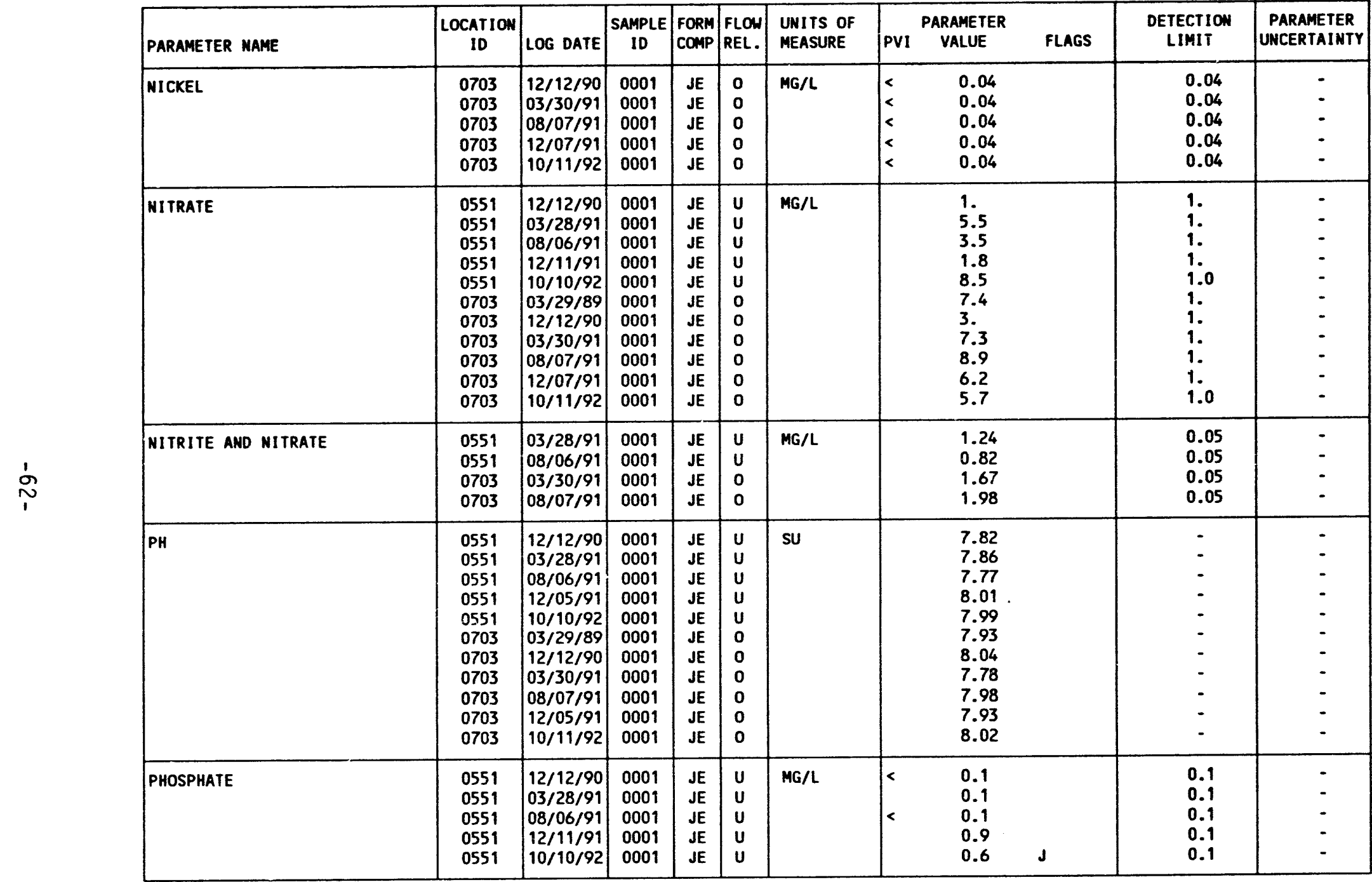

FORMATION OF COMPLETION CODE:

JE - JURASSIC ENTRADA SANDSTONE FORMATION

FLOW RELATIONSHIP COOE:

O - ON-SITE

$U$ - UPGRADIENT

PARAMETER VALUE INDICATOR (PVI): < - LESS THAN DETECTION LIMIT

SAMPLE ID CODES:

0001 - FILTERED SAMPLE (.45 MICROWS)

OTHER PARAMETER VALUE FLAGS:

I - ESTIMATED VALUE 
TABLE 3.11 BACKGROUND GROUNDWATER QUALITY DATA BY PARAMETER FOR THE ENTRADA

FORMATION, UC PROCESSING SITE, SLICK ROCK, COLORADO

SITE: SRKO1 SLICK ROCK (BOTH SITES)

03/29/89 TO $10 / 11 / 92$

\begin{tabular}{|c|c|c|c|c|c|c|c|c|c|c|c|}
\hline PARAMETER NAME & $\begin{array}{c}\text { LOCATION } \\
\text { ID }\end{array}$ & LOG DATE & $\begin{array}{c}\text { SAMPLE } \\
\text { ID }\end{array}$ & $\begin{array}{l}\text { FORM } \\
\text { COMP }\end{array}$ & $\begin{array}{l}\text { FLOW } \\
\text { REL. }\end{array}$ & $\begin{array}{l}\text { UNITS OF } \\
\text { MEASURE }\end{array}$ & PVI & $\begin{array}{l}\text { ARAMETER } \\
\text { VALUE }\end{array}$ & FLAGS & $\begin{array}{l}\text { DETECTION } \\
\text { LIMIT }\end{array}$ & $\begin{array}{l}\text { PARAMETER } \\
\text { UNCERTAINTY }\end{array}$ \\
\hline PHOSPHATE & $\begin{array}{l}0703 \\
0703 \\
0703 \\
0703 \\
0703 \\
0703\end{array}$ & $\begin{array}{l}03 / 29 / 89 \\
12 / 12 / 90 \\
03 / 30 / 91 \\
08 / 07 / 91 \\
12 / 07 / 91 \\
10 / 11 / 92\end{array}$ & $\begin{array}{l}0001 \\
0001 \\
0001 \\
0001 \\
0001 \\
0001\end{array}$ & $\begin{array}{l}\text { JE } \\
\text { JE } \\
J E \\
J E \\
J E \\
J E\end{array}$ & $\begin{array}{l}0 \\
0 \\
0 \\
0 \\
0 \\
0\end{array}$ & $M G / L$ & $<$ & $\begin{array}{l}0.1 \\
0.1 \\
0.1 \\
0.1 \\
0.1 \\
0.5\end{array}$ & $\mathbf{J}$ & $\begin{array}{l}0.1 \\
0.1 \\
0.1 \\
0.1 \\
0.01 \\
0.1\end{array}$ & :- \\
\hline POLONIUM-210 & $\begin{array}{l}0551 \\
0551 \\
0703 \\
0703\end{array}$ & $\begin{array}{l}08 / 06 / 91 \\
12 / 05 / 91 \\
08 / 07 / 91 \\
12 / 05 / 91\end{array}$ & $\begin{array}{l}0001 \\
0001 \\
0001 \\
0001\end{array}$ & $\begin{array}{l}\mathrm{JE} \\
\mathrm{JE} \\
\mathrm{JE} \\
\mathrm{JE}\end{array}$ & $\begin{array}{l}u \\
u \\
0 \\
0\end{array}$ & $\mathrm{PCl} / \mathrm{L}$ & & $\begin{array}{l}0.1 \\
0.1 \\
0.1 \\
0.0\end{array}$ & & $\begin{array}{l}1 . \\
1 . \\
1 .\end{array}$ & $\begin{array}{l}0.4 \\
0.5 \\
0.3 \\
0.6\end{array}$ \\
\hline POTASSIUM & $\begin{array}{l}0551 \\
0551 \\
0551 \\
0551 \\
0551 \\
0703 \\
0703 \\
0703 \\
0703 \\
0703 \\
0703\end{array}$ & $\begin{array}{l}12 / 12 / 90 \\
03 / 28 / 91 \\
08 / 06 / 91 \\
12 / 11 / 91 \\
10 / 10 / 92 \\
03 / 29 / 89 \\
12 / 12 / 90 \\
03 / 30 / 91 \\
08 / 07 / 91 \\
12 / 07 / 91 \\
10 / 11 / 92\end{array}$ & $\begin{array}{l}0001 \\
0001 \\
0001 \\
0001 \\
0001 \\
0001 \\
0001 \\
0001 \\
0001 \\
0001 \\
0001\end{array}$ & $\begin{array}{l}J E \\
J E \\
J E \\
J E \\
J E \\
J E \\
J E \\
J E \\
J E \\
J E \\
J E\end{array}$ & $\begin{array}{l}U \\
U \\
U \\
U \\
U \\
0 \\
0 \\
0 \\
0 \\
0 \\
0\end{array}$ & MG/L & & $\begin{array}{l}12.5 \\
7.3 \\
6.9 \\
7.45 \\
7.08 \\
5.9 \\
7.8 \\
8.2 \\
4.5 \\
3.82 \\
5.93\end{array}$ & & $\begin{array}{l}0.01 \\
0.01 \\
0.01 \\
0.01 \\
0.01 \\
0.01 \\
0.01 \\
0.01 \\
0.01 \\
0.01 \\
0.01\end{array}$ & $\begin{array}{l}- \\
- \\
- \\
- \\
- \\
- \\
- \\
-\end{array}$ \\
\hline RADIUM-226 & $\begin{array}{l}0551 \\
0551 \\
0551 \\
0551 \\
0551 \\
0703 \\
0703 \\
0703 \\
0703 \\
0703\end{array}$ & $\begin{array}{l}12 / 12 / 90 \\
03 / 28 / 91 \\
08 / 06 / 91 \\
12 / 05 / 91 \\
10 / 10 / 92 \\
12 / 12 / 90 \\
03 / 30 / 91 \\
08 / 07 / 91 \\
12 / 05 / 91 \\
10 / 11 / 92\end{array}$ & $\begin{array}{l}0001 \\
0001 \\
0001 \\
0001 \\
0001 \\
0001 \\
0001 \\
0001 \\
0001 \\
0001\end{array}$ & $\begin{array}{l}\text { JE } \\
\text { JE } \\
\text { JE } \\
\text { JE } \\
J E \\
\text { JE } \\
\text { JE } \\
\text { JE } \\
\text { JE } \\
\text { JE }\end{array}$ & $\begin{array}{l}U \\
U \\
U \\
U \\
U \\
0 \\
0 \\
0 \\
0 \\
0\end{array}$ & $\mathrm{PCI} / \mathrm{L}$ & & $\begin{array}{l}0.2 \\
0.2 \\
0.1 \\
0.3 \\
0.9 \\
0.6 \\
0.4 \\
0.4 \\
0.3 \\
0.0\end{array}$ & c & $\begin{array}{l}0.4 \\
1 . \\
1 . \\
1 . \\
0.8 \\
1 . \\
1 . \\
1 . \\
1 . \\
0.8\end{array}$ & $\begin{array}{l}0.2 \\
0.2 \\
0.2 \\
0.2 \\
0.6 \\
0.4 \\
0.2 \\
0.2 \\
0.3 \\
0.4\end{array}$ \\
\hline RADIUM-226 + RADIUM-228 & $\begin{array}{l}0551 \\
0551 \\
0551\end{array}$ & $\begin{array}{l}12 / 12 / 90 \\
03 / 28 / 91 \\
08 / 06 / 91\end{array}$ & $\begin{array}{l}0001 \\
0001 \\
0001\end{array}$ & $\begin{array}{l}\mathrm{JE} \\
\mathrm{JE} \\
\mathrm{JE}\end{array}$ & $\begin{array}{l}u \\
u \\
u\end{array}$ & $\mathrm{PCl} / \mathrm{L}$ & & $\begin{array}{l}1.50 \\
2.40 \\
0.10\end{array}$ & & - & : \\
\hline
\end{tabular}

FORMATION OF COMPLETION COOE:

JE - JURASSIC ENTRADA SANDSTONE FORMATION

FLOW RELATIONSHIP COOE:

PARAMETER VALUE INDICATOR (PVI): < - LESS THAN DETECTION LIMIT

U - UPGRADIENT

SAMPLE ID COOES:

0001 - FILTERED SAMPLE (.45 MICRONS)

OTHER PARAMETER VALUE FLAGS:

J - ESTIMATED VALUE

c - CHANGED DETECTION LIMIT 
TABLE 3.11 BACKGROUND GROUNDWATER QUALITY DATA BY PARAMETER FOR THE ENTRADA

FORMATION, UC PROCESSING SITE, SLICK ROCK, COLORADO

SITE: SRKO1 SLICK ROCK (BOTH SITES)

$03 / 29 / 89$ TO $10 / 11 / 92$

REPORT DATE : 06/17/93

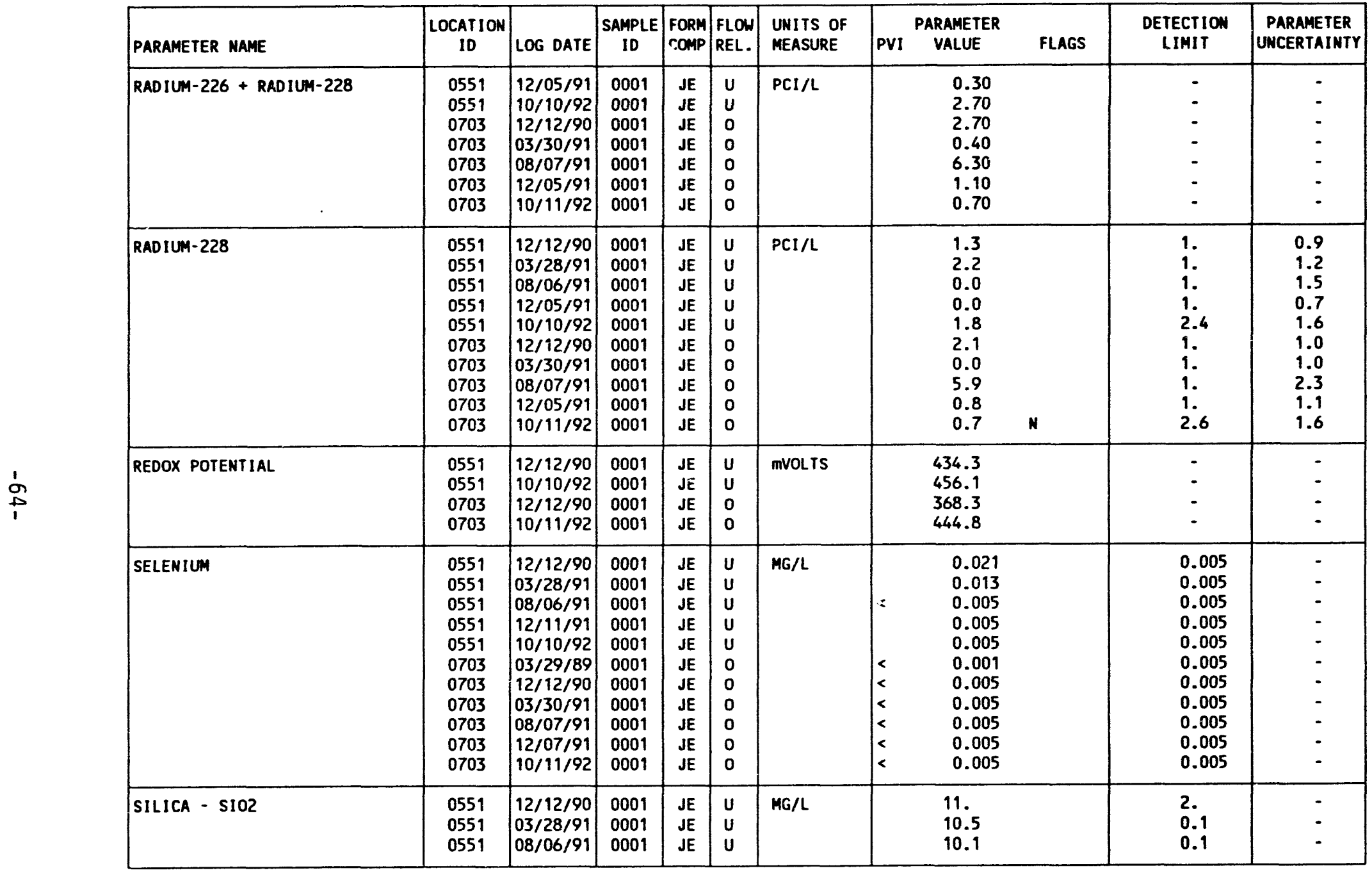

FORMATION OF COAPLETION CODE:

JE - JURASSIC ENTRADA SANDSTONE FORMATION

FLON RELATIONSHIP COOE:

$U$ - UPGRADIENT

O - ON-SITE

PARAMETER VALUE INDICATOR (PVI): - - LESS thaN DETECTION LIMIT

SAMPLE ID CODES:

0001 - FILTERED SAMPLE (.45 MICRONS)

OTHER PARAMETER VALUE FLAGS:

N - SPIKE SAMPLE RECOVERY MOT HITHIN CONTROL LIMITS 
TABLE 3.11 BACKGROUND GROUNDWATER QUALITY DATA BY PARAMETER FOR THE ENTRADA FORMATION, UC PROCESSING SITE, SLICK ROCK, COLORADO

SITE: SRKO1 SLICK ROCK (BOTH SITES)

$03 / 29 / 89$ TO $10 / 11 / 92$

REPORT DATE: 06/17/93

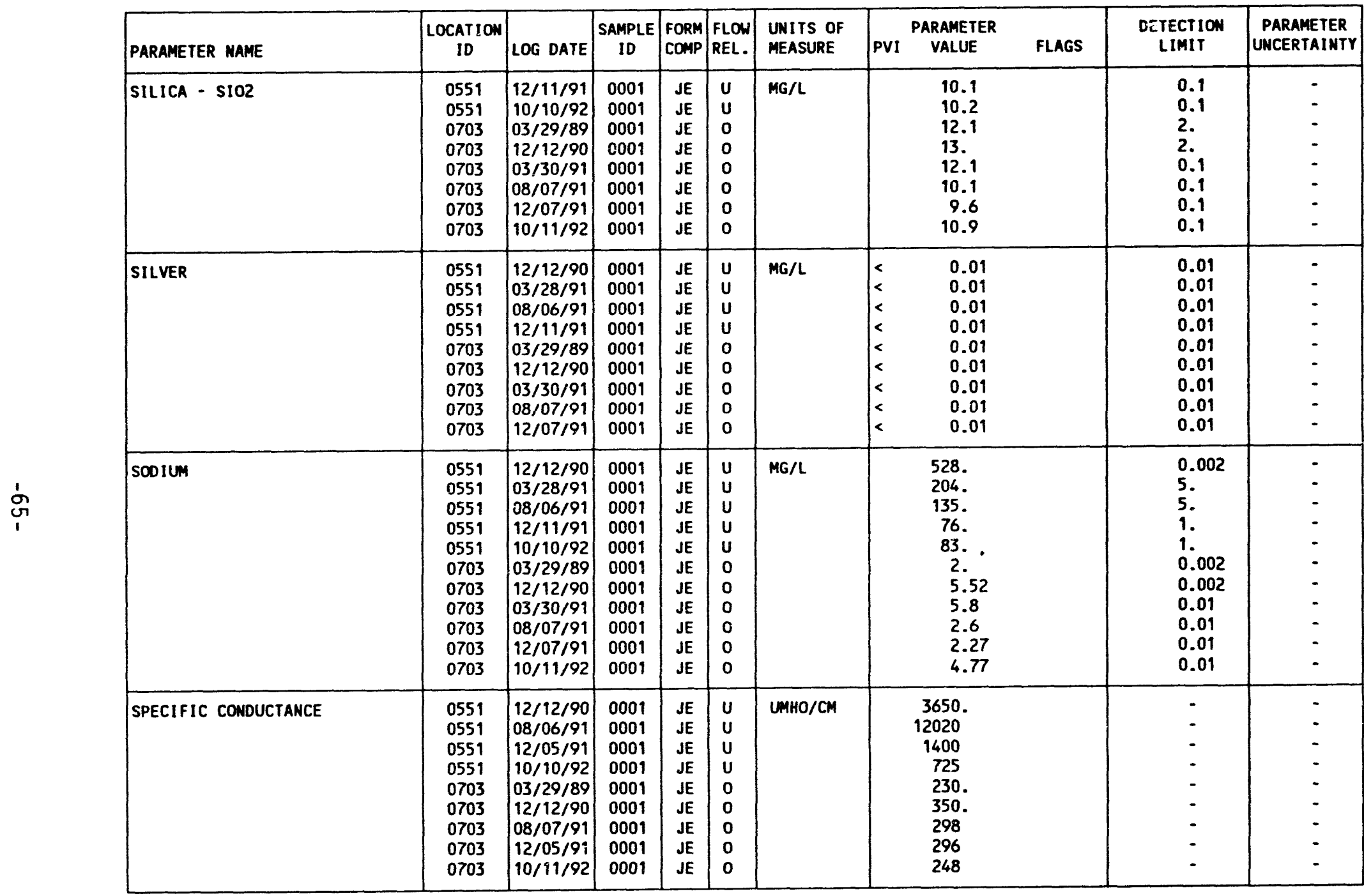

FORMATION OF COMPLETION CODE:

JE - JURASSIC ENTRADA SANDSTONE FORMATION
FLOW RELATIONSHIP COOE:

U - UPGRADIENT

O - ON-SITE

PARAMETER VALUE INDICATOR (PVI): - - LESS THAN DETECTION LIMIT 
TABLE 3.11 BACKGROUND GROUMDUATER QUALITY DATA BY PARAMETER FOR THE ENTRADA FORMATION, UC PROCESSING SITE, SLICK ROCK, COLORADO

SITE: SRKO1 SLICK ROCK (BOTH SITES)

SITE: SRK01 SLICK ROCK

REPORT DATE : 06/17/93

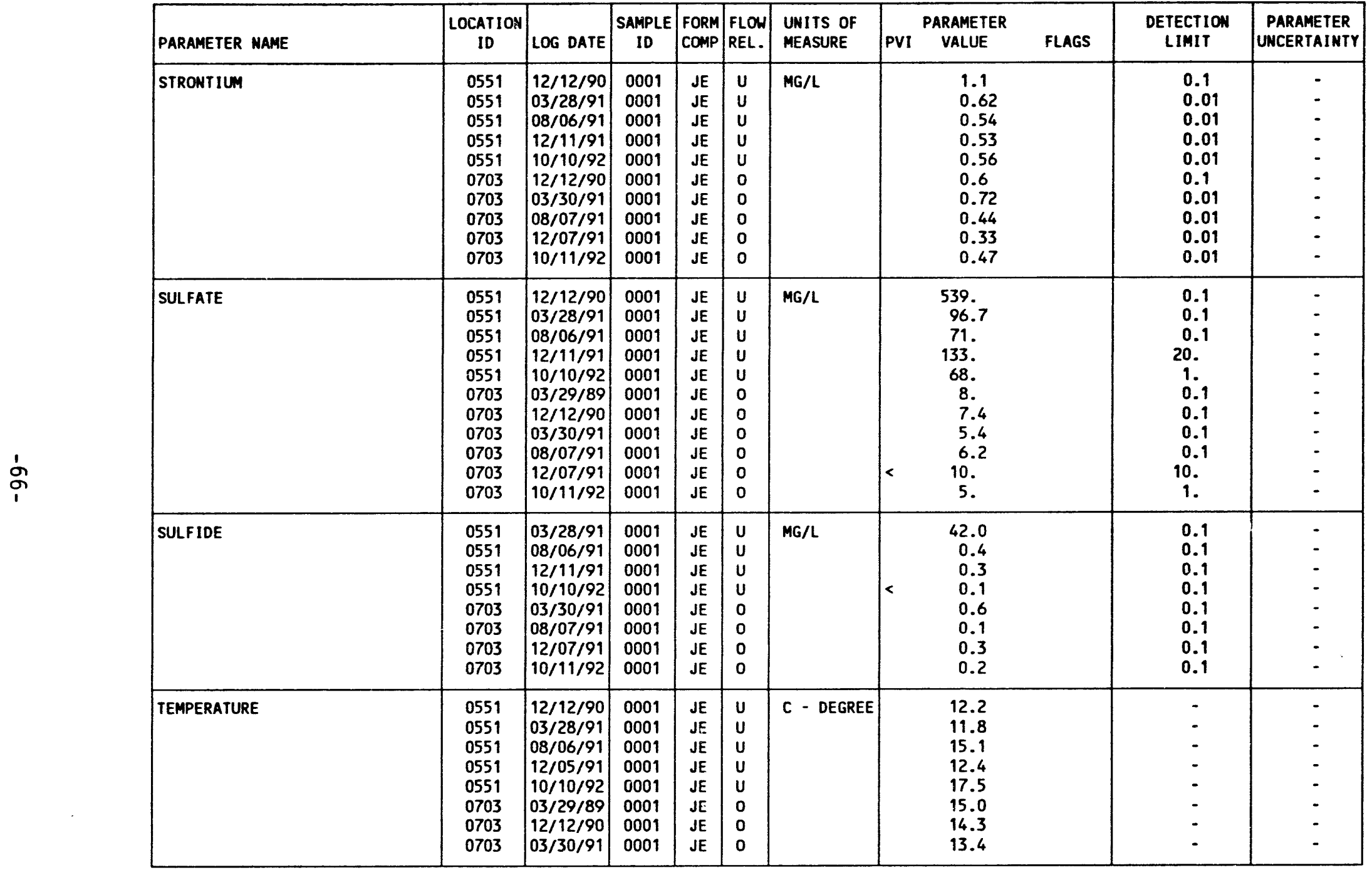

FORMATION OF COMPLETION CODE:

JE - JURASSIC ENTRADA SANDSTONE FORMATION
FLOW RELATIONSHIP CODE:

U - UPGRADIENT

O - ON-SITE

SAMPLE ID CODES:

0001 - FILTERED SAMPLE (.45 MICRONS)

PARAMETER VALUE INDICATOR (PVI): < - LESS THAN DETECTION LIMIT 
TABLE 3.19 BACKGROUND GROUNDWATER QUALITY DATA BY PARAMETER FOR THE ENTRADA FORMATION, UC PROCESSING SITE, SLICK ROCK, COLORADO

SITE: SRKO1 SLICK ROCK (BOTH SITES)

$03 / 29 / 89$ TO $10 / 11 / 92$

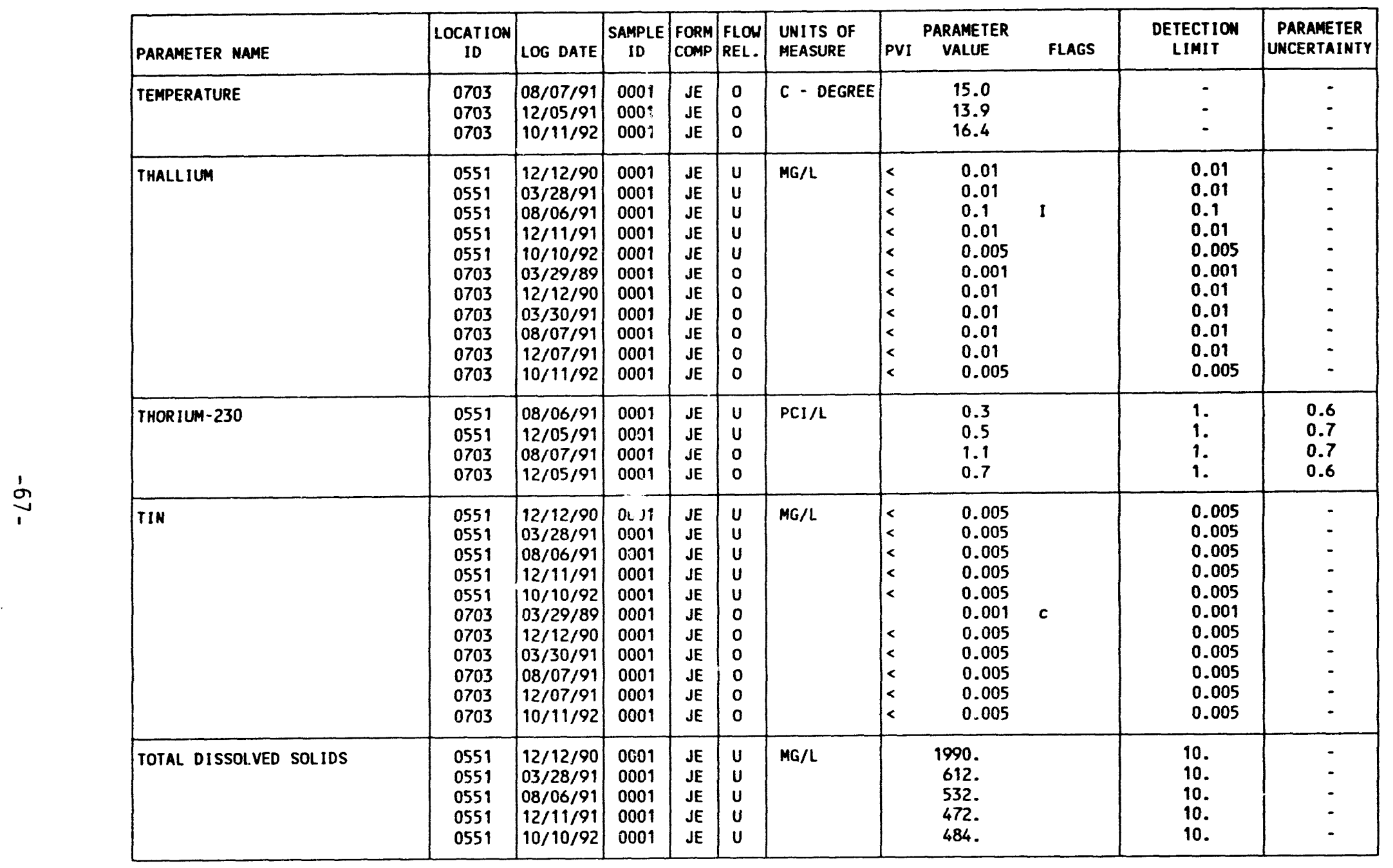

FORMATION OF COMPLETION COOE:

JE - JURASSIC ENTRADA SANDSTONE FORMATION

FLOW RELATIONSHIP CODE:

O - ON-SITE

PARAMETER VALUE INDICATOR (PVI): < - LESS THAN DETECTION LIMIT

0001 - FILTERED SAMPLE (.45 MICRONS)

OTHER PARAMETER VALUE FLAGS:

1 - INCREASED DETECTION LIMIT DUE TO REQUIRED DILUTION

c - CHANGED DETECTION LIMIT 
TABLE 3.11 BACKGROUND GROUNDWATER QUALITY DATA BY PARAMETER FOR THE ENTRADA FORMATION, UC PROCESSING SITE, SLICK ROCK, COLORADD

SITE: SRKO1 SLICK ROCK (BOTH SITES)

03/29/89 TO $10 / 11 / 92$

REPORT DATE: $06 / 17 / 93$

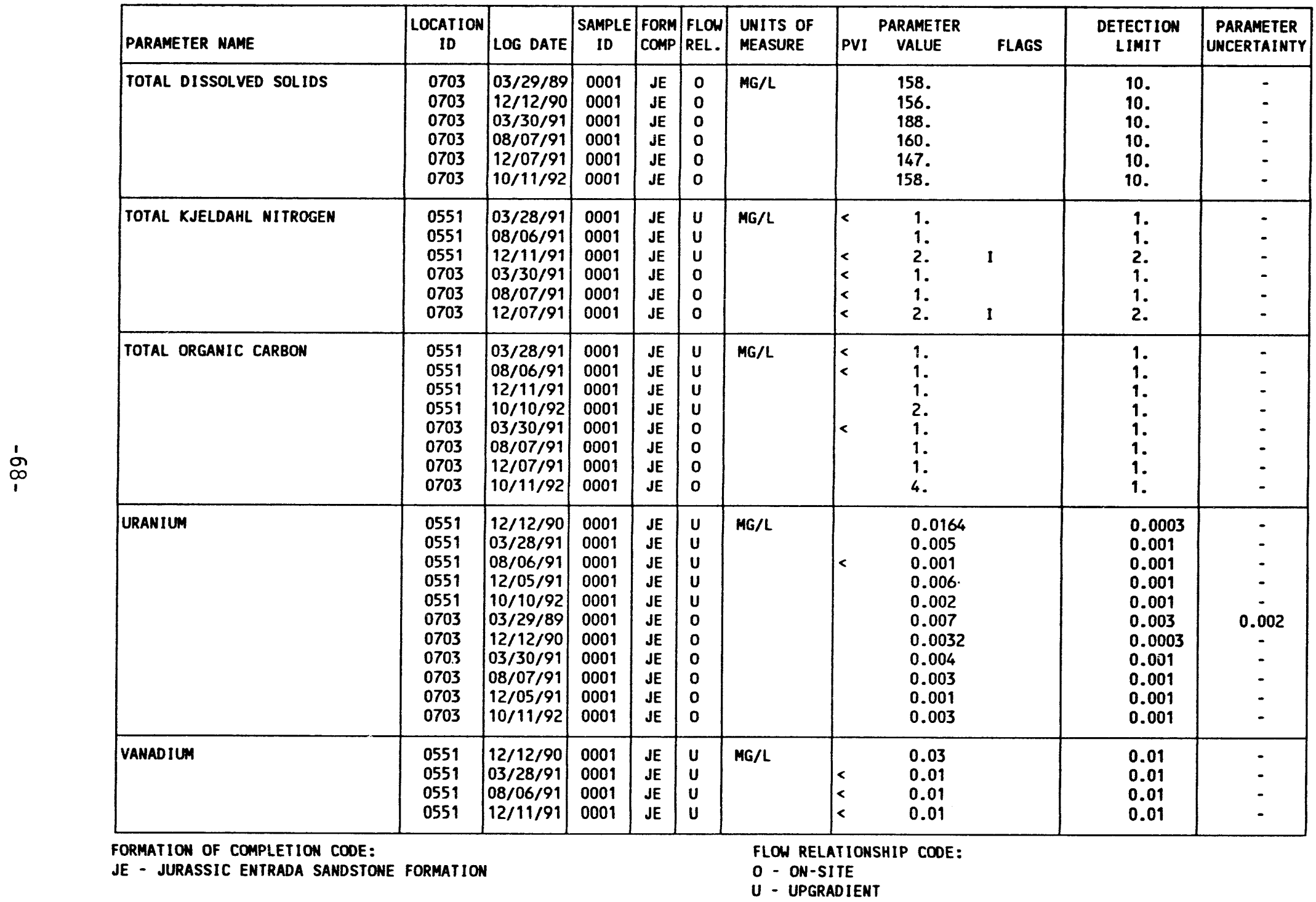

PARAMETER VALUE INDICATOR (PVI): — LESS THAN DETECTION LIMIT SAMPLE ID CODES:

0001 - FILTERED SAMPLE (.45 MICRONS)

OTHER PARAMETER VALUE FLAGS:

I - INCREASED DETECTION LIMIT DUE TO REQUIRED DILUTION 
TABLE 3.11 BACKGROUND GROUNDWATER QUALITY DATA BY PARAMETER FOR THE ENTRADA

FORMATION, UC PROCESSING SITE, SLICK ROCK, COLORADO

FORMATION, UC PROCESSING SITE, SLICK RC

SITE: SRKO1 SLICK ROCK

REPORT DATE: $06 / 17 / 93$

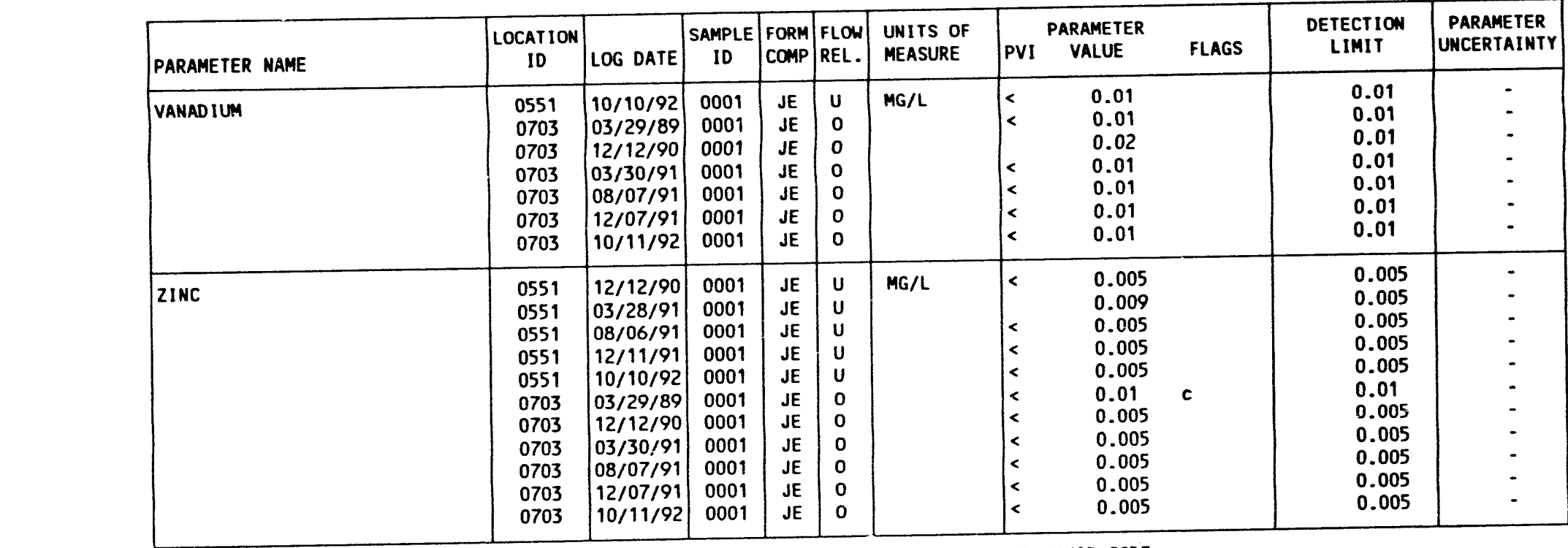

á FORMATION OF COMPLETION COOE:

if JE - JURASSIC ENTRADA SANDSTONE FORMATION

FLOW RELATIONSHIP COOE:

$U$ - UPGRADIENT

O - ON-SITE

PARAMETER VALUE INDICATOR (PVI): < - LESS THAN DETECTION LIMIT

SAMPLE ID COOES:

0001 - FILTERED SAMPLE (.45 MICRONS)

OTHER PARAMETER VALUE FLAGS:

C. CHANGED DETECTION LIMIT

DATA FILE NAME: M: IDARTISRK01\GWQ10024.DAT 
TABLE 3.12 BACKGROUN GROUNDUATER OUALITY DATA BY PARAMETER

FOR THE ENTRADA FORMATION, UC PROCESSING SITE, SLICK ROCK, COLORADO

SITE: SRKO1 SLICK ROCK (BOTH SITES)

03/29/89 TO 10/11/92

REPORT DATE : 07/26/93

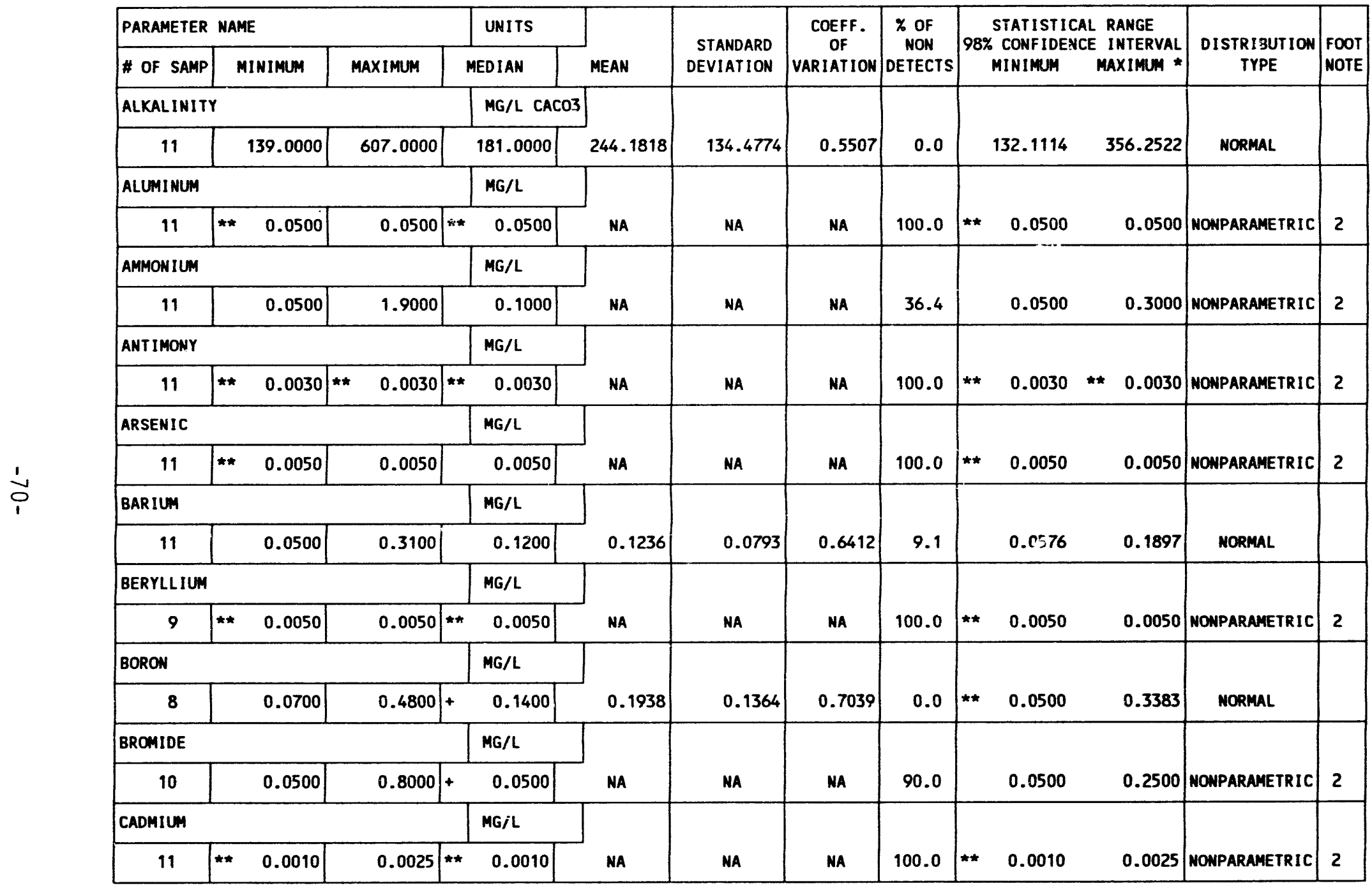

** The reported value is the minimum detection limit of the data set

+ The sample size is even, so the median value is the arithmetic average of the two middle values

* The statistical maximum is the 99 percent one sided confidence interval, $\alpha=0.01$

2) The nonparametric distribution was used because the nondetected values comprise more than $15 \%$ of the samples. 
TABLE 3.12 BACKGROUN GROUNDUATER QUALITY DATA BY PARAMETER

TOR THE ENTRADA FOPMATION, UC PROCESSING SITE, SLICK ROCK, COLORADO

FITE: SRKOI SLICK ROCK

$03 / 29 / 89$ TO $10 / 11 / 92$

REPORT DATE: $07 / 26 / 93$

\begin{tabular}{|c|c|c|c|c|c|c|c|c|c|c|c|}
\hline \multicolumn{3}{|c|}{ PARAMETER NAME } & UNITS & \multirow[b]{2}{*}{ MEAN } & \multirow{2}{*}{$\begin{array}{r}\text { STANDARD } \\
\text { DEVIATION }\end{array}$} & \multirow{2}{*}{$\begin{array}{c}\text { COEFF. } \\
\text { OF } \\
\text { VARIATION } \\
\end{array}$} & \multirow{2}{*}{$\begin{array}{l}\% \text { OF } \\
\text { NON } \\
\text { DETECTS }\end{array}$} & \multirow{2}{*}{\multicolumn{2}{|c|}{$\begin{array}{l}\text { STATISTICAL RANGE } \\
\text { 98\% CONFIDENCE INTERVAL } \\
\text { MINIMUM MAXIMM * }\end{array}$}} & \multirow{2}{*}{$\begin{array}{c}\text { DISTRIBUTION } \\
\text { TYPE }\end{array}$} & \multirow{2}{*}{$\begin{array}{l}\text { FOOT } \\
\text { NOTE }\end{array}$} \\
\hline \# OF SAMP & MINIMU & MAXIMUN & MEDIAN & & & & & & & & \\
\hline \multicolumn{3}{|l|}{ CALCIUM } & MG/L & \multirow[b]{2}{*}{27.5455} & \multirow[b]{2}{*}{9.3065} & \multirow[b]{2}{*}{0.3379} & \multirow[b]{2}{*}{0.0} & \multirow[b]{2}{*}{19.7896} & \multirow[b]{2}{*}{35.3013} & \multirow[b]{2}{*}{ NORMAL } & \\
\hline 11 & 18.5000 & 54.2000 & 26.0000 & & & & & & & & \\
\hline \multicolumn{3}{|l|}{ CHLOR IDE } & MG/L & \multirow[b]{2}{*}{22.6496} & \multirow[b]{2}{*}{7.2023} & \multirow[b]{2}{*}{ NA } & \multirow[b]{2}{*}{0.0} & \multirow[b]{2}{*}{4.3698} & \multirow[b]{2}{*}{117.3974} & \multirow[b]{2}{*}{ LOGNORMAL } & \multirow[b]{2}{*}{7,8} \\
\hline 11 & 4.0000 & 696.0000 & 4.8000 & & & & & & & & \\
\hline \multicolumn{3}{|l|}{ CHROMIUM } & $M G / L$ & \multirow[b]{2}{*}{ NA } & \multirow[b]{2}{*}{ NA } & \multirow[b]{2}{*}{ NA } & \multirow[b]{2}{*}{100.0} & \multirow[b]{2}{*}{0.0100} & \multirow[b]{2}{*}{$\star \quad 0.0100$} & & \\
\hline 11 & $\star \quad 0.0100$ & $\star \quad 0.0100$ & $\star \star \quad 0.0100$ & & & & & & & NONPARAMETRIC & 2 \\
\hline COBALT & & & MG/L & & & & & & & & \\
\hline 9 & ** $\quad 0.0300$ & $\star \quad 0.0300$ & $\star \star \quad 0.0300$ & NA & NA & NA & 100.0 & $\star \star \quad 0.0300$ & $* \pi \quad 0.0300$ & HONPARAMETRIC & 2 \\
\hline COPPER & & & $M G / L$ & & & & & & & & \\
\hline 11 & $\star * \quad 0.0100$ & 0.0100 & $\star * \quad 0.0100$ & NA & NA & NA & 100.0 & 0.0100 & 0.0100 & MONPARAMETRIC & 2 \\
\hline CYANIDE & & & $M G / L$ & & & & & & & & \\
\hline 9 & 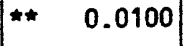 & $\star \star \quad 0.0100$ & 0.0100 & NA & NA & NA & 100.0 & $\star \quad .0 .0100$ & $\star 0.0100$ & MONPARAMETRIC & 2 \\
\hline FLUORIDE & & & $M G / L$ & & & & & & & & \\
\hline 11 & 0.3000 & 0.7000 & 0.6000 & 0.5364 & 0.1433 & 0.2672 & 0.0 & 0.4169 & 0.6558 & NORMAL & \\
\hline GROSS ALPF & & & $\mathrm{PCI} / \mathrm{L}$ & & & & & & & & \\
\hline 10 & $\star * \quad 1.0000$ & 7.7000 & 1.9500 & NA & NA & NA & 0.0 & 1.0000 & 6.3000 & MONPARAMETRIC & 9 \\
\hline GROSS BETA & & & $\mathrm{PCI} / \mathrm{L}$ & & & & & & & & \\
\hline 11 & ** $\quad 0.5000$ & 24.0000 & 6.0000 & MA & NA & NA & 0.0 & 0.5000 & 11.0000 & NONPARAMETRIC & 9 \\
\hline
\end{tabular}

* The reported value is the minimem detection limit of the data set

The sample size values

- The statistical maximm is the 99 percent one sided confidence interval, $\alpha=0.01$

政

7) The lognormal distribution was used because the data failed the normal distribution test.

(8) The logne geometric mean.

8) The mean is geometric. The standard deviation is the value to divide or multistribution test and includes values $\leq 0$. 
TABLE 3.12 BACKGROUN GROUNDWATER QUALITY DATA BY PARAMETER

FOR THE ENTRADA FORMATION, UC PROCESSING SITE, SLICK ROCK, COLORADO

SITE: SRKO1 SLICK ROCK (BOTH S

03/29/89 TO $10 / 11 / 92$

REPORT DATE: $07 / 26 / 93$

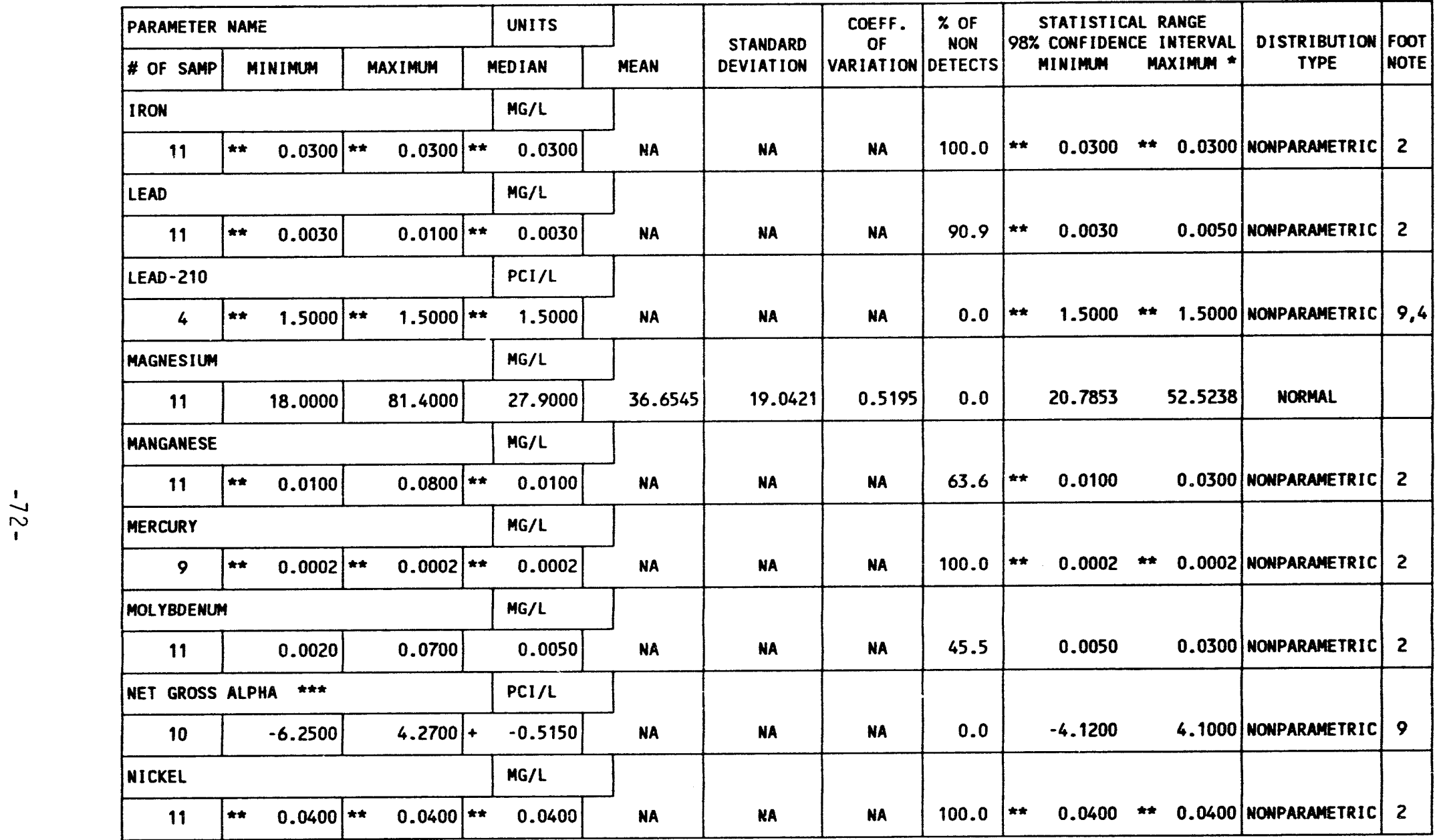

*\#\# NET GROSS ALPHA (GROSS ALPHA - URANIUM) WITH 1 MG URANIUM = 686 PCI

** The reported value is the minimum detection limit of the data set

+ The sampled

* The statistical maximum is the 99 percent one sided confidence interval, $a=0.01$

2) The nomparametric distribution was used because the nondetected values comprise more than $15 \%$ of the samples.

4) The stat. range is the $87.5 \%$ confidence interval due to a sample size of 4 . The maximum is the $93.8 \%$ one sided confidence int.

9) The nonparametic distribution was used because the data failed the normal distribution test and includes values $\leq 0$. 
TABLE 3.12 BACKGROUN GROUNDWATER QUALITY DATA BY PARAMETER

TAB THE ENTRADA FOPMATIOU UC PROCESSING SITE, SLICK ROCK, COLORADO

SITE: SRKO1 SLICK ROCK (BOTH SITES)

SITE: SRKO1 SLICK ROCK

REPORT DATE: $07 / 26 / 93$

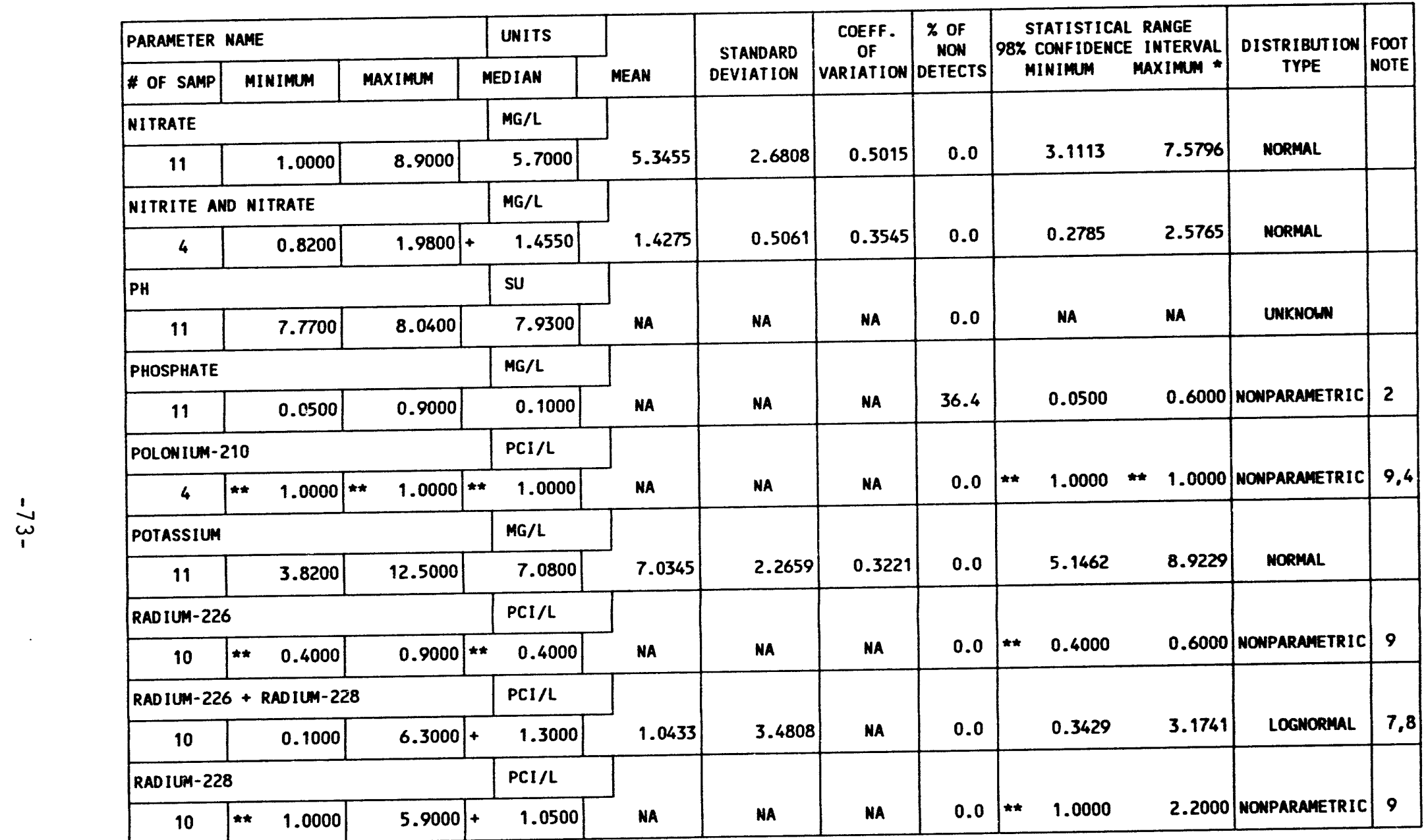

** The reported value is the minimum detection limit of the data set

- The sample size is even, so the median value is the arithmetic average of the two middle values

* The statistical maximum is the 99 percent one sided confidence interval, $\alpha=0.01$

1) A minimm of 4 samples must be available for the statistical analysis.

2) Ahe nonperametric distribution uas used because the nondetected values comprise more than $15 \%$ of the samples.

2) The nonparametric distribution was used because the

4) The stat. range is the

7) The lognormal distribution was used because the data failed the nivide or multiply with the geometric mean.

8) The mean is geometric. The standard deviation is the value to divide or multiply with the geonetriclues
9) The nonparametic distribution was used because the data failed the normal distribution test and includes values $\leq 0$. 
TABLE 3.12 BACKGROUN GROUNDHATER OUALITY DATA BY PARAMETER

FOR THE ENTRADA FORMATION, UC PROCESSING SITE, SLICK ROCK, COLORADO

$03 / 29 / 89$ TO $10 / 11 / 92$

REPORT DATE : $07 / 26 / 93$

\begin{tabular}{|c|c|c|c|c|c|c|c|c|c|c|c|}
\hline \multicolumn{3}{|c|}{ PARAMETER NAME } & UNITS & \multirow[b]{2}{*}{ MEAN } & \multirow{2}{*}{$\begin{array}{l}\text { STANDARD } \\
\text { DEVIATION }\end{array}$} & \multirow{2}{*}{$\begin{array}{c}\text { COEFF. } \\
\text { OF } \\
\text { VARIATION }\end{array}$} & \multirow{2}{*}{$\begin{array}{c}* \text { OF } \\
\text { NON } \\
\text { DETECTS }\end{array}$} & \multirow{2}{*}{\multicolumn{2}{|c|}{$\begin{array}{l}\text { STATISTICAL RANGE } \\
\text { 98\% CONFIDENCE INTERVAL } \\
\text { MINIMUM MAXIMUM * }\end{array}$}} & \multirow{2}{*}{$\begin{array}{c}\text { DISTRIBUTION } \\
\text { TYPE }\end{array}$} & \multirow{2}{*}{$\begin{array}{l}\text { FOOT } \\
\text { NOTE }\end{array}$} \\
\hline \# OF SAMP & MINIMUM & MAXIMUM & MEDIAN & & & & & & & & \\
\hline \multicolumn{3}{|c|}{ REDOX POTENTIAL } & mVOLTS & \multirow[b]{2}{*}{425.8730} & \multirow[b]{2}{*}{39.4021} & \multirow[b]{2}{*}{0.0925} & \multirow[b]{2}{*}{0.0} & \multirow[b]{2}{*}{336.4126} & \multirow[b]{2}{*}{515.3374} & \multirow[b]{2}{*}{ MORMAL } & \\
\hline 4 & 368.3000 & 456.1000 & +439.5500 & & & & & & & & \\
\hline \multicolumn{3}{|l|}{ SELENIUM } & $M G / L$ & \multirow[b]{2}{*}{ NA } & \multirow[b]{2}{*}{ NA } & \multirow[b]{2}{*}{ NA } & \multirow[b]{2}{*}{63.6} & \multirow[b]{2}{*}{0.0050} & \multirow[b]{2}{*}{0.0130} & \multirow[b]{2}{*}{ NOWPARAMETRIC } & \multirow[b]{2}{*}{2} \\
\hline 11 & \#* $\quad 0.0050$ & 0.0210 & $\star \star \quad 0.0050$ & & & & & & & & \\
\hline \multicolumn{3}{|c|}{ SILICA - SIOZ } & MGiL & \multirow[b]{2}{*}{10.8818} & \multirow[b]{2}{*}{1.0750} & \multirow[b]{2}{*}{0.0988} & \multirow[b]{2}{*}{0.0} & \multirow[b]{2}{*}{9.9859} & & & \\
\hline 11 & 9.6000 & 13.0000 & 10.5000 & & & & & & 11.777 & MORMAL & \\
\hline SILVER & & & $M G / L$ & & & & & & & & \\
\hline 9 & $\star \star \quad 0.0100$ & $\star \star \quad 0.0100$ & $\star \star \quad 0.0100$ & NA & NA & NA & 100.0 & 0.0100 & $\star \quad 0.0100$ & MONPARAMETRIC & 2 \\
\hline SODIUM & & & $M G / L$ & & & & & & & & \\
\hline 11 & 2.0000 & 528.0000 & 5.8000 & 19.6147 & 7.9540 & NA & 0.0 & 3.4838 & 110.4361 & LOGMORMAL & 7,8 \\
\hline SPECIFIC & CONDUCTANCE & & UМно/СM & & & & & & & & \\
\hline 9 & 230.0000 & 12020.0000 & 350.0000 & 753.6291 & 4.0244 & MA & 0.0 & 196.5239 & 2890.0137 & LOGNORMAL & 7,8 \\
\hline STRONTIUM & & & MG/L & & & & & & & & \\
\hline 10 & 0.3300 & 1.1000 & 0.5500 & 0.5910 & 0.2080 & 0.3520 & 0.0 & 0.4054 & 0.7766 & NORMAL & \\
\hline SULFATE & & & MG/L & & & & & & & & \\
\hline 11 & 5.0000 & 539.0000 & 8.0000 & 24.1884 & 5.3915 & NA & 9.1 & 5.9404 & 98.4909 & LOGNORMAL & 7,8 \\
\hline SULFIDE & & & $M G / L$ & & & & & & & & \\
\hline 8 & $\star \quad 0.1000$ & 42.0000 & 0.3000 & 0.4166 & 7.5756 & NA & 12.5 & 0.1000 & 3.5633 & LOGNORMAL & 7,8 \\
\hline TEMPERATUR & & & C - DEGR & & & & & & & & \\
\hline 11 & 11.8000 & 17.5000 & 14.3000 & 14.2727 & 1.7749 & 0.1244 & 0.0 & 12.7936 & 15.7519 & NORMAL & \\
\hline
\end{tabular}

** The reported value is the minimum detection limit of the data set

+ The sample size is even, so the median value is the arithmetic average of the two middle values

- The statistical maximum is the 99 percent one sided confidence interval, $a=0.01$

2) The nonparametric distribution was used because the nondetected values comprise more than $15 \%$ of the samples.

7) The lognormal distribution was used because the data failed the normal distribution test.

8) The mean is geometric. The standard deviation is the value to divide or multiply with the geometric mean. 
TABLE 3.12 BACKGROUN GROUNDHATER QUALITY DATA BY PARAMETER

FOR THE EMTRADA FORMATION, UC PROCESSING SITE, SLICK ROCK, COLORADO

SITE: SRKO1 SLICK ROCK (BOTH SITES)

SITE: SRKO1 SLICK ROC1

REPORT DATE: $07 / 26 / 93$

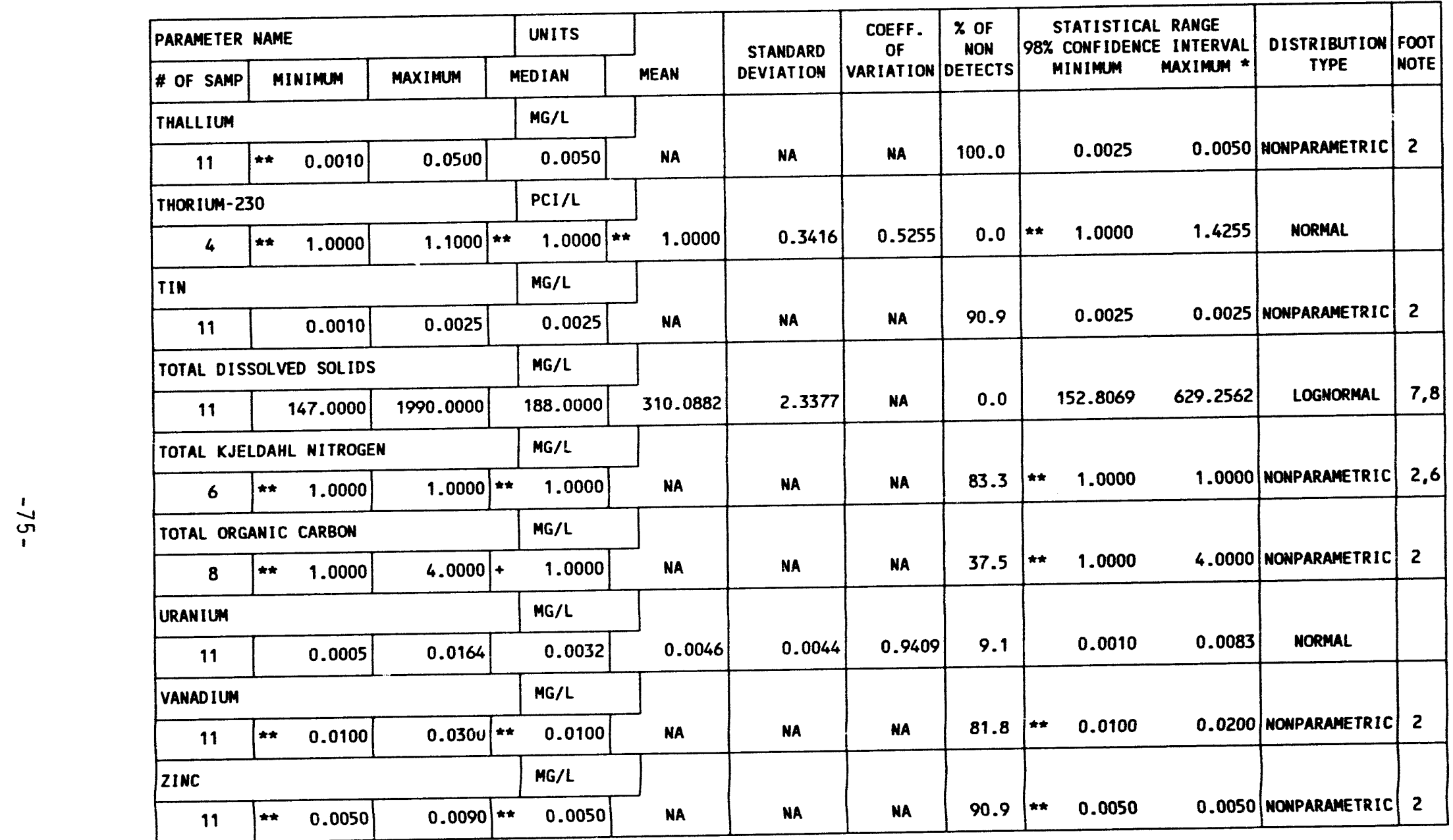

** The reported value is the minimum detection limit of the data set

- The statistical maximum is the 99 percent one sided confidence interval, $a=0.01$

2) The nomparametric distribution us used because the nondetected values comprise more than $15 \%$ of the samples.

6) The

7) The lognormal distribution was used because the data failed the normal distribution test.

8) The 
Table 3.13 Summary of regulated constituents in the Entrada Formation background groundwater, UC processing site, Slick Rock, Colorado

\begin{tabular}{|c|c|c|c|}
\hline \multicolumn{4}{|c|}{ Constituents with $\mathrm{MCL}^{\mathrm{a}}$} \\
\hline Parameter & MCLs & $\begin{array}{l}\text { Mean or } \\
\text { Median }\end{array}$ & $\begin{array}{c}\text { statistical } \\
\text { maximum }\end{array}$ \\
\hline Arsenic & 0.05 & $0.01^{e}$ & $0.01^{\mathrm{e}}$ \\
\hline Barium & 1.00 & $0.12^{\mathrm{d}}$ & 0.19 \\
\hline Cadmium & 0.01 & $0.001^{e}$ & 0.002 \\
\hline Chromium & 0.05 & $0.01^{\mathrm{e}}$ & $0.01^{\mathrm{e}}$ \\
\hline Net gross alphab & 15.0 & -0.515 & 4.10 \\
\hline Lead & 0.05 & $0.01^{\circ}$ & $0.01^{e}$ \\
\hline Mercury & 0.002 & $0.0002^{e}$ & $0.0002^{e}$ \\
\hline Molybdenum & 0.10 & $0.01^{\mathrm{c}}$ & 0.03 \\
\hline Nitrate & 44.0 & $5.34^{\mathrm{d}}$ & 7.58 \\
\hline Radium-226 and $-228^{b}$ & 5.00 & $.04^{d}$ & 3.17 \\
\hline Selenium & 0.01 & $0.005^{\mathrm{e}}$ & 0.013 \\
\hline Silver & 0.05 & $0.01^{e}$ & $0.01^{\mathrm{e}}$ \\
\hline Uranium & 0.044 & $0.005^{d}$ & 0.0083 \\
\hline
\end{tabular}


Table 3.13 Summary of regulated constituents in the Entrada Formation background groundwater, UC processing site, Slick Rock, Colorado (concluded)

Constituents without MCLs"

\begin{tabular}{lll}
\hline \multicolumn{1}{c}{ Parameter } & $\begin{array}{c}\text { Mean or } \\
\text { Median }\end{array}$ & $\begin{array}{c}\text { Statistical } \\
\text { maximum }\end{array}$ \\
\hline Antimony & $0.003^{\mathrm{e}}$ & $0.003^{\mathrm{e}}$ \\
Beryllium & $0.01^{\mathrm{e}}$ & $0.01^{\mathrm{e}}$ \\
Cobalt & $0.05^{\mathrm{e}}$ & $0.05^{\mathrm{e}}$ \\
Copper & $0.02^{\mathrm{e}}$ & $0.02^{\mathrm{e}}$ \\
Cyanide & $0.01^{\mathrm{e}}$ & $0.01^{\mathrm{e}}$ \\
Nickel & $0.04^{\mathrm{e}}$ & $0.04^{\mathrm{e}}$ \\
Sulfide & $0.42^{\mathrm{c}}$ & 3.56 \\
Thallium & $0.01^{\mathrm{e}}$ & $0.01^{\mathrm{c}}$ \\
Tin & $0.005^{\mathrm{e}}$ & $0.005^{\mathrm{e}}$ \\
Vanadium & $0.01^{\mathrm{e}}$ & $0.02^{\mathrm{c}}$ \\
Zinc & $0.005^{\mathrm{e}}$ & $0.005^{\mathrm{e}}$ \\
\hline
\end{tabular}

"All units are $\mathrm{mg} / \mathrm{l}$ unless othervise noted.

bunits are $\mathrm{pCi} / \mathrm{l}$.

'Mean value, Lognormal distribution, mean is geometric.

Mean value, Normal distribution, mean is arithmetic.

'Statistical values are below laboratory detection limits in

Table 8.1 of the Technical Approach Document (DOE, 1989). 
TABLE 3.14 GROUNDWATER OUALITY MEASUREMENTS EXCEED ING MAXIMUM CONCENTRATION

LIMITS IN ENTRADA FORMATICN BACKGROUMD GROUNDWATER, UC PROCESSING SITE

SITE: SRK01 SLICK ROCK (BOTH SITES)

03/29/89 TO $10 / 11 / 92$

REPORT DATE : $06 / 17 / 93$

\begin{tabular}{|c|c|c|c|c|c|c|c|c|c|c|c|}
\hline PARAMETER MAME & $\begin{array}{l}\text { TOTAL } \\
\text { \# OF } \\
\text { SAMP. }\end{array}$ & $\begin{array}{l}\text { UNITS } \\
\text { OF } \\
\text { MEASURE }\end{array}$ & $\begin{array}{l}\text { Maximum } \\
\text { CONC. } \\
\text { LIMIT }\end{array}$ & $\begin{array}{l}\text { LOC. } \\
\text { ID }\end{array}$ & LOG DATE & $\underset{\text { ID }}{\text { SAMP }}$ & $\begin{array}{c}\text { FORM } \\
\text { OF } \\
\text { COMP }\end{array}$ & $\begin{array}{l}\text { HYDR } \\
\text { FLOW } \\
\text { REL. }\end{array}$ & $\begin{array}{c}\text { RESULT EXCEEDING MAX. } \\
\text { CONCENTRATION LIMIT } \\
\text { VALUE } \\
\text { FLAGS }\end{array}$ & $\begin{array}{l}\text { DETECTION } \\
\text { LIMIT }\end{array}$ & $\begin{array}{c}\text { PARAMETER } \\
\text { UNCERT. }\end{array}$ \\
\hline ARSENIC & 11 & $M G / L$ & 0.0500 & - & - & - & - & - & $\cdot$ & - & - \\
\hline ARSENIC (TOTAL) & 0 & $M G / L$ & 0.0500 & - & - & - & - & $\cdot$ & - & $\cdot$ & - \\
\hline BARIUM & 11 & $M G / L$ & 1.0000 & - & - & - & - & - & $\cdot$ & - & - \\
\hline BARIUM (TOTAL) & 0 & $M G / L$ & 1.0000 & - & - & - & - & - & - & - & - \\
\hline CADMIUM & 11 & $M G / L$ & 0.0100 & - & - & - & - & - & - & - & - \\
\hline CADMIUM (TOTAL) & 0 & $M G / L$ & 0.0100 & - & $\cdot$ & - & - & - & - & - & - \\
\hline CHROMIUM & 11 & $M G / L$ & 0.0500 & - & - & - & - & - & - & - & $\cdot$ \\
\hline CHROMIUM (TOTAL) & 0 & $M G / L$ & 0.0500 & - & - & - & - & - & - & - & - \\
\hline GROSS ALPHA & 10 & $\mathrm{PCI} / \mathrm{L}$ & 15.0000 & - & - & - & - & - & - & - & - \\
\hline GROSS ALPHA (TOTAL) & 0 & $\mathrm{PCl} / \mathrm{L}$ & 15.0000 & - & - & - & - & - & - & - & - \\
\hline LEAD & 11 & $M G / L$ & 0.0500 & - & - & - & - & - & - & - & - \\
\hline LEAD (TOTAL) & 0 & $M G / L$ & 0.0500 & - & - & - & - & - & - & - & - \\
\hline MERCURY & 9 & $M G / L$ & 0.0020 & - & - & - & - & - & - & - & - \\
\hline MERCURY (TOTAL) & 0 & $M G / L$ & 0.0020 & - & - & - & - & - & - & - & - \\
\hline MOLYBDENUM & 11 & $M G / L$ & 0.1000 & - & - & - & - & - & - & - & - \\
\hline MOL YBDENUM (TOTAL) & 0 & $M G / L$ & 0.1000 & - & - & - & - & - & - & - & - \\
\hline NET GROSS ALPHA * & 10 & $\mathrm{PCI} / \mathrm{L}$ & 15.0000 & - & - & - & - & - & - & - & - \\
\hline NET GROSS ALPHA (TOTAL) $\star \star$ & 0 & $\mathrm{PCI} / \mathrm{L}$ & 15.0000 & - & - & - & - & - & - & - & - \\
\hline NITRATE & 11 & $M G / L$ & 44.0000 & - & - & - & - & - & - & - & - \\
\hline
\end{tabular}

* net gross alPHa (GROSS alPHa - URANIUM)

WITH 1 MG URANIUM $=686 \mathrm{PCI}$

* total net gross alpha (total gross alpha - total URANiUm) 
TABLE 3.14 GROUNDWATER OUALITY MEASUREMENTS EXCEEDING MAXIMUM CONCENTRATION

LIMITS IN ENTRADA FORMATION BACKGROUND GROUNDWATER, UC PROCESSING SITE

SITE: SRKO1 SLICK ROCK (BOTH SITES)

$03 / 29 / 89$ TO $10 / 11 / 92$

REPORT DATE: 06/17/93

\begin{tabular}{|c|c|c|c|c|c|c|c|c|c|c|c|}
\hline PARAMETER NAME & $\begin{array}{l}\text { TOTAL } \\
\text { \# OF } \\
\text { SAMP. }\end{array}$ & $\begin{array}{l}\text { UNITS } \\
\text { OF } \\
\text { MEASURE }\end{array}$ & $\begin{array}{l}\text { MAXIMUM } \\
\text { CONC. } \\
\text { LIMIT }\end{array}$ & $\begin{array}{l}\text { LOC. } \\
\text { ID }\end{array}$ & LOG DATE & $\begin{array}{c}\text { SAMP } \\
\text { ID }\end{array}$ & $\begin{array}{l}\text { FORM } \\
\text { OF } \\
\text { COMP }\end{array}$ & $\begin{array}{l}\text { HYDR } \\
\text { FLOW } \\
\text { REL. }\end{array}$ & $\begin{array}{c}\text { RESULT EXCEEDING MAX. } \\
\text { CONCENTRATION LIMIT } \\
\text { VALUE FLAGS }\end{array}$ & $\begin{array}{l}\text { DETECTION } \\
\text { LIMIT }\end{array}$ & $\begin{array}{l}\text { PARAMETER } \\
\text { UNCERT. }\end{array}$ \\
\hline NITRATE (TOTAL) & $\mathbf{0}$ & MG/L & 44.0000 & - & $\cdot$ & - & - & - & - & - & - \\
\hline RA-226 \& RA-228 & 10 & $\mathrm{PCI} / \mathrm{L}$ & 5.0000 & 0703 & $08 / 07 / 91$ & 0001 & JE & $\mathbf{0}$ & 6.3 & - & - \\
\hline RA-226 \& RA-228 (TOTAL) & 0 & PCI/L & 5.0000 & - & - & - & - & - & - & - & - \\
\hline SELENIUM & 11 & $M G / L$ & 0.0100 & $\begin{array}{l}0551 \\
0551\end{array}$ & $\begin{array}{l}12 / 12 / 90 \\
03 / 28 / 91\end{array}$ & $\begin{array}{l}0001 \\
0001\end{array}$ & $\begin{array}{l}\text { JE } \\
\text { JE }\end{array}$ & $\begin{array}{l}u \\
u\end{array}$ & $\begin{array}{l}0.021 \\
0.013\end{array}$ & $\begin{array}{l}0.005 \\
0.005\end{array}$ & - \\
\hline SELENIUM (TOTAL) & 0 & $M G / L$ & 0.0100 & - & - & - & - & - & $\cdot$ & - & - \\
\hline SILVER & 9 & MG/L & 0.0500 & - & - & - & - & - & - & - & - \\
\hline SILVER (TOTAL) & 0 & MG/L & 0.0500 & - & - & - & - & - & - & - & - \\
\hline URANIUM & 11 & $M G / L$ & 0.0440 & - & - & - & - & - & - & - & - \\
\hline URANIUM (TOTAL) & 0 & MG/L & 0.0440 & - & - & - & - & - & - & - & - \\
\hline
\end{tabular}

FORMATION OF COMPLETION CODE:

JE - JURASSIC ENTRADA SANDSTONE FORMATION

FLOW RELATIONSHIP COOE:

O - ON-SITE

SAMPLE ID CODES:

0001 - FILTERED SAMPLE (.45 MICRONS)

DATA FILE NAME: M: VDARTISRK01\GWQ10024.DAT 
TABLE 3.15 BACKGROUND GROUMDHATER QUALITY DATA BY PARAMETER FOR THE MAVAJO SAMDSTONE, MC AND UC PROCESSING SITE, SLICK ROCK, COLORADO

SITE: SRKO1 SLICK ROCK (BOTH SITES)

TES $10 / 12 / 92$

REPORT DATE : $06 / 17 / 93$

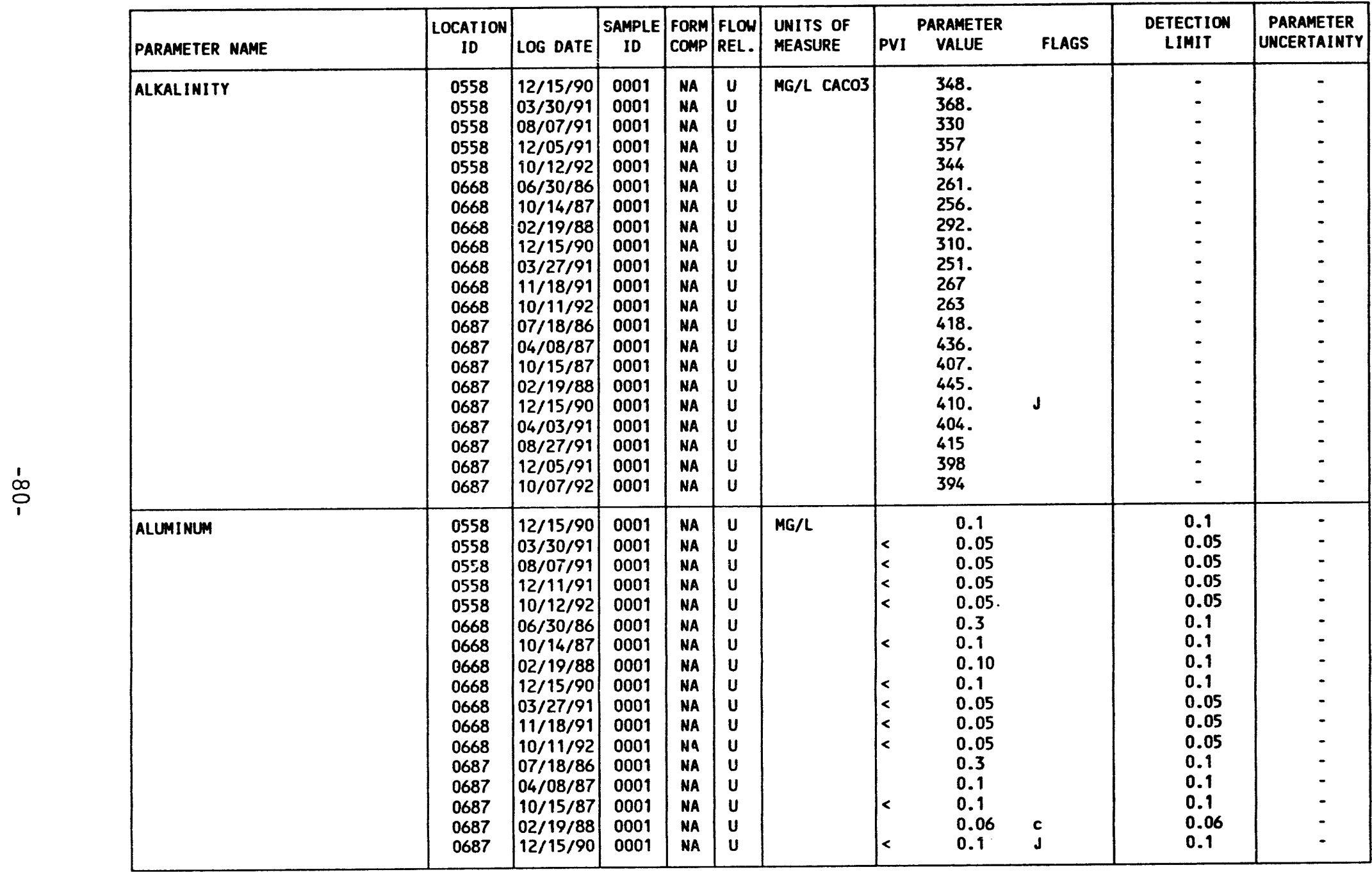

FORMATION OF COMPLETION COOE:

FLOW RELATIONSHIP CODE:

MA - NAVAJO SANDSTONE

U - UPGRADIENT

PARAMETER VALUE INDICATOR (PVI): < - LESS THAN DETECTION LIMIT

SAMPLE ID CODES:

0001 - FILTERED SAMPLE (.45 MICRONS)

OTHER PARAMETER VALUE FLAGS:

$J$ - ESTIMATED VALUE

c - CHANGED DETECTION LIMIT 
TABLE 3.15 BACKGROUND GROUNDWATER QUALITY DATA BY PARAMETER FOR THE NAVAJO SANDSTONE, NC AND UC PROCESSING SITE, SLICK ROCK, COLORADO

SITE: SRKO1 SLICK ROCK (BOTH SITES)

$06 / 30 / 86$ TO $10 / 12 / 92$

REPORT DATE: 06/17/93

\begin{tabular}{|c|c|c|c|c|c|c|c|c|c|c|c|}
\hline PARAMETER MAME & $\begin{array}{c}\text { LOCATION } \\
\text { ID }\end{array}$ & LOG DATE & $\begin{array}{c}\text { SAMPLE } \\
\text { ID }\end{array}$ & $\begin{array}{l}\text { FORM } \\
\text { COMP }\end{array}$ & $\begin{array}{l}\text { FLOW } \\
\text { REL. }\end{array}$ & $\begin{array}{l}\text { UNITS OF } \\
\text { MEASURE }\end{array}$ & PVI & $\begin{array}{l}\text { ARAMETER } \\
\text { VALUE }\end{array}$ & FLAGS & $\begin{array}{l}\text { DETECTION } \\
\text { LIMIT }\end{array}$ & $\begin{array}{l}\text { PARAMETER } \\
\text { UNCERTAINTY }\end{array}$ \\
\hline ALUMINUM & $\begin{array}{l}3687 \\
0687 \\
0687 \\
0687\end{array}$ & $\begin{array}{l}04 / 03 / 91 \\
08 / 27 / 91 \\
12 / 10 / 91 \\
10 / 07 / 92\end{array} \mid$ & $\begin{array}{l}0001 \\
0001 \\
0001 \\
0001\end{array}$ & $\begin{array}{l}\text { NA } \\
\text { NA } \\
\text { NA } \\
\text { NA }\end{array}$ & $\begin{array}{l}u \\
U \\
U \\
U\end{array}$ & $M G / L$ & $k$ & $\begin{array}{l}0.05 \\
0.05 \\
0.05 \\
0.05\end{array}$ & & $\begin{array}{l}0.05 \\
0.05 \\
0.05 \\
0.05\end{array}$ & : \\
\hline AMHONIUM & $\begin{array}{l}0558 \\
0558 \\
0558 \\
0558 \\
0558 \\
0668 \\
0668 \\
0668 \\
0668 \\
0668 \\
0668 \\
0687 \\
0687 \\
0687 \\
0687 \\
0687 \\
0687 \\
0687 \\
0687 \\
0687\end{array}$ & \begin{tabular}{|l|}
$12 / 15 / 90$ \\
$03 / 30 / 91$ \\
$08 / 07 / 91$ \\
$12 / 11 / 91$ \\
$10 / 12 / 92$ \\
$10 / 14 / 87$ \\
$02 / 19 / 88$ \\
$12 / 15 / 90$ \\
$03 / 27 / 91$ \\
$11 / 18 / 91$ \\
$10 / 11 / 92$ \\
$07 / 18 / 86$ \\
$04 / 08 / 87$ \\
$10 / 15 / 87$ \\
$02 / 19 / 88$ \\
$12 / 15 / 90$ \\
$04 / 03 / 91$ \\
$08 / 27 / 91$ \\
$12 / 10 / 91$ \\
$10 / 07 / 92$
\end{tabular} & $\begin{array}{l}0001 \\
0001 \\
0001 \\
0001 \\
0001 \\
0001 \\
0001 \\
0001 \\
0001 \\
0001 \\
0001 \\
0001 \\
0001 \\
0001 \\
0001 \\
0001 \\
0001 \\
0001 \\
0001 \\
0001\end{array}$ & $\begin{array}{l}\text { NA } \\
\text { NA } \\
\text { NA } \\
\text { NA } \\
\text { NA } \\
\text { NA } \\
\text { NA } \\
\text { NA } \\
\text { NA } \\
\text { NA } \\
\text { NA } \\
\text { NA } \\
\text { NA } \\
\text { NA } \\
\text { NA } \\
\text { NA } \\
\text { NA } \\
\text { NA } \\
\text { NA } \\
\text { NA }\end{array}$ & $\begin{array}{l}u \\
U \\
U \\
U \\
U \\
U \\
U \\
U \\
U \\
U \\
U \\
U \\
U \\
U \\
U \\
U \\
U \\
U \\
U \\
U\end{array}$ & MG/L & $\begin{array}{l}< \\
< \\
< \\
< \\
< \\
< \\
< \\
< \\
< \\
< \\
< \\
<\end{array}$ & $\begin{array}{l}0.1 \\
0.1 \\
0.1 \\
0.1 \\
0.1 \\
0.1 \\
0.1 \\
0.1 \\
0.1 \\
0.1 \\
0.2 \\
0.1 \\
0.1 \\
0.3 \\
0.1 \\
0.1 \\
0.4 \\
0.5 \\
0.4 \\
0.6\end{array}$ & $J$ & $\begin{array}{l}0.1 \\
0.1 \\
0.1 \\
0.1 \\
0.1 \\
0.1 \\
0.1 \\
0.1 \\
0.1 \\
0.1 \\
0.1 \\
0.1 \\
0.1 \\
0.1 \\
0.1 \\
0.1 \\
0.1 \\
0.1 \\
0.1 \\
0.1\end{array}$ & $\begin{array}{l}- \\
: \\
- \\
- \\
- \\
- \\
- \\
- \\
- \\
- \\
- \\
- \\
- \\
-\end{array}$ \\
\hline ANTIMONY & $\begin{array}{l}0558 \\
0558 \\
0558 \\
0558 \\
0558 \\
0668 \\
0668 \\
0668 \\
0668 \\
0687 \\
0687 \\
0687 \\
0687 \\
0687\end{array}$ & $\begin{array}{l}12 / 15 / 90 \\
03 / 30 / 91 \\
08 / 07 / 91 \\
12 / 11 / 91 \\
10 / 12 / 92 \\
12 / 15 / 90 \\
03 / 27 / 91 \\
11 / 18 / 91 \\
10 / 11 / 92 \\
07 / 18 / 86 \\
04 / 08 / 87 \\
12 / 15 / 90 \\
04 / 03 / 91 \\
08 / 27 / 91\end{array}$ & $\begin{array}{l}0001 \\
0001 \\
0001 \\
0001 \\
0001 \\
0001 \\
0001 \\
0001 \\
0001 \\
0001 \\
0001 \\
0001 \\
0001 \\
0001\end{array}$ & $\begin{array}{l}\text { NA } \\
\text { NA } \\
\text { NA } \\
\text { NA } \\
\text { NA } \\
\text { NA } \\
\text { NA } \\
\text { NA } \\
\text { NA } \\
\text { NA } \\
\text { NA } \\
\text { NA } \\
\text { NA } \\
\text { HA }\end{array}$ & $\begin{array}{l}u \\
U \\
U \\
U \\
U \\
U \\
U \\
U \\
U \\
U \\
U \\
U \\
U \\
U\end{array}$ & $M G / L$ & $\begin{array}{l}< \\
< \\
< \\
< \\
< \\
< \\
< \\
< \\
< \\
< \\
< \\
< \\
< \\
<\end{array}$ & $\begin{array}{l}0.003 \\
0.003 \\
0.003 \\
0.003 \\
0.003 \\
0.003 \\
0.003 \\
0.003 \\
0.003 \\
0.003 \\
0.003 \\
0.003 \\
0.003 \\
0.003\end{array}$ & J & $\begin{array}{l}0.003 \\
0.003 \\
0.003 \\
0.003 \\
0.003 \\
0.003 \\
0.003 \\
0.003 \\
0.003 \\
0.003 \\
0.003 \\
0.003 \\
0.003 \\
0.003\end{array}$ & $\begin{array}{l}- \\
: \\
: \\
: \\
- \\
- \\
- \\
- \\
-\end{array}$ \\
\hline
\end{tabular}

FORMATION OF COMPLETION COOE:

MA - MAVAJO SANDSTONE

PARAMETER VALUE INDICATOR (PVI): < - LESS THAN DETECTION LIMIT
FLOW RELATIONSHIP COOE:

SAMPLE IO COOES:

0001 - FILTERED SAMPLE. (.45 MICRONS) 
TABLE 3.15 BACKGROUND GROUNDHATER QUALITY DATA BY PARAMETER FOR THE NAVAJO SANDSTONE, NC AND UC PROCESSING SITE, SLICK ROCK, COLORADO

SITE: SRKO1 SLICK ROCK (BOTH SITES)

$06 / 30 / 86$ TO $10 / 12 / 92$

REPORT DATE: $06 / 17 / 93$

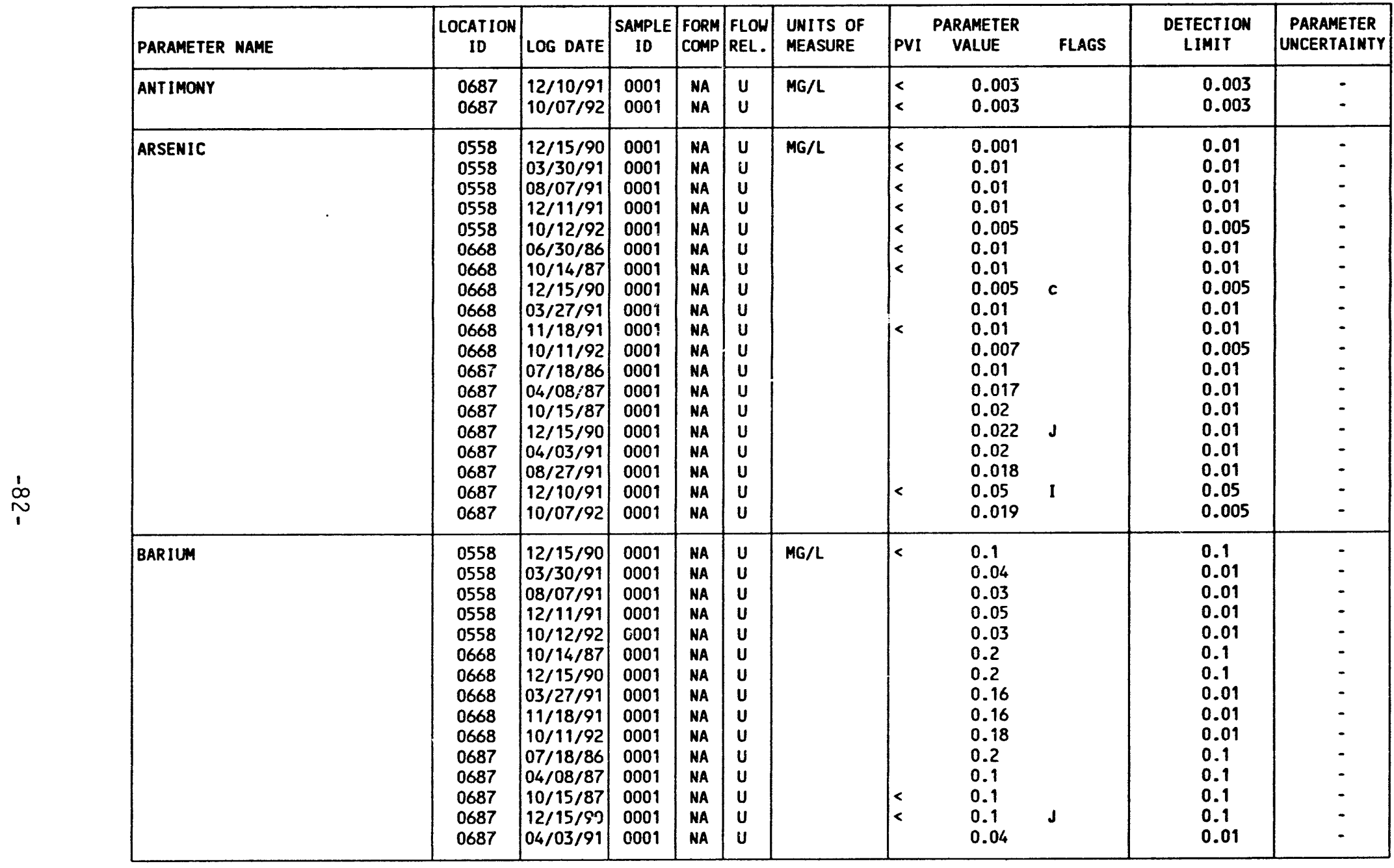

FORMATION OF COMPLETION COOE:

NA - NAVAJO SANDSTONE

PARAMETER VALUE INDICATOR (PVI): < - LESS THAN DETECTION LIMIT
FLOW RELATIONSHIP CODE:

U - UPGRADIENT

0001 - FILTERED SAMPLE (.45 MICRONS)

OTHER PARAMETER VALUE FLAGS:

1 - INCREASED DETECTION LIMIT DUE TO REQUIRED DILUTION

J - ESTILATED VALUE

= CHANGED DETECTION LIMIT 
TABLE 3.15 BACKGROUMD GROUNDWATER QUALITY DATA BY PARAMETER FOR THE NAVAJO SANDSTONE, NC AND ULC PROCESSING SITE, SLICK ROCK, COLORADO

SANDSTONE, NC AND UC PROCESSING SITE,
SITE: SRKO1 SLICK ROCK (BOTH SITES)

$06 / 30 / 86$ to $10 / 12 / 92$

REPORT DATE: $06 / 17 / 93$

\begin{tabular}{|c|c|c|c|c|c|c|c|c|c|c|c|}
\hline PARAMETER NAME & $\begin{array}{l}\text { LOCATION } \\
\text { ID }\end{array}$ & LOG DATE & $\begin{array}{c}\text { SAMPLE } \\
\text { ID }\end{array}$ & $\begin{array}{l}\text { FORM } \\
\text { COMP }\end{array}$ & $\begin{array}{l}\text { FLOW } \\
\text { REL. }\end{array}$ & $\begin{array}{l}\text { UNITS OF } \\
\text { MEASURE }\end{array}$ & PVI & $\begin{array}{l}\text { ARAMETER } \\
\text { VALUE }\end{array}$ & FLAGS & $\begin{array}{l}\text { DETECTION } \\
\text { LIMIT }\end{array}$ & $\begin{array}{l}\text { PARAMETER } \\
\text { UNCERTAINTY }\end{array}$ \\
\hline BARIUM & $\begin{array}{l}0687 \\
0687 \\
0687\end{array}$ & $\begin{array}{l}08 / 27 / 91 \\
12 / 10 / 91 \\
10 / 07 / 92\end{array}$ & $\begin{array}{l}0001 \\
0001 \\
0001\end{array}$ & $\begin{array}{l}\text { NA } \\
\text { NA } \\
\text { NA }\end{array}$ & $\begin{array}{l}U \\
U \\
U\end{array}$ & MG/L & & $\begin{array}{l}0.04 \\
0.04 \\
0.04\end{array}$ & & $\begin{array}{l}0.01 \\
0.01 \\
0.01\end{array}$ & - \\
\hline GERYLLIUM & $\begin{array}{l}0558 \\
0558 \\
0558 \\
0558 \\
0668 \\
0668 \\
0668 \\
0687 \\
0687 \\
0687 \\
0687\end{array}$ & $\begin{array}{l}12 / 15 / 90 \\
03 / 30 / 91 \\
08 / 07 / 91 \\
12 / 11 / 91 \\
12 / 15 / 90 \\
03 / 27 / 91 \\
11 / 18 / 91 \\
12 / 15 / 90 \\
04 / 03 / 91 \\
08 / 27 / 91 \\
12 / 10 / 91\end{array}$ & $\begin{array}{l}0001 \\
0001 \\
0001 \\
0001 \\
0001 \\
0001 \\
0001 \\
0001 \\
0001 \\
0001 \\
0001\end{array}$ & $\begin{array}{l}\text { NA } \\
\text { NA } \\
\text { NA } \\
\text { NA } \\
\text { NA } \\
\text { NA } \\
\text { NA } \\
\text { NA } \\
\text { NA } \\
\text { NA } \\
\text { NA }\end{array}$ & $\begin{array}{l}u \\
U \\
u \\
U \\
U \\
U \\
U \\
U \\
U \\
U \\
U\end{array}$ & $M G / L$ & $\begin{array}{l}< \\
< \\
< \\
< \\
< \\
< \\
< \\
< \\
< \\
< \\
<\end{array}$ & $\begin{array}{l}0.01 \\
0.005 \\
0.005 \\
0.005 \\
0.01 \\
0.005 \\
0.005 \\
0.01 \\
0.005 \\
0.005 \\
0.005\end{array}$ & J & $\begin{array}{l}0.01 \\
0.005 \\
0.005 \\
0.005 \\
0.01 \\
0.005 \\
0.005 \\
0.01 \\
0.005 \\
0.005 \\
0.005\end{array}$ & $\begin{array}{l}: \\
: \\
- \\
- \\
- \\
-\end{array}$ \\
\hline BORON & $\begin{array}{l}0558 \\
0558 \\
0558 \\
0558 \\
0668 \\
0668 \\
0668 \\
0668 \\
0687 \\
0687 \\
0687 \\
0687 \\
0687 \\
0687\end{array}$ & $\begin{array}{l}12 / 15 / 90 \\
03 / 30 / 91 \\
08 / 07 / 91 \\
12 / 11 / 91 \\
10 / 14 / 87 \\
12 / 15 / 90 \\
03 / 27 / 91 \\
11 / 18 / 91 \\
07 / 18 / 86 \\
10 / 15 / 87 \\
12 / 15 / 90 \\
04 / 03 / 91 \\
08 / 27 / 91 \\
12 / 10 / 91\end{array}$ & $\begin{array}{l}0001 \\
0001 \\
0001 \\
0001 \\
0001 \\
0001 \\
0001 \\
0001 \\
0001 \\
0001 \\
0001 \\
0001 \\
0001 \\
0001\end{array}$ & $\begin{array}{l}\text { NA } \\
\text { NA } \\
\text { NA } \\
\text { NA } \\
\text { NA } \\
\text { NA } \\
\text { NA } \\
\text { NA } \\
\text { NA } \\
\text { NA } \\
\text { NA } \\
\text { NA } \\
\text { NA } \\
\text { NA }\end{array}$ & $\begin{array}{l}u \\
U \\
U \\
U \\
U \\
U \\
U \\
U \\
U \\
U \\
U \\
U \\
U \\
U\end{array}$ & $M G / L$ & k & $\begin{array}{l}0.3 \\
0.38 \\
0.48 \\
0.66 \\
0.1 \\
0.1 \\
0.11 \\
0.13 . \\
0.1 \\
1.6 \\
1.6 \\
1.56 \\
1.63 \\
1.62\end{array}$ & J & $\begin{array}{l}0.1 \\
0.05 \\
0.05 \\
0.05 \\
0.1 \\
0.1 \\
0.05 \\
0.05 \\
0.1 \\
0.1 \\
0.1 \\
0.05 \\
0.05 \\
0.05\end{array}$ & $\begin{array}{l}- \\
- \\
- \\
- \\
- \\
- \\
- \\
- \\
-\end{array}$ \\
\hline BROMIDE & $\begin{array}{l}0558 \\
0558 \\
0558 \\
0558 \\
0558 \\
0668 \\
0668\end{array}$ & $\begin{array}{l}12 / 15 / 90 \\
03 / 30 / 91 \\
08 / 07 / 91 \\
12 / 11 / 91 \\
10 / 12 / 92 \\
12 / 15 / 90 \\
03 / 27 / 91\end{array}$ & $\begin{array}{l}0001 \\
0001 \\
0001 \\
0001 \\
0001 \\
0001 \\
0001\end{array}$ & $\begin{array}{l}\text { NA } \\
\text { NA } \\
\text { NA } \\
\text { NA } \\
\text { NA } \\
\text { NA } \\
\text { NA }\end{array}$ & $\begin{array}{l}u \\
U \\
U \\
U \\
U \\
u \\
U\end{array}$ & $M G / L$ & $<$ & $\begin{array}{l}0.1 \\
0.4 \\
0.4 \\
0.5 \\
0.3 \\
0.1 \\
0.4\end{array}$ & $\begin{array}{l}\text { I } \\
\text { c }\end{array}$ & $\begin{array}{l}0.1 \\
0.1 \\
0.4 \\
0.1 \\
0.3 \\
0.1 \\
0.1\end{array}$ & $\begin{array}{l}- \\
- \\
- \\
-\end{array}$ \\
\hline
\end{tabular}

FORMATION OF COMPLETION COOE:

FLOW RELATIONSHIP CODE

NA - NAVAJO SANDSTONE

$U$ - UPGRADIENT

PARAMETER VALUE INDICATOR (PVI): < - LESS THAN DETECTION LIMIT

0001 - FILTERED SAMPLE (.45 MICRONS)

OTHER PARAMEYER VALUE FLAGS:

1 - INCREASED DETECTION LIMIT DUE TO REQUIRED DILUTION

$J$ - ESTIMATED VALUE

c - CHAMGED DETECTION LIMIT 
TABLE 3.15 BACKGROUND GROUNDWATER QUALITY DATA BY PARAMETER FOR THE NAVAJO

SANDSTONE, NC AND UC PROCESSING SITE, SLICK ROCK, COLORADO

SITE: SRKD 1 SLICK ROCK (BOTH SITES)

06/30/86 TO $10 / 12 / 92$

REPORT DATE: $06 / 17 / 93$

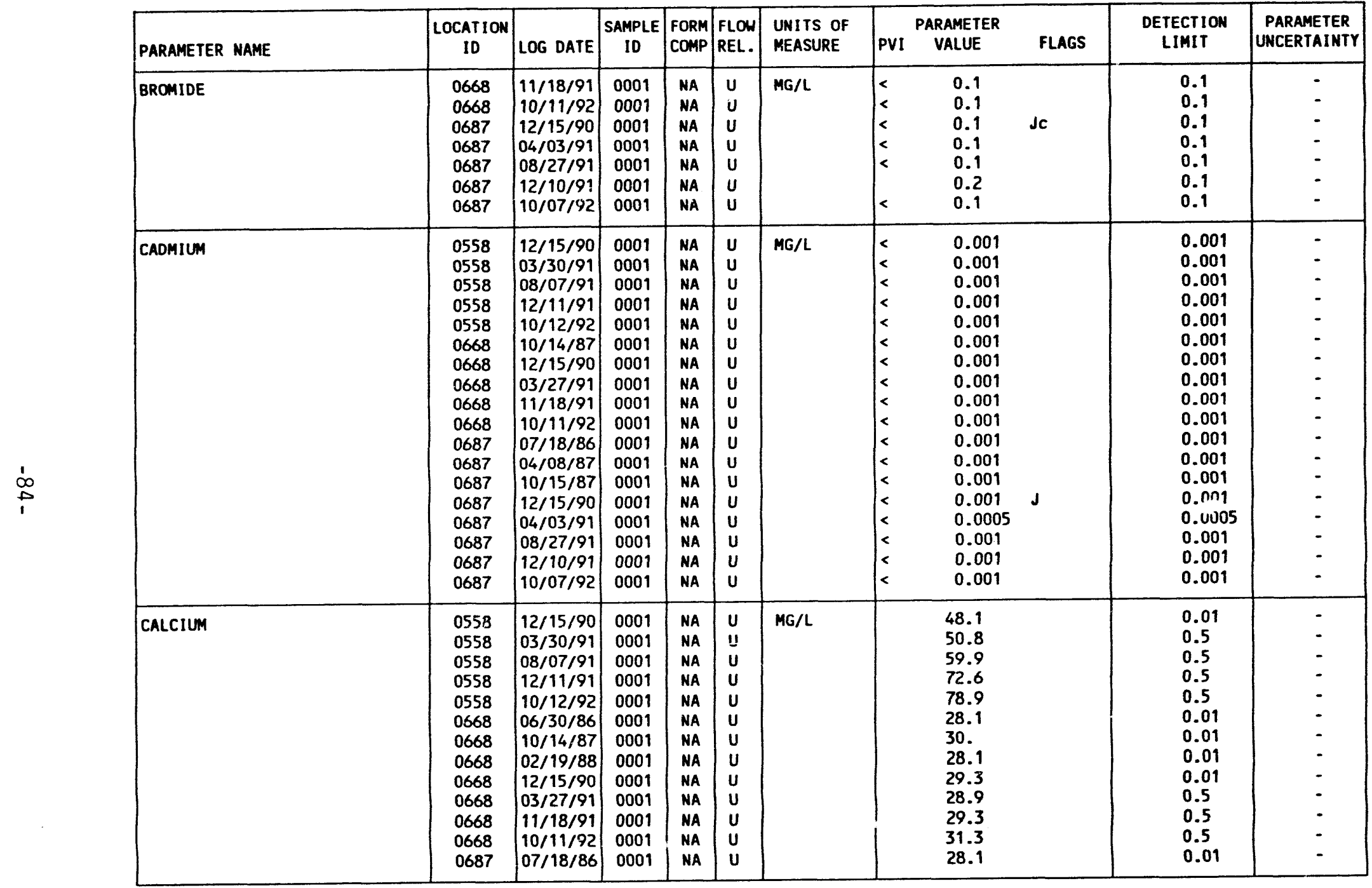

FORMATION OF COMPLETION COOE:

FLOW RELATIONSHIP CODE:

MA - MAVAJO SAMDSTONE

- UPGRADIENT

PARAMETER VALUE INDICATOR (PVI): < - LESS THAN DETECTION LIMIT

SAMPLE ID CODES:

0001 - FILTERED SAMPLE (.45 MICRONS)

OTHER PARAMETER VALUE FLAGS:

J - ESTIMATED VALUE

c - CHANGED DETECTION LIMIT 
TABLE 3.15 BACKGROUND GROUNDWATER QUALITY DATA BY PARAMETER FOR THE MAVAJO SANDSTONE, NC AND UC PROCESSING SITE, SLICK ROCK, COLORADO

SANDSTONE, NC AND UC PROCESSING SITE,
SITE: SRKO1 SLICK ROCK (BOTH SITES)

SITE: SRKO1 SLICK ROCK

REPORT DATE: $06 / 17 / 93$

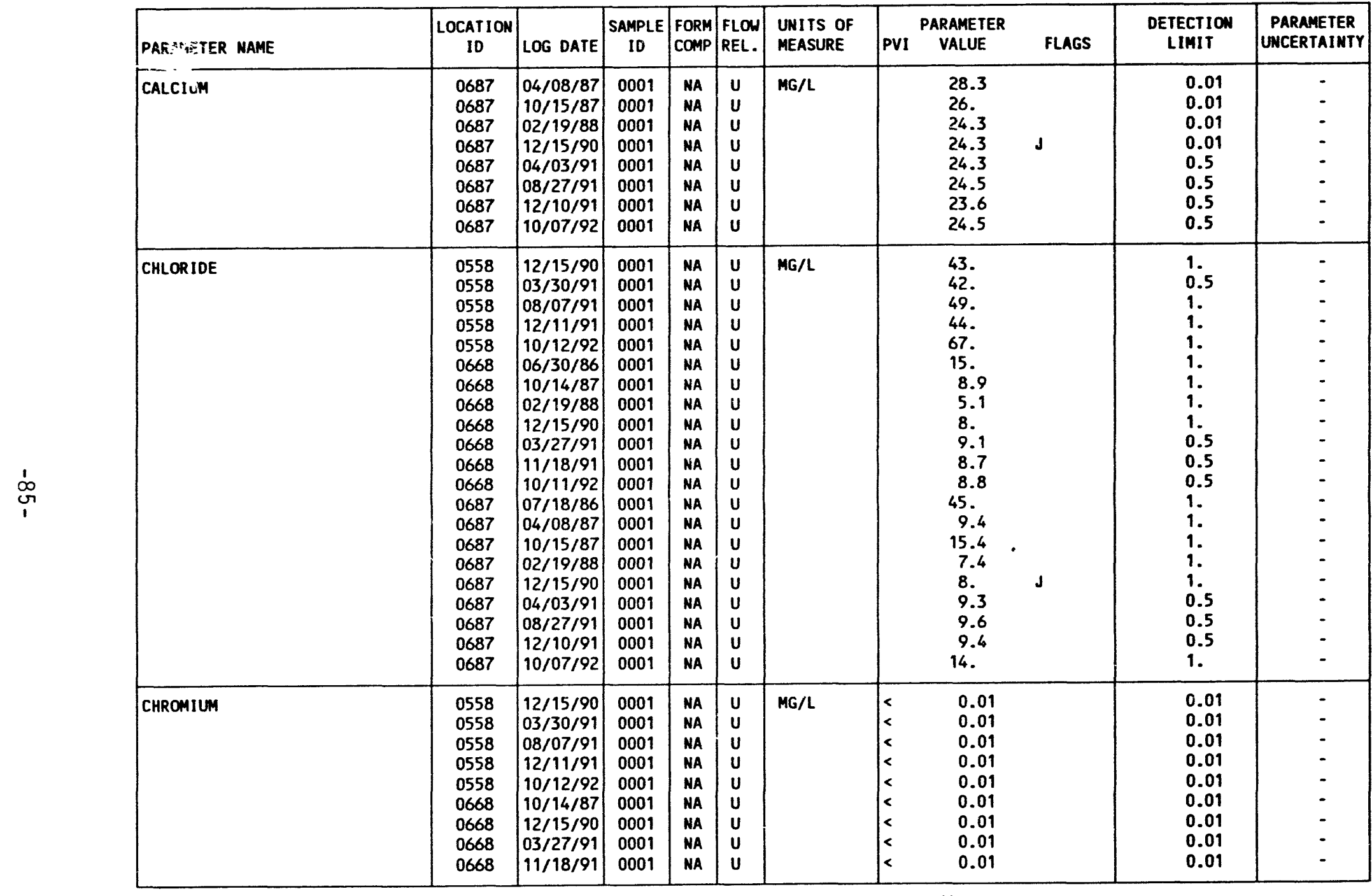

FORMATION OF CCMPLETION COOE:

MA - NAVAJO SANDSTONE

PARAMETER VALUE INDICATOR (PVI): < - LESS THAN DETECTION LIMIT
FLOW RELATIONSHIP CODE:

U - UPGRADIENT

\section{SAMPLE ID CODES:}

SAMPLE ID CODES:

OTHER PARAMETER VALUE fLAGS:

$J$ - ESTIMATED VALUE 
TABLE 3.15 BACKGROUND GROUNDWATER QUALITY DATA BY PARAMETER FOR THE MAVAJO SANDSTONE, NC AND UC PROCESSING SITE, SLICK ROCK, COLORADO

SITE: SRKO1 SLICK ROCK (BOTH SITES)

$06 / 30 / 86$ TO $10 / 12 / 92$

REPORT DATE: $06 / 17 / 93$

\begin{tabular}{|c|c|c|c|c|c|c|c|c|c|c|c|}
\hline PARAMETER NAME & $\begin{array}{c}\text { LOCATION } \\
\text { ID }\end{array}$ & LOG DATE & $\begin{array}{c}\text { SAMPLE } \\
\text { ID }\end{array}$ & $\begin{array}{l}\text { FORM } \\
\text { COMP }\end{array}$ & $\begin{array}{l}\text { FLON } \\
\text { REL. }\end{array}$ & $\begin{array}{l}\text { UNITS OF } \\
\text { MEASURE }\end{array}$ & PVI & $\begin{array}{l}\text { PARAMETER } \\
\text { VALUE }\end{array}$ & FLAGS & $\begin{array}{l}\text { DETECTION } \\
\text { LIMIT }\end{array}$ & $\begin{array}{l}\text { PARAMETER } \\
\text { UNCERTAINTY }\end{array}$ \\
\hline CHROMIUM & $\begin{array}{l}0668 \\
0687 \\
0687 \\
0687 \\
0687 \\
0687 \\
0687 \\
0687 \\
0687\end{array}$ & $\begin{array}{l}10 / 11 / 92 \\
07 / 18 / 86 \\
04 / 08 / 87 \\
10 / 15 / 87 \\
12 / 15 / 90 \\
04 / 03 / 91 \\
08 / 27 / 91 \\
12 / 10 / 91 \\
10 / 07 / 92\end{array}$ & $\begin{array}{l}0001 \\
0001 \\
0001 \\
0001 \\
0001 \\
0001 \\
0001 \\
0001 \\
0001\end{array}$ & $\begin{array}{l}\text { NA } \\
\text { NA } \\
\text { NA } \\
\text { NA } \\
\text { NA } \\
\text { NA } \\
\text { NA } \\
\text { NA } \\
\text { NA }\end{array}$ & $\begin{array}{l}u \\
U \\
U \\
U \\
U \\
U \\
U \\
U \\
U\end{array}$ & $M G / L$ & $\begin{array}{l}< \\
< \\
< \\
< \\
< \\
< \\
<\end{array}$ & $\begin{array}{l}0.01 \\
0.05 \\
0.01 \\
0.01 \\
0.01 \\
0.01 \\
0.01 \\
0.01 \\
0.01\end{array}$ & $J$ & $\begin{array}{l}0.01 \\
0.01 \\
0.01 \\
0.01 \\
0.01 \\
0.01 \\
0.01 \\
0.01 \\
0.01\end{array}$ & $\begin{array}{l}- \\
- \\
- \\
- \\
- \\
-\end{array}$ \\
\hline COBALT & $\begin{array}{l}0558 \\
0558 \\
0558 \\
0558 \\
0668 \\
0668 \\
0668 \\
0687 \\
0687 \\
0687 \\
0687\end{array}$ & $\begin{array}{l}12 / 15 / 90 \\
03 / 30 / 91 \\
08 / 07 / 91 \\
12 / 11 / 91 \\
12 / 15 / 90 \\
03 / 27 / 91 \\
11 / 18 / 91 \\
12 / 15 / 90 \\
04 / 03 / 91 \\
08 / 27 / 91 \\
12 / 10 / 91\end{array}$ & $\begin{array}{l}0001 \\
0001 \\
0001 \\
0001 \\
0001 \\
0001 \\
0001 \\
0001 \\
0001 \\
0001 \\
0001\end{array}$ & $\begin{array}{l}\text { NA } \\
\text { NA } \\
\text { NA } \\
\text { NA } \\
\text { NA } \\
\text { NA } \\
\text { NA } \\
\text { NA } \\
\text { NA } \\
\text { NA } \\
\text { NA }\end{array}$ & $\begin{array}{l}u \\
u \\
u \\
u \\
u \\
u \\
U \\
U \\
U \\
U \\
U\end{array}$ & MG/L & $\begin{array}{l}< \\
< \\
< \\
< \\
< \\
< \\
< \\
< \\
< \\
< \\
<\end{array}$ & $\begin{array}{l}0.05 \\
0.03 \\
0.03 \\
0.03 \\
0.05 \\
0.03 \\
0.03 \\
0.05 \\
0.03 \\
0.03 \\
0.03\end{array}$ & $J$ & $\begin{array}{l}0.05 \\
0.03 \\
0.03 \\
0.03 \\
0.05 \\
0.03 \\
0.03 \\
0.05 \\
0.03 \\
0.03 \\
0.03\end{array}$ & $\begin{array}{l}- \\
- \\
- \\
- \\
- \\
- \\
-\end{array}$ \\
\hline COPPER & $\begin{array}{l}0558 \\
0558 \\
0558 \\
0558 \\
0558 \\
0668 \\
0668 \\
0668 \\
0668 \\
0668 \\
0687 \\
0687 \\
0687 \\
0687 \\
0687 \\
0687 \\
0687 \\
0687\end{array}$ & $\begin{array}{l}12 / 15 / 90 \\
03 / 30 / 91 \\
08 / 07 / 91 \\
12 / 11 / 91 \\
10 / 12 / 92 \\
10 / 14 / 87 \\
12 / 15 / 90 \\
03 / 27 / 91 \\
11 / 18 / 91 \\
10 / 11 / 92 \\
07 / 18 / 86 \\
04 / 08 / 87 \\
10 / 15 / 87 \\
12 / 15 / 90 \\
04 / 03 / 91 \\
08 / 27 / 91 \\
12 / 10 / 91 \\
10 / 07 / 92\end{array}$ & $\begin{array}{l}0001 \\
0001 \\
0001 \\
0001 \\
0001 \\
0001 \\
0001 \\
0001 \\
0001 \\
0001 \\
0001 \\
0001 \\
0001 \\
0001 \\
0001 \\
0001 \\
0001 \\
0001\end{array}$ & $\begin{array}{l}\text { NA } \\
\text { NA } \\
\text { NA } \\
\text { NA } \\
\text { NA } \\
\text { NA } \\
\text { NA } \\
\text { NA } \\
\text { NA } \\
\text { NA } \\
\text { NA } \\
\text { NA } \\
\text { NA } \\
\text { NA } \\
\text { NA } \\
\text { NA } \\
\text { NA } \\
\text { NA }\end{array}$ & 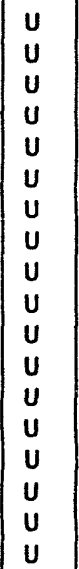 & $M G / L$ & $\begin{array}{l}< \\
< \\
< \\
< \\
< \\
< \\
< \\
< \\
< \\
< \\
< \\
< \\
< \\
< \\
< \\
< \\
<\end{array}$ & $\begin{array}{l}0.02 \\
0.01 \\
0.01 \\
0.01 \\
0.01 \\
0.02 \\
0.02 \\
0.01 \\
0.01 \\
0.01 \\
0.03 \\
0.01 \\
0.02 \\
0.02 \\
0.01 \\
0.01 \\
0.01 \\
0.01\end{array}$ & J & $\begin{array}{l}0.02 \\
0.01 \\
0.01 \\
0.01 \\
0.01 \\
0.02 \\
0.02 \\
0.01 \\
0.01 \\
0.01 \\
0.02 \\
0.02 \\
0.02 \\
0.02 \\
0.01 \\
0.01 \\
0.01 \\
0.01\end{array}$ & $\begin{array}{l}- \\
- \\
- \\
- \\
- \\
- \\
- \\
- \\
- \\
- \\
- \\
- \\
- \\
-\end{array}$ \\
\hline
\end{tabular}

FORMATION OF COMPLETION COOE:

NA - NAVAJO SANDSTONE

PARAMETER VALUE INDICATOR (PVI): < - LESS THAN DETECTION LIMIT
FLOW RELATIONSHIP CODE:

U - UPGRADIENT

SAMPLE ID CODES:

0001 - FILTERED SAMPLE (.45 MICRONS)

OTHER PARAMETER VALUE FLAGS:

$J$ - ESTIMATED VALUE 
TABLE 3.15 BACKGROUMD GROUNDHATER QUALITY DATA BY PARAMETER FOR THE MAVAJO TABLE 3.

SITE: SRKO 1 SLICK ROCK (BOTH SITES)

SITE: SRK01 SLICK ROCK

REPORT DATE: 06/17/93

\begin{tabular}{|c|c|c|c|c|c|c|c|c|c|c|c|}
\hline PARAMETER MAME & $\underset{\text { ID }}{\text { LOCATION }}$ & LOG DATE & $\begin{array}{c}\text { SAMPLE } \\
\text { ID }\end{array}$ & $\begin{array}{l}\text { FORM } \\
\text { COMP }\end{array}$ & $\begin{array}{l}\text { FLOW } \\
\text { REL. }\end{array}$ & $\begin{array}{l}\text { UNITS OF } \\
\text { MEASURE }\end{array}$ & PVI & $\begin{array}{l}\text { ARAMETER } \\
\text { VALUE }\end{array}$ & FLAGS & $\begin{array}{l}\text { DETECTION } \\
\text { LIMIT }\end{array}$ & $\begin{array}{l}\text { PARAMETER } \\
\text { UNCERTAINTY }\end{array}$ \\
\hline CYANIDE & $\begin{array}{l}0558 \\
0558 \\
0558 \\
0558 \\
0668 \\
0668 \\
0668 \\
0687 \\
0687 \\
0687 \\
0687\end{array}$ & $\begin{array}{l}12 / 15 / 90 \\
03 / 30 / 91 \\
08 / 07 / 91 \\
12 / 11 / 91 \\
12 / 15 / 90 \\
03 / 27 / 91 \\
11 / 18 / 91 \\
12 / 15 / 90 \\
04 / 03 / 91 \\
08 / 27 / 91 \\
12 / 10 / 91\end{array}$ & $\begin{array}{l}0001 \\
0001 \\
0001 \\
0001 \\
0001 \\
0001 \\
0001 \\
0001 \\
0001 \\
0001 \\
0001\end{array}$ & $\begin{array}{l}\text { NA } \\
\text { NA } \\
\text { NA } \\
\text { NA } \\
\text { NA } \\
\text { NA } \\
\text { NA } \\
\text { NA } \\
\text { NA } \\
\text { NA } \\
\text { NA }\end{array}$ & $\begin{array}{l}U \\
U \\
U \\
U \\
U \\
U \\
U \\
U \\
U \\
U \\
U\end{array}$ & $M G / L$ & $\begin{array}{l}< \\
< \\
< \\
< \\
< \\
\vdots \\
< \\
< \\
< \\
< \\
<\end{array}$ & $\begin{array}{l}0.01 \\
0.01 \\
0.01 \\
0.01 \\
0.01 \\
0.01 \\
0.01 \\
0.01 \\
0.01 \\
0.01 \\
0.01\end{array}$ & J & $\begin{array}{l}0.01 \\
0.01 \\
0.01 \\
0.01 \\
0.01 \\
0.01 \\
0.01 \\
0.01 \\
0.01 \\
0.01 \\
0.01\end{array}$ & $\begin{array}{l}- \\
- \\
- \\
- \\
- \\
- \\
- \\
-\end{array}$ \\
\hline DISSOLVED OXYGEN & $\begin{array}{l}0668 \\
0687\end{array}$ & $\begin{array}{l}10 / 11 / 92 \\
10 / 07 / 92\end{array} \mid$ & $\begin{array}{l}0001 \\
0001\end{array}$ & $\begin{array}{l}\text { NA } \\
\text { NA }\end{array}$ & $\begin{array}{l}u \\
U\end{array}$ & $M G / L$ & & $\begin{array}{l}0.3 \\
0.9\end{array}$ & & - & - \\
\hline FIELD FE (2+) & $\begin{array}{l}0668 \\
0687\end{array}$ & $\begin{array}{l}10 / 11 / 92 \\
10 / 07 / 92\end{array}$ & $\begin{array}{l}0001 \\
0001\end{array}$ & $\begin{array}{l}\text { NA } \\
\text { NA }\end{array}$ & $\begin{array}{l}u \\
U\end{array}$ & $M G / L$ & & $\begin{array}{l}0.06 \\
0.05\end{array}$ & & - & - \\
\hline FIELD FE (TOTAL) & 0668 & $10 / 11 / 92$ & 0001 & NA & u & $M G / L$ & & 0.07 & & $\cdot$ & - \\
\hline FLUORIDE & $\begin{array}{l}0558 \\
0558 \\
0558 \\
0558 \\
0558 \\
0668 \\
0668 \\
0668 \\
0668 \\
0668 \\
0668 \\
0687 \\
0687 \\
0687 \\
0687 \\
0687 \\
0687 \\
0687 \\
0687 \\
0687\end{array}$ & $\begin{array}{l}12 / 15 / 90 \\
03 / 30 / 91 \\
08 / 07 / 91 \\
12 / 11 / 91 \\
10 / 12 / 92 \\
10 / 14 / 87 \\
02 / 19 / 88 \\
12 / 15 / 90 \\
03 / 27 / 91 \\
11 / 18 / 91 \\
10 / 11 / 92 \\
07 / 18 / 86 \\
04 / 08 / 87 \\
10 / 15 / 87 \\
02 / 19 / 88 \\
12 / 15 / 90 \\
04 / 03 / 91 \\
08 / 27 / 91 \\
12 / 10 / 91 \\
10 / 07 / 92\end{array}$ & $\begin{array}{l}0001 \\
0001 \\
0001 \\
0001 \\
0001 \\
0001 \\
0001 \\
0001 \\
0001 \\
0001 \\
0001 \\
0001 \\
0001 \\
0001 \\
0001 \\
0001 \\
0001 \\
0001 \\
0001 \\
0001\end{array}$ & $\begin{array}{l}\text { NA } \\
\text { NA } \\
\text { NA } \\
\text { NA } \\
\text { NA } \\
\text { NA } \\
\text { NA } \\
\text { NA } \\
\text { NA } \\
\text { NA } \\
\text { NA } \\
\text { NA } \\
\text { NA } \\
\text { NA } \\
\text { NA } \\
\text { NA } \\
\text { NA } \\
\text { NA } \\
\text { NA } \\
\text { NA }\end{array}$ & $\begin{array}{l}u \\
U \\
U \\
u \\
u \\
u \\
u \\
U \\
U \\
U \\
U \\
U \\
U \\
u \\
U \\
U \\
U \\
U \\
U \\
U\end{array}$ & $M G / L$ & & $\begin{array}{l}0.6 \\
0.5 \\
0.7 \\
0.6 \\
0.6 \\
0.7 \\
0.74 \\
0.7 \\
0.7 \\
0.7 \\
0.8 \\
0.7 \\
0.87 \\
0.8 \\
0.85 \\
0.8 \\
0.8 \\
0.8 \\
0.5 \\
0.5\end{array}$ & $\mathbf{J}$ & $\begin{array}{l}0.1 \\
0.1 \\
0.1 \\
0.1 \\
0.1 \\
0.1 \\
0.1 \\
0.1 \\
0.1 \\
0.1 \\
0.1 \\
0.1 \\
0.1 \\
0.1 \\
0.1 \\
0.1 \\
0.1 \\
0.1 \\
0.1 \\
0.1\end{array}$ & $\begin{array}{l}- \\
- \\
- \\
- \\
- \\
- \\
- \\
- \\
- \\
- \\
- \\
- \\
- \\
- \\
- \\
-\end{array}$ \\
\hline
\end{tabular}

FORMATION OF COMPLETION CODE:

NA - MAVAJO SANDSTONE

PARAMETER VALUE INDICATOR (PVI): < - LESS THAN DETECTION LIMIT
FLON RELATIONSHIP CODE:

U - UPGRADIENT

SAMPL - FILTERED SAMPLE (.45 MICRONS) 
TABLE 3.15 BACKGROUND GROUNDHATER QUALITY DATA BY PARAMETER FOR THE MAVAJO SANDSTONE, NC AND UC PROCESSING SITE, SLICK ROCK, COLORADO

SITE: SRKO1 SLICK ROCK (BOTH SITES)

$06 / 30 / 86$ TO $10 / 12 / 92$

REPORT DATE: $06 / 17 / 93$

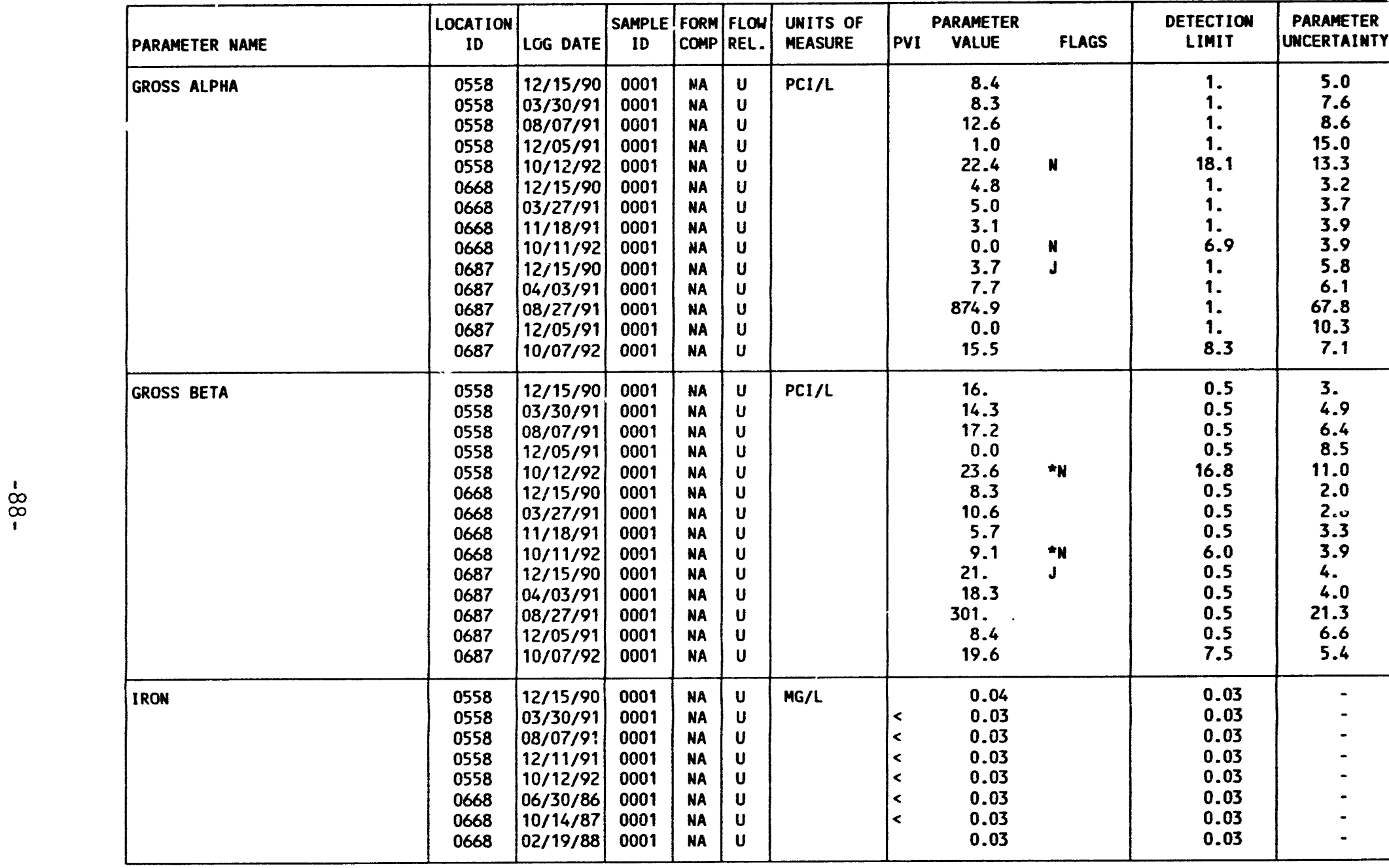

FORMATION OF COMPLETION COOE:

NA - NAVAJO SANDSTONE

PARAMETER VALUE INDICATOR (PVI): < - LESS THAN DETECTION LIMIT
FLOW RELATIONSHIP COOE:

0001 - FILTERED SAMPLE (.45 MICROMS)

OTHER PARAMETER VALUE FLAGS:

* - DUPLicate analysis nOt Hithin CONTROL limits

J - estimated Value

N - SPIKE SAMPLE RECOVERY NOT WITHIN CONTROL LIMITS 


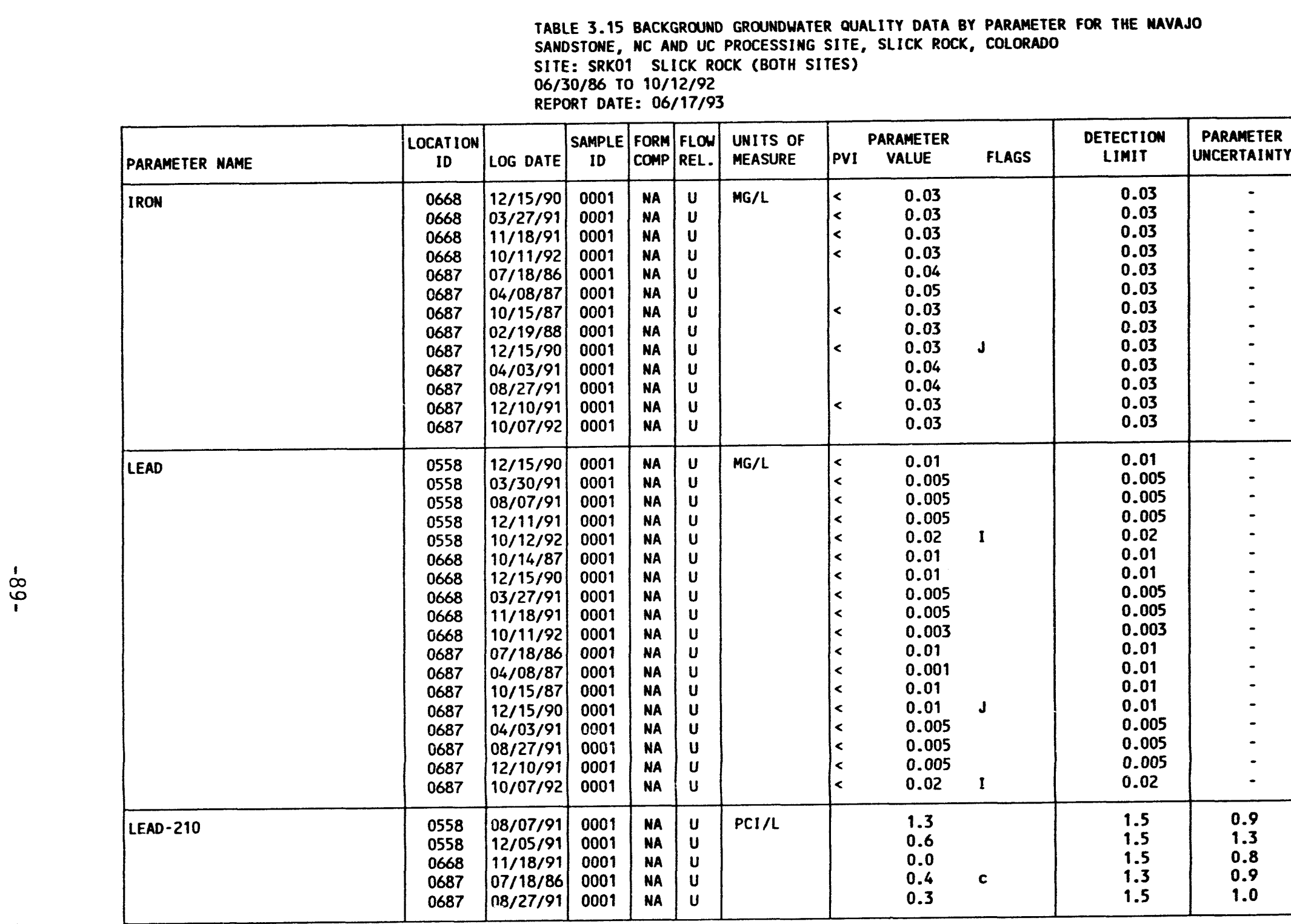

FORMATION OF COMPLETION CODE:

NA - WAVAJO SANDSTONE

PARAMETER VALUE INDICATOR (PVI): < - LESS THAN DETECTION LIMIT
FLOW RELATIONSHIP COOE:

U - UPGRADIENT

0001 - FILTERED SAMPLE (.45 MICRONS)

OTHER PARAMETER VALUE FLAGS:

I - INCREASED DETECTION LIMIT DUE TO REQUIRED DILUTION

J - estimated VALUE

c - CHANGED DETECTION LIMIT 


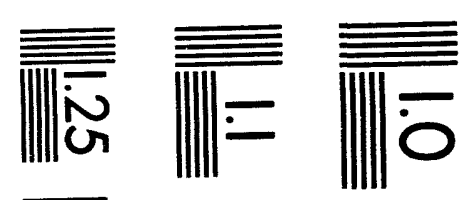

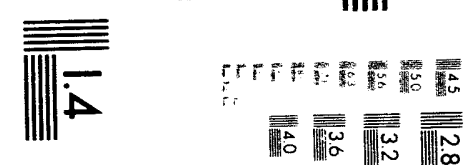

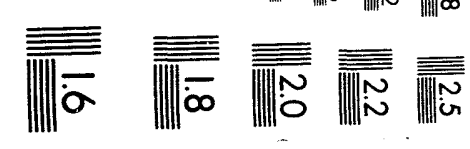



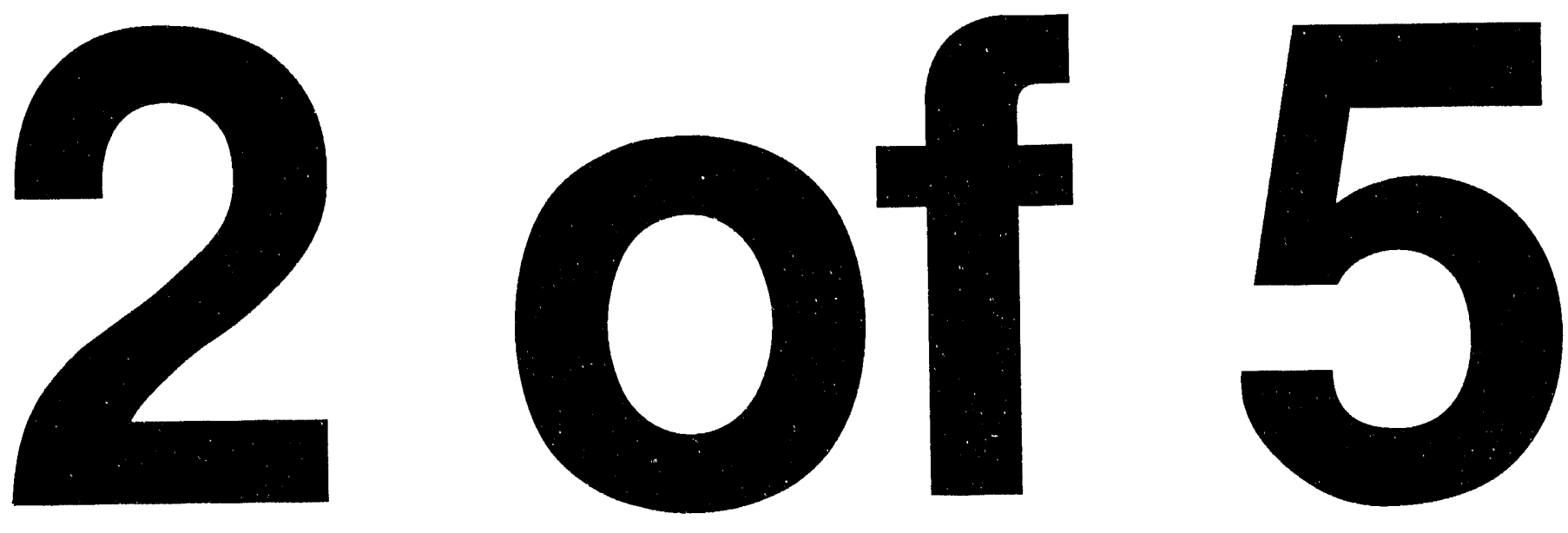
TABLE 3.15 BACKGROUND GROUNDWATER OUALITY DATA BY PARAMETER FOR THE MAVAJO SANDSTONE, HC AND UC PROCESSING SITE, SLICK ROCK, COLORADO

SITE: SRKO1 SLICK ROCK (BOTH SITES)

06/30/86 TO $10 / 12 / 92$

\begin{tabular}{|c|c|c|c|c|c|c|c|c|c|c|c|c|}
\hline & PARAMETER NAME & $\underset{\text { ID }}{\text { LOCATION }}$ & LOG DATE & $\begin{array}{c}\text { SAMPLE } \\
\text { ID }\end{array}$ & $\begin{array}{l}\text { FORM } \\
\text { COMP }\end{array}$ & $\begin{array}{l}\text { FLOW } \\
\text { REL. }\end{array}$ & $\begin{array}{l}\text { UNITS OF } \\
\text { MEASURE }\end{array}$ & PVI & $\begin{array}{l}\text { ARAMETER } \\
\text { VALUE }\end{array}$ & FLAGS & $\begin{array}{l}\text { DETECTION } \\
\text { LIMIT }\end{array}$ & \begin{tabular}{|} 
PARAMETER \\
UNCERTAINTY
\end{tabular} \\
\hline & LEAD-210 & 0687 & $12 / 05 / 91$ & 0001 & NA & $\mathbf{u}$ & $\mathrm{PCI} / \mathrm{L}$ & & 0.0 & & 1.5 & 1.3 \\
\hline & MAGNESIUM & $\begin{array}{l}0558 \\
0558 \\
0558 \\
0558 \\
0558 \\
0668 \\
0668 \\
0668 \\
0668 \\
0668 \\
0668 \\
0668 \\
0687 \\
0687 \\
0687 \\
0687 \\
0687 \\
0687 \\
0687 \\
0687 \\
0687\end{array}$ & $\begin{array}{l}12 / 15 / 90 \\
03 / 30 / 91 \\
08 / 07 / 91 \\
12 / 11 / 91 \\
10 / 12 / 92 \\
06 / 30 / 86 \\
10 / 14 / 87 \\
02 / 19 / 88 \\
12 / 15 / 90 \\
03 / 27 / 91 \\
11 / 18 / 91 \\
10 / 11 / 92 \\
07 / 18 / 86 \\
04 / 08 / 87 \\
10 / 15 / 87 \\
02 / 19 / 88 \\
12 / 15 / 90 \\
04 / 03 / 91 \\
08 / 27 / 91 \\
12 / 10 / 91 \\
10 / 07 / 92\end{array}$ & $\begin{array}{l}0001 \\
0001 \\
0001 \\
0001 \\
0001 \\
0001 \\
0001 \\
0001 \\
0001 \\
0001 \\
0001 \\
0001 \\
0001 \\
0001 \\
0001 \\
0001 \\
0001 \\
0001 \\
0001 \\
0001 \\
0001\end{array}$ & $\begin{array}{l}\text { NA } \\
\text { NA } \\
\text { NA } \\
\text { NA } \\
\text { NA } \\
\text { NA } \\
\text { NA } \\
\text { NA } \\
\text { NA } \\
\text { NA } \\
\text { NA } \\
\text { NA } \\
\text { NA } \\
\text { NA } \\
\text { NA } \\
\text { NA } \\
\text { NA } \\
\text { NA } \\
\text { NA } \\
\text { NA } \\
\text { NA }\end{array}$ & 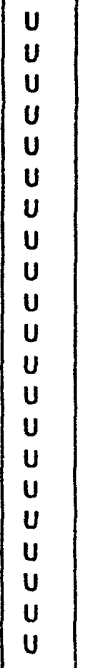 & MG/L & & $\begin{array}{c}66.7 \\
74.1 \\
91.4 \\
99.1 \\
109 . \\
44.4 \\
45 . \\
44.8 \\
45.9 \\
45.1 \\
44.3 \\
40.9 \\
19.3 \\
20.8 \\
21 . \\
19.5 \\
19.1 \\
19.5 \\
19.8 \\
20.0 \\
19.2\end{array}$ & . & $\begin{array}{l}0.001 \\
0.5 \\
0.5 \\
0.5 \\
0.5 \\
0.001 \\
0.001 \\
0.001 \\
0.001 \\
0.1 \\
0.1 \\
0.1 \\
0.001 \\
0.001 \\
0.001 \\
0.001 \\
0.001 \\
0.1 \\
0.1 \\
0.1 \\
0.1\end{array}$ & $\begin{array}{l}- \\
- \\
- \\
- \\
- \\
- \\
- \\
- \\
- \\
- \\
- \\
- \\
- \\
- \\
- \\
- \\
- \\
-\end{array}$ \\
\hline & MANGANESE & $\begin{array}{l}0558 \\
0558 \\
0558 \\
0558 \\
0558 \\
0668 \\
0668 \\
0668 \\
0668 \\
0668 \\
0668 \\
0668 \\
0687 \\
0687 \\
0687 \\
0687\end{array}$ & $\begin{array}{l}12 / 15 / 90 \\
03 / 30 / 91 \\
08 / 07 / 91 \\
12 / 11 / 91 \\
10 / 12 / 92 \\
06 / 30 / 86 \\
10 / 14 / 87 \\
02 / 19 / 88 \\
12 / 15 / 90 \\
03 / 27 / 91 \\
11 / 18 / 91 \\
10 / 111 / 92 \\
07 / 18 / 86 \\
04 / 08 / 87 \\
10 / 15 / 87 \\
02 / 19 / 88\end{array}$ & $\begin{array}{l}0001 \\
0001 \\
0001 \\
0001 \\
0001 \\
0001 \\
0001 \\
0001 \\
0001 \\
0001 \\
0001 \\
0001 \\
0001 \\
0001 \\
0001 \\
0001\end{array}$ & $\begin{array}{l}\text { NA } \\
\text { NA } \\
\text { NA } \\
\text { NA } \\
\text { NA } \\
\text { NA } \\
\text { NA } \\
\text { NA } \\
\text { NA } \\
\text { NA } \\
\text { NA } \\
\text { NA } \\
\text { NA } \\
\text { NA } \\
\text { NA } \\
\text { NA }\end{array}$ & $\begin{array}{l}u \\
U \\
U \\
U \\
U \\
U \\
U \\
U \\
U \\
U \\
U \\
U \\
U \\
U \\
U \\
U\end{array}$ & $M G / L$ & $<$ & $\begin{array}{l}0.06 \\
0.05 \\
0.02 \\
0.01 \\
0.01 \\
0.04 \\
0.01 \\
0.01 \\
0.01 \\
0.01 \\
0.01 \\
0.06 \\
0.08 \\
0.04 \\
0.02 \\
0.03\end{array}$ & & $\begin{array}{l}0.01 \\
0.01 \\
0.01 \\
0.01 \\
0.01 \\
0.01 \\
0.01 \\
0.01 \\
0.01 \\
0.01 \\
0.01 \\
0.01 \\
0.01 \\
0.01 \\
0.01 \\
0.01\end{array}$ & $\begin{array}{l}- \\
- \\
- \\
- \\
- \\
- \\
- \\
- \\
- \\
-\end{array}$ \\
\hline
\end{tabular}

FORMATION OF COMPLETION COOE:

NA - NAVAJO SANDSTONE

FLOW RELATIONSHIP CODE:

PARAMETER VALUE INDICATOR (PVI): < - LESS THAN DETECTION LIMIT

SAMPLE ID CODES:

0001 - FILTERED SAMPLE (.45 MICRONS)

OTHER PARAMETER VALUE FLAGS:

$J$ - ESTIMATED VALUE 
TABLE 3.15 BACKGROUND GROUNDWATER QUALITY DATA BY PARAMETER FOR THE NAVAJO TABLE 3.15 BACKGROUND GROUNDWATER QUALITY OATA BY PARAMETER SANES: SRKO1 SLICK ROCK (BOTH SITES)

SITE: SRKO1 SLICK ROCK
$06 / 30 / 86$ TO $10 / 12 / 92$

REPORT DATE: $06 / 17 / 93$

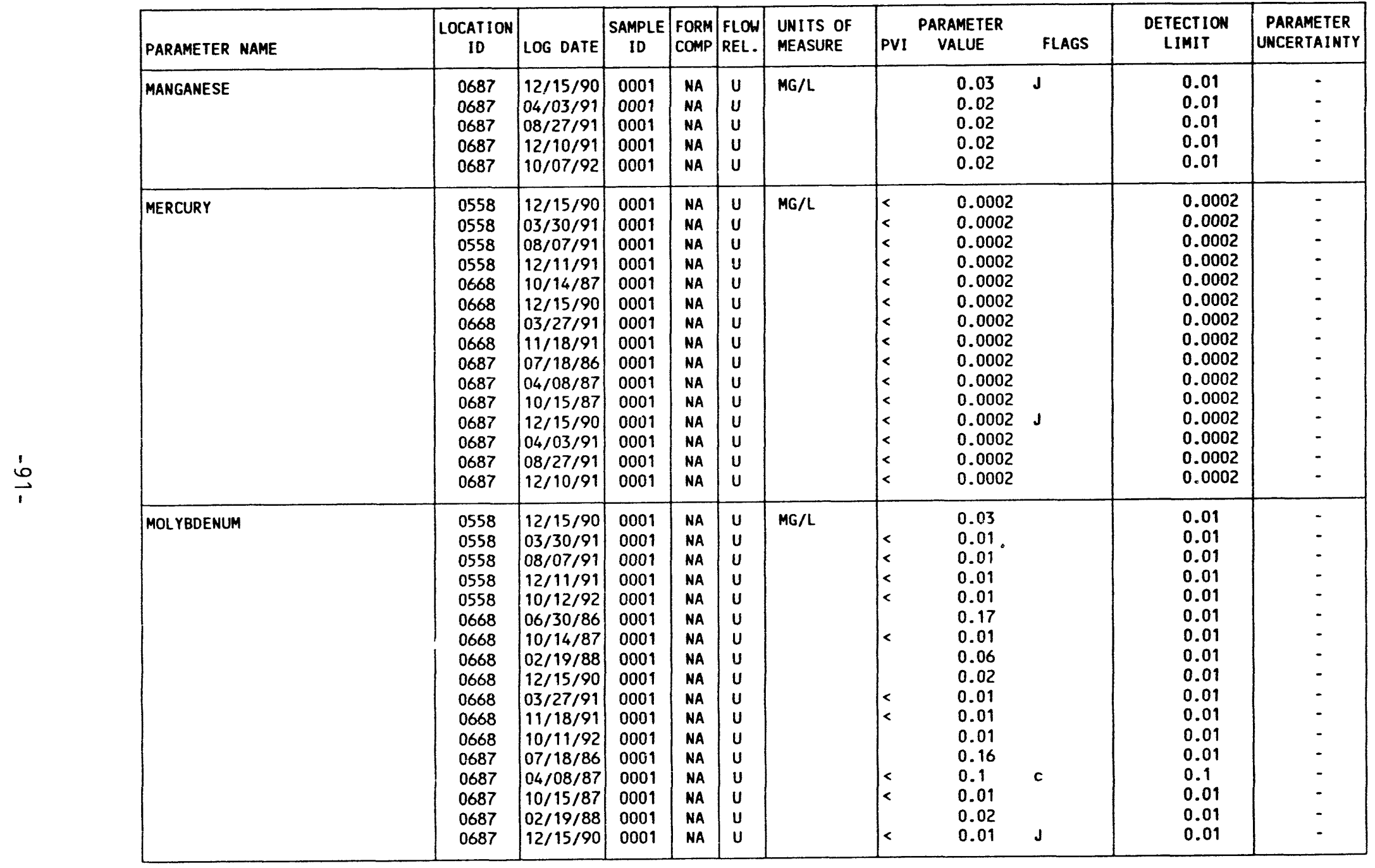

FORMATION OF COMPLETION CODE:

NA - NAVAJO SANDSTONE
FLOW RELATIONSHIP CODE:

OTHER PARAMETER VALUE FLAGS

$J$ - ESTIMATED VALUE

c - CHANGED DETECTION LIMIT 
TABLE 3.15 BACKGROUND GROUNDWATER OUALITY DATA BY PARAMETER FOR THE NAVAJO SAMDSTONE, MC AND UC PROCESSING SITE, SLICK ROCK, COLORADD

SITE: SRKO1 SLICK ROCK (BOTH SITES)

$06 / 30 / 86$ TO $10 / 12 / 92$

REPORT DATE: $06 / 17 / 93$

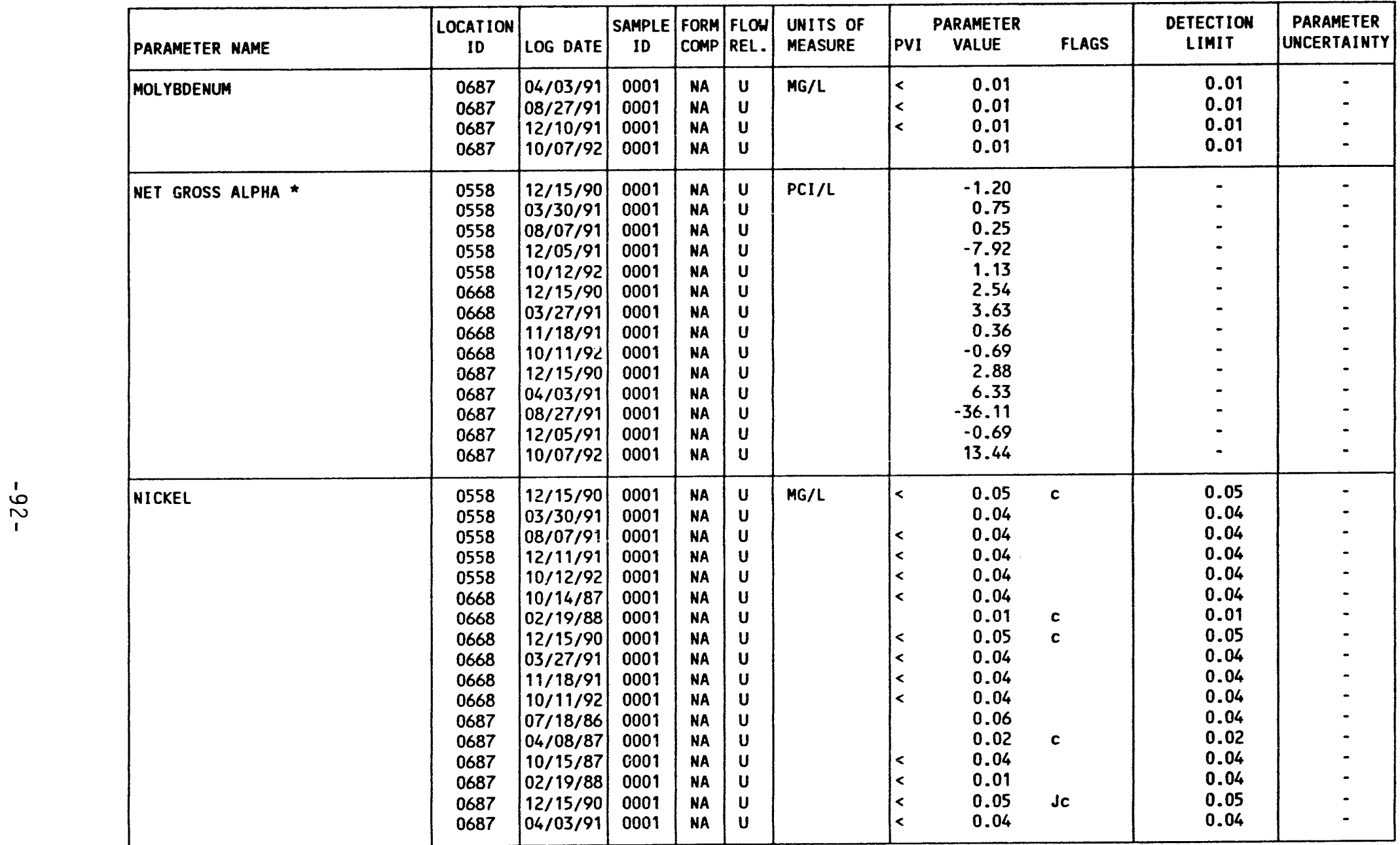

* NET GROSS ALPHA (GROSS ALPHA - URANIUM) WITH 1 MG URANIUM $=686$ PCI

FORMATION OF COMPLETION CODE:

NA - NAVAJO SANDSTONE

PARAMETER VALUE INDICATOR (PVI): < - LESS THAN DETECTION LIMIT
FLOW RELATIONSHIP CODE:

$U$ - UPGRADIENT

\section{SAMPLE ID CODES:}

0001 - FILTERED SAMPLE (.45 MICRONS)

OTHER PARAMETER VALUE FLAGS

$J$ - ESTIMATED VALUE

c - CHANGED DETECTION LIMIT 
TABLE 3.15 BACKGROUND GROUNDWATER QUALITY DATA BY PARAMETER FOR THE NAVAJO SANDSTONE, NC AND UC PROCESSING SITE, SLICK ROCK, COLORADO

SANDSTONE, NC AND UC PROCESSING SITE,

SITE: SRKO1 SLICK ROCK

REPORT DATE: $06 / 17 / 93$

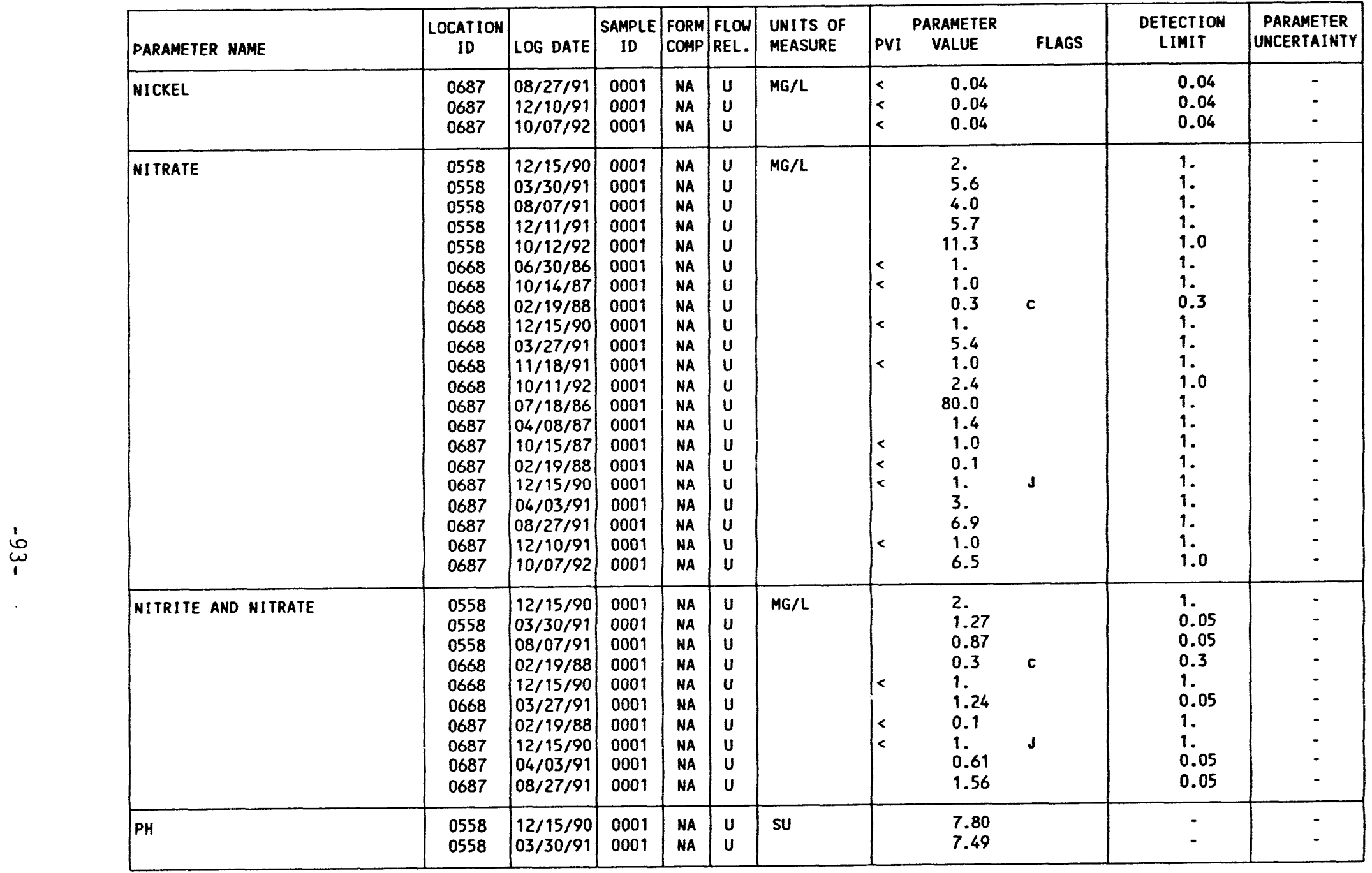

FORMATION OF COMPLETION COOE:

NA - NAVAJO SANDSTONE

PARAMETER VALUE INDICATOR (PVI): < - LESS THAN DETECTION LIMIT
FLOW RELATIONSHIP CODE:

0001 - FILTERED SAMPLE (.45 MICRONS)

OTHER PARAMETER VALUE FLAGS:

$J$ - ESTIMATED VALUE

c - CHANGED DETECTION LIMIT 
TABLE 3.15 BACKGROUND GROUNDWATER QUALITY DATA BY PARAMETER FOR THE NAVAJO SANDSTONE NC AND UC PROCESSING SITE, SLICK ROCK, COLORADO

SITE: SRKO1 SLICK ROCK (BOTH SITES)

$06 / 30 / 86$ TO $10 / 12 / 92$

REPORT DATE: $06 / 17 / 93$

\begin{tabular}{|c|c|c|c|c|c|c|c|c|c|c|c|}
\hline PARAMETER NAME & $\begin{array}{c}\text { LOCATION } \\
\text { ID }\end{array}$ & LOG DATE & $\begin{array}{c}\text { SAMPLE } \\
10\end{array}$ & $\begin{array}{l}\text { FORM } \\
\text { COMP }\end{array}$ & $\begin{array}{l}\text { FLOW } \\
\text { REL. }\end{array}$ & $\begin{array}{l}\text { UNITS OF } \\
\text { MEASURE }\end{array}$ & PVI & $\begin{array}{l}\text { ARAMETE } \\
\text { VALUE }\end{array}$ & FLAGS & $\begin{array}{l}\text { DETECTION } \\
\text { LIMIT }\end{array}$ & $\begin{array}{l}\text { PARAMETER } \\
\text { UNCERTAINTY }\end{array}$ \\
\hline $\mathrm{PH}$ & $\begin{array}{l}0558 \\
0558 \\
0558 \\
0668 \\
0668 \\
0668 \\
0668 \\
0668 \\
0668 \\
0668 \\
0687 \\
0687 \\
0687 \\
0687 \\
0687 \\
0687 \\
0687 \\
0687 \\
0687\end{array}$ & $\begin{array}{l}08 / 07 / 91 \\
12 / 05 / 91 \\
10 / 12 / 92 \\
06 / 30 / 86 \\
10 / 14 / 87 \\
02 / 19 / 88 \\
12 / 15 / 90 \\
03 / 27 / 91 \\
11 / 18 / 91 \\
10 / 11 / 92 \\
07 / 18 / 86 \\
04 / 08 / 87 \\
10 / 15 / 87 \\
02 / 19 / 88 \\
12 / 15 / 90 \\
04 / 03 / 91 \\
08 / 27 / 91 \\
12 / 05 / 91 \\
10 / 07 / 92\end{array}$ & $\begin{array}{l}0001 \\
0001 \\
0001 \\
0001 \\
0001 \\
0001 \\
0001 \\
0001 \\
0001 \\
0001 \\
0001 \\
0001 \\
0001 \\
0001 \\
0001 \\
0001 \\
0001 \\
0001 \\
0001\end{array}$ & $\begin{array}{l}\text { NA } \\
\text { NA } \\
\text { NA } \\
\text { NA } \\
\text { NA } \\
\text { NA } \\
\text { NA } \\
\text { NA } \\
\text { NA } \\
\text { NA } \\
\text { NA } \\
\text { NA } \\
\text { NA } \\
\text { NA } \\
\text { NA } \\
\text { NA } \\
\text { NA } \\
\text { NA } \\
\text { NA }\end{array}$ & $\begin{array}{l}U \\
U \\
U \\
U \\
U \\
U \\
U \\
U \\
U \\
U \\
U \\
U \\
U \\
U \\
U \\
U \\
U \\
U \\
U\end{array}$ & su & & $\begin{array}{l}7.58 \\
7.59 \\
7.47 \\
7.47 \\
7.43 \\
7.41 \\
7.65 \\
7.69 \\
7.82 \\
7.64 \\
7.24 \\
7.51 \\
7.18 \\
7.34 \\
7.47 \\
7.37 \\
7.41 \\
7.64 \\
7.41\end{array}$ & $\mathbf{J}$ & $\begin{array}{l}- \\
: \\
- \\
: \\
: \\
- \\
- \\
- \\
- \\
- \\
- \\
- \\
-\end{array}$ & $\begin{array}{l}- \\
- \\
- \\
- \\
- \\
- \\
- \\
- \\
- \\
- \\
- \\
- \\
- \\
- \\
-\end{array}$ \\
\hline PHOSPHATE & $\begin{array}{l}0558 \\
0558 \\
0558 \\
0558 \\
0558 \\
0658 \\
0668 \\
0668 \\
0668 \\
0668 \\
0687 \\
0687 \\
0687 \\
0687 \\
0687 \\
0687 \\
0687 \\
0687\end{array}$ & $\begin{array}{l}12 / 15 / 90 \\
03 / 30 / 91 \\
08 / 07 / 91 \\
12 / 11 / 91 \\
10 / 12 / 92 \\
10 / 14 / 87 \\
12 / 15 / 90 \\
03 / 27 / 91 \\
11 / 18 / 91 \\
10 / 11 / 92 \\
07 / 18 / 86 \\
04 / 08 / 87 \\
10 / 15 / 87 \\
12 / 15 / 90 \\
04 / 03 / 91 \\
08 / 27 / 91 \\
12 / 10 / 91 \\
10 / 07 / 92\end{array}$ & $\begin{array}{l}0001 \\
0001 \\
0001 \\
0001 \\
0001 \\
0001 \\
0001 \\
0001 \\
0001 \\
0001 \\
0001 \\
0001 \\
0001 \\
0001 \\
0001 \\
0001 \\
0001 \\
0001\end{array}$ & $\begin{array}{l}\text { NA } \\
\text { NA } \\
\text { NA } \\
\text { NA } \\
\text { NA } \\
\text { NA } \\
\text { NA } \\
\text { NA } \\
\text { NA } \\
\text { NA } \\
\text { NA } \\
\text { NA } \\
\text { NA } \\
\text { NA } \\
\text { NA } \\
\text { NA } \\
\text { NA } \\
\text { NA }\end{array}$ & $\begin{array}{l}u \\
u \\
u \\
u \\
u \\
u \\
u \\
u \\
u \\
u \\
u \\
u \\
u \\
u \\
u \\
u \\
U \\
U\end{array}$ & $M G / L$ & $\begin{array}{l}< \\
< \\
< \\
< \\
< \\
< \\
< \\
< \\
< \\
< \\
< \\
<\end{array}$ & $\begin{array}{l}0.1 \\
0.1 \\
0.1 \\
0.2 \\
0.8 \\
0.1 \\
0.1 \\
0.1 \\
0.2 \\
0.1 \\
0.1 \\
0.1 \\
0.1 \\
0.1 \\
0.1 \\
0.1 \\
0.2 \\
0.1\end{array}$ & $\begin{array}{l}\text { J } \\
\text { J } \\
\text { J }\end{array}$ & $\begin{array}{l}0.1 \\
0.1 \\
0.1 \\
0.1 \\
0.1 \\
0.1 \\
0.1 \\
0.1 \\
0.1 \\
0.1 \\
0.1 \\
0.1 \\
0.1 \\
0.1 \\
0.1 \\
0.1 \\
0.1 \\
0.1\end{array}$ & $\begin{array}{l}- \\
- \\
- \\
- \\
- \\
- \\
- \\
- \\
- \\
- \\
- \\
- \\
- \\
- \\
-\end{array}$ \\
\hline POLONIUM-210 & 0558 & $08 / 07 / 91$ & 0001 & NA & $U$ & $\mathrm{PCI} / \mathrm{L}$ & & 0.3 & & 1. & 0.4 \\
\hline
\end{tabular}

FORMATION OF COMPLETION CODE:

NA - NAVAJO SANDSTONE

PARAMETER VALUE INDICATOR (PVI): < - LESS THAN DETECTION LIMIT
FLON RELATIONSHIP CODE:

$U$ - UPGRADIENT

\section{SAMPLE ID CODES:}

0001 - FILTERED SAMPLE (.45 MICRONS)

OTHER PARAMETER VALUE FLAGS:

J - eSTIMATED VALUE 
TABLE 3.15 BACKGROUND GROUNDWATER QUALITY DATA BY PARAMETER FOR THE NAVAJO SANDSTONE, NC AND UC PROCESSING SITE, SLICK ROCK, COLORADO

SITE: SRK01 SLICK ROCK (BOTH SITES)

$06 / 30 / 86$ TO $10 / 12 / 92$

REPORT DATE: $06 / 17 / 93$

\begin{tabular}{|c|c|c|c|c|c|c|c|c|c|c|c|c|}
\hline & PARAMETER NAME & ${ }_{\text {ID }}^{\text {LOCATION }}$ & LOG DATE & $\begin{array}{c}\text { SAMPLE } \\
\text { ID }\end{array}$ & $\begin{array}{l}\text { FORM } \\
\text { COMP }\end{array}$ & $\begin{array}{l}\text { FLOW } \\
\text { REL. }\end{array}$ & $\begin{array}{l}\text { UNITS OF } \\
\text { MEASURE }\end{array}$ & PVI & $\begin{array}{l}\text { PARAMETER } \\
\text { VALUE }\end{array}$ & FLAGS & $\begin{array}{l}\text { DETECTION } \\
\text { LIMIT }\end{array}$ & $\begin{array}{l}\text { PARAMETER } \\
\text { UNCERTAINTY }\end{array}$ \\
\hline & POLONIUM-210 & $\begin{array}{l}0558 \\
0668 \\
0687 \\
0687 \\
0687\end{array}$ & $\mid \begin{array}{l}12 / 05 / 91 \\
11 / 18 / 91 \\
07 / 18 / 86 \\
08 / 27 / 91 \\
12 / 05 / 91\end{array}$ & $\left|\begin{array}{l}0001 \\
0001 \\
0001 \\
0001 \\
0001\end{array}\right|$ & $\begin{array}{l}\text { NA } \\
\text { NA } \\
\text { NA } \\
\text { NA } \\
\text { NA }\end{array}$ & $\begin{array}{l}u \\
u \\
u \\
u \\
u\end{array}$ & PCI/L & $<$ & $\begin{array}{l}0.1 \\
0.0 \\
0.5 \\
0.1 \\
0.0\end{array}$ & b & $\begin{array}{l}1 . \\
1 . \\
1 . \\
1 .\end{array}$ & $\begin{array}{l}0.4 \\
0.4 \\
0.5 \\
0.3 \\
0.2\end{array}$ \\
\hline & POTASSIUM & $\begin{array}{l}0558 \\
0558 \\
0558 \\
0558 \\
0558 \\
0668 \\
0668 \\
0668 \\
0668 \\
0668 \\
0668 \\
0668 \\
0687 \\
0687 \\
0687 \\
0687 \\
0687 \\
0687 \\
0687 \\
0687 \\
0687\end{array}$ & \begin{tabular}{|l|}
$12 / 15 / 90$ \\
$03 / 30 / 91$ \\
$08 / 07 / 91$ \\
$12 / 11 / 91$ \\
$10 / 12 / 92$ \\
$06 / 30 / 86$ \\
$10 / 14 / 87$ \\
$02 / 19 / 88$ \\
$12 / 15 / 90$ \\
$03 / 27 / 91$ \\
$11 / 18 / 91$ \\
$10 / 11 / 92$ \\
$07 / 18 / 86$ \\
$04 / 08 / 87$ \\
$10 / 15 / 87$ \\
$02 / 19 / 88$ \\
$12 / 15 / 90$ \\
$04 / 03 / 91$ \\
$08 / 27 / 91$ \\
$12 / 10 / 91$ \\
$10 / 07 / 92$
\end{tabular} & $\begin{array}{l}0001 \\
0001 \\
0001 \\
0001 \\
0001 \\
0001 \\
0001 \\
0001 \\
0001 \\
0001 \\
0001 \\
0001 \\
0001 \\
0001 \\
0001 \\
0001 \\
0001 \\
0001 \\
0001 \\
0001 \\
0001\end{array}$ & $\begin{array}{l}\text { NA } \\
\text { NA } \\
\text { NA } \\
\text { NA } \\
\text { NA } \\
\text { NA } \\
\text { NA } \\
\text { NA } \\
\text { NA } \\
\text { NA } \\
\text { NA } \\
\text { NA } \\
\text { NA } \\
\text { NA } \\
\text { NA } \\
\text { NA } \\
\text { NA } \\
\text { NA } \\
\text { NA } \\
\text { NA } \\
\text { NA }\end{array}$ & 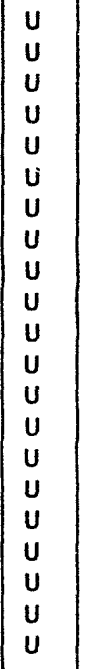 & $M G / L$ & & $\begin{array}{c}14.5 \\
9.4 \\
10.9 \\
12 . \\
10 . \\
9.12 \\
9.1 \\
8.60 \\
9.1 \\
8.5 \\
7.89 \\
8.11 \\
30.1 \\
24.4 \\
25 . \\
26.1 \\
25.5 \\
23 . \\
23 . \\
24 . \\
23 .\end{array}$ & $J$ & $\begin{array}{l}0.01 \\
0.01 \\
0.01 \\
5 . \\
5 . \\
0.01 \\
0.01 \\
0.01 \\
0.01 \\
0.01 \\
0.01 \\
0.01 \\
0.01 \\
0.01 \\
0.01 \\
0.01 \\
0.01 \\
5 . \\
5 . \\
5 . \\
5 .\end{array}$ & $\begin{array}{l}- \\
- \\
- \\
- \\
- \\
- \\
- \\
- \\
- \\
- \\
- \\
- \\
- \\
- \\
- \\
-\end{array}$ \\
\hline & RADIUM-226 & $\begin{array}{l}0558 \\
0558 \\
0558 \\
0558 \\
0558 \\
0668 \\
0668 \\
0668 \\
0668 \\
0668\end{array}$ & $\begin{array}{l}12 / 15 / 90 \\
03 / 30 / 91 \\
08 / 07 / 91 \\
12 / 05 / 91 \\
10 / 12 / 92 \\
10 / 14 / 87 \\
02 / 19 / 88 \\
12 / 15 / 90 \\
03 / 27 / 91 \\
11 / 18 / 91\end{array}$ & \begin{tabular}{l|}
0001 \\
0001 \\
0001 \\
0001 \\
0001 \\
0001 \\
0001 \\
0001 \\
0001 \\
0001
\end{tabular} & $\begin{array}{l}\text { NA } \\
\text { NA } \\
\text { NA } \\
\text { NA } \\
\text { NA } \\
\text { NA } \\
\text { NA } \\
\text { NA } \\
\text { NA } \\
\text { NA }\end{array}$ & $\begin{array}{l}U \\
U \\
U \\
U \\
U \\
U \\
U \\
U \\
U \\
U\end{array}$ & $\mathrm{PCI} / \mathrm{L}$ & & $\begin{array}{l}0.4 \\
0.2 \\
0.3 \\
0.5 \\
0.3 \\
0.8 \\
0.4 \\
0.8 \\
0.3 \\
0.5\end{array}$ & c & $\begin{array}{l}0.7 \\
1 . \\
1 . \\
1 . \\
0.8 \\
1 . \\
0.6 \\
1 . \\
1 . \\
1 .\end{array}$ & $\begin{array}{l}0.3 \\
0.2 \\
0.2 \\
0.3 \\
0.5 \\
0.3 \\
0.2 \\
0.3 \\
0.2 \\
0.4\end{array}$ \\
\hline
\end{tabular}

FORMATION OF COMPLETION CODE:

NA - NAVAJO SANDSTONE

PARAMETER VALUE INDICATOR (PVI): < - LESS THAN DETECTION LIMIT
FLOW RELATIONSHIP COOE:

$U$ - UPGRADIENT

0001 - FILITERED SAMPLE (.45 MICRONS)

OTHER PARAMETER VALUE FLAGS:

$J$ - ESTIMATED VALUE

b - CHANGED PARAMETER VALUE

c - CHANGED DETECTION LIMI 
TABLE 3.15 BACKGROUND GROUNDWATER QUALITY DATA BY PARAMETER FOR THE NAVAJO SANDSTONE, NC AND UC PROCESSING SITE, SLICK ROCK, COLORADO

SITE: SRKO1 SLICK ROCK (BOTH SITES)

$06 / 30 / 86$ TO $10 / 12 / 92$

REPORT DATE : 06/17/93

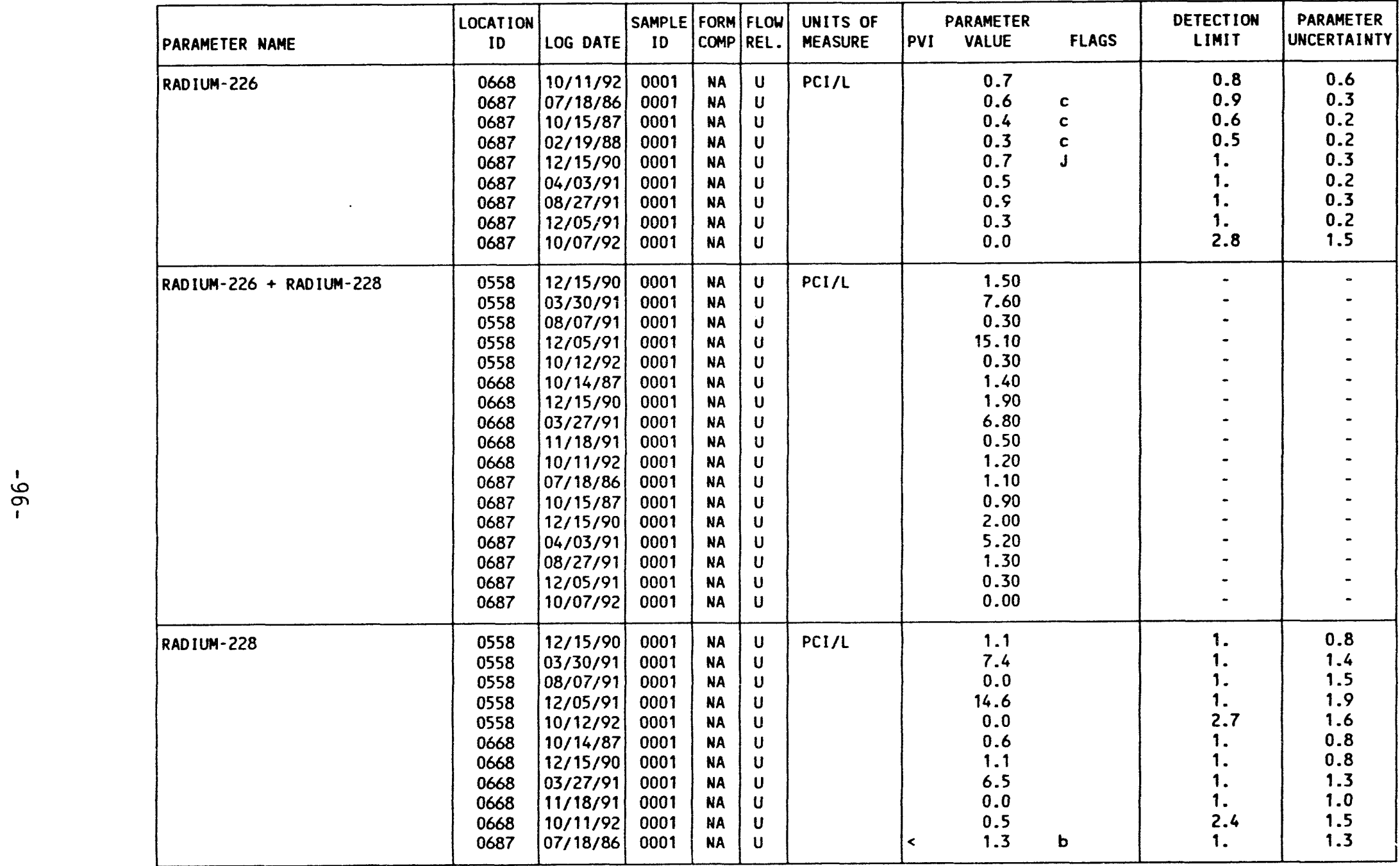

FORMATION OF COMPLETION COOE:

MA - NAVAJO SANDSTONE

PARAMETER VALUE INDICATOR (PVI): < - LESS THAN DETECTION LIMIT
FLOW RELATIONSHIP CODE:

SAMPLE ID CODES:

0001 - FILTERED SAMPLE (.45 MICRONS)

OTHER PARAMETER VALUE FLAGS:

$J$ - ESTIMATED VALUE
b - CHANGED PARAMETER VALUE

c - CHANGED DETECTION LIMIT 
TABLE 3.15 BACKGROUND GROUNOWATER QUALITY DATA BY PARAMETER FOR THE NAVAJO SANDSTONE, NC AND UC PROCESSING SITE, SLICK ROCK, COLORADO

SITE: SRK01 SLICK ROCK (BOTH SITES)

$06 / 30 / 86$ TO $10 / 12 / 92$

REPORT DATE: $06 / 17 / 93$

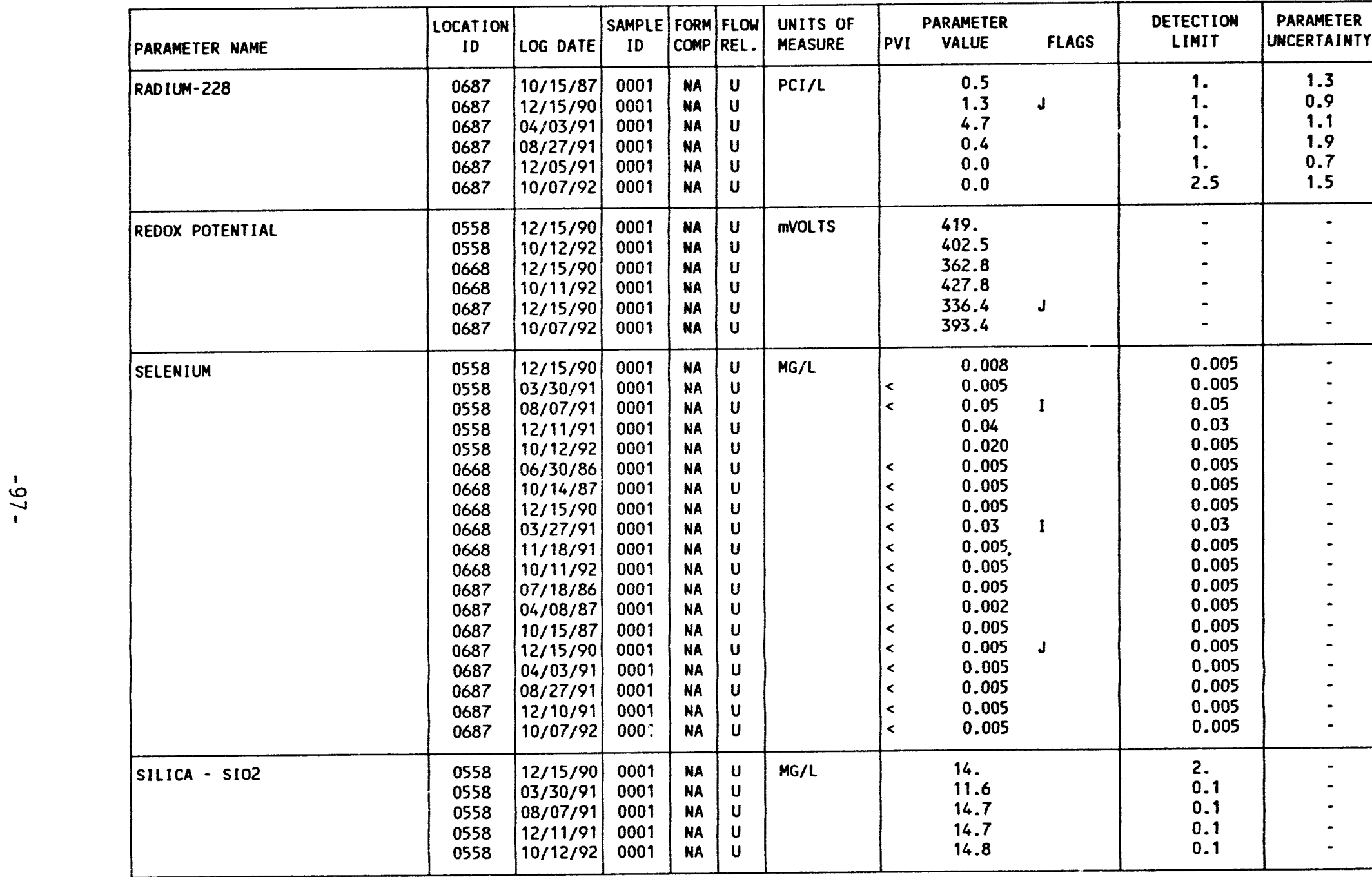

FORMATION OF COMPLETION COOE:

NA - NAVAJO SANDSTONE

PARAMETER VALUE INDICATOR (PVI): < - LESS THAN DETECTION LIMIT
FLOW RELATIONSHIP COOE:

U - UPGRADIENT

0001 - FILTERED SAMPLE (.45 MICRONS)

OTHER PARAMETER VALUE FLAGS:

1 - INCREASED DETECTION LIMIT DUE TO REQUIRED DILUTION

J - estimated VALUE 
TABLE 3.15 BACKGROUND GROUNDHATER QUALITY DATA BY PARAMETER FOR THE MAVAJO SANDSTONE, NC AND UC PROCESSING SITE, SLICK ROCK, COLORADO

SITE: SRKO1 SLICK ROCK (BOTH SITES)

$06 / 30 / 86$ TO $10 / 12 / 92$

REPORT DATE: $06 / 17 / 93$

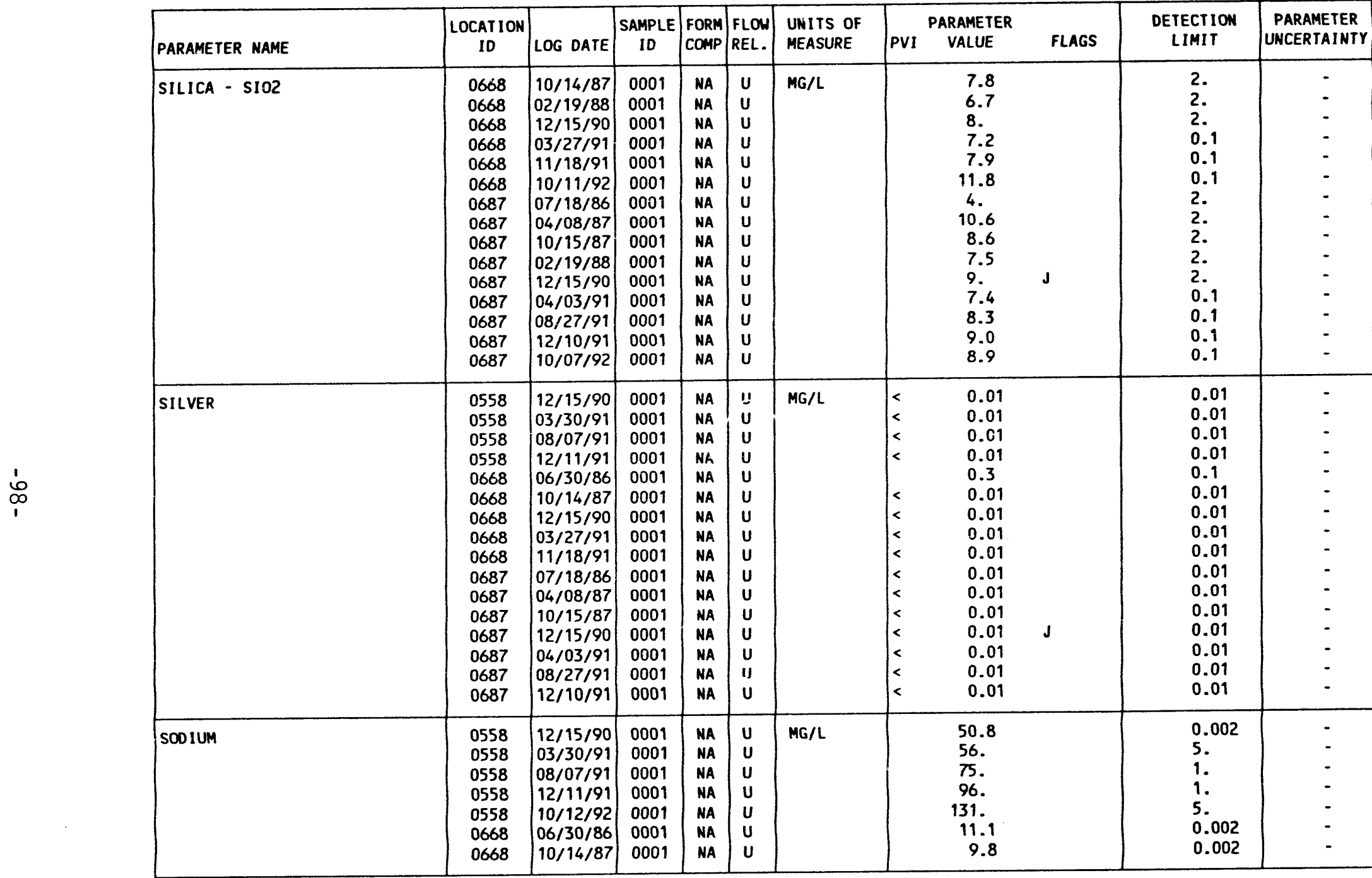

FORMATION OF COMPLETION CODE:

NA - NAVAJO SANDSTONE

PARAMETER VALUE INDICATOR (PVI): < - LESS THAN DETECTION LIMIT

\section{FLOW RELATIONSHIP CODE:}

\section{- UPGRADIENT}

0001 - FILTERED SAMPLE (.45 MICRONS)

OTHER PARAMETER VALUE FLAGS:

$J$ - ESTIMATED VALUE 
TABLE 3.15 BACKGROUND GROUNDUATER OUALITY DATA BY PARAMETER FOR THE NAVAJO SANDSTONE, NC AND UC PROCESSING SITE, SLICK ROCK, COLORADO

SITE: SRKO1 SLICK ROCK (BOTH SITES)

SITE: SRK01 SLICK ROCK

REPORT DATE : $06 / 17 / 93$

\begin{tabular}{|c|c|c|c|c|c|c|c|c|c|c|c|c|}
\hline & PARAMETER NAME & $\begin{array}{c}\text { LOCATION } \\
\text { ID }\end{array}$ & LOG DATE & $\begin{array}{c}\text { SAMPLE } \\
10\end{array}$ & $\begin{array}{l}\text { FORM } \\
\text { COMP }\end{array}$ & $\begin{array}{l}\text { FLON } \\
\text { REL. }\end{array}$ & $\begin{array}{l}\text { UNITS OF } \\
\text { MEASURE }\end{array}$ & PVI & $\begin{array}{l}\text { PARAMETE } \\
\text { VALUE }\end{array}$ & FLAGS & $\begin{array}{l}\text { DETECTION } \\
\text { LIMIT }\end{array}$ & $\begin{array}{l}\text { PARAMETER } \\
\text { UNCERTAINTY }\end{array}$ \\
\hline & SOOIUM & $\begin{array}{l}0668 \\
0668 \\
0668 \\
0668 \\
0668 \\
0687 \\
0687 \\
0687 \\
0687 \\
0687 \\
0687 \\
0687 \\
0687 \\
0687\end{array}$ & \begin{tabular}{|l|}
$02 / 19 / 88$ \\
$12 / 15 / 90$ \\
$03 / 27 / 91$ \\
$11 / 18 / 91$ \\
$10 / 11 / 92$ \\
$07 / 18 / 86$ \\
$04 / 08 / 87$ \\
$10 / 15 / 87$ \\
$02 / 19 / 88$ \\
$12 / 15 / 90$ \\
$04 / 03 / 91$ \\
$08 / 27 / 91$ \\
$12 / 10 / 91$ \\
$10 / 07 / 92$
\end{tabular} & $\begin{array}{l}0001 \\
0001 \\
0001 \\
0001 \\
0001 \\
0001 \\
0001 \\
0001 \\
0001 \\
0001 \\
0001 \\
0001 \\
0001 \\
0001\end{array}$ & $\begin{array}{l}\text { NA } \\
\text { NA } \\
\text { NA } \\
\text { NA } \\
\text { NA } \\
\text { NA } \\
\text { NA } \\
\text { NA } \\
\text { NA } \\
\text { NA } \\
\text { NA } \\
\text { NA } \\
\text { NA } \\
\text { NA }\end{array}$ & $\begin{array}{l}u \\
u \\
u \\
u \\
u \\
u \\
U \\
U \\
U \\
u \\
U \\
u \\
u \\
U\end{array}$ & $M G / L$ & & $\begin{array}{c}10.4 \\
9.93 \\
5.0 \\
10.0 \\
15 . \\
177 . \\
158 . \\
148 . \\
145 . \\
137 . \\
136 . \\
140 . \\
136 . \\
141 .\end{array}$ & $d$ & $\begin{array}{l}0.002 \\
0.002 \\
0.01 \\
0.01 \\
1 . \\
0.002 \\
0.002 \\
0.002 \\
0.002 \\
0.002 \\
5 . \\
5 . \\
5 . \\
5 .\end{array}$ & $\begin{array}{l}- \\
- \\
: \\
- \\
- \\
- \\
- \\
- \\
-\end{array}$ \\
\hline & SPECIFIC CONDUCTANCE & $\begin{array}{l}0558 \\
0558 \\
0558 \\
0558 \\
0668 \\
0668 \\
0668 \\
0668 \\
0668 \\
0668 \\
0687 \\
0687 \\
0687 \\
0687 \\
0687 \\
0687 \\
0687 \\
0687 \\
0687\end{array}$ & $\begin{array}{l}12 / 15 / 90 \\
08 / 07 / 91 \\
12 / 05 / 91 \\
10 / 12 / 92 \\
06 / 30 / 86 \\
10 / 14 / 87 \\
02 / 19 / 88 \\
12 / 15 / 90 \\
11 / 18 / 91 \\
10 / 11 / 92 \\
07 / 18 / 86 \\
04 / 08 / 87 \\
10 / 15 / 87 \\
02 / 19 / 88 \\
12 / 15 / 90 \\
04 / 03 / 91 \\
08 / 27 / 91 \\
12 / 05 / 91 \\
10 / 07 / 92\end{array}$ & $\begin{array}{l}0001 \\
0001 \\
0001 \\
0001 \\
0001 \\
0001 \\
0001 \\
0001 \\
0001 \\
0001 \\
0001 \\
0001 \\
0001 \\
0001 \\
0001 \\
0001 \\
0001 \\
0001 \\
0001\end{array}$ & $\begin{array}{l}\text { NA } \\
\text { NA } \\
\text { NA } \\
\text { NA } \\
\text { NA } \\
\text { NA } \\
\text { NA } \\
\text { NA } \\
\text { NA } \\
\text { NA } \\
\text { NA } \\
\text { NA } \\
\text { NA } \\
\text { NA } \\
\text { NA } \\
\text { NA } \\
\text { NA } \\
\text { NA } \\
\text { NA }\end{array}$ & $\begin{array}{l}u \\
u \\
u \\
u \\
u \\
u \\
u \\
u \\
u \\
u \\
u \\
u \\
u \\
u \\
u \\
U \\
U \\
U \\
U\end{array}$ & UМно/CM & & $\begin{array}{c}960 . \\
997 \\
1420 \\
1330 \\
390 . \\
300 . \\
370 . \\
521 . \\
530 \\
410 \\
500 . \\
550 . \\
450 . \\
650 . \\
887 . \\
877 . \\
883 \\
886 \\
685\end{array}$ & $J$ & $\begin{array}{l}- \\
: \\
- \\
- \\
- \\
- \\
- \\
- \\
- \\
- \\
- \\
- \\
- \\
-\end{array}$ & $\begin{array}{l}- \\
- \\
- \\
- \\
- \\
- \\
- \\
- \\
- \\
- \\
- \\
- \\
- \\
-\end{array}$ \\
\hline & STRONTIUM & $\begin{array}{l}0558 \\
0558 \\
0558 \\
0558 \\
0558\end{array}$ & \begin{tabular}{|l|}
$12 / 15 / 90$ \\
$03 / 30 / 91$ \\
$08 / 07 / 91$ \\
$12 / 11 / 91$ \\
$10 / 12 / 92$
\end{tabular} & $\begin{array}{l}0001 \\
0001 \\
0001 \\
0001 \\
0001\end{array}$ & $\begin{array}{l}\text { NA } \\
\text { NA } \\
\text { NA } \\
\text { NA } \\
\text { NA }\end{array}$ & $\begin{array}{l}u \\
u \\
u \\
u \\
u\end{array}$ & $M G / L$ & & $\begin{array}{l}0.9 \\
0.93 \\
1.13 \\
1.29 \\
1.27\end{array}$ & & $\begin{array}{l}0.1 \\
0.01 \\
0.01 \\
0.01 \\
0.01\end{array}$ & : \\
\hline
\end{tabular}

FORMATIOH OF COMPLETION CODE:

NA - NAVAJO SANDSTONE

PARAMETER VALUE INDICATOR (PVI): < - LESS THAN DETECTION LIMIT
FLOW RELATIONSHIP CODE:

U - UPGRADIENT

0001 - FILTERED SAMPLE (.45 MICRONS)

OTHER PARAMETER VALUE FLAGS:

$J$ - ESTIMATED VALUE 
TABLE 3.15 BACKGROUND GROUNDHATER QUALITY DATA BY PARAMETER FOR THE NAVAJO SANDSTONE, NC AND UC PROCESSING SITE, SLICK ROCK, COLORADO

SITE: SRKO1 SLICK ROCK (BOTH SITES)

$06 / 30 / 86$ TO $10 / 12 / 92$

REPORT DATE : $06 / 17 / 93$

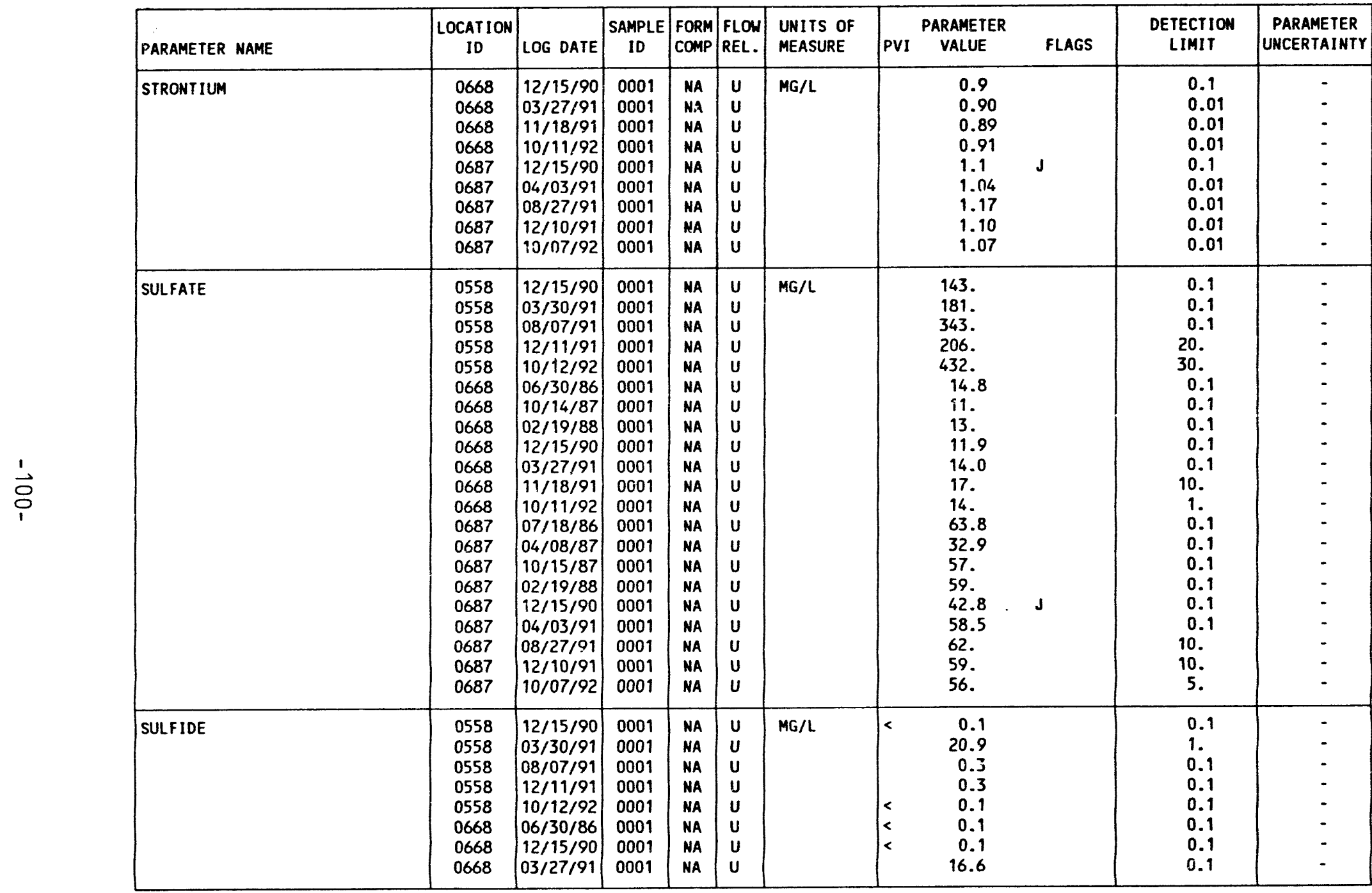

FORMATION OF COMPLETION CODE:

NA - NAVAJO SANDSTONE

PARAMETER VALUE INDICATOR (PVI): < - LESS THAN DETECTION LIMIT
FLON RELATIONSHIP COOE:

U - UPGRADIENT

0001 - FILTERED SAMPLE (.45 MICRONS)

OTHER PARAMETER VALUE FLAGS:

$J$ - ESTIMATED VALUE 
TABLE 3.15 BACKGROUND GROUNDWATER QUALITY DATA BY PARAMETER FOR THE MAVAJO SANDSTONE, NC AND UC PROCESSING SITE, SLICK ROCK, COLORADO

SITE: SRK01 SLICK ROCK (BOTH SITES)

06/30/86 TO $10 / 12 / 92$

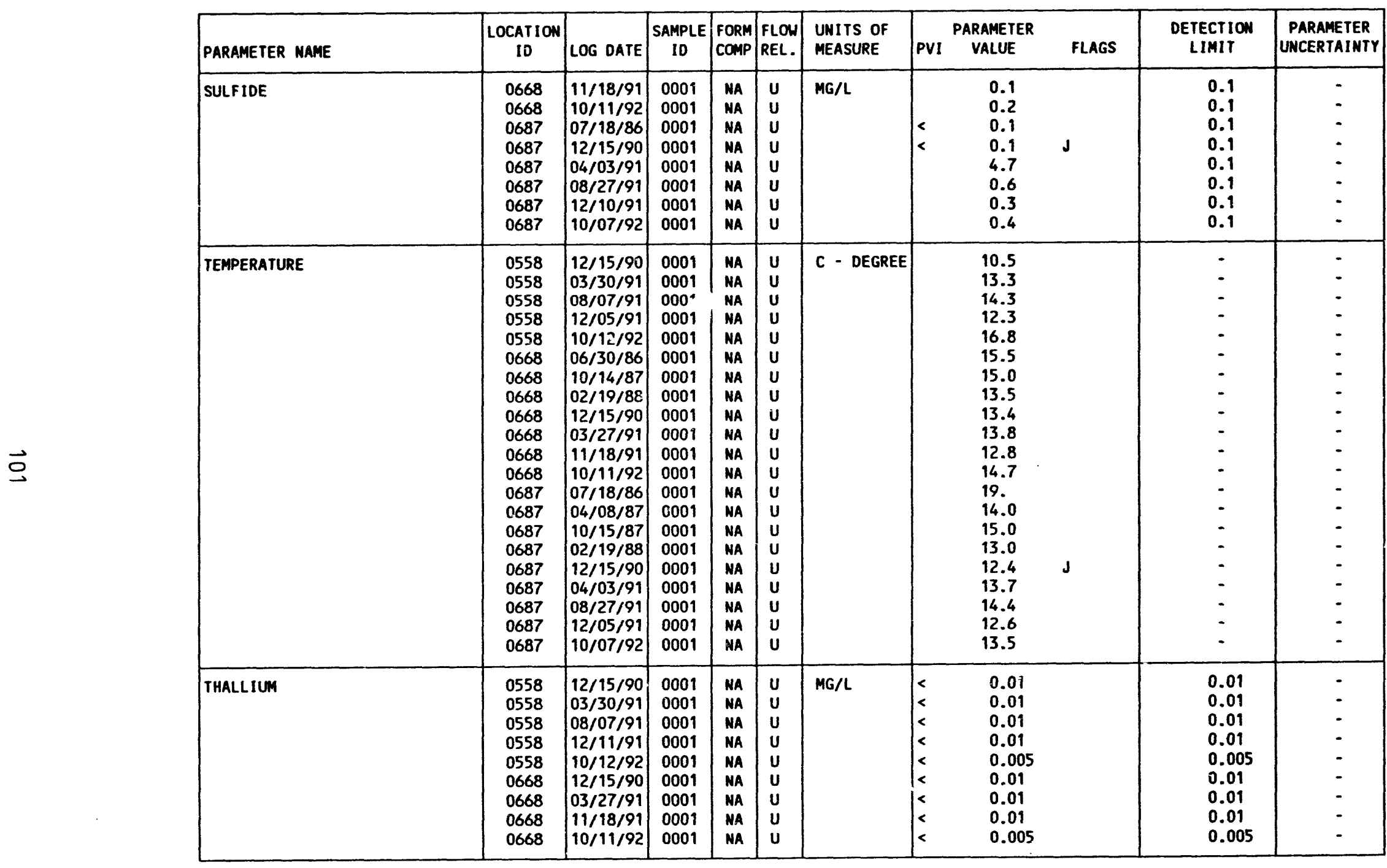

FORMATION OF COMPLETION CODE:

MA - NAVAJO SANDSTONE

PARAMETER VALUE INDICATOR (PVI): < - LESS THAN DETECTION LIMIT
FLOW RELATIONSHIP CODE:

U - UPGRADIENT

SAMPLE ID COOES:

SAMPLE 10 COOES: 
TABLE 3.15 BACKGROUND GROUNDWATER OUALITY DATA BY PARAMETER FOR THE MAVAJO SANDSTONE, NC AND UC PROCESSING SITE, SLICK ROCK, COLORADO

SITE: SRKO1 SLICK ROCK (BOTH SITES)

$06 / 30 / 86$ TO $10 / 12 / 92$

REPORT DATE: $06 / 17 / 93$

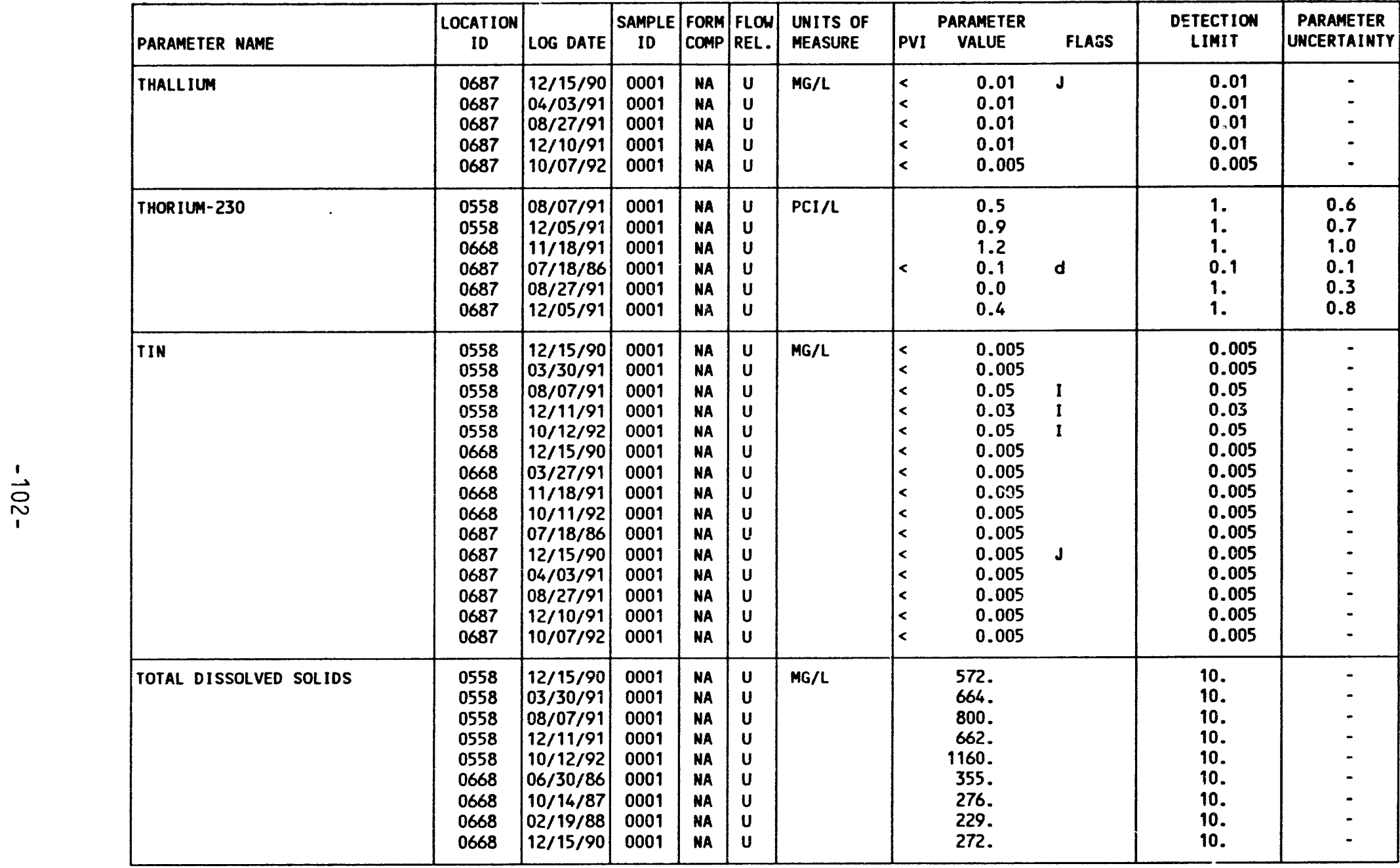

FORMATION OF COMPLETION COOE:

HA - NAVAJO SANDSTONE

PARAMETER VALUE INDICATOR (PVI): < - LESS THAN DETECTION LIMIT
FLOW RELATIONSHIP CODE:

$U$ - UPGRADIENT

0001 - FILTERED SAMPLE (.45 MICRONS)

OTHER PARAMETER VALUE FLAGS:

I - INCREASED DETECTION LIMIT DUE TO REOUIRED DILUTION j - ESTIMATED VALUE

d - Changed detection limit and parameter value 
TABLE 3.15 BACKGROMND GROUNDHATER OUALITY DATA BY PARAMETER FOR THE MAVAJO TABLE 3.15 BACKGROUND GROUNDING SITE, SLICK ROCK, COLORADO

SITE. SRKO 1 SLICK ROCK (BOTH SITES)

06/30/86 TO 10/12/92

REPORT DATE: $06 / 17 / 93$

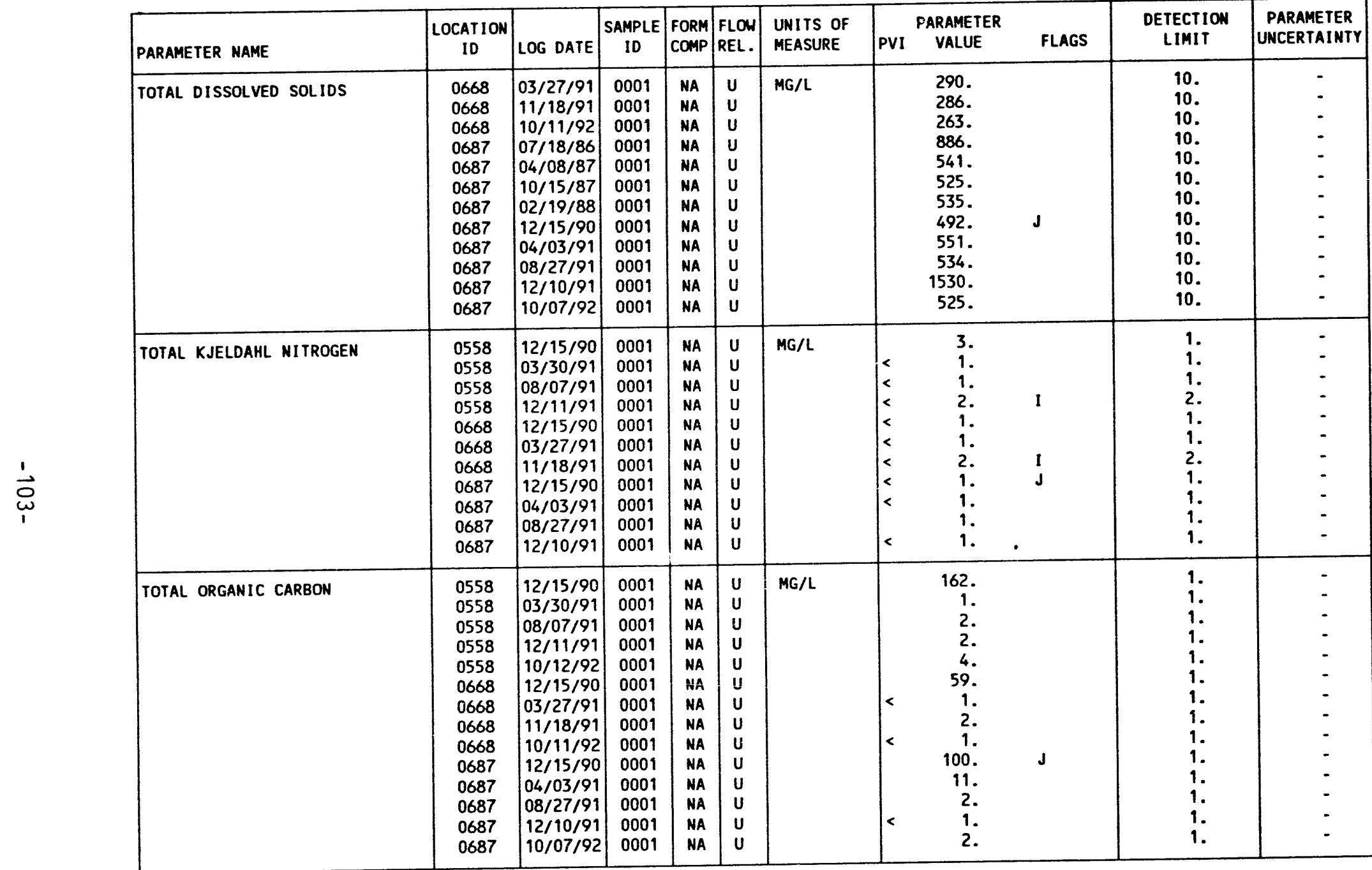

FOPMATION OF COMPLETIOH CODE:

HA - MAVAJO SANDSTONE

PARAMETER VALUE INDICATOR (PVI): < - LESS THAN DETECTION LIMIT
FLON RELATIONSHIP COOE:

SAMPLE 10 CODES: SAMPLE (.45 MICRONS)

OTHER PARAMETER VALUE FLAGS:

I - INCREASED DETECTION LIMIT DUE TO REQUIRED DILUTION

J. ESTIMATED VALUE 
TABLE 3.15 BACKGROUND GROUNDWATER OUALITY DATA BY PARAMETER FOR THE MAVAJO SANDSTONE, NC AND UC PROCESSING SITE, SLICK ROCK, COLORADO SITE: SRKO1 SLICK ROCK (BOTH SITES)

O6/30/86 TO $10 / 12 / 92$

REPORT DATE: $06 / 17 / 93$

\begin{tabular}{|c|c|c|c|c|c|c|c|c|c|c|c|}
\hline PARAMETER NAME & $\begin{array}{c}\text { LOCATION } \\
\text { ID }\end{array}$ & LOG DATE & $\begin{array}{c}\text { SAMPLE } \\
\text { ID }\end{array}$ & $\begin{array}{l}\text { FORM } \\
\text { COMP }\end{array}$ & $\begin{array}{l}\text { FLOW } \\
\text { REL. }\end{array}$ & $\begin{array}{l}\text { UNITS OF } \\
\text { MEASURE }\end{array}$ & PVI & $\begin{array}{l}\text { PARAMETER } \\
\text { VALUE }\end{array}$ & FLAGS & $\begin{array}{l}\text { DETECTION } \\
\text { LIMIT }\end{array}$ & $\begin{array}{l}\text { PARAMETER } \\
\text { UNCERTAINTY }\end{array}$ \\
\hline URANIUM & $\begin{array}{l}0558 \\
0558 \\
0558 \\
0558 \\
0558 \\
0668 \\
0668 \\
0668 \\
0668 \\
0668 \\
0668 \\
0668 \\
0687 \\
0687 \\
0687 \\
0687 \\
0687 \\
0687 \\
0687 \\
0687 \\
0687\end{array}$ & $\begin{array}{l}12 / 15 / 90 \\
03 / 30 / 91 \\
08 / 07 / 91 \\
12 / 05 / 91 \\
10 / 12 / 92 \\
06 / 30 / 86 \\
10 / 14 / 87 \\
02 / 19 / 88 \\
12 / 15 / 90 \\
03 / 27 / 91 \\
11 / 18 / 91 \\
10 / 11 / 92 \\
07 / 18 / 86 \\
04 / 08 / 87 \\
10 / 15 / 87 \\
02 / 19 / 88 \\
12 / 15 / 90 \\
04 / 03 / 91 \\
08 / 27 / 91 \\
12 / 05 / 91 \\
10 / 07 / 92\end{array}$ & $\begin{array}{l}0001 \\
0001 \\
0001 \\
0001 \\
0001 \\
0001 \\
0001 \\
0001 \\
0001 \\
0001 \\
0001 \\
0001 \\
0001 \\
0001 \\
0001 \\
0001 \\
0001 \\
0001 \\
0001 \\
0001 \\
0001\end{array}$ & $\begin{array}{l}\text { NA } \\
\text { NA } \\
\text { NA } \\
\text { NA } \\
\text { NA } \\
\text { NA } \\
\text { NA } \\
\text { NA } \\
\text { NA } \\
\text { NA } \\
\text { NA } \\
\text { NA } \\
\text { NA } \\
\text { NA } \\
\text { NA } \\
\text { NA } \\
\text { NA } \\
\text { NA } \\
\text { NA } \\
\text { NA } \\
\text { NA }\end{array}$ & $\begin{array}{l}U \\
U \\
U \\
U \\
U \\
U \\
U \\
U \\
U \\
U \\
U \\
U \\
U \\
U \\
U \\
U \\
U \\
U \\
U \\
U \\
U\end{array}$ & $\begin{array}{l}M G / L \\
\ldots \ldots \ldots\end{array}$ & & $\begin{array}{l}0.0140 \\
0.011 \\
0.018 \\
0.013 \\
0.031 \\
0.0028 \\
0.003 \\
0.0028 \\
0.0033 \\
0.002 \\
0.004 \\
0.001 \\
0.003 \\
0.0022 \\
0.005 \\
0.0021 \\
0.0012 \\
0.002 \\
1.328 \\
0.001 \\
0.003\end{array}$ & $\begin{array}{l}\text { c } \\
\text { c } \\
\text { c } \\
\text { c } \\
\text { J }\end{array}$ & $\begin{array}{l}0.0003 \\
0.001 \\
0.001 \\
0.001 \\
0.001 \\
0.0028 \\
0.003 \\
0.0028 \\
0.0003 \\
0.001 \\
0.001 \\
0.001 \\
0.003 \\
0.0022 \\
0.003 \\
0.0021 \\
0.0003 \\
0.001 \\
0.001 \\
0.001 \\
0.001\end{array}$ & $\begin{array}{l}- \\
- \\
- \\
- \\
- \\
- \\
- \\
- \\
- \\
- \\
- \\
- \\
- \\
- \\
-\end{array}$ \\
\hline VANADIUM & $\begin{array}{l}0558 \\
0558 \\
0558 \\
0558 \\
0558 \\
0668 \\
0668 \\
0668 \\
0668 \\
0668 \\
0668 \\
0687 \\
0687 \\
0687 \\
0687 \\
0687 \\
0687\end{array}$ & $\begin{array}{l}12 / 15 / 90 \\
03 / 30 / 91 \\
08 / 07 / 91 \\
12 / 11 / 91 \\
10 / 12 / 92 \\
06 / 30 / 86 \\
10 / 14 / 87 \\
12 / 15 / 90 \\
03 / 27 / 91 \\
11 / 18 / 91 \\
10 / 11 / 92 \\
07 / 18 / 86 \\
04 / 08 / 87 \\
10 / 15 / 87 \\
12 / 15 / 90 \\
04 / 03 / 91 \\
08 / 27 / 91\end{array}$ & $\begin{array}{l}0001 \\
0001 \\
0001 \\
0001 \\
0001 \\
0001 \\
0001 \\
0001 \\
0001 \\
0001 \\
0001 \\
0001 \\
0001 \\
0001 \\
0001 \\
0001 \\
0001\end{array}$ & $\begin{array}{l}\text { NA } \\
\text { NA } \\
\text { NA } \\
\text { NA } \\
\text { NA } \\
\text { NA } \\
\text { NA } \\
\text { NA } \\
\text { NA } \\
\text { NA } \\
\text { NA } \\
\text { NA } \\
\text { NA } \\
\text { NA } \\
\text { NA } \\
\text { NA } \\
\text { NA }\end{array}$ & $\begin{array}{l}u \\
U \\
u \\
U \\
u \\
u \\
U \\
u \\
u \\
U \\
U \\
U \\
U \\
U \\
U \\
U \\
U\end{array}$ & $M G / L$ & $\begin{array}{l}< \\
< \\
< \\
< \\
< \\
< \\
< \\
< \\
< \\
< \\
< \\
< \\
< \\
< \\
< \\
< \\
<\end{array}$ & $\begin{array}{l}0.01 \\
0.01 \\
0.01 \\
0.01 \\
0.01 \\
0.44 \\
0.01 \\
0.01 \\
0.01 \\
0.01 \\
0.01 \\
0.43 \\
0.2 \\
0.01 \\
0.01 \\
0.01 \\
0.01\end{array}$ & $\begin{array}{l}c \\
J\end{array}$ & $\begin{array}{l}0.01 \\
0.01 \\
0.01 \\
0.01 \\
0.01 \\
0.01 \\
0.01 \\
0.01 \\
0.01 \\
0.01 \\
0.01 \\
0.01 \\
0.2 \\
0.01 \\
0.01 \\
0.01 \\
0.01\end{array}$ & $\begin{array}{l}- \\
- \\
- \\
- \\
- \\
- \\
- \\
- \\
- \\
- \\
- \\
- \\
- \\
-\end{array}$ \\
\hline
\end{tabular}

FORMATION OF COMPLETION CODE:

NA - NAVAJO SANDSTONE

PARAMETER VALUE INDICATOR (PVI): < - LESS THAN DETECTION LIMIT
FLOW RELATIONSHIP CODE:

$U$ - UPGRADIENT

0001 - FILTERED SAMPLE (.45 MICRONS)

OTHER PARAMETER VALUE FLAGS:

J - ESTIMATED VALUE

c - CHANGED DETECTION LIMIT 
TABLE 3.15 BACKGROUND GROUNDWATER QUALITY DATA BY PARAMETER FOR THE NAVAJO SANDSTONE, NC AND UC PROCESSING SITE, SLICK ROCK, COLORADO SITE: SRKO1 SLICK ROCK (BOTH SITES)

SITE: SRKO1 SLICK ROCK

REPORT DATE : $06 / 17 / 93$

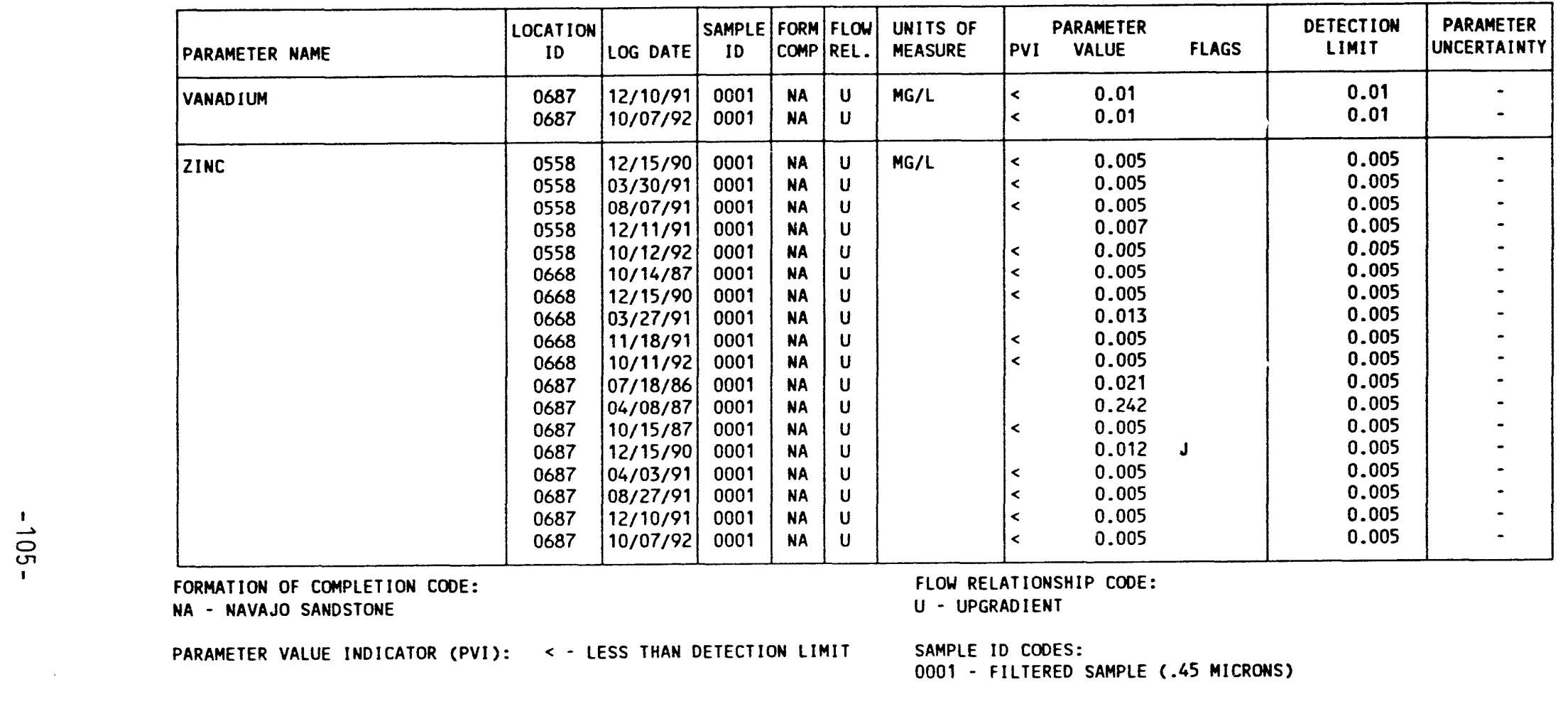

OTHER PARAMETER VALUE fLAGS:

J - ESTIMATED VALUE

DATA FILE NAME: M: IDARTISRK01\GWQ10025.DAT 
TABLE 3.16 BACKGROUND GROUNDWATER OUALITY STATISTICS BY PARAMETER FOR THE NAVAJO SANDSTONE, NC PROCESSING SITE, SLICK ROCK, COLORADO SITE: SRK01 SLICK ROCK (BOTH SITES)

07/18/86 TO $10 / 07 / 92$

REPORT DATE: $07 / 26 / 93$

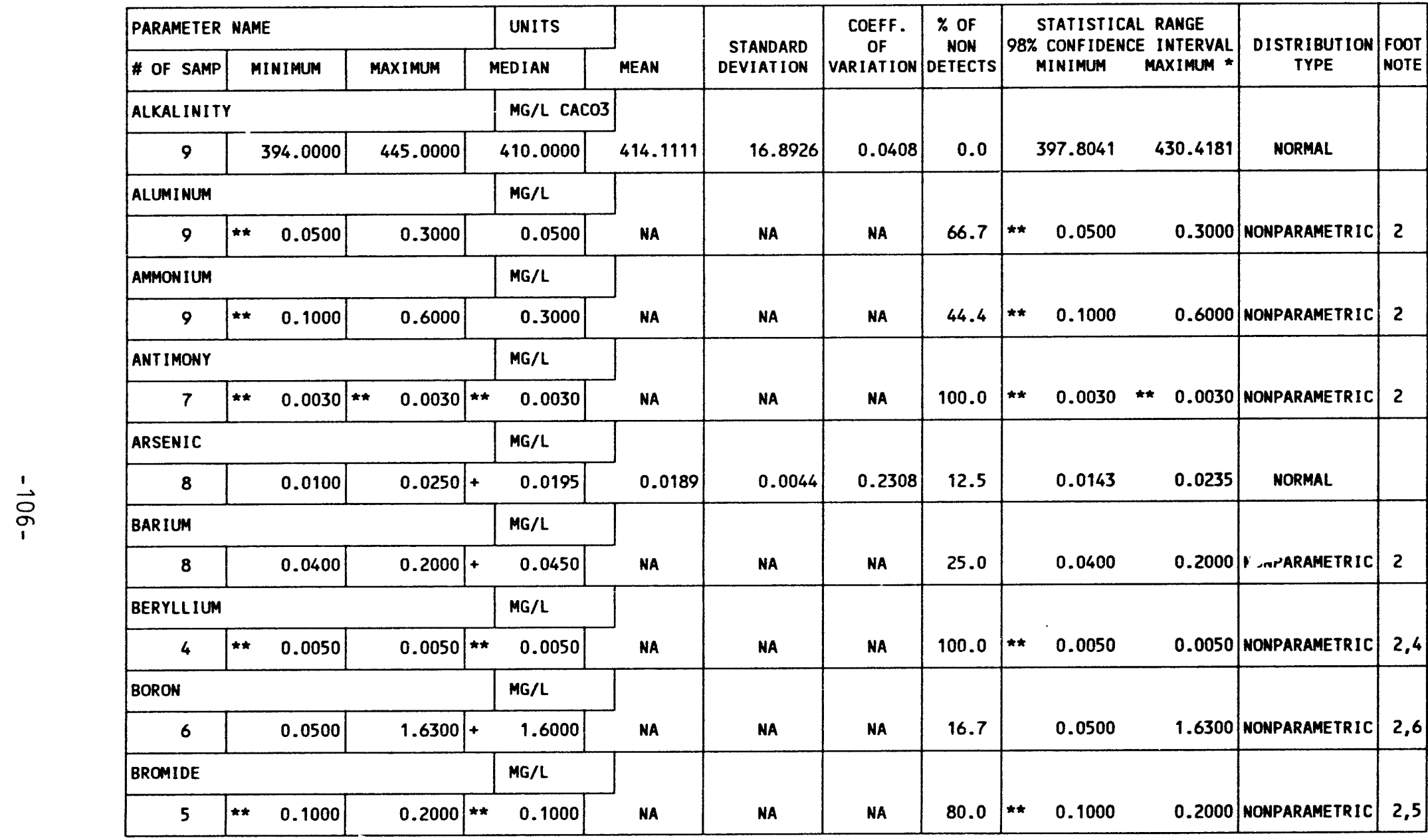

** The reported value is the minimum detection limit of the data set

+ The sample size is even, so the median value is the arithmetic average of the two middle values

* The statistical maximem is the 99 percent one sided confidence interval $a=0.01$

2) The nonparametric distribution was used because the nondetected values comprise more than $15 \%$ of the samples.

4) The stat. range is the $87.5 \%$ confidence interval due to a sample size of 4 . The maximum is the $93.8 \%$ one sided confidence int.

5) The stat. range is the $93.8 \%$ confidence interval due to a sample size of 5 . The maximum is the $96.9 \%$ one sided confidence int.

6) The stat. range is the $96.9 \%$ confidence interval due to a sample size of 6 . The maximm is the $98.5 \%$ one sided confidence int. 
TABLE 3.16 BACKGROUND GROUNDHATER QUALITY STATISTICS BY PARAMETER FOR THE NAVAJO SANDSTONE, NC PROCESSING SITE, SLICK ROCK, COLORADO SITE: SRKO1 SLICK ROCK (BOTH SITES)

SITE: SRKO1 SLICK ROCK
$07 / 18 / 86$ TO $10 / 07 / 92$

REPORT DATE: $07 / 26 / 93$

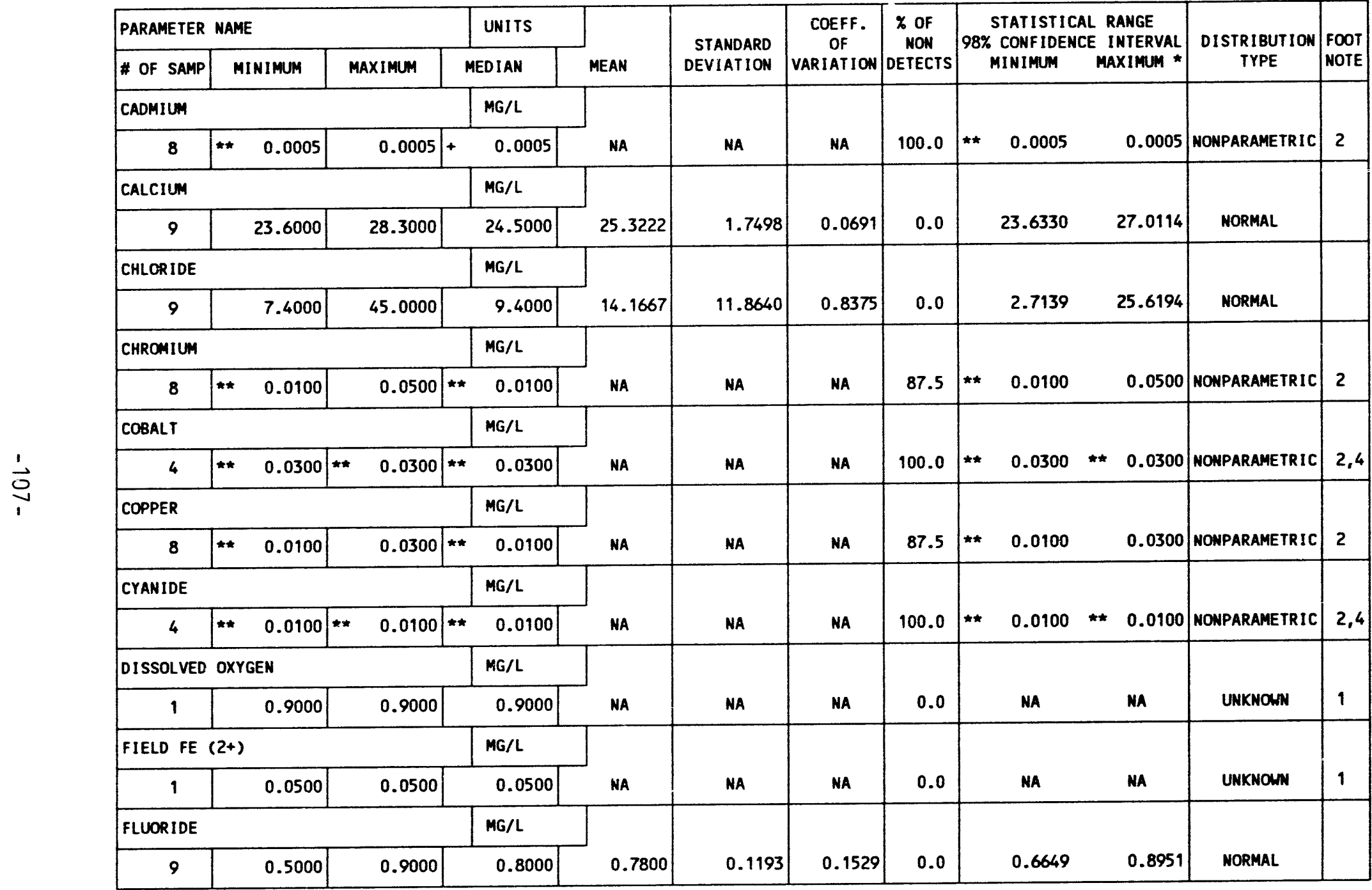

** The reported value is the minimum detection limit of the data set

+ The sample size is even so the median value is the arithmetic average of the two middle values

- The statistical maximu is the 99 percent one sided confidence interval, $a=0.01$

1) A minimm of 4 samples must be available for the statistical analysis.

2) The nomparametric distribution was used because the nondetected values comprise more than $15 \%$ of the samples.

4) The stat. range is the $87.5 \%$ confidence interval due to a sample size of 4 . The maximu is the $93.8 \%$ one sided confi lence int. 
TABLE 3.16 BACKGROUND GROUNDWATER QUALITY STATISTICS BY PARAMETER TOR THE MAVAJO SANDSTONE, NC PROCESSIMG SITE, SLICK ROCK, COLORADO SITE: SRKO1 SLICK ROCK (BOTH SITES)

DT/18/86 TO $10 / 07 / 92$

REPORT DATE: $07 / 26 / 93$

\begin{tabular}{|c|c|c|c|c|c|c|c|c|c|c|c|c|}
\hline \multicolumn{3}{|c|}{ PARAMETER NAME } & UNITS & \multirow[b]{2}{*}{ MEAN } & \multirow{2}{*}{$\begin{array}{l}\text { STANDARD } \\
\text { DEVIATION }\end{array}$} & \multirow{2}{*}{$\begin{array}{c}\text { COEFF. } \\
\text { OF } \\
\text { VARIATION }\end{array}$} & \multirow{2}{*}{$\begin{array}{c}\% \text { OF } \\
\text { NON } \\
\text { DETECTS }\end{array}$} & \multirow{2}{*}{\multicolumn{3}{|c|}{$\begin{array}{l}\text { STATISTICAL RANGE } \\
\text { 98\% CONFIDENCE INTERVAL } \\
\text { MINIMUM MAXIMUM * }\end{array}$}} & \multirow{2}{*}{$\begin{array}{l}\text { DISTRIBUTION } \\
\text { TYPE }\end{array}$} & \multirow{2}{*}{$\begin{array}{l}\text { FOOT } \\
\text { NOTE }\end{array}$} \\
\hline \# OF SAMP & MINIMUM & MAXIMUM & MEDIAN & & & & & & & & & \\
\hline \multicolumn{3}{|c|}{ GROSS ALPHA } & PCI/L & \multirow[b]{2}{*}{ NA } & \multirow[b]{2}{*}{ NA } & \multirow[b]{2}{*}{ NA } & \multirow[b]{2}{*}{0.0} & \multirow[b]{2}{*}{$\star \star$} & \multirow[b]{2}{*}{1.0000} & \multirow[b]{2}{*}{874.9000} & \multirow[b]{2}{*}{ |NONPARAMETRIC } & \multirow[b]{2}{*}{9,5} \\
\hline 5 & $\star * \quad 1.0000$ & 874.9000 & 7.7000 & & & & & & & & & \\
\hline \multicolumn{3}{|c|}{ GROSS BETA } & $\mathrm{PCI} / \mathrm{L}$ & \multirow[b]{2}{*}{28.5729} & \multirow[b]{2}{*}{3.9249} & \multirow[b]{2}{*}{ NA } & \multirow[b]{2}{*}{0.0} & \multirow{2}{*}{\multicolumn{2}{|c|}{2.8898}} & \multirow[b]{2}{*}{282.5154} & \multirow[b]{2}{*}{ LOGNORMAL } & \multirow[b]{2}{*}{7,8} \\
\hline 5 & 8.4000 & 301.0000 & 19.6000 & & & & & & & & & \\
\hline \multicolumn{3}{|l|}{ IRON } & MG/L & \multirow[b]{2}{*}{ NA } & \multirow[b]{2}{*}{ NA } & \multirow[b]{2}{*}{ NA } & \multirow[b]{2}{*}{33.3} & \multirow[b]{2}{*}{$\star \star$} & & & & \\
\hline 9 & $\star \star \quad 0.0300$ & 0.0500 & 0.0300 & & & & & & 0.0300 & 0.0500 & NONPARAMETRIC & 2 \\
\hline LEAD & & & $M G / L$ & & & & & & & & & \\
\hline 8 & $\star \quad 0.0050$ & 0.0100 & 0.0050 & NA & NA & NA & 100.0 & $\star \star$ & 0.0050 & 0.0100 & NONPARAMETRIC & 2 \\
\hline LEAD-210 & & & $\mathrm{PCI} / \mathrm{L}$ & & & & & & & & & \\
\hline 3 & $\# \quad 1.3000$ & $\star \star \quad 1.3000$ & ** $\quad 1.3000$ & NA & NA & NA & 0.0 & & NA & NA & UNKNOWN & 1 \\
\hline MAGNESIUM & & & $M G / L$ & & & & & & & & & \\
\hline 9 & $19 .\{000$ & 21.0000 & 19.5000 & 19.8000 & 0.6856 & 0.0346 & 0.0 & & 19.1382 & 20.4618 & NORMAL & \\
\hline MANGANESE & & & $\mathrm{MG} / \mathrm{L}$ & & & & & & & & & \\
\hline 9 & 0.0200 & 0.0800 & 0.0200 & 0.0311 & 0.0196 & 0.6316 & 0.0 & & 0.0121 & 0.0501 & NORMAL & \\
\hline MERCURY & & & $M G / L$ & & & & & & & & & \\
\hline 7 & $\star \star \quad 0.0002$ & ** $\quad 0.0002$ & $\star \star \quad 0.0002$ & NA & NA & NA & 100.0 & $\star \star$ & 0.0002 & $\star 0.0002$ & NONPARAMETRIC & 2 \\
\hline MOL YBDENU & & & $M G / L$ & & & & & & & & & \\
\hline 9 & $\star \star \quad 0.0100$ & 0.1600 & $\star * \quad 0.0100$ & NA & NA & NA & 66.7 & $\star \star$ & 0.0100 & 0.1600 & NONPARAMETRIC & 2 \\
\hline
\end{tabular}

* The reported value is the minimum detection limit of the data set

+ The sample size is even, so the median value is the arithmetic average of the two middle values

* The statistical maximum is the 99 percent one sided confidence interval, $\alpha=0.01$

1) A minimum of 4 samples must be available for the statistical analysis.

2) The nonparameiric distribution was used because the nondetected values comprise more than 15\% of the samples.

5) The stat. range is the $93.8 \%$ confidence interval due to a sample size of 5 . The maximum is the $96.9 \%$ one sided confidence int.

7) The lognormal distribution was used because the data failed the normal distribution test.

8) The mean is geometric. The standard deviation is the value to divide or multiply with the geometric mean.

9) The nonparametic distribution was used because the data failed the normal distribution test and includes values $\leq 0$. 
TABLE 3.16 BACKGROUND GROUNDWATER QUALITY STATISTICS BY PARAMETER TAB THE NAVAJO SANDSTONE, NC FROCESSING SITE, SLICK ROCK, COLORADO

SITE: SRKO1 SLICK ROCK (BOTH SITES)

SITE: SRKO1 SLICK ROCK

REPORT DATE: $07 / 26 / 93$

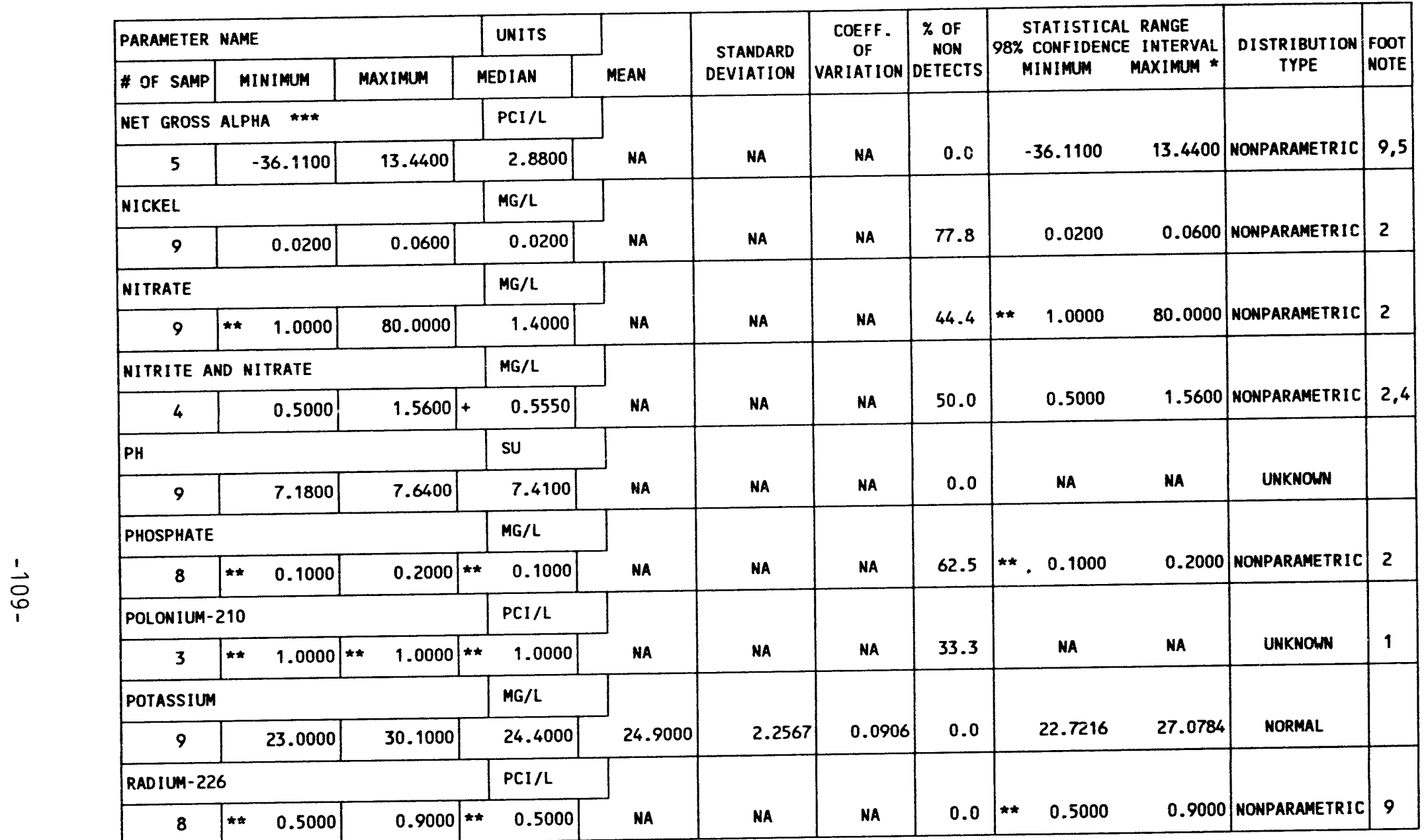

$* \star *$ NET GROSS ALPHA (GROSS ALPHA - URANIUM) WITH 1 MG URANIUM = 686 PCI

* The reported value is the minimum detection limit of the data set

+ The sample size is even, so the median value is the arithmetic average of the two middle values

* The statistical maximum is the 99 percent one sided confidence interval, $a=0.01$

1) A minimu of 4 samples must be available for the statistical analysis.

1) A minimum of 4 (he samples.

2) The nonparametric distribur

4) The stat. range is the $87.5 \%$ confidence interval due to a sample size of 5 . The maximum is the $96.9 \%$ one sided confidence int.

9) The nonparanetic distribution was used because the data failed the normal distribution test and includes values $\leq 0$. 
TABLE 3.16 BACKGROUND GROUNDWATER OUALITY STATISTIIS BY PARAMETER FOR THE NAVAJO SAMDSTOME MC PROCESSING SITE, SLICK ROCK, COLORADO

SITE: SRKO1 SLICK ROCK (BOTH SITES)

$07 / 18 / 86$ TO $10 / 07 / 92$

REPORT DATE: $07 / 26 / 93$

\begin{tabular}{|c|c|c|c|c|c|c|c|c|c|c|c|}
\hline \multicolumn{3}{|c|}{ PARAMETER NAME } & UNITS & \multirow[b]{2}{*}{ MEAN } & \multirow{2}{*}{$\begin{array}{r}\text { STANDARD } \\
\text { DEVIATION }\end{array}$} & \multirow{2}{*}{$\begin{array}{c}\text { COEFF. } \\
\text { OF } \\
\text { VARIATION }\end{array}$} & \multirow{2}{*}{$\begin{array}{c}\% \text { OF } \\
\text { NON } \\
\text { DETECTS }\end{array}$} & \multicolumn{2}{|c|}{$\begin{array}{l}\text { STATISTIICAL RANGE } \\
\text { 98\% CONFIDENCE INTERVAL }\end{array}$} & \multirow{2}{*}{$\begin{array}{c}\text { DISTRIBUTION } \\
\text { TYPE }\end{array}$} & \multirow{2}{*}{$\begin{array}{l}\text { FOOT } \\
\text { NOTE }\end{array}$} \\
\hline \# OF SAMP & MINIMUM & MAXIMUM & MEDIAN & & & & & MINIMUM & MAXIMUM * & & \\
\hline \multicolumn{3}{|c|}{ RADIUM-226 + RADIUM-228 } & $\mathrm{PCI} / \mathrm{L}$ & \multirow[b]{2}{*}{ NA } & \multirow[b]{2}{*}{ NA } & \multirow[b]{2}{*}{ NA } & \multirow[b]{2}{*}{0.0} & \multirow[b]{2}{*}{0.0000} & \multirow[b]{2}{*}{5.2000} & \multirow[b]{2}{*}{ NONPARAMETRIC } & \multirow[b]{2}{*}{9} \\
\hline 7 & 0.0000 & 5.2000 & 1.1000 & & & & & & & & \\
\hline \multicolumn{3}{|c|}{ RADIUM-228 } & $\mathrm{PCl} / \mathrm{L}$ & \multirow[b]{2}{*}{ NA } & \multirow[b]{2}{*}{ NA } & \multirow[b]{2}{*}{ NA } & \multirow[b]{2}{*}{14.3} & \multirow[b]{2}{*}{1.0000} & \multirow[b]{2}{*}{4.7000} & \multirow[b]{2}{*}{ NONPARAMETRIC } & \multirow[b]{2}{*}{9} \\
\hline 7 & $\star \star \quad 1.0000$ & 4.7000 & $\star * \quad 1.0000$ & & & & & & & & \\
\hline \multicolumn{3}{|c|}{ REDOX POTENTIAL } & mVOLTS & \multirow[b]{2}{*}{ NA } & \multirow[b]{2}{*}{ NA } & \multirow[b]{2}{*}{ NA } & \multirow[b]{2}{*}{0.0} & & & & \\
\hline 2 & 336.4000 & 393.4000 & +364.9000 & & & & & NA & NA & UNKNONN & 1 \\
\hline SELENIUM & & & $M G / L$ & & & & & & & & \\
\hline 8 & $\star \star \quad 0.0050$ & $\approx * \quad 0.0050$ & $* * \quad 0.0050$ & NA & NA & NA & 100.0 & 0.0050 & $\star \star \quad 0.0050$ & NONPARAMETRIC & 2 \\
\hline SILICA - & 5102 & & MG/L & & & & & & & & \\
\hline 9 & 4.0000 & 10.6000 & 8.6000 & 8.1444 & 1.8180 & 0.2232 & 0.0 & 6.3894 & 9.8995 & NORMAL & \\
\hline SILVER & & & MG/L & & & & & & & & \\
\hline 7 & $\approx \quad 0.0100$ & $\star \star \quad 0.0100$ & $\star \star \quad 0.0100$ & NA & NA & NA & 100.0 & 0.0100 & $\star \quad 0.0100$ & NONPARAMETRIC & 2 \\
\hline SOOIUM & & & $\mathrm{MG} / \mathrm{L}$ & & & & & & & & \\
\hline 9 & 136.0000 & 177.0000 & 141.0000 & 146.4444 & 13.4639 & 0.0919 & 0.0 & 133.4473 & 159.4416 & NORMAL & \\
\hline SPECIFIC & CONDUCTANCE & & UMHO/CM & & & & & & & & \\
\hline 9 & 450.0000 & 887.0000 & 685.0000 & 707.5556 & 180.8294 & 0.2556 & 0.0 & 532.9949 & 882.1162 & NORMAL & \\
\hline STRONT IUM & & & $M G / L$ & & & & & & & & \\
\hline 5 & 1.0400 & 1.1700 & 1.1000 & 1.0960 & 0.0483 & 0.0440 & 0.0 & 1.0151 & 1.1769 & NORMAL & \\
\hline SULFATE & & & $\mathrm{MG} / \mathrm{L}$ & & & & & & & & \\
\hline 9 & 32.9000 & 63.8000 & 58.5000 & 54.5556 & 10.0695 & 0.1846 & 0.0 & 44.8351 & 64.2760 & NORMAL & \\
\hline
\end{tabular}

* The reported value is the minimum detection limit of the data set

+ The sample size is even, so the median value is the arithmetic average of the two middle values

* The statistical maximum is the 99 percent one sided confidence interval, $\alpha=0.01$

1) A minimm of 4 samples must be available for the statistical analysis.

2) The nomparametric distribution was used because the nondetected values comprise more than $15 \%$ of the samples.

2) The nonparametric distribution was used because the data failed the normal distribution test and includes values $\leq 0$. 
TABLE 3.16 GACKGROUND GROUNDWATER QUALITY STATISTICS BY PARAMETER TABLE 3.16 BACKGROUNO GROUNWATE QUAL SITE, SLICK ROCK, COLORADO FOR THE NAVAJO SANDSTONE, NC PROCESSIN

SITE: SRKOI SLICK ROCK (BOTH SITES)

$07 / 18 / 86$ TO $10 / 07 / 92$

REPORT DATE: $07 / 26 / 93$

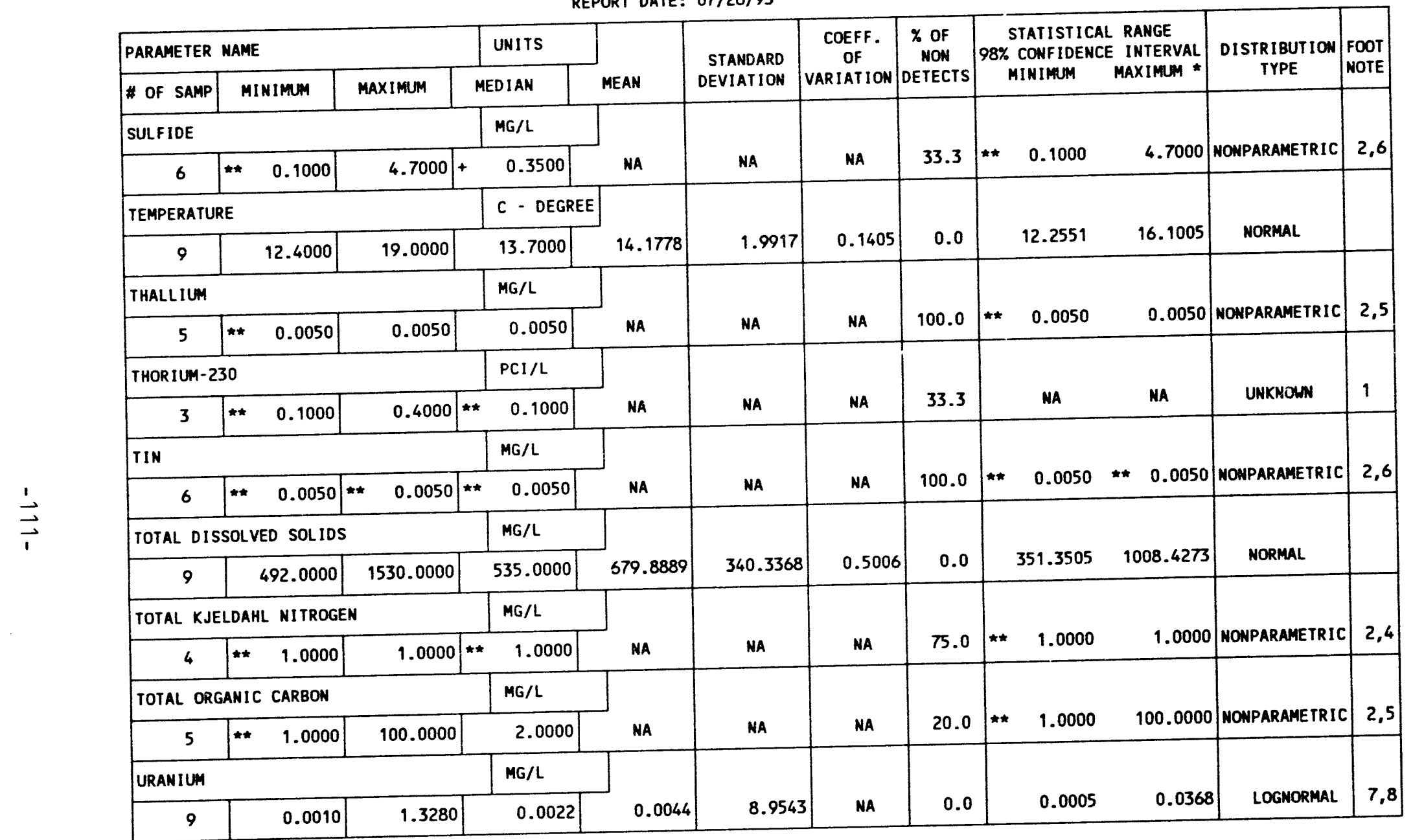

* The reported value is the minimum detection limit of the data set

of the two middle values

+ The sample size is even, so the 99 percent one sided confidence interval, $\alpha=0.01$

* The statistical maximum is the

1) A minimm of 4 samples must be available for the statistical analysis. comprise more than $15 \%$ of the samples.

2) The nomparametric distribution was used because the nondetected values conprise more imm is the $93.8 \%$ one sided confidence int.

4) The stat. range is the $87.5 \%$ confidence interval due to a sample size of 5 . The maximum is the $96.9 \%$ one sided conf idence int.

5) The stat. range is the $93.8 \%$ confidence interval due to a sample size of 6 . The maximm is the $98.5 \%$ one sided confidence int.

6) The stat. range is the $96.9 \%$ confidence interval due to al same normal distribution test.

7) The lognormal distribution was used because the data failed the nivide or multiply uith the geometric mean.

8) The mean is geometric. The standard deviation is the value to divide or multiply with the geometric mean. 
TABLE 3.16 BACKGROUND GROUNDHATER QUALITY STATISTICS BY PARAMETER FOR THE NAVAJO SANDSTONE, NC PROCESSING SITE, SLICK ROCK, COLORADO SITE: SRKO1 SLICK ROCK (BOTH SITES)

$07 / 18 / 86$ TO $10 / 07 / 92$

REPORT DATE: $07 / 26 / 93$

\begin{tabular}{|c|c|c|c|c|c|c|c|c|c|c|c|c|}
\hline \multicolumn{3}{|c|}{ PARAMETER NAME } & UNITS & \multirow[b]{2}{*}{ MEAN } & \multirow{2}{*}{$\begin{array}{r}\text { STANDARD } \\
\text { DEVIATION }\end{array}$} & \multirow{2}{*}{$\begin{array}{c}\text { COEFF. } \\
\text { OF } \\
\text { VARIATION }\end{array}$} & \multirow{2}{*}{$\mid \begin{array}{c}\% \text { OF } \\
\text { HON } \\
\text { DETECTS }\end{array}$} & \multirow{2}{*}{\multicolumn{3}{|c|}{$\begin{array}{l}\text { STATISTICAL RANGE } \\
\text { 98\% CONFIDENCE INTERVAL } \\
\text { MINIMUM } \\
\text { MAXIMUM }\end{array}$}} & \multirow{2}{*}{$\begin{array}{c}\text { DISTRIBUTION } \\
\text { TYPE }\end{array}$} & \multirow{2}{*}{$\begin{array}{l}\text { FOOT } \\
\text { NOTE }\end{array}$} \\
\hline \# OF SAMP & MINIMUM & MAXIMUM & MEDIAN & & & & & & & & & \\
\hline \multicolumn{3}{|l|}{ VANADIUM } & $M G / L$ & \multirow[b]{2}{*}{ NA } & \multirow[b]{2}{*}{ NA } & \multirow[b]{2}{*}{ NA } & \multirow[b]{2}{*}{87.5} & \multirow[b]{2}{*}{$\star \star$} & \multirow[b]{2}{*}{0.0100} & \multirow[b]{2}{*}{0.4300} & \multirow[b]{2}{*}{ MONPARAMETRIC } & \multirow[b]{2}{*}{2} \\
\hline 8 & $\star * \quad 0.0100$ & 0.4300 & 0.0100 & & & & & & & & & \\
\hline \multicolumn{3}{|l|}{ ZINC } & $M G / L$ & \multirow[b]{2}{*}{ NA } & \multirow[b]{2}{*}{ MA } & \multirow[b]{2}{*}{ NA } & \multirow[b]{2}{*}{62.5} & \multirow[b]{2}{*}{$\star \star$} & \multirow[b]{2}{*}{0.0050} & \multirow[b]{2}{*}{0.2420} & \multirow[b]{2}{*}{ MONPARAMETRIC } & \multirow[b]{2}{*}{2} \\
\hline 8 & 0.0050 & 0.2420 & 0.0050 & & & & & & & & & \\
\hline
\end{tabular}

** The reported value is the minimum detection limit of the data set

* The statistical maximum is the 99 percent one sided confidence interval, $a=0.01$

2) The nonparametric distribution was used because the nondetected values comprise more than $15 \%$ of the samples.

INPUT DATA FILENAME: M: IDARTISRKO1IGWO10033.DAT 
Table 3.17 Summary of regulated constituents in the Navajo Sandstone background groundwater, NC processing site, Slick Rock, Colorado

\begin{tabular}{|c|c|c|c|}
\hline \multicolumn{4}{|c|}{ Constituents with MCLsa } \\
\hline Parameter & MCLs & $\begin{array}{l}\text { Mean or } \\
\text { Median }\end{array}$ & $\begin{array}{l}\text { statistical } \\
\text { maximum }\end{array}$ \\
\hline Arsenic & 0.05 & $0.019^{d}$ & 0.024 \\
\hline Barium & 1.00 & $0.10^{\circ}$ & 0.200 \\
\hline Cadmium & 0.01 & $0.001^{e}$ & $0.001^{e}$ \\
\hline Chromium & 0.05 & $0.01^{e}$ & 0.05 \\
\hline Net gross alphab & 15.0 & 2.88 & 13.4 \\
\hline Lead & 0.05 & $0.01^{\mathrm{c}}$ & $0.01^{\mathrm{e}}$ \\
\hline Mercury & 0.002 & $0.0002^{\mathrm{c}}$ & $0.0002^{e}$ \\
\hline Molybdenum & 0.10 & $0.01^{e}$ & 0.16 \\
\hline Nitrate & 44.0 & 1.40 & 80.0 \\
\hline Radium-226 and $-228^{b}$ & 5.00 & 1.10 & 5.20 \\
\hline Selenium & 0.01 & $0.005^{\mathrm{e}}$ & $0.005^{\mathrm{e}}$ \\
\hline Silver & 0.05 & $0.01^{e}$ & $0.01^{\mathrm{e}}$ \\
\hline Uranium & 0.044 & $0.004^{\mathrm{c}}$ & 0.037 \\
\hline
\end{tabular}


Table 3.17 Summary of regulated constituents

in the Navajo Sandstone background groundwater,

NC processing site, Slick Rock, Colorado (concluded)

Constituents without MCLs ${ }^{a}$

\begin{tabular}{lll}
\hline \multicolumn{1}{c}{ Parameter } & $\begin{array}{c}\text { Mean or } \\
\text { Median }\end{array}$ & $\begin{array}{c}\text { Statistical } \\
\text { maximum }\end{array}$ \\
\hline Antimony & $0.003^{\mathrm{e}}$ & $0.003^{\mathrm{e}}$ \\
Beryllium & $0.01^{\mathrm{e}}$ & $0.01^{\mathrm{e}}$ \\
Cobalt & $0.05^{\mathrm{e}}$ & $0.05^{\mathrm{e}}$ \\
Copper & $0.02^{\mathrm{e}}$ & 0.03 \\
Cyanide & $0.01^{\mathrm{e}}$ & $0.01^{\mathrm{e}}$ \\
Nickel & $0.04^{\mathrm{e}}$ & 0.06 \\
Sulfide & $0.35^{-06}$ & 4.70 \\
Thallium & $0.01^{\mathrm{e}}$ & $0.01^{\mathrm{e}}$ \\
Tin & $0.005^{\mathrm{e}}$ & $0.005^{\mathrm{e}}$ \\
Vanadium & $0.01^{\mathrm{e}}$ & 0.43 \\
Zinc & $0.005^{\mathrm{e}}$ & 0.242 \\
\hline
\end{tabular}

${ }^{a}$ All units are $\mathrm{mg} / \mathrm{l}$ unless otherwise noted.

bunits are $\mathrm{pCi} / \mathrm{l}$.

Mean value, Lognormal distribution, mean is geometric.

Mean value, Normal distribution, mean is arithmetic.

'Statistical values are below laboratory detection limits in

Table 8.1 of the Technical Approach Document (DOE, 1989). 
TABLE 3.18 GROUNDWATER QUALITY MEASUREMENTS EXCEEDING MAXIMUM CONCENTRATION TABLE 3. 18 MROUNDUAER QUALITY MEASUREMENTS EXCER MC \& UC PROCESSING SITES

SITE: SRKO1 SLICK ROCK (BOTH SITES)

SITE: SRKO1 SLICK ROCK

REPORT DATE: 06/17/93

\begin{tabular}{|c|c|c|c|c|c|c|c|c|c|c|c|c|}
\hline PARAMETER NAME & $\begin{array}{l}\text { TOTAL } \\
\text { \# OF } \\
\text { SAMP. }\end{array}$ & $\begin{array}{c}\text { UNITS } \\
\text { OF } \\
\text { MEASURE }\end{array}$ & $\begin{array}{l}\text { MAXIMUM } \\
\text { CONC. } \\
\text { LIMIT }\end{array}$ & $\begin{array}{c}\text { LOC. } \\
\text { ID }\end{array}$ & LOG DAIE & $\begin{array}{c}\text { SAMP } \\
\text { ID }\end{array}$ & $\begin{array}{c}\text { FORM } \\
\text { OF } \\
\text { COMP }\end{array}$ & $\begin{array}{l}\text { HYDR } \\
\text { FLOW } \\
\text { REL. }\end{array}$ & $\begin{array}{c}\text { RESULT EXCEE } \\
\text { CONCENTRATIO } \\
\text { VALUE }\end{array}$ & $\begin{array}{l}\text { DING MAX. } \\
\text { N LIMIT } \\
\text { FLAGS }\end{array}$ & $\begin{array}{l}\text { DETECTION } \\
\text { LIMIT }\end{array}$ & $\begin{array}{l}\text { PARAMETER } \\
\text { UNCERT. }\end{array}$ \\
\hline ARSENIC & 19 & MG/L & 0.0500 & 0687 & $12 / 10 / 91$ & 0001 & HA & u & 0.05 & 1 & 0.05 & - \\
\hline ARSENIC (TOTAL) & 0 & MG/L & 0.0500 & $\cdot$ & - & - & - & - & $\cdot$ & & - & - \\
\hline BARIUM & 18 & $M G / L$ & 1.0000 & - & - & - & - & - & - & & - & $\cdot$ \\
\hline BARIUM (TOTAL) & 0 & $M G / L$ & 1.0000 & - & - & - & - & - & - & & - & - \\
\hline CADMIUM & 18 & $M G / L$ & 0.0100 & - & - & - & - & - & - & & - & - \\
\hline CADMIUM (TOTAL) & 0 & MG/L & 0.0100 & - & - & - & - & - & - & & - & - \\
\hline CHROMIUN & 18 & MG/L & 0.0500 & 0687 & $07 / 18 / 86$ & 0001 & MA & $u$ & 0.05 & & 0.01 & - \\
\hline CHROMIUM (TOTAL) & 0 & $M G / L$ & 0.0500 & - & $\cdot$ & - & - & - & - & & - & - \\
\hline GROSS ALPHA & 14 & $\mathrm{PCI} / \mathrm{L}$ & 15.0000 & $\begin{array}{l}0558 \\
0687 \\
0687\end{array} \mid$ & $\begin{array}{l}10 / 12 / 92 \\
08 / 27 / 91 \\
10 / 07 / 92\end{array}$ & $\left|\begin{array}{l}0001 \\
0001 \\
0001\end{array}\right|$ & $\begin{array}{l}\text { MA } \\
\text { NA } \\
\text { MA }\end{array}$ & $\begin{array}{l}u \\
u \\
u\end{array}$ & $\begin{array}{r}22.4 \\
874.9 \\
15.5\end{array}$ & $\mathbf{N}$ & $\begin{array}{c}18.1 \\
1 . \\
8.3\end{array}$ & $\begin{array}{r}13.3 \\
67.8 \\
7.1\end{array}$ \\
\hline GROSS ALPHA (TOTAL) & 0 & $\mathrm{PCI} / \mathrm{L}$ & 15.0000 & - & - & - & - & - & - & & - & - \\
\hline LEAD & 18 & $M G / L$ & 0.0500 & - & - & - & - & - & . - & & - & - \\
\hline LEAD (TOTAL) & 0 & HG/L & 0.0500 & - & - & - & - & - & - & & $\cdot$ & - \\
\hline MERCURY & 15 & $M G / L$ & 0.0020 & - & - & - & - & - & - & & - & - \\
\hline MERCURY (TOTAL) & 0 & $M G / L$ & 0.0020 & - & $\cdot$ & - & - & - & - & & - & - \\
\hline MOLYBDENUM & 21 & $M G / L$ & 0.1000 & $\left|\begin{array}{l}0668 \\
0687 \\
0687\end{array}\right|$ & $\begin{array}{l}06 / 30 / 86 \\
07 / 18 / 86 \\
04 / 08 / 87\end{array}$ & $\begin{array}{l}0001 \\
0001 \\
0001\end{array}$ & $\begin{array}{l}\text { NA } \\
\text { NA } \\
\text { NA }\end{array}$ & $\begin{array}{l}u \\
u \\
u\end{array}$ & $\begin{array}{l}0.17 \\
0.16 \\
0.1\end{array}$ & c & $\begin{array}{l}0.01 \\
0.01 \\
0.1\end{array}$ & : \\
\hline MOLYBDENUM (TOTAL) & 0 & $M G / L$ & 0.1000 & - & - & $\cdot$ & - & - & - & & - & - \\
\hline
\end{tabular}

$<$ - the data is flagged as a nON-Detect, so the result is an estimated value or the detection limit

FORMATION OF COMPLETION COOE:

MA - NAVAJO SANDSTONE

OTHER PARAMETER VALUE FLAGS:

I - INCREASED DETECTION LIMIT DUE TO REOUIRED DILITION

1 - SPIKE SAMPLE RECOVERY NOT UITHIM CONTROL LIMITS

C - CHANGED DETECTION LIMIT
FLOW RELATIONSHIP CODE:

$U$ - UPGRADIENT

SAMPLE ID CODES:

0001 - FILTERED SAMPLE (.45 MICRONS) 
TABLE 3.18 GROUNDWATER OUALITY MEASUREMENTS EXCEEDING MAXIMUM CONCENTRATION LIMITS IN NAVAJO SANSTONE BACKGROUND GROUNDWATER, NC \& UC PROCESSING SITES SITE: SRKO1 SLICK ROCK (BOTH SITES)

06/30/86 TO $10 / 12 / 92$

REPORT DATE: 06/17/93

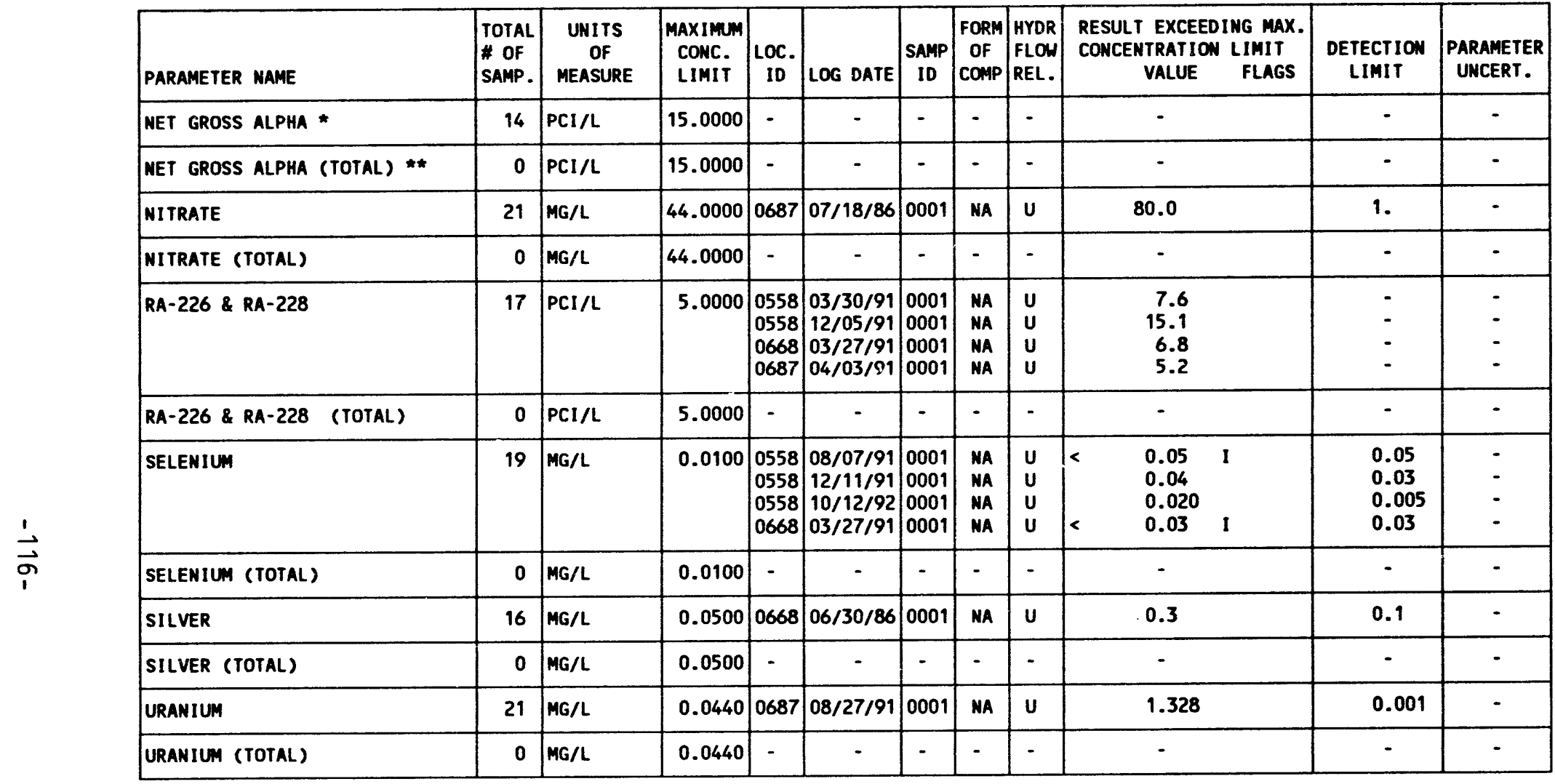

* NET GROSS ALPHA (GROSS ALPHA - URANIUM) WITH 1 MG URANIUM = 686 PCI

* * TOTAL NET GROSS ALPHA (TOTAL GROSS ALPHA - TOTAL URANIUM)

FORMATION OF COMPLETION CODE:

MA - NAVAJO SANDSTONE

OTHER PARAMETER VALUE FLAGS:

1 - INCREASED DETECTION LIMIT DUE TO REQUIRED DILUTION

DATA FILE NAME: M: IDARTISRK01\GWQ10025.DAT
FLON RELATIONSHIP COOE:

U - UPGRADIENT

SAMPLE ID CODES:

0001 - FILTERED SAMPLE (.45 MICRONS) 
TABLE 3.19 BACKGROUND GROUNDWATER QUALITY STATISTICS BY PARAMETER FOR THE NAVAJO SANDSTONE, UC PROCESSING SITE, SLICK ROCK, COLORADO

SITE: SPKOI SLICK ROCK (BOTH SITES)

$06 / 30 / 86$ TO $10 / 12 / 92$

REPORT DATE: $07 / 26 / 93$

\begin{tabular}{|c|c|c|c|c|c|c|c|c|c|c|c|c|}
\hline \multicolumn{3}{|c|}{ PARAMETER NAME } & UNITS & \multirow[b]{2}{*}{ MEAN } & \multirow{2}{*}{$\begin{array}{r}\text { STANDARD } \\
\text { DEVIATION }\end{array}$} & \multirow{2}{*}{$\begin{array}{c}\text { COEFF. } \\
\text { OF } \\
\text { VARIATION }\end{array}$} & \multirow{2}{*}{$\begin{array}{c}\% \text { OF } \\
\text { NON } \\
\text { DETECTS }\end{array}$} & \multirow{2}{*}{\multicolumn{3}{|c|}{$\begin{array}{c}\text { STATISTICAL RANGE } \\
\text { 98\% CONFIDENCE INTERVAL } \\
\text { MINIMUM } \\
\text { MAXIMUM }\end{array}$}} & \multirow{2}{*}{$\begin{array}{c}\text { DISTRIBUTION } \\
\text { TYPE }\end{array}$} & \multirow{2}{*}{$\begin{array}{l}\text { FOOT } \\
\text { NOTE }\end{array}$} \\
\hline \# OF SAMP & MINIMUM & MAXIMUM & MEDIAN & & & & & & & & & \\
\hline \multicolumn{3}{|l|}{ ALKALINITY } & MG/L CACO3 & \multirow[b]{2}{*}{303.9167} & \multirow[b]{2}{*}{44.0133} & \multirow[b]{2}{*}{0.1448} & \multirow[b]{2}{*}{0.0} & \multirow{2}{*}{\multicolumn{2}{|c|}{269.3830}} & \multirow[b]{2}{*}{338.4504} & \multirow[b]{2}{*}{ NORMAL } & \\
\hline 12 & 251.0000 & 368.0000 & +301.0000 & & & & & & & & & \\
\hline \multicolumn{3}{|l|}{ ALUMINUM } & $M G / L$ & \multirow[b]{2}{*}{ NA } & \multirow[b]{2}{*}{ NA } & \multirow[b]{2}{*}{ NA } & \multirow[b]{2}{*}{75.0} & \multirow[b]{2}{*}{$\star \star \star$} & \multirow[b]{2}{*}{0.0500} & \multirow[b]{2}{*}{0.1000} & \multirow[b]{2}{*}{ NONPARAMETRIC } & \multirow[b]{2}{*}{2} \\
\hline 12 & $\star \star \quad 0.0500$ & 0.3000 & $\star \star \quad 0.0500$ & & & & & & & & & \\
\hline \multicolumn{3}{|l|}{ AMMONIUM } & MG/L & & & & & & & & & \\
\hline 11 & $\star * \quad 0.1000$ & 0.2000 & $\star \star \quad 0.1000$ & NA & NA & NA & 63.6 & $\star \star \star *$ & 0.1000 & 0.1000 & NONPARAMETRIC] & 2 \\
\hline \multicolumn{3}{|l|}{ ANT IMONY } & $M G / L$ & \multirow[b]{2}{*}{ NA } & \multirow[b]{2}{*}{ NA } & \multirow[b]{2}{*}{ NA } & & & & & & \\
\hline 9 & $* \quad 0.0030$ & 0.0030 & ** $\quad 0.0030$ & & & & 88.9 & ** & 0.0030 & 0.0030 & NONPARAMETRIC & 2 \\
\hline ARSENIC & & & $M G / L$ & & & & & & & & & \\
\hline 11 & $\begin{array}{ll}\star \star & 0.0050\end{array}$ & 0.0100 & 0.0050 & NA & NA & NA & 72.7 & & 0.0050 & 0.0070 & NONPARAMETRIC & 2 \\
\hline BARIUM & & & $M G / L$ & & & & & & & & & \\
\hline 10 & 0.0300 & 0.2000 & 0.1050 & 0.1100 & 0.0753 & 0.6843 & 10.0 & & 0.0428 & 0.1772 & NORMAL & \\
\hline BERYLLILM & & & $M G / L$ & & & & & & & & & \\
\hline 7 & $\star \star \quad 0.0050$ & 0.0050 & $\star \star \quad \quad 0.0050$ & NA & NA & NA & 100.0 & $\star \star \star$ & 0.0050 & 0.0050 & NONPARAMETRIC & 2 \\
\hline BORON & & & MG $/ L$ & & & & & & & & & \\
\hline 8 & 0.1000 & 0.6600 & 0.2150 & 0.2825 & 0.2108 & 0.7461 & 0.0 & & 0.0591 & 0.5059 & NORMAL & \\
\hline BROMIDE & & & $M G / L$ & & & & & & & & & \\
\hline 9 & $* \quad 0.1000$ & 0.5000 & 0.1500 & NA & NA & NA & 55.6 & $\star \star$ & 0.1000 & 0.5000 & MONPARAMETRIC & 2 \\
\hline CADMIUM & & & $M G / L$ & & & & & & & & & \\
\hline 10 & $\begin{array}{ll}* & 0.0010\end{array}$ & ** $\quad 0.0010$ & 0.0010 & NA & NA & NA & 100.0 & $\star *$ & 0.0010 & $\star \quad 0.0010$ & NONPARAMETRIC & 2 \\
\hline
\end{tabular}

* The reported value is the minimum detection limit of the data set

+ The sample size is even, so the median value is the arithmetic average of the two middle values

* The statistical maximum is the 99 percent one sided confidence interval, $a=0.01$

2) The nomparametric distribution was used because the nondetected values comprise more than 15\% of the samples. 
TABLE 3.19 BACKGROUND GROUNDWATER OUALITY STATISTICS BY PARAMETER FOR THE NAVAJO SANDSTONE, UC PROCESSING SITE, SLICK ROCK, COLORADO SITE: SRK01 SLICK ROCK (BOTH SITES)

06/30/86 TO 10/12/92

REPORT DATE : $07 / 26 / 93$

\begin{tabular}{|c|c|c|c|c|c|c|c|c|c|c|c|}
\hline \multicolumn{3}{|c|}{ PARAMETER NAME } & UNITS & \multirow[b]{2}{*}{ MEAN } & \multirow{2}{*}{$\begin{array}{r}\text { STANDARD } \\
\text { DEVIATION }\end{array}$} & \multirow{2}{*}{$\begin{array}{c}\text { COEFF. } \\
\text { OF } \\
\text { VARIATION }\end{array}$} & \multirow{2}{*}{$\begin{array}{c}\chi \text { OF } \\
\text { NON } \\
\text { DETECTS }\end{array}$} & \multirow{2}{*}{\multicolumn{2}{|c|}{$\begin{array}{c}\text { STATISTICAL RANGE } \\
\text { 98\% CONFIDENCE INTERVAL } \\
\text { MINIMUM }\end{array}$}} & \multirow{2}{*}{$\begin{array}{c}\text { DISTRIBUTION } \\
\text { TYPE }\end{array}$} & \multirow{2}{*}{$\begin{array}{l}\text { FOOT } \\
\text { NOTE }\end{array}$} \\
\hline \# OF SAMP & MINIMUM & MAXIMUM & MEDIAN & & & & & & & & \\
\hline \multicolumn{3}{|l|}{ CALCIUM } & $M G / L$ & \multirow[b]{2}{*}{42.9417} & \multirow[b]{2}{*}{18.7362} & \multirow[b]{2}{*}{0.4363} & \multirow[b]{2}{*}{0.0} & \multirow[b]{2}{*}{28.2409} & \multirow[b]{2}{*}{57.6424} & \multirow[b]{2}{*}{ NORMAL } & \\
\hline 12 & 28.1000 & 78.9000 & $+\quad 30.6500$ & & & & & & & & \\
\hline \multicolumn{3}{|l|}{ CHLORIDE } & $M G / L$ & \multirow[b]{2}{*}{25.7167} & \multirow[b]{2}{*}{21.6018} & \multirow[b]{2}{*}{0.8400} & \multirow[b]{2}{*}{0.0} & \multirow[b]{2}{*}{8.7675} & \multirow[b]{2}{*}{42.6658} & \multirow[b]{2}{*}{ NORMAL } & \\
\hline 12 & 5.1000 & 67.0000 & $+\quad 12.0500$ & & & & & & & & \\
\hline \multicolumn{3}{|l|}{ CHROMIUM } & $M G / L$ & \multirow[b]{2}{*}{ NA } & \multirow[b]{2}{*}{ NA } & \multirow[b]{2}{*}{ NA } & \multirow[b]{2}{*}{100.0} & \multirow[b]{2}{*}{0.0100} & \multirow[b]{2}{*}{$\star * 0.0100$} & & \\
\hline 10 & 0.0100 & 0.0100 & $\star * \quad 0.0100$ & & & & & & & NONPARAMETRIC & 2 \\
\hline COBALT & & & $\mathrm{MG} / \mathrm{L}$ & & & & & & & & \\
\hline 7 & $\begin{array}{ll}* * & 0.0300\end{array}$ & $\begin{array}{ll}* * & 0.0300 \\
\end{array}$ & $\star * \quad 0.0300$ & NA & NA & NA & 100.0 & 0.0300 & $\star * \quad 0.0300$ & NONPARAMETRIC & 2 \\
\hline COPPER & & & $M G / L$ & & & & & & & & \\
\hline 10 & ** $\quad 0.0100$ & 0.0100 & $\begin{array}{ll}* & 0.0100\end{array}$ & NA & NA & NA & 100.0 & 0.0100 & 0.0100 & NONPARAMETRIC & 2 \\
\hline CYANIDE & & & $M G / L$ & & & & & & & & \\
\hline 7 & $\star \star \quad 0.0100$ & \begin{tabular}{ll|}
$*$ & 0.0100 \\
\end{tabular} & $\begin{array}{ll}* * & 0.0100\end{array}$ & NA & NA & NA & 100.0 & ** $\quad 0.0100$ & $\star * 0.0100$ & NONPARAMETRIC & 2 \\
\hline DISSOLVED & OXYGEN & & $M G / L$ & & & & & & & & \\
\hline 1 & 0.3000 & 0.3000 & 0.3000 & NA & NA & MA & 0.0 & NA & NA & UNKNOWN & 1 \\
\hline FIELD FE ( & $(2+)$ & & $M G / L$ & & & & & & & & \\
\hline 1 & 0.0600 & 0.0600 & 0.0600 & NA & NA & NA & 0.0 & MA & MA & UNKNONM & 1 \\
\hline FIELD FE ( & (TOTAL) & & $M G / L$ & & & & & & & & \\
\hline 1 & 0.0700 & 0.0700 & 0.0700 & NA & NA & NA & 0.0 & MA & NA & UNKNOWN & 1 \\
\hline FLUORIDE & & & $M G / L$ & & & & & & & & \\
\hline 11 & 0.5000 & 0.8000 & 0.7000 & 0.6673 & 0.0836 & 0.1252 & 0.0 & 0.5976 & 0.7369 & NORMAL & \\
\hline
\end{tabular}

* The reported value is the minimum detection limit of the data set

+ The sample size is even, so the median value is the arithmetic average of the two middle values

* The statistical maximm is the 99 percent one sided confidence interval, $a=0.01$

1) A minimu of 4 samples must be available for the statistical analysis.

2) The nonparametric distribution was used because the nondetected values comprise more than $15 \%$ of the samples. 
TABLE 3.19 BACKGROUND GROUNDWATER QUALITY STATISTICS BY PARAMETER FOR THE NAVAJO SANDSTONE, UC PROCESSING SITE, SLICK ROCK, COLORADO

SITE: SRKO1 SLICK ROCK (BOTH SITES)

$06 / 30 / 86$ TO $10 / 12 / 92$

REPORT DATE: 07/26/93

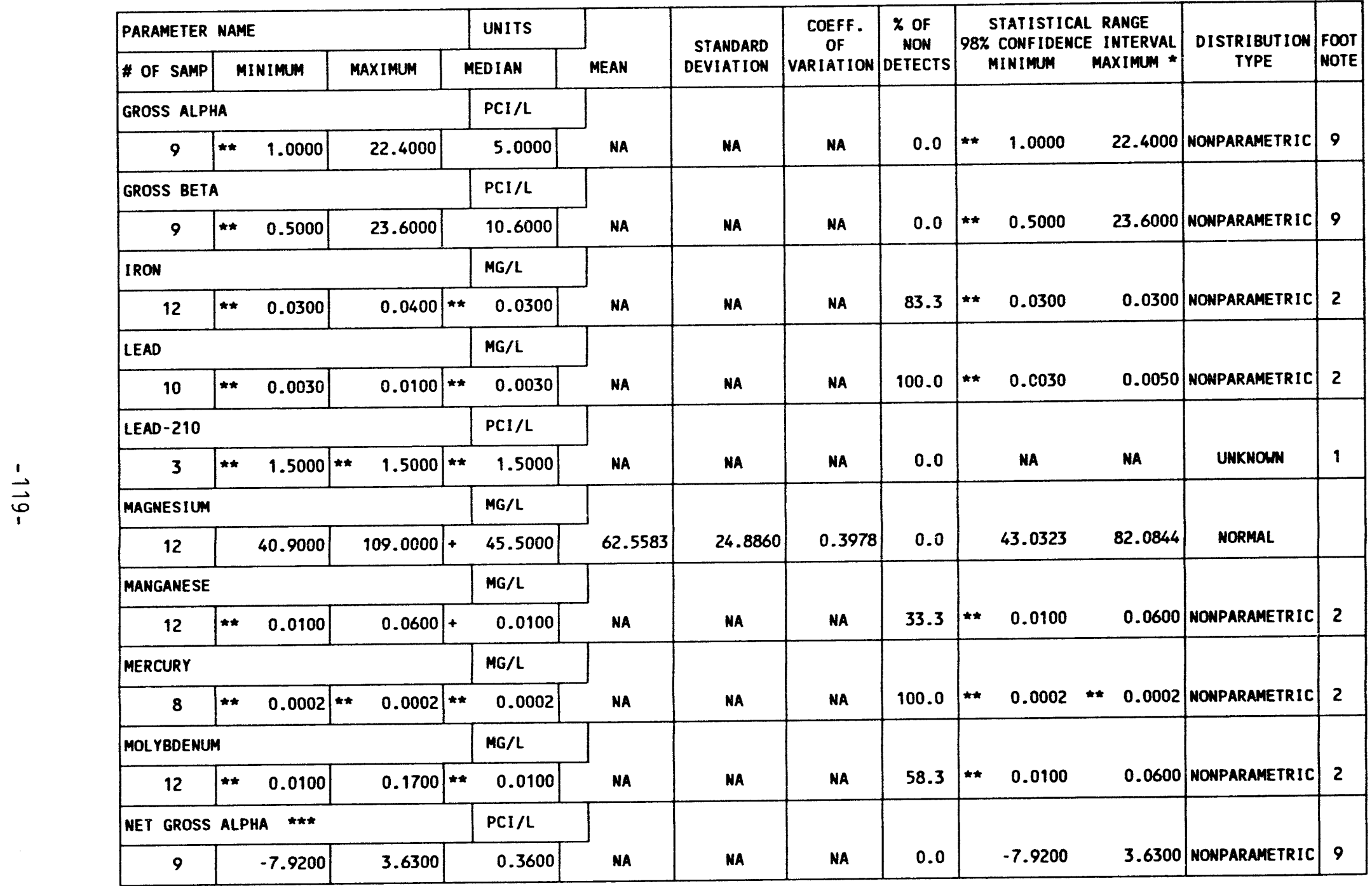

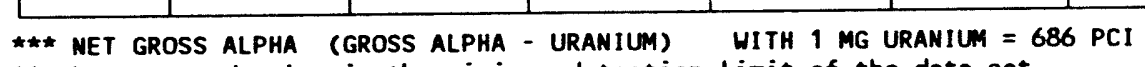

* The reported value is the minimum detection limit of the data set

+ The sample size is even, so the median value is the arithmetic average of the two middle values

- The statistical maximm is the 99 percent one sided confidence interval, $a=0.01$

1) A minimum of 4 samples must be available for the statistical analysis.

2) A me nonparametric distribution us used because the nondetected values comprise more than $15 \%$ of the samples.

9) The nonparametic distribution was used because the data failed the normal distribution test and includes values $\leq 0$. 
TABLE 3.19 BACKGROUND GROUNDHATER QUALITY STATISTICS BY PARAMETER SITE: SRKO1 SLICK ROCK (BOTH SITES)

SITE: SRKO1 SLICK ROC

REPORT DATE: $07 / 26 / 93$

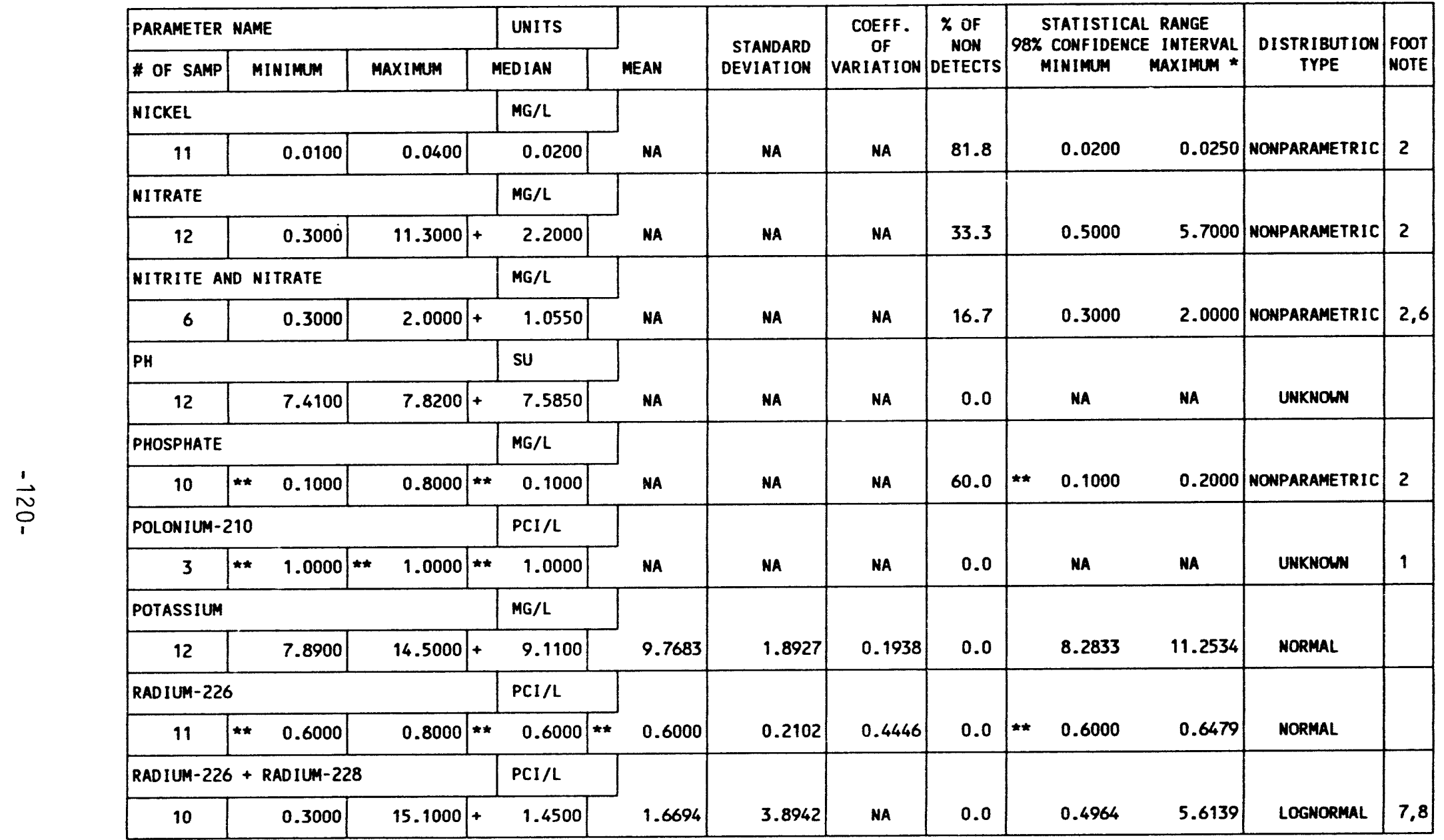

** The reported value is the minimum detection limit of the data set

+ The sample size is even, so the median value is the arithmetic average of the two middle values

* The stitistical maximem is the 99 percent one sided confidence interval, $a=0.01$

1) A minimum of 4 samples must be available for the statistical analysis.

2) The nonparametric distribution was used because the nondetected values comprise more than $15 \%$ of the samples.

6) The stat. range is the $96.9 \%$ confidence interval due to a sample size of 6 . The maximu is the $98.5 \%$ one sided confidence int.

7) The lognormal distribution was used because the data failed the normal distribution test.

8) The mean is geometric. The standard deviation is the value to divide or multiply with the geometric mean. 
TABLE 3.19 BACKGROUND GROUNDWATER OUALITY STATISTICS BY PARAMETER FOR THE NAVAJO SAMDSTONE, UC PROCESSING SITE, SLICK ROCK, COLORADO SITE: SRKO1 SLICK ROCK (BOTH SITES)

$06 / 30 / 86$ TO $10 / 12 / 92$

REPORT DATE : $07 / 26 / 93$

\begin{tabular}{|c|c|c|c|c|c|c|c|c|c|c|c|}
\hline \multicolumn{3}{|c|}{ PARAMETER NAME } & UNITS & \multirow[b]{2}{*}{ MEAN } & \multirow{2}{*}{$\begin{array}{l}\text { STANDARD } \\
\text { DEVIATION }\end{array}$} & \multirow{2}{*}{$\begin{array}{c}\text { COEFF. } \\
\text { OF } \\
\text { VARIATION }\end{array}$} & \multirow{2}{*}{$\begin{array}{l}X \text { OF } \\
\text { NON } \\
\text { DETECTS }\end{array}$} & \multirow{2}{*}{\multicolumn{2}{|c|}{$\begin{array}{c}\text { STATISTICAL RANGE } \\
\text { 98\% CONFIDEN CE INTERVAL } \\
\text { MINIMUM MAXIMUM * }\end{array}$}} & \multirow{2}{*}{$\begin{array}{c}\text { DISTRIBUTION } \\
\text { TYPE }\end{array}$} & \multirow{2}{*}{$\begin{array}{l}\text { FOOT } \\
\text { NOTE }\end{array}$} \\
\hline \# OF SAMP & MINIMUM & MAXIMUN & MEDIAN & & & & & & & & \\
\hline \multicolumn{3}{|l|}{ RADIUM-228 } & $\mathrm{PCI} / \mathrm{L}$ & \multirow[b]{2}{*}{ NA } & \multirow[b]{2}{*}{ NA } & \multirow[b]{2}{*}{ HA } & \multirow[b]{2}{*}{0.0} & \multirow[b]{2}{*}{$\approx \quad 1.0000$} & \multirow[b]{2}{*}{7.4000} & \multirow[b]{2}{*}{ NONPARAMETRIC } & \multirow[b]{2}{*}{9} \\
\hline 10 & 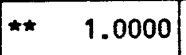 & 14.6000 & 1.0000 & & & & & & & & \\
\hline \multicolumn{3}{|c|}{ REDOX POTENTIAL } & mVOLTS & \multirow[b]{2}{*}{403.0250} & \multirow[b]{2}{*}{28.7943} & \multirow[b]{2}{*}{0.0714} & \multirow[b]{2}{*}{0.0} & \multirow[b]{2}{*}{337.6476} & \multirow[b]{2}{*}{468.4024} & \multirow[b]{2}{*}{ MORMAL } & \\
\hline 4 & 362.8000 & 427.8000 & +410.7500 & & & & & & & & \\
\hline \multicolumn{3}{|l|}{ SELENIUN } & $M G / L$ & \multirow[b]{2}{*}{ NA } & \multirow[b]{2}{*}{ NA } & \multirow[b]{2}{*}{ NA } & \multirow[b]{2}{*}{72.7} & \multirow[b]{2}{*}{0.0050} & \multirow[b]{2}{*}{0.0250} & & \\
\hline 11 & $\begin{array}{ll}* * & 0.0050\end{array}$ & 0.0400 & 0.0050 & & & & & & & MONPARAMETRIC & 2 \\
\hline SILICA - S & 5102 & & $M G / L$ & & & & & & & & \\
\hline 11 & 6.7000 & 14.8000 & 11.6000 & 10.8364 & 3.3661 & 0.3106 & 0.0 & 8.0311 & 13.6416 & MORMRL & \\
\hline SILVER & & & $M G / L$ & & & & & & & & \\
\hline 9 & 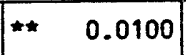 & 0.3000 & $\star \star \quad 0.0100$ & NA & NA & NA & 88.9 & 0.0100 & 0.3000 & MOMPARAMETRIC & 2 \\
\hline soolum & & & $M G / L$ & & & & & & & & \\
\hline 12 & 9.0000 & 131.0000 & $+\quad 13.0500$ & 24.2174 & 2.8671 & NA & 0.0 & 10.5976 & 55.3409 & LOGMORMAL & 7,8 \\
\hline SPECIFIC $C$ & CONDUCTANCE & & UМно/CM & & & & & & & & \\
\hline 10 & 300.0000 & 1420.0000 & +525.5000 & 722.8000 & 418.4564 & 0.5789 & 0.0 & 349.5041 & 1096.0959 & NORMAL & \\
\hline STRONTIUM & & & $M G / L$ & & & & & & & & \\
\hline 9 & 0.8900 & 1.2900 & 0.9100 & 1.0133 & 0.1686 & 0.1664 & 0.0 & 0.8506 & 1.1761 & NORMAL & \\
\hline SULFATE & & & $M G / L$ & & & & & & & & \\
\hline 12 & 11.0000 & 432.0000 & 15.9000 & 44.8531 & 4.5205 & NA & 0.0 & 13.7316 & 146.5086 & LOGNORMAL & 7,8 \\
\hline
\end{tabular}

** The reported value is the minimum detection limit of the data set

+ The sample size is even, so the median value is the arithmetic average of the two middle values

* The statistical maximm is the 99 percent one sided confidence interval, $a=0.01$

2) The statistical maximum is the

2) The nonparametric distribution was used because the nondetected values comprise more than

7) The lognormal distribution was used because the data failed the norist distribution test.

8) The mean is geometric. The standard deviation is the value to divide or multiply with the geonetric mean.

9) The nonparametic distribution was used because the data failed the normal distribution test and includes values $\leq 0$. 
TABLE 3.19 BACKGROUND GROUNDWATER QUALITY STATISTICS BY PARAMETER FOR THE NAVAJO SANDSTONE, UC PROCESSING SITE, SLICK ROCK, COLORADO

SITE: SRKO1 SLICK ROCK (BOTH SITES)

$06 / 30 / 86$ TO $10 / 12 / 92$

REPORT DATE: $07 / 26 / 93$

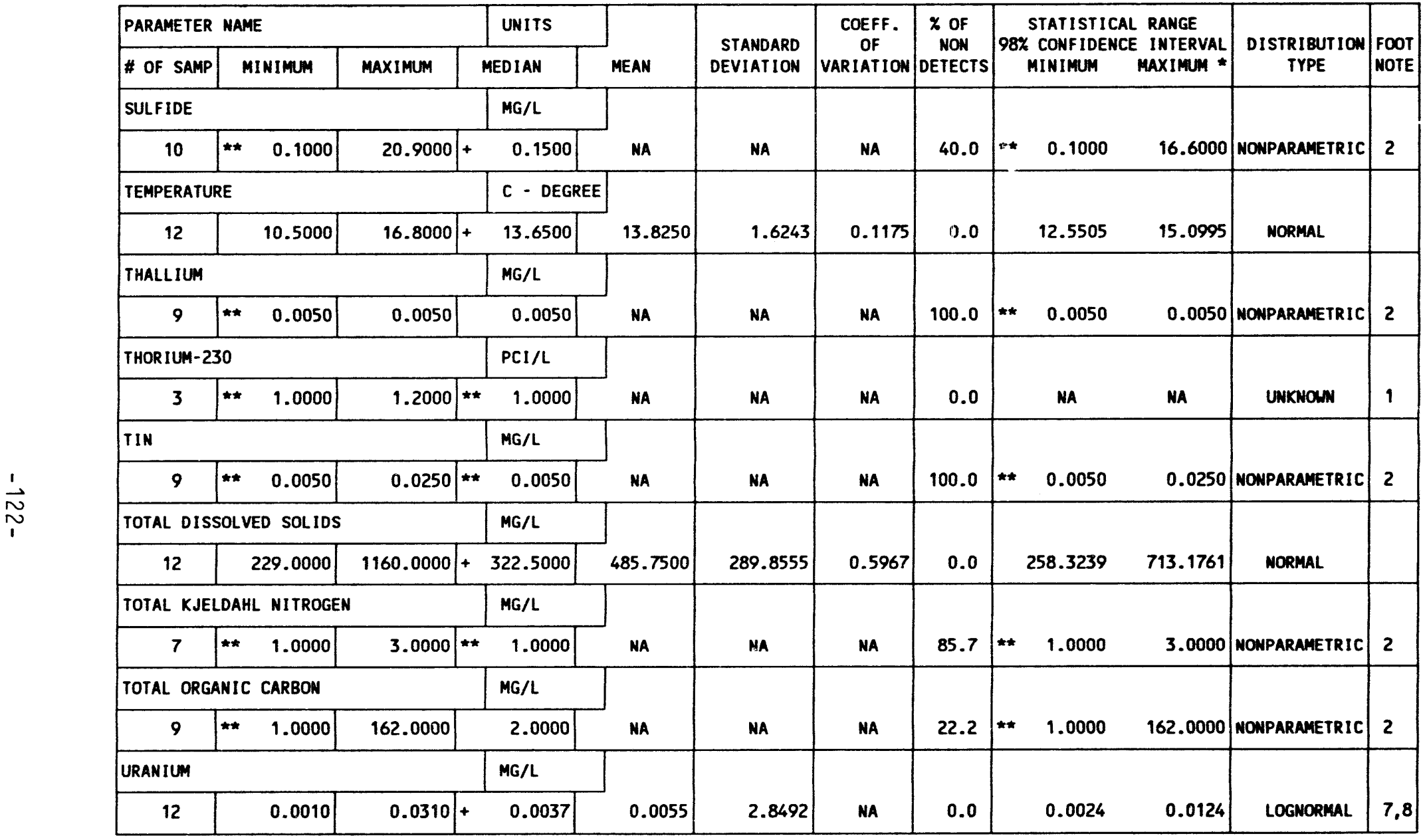

** The reported value is the minimum detection limit of the data set

+ The sample size is even, so the median value is the arithmetic average of the two middle values

* The statistical maximum is the 99 percent one sided confidence interval, $\alpha=0.01$

1) A minimum of 4 samples must be available for the statistical analysis.

2) The nomparametric distribution was used because the nondetected values comprise more than $15 \%$ of the samples.

7) The lognormal distribution was used because the data failed the normal distribution test.

8) The mean is geometric. The standard deviation is the value to divide or multiply with the geometric mean. 
TABLE 3.19 BACKGROUND GROUWDWATER OUALITY STATISTICS BY PARAMETER TERTE, UC PROCESSING SITE, SLICK ROCK, COLORADO

SITE: SRKOI SLICK ROCK CBOTH SITE

$06 / 30 / 86$ TO $10 / 12 / 92$

REPORT DATE : $07 / 26 / 93$

\begin{tabular}{|c|c|c|c|c|c|c|c|c|c|c|c|c|c|}
\hline \multicolumn{3}{|c|}{ PARAMETER HAME } & \multirow{2}{*}{$\frac{\text { UNITS }}{\text { MEDIAN }}$} & \multirow[b]{2}{*}{ MEAN } & \multirow{2}{*}{$\begin{array}{r}\text { STANDARD } \\
\text { DEVIATION }\end{array}$} & \multirow{2}{*}{$\begin{array}{c}\text { COEFF. } \\
\text { OF } \\
\text { VARIATION }\end{array}$} & \multirow{2}{*}{$\begin{array}{c}x \text { OF } \\
\text { NON } \\
\text { OETECTS }\end{array}$} & \multirow{2}{*}{\multicolumn{4}{|c|}{$\begin{array}{l}\text { STATISTICAL RANGE } \\
\text { 98\% CONFIDENCE INTERVAL } \\
\text { MINIMUM MAXIMM }\end{array}$}} & \multirow{2}{*}{$\begin{array}{c}\text { DISTRIBUTION } \\
\text { TYPE }\end{array}$} & \multirow{2}{*}{$\begin{array}{l}\text { FOOT } \\
\text { MOTE }\end{array}$} \\
\hline \# OF SAMP & MINIMUM & Maximur & & & & & & & & & & & \\
\hline \multicolumn{3}{|l|}{ VANADIUM } & $M G / L$ & \multirow[b]{2}{*}{ MA } & \multirow[b]{2}{*}{ MA } & \multirow[b]{2}{*}{ NA } & \multirow[b]{2}{*}{90.9} & \multirow[b]{2}{*}{$\neq \star$} & \multirow[b]{2}{*}{0.0100} & \multirow[b]{2}{*}{$*$} & \multirow[b]{2}{*}{0.0100} & \multirow[b]{2}{*}{ MOMPARAMETRIC } & \multirow[b]{2}{*}{2} \\
\hline 11 & $\begin{array}{ll}* * & 0.0100\end{array}$ & 0.4400 & 0.0100 & & & & & & & & & & \\
\hline \multicolumn{3}{|l|}{ ZINC } & MG/L & \multirow[b]{2}{*}{ NA } & \multirow[b]{2}{*}{ NA } & \multirow[b]{2}{*}{ NA } & \multirow[b]{2}{*}{80.0} & \multirow[b]{2}{*}{$\star \star \star$} & \multirow[b]{2}{*}{0.0050} & \multirow{2}{*}{\multicolumn{2}{|c|}{0.0070}} & \multirow[b]{2}{*}{ NOMPARAMETRIC } & \multirow[b]{2}{*}{2} \\
\hline 10 & 0.0050 & 0.0130 & 0.0050 & & & & & & & & & & \\
\hline
\end{tabular}

* The reported value is the minimum detection limit of the data set

* The statistical maximm is the 99 percent one sided confidence interval, $a=0.01$

2) The nomparametric distribution un used because the nondetected values comprise more than $15 \%$ of the samples.

INPUT DATA FILENAME: M: IDARTISRK01 \GWO10032.DAT 
Table 3.20 Summary of regulated constituents in the Navajo Sandstone background groundwater, UC processing site, Slick Rock, Colorado

\section{Constituents with MCLs ${ }^{a}$}

\begin{tabular}{llll}
\hline \multicolumn{1}{c}{ Parameter } & \multicolumn{1}{c}{ MCLs } & $\begin{array}{c}\text { Mean or } \\
\text { Median }\end{array}$ & $\begin{array}{c}\text { Statistical } \\
\text { maximum }\end{array}$ \\
\hline Arsenic & 0.05 & $0.01^{\mathrm{c}}$ & $0.01^{\mathrm{c}}$ \\
Barium & 1.00 & $0.11^{\mathrm{d}}$ & 0.18 \\
Cadmium & 0.01 & $0.001^{\mathrm{c}}$ & $0.001^{\mathrm{c}}$ \\
Chromium & 0.05 & $0.01^{\mathrm{c}}$ & $0.01^{\mathrm{c}}$ \\
Net gross alphab & 15.0 & 0.36 & 3.63 \\
Lead & 0.05 & $0.01^{\mathrm{e}}$ & $0.01^{\mathrm{c}}$ \\
Mercury & 0.002 & $0.0002^{\mathrm{c}}$ & $0.0002^{\mathrm{c}}$ \\
Molybdenum & 0.10 & $0.01^{\mathrm{c}}$ & 0.06 \\
Nitrate & 44.0 & 2.20 & 5.70 \\
Radium-226 and $-228^{\mathrm{b}}$ & 5.00 & $1.67^{\mathrm{c}}$ & 5.61 \\
Selenium & 0.01 & $0.005^{\mathrm{c}}$ & 0.025 \\
Silver & 0.05 & $0.01^{\mathrm{c}}$ & 0.30 \\
Uranium & 0.044 & $0.006^{\mathrm{d}}$ & 0.012 \\
\hline
\end{tabular}


Table 3.20 Summary of regulated constituents in the Navajo Sandstone background groundwater, UC processing site, Slick Rock, Colorado (concluded)

\section{Constituents without MCLsa}

\begin{tabular}{llc}
\hline \multicolumn{1}{c}{ Parameter } & $\begin{array}{c}\text { Mean or } \\
\text { Median }\end{array}$ & $\begin{array}{c}\text { Statistical } \\
\text { maximum }\end{array}$ \\
\hline Antimony & $0.003^{\mathrm{e}}$ & $0.003^{\mathrm{c}}$ \\
Beryllium & $0.01^{\mathrm{e}}$ & $0.01^{\mathrm{e}}$ \\
Cobalt & $0.05^{\mathrm{e}}$ & $0.05^{\mathrm{e}}$ \\
Copper & $0.02^{\mathrm{c}}$ & $0.02^{\mathrm{e}}$ \\
Cyanide & $0.01^{\mathrm{e}}$ & $0.01^{\mathrm{c}}$ \\
Nickel & $0.04^{\mathrm{e}}$ & $0.04^{\mathrm{e}}$ \\
Sulfide & 0.15 & 16.6 \\
Thallium & $0.01^{\mathrm{e}}$ & $0.01^{\mathrm{c}}$ \\
Tin & $0.005^{\mathrm{c}}$ & 0.025 \\
Vanadium & $0.01^{\mathrm{e}}$ & $0.01^{\mathrm{c}}$ \\
Zinc & $0.005^{\mathrm{e}}$ & 0.007 \\
\hline
\end{tabular}

"All units are $\mathrm{mg} / \mathrm{l}$ unless otherwise noted.

bunits are pCi/l.

'Mean value, Lognormal distribution, mean is geometric.

Mean value, Normal distribution, mean is arithmetic.

'Statistical values are below laboratory detection limits in

Table 8.1 of the Technical Approach Document (DOE, 1989). 
TABLE 3.21 TAILINGS PORE FLUID MATER OUALITY DATA BY PARAMETER, MC AMD UC PROCESSING SITES, SLICK ROCK, COLORADO

SITE: SRKO1 SLICK ROCK (BOTH SITES)

11/12/89 TO $10 / 14192$

REPORT DATE: $06 / 17 / 93$

\begin{tabular}{|c|c|c|c|c|c|c|c|c|c|c|c|}
\hline PARAMETER NAME & $\underset{\text { ID }}{\text { LOCATION }}$ & LOG DATE & $\begin{array}{c}\text { SAMPLE } \\
\text { ID }\end{array}$ & $\begin{array}{l}\text { MAT. } \\
\text { SAMP }\end{array}$ & $\begin{array}{l}\text { FLOW } \\
\text { REL. }\end{array}$ & $\begin{array}{l}\text { UNITS OF } \\
\text { MEASURE }\end{array}$ & PVI & $\begin{array}{l}\text { ARAMETER } \\
\text { VALUE }\end{array}$ & FLAGS & $\begin{array}{l}\text { DETECTION } \\
\text { LIMIT }\end{array}$ & $\begin{array}{c}\text { PARAMETER } \\
\text { UNCERTAINTY }\end{array}$ \\
\hline ALKALINITY & $\begin{array}{l}0202 \\
0203 \\
0203 \\
0203 \\
0204 \\
0204 \\
0205 \\
0206 \\
0206 \\
0514 \\
0515 \\
0515 \\
0515\end{array}$ & $\begin{array}{l}12 / 11 / 91 \\
12 / 12 / 90 \\
04 / 17 / 91 \\
12 / 11 / 91 \\
08 / 07 / 91 \\
12 / 11 / 91 \\
12 / 11 / 91 \\
12 / 12 / 90 \\
08 / 07 / 91 \\
01 / 12 / 89 \\
01 / 12 / 89 \\
04 / 17 / 91 \\
12 / 09 / 91\end{array}$ & $\begin{array}{l}0001 \\
N 001 \\
0001 \\
0001 \\
0001 \\
0001 \\
0001 \\
\text { M001 } \\
0001 \\
0001 \\
0001 \\
0001 \\
0001\end{array}$ & $\begin{array}{l}A L \\
A L \\
A L \\
A L \\
A L \\
A L \\
A L \\
A L \\
A L \\
T A \\
T A \\
T A \\
T A\end{array}$ & $\begin{array}{l}N \\
N \\
N \\
N \\
N \\
N \\
N \\
N \\
N \\
0 \\
0 \\
0 \\
0\end{array}$ & $\mathrm{MG} / \mathrm{L} \mathrm{CACO} 3$ & & $\begin{array}{c}312 \\
441 . \\
390 . \\
449 \\
43 \\
42 \\
681 \\
316 . \\
269 \\
80 . \\
60 . \\
44 . \\
11\end{array}$ & & $\begin{array}{l}- \\
- \\
- \\
- \\
- \\
- \\
- \\
- \\
-\end{array}$ & $\begin{array}{l}- \\
- \\
- \\
- \\
- \\
- \\
- \\
- \\
-\end{array}$ \\
\hline ALUMINUM & $\begin{array}{l}0202 \\
0202 \\
0202 \\
0203 \\
0203 \\
0203 \\
0203 \\
0204 \\
0204 \\
0204 \\
0204 \\
0205 \\
0205 \\
0205 \\
0206 \\
0206 \\
0206 \\
0207 \\
0207 \\
0514 \\
0515 \\
0515 \\
0515\end{array}$ & $\begin{array}{l}04 / 17 / 91 \\
12 / 11 / 91 \\
10 / 14 / 92 \\
04 / 17 / 91 \\
08 / 07 / 91 \\
12 / 11 / 91 \\
10 / 14 / 92 \\
04 / 17 / 91 \\
08 / 07 / 91 \\
12 / 11 / 91 \\
10 / 14 / 92 \\
04 / 17 / 91 \\
12 / 11 / 91 \\
10 / 14 / 92 \\
04 / 17 / 91 \\
08 / 07 / 91 \\
10 / 14 / 92 \\
08 / 07 / 91 \\
10 / 14 / 92 \\
01 / 12 / 89 \\
01 / 12 / 89 \\
04 / 17 / 91 \\
08 / 07 / 91\end{array}$ & $\begin{array}{l}0001 \\
0001 \\
0001 \\
0001 \\
0001 \\
0001 \\
0001 \\
0001 \\
0001 \\
0001 \\
0001 \\
0001 \\
0001 \\
0001 \\
0001 \\
0001 \\
0001 \\
0001 \\
0001 \\
0001 \\
0001 \\
0001 \\
0001\end{array}$ & $\begin{array}{l}A L \\
A L \\
A L \\
A L \\
A L \\
A L \\
A L \\
A L \\
A L \\
A L \\
A L \\
A L \\
A L \\
A L \\
A L \\
A L \\
A L \\
A L \\
A L \\
T A \\
T A \\
T A \\
T A\end{array}$ & $\begin{array}{l}N \\
N \\
N \\
N \\
N \\
N \\
N \\
N \\
N \\
N \\
N \\
N \\
N \\
N \\
N \\
N \\
N \\
N \\
0 \\
0 \\
0 \\
0\end{array}$ & $M G / L$ & $\begin{array}{l}< \\
\\
\\
< \\
< \\
< \\
< \\
< \\
< \\
< \\
< \\
< \\
<\end{array}$ & $\begin{array}{l}0.06 \\
0.05 \\
0.05 \\
0.10 \\
0.10 \\
0.11 \\
0.09 \\
0.09 \\
0.12 \\
0.15 \\
0.37 \\
0.2 \\
0.21 \\
0.2 \\
0.05 \\
0.05 \\
0.05 \\
0.05 \\
0.05 \\
0.1 \\
0.1 \\
0.06 \\
0.05\end{array}$ & $\begin{array}{l}1 \\
1\end{array}$ & $\begin{array}{l}0.05 \\
0.05 \\
0.05 \\
0.05 \\
0.05 \\
0.05 \\
0.05 \\
0.05 \\
0.05 \\
0.05 \\
0.05 \\
0.2 \\
0.05 \\
0.2 \\
0.05 \\
0.05 \\
0.05 \\
0.05 \\
0.05 \\
0.1 \\
0.1 \\
0.05 \\
0.05\end{array}$ & $\begin{array}{l}- \\
- \\
- \\
- \\
- \\
- \\
- \\
- \\
- \\
- \\
- \\
- \\
- \\
- \\
- \\
- \\
-\end{array}$ \\
\hline ALLMINUM (TOTAL) & 0203 & $12 / 12 / 90$ & N001 & AL & N & $M G / L$ & $<$ & 0.1 & & 0.1 & - \\
\hline
\end{tabular}

MATERIAL OF SAMPLING CODE:

AL - ALLUVIUM

TA - URAMIUM MILL TAILIMGS

PARAMETER VALUE INDICATOR (PVI): < - LESS thaN DETECTION LIMIT

OTHER PARAMETER VALUE FLAGS:

I - INCREASED DETECTION LIMIT DUE TO REQUIRED DILUTION
FLOW RELATIONSHIP COOE:

N - UNKNOWN
0 - ON-SITE

SAMPLE ID COOES:

0001 - FILTERED SAMPLE (.45 MICRONS)

N001 - UNFILTERED SAMPLE 
TABLE 3.21 TAILINGS PORE FLUID MATER QUALITY DATA BY PARAMETER, HC AND UC PROCESSING SITES, SLICK ROCK, COLORADO

SITE: SRKO1 SLICK ROCK (BOTH SITES)

01/12/89 TO $10 / 14 / 92$

REPORT DATE: $06 / 17 / 93$

\begin{tabular}{|c|c|c|c|c|c|c|c|c|c|c|c|}
\hline PARAMETER NAME & $\underset{10}{\text { LOCATION }}$ & LOG DATE & $\begin{array}{c}\text { SAMPLE } \\
\text { ID }\end{array}$ & $\begin{array}{l}\text { MAT. } \\
\text { SAMP }\end{array}$ & FLOW & $\begin{array}{l}\text { UNITS OF } \\
\text { MEASURE }\end{array}$ & PVI & $\begin{array}{l}\text { PARAMETER } \\
\text { VALUE }\end{array}$ & FLAGS & $\begin{array}{l}\text { DETECTION } \\
\text { LIMIT }\end{array}$ & \begin{tabular}{|} 
PARAMETER \\
UWCERTAINTY
\end{tabular} \\
\hline ALUMINUM (TOTAL) & $\begin{array}{l}0204 \\
0206 \\
0207 \\
0208 \\
0210 \\
0515\end{array}$ & $\begin{array}{l}12 / 12 / 90 \\
12 / 12 / 90 \\
12 / 12 / 90 \\
10 / 14 / 92 \\
12 / 12 / 90 \\
10 / 14 / 92\end{array}$ & $\begin{array}{l}\text { NO01 } \\
\text { NO01 } \\
\text { NO01 } \\
\text { NO01 } \\
\text { NO01 } \\
\text { N001 }\end{array}$ & $\begin{array}{l}A L \\
A L \\
A L \\
M R \\
A L \\
T A\end{array}$ & $\begin{array}{l}N \\
N \\
N \\
N \\
N \\
0\end{array}$ & $M G / L$ & $\mid \begin{array}{l}< \\
< \\
<\end{array}$ & $\begin{array}{l}0.1 \\
0.1 \\
0.1 \\
0.05 \\
0.1 \\
0.13\end{array}$ & & $\begin{array}{l}0.1 \\
0.1 \\
0.1 \\
0.05 \\
0.1 \\
0.05\end{array}$ & $\begin{array}{l}- \\
- \\
- \\
- \\
-\end{array}$ \\
\hline AMMONIUM & $\begin{array}{l}0206 \\
0514 \\
0515\end{array}$ & $\begin{array}{l}08 / 07 / 91 \\
01 / 12 / 89 \\
01 / 12 / 89\end{array}$ & $\begin{array}{l}0001 \\
0001 \\
0001\end{array}$ & $\begin{array}{l}\text { AL } \\
\text { TA } \\
\text { TA }\end{array}$ & $\begin{array}{l}N \\
0 \\
0\end{array}$ & $M G / L$ & & $\begin{array}{l}0.2 \\
4.3 \\
1.6\end{array}$ & & $\begin{array}{l}0.1 \\
0.1 \\
0.1\end{array}$ & - \\
\hline ANTIMONY & $\begin{array}{l}0202 \\
0202 \\
0202 \\
0203 \\
0203 \\
0203 \\
0203 \\
0204 \\
0204 \\
0204 \\
0204 \\
0205 \\
0205 \\
0205 \\
0206 \\
0206 \\
0206 \\
0207 \\
0207 \\
0514 \\
0515 \\
0515 \\
0515\end{array}$ & $\begin{array}{l}04 / 17 / 91 \\
12 / 11 / 91 \\
10 / 14 / 92 \\
04 / 17 / 91 \\
08 / 07 / 91 \\
12 / 11 / 91 \\
10 / 14 / 92 \\
04 / 17 / 91 \\
08 / 07 / 91 \\
12 / 11 / 91 \\
10 / 14 / 92 \\
04 / 17 / 91 \\
12 / 11 / 91 \\
10 / 14 / 92 \\
04 / 17 / 91 \\
08 / 07 / 91 \\
10 / 14 / 92 \\
08 / 07 / 91 \\
10 / 14 / 92 \\
01 / 12 / 89 \\
01 / 12 / 89 \\
04 / 17 / 91 \\
08 / 07 / 91\end{array}$ & $\begin{array}{l}0001 \\
0001 \\
0001 \\
0001 \\
0001 \\
0001 \\
0001 \\
0001 \\
0001 \\
0001 \\
0001 \\
0001 \\
0001 \\
0001 \\
0001 \\
0001 \\
0001 \\
0001 \\
0001 \\
0001 \\
0001 \\
0001 \\
0001\end{array}$ & $\begin{array}{l}A L \\
A L \\
A L \\
A L \\
A L \\
A L \\
A L \\
A L \\
A L \\
A L \\
A L \\
A L \\
A L \\
A L \\
A L \\
A L \\
A L \\
A L \\
A L \\
T A \\
T A \\
T A \\
T A\end{array}$ & $\begin{array}{l}N \\
N \\
N \\
N \\
N \\
N \\
N \\
N \\
N \\
N \\
N \\
N \\
N \\
N \\
N \\
N \\
N \\
N \\
0 \\
0 \\
0 \\
0\end{array}$ & $M G / L$ & $\begin{array}{l}< \\
< \\
< \\
< \\
< \\
< \\
< \\
< \\
< \\
< \\
< \\
< \\
< \\
< \\
< \\
< \\
< \\
<\end{array}$ & $\begin{array}{l}0.030 \\
0.03 \\
0.01 \\
0.02 \\
0.03 \\
0.03 \\
0.02 \\
0.003 \\
0.015 \\
0.03 \\
0.003 \\
0.03 \\
0.2 \\
0.02 \\
0.036 \\
0.015 . \\
0.004 \\
0.015 \\
0.02 \\
0.003 \\
0.005 \\
0.018 \\
0.015\end{array}$ & $\begin{array}{l}1 \\
1 \\
1 \\
1 \\
1 \\
1 \\
1 \\
1 \\
1 \\
1 \\
1 \\
1 \\
1 \\
1\end{array}$ & $\begin{array}{l}0.01 \\
0.03 \\
0.01 \\
0.02 \\
0.03 \\
0.03 \\
0.02 \\
0.003 \\
0.015 \\
0.03 \\
0.003 \\
0.03 \\
0.2 \\
0.02 \\
0.003 \\
0.015 \\
0.003 \\
0.015 \\
0.02 \\
0.003 \\
0.003 \\
0.003 \\
0.015\end{array}$ & $\begin{array}{l}- \\
- \\
- \\
- \\
- \\
- \\
- \\
- \\
- \\
- \\
- \\
- \\
- \\
- \\
- \\
- \\
- \\
-\end{array}$ \\
\hline ANTIMONY (TOTAL) & $\begin{array}{l}0203 \\
0204 \\
0206\end{array}$ & $\begin{array}{l}12 / 12 / 90 \\
12 / 12 / 90 \\
12 / 12 / 90\end{array}$ & $\begin{array}{l}\text { NO01 } \\
\text { No01 } \\
\text { N001 }\end{array}$ & $\begin{array}{l}A L \\
A L \\
A L\end{array}$ & $\begin{array}{l}N \\
N \\
N\end{array}$ & $M G / L$ & $<$ & $\begin{array}{l}0.003 \\
0.003 \\
0.003\end{array}$ & & $\begin{array}{l}0.003 \\
0.003 \\
0.003\end{array}$ & : \\
\hline
\end{tabular}

MATERIAL OF SAMPLING COOE:

AL - ALLUVIUM

NR - NO RECOVERY OF DATA FOR CLASSIFYING

TA - URANIUM MILL TAILINGS

PARAMETER VALUE INDICATOR (PVI): < - LESS THAN DETECTION LIMIT

OTHER PARAMETER VALUE FLAGS:

I - INCREASED DETECTION LIMIT DUE TO REQUIRED DILUTION
FLON RELATIONSHIP COOE:

N - UNKNOWN
O - ON-SITE

SAMPLE ID COOES:

0001 - FILTERED SAMPLE (.45 MICRONS)

NO01 - UNFILTERED SAMPLE 
TABLE 3.21 TAILINGS PORE FLUID WATER QUALITY DATA BY PARAMETER, NC AND UC PROCESSING SITES, SLICK ROCK, COLORADO

SITE: SRKO1 SLICK ROCK (BOTH SITES)

01/12/89 TO $10 / 14 / 92$

REPORT DATE: $06 / 17 / 93$

\begin{tabular}{|c|c|c|c|c|c|c|c|c|c|c|c|}
\hline PARAMETER MAME & $\underset{\text { ID }}{\text { LOCATION }}$ & LOG DATE & $\begin{array}{c}\text { SAMPLE } \\
\text { ID }\end{array}$ & $\begin{array}{l}\text { MAT. } \\
\text { SAMP }\end{array}$ & $\begin{array}{l}\text { FLOW } \\
\text { REL. }\end{array}$ & $\begin{array}{l}\text { UNITS OF } \\
\text { MEASURE }\end{array}$ & PVI & $\begin{array}{l}\text { ARAMETER } \\
\text { VALUE }\end{array}$ & FLAGS & $\begin{array}{l}\text { DETECTION } \\
\text { LIMIT }\end{array}$ & $\begin{array}{l}\text { PARAMETER } \\
\text { UNCERTAINTY }\end{array}$ \\
\hline ANTIMONY (TOTAL) & $\begin{array}{l}0207 \\
0208 \\
0210\end{array}$ & $\begin{array}{l}12 / 12 / 90 \\
10 / 14 / 92 \\
12 / 12 / 90\end{array}$ & $\begin{array}{l}\text { NO01 } \\
\text { N001 } \\
\text { N001 }\end{array}$ & $\begin{array}{l}\text { AL } \\
\text { NR } \\
\text { AL }\end{array}$ & $\begin{array}{l}N \\
N \\
N\end{array}$ & $M G / L$ & & $\begin{array}{l}0.007 \\
0.005 \\
0.005\end{array}$ & & $\begin{array}{l}0.003 \\
0.003 \\
0.003\end{array}$ & $\dot{-}$ \\
\hline ARSENIC & $\begin{array}{l}0202 \\
0202 \\
0202 \\
0203 \\
0203 \\
0203 \\
0203 \\
0204 \\
0204 \\
0204 \\
0204 \\
0205 \\
0205 \\
0205 \\
0206 \\
0206 \\
0206 \\
0207 \\
0207 \\
0514 \\
0515 \\
0515 \\
0515\end{array}$ & $\begin{array}{l}04 / 17 / 91 \\
12 / 11 / 91 \\
10 / 14 / 92 \\
04 / 17 / 91 \\
08 / 07 / 91 \\
12 / 11 / 91 \\
10 / 14 / 92 \\
04 / 17 / 91 \\
08 / 07 / 91 \\
12 / 11 / 91 \\
10 / 14 / 92 \\
04 / 17 / 91 \\
12 / 11 / 91 \\
10 / 14 / 92 \\
04 / 17 / 91 \\
08 / 07 / 91 \\
10 / 14 / 92 \\
08 / 07 / 91 \\
10 / 14 / 92 \\
01 / 12 / 89 \\
01 / 12 / 89 \\
04 / 17 / 91 \\
08 / 07 / 91\end{array}$ & $\begin{array}{l}0001 \\
0001 \\
0001 \\
0001 \\
0001 \\
0001 \\
0001 \\
0001 \\
0001 \\
0001 \\
0001 \\
0001 \\
0001 \\
0001 \\
0001 \\
0001 \\
0001 \\
0001 \\
0001 \\
0001 \\
0001 \\
0001 \\
0001\end{array}$ & $\begin{array}{l}A L \\
A L \\
A L \\
A L \\
A L \\
A L \\
A L \\
A L \\
A L \\
A L \\
A L \\
A L \\
A L \\
A L \\
A L \\
A L \\
A L \\
A L \\
A L \\
T A \\
T A \\
T A \\
T A\end{array}$ & $\begin{array}{l}N \\
N \\
N \\
N \\
N \\
N \\
N \\
N \\
N \\
N \\
N \\
N \\
N \\
N \\
N \\
N \\
N \\
N \\
0 \\
0 \\
0 \\
0\end{array}$ & $M G / L$ & $\begin{array}{l}< \\
< \\
< \\
< \\
< \\
< \\
< \\
< \\
< \\
< \\
< \\
< \\
< \\
< \\
< \\
< \\
< \\
< \\
< \\
< \\
< \\
<\end{array}$ & $\begin{array}{l}0.03 \\
0.1 \\
0.2 \\
0.03 \\
0.1 \\
0.1 \\
0.1 \\
0.05 \\
0.1 \\
0.1 \\
0.3 \\
0.05 \\
1.0 \\
0.3 \\
0.03 \\
0.01 \\
0.05 \\
0.1 \\
0.006 \\
0.01 \\
0.01 \\
0.07 \\
0.02\end{array}$ & $\begin{array}{l}1 \\
1 \\
1 \\
1 \\
1 \\
1 \\
1 \\
1 \\
1 \\
1 \\
1 \\
1 \\
1 \\
1 \\
1\end{array}$ & $\begin{array}{l}0.01 \\
0.1 \\
0.2 \\
0.03 \\
0.1 \\
0.1 \\
0.1 \\
0.01 \\
0.1 \\
0.1 \\
0.3 \\
0.05 \\
1 . \\
0.3 \\
0.03 \\
0.01 \\
0.05 \\
0.1 \\
0.005 \\
0.01 \\
0.01 \\
0.01 \\
0.01\end{array}$ & $\begin{array}{l}- \\
- \\
- \\
- \\
- \\
- \\
- \\
- \\
- \\
- \\
- \\
- \\
- \\
- \\
- \\
- \\
- \\
- \\
-\end{array}$ \\
\hline ARSENIC (TOTAL) & $\begin{array}{l}0203 \\
0204 \\
0206 \\
0207 \\
0210\end{array}$ & $\begin{array}{l}12 / 12 / 90 \\
12 / 12 / 90 \\
12 / 12 / 90 \\
12 / 12 / 90 \\
12 / 12 / 90\end{array}$ & $\begin{array}{l}\text { N001 } \\
\text { No01 } \\
\text { N001 } \\
\text { N001 } \\
\text { N001 }\end{array}$ & $\begin{array}{l}A L \\
A L \\
A L \\
A L \\
A L\end{array}$ & $\begin{array}{l}N \\
N \\
N \\
N \\
N\end{array}$ & $M G / L$ & & $\begin{array}{l}0.04 \\
0.06 \\
0.02 \\
0.03 \\
0.06\end{array}$ & & $\begin{array}{l}0.01 \\
0.01 \\
0.01 \\
0.01 \\
0.01\end{array}$ & $\begin{array}{l}- \\
- \\
-\end{array}$ \\
\hline BARIUM & $\begin{array}{l}0202 \\
0202 \\
0202 \\
0203\end{array}$ & $\begin{array}{l}04 / 17 / 91 \\
12 / 11 / 91 \\
10 / 14 / 92 \\
04 / 17 / 91\end{array}$ & $\begin{array}{l}0001 \\
0001 \\
0001 \\
0001\end{array}$ & $\begin{array}{l}A L \\
A L \\
A L \\
A L\end{array}$ & $\begin{array}{l}N \\
N \\
N \\
N\end{array}$ & $M G / L$ & & $\begin{array}{l}0.07 \\
0.05 \\
0.05 \\
0.04\end{array}$ & & $\begin{array}{l}0.01 \\
0.01 \\
0.01 \\
0.01\end{array}$ & : \\
\hline
\end{tabular}

MATERIAL OF SAMPLING COOE:

AL - ALLUVIUM

UR - NO RECOVERY OF DATA FOR CLASSIFYING

FLOW RELATIONSHIP CODE:

TA - URANIUM MILL TAILINGS

N - UNKNOWN

PARAMETER VALUE INDICATOR (PVI): < - LESS THAN DETECTION LIMIT

SAMPLE ID CODES:

0001 - FILTERED SAMPLE (.45 MICRONS)

OTHER PARAMETER VALUE FLAGS:

MO01 - UNFILTERED SAMPLE

I - IMCREASED DETECTION LIMIT DUE TO REQUIRED DILUTION 
TABLE 3.21 TAILINGS PORE FLUID WATER QUALITY DATA BY PARAMETER, NC AND UC PROCESSING SITES SLICK ROCK, COLORADO

SITE: SRK01 SLICK ROCK (BOTH SITES)

$01 / 12 / 8$ ? TO $10 / 14 / 92$
REPORT DATE: $06 / 17 / 93$

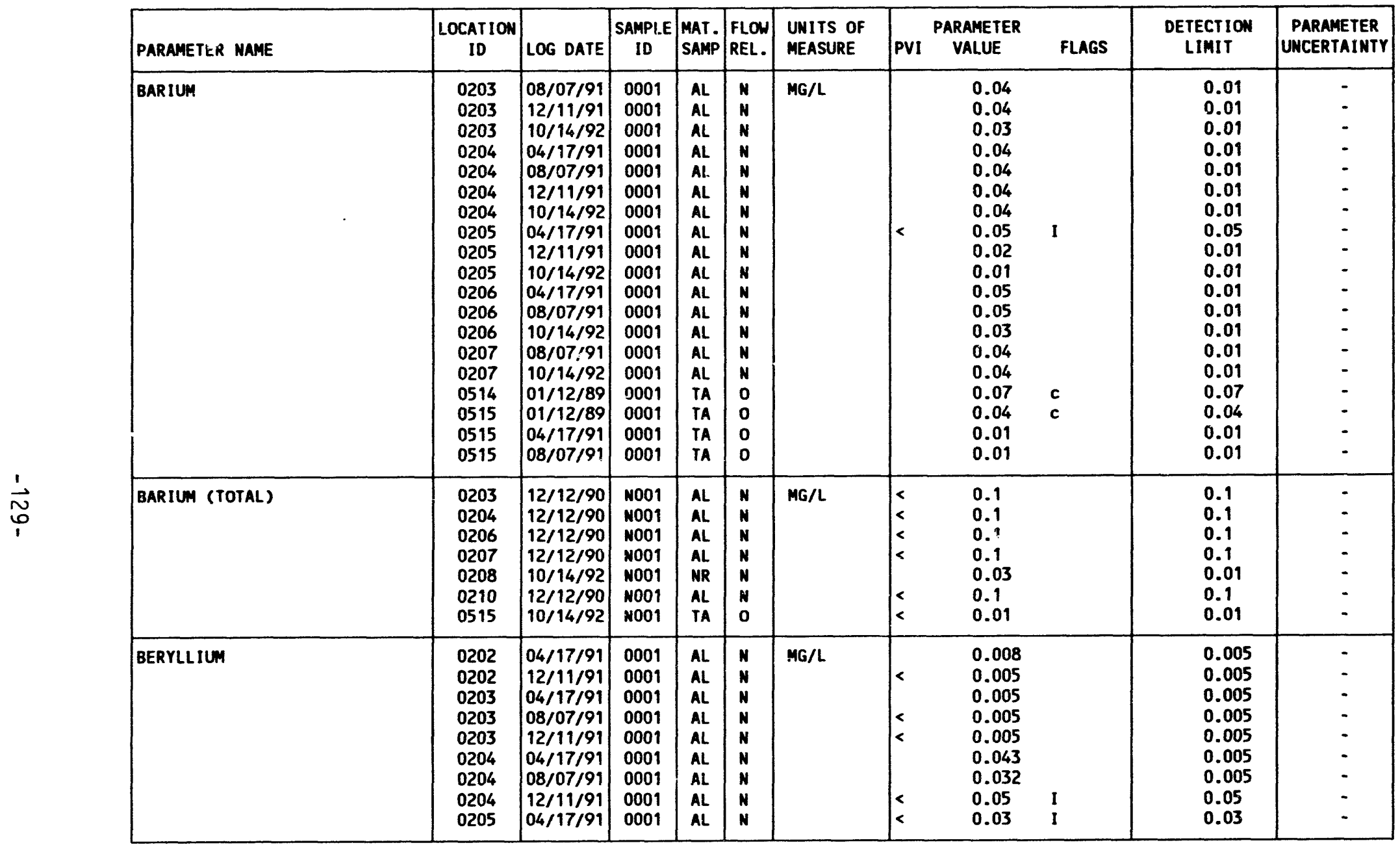

MATERIAL OF SAMPLINA COOE:

AL - ALLUVIUM

TA - URANIUM MILL TAILIMGS

NR - NO RECOVERY OF DATA FOR CLASSIFYING

FLON RELATIONSHIP COOE:

N - UNKMONN
O - ON-SITE

PARAMETER VALUE INDICATOR (PVI): < - LESS THAN DETECTION LIMIT

SAMPLE ID CODES:

OTHER PARAMETER VALUE fLAGS:

0001 - FILTERED SAMPLE (.45 MICRONS)

I - INCREASED DETECTION LIMIT DUE TO REQUIRED DILUTION

N001 - UMFILTERED SAMPLE 
TABLE 3.21 TAILINGS PORE FLUID MATER QUALITY DATA BY PARAMETER, NC AND UC PROCESSING SITES, SLICK ROCK, COLORADD

SITE: SRKO1 SLICK ROCK (BOTH SITES)

01/12/89 TO $10 / 14 / 92$

REPORT DATE: $06 / 17 / 93$

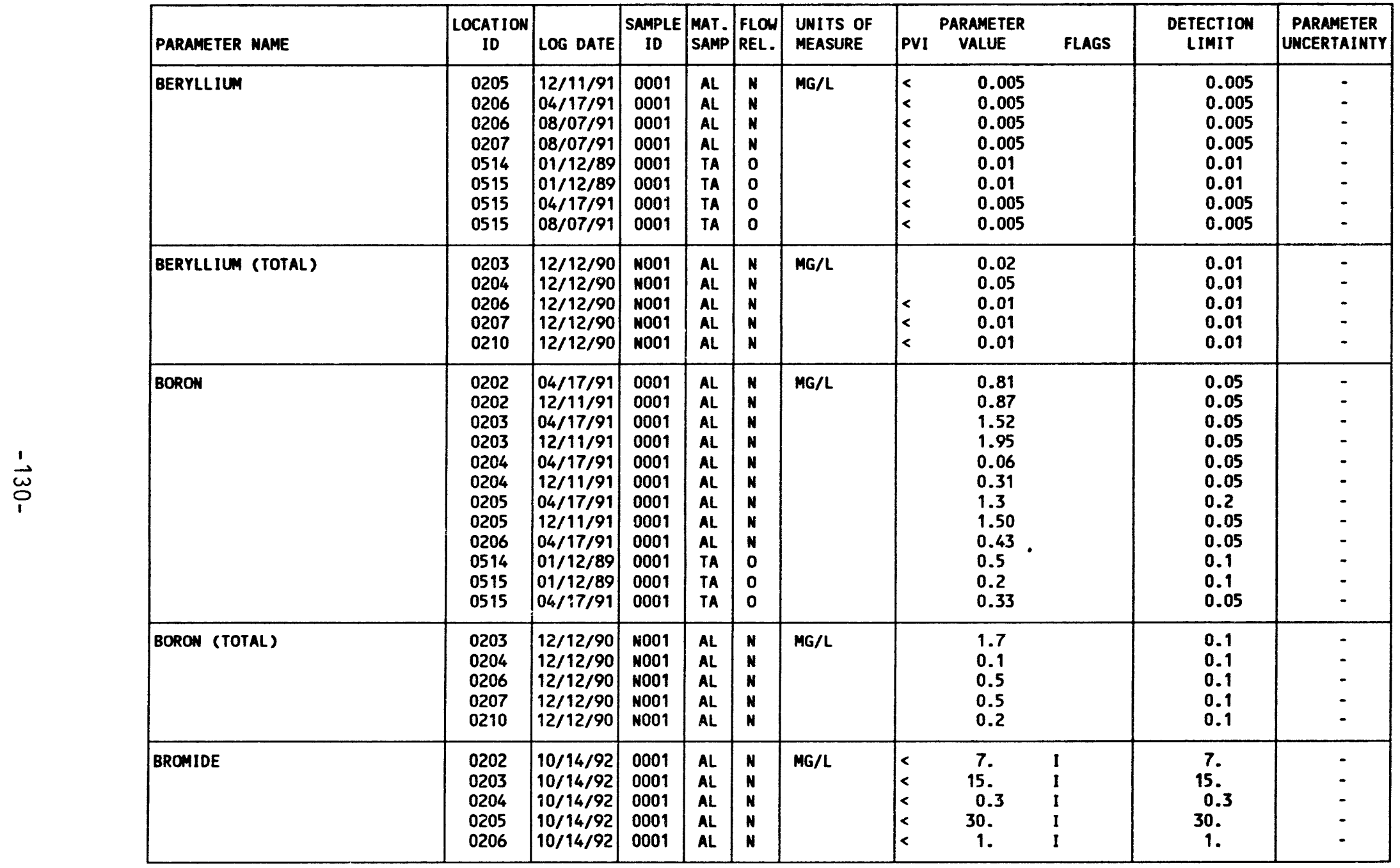

MATERIAL OF SAMPLING COOE:

AL - ALLUVIUM

TA - URANIUM MILL TAILINGS

PARAMETER VALUE INDICATOR (PVI): < - LESS THAN DETECTION LIMIT

OTHER PARAMETER VALUE FLAGS:

I - INCREASED DETECTION LIMIT DUE TO REQUIRED DILUTION
FLOW RELATIONSHIP COOE:

N - ON-SITE

SAMPLE ID CODES:

0001 - FILTERED SAMPLE (.45 MICRONS)

NOO1 - UNFILTERED SAMPLE 
TABLE 3.21 TAILINGS PORE FLUID MATER QUALITY DATA BY PARAMETER, NC AND UC PROCESSING SITES, SLICK ROCK, COLORADO

SITE: SRKO1 SLICK ROCK (BOTH SITES)

01/12/89 TO $10 / 14 / 92$

REPORT DATE: 06/17/93

\begin{tabular}{|c|c|c|c|c|c|c|c|c|c|c|c|c|}
\hline & PARAMETER MAME & $\underset{\text { ID }}{\text { LOCATION }}$ & LOG DATE & $\begin{array}{c}\text { SAMPLE } \\
\text { ID }\end{array}$ & $\begin{array}{l}\text { MAT. } \\
\text { SAMP }\end{array}$ & $\begin{array}{l}\text { FLOW } \\
\text { REL. }\end{array}$ & $\begin{array}{l}\text { UNITS OF } \\
\text { MEASURE }\end{array}$ & PVI & $\begin{array}{l}\text { ARAMETER } \\
\text { VALUE }\end{array}$ & FLAGS & $\begin{array}{l}\text { DETECTION } \\
\text { LIMIT }\end{array}$ & \begin{tabular}{|} 
PARAMETER \\
UNCERTAINTY
\end{tabular} \\
\hline & BROMIOE & $\begin{array}{l}0207 \\
0514 \\
0515\end{array}$ & $\begin{array}{l}10 / 14 / 92 \\
01 / 12 / 89 \\
01 / 12 / 89\end{array}$ & $\begin{array}{l}0001 \\
0001 \\
0001\end{array}$ & $\begin{array}{l}\text { AL } \\
\text { TA } \\
\text { TA }\end{array}$ & $\begin{array}{l}N \\
0 \\
0\end{array}$ & $M G / L$ & $\mid<$ & $\begin{array}{l}0.5 \\
0.1 \\
0.1\end{array}$ & 1 & $\begin{array}{l}0.5 \\
0.1 \\
0.1\end{array}$ & : \\
\hline & BROMIDE (TOTAL) & $\begin{array}{l}0202 \\
0203 \\
0204 \\
0205 \\
0206 \\
0210\end{array}$ & $\begin{array}{l}12 / 12 / 90 \\
12 / 12 / 90 \\
12 / 12 / 90 \\
12 / 12 / 90 \\
12 / 12 / 90 \\
12 / 12 / 90\end{array}$ & $\begin{array}{l}\text { N001 } \\
\text { N001 } \\
\text { N001 } \\
\text { N001 } \\
\text { N001 } \\
\text { N001 }\end{array}$ & $\begin{array}{l}A L \\
A L \\
A L \\
A L \\
A L \\
A L\end{array}$ & $\begin{array}{l}N \\
N \\
N \\
N \\
N \\
N\end{array}$ & $M G / L$ & $\mid \begin{array}{l}< \\
< \\
<\end{array}$ & $\begin{array}{l}1.4 \\
3.2 \\
0.1 \\
3.3 \\
0.1 \\
0.1\end{array}$ & $\begin{array}{l}c \\
c \\
c\end{array}$ & $\begin{array}{l}0.01 \\
0.01 \\
0.1 \\
0.01 \\
0.1 \\
0.1\end{array}$ & $\begin{array}{l}- \\
- \\
- \\
-\end{array}$ \\
\hline$\frac{1}{4}$ & CADMIUM & $\begin{array}{l}0202 \\
0202 \\
0202 \\
0203 \\
0203 \\
0203 \\
0203 \\
0204 \\
0204 \\
0204 \\
0204 \\
0205 \\
0205 \\
0205 \\
0206 \\
0206 \\
0206 \\
0207 \\
0207 \\
0514 \\
0515 \\
0515 \\
0515\end{array}$ & $\begin{array}{l}04 / 17 / 91 \\
12 / 11 / 91 \\
10 / 14 / 92 \\
04 / 17 / 91 \\
08 / 07 / 91 \\
12 / 11 / 91 \\
10 / 14 / 92 \\
04 / 17 / 91 \\
08 / 07 / 91 \\
12 / 11 / 91 \\
10 / 14 / 92 \\
04 / 17 / 91 \\
12 / 11 / 91 \\
10 / 14 / 92 \\
04 / 17 / 91 \\
08 / 07 / 91 \\
10 / 14 / 92 \\
08 / 07 / 91 \\
10 / 14 / 92 \\
01 / 12 / 89 \\
01 / 12 / 89 \\
04 / 17 / 91 \\
08 / 07 / 91\end{array}$ & $\begin{array}{l}0001 \\
0001 \\
0001 \\
0001 \\
0001 \\
0001 \\
0001 \\
0001 \\
0001 \\
0001 \\
0001 \\
0001 \\
0001 \\
0001 \\
0001 \\
0001 \\
0001 \\
0001 \\
0001 \\
0001 \\
0001 \\
0001 \\
0001\end{array}$ & $\begin{array}{l}A L \\
A L \\
A L \\
A L \\
A L \\
A L \\
A L \\
A L \\
A L \\
A L \\
A L \\
A L \\
A L \\
A L \\
A L \\
A L \\
A L \\
A L \\
A L \\
T A \\
T A \\
T A \\
T A\end{array}$ & $\begin{array}{l}N \\
N \\
N \\
N \\
N \\
N \\
N \\
N \\
N \\
N \\
N \\
N \\
N \\
N \\
N \\
N \\
N \\
N \\
0 \\
0 \\
0 \\
0\end{array}$ & MG/L & $\begin{array}{l}< \\
< \\
< \\
< \\
< \\
< \\
< \\
< \\
< \\
<\end{array}$ & $\begin{array}{l}0.006 \\
0.01 \\
0.12 \\
0.001 \\
0.001 \\
0.01 \\
0.18 \\
0.008 \\
0.03 \\
0.01 \\
0.02 \\
0.003 \\
0.01 \\
0.23 \\
0.002 \\
0.001 \\
0.001 \\
0.001 \\
0.005 \\
0.652 \\
0.207 \\
0.194 \\
0.1\end{array}$ & $\begin{array}{l}1 \\
1 \\
I \\
I \\
I\end{array}$ & $\begin{array}{l}0.001 \\
0.01 \\
0.03 \\
0.001 \\
0.001 \\
0.01 \\
0.03 \\
0.001 \\
0.03 \\
0.01 \\
0.02 \\
0.001 \\
0.01 \\
0.03 \\
0.001 \\
0.001 \\
0.001 \\
0.001 \\
0.005 \\
0.001 \\
0.001 \\
0.005 \\
0.1\end{array}$ & $\begin{array}{l}- \\
: \\
: \\
: \\
- \\
: \\
: \\
- \\
- \\
- \\
- \\
- \\
- \\
- \\
- \\
- \\
- \\
-\end{array}$ \\
\hline & CADMIUM (TOTAL) & $\begin{array}{l}0203 \\
0204 \\
0206\end{array}$ & $\begin{array}{l}12 / 12 / 90 \\
12 / 12 / 90 \\
12 / 12 / 90\end{array}$ & $\begin{array}{l}\text { N001 } \\
\text { N001 } \\
\text { N001 }\end{array}$ & $\begin{array}{l}A L \\
A L \\
A L\end{array}$ & $\begin{array}{l}N \\
N \\
N\end{array}$ & $M G / L$ & $<$ & $\begin{array}{l}0.001 \\
0.002 \\
0.001\end{array}$ & & $\begin{array}{l}0.001 \\
0.001 \\
0.001\end{array}$ & - \\
\hline
\end{tabular}

MATERIAL OF SAMPLING COOE:

AL - ALLUVIUM

TA - URANIUM MILL TAILINGS

FLOW RELATIONSHIP CODE:

PARAMETER VALUE INDICATOR (PVI): < - LESS THAN DETECTION LIMIT

N - UNKNOWN
O - ON-SITE

OTHER PARAMETER VALUE FLAGS:

SAMPLE ID CODES:

0001 - FILTERED SAMPLE (.45 MICRONS)

I - INCREASED DETECTION LIMIT DUE TO REQUIRED DILUTION

NOO1 - UNFILTERED SAMPLE

c - CHANGED DETECTION LIMIT 
TABLE 3.21 TAILINGS PORE FLUID WATER QUALITY DATA BY PARAMETER, MC AND UC PROCESSING SITES, SLICK ROCK, COLORADO

SITE: SRKO1 SLICK ROCK (BOTH SITES)

$01 / 12 / 89$ TO $10 / 14 / 92$

REPORT DATE: 06/17/93

\begin{tabular}{|c|c|c|c|c|c|c|c|c|c|c|}
\hline PARAMETER NAME & $\underset{10}{\text { LOCATION }}$ & LOG DATE & $\begin{array}{c}\text { SAMPLE } \\
\text { ID }\end{array}$ & $\begin{array}{l}\text { MAT. } \\
\text { SAMP }\end{array}$ & $\begin{array}{l}\text { FLOW } \\
\text { REL. }\end{array}$ & $\begin{array}{l}\text { UNITS OF } \\
\text { MEASURE }\end{array}$ & PVI & $\begin{array}{l}\text { ARAMETER } \\
\text { VALUE }\end{array}$ & $\begin{array}{c}\text { DETECTION } \\
\text { LIMIT }\end{array}$ & $\begin{array}{c}\text { PARAMETER } \\
\text { UNCERTAINTY }\end{array}$ \\
\hline CADMIUM (TOTAL) & $\begin{array}{l}0207 \\
0208 \\
0210 \\
0515\end{array}$ & $\begin{array}{l}12 / 12 / 90 \\
10 / 14 / 92 \\
12 / 12 / 90 \\
10 / 14 / 92\end{array}$ & $\begin{array}{l}\text { N001 } \\
\text { N001 } \\
\text { N001 } \\
\text { N001 }\end{array}$ & $\begin{array}{l}A L \\
\text { NR } \\
A L \\
T A\end{array}$ & $\begin{array}{l}\mathbf{N} \\
\mathbf{N} \\
\mathbf{N} \\
\mathbf{0}\end{array}$ & $M G / L$ & $<$ & $\begin{array}{l}0.001 \\
0.005 \\
0.006 \\
0.053\end{array}$ & $\begin{array}{l}0.001 \\
0.005 \\
0.001 \\
0.005\end{array}$ & $\begin{array}{l}- \\
- \\
-\end{array}$ \\
\hline CALCIUM & $\begin{array}{l}0202 \\
0202 \\
0202 \\
0203 \\
0203 \\
0203 \\
0203 \\
0204 \\
0204 \\
0204 \\
0204 \\
0205 \\
0205 \\
0205 \\
0206 \\
0206 \\
0206 \\
0207 \\
0207 \\
0514 \\
0515 \\
0515 \\
0515 \\
\end{array}$ & $\begin{array}{l}04 / 17 / 91 \\
12 / 11 / 91 \\
10 / 14 / 92 \\
04 / 17 / 91 \\
08 / 07 / 91 \\
12 / 11 / 91 \\
10 / 14 / 92 \\
04 / 17 / 91 \\
08 / 07 / 91 \\
12 / 11 / 91 \\
10 / 14 / 92 \\
04 / 17 / 91 \\
12 / 11 / 91 \\
10 / 14 / 92 \\
04 / 17 / 91 \\
08 / 07 / 91 \\
10 / 14 / 92 \\
08 / 07 / 91 \\
10 / 14 / 92 \\
01 / 12 / 89 \\
01 / 12 / 89 \\
04 / 17 / 91 \\
08 / 07 / 91\end{array}$ & $\begin{array}{l}0001 \\
0001 \\
0001 \\
0001 \\
0001 \\
0001 \\
0001 \\
0001 \\
0001 \\
0001 \\
0001 \\
0001 \\
0001 \\
0001 \\
0001 \\
0001 \\
0001 \\
0001 \\
0001 \\
0001 \\
0001 \\
0001 \\
0001\end{array}$ & $\begin{array}{l}A L \\
A L \\
A L \\
A L \\
A L \\
A L \\
A L \\
A L \\
A L \\
A L \\
A L \\
A L \\
A L \\
A L \\
A L \\
A L \\
A L \\
A L \\
A L \\
T A \\
T A \\
T A \\
T A\end{array}$ & $\begin{array}{l}N \\
N \\
N \\
N \\
N \\
N \\
N \\
N \\
N \\
N \\
N \\
N \\
N \\
N \\
N \\
N \\
N \\
N \\
0 \\
0 \\
0 \\
0\end{array}$ & $\mathrm{MG} / \mathrm{L}$ & & $\begin{array}{l}445 . \\
400 . \\
413 . \\
424 . \\
427 . \\
427 . \\
407 . \\
582 . \\
634 . \\
605 . \\
546 . \\
505 . \\
450 . \\
436 . \\
750 . \\
770 . \\
715 . \\
720 . \\
650 . \\
578 . \\
527 . \\
488 . \\
409 .\end{array}$ & $\begin{array}{l}2 . \\
0.5 \\
0.5 \\
2.0 \\
0.5 \\
0.5 \\
0.5 \\
5 . \\
5 . \\
2 . \\
5 . \\
2 . \\
0.5 \\
0.5 \\
2 . \\
2 . \\
2 . \\
2 . \\
2 . \\
0.01 \\
0.01 \\
2 . \\
0.5\end{array}$ & $\begin{array}{l}- \\
- \\
- \\
- \\
- \\
- \\
- \\
- \\
- \\
- \\
- \\
- \\
- \\
- \\
- \\
- \\
-\end{array}$ \\
\hline CALCIUM (TOTAL) & $\begin{array}{l}0203 \\
0204 \\
0206 \\
0207 \\
0208 \\
0210 \\
0515\end{array}$ & $\begin{array}{l}12 / 12 / 90 \\
12 / 12 / 90 \\
12 / 12 / 90 \\
12 / 12 / 90 \\
10 / 14 / 92 \\
12 / 12 / 90 \\
10 / 14 / 92\end{array}$ & $\begin{array}{l}\text { N001 } \\
\text { N001 } \\
\text { N001 } \\
\text { N001 } \\
\text { N001 } \\
\text { N001 } \\
\text { N001 }\end{array}$ & $\begin{array}{l}A L \\
A L \\
A L \\
A L \\
N R \\
A L \\
T A\end{array}$ & $\begin{array}{l}N \\
N \\
N \\
N \\
N \\
N \\
0\end{array}$ & $M G / L$ & & $\begin{array}{l}369 . \\
516 . \\
697 . \\
616 . \\
695 . \\
491 . \\
350 .\end{array}$ & $\begin{array}{l}0.01 \\
0.01 \\
0.01 \\
0.01 \\
2 . \\
0.01 \\
0.5\end{array}$ & $\begin{array}{l}- \\
: \\
: \\
-\end{array}$ \\
\hline CHLORIDE & 0202 & $10 / 14 / 92$ & 0001 & AL & N & $M G / L$ & & 960. & 10. & - \\
\hline
\end{tabular}

MATERIAL OF SAMPLING CODE:

AL - ALLUVIUM

MR - MO RECOVERY OF DATA FOR CLASSIFYING

FLOW RELATIONSHIP CODE:

TA - URANIUM MILL TAILINGS

PARAMETER VALUE INDICATOR (PVI): < - LESS THAN DETECTION LIMIT

SAMPLE ID COOES:

0001 - FILTERED SAMPLE (.45 MICRONS)

OTHER PARAMETER VALUE FLAGS:

N001 - UNFILTERED SAMPLE

1 - INCREASED DETECTION LIMIT DUE TO REQUIRED DILUTION 
TABLE 3.21 TAILINGS PORE FLUID WATER QUALITY DATA BY PARAMETER, MC AND UC PROCESSING SITES, SLICK ROCK, COLORADO

SITE: SRKO1 SLICK ROCK (BOTH SITES)

01/12/89 TO $10 / 14 / 92$

REPORT DATE: 06/17/93

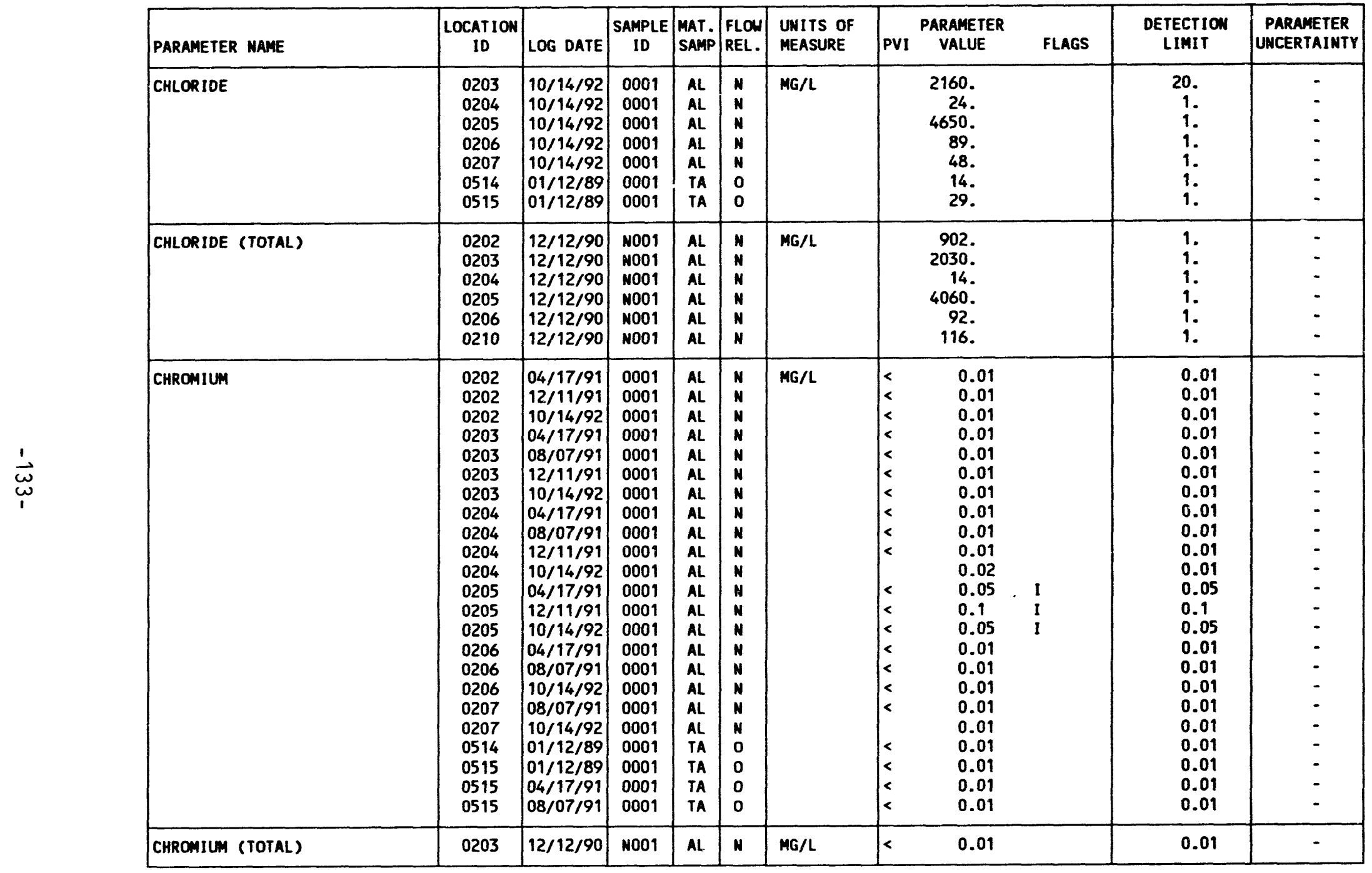

MATERIAL OF SAMPLING CODE:

AL - ALLUVIUM

TA - URANIUN MILL TAILINGS

PARAMETER VALUE INDICATOR (PVI): < - LESS THAN DETECTION LIMIT

OTHER PARAMETER VALUE FLAGS:

1 - INCREASED DETECTION LIMIT DUE TO REQUIRED DILUTION
FLOW RELATIONSHIP COOE:

N - UNKHOWN
O - ON-SITE

SAMPLE ID COOES:

0001 - FILTERED SAMPLE (.45 MICRONS)

NOO1 - UNFILTERED SAMPLE 
TABLE 3.21 TAILINGS PORE FLUID MATER QUALITY DATA BY PARAMETER, MC AND UC PROCESSING SITES, SLICK ROCK, COLORADO

SITE: SRKO1 SLICK ROCK (BOTH SITES)

01/12/89 TO $10 / 14 / 92$

REPORT DATE: 06/17/93

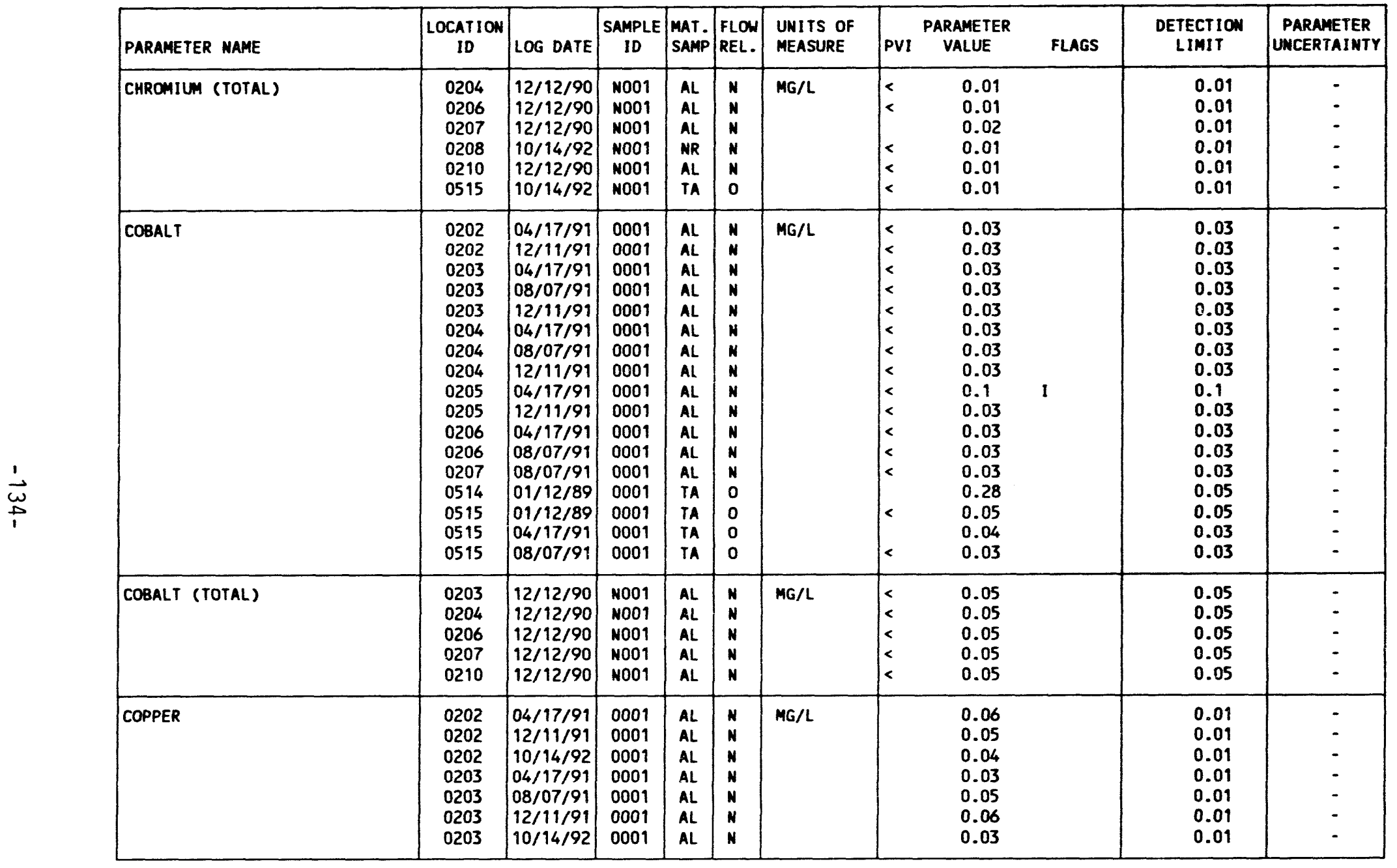

\section{MATERIAL OF SAMPLING COOE:}

AL. - ALLUVIUM

NR - NO RECOVERY OF DATA FOR CLASSIFYING

TA - URANIUM MILL TAILINGS

PARAMETER VALUE INDICATOR (PVI): < - LESS THAM DETECTION LIMIT

OTHER PARAMETER VALUE FLAGS:

1 - INCREASED DETECTION LIMIT DUE TO REQUIRED DILUTION
FLOW RELATIONSHIP CODE:

N - UNKNOWN

SAMPLE ID COOES:

0001 - FILTERED SAMPLE (.45 MICRONS)

N001 - UNFILTERED SAMPLE 
TABLE 3.21 TAILINGS PORE FLUID MATER QUALITY DATA BY PARAMETER, NC AND UC PROCESSING SITES, SLICK ROCK, COLORADO

SITE: SRKO1 SLICK ROCK (BOTH SITES)

01/12/89 TO $10 / 14 / 92$

REPORT DATE: 06/17/93

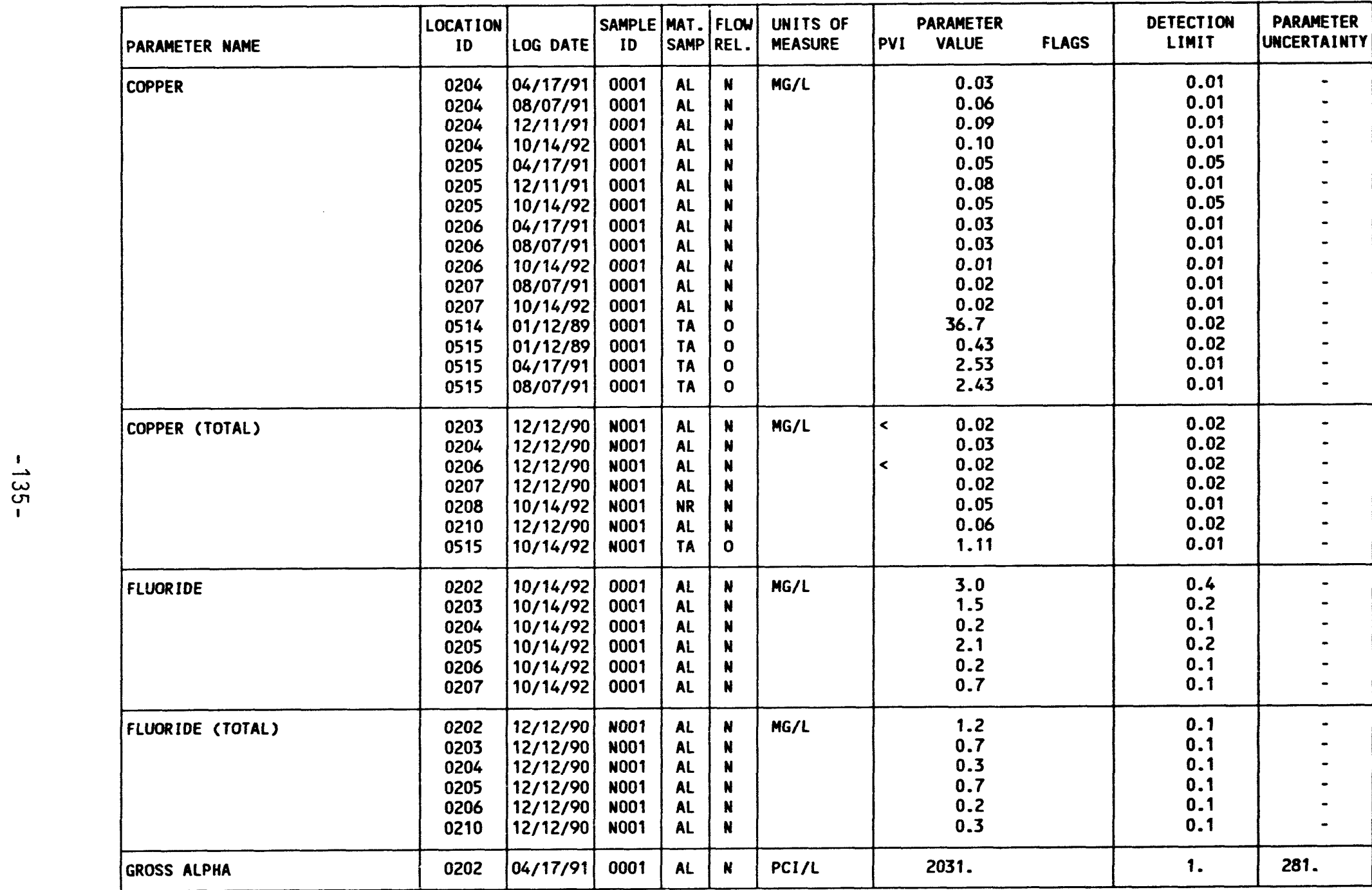

MATERIAL OF SAMPLING CODE:

AL - ALLUVIUM

TA - URANIUM MILL TAILINGS

NR - NO RECOVERY OF DATA FOR CLASSIFYING

PARAMETER VALUE INDICATOR (PVI): < - LESS THAN DETECTION LIMIT
FLOW RELATIONSHIP CODE:

N - UNKNOWN

SAMPLE ID CODES:

0001 - FILTERED SAMPLE (.45 MICRONS)

N001 - UNFILTERED SAMPLE 
TABLE 3.21 TAILINGS PORE FLUID WATER OUALITY DATA BY PARAMETER, NC AMD UC PROCESSING SITES, SLICK ROCK, COLORADO

SITE: SRKO1 SLICK ROCK (BOTH SITES)

SITE: SRKO1 SLICK ROCK

REPORT DATE: $06 / 17 / 93$

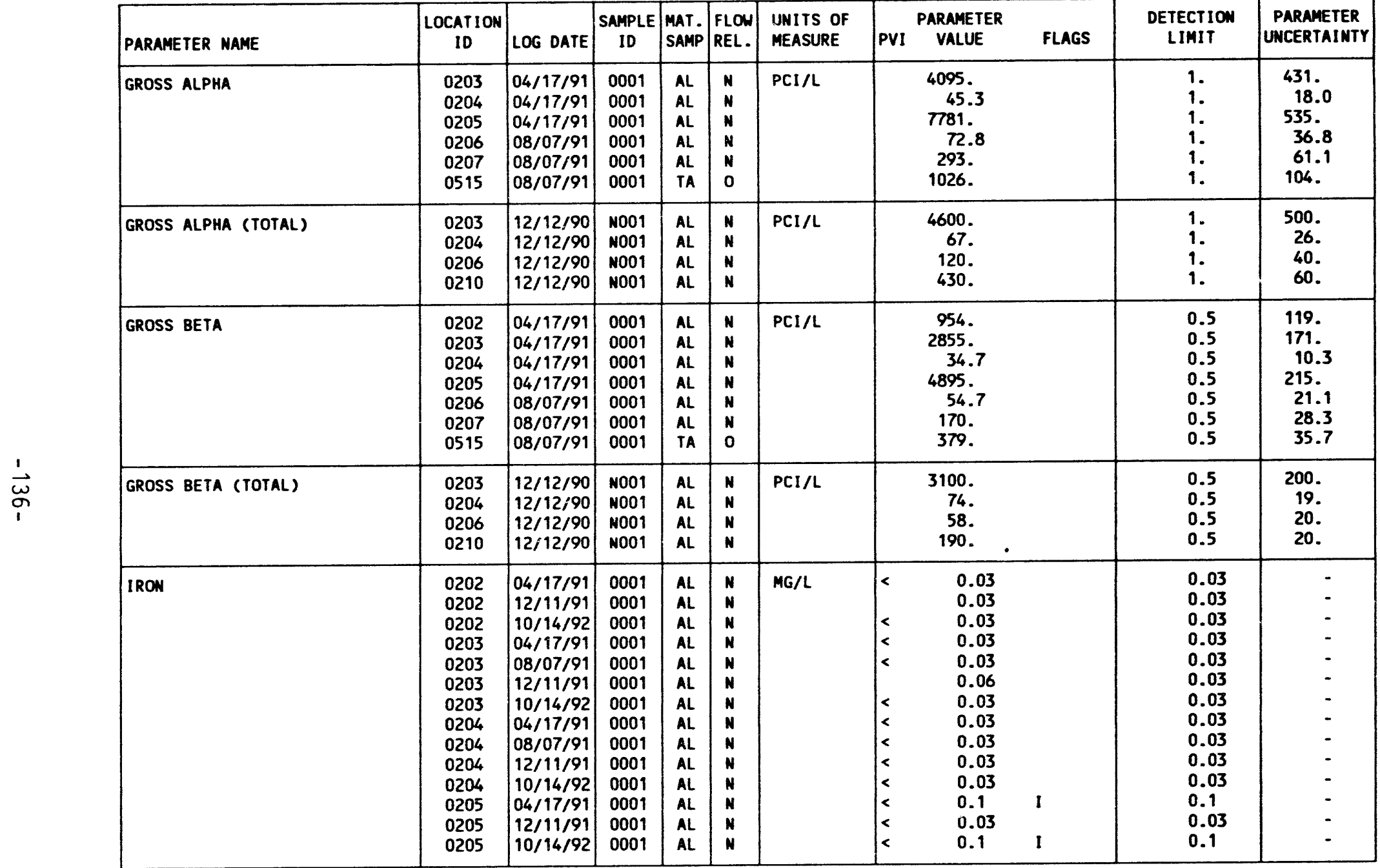

MATERIAL OF SAMPLING COOE:

AL - ALLUVIUM

TA - URANIUM MILL TAILINGS

FLON RELATIONSHIP COOE:

N - UNKNOWN
O - ON-SITE

PARAMETER VALUE INDICATOR (PVI): < - LESS THAN DETECTION LIMIT

SAMPLE ID COOES:

0001 - FILTERED SAMPLE (.45 MICRONS)

OTHER PARAMETER VALLEE FLAGS:

N001 - UMFILTERED SAMPLE

I - IMCREASED DETECTION LIMIT DUE TO REQUIRED DILUTION 
TABLE 3.21 TAILINGS PORE FLUID MATER QUALITY DATA BY PARAMETER, MC AMD UC PROCESSING SITES, SLICK ROCK, COLORADO

SITE: SRKO1 SLICK ROCK (BOTH SITES)

$01 / 12 / 89$ TO $10 / 14 / 92$

\begin{tabular}{|c|c|c|c|c|c|c|c|c|c|c|c|c|}
\hline & PARAMETER NAME & $\begin{array}{c}\text { LOCATION } \\
\text { ID }\end{array}$ & LOG DATE & $\begin{array}{c}\text { SAMPLE } \\
\text { ID }\end{array}$ & $\begin{array}{l}\text { MAT. } \\
\text { SAMP }\end{array}$ & $\begin{array}{l}\text { FLOW } \\
\text { REL. }\end{array}$ & $\begin{array}{l}\text { UNITS OF } \\
\text { MEASURE }\end{array}$ & PVI & $\begin{array}{l}\text { PARAMETER } \\
\text { VALUE }\end{array}$ & FLAGS & $\begin{array}{l}\text { DETECTION } \\
\text { LIMIT }\end{array}$ & \begin{tabular}{|l} 
PARAMETER \\
UNCERTAINTY
\end{tabular} \\
\hline & IRON & $\begin{array}{l}0206 \\
0206 \\
0206 \\
0207 \\
0207 \\
0514 \\
0515 \\
0515 \\
0515\end{array}$ & $\begin{array}{l}04 / 17 / 91 \\
08 / 07 / 91 \\
10 / 14 / 92 \\
08 / 07 / 91 \\
10 / 14 / 92 \\
01 / 12 / 89 \\
01 / 12 / 89 \\
04 / 17 / 91 \\
08 / 07 / 91\end{array}$ & $\begin{array}{l}0001 \\
0001 \\
0001 \\
0001 \\
0001 \\
0001 \\
0001 \\
0001 \\
0001\end{array}$ & $\begin{array}{l}\text { AL } \\
A L \\
A L \\
A L \\
A L \\
T A \\
\text { TA } \\
\text { TA } \\
\text { TA }\end{array}$ & $\begin{array}{l}N \\
N \\
N \\
N \\
N \\
0 \\
0 \\
0 \\
0\end{array}$ & $M G / L$ & 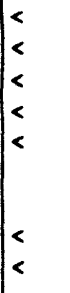 & $\begin{array}{l}0.03 \\
0.03 \\
0.03 \\
0.03 \\
0.03 \\
0.08 \\
0.10 \\
0.03 \\
0.03\end{array}$ & & $\begin{array}{l}0.03 \\
0.03 \\
0.03 \\
0.03 \\
0.03 \\
0.03 \\
0.03 \\
0.03 \\
0.03\end{array}$ & $\begin{array}{l}: \\
: \\
: \\
: \\
-\end{array}$ \\
\hline & IRON (TOTAL) & $\begin{array}{l}0203 \\
0204 \\
0206 \\
0207 \\
0208 \\
0210 \\
0515\end{array}$ & $\begin{array}{l}12 / 12 / 90 \\
12 / 12 / 90 \\
12 / 12 / 90 \\
12 / 12 / 90 \\
10 / 14 / 92 \\
12 / 12 / 90 \\
10 / 14 / 92\end{array}$ & $\begin{array}{l}\text { N001 } \\
\text { N001 } \\
\text { N001 } \\
\text { N001 } \\
\text { N001 } \\
\text { N001 } \\
\text { N001 }\end{array}$ & $\begin{array}{l}A L \\
A L \\
A L \\
A L \\
N R \\
A L \\
T A\end{array}$ & $\begin{array}{l}N \\
N \\
N \\
N \\
N \\
N \\
0\end{array}$ & $M G / L$ & & $\begin{array}{l}0.78 \\
0.09 \\
0.27 \\
0.19 \\
0.05 \\
0.11 \\
0.04\end{array}$ & & $\begin{array}{l}0.03 \\
0.03 \\
0.03 \\
0.03 \\
0.03 \\
0.03 \\
0.03\end{array}$ & $\begin{array}{l}- \\
- \\
- \\
-\end{array}$ \\
\hline$\underset{1}{\vec{\omega}}$ & LEAD & $\begin{array}{l}0202 \\
0202 \\
0202 \\
0203 \\
0203 \\
0203 \\
0203 \\
0204 \\
0204 \\
0204 \\
0204 \\
0205 \\
0205 \\
0205 \\
0206 \\
0206 \\
0206 \\
0207 \\
0207 \\
0514\end{array}$ & $\begin{array}{l}04 / 17 / 91 \\
12 / 11 / 91 \\
10 / 14 / 92 \\
04 / 17 / 91 \\
08 / 07 / 91 \\
12 / 11 / 91 \\
10 / 14 / 92 \\
04 / 17 / 91 \\
08 / 07 / 91 \\
12 / 11 / 91 \\
10 / 14 / 92 \\
04 / 17 / 91 \\
12 / 11 / 91 \\
10 / 14 / 92 \\
04 / 17 / 91 \\
08 / 07 / 91 \\
10 / 14 / 92 \\
08 / 07 / 91 \\
10 / 14 / 92 \\
01 / 12 / 89\end{array}$ & $\begin{array}{l}0001 \\
0001 \\
0001 \\
0001 \\
0001 \\
0001 \\
0001 \\
0001 \\
0001 \\
0001 \\
0001 \\
0001 \\
0001 \\
0001 \\
0001 \\
0001 \\
0001 \\
0001 \\
0001 \\
0001\end{array}$ & $\begin{array}{l}A L \\
A L \\
A L \\
A L \\
A L \\
A L \\
A L \\
A L \\
A L \\
A L \\
A L \\
A L \\
A L \\
A L \\
A L \\
A L \\
A L \\
A L \\
A L \\
T A\end{array}$ & $\begin{array}{l}N \\
N \\
N \\
N \\
N \\
N \\
N \\
N \\
N \\
N \\
N \\
N \\
N \\
N \\
N \\
N \\
N \\
N \\
0\end{array}$ & $M G / L$ & $\begin{array}{l}< \\
< \\
< \\
< \\
< \\
< \\
< \\
< \\
< \\
< \\
< \\
< \\
< \\
< \\
< \\
< \\
< \\
< \\
< \\
< \\
< \\
< \\
<\end{array}$ & $\begin{array}{l}0.03 \\
0.3 \\
0.02 \\
0.03 \\
0.3 \\
0.05 \\
0.02 \\
0.03 \\
0.03 \\
0.05 \\
0.003 \\
0.03 \\
0.05 \\
0.02 \\
0.03 \\
0.005 \\
0.003 \\
0.03 \\
0.003 \\
0.01\end{array}$ & $\begin{array}{l}1 \\
1 \\
1 \\
1 \\
1 \\
1 \\
1 \\
1 \\
1 \\
1 \\
1 \\
1 \\
1 \\
1 \\
1\end{array}$ & $\begin{array}{l}0.03 \\
0.3 \\
0.02 \\
0.03 \\
0.3 \\
0.05 \\
0.02 \\
0.03 \\
0.03 \\
0.05 \\
0.003 \\
0.03 \\
0.05 \\
0.02 \\
0.03 \\
0.005 \\
0.003 \\
0.03 \\
0.003 \\
0.01\end{array}$ & $\begin{array}{l}- \\
- \\
- \\
- \\
- \\
- \\
- \\
- \\
- \\
- \\
- \\
- \\
- \\
- \\
-\end{array}$ \\
\hline
\end{tabular}

MATERIAL OF SAMPLING CODE:

AL - ALLUVIUM

FLOU RELATIONSHIP CODE:

TA - URANIUM MILL TAILINGS

N - UNKNOWN

NR - NO RECOVERY OF DATA FOR CLASSIFYING

PARAMETER VALUE INDICATOR (PVI): < - LESS THAN DETECTION LIMIT

SAMPLE ID COOES:

OTHER PARAMETER VALUE fLAGS:

0001 - FILTERED SAMPLE (.45 MICRONS)

I - INCREASED DETECTIOW LIMIT DUE TO REQUIRED DILUTION

N001 - UNFILTERED SAMPLE 
TABLE 3.21 TAILINGS PORE FLUID HATER OUALITY DATA BY PARNAETER, NC AMD UC

COLORADO

SITE: SRKO1 SLICK ROCK (BOTH SITES)

01/12/89 TO $10 / 14 / 92$

REPORT DATE: 06/17/93

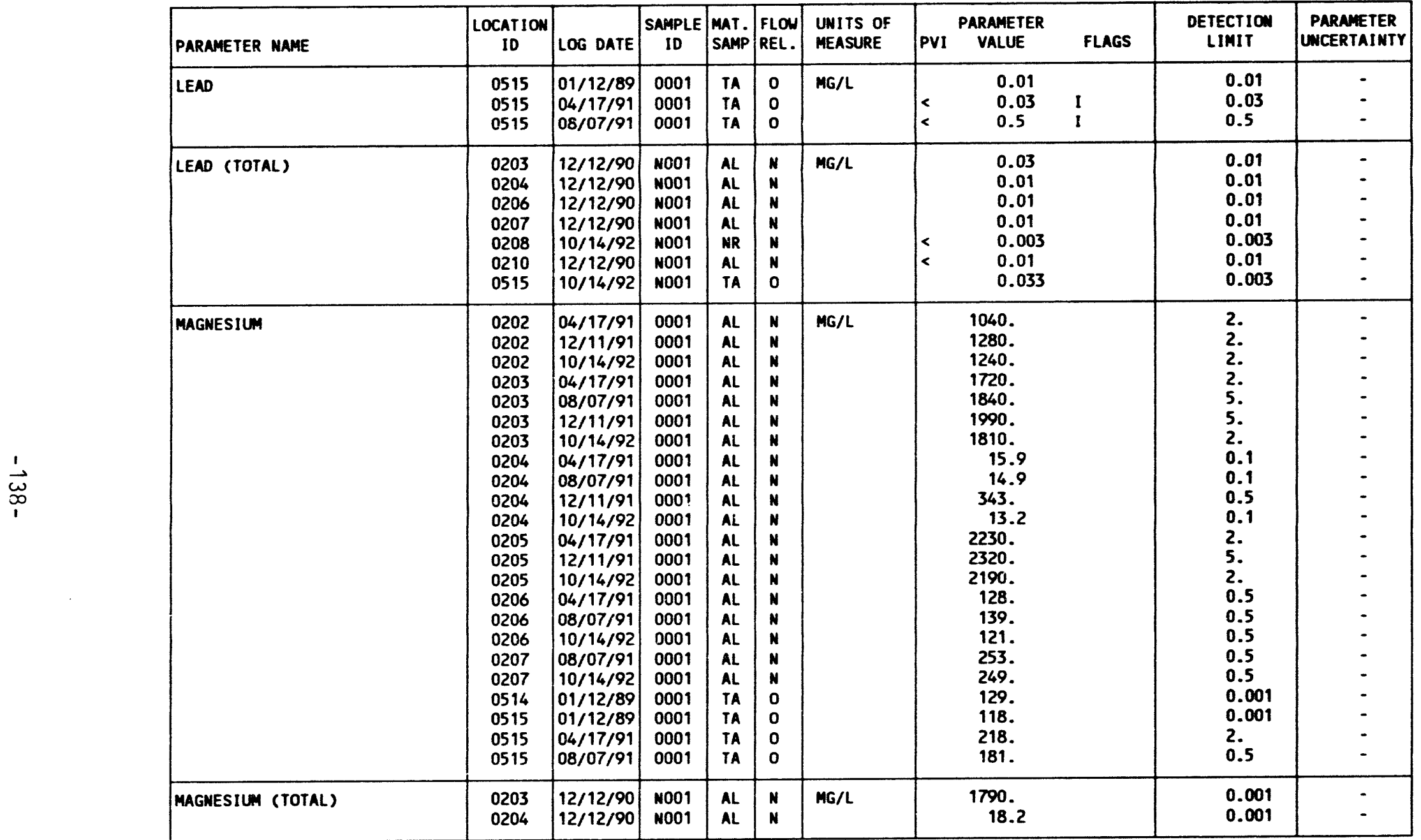

MATERIAL OF SAMPLING CODE:

TA - URANIUM MILL TAILINGS

AL - ALLUVIUN

MR - MO RECOVERY OF DATA FOR CLASSIFYING

PARAMETER VALUE IMDICATOR (PVI): < - LESS thaN DETECTION LIMIT

FLON RELATIONSHIP COOE:

o - ON-SITE

N - UNKMON

SAMPLE ID COOES:

OTHER PARAMETER VALUE FLAGS:

0001 - FILTERED SAMPLE (.45 MICRONS)

N001 - UNFILTERED SAMPLE

1 - IMCREASED DETECTION LIMIT DUE TO REQUIRED DILUTION 
TABLE 3.21 TAILINGS PORE FLUID WATER QUALITY DATA BY PARAMETER, MC AMO UC PROCESSING SITES, SLICK ROCK, COLORADO

SITE: SRKO1 SLICK ROCK (BOTH SITES)

01/12/89 TO $10 / 14 / 92$

REPORT DATE: 06/17/93

\begin{tabular}{|c|c|c|c|c|c|c|c|c|c|c|c|c|}
\hline & PARAMETER MAME & $\underset{\text { ID }}{\text { LOCATION }}$ & LOG DATE & $\underset{\text { ID }}{\text { SAMPLE }}$ & $\begin{array}{l}\text { MAT. } \\
\text { SAMP }\end{array}$ & $\begin{array}{l}\text { FLOW } \\
\text { REL. }\end{array}$ & $\begin{array}{l}\text { UNITS OF } \\
\text { MEASURE }\end{array}$ & PVI & $\begin{array}{l}\text { ARAMETER } \\
\text { VALUE }\end{array}$ & FLAGS & $\begin{array}{l}\text { DETECTION } \\
\text { LIMIT }\end{array}$ & $\begin{array}{l}\text { PARAMETER } \\
\text { UWCERTAINTY }\end{array}$ \\
\hline & MAGNESIUN (TOTAL) & $\begin{array}{l}0206 \\
0207 \\
0208 \\
0210 \\
0515\end{array}$ & $\begin{array}{l}12 / 12 / 90 \\
12 / 12 / 90 \\
10 / 14 / 92 \\
12 / 12 / 90 \\
10 / 14 / 92\end{array}$ & $\begin{array}{l}\text { N001 } \\
\text { N001 } \\
\text { N001 } \\
\text { N001 } \\
\text { N001 }\end{array}$ & $\begin{array}{l}\text { AL } \\
A L \\
\text { NR } \\
\text { AL } \\
\text { TA }\end{array}$ & $\begin{array}{l}N \\
N \\
N \\
N\end{array}$ & MG/L & & $\begin{array}{l}130 . \\
230 . \\
134 . \\
257 . \\
120 .\end{array}$ & & $\begin{array}{l}0.001 \\
0.001 \\
0.5 \\
0.001 \\
0.5\end{array}$ & : \\
\hline & MANGANESE & $\begin{array}{l}0202 \\
0202 \\
0202 \\
0203 \\
0203 \\
0203 \\
0203 \\
0204 \\
0204 \\
0204 \\
0204 \\
0205 \\
0205 \\
0205 \\
0206 \\
0206 \\
0206 \\
0207 \\
0207 \\
0514 \\
0515 \\
0515 \\
0515\end{array}$ & $\begin{array}{l}04 / 17 / 91 \\
12 / 11 / 91 \\
10 / 14 / 92 \\
04 / 17 / 91 \\
08 / 07 / 91 \\
12 / 11 / 91 \\
10 / 14 / 92 \\
04 / 17 / 91 \\
08 / 07 / 91 \\
12 / 11 / 91 \\
10 / 14 / 92 \\
04 / 17 / 91 \\
12 / 11 / 91 \\
10 / 14 / 92 \\
04 / 17 / 91 \\
08 / 07 / 91 \\
10 / 14 / 92 \\
08 / 07 / 91 \\
10 / 14 / 92 \\
01 / 12 / 89 \\
01 / 12 / 89 \\
04 / 17 / 91 \\
08 / 07 / 91\end{array}$ & $\begin{array}{l}0001 \\
0001 \\
0001 \\
0001 \\
0001 \\
0001 \\
0001 \\
0001 \\
0001 \\
0001 \\
0001 \\
0001 \\
0001 \\
0001 \\
0001 \\
0001 \\
0001 \\
0001 \\
0001 \\
0001 \\
0001 \\
0001 \\
0001\end{array}$ & $\begin{array}{l}A L \\
A L \\
A L \\
A L \\
A L \\
A L \\
A L \\
A L \\
A L \\
A L \\
A L \\
A L \\
A L \\
A L \\
A L \\
A L \\
A L \\
A L \\
A L \\
T A \\
T A \\
T A \\
T A\end{array}$ & $\begin{array}{l}N \\
N \\
N \\
N \\
N \\
N \\
N \\
N \\
N \\
N \\
N \\
N \\
N \\
N \\
N \\
N \\
0 \\
0 \\
0 \\
0\end{array}$ & $M G / L$ & $\mid \begin{array}{l}< \\
< \\
< \\
< \\
< \\
< \\
< \\
< \\
< \\
< \\
< \\
< \\
< \\
< \\
< \\
< \\
<\end{array}$ & $\begin{array}{l}0.05 \\
0.1 \\
0.05 \\
0.05 \\
0.1 \\
0.1 \\
0.05 \\
0.19 \\
0.18 \\
0.13 \\
0.16 \\
0.1 \\
0.2 \\
0.05 \\
0.01 \\
0.01 \\
0.01 \\
0.05 \\
0.05 \\
1.12 \\
0.63 \\
0.45 \\
0.28\end{array}$ & $\begin{array}{l}\text { I } \\
\text { I } \\
\text { I }\end{array}$ & $\begin{array}{l}0.05 \\
0.1 \\
0.05 \\
0.05 \\
0.1 \\
0.1 \\
0.05 \\
0.01 \\
0.01 \\
0.01 \\
0.01 \\
0.1 \\
0.2 \\
0.05 \\
0.01 \\
0.01 \\
0.01 \\
0.05 \\
0.05 \\
0.01 \\
0.01 \\
0.01 \\
0.01\end{array}$ & $\begin{array}{l}- \\
- \\
- \\
- \\
- \\
- \\
- \\
- \\
- \\
- \\
- \\
- \\
- \\
- \\
- \\
-\end{array}$ \\
\hline & MANGANESE (TOTAL) & $\begin{array}{l}0203 \\
0204 \\
0206 \\
0207 \\
0208 \\
0210 \\
0515\end{array}$ & $\begin{array}{l}12 / 12 / 90 \\
12 / 12 / 90 \\
12 / 12 / 90 \\
12 / 12 / 90 \\
10 / 14 / 92 \\
12 / 12 / 90 \\
10 / 14 / 92\end{array}$ & $\begin{array}{l}\text { N001 } \\
\text { N001 } \\
\text { N001 } \\
\text { N001 } \\
\text { N001 } \\
\text { N001 } \\
\text { N001 }\end{array}$ & $\begin{array}{l}A L \\
A L \\
A L \\
A L \\
M R \\
A L \\
T A\end{array}$ & $\begin{array}{l}N \\
N \\
N \\
N \\
N \\
N \\
0\end{array}$ & $M G / L$ & $<<$ & $\begin{array}{l}0.04 \\
0.14 \\
0.03 \\
0.03 \\
0.01 \\
0.36 \\
0.13\end{array}$ & & $\begin{array}{l}0.01 \\
0.01 \\
0.01 \\
0.01 \\
0.01 \\
0.01 \\
0.01\end{array}$ & $\begin{array}{l}: \\
: \\
-\end{array}$ \\
\hline & MERCURY & 0202 & $12 / 11 / 91$ & 0001 & AL & N & $M G / L$ & & - & $J$ & - & - \\
\hline
\end{tabular}

MATERIAL OF SAMPLING COOE:

AL - ALLUVILM

NR - NO RECOVERY OF DATA FOR CLASSIFYING

TA - URANIUM MILL TAILINGS

PARAMETER VALUE INDICATOR (PVI): < - LESS thaM DETECTION LIMIT

OTHER PARAMETER VALUE fLAGS:

I - INCREASED DETECTION LIMIT DUE TO REQUIRED DILUTION

I - INCREASED DETECTIC
FLON RELATIONSHIP COOE:

N - UNKNOW
0 - ON-SITE

SAMPLE ID COOES:

0001 - FILTERED SAMPLE (.45 MICRONS)

NOO1 - UNFILTERED SAMPLE 
TABLE 3.21 TAILINGS PORE FLUID HATER QUALITY DATA BY PARAMETER, NC AND UC PROCESSING SITES, SLICK ROCK, COLORADO

SITE: SRKO1 SLICK ROCK (BOTH SITES)

01/12/89 TO $10 / 14 / 92$

REPORT DATE: 06/17/93

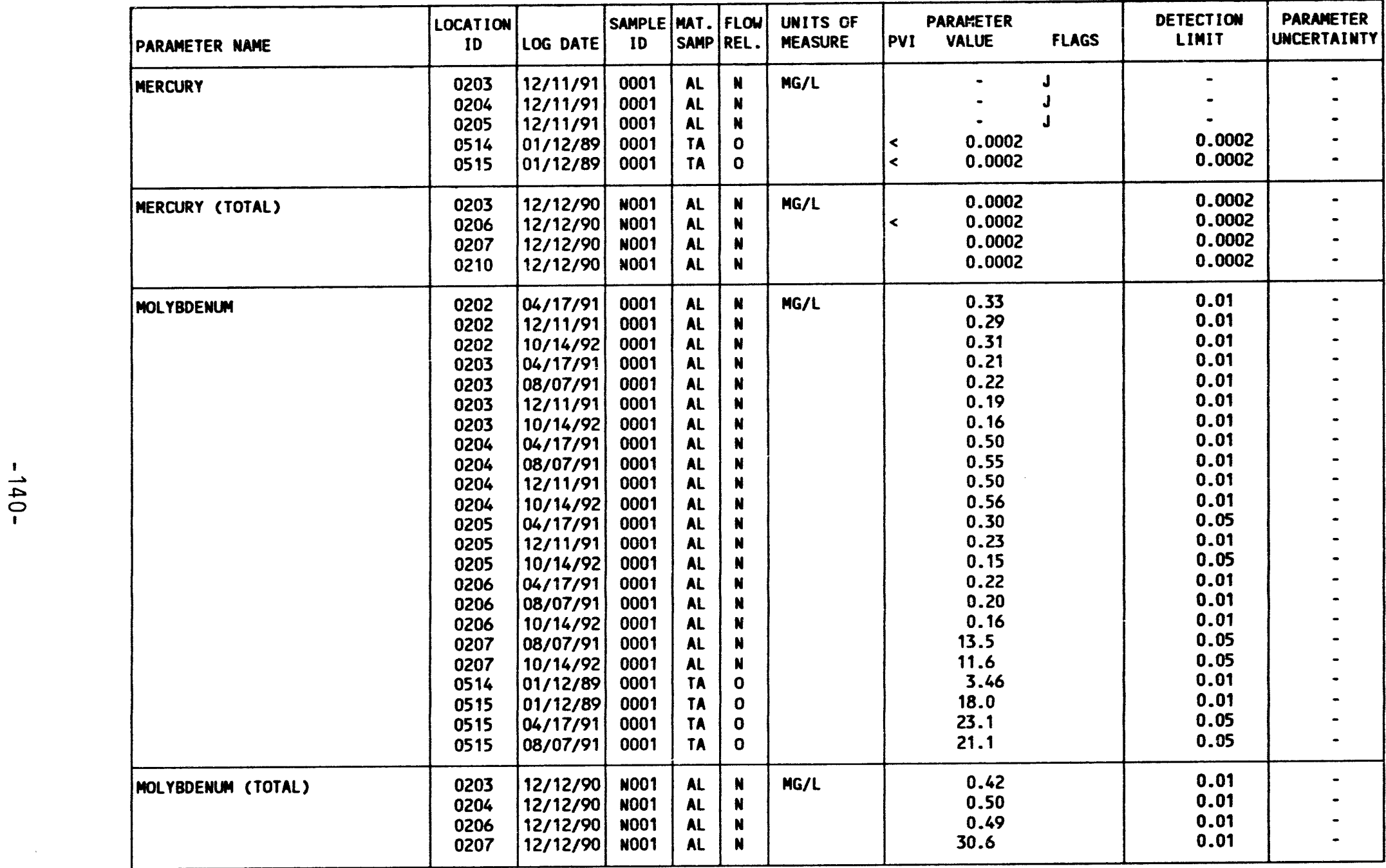

MATERIAL OF SAMPLING CODE:

AL - ALLUVIUUM

TA - URAMIUH MILL TAILINGS

PARAMETER VALUE INDICATOR (PVI): < - LESS than DETECTION LIMIT

OTHER PARAMETER VALUE FLAGS:

$J$ - ESTIMATED VALUE
FLOU RELATIONSHIP CODE:

N - UNKNOWN

SAMPLE ID CODES:

0001 - FILTERED SAMPLE (.45 MICRONS)

M001 - UNFILTERED SAMPLE 
TABLE 3.21 TAILINGS PORE FLUID MATER QUALITY DATA BY PARAMETER, MC AMD UC PROCESSING SITES, SLICK ROCK, COLORADO

SITE: SRKO1 SLICK ROCK (BOTH SITES)

01/12/89 TO 10/14/92

REPORT DATE: 06/17/93

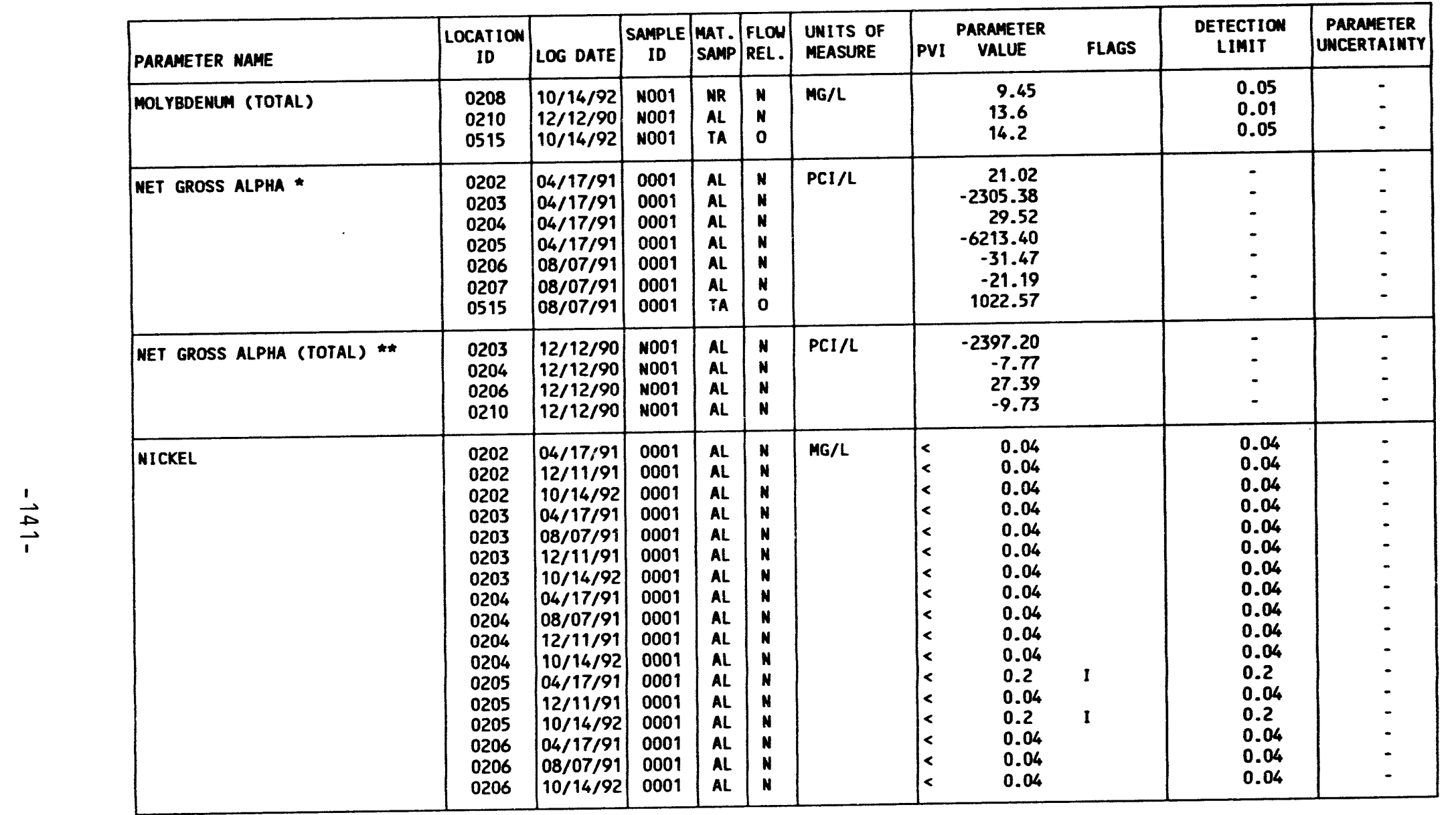

* MET GROSS ALPHA (GROSS ALPHA - URANIUM) WITH 1 MG URANIUM = 686 PCI

* MET GROSS ALPHA (TOTAL) (TOTAL GROSS ALPHA - TOTAL URANIUTA)

MATERIAL OF SAMPLING CODE:

MR - NO RECOVERY OF DATA FOR CLASSIFYING

AL - ALLUVIUM

TA - URANIUM MILL TAILINGS

PARAMETER VALUE INDICATOR (PVI): < - LESS THAN DETECTION LIMIT

OTHER PARAMETER VALUE FLAGS:

I - INCREASED DETECTION LIMIT DUE TO REQUIRED DILUTION
FLON RELATIONSHIP CCOE:

N - UNKNOWN

N - UNKNOWN
0 - ON-SITE

SAMPLE ID CODES:

0001 - FILTERED SAMPLE (.45 MICRONS)

N001 - UNFILTERED SAMPLE 
TABLE 3.21 TAILINGS PORE FLUID HATER QUALITY DATA BY PARAMETER, NC AND UC PROCESSING SITES, SLICK ROCK, COLORADO

SITE: SRKO1 SLICK ROCK (BOTH SITES)

SITE: SRKO1 SLICK ROCK

REPORT DATE: $06 / 17 / 93$

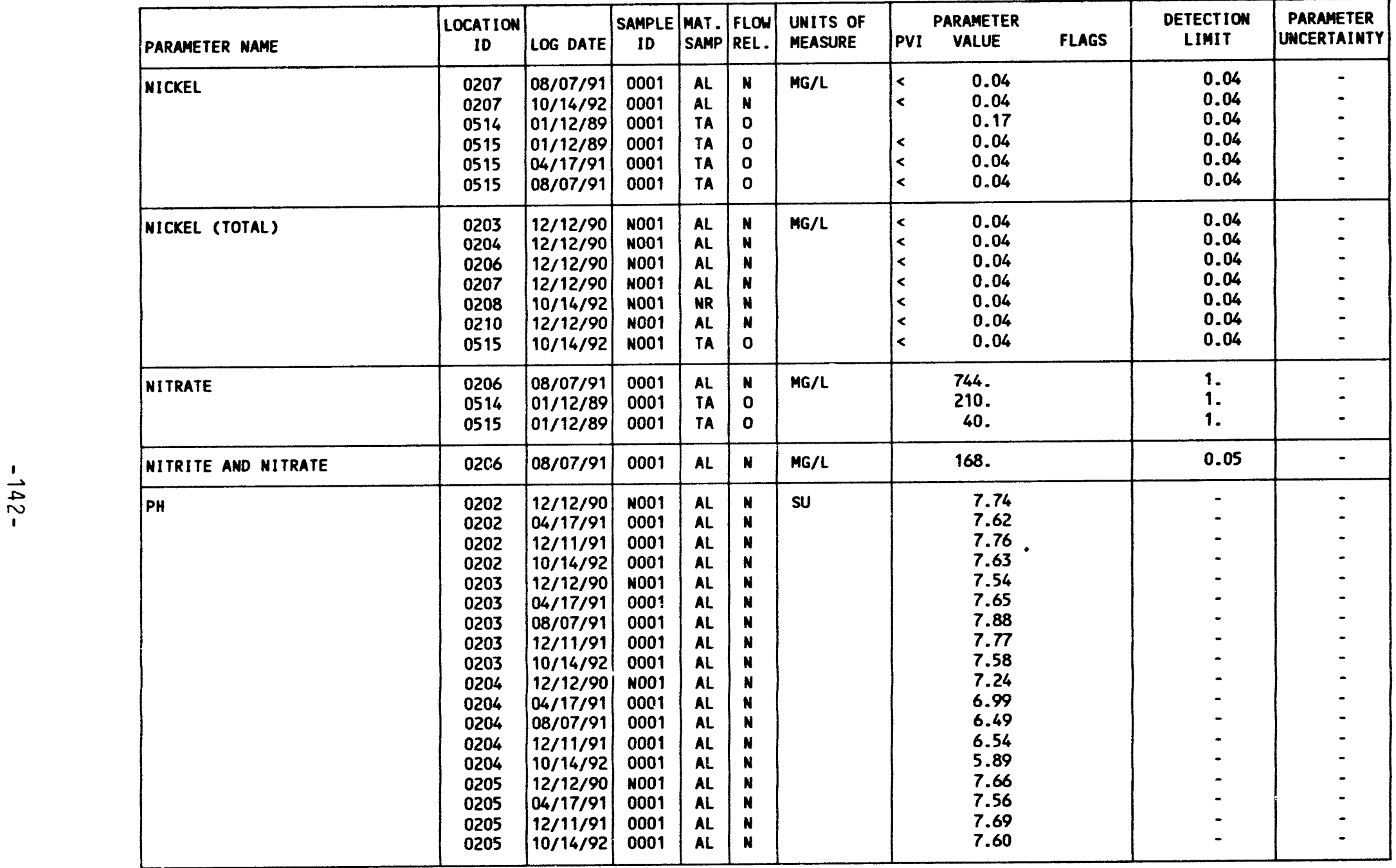

MATERIAL OF SAMPLING COOE:

AL - ALLUVIUM

TA - URANIUM MILL TAILINGS

NR - NO RECOVERY OF DATA FOR CLASSIFYING

PARAMETER VALUE INDICATOR (PVI): < - LESS THAN DETECTION LIMIT
FLON RELATIONSHIP COOE:

N - UNKNOWN
O - ON-SITE

SAMPLE ID COOES:

0001 - FILTERED SAMPLE (.45 MICRONS)

M001 - LINFILTERED SAMPLE 
TABLE 3.21 TAILINGS PORE FLUID MATER QUALITY DATA BY PARAMETER, NC AMD UC PROCESSING SITES, SLICK ROCK, COLORADO

SITE: SRKO1 SLICK ROCK (BOTH SITES)

01/12/89 TO $10 / 14 / 92$

REPORT DATE: 06/17/93

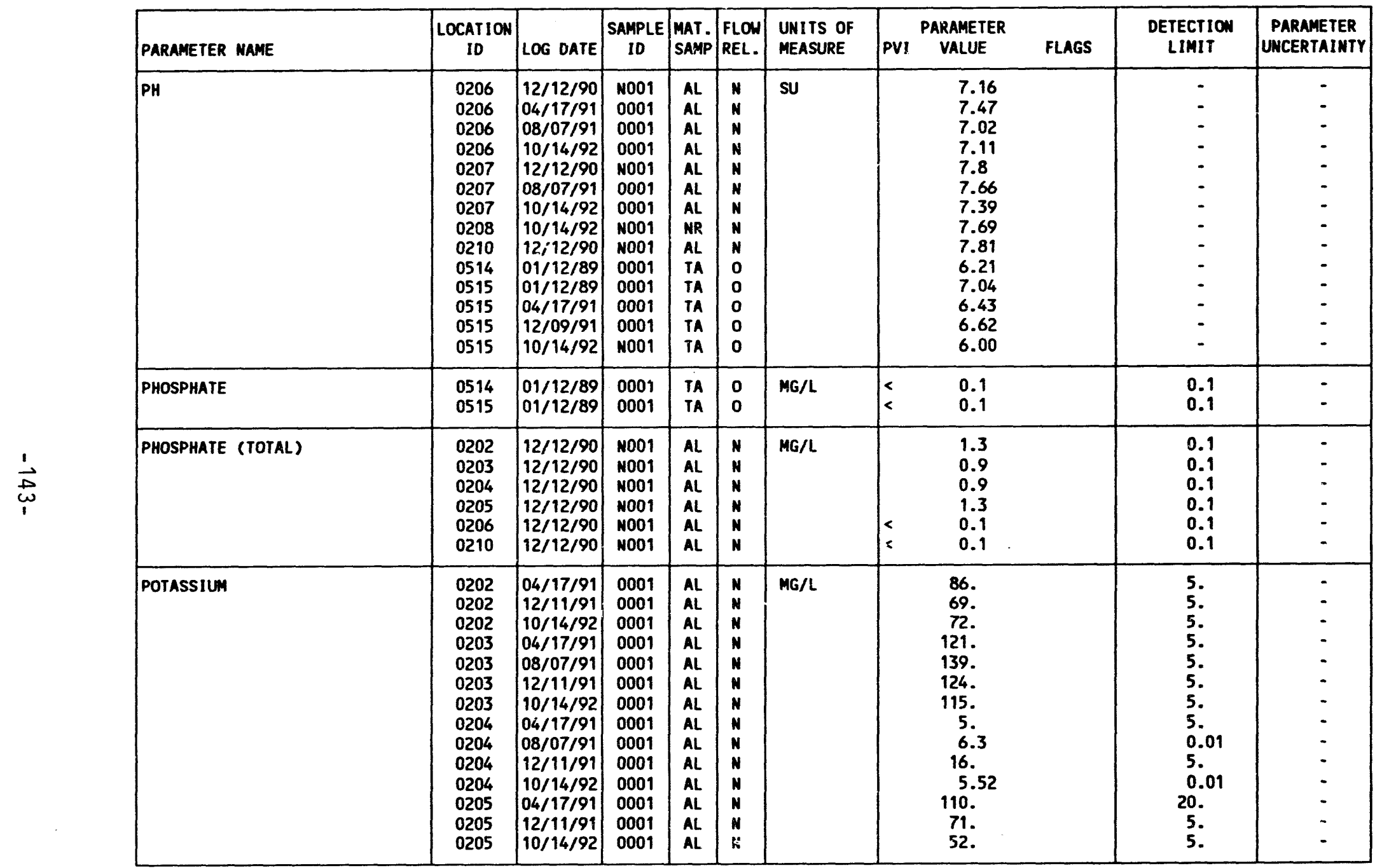

MATERIAL OF SAMPLING CODE:

AL - ALLUVIUM

NR - NO RECOVERY OF DATA FOR CLASSIFYING

TA - URANIUM MILL TAILINGS

PARAMETER VALUE INDICATOR (PVI): < - LESS than DETECTION LIMIT
FLOW RELATIONSHIP COOE:

N - UNKNOWN

SAMPLE ID CODES:

0001 - FILTERED SAMPLE (.45 MICRONS)

NO01 - UNFILTERED SAMPLE 
TABLE 3.21 TAILINGS PORE FLUID MATER QUALITY DATA BY PARAMETER, NC AND UC PROCESSING S!TES, SLICK ROCK, COLORADO

SITE: SRKO1 SLICK ROCK (BOTH SITES)

01/12/89 TO $10 / 14 / 92$

REPORT DATE: 06/17/93

\begin{tabular}{|c|c|c|c|c|c|c|c|c|c|c|}
\hline PARAMETER NAME & $\underset{\text { ID }}{\text { LOCATION }}$ & LOG DATE & $\begin{array}{c}\text { SAMPLE } \\
\text { ID }\end{array}$ & MAT. & $\begin{array}{l}\text { FLOW } \\
\text { REL. }\end{array}$ & $\begin{array}{l}\text { UNITS OF } \\
\text { MEASURE }\end{array}$ & $\begin{array}{ll} & \text { PARAMETER } \\
\text { PVI } & \text { VALUE }\end{array}$ & FLAGS & $\begin{array}{l}\text { DETECTION } \\
\text { LIMIT }\end{array}$ & $\begin{array}{l}\text { PARAMETER } \\
\text { UNCERTAINTY }\end{array}$ \\
\hline POTASSIUM & $\begin{array}{l}0206 \\
0206 \\
0206 \\
0207 \\
0207 \\
0514 \\
0515 \\
0515 \\
0515\end{array}$ & $\begin{array}{l}04 / 17 / 91 \\
08 / 07 / 91 \\
10 / 14 / 92 \\
08 / 07 / 91 \\
10 / 14 / 92 \\
01 / 12 / 89 \\
01 / 12 / 89 \\
04 / 17 / 91 \\
08 / 07 / 91\end{array}$ & $\begin{array}{l}0001 \\
0001 \\
0001 \\
0001 \\
0001 \\
0001 \\
0001 \\
0001 \\
0001\end{array}$ & $\begin{array}{l}A L \\
A L \\
A L \\
A L \\
A L \\
T A \\
T A \\
T A \\
T A\end{array}$ & $\begin{array}{l}N \\
N \\
N \\
N \\
N \\
0 \\
0 \\
0 \\
0\end{array}$ & MG $/ L$ & $\begin{array}{l}5.2 \\
4.7 \\
3.61 \\
4.8 \\
3.34 \\
6.3 \\
2.1 \\
4.1 \\
4.7\end{array}$ & & $\begin{array}{l}0.1 \\
0.01 \\
0.01 \\
0.01 \\
0.01 \\
0.01 \\
0.01 \\
0.1 \\
0.01\end{array}$ & $\begin{array}{l}: \\
: \\
: \\
- \\
-\end{array}$ \\
\hline POTASSIUM (TOTAL) & $\begin{array}{l}0203 \\
0204 \\
0206 \\
0207 \\
0210\end{array}$ & $\begin{array}{l}12 / 12 / 90 \\
12 / 12 / 90 \\
12 / 12 / 90 \\
12 / 12 / 90 \\
12 / 12 / 90\end{array}$ & $\begin{array}{l}\text { N001 } \\
\text { N001 } \\
\text { N001 } \\
\text { N001 } \\
\text { N001 }\end{array}$ & $\begin{array}{l}A L \\
A L \\
A L \\
A L \\
A L\end{array}$ & $\begin{array}{l}N \\
N \\
N \\
N \\
N\end{array}$ & MG/L & $\begin{array}{r}175 . \\
7.2 \\
8.2 \\
28.4 \\
10.6\end{array}$ & & $\begin{array}{l}0.01 \\
0.01 \\
0.01 \\
0.01 \\
0.01\end{array}$ & : \\
\hline RADIUM-228 & $\begin{array}{l}0202 \\
0203 \\
0204\end{array}$ & $\begin{array}{l}10 / 14 / 92 \\
10 / 14 / 92 \\
10 / 14 / 92\end{array}$ & $\begin{array}{l}0001 \\
0001 \\
0001\end{array}$ & $\begin{array}{l}A L \\
A L \\
A L\end{array}$ & $\begin{array}{l}\mathrm{N} \\
\mathrm{N} \\
\mathrm{N}\end{array}$ & $\mathrm{PCI} / \mathrm{L}$ & $\begin{array}{l}5.8 \\
0.0 \\
0.0\end{array}$ & & $\begin{array}{l}4.4 \\
4.4 \\
4.4\end{array}$ & $\begin{array}{l}2.8 \\
2.5 \\
2.5\end{array}$ \\
\hline REDOX POTENTIAL & $\begin{array}{l}0202 \\
0203 \\
0204 \\
0205 \\
0206 \\
0207\end{array}$ & $\begin{array}{l}12 / 12 / 90 \\
12 / 12 / 90 \\
12 / 12 / 90 \\
12 / 12 / 90 \\
12 / 12 / 90 \\
12 / 12 / 90\end{array}$ & $\begin{array}{l}\text { NO01 } \\
\text { NO01 } \\
\text { N001 } \\
\text { N001 } \\
\text { N001 } \\
\text { N001 }\end{array}$ & $\begin{array}{l}A L \\
A L \\
A L \\
A L \\
A L \\
A L\end{array}$ & $\begin{array}{l}N \\
N \\
N \\
N \\
N \\
N\end{array}$ & mVOLTS & $\begin{array}{l}420.5 \\
442.7 \\
487.8 \\
432.1 \\
406.3 \\
324.7\end{array}$ & & $\begin{array}{l}- \\
- \\
- \\
-\end{array}$ & $\begin{array}{l}- \\
- \\
-\end{array}$ \\
\hline SELENIUM & $\begin{array}{l}0202 \\
0202 \\
0202 \\
0203 \\
0203 \\
0203 \\
0203 \\
0204 \\
0204 \\
0204 \\
0204 \\
0205 \\
0205\end{array}$ & $\begin{array}{l}04 / 17 / 91 \\
12 / 11 / 91 \\
10 / 14 / 92 \\
04 / 17 / 91 \\
08 / 07 / 91 \\
12 / 11 / 91 \\
10 / 14 / 92 \\
04 / 17 / 91 \\
08 / 07 / 91 \\
12 / 11 / 91 \\
10 / 14 / 92 \\
04 / 17 / 91 \\
12 / 11 / 91\end{array}$ & $\begin{array}{l}0001 \\
0001 \\
0001 \\
0001 \\
0001 \\
0001 \\
0001 \\
0001 \\
0001 \\
0001 \\
0001 \\
0001 \\
0001\end{array}$ & $\begin{array}{l}A L \\
A L \\
A L \\
A L \\
A L \\
A L \\
A L \\
A L \\
A L \\
A L \\
A L \\
A L \\
A L\end{array}$ & $\begin{array}{l}N \\
N \\
N \\
N \\
N \\
N \\
N \\
N \\
N \\
N \\
N \\
N \\
N \\
N\end{array}$ & $M G / L$ & $\begin{array}{c}6.0 \\
10 . \\
7.0 \\
6.0 \\
6.5 \\
13 . \\
6.0 \\
1.3 \\
1.5 \\
2.4 \\
3 . \\
0.140 \\
2.6\end{array}$ & & $\begin{array}{l}0.5 \\
5.0 \\
0.5 \\
0.5 \\
0.5 \\
5 . \\
0.5 \\
0.1 \\
0.1 \\
0.5 \\
1 . \\
0.005 \\
0.5\end{array}$ & $\begin{array}{l}- \\
- \\
- \\
- \\
- \\
- \\
- \\
- \\
-\end{array}$ \\
\hline
\end{tabular}

MATERIAL OF SAMPLING COOE:

TA - URANIUM MILL TAILINGS

FLOW RELATIONSHIP CODE

O - ON-SITE

PARAMETER VALUE INDICATOR (PVI): < - LESS THAN DETECTION LIMIT 


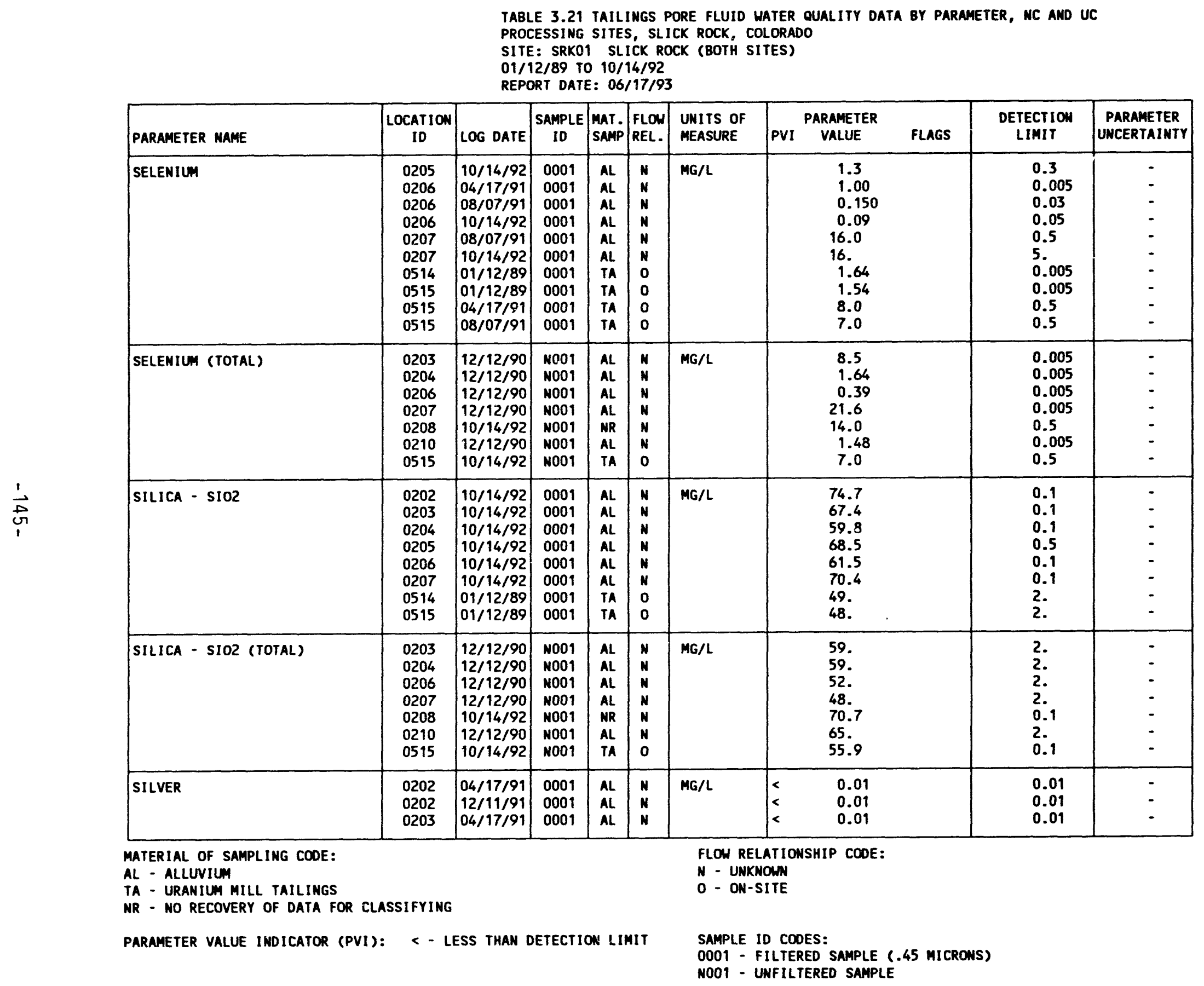


TABLE 3.21 TAILINGS PORE FLUID MATER QUALITY DATA BY PARAMETER, NC AND UC PROCESSING SITES, SLICK ROCK, COLORADO

SITE: SRKO1 SLICK ROCK (BOTH SITES)

$01 / 12 / 89$ TO $10 / 14 / 92$

REPORT DATE: $06 / 17 / 93$

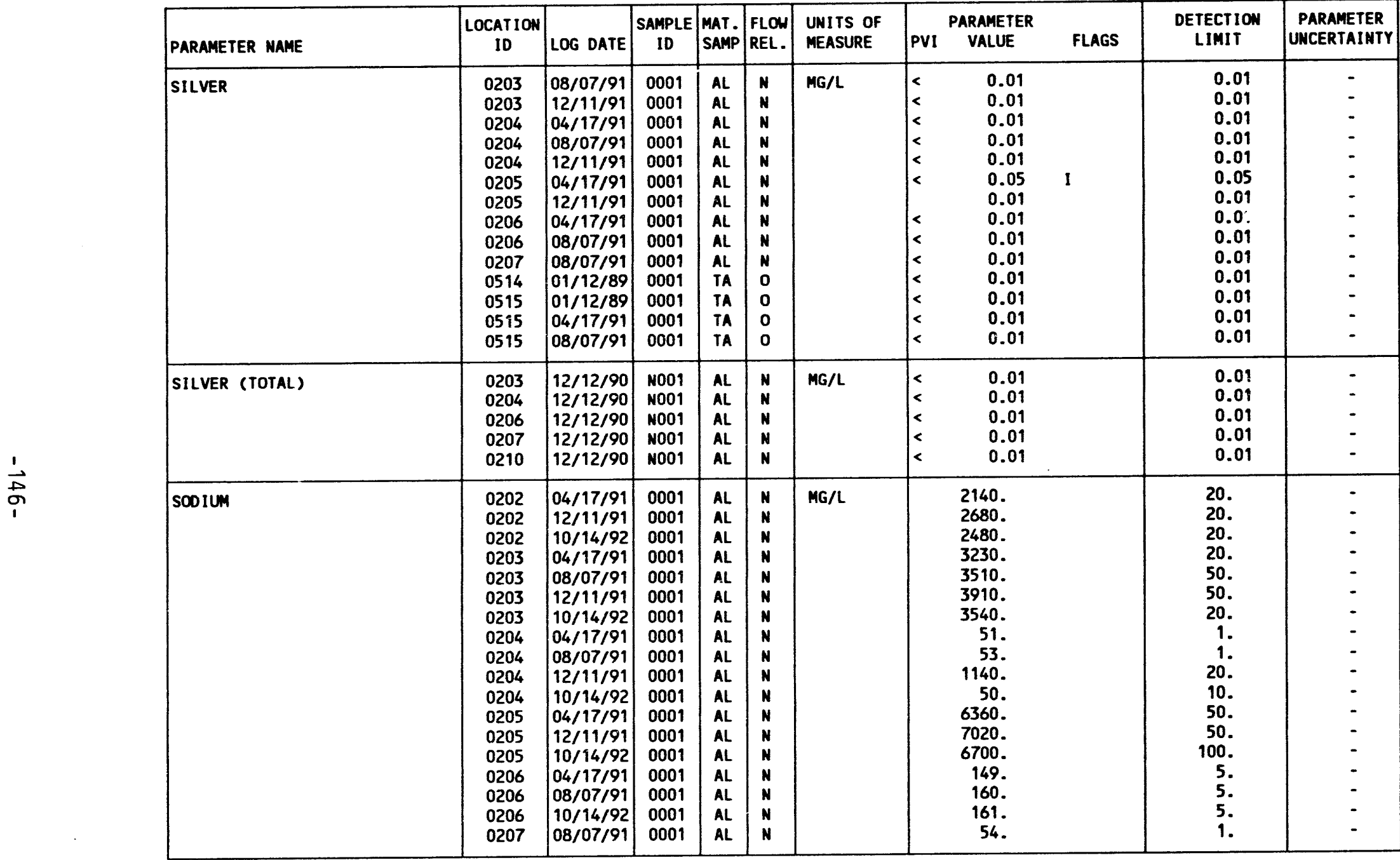

MATERIAL OF SAMPLING CODE:

AL - ALLUVIUM

TA - URANIUM MILL TAILINGS

PARAMETER VALUE IMDICATOR (PVI): < - LESS THAN DETECTION LIMIT

OTHER PARAMETER VALUE FLAGS:

I - INCREASED DETECTION LIMIT DUE TO REQUIRED DILUTION
FLOW RELATIONSHIP CODE:

N - UNKNONN
O - ON-SITE

SAMPLE ID COOES:

0001 - FILTERED SAMPLE (.45 MICRONS)

M001 - UNFILTERED SAMPLE 


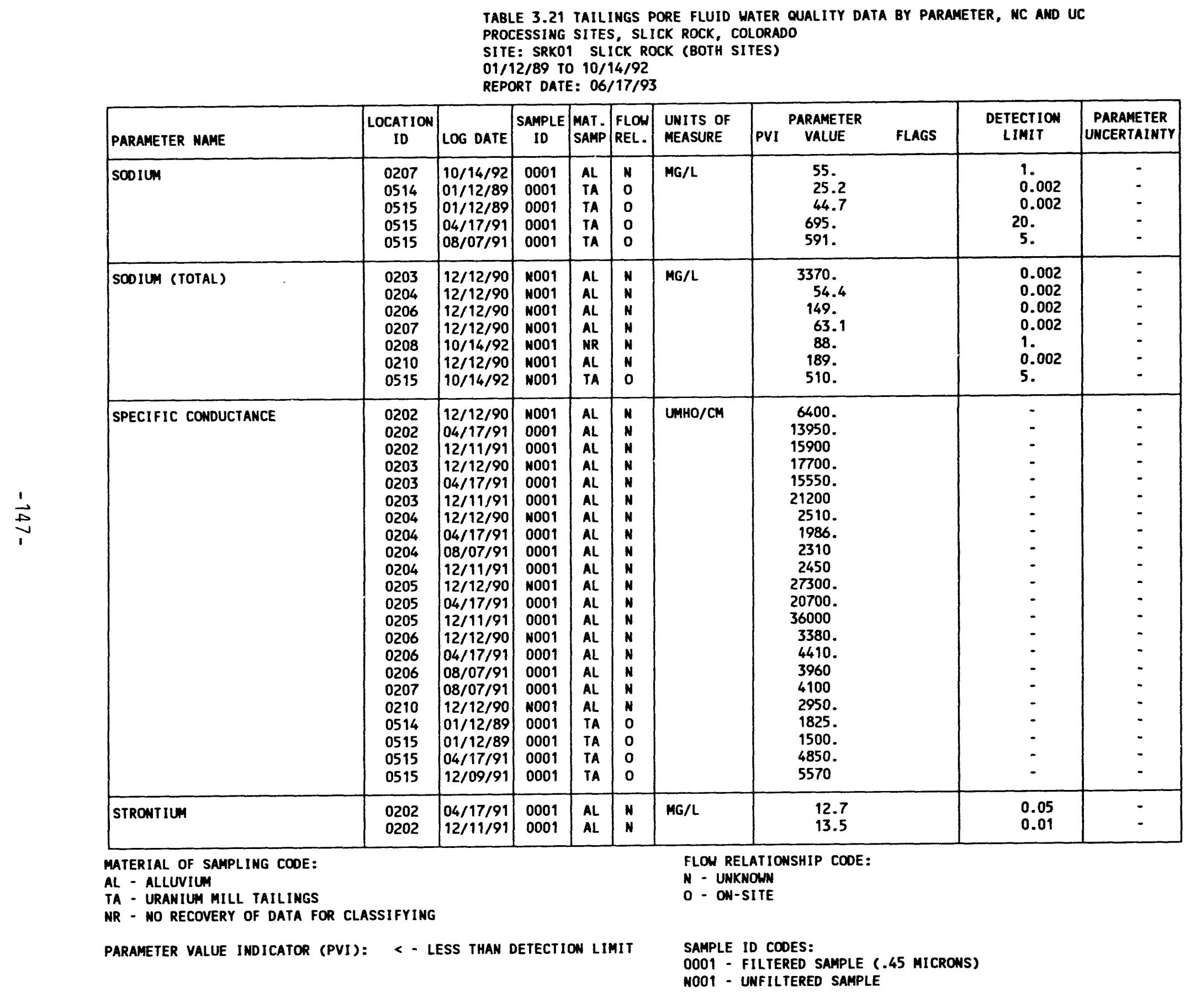


TABLE 3.21 TAILINGS PORE FLUID MATER QUALITY DATA BY PARAMETER, NC AND UC PROCESSING SITES, SLICK ROCK, COLORADO

SITE: SRKO1 SLICK ROCK (BOTH SITES)

$01 / 12 / 89$ TO $10 / 14 / 92$

REPOPT DATE: $06 / 17 / 93$

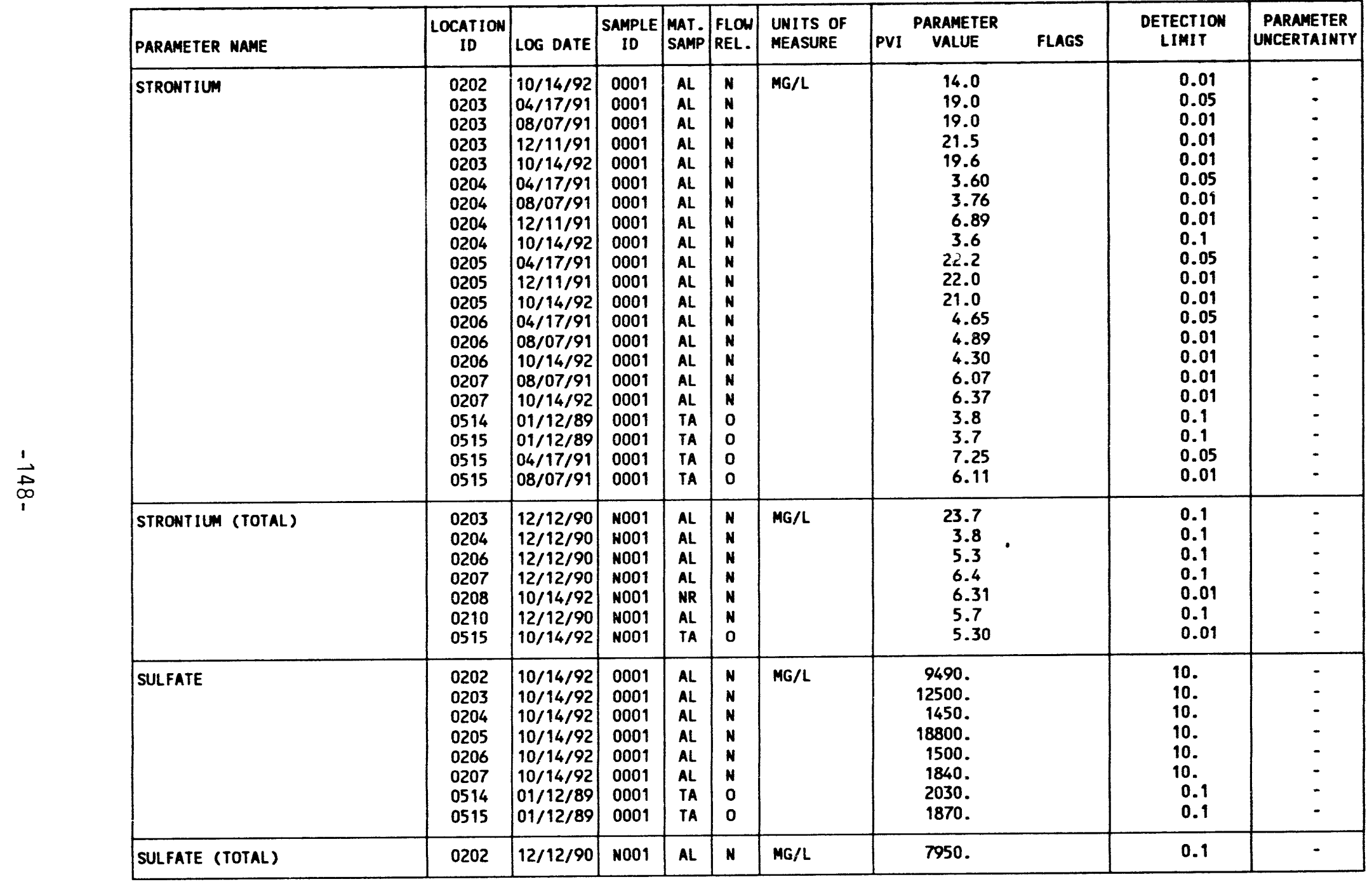

MATERIAL OF SAMPLING COOE:

AL - ALLUVIUA

TA - URANIUM MILL TAILINGS

FLOW RELATIONSHIP COOE:

o - ON-SITE

MR - NO RECOVERY OF DATA FOR CLASSIFYING

PARAMETER VALUE INDICATOR (PVI): < - LESS than DETECTION LIMIT

SAMPLE ID CODES:

0001 - FILTERED SAMPLE (.45 MICRONS)

N001 - UNFILTERED SAMPLE 
TABLE 3.21 TAILINGS PORE FLUID WATER QUALITY DATA BY PARAMETER, NC AND UC PROCESSING SITES, SLICK ROCK, COLORADO

SITE: SRKO1 SLICK ROCK (BOTH SITES)

01/12/89 TO $10 / 14 / 92$

REPORT DATE: $06 / 17 / 93$

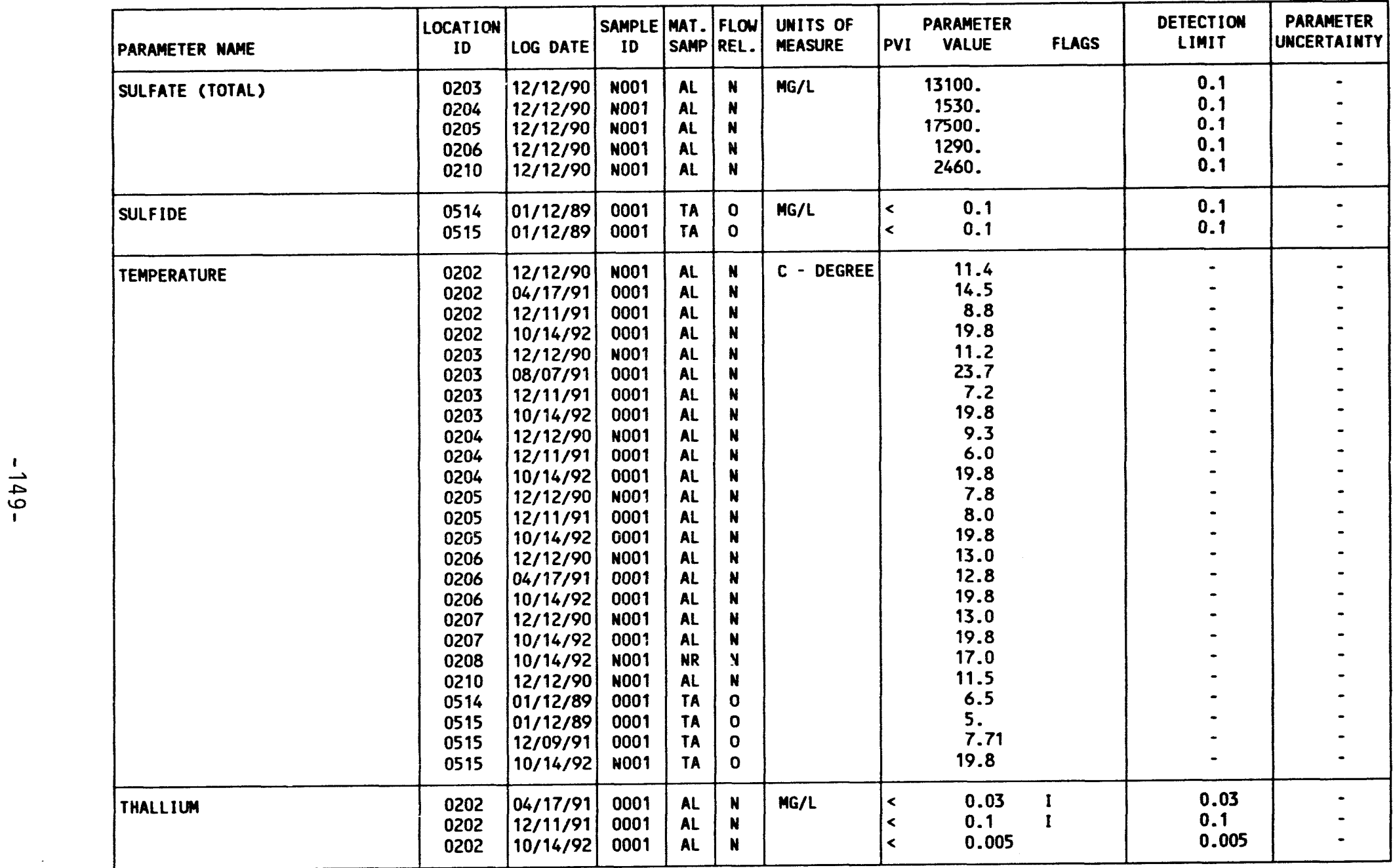

MATERIAL OF SAMPLING COOE:

AL - ALLUVIUM

TA - UHANIUM MILL TAILINGS

NR - NO RECOVERY OF DATA FOR CLASSIFYING

PARAMETER VALUE INDICATOR (PVI): < - LESS THAN DETECTION LIMIT

OTHER PARAMETER VALUE FLAGS:

I - INCREASED DETECTION LIMIT DUE TO REQUIRED DILUTION
FLOW RELATIONSHIP COOE:

N - UNKNOWN
O - ON-SITE

SAMPLE ID CODES:

0001 - FILTERED SAMPLE (.45 MICRONS)

N001 - UNFILTERED SAMPLE 
TABLE 3.21 TAILINGS PORE FLUID WATER QUALITY DATA BY PARAMETER, MC AND UC PROCESSING SITES, SLICK ROCK, COLORADO

SITE: SRK01 SLICK ROCK (BOTH SITES)

01/12/89 TO $10 / 14 / 92$

PEPORT DATE: $06 / 17 / 93$

\begin{tabular}{|c|c|c|c|c|c|c|c|c|c|c|c|c|}
\hline & PARAMETER NAME & $\underset{\text { ID }}{\text { LOCATION }}$ & LOG DATE & $\begin{array}{c}\text { SAMPLE } \\
\text { ID }\end{array}$ & $\begin{array}{l}\text { MAT. } \\
\text { SAMP }\end{array}$ & $\begin{array}{l}\text { FLOW } \\
\text { REL. }\end{array}$ & $\begin{array}{l}\text { UNITS OF } \\
\text { MEASURE }\end{array}$ & PVI & $\begin{array}{l}\text { PARAMETER } \\
\text { VALUE }\end{array}$ & FLAGS & $\begin{array}{l}\text { DETECTION } \\
\text { LIMIT }\end{array}$ & $\begin{array}{l}\text { PARAMETER } \\
\text { UNCERTAINTY }\end{array}$ \\
\hline & THALLIUM & $\begin{array}{l}0203 \\
0203 \\
0203 \\
0203 \\
0204 \\
0204 \\
0204 \\
0204 \\
0205 \\
0205 \\
0205 \\
0206 \\
0206 \\
0206 \\
0207 \\
0207 \\
0514 \\
0515 \\
0515 \\
0515\end{array}$ & $\begin{array}{l}04 / 17 / 91 \\
08 / 07 / 91 \\
12 / 11 / 91 \\
10 / 14 / 92 \\
04 / 17 / 91 \\
08 / 07 / 91 \\
12 / 11 / 91 \\
10 / 14 / 92 \\
04 / 17 / 91 \\
12 / 11 / 91 \\
10 / 14 / 92 \\
04 / 17 / 91 \\
08 / 07 / 91 \\
10 / 14 / 92 \\
08 / 07 / 91 \\
10 / 14 / 92 \\
01 / 12 / 89 \\
01 / 12 / 89 \\
04 / 17 / 91 \\
08 / 07 / 91\end{array}$ & $\begin{array}{l}0001 \\
0001 \\
0001 \\
0001 \\
0001 \\
0001 \\
0001 \\
0001 \\
0001 \\
0001 \\
0001 \\
0001 \\
0001 \\
0001 \\
0001 \\
0001 \\
0001 \\
0001 \\
0001 \\
0001\end{array}$ & $\begin{array}{l}A L \\
A L \\
A L \\
A L \\
A L \\
A L \\
A L \\
A L \\
A L \\
A L \\
A L \\
A L \\
A L \\
A L \\
A L \\
A L \\
T A \\
T A \\
T A \\
T A\end{array}$ & $\begin{array}{l}N \\
N \\
N \\
N \\
N \\
N \\
N \\
N \\
N \\
N \\
N \\
N \\
N \\
N \\
N \\
0 \\
0 \\
0 \\
0\end{array}$ & $M G / L$ & $\begin{array}{l}< \\
< \\
< \\
< \\
< \\
< \\
< \\
< \\
< \\
< \\
< \\
< \\
< \\
< \\
< \\
< \\
< \\
< \\
< \\
< \\
<\end{array}$ & $\begin{array}{l}0.03 \\
0.01 \\
0.1 \\
0.02 \\
0.01 \\
0.01 \\
0.1 \\
0.005 \\
0.1 \\
0.1 \\
0.02 \\
0.01 \\
0.05 \\
0.005 \\
0.01 \\
0.005 \\
0.01 \\
0.01 \\
0.01 \\
0.01\end{array}$ & $\begin{array}{l}1 \\
1 \\
1 \\
1 \\
1 \\
1 \\
1 \\
1\end{array}$ & $\begin{array}{l}0.03 \\
0.01 \\
0.1 \\
0.02 \\
0.01 \\
0.01 \\
0.1 \\
0.005 \\
0.1 \\
0.1 \\
0.02 \\
0.01 \\
0.05 \\
0.005 \\
0.01 \\
0.005 \\
0.01 \\
0.01 \\
0.01 \\
0.01\end{array}$ & $\begin{array}{l}- \\
- \\
: \\
: \\
- \\
- \\
- \\
- \\
- \\
- \\
- \\
- \\
- \\
-\end{array}$ \\
\hline & THALLIUM (TOTAL) & $\begin{array}{l}0203 \\
0204 \\
0206 \\
0207 \\
0208 \\
0210\end{array}$ & $\begin{array}{l}12 / 12 / 90 \\
12 / 12 / 90 \\
12 / 12 / 90 \\
12 / 12 / 90 \\
10 / 14 / 92 \\
12 / 12 / 90\end{array}$ & $\begin{array}{l}\text { N001 } \\
\text { N001 } \\
\text { N001 } \\
\text { N001 } \\
\text { N001 } \\
\text { N001 }\end{array}$ & $\begin{array}{l}A L \\
A L \\
A L \\
A L \\
N R \\
A L\end{array}$ & $\begin{array}{l}N \\
N \\
N \\
N \\
N \\
N\end{array}$ & $M G / L$ & $\mid \begin{array}{l}< \\
< \\
< \\
< \\
< \\
<\end{array}$ & $\begin{array}{l}0.01 \\
0.01 \\
0.01 \\
0.01 \\
0.005 \\
0.01\end{array}$ & & $\begin{array}{l}0.01 \\
0.01 \\
0.01 \\
0.01 \\
0.005 \\
0.01\end{array}$ & $\begin{array}{l}- \\
- \\
- \\
-\end{array}$ \\
\hline & TIN & $\begin{array}{l}0202 \\
0202 \\
0202 \\
0203 \\
0203 \\
0203 \\
0203 \\
0204 \\
0204 \\
0204\end{array}$ & $\begin{array}{l}04 / 17 / 91 \\
12 / 11 / 91 \\
10 / 14 / 92 \\
04 / 17 / 91 \\
08 / 07 / 91 \\
12 / 11 / 91 \\
10 / 14 / 92 \\
04 / 17 / 91 \\
08 / 07 / 91 \\
12 / 11 / 91\end{array}$ & $\begin{array}{l}0001 \\
0001 \\
0001 \\
0001 \\
0001 \\
0001 \\
0001 \\
0001 \\
0001 \\
0001\end{array}$ & $\begin{array}{l}A L \\
A L \\
A L \\
A L \\
A L \\
A L \\
A L \\
A L \\
A L \\
A L\end{array}$ & $\begin{array}{l}N \\
N \\
N \\
N \\
N \\
N \\
N \\
N \\
N \\
N\end{array}$ & $M G / L$ & $\begin{array}{l}< \\
< \\
< \\
< \\
< \\
< \\
< \\
< \\
< \\
<\end{array}$ & $\begin{array}{l}0.05 \\
0.5 \\
0.2 \\
0.05 \\
0.3 \\
0.03 \\
0.2 \\
0.01 \\
0.005 \\
0.03\end{array}$ & $\begin{array}{l}1 \\
1 \\
1 \\
1 \\
1 \\
1 \\
1 \\
1 \\
1\end{array}$ & $\begin{array}{l}0.05 \\
0.5 \\
0.2 \\
0.05 \\
0.3 \\
0.03 \\
0.2 \\
0.01 \\
0.005 \\
0.03\end{array}$ & $\begin{array}{l}- \\
- \\
- \\
- \\
- \\
- \\
-\end{array}$ \\
\hline
\end{tabular}

MATERIAL OF SAMPLING COOE:

AL - ALLUVIUM

TA - URANIUM MILL TAILINGS

NR - NO RECOVERY OF DATA FOR CLASSIFYING

FLOW RELATIONSHIP CODE:

N - UNKNOWN
O - ON-SITE

PARAMETER VALUE INDICATOR (PVI): < - LESS THAN DETECTION LIMIT

SAMPLE ID CODES:

0001 - FILTERED SAMPLE (.45 MICRONS)

OTHER PARAMETER VALUE FLAGS:

N001 - UNFILTERED SAMPLE

1. INCREASED DETECTION LIMIT DUE TO REQUIRED DILUTION 
TABLE 3.21 TAILINGS PORE FLUID WATER QUALITY DATA BY PARAMETER, NC AND UC PROCESSING SITES, SLICK ROCK, COLORADO

SITE: SRKO1 SLICK ROCK (BOTH SITES)

$01 / 12 / 89$ TO $10 / 14 / 92$

REPORT DATE: $06 / 17 / 93$

\begin{tabular}{|c|c|c|c|c|c|c|c|c|c|c|c|}
\hline PARAMETER NAME & $\begin{array}{c}\text { LOCATION } \\
\text { ID }\end{array}$ & LOG DATE & $\begin{array}{c}\text { SAMPLE } \\
\text { ID }\end{array}$ & $\begin{array}{l}\text { MAT. } \\
\text { SAMPP }\end{array}$ & $\begin{array}{l}\text { FLOW } \\
\text { REL. }\end{array}$ & $\begin{array}{l}\text { UNITS OF } \\
\text { MEASURE }\end{array}$ & PVI & $\begin{array}{l}\text { PARAMETER } \\
\text { VALUE }\end{array}$ & FLAGS & $\begin{array}{l}\text { DETECTION } \\
\text { LIMIT }\end{array}$ & $\begin{array}{l}\text { PARAMETER } \\
\text { UNCERTAINTY }\end{array}$ \\
\hline TIN & $\begin{array}{l}0204 \\
0205 \\
0205 \\
0205 \\
0206 \\
0206 \\
0206 \\
0207 \\
0207 \\
0514 \\
0515 \\
0515 \\
0515\end{array}$ & $\begin{array}{l}10 / 14 / 92 \\
04 / 17 / 91 \\
12 / 11 / 91 \\
10 / 14 / 92 \\
04 / 17 / 91 \\
08 / 07 / 91 \\
10 / 14 / 92 \\
08 / 07 / 91 \\
10 / 14 / 92 \\
01 / 12 / 89 \\
01 / 12 / 89 \\
04 / 17 / 91 \\
08 / 07 / 91\end{array}$ & $\begin{array}{l}0001 \\
0001 \\
0001 \\
0001 \\
0001 \\
0001 \\
0001 \\
0001 \\
0001 \\
0001 \\
0001 \\
0001 \\
0001\end{array}$ & $\begin{array}{l}A L \\
A L \\
A L \\
A L \\
A L \\
A L \\
A L \\
A L \\
A L \\
T A \\
T A \\
T A \\
T A\end{array}$ & $\begin{array}{l}N \\
N \\
N \\
N \\
N \\
N \\
N \\
N \\
N \\
0 \\
0 \\
0 \\
0\end{array}$ & MG/L & $\begin{array}{l}< \\
< \\
< \\
< \\
< \\
< \\
< \\
< \\
< \\
< \\
< \\
<\end{array}$ & $\begin{array}{l}0.005 \\
0.05 \\
0.5 \\
0.2 \\
0.01 \\
0.01 \\
0.005 \\
0.005 \\
0.05 \\
0.006 \\
0.008 \\
0.01 \\
0.05\end{array}$ & $\begin{array}{l}1 \\
1 \\
1 \\
1 \\
1 \\
1 \\
1 \\
1\end{array}$ & $\begin{array}{l}0.005 \\
0.05 \\
0.5 \\
0.2 \\
0.01 \\
0.01 \\
0.005 \\
0.005 \\
0.05 \\
0.005 \\
0.005 \\
0.01 \\
0.05\end{array}$ & $\begin{array}{l}- \\
- \\
- \\
- \\
- \\
- \\
- \\
- \\
- \\
-\end{array}$ \\
\hline TIN (TOTAL) & $\begin{array}{l}0203 \\
0204 \\
0206 \\
0207 \\
0210\end{array}$ & $\left|\begin{array}{l}12 / 12 / 90 \\
12 / 12 / 90 \\
12 / 12 / 90 \\
12 / 12 / 90 \\
12 / 12 / 90\end{array}\right|$ & $\begin{array}{l}\text { N001 } \\
\text { N001 } \\
\text { N001 } \\
\text { N001 } \\
\text { N001 }\end{array}$ & $\begin{array}{l}\text { AL } \\
\text { AL } \\
\text { AL } \\
\text { AL } \\
\text { AL }\end{array}$ & $\begin{array}{l}N \\
N \\
N \\
N \\
N\end{array}$ & MG/L & $<$ & $\begin{array}{l}0.012 \\
0.012 \\
0.005 \\
0.005 \\
0.15\end{array}$ & & $\begin{array}{l}0.005 \\
0.005 \\
0.005 \\
0.005 \\
0.005\end{array}$ & : \\
\hline TOTAL DISSOLVED SOLIDS & $\begin{array}{l}0202 \\
0203 \\
0204 \\
0205 \\
0206 \\
0207 \\
0514 \\
0515\end{array}$ & $\begin{array}{l}10 / 14 / 92 \\
10 / 14 / 92 \\
10 / 14 / 92 \\
10 / 14 / 92 \\
10 / 14 / 92 \\
10 / 14 / 92 \\
01 / 12 / 89 \\
01 / 12 / 89\end{array}$ & $\begin{array}{l}0001 \\
0001 \\
0001 \\
0001 \\
0001 \\
0001 \\
0001 \\
0001\end{array}$ & $\begin{array}{l}A L \\
A L \\
A L \\
A L \\
A L \\
A L \\
T A \\
T A\end{array}$ & $\begin{array}{l}N \\
N \\
N \\
N \\
N \\
N \\
0 \\
0\end{array}$ & MG/L & & $\begin{array}{l}16300 . \\
22300 . \\
2430 . \\
33900 . \\
3520 . \\
4100 . \\
3130 . \\
2800 .\end{array}$ & $\begin{array}{l}H \\
H \\
H \\
H \\
H \\
H\end{array}$ & $\begin{array}{l}10 . \\
10 . \\
10 . \\
10 . \\
10 . \\
10 . \\
10 . \\
10 .\end{array}$ & $\begin{array}{l}- \\
- \\
- \\
- \\
-\end{array}$ \\
\hline TOTAL KJELDAHL NITROGEN & 0206 & $08 / 07 / 91$ & 0001 & AL & N & $M G / L$ & & 1. & & 1. & - \\
\hline URANIUM & $\begin{array}{l}0202 \\
0202 \\
0203 \\
0203 \\
0204 \\
0204 \\
0205\end{array}$ & $\begin{array}{l}04 / 17 / 91 \\
10 / 14 / 92 \\
04 / 17 / 91 \\
10 / 14 / 92 \\
04 / 17 / 91 \\
10 / 14 / 92 \\
04 / 17 / 91\end{array}$ & $\begin{array}{l}0001 \\
0001 \\
0001 \\
0001 \\
0001 \\
0001 \\
0001\end{array}$ & $\begin{array}{l}\text { AL } \\
A L \\
A L \\
A L \\
A L \\
A L \\
A L\end{array}$ & $\begin{array}{l}N \\
N \\
N \\
N \\
N \\
N \\
N\end{array}$ & $M G / L$ & $<$ & $\begin{array}{c}2.93 \\
5.19 \\
9.33 \\
10.7 \\
0.023 \\
0.001 \\
20.4\end{array}$ & & $\begin{array}{l}0.001 \\
0.001 \\
0.001 \\
0.001 \\
0.001 \\
0.001 \\
0.001\end{array}$ & $\begin{array}{l}- \\
- \\
- \\
- \\
-\end{array}$ \\
\hline
\end{tabular}

MATERIAL OF SAMPLING COOE:

AL - ALLUVIUM

TA - URANIUM MILL TAILINGS

PARAMETER VALUE INDICATOR (PVI): < - LESS THAN DETECTION LIMIT

OTHER PARAMETER VALUE FLAGS:

H - HOLD TIME EXPIRED, VALUE SUSPECT

H - HOLD TIME EXPIRED, VALUE SUSPECT
FLOW RELATIONSHIP COOE:

N - UNKNOWN
O - ON-SITE

SAMPLE ID CODES

0001 - FILTERED SAMPLE (.45 MICRONS)

N001 - UNFILTERED SAMPLE 
TABLE 3.21 TAILINGS PORE FLUID HATER QUALITY DATA BY PARAMETER, MC AND UC PROCESSING SITES, SLICK ROCK, COLORADO

SITE. SRKO1 SLICK ROCK (BOTH SITES)

01/12/89 TO $10 / 14 / 92$

REPORT DATE: $06 / 17 / 93$

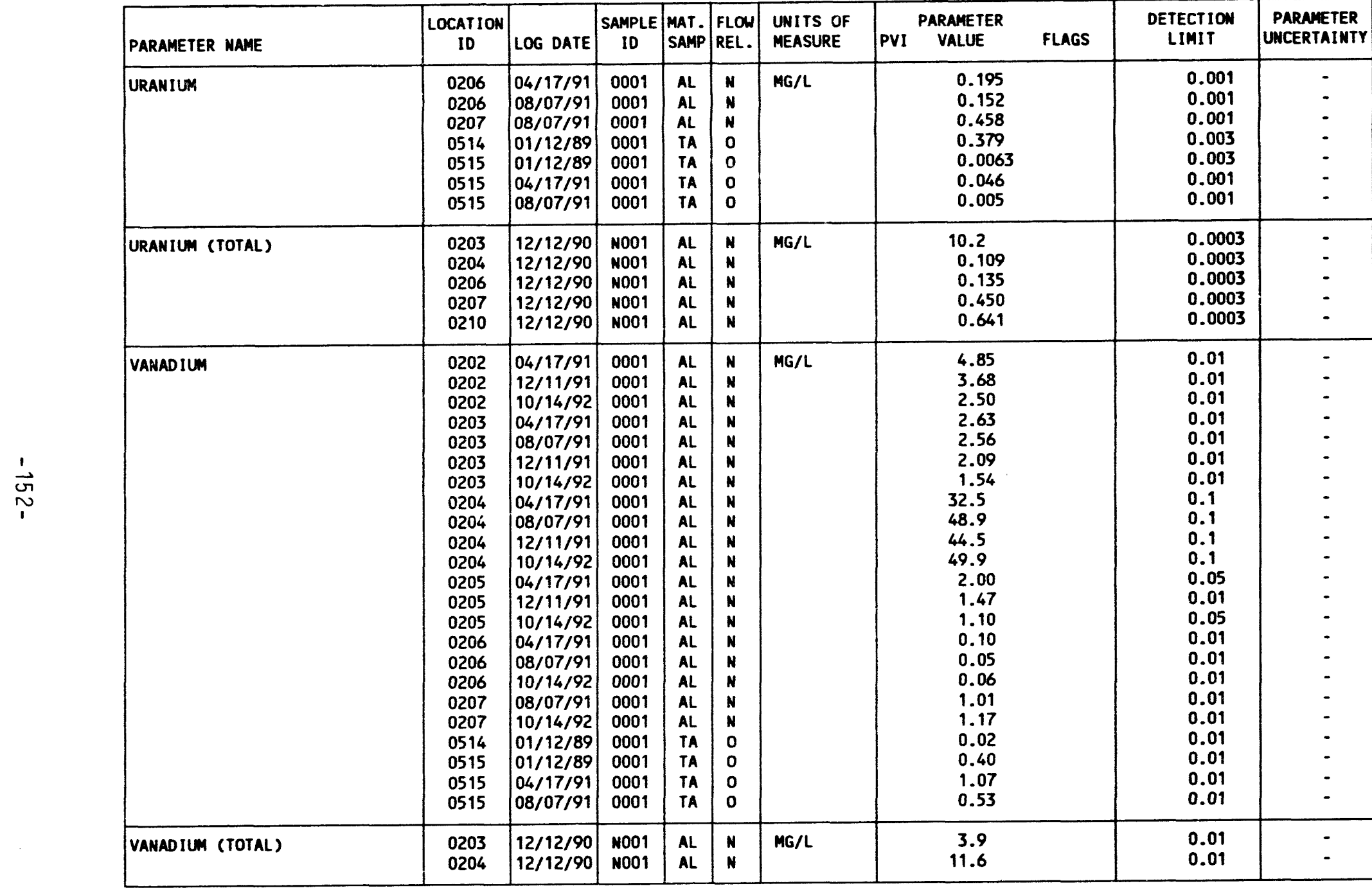

MATERIAL OF SAMPLING COOE:

AL - ALLUVIUM

TA - URANIUM MILL TAILINGS

PARAMETER VAlUE INDICATOR (PVI): < - LESS than DETECTION LIMIT
FLOW RELATIONSHIP COOE:

N - UNKNOWN
O - ON-SITE

SAMPLE ID COOES:

0001 - FILTERED SAMPLE (.45 MICRONS)

NO01 - UNFILTERED SAMPLE 


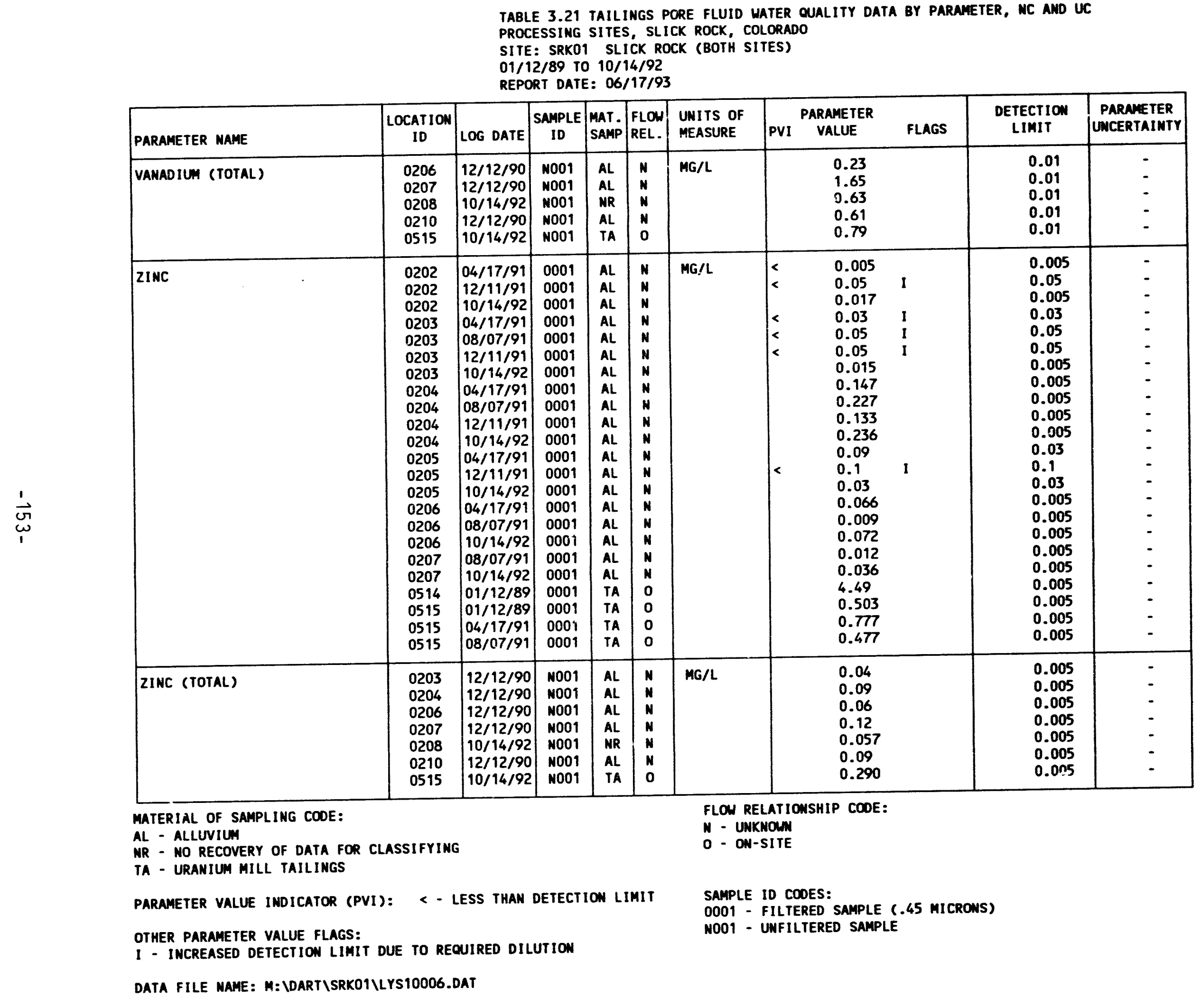


TABLE 3.22 TAILINGS PORE FLUID MATER QUALITY STATISTICS BY PARAMETER, NC PROCESSING SITE, SLICK ROCK, COLORADO

SITE: SRKO1 SLICK ROCK (BOTH SITES)

12/12/90 TO $10 / 14 / 92$

REPORT DATE : $07 / 26 / 93$

\begin{tabular}{|c|c|c|c|c|c|c|c|c|c|c|c|}
\hline \multicolumn{3}{|c|}{ PARAMETER NAME } & UNITS & \multirow[b]{2}{*}{ MEAN } & \multirow{2}{*}{$\begin{array}{l}\text { STANDARD } \\
\text { DEVIATION }\end{array}$} & \multirow{2}{*}{$\begin{array}{c}\text { COEFF. } \\
\text { OF } \\
\text { VARIATION }\end{array}$} & \multirow{2}{*}{$\begin{array}{c}\% \text { OF } \\
\text { NON } \\
\text { DETECTS }\end{array}$} & \multicolumn{2}{|c|}{$\begin{array}{l}\text { STATISTICAL RANGE } \\
98 \% \text { CONFIDENCE INTERVAL }\end{array}$} & \multirow{2}{*}{$\begin{array}{l}\text { DISTRIBUTION } \\
\text { TYPE }\end{array}$} & \multirow{2}{*}{$\begin{array}{l}\text { FOOT } \\
\text { MOTE }\end{array}$} \\
\hline \# OF LOC. & MINIMUM & MAXIMUM & MEDIAN & & & & & MINIMUM & MAXIMUA & & \\
\hline \multicolumn{3}{|c|}{ ALKALINITY } & MG/L CACO & \multirow[b]{2}{*}{365.5417} & \multirow[b]{2}{*}{264.8728} & \multirow[b]{2}{*}{0.7246} & \multirow[b]{2}{*}{0.0} & \multirow[b]{2}{*}{-235.8521} & \multirow[b]{2}{*}{966.9354} & \multirow[b]{2}{*}{ NORMAL } & \\
\hline 4 & 42.5000 & 681.0000 & +369.3333 & & & & & & & & \\
\hline \multicolumn{3}{|l|}{ ALUMINUM } & $M G / L$ & \multirow[b]{2}{*}{ NA } & \multirow[b]{2}{*}{ NA } & \multirow[b]{2}{*}{ NA } & \multirow[b]{2}{*}{21.4} & \multirow[b]{2}{*}{ ** $\quad 0.0500$} & \multirow[b]{2}{*}{0.1825} & \multirow[b]{2}{*}{ NONPARAMETRIC } & \multirow[b]{2}{*}{2,4} \\
\hline 4 & $\star * \quad 0.0500$ & 0.1825 & 0.1183 & & & & & & & & \\
\hline \multicolumn{3}{|c|}{ ALUMINUM (TOTAL) } & $M G / L$ & \multirow[b]{2}{*}{ NA } & \multirow[b]{2}{*}{ NA } & \multirow[b]{2}{*}{ NA } & \multirow[b]{2}{*}{100.0} & \multirow[b]{2}{*}{ NA } & \multirow[b]{2}{*}{ NA } & & \\
\hline 2 & $\# \quad 0.1000$ & $\begin{array}{ll}* & 0.1000\end{array}$ & 0.1000 & & & & & & & JANKNOWN & 1 \\
\hline ANTIMONY & & & $M G / L$ & & & & & & & & \\
\hline 4 & 0.0083 & 0.0417 & 0.0146 & NA & NA & NA & 85.7 & 0.0083 & 0.0417 & MONPARAMETRIC & 2,4 \\
\hline ANTIMONY & (TOTAL) & & $M G / L$ & & & & & & & & \\
\hline 2 & $\approx \quad 0.0030$ & 0.0030 & 0.0030 & NA & NA & MA & 50.0 & MA & MA & UNKMOWN & 1 \\
\hline ARSENIC & & & $M G / L$ & & & & & & & & \\
\hline 4 & 0.0413 & 0.2250 & 0.0675 & NA & MA & NA & 85.7 & 0.0413 & 0.2250 & NONPARAMETRIC & 2,4 \\
\hline ARSENIC C & TOTAL) & & $\mathrm{MG} / \mathrm{L}$ & & & & & & & & \\
\hline 2 & 0.0400 & 0.0600 & 0.0500 & NA & NA & NA & 0.0 & MA & MA & UNKNOWN & 1 \\
\hline BARIUM & & & $M G / L$ & & & & & & & & \\
\hline 4 & 0.0183 & 0.0567 & 0.0387 & 0.0381 & 0.0157 & 0.4118 & 7.1 & 0.0100 & 0.0738 & NORMAL & \\
\hline BARIUM CT & OTAL) & & $M G / L$ & & & & & & & & \\
\hline 2 & $\approx * \quad 0.1000$ & $\star * \quad 0.1000$ & $\star \star \quad 0.1000$ & NA & NA & NA & 100.0 & MA & MA & UNKNONN & 1 \\
\hline
\end{tabular}

** The reported value is the minimum detection limit of the data set

+ The sample size is even, so the median value is the arithmetic average of the two middle values

* The sample size is even, so the median value is the arithmetic average of the two $a=0.01$

1) Data from a minimum of 4 locations must be available for the statistical analysis.

2) The nonparametric distribution was used because the nondetected values comprise more than $15 \%$ of the samples.

4) The stat. range is the $\mathbf{8 7 . 5 \%}$ confidence interval due to a sample size of 4 . The maximum is the $93.8 \%$ one sided confidence int.

Note the data at each location was averaged before the statistical calculations were performed 
TABLE 3.22 TAILINGS PORE FLUID HATER QUALITY STATISTICS BY PARAMETER,

NC PROCESSING SITE, SLICK ROCK, COLORADO

SITE: SRKO1 SLICK ROCK (80TH SITES)

$12 / 12 / 90$ TO $10 / 14 / 92$

REPORT DATE : $07 / 26 / 93$

\begin{tabular}{|c|c|c|c|c|c|c|c|c|c|c|c|}
\hline \multicolumn{3}{|c|}{ PARAMETER NAME } & UNITS & \multirow[b]{2}{*}{ MEAN } & \multirow{2}{*}{$\begin{array}{r}\text { STANDARD } \\
\text { DEVIATION }\end{array}$} & \multirow{2}{*}{$\begin{array}{c}\text { COEFF. } \\
\text { OF } \\
\text { VARIATION }\end{array}$} & \multirow{2}{*}{$\begin{array}{c}\% \text { OF } \\
\text { NON } \\
\text { DETECTS }\end{array}$} & \multirow{2}{*}{\multicolumn{2}{|c|}{\begin{tabular}{|c|} 
STATISTICAL RANGE \\
$98 \%$ CONFIDENCE INTERVAL \\
MINIMM
\end{tabular}}} & \multirow{2}{*}{$\begin{array}{c}\text { DISTRIBUTION } \\
\text { TYPE }\end{array}$} & \multirow{2}{*}{$\begin{array}{l}\text { FOOT } \\
\text { NOTE }\end{array}$} \\
\hline \# OF LOC. & MINIMUM & MAXIMUM & MEDIAN & & & & & & & & \\
\hline \multicolumn{3}{|l|}{ BERYLLIUM } & MG/L & \multirow[b]{2}{*}{ NA } & \multirow[b]{2}{*}{ NA } & \multirow[b]{2}{*}{ NA } & \multirow[b]{2}{*}{60.0} & \multirow[b]{2}{*}{$\neq \quad 0.0050$} & \multirow[b]{2}{*}{0.0333} & \multirow[b]{2}{*}{ WONPARAMETRIC } & \multirow[b]{2}{*}{2,4} \\
\hline 4 & $\# \quad 0.0050$ & 0.0333 & 0.0070 & & & & & & & & \\
\hline \multicolumn{3}{|c|}{ BERYLLIUM (TOTAL) } & $M G / L$ & \multirow[b]{2}{*}{ BiA } & \multirow[b]{2}{*}{ NA } & \multirow[b]{2}{*}{ NA } & \multirow[b]{2}{*}{0.0} & \multirow[b]{2}{*}{ NA } & \multirow[b]{2}{*}{ NA } & \multirow[b]{2}{*}{ UNKNOWN } & \multirow[b]{2}{*}{1} \\
\hline 2 & $0.0 ? 00$ & 0.0500 & 0.0350 & & & & & & & & \\
\hline \multicolumn{3}{|l|}{ BORON } & $M G / L$ & \multirow[b]{2}{*}{1.0400} & \multirow[b]{2}{*}{0.6791} & \multirow[b]{2}{*}{0.6530} & \multirow[b]{2}{*}{0.0} & \multirow[b]{2}{*}{$\star \star \quad 0.0500$} & \multirow[b]{2}{*}{2.5820} & & \\
\hline 4 & 0.1850 & 1.7350 & 1.1200 & & & & & & & NORMAL & \\
\hline BORON CTOT & (AL) & & MG/L & & & & & & & & \\
\hline 2 & 0.1000 & 1.7000 & 0.9000 & NA & NA & NA & 0.0 & NA & NA & UNKNOWN & 1 \\
\hline BROMIDE & & & $M G / L$ & & & & & & & & \\
\hline 4 & $\star \quad 0.3000$ & 15.0000 & 5.5000 & NA & NA & NA & 100.0 & 0.3000 & 15.0000 & HONPARAMETRIC & 2,4 \\
\hline BROMIDE (T & roTAL) & & $\mathrm{MG} / \mathrm{L}$ & & & & & & & & \\
\hline 4 & 0.0500 & 3.3000 & 2.3000 & NA & MA & NA & 25.0 & 0.0500 & 3.3000 & NOMPARAMETRIC & 2,4 \\
\hline CADMIUM & & & MG/L & & & & & & & & \\
\hline 4 & 0.0095 & 0.0793 & 0.0452 & NA & NA & NA & 42.9 & 0.0095 & 0.0793 & NONPARAMETRIC & 2,4 \\
\hline CADMIUM CT & (OTAL) & & $M G / L$ & & & & & & & & \\
\hline 2 & $\# \quad 0.0010$ & 0.0020 & 0.0013 & NA & NA & NA & 50.0 & MA & NA & UNKNOWN & 1 \\
\hline CALCIUM & & & $M G / L$ & & & & & & & & \\
\hline 4 & 419.3333 & 591.7500 & +442.4583 & 474.0000 & 81.1230 & 0.1711 & 0.0 & 289.8101 & 658.1899 & MORMAL & \\
\hline
\end{tabular}

* The reported value is the minimum detection limit of the data set

* The reported value is the minimum detection limit of the data set

+ The sample size is even, so the median value is the arite

- The statistical maximum is the 99 percent one sided confidence interval a

1) Data from a minimum of 4 locations must be available for the statistical analysis.

2) The nonparametric distribution was used because the nondetected values conprise more than is the $93.8 \%$ one sided confidence int.

4) The stat. range is the $87.5 \%$ confidence interval due to a sample size of 4 . The maximum is 
TABLE 3.22 TAILINGS PORE FLUID MATER QUALITY STATISTICS BY PARAMETER, MC PROCESSING SITE, SLICK ROCK, COLORADO

SITE: SRK01 SLICK ROCK (BOTH SITES)

$12 / 12 / 90$ TO $10 / 14 / 92$

REPORT DATE: $07 / 26 / 93$

\begin{tabular}{|c|c|c|c|c|c|c|c|c|c|c|c|}
\hline \multicolumn{3}{|c|}{ PARAMETER NAME } & UNITS & \multirow[b]{2}{*}{ MEAN } & \multirow{2}{*}{$\begin{array}{r}\text { STANDARD } \\
\text { DEVIATION }\end{array}$} & \multirow{2}{*}{$\begin{array}{c}\text { COEFF. } \\
\text { OFF } \\
\text { VARIATION }\end{array}$} & \multirow{2}{*}{$\begin{array}{c}x \text { OF } \\
\text { NON } \\
\text { DETECTS }\end{array}$} & \multirow{2}{*}{\multicolumn{2}{|c|}{$\begin{array}{l}\text { STATISTICAL RANGE } \\
\text { 98\% CONFIDENCE INTERVAL } \\
\text { MINIMUM MAXIMUM * }\end{array}$}} & \multirow{2}{*}{$\begin{array}{c}\text { DISTRIBUTION } \\
\text { TYPE }\end{array}$} & \multirow{2}{*}{$\begin{array}{l}\text { FOOT } \\
\text { NOTE }\end{array}$} \\
\hline \# OF LOC. & MINIMUM & MAXIMUM & MEDIAN & & & & & & & & \\
\hline \multicolumn{3}{|c|}{ CALCIUM (TOTAL) } & $M G / L$ & \multirow[b]{2}{*}{ NA } & \multirow[b]{2}{*}{ MA } & \multirow[b]{2}{*}{ NA } & \multirow[b]{2}{*}{0.0} & \multirow[b]{2}{*}{ MA } & \multirow[b]{2}{*}{ MA } & \multirow[b]{2}{*}{ UNKNOWN } & \multirow[b]{2}{*}{1} \\
\hline 2 & 369.0000 & 516.0000 & +442.5000 & & & & & & & & \\
\hline \multicolumn{3}{|l|}{ CHLORIDE } & $M G / L$ & \multirow[b]{2}{*}{693.5812} & \multirow[b]{2}{*}{10.3112} & \multirow[b]{2}{*}{ NA } & \multirow[b]{2}{*}{0.0} & \multirow{2}{*}{\multicolumn{2}{|c|}{$3.4704 \quad 138616.2884$}} & \multirow[b]{2}{*}{ LOGNORMAL } & \multirow[b]{2}{*}{7,8} \\
\hline 4 & 24.0000 & 4650.0000 & +1560.0000 & & & & & & & & \\
\hline \multicolumn{3}{|c|}{ CHLORIDE (TOTAL) } & $M G / L$ & \multirow[b]{2}{*}{1751.5000} & \multirow[b]{2}{*}{1746.1664} & \multirow[b]{2}{*}{0.9970} & \multirow[b]{2}{*}{0.0} & \multirow[b]{2}{*}{1.0000} & \multirow[b]{2}{*}{5716.1707} & & \\
\hline 4 & 14.0000 & 4060.0000 & +1466.0000 & & & & & & & MORMAL & \\
\hline CHROMIUM & & & $M G / L$ & & & & & & & & \\
\hline 4 & $\star \quad 0.0100$ & 0.0333 & 0.0100 & NA & NA & NA & 92.9 & 0.0100 & 0.0333 & MONPARAMETRIC & 2,4 \\
\hline CHROMIUM & (TOTAL) & & $M G / L$ & & & & & & & & \\
\hline 2 & $\star \quad 0.0100$ & $\# \quad 0.0100$ & 0.0100 & MA & NA & NA & 100.0 & MA & MA & UMкмоN & 1 \\
\hline COBALT & & & $M G / L$ & & & & & & & & \\
\hline 4 & $\star \quad \quad 0.0300$ & 0.0325 & 0.0300 & NA & NA & NA & 100.0 & 0.0300 & 0.0325 & MONPARAMETRIC & 2,4 \\
\hline COBALT (T & DTAL) & & $M G / L$ & & & & & & & & \\
\hline 2 & $\star \star \quad 0.0500$ & $\star \quad 0.0500$ & 0.0500 & MA & NA & NA & 100.0 & MA & MA & UNKNOWN & 1 \\
\hline COPPER & & & $M G / L$ & & & & & & & & \\
\hline 4 & 0.0425 & 0.0700 & 0.0550 & 0.0556 & 0.0120 & 0.2152 & 0.0 & 0.0285 & 0.0828 & NORMAL & \\
\hline COPPER (TC & JTAL) & & $M G / L$ & & & & & & & & \\
\hline 2 & $\star \star \quad 0.0200$ & 0.0300 & 0.0200 & NA & NA & NA & 50.0 & MA & NA & UNKNOAN & 1 \\
\hline
\end{tabular}

** The reported value is the minimum detection limit of the data set

- The sample size is even, so the median value is the arithmetic average of the two middle values

- The statistical maximm is the 99 percent one sided confidence interval, $a=0.01$

1) Data from a minimum of 4 locations must be available for the statistical analysis.

2) The nomparametric distribution was used because the nondetected values comprise more than $15 \%$ of the samples.

4) The stat. range is the $\mathbf{8 7 . 5 \%}$ confidence interval due to a sample size of 4 . The maximm is the $93.8 \%$ one sided confidence int.

7) The lçnormal distribution was used because the data failed the normal distribution test.

8) The mean is geometric. The standard deviation is the value to divide or multiply with the geometric mean.

Wote the data ach location uas averaged before the statistical calculations were performed 
TABLE 3.22 TAILINGS PORE FLUID HATER QUALITY STATISTICS BY PARAMETER, NC PROCESSING SITE, SLICK ROCK, COLORADO

$12 / 12 / 90$ TO $10 / 14 / 92$

REPORT DATE: $07 / 26 / 93$

\begin{tabular}{|c|c|c|c|c|c|c|c|c|c|c|c|c|}
\hline \multicolumn{3}{|c|}{ PARAMETER NAME } & UNITS & \multirow[b]{2}{*}{ MEAN } & \multirow{2}{*}{$\begin{array}{l}\text { STANDARD } \\
\text { DEVIATION }\end{array}$} & \multirow{2}{*}{$\begin{array}{c}\text { COEFF. } \\
\text { OF } \\
\text { VARIATION }\end{array}$} & \multirow{2}{*}{$\begin{array}{c}\% \text { OF } \\
\text { NON } \\
\text { DETECTS }\end{array}$} & \multirow{2}{*}{\multicolumn{3}{|c|}{$\begin{array}{c}\text { STATISTICAL RANGE } \\
\text { 98\% CONFIDENCE INTERVAL } \\
\text { MINIMUM } \\
\text { MAXIMUM * }\end{array}$}} & \multirow{2}{*}{$\begin{array}{c}\text { DISTRIBUTION } \\
\text { TYPE }\end{array}$} & \multirow{2}{*}{$\begin{array}{l}\text { FOOT } \\
\text { NOTE }\end{array}$} \\
\hline \# OF LOC. & MINIMUM & maximum & MEDIAN & & & & & & & & & \\
\hline \multicolumn{3}{|l|}{ FLUORIDE } & $M G / L$ & \multirow[b]{2}{*}{1.7000} & \multirow[b]{2}{*}{1.1747} & \multirow[b]{2}{*}{0.6910} & \multirow[b]{2}{*}{0.0} & \multirow[b]{2}{*}{$\star \star$} & \multirow[b]{2}{*}{0.1000} & \multirow[b]{2}{*}{4.3672} & \multirow[b]{2}{*}{ NORMAL } & \\
\hline 4 & 0.2000 & 3.0000 & 1.8000 & & & & & & & & & \\
\hline \multicolumn{3}{|c|}{ FLUORIDE (TOTAL) } & MG/L & \multirow[b]{2}{*}{0.7250} & \multirow[b]{2}{*}{0.3686} & \multirow[b]{2}{*}{0.5084} & \multirow[b]{2}{*}{0.0} & \multirow[b]{2}{*}{$\star \star$} & \multirow[b]{2}{*}{0.1000} & \multirow[b]{2}{*}{1.5618} & \multirow[b]{2}{*}{ NORMAL } & \\
\hline 4 & 0.3000 & 1.2000 & 0.7000 & & & & & & & & & \\
\hline \multicolumn{3}{|c|}{ GROSS ALPHA } & $\mathrm{PCI} / \mathrm{L}$ & & \multirow[b]{2}{*}{3305.2146} & \multirow[b]{2}{*}{0.9476} & \multirow[b]{2}{*}{0.0} & \multirow[b]{2}{*}{$\star \star$} & \multirow[b]{2}{*}{1.0000} & \multirow[b]{2}{*}{10992.5647} & & \\
\hline 4 & 45.3000 & 7781.0000 & +3063.0000 & 3488.0750 & & & & & & & NORMAL & \\
\hline GROSS ALPH & IA (TOTAL) & & $\mathrm{PCl} / \mathrm{L}$ & & & & & & & & & \\
\hline 2 & 67.0000 & 4600.0000 & +2333.5000 & NA & NA & NA & 0.0 & & MA & NA & UNKNOWN & 1 \\
\hline GROSS BETA & & & PCI/L & & & & & & & & & \\
\hline 4 & 34.7000 & 4895.0000 & +1904.5000 & 2184.6750 & 2155.0059 & 0.9864 & 0.0 & $\star \star$ & 0.5000 & 7077.6158 & NORMAL & \\
\hline GROSS BETA & (TOTAL) & & $\mathrm{PCI} / \mathrm{L}$ & & & & & & & & & \\
\hline 2 & 74.0000 & 3100.0000 & +1587.0000 & NA & NA & NA & 0.0 & & MA & NA & UNKNOWN & 1 \\
\hline IRON & & & $M G / L$ & & & & & & & & & \\
\hline 4 & $\star * \quad 0.0300$ & 0.0383 & $\begin{array}{ll}* & 0.0300\end{array}$ & NA & NA & NA & 85.7 & $\star \star$ & 0.0300 & 0.0383 & MONPARAMETRIC & 2,4 \\
\hline IRON CTOTA & & & $M G / L$ & & & & & & & & & \\
\hline 2 & 0.0900 & 0.7800 & 0.4350 & NA & NA & NA & 0.0 & & MA & NA & UNKNOWN & 1 \\
\hline LEAD & & & $M G / L$ & & & & & & & & & \\
\hline 4 & 0.0141 & 0.0583 & 0.0333 & NA & NA & NA & 100.0 & & 0.0141 & 0.0583 & MONPARAMETRIC & 2,4 \\
\hline
\end{tabular}

** The reported value is the minimum detection limit of the data set

+ The sample siz is even, so the median value is the arithmetic average of the two middle values

* The statistical maximum is the 99 percent one sided confidence interval, $\alpha=0.01$

1) Data from a minimum of 4 locations must be available for the statistical analysis.

2) The nonparametric distribution was used because the nondetected values comprise more than $15 \%$ of the samples.

4) The stat, range is the $\mathbf{8 7 . 5 \%}$ confidence interval due to a sample size of 4 . The maximu is the $93.8 \%$ one sided confidence int. Note the dats at each location was averaged before the statistical calculations were performed 
TABLE 3.22 TAILIHGS PORE FLUID MATER QUALITY STATISTICS BY PARAMETER,

NC PROCESSING SITE, SLICK ROCK, COLORADO

SITE: SRKO1 SLICK ROCK (BOTH SITES)

$12 / 12 / 90$ TO $10 / 14 / 92$

REPORT DATE: $07 / 26 / 93$

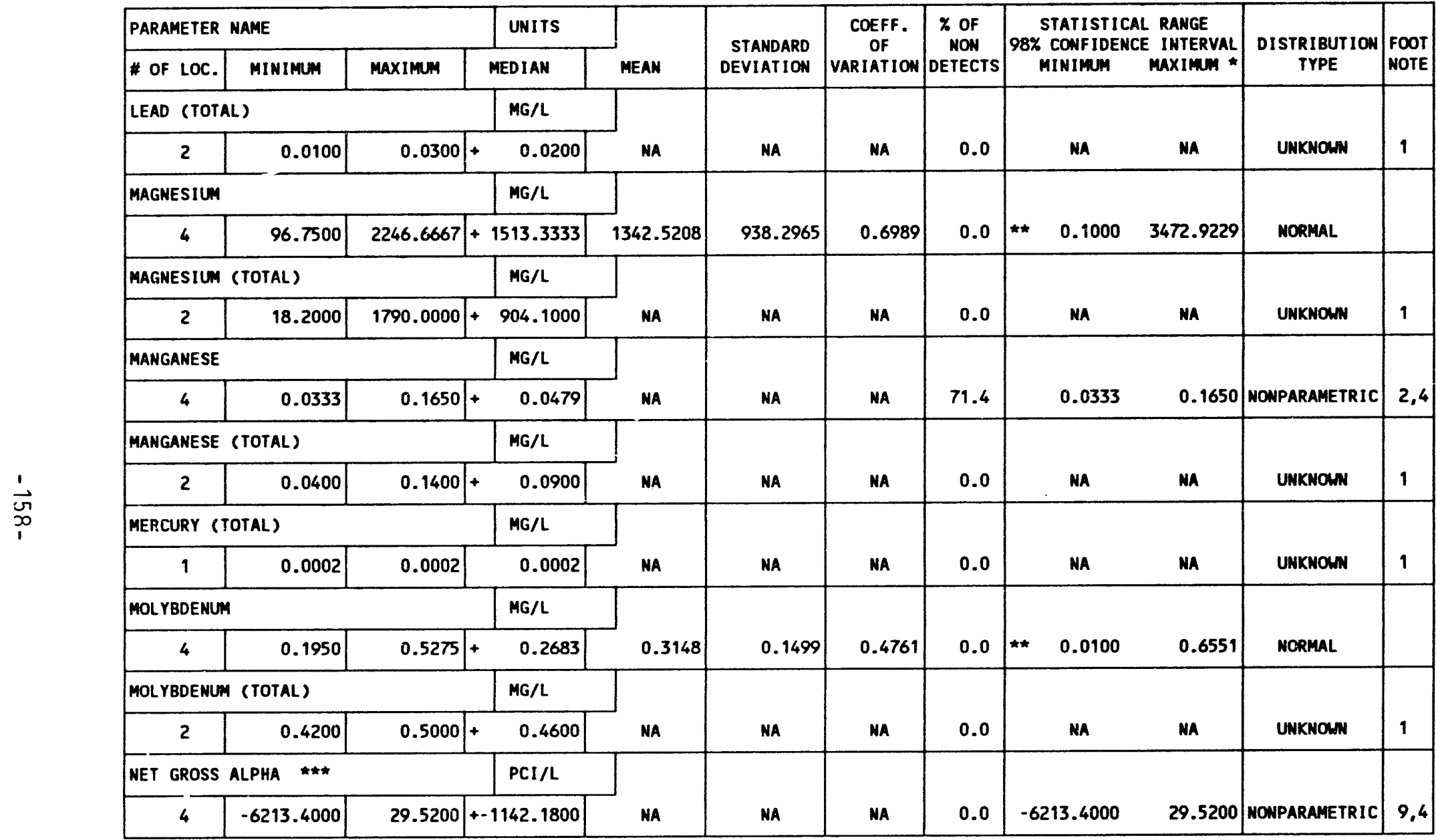

*** NET GROSS ALPHA (GROSS ALPHA - URANIUM) WITH 1 MG URANIUM = 686 PCI

* The reported value is the minimum detection limit of the data set

+ The sample size is even, so the median value is the arithmetic average of the two middle values

* The statistical maximum is the 99 percent one sided confidence interval, $a=0.01$

1) Data from a minime of 4 locations must be available for the statistical analysis.

2) The nonparametric distribution was used because the nondetected values comprise more than 15\% of the samples.

4) The stat. range is the $\mathbf{8 7 . 5 \%}$ confidence interval due to a sample size of 4 . The maximum is the $93.8 \%$ one sided confidence int.

9) The nonparametic distribution was used because the data failed the normal distribution test and includes values $\leq 0$.

Note the data at each location was averaged before the statistical calculations were performed 
TABLE 3.22 TAILINGS PORE FLUID MATER QUALITY STATISTICS BY PARAMETER,

NC PROCESSING SITE, SLICK ROCK, COLORADO

SITE: SRKO1 SLICK ROCK (BOTH SITES)

$12 / 12 / 90$ TO $10 / 14 / 92$

REPORT DATE: $07 / 26 / 93$

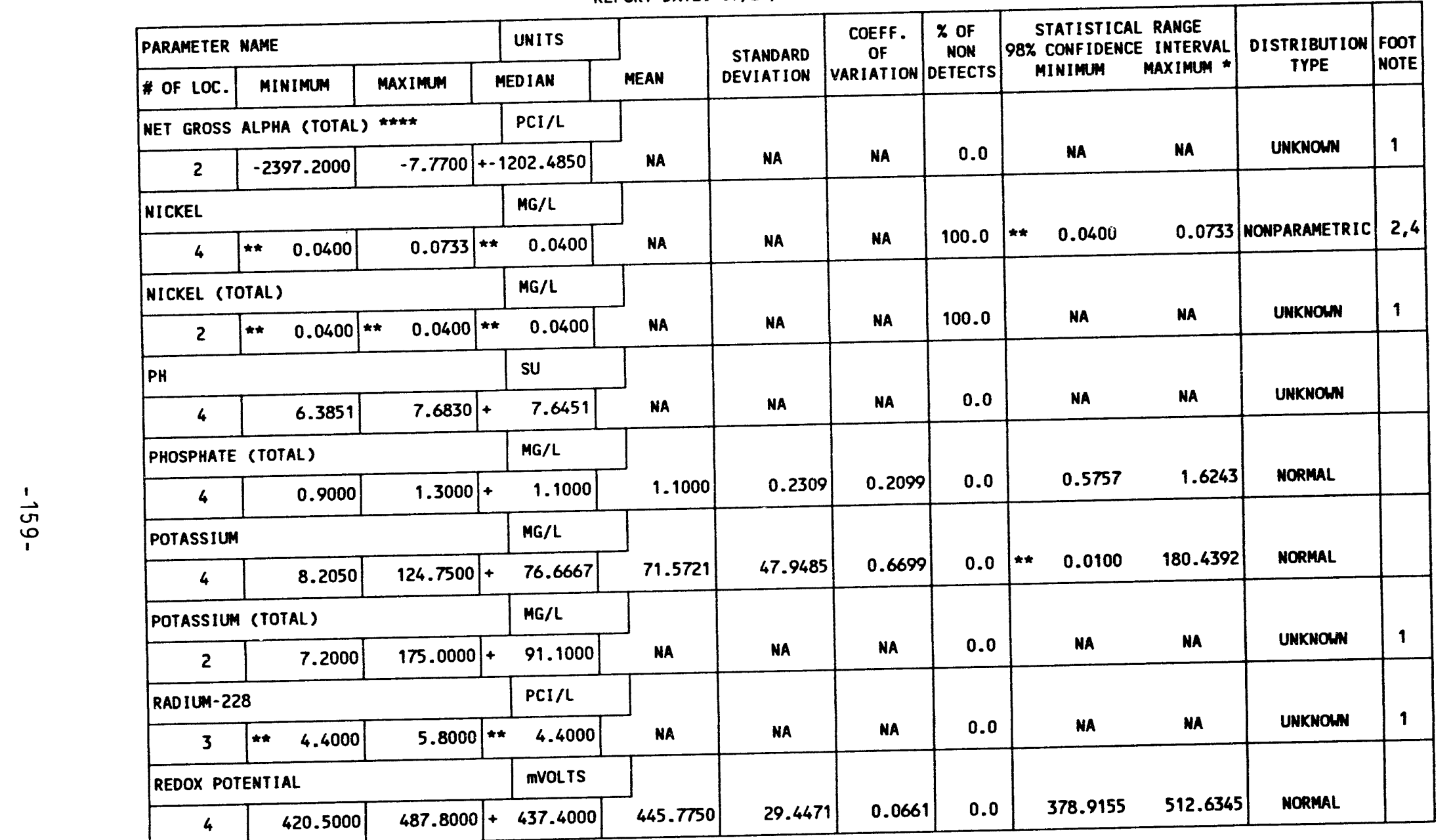

$\star \star \star \star$ NET GROSS ALPHA (TOTAL) (TOTAL GROSS ALPHA - TOTAL URANIUM)

* The reported value is the minimum detection limit of the data set

+ The sample size is even, so the median value is the arithmetic average of the $a=0.01$

* The statistical maximm is the 99 percent one sided confidence interval, $\alpha=0.01$

1) Data from a minimu of 4 locations must be available for the statistical analysis.

2) The nonparametric distribution was used because the nondetected values comprise more than 15\% of the samples.

4) The stat. range is the $87.5 \%$ confidence interval due to a sample size of 4 . The maximum is

4) The stat. range is the 
TABLE 3.22 TAILINGS PORE FLUID WATER QUALITY STATISTICS BY PARAMETER,

NC PROCESSING SITE, SLICK ROCK, COLORADO

SITE: SRKO1 SLICK ROCK (BOTH SITES)

$12 / 12 / 90$ TO $10 / 14 / 92$

REPORT DATE: $07 / 26 / 93$

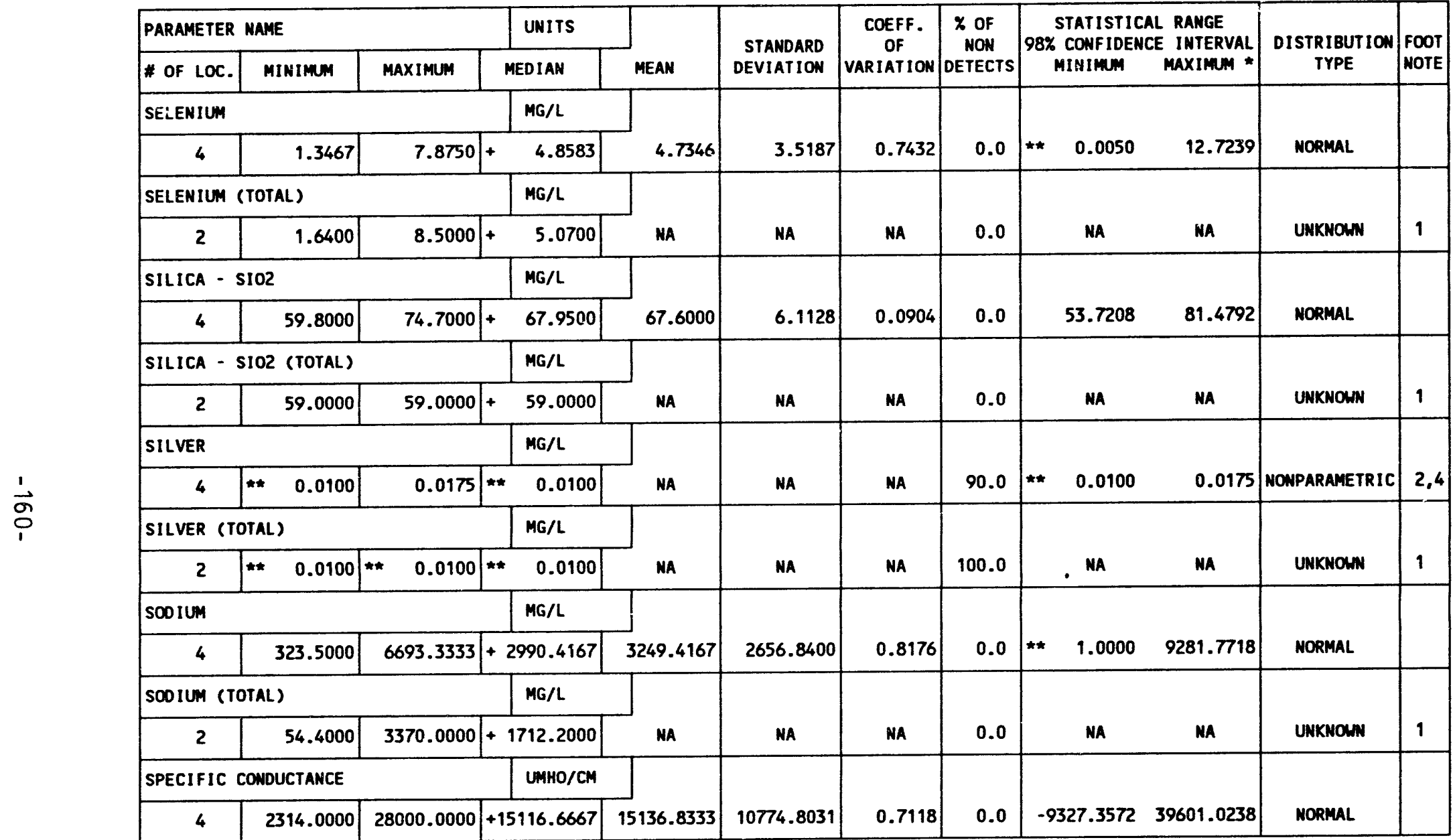

* The reported value is the minimum detection limit of the data set

+ The sample size is even, so the median value is the arithmetic average of the two middle values

- The statistical maximum is the 99 percent one sided confidence interval, $a=0.01$

1) Data from a minimum of 4 locations must be available for the statistical analysis.

2) The nomparametric distribution was used because the nondetected values comprise more than $15 \%$ of the samples.

4) The stat. range is the $87.5 \%$ confidence interval due to a sample size of 4 . The maximm is the $93.8 \%$ one sided confidence int.

Note the data at each location was averaged before the statistical calculations were performed 
TABLE 3.22 TAILINGS PORE FLUID MATER QUALITY STATISTICS BY PARAMETER,

NC PROCESSING SITE, SLICK ROCK, COLORADO

SITE: SRKO1 SLICK ROCK (BOTH SITES)

$12 / 12 / 90$ TO $10 / 14 / 92$

REPORT DATE: $07 / 26 / 93$

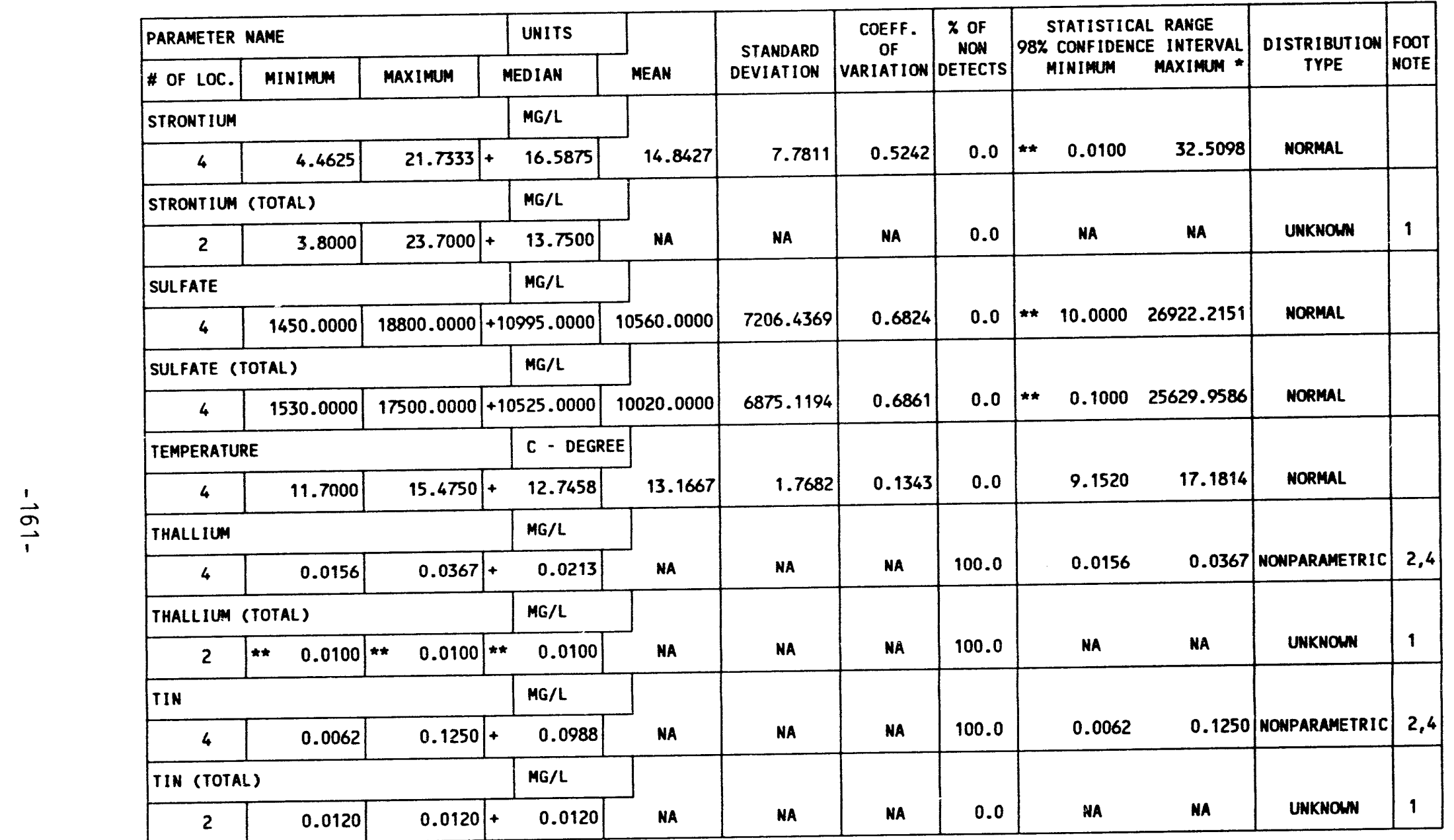

* The reported value is the minimum detection limit of the data set

+ The sample size is even, so the median value is the arithmetic average of the two middle values

* The statistical maximum is the 99 percent one sided confidence interval, $\alpha=0.01$

1) Data from a minimum of 4 locations must be available for the statistical analysis.

2) The nomparametric distribution was used because the nondetected values comprise more than $15 \%$ of the samples.

4) The nonparame size of 4 . The maximum is the $93.8 \%$ one sided confidence int.

4) The state ratistical calculations were performed 
TABLE 3.22 TAILINGS PORE FLUID WATER QUALITY STATISTICS BY PARAMETER, NC PROCESSING SITE, SLICK ROCK, COLORADO

SITE: SRK01 SLICK ROCK (BOTH SITES)

$12 / 12 / 90$ TO $10 / 14 / 92$

REPORT DATE: $07 / 26 / 93$

\begin{tabular}{|c|c|c|c|c|c|c|c|c|c|c|c|}
\hline \multicolumn{3}{|c|}{ PARAMETER NAME } & UNITS & \multirow[b]{2}{*}{ MEAN } & \multirow{2}{*}{$\begin{array}{l}\text { STANDARD } \\
\text { DEVIATION }\end{array}$} & \multirow{2}{*}{$\begin{array}{c}\text { COEFF. } \\
\text { OF } \\
\text { VARIATION }\end{array}$} & \multirow{2}{*}{$\begin{array}{c}x \text { OF } \\
\text { NON } \\
\text { DETECTS }\end{array}$} & \multicolumn{2}{|c|}{$\begin{array}{l}\text { STATISTICAL RANGE } \\
98 \% \text { CONFIDENCE INTERVAL }\end{array}$} & \multirow{2}{*}{$\begin{array}{l}\text { DISTRIBUTION } \\
\text { TYPE }\end{array}$} & \multirow{2}{*}{$\begin{array}{l}\text { FOOT } \\
\text { NOTE }\end{array}$} \\
\hline$\#$ OF LOC. & MINIMUM & MAXIMUM & MEDIAN & & & & & MINIMUN & $\operatorname{MAXIMM} *$ & & \\
\hline \multicolumn{3}{|c|}{ TOTAL DISSOLVED SOLIDS } & MG/L & & \multirow[b]{2}{*}{13095.4022} & \multirow[b]{2}{*}{0.6991} & \multirow[b]{2}{*}{0.0} & \multirow[b]{2}{*}{10.0000} & \multirow[b]{2}{*}{48465.6107} & \multirow[b]{2}{*}{ NORMAL } & \\
\hline 4 & 2430.0000 & 33900.0000 & +19300.0000 & 18732.5000 & & & & & & & \\
\hline \multicolumn{3}{|l|}{ URANIUM } & MG/L & \multirow[b]{2}{*}{1.7669} & \multirow[b]{2}{*}{30.1669} & \multirow[b]{2}{*}{ NA } & \multirow[b]{2}{*}{14.3} & \multirow[b]{2}{*}{0.0010} & \multirow[b]{2}{*}{4040.9812} & \multirow[b]{2}{*}{ LOGNORMAL } & \multirow[b]{2}{*}{7,8} \\
\hline 4 & 0.0118 & 20.4000 & 7.0375 & & & & & & & & \\
\hline \multicolumn{3}{|c|}{ URANIUN (TOTAL) } & $M G / L$ & \multirow[b]{2}{*}{ NA } & \multirow[b]{2}{*}{ NA } & \multirow[b]{2}{*}{ NA } & \multirow[b]{2}{*}{0.0} & \multirow[b]{2}{*}{ NA } & \multirow[b]{2}{*}{ MA } & \multirow[b]{2}{*}{ UNKNOWN } & \multirow[b]{2}{*}{1} \\
\hline 2 & 0.1090 & 10.2000 & 5.1545 & & & & & & & & \\
\hline VANADIUM & & & MG/L & & & & & & & & \\
\hline 4 & 1.5233 & 43.9500 & 2.9408 & 4.8267 & 4.5551 & NA & 0.0 & 0.1544 & 150.9304 & LOGNORMAL & 7,8 \\
\hline VANADIUM & OTAL) & & $M G / L$ & & & & & & & & \\
\hline 2 & 3.9000 & 11.6000 & 7.7500 & NA & NA & NA & 0.0 & NA & MA & UNKNOWN & 1 \\
\hline ZINC & & & $M G / L$ & & & & & & & & \\
\hline 4 & 0.0148 & 0.1857 & 0.0383 & NA & MA & NA & 42.9 & 0.0148 & 0.1857 & NONPARAMETRIC & 2,4 \\
\hline ZINC (тоT) & & & $M G / L$ & & & & & & & & \\
\hline 2 & 0.0400 & 0.0900 & 0.0650 & NA & NA & NA & 0.0 & NA & MA & UNKNOWN & 1 \\
\hline
\end{tabular}

** The reported value is the minimum detection limit of the data set

- The reported value is the minime two middle values

* The sample size is even, so the median value ided confidence interval $a=0.01$

The statistical maximm is the 99 percent one sided confidence interval a $=0.01$

1) Data from a minimum of 4 locations must be available for the statistue comprise more than $15 \%$ of the samples.

4) The nonparametric distribution was used because the nondetected value of 4 . The maximm is the $93.8 \%$ one sided confidence int.

7) The stat. range is the $87.5 \%$ confidence interval due to a sample size of 4 . The max

8) The mean is geometric. The standard deviation is the value to divide or multiply with the geometric mean.

Note the data at each location was averaged before the statistical calculations were performed

INPUT DATA FILENAME: M: IDARTISRKO1YLYS10004.DAT 
Table 3.23 summary of regulated constituents in tailings pore fluid samples, NC processing site, Slick Rock, Colorado

Constituents with MCLs"

\begin{tabular}{|c|c|c|c|c|}
\hline Parameter & Median & MCL & Background & Exceed \\
\hline Arsenic & $0.07^{e}$ & 0.05 & $0.01^{\mathrm{g}}$ & $1.4 \mathrm{x}$ \\
\hline Barium & $0.04^{d}$ & 1.00 & $0.05^{\mathrm{e}}$ & - \\
\hline Cadmium & $0.04^{e}$ & 0.01 & $0.001^{\mathrm{g}}$ & $4 x$ \\
\hline Chromium & $0.01^{8}$ & 0.05 & $0.01^{8}$ & -- \\
\hline Net gross alphaf & $-1142.18^{\mathrm{e}}$ & 15.00 & $6.96^{\mathrm{e}}$ & -- \\
\hline Lead & $0.03^{e}$ & 0.05 & $0.01^{g}$ & - \\
\hline Mercury & -- & 0.002 & $0.0002^{8}$ & - \\
\hline Molybdenum & $0.31^{d}$ & 0.10 & $0.02^{\mathrm{g}}$ & $3 x$ \\
\hline Nitrate & - & 44.0 & $4.4^{e}$ & - \\
\hline Radium-226 and $-228^{f}$ & -- & 5.0 & $1.80^{d}$ & $\cdots$ \\
\hline Selenium & $4.73^{d}$ & 0.01 & $0.012^{\mathrm{g}}$ & $473 x$ \\
\hline Silver & $0.01^{\mathrm{g}}$ & 0.05 & $0.01^{\mathrm{g}}$ & -- \\
\hline Uranium & $1.77^{\mathrm{c}}$ & 0.044 & $0.019^{\circ}$ & $40 x$ \\
\hline
\end{tabular}


Table 3.23 Summary of regulated constituents in tailings pore fluid samples, NC processing site, Slick Rock, Colorado (concluded)

Constituents without MCLs"

\begin{tabular}{lcccr}
\hline \multicolumn{1}{c}{ Parameter } & Median & MCL & Background & Exceed \\
Antimony & $0.015^{\mathrm{e}}$ & None & $0.003^{\mathrm{g}}$ & $5 \mathrm{x}$ \\
Beryllium & $0.007^{\mathrm{e}}$ & None & $0.01^{\mathrm{g}}$ & - \\
Cobalt & $0.05^{\mathrm{g}}$ & None & $0.05^{\mathrm{g}}$ & -- \\
Copper & $0.06^{\mathrm{d}}$ & None & $0.02^{\mathrm{g}}$ & $3 \mathrm{x}$ \\
Cyanide & - & None & $0.01^{\mathrm{g}}$ & -- \\
Nickel & $0.04^{\mathrm{g}}$ & None & $0.04^{\mathrm{g}}$ & - \\
Sulfide & - & None & $1.0^{\mathrm{e}}$ & - \\
Thallium & $0.02^{\mathrm{c}}$ & None & $0.01^{\mathrm{g}}$ & $2 \mathrm{x}$ \\
Tin & $0.099^{\mathrm{e}}$ & None & $0.005^{\mathrm{g}}$ & $20 \mathrm{x}$ \\
Vanadium & $4.83^{\mathrm{c}}$ & None & $0.02^{\mathrm{e}}$ & $242 \mathrm{x}$ \\
Zinc & $0.038^{\mathrm{e}}$ & None & $0.01^{\mathrm{e}}$ & $4 \mathrm{x}$ \\
\hline
\end{tabular}

All units are $\mathrm{mg} / \mathrm{l}$ unless otherwise noted.

'Disposal site background groundwater statistical maximum (upper sandstone unit).

'Lognormal distribution, mean is geometric.

dNormal distribution, mean is arithmetic.

'Nonparametric distribution

fUnits are pCi/l.

'Statistical values are below laboratory detection limits in

Table 8.1 of the Technical Approach Document (DOE, 1989) 
TABLE 3.24 TAILINGS PORE FLUID MEASUREMENTS EXCEEDING MAXIMM CONCENTRATION

LIMITS NC AND UC PROCESSING SITES, SLICK ROCK, COLORADO

SITE: SRKO1 SLICK ROCK (BOTH SITES

$01 / 12 / 89$ TO $10 / 14 / 92$

REPORT DATE: 06/17/93

\begin{tabular}{|c|c|c|c|c|c|c|c|c|c|c|c|c|c|}
\hline & PARAMETER MAME & $\begin{array}{l}\text { TOTAL } \\
\text { \# OF } \\
\text { SAMP. }\end{array}$ & $\begin{array}{c}\text { UNITS } \\
\text { OF } \\
\text { MEASURE }\end{array}$ & \begin{tabular}{|} 
MAXIMUM \\
CONC. \\
LIMIT
\end{tabular} & LOC. & LOG DATE & SAMP & $\begin{array}{c}\text { MAT. } \\
\text { OF } \\
\text { SAMPP }\end{array}$ & $\begin{array}{l}\text { HYDR } \\
\text { FLOW } \\
\text { REL. }\end{array}$ & $\begin{array}{c}\text { RESULT EXCEED } \\
\text { CONCENTRATION } \\
\text { VALUE }\end{array}$ & $\begin{array}{l}\text { ING MAX. } \\
\text { LIMIT } \\
\text { FLAGS }\end{array}$ & $\begin{array}{l}\text { DETECTION } \\
\text { LIMIT }\end{array}$ & $\begin{array}{l}\text { PARAMETER } \\
\text { UNCERT. }\end{array}$ \\
\hline & ARSENIC & 23 & $M G / L$ & 0.0500 & $\begin{array}{l}0202 \\
0202 \\
0203 \\
0203 \\
0203 \\
0204 \\
0204 \\
0204 \\
0204 \\
0205 \\
0205 \\
0205 \\
0206 \\
0207 \\
0515\end{array}$ & $\begin{array}{l}12 / 11 / 91 \\
10 / 14 / 92 \\
08 / 07 / 91 \\
12 / 11 / 91 \\
10 / 14 / 92 \\
04 / 17 / 91 \\
08 / 07 / 91 \\
12 / 11 / 91 \\
10 / 14 / 92 \\
04 / 17 / 91 \\
12 / 11 / 91 \\
10 / 14 / 92 \\
10 / 14 / 92 \\
08 / 07 / 91 \\
04 / 17 / 91\end{array}$ & $\begin{array}{l}0001 \\
0001 \\
0001 \\
0001 \\
0001 \\
0001 \\
0001 \\
0001 \\
0001 \\
0001 \\
0001 \\
0001 \\
0001 \\
0001 \\
0001\end{array} \mid$ & $\begin{array}{l}A L \\
A L \\
A L \\
A L \\
A L \\
A L \\
A L \\
A L \\
A L \\
A L \\
A L \\
A L \\
A L \\
A L \\
T A\end{array}$ & $\begin{array}{l}N \\
N \\
N \\
N \\
N \\
N \\
N \\
N \\
N \\
N \\
N \\
N \\
N \\
N \\
0\end{array}$ & $\begin{array}{l}0.1 \\
0.2 \\
0.1 \\
0.1 \\
0.1 \\
0.05 \\
0.1 \\
0.1 \\
0.3 \\
0.05 \\
1.1 \\
0.3 \\
0.05 \\
0.1 \\
0.07\end{array}$ & $\begin{array}{l}\text { I } \\
\text { I } \\
\text { I } \\
1 \\
1 \\
1 \\
\text { I } \\
\text { I } \\
1 \\
1 \\
1 \\
1 \\
1\end{array}$ & $\begin{array}{l}0.1 \\
0.2 \\
0.1 \\
0.1 \\
0.1 \\
0.01 \\
0.1 \\
0.1 \\
0.3 \\
0.05 \\
1.0 \\
0.3 \\
0.05 \\
0.1 \\
0.01\end{array}$ & $\begin{array}{l}- \\
- \\
- \\
- \\
- \\
- \\
- \\
- \\
- \\
- \\
- \\
-\end{array}$ \\
\hline & ARSENIC (TOTAL) & 5 & $M G / L$ & 0.0500 & $\begin{array}{l}0204 \\
0210\end{array}$ & $\begin{array}{l}12 / 12 / 90 \\
12 / 12 / 90\end{array} \mid$ & N001 & $\begin{array}{l}A L \\
A L\end{array}$ & N & $\begin{array}{l}0.06 \\
0.06\end{array}$ & & $\begin{array}{l}0.01 \\
0.01\end{array}$ & - \\
\hline & BARIUM & 23 & $M G / L$ & 1.0000 & - & - & - & - & - & - & & - & - \\
\hline & BARIUM (TOTAL) & 7 & $M G / L$ & 1.0000 & - & - & - & - & - & - & & - & - \\
\hline & CADMIUM & 23 & $M G / L$ & 0.0100 & $\begin{array}{l}0202 \\
0202 \\
0203 \\
0203 \\
0204 \\
0204 \\
0204 \\
0205 \\
0205 \\
0514 \\
0515 \\
0515\end{array}$ & \begin{tabular}{|l|}
$12 / 11 / 91$ \\
$10 / 14 / 92$ \\
$12 / 11 / 91$ \\
$10 / 14 / 92$ \\
$08 / 07 / 91$ \\
$12 / 11 / 91$ \\
$10 / 14 / 92$ \\
$12 / 11 / 91$ \\
$10 / 14 / 92$ \\
$01 / 12 / 89$ \\
$01 / 12 / 89$ \\
$04 / 17 / 91$
\end{tabular} & $\left|\begin{array}{l}0001 \\
0001 \\
0001 \\
0001 \\
0001 \\
0001 \\
0001 \\
0001 \\
0001 \\
0001 \\
0001 \\
0001\end{array}\right|$ & $\begin{array}{l}A L \\
A L \\
A L \\
A L \\
A L \\
A L \\
A L \\
A L \\
A L \\
T A \\
T A \\
T A\end{array}$ & $\begin{array}{l}N \\
N \\
N \\
N \\
N \\
N \\
N \\
N \\
N \\
0 \\
0 \\
0\end{array}$ & $\begin{array}{l}0.01 \\
0.12 \\
0.01 \\
0.18 \\
0.03 \\
0.01 \\
0.02 \\
0.01 \\
0.23 \\
0.652 \\
0.207 \\
0.194\end{array}$ & $\begin{array}{l}1 \\
1 \\
1 \\
1 \\
1 \\
1\end{array}$ & $\begin{array}{l}0.01 \\
0.03 \\
0.01 \\
0.03 \\
0.03 \\
0.01 \\
C .02 \\
0.01 \\
0.03 \\
0.001 \\
0.001 \\
0.005\end{array}$ & $\begin{array}{l}- \\
- \\
- \\
- \\
- \\
- \\
- \\
- \\
-\end{array}$ \\
\hline
\end{tabular}

< - the data is flagged as a nON-DEtect, so the RESUlt is an estimated VALUe OR the detection Limit

MATERIAL OF SAMPLING COOE:

AL - ALLUVIUM

TA - URANIUM MILL TAILINGS

OTHER PARAMETER VALUE FLAGS:

I - INCREASED DETECTION LIMIT DUE TO REQUIRED DILUTION
FLOW RELATIONSHIP COOE:

N - UNKMONN

O - ON-SITE

SAMPLE ID COOES:

0001 - FILTERED SAMPLE (.45 MICRONS)

NO01 - UNFILTERED SAMPLE 


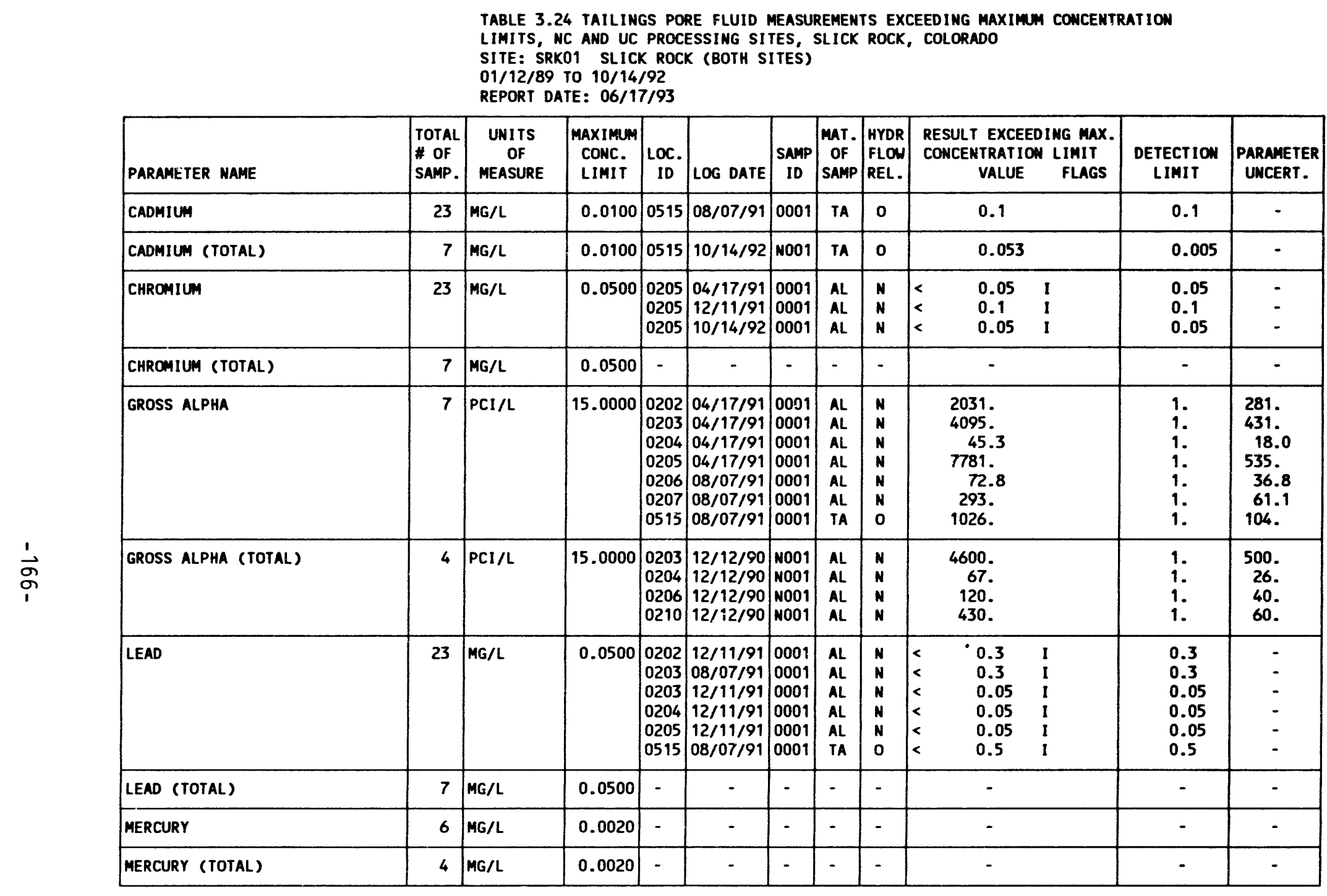

< - the data is flagged as a now-detect, so the result is an estimated value or the detection limit

MATERIAL OF SAMPLING COOE:

TA - URANIUM MILL TAILINGS

AL - ALLUVIU⿴囗十⺝

OTHER PARAMETER VALUE FLAGS:

I - INCREASED DETECTION LIMIT DUE TO REQUIRED DILUTION
FLON RELATIONSHIP COOE:

O - ON-SITE

- UNKNOWH

SAMPLE ID CODES:

0001 - FILTERED SAMPLE (.45 MICRONS)

NO01 - UNFILTERED SAMPLE 
TABLE 3.24 TAILINGS PORE FLUID MEASUREMENTS EXCEEDING MAXIMM CONCENTRATION

LIMITS, NC AND UC PROCESSING SITES, SLICK ROCK, COLORADO

SITE: SRKO1 SLICK ROCK (BOTH SITES)

01/12/89 TO $10 / 14 / 92$

REPORT DATE: $06 / 17 / 93$

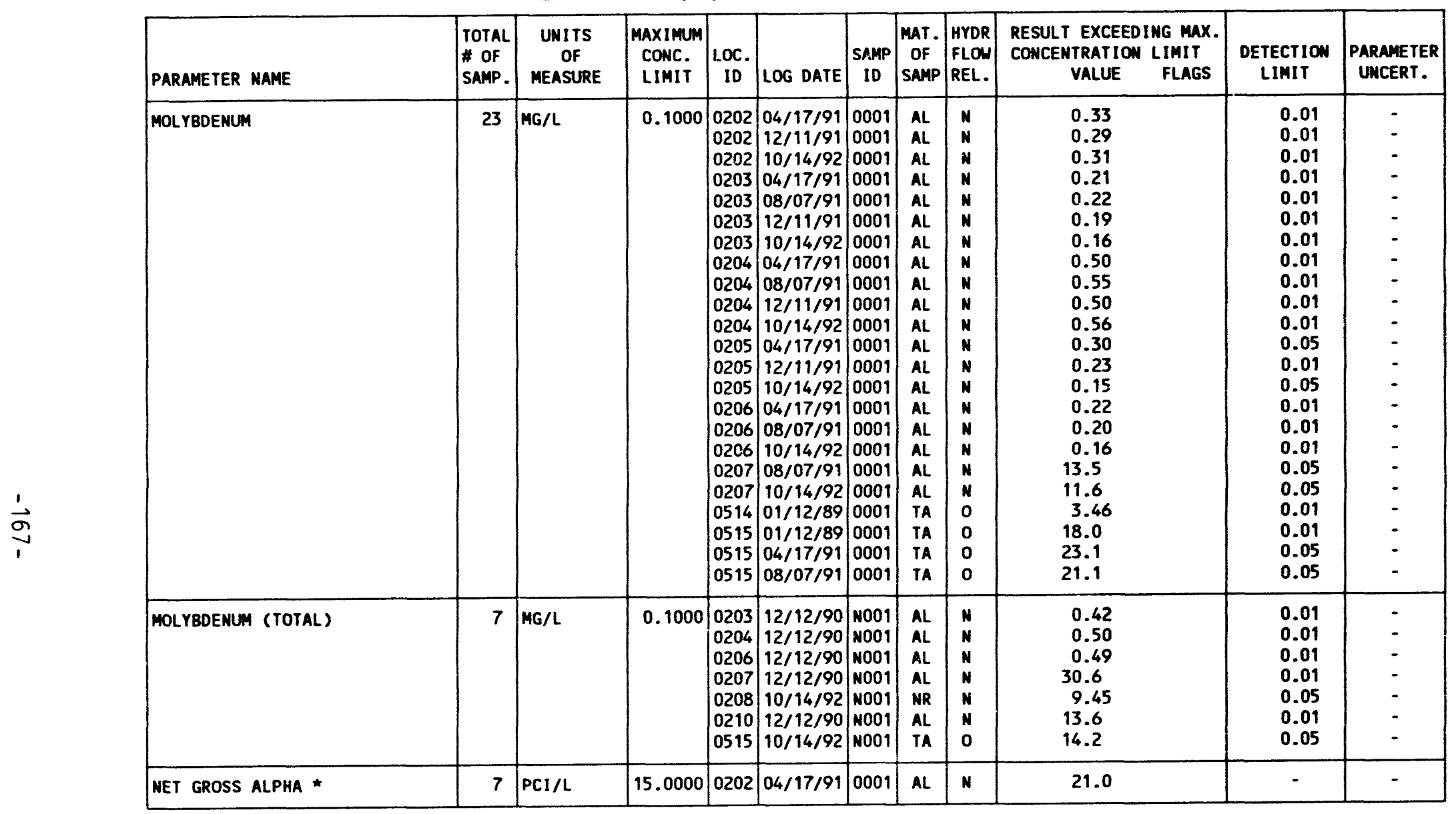

* Net gross ALPHA (GROSS ALPHA - URANIUM) WITH 1 Mg URANIUM = 686 PCI

MATERIAL OF SAMPLING COOE:

AL - ALLUVIUM

TA - URANIUM MILL TAILINGS

NR - NO RECOVERY OF DATA FOR CLASSIFYING
FLOW RELATIONSHIP COOE:

N - UNKNOWN
O - ON-SITE

SAMPLE ID COOES:

0001 - FILTERED SAMPLE (.45 MICRONS)

N001 - UNFILTERED SAMPLE 
TABLE 3.24 TAILINGS PORE FLUID MEASUREMENTS EXCEEDING MAXIMUM CONCENTRATION LIMITS, NC AND UC PROCESSING SITES, SLICK ROCK, COLORADO

SITE: SRKO1 SLICK ROCK (BOTH SITES)

$01 / 12 / 89$ TO $10 / 14 / 92$

\begin{tabular}{|c|c|c|c|c|c|c|c|c|c|c|c|c|}
\hline & PARAMETER MAME & $\begin{array}{l}\text { TOTAL } \\
\text { \# OF } \\
\text { SAMP. }\end{array}$ & $\begin{array}{l}\text { UNITS } \\
\text { OF } \\
\text { MEASURE }\end{array}$ & $\begin{array}{l}\text { maximum } \\
\text { CONC. } \\
\text { LIMIT }\end{array}$ & LOC. & LOG DATE & $\underset{\text { SAMP }}{\operatorname{SA}}$ & $\begin{array}{c}\text { Mat. } \\
\text { Of } \\
\text { SAMP }\end{array}$ & $\begin{array}{l}\text { HYDR } \\
\text { FLOW } \\
\text { REL. }\end{array}$ & $\begin{array}{l}\text { RESULT EXCEEDING MAX. } \\
\text { CONCENTRATION LIMIT } \\
\text { VALUE FLAGS }\end{array}$ & $\begin{array}{l}\text { DETECTION } \\
\text { LIMIT }\end{array}$ & $\begin{array}{l}\text { PARAMETER } \\
\text { UNCERT. }\end{array}$ \\
\hline & NET GROSS ALPHA * & 7 & $\mathrm{PCl} / \mathrm{L}$ & 15.0000 & $\begin{array}{l}0204 \\
0515\end{array}$ & $\mid \begin{array}{l}04 / 17 / 91 \\
08 / 07 / 91\end{array}$ & $\begin{array}{l}0001 \\
0001\end{array}$ & $\begin{array}{l}A L \\
T A\end{array}$ & $\begin{array}{l}\text { N } \\
\text { O }\end{array}$ & $\begin{array}{r}29.5 \\
1022.6\end{array}$ & - & - \\
\hline & NET GROSS ALPHA (TOTAL) ** & 4 & $\mathrm{PCl} / \mathrm{L}$ & 15.0000 & 0206 & $12 / 12 / 90$ & n001 & AL & N & 27.4 & - & $\cdot$ \\
\hline & NITRATE & 3 & MG/L & 44.0000 & $\begin{array}{l}0206 \\
0514\end{array}$ & $\begin{array}{l}08 / 07 / 91 \\
01 / 12 / 89\end{array}$ & $\begin{array}{l}0001 \\
0001\end{array}$ & $\begin{array}{l}\text { AL } \\
\text { TA }\end{array}$ & $\begin{array}{l}N \\
0\end{array}$ & $\begin{array}{l}744 . \\
210 .\end{array}$ & 1. & : \\
\hline & NITRATE (TOTAL) & 0 & $M G / L$ & 44.0000 & - & - & - & - & - & - & - & - \\
\hline & $R A-226 \& R A-228$ & 0 & $\mathrm{PCl} / \mathrm{L}$ & 5.0000 & - & - & - & - & - & - & $\cdot$ & - \\
\hline & RA-226 \& RA-228 (TOTAL) & 0 & $\mathrm{PCI} / \mathrm{L}$ & 5.0000 & - & - & - & $\cdot$ & - & - & - & $\cdot$ \\
\hline $\begin{array}{l}9 \\
\infty \\
1\end{array}$ & SELENIUM & 23 & $M G / L$ & 0.0100 & $\begin{array}{l}0202 \\
0202 \\
0202 \\
0203 \\
0203 \\
0203 \\
0203 \\
0204 \\
0204 \\
0204 \\
0204 \\
0205 \\
0205 \\
0205 \\
0206 \\
0206 \\
0206 \\
0207\end{array}$ & $\begin{array}{l}04 / 17 / 91 \\
12 / 11 / 91 \\
10 / 14 / 92 \\
04 / 17 / 91 \\
08 / 07 / 91 \\
12 / 11 / 91 \\
10 / 14 / 92 \\
04 / 17 / 91 \\
08 / 07 / 91 \\
12 / 11 / 91 \\
10 / 14 / 92 \\
04 / 17 / 91 \\
12 / 11 / 91 \\
10 / 14 / 92 \\
04 / 17 / 91 \\
08 / 07 / 91 \\
10 / 14 / 92 \\
08 / 07 / 91\end{array}$ & $\begin{array}{l}0001 \\
0001 \\
0001 \\
0001 \\
0001 \\
0001 \\
0001 \\
0001 \\
0001 \\
0001 \\
0001 \\
0001 \\
0001 \\
0001 \\
0001 \\
0001 \\
0001 \\
0001\end{array}$ & $\begin{array}{l}A L \\
A L \\
A L \\
A L \\
A L \\
A L \\
A L \\
A L \\
A L \\
A L \\
A L \\
A L \\
A L \\
A L \\
A L \\
A L \\
A L \\
A L\end{array}$ & $\begin{array}{l}N \\
N \\
N \\
N \\
N \\
N \\
N \\
N \\
N \\
N \\
N \\
N \\
N \\
N \\
N \\
N \\
N \\
N\end{array}$ & $\begin{array}{c}6.0 \\
10.0 \\
7.0 \\
6.0 \\
6.5 \\
13 . \\
6.0 \\
1.3 \\
1.5 \\
2.4 \\
3 . \\
0.140 \\
2.6 \\
1.3 \\
1.00 \\
0.150 \\
0.09 \\
16.0\end{array}$ & $\begin{array}{l}0.5 \\
5 . \\
0.5 \\
0.5 \\
0.5 \\
5 . \\
0.5 \\
0.1 \\
0.1 \\
0.5 \\
1 . \\
0.005 \\
0.5 \\
0.3 \\
0.005 \\
0.03 \\
0.05 \\
0.5\end{array}$ & $\begin{array}{l}- \\
- \\
- \\
- \\
- \\
- \\
- \\
- \\
- \\
- \\
- \\
- \\
- \\
- \\
-\end{array}$ \\
\hline
\end{tabular}

- net gross alpha (gross alpha - URANium)

WITH 1 MG URANIUM $=686 \mathrm{PCI}$

* total met gRoss alPHa (TOTAL gRoss alPHa - total URANiUm)

MATERIAL OF SAMPLING CODE:

AL - ALLUVIUM

TA - URANIUM MILL TAILINGS
FLON RELATIONSHIP COOE:

N - UNKMOM

O - ON-SITE

SAMPLE ID CODES:

0001 - FILTERED SAMPLE (.45 MICRONS)

NO01 - UNFILTERED SAMPLE 
TABLE 3.24 TAILINGS PORE FLUID MEASUREMENTS EXCEEDING MAXIMUM CONCENTRATION

LIMITS, NC AND UC PROCESSING SITES, SLICK ROCK, COLORADO

SITE: SRKO1 SLICK ROCK (BOTH SITES)

$01 / 12 / 89$ TO $10 / 14 / 92$

REPORT DATE: $06 / 17 / 93$

\begin{tabular}{|c|c|c|c|c|c|c|c|c|c|c|c|}
\hline PARAMETER MAME & $\begin{array}{l}\text { TOTAL } \\
\# \text { OF } \\
\text { SAMP. }\end{array}$ & $\begin{array}{c}\text { UNITS } \\
\text { OF } \\
\text { MEASURE }\end{array}$ & $\begin{array}{l}\text { MAXIMUM } \\
\text { CONC. } \\
\text { LIMIT }\end{array}$ & $\begin{array}{c}10 C . \\
10\end{array}$ & LOG DATE & $\begin{array}{c}\text { SAMP } \\
\text { ID }\end{array}$ & $\begin{array}{c}\text { MAT. } \\
\text { OF } \\
\text { SAMP }\end{array}$ & $\begin{array}{l}\text { HYDR } \\
\text { FLOW } \\
\text { REL. }\end{array}$ & $\begin{array}{l}\text { RESULT EXCEEDING MAX. } \\
\text { CONCENTRATION LIMIT } \\
\text { VALUE FLAGS }\end{array}$ & $\begin{array}{l}\text { DETECTION } \\
\text { LIMIT }\end{array}$ & $\begin{array}{l}\text { PARAMETER } \\
\text { UNCERT. }\end{array}$ \\
\hline SELENIUM & 23 & $M G / L$ & 0.0100 & $\begin{array}{l}0207 \\
0514 \\
0515 \\
0515 \\
0515\end{array}$ & $\begin{array}{l}10 / 14 / 92 \\
01 / 12 / 89 \\
01 / 12 / 89 \\
04 / 17 / 91 \\
08 / 07 / 91\end{array}$ & $\left|\begin{array}{l}0001 \\
0001 \\
0001 \\
0001 \\
0001\end{array}\right|$ & $\begin{array}{l}\text { AL } \\
\text { TA } \\
\text { TA } \\
\text { TA } \\
\text { TA }\end{array}$ & $\begin{array}{l}N \\
0 \\
0 \\
0 \\
0\end{array}$ & $\begin{array}{c}16 . \\
1.64 \\
1.54 \\
8.0 \\
7.0\end{array}$ & $\begin{array}{l}5 . \\
0.005 \\
0.005 \\
0.5 \\
0.5\end{array}$ & $\begin{array}{l}- \\
- \\
-\end{array}$ \\
\hline SELENIUM (TOTAL) & 7 & $M G / L$ & 0.0100 & $\left|\begin{array}{l}0203 \\
0204 \\
0206 \\
0207 \\
0208 \\
0210 \\
0515\end{array}\right|$ & $\begin{array}{l}12 / 12 / 90 \\
12 / 12 / 90 \\
12 / 12 / 90 \\
12 / 12 / 90 \\
10 / 14 / 92 \\
12 / 12 / 90 \\
10 / 14 / 92\end{array}$ & $\begin{array}{l}N 001 \\
N 001 \\
N 001 \\
N 001 \\
N 001 \\
N 001\end{array}$ & $\begin{array}{l}A L \\
A L \\
A L \\
A L \\
\text { NR } \\
\text { AL } \\
\text { TA }\end{array}$ & $\begin{array}{l}N \\
N \\
N \\
N \\
N \\
N \\
0\end{array}$ & $\begin{array}{c}8.5 \\
1.64 \\
0.39 \\
21.6 \\
14.0 \\
1.48 \\
7.0\end{array}$ & $\begin{array}{l}0.005 \\
0.005 \\
0.005 \\
0.005 \\
0.5 \\
0.005 \\
0.5\end{array}$ & $\begin{array}{l}- \\
. \\
- \\
- \\
-\end{array}$ \\
\hline SILVER & 17 & $M G / L$ & 0.0500 & 0205 & $04 / 17 / 91$ & 0001 & AL & N & $0.05 \quad 1$ & 0.05 & - \\
\hline SILVER (TOTAL) & 5 & $M G / L$ & 0.0500 & - & - & - & - & - & - & - & - \\
\hline URANIUM & 14 & $M G / L$ & 0.0440 & $\begin{array}{l}0202 \\
0202 \\
0203 \\
0203 \\
0205 \\
0206 \\
0206 \\
0207 \\
0514 \\
0515\end{array}$ & $\begin{array}{l}04 / 17 / 91 \\
10 / 14 / 92 \\
04 / 17 / 91 \\
10 / 14 / 92 \\
04 / 17 / 91 \\
04 / 17 / 91 \\
08 / 07 / 91 \\
08 / 07 / 91 \\
01 / 12 / 89 \\
04 / 17 / 91\end{array}$ & $\left|\begin{array}{l}0001 \\
0001 \\
0001 \\
0001 \\
0001 \\
0001 \\
0001 \\
0001 \\
0001 \\
0001\end{array}\right|$ & $\begin{array}{l}A L \\
A L \\
A L \\
A L \\
A L \\
A L \\
A L \\
A L \\
T A \\
T A\end{array}$ & $\begin{array}{l}N \\
N \\
N \\
N \\
N \\
N \\
N \\
N \\
0 \\
0\end{array}$ & $\begin{array}{c}2.93 \\
5.19 \\
9.33 \\
10.7 \\
20.4 \\
0.195 \\
0.152 \\
0.458 \\
0.379 \\
0.046\end{array}$ & $\begin{array}{l}0.001 \\
0.001 \\
0.001 \\
0.001 \\
0.001 \\
0.001 \\
0.001 \\
0.001 \\
0.003 \\
0.001\end{array}$ & $\begin{array}{l}- \\
- \\
- \\
- \\
- \\
- \\
- \\
-\end{array}$ \\
\hline URANIUM (TOTAL) & 5 & $M G / L$ & 0.0440 & $\left|\begin{array}{l}0203 \\
0204 \\
0206 \\
0207 \\
0210\end{array}\right|$ & $\begin{array}{l}12 / 12 / 90 \\
12 / 12 / 90 \\
12 / 12 / 90 \\
12 / 12 / 90 \\
12 / 12 / 90\end{array}$ & $\begin{array}{l}\text { NO01 } \\
\text { NO01 } \\
\text { NO01 } \\
\text { NO01 } \\
\text { NO01 }\end{array}$ & $\begin{array}{l}\text { AL } \\
A L \\
A L \\
A L \\
A L\end{array}$ & $\begin{array}{l}N \\
N \\
N \\
N \\
N\end{array}$ & $\begin{array}{l}10.2 \\
0.109 \\
0.135 \\
0.450 \\
0.641\end{array}$ & $\begin{array}{l}0.0003 \\
0.0003 \\
0.0003 \\
0.0003 \\
0.0003\end{array}$ & $\begin{array}{l}- \\
- \\
-\end{array}$ \\
\hline
\end{tabular}

< - the data is flagged as a non-detect, so the result is an estimated value or the detection limit

MATERIAL OF SAMPLIMG COOE:

TA - URANIUM MILL TAILINGS

AL - ALLUVIUTM

NR - NO RECOVERY OF DATA FOR CLASSIFYING

OTHER PARAMETER VALUE FLAGS:

I - INCREASED DETECTION LIMIT DUE TO REQUIRED DILUTION
FLOW RELATIONSHIP COOE:

O - ON-SITE

N - UNKNOW

SAMPIE ID COOES:

(.45 MICRONS)

NO01 - UNFILTERED SAMPLE 
TABLE 3.25 TAILINGS PORE FLUID WATER QUALITY STATISTICS BY PARAMETER, UC PROCESSING SITE, SLICK ROCK, COLORADO

SITE: SRKO1 SLICK ROCK (BOTH SITES)

$01 / 12 / 89$ TO $10 / 14 / 92$

REPORT DATE: 06/17/93

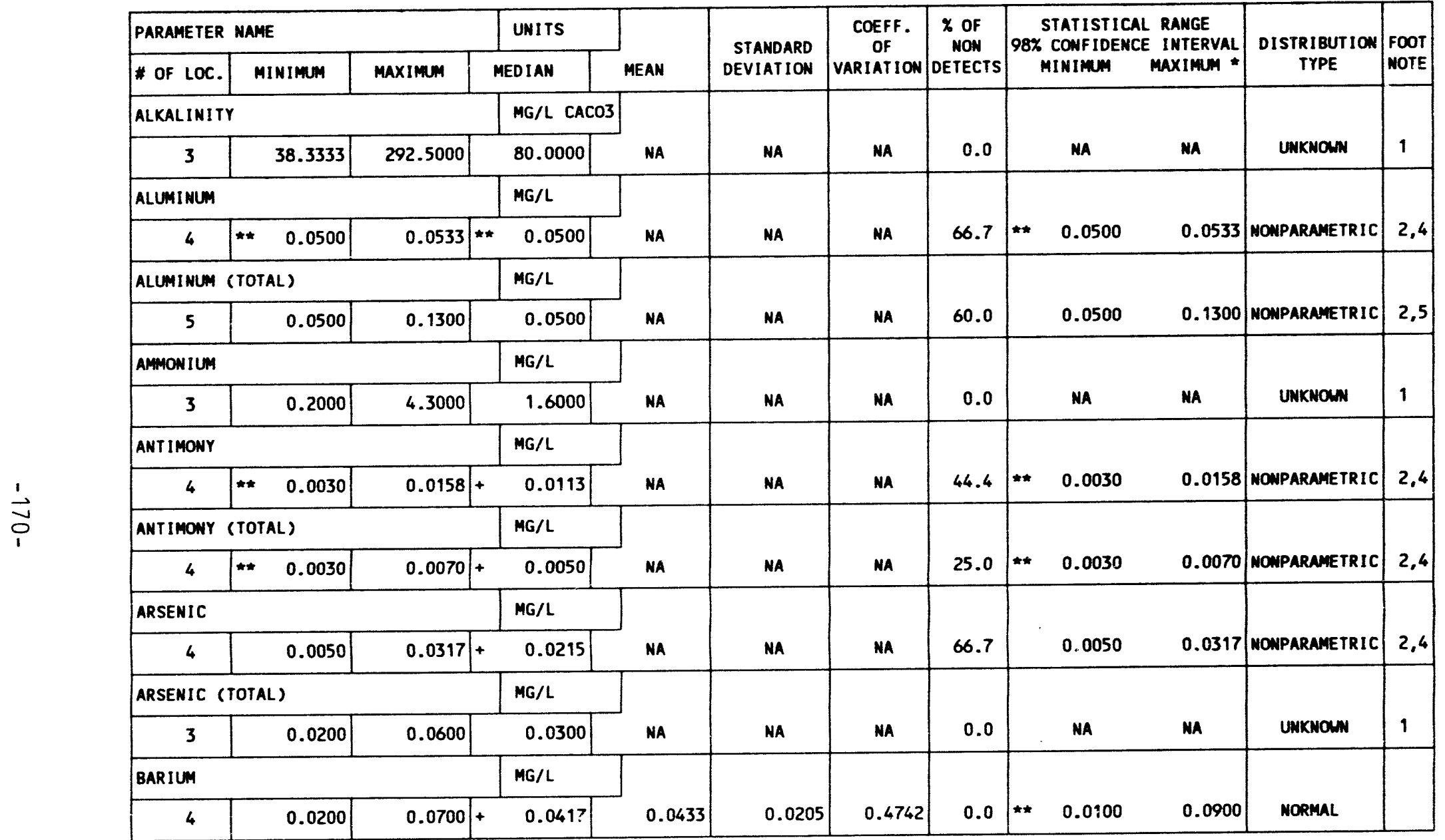

** The reported value is the minimum detection limit of the data set

+ The sample size is even, so the median value is the arithmetic average of the two middle values

* The statistical maximm is the 99 percent one sided confidence interval, $\alpha=0.01$

1) Data from istical maximm is the 99 percent one sided confidence interval, $\alpha=0.01$

2) The nomparaminimum if 4 locations must be available for the statistical analysis.

4) The stat. range is the $87.5 \%$ confidence interval due to a sample size of 4 . The maximm is the $93.8 \%$ one sided confidence int.

5) The stat. range is the $93.8 \%$ confidence interval due to a sample size of 5 . The maximm is the $96.9 \%$ one sided confidence int.

Note the data each location was averag. I before the statistical calculations were performed 
TABLE 3.25 TAILINGS PORE FLUID MATER QUALITY STATISTICS BY PARAMETER, UC TABLE 3.25 TAILINGS PORE FLU, COLORADO

PROCESSING SITE, SLICK ROCK, COLORADO

SITE: SRKOI SLICK ROCK (BOTH SITES)

01/12/89 TO $10 / 14 / 92$

REPORT DATE: $06 / 17 / 93$

\begin{tabular}{|c|c|c|c|c|c|c|c|c|c|c|c|c|c|}
\hline \multicolumn{4}{|c|}{ PARAMETER NAME } & UNITS & \multirow[b]{2}{*}{ MEAN } & \multirow{4}{*}{$\begin{array}{c}\begin{array}{r}\text { STANDARD } \\
\text { DEVIATION }\end{array} \\
\text { NA }\end{array}$} & \multirow{4}{*}{$\begin{array}{c}\text { COEFF. } \\
\text { OF } \\
\text { VARIATION } \\
\\
\\
\text { NA }\end{array}$} & \multirow{4}{*}{\begin{tabular}{|c|}
$\begin{array}{c}\% \text { OF } \\
\text { NON } \\
\text { DETECTS }\end{array}$ \\
80.0 \\
\end{tabular}} & \multirow{2}{*}{\multicolumn{3}{|c|}{$\begin{array}{c}\text { STATISTICAL RANGE } \\
98 \% \text { CONFIDENCE INTERVAL } \\
\text { MINIMUM }\end{array}$}} & \multirow{2}{*}{$\begin{array}{c}\text { DISTRIBUTION } \\
\text { TYPE }\end{array}$} & \multirow{2}{*}{$\begin{array}{l}\text { FOOT } \\
\text { MOTE }\end{array}$} \\
\hline \# of LOC. & & VIMUN & MAXIMUM & MEDIAN & & & & & & & & & \\
\hline BARIUM (TO & TAL) & & & $M G / L$ & \multirow[b]{2}{*}{ NA } & & & & & & & & \\
\hline 5 & $\star \star$ & 0.0100 & 0.0500 & 0.0500 & & & & & $\star \star$ & 0.0100 & 0.0500 & MONPARAMETRIC & 2,5 \\
\hline BERYLLIUM & & & & MG/L & & \multirow[b]{2}{*}{ MA } & \multirow[b]{2}{*}{ NA } & \multirow[b]{2}{*}{100.0} & \multirow[b]{2}{*}{$\star \star$} & \multirow[b]{2}{*}{0.0050} & \multirow[b]{2}{*}{0.0050} & \multirow[b]{2}{*}{ NONPARAMETRIC } & \multirow[b]{2}{*}{2,4} \\
\hline 4 & $\star \star$ & 0.0050 & 0.0050 & $\star \quad 0.0050$ & NA & & & & & & & & \\
\hline \multicolumn{4}{|c|}{ BERYLLIUM (TOTAL) } & MG/L & \multirow[b]{2}{*}{ NA } & \multirow[b]{2}{*}{ MA } & \multirow[b]{2}{*}{ NA } & \multirow[b]{2}{*}{100.0} & \multirow{2}{*}{\multicolumn{2}{|c|}{ MA }} & \multirow[b]{2}{*}{ MA } & \multirow[b]{2}{*}{ UAKNOWN } & \multirow[b]{2}{*}{1} \\
\hline 3 & $\star \star \star$ & 0.0100 & $\star \quad 0.0100$ & $\star \quad 0.0100$ & & & & & & & & & \\
\hline \multicolumn{4}{|l|}{ BORON } & $M G / L$ & \multirow[b]{2}{*}{ NA } & \multirow{4}{*}{ NA } & \multirow[b]{2}{*}{$\mathrm{Na}$} & \multirow[b]{2}{*}{0.0} & & & & & \\
\hline 3 & & 0.2650 & 0.5000 & 0.4300 & & & & & & MA & MA & UNKNOWN & 1 \\
\hline BORON CTOT & $H_{-1}$ & & & MG/L & & & & & & & & & \\
\hline 3 & & 0.2000 & 0.5000 & 0.5000 & MA & & NA & 0.0 & & MA & MA & UNKNOWN & 1 \\
\hline BROMIDE & & & & $M G / L$ & & & & & & & & & \\
\hline 4 & $* \star$ & 0.1000 & 0.5000 & 0.1500 & NA & MA & MA & 100.0 & \#*. & 0.1000 & 0.5000 & NONPARAMETRIC & 2,4 \\
\hline BROMIDE (T & TOTAL & & & $M G / L$ & & & & & & & & & \\
\hline 2 & $\star \star$ & 0.1000 & $\star \quad 0.1000$ & $\star \quad 0.1000$ & MA & NA & NA & 100.0 & & NA & NA & UNKNOWN & 1 \\
\hline CADMIUM & & & & MG/L & & & & & & & & & \\
\hline 4 & & 0.0012 & 0.6520 & 0.0843 & MA & NA & MA & 33.3 & & 0.0012 & 0.6520 & MONPARAMETRIC & 2,4 \\
\hline CADMIUN $(T$ & TOTAL & & & $M G / L$ & & & & & & & & & \\
\hline 5 & $\star \star$ & 0.0010 & 0.0530 & 0.0025 & NA & NA & NA & 40.0 & $\star \star \star$ & 0.0010 & 0.0530 & NONPARAMETRIC & 2,5 \\
\hline
\end{tabular}

** The reported value is the minimum detection limit of the data set

+ The sample size is even, so the median value is the arithmetic average of the two middle values

* The statistical maximm is the 99 percent one sided confidence interval, $x=0.01$

1) The statististical analysis.

1) Data from a minimum

2) The nonparametric distribution was used because

4) The stat. range is the $87.5 \%$ confidence incerval due to a sample size of 5 . The maximm is the $96.9 \%$ one sided confidence int.

5) The stat. range is the $93.8 \%$ confidence interval due to a sample size of 
TABLE 3.25 TAILINGS PORE FLUID HATER QUALITY STATISTICS BY PARAMETER, UC

PROCESSING SITE, SLICK ROCK, COLORADO

SITE: SRKO1 SLICK ROCK (BOTH SITES)

$01 / 12 / 89$ TO $10 / 14 / 92$

REPORT DATE: 06/17/93

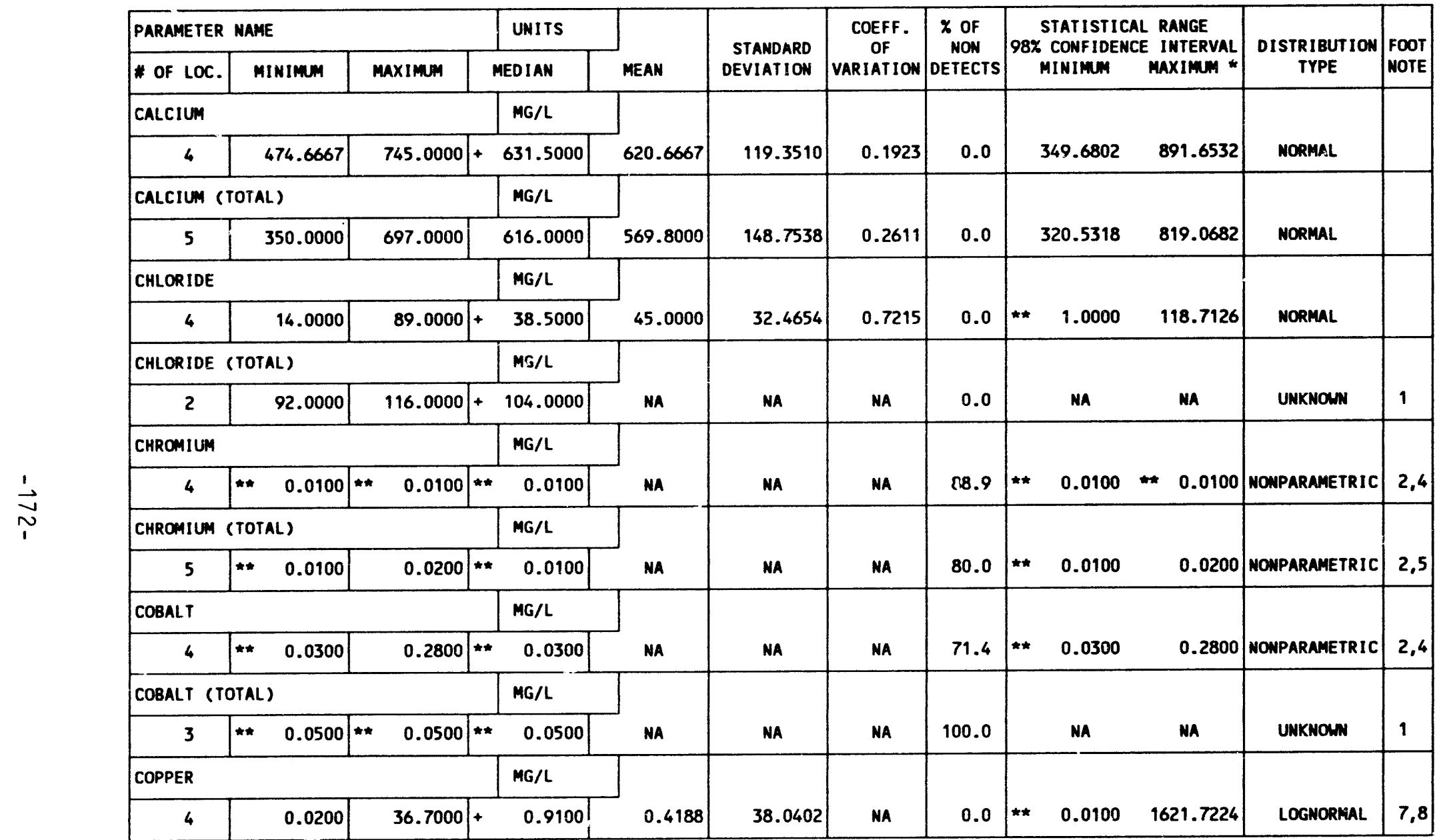

* The reported value is the minimum detection limit of the data set

+ The sample size is even, so the median value is the arithmetic average of the two middle values

* The statistical maximm is the 99 percent one sided confidence interval, $a=0.01$

1) Data from a minimum of 4 locations must be availeble for the statistical analysis.

2) The nonparametric distribution was used because the nondetected values comprise more than $15 \%$ of the samples.

4) The stat. renge is the $87.5 \%$ confidence interval due to sample size of 4 . The maximm is the $93.8 \%$ one sided confidence int.

5) The stat. rance is the $93.8 \%$ confidence interval due to a sample size of 5 . The maximum is the $96.9 \%$ one sided confidence int.

7) The lognormal distribution was used because the data failed the normal distribution test.

8) The mean is geometric. The standard deviation is the value to divide or multiply with the geometric mean.

Note the data at each location was averaged before the statistical calculations were performed 
TABLE 3.25 TAILINGS PORE FLUID WATER QUALITY STATISTICS BY PARAMETER, UC PROCESSING SITE, SLICK ROCK, COLORADO

SITE: SRKO1 SLICK ROCK (BOTH SITES)

$01 / 12 / 89$ TO $10 / 14 / 92$

REPORT DATE: $06 / 17 / 93$

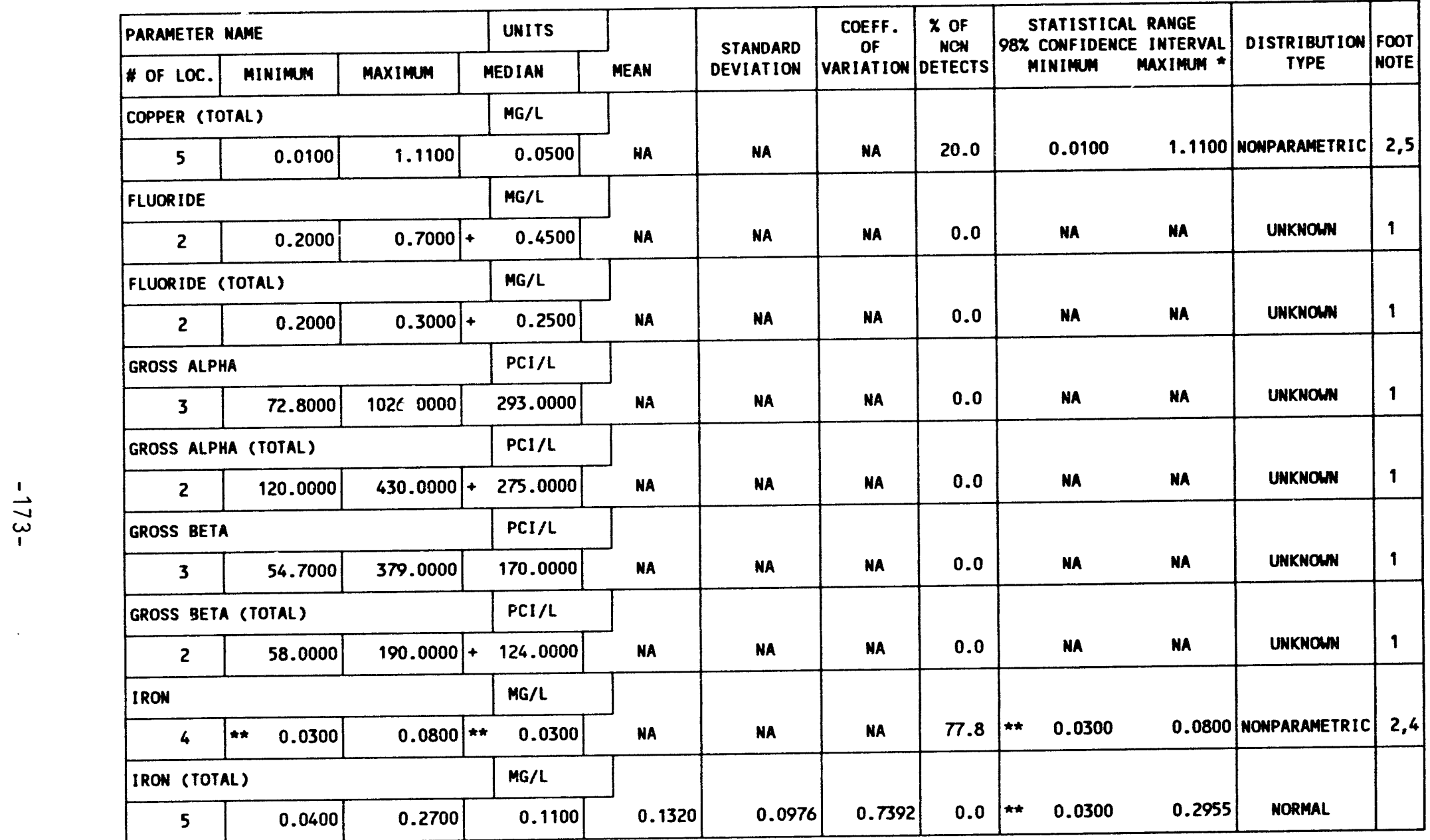

** The reported value is the minimum detection limit of the data set

+ The sample size is even, so the median value is the arithmetic average of the two middle values

- The statistical maximm is the 99 percent one sided confidence interval, $a=0.01$

1) Data from a minimum of 4 locations must be available for the statistical analysis.

2) The nonparametric distribution was used because the nondetected values comprise more than 15\% of the samples.

2) The nonparim is the $93.8 \%$ one sided confidence int.

5) The stat range is the $93.8 \%$ confidence interval due to a sample size of 5 . The maximm is the $96.9 \%$ one sided confidence int.

5) The stat. range is the $93.8 \%$ conf averaged before the statistical calculations were performed 
TABLE 3.25 TAILINGS PORE FLUID WATER QUALITY STATISTICS BY PARAMETER, UC PROCESSING SITE, SLICK ROCK, COLORADO

SITE : SRKO1 SLICK ROCK (BOTH SITES)

$01 / 12 / 89$ TO $10 / 14 / 92$

REPORT DATE: 06/17/93

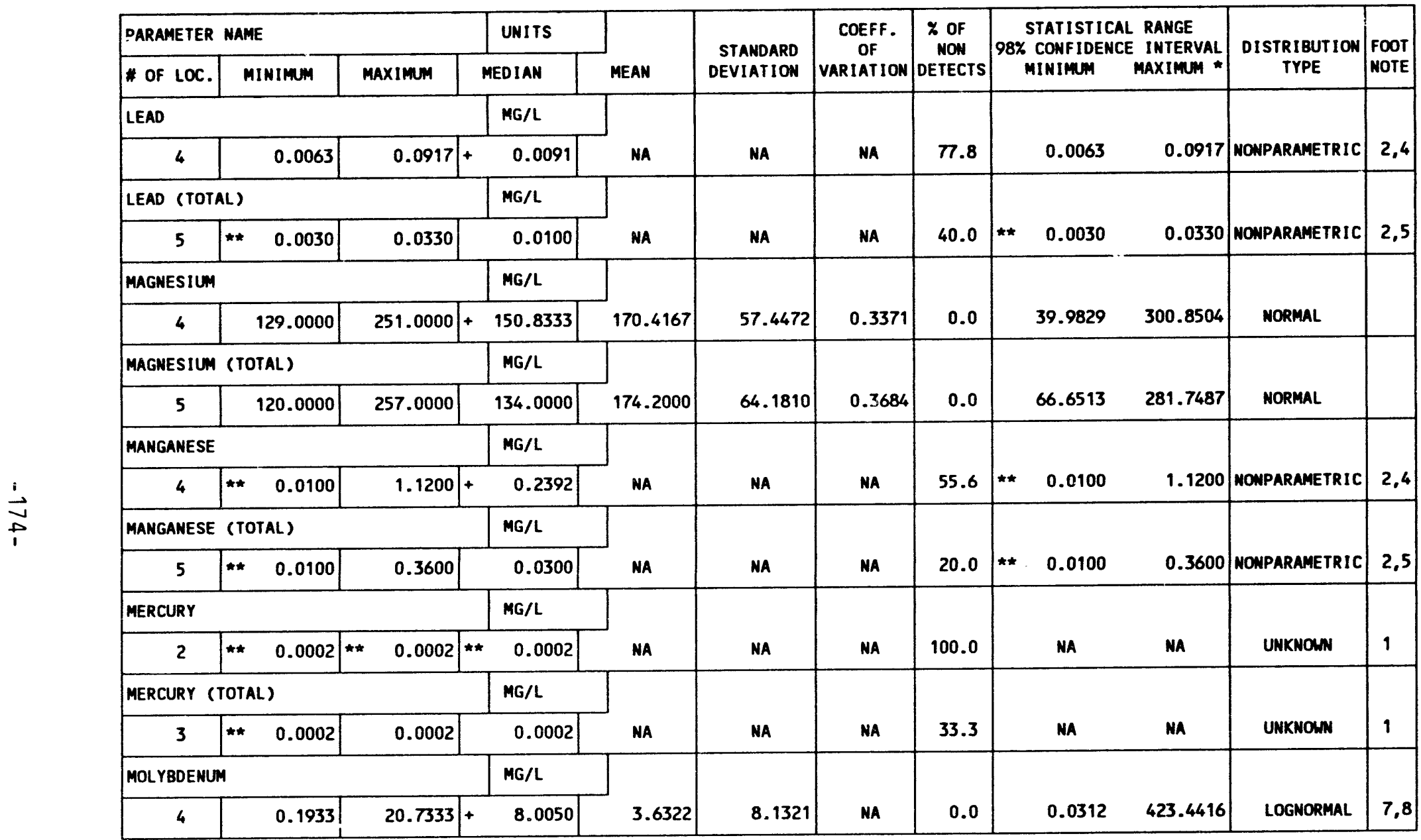

** The reported value is the minimum detection limit of the data set

+ The sample size is even, so the meciian value is the arithmetic average of the two middle values

* The statistical maximum is the 99 percent one sided confidence interval, $a=0.01$

1) Da

1) Data from a minimum of 4 locations must be available for the statistical analysis.

4) The stat. range is tine $87.5 \%$ confidence interval due to a sample size of 4 . The maximum is the $93.8 \%$ one sided confidence int.

5) The stat. range is the $93.8 \%$ confidence interval due to a sample size of 5 . The maximum is the $96.9 \%$ one sided confidence int.

7) The lognormal distribution was used because the data failed the normal distribution test.

8) The mean is geometric. The standard deviation is the value to divide or multiply with the geometric mean.

Note the data each location was averaged before the statistical calculations were performed 
TABLE 3.25 TAILINGS PORE FLUID WATER QUALITY STATISTICS BY PARAMETER, UC PROCESSING SITE, SLICK ROCK, COLORADO

SITE: SRKO1 SLICK ROCK (BOTH SITES)

SITE: SRKO1 SLICK ROCK

REPORT DATE: $06 / 17 / 93$

\begin{tabular}{|c|c|c|c|c|c|c|c|c|c|c|c|}
\hline \multicolumn{3}{|c|}{ PARAMETER NAME } & UNITS & \multirow[b]{2}{*}{ MEAN } & \multirow{2}{*}{$\begin{array}{r}\text { STANDARD } \\
\text { DEVIATION }\end{array}$} & \multirow{2}{*}{$\begin{array}{c}\text { COEFF. } \\
\text { OF } \\
\text { VARIATION }\end{array}$} & \multirow{2}{*}{$\begin{array}{c}\% \text { OF } \\
\text { NON } \\
\text { DETECTS }\end{array}$} & \multirow{2}{*}{\multicolumn{2}{|c|}{$\begin{array}{l}\text { STATISTICAL RANGE } \\
\text { 98\% CONFIDENCE INTERVAL } \\
\text { MINIMUM MAXIMM * }\end{array}$}} & \multirow{2}{*}{$\begin{array}{c}\text { DISTRIBUTIIOW } \\
\text { TYPE }\end{array}$} & \multirow{2}{*}{$\begin{array}{l}\text { FOOT } \\
\text { NOTE }\end{array}$} \\
\hline \# OF LOC. & MINIMUM & MAXIMUM & MEDIAN & & & & & & & & \\
\hline \multicolumn{3}{|c|}{ MOLYBDENUM (TOTAL) } & $M G / L$ & \multirow[b]{2}{*}{13.6680} & \multirow[b]{2}{*}{10.9365} & \multirow[b]{2}{*}{0.8002} & \multirow[b]{2}{*}{0.0} & \multirow[b]{2}{*}{0.0100} & \multirow[b]{2}{*}{31.9945} & \multirow[b]{2}{*}{ NORMAL } & \\
\hline 5 & 0.4900 & 30.6000 & 13.6000 & & & & & & & & \\
\hline \multicolumn{3}{|c|}{ 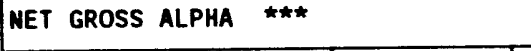 } & $\mathrm{PCI} / \mathrm{L}$ & \multirow[b]{2}{*}{ NA } & \multirow[b]{2}{*}{ NA } & \multirow[b]{2}{*}{ NA } & \multirow[b]{2}{*}{0.0} & \multirow[b]{2}{*}{ NA } & \multirow[b]{2}{*}{ NA } & \multirow[b]{2}{*}{ UNKNON } & \multirow[b]{2}{*}{1} \\
\hline 3 & -31.4700 & 1022.5700 & -21.1900 & & & & & & & & \\
\hline \multicolumn{2}{|c|}{ NET GROSS ALPHA (TOTAL) } & 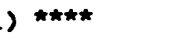 & $\mathrm{PCI} / \mathrm{L}$ & \multirow[b]{2}{*}{ NA } & \multirow[b]{2}{*}{ NA } & \multirow[b]{2}{*}{ NA } & \multirow[b]{2}{*}{0.0} & \multirow[b]{2}{*}{ MA } & \multirow[b]{2}{*}{ NA } & \multirow[b]{2}{*}{ UNKNOWN } & \\
\hline 2 & -9.7300 & 27.3900 & 8.8300 & & & & & & & & 1 \\
\hline NICKEL & & & MG/L & & & & & & & & \\
\hline 4 & $\star \star \quad 0.0400$ & 0.1700 & $\begin{array}{ll}* & 0.0400\end{array}$ & NA & NA & NA & 88.9 & 0.0400 & 0.1700 & NONPARAMETRIC & 2,4 \\
\hline NICKEL (TO & DTAL ) & & MG/L & & & & & & & & \\
\hline 5 & $\star \quad 0.0400$ & $\star \quad 0.0400$ & $\star \star \quad 0.0400$ & NA & NA & NA & 100.0 & 0.0400 & $\star 0.0400$ & NONPARAMETRIC & 2,5 \\
\hline NI TRATE & & & $M G / L$ & & & & & & & & \\
\hline 3 & 40.0000 & 744.0000 & 210.0000 & NA & NA & NA & 0.0 & NA & NA & UNKNOWN & 1 \\
\hline NITRITE A! & ND NITRATE & & $M G / L$ & & & & & & & & \\
\hline 1 & 168.0000 & 168.0000 & 168.0000 & NA & NA & NA & 0.0 & NA & MA & UNKNOWN & 1 \\
\hline PH & & & su & & & & & & & & \\
\hline 6 & 6.2100 & 7.8100 & 7.3224 & NA & NA & HA & 0.0 & NA & NA & UNKNOWY & \\
\hline
\end{tabular}

*** NET GROSS ALPHA (GROSS ALPHA - URANIUM) WITH 1 MG URANIUM = 686 PCI

\#\#* MET GROSS ALPHA (TOTAL) (TOTAL GROSS ALPHA - TOTAL URANIUM)

* The reported value is the minim (TOTAL GROSS ALPHA

+ The sample size is even, so the median value is the arithmetic average of the two middle values

- The sample size is even, so the 99 percent one sided confidence interval, $a=0.01$

1) The statistical maximum is the 99 percent ore sided confidence interval a

1) Data from a minimm of 4 locations must be available for the statistical analysis.

4) The stat. range is the $87.5 \%$ confidence interval due to a sample size of 4. The maximm is the $93.8 \%$ one sided confidence int.

5) The stat. range is the $93.8 \%$ confidence interval due to a sample size of 5 . The maximm is the $96.9 \%$ one sided confidence int

Note 
TABLE 3.25 TAILINGS PORE FLUID MATER QUALITY STATISTICS BY PARAMETER, UC

PROCESSING SITE, SLICK ROCK, COLORADO

SITE: SRKO1 SLICK ROCK (BOTH SITES)

$01 / 12 / 89$ TO $10 / 14 / 92$

REPORT DATE: 06/17/93

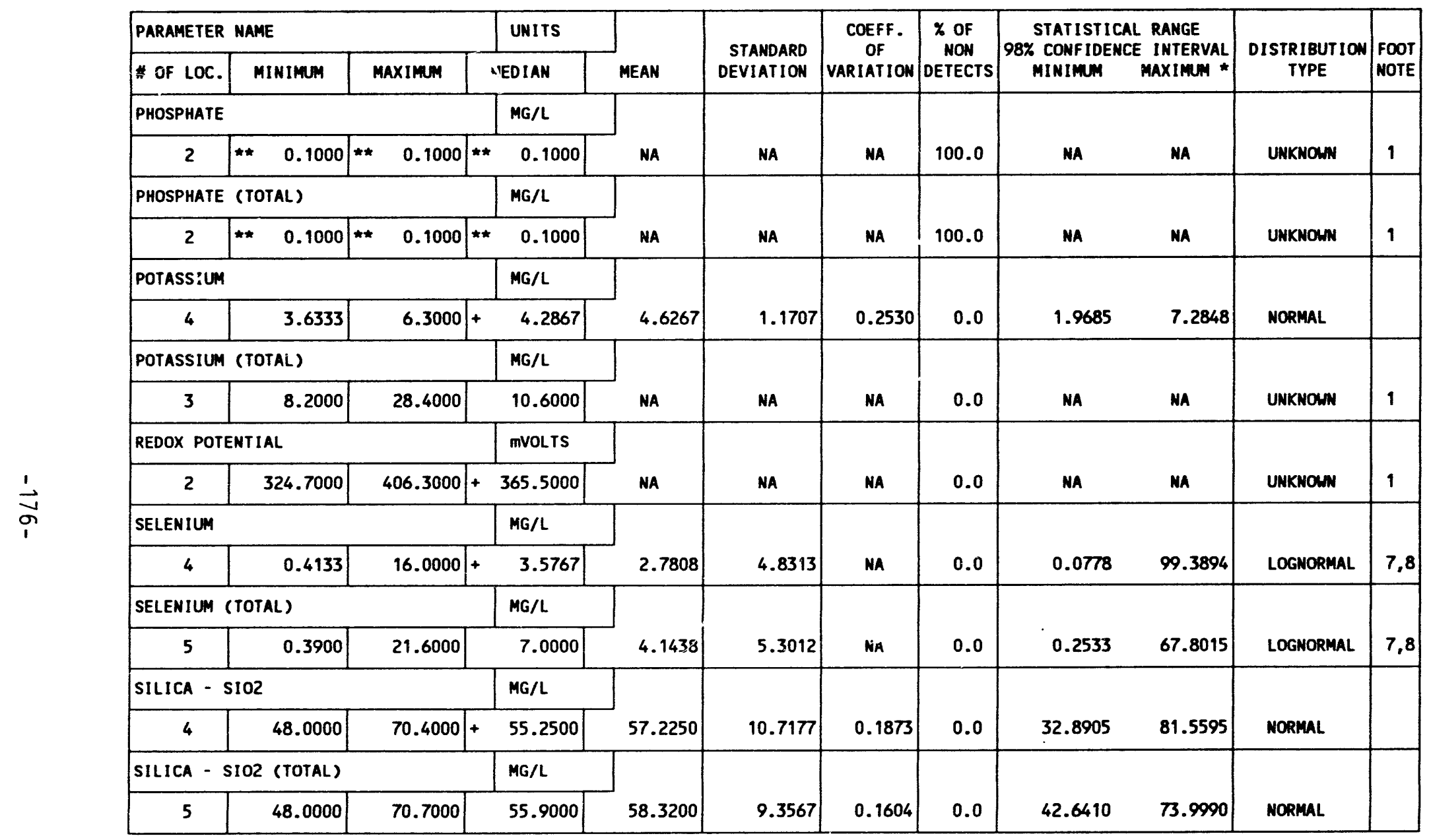

** The reported value is the minimum detection limit of the data set

+ The sample size is even, so the median value is the arithmetic average of the two middle values

* The statistical maximm is the 99 percent one sided confidence interval, $a=0.01$

1) Data from a minimum of 4 locations must be available for the statistical analysis.

7) The lognormal distribution was used because the data failed the normal distribution test.

8) The mean is geometric. The standard deviation is the value to divide or multiply with the geometric mean.

Note the data at each location was averaged before the statistical calculations were performed 
TABLE 3.25 TAILINGS PORE FLUID WATER QUALITY STATISTICS BY PARAMETER, UC PROCESSING SITE, SLICK ROCK, COLORADO

SITE: SRK01 SLICK ROCK (BOTH SITES)

01/12/89 TO $10 / 14 / 92$

REPORT DATE: 06/17/93

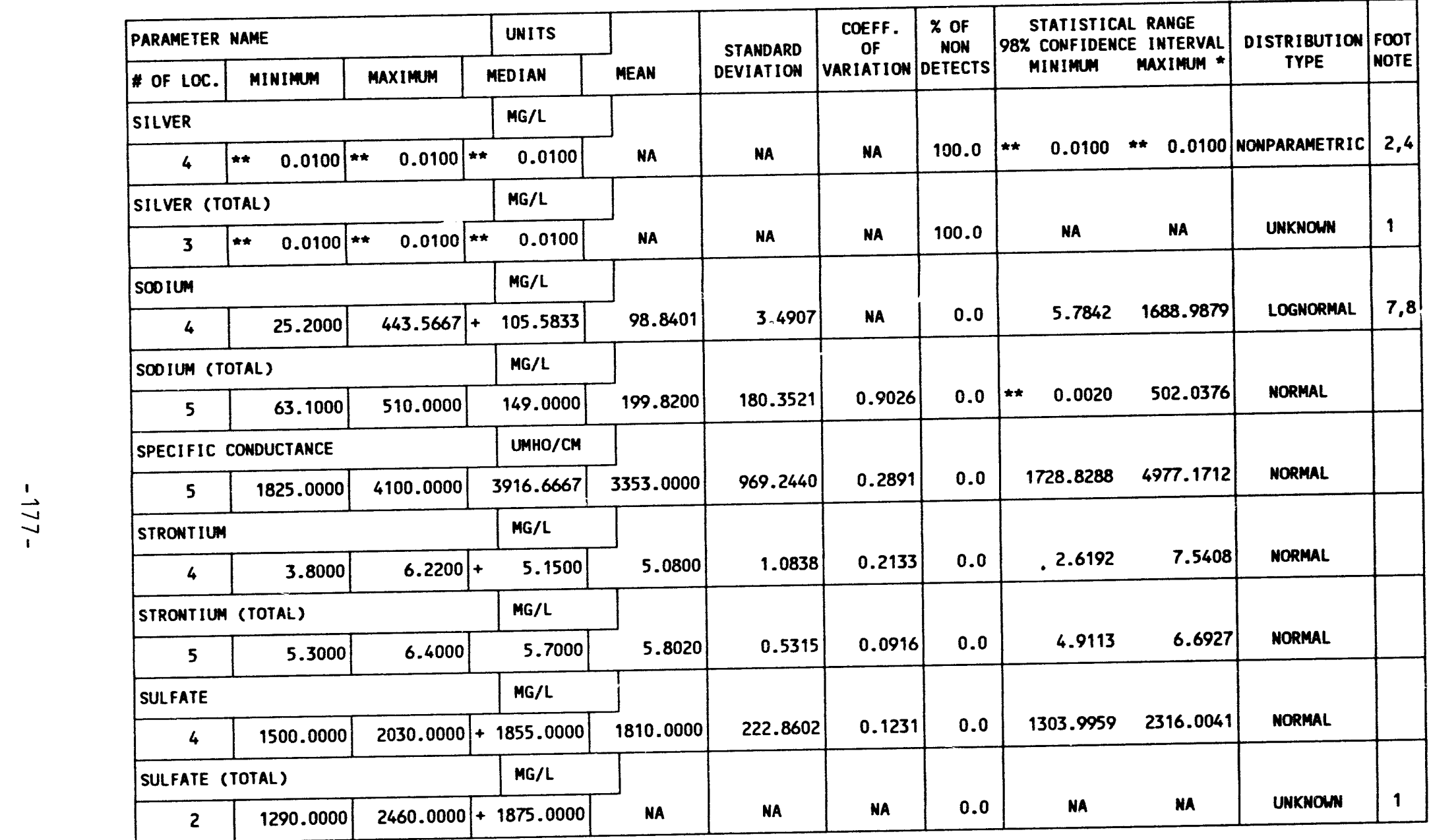

* The reported value is the minimum detection limit of the data set

+ The sample size is even, so the median ve sided confidence interval, $\alpha=0.01$

* The statistical maximu is the

1) Data from a minimum of 4 locations must be available for the statistues comprise more than $15 \%$ of the samples.

2) The nonparametric distribution was used because the

4) The stat. range is the $\mathbf{8 7 . 5 \%}$ confidence interval due to a sample size of 4 . The mat ibution test.

7) The lognormal distribution was used because the data failed the normal distribuly with the geometric mean.

8) The mean is geometric. The standard deviation is the value to divide or multiply with the ged
Note the data at each location was averaged before the statistical calculations were performed 
TABLE 3.25 TAILINGS PORE FLUID WATER QUALITY STATISTICS BY PARAMETER, UC

PROCESSING SITE, SLICK ROCK, COLORADO

SITE: SRKO1 SLICK ROCK (BOTH SITES)

01/12/89 TO $10 / 14 / 92$

REPORT DATE: 06/17/93

\begin{tabular}{|c|c|c|c|c|c|c|c|c|c|c|c|}
\hline \multicolumn{3}{|c|}{ PARAMETER NAME } & UNITS & \multirow[b]{2}{*}{ MEAN } & \multirow{2}{*}{$\begin{array}{r}\text { STANDARD } \\
\text { DEVIATION }\end{array}$} & \multirow{2}{*}{$\begin{array}{c}\text { COEFF. } \\
\text { OF } \\
\text { VARIATION }\end{array}$} & \multirow{2}{*}{$\begin{array}{c}\% \text { OF } \\
\text { NON } \\
\text { DETECTS }\end{array}$} & \multirow{2}{*}{\multicolumn{2}{|c|}{$\begin{array}{l}\text { STATISTICAL RANGE } \\
\text { 98\% CONFIDENCE INTERVAL } \\
\text { MINIMUM MAXIMUM * }\end{array}$}} & \multirow{2}{*}{$\begin{array}{l}\text { DISTRIBUTION } \\
\text { TYPE }\end{array}$} & \multirow{2}{*}{$\begin{array}{l}\text { FOOT } \\
\text { NOTE }\end{array}$} \\
\hline \# OF LOC. & MINIMUM & MAXIMUM & MEDIAN & & & & & & & & \\
\hline SULFIDE & & & $M G / L$ & \multirow[b]{2}{*}{ NA } & \multirow[b]{2}{*}{ NA } & \multirow[b]{2}{*}{ NA } & \multirow[b]{2}{*}{100.0} & \multirow[b]{2}{*}{ NA } & \multirow[b]{2}{*}{ MA } & \multirow[b]{2}{*}{ UNKNOWN } & \multirow[b]{2}{*}{1} \\
\hline 2 & $\star \quad 0.1000$ & $\begin{array}{ll}* \quad & 0.1000\end{array}$ & $\star \quad 0.1000$ & & & & & & & & \\
\hline \multicolumn{3}{|c|}{ TEMPERATURE } & C - DEGR & \multirow[b]{2}{*}{12.9061} & \multirow[b]{2}{*}{4.0380} & \multirow[b]{2}{*}{0.3129} & \multirow[b]{2}{*}{0.0} & \multirow[b]{2}{*}{7.3589} & \multirow[b]{2}{*}{18.4533} & \multirow[b]{2}{*}{ NORMAL } & \\
\hline 6 & 6.5000 & 17.0000 & $+\quad 13.3500$ & & & & & & & & \\
\hline \multicolumn{3}{|l|}{ THALLIUM } & $M G / L$ & \multirow[b]{2}{*}{ NA } & \multirow[b]{2}{*}{ NA } & \multirow[b]{2}{*}{ NA } & \multirow[b]{2}{*}{100.0} & \multirow[b]{2}{*}{0.0050} & \multirow[b]{2}{*}{0.0108} & & \\
\hline 4 & $\star \star \quad 0.0050$ & 0.0108 & 0.0050 & & & & & & & NONPARAMETRIC & 2,4 \\
\hline THALLIUM & (TOTAL) & & $M G / L$ & & & & & & & & \\
\hline 4 & $\begin{array}{ll}* & 0.0050\end{array}$ & 0.0050 & 0.0050 & NA & NA & NA & 100.0 & 0.0050 & 0.0050 & NONPARAMETRIC & 2,4 \\
\hline TIN & & & $M G / L$ & & & & & & & & \\
\hline 4 & $\begin{array}{ll}* & 0.0050\end{array}$ & 0.0138 & 0.0093 & NA & NA & NA & 77.8 & 0.0050 & 0.0138 & NONPARAMETRIC & 2,4 \\
\hline TIN CTOTAL & & & $M G / L$ & & & & & & & & \\
\hline 3 & ** $\quad 0.0050$ & 0.1500 & $\star \quad 0.0050$ & NA & NA & NA & 66.7 & NA & NA & UNKNOWN & 1 \\
\hline TOTAL DISS & SOLVED SOLIDS & & $M G / L$ & & & & & & & & \\
\hline 4 & 2800.0000 & 4100.0000 & +3325.0000 & 3387.5000 & 558.7710 & 0.1650 & 0.0 & 2118.8105 & 4656.1895 & NORMAL & \\
\hline TOTAL KJEI & LDAHL NITROGE & & $M G / L$ & & & & & & & & \\
\hline 1 & 1.0000 & 1.0000 & 1.0000 & NA & NA & NA & 0.0 & MA & NA & UNKNOWN & 1 \\
\hline URANIUM & & & $M G / L$ & & & & & & & & \\
\hline 4 & 0.0191 & 0.4580 & 0.2762 & 0.2574 & 0.1990 & 0.7733 & 0.0 & 0.0010 & 0.7093 & NORMAL & \\
\hline
\end{tabular}

** The reported value is the minimum detection limit of the data set

+ The sample size is even, so the median value is the arithmetic average of the two middle values

- The statistical maximum is the 99 percent one sided confidence interval, $\alpha=0.01$

1) Data from a minimum of 4 locations must be available for the statistical analysis.

2) The nonparametric distribution was used because the nondetected values comprise more than 15\% of the samples.

4) The stat. range is the $87.5 \%$ confidence interval due to a sample size of 4 . The maximm is the $93.8 \%$ one sided confidence int.

Note the data at each location was averaged before the statistical calculations were performed 
TABLE 3.25 TAILINGS PORE FLUID MATER QUALITY STATISTIES BY PARAMETER, UC PROCESSING SITE, SLICK ROCK, COLORADO

SITE: SRKO1 SLICK ROCK (BOTH SITES)

01/12/89 TO $10 / 14 / 92$

REPORT DATE: $06 / 17 / 93$

\begin{tabular}{|c|c|c|c|c|c|c|c|c|c|c|c|c|}
\hline \multicolumn{3}{|c|}{ PARAMETER NAME } & UNITS & \multirow[b]{2}{*}{ MEAN } & \multirow{2}{*}{$\begin{array}{l}\text { STANDARD } \\
\text { DEVIATION }\end{array}$} & \multirow{2}{*}{$\begin{array}{c}\text { COEFF. } \\
\text { OF } \\
\text { VARIATION }\end{array}$} & \multirow{2}{*}{$\left|\begin{array}{c}\% \text { OF } \\
\text { NON } \\
\text { DETECTS }\end{array}\right|$} & \multirow{2}{*}{\multicolumn{3}{|c|}{$\begin{array}{c}\text { STATISTICAL RANGE } \\
\text { 98\% CONFIDENCE INTERVAL } \\
\text { MINIMUM }\end{array}$}} & \multirow{2}{*}{$\begin{array}{c}\text { DISTRIBUTION } \\
\text { TYPE }\end{array}$} & \multirow{2}{*}{$\begin{array}{l}\text { FOOT } \\
\text { NOTE }\end{array}$} \\
\hline * of LOC. & MINIMUM & MAXIMUM & MEDIAN & & & & & & & & & \\
\hline \multicolumn{3}{|c|}{ URANIUM (TOTAL) } & $M G / L$ & \multirow[b]{2}{*}{ NA } & \multirow[b]{2}{*}{ NA } & \multirow[b]{2}{*}{ NA } & \multirow[b]{2}{*}{0.0} & \multirow{2}{*}{\multicolumn{2}{|c|}{ NA }} & \multirow[b]{2}{*}{ NA } & \multirow[b]{2}{*}{ UNKMOWN } & \multirow[b]{2}{*}{1} \\
\hline 3 & 0.1350 & 0.6410 & 0.4500 & & & & & & & & & \\
\hline \multicolumn{3}{|l|}{ VANADIUM } & $M G / L$ & \multirow[b]{2}{*}{0.1786} & \multirow[b]{2}{*}{6.5967} & \multirow[b]{2}{*}{ NA } & \multirow[b]{2}{*}{0.0} & \multirow[b]{2}{*}{$\star \star$} & \multirow[b]{2}{*}{0.0100} & \multirow[b]{2}{*}{12.9463} & \multirow[b]{2}{*}{ LOGNORMAL } & \multirow[b]{2}{*}{7,8} \\
\hline 4 & 0.0200 & 1.0900 & 0.3683 & & & & & & & & & \\
\hline \multicolumn{3}{|c|}{ VANADIUM (TOTAL) } & MG/1 & \multirow[b]{2}{*}{0.7820} & \multirow[b]{2}{*}{0.5270} & \multirow[b]{2}{*}{0.6739} & \multirow[b]{2}{*}{0.0} & \multirow[b]{2}{*}{$\star \star \star$} & \multirow[b]{2}{*}{0.0100} & \multirow[b]{2}{*}{1.6651} & \multirow[b]{2}{*}{ MORMAL } & \\
\hline 5 & 0.2300 & 1.6500 & 0.6300 & & & & & & & & & \\
\hline \multicolumn{3}{|l|}{ ZINC } & $M G / L$ & & & & & & & & & \\
\hline 4 & 0.0240 & 4.4900 & 0.3173 & 0.2358 & 10.9618 & NA & 0.0 & $\star \star$ & 0.0050 & 54.1540 & LOGNORMAL & 7,8 \\
\hline ZINC (TOTA & & & $M G / L$ & & & & & & & & & \\
\hline 5 & 0.0570 & 0.2900 & 0.0900 & 0.1234 & 0.0966 & 0.7827 & 0.0 & $\star \star$ & 0.0050 & 0.2852 & MREMAL & \\
\hline
\end{tabular}

** The reported value is the minimum detection limit of the data set

+ The sample size is even, so the median value is the arithmetic average of the two middle values

* The sample size is even, so the median value is the arithetic average of the two

1) Data from a minimum of 4 locations must be available for the statistical analysis.

1) The lognormal distribution was used because the data failed the normal distribution test.

8) The mean is geometric. The standard deviation is the value to divide or multiply with the geometric mean.

8) The mean is geometric. The standard deviation is the value to divide or multiply with the
Note the data at each location was averaged before the statistical calculations were performed

INPUT DATA FILENA.E: M: IDARTISRKO1ILYS10005.DAT 
Table 3.26 Summary of regulated constituents in tailings pore fluid samples, UC processing site, slick Rock, Colorado

\begin{tabular}{|c|c|c|c|c|}
\hline \multicolumn{5}{|c|}{ Constituents with MCLs ${ }^{a}$} \\
\hline Parameter & Median & MCL & Background ${ }^{b}$ & Exceed \\
\hline Arsenic & $0.02^{\circ}$ & 0.05 & $0.01^{8}$ & - \\
\hline Barium & $0.04^{d}$ & 1.00 & $0.05^{\mathrm{e}}$ & $\cdots$ \\
\hline Cadmium & $0.08^{e}$ & 0.01 & $0.001^{8}$ & $8 x$ \\
\hline Chromium & $0.01^{8}$ & 0.05 & $0.01^{\mathrm{g}}$ & $\cdots$ \\
\hline Net gross alphaf & -21.19 & 15.00 & $6.96^{\mathrm{c}}$ & - \\
\hline Lead & $0.009^{e}$ & 0.05 & $0.01^{\mathrm{g}}$ & -- \\
\hline Mercury & $0.0002^{\mathrm{g}}$ & 0.002 & $0.0002^{\mathrm{g}}$ & - \\
\hline Molybdenum & $3.63^{c}$ & 0.10 & $0.02^{\mathrm{e}}$ & $36 x$ \\
\hline Nitrate & 210.0 & 44.0 & $4.4^{e}$ & $5 x$ \\
\hline Radium-226 and $-228^{f}$ & - & 5.0 & $1.80^{d}$ & $\cdots$ \\
\hline selenium & $2.78^{\mathrm{c}}$ & 0.01 & $0.012^{\mathrm{g}}$ & $278 x$ \\
\hline Silver & $0.01^{8}$ & 0.05 & $0.01^{\mathrm{g}}$ & - \\
\hline Uranium & $0.26^{d}$ & 0.044 & $0.019^{\mathrm{e}}$ & $6 x$ \\
\hline
\end{tabular}


Table 3.26 Summary of regulated constituents in tailings pore fluid samples, UC processing site, slick Rock, Colorado (concluded)

\begin{tabular}{|c|c|c|c|c|}
\hline & Constituents & without $\mathrm{M}$ & & \\
\hline Parameter & Median & MCL & Background & Exceed \\
\hline Antimony & $0.011^{\mathrm{e}}$ & None & $0.003^{B}$ & $4 x$ \\
\hline Beryllium & $0.01^{\mathrm{g}}$ & None & $0.01^{8}$ & - \\
\hline Cobalt & $0.03^{\circ}$ & None & $0.05^{\mathrm{B}}$ & -- \\
\hline Copper & $0.42^{c}$ & None & $0.02^{\mathrm{g}}$ & $21 x$ \\
\hline Cyanide & -- & None & $0.01^{\mathrm{B}}$ & - \\
\hline Nickel & $0.04^{8}$ & None & $0.04^{\mathrm{g}}$ & -- \\
\hline Sulfide & $0.1^{\mathrm{g}}$ & None & $1.0^{e}$ & - \\
\hline Thallium & $0.01^{\mathrm{g}}$ & None & $0.01^{8}$ & -- \\
\hline Tin & $0.009^{e}$ & None & $0.005^{8}$ & $2 x$ \\
\hline Vanadium & $0.18^{\mathrm{c}}$ & None & $0.02^{e}$ & $9 x$ \\
\hline Zinc & $0.236^{c}$ & None & $0.01^{\mathrm{e}}$ & $24 x$ \\
\hline
\end{tabular}

"All units are $\mathrm{mg} / \mathrm{l}$ unless otherwise noted.

bisposal site background groundwater statistical maximum (upper sandstone unit).

'Lognormal distribution, mean is geometric.

'Normal distribution, mean is arithmetic.

"Nonparametric distribution

Units are $\mathrm{pCi} / 1$.

SStatistical values are below laboratory detection limits in

Table 8.1 of the Technical Approach Document (DOE, 1989) 
TABLE 3.27 BASELINE GROUNDWATER QUALITY DATA BY PARAMETER FOR THE ALLUVIUM NC AND UC PROCESSING SITES, SLICK ROCK, COLORADO

SITE: SRK01 SLICK ROCK (BOTH SITES)

$06 / 30 / 86$ TO $10 / 13 / 92$

REPORT DATE: $07 / 26 / 93$

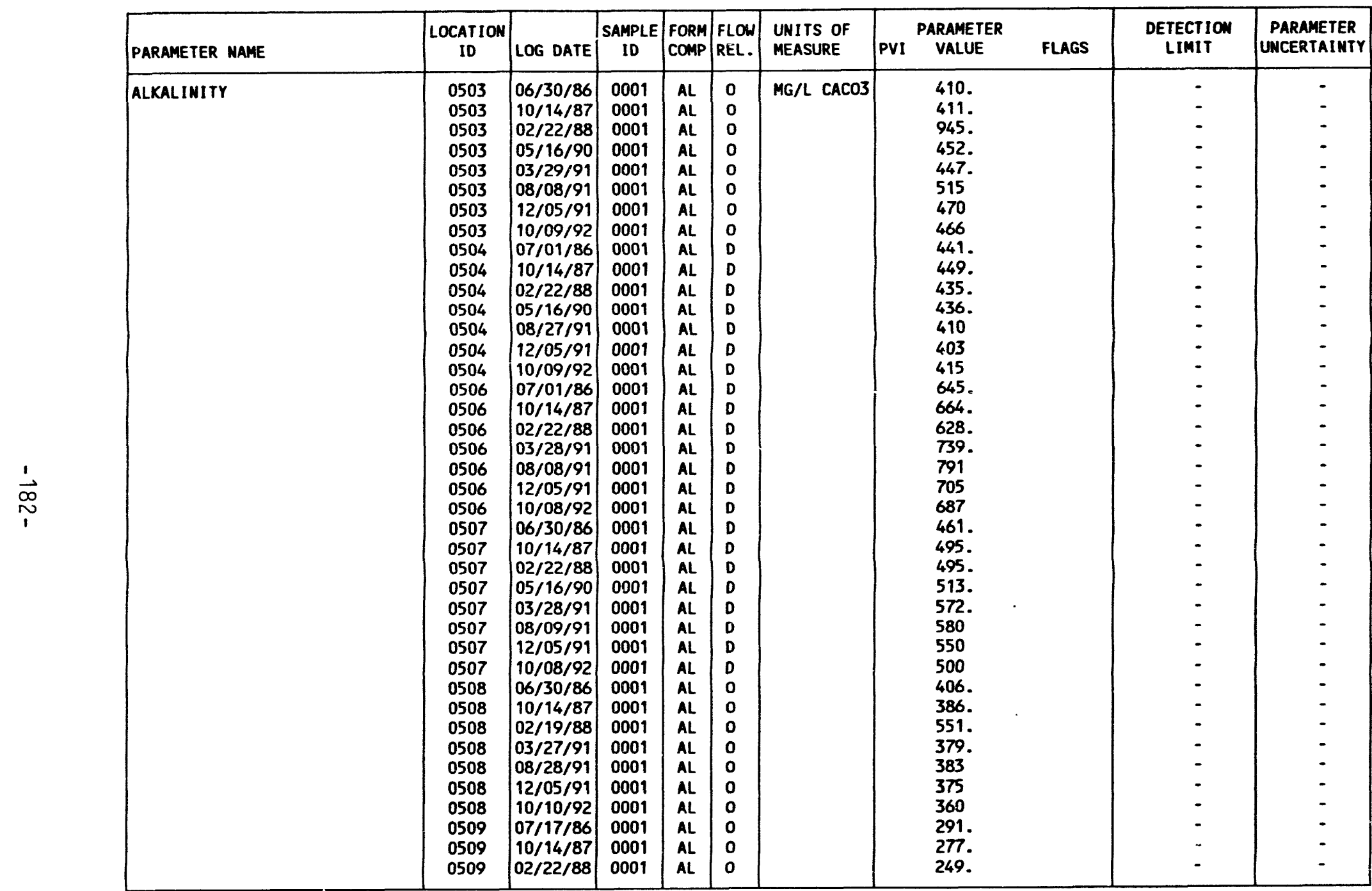

FORMATION OF COMPLETION CODE:

AL - ALLUVIUM

FLON RELATIONSHIP COOE:

O- ON-SITE

D - DON GRADIENT

PARAMETER VAlUe INDICATOR (PVI): < - LESS than DETECTION LIMI 
TABLE 3.27 BASELINE GROUNDWATER QUALITY DATA BY PARAMETER FOR THE ALLUVIUM NC AND UC PROCESSING SITES, SLICK ROCK, COLORADO

SITE: SRKO1 SLICK ROCK (BOTH SITES)

06/30/86 TO $10 / 13 / 92$

REPORT DATE: 07/26/93

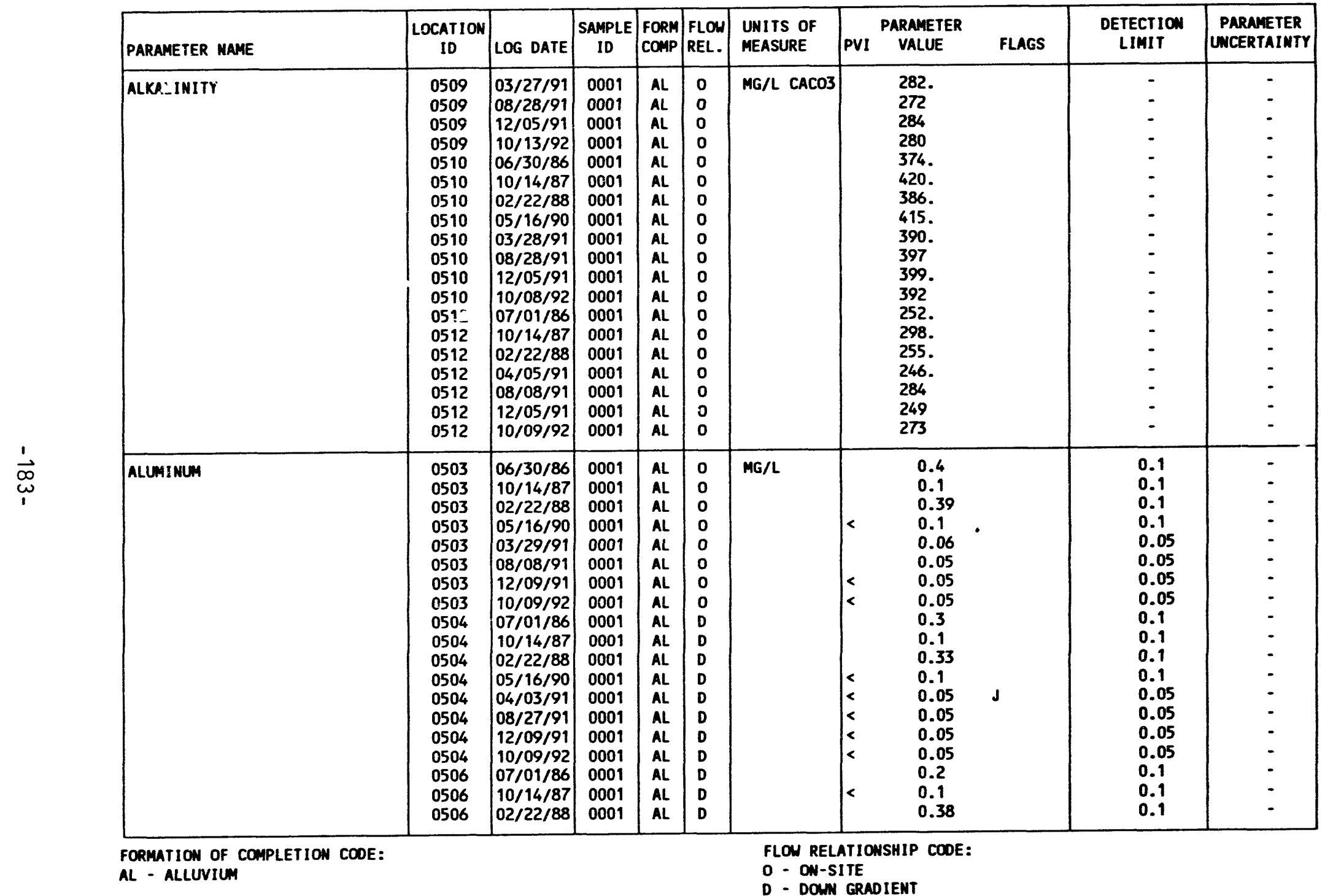

PARAMETER VALUE INDICATOR (PVI): < - LESS THAN DETECTION LIMIT

SAMPLE ID COOES:

0001 - FILTERED SAMPLE (.45 MICRONS)

OTHER PARAMETER VALUE FLAGS:

J- ESTIMATED VALUE 
TABLE 3.27 BASELINE GROUNDWATER QUALITY DATA BY PARAMETER FOR THE ALLUVIUM NC AND UC PROCESSING SITES, SLICK ROCK, COLORADO

SITE: SRKO1 SLICK ROCK (BOTH SITES)

$06 / 30 / 86$ TO $10 / 13 / 92$

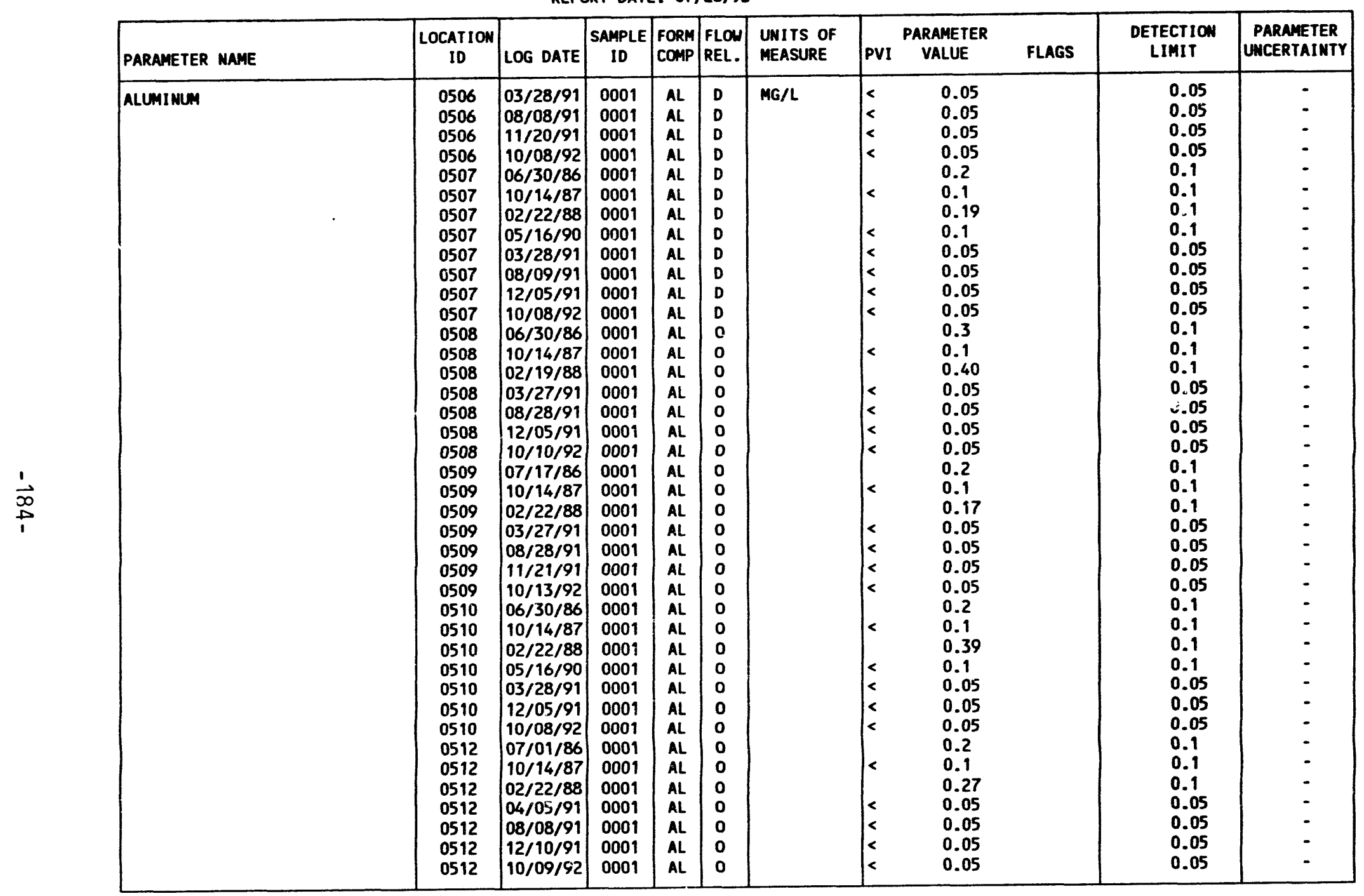

FORMATION OF COAPLETION CODE:

FLOW RELATIONSHIP CODE:

AL - ALLUVIUN

D - DOWN GRADIENT

O - ON-SITE

PARAMETER VALUE INDICATOR (PVI): < - LESS THAN DETECTION LIMIT

SAMPLE ID CODES:

0001 - FILTERED SAMPLE (.45 MICRONS) 


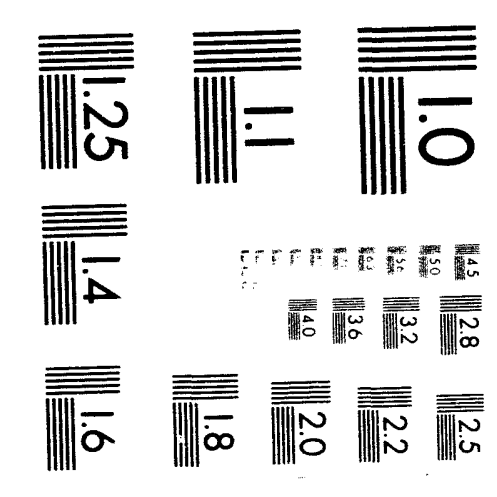



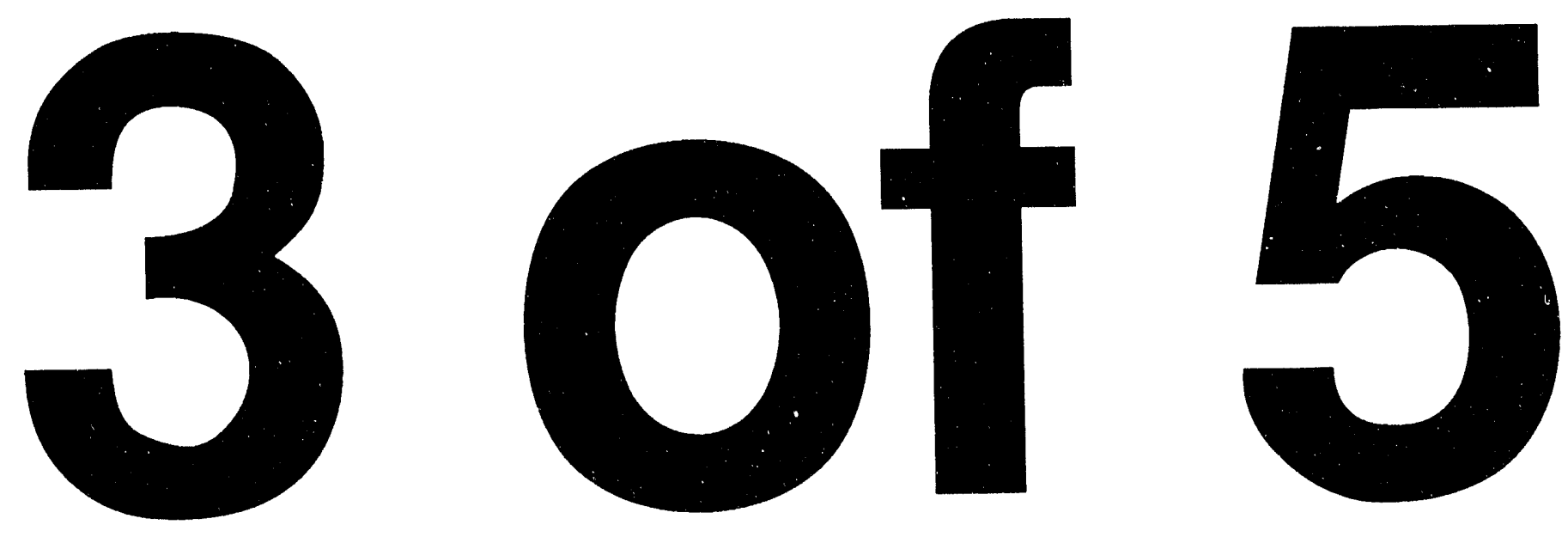
TABLE 3.27 BASELINE GROUNDWATER QUALITY DATA BY PARAMETER FOR THE ALLUVIUM

NC AND UC PROCESSING SITES, SLICK ROCK, COLORADO

SITE: SRK01 SLICK ROCK (BOTH SITES)

06/30/86 TO $10 / 13 / 92$

\begin{tabular}{|c|c|c|c|c|c|c|c|c|c|c|c|c|}
\hline & PARAMETER NAME & $\begin{array}{c}\text { LOCATION } \\
\text { ID }\end{array}$ & LOG DATE & $\begin{array}{c}\text { SAMPLE } \\
\text { ID }\end{array}$ & $\begin{array}{l}\text { FORM } \\
\text { COMP }\end{array}$ & $\begin{array}{l}\text { FLON } \\
\text { REL. }\end{array}$ & $\begin{array}{l}\text { UNITS OF } \\
\text { MEASURE }\end{array}$ & PVI & $\begin{array}{l}\text { PARAMETER } \\
\text { VALUE }\end{array}$ & FLAGS & $\begin{array}{l}\text { DETECTION } \\
\text { LIMIT }\end{array}$ & $\begin{array}{l}\text { PARAMETER } \\
\text { UNCERTAINTY }\end{array}$ \\
\hline $\begin{array}{l}\text { '. } \\
\text { ' }\end{array}$ & AMMONIUM & $\begin{array}{l}0503 \\
0503 \\
0503 \\
0503 \\
0503 \\
0503 \\
0503 \\
0503 \\
0504 \\
0504 \\
0504 \\
0504 \\
0504 \\
0504 \\
0504 \\
0506 \\
0506 \\
0506 \\
0506 \\
0506 \\
0506 \\
0507 \\
0507 \\
0507 \\
0507 \\
0507 \\
0507 \\
0507 \\
0508 \\
0508 \\
0508 \\
0508 \\
0508 \\
0508 \\
0509 \\
0509 \\
0509 \\
0509\end{array}$ & $\begin{array}{l}06 / 30 / 86 \\
10 / 14 / 87 \\
02 / 22 / 88 \\
05 / 16 / 90 \\
03 / 29 / 91 \\
08 / 08 / 91 \\
12 / 09 / 91 \\
10 / 09 / 92 \\
10 / 14 / 87 \\
02 / 22 / 88 \\
05 / 16 / 90 \\
04 / 03 / 91 \\
08 / 27 / 91 \\
12 / 09 / 91 \\
10 / 09 / 92 \\
10 / 14 / 87 \\
02 / 22 / 88 \\
03 / 28 / 91 \\
08 / 08 / 91 \\
11 / 20 / 91 \\
10 / 08 / 92 \\
10 / 14 / 87 \\
02 / 22 / 88 \\
05 / 16 / 90 \\
03 / 28 / 91 \\
08 / 09 / 91 \\
12 / 05 / 91 \\
10 / 08 / 92 \\
10 / 14 / 87 \\
02 / 19 / 88 \\
03 / 27 / 91 \\
08 / 28 / 91 \\
12 / 05 / 91 \\
10 / 10 / 92 \\
10 / 14 / 87 \\
02 / 22 / 88 \\
03 / 27 / 91 \\
08 / 28 / 91\end{array}$ & $\begin{array}{l}0001 \\
0001 \\
0001 \\
0001 \\
0001 \\
0001 \\
0001 \\
0001 \\
0001 \\
0001 \\
0001 \\
0001 \\
0001 \\
0001 \\
0001 \\
0001 \\
0001 \\
0001 \\
0001 \\
0001 \\
0001 \\
0001 \\
0001 \\
0001 \\
0001 \\
0001 \\
0001 \\
0001 \\
0001 \\
0001 \\
0001 \\
0001 \\
0001 \\
0001 \\
0001 \\
0001 \\
0001 \\
0001\end{array}$ & $\begin{array}{l}A L \\
A L \\
A L \\
A L \\
A L \\
A L \\
A L \\
A L \\
A L \\
A L \\
A L \\
A L \\
A L \\
A L \\
A L \\
A L \\
A L \\
A L \\
A L \\
A L \\
A L \\
A L \\
A L \\
A L \\
A L \\
A L \\
A L \\
A L \\
A L \\
A L \\
A L \\
A L \\
A L \\
A L \\
A L \\
A L \\
A L \\
A L\end{array}$ & $\begin{array}{l}0 \\
0 \\
0 \\
0 \\
0 \\
0 \\
0 \\
0 \\
D \\
D \\
D \\
D \\
D \\
D \\
D \\
D \\
D \\
D \\
D \\
D \\
D \\
D \\
D \\
D \\
D \\
D \\
D \\
D \\
0 \\
0 \\
0 \\
0 \\
0 \\
0 \\
0 \\
0 \\
0 \\
0 \\
\end{array}$ & $M G / L$ & $\mid<$ & $\begin{array}{c}0.1 \\
0.1 \\
0.4 \\
0.1 \\
0.1 \\
0.2 \\
0.1 \\
0.1 \\
0.3 \\
0.1 \\
0.1 \\
0.2 \\
0.4 \\
1.6 \\
2.7 \\
175 . \\
170 . \\
143 . \\
139 . \\
152 . \\
115 . \\
67 . \\
71 . \\
48.5 \\
31.5 \\
22.9 \\
22.8 \\
39 . \\
188 . \\
190 . \\
84.9 \\
164 . \\
169 . \\
165 . \\
75 . \\
61 . \\
160 . \\
102 .\end{array}$ & H & $\begin{array}{c}0.1 \\
0.1 \\
0.1 \\
0.1 \\
0.1 \\
0.1 \\
0.1 \\
0.1 \\
0.1 \\
0.1 \\
0.1 \\
0.1 \\
0.1 \\
0.1 \\
0.2 \\
0.1 \\
0.1 \\
0.1 \\
0.1 \\
10 . \\
20.1 \\
0.1 \\
0.1 \\
0.1 \\
0.1 \\
0.1 \\
1 . \\
3 . \\
0.1 \\
0.1 \\
0.1 \\
0.1 \\
15 . \\
10.1 \\
0.1 \\
0.1 \\
0.1 \\
0.1\end{array}$ & $\begin{array}{l}- \\
- \\
- \\
- \\
- \\
- \\
- \\
- \\
: \\
- \\
- \\
- \\
- \\
- \\
- \\
: \\
- \\
- \\
- \\
- \\
- \\
- \\
- \\
- \\
- \\
-\end{array}$ \\
\hline
\end{tabular}

FORMATION OF COMPLETION COOE:

FLOW RELATIONSHIP COOE:

AL - ALLUVIUMA

PARAMETER VALUE INDICATOR (PVi): < - LESS THAN DETECTION LIMIT

SAMPLE ID CODES:

0001 - FILTERED SAMPLE (.45 MICRONS)

OTHER PARAMETER VALUE FLAGS:

H - hOLD TIME EXPIRED, VALUE SUSPECT

$J$ - estimated VALUE 
TABLE 3.27 BASELINE GROUNDWATER QUALITY DATA BY PARAMETER FOR THE ALLUVIUM NC AND UC PROCESSING SITES, SLICK ROCK, COLORADO

SITE: SRKO1 SLICK ROCK (BOTH SITES)

06/30/86 TO $10 / 13 / 92$

REPORT DATE: $07 / 36 / 93$

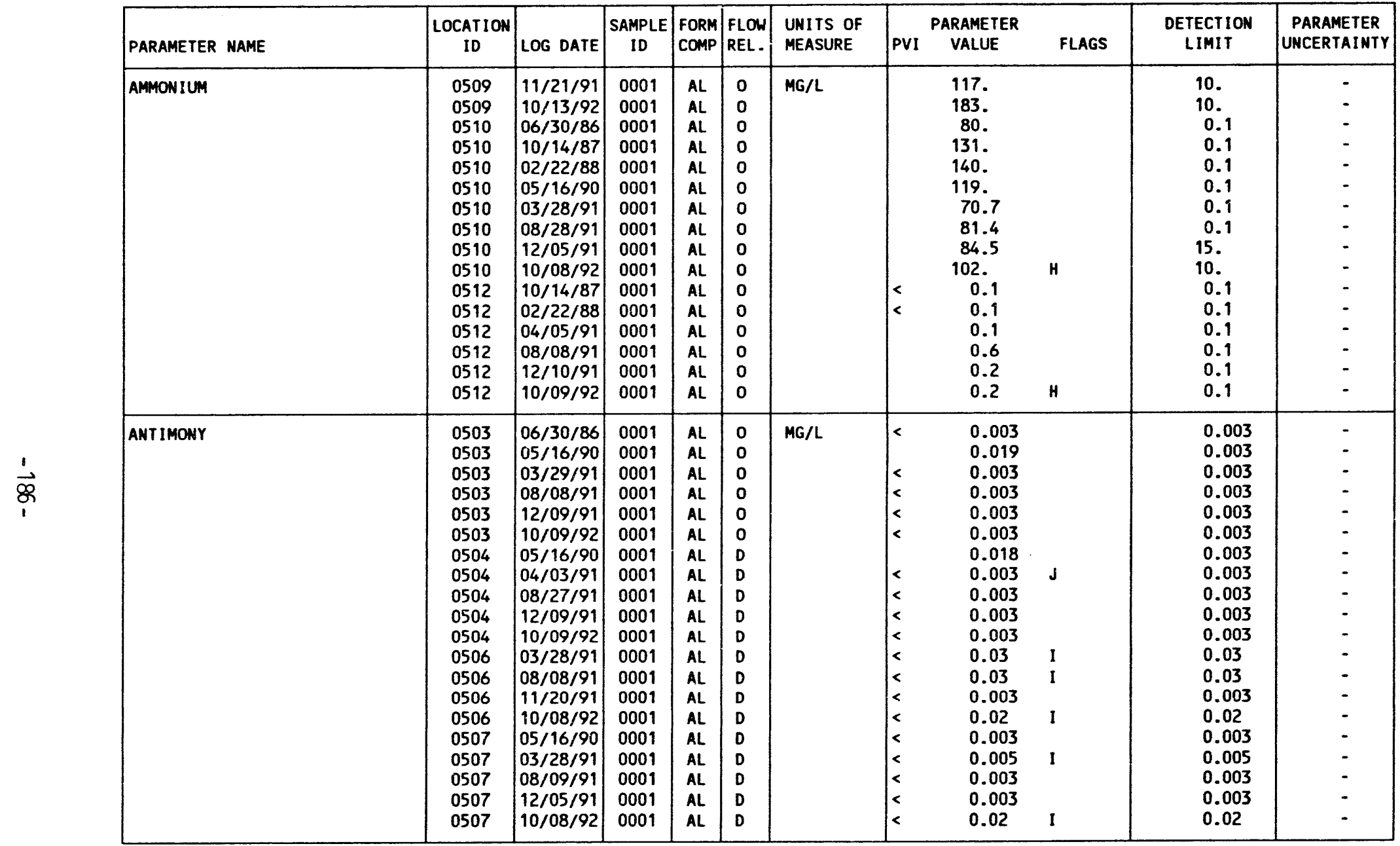

FORMATION OF COMPLETION CODE:

FLOW RELATIONSHIP CODE:

AL - ALLUVIUM

FLON RELATIONS
O - ON-SITE

- DOWN GRADIENT

PARAMETER VALUE INDICATOR (PVI): < - LESS THAN DETECTION LIMIT

SAMPLE ID CODES:

0001 - FILTERED SAMPLE (.45 MICRONS)

OTHER PARAMETER VALUE FLAGS:

H - HOLD TIME EXPIRED, VALUE SUSPECT

1 - INCREASED DETECTIÓN LIMIT DUE TO REQUIRED DILUTION

J - ESTIMATED VALUE 
TABLE 3.27 BASELINE GROUNDWATER QUALITY DATA BY PARAMETER FOR THE ALLUVIUM NC AND UC PROCESSING SITES, SLICK ROCK, COLORADO

SITE: SRKO1 SLICK ROCK (BOTH SITES)

SITE: SRKO1 SLICK ROCK

REPORT DATE: $07 / 26 / 93$

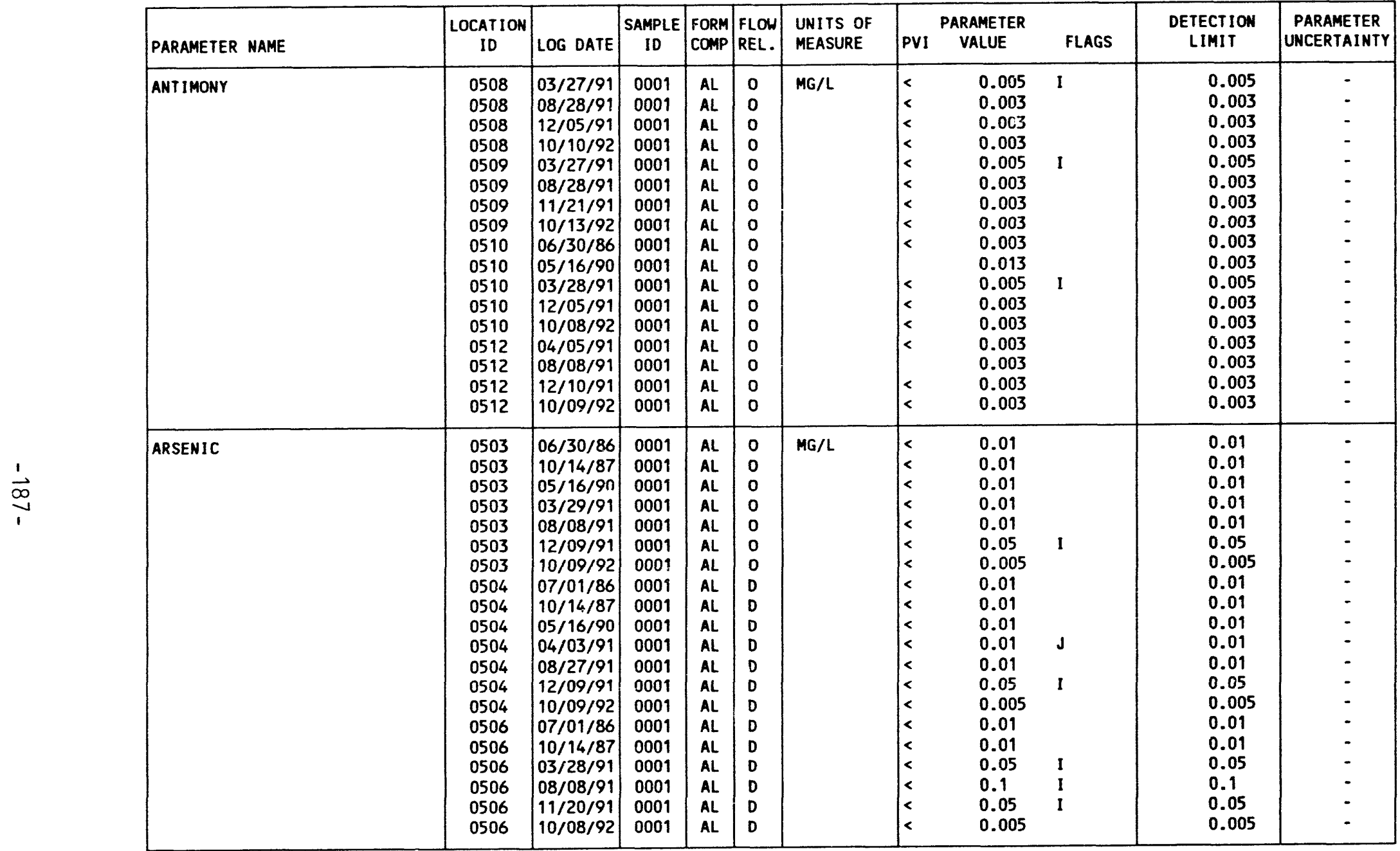

FORMATION OF COMPLETION CODE:

AL - ALLUVIUM

PARAMETER VALUE INDICATOR (PVI): < - LESS THAN DETECTION LIMIT
FLOW RELATIONSHIP COOE:

O - ON-SITE

D - DOWN GRADIENT

0001 - FILTERED SAMPLE (.45 MICRONS)

OTHER PARAMETER VALUE FLAGS:

I - INCREASED DETECTION LIMIT DUE TO REQUIRED DILUTION

$\mathrm{j}$ - ESTIMATED VALUE 
TABLE 3.27 BASELINE GROUNDHATER OUALITY DATA BY PARAMETER FOR THE ALLUVIUM NC AND UC PROCESSING SITES, SLICK ROCK, COLORADO SITE: SRKO1 SLICK ROCK (BOTH SITES)

$06 / 30 / 86$ TO $10 / 13 / 92$

REPORT DATE: 07/26/93

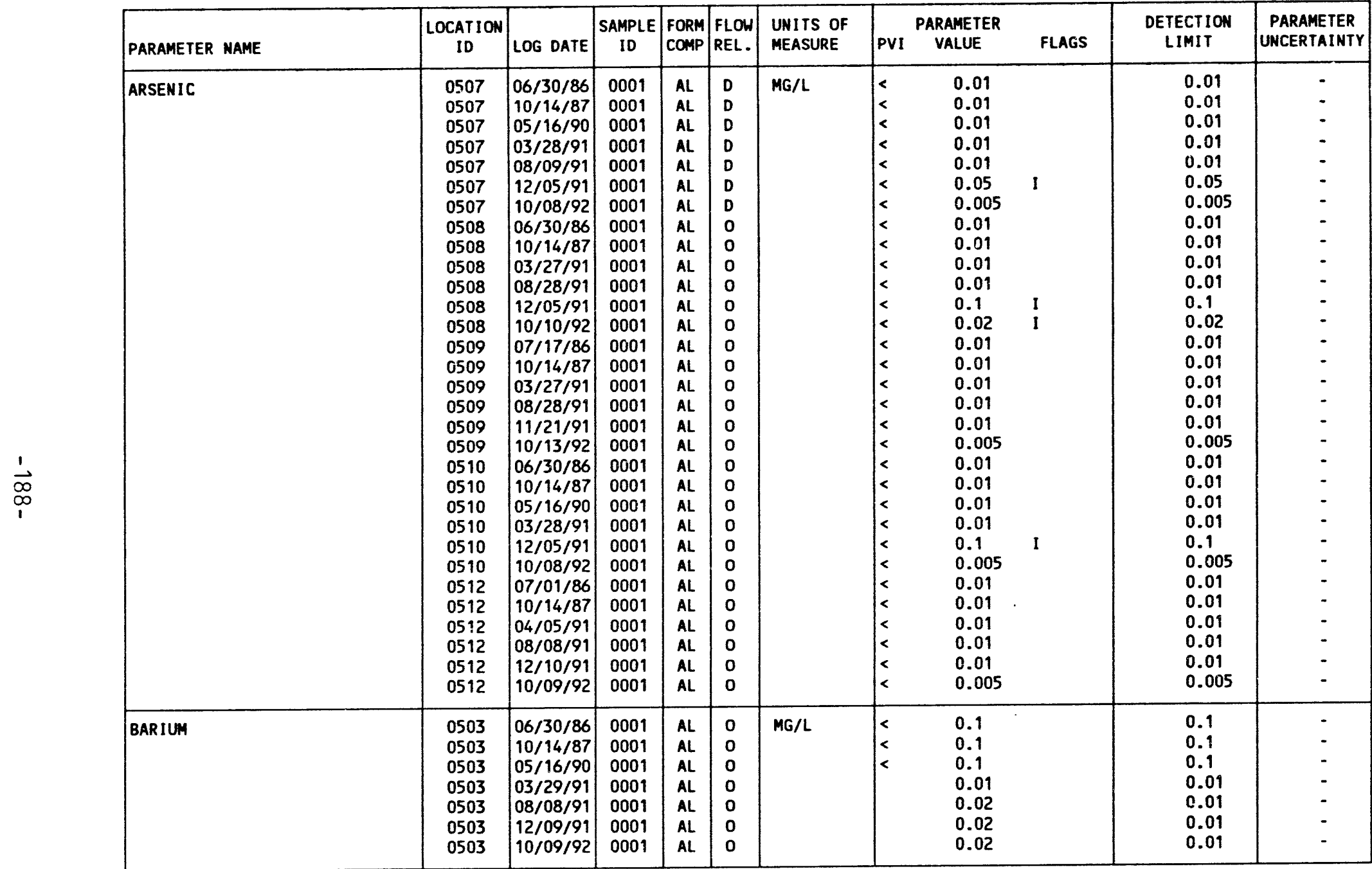

FORMATION OF COMPLETION COOE:

AL - ALlUViUM

FLOW RELATIONSHIP COOE:

D - DOWN GRADIENT

O - ON-SITE

PARAMETER VALUE INDICATOR (PVI): < - LESS THAN DETECTION LIMIT

SAMPLE ID CODES:

0001 - FILTERED SAMPLE (.45 MICRONS)

OTHER PARAMETER VALUE FLAGS:

I - INCREASED DETECTION LIMIT DUE TO REQUIRED DILUTION 
TABLE 3.27 BASELINE GROUNDWATER OUALITY DATA BY PARAMETER FOR THE ALLUVIUM NC AND UC PROCESSING SITES, SLICK ROCK, COLORADO

SITE: SRKO1 SLICK ROCK (BOTH SITES)

06/30/86 TO $10 / 13 / 92$

REPORT DATE: 07/26/93

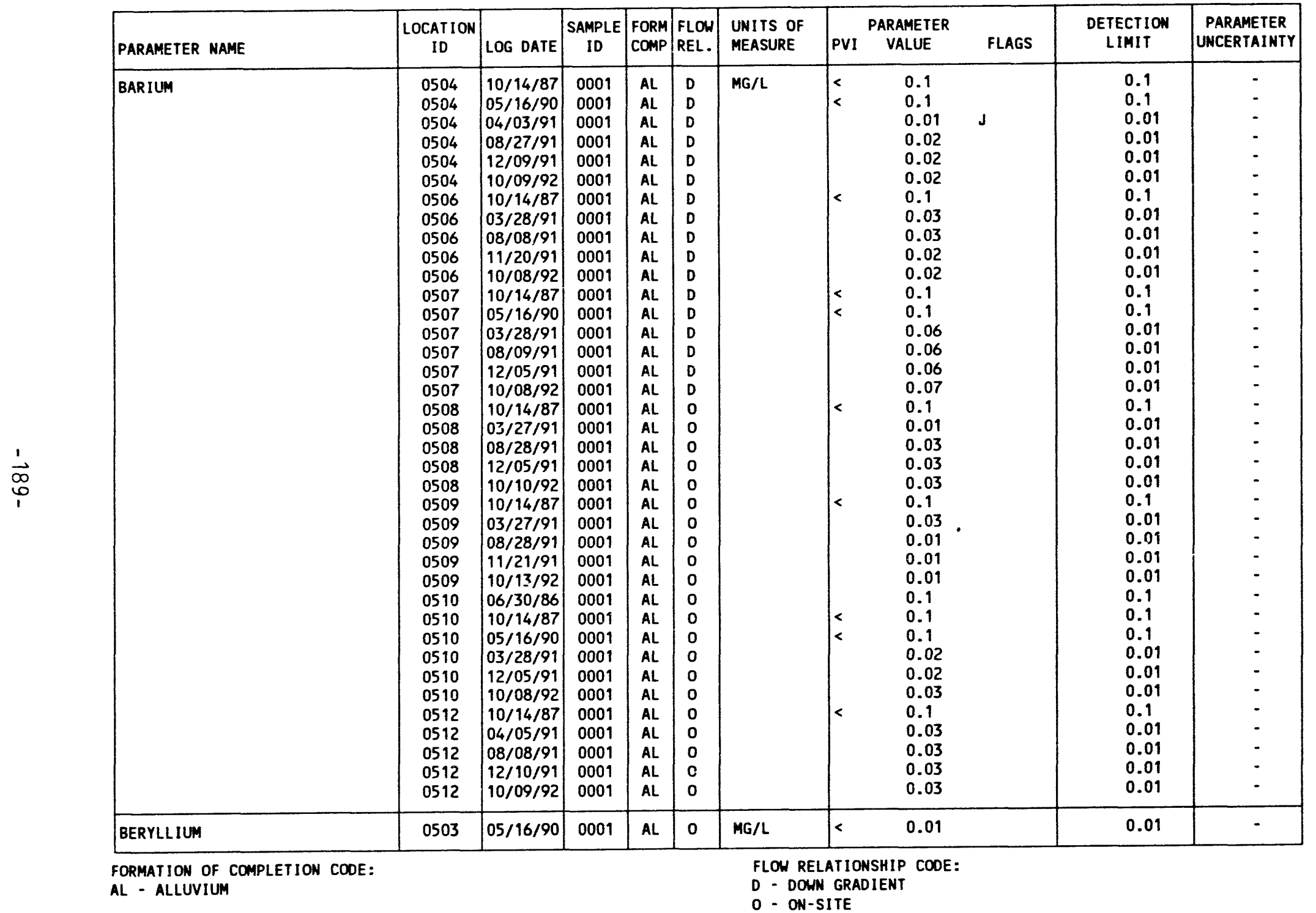

PARAMETER VALUE INDICATOR (PVI): < - LESS THAN DETECTION LIMIT

SAPLE ID CODES:

0001 - FILTERED SAMPLE (.45 MICRONS)

OTHER PARAMETER VALUE FLAGS:

$J$ - ESTIMATED VALUE 
TABLE 3.27 BASELINE GROUNDHATER QUALITY DATA BY PARAMETER FOR THE ALLUVIUM NC AND UC PROCESSING SITES, SLICK ROCK, COLORADO

SITE: SRKO1 SLICK ROCK (BOTH SITES)

O6/30/86 IO $10 / 13 / 92$

REPORT DATE: $07 / 26 / 93$

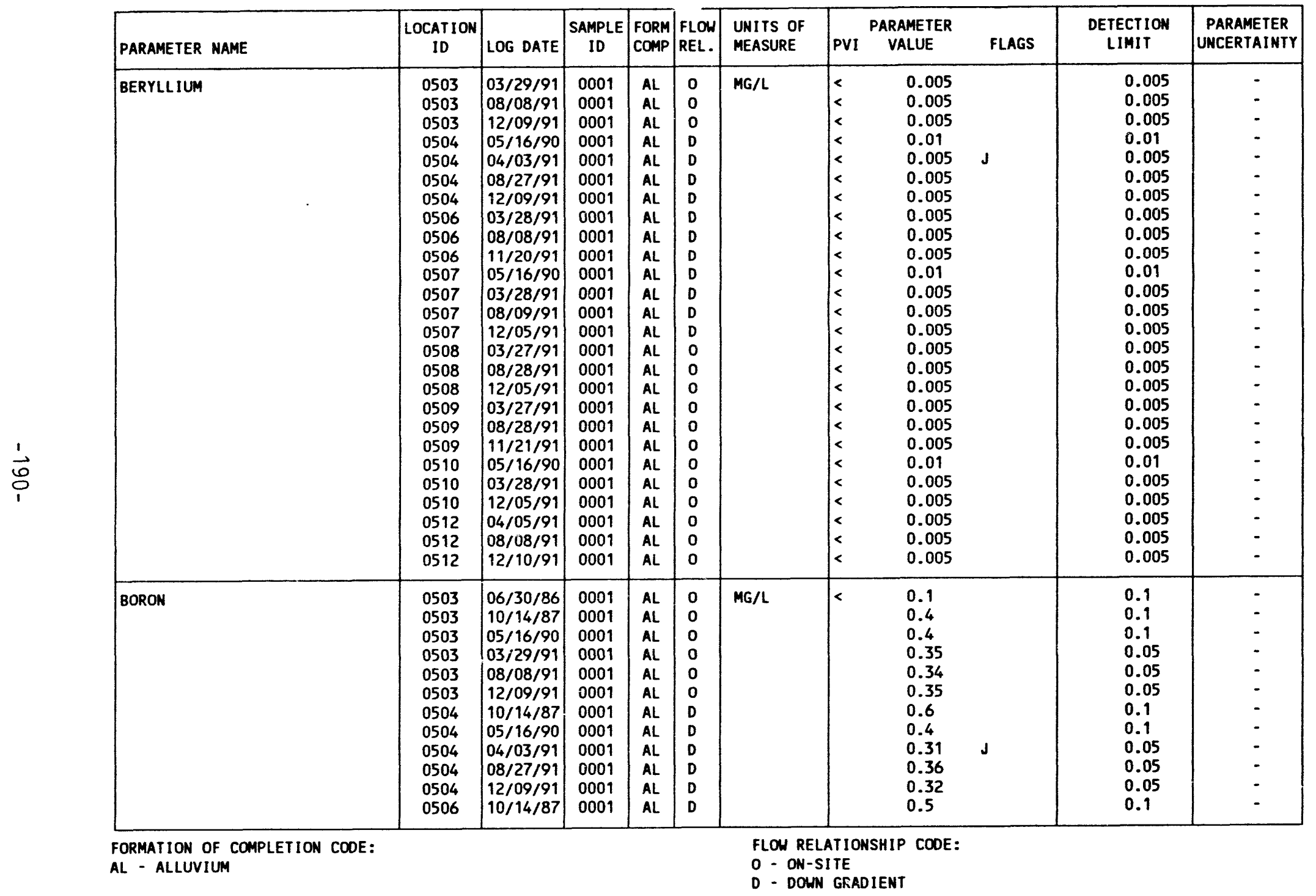

PARAMETER VALUE INDICATOR (PVI): < - LESS THAN DETECTION LIMIT SAMPLE ID CODES:

OTHER PARAMETER VALUE FLAGS:

$J$ - ESTIMATED VALUE

0001 - FILTERED SAMPLE (.45 MICRONS) 
TABLE 3.27 BASELINE GROUNDWATER OUALITY DATA BY PARAMETER FOR THE ALLUVIUM

NC AND UC PROCESSING SITES, SLICK ROCK, COLORADO

SITE: SRK01 SLICK ROCK (BOTH SITES)

06/30/86 TO $10 / 13 / 92$

REPORT DATE: $07 / 26 / 93$

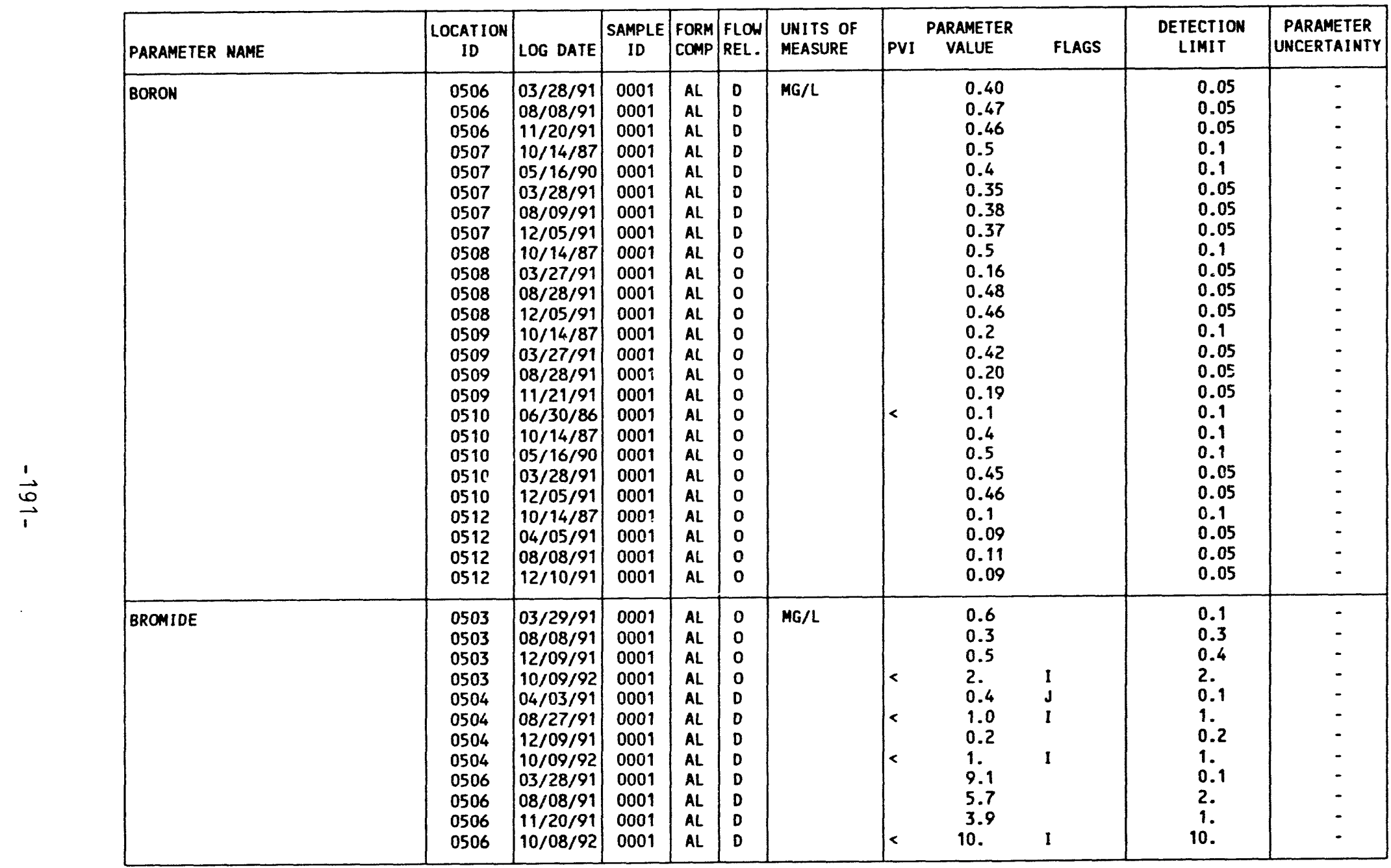

FORMATION OF COMPLETION CODE:

AL - ALLUVIUM

PARAMETER VALUE INDICATOR (PVI): < - LESS THAN DETECTION LIMIT
FLOW RELATIONSHIP CODE:

D - DOWN GRADIENT

O - ON-SITE

SAMPLE ID COOES:

0001 - FILTERED SAMPLE (.45 MICRONS)

OTHER PARAMETER VALUE FLAGS:

1 - INCREASED DETECTION LIMIT DUE TO REQUIRED DILUTION

$J$ - ESTIMATED VALUE 
TABLE 3.27 BASELINE GROUNDHATER QUALITY DATA BY PARAMETER FOR THE ALLUVIUM NC AND UC PROCESSING SITES, SLICK ROCK, COLORADO

SITE: SRKO1 SLICK ROCK (BOTH SITES)

$06 / 30 / 86$ TO $10 / 13 / 92$

REPORT DATE: $07 / 26 / 93$

\begin{tabular}{|c|c|c|c|c|c|c|c|c|c|c|c|c|}
\hline & PARAMETER NAME & $\begin{array}{l}\text { LOC.ATION } \\
\text { ID }\end{array}$ & LOG DATE & $\begin{array}{c}\text { SAMPLE } \\
\text { ID }\end{array}$ & $\begin{array}{l}\text { FORM } \\
\text { COMP }\end{array}$ & $\begin{array}{l}\text { FLOW } \\
\text { REL. }\end{array}$ & $\begin{array}{l}\text { UNITS OF } \\
\text { MEASURE }\end{array}$ & PVI & $\begin{array}{l}\text { PARAMETER } \\
\text { VALUE }\end{array}$ & FLAGS & $\begin{array}{l}\text { DETECTION } \\
\text { LIMIT }\end{array}$ & $\begin{array}{l}\text { PARAMETER } \\
\text { UNCERTAINTY }\end{array}$ \\
\hline & BROMIDE & $\begin{array}{l}0507 \\
0507 \\
0507 \\
0507 \\
0508 \\
0508 \\
0508 \\
0508 \\
0509 \\
0509 \\
0509 \\
0509 \\
0510 \\
0510 \\
0510 \\
0510 \\
0512 \\
0512 \\
0512 \\
0512\end{array}$ & $\begin{array}{l}03 / 28 / 91 \\
08 / 09 / 91 \\
12 / 05 / 91 \\
10 / 08 / 92 \\
03 / 27 / 91 \\
08 / 28 / 91 \\
12 / 05 / 91 \\
10 / 10 / 92 \\
03 / 27 / 91 \\
08 / 28 / 91 \\
11 / 21 / 91 \\
10 / 13 / 92 \\
03 / 28 / 91 \\
08 / 28 / 91 \\
12 / 05 / 91 \\
10 / 08 / 92 \\
04 / 05 / 91 \\
08 / 08 / 91 \\
12 / 10 / 91 \\
10 / 09 / 92\end{array}$ & $\begin{array}{l}0001 \\
0001 \\
0001 \\
0001 \\
0001 \\
0001 \\
0001 \\
0001 \\
0001 \\
0001 \\
0001 \\
0001 \\
0001 \\
0001 \\
0001 \\
0001 \\
0001 \\
0001 \\
0001 \\
0001\end{array}$ & $\begin{array}{l}A L \\
A L \\
A L \\
A L \\
A L \\
A L \\
A L \\
A L \\
A L \\
A L \\
A L \\
A L \\
A L \\
A L \\
A L \\
A L \\
A L \\
A L \\
A L \\
A L\end{array}$ & $\begin{array}{l}D \\
D \\
D \\
D \\
0 \\
0 \\
0 \\
0 \\
0 \\
0 \\
0 \\
0 \\
0 \\
0 \\
0 \\
0 \\
0 \\
0 \\
0 \\
0\end{array}$ & $M G / L$ & $\mid \begin{array}{l}< \\
< \\
< \\
< \\
< \\
< \\
< \\
< \\
< \\
<\end{array}$ & $\begin{array}{l}0.8 \\
0.5 \\
0.6 \\
0.6 \\
0.3 \\
5.0 \\
5.0 \\
0.1 \\
3.2 \\
1.0 \\
0.1 \\
1 . \\
4.0 \\
5.0 \\
4.0 \\
0.8 \\
0.2 \\
0.2 \\
0.1 \\
0.5\end{array}$ & $\begin{array}{l}1 \\
1 \\
1 \\
1 \\
1 \\
1 \\
1 \\
1\end{array}$ & $\begin{array}{l}0.1 \\
0.5 \\
0.1 \\
0.6 \\
0.1 \\
5 . \\
5 . \\
0.1 \\
0.1 \\
1 . \\
0.1 \\
1.1 \\
0.1 \\
5 . \\
4 . \\
0.8 \\
0.1 \\
0.2 \\
0.1 \\
0.5\end{array}$ & $\begin{array}{l}- \\
- \\
- \\
- \\
- \\
- \\
- \\
- \\
- \\
- \\
- \\
- \\
- \\
- \\
-\end{array}$ \\
\hline & CADMIUM & $\begin{array}{l}0503 \\
0503 \\
0503 \\
0503 \\
0503 \\
0503 \\
0503 \\
0504 \\
0504 \\
0504 \\
0504 \\
0504 \\
0504 \\
0506 \\
0506 \\
0506 \\
0506\end{array}$ & $\begin{array}{l}06 / 30 / 86 \\
10 / 14 / 87 \\
05 / 16 / 90 \\
03 / 29 / 91 \\
08 / 08 / 91 \\
12 / 09 / 91 \\
10 / 09 / 92 \\
10 / 14 / 87 \\
05 / 16 / 90 \\
04 / 03 / 91 \\
08 / 27 / 91 \\
12 / 09 / 91 \\
10 / 09 / 92 \\
10 / 14 / 87 \\
03 / 28 / 91 \\
08 / 08 / 91 \\
11 / 20 / 91\end{array}$ & $\begin{array}{l}0001 \\
0001 \\
0001 \\
0001 \\
0001 \\
0001 \\
0001 \\
0001 \\
0001 \\
0001 \\
0001 \\
0001 \\
0001 \\
0001 \\
0001 \\
0001 \\
0001\end{array}$ & $\begin{array}{l}A L \\
A L \\
A L \\
A L \\
A L \\
A L \\
A L \\
A L \\
A L \\
A L \\
A L \\
A L \\
A L \\
A L \\
A L \\
A L \\
A L\end{array}$ & $\begin{array}{l}0 \\
0 \\
0 \\
0 \\
0 \\
0 \\
0 \\
D \\
D \\
D \\
D \\
D \\
D \\
D \\
D \\
D \\
D\end{array}$ & $M G / L$ & $\begin{array}{l}< \\
< \\
< \\
< \\
< \\
< \\
< \\
< \\
< \\
< \\
< \\
< \\
< \\
< \\
< \\
< \\
<\end{array}$ & $\begin{array}{l}0.001 \\
0.001 \\
0.001 \\
0.0005 \\
0.001 \\
0.001 \\
0.001 \\
0.001 \\
0.001 \\
0.0005 \\
0.001 \\
0.001 \\
0.001 \\
0.001 \\
0.0012 \\
0.001 \\
0.001\end{array}$ & $J$ & $\begin{array}{l}0.001 \\
0.001 \\
0.001 \\
0.0005 \\
0.001 \\
0.001 \\
0.001 \\
0.001 \\
0.001 \\
0.0005 \\
0.001 \\
0.001 \\
0.001 \\
0.001 \\
0.001 \\
0.001 \\
0.001\end{array}$ & $\begin{array}{l}- \\
- \\
- \\
- \\
- \\
- \\
- \\
- \\
- \\
- \\
- \\
-\end{array}$ \\
\hline
\end{tabular}

FORMATION OF COMPLETION COOE:

AL - ALLUVIUM
FLOW RELATIONSHIP COOE:

D - DOWN GRADIENT

O - ON-SITE

0001 - FILTERED SAMPLE (.45 MICRONS)

PARAMETER VALUE INDICATOR (PVI): < - LESS THAN DETECTION LIMIT

OTHER PARAMETER VALUE FLAGS:

I - INCREASED DETECTION LIMIT DUE TO REQUIRED DILUTION

J- ESTIMATED VALUE 
TABLE 3.27 BASELINE GROUNDHATER QUALITY DATA BY PARAMETER FOR THE ALLUVIUM NC AND UC PROCESSING SITES, SLICK ROCK, COLORADO

SITE: SRKO1 SLICK ROCK (BOTH SITES)

06/30/86 TO $10 / 13 / 92$

REPORT DATE : $07 / 26 / 93$

\begin{tabular}{|c|c|c|c|c|c|c|c|c|c|c|c|c|}
\hline & PARAMETER NAME & $\underset{\text { ID }}{\text { LOCATION }}$ & LOG DATE & $\begin{array}{c}\text { SAMPLE } \\
10\end{array}$ & $\begin{array}{l}\text { FORM } \\
\text { COMP }\end{array}$ & $\begin{array}{l}\text { FLOW } \\
\text { REL. }\end{array}$ & $\begin{array}{l}\text { UNITS OF } \\
\text { MEASURE }\end{array}$ & PVI & $\begin{array}{l}\text { PARAMETER } \\
\text { VALUE }\end{array}$ & FLAGS & $\begin{array}{l}\text { DETECTION } \\
\text { LIMIT }\end{array}$ & $\begin{array}{c}\text { PARAMETER } \\
\text { UNCERTAINTY }\end{array}$ \\
\hline$\vec{c}$ & CADMIUM & $\begin{array}{l}0506 \\
0507 \\
0507 \\
0507 \\
0507 \\
0507 \\
0507 \\
0508 \\
0508 \\
0508 \\
0508 \\
0508 \\
0509 \\
0509 \\
0509 \\
0509 \\
0509 \\
0510 \\
0510 \\
0510 \\
0510 \\
0510 \\
0510 \\
0512 \\
0512 \\
0512 \\
0512 \\
0512\end{array}$ & \begin{tabular}{|l|}
$10 / 08 / 92$ \\
$10 / 14 / 87$ \\
$05 / 16 / 90$ \\
$03 / 28 / 91$ \\
$08 / 09 / 91$ \\
$12 / 05 / 91$ \\
$10 / 08 / 92$ \\
$10 / 14 / 87$ \\
$03 / 27 / 91$ \\
$08 / 28 / 91$ \\
$12 / 05 / 91$ \\
$10 / 10 / 92$ \\
$10 / 14 / 87$ \\
$03 / 27 / 91$ \\
$08 / 28 / 91$ \\
$11 / 21 / 91$ \\
$10 / 13 / 92$ \\
$06 / 30 / 86$ \\
$10 / 14 / 87$ \\
$05 / 16 / 90$ \\
$03 / 28 / 91$ \\
$12 / 05 / 91$ \\
$10 / 08 / 92$ \\
$10 / 14 / 87$ \\
$04 / 05 / 91$ \\
$08 / 08 / 91$ \\
$12 / 10 / 91$ \\
$10 / 09 / 92$
\end{tabular} & $\begin{array}{l}0001 \\
0001 \\
0001 \\
0001 \\
0001 \\
0001 \\
0001 \\
0001 \\
0001 \\
0001 \\
0001 \\
0001 \\
0001 \\
0001 \\
0001 \\
0001 \\
0001 \\
0001 \\
0001 \\
0001 \\
0001 \\
0001 \\
0001 \\
0001 \\
0001 \\
0001 \\
0001 \\
0001\end{array}$ & $\begin{array}{l}A L \\
A L \\
A L \\
A L \\
A L \\
A L \\
A L \\
A L \\
A L \\
A L \\
A L \\
A L \\
A L \\
A L \\
A L \\
A L \\
A L \\
A L \\
A L \\
A L \\
A L \\
A L \\
A L \\
A L \\
A L \\
A L \\
A L \\
A L\end{array}$ & $\begin{array}{l}D \\
D \\
D \\
D \\
D \\
D \\
D \\
0 \\
0 \\
0 \\
0 \\
0 \\
0 \\
0 \\
0 \\
0 \\
0 \\
0 \\
0 \\
0 \\
0 \\
0 \\
0 \\
0 \\
0 \\
0 \\
0 \\
0\end{array}$ & MG/L & $\begin{array}{l}< \\
< \\
< \\
< \\
< \\
< \\
< \\
< \\
< \\
< \\
< \\
< \\
< \\
< \\
< \\
< \\
< \\
< \\
< \\
< \\
<\end{array}$ & $\begin{array}{l}0.01 \\
0.001 \\
0.001 \\
0.001 \\
0.001 \\
0.001 \\
0.001 \\
0.002 \\
0.001 \\
0.05 \\
0.05 \\
0.027 \\
0.001 \\
0.0080 \\
0.001 \\
0.001 \\
0.001 \\
0.001 \\
0.001 \\
0.001 \\
0.0010 \\
0.001 \\
0.001 \\
0.001 \\
0.0005 \\
0.001 \\
0.001 \\
0.001\end{array}$ & $\begin{array}{l}1 \\
1\end{array}$ & $\begin{array}{l}0.01 \\
0.001 \\
0.001 \\
0.001 \\
0.001 \\
0.001 \\
0.001 \\
0.001 \\
0.001 \\
0.05 \\
0.05 \\
0.005 \\
0.001 \\
0.001 \\
0.001 \\
0.001 \\
0.001 \\
0.001 \\
0.001 \\
0.001 \\
0.001 \\
0.001 \\
0.001 \\
0.001 \\
0.0005 \\
0.001 \\
0.001 \\
0.001\end{array}$ & $\begin{array}{l}- \\
- \\
- \\
- \\
- \\
- \\
- \\
- \\
- \\
- \\
- \\
- \\
- \\
- \\
- \\
- \\
- \\
- \\
- \\
-\end{array}$ \\
\hline & CALCIUM & $\begin{array}{l}0503 \\
0503 \\
0503 \\
0503 \\
0503 \\
0503 \\
0503 \\
0503 \\
0504 \\
0504\end{array}$ & $\begin{array}{l}06 / 30 / 86 \\
10 / 14 / 87 \\
02 / 22 / 88 \\
05 / 16 / 90 \\
03 / 29 / 91 \\
08 / 08 / 91 \\
12 / 09 / 91 \\
10 / 09 / 92 \\
07 / 01 / 86 \\
10 / 14 / 87\end{array}$ & $\begin{array}{l}0001 \\
0001 \\
0001 \\
0001 \\
0001 \\
0001 \\
0001 \\
0001 \\
0001 \\
0001\end{array}$ & $\begin{array}{l}A L \\
A L \\
A L \\
A L \\
A L \\
A L \\
A L \\
A L \\
A L \\
A L\end{array}$ & $\begin{array}{l}0 \\
0 \\
0 \\
0 \\
0 \\
0 \\
0 \\
0 \\
D \\
D\end{array}$ & $\mathbf{M G} / \mathbf{L}$ & & $\begin{array}{l}264 . \\
237 . \\
234 . \\
213 . \\
200 . \\
204 . \\
179 . \\
174 . \\
226 . \\
244 .\end{array}$ & & $\begin{array}{l}0.01 \\
0.01 \\
0.01 \\
0.01 \\
0.5 \\
0.5 \\
0.5 \\
0.5 \\
0.01 \\
0.01\end{array}$ & $\begin{array}{l}- \\
- \\
- \\
- \\
- \\
- \\
- \\
-\end{array}$ \\
\hline
\end{tabular}

FORMATION OF COMPLETION COOE:

AL - ALLUVIUM

PARAMETER VALUE INDICATOR (PVI)
FLOW RELATIONSHIP COOE:

D - DOWN GRADIENT

\section{ON-SITE}

SAMPLE ID COOES:

0001 - FILTERED SAMPLE (.45 MICRONS)

OTHER PARAMETER VALUE FLAGS:

1 - INCREASED DETECTION LIMIT DUE TO REQUIRED DILUTION 
TABLE 3.27 BASELINE GROUNDWATER QUALITY DATA BY PARAMETER FOR THE ALLUVIUM NC AND UC PROCESSING SITES, SLICK ROCK, COLORADO

SITE: SRKO1 SLICK ROCK (BOTH SITES)

$06 / 30 / 86$ TO $10 / 13 / 92$

O6PORT DATE: $07 / 26 / 93$

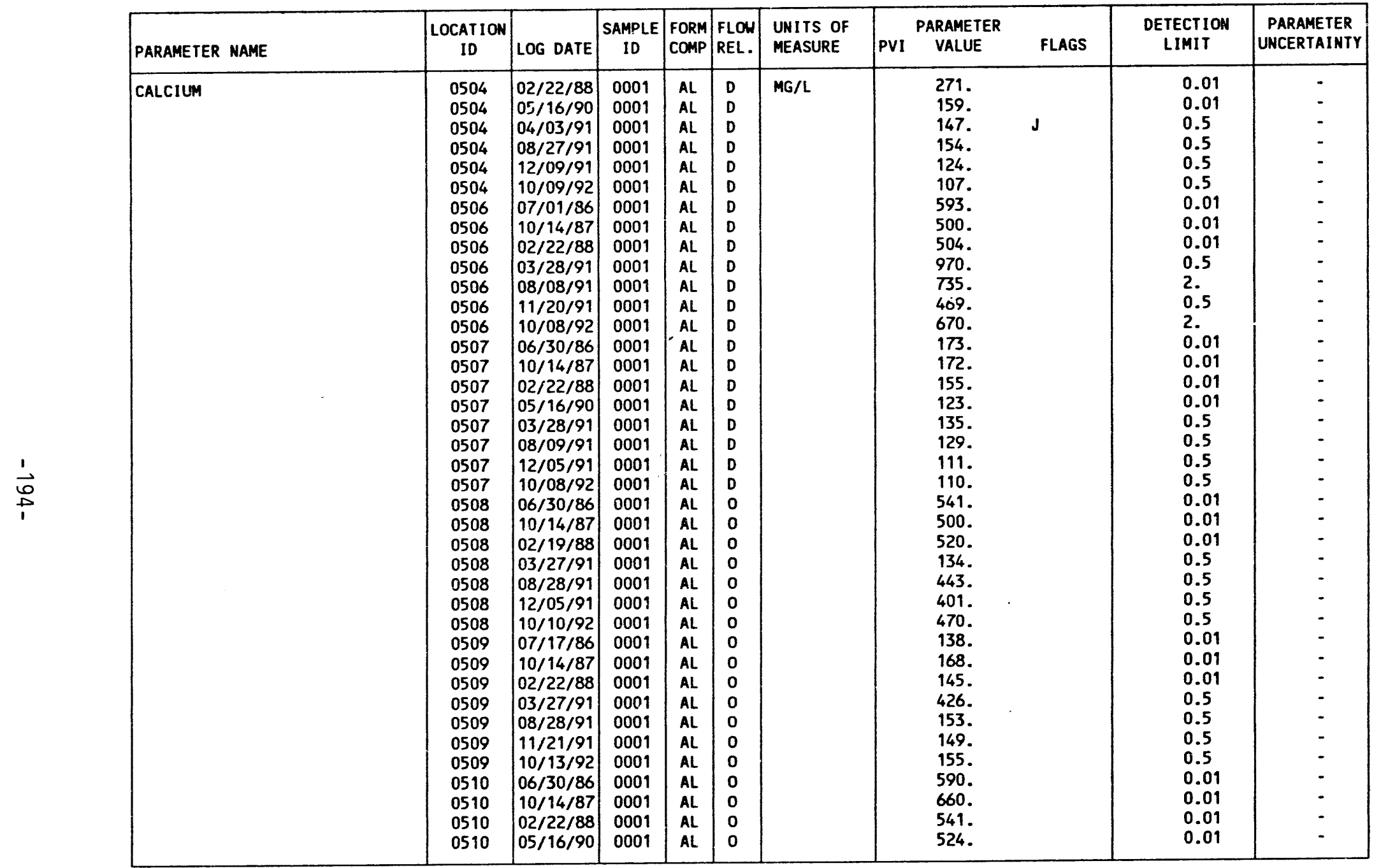

FORMATION OF COMPLETION CODE:

AL - AlluviUim

PARAMETER VALUE INDICATOR (PVI): < - LESS THAN DETECTION LIMIT
FLOW RELATIONSHIP CODE:

D - DOWN GRADIENT

O - ON-SITE

SAMPLE ID COOES:

0001 - FILTERED SAMPLE (.45 MICRONS)

OTHER PARAMETER VALUE FLAGS:

$J$ - ESTIMATED VALUE 
TABLE 3.27 BASELINE GROUNDWATER QUALITY DATA BY PARAMETER FOR THE ALLUVIUM NC AND UC PROCESSING SITES, SLICK ROCK, COLORADO

SITE: SRKO1 SLICK ROCK (BOTH SITES)

06/30/86 TO $10 / 13 / 92$

REPORT DATE: $07 / 26 / 93$

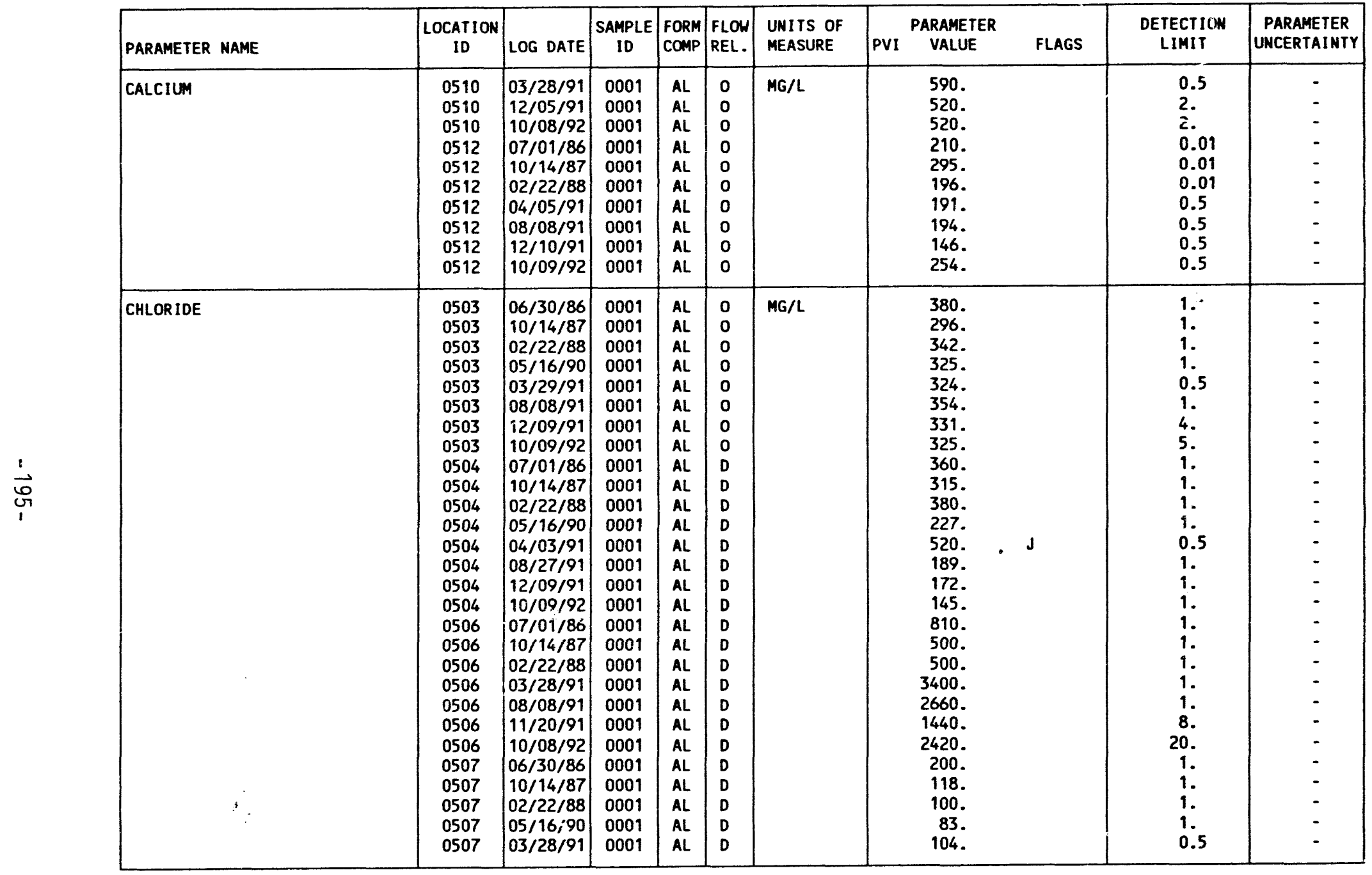

FORMATION OF COMPLETION CODE:

AL - ALLUVIUM
FLOW RELATIONSHIP COOE:

D - DON GRADIENT

PARAMETER VALUE INDICATOR (PVI): < - LESS THAN DETECTION LIMIT

SAMPLE ID CODES:

0001 - FILTERED SAMPLE (.45 MICRONS)

OTHER PARAMETER VALUE FLAGS:

$J$ - ESTIMATED VALUE 
TABLE 3.27 BASELINE GROUNDWATER QUALITY DATA BY PARAMETER FOR THE ALLUVIUM NC AMD UC PROCESSING SITES, SLICK ROCK, COLORADO

SITE: SRKO1 SLICK ROCK (BOTH SITES)

06/30/86 TO $10 / 13 / 92$

REPORT DATE: $07 / 26 / 93$

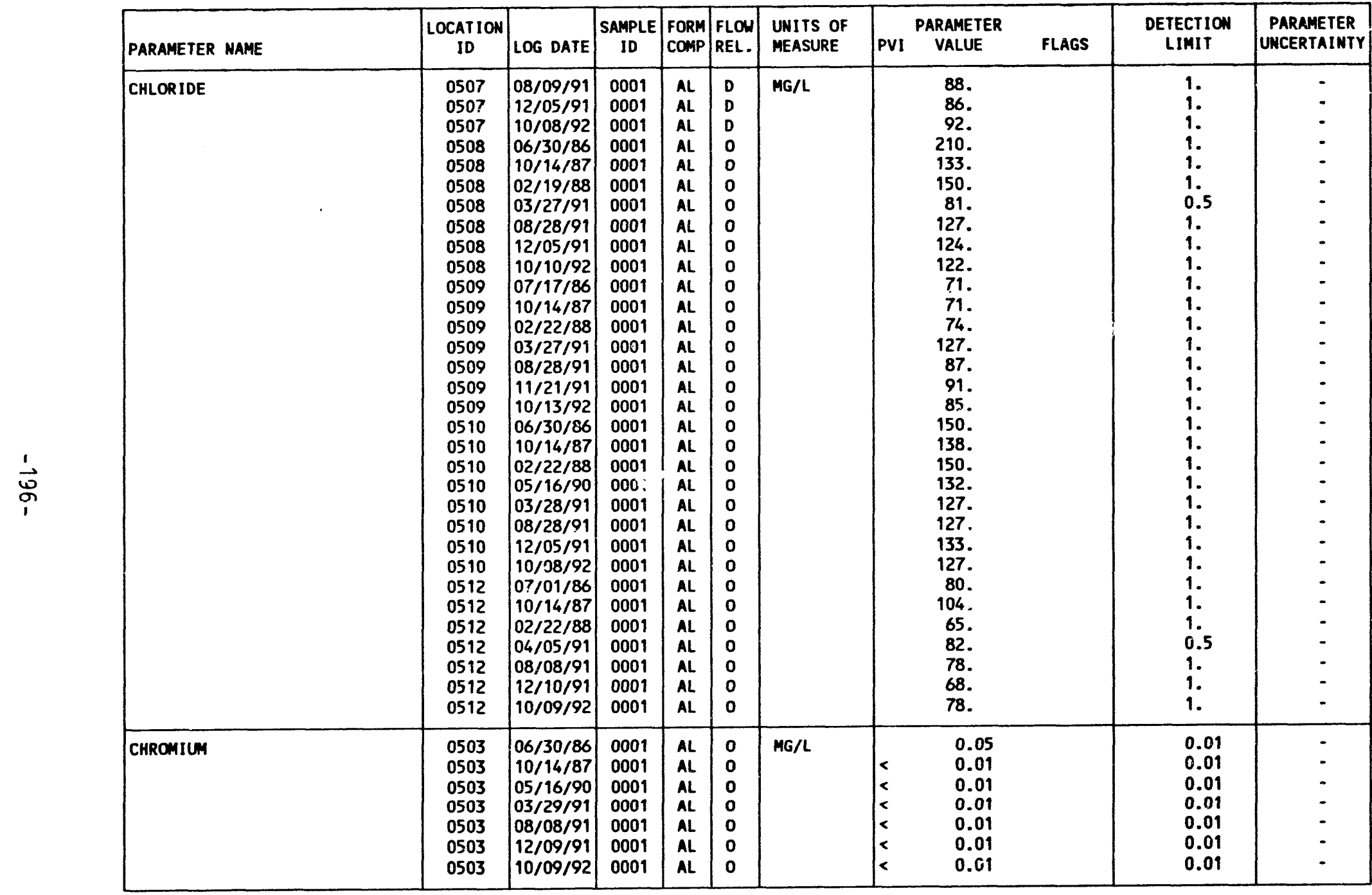

FORMATION OF COMPLETION CODE:

AL - ALLUVIUM

PARAMETER VAlUE INDICATOR (PVI): < - LESS than DETECTION LIMIT
FLOW RELATIONSHIP COOE:

D- DON GRADIENT

O - ON-SITE

SAMPLE I CODES:

0001 - FILTERED SAMPLE (.45 MICRONS) 
TABLE 3.27 BASELINE GROUNDWATER OUALITY DATA BY PARAMETER FOR THE ALLUVIUM MC AND UC PROCESSING SITES, SLICK ROCK, COLORADO

SITE: SRKO1 SLICK ROCK (BDTH SITES)

$06 / 30 / 86$ TO $10 / 13 / 92$

REPORT DATE: $07 / 26 / 93$

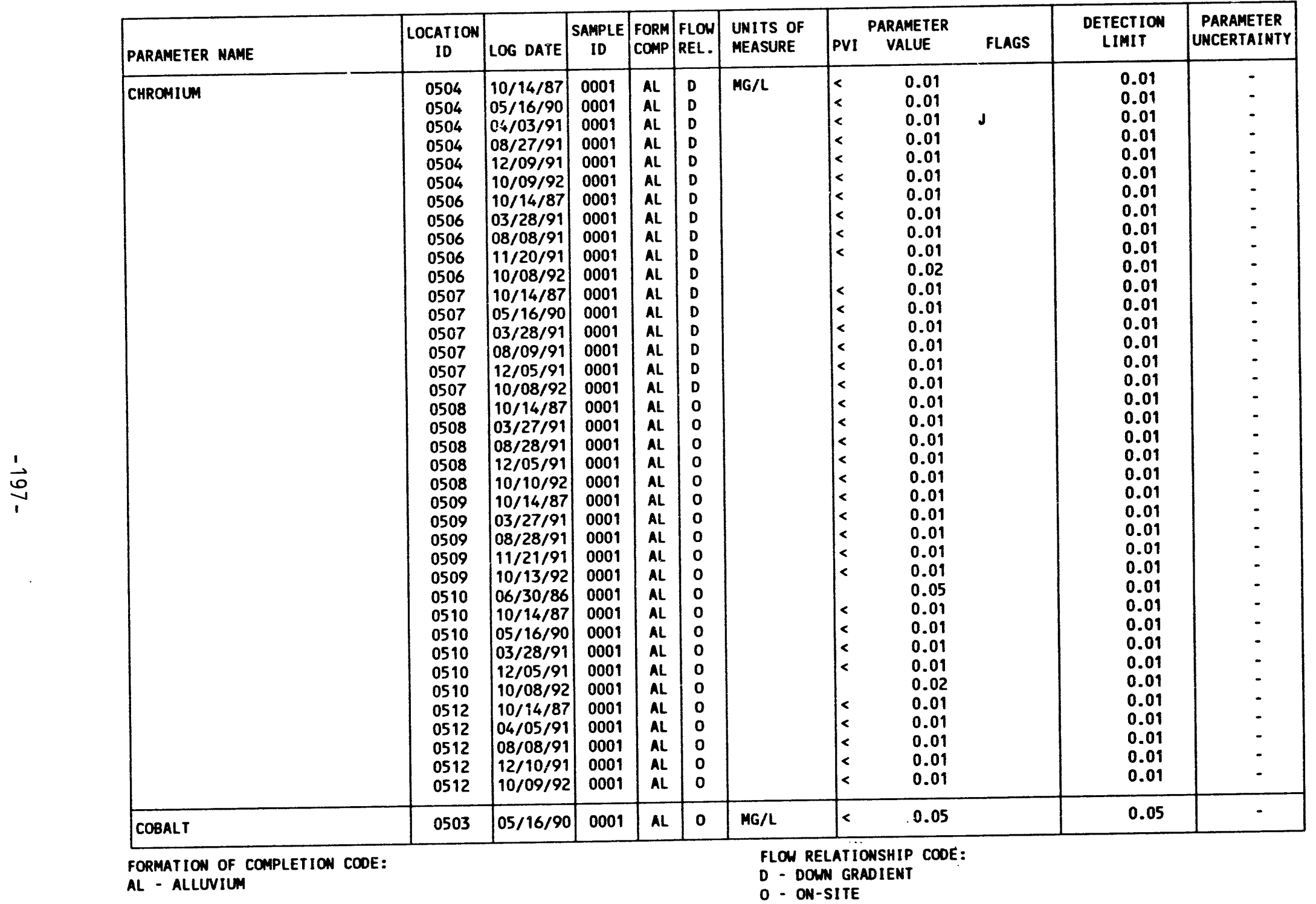

PARAMETER VALUE INDICATOR (PVI): < - LESS THAN DETECTION LIMIT

0001 - FILTERED SAMPLE (.45 MICRONS)

OTHER PARAMETER VALUE FLAGS:

J - ESTIMATED VALUE 
TABLE 3.27 BASELINE GROUNDWATER QUALITY DATA BY PARAMETER FOR THE ALLUVIUM

NC AND UC PROCESSING SITES, SLICK ROCK, COLORADO

SITE: SRK01 SLICK ROCK (BOTH SITES)

06/30/86 TO 10/13/92

REPORT DATE : $07 / 26 / 93$

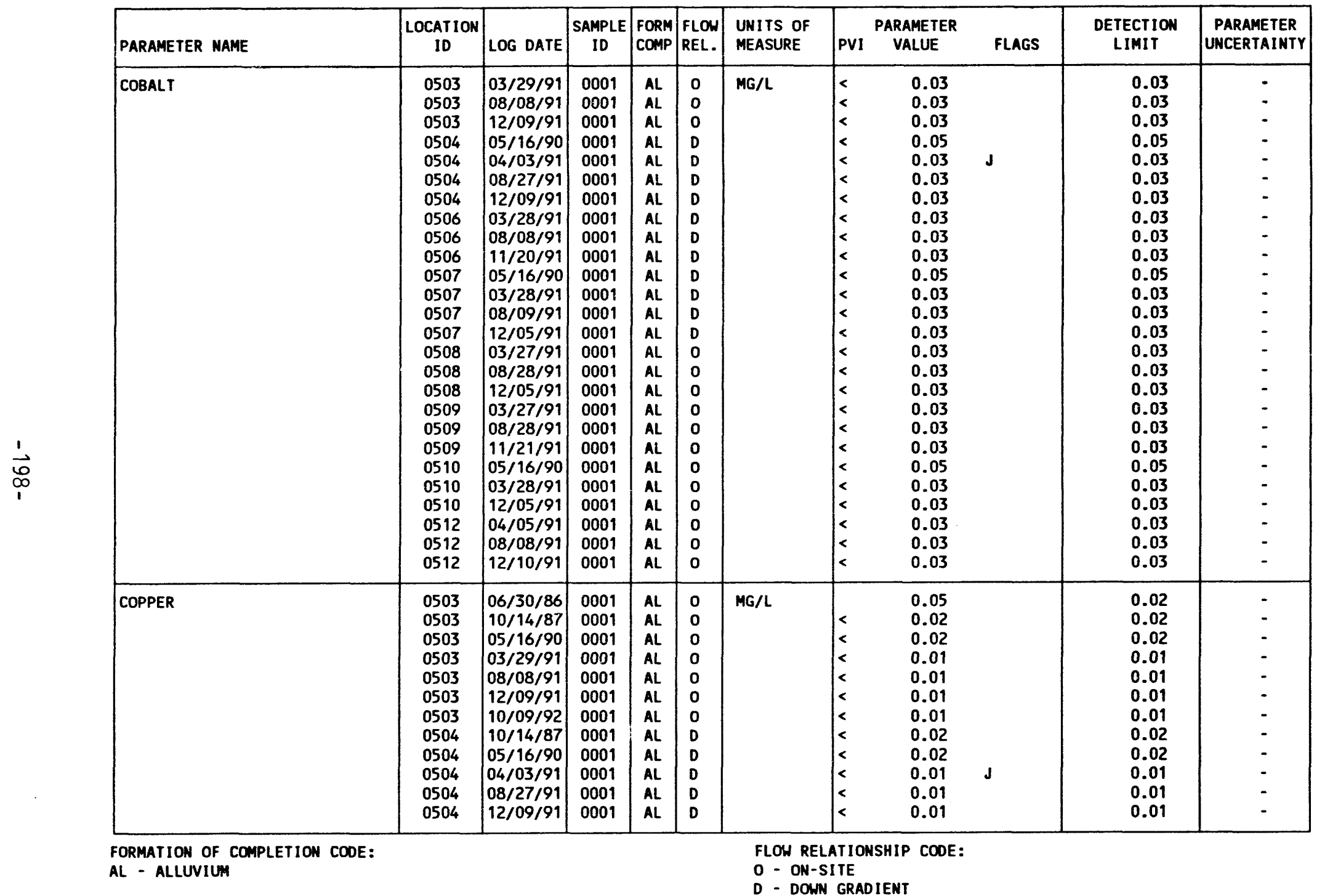

PARAMETER VALUE INDICATOR (PVI): < - LESS THAN DETECTION LIMIT

SAMPLE ID CODES:

0001 - FILTERED SAMPLE (.45 MICRONS)

OTHER PARAMETER VALUE fLAGS:

$J$ - ESTIMATED VALUE 


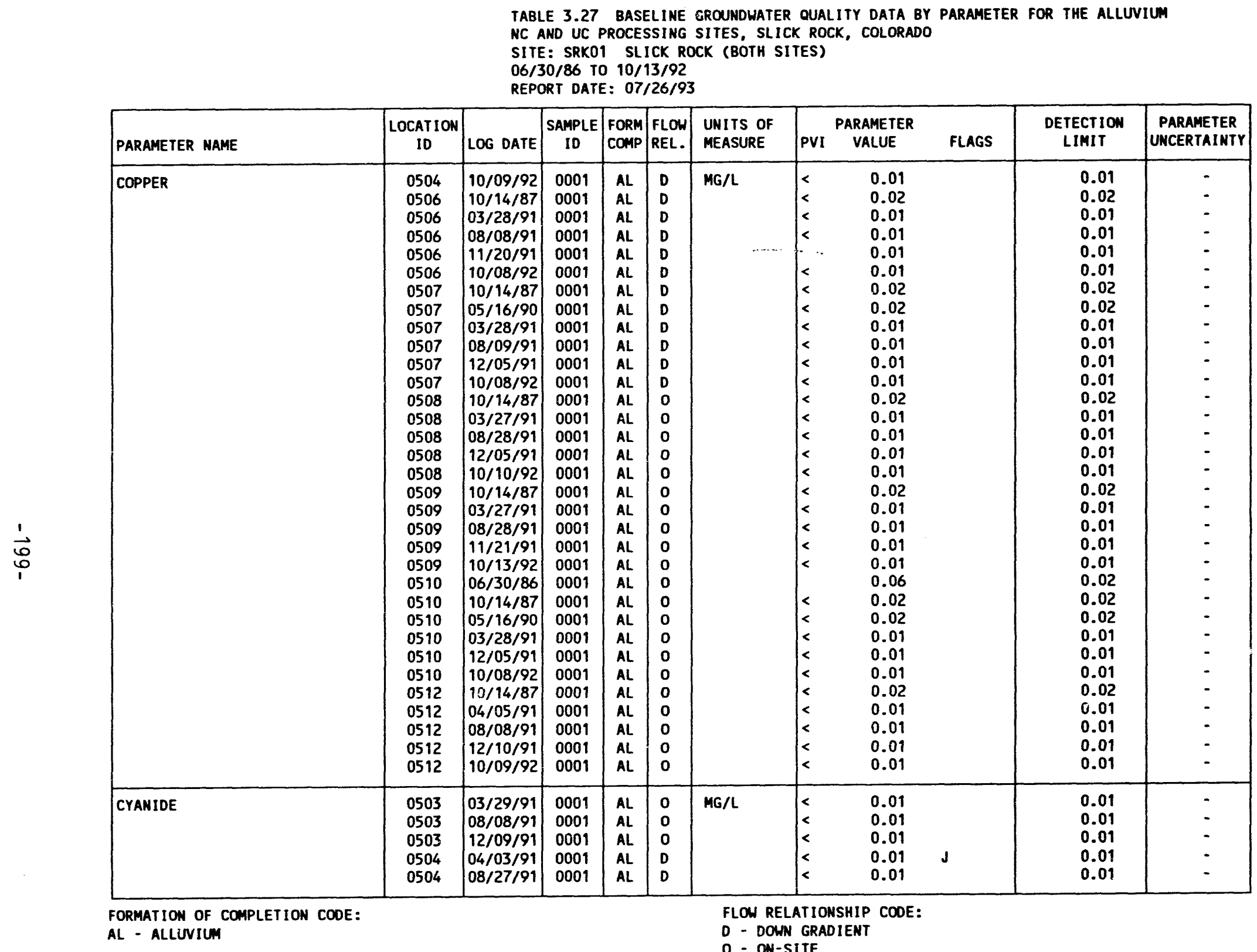

PARAMETER VALUE INDICATOR (PVI): < - LESS than DETECTION LIMIT SAMPLE ID CODES:

0001 - FILTERED SAMPLE (.45 MICRONS)

OTHER PARAMETER VALUE FLAGS:

$J$ - ESTIMATED VALUE 
TABLE 3.27 BASELINE GROUMDUATER OUALITY DATA BY PARAMETER FOR THE ALLUVILM NC AND UC PROCESSING SITES, SLICK ROCK, COLORADO

SITE:- SRKO1 SLICK ROCK (BOTH SITES)

$06 / 30 / 86$ TO $10 / 13 / 92$

REPORT DATE: $07 / 26 / 93$

\begin{tabular}{|c|c|c|c|c|c|c|c|c|c|c|}
\hline PARAMETER NAME & $\begin{array}{c}\text { LOCATION } \\
\text { ID }\end{array}$ & LOG DATE & $\underset{10}{\text { SAMPLE }}$ & $\begin{array}{l}\text { FORM } \\
\text { COMP }\end{array}$ & $\begin{array}{l}\text { FLOW } \\
\text { REL. }\end{array}$ & $\begin{array}{l}\text { UNITS OF } \\
\text { MEASURE }\end{array}$ & PVI & $\begin{array}{l}\text { PARAMETER } \\
\text { VALUE }\end{array}$ & $\begin{array}{l}\text { DETECTION } \\
\text { LIMIT }\end{array}$ & $\begin{array}{l}\text { PARAMETER } \\
\text { UNCERTAINTY }\end{array}$ \\
\hline CYANIDE & $\begin{array}{l}0504 \\
0506 \\
0506 \\
0506 \\
0507 \\
0507 \\
0507 \\
0508 \\
0508 \\
0508 \\
0509 \\
0509 \\
0509 \\
0510 \\
0510 \\
0510 \\
0512 \\
0512 \\
0512\end{array}$ & $\begin{array}{l}12 / 09 / 91 \\
03 / 28 / 91 \\
08 / 08 / 91 \\
11 / 20 / 91 \\
03 / 28 / 91 \\
08 / 09 / 91 \\
12 / 05 / 91 \\
03 / 27 / 91 \\
08 / 28 / 91 \\
12 / 05 / 91 \\
03 / 27 / 91 \\
08 / 28 / 91 \\
11 / 21 / 91 \\
03 / 28 / 91 \\
08 / 28 / 91 \\
12 / 05 / 91 \\
04 / 05 / 91 \\
08 / 08 / 91 \\
12 / 10 / 91\end{array}$ & $\begin{array}{l}0001 \\
0001 \\
0001 \\
0001 \\
0001 \\
0001 \\
0001 \\
0001 \\
0001 \\
0001 \\
0001 \\
0001 \\
0001 \\
0001 \\
0001 \\
0001 \\
0001 \\
0001 \\
0001\end{array}$ & $\begin{array}{l}A L \\
A L \\
A L \\
A L \\
A L \\
A L \\
A L \\
A L \\
A L \\
A L \\
A L \\
A L \\
A L \\
A L \\
A L \\
A L \\
A L \\
A L \\
A L\end{array}$ & $\begin{array}{l}D \\
D \\
D \\
D \\
D \\
D \\
D \\
0 \\
0 \\
0 \\
0 \\
0 \\
0 \\
0 \\
0 \\
0 \\
0 \\
0 \\
0\end{array}$ & MG/L & $\begin{array}{l}< \\
< \\
< \\
< \\
< \\
< \\
< \\
< \\
< \\
< \\
< \\
< \\
< \\
< \\
< \\
< \\
< \\
<\end{array}$ & $\begin{array}{l}0.01 \\
0.01 \\
0.01 \\
0.01 \\
0.01 \\
0.01 \\
0.01 \\
0.01 \\
0.01 \\
0.01 \\
0.01 \\
0.01 \\
0.01 \\
0.01 \\
0.01 \\
0.01 \\
0.01 \\
0.02 \\
0.01\end{array}$ & $\begin{array}{l}0.01 \\
0.01 \\
0.01 \\
0.01 \\
0.01 \\
0.01 \\
0.01 \\
0.01 \\
0.01 \\
0.01 \\
0.01 \\
0.01 \\
0.01 \\
0.01 \\
0.01 \\
0.01 \\
0.01 \\
0.01 \\
0.01\end{array}$ & $\begin{array}{l}- \\
- \\
- \\
- \\
- \\
- \\
- \\
- \\
- \\
- \\
- \\
- \\
- \\
- \\
-\end{array}$ \\
\hline DISSOLVED OXYGEN & $\begin{array}{l}0503 \\
0504 \\
0506 \\
0507 \\
0508 \\
0509 \\
0510 \\
0512\end{array}$ & \begin{tabular}{|l|}
$10 / 09 / 92$ \\
$10 / 09 / 92$ \\
$10 / 08 / 92$ \\
$10 / 08 / 92$ \\
$10 / 10 / 92$ \\
$10 / 13 / 92$ \\
$10 / 08 / 92$ \\
$10 / 09 / 92$
\end{tabular} & $\begin{array}{l}0001 \\
0001 \\
0001 \\
0001 \\
0001 \\
0001 \\
0001 \\
0001\end{array}$ & $\begin{array}{l}A L \\
A L \\
A L \\
A L \\
A L \\
A L \\
A L \\
A L\end{array}$ & $\begin{array}{l}0 \\
D \\
D \\
D \\
0 \\
0 \\
0 \\
0\end{array}$ & $M G / L$ & & $\begin{array}{l}0.1 \\
0.1 \\
0.2 \\
0.0 \\
0.0 \\
0.0 \\
0.2 \\
1.1\end{array}$ & $\begin{array}{l}- \\
- \\
- \\
- \\
-\end{array}$ & $\begin{array}{l}- \\
- \\
- \\
- \\
-\end{array}$ \\
\hline FIELD FE $(2+)$ & $\begin{array}{l}0503 \\
0504 \\
0506 \\
0507 \\
0508 \\
0509 \\
0512\end{array}$ & $\begin{array}{l}10 / 09 / 92 \\
10 / 09 / 92 \\
10 / 08 / 92 \\
10 / 08 / 92 \\
10 / 10 / 92 \\
10 / 13 / 92 \\
10 / 09 / 92\end{array}$ & $\begin{array}{l}0001 \\
0001 \\
0001 \\
0001 \\
0001 \\
0001 \\
0001\end{array}$ & $\begin{array}{l}A L \\
A L \\
A L \\
A L \\
A L \\
A L \\
A L\end{array}$ & $\begin{array}{l}0 \\
D \\
D \\
D \\
0 \\
0 \\
0\end{array}$ & $\mathrm{MG} / \mathrm{L}$ & & $\begin{array}{l}2.34 \\
3.58 \\
3.37 \\
2.43 \\
0.01 \\
0.0 \\
0.75\end{array}$ & $\begin{array}{l}- \\
- \\
- \\
-\end{array}$ & $\begin{array}{l}- \\
- \\
- \\
-\end{array}$ \\
\hline FIELD FE (TOTAL) & $\begin{array}{l}0503 \\
0506 \\
0509\end{array}$ & $\begin{array}{l}10 / 09 / 92 \\
10 / 08 / 92 \\
10 / 13 / 92\end{array}$ & $\begin{array}{l}0001 \\
0001 \\
0001\end{array}$ & $\begin{array}{l}A L \\
A L \\
A L\end{array}$ & $\begin{array}{l}0 \\
D \\
0\end{array}$ & $M G / L$ & & $\begin{array}{l}2.42 \\
5.42 \\
0.1\end{array}$ & $\begin{array}{l}- \\
-\end{array}$ & $\begin{array}{l}- \\
-\end{array}$ \\
\hline
\end{tabular}

FORMATION OF COMPLETION CODE:

FLOW RELATIONSHIP CODE:

AL - ALLUVIUM

O - ON-SITE

PARAMETER VALUE INDICATOR (PVI): < - LESS THAN DETECTION LIMIT SAMPLE ID CODES:

0001 - FILTERED SAMPLE (.45 MICRONS) 
TABLE 3.27 BASELINE GROUNDWATER OUALITY DATA BY PARAMETER FOR THE ALLUVIUM NC AND UC PROCESSING SITES, SLICK ROCK, COLORADO

SITE: SRKO1 SLICK ROCK (BOTH SITES)

SITE: SRKO1 SLICK ROCK

REPORT DATE: 07/26/93

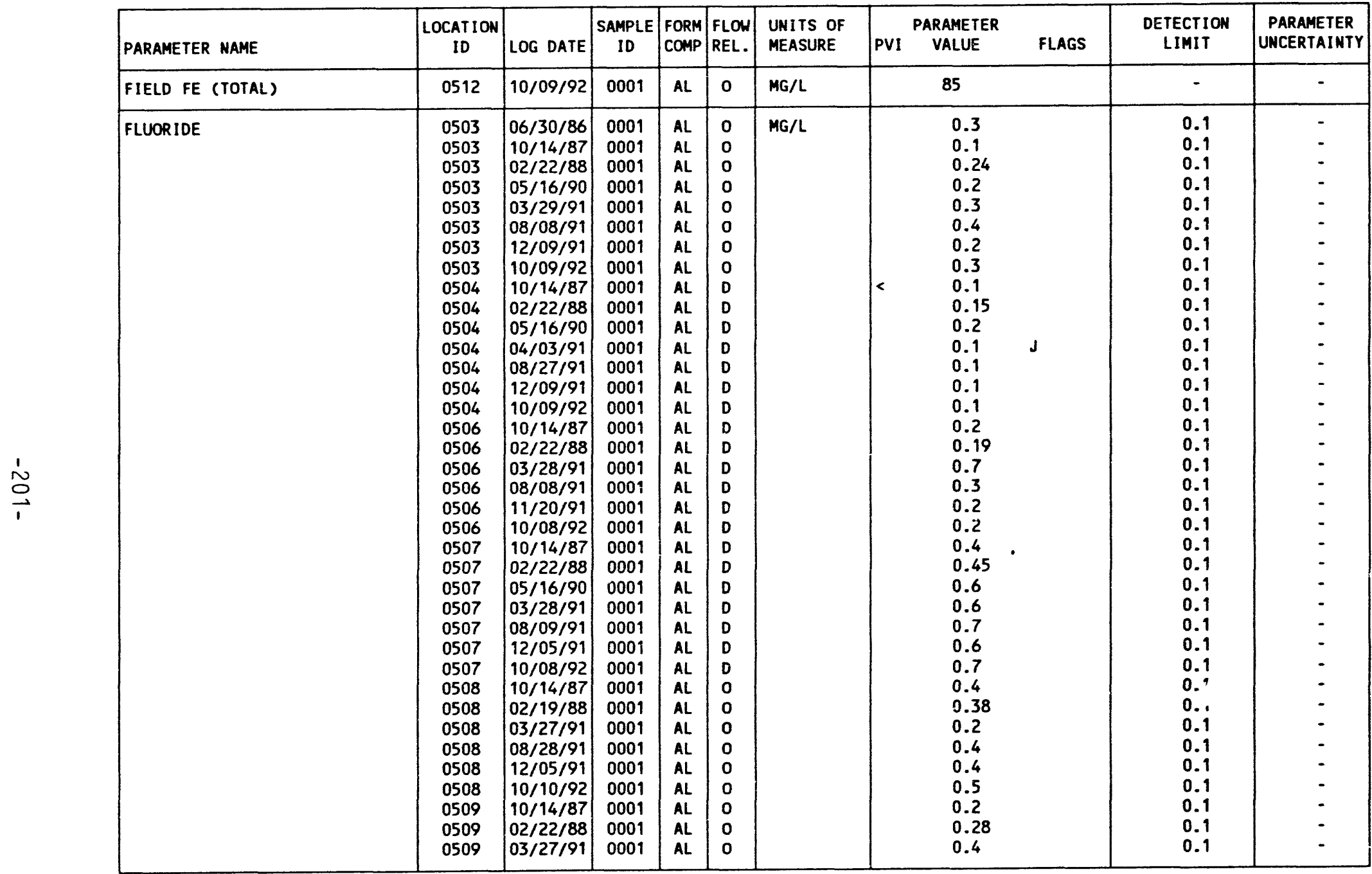

FORMATION OF COMPLETION COOE:

AL - ALLUVIUM

PARAMETER VALUE INDICATOR (PVI): < - LESS THAN DETECTION LIMIT
FLOW RELATIONSHIP COOE:

O - ON-SITE

D - DOWN GRADIENT

SAMPLE ID COOES:

0001 - FILTERED SAMPLE (.45 MICRONS)

OTHER PARAMETER VALUE FLAGS:

$J$ - ESTIMATED VALUE 
TABLE 3.27 BASELINE GROUNDUATER OUALITY DATA BY PARAMETER FOR THE ALLUVIUM NC AND UC PROCESSING SITES, SLICK ROCK, COLORADO

SITE: SRKOI SLICK ROCK (BOTH SITES)

D6/30/86 TO $10 / 13 / 92$

REPORT DATE : $07 / 26 / 93$

\begin{tabular}{|c|c|c|c|c|c|c|c|c|c|c|c|c|}
\hline & PARAMETER NAME & $\begin{array}{c}\text { LOCATION } \\
\text { ID }\end{array}$ & LOG DATE & $\begin{array}{c}\text { SAMPLE } \\
\text { ID }\end{array}$ & $\begin{array}{l}\text { FORM } \\
\text { COMP }\end{array}$ & $\begin{array}{l}\text { FLON } \\
\text { REL. }\end{array}$ & $\begin{array}{l}\text { UNITS OF } \\
\text { MEASURE }\end{array}$ & PVI & $\begin{array}{l}\text { PARAMETER } \\
\text { VALIIF }\end{array}$ & FLAGS & $\begin{array}{l}\text { DETECTION } \\
\text { LIMIT }\end{array}$ & $\begin{array}{l}\text { PARAMETER } \\
\text { UNCERTAINTY }\end{array}$ \\
\hline & FLUORIDE & $\begin{array}{l}0509 \\
0509 \\
0509 \\
0510 \\
0510 \\
0510 \\
0510 \\
0510 \\
0510 \\
0510 \\
0510 \\
0512 \\
0512 \\
0512 \\
0512 \\
0512 \\
0512\end{array}$ & \begin{tabular}{|l|}
$08 / 28 / 91$ \\
$11 / 21 / 91$ \\
$10 / 13 / 92$ \\
$06 / 30 / 86$ \\
$10 / 14 / 87$ \\
$02 / 22 / 88$ \\
$05 / 16 / 90$ \\
$03 / 28 / 91$ \\
$08 / 28 / 91$ \\
$12 / 05 / 91$ \\
$10 / 08 / 92$ \\
$10 / 14 / 87$ \\
$02 / 22 / 88$ \\
$04 / 05 / 91$ \\
$08 / 08 / 91$ \\
$12 / 10 / 91$ \\
$10 / 09 / 92$
\end{tabular} & $\begin{array}{l}0001 \\
0001 \\
0001 \\
0001 \\
0001 \\
0001 \\
0001 \\
0001 \\
0001 \\
0001 \\
0001 \\
0001 \\
0001 \\
0001 \\
0001 \\
0001 \\
0001\end{array}$ & $\begin{array}{l}A L \\
A L \\
A L \\
A L \\
A L \\
A L \\
A L \\
A L \\
A L \\
A L \\
A L \\
A L \\
A L \\
A L \\
A L \\
A L \\
A L\end{array}$ & $\begin{array}{l}0 \\
0 \\
0 \\
0 \\
0 \\
0 \\
0 \\
0 \\
0 \\
0 \\
0 \\
0 \\
0 \\
0 \\
0 \\
0 \\
0\end{array}$ & $M G / L$ & & $\begin{array}{l}0.3 \\
0.2 \\
0.3 \\
0.4 \\
0.3 \\
0.34 \\
0.3 \\
0.3 \\
0.3 \\
0.4 \\
0.4 \\
0.3 \\
0.32 \\
0.3 \\
0.3 \\
0.3 \\
0.3\end{array}$ & & $\begin{array}{l}0.1 \\
0.1 \\
0.1 \\
0.1 \\
0.1 \\
0.1 \\
0.1 \\
0.1 \\
0.1 \\
0.1 \\
0.1 \\
0.1 \\
0.1 \\
0.1 \\
0.1 \\
0.1 \\
0.1\end{array}$ & $\begin{array}{l}- \\
- \\
- \\
- \\
- \\
- \\
- \\
- \\
- \\
- \\
- \\
- \\
-\end{array}$ \\
\hline 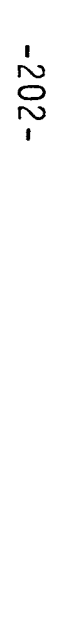 & GROSS ALPHA & $\begin{array}{l}0503 \\
0503 \\
0503 \\
0503 \\
0504 \\
0504 \\
0504 \\
0504 \\
0506 \\
0506 \\
0506 \\
0506 \\
0507 \\
0507 \\
0507 \\
0507 \\
0508 \\
0508 \\
0508 \\
0508\end{array}$ & $\begin{array}{l}03 / 29 / 91 \\
08 / 08 / 91 \\
12 / 05 / 91 \\
10 / 09 / 92 \\
04 / 03 / 91 \\
08 / 27 / 91 \\
12 / 05 / 91 \\
10 / 09 / 92 \\
03 / 28 / 91 \\
08 / 08 / 91 \\
12 / 05 / 91 \\
10 / 08 / 92 \\
03 / 28 / 91 \\
08 / 09 / 91 \\
12 / 05 / 91 \\
10 / 08 / 92 \\
03 / 27 / 91 \\
08 / 28 / 91 \\
12 / 05 / 91 \\
10 / 10 / 92\end{array}$ & $\begin{array}{l}0001 \\
0001 \\
0001 \\
0001 \\
0001 \\
0001 \\
0001 \\
0001 \\
0001 \\
0001 \\
0001 \\
0001 \\
0001 \\
0001 \\
0001 \\
0001 \\
0001 \\
0001 \\
0001 \\
0001\end{array}$ & $\begin{array}{l}A L \\
A L \\
A L \\
A L \\
A L \\
A L \\
A L \\
A L \\
A L \\
A L \\
A L \\
A L \\
A L \\
A L \\
A L \\
A L \\
A L \\
A L \\
A L \\
A L\end{array}$ & $\begin{array}{l}0 \\
0 \\
0 \\
0 \\
D \\
D \\
D \\
D \\
D \\
D \\
D \\
D \\
D \\
D \\
D \\
D \\
0 \\
0 \\
0 \\
0\end{array}$ & $\mathrm{PCI} / \mathrm{L}$ & & $\begin{array}{c}2299 . \\
1821 . \\
2175 . \\
1610 . \\
1177 . \\
768.3 \\
718 . \\
641 . \\
191 . \\
23.0 \\
0.0 \\
189 . \\
41.0 \\
30.6 \\
19.3 \\
5.0 \\
63.2 \\
67.2 \\
0.0 \\
23.1\end{array}$ & $\begin{array}{l}\mathbf{N} \\
\mathbf{J}\end{array}$ & $\begin{array}{c}1 . \\
1 . \\
1 . \\
37.8 \\
1 . \\
1 . \\
1 . \\
25.0 \\
1 . \\
1 . \\
1 . \\
82.4 \\
1 . \\
1 . \\
1 . \\
6.4 \\
1 . \\
1 . \\
1 . \\
48.4\end{array}$ & $\begin{array}{c}118 . \\
108 . \\
165 . \\
99.3 \\
85.7 \\
63.7 \\
80.4 \\
51.7 \\
140 . \\
71.2 \\
116 . \\
74.3 \\
17.0 \\
13.6 \\
26.0 \\
4.6 \\
23.2 \\
34.2 \\
62.4 \\
31.6\end{array}$ \\
\hline
\end{tabular}

FORMATION OF COMPLETION CODE:

AL - ALLUVIUM

PARAMETER VALUE INDICATOR (PVI): < - LESS THAN DETECTION LIMIT
FLOW RELATIONSHIP COOE:

O - ON-SITE

D - DOWN GRADIENT

SAMPLE ID CODES:

0001 - FILTERED SAMPLE (.45 MICRONS)

OTHER PARAMETER VALUE FLAGS:

$J$ - ESTIMATED VALUE
N - SPIKE SAMPLE RECOVERY NOT WITHIN CONTROL LIMITS 
TABLE 3.27 BASELINE GROUNDWATER QUALITY DATA BY PARAMETER FOR THE ALLUVIUM NC AND UC PROCESSING SITES, SLICK ROCK, COLORADO

SITE: SRKO1 SLICK ROCK (BOTH SITES)

SITE: SRKO1 SLICK ROCK

REPORT DATE: $07 / 26 / 93$

\begin{tabular}{|c|c|c|c|c|c|c|c|c|c|c|c|}
\hline PARAMETER NAME & $\begin{array}{c}\text { LOCATION } \\
\text { ID }\end{array}$ & LOG DATE & $\begin{array}{c}\text { SAMPLE } \\
\text { ID }\end{array}$ & $\begin{array}{l}\text { FORM } \\
\text { COMP }\end{array}$ & $\begin{array}{l}\text { FLOW } \\
\text { REL. }\end{array}$ & $\begin{array}{l}\text { UNITS OF } \\
\text { MEASURE }\end{array}$ & PVI & $\begin{array}{l}\text { ARAMETER } \\
\text { VALUE }\end{array}$ & FLAGS & $\begin{array}{l}\text { DETECTION } \\
\text { LIMIT }\end{array}$ & $\begin{array}{l}\text { PARAMETER } \\
\text { UNCERTAINTY }\end{array}$ \\
\hline GROSS ALPHA & $\begin{array}{l}0509 \\
0509 \\
0509 \\
0509 \\
0510 \\
0510 \\
0510 \\
0510 \\
0512 \\
0512 \\
0512 \\
0512\end{array}$ & $\begin{array}{l}03 / 27 / 91 \\
08 / 28 / 91 \\
12 / 05 / 91 \\
10 / 13 / 92 \\
03 / 28 / 91 \\
08 / 28 / 91 \\
12 / 05 / 91 \\
10 / 08 / 92 \\
04 / 05 / 91 \\
08 / 08 / 91 \\
12 / 05 / 91 \\
10 / 09 / 92\end{array}$ & $\begin{array}{l}0001 \\
0001 \\
0001 \\
0001 \\
0001 \\
0001 \\
0001 \\
0001 \\
0001 \\
0001 \\
0001 \\
0001\end{array}$ & $\begin{array}{l}A L \\
A L \\
A L \\
A L \\
A L \\
A L \\
A L \\
A L \\
A L \\
A L \\
A L \\
A L\end{array}$ & $\begin{array}{l}0 \\
0 \\
0 \\
0 \\
0 \\
0 \\
0 \\
0 \\
0 \\
0 \\
0 \\
0\end{array}$ & $\mathrm{PCI} / \mathrm{L}$ & & $\begin{array}{c}111 . \\
23.5 \\
19.0 \\
16.1 \\
132 . \\
84.2 \\
0.0 \\
118 . \\
122 . \\
916 . \\
870 . \\
1460 .\end{array}$ & N & $\begin{array}{c}1 . \\
1 . \\
1 . \\
20.2 \\
1 . \\
1 . \\
1 . \\
41.2 \\
1 . \\
1 . \\
1 . \\
22.5\end{array}$ & $\begin{array}{l}70.7 \\
12.0 \\
23.8 \\
13.9 \\
73.1 \\
37.6 \\
57.9 \\
40.0 \\
58.2 \\
51.1 \\
66.1 \\
72.3\end{array}$ \\
\hline GROSS BETA & $\begin{array}{l}0503 \\
0503 \\
0503 \\
0503 \\
0504 \\
0504 \\
0504 \\
0504 \\
0506 \\
0506 \\
0506 \\
0506 \\
0507 \\
0507 \\
0507 \\
0507 \\
0508 \\
0508 \\
0508 \\
0508 \\
0509 \\
0509 \\
0509 \\
0509\end{array}$ & $\begin{array}{l}03 / 29 / 91 \\
08 / 08 / 91 \\
12 / 05 / 91 \\
10 / 09 / 92 \\
04 / 03 / 91 \\
08 / 27 / 91 \\
12 / 05 / 91 \\
10 / 09 / 92 \\
03 / 28 / 91 \\
08 / 08 / 91 \\
12 / 05 / 91 \\
10 / 08 / 92 \\
03 / 28 / 91 \\
08 / 09 / 91 \\
12 / 05 / 91 \\
10 / 08 / 92 \\
03 / 27 / 91 \\
08 / 28 / 91 \\
12 / 05 / 91 \\
10 / 10 / 92 \\
03 / 27 / 91 \\
08 / 28 / 91 \\
12 / 05 / 91 \\
10 / 13 / 92\end{array}$ & $\begin{array}{l}0001 \\
0001 \\
0001 \\
0001 \\
0001 \\
0001 \\
0001 \\
0001 \\
0001 \\
0001 \\
0001 \\
0001 \\
0001 \\
0001 \\
0001 \\
0001 \\
0001 \\
0001 \\
0001 \\
0001 \\
0001 \\
0001 \\
0001 \\
0001\end{array}$ & $\begin{array}{l}A L \\
A L \\
A L \\
A L \\
A L \\
A L \\
A L \\
A L \\
A L \\
A L \\
A L \\
A L \\
A L \\
A L \\
A L \\
A L \\
A L \\
A L \\
A L \\
A L \\
A L \\
A L \\
A L \\
A L\end{array}$ & $\begin{array}{l}0 \\
0 \\
0 \\
0 \\
D \\
D \\
D \\
D \\
D \\
D \\
D \\
D \\
D \\
D \\
D \\
D \\
0 \\
0 \\
0 \\
0 \\
0 \\
0 \\
D \\
0\end{array}$ & $\mathrm{PCI} / \mathrm{L}$ & & $\begin{array}{r}875 . \\
984 . \\
885 . \\
577 . \\
340 . \\
319 . \\
264 . \\
188 . \\
165 . \\
16.1 \\
0.0 \\
145 . \\
23.4 \\
19.8 \\
0.0 \\
11.8 \\
42.8 \\
54.1 \\
0.0 \\
25.1 \\
87.7 \\
23.6 \\
4.9 \\
37.5\end{array}$ & $\begin{array}{l}\star_{N} \\
J \\
\star_{N}\end{array}$ & $\begin{array}{r}0.5 \\
0.5 \\
0.5 \\
33.7 \\
0.5 \\
0.5 \\
0.5 \\
22.8 \\
0.5 \\
0.5 \\
0.5 \\
63.8 \\
0.5 \\
0.5 \\
0.5 \\
7.8 \\
0.5 \\
0.5 \\
0.5 \\
41.0 \\
0.5 \\
0.5 \\
0.5 \\
16.6\end{array}$ & $\begin{array}{r}37.3 \\
44.0 \\
55.6 \\
37.9 \\
25.6 \\
21.7 \\
27.9 \\
20.3 \\
84.5 \\
55.5 \\
79.1 \\
45.1 \\
8.6 \\
8.7 \\
15.3 \\
5.2 \\
11.6 \\
19.4 \\
40.4 \\
25.5 \\
45.5 \\
6.9 \\
15.0 \\
11.5\end{array}$ \\
\hline
\end{tabular}

FORMATION OF COMPLETION COOE:

AL - ALLUVIUM

PARAMETER VALUE INOICATOR (PVI): < - LESS THAN DETECTION LIMIT
FLON RELATIONSHIP COOE:

O- ON-SITE

D - DOWN GRADIENT

SAMPLE ID CODES:

0001 - FILTERED SAMPLE (.45 MICRONS)

OtHeR PARAMETER VALUE fLAGS:

- DUPLicate analysis hot hithin CONTROL limits

$J$ - ESTIMATED VALUE
N - SPIKE SAMPLE RECOVERY nOT HITHIN CONTROL LIMITS 
TABLE 3.27 BASELINE GROUNDWATER QUALITY DATA BY PARAMETER FOR THE ALLUVIUM NC AND UC PROCESSING SITES, SLICK ROCK, COLORADO

SITE: SRKO1 SLICK ROCK (BOTH SITES)

$06 / 30 / 86$ TO $10 / 13 / 92$

REPORT DATE: $07 / 26 / 93$

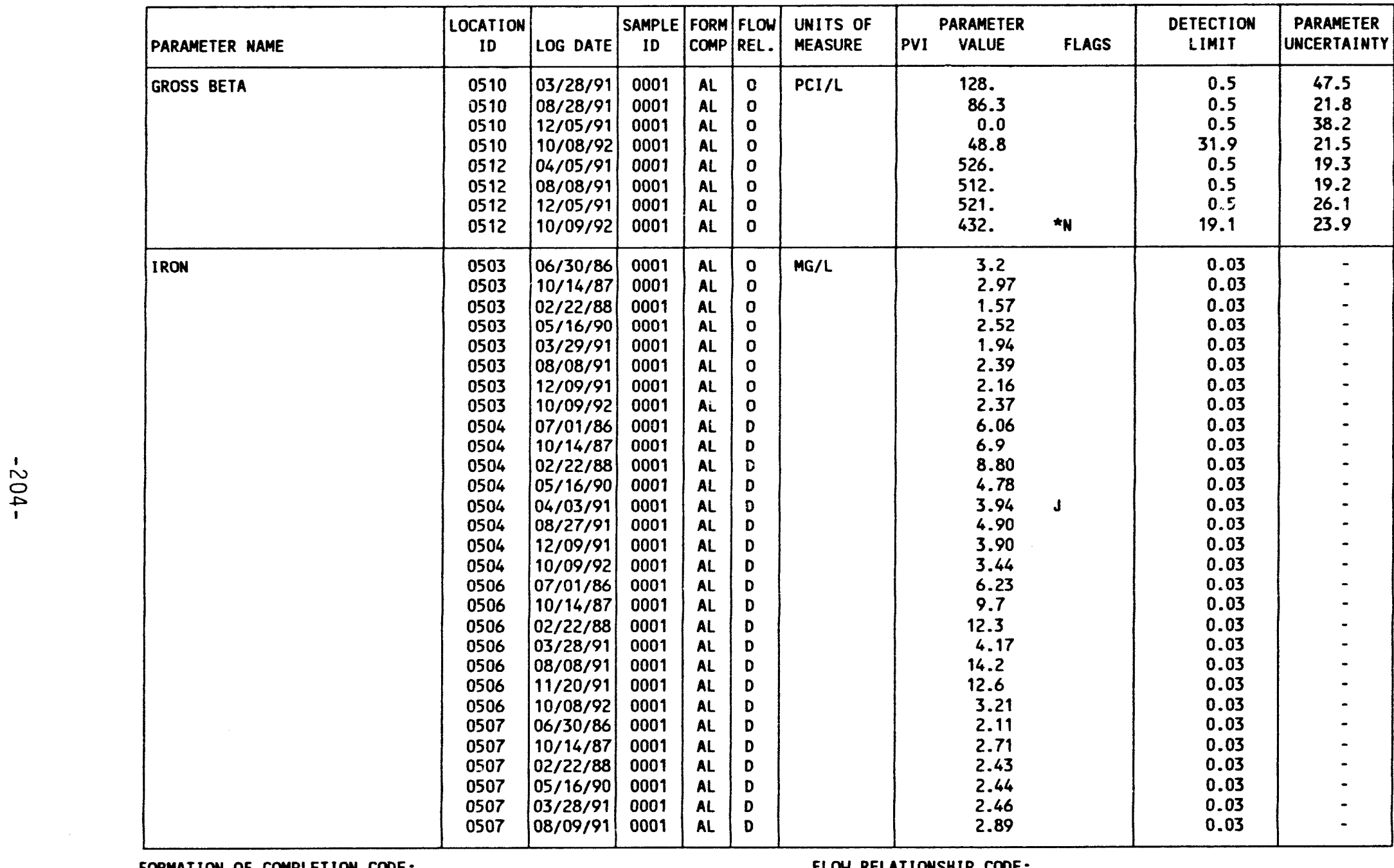

FORMATION OF COMPLETION COOE:

AL - ALLUVIUM

FLOW RELATIONSHIP CODE:

D - DOWN GRADIENT

PARAMETER VALUe INDICATOR (PVI): < - LESS than DETECTION LIMIT

0001 - FILTERED SAMPLE (.45 MICRONS)

OTHER PARAMETER VALUE FLAGS:

* - DUPLICATE ANALYSIS MOT Y्रITHIN CONTROL LIMITS

$J$ - estimated value

N - SPIKE SAMPLE RECOVERY NOT WITHIN CONTROL LIMITS 
TABLE 3.27 BASELIME GROUNDWATER QUALITY DATA BY PARAMETER FOR THE ALLUVIUM

NC AND UC PROCESSING SITES, SLICK ROCK, COLORADO

SITE: SRKO1 SLICK ROCK (BOTH SITES)

O6/30/86 TO $10 / 13 / 92$

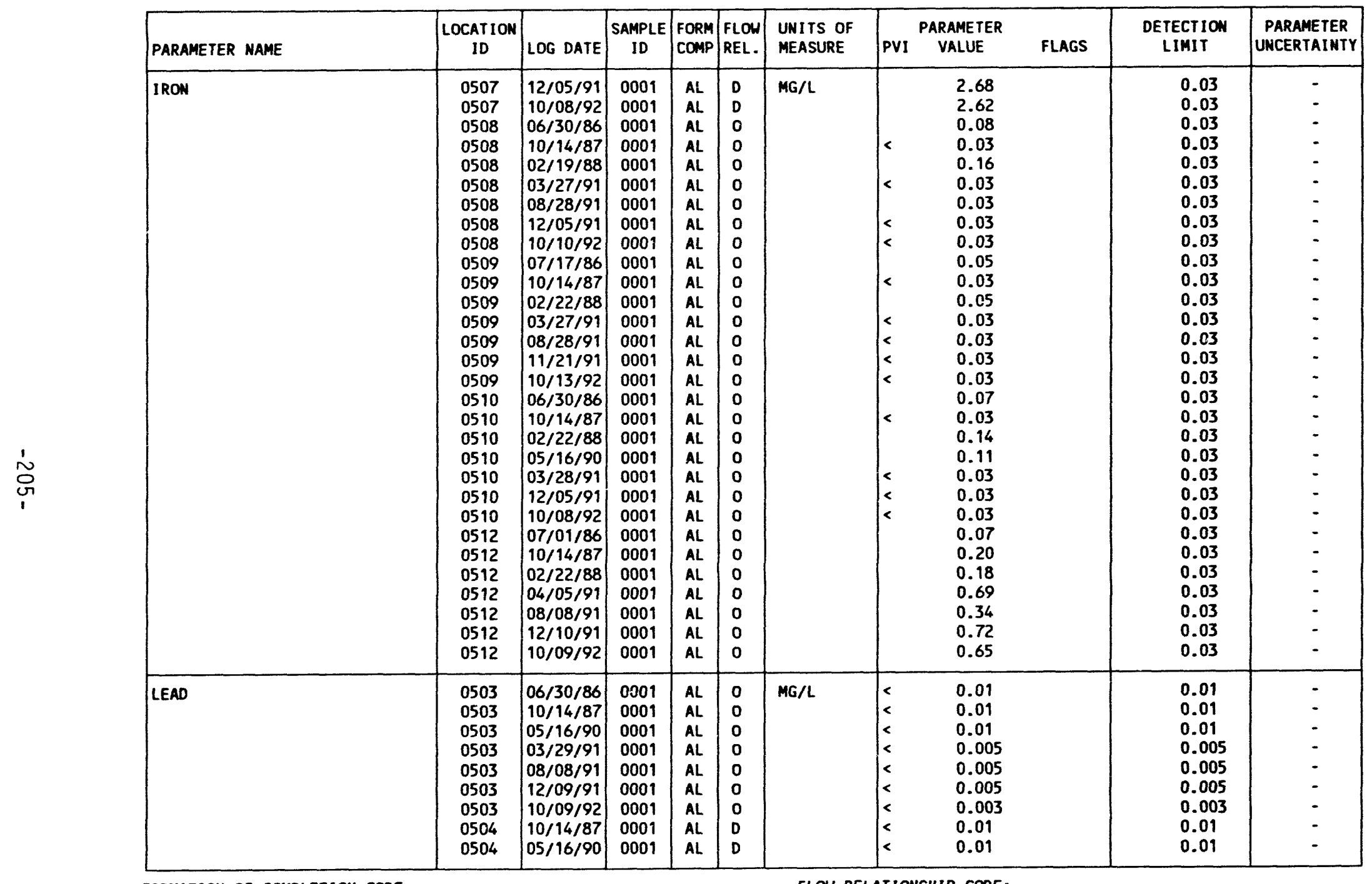

FORMATION OF COMPLETION CODE:

AL - ALLUVIUM
FLOW RELATIONSHIP COOE:

D - DONN GRADIENT

O - ON-SITE

PARAMETER VALUE INDICATOR (PVI): < - LESS TKAN DETECTION LIMIT

0001 - FILTERED SAMPLE (.45 MICRONS) 
TABLE 3.27 BASELINE GROUNDWATER OUALITY DATA BY PARAMETER FOR THE ALLUVIUM NC AND UC PROCESSING SITES, SLICK ROCK, COLORADO

SITE: SRKO1 SLICK ROCK (BOTH SITES)

06/30/86 TO 10/13/92

REPORT DATE: 07/26/93

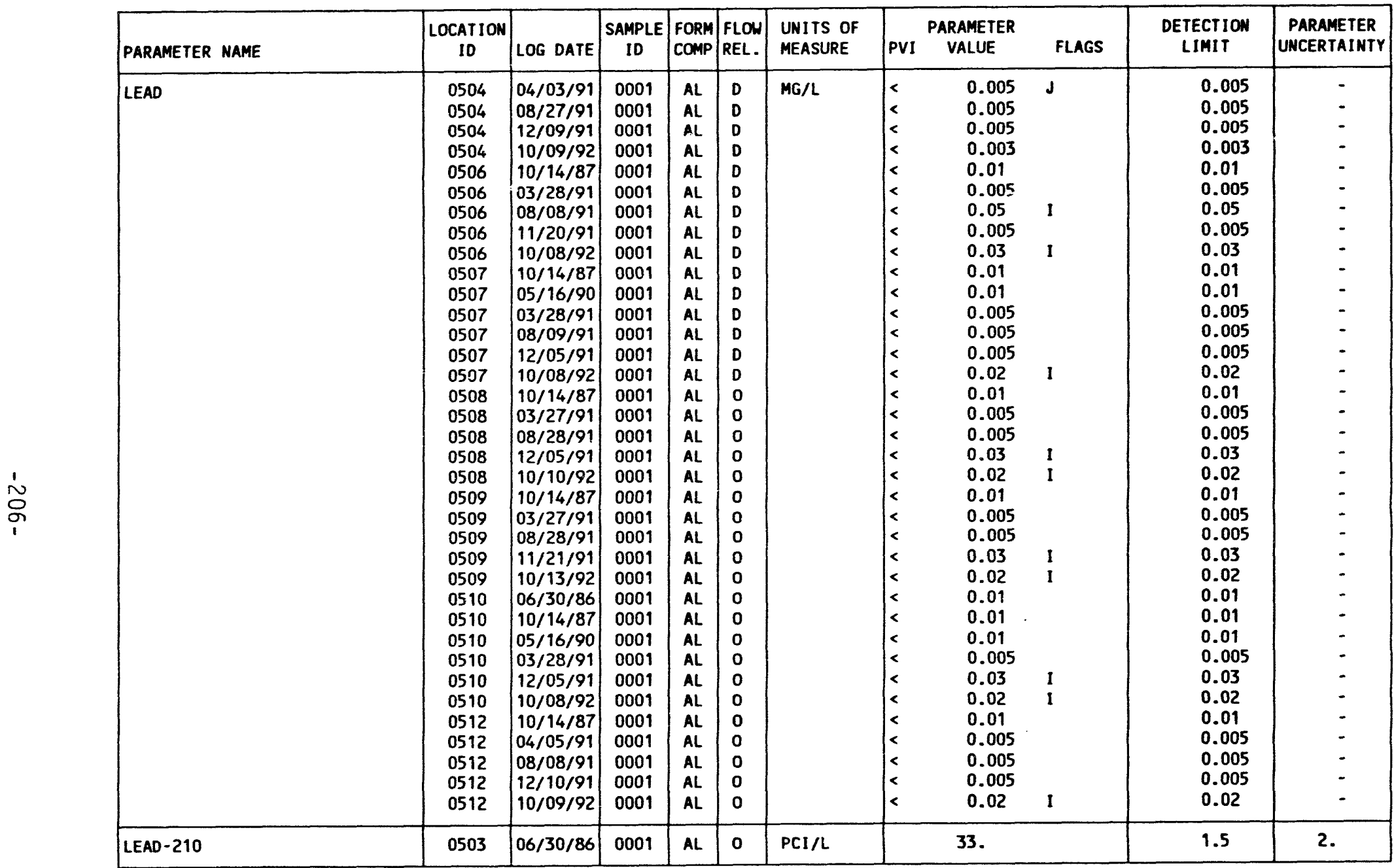

FORMATION OF COMPLETION CODE:

AL - ALLUVIUM

PARAMETER VALUE INDICATOR (PVI): < - LESS THAN DETECTION LIMIT
FLOW RELATIONSHIP COOE:

D - DOWN GRADIENT

O - ON-SITE

SAMPLE ID CODES:
0001 - FILTERED SAMPLE (.45 MICRONS)

OTHER PARAMETER VALUE FLAGS:

I - INCREASED DETECTION LIMIT DUE TO REQUIRED DILUTION J - ESTIMATED VALUE 
TABLE 3.27 BASELINE GROUNDWATER QUALITY DATA BY PARAMETER FOR THE ALLUUIUM NC ANE UC PFOCESSING SITES, SLICK ROCK, COLORADO

SITE: SRKO! SLICK ROCK (BOTH SITES)

$06 / 30 / 86$ TO $10 / 13 / 92$

REPOP: UATE: $07 / 26 / 93$

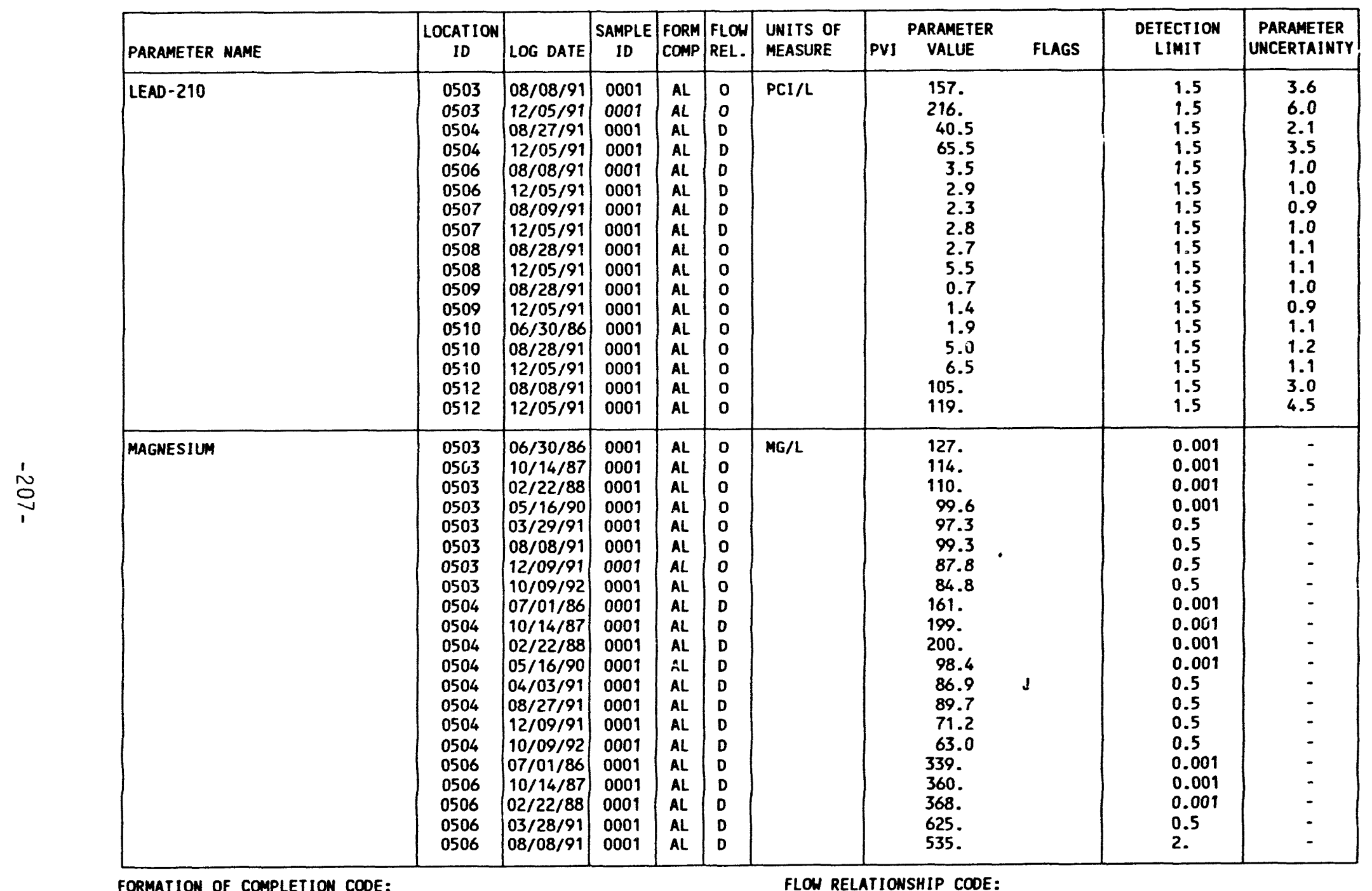

FORMATION OF COMPLETION CODE:

AL - ALLUVIUM

PARAMETER VALUE INDICATOR (PVI): < - LESS THAN DETECTION LIMIT

OTHER PARAMETER VALUE FLAGS:
J. ESTIMATED VALUE

$J$ - ESTIMATED VALUE
FLOW RELATIONSHIP COOE:

O - ON-SITE
D - DOWN GRADIENT

SAMPLE ID COOES:

0001 - FILTERED SAMPLE (.45 MICRONS) 
TABLE 3.27 BASELINE GROUNDWATER QUALITY DATA BY PARAMETER FOR THE ALLUVIUM NC AMD UC PROCESSING SITES, SLICK ROCK, COLORADO

SITE: $S R K O 1$ SLII

$06 / 30 / 86$ TO $10 / 13 / 92$

REPORT DATE: 07/26/93

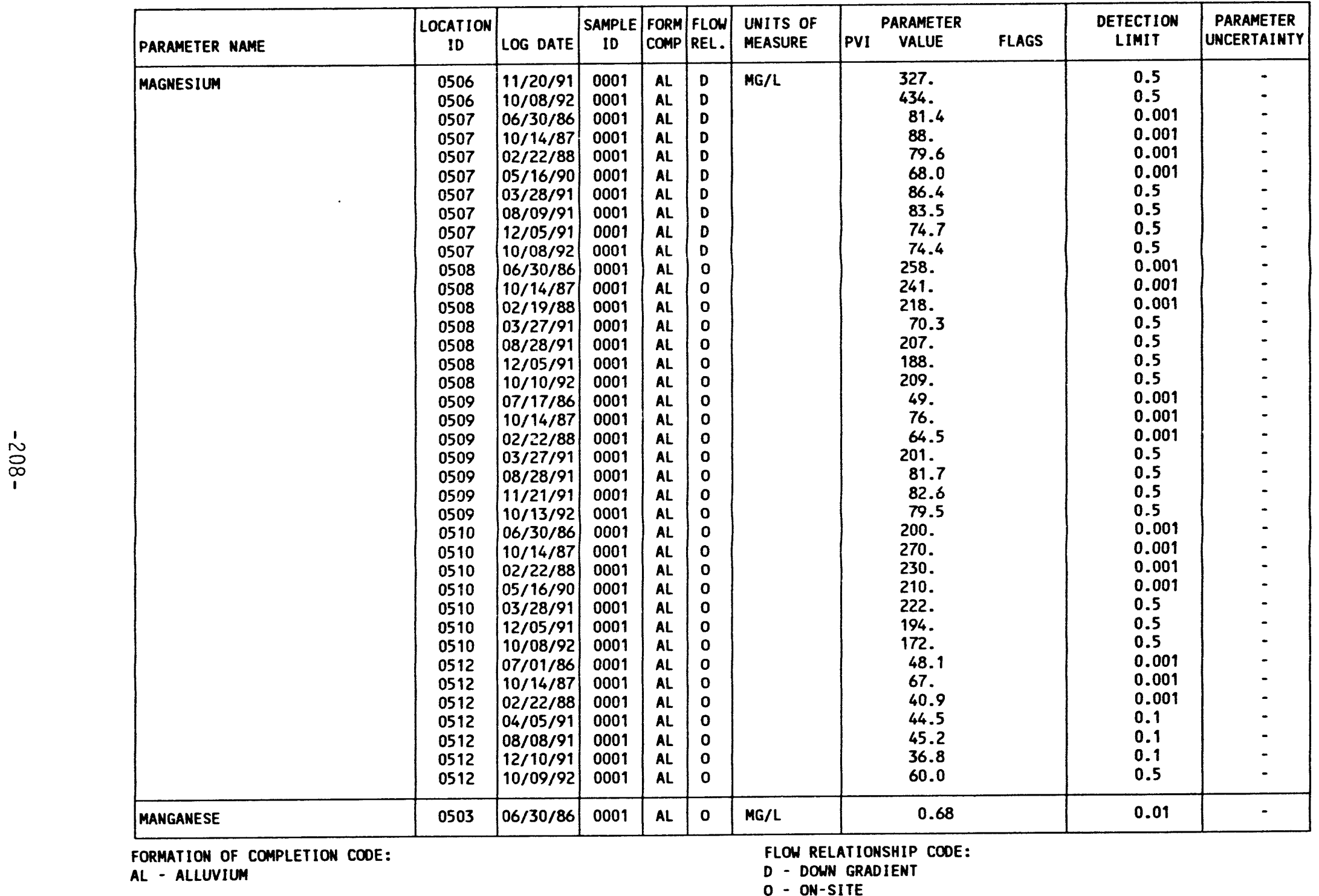

PARAMETER VALUE INDICATOR (PVI): < - LESS THAN DETECTION LIMIT

SAMPLE ID CODES:

0001 - FILTERED SAMPLE (.45 MICRONS) 
TABLE 3.27 BASELINE GROUNDWATER QUALITY DATA BY PARAMETER FOR THE ALLUVIUM NC AND UC PROCESSING SITES, SLICK ROCK, COLORADO

SITE: SRKO1 SLICK ROCK (BOTH SITES)

06/30/86 TO $10 / 13 / 92$

REPORT DATE: $07 / 26 / 93$

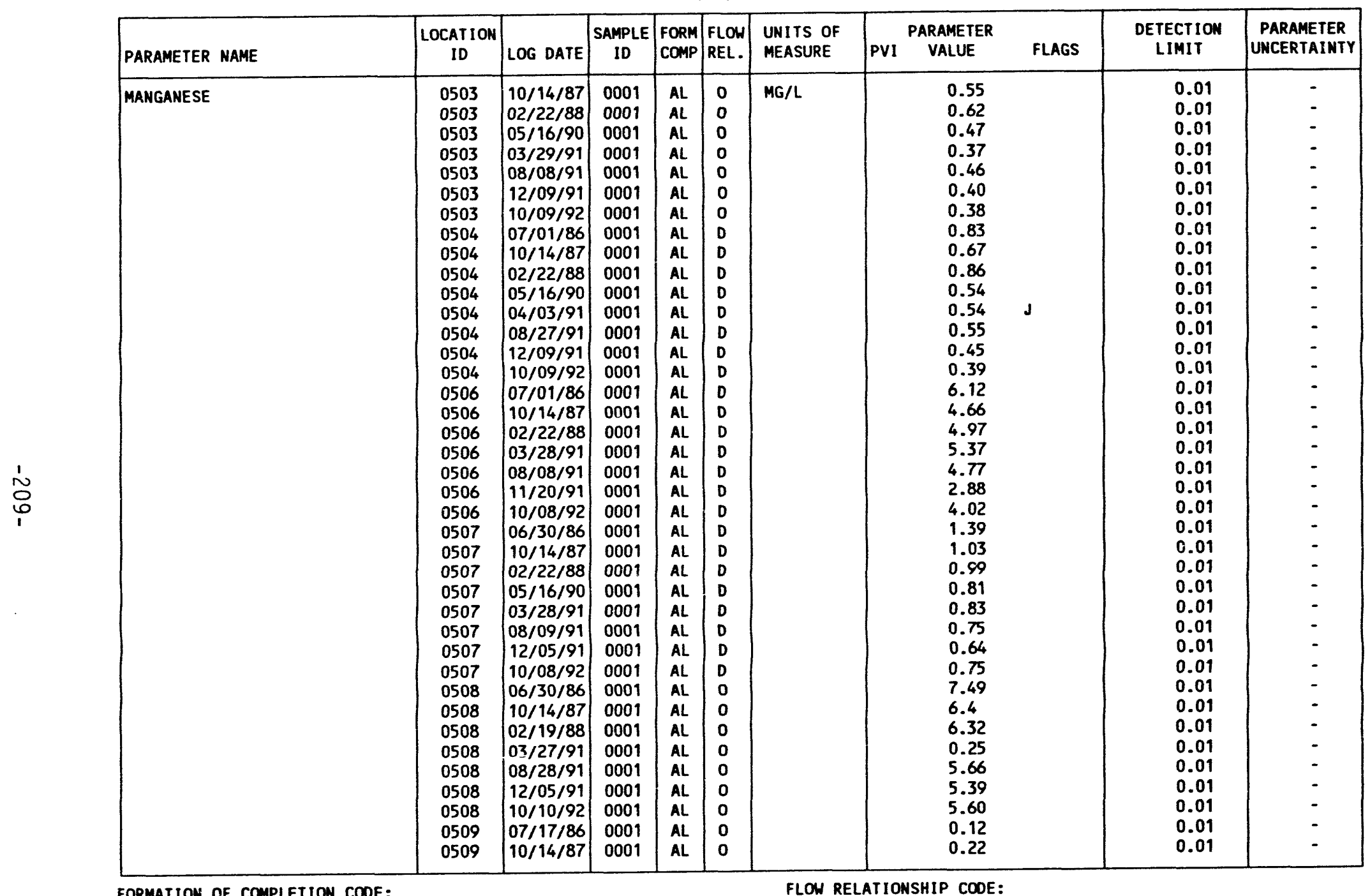

FORMATION OF COMPLETION COOE:

AL - ALLUVIUM

PARAMETER VALUE INDICATOR (PVI): < - LESS THAN DETECTION LIMIT
FLOW RELATIONSHIP COOE:

D - DOWN GRADIENT

\section{SAMPLE ID CODES:}

0001 - FILTERED SAMPLE (.45 MICRONS)

OTHER PARAMETER VALUE FLAGS:

$J$ - ESTIMATED VALUE 
TABLE 3.27 BASELINE GROUNDHATER QUALITY DATA BY PARAMETER FOR THE ALLUVILM NC AND UC PROCESSING SITES, SLICK ROCK, COLORADO

SITE: SRK01 SLICK ROCK (BOTH SITES)

06/30/86 TO $10 / 13 / 92$

REPORT DATE: $07 / 26 / 93$

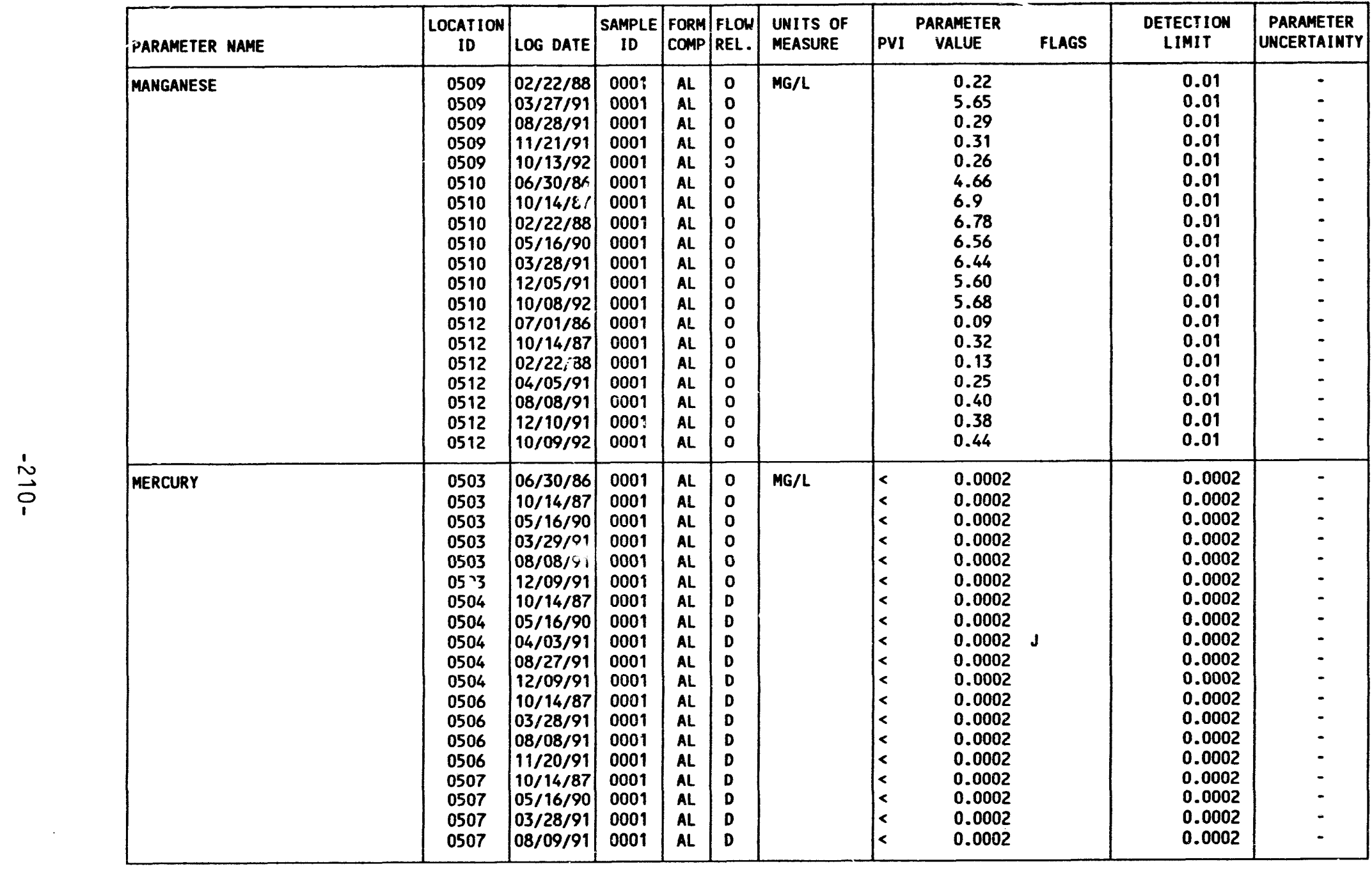

FORMATION OF COMPLETION CODE:

AL - ALLUVIUM

FLOW RELATIONSHIP COOE:

D - DOWN GRADIENT

PARAMETER VALUE INDICATOR (PVI): < - LESS than DETECTION LIMIT

SAMPLE ID CODES:

0001 - FILTERED SAMPLE (.45 MICRONS) 
TABLE 3.27 BASELINE GROUNDHATER QUALITY DATA BY PARAMETER FOR THE ALLUVIUM

NC AND UC PROCESSING SITES, SLICK ROCK COLORADO

SITE: SRKO1 SLICK ROCK (BOTH SITES)

$06 / 30 / 86$ TO $10 / 13 / 92$

REPORT DATE: $07 / 26 / 93$

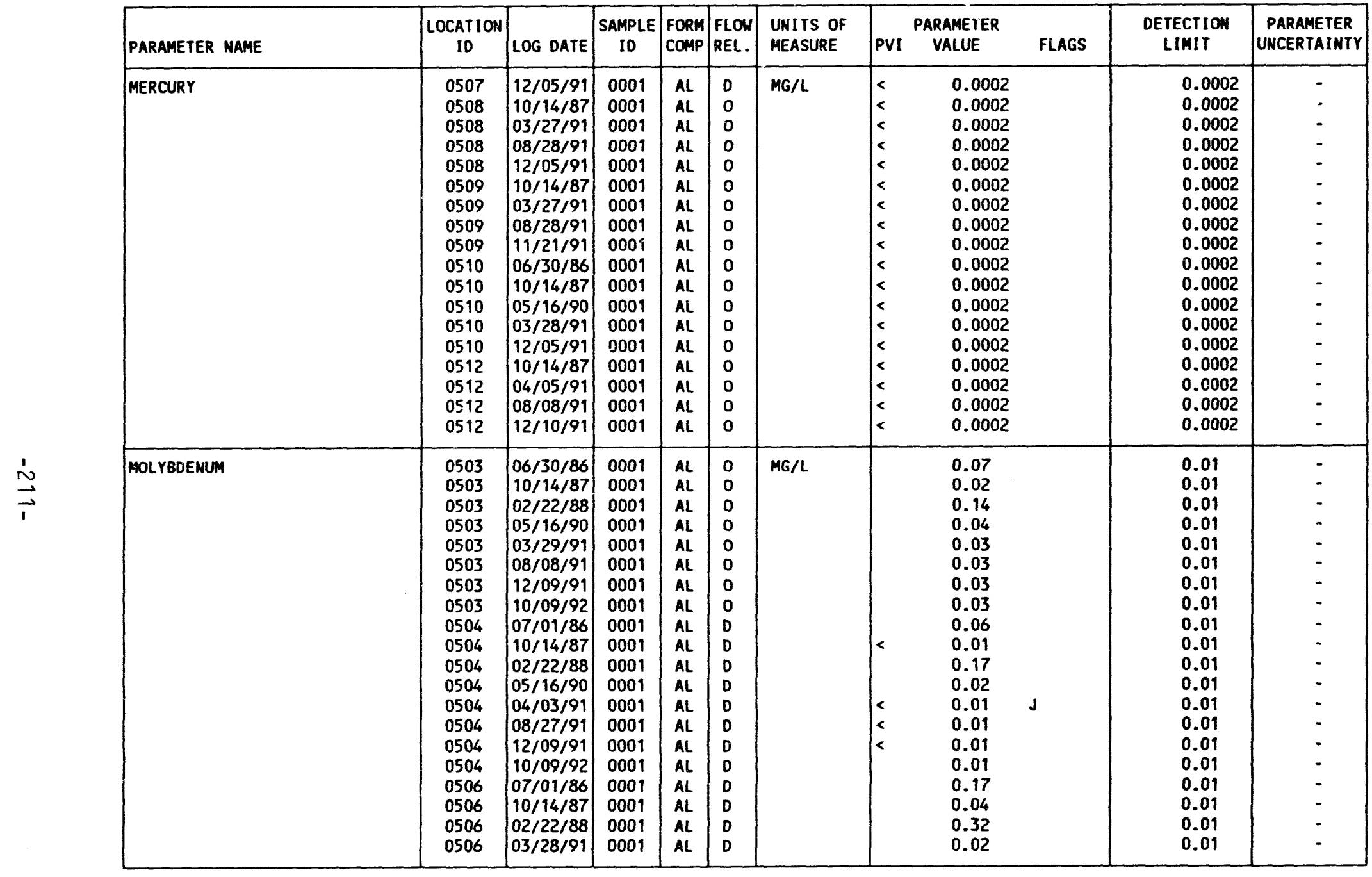

FORMATION OF COMPLETION CODE:

AL - ALLUVIUM
FLOW RELATIONSHIP COOE:

D - DOWN GRADIENT

O - ON-SITE

PARAMETER VALUE INDICATOR (PVI): < - LESS THAN DETECTION LIMIT

SAMPLE ID CODES:

0001 - FILTERED SAMPLE (.45 MICRONS)

OTHER PARAMETER VALUE FLAGS:

J- ESTIMATED VALUE 
TABLE 3.27 BASELINE GROUNDHATER QUALITY DATA BY PARAMETER FOR THE ALLUVIUM NC AND UC PROCESSING SITES, SLICK ROCK, COLORADO

SITE: SRKO1 SLICK ROCK (BOTH SITES)

06/30/86 TO 10/13/92

REPORT DATE: $07 / 26 / 93$

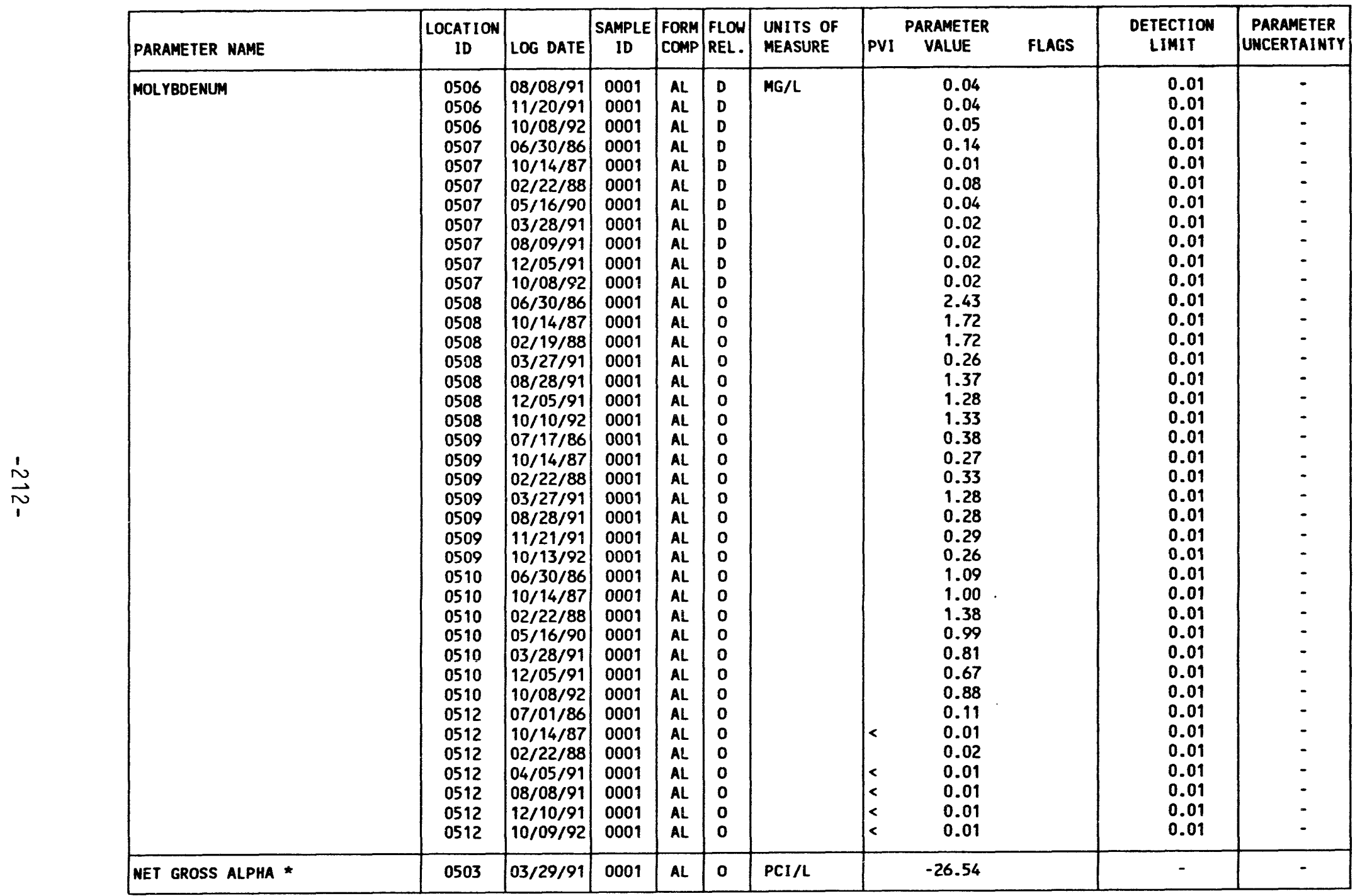

* NET GROSS ALPHA (GROSS ALPHA - URANIUM) HITH 1 MG URANIUM = 686 PCI

\begin{abstract}
FORMATION OF COMPLETION CODE:
\end{abstract} AL - ALLUVIUM
FLOU RELATIONSHIP COOE:

D - DOWN GRADIENT

O - ON-SITE

PARAMETER VALUE INDICATOR (PVI): < - LeSS than DETECTION LIMIT 


\begin{tabular}{|c|c|c|c|c|c|c|c|c|c|c|c|}
\hline & \multicolumn{8}{|c|}{$\begin{array}{l}\text { TABLE } 3.27 \text { BASELINE GROUNDWATER QUALITY DATA BY } \\
\text { NC AND UC PROCESSING SITES, SLICK ROCK, COLORADO } \\
\text { SITE: SRKO1 SLICK ROCK (BOTH SITES) } \\
\text { O6/30/86 TO } 10 / 13 / 92 \\
\text { REPORT DATE: } 07 / 26 / 93\end{array}$} & \multicolumn{3}{|c|}{ PARAMETER FOR THE ALLUVIUM } \\
\hline PARAMETER NAME & $\underset{\text { ID }}{\text { LOCATION }}$ & LOG DATE & $\begin{array}{c}\text { SAMPLE } \\
\text { ID }\end{array}$ & $\begin{array}{l}\text { FORM } \\
\text { COMP }\end{array}$ & $\begin{array}{l}\text { FLOW } \\
\text { REL. }\end{array}$ & $\begin{array}{l}\text { UNITS OF } \\
\text { MEASURE }\end{array}$ & PVI & $\begin{array}{l}\text { PARAMETER } \\
\text { VALUE }\end{array}$ & FLAGS & $\begin{array}{l}\text { DETECTION } \\
\text { LIMIT }\end{array}$ & $\begin{array}{l}\text { PARAMETER } \\
\text { UNCERTAINTY }\end{array}$ \\
\hline NET GROSS ALPHA * & $\begin{array}{l}0503 \\
0503 \\
0503 \\
0504 \\
0504 \\
0504 \\
0504 \\
0506 \\
0506 \\
0506 \\
0506 \\
0507 \\
0507 \\
0507 \\
0507 \\
0508 \\
0508 \\
0508 \\
0508 \\
0509 \\
0509 \\
0509 \\
0509 \\
0510 \\
0510 \\
0510 \\
0510 \\
0512 \\
0512 \\
0512 \\
0512\end{array}$ & $\begin{array}{l}08 / 08 / 91 \\
12 / 05 / 91 \\
10 / 09 / 92 \\
04 / 03 / 91 \\
08 / 27 / 91 \\
12 / 05 / 91 \\
10 / 09 / 92 \\
03 / 28 / 91 \\
08 / 08 / 91 \\
12 / 05 / 91 \\
10 / 08 / 92 \\
03 / 28 / 91 \\
08 / 09 / 91 \\
12 / 05 / 91 \\
10 / 08 / 92 \\
03 / 27 / 91 \\
08 / 28 / 91 \\
12 / 05 / 91 \\
10 / 10 / 92 \\
03 / 27 / 91 \\
08 / 28 / 91 \\
12 / 05 / 91 \\
10 / 13 / 92 \\
03 / 28 / 91 \\
08 / 28 / 91 \\
12 / 05 / 91 \\
10 / 08 / 92 \\
04 / 05 / 91 \\
08 / 08 / 91 \\
12 / 05 / 91 \\
10 / 09 / 92\end{array}$ & $\begin{array}{l}0001 \\
0001 \\
0001 \\
0001 \\
0001 \\
0001 \\
0001 \\
0001 \\
0001 \\
0001 \\
0001 \\
0001 \\
0001 \\
0001 \\
0001 \\
0001 \\
0001 \\
0001 \\
0001 \\
0001 \\
0001 \\
0001 \\
0001 \\
0001 \\
0001 \\
0001 \\
0001 \\
0001 \\
0001 \\
0001 \\
0001\end{array}$ & $\begin{array}{l}A L \\
A L \\
A L \\
A L \\
A L \\
A L \\
A L \\
A L \\
A L \\
A L \\
A L \\
A L \\
A L \\
A L \\
A L \\
A L \\
A L \\
A L \\
A L \\
A L \\
A L \\
A L \\
A L \\
A L \\
A L \\
A L \\
A L \\
A L \\
A L \\
A L \\
A L\end{array}$ & $\begin{array}{l}0 \\
0 \\
0 \\
D \\
D \\
D \\
D \\
D \\
D \\
D \\
D \\
D \\
D \\
D \\
D \\
0 \\
0 \\
0 \\
0 \\
0 \\
0 \\
0 \\
0 \\
0 \\
0 \\
0 \\
0 \\
0 \\
0 \\
0 \\
0\end{array}$ & $\mathrm{PCI} / \mathrm{L}$ & & $\begin{array}{r}-136.84 \\
123.86 \\
-399.98 \\
99.98 \\
139.92 \\
121.18 \\
33.20 \\
149.84 \\
-4.44 \\
-21.27 \\
133.43 \\
21.11 \\
7.28 \\
0.78 \\
-14.21 \\
48.79 \\
17.12 \\
-70.66 \\
-48.24 \\
57.49 \\
4.98 \\
3.91 \\
-0.36 \\
68.89 \\
7.37 \\
-90.55 \\
14.41 \\
-493.00 \\
-622.70 \\
-296.20 \\
-440.22\end{array}$ & & $\begin{array}{l}- \\
- \\
- \\
- \\
- \\
- \\
- \\
- \\
- \\
- \\
- \\
- \\
- \\
- \\
- \\
- \\
- \\
- \\
- \\
- \\
- \\
-\end{array}$ & $\begin{array}{l}- \\
- \\
- \\
\vdots \\
\vdots \\
- \\
- \\
- \\
- \\
- \\
- \\
- \\
- \\
- \\
- \\
- \\
- \\
- \\
- \\
- \\
-\end{array}$ \\
\hline NICKEL & $\begin{array}{l}0503 \\
0503 \\
0503 \\
0503 \\
0503 \\
0503\end{array}$ & $\begin{array}{l}06 / 30 / 86 \\
10 / 14 / 87 \\
02 / 22 / 88 \\
05 / 16 / 90 \\
03 / 29 / 91 \\
08 / 08 / 91\end{array}$ & $\begin{array}{l}0001 \\
0001 \\
0001 \\
0001 \\
0001 \\
0001\end{array}$ & $\begin{array}{l}A L \\
A L \\
A L \\
A L \\
A L \\
A L\end{array}$ & $\begin{array}{l}0 \\
0 \\
0 \\
0 \\
0 \\
0\end{array}$ & $M G / L$ & $\begin{array}{l}< \\
< \\
< \\
< \\
<\end{array}$ & $\begin{array}{l}0.04 \\
0.04 \\
0.04 \\
0.04 \\
0.04 \\
0.04\end{array}$ & & $\begin{array}{l}0.04 \\
0.04 \\
0.04 \\
0.04 \\
0.04 \\
0.04\end{array}$ & $\begin{array}{l}- \\
- \\
- \\
-\end{array}$ \\
\hline
\end{tabular}

* NET GROSS ALPHA (GROSS ALPHA - URANIUM) WITH 1 MG URANIUM = 686 PCI

FORMATION OF COMPLETION COOE:

AL - ALLUVIUM
FLON RELATIONSHIP COOE:

O - ON-SITE

D - DOWN GRADIENT

PARAMETER VALUE INDICATOR (PVI): < - LESS THAN DETECTION LIMIT SAMPLE ID CODES:

0001 - FILTERED SAMPLE (.45 MICRONS) 
TABLE 3.27 BASELINE GROUNDWATER QUALITY DATA BY PARAMETER FOR THE ALLUVIUM NC AND UC PROCESSING SITES, SLICK ROCK, COLORADO

SITE: SRKO1 SLICK ROCK (BOTH SITES)

06/30/86 TO $10 / 13 / 92$

REPORT DATE: $07 / 26 / 93$

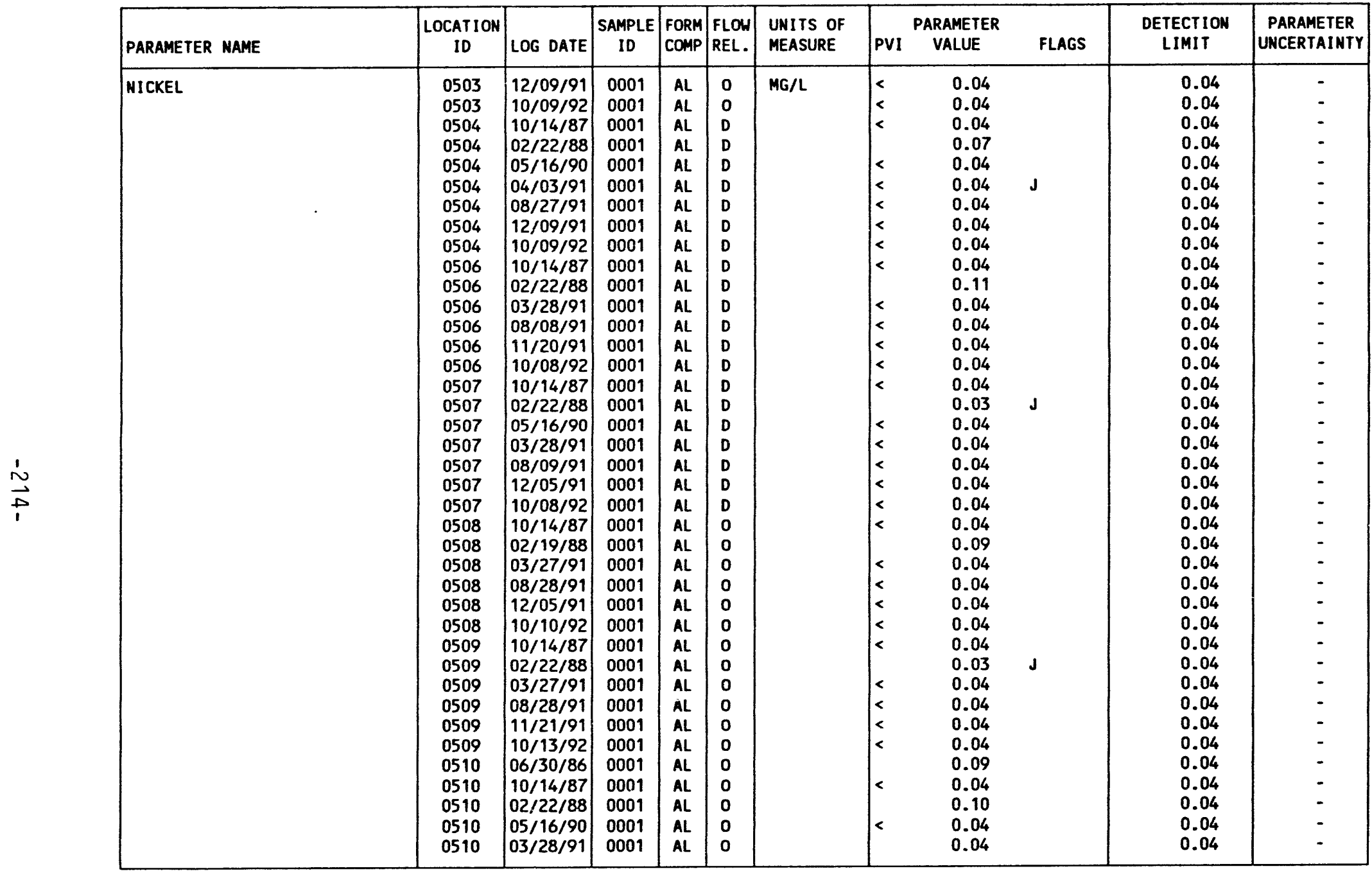

FORMATION OF COMPLETION COOE:

AL - ALLUVIUM

FLOW RELATIONSHIP COOE:

O - ON-SITE

SAMPLE ID COOES:

0001 - FILTERED SAMPLE (.45 MICRONS)

PARAMETER VALUE INDICATOR (PVI): < - LESS THAN DETECTION LIMIT

\section{OTHER PARAMETER VALUE FLAGS}

$J$ - ESTIMATED VALUE 
TABLE 3.27 BASELINE GROUNDWATER QUALITY DATA BY PARAMETER FOR THE ALLUVIUM NC AND UC PROCESSING SITES, SLICK ROCK, COLORADO

SITE: SRKO1 SLICK ROCK (BOTH SITES)

06/30/86 TO $10 / 13 / 92$

REPORT DATE: $07 / 26 / 93$

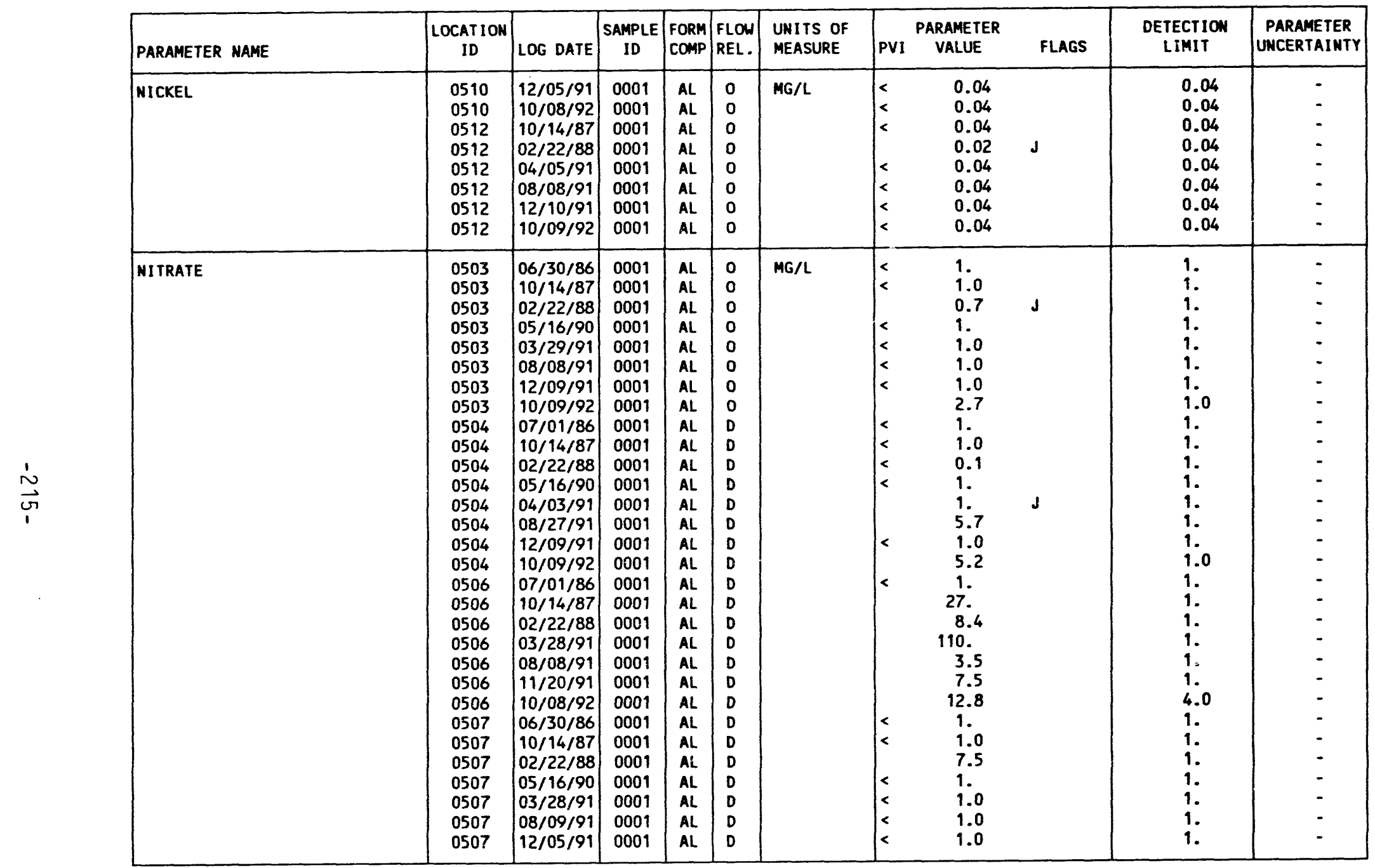

FORMATION OF COMPLETION CODE:

AL - ALLUVILM
FLOW RELATIONSHIP COOE:

O- OW-SITE

D - DOWN GRADIENT

PARAMETER VALUE INDICATOR (PVI): < - LESS THAN DETECTION LIMIT

SAMPLE ID COOES:

0001 - FILTERED SAMPLE (.45 MICRONS)

OTHER PARAMETER VALUE FLAGS:

$J$ - ESTIMATED VALUE 
TABLE 3.27 BASELINE GROUNDHATER QUALITY DATA BY PARAMETER FOR THE ALLUVIUM NC AND UC PROCESSING SITES, SLICK ROCK, COLORADO

SITE: SRKO1 SLICK ROCK (BOTH SITES)

06/30/86 TO $10 / 13 / 92$

REPORT DATE: 07/26/93

\begin{tabular}{|c|c|c|c|c|c|c|c|c|c|c|c|}
\hline PARAMETER NAME & $\begin{array}{l}\text { LOCATION } \\
\text { ID }\end{array}$ & LOG DATE & $\begin{array}{c}\text { SAMPLE } \\
\text { ID }\end{array}$ & $\begin{array}{l}\text { FORM } \\
\text { COMP }\end{array}$ & $\begin{array}{l}\text { FLOW } \\
\text { REL. }\end{array}$ & $\begin{array}{l}\text { UNITS OF } \\
\text { MEASURE }\end{array}$ & PVI & $\begin{array}{l}\text { ARAMETER } \\
\text { VALUE }\end{array}$ & FLAGS & $\begin{array}{l}\text { DETECTION } \\
\text { LIMIT }\end{array}$ & $\begin{array}{l}\text { PARAMETER } \\
\text { UMCERTAINTY }\end{array}$ \\
\hline NITRATE & $\begin{array}{l}0507 \\
0508 \\
0508 \\
0508 \\
0508 \\
0508 \\
0508 \\
0508 \\
0509 \\
0509 \\
0509 \\
0509 \\
0509 \\
0509 \\
0509 \\
0510 \\
0510 \\
0510 \\
0510 \\
0510 \\
0510 \\
0510 \\
0510 \\
0512 \\
0512 \\
0512 \\
0512 \\
0512 \\
0512 \\
0512\end{array}$ & $\begin{array}{l}10 / 08 / 92 \\
06 / 30 / 86 \\
10 / 14 / 87 \\
02 / 19 / 88 \\
03 / 27 / 91 \\
08 / 28 / 91 \\
12 / 05 / 91 \\
10 / 10 / 92 \\
07 / 17 / 86 \\
10 / 14 / 87 \\
02 / 22 / 88 \\
03 / 27 / 91 \\
08 / 28 / 91 \\
11 / 21 / 91 \\
10 / 13 / 92 \\
06 / 30 / 86 \\
10 / 14 / 87 \\
02 / 22 / 88 \\
05 / 16 / 90 \\
03 / 28 / 91 \\
08 / 28 / 91 \\
12 / 05 / 91 \\
10 / 08 / 92 \\
07 / 01 / 86 \\
10 / 14 / 87 \\
02 / 22 / 88 \\
04 / 05 / 91 \\
08 / 08 / 91 \\
12 / 10 / 91 \\
10 / 09 / 92\end{array}$ & $\begin{array}{l}0001 \\
0001 \\
0001 \\
0001 \\
0001 \\
0001 \\
0001 \\
0001 \\
0001 \\
0001 \\
0001 \\
0001 \\
0001 \\
0001 \\
0001 \\
0001 \\
0001 \\
0001 \\
0001 \\
0001 \\
0001 \\
0001 \\
0001 \\
0001 \\
0001 \\
0001 \\
0001 \\
0001 \\
0001 \\
0001\end{array}$ & $\begin{array}{l}A L \\
A L \\
A L \\
A L \\
A L \\
A L \\
A L \\
A L \\
A L \\
A L \\
A L \\
A L \\
A L \\
A L \\
A L \\
A L \\
A L \\
A L \\
A L \\
A L \\
A L \\
A L \\
A L \\
A L \\
A L \\
A L \\
A L \\
A L \\
A L \\
A L\end{array}$ & $\begin{array}{l}D \\
0 \\
0 \\
0 \\
0 \\
0 \\
0 \\
0 \\
0 \\
0 \\
0 \\
0 \\
0 \\
0 \\
0 \\
0 \\
0 \\
0 \\
0 \\
0 \\
0 \\
0 \\
0 \\
0 \\
0 \\
0 \\
0 \\
0 \\
0 \\
0\end{array}$ & $M G / L$ & 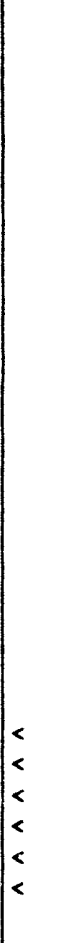 & $\begin{array}{c}6.8 \\
290 . \\
1250 . \\
1220 . \\
32.9 \\
1040 . \\
1200 . \\
1360 . \\
5 . \\
42 . \\
35 . \\
1050 . \\
28.3 \\
19.5 \\
34 . \\
1000 . \\
1620 . \\
1190 . \\
1000 . \\
943 . \\
947 . \\
837 . \\
257 . \\
1 . \\
1.0 \\
0.1 \\
1.0 \\
1.0 \\
1.0 \\
6.5\end{array}$ & & $\begin{array}{c}1.0 \\
1 . \\
1 . \\
1 . \\
1 . \\
75 . \\
125 . \\
150 . \\
1 . \\
1 . \\
1 . \\
1 . \\
5 . \\
1 . \\
5 . \\
1 . \\
1 . \\
1 . \\
1 . \\
1 . \\
75 . \\
125 . \\
10 . \\
1 . \\
1 . \\
1 . \\
1 . \\
1 . \\
1 . \\
1.0\end{array}$ & $\begin{array}{l}- \\
- \\
- \\
- \\
- \\
- \\
- \\
- \\
- \\
- \\
- \\
- \\
- \\
- \\
- \\
- \\
- \\
- \\
- \\
- \\
- \\
-\end{array}$ \\
\hline NITRITE AND NITRATE & $\begin{array}{l}0503 \\
0503 \\
0503 \\
0503 \\
0504 \\
0504 \\
0504 \\
0504\end{array}$ & $\begin{array}{l}02 / 22 / 88 \\
05 / 16 / 90 \\
03 / 29 / 91 \\
08 / 08 / 91 \\
02 / 22 / 88 \\
05 / 16 / 90 \\
04 / 03 / 91 \\
08 / 27 / 91\end{array}$ & $\begin{array}{l}0001 \\
0001 \\
0001 \\
0001 \\
0001 \\
0001 \\
0001 \\
0001\end{array}$ & $\begin{array}{l}A L \\
A L \\
A L \\
A L \\
A L \\
A L \\
A L \\
A L\end{array}$ & $\begin{array}{l}0 \\
0 \\
0 \\
0 \\
D \\
D \\
D \\
D\end{array}$ & MG/L & $<$ & $\begin{array}{l}0.4 \\
1 . \\
0.24 \\
0.13 \\
0.1 \\
1 . \\
0.35 \\
1.29\end{array}$ & J & $\begin{array}{l}1 . \\
1.05 \\
0.05 \\
0.05 \\
1 . \\
1 . \\
0.05 \\
0.05\end{array}$ & $\begin{array}{l}- \\
- \\
- \\
- \\
-\end{array}$ \\
\hline
\end{tabular}

FORMATION OF COMPLETION COOE:

AL - ALLUVIUM
FLON RELATIONSHIP COOE:

D - DOWN GRADIENT

PARAMETER VALUE INDICATOR (PVI): < - LESS THAN DETECTION LIMIT

0001 - FILTERED SAMPLE (.45 MICRONS)

OTHER PARAMETER VALUE FLAGS:

$J$ - ESTIMATED VALUE 
TABLE 3.27 BASELINE GROUNDWATER QUALITY DATA BY PARAMETER FOR THE ALLUVIUM NC AND UC PROCESSING SITES, SLICK ROCK, COLORADO

SITE: SRKO1 SLICK ROCK (BOTH SITES)

06/30/86 TO $10 / 13 / 92$

REPORT DATE: $07 / 26 / 93$

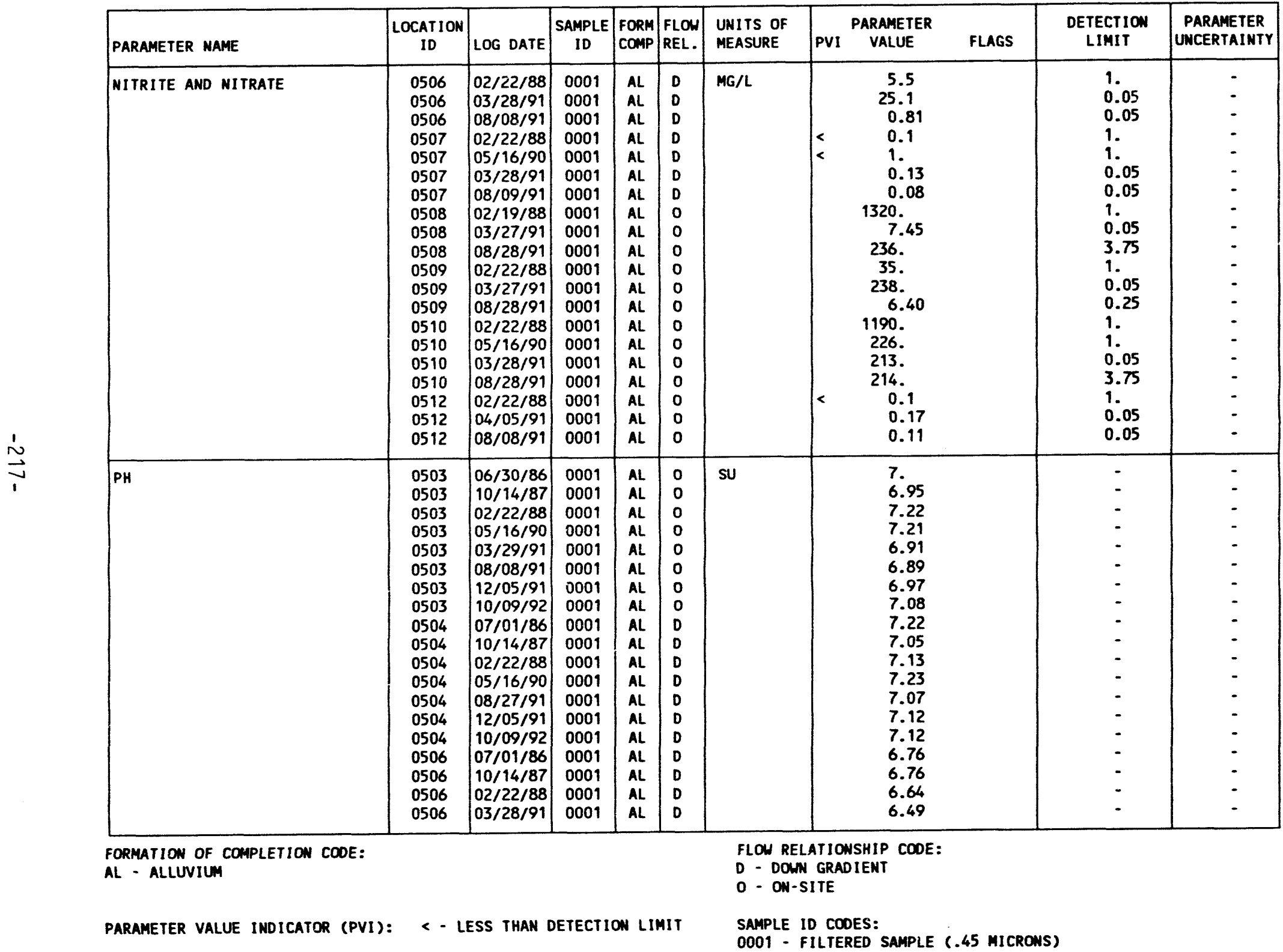


TABLE 3.27 BASELINE GROMNDWATER OUALITY DATA BY PARAMETER FOR THE ALLUVIUM MC AND UC PROCESSING SITES, SLICK ROCK, COLORADO

SITE: SRKO1 SLICK ROCK (BOTH SITES)

06/30/86 TO $10 / 13 / 92$

REPORT DATE: $07 / 26 / 93$

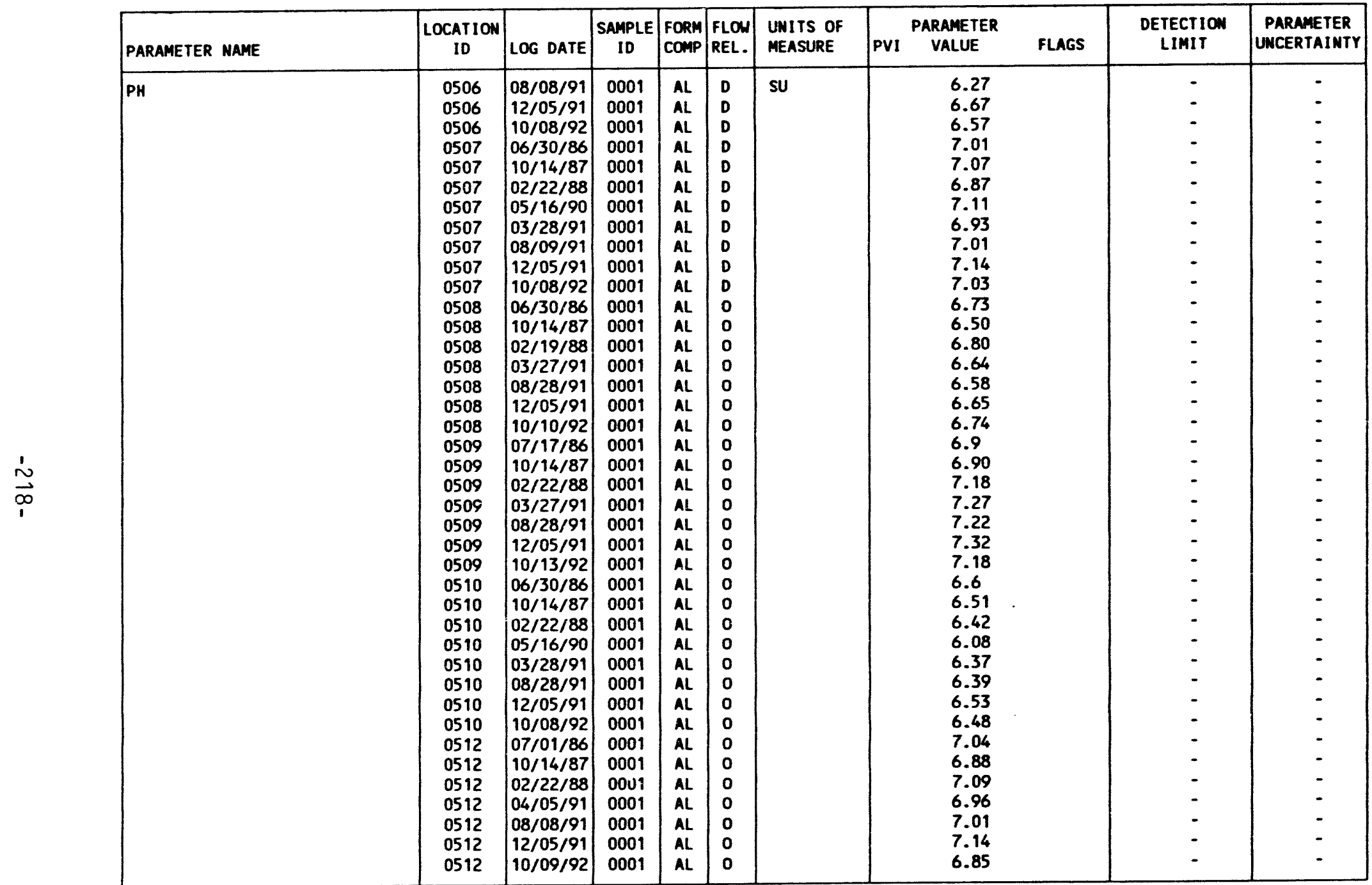

FORMATION OF COMPLETION COOE:

AL - ALLUVIUM

PARAMETEP VALUE INDICATOR (PVI): \& LESS THAN DETECTION LIMIT
FLON RELATIONSHIP CODE:

D - DOWN GRADIENT

O - ON-SITE

0001 - FILTERED SAMPLE (.45 MICRONS) 
TABLE 3.27 BASELIME GROUNDWATER QUALITY DATA BY PARAMETER FOR THE ALLUVIUM NC AND UC PROCESSING SITES, SLICK ROCK, COLORADO

SITE: SRKO1 SLICK ROCK (BOTH SITES)

06/30/86 TO $10 / 13 / 92$

REPORT DATE: 07/26/93

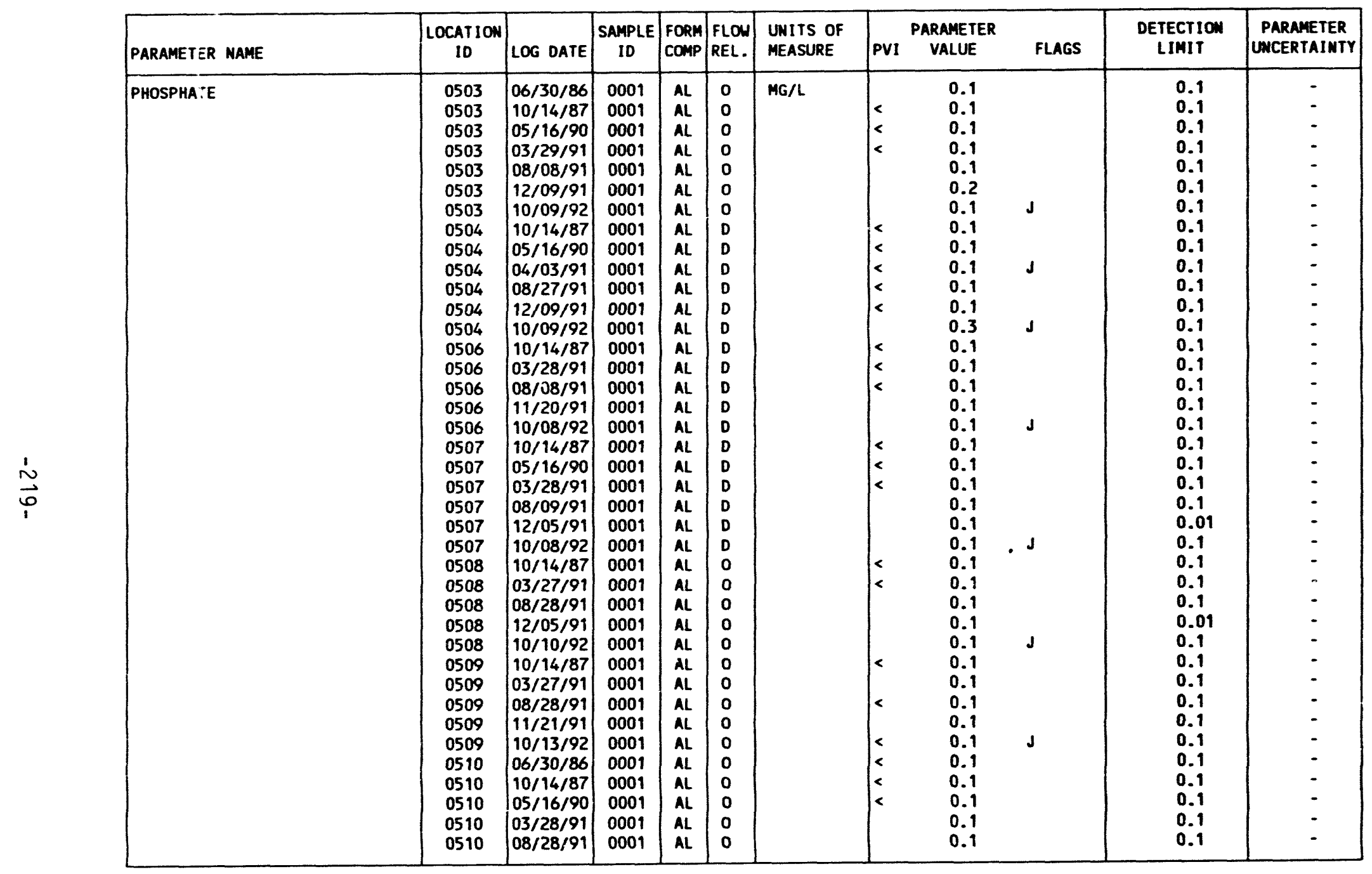

FORMATION OF COMPLETION COOE:

AL - ALLUVIUH

PARAMETER VALUE IMDICATOR (PVI): < - LESS THAN DETECTION LIMIT
FLON RELATIONSHIP CODE:

O - ON-SITE

D - DOWN GRADIENT

SAMPLE 10 COOES:

0001 - FILTERED SAMPLE (.45 MICRONS)

OTHER PARAMETER VALUE FLAGS:

J - estimated VALUE 
TABLE 3.27 BASELIME GROUNDWATER OUALITY DATA BY PARAMETER FOR THE ALLUVIUM NC AND UC PROCESSING SITES, SLICK ROCK, COLORADO

SITE: SRKC1 SLICK ROCK (BOTH SITES)

$06 / 30 / 86$ TO $10 / 13 / 92$

REPORT DATE: $07 / 26 / 93$

\begin{tabular}{|c|c|c|c|c|c|c|c|c|c|c|c|}
\hline PARAMETER NAME & $\underset{10}{\text { LOCATION }}$ & LOG DATE & $\begin{array}{c}\text { SAMPLE } \\
10\end{array}$ & $\begin{array}{l}\text { FORM } \\
\text { COMP }\end{array}$ & $\begin{array}{l}\text { FLOW } \\
\text { REL. }\end{array}$ & $\begin{array}{l}\text { UNITS OF } \\
\text { MEASURE }\end{array}$ & PVI & $\begin{array}{l}\text { PARAMETER } \\
\text { VALUE }\end{array}$ & FLAGS & $\begin{array}{l}\text { DETECTION } \\
\text { LIMIT }\end{array}$ & $\begin{array}{l}\text { PARAMETER } \\
\text { UNCERTAINTY }\end{array}$ \\
\hline PHOSPHATE & $\begin{array}{l}0510 \\
0510 \\
0512 \\
0512 \\
0512 \\
0512 \\
0512\end{array}$ & $\begin{array}{l}12 / 05 / 91 \\
10 / 08 / 92 \\
10 / 14 / 87 \\
04 / 05 / 91 \\
08 / 08 / 91 \\
12 / 10 / 91 \\
10 / 09 / 92\end{array}$ & $\begin{array}{l}0001 \\
0001 \\
0001 \\
0001 \\
0001 \\
0001 \\
0001\end{array}$ & $\begin{array}{l}A L \\
A L \\
A L \\
A L \\
A L \\
A L \\
A L\end{array}$ & $\begin{array}{l}0 \\
0 \\
0 \\
0 \\
0 \\
0 \\
0\end{array}$ & $M G / L$ & $<$ & $\begin{array}{l}0.01 \\
0.1 \\
0.1 \\
0.1 \\
0.1 \\
0.1 \\
0.1\end{array}$ & $\mathbf{J}$ & $\begin{array}{l}0.01 \\
0.1 \\
0.1 \\
0.1 \\
0.1 \\
0.1 \\
0.1\end{array}$ & $\begin{array}{l}: \\
: \\
-\end{array}$ \\
\hline POLONIUM-210 & $\begin{array}{l}0503 \\
0503 \\
0503 \\
0504 \\
0504 \\
0506 \\
0506 \\
0507 \\
0507 \\
0508 \\
0508 \\
0509 \\
0509 \\
0510 \\
0510 \\
0510 \\
0512 \\
0512\end{array}$ & $\begin{array}{l}06 / 30 / 86 \\
08 / 08 / 91 \\
12 / 05 / 91 \\
08 / 27 / 91 \\
12 / 05 / 91 \\
08 / 08 / 91 \\
12 / 05 / 91 \\
08 / 09 / 91 \\
12 / 05 / 91 \\
08 / 28 / 91 \\
12 / 05 / 91 \\
08 / 28 / 91 \\
12 / 05 / 91 \\
06 / 30 / 86 \\
08 / 28 / 91 \\
12 / 05 / 91 \\
08 / 08 / 91 \\
12 / 05 / 91\end{array}$ & $\begin{array}{l}0001 \\
0001 \\
0001 \\
0001 \\
0001 \\
0001 \\
0001 \\
0001 \\
0001 \\
0001 \\
0001 \\
0001 \\
0001 \\
0001 \\
0001 \\
0001 \\
0001 \\
0001\end{array}$ & $\begin{array}{l}A L \\
A L \\
A L \\
A L \\
A L \\
A L \\
A L \\
A L \\
A L \\
A L \\
A L \\
A L \\
A L \\
A L \\
A L \\
A L \\
A L \\
A L\end{array}$ & $\begin{array}{l}0 \\
0 \\
0 \\
0 \\
0 \\
0 \\
D \\
D \\
0 \\
0 \\
0 \\
0 \\
0 \\
0 \\
0 \\
0 \\
0 \\
0\end{array}$ & $\mathrm{PCI} / \mathrm{L}$ & & $\begin{array}{l}0.8 \\
0.1 \\
0.0 \\
0.1 \\
0.1 \\
0.1 \\
0.4 \\
0.1 \\
0.2 \\
0.1 \\
0.1 \\
0.1 \\
0.0 \\
0 . \\
0.2 \\
0.0 \\
0.3 \\
0.0\end{array}$ & & $\begin{array}{l}1 . \\
1 . \\
1 . \\
1 . \\
1 . \\
1 . \\
1 . \\
1 . \\
1 . \\
1 . \\
1 . \\
1 . \\
1 . \\
1 . \\
1 . \\
1 . \\
1 .\end{array}$ & $\begin{array}{l}0.7 \\
0.2 \\
0.4 \\
0.3 \\
0.5 \\
0.4 \\
0.9 \\
0.2 \\
0.6 \\
0.4 \\
0.5 \\
0.4 \\
0.4 \\
0.6 \\
0.5 \\
0.4 \\
0.4 \\
0.3\end{array}$ \\
\hline POTASSIUM & $\begin{array}{l}0503 \\
0503 \\
0503 \\
0503 \\
0503 \\
0503 \\
0503 \\
0503 \\
0504 \\
0504 \\
0504 \\
0504\end{array}$ & \begin{tabular}{|l|}
$06 / 30 / 86$ \\
$10 / 14 / 87$ \\
$02 / 22 / 88$ \\
$05 / 16 / 90$ \\
$03 / 29 / 91$ \\
$08 / 08 / 91$ \\
$12 / 09 / 91$ \\
$10 / 09 / 92$ \\
$07 / 01 / 86$ \\
$10 / 14 / 87$ \\
$02 / 22 / 88$ \\
$05 / 16 / 90$
\end{tabular} & $\begin{array}{l}0001 \\
0001 \\
0001 \\
0001 \\
0001 \\
0001 \\
0001 \\
0001 \\
0001 \\
0001 \\
0001 \\
0001\end{array}$ & $\begin{array}{l}A L \\
A L \\
A L \\
A L \\
A L \\
A L \\
A L \\
A L \\
A L \\
A L \\
A L \\
A L\end{array}$ & $\begin{array}{l}0 \\
0 \\
0 \\
0 \\
0 \\
0 \\
0 \\
0 \\
D \\
0 \\
0 \\
D\end{array}$ & MG/L & & $\begin{array}{l}44.7 \\
41 . \\
49.1 \\
41.7 \\
35 . \\
38 . \\
32 . \\
32 . \\
12.4 \\
12.6 \\
14.0 \\
10.6\end{array}$ & & $\begin{array}{l}0.01 \\
0.01 \\
0.01 \\
0.01 \\
5 . \\
5 . \\
5 . \\
5 . \\
0.01 \\
0.01 \\
0.01 \\
0.01\end{array}$ & $\begin{array}{l}- \\
- \\
- \\
- \\
- \\
- \\
- \\
-\end{array}$ \\
\hline
\end{tabular}

FORMATION OF COMPLETION CODE:

FLOW RELATIONSHIP CODE:

AL - ALLUVIUM

O - ON-SITE

D - DOWN GRADIENT

PARAMETER VALUE INDICATOR (PVI): < - LESS than DETECTION LIMIT

SAMPLE ID COOES:

0001 - FILTERED SAMPLE (.45 MICRONS)

OTHER PARAMETER VALUE fLAGS:

$J$ - estimated VALUE 
TABLE 3.27 BASELIME GROUMUATER OUALITY DATA BY PARAMETER FOR THE ALLUVIU: NC AND UC PROCESSING SITES, SLICK ROCK, COLORADO

SITE: SRK01 SLICK ROCK (BOTH SITES)

06/30/86 TO 10/13/92

REPORT DATE: $07 / 26 / 93$

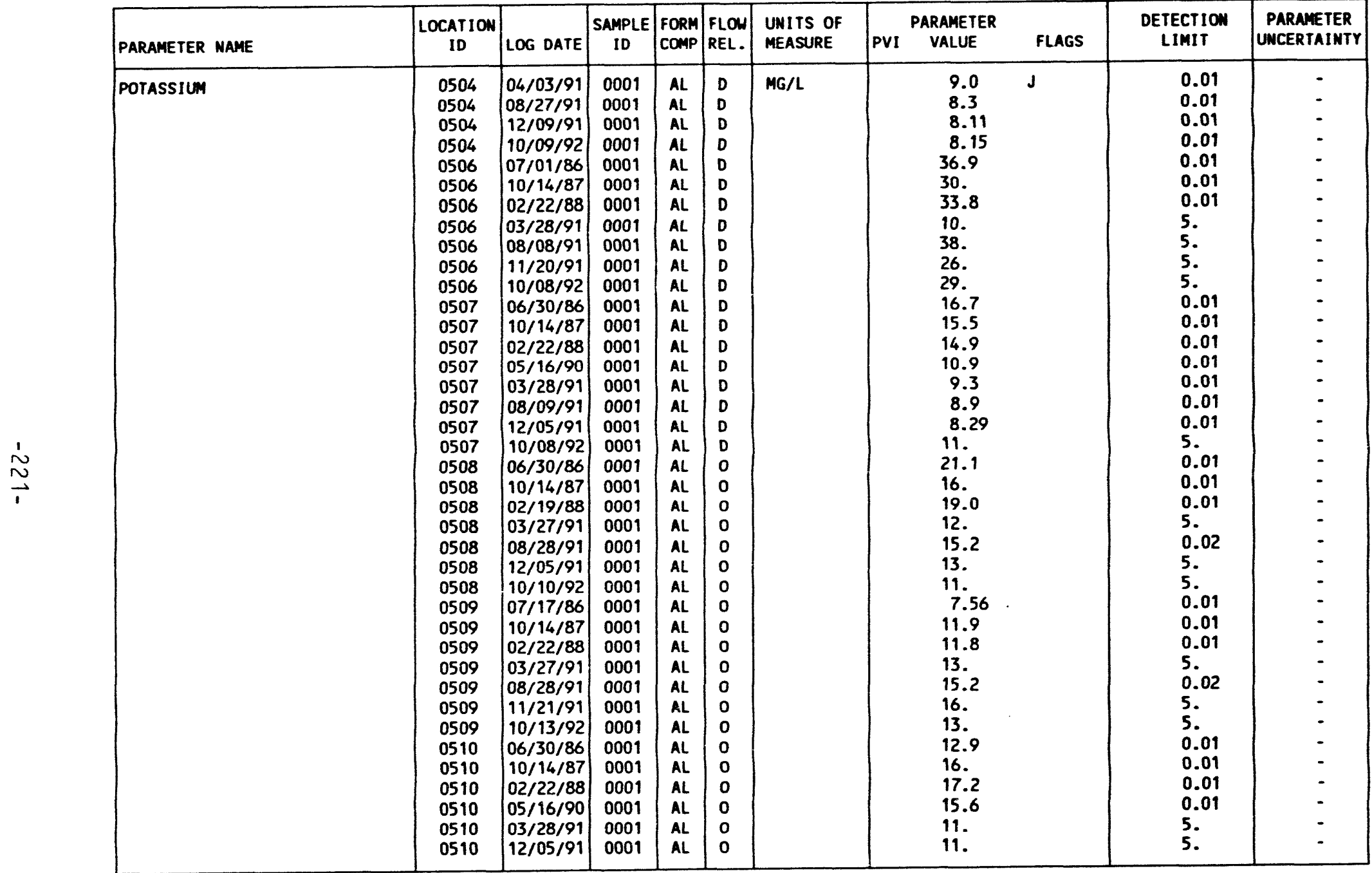

FORMATION OF COMPLETION COOE:

AL - ALLUVIUU

PARAMETER VALUE INDICATOR (PVI): < - LESS THAN DETECTION LIMIT
FLOW RELATIONSHIP CODE:

D - DOWN GRADIENT

SAMPLE ID COOES

0001 - FILTERED SAMPLE (.45 MICRONS)

OTHER PARAMETER VALUE fLAGS:

$J$ - eSTIMATED VALUE 
TABLE 3.27 BASELINE GROUNDWATER QUALITY DATA BY PARAMETER FOR THE ALLUUVIUM NC AND UC PROCESSING SITES, SLICK ROCK, COLORADO

SITE: SRKO1 SLICK ROCK (BOTH SITES)

O6/30/86 TO $10 / 13 / 92$

REPORT DATE: $07 / 26 / 93$

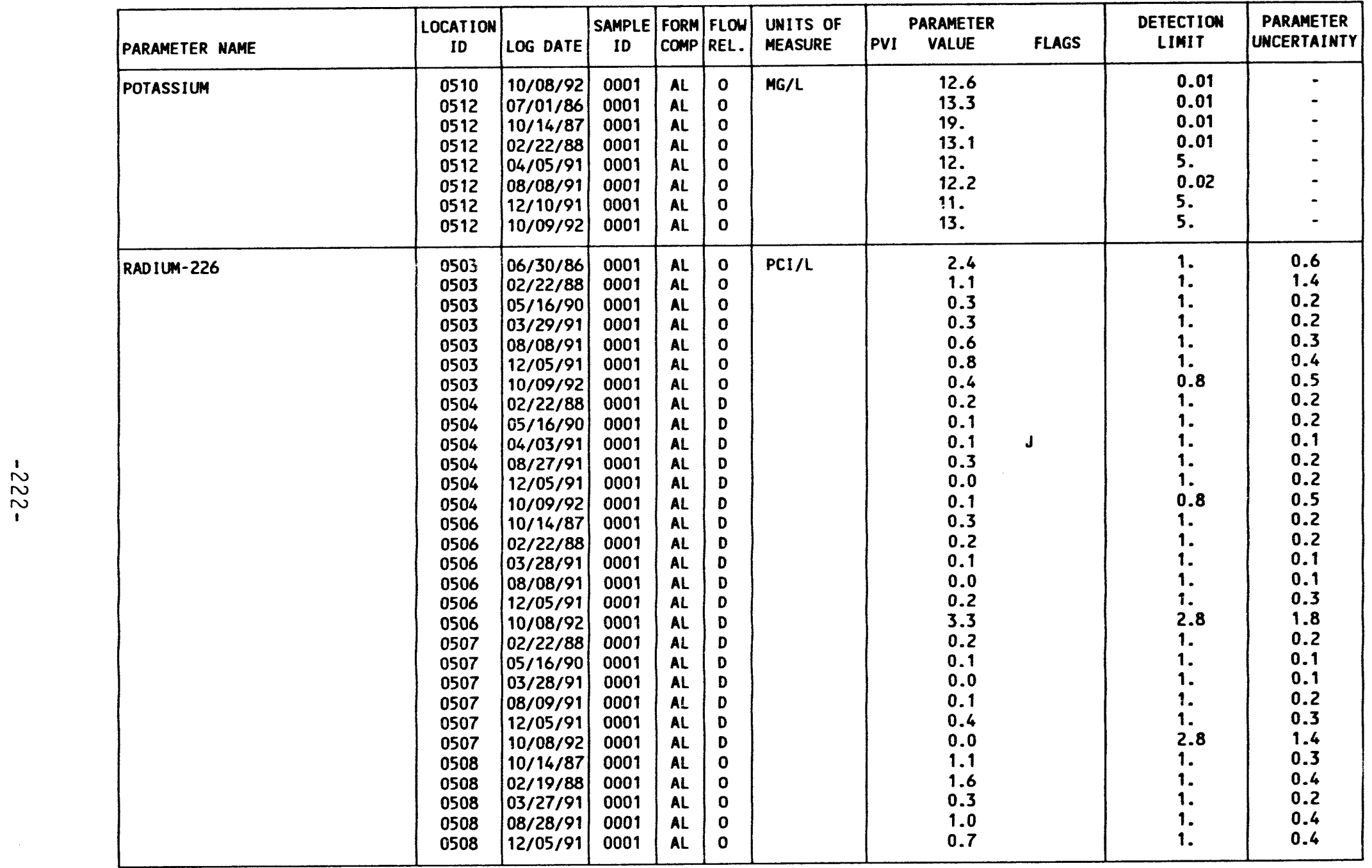

FORMATION OF COMPLETION CODE:

AL - ALLUVIUM

DARAMETER VALUE INDICATOR (PVI): < - LESS THAN DETECTION LIMIT
FLON RELATIONSHIP CODE:

O - ON-SITE

D - DOW GRADIENT

SAMPLE ID COCES:

0001 - FILTERED SAMPLE (.45 MICRONS)

OTHER PARAMETER VALUE FLAGS:

$J$ - ESTIMATED VALUE 
NC AND UC PROCESSING SITES, SLICK ROCK, COLORADO

SITE: SRKO1 SLICK ROCK (BOTH SITES)

06/33/86 TO $10 / 13 / 92$

REPORT DATE: $07 / 26 / 93$

\begin{tabular}{|c|c|c|c|c|c|c|c|c|c|c|}
\hline PARAMETER NAME & $\underset{\text { ID }}{\text { LOCATION }}$ & LOG DATE & $\begin{array}{l}\text { SAMPLE } \\
\text { ID }\end{array}$ & $\begin{array}{l}\text { FORM } \\
\text { COMP }\end{array}$ & $\begin{array}{l}\text { FLOW } \\
\text { REL. }\end{array}$ & $\begin{array}{l}\text { UNITS OF } \\
\text { MEASURE }\end{array}$ & PVI & $\begin{array}{l}\text { ARAMETER } \\
\text { VALUE }\end{array}$ & $\begin{array}{l}\text { DETECTION } \\
\text { LIMIT }\end{array}$ & $\begin{array}{l}\text { PARAMETER } \\
\text { UNCERTAINTY }\end{array}$ \\
\hline RADIUM-226 & $\begin{array}{l}0508 \\
0509 \\
0509 \\
0509 \\
0509 \\
0509 \\
0509 \\
0510 \\
0510 \\
0510 \\
0510 \\
0510 \\
0510 \\
0510 \\
0510 \\
0512 \\
0512 \\
0512 \\
0512 \\
0512\end{array}$ & $\begin{array}{l}10 / 10 / 92 \\
10 / 14 / 87 \\
02 / 22 / 88 \\
03 / 27 / 91 \\
08 / 28 / 91 \\
12 / 05 / 91 \\
10 / 13 / 92 \\
06 / 30 / 86 \\
10 / 14 / 87 \\
02 / 22 / 88 \\
05 / 16 / 90 \\
03 / 28 / 91 \\
08 / 28 / 91 \\
12 / 05 / 91 \\
10 / 08 / 92 \\
02 / 22 / 88 \\
04 / 05 / 91 \\
08 / 08 / 91 \\
12 / 05 / 91 \\
10 / 09 / 92\end{array}$ & $\begin{array}{l}0001 \\
0001 \\
0001 \\
0001 \\
0001 \\
0001 \\
0001 \\
0001 \\
0001 \\
0001 \\
0001 \\
0001 \\
0001 \\
0001 \\
0001 \\
0001 \\
0001 \\
0001 \\
0001 \\
0001\end{array}$ & $\begin{array}{l}A L \\
A L \\
A L \\
A L \\
A L \\
A L \\
A L \\
A L \\
A L \\
A L \\
A L \\
A L \\
A L \\
A L \\
A L \\
A L \\
A L \\
A L \\
A L \\
A L\end{array}$ & $\begin{array}{l}0 \\
0 \\
0 \\
0 \\
0 \\
0 \\
0 \\
0 \\
0 \\
0 \\
0 \\
0 \\
0 \\
0 \\
0 \\
0 \\
0 \\
0 \\
0 \\
0\end{array}$ & $\mathrm{PCI} / \mathrm{L}$ & & $\begin{array}{l}1.2 \\
1.5 \\
0.1 \\
1.3 \\
0.5 \\
0.2 \\
1.3 \\
1.1 \\
1.3 \\
0.5 \\
0.4 \\
0.5 \\
0.8 \\
0.3 \\
0.0 \\
0.0 \\
0.1 \\
0.1 \\
0.4 \\
0.7\end{array}$ & $\begin{array}{l}0.8 \\
1 . \\
1 . \\
1 . \\
1 . \\
1 . \\
0.8 \\
1 . \\
1 . \\
1 . \\
1 . \\
1 . \\
1 . \\
1 . \\
2.8 \\
1 . \\
1 . \\
1 . \\
1 . \\
0.8\end{array}$ & $\begin{array}{l}0.6 \\
0.4 \\
0.2 \\
0.4 \\
0.3 \\
0.2 \\
0.6 \\
0.4 \\
0.3 \\
0.2 \\
0.2 \\
0.3 \\
0.3 \\
0.3 \\
1.5 \\
0.1 \\
0.1 \\
0.2 \\
0.3 \\
0.6\end{array}$ \\
\hline RADIUM-226 + RADIUM-228 & $\begin{array}{l}0503 \\
0503 \\
0503 \\
0503 \\
0503 \\
0503 \\
0504 \\
0504 \\
0504 \\
0504 \\
0504 \\
0506 \\
0506 \\
0506 \\
0506 \\
0506 \\
0507 \\
0507 \\
0507\end{array}$ & $\begin{array}{l}06 / 30 / 86 \\
05 / 16 / 90 \\
03 / 29 / 91 \\
08 / 08 / 91 \\
12 / 05 / 91 \\
10 / 09 / 92 \\
05 / 16 / 90 \\
04 / 03 / 91 \\
08 / 27 / 91 \\
12 / 05 / 91 \\
10 / 09 / 92 \\
10 / 14 / 87 \\
03 / 28 / 91 \\
08 / 08 / 91 \\
12 / 05 / 91 \\
10 / 08 / 92 \\
05 / 16 / 90 \\
03 / 28 / 91 \\
08 / 09 / 91\end{array}$ & $\begin{array}{l}0001 \\
0001 \\
0001 \\
0001 \\
0001 \\
0001 \\
0001 \\
0001 \\
0001 \\
0001 \\
0001 \\
0001 \\
0001 \\
0001 \\
0001 \\
0001 \\
0001 \\
0001 \\
0001\end{array}$ & $\begin{array}{l}A L \\
A L \\
A L \\
A L \\
A L \\
A L \\
A L \\
A L \\
A L \\
A L \\
A L \\
A L \\
A L \\
A L \\
A L \\
A L \\
A L \\
A L \\
A L\end{array}$ & $\begin{array}{l}0 \\
0 \\
0 \\
0 \\
0 \\
0 \\
D \\
D \\
D \\
D \\
D \\
D \\
D \\
D \\
D \\
D \\
D \\
D \\
D\end{array}$ & $\mathrm{PCI} / \mathrm{L}$ & & $\begin{array}{l}3.50 \\
1.00 \\
4.10 \\
0.60 \\
1.70 \\
1.10 \\
0.60 \\
4.80 \\
0.80 \\
1.00 \\
0.80 \\
1.60 \\
0.50 \\
1.50 \\
1.60 \\
7.30 \\
1.30 \\
0.00 \\
1.80\end{array}$ & $\begin{array}{l}\overline{-} \\
- \\
- \\
- \\
- \\
- \\
- \\
- \\
- \\
- \\
- \\
- \\
- \\
- \\
- \\
- \\
-\end{array}$ & $\begin{array}{l}- \\
\overline{-} \\
- \\
- \\
- \\
- \\
- \\
- \\
- \\
- \\
- \\
- \\
- \\
- \\
- \\
- \\
- \\
-\end{array}$ \\
\hline
\end{tabular}

FORMATION OF COMPLETION COOE:

AL - Alluvium
FLOW RELATIONSHIP CODE:

D - DON GRADIEMT

PARAMETER VALUE INDICATOR (PVI): < - LESS THAN DETECTION LIMIT 
TABLE 3.27 BASELINE GROUNDWATER QUALITY DATA BY PARAMETER FOR THE ALLUVIUM NC AMD UC PROCESSING SITES, SLICK ROCK, COLORADO

SITE: SRKO1 SLICK ROCK (BOTH SITES)

$06 / 30 / 86$ TO $10 / 13 / 92$

REPORT DATE : 07/26/93

\begin{tabular}{|c|c|c|c|c|c|c|c|c|c|c|c|}
\hline PARAMETER NAME & $\underset{\text { LOCATION }}{\text { ID }}$ & LOG DATE & $\begin{array}{c}\text { SAMPLE } \\
\text { ID }\end{array}$ & $\begin{array}{l}\text { FORM } \\
\text { COMP }\end{array}$ & $\begin{array}{l}\text { FLOW } \\
\text { REL. }\end{array}$ & $\begin{array}{l}\text { UNITS OF } \\
\text { MEASURE }\end{array}$ & PVI & $\begin{array}{l}\text { PARAMETER } \\
\text { VALUE }\end{array}$ & FLAGS & $\begin{array}{l}\text { DETECTION } \\
\text { LIMIT }\end{array}$ & $\begin{array}{l}\text { PARAMETER } \\
\text { UNCERTAINTY }\end{array}$ \\
\hline RADIUM-226 + RADIUA-228 & $\begin{array}{l}0507 \\
0507 \\
0508 \\
0508 \\
0508 \\
0508 \\
0508 \\
0509 \\
0509 \\
0509 \\
0509 \\
0509 \\
0510 \\
0510 \\
0510 \\
0510 \\
0510 \\
0510 \\
0510 \\
0512 \\
0512 \\
0512 \\
0512\end{array}$ & $\begin{array}{l}12 / 05 / 91 \\
10 / 08 / 92 \\
10 / 14 / 87 \\
03 / 27 / 91 \\
08 / 28 / 91 \\
12 / 05 / 91 \\
10 / 10 / 92 \\
10 / 14 / 87 \\
03 / 27 / 91 \\
03 / 28 / 91 \\
12 / 05 / 91 \\
10 / 13 / 92 \\
06 / 30 / 86 \\
10 / 14 / 87 \\
05 / 16 / 90 \\
03 / 28 / 91 \\
08 / 28 / 91 \\
12 / 05 / 91 \\
10 / 08 / 92 \\
04 / 05 / 91 \\
08 / 08 / 91 \\
12 / 05 / 91 \\
10 / 09 / 92\end{array}$ & $\begin{array}{l}0001 \\
0001 \\
0001 \\
0001 \\
0001 \\
0001 \\
0001 \\
0001 \\
0001 \\
0001 \\
0001 \\
0001 \\
0001 \\
0001 \\
0001 \\
0001 \\
0001 \\
0001 \\
0001 \\
0001 \\
0001 \\
0001 \\
0001\end{array}$ & $\begin{array}{l}A_{-}^{\prime} \\
A L \\
A L \\
A L \\
A L \\
A L \\
A L \\
A L \\
A L \\
A L \\
A L \\
A L \\
A L \\
A L \\
A L \\
A L \\
A L \\
A L \\
A L \\
A L \\
A L \\
A L \\
A L\end{array}$ & $\begin{array}{l}0 \\
D \\
0 \\
0 \\
0 \\
0 \\
0 \\
0 \\
0 \\
0 \\
0 \\
0 \\
0 \\
0 \\
0 \\
0 \\
0 \\
0 \\
0 \\
0 \\
0 \\
0 \\
0\end{array}$ & $\mathrm{PCl} / \mathrm{L}$ & & $\begin{array}{l}0.40 \\
0.60 \\
2.10 \\
5.50 \\
1.20 \\
1.50 \\
1.20 \\
1.70 \\
8.30 \\
2.70 \\
0.30 \\
4.20 \\
1.40 \\
2.00 \\
1.50 \\
4.50 \\
2.10 \\
1.10 \\
0.00 \\
5.70 \\
0.80 \\
6.50 \\
1.70\end{array}$ & & $\begin{array}{l}- \\
: \\
- \\
- \\
- \\
- \\
- \\
- \\
- \\
- \\
- \\
- \\
- \\
- \\
- \\
- \\
-\end{array}$ & $\begin{array}{l}- \\
: \\
- \\
- \\
- \\
- \\
- \\
- \\
- \\
- \\
- \\
- \\
- \\
- \\
- \\
- \\
- \\
-\end{array}$ \\
\hline RAD I:MM-228 & $\begin{array}{l}0503 \\
0503 \\
0503 \\
0503 \\
0503 \\
0503 \\
0504 \\
0504 \\
0504 \\
0504 \\
0504 \\
0506 \\
0506 \\
0506 \\
0506\end{array}$ & $\begin{array}{l}06 / 30 / 86 \\
05 / 16 / 90 \\
03 / 29 / 91 \\
08 / 08 / 91 \\
12 / 05 / 91 \\
10 / 09 / 92 \\
05 / 16 / 90 \\
04 / 03 / 91 \\
08 / 27 / 91 \\
12 / 05 / 91 \\
10 / 09 / 92 \\
10 / 14 / 87 \\
03 / 28 / 91 \\
08 / 08 / 91 \\
12 / 05 / 91\end{array}$ & $\begin{array}{l}0001 \\
0001 \\
0001 \\
0.901 \\
0001 \\
0001 \\
0001 \\
0001 \\
0001 \\
0001 \\
0001 \\
0001 \\
0001 \\
0001 \\
0001\end{array}$ & $\begin{array}{l}A L \\
A L \\
A L \\
A L \\
A L \\
A L \\
A L \\
A L \\
A L \\
A L \\
A L \\
A L \\
A L \\
A L \\
A L\end{array}$ & $\begin{array}{l}0 \\
0 \\
0 \\
0 \\
0 \\
0 \\
D \\
D \\
D \\
D \\
D \\
D \\
D \\
D \\
D\end{array}$ & $\mathrm{PCI} / \mathrm{L}$ & & $\begin{array}{l}1.1 \\
0.7 \\
3.8 \\
0.0 \\
0.9 \\
0.7 \\
0.5 \\
4.7 \\
0.5 \\
1.0 \\
0.7 \\
1.3 \\
0.4 \\
1.5 \\
1.4\end{array}$ & $\mathbf{J}$ & $\begin{array}{l}1 . \\
1 . \\
1 . \\
1 . \\
1 . \\
2.7 \\
1 . \\
1 . \\
1 . \\
1 . \\
2.4 \\
1 . \\
1 . \\
1 .\end{array}$ & $\begin{array}{l}1.2 \\
0.7 \\
1.0 \\
1.5 \\
0.9 \\
1.7 \\
0.7 \\
1.1 \\
2.0 \\
0.9 \\
1.5 \\
1.0 \\
1.1 \\
1.9 \\
1.2\end{array}$ \\
\hline
\end{tabular}

FORMATION OF COMPLETION CODE:

AL - ALLUVIUU
FLOW RELATIONSHIP CODE:

D - DOWN GRADIENT

O - OW-SITE

PARAMETER VALUE INDICATOR (PVI): < - LESS than DETECTION LIMIT

SAMPLE ID COOES:
0001 - FILTERED SAMPLE (.45 MICRONS)

OTHER PARAMETER YALUE FLAGS:

$J$ - ESTIMATED VALUE 
TABLE 3.27 BASELINE GROUNDHATER OUALITY DATA BY PARAMETER FOR THE ALLUVIUM NC AND UC PROCESSING SITES, SLICK ROCK, COLORADO

SITE: SRKO1 SLICK ROCK (BOTH SITES)

SITE: SRKO1 SLICK ROCK

REPORT DATE: $07 / 26 / 93$

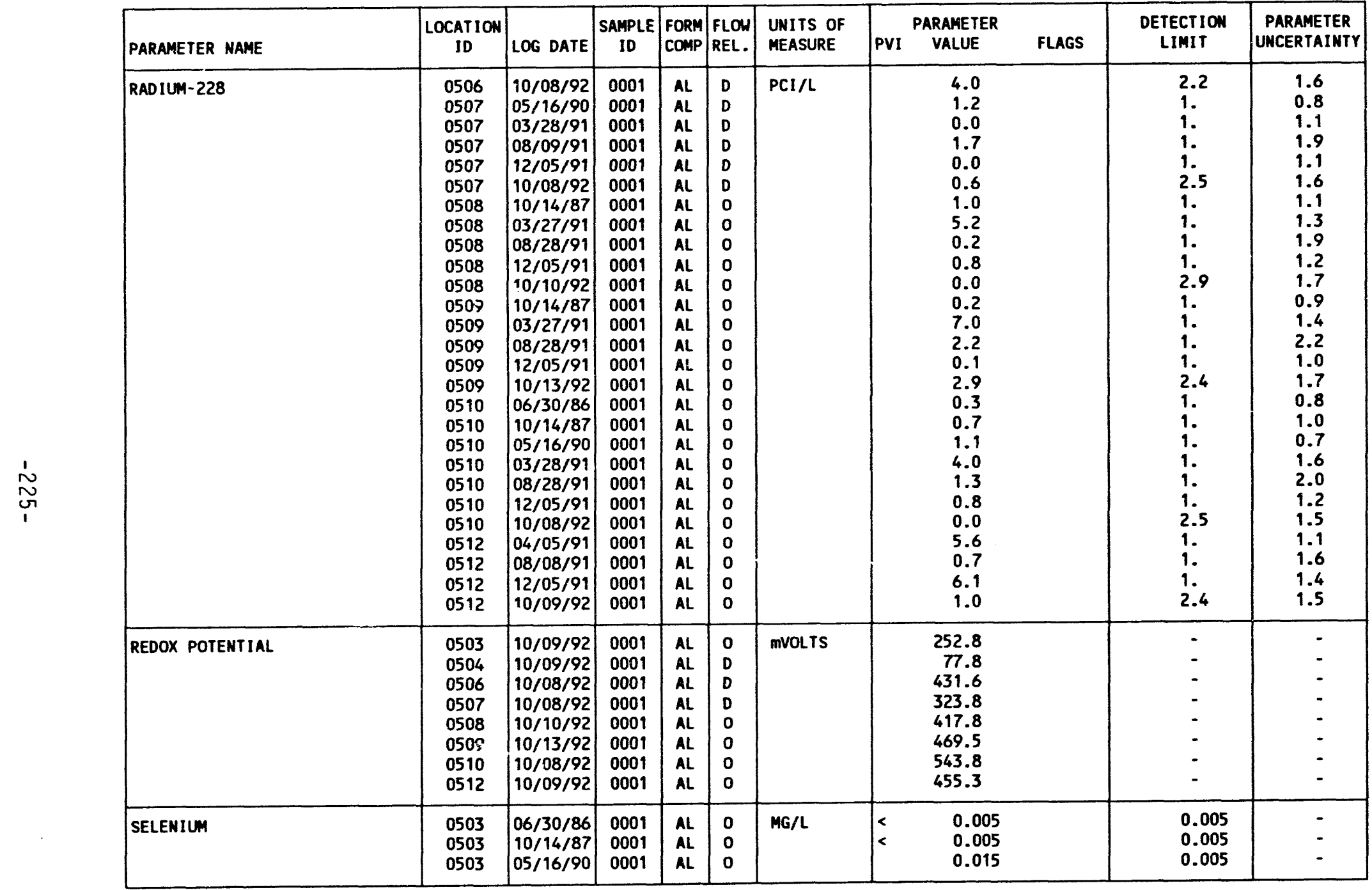

FORMATION OF COMPLETION COOE:

AL - ALLUVIUUM
FLOW RELATIONSHIP COOE:

D - DOWN GRADIENT
O - ON-SITE

PARAMETER VALUE INDICATOR (PVI): - - LESS thAN DETECTION LIMIT SAMPLE ID COOES:

0001 - FILTERED SAMPLE (.45 MICRONS) 
TABLE 3.27 BASELINE GROUNDHATER QUALITY DATA BY PARAMETER FOR THE ALLUVIUM NC AND UC PROCESSING SITES, SLICK ROCK, COLORADO

SITE: SRKO1 SLICK ROCK (BOTH SITES)

06/30/86 TO $10 / 13 / 92$

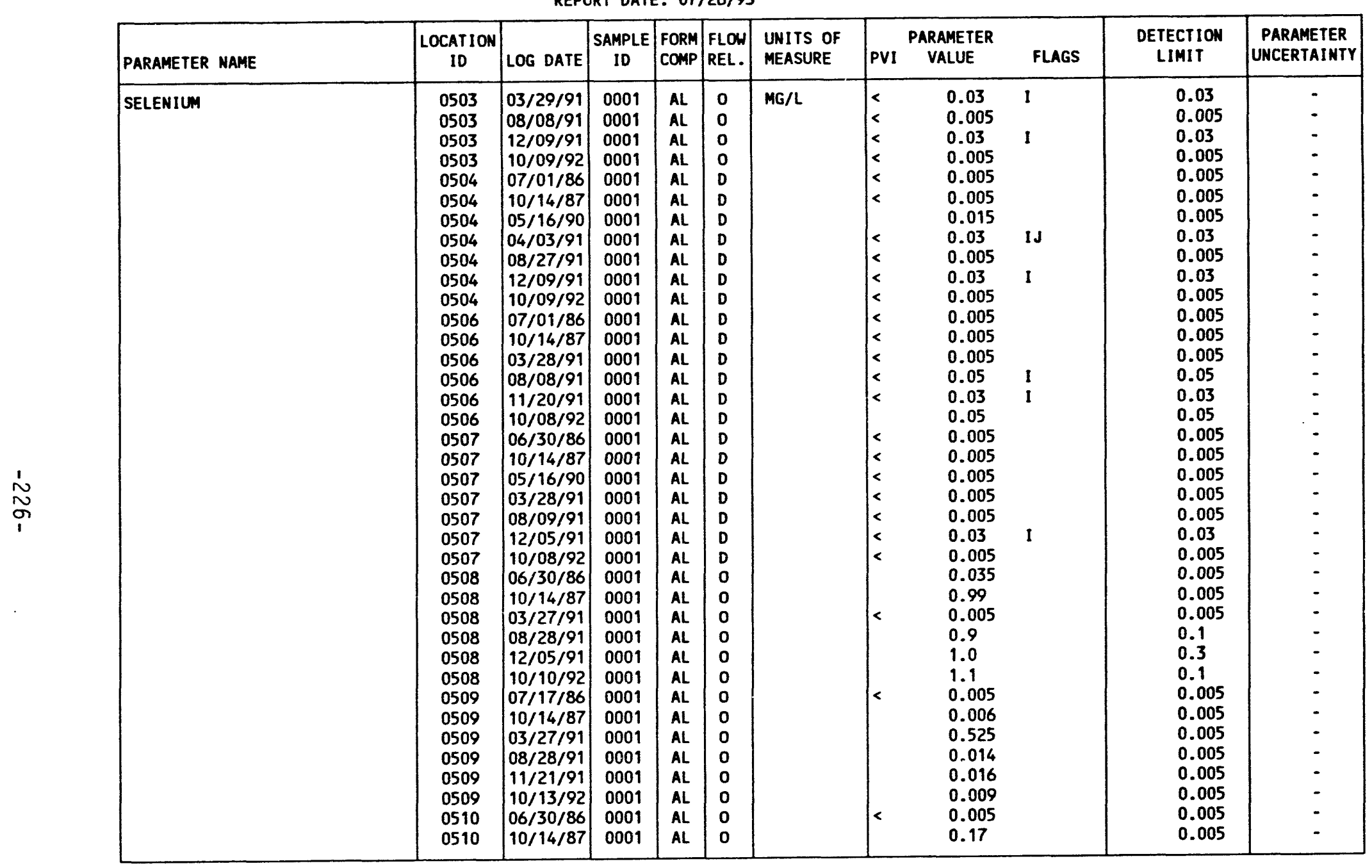

FORMATION OF COMPLETION CODE:

AL - ALLUVIUM
FLOW RELATIONSHIP CODE:

- DOWN GRADIENT

PARAMETER VALUE INDICATOR (PVI): < - LESS THAN DETECTION LIMIT

SAMPLE ID CODES:

OO01 - FILTERED SAMPLE (.45 MICRONS)

OTHER PARAMETER VALUE FLAGS:

I - INCREASED DETECTION LIMIT DUE TO REQUIRED DILUTION

$J$ - ESTIMATED VALUE 
TABLE 3.27 BASELINE GROUNDWATER QUALITY DATA BY PARAMETER FOR THE ALLUVIUM NC AND UC PROCESSING SITES, SLICK ROCK, COLORADO

SITE: SRKO1 SLICK ROCK (BOTH SITES)

$06 / 30 / 86$ TO $10 / 13 / 92$

REPORT DATE : 07/26/93

\begin{tabular}{|c|c|c|c|c|c|c|c|c|c|c|c|c|}
\hline & PARAMETER NAME & $\begin{array}{c}\text { LOCATION } \\
\text { ID }\end{array}$ & LOG DATE & $\begin{array}{c}\text { SAMPLE } \\
\text { ID }\end{array}$ & $\begin{array}{l}\text { FORM } \\
\text { COMP }\end{array}$ & $\begin{array}{l}\text { FLOW } \\
\text { REL. }\end{array}$ & $\begin{array}{l}\text { UNITS OF } \\
\text { MEASURE }\end{array}$ & PVI & $\begin{array}{l}\text { PARAMETER } \\
\text { VALUE }\end{array}$ & FLAGS & $\begin{array}{l}\text { DETECTION } \\
\text { LIMIT }\end{array}$ & $\begin{array}{l}\text { PARAMETER } \\
\text { UNCERTAINTY }\end{array}$ \\
\hline & SELENIUM & $\begin{array}{l}0510 \\
0510 \\
0510 \\
0510 \\
0512 \\
0512 \\
0512 \\
0512 \\
0512 \\
0512\end{array}$ & $\begin{array}{l}05 / 16 / 90 \\
03 / 28 / 91 \\
12 / 05 / 91 \\
10 / 08 / 92 \\
07 / 01 / 86 \\
10 / 14 / 87 \\
04 / 05 / 91 \\
08 / 08 / 91 \\
12 / 10 / 91 \\
10 / 09 / 92\end{array}$ & $\begin{array}{l}0001 \\
0001 \\
0001 \\
0001 \\
0001 \\
0001 \\
0001 \\
0001 \\
0001 \\
0001\end{array}$ & $\begin{array}{l}A L \\
A L \\
A L \\
A L \\
A L \\
A L \\
A L \\
A L \\
A L \\
A L\end{array}$ & $\begin{array}{l}0 \\
0 \\
0 \\
0 \\
0 \\
0 \\
0 \\
0 \\
0 \\
0\end{array}$ & $M G / L$ & $\begin{array}{l}< \\
< \\
< \\
< \\
< \\
<\end{array}$ & $\begin{array}{l}0.016 \\
0.065 \\
0.10 \\
0.2 \\
0.005 \\
0.005 \\
0.03 \\
0.005 \\
0.005 \\
0.005\end{array}$ & 1 & $\begin{array}{l}0.005 \\
0.005 \\
0.05 \\
0.2 \\
0.005 \\
0.005 \\
0.03 \\
0.005 \\
0.005 \\
0.005\end{array}$ & $\begin{array}{l}- \\
- \\
- \\
- \\
- \\
- \\
-\end{array}$ \\
\hline & SILICA - SIO2 & $\begin{array}{l}0503 \\
0503 \\
0503 \\
0503 \\
0503 \\
0503 \\
0503 \\
0503 \\
0504 \\
0504 \\
0504 \\
0504 \\
0504 \\
0504 \\
0504 \\
0506 \\
0506 \\
0506 \\
0506 \\
0506 \\
0506 \\
0507 \\
0507 \\
0507 \\
0507 \\
0507 \\
0507\end{array}$ & $\begin{array}{l}06 / 30 / 86 \\
10 / 14 / 87 \\
02 / 22 / 88 \\
05 / 16 / 90 \\
03 / 29 / 91 \\
08 / 08 / 91 \\
12 / 09 / 91 \\
10 / 09 / 92 \\
10 / 14 / 87 \\
02 / 22 / 88 \\
05 / 16 / 90 \\
04 / 03 / 91 \\
08 / 27 / 91 \\
12 / 09 / 91 \\
10 / 09 / 92 \\
10 / 14 / 87 \\
02 / 22 / 88 \\
03 / 28 / 91 \\
08 / 08 / 91 \\
11 / 20 / 91 \\
10 / 08 / 92 \\
10 / 14 / 87 \\
02 / 22 / 88 \\
05 / 16 / 90 \\
03 / 28 / 91 \\
08 / 09 / 91 \\
12 / 05 / 91\end{array}$ & $\begin{array}{l}0001 \\
0001 \\
0001 \\
0001 \\
0001 \\
0001 \\
0001 \\
0001 \\
0001 \\
0001 \\
0001 \\
0001 \\
0001 \\
0001 \\
0001 \\
0001 \\
0001 \\
0001 \\
0001 \\
0001 \\
0001 \\
0001 \\
0001 \\
0001 \\
0001 \\
0001 \\
0001\end{array}$ & $\begin{array}{l}A L \\
A L \\
A L \\
A L \\
A L \\
A L \\
A L \\
A L \\
A L \\
A L \\
A L \\
A L \\
A L \\
A L \\
A L \\
A L \\
A L \\
A L \\
A L \\
A L \\
A L \\
A L \\
A L \\
A L \\
A L \\
A L \\
A L\end{array}$ & $\begin{array}{l}0 \\
0 \\
0 \\
0 \\
0 \\
0 \\
0 \\
0 \\
D \\
D \\
D \\
D \\
D \\
D \\
D \\
D \\
D \\
D \\
D \\
D \\
D \\
D \\
D \\
D \\
D \\
D \\
D\end{array}$ & $M G / L$ & & $\begin{array}{c}7 . \\
13.9 \\
13.4 \\
15 . \\
12.2 \\
14.2 \\
14.1 \\
14.6 \\
12.4 \\
13.9 \\
12 . \\
10.2 \\
12.3 \\
12.1 \\
11.9 \\
11.6 \\
13.3 \\
10.3 \\
12.5 \\
11.8 \\
12.5 \\
9.8 \\
9.9 \\
10 . \\
9.3 \\
10.2 \\
9.6\end{array}$ & $\mathbf{J}$ & $\begin{array}{l}2 . \\
2 . \\
2 . \\
2 . \\
0.1 \\
0.1 \\
0.1 \\
0.1 \\
2 . \\
2 . \\
2.1 \\
0.1 \\
0.1 \\
0.1 \\
0.1 \\
2 . \\
2 . \\
0.1 \\
0.1 \\
0.1 \\
0.1 \\
2 . \\
2 . \\
2 . \\
0.1 \\
0.1 \\
0.1\end{array}$ & $\begin{array}{l}- \\
: \\
- \\
: \\
- \\
- \\
- \\
- \\
- \\
- \\
- \\
- \\
- \\
- \\
- \\
- \\
- \\
- \\
-\end{array}$ \\
\hline
\end{tabular}

FORMATION OF COMPLETION CODE:

AL - ALLUVIUM

PARAMETER VALUE INDICATOR (PVI): < - LESS THAN DETECTION LIMIT
FLON RELATIONSHIP COOE:

O- ON-SITE

D - DOWN GRADIENT

0001 - FILTERED SAMPLE (.45 MICRONS)

OTHER PARAMETER VALUE FLAGS:

1 - INCREASED DETECTION LIMIT DUE TO REQUIRED DILUTION

1 - INCREASED DETECTION
$\mathrm{J}$ - ESTIMATED VALUE 
TABLE 3.27 BASELINE GROUNDWATER QUALITY DATA BY PARAMETER FOR THE ALLUVIUM NC AND UC PROCESSING SITES, SLICK ROCK, COLORADO

SITE: SRKO1 SLICK ROCK (BOTH SITES)

06/30/86 TO $10 / 13 / 92$

REPORT DATE: $07 / 26 / 93$

\begin{tabular}{|c|c|c|c|c|c|c|c|c|c|c|c|}
\hline PARAMETER NAME & $\underset{\text { LOCATION }}{\text { ID }}$ & LOG DATE & $\begin{array}{c}\text { SAMPLE } \\
\text { ID }\end{array}$ & $\begin{array}{l}\text { FORM } \\
\text { COMP }\end{array}$ & $\begin{array}{l}\text { FLOW } \\
\text { REL. }\end{array}$ & $\begin{array}{l}\text { UNITS OF } \\
\text { MEASURE }\end{array}$ & PVI & $\begin{array}{l}\text { PARAMETER } \\
\text { VALUE }\end{array}$ & FLAGS & $\begin{array}{l}\text { DETECTION } \\
\text { LIMIT }\end{array}$ & $\begin{array}{l}\text { PARAMETER } \\
\text { UNCERTAINTY }\end{array}$ \\
\hline SILICA - SIO2 & $\begin{array}{l}0507 \\
0508 \\
0508 \\
0508 \\
0508 \\
0508 \\
0508 \\
0509 \\
0509 \\
0509 \\
0509 \\
0509 \\
0509 \\
0510 \\
0510 \\
0510 \\
0510 \\
0510 \\
0510 \\
0510 \\
0510 \\
0512 \\
0512 \\
0512 \\
0512 \\
0512 \\
0512\end{array}$ & $\begin{array}{l}10 / 08 / 92 \\
10 / 14 / 87 \\
02 / 19 / 88 \\
03 / 27 / 91 \\
08 / 28 / 91 \\
12 / 05 / 91 \\
10 / 10 / 92 \\
10 / 14 / 87 \\
02 / 22 / 88 \\
03 / 27 / 91 \\
08 / 28 / 91 \\
11 / 21 / 91 \\
10 / 13 / 92 \\
06 / 30 / 86 \\
10 / 14 / 87 \\
02 / 22 / 88 \\
05 / 16 / 90 \\
03 / 28 / 91 \\
08 / 28 / 91 \\
12 / 05 / 91 \\
10 / 08 / 92 \\
10 / 14 / 87 \\
02 / 22 / 88 \\
04 / 05 / 91 \\
08 / 08 / 91 \\
12 / 10 / 91 \\
10 / 09 / 92\end{array}$ & $\begin{array}{l}0001 \\
0001 \\
0001 \\
0001 \\
0001 \\
0001 \\
0001 \\
0001 \\
0001 \\
0001 \\
0001 \\
0001 \\
0001 \\
0001 \\
0001 \\
0001 \\
0001 \\
0001 \\
0001 \\
0001 \\
0001 \\
0001 \\
0001 \\
0001 \\
0001 \\
0001 \\
0001\end{array}$ & $\begin{array}{l}A L \\
A L \\
A L \\
A L \\
A L \\
A L \\
A L \\
A L \\
A L \\
A L \\
A L \\
A L \\
A L \\
A L \\
A L \\
A L \\
A L \\
A L \\
A L \\
A L \\
A L \\
A L \\
A L \\
A L \\
A L \\
A L \\
A L\end{array}$ & $\begin{array}{l}D \\
0 \\
0 \\
0 \\
0 \\
0 \\
0 \\
0 \\
0 \\
0 \\
0 \\
0 \\
0 \\
0 \\
0 \\
0 \\
0 \\
0 \\
0 \\
0 \\
0 \\
0 \\
0 \\
0 \\
0 \\
0 \\
0\end{array}$ & $M G / L$ & & $\begin{array}{c}10.9 \\
22 . \\
19.7 \\
7.9 \\
20.7 \\
19.7 \\
21.1 \\
8.8 \\
7.7 \\
19.1 \\
9.0 \\
8.9 \\
9.5 \\
7 . \\
15.6 \\
16.9 \\
16 . \\
14.4 \\
15.6 \\
13.9 \\
16.3 \\
8.6 \\
8.7 \\
7.3 \\
9.1 \\
8.9 \\
9.9\end{array}$ & & $\begin{array}{l}0.1 \\
2 . \\
2 . \\
0.1 \\
0.1 \\
0.1 \\
0.1 \\
2 . \\
2 . \\
0.1 \\
0.1 \\
0.1 \\
0.1 \\
2 . \\
2 . \\
2 . \\
2 . \\
0.1 \\
0.1 \\
0.1 \\
0.1 \\
2 . \\
2 . \\
0.1 \\
0.1 \\
0.1 \\
0.1\end{array}$ & $\begin{array}{l}- \\
- \\
- \\
- \\
- \\
- \\
- \\
- \\
- \\
- \\
- \\
- \\
- \\
- \\
- \\
- \\
- \\
- \\
- \\
- \\
-\end{array}$ \\
\hline SILVER & $\begin{array}{l}0503 \\
0503 \\
0503 \\
0503 \\
0503 \\
0503 \\
0504 \\
0504 \\
0504 \\
0504 \\
0504\end{array}$ & \begin{tabular}{|l|}
$06 / 30 / 86$ \\
$10 / 14 / 87$ \\
$05 / 16 / 90$ \\
$03 / 29 / 91$ \\
$08 / 08 / 91$ \\
$12 / 09 / 91$ \\
$10 / 14 / 87$ \\
$05 / 16 / 90$ \\
$04 / 03 / 91$ \\
$08 / 27 / 91$ \\
$12 / 09 / 91$
\end{tabular} & $\begin{array}{l}0001 \\
0001 \\
0001 \\
0001 \\
0001 \\
0001 \\
0001 \\
0001 \\
0001 \\
0001 \\
0001\end{array}$ & $\begin{array}{l}A L \\
A L \\
A L \\
A L \\
A L \\
A L \\
A L \\
A L \\
A L \\
A L \\
A L\end{array}$ & $\begin{array}{l}0 \\
0 \\
0 \\
0 \\
0 \\
0 \\
D \\
D \\
D \\
D \\
D\end{array}$ & $M G / L$ & $\begin{array}{l}< \\
< \\
< \\
< \\
< \\
< \\
< \\
< \\
< \\
< \\
<\end{array}$ & $\begin{array}{l}0.01 \\
0.01 \\
0.01 \\
0.01 \\
0.01 \\
0.01 \\
0.01 \\
0.01 \\
0.01 \\
0.01 \\
0.01\end{array}$ & J & $\begin{array}{l}0.01 \\
0.01 \\
0.01 \\
0.01 \\
0.01 \\
0.01 \\
0.01 \\
0.01 \\
0.01 \\
0.01 \\
0.01\end{array}$ & $\begin{array}{l}- \\
- \\
- \\
- \\
- \\
- \\
-\end{array}$ \\
\hline
\end{tabular}

FORMATION OF COMPLETION CODE:

AL - ALLUVIUM

FLOW RELATIONSHIP COOE:

D - DOWN GRADIENT

O - ON-SITE

PARAMETER VALUE INDICATOR (PVI): < - LESS THAN DETECTION LIMIT

SAMPLE ID CODES:

0001 - FILTERED SAMPLE ( .45 MICRONS) 
TABLE 3.27 BASELINE GROUNDWATER QUALITY DATA BY PARAMETER FOR THE ALLUVIUM NC AND UC PROCESSING SITES, SLICK ROCK, COLORADO

SITE: SRK01 SLICK ROCK (BOTH SITES)

06/30/86 TO $10 / 13 / 92$

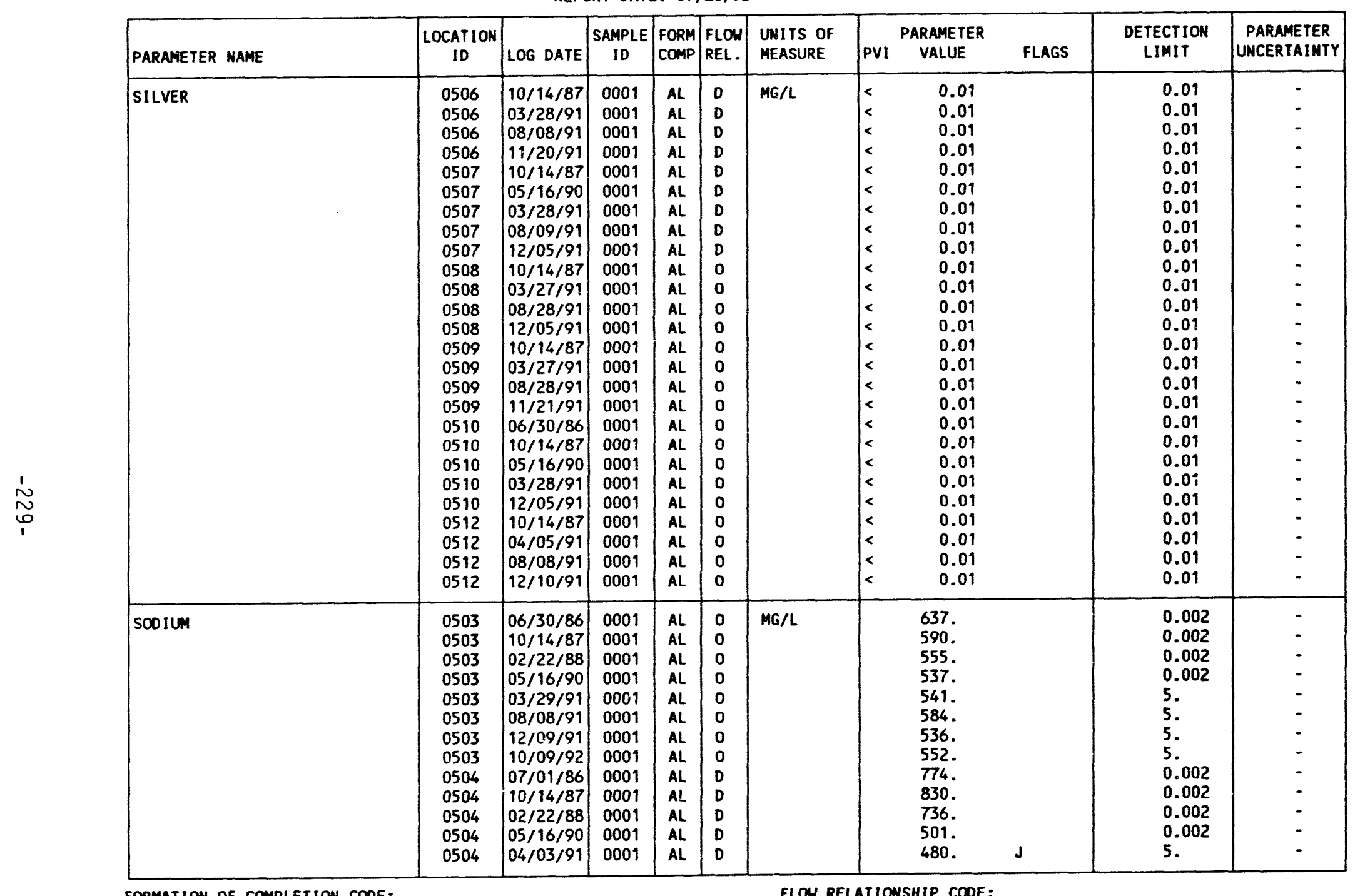

FORMATION OF COMPLETION COOE:

AL - ALLUVIUM
FLON RELATIONSHIP COOE:

D- DOWN GRADIENT

PARAMETER VALUE INDICATOR (PVI): < - LESS THAN DETECTION LIMIT SAMPLE ID COOES: 0001 - FILTERED SAMPLE (.45 MICRONS) 
TABLE 3.27 BASELINE GROUNDWATER QUALITY DATA BY PARAMETER FOR THE ALLUVIUM TC AND UC PROCESSING SITES, SLICK ROCK, COLORADO

SITE: SRKO1 SLICK ROCK (BOTH SITES)

$06 / 30 / 86$ TO $10 / 13 / 92$

REPORT DATE: $07 / 26 / 93$

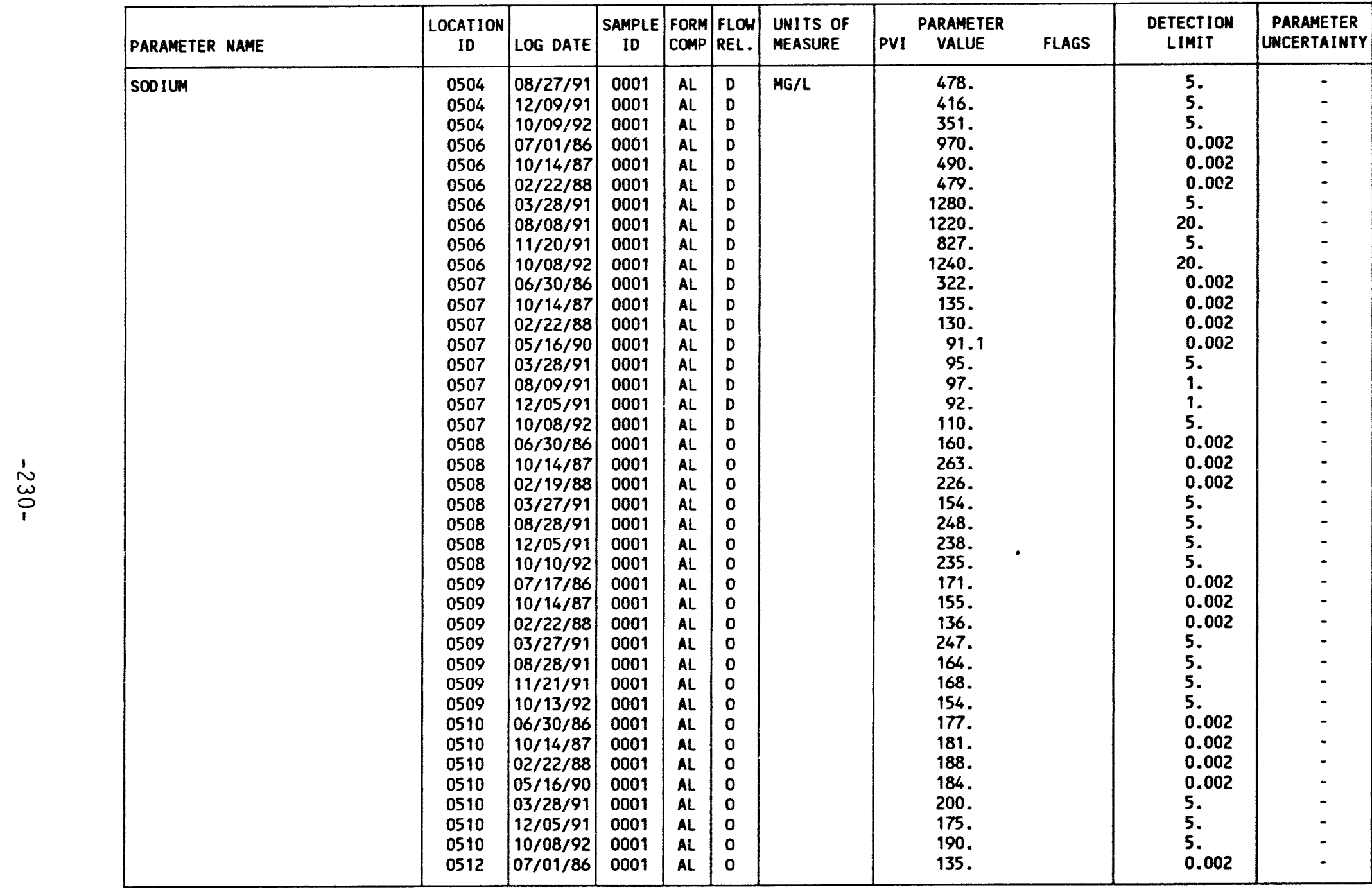

FORMATION OF COMPLETION COOE:

FLOW RELATIONSHIP COOE:

AL - ALLUVIUM

PARAMETER VALUE INDICATOR (PVI): < - LESS THAN DETECTION LIMIT

SAMPLE ID CODES:

0001 - FILTERED SAMPLE (.45 MICRONS) 
TABLE 3.27 BASELINE GROUNDWATER OUALITY DATA BY PARAMETER FOR THE ALLUVIUA

NC AND UC PROCESSING SITES, SLICK ROCK, COLORADO

SITE: SRKO1 SLICK ROCK (BOTH SITES)

$06 / 30 / 86$ TO $10 / 13 / 92$

REPORT DATE: $07 / 26 / 93$

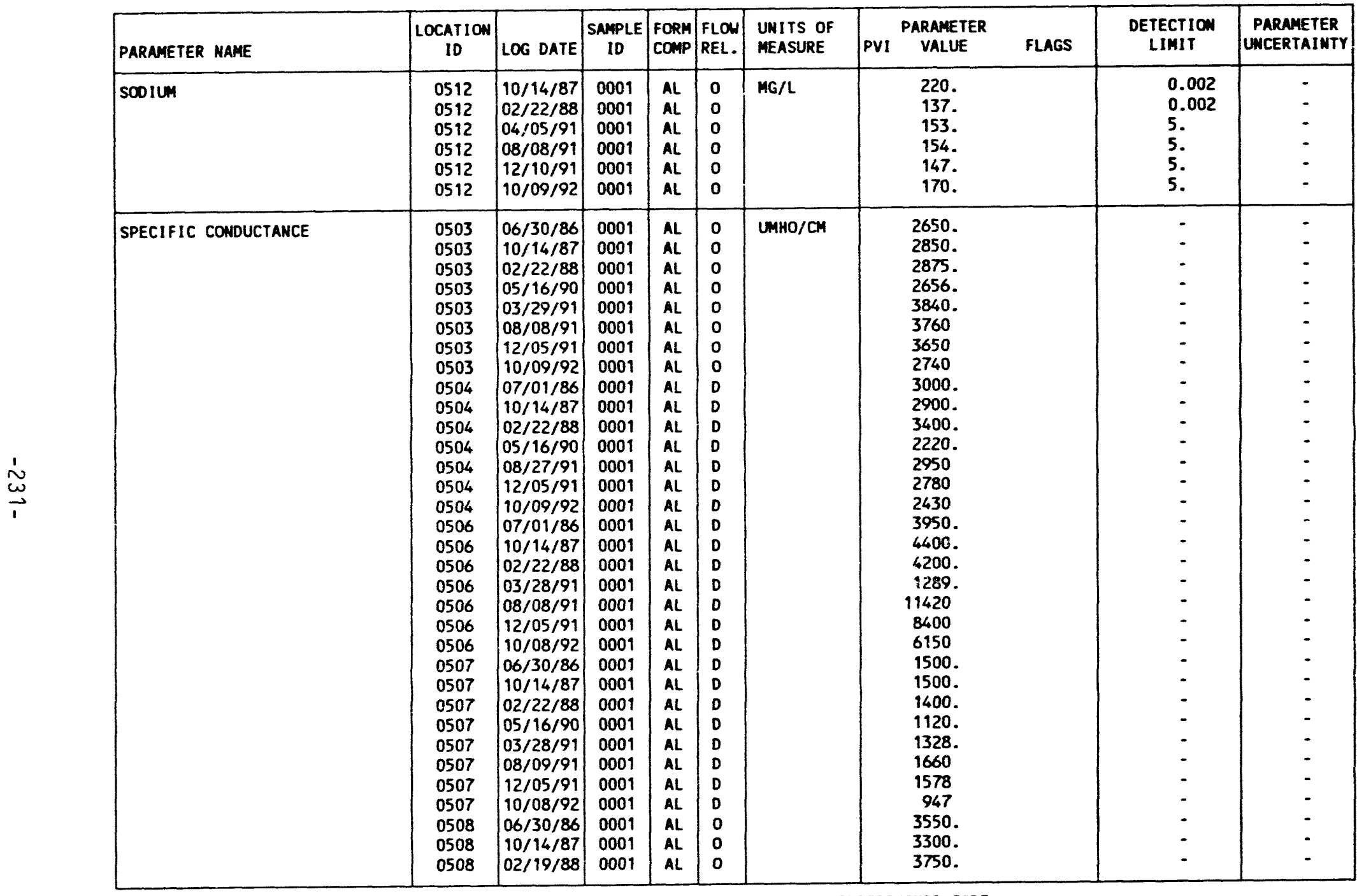

FORMATION OF COMPLETION COOE:

AL - ALLUVIUM
FLOW RELATIONSHIP CODE:

PARAMETER VALUE INDICATOR (PVI): < - LESS THAN DETECTION LIMIT 
TABLE 3.27 BASELINE GROUNDWATER QUALITY DATA BY PARAMETER FOR THE ALLUVIUM

NC AND UC PROCESSING SITES, SLICK ROCK, COLORADO

SITE: SRKO1 SLICK ROCK (BOTH SITES)

06/30/86 TO $10 / 13 / 92$

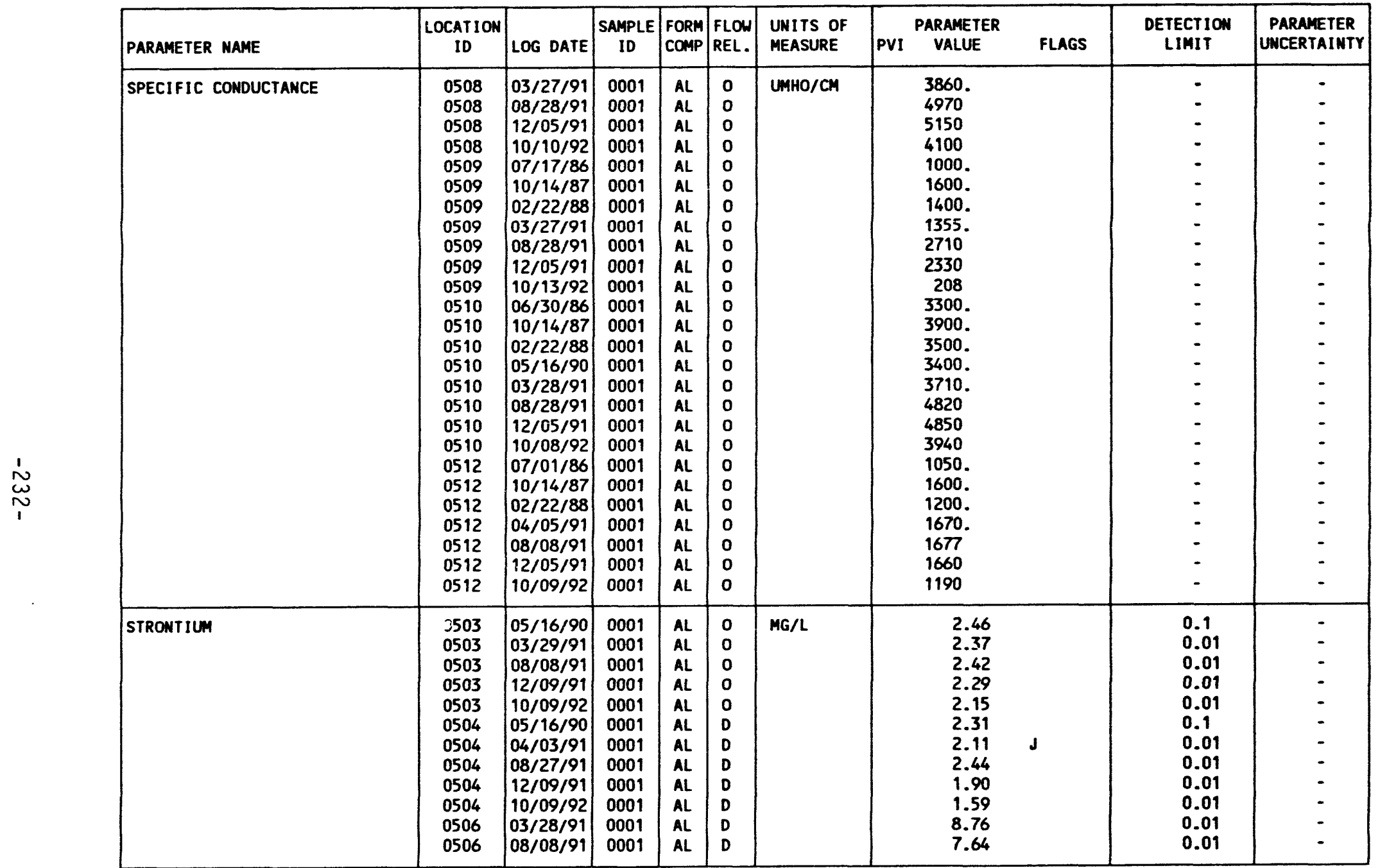

FORMATION OF COMPLETION CODE:

AL - ALLUVIUM

FLON RELATIONSHIP CODE:

o - ON-SITE

D - DOWN GRADIENT

PARAMETER VALUE INDICATOR (PVI): < - LESS THAN DETECTION LIMIT

0001 - FILTERED SAMPLE (.45 MICRONS)

OTHER PARAMETER VALUE FLAGS:

$J$ - ESTIMATED VALUE 
TABLE 3.27 BASELINE GROUMDUATER QUALITY DATA BY PARAMETER FOR THE ALLUVIUM NC AND UC PROCESSING SITES, SLICK ROCK, COLORADO

SITE: SRK01 SLICK ROCK (BOTH SITES)

06/30/86 TO $10 / 13 / 92$

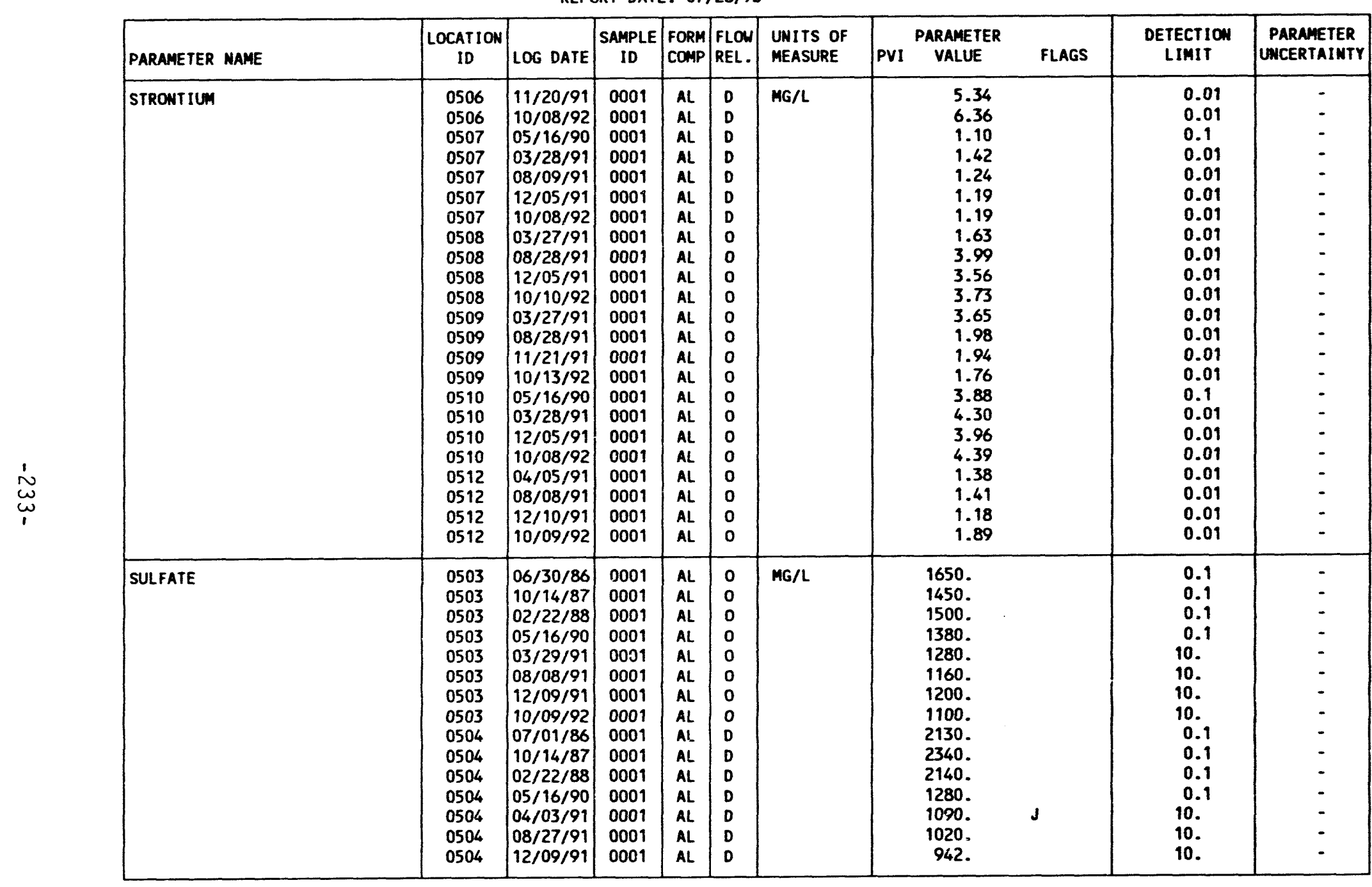

FORMATION OF COMPLETION COOE:

AL - ALLUVIUN

PARAMETER VALUE INDICATOR (PVI):
FLOW RELATIONSHIP COOE:

D - DOWN GRADIENT

O - ON-SITE

SAMPLE ID COOES:

0001 - FILTERED SAMPLE (.45 MICRONS)

OTHER PARAMETER VALUE fLAGS:

J - ESTIMATED VALUE 
TABLE 3.27 BASELINE GROUNDWATER OUALITY DATA BY PARAMETER FOR THE ALLUVIUA

NC AND UC PROCESSING SITES, SLICK ROCK, COLORADO

SITE: SRKO1 SLICK ROCK (BOTH SITES)

06/30/86 TO $10 / 13 / 92$

REPORT DATE: 07/26/93

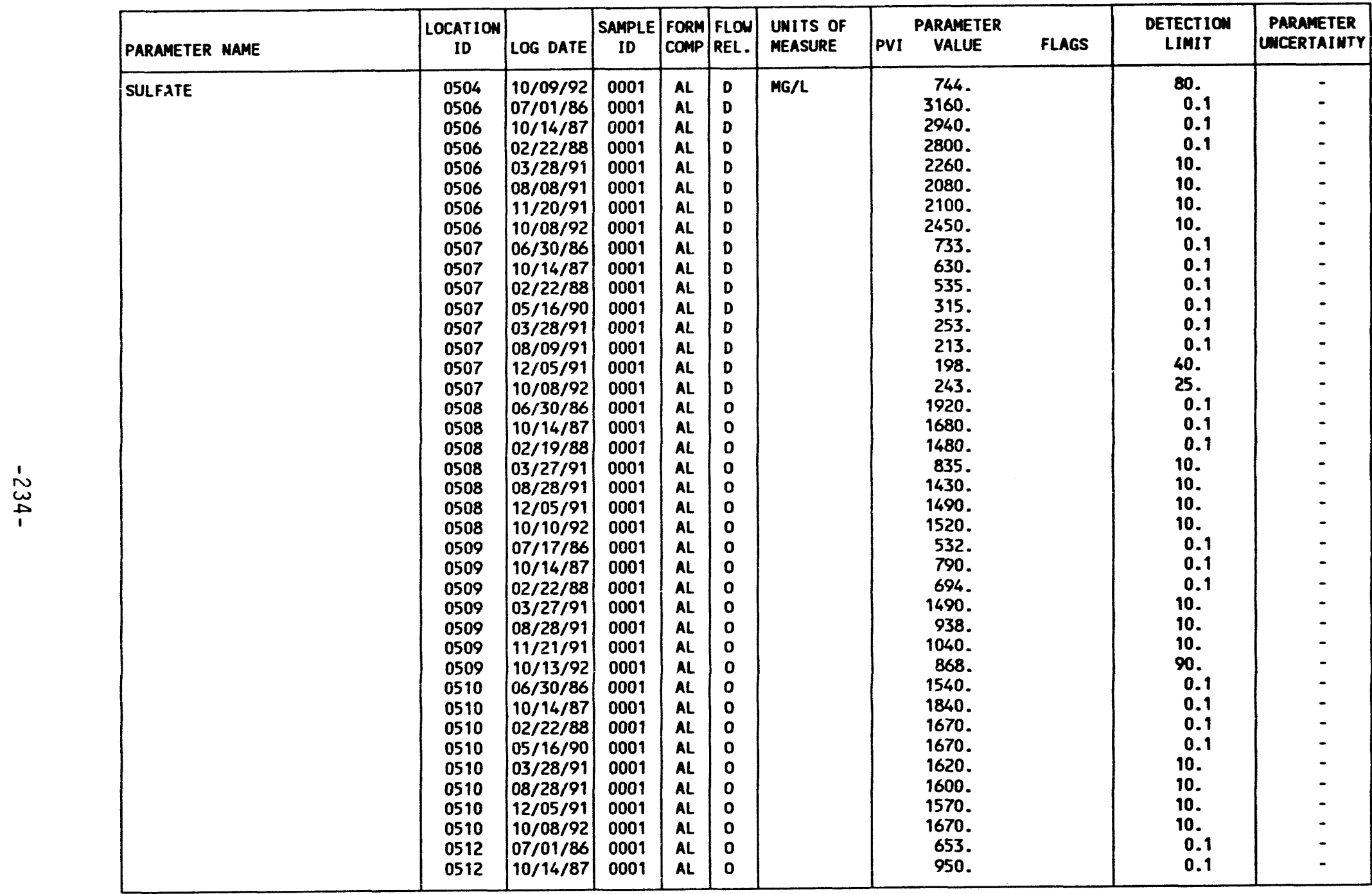

FORMATION OF COMPLETION COOE:

AL - ALLUVIUM

FLOU RELATIONSHIP COOE:

D - DOWN GRADIENT

O - ON-SITE

PARAMETER VALUE INDICATOR (PVI): < - LESS THAN DETECTION LIMIT

0001 - FILTERED SAMPLE (.45 MICRONS) 
TABLE 3.27 BASELINE GROUNDHATER QUALITY DATA BY PARAMETER FOR THE ALLUVIUM

MC AND UC PROCESSING SITES, SLICK ROCK, COLORADO

SITE: SRKO1 SLICK ROCK (BOTH SITES)

06/30/86 TO $10 / 13 / 92$

REPORT DATE: $07 / 26 / 93$

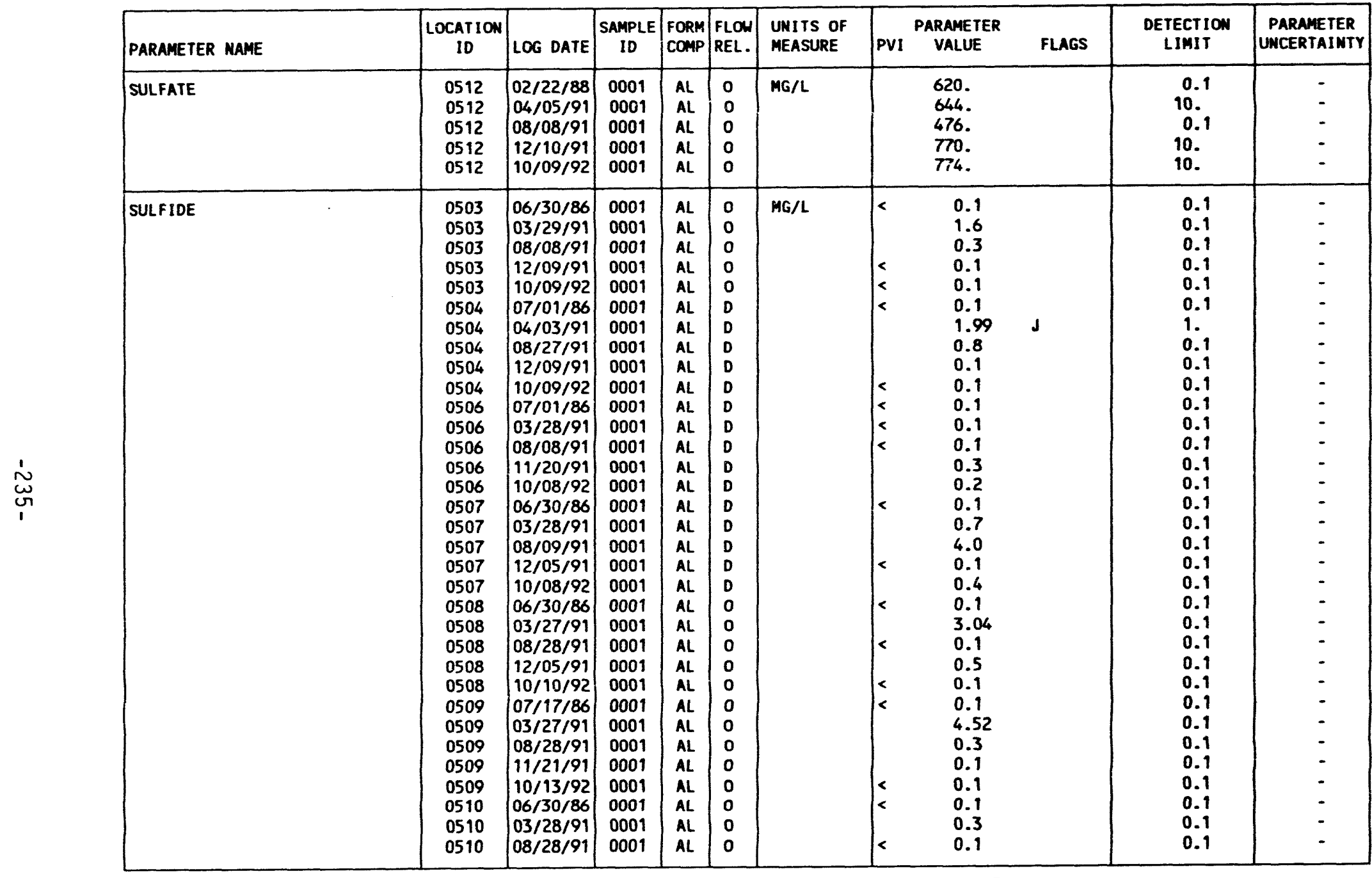

FORMATION OF COMPLETION COOE:

AL - ALLUVIUM
FLOW RELATIOWSHIP COOE:

D - DON GRADIENT

PARAMETER VALUE INDICATOR (PVI): < - LESS thaN DETECTION LIMIT 
TABLE 3.27 BASELINE GROUNDWATER QUALITY DATA BY PARAMETER FOR THE ALLUVIUM NC AND UC PROCESSING SITES, SLICK ROCK, COLORADO

SITE: SRKO1 SLICK ROCK (BOTH SITES)

06/30/86 TO $10 / 13 / 92$

REPORT DATE: $07 / 26 / 93$

\begin{tabular}{|c|c|c|c|c|c|c|c|c|c|c|}
\hline PARAMETER NAME & $\begin{array}{c}\text { LOCATION } \\
\text { ID }\end{array}$ & LOG DATE & $\underset{\text { SAMPLE }}{\text { ID }}$ & $\begin{array}{l}\text { FORM } \\
\text { COMP }\end{array}$ & $\begin{array}{l}\text { FLOW } \\
\text { REL. }\end{array}$ & $\begin{array}{l}\text { UNITS OF } \\
\text { MEASURE }\end{array}$ & $\begin{array}{c}\text { PARAMETER } \\
\text { PVI } \\
\text { VALUE }\end{array}$ & FLAGS & $\begin{array}{l}\text { DETECTION } \\
\text { LIMIT }\end{array}$ & $\begin{array}{l}\text { PARAMETER } \\
\text { UNCERTAINTY }\end{array}$ \\
\hline SULFIDE & $\begin{array}{l}0510 \\
0510 \\
0512 \\
0512 \\
0512 \\
0512 \\
0512\end{array}$ & $\begin{array}{l}12 / 05 / 91 \\
10 / 08 / 92 \\
07 / 01 / 86 \\
04 / 05 / 91 \\
08 / 08 / 91 \\
12 / 10 / 91 \\
10 / 09 / 92\end{array}$ & $\begin{array}{l}0001 \\
0001 \\
0001 \\
0001 \\
0001 \\
0001 \\
0001\end{array}$ & $\begin{array}{l}A L \\
A L \\
A L \\
A L \\
A L \\
A L \\
A L\end{array}$ & $\begin{array}{l}0 \\
0 \\
0 \\
0 \\
0 \\
0 \\
0\end{array}$ & $M G / L$ & $\begin{array}{r}0.1 \\
0.1 \\
0.1 \\
32.9 \\
1.1 \\
0.3 \\
0.2\end{array}$ & & $\begin{array}{l}0.1 \\
0.1 \\
0.1 \\
0.1 \\
0.2 \\
0.1 \\
0.1\end{array}$ & $\begin{array}{l}- \\
- \\
- \\
- \\
-\end{array}$ \\
\hline TEMPERATURE & $\begin{array}{l}0503 \\
0503 \\
0503 \\
0503 \\
0503 \\
0503 \\
0503 \\
0503 \\
0504 \\
0504 \\
0504 \\
0504 \\
0504 \\
0504 \\
0504 \\
0506 \\
0506 \\
0506 \\
0506 \\
0506 \\
0506 \\
0506 \\
0507 \\
0507 \\
0507 \\
0507 \\
0507 \\
0507 \\
0507 \\
0507 \\
0508 \\
0508\end{array}$ & $\begin{array}{l}06 / 30 / 86 \\
10 / 14 / 87 \\
02 / 22 / 88 \\
05 / 16 / 90 \\
03 / 29 / 91 \\
08 / 08 / 91 \\
12 / 05 / 91 \\
10 / 09 / 92 \\
07 / 01 / 86 \\
10 / 14 / 87 \\
02 / 22 / 88 \\
05 / 16 / 90 \\
08 / 27 / 91 \\
12 / 05 / 91 \\
10 / 09 / 92 \\
07 / 01 / 86 \\
10 / 14 / 87 \\
02 / 22 / 88 \\
03 / 28 / 91 \\
08 / 08 / 91 \\
12 / 05 / 91 \\
10 / 08 / 92 \\
06 / 30 / 86 \\
10 / 14 / 87 \\
02 / 22 / 88 \\
05 / 16 / 90 \\
03 / 28 / 91 \\
08 / 09 / 91 \\
12 / 05 / 91 \\
10 / 08 / 92 \\
06 / 30 / 86 \\
10 / 14 / 87\end{array}$ & $\begin{array}{l}0001 \\
0001 \\
0001 \\
0001 \\
0001 \\
0001 \\
0001 \\
0001 \\
0001 \\
0001 \\
0001 \\
0001 \\
0001 \\
0001 \\
0001 \\
0001 \\
0001 \\
0001 \\
0001 \\
0001 \\
0001 \\
0001 \\
0001 \\
0001 \\
0001 \\
0001 \\
0001 \\
0001 \\
0001 \\
0001 \\
0001 \\
0001\end{array}$ & $\begin{array}{l}A L \\
A L \\
A L \\
A L \\
A L \\
A L \\
A L \\
A L \\
A L \\
A L \\
A L \\
A L \\
A L \\
A L \\
A L \\
A L \\
A L \\
A L \\
A L \\
A L \\
A L \\
A L \\
A L \\
A L \\
A L \\
A L \\
A L \\
A L \\
A L \\
A L \\
A L \\
A L\end{array}$ & $\begin{array}{l}0 \\
0 \\
0 \\
0 \\
0 \\
0 \\
0 \\
0 \\
D \\
D \\
D \\
D \\
D \\
D \\
D \\
D \\
D \\
D \\
D \\
D \\
D \\
D \\
D \\
D \\
D \\
D \\
D \\
D \\
D \\
D \\
0 \\
D\end{array}$ & C - DEGREE & $\begin{array}{l}15 . \\
14.5 \\
13.0 \\
13.5 \\
13.1 \\
14.2 \\
14.0 \\
14.7 \\
12 . \\
13.0 \\
11.0 \\
12.2 \\
14.0 \\
12.7 \\
15.2 \\
13 . \\
14.5 \\
10.0 \\
9.8 \\
14.1 \\
13.6 \\
15.0 \\
12 . \\
14.0 \\
10.0 \\
11.0 \\
9.5 \\
12.6 \\
12.0 \\
12.8 \\
13 . \\
15.0\end{array}$ & & $\begin{array}{l}- \\
- \\
- \\
- \\
- \\
- \\
- \\
- \\
- \\
- \\
- \\
- \\
- \\
- \\
- \\
- \\
- \\
- \\
- \\
- \\
- \\
- \\
- \\
- \\
-\end{array}$ & $\begin{array}{l}- \\
- \\
- \\
- \\
- \\
- \\
- \\
- \\
- \\
- \\
- \\
- \\
- \\
- \\
- \\
- \\
- \\
- \\
- \\
- \\
- \\
- \\
- \\
-\end{array}$ \\
\hline
\end{tabular}

FORMATION OF COMPLETION COOE

AL - ALLUVIUM
FLON RELATIONSHIP COOE:

PARAMETER VALUE INDICATOR (PVI): < - LESS THAN DETECTIGN LIMIT

SAMPLE ID COOES:

0001 - FILTERED SAMPLE (.45 MICRONS) 


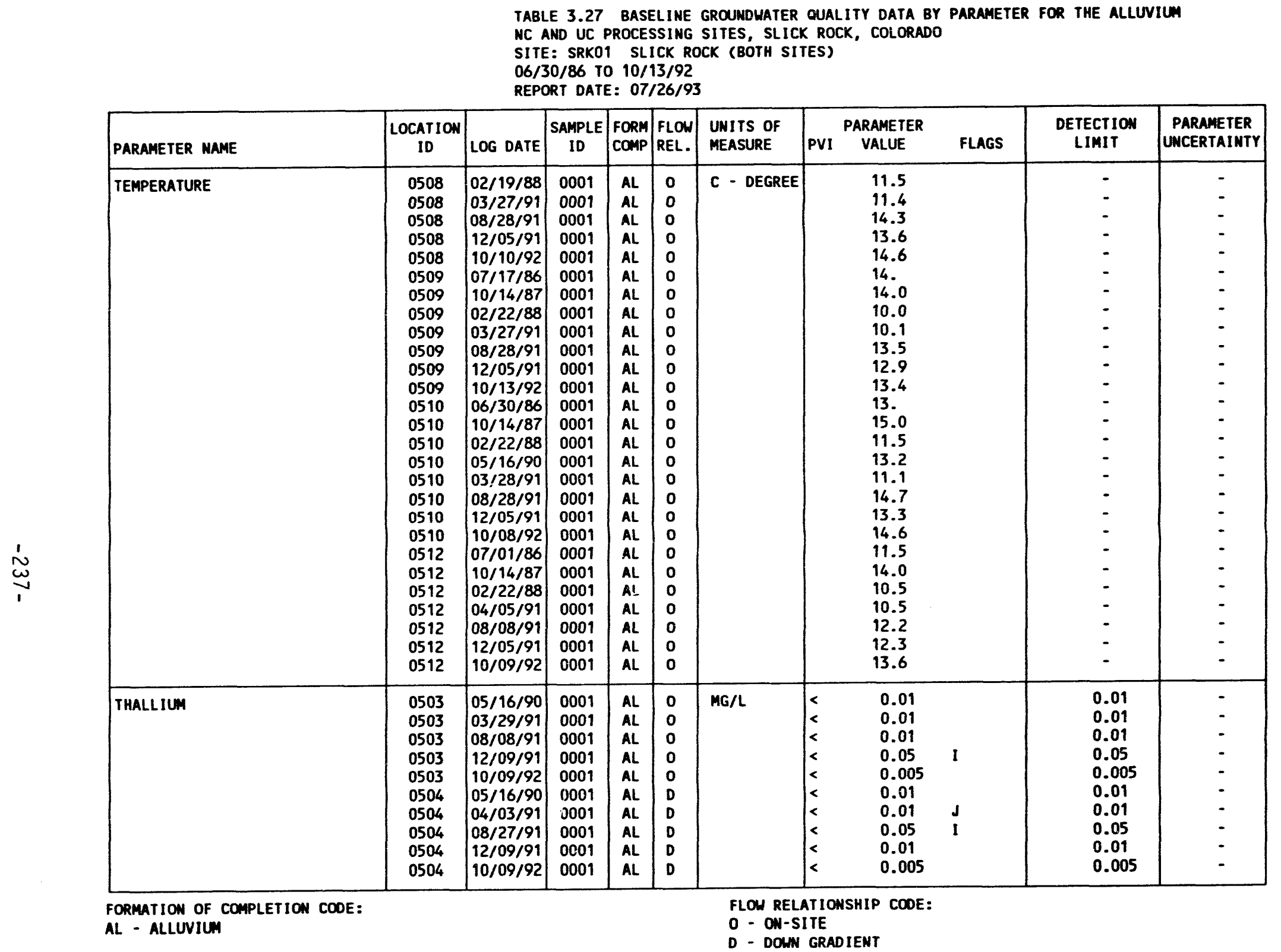

PARAMETER VALUE IMOICATOR (PVI): < - LESS THAN DETECTION LIMIT

SAMPLE ID COOES:

0001 - FILTERED SAMPLE (.45 MICRONS)

OTHER PARAMETER VALUE FLAGS:

I - INCREASED DETECTION LIMIT DUE TO REOUIRED DILUTION

J - ESTIMATED VALUE 
TABLE 3.27 BASELINE GROUNDWATER QUALITY DATA BY PARAMETER FOR THE ALLUVIUM NC AND UC PROCESSING SITES, SLICK ROCK, COLORADO

SITE: SRKO1 SLICK ROCK (BOTH SITES)

06/30/86 TO $10 / 13 / 92$

REPORT DATE: $07 / 26 / 93$

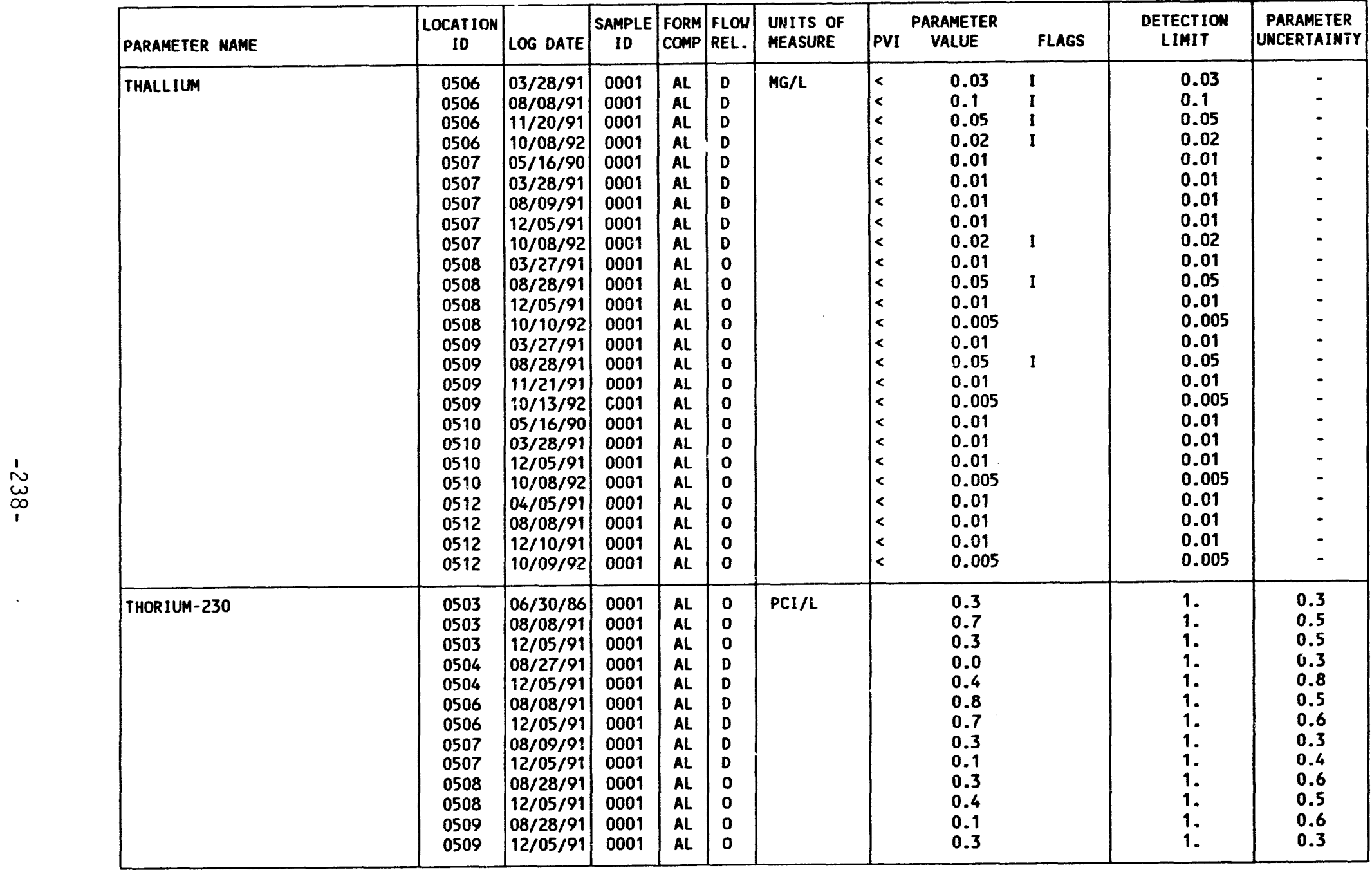

FORMATION OF COMPLETION CODE:

AL - ALLUVIUM
FLOW RELATIONSHIP CODE:

- DOWN GRADIENT

O - ON-SITE

\section{SAMPLE ID CODES:}

0001 - FILTERED SAMPLE (.45 MICRONS)

OTHER PARAMETER VALUE FLAGS:

I - INCREASED DETECTION LIMIT DUE TO REQUIRED DILUTION 
TABLE 3.27 BASELINE GROUNDWATER QUALITY DATA BY PARAMETER FOR THE ALLUVIUM NC AND UC PROCESSING SITES, SLICK ROCK, COLORADO

SITE: SRKO1 SLICK ROCK (BOTH SITES)

06/30/86 TO 10/13/92

\begin{tabular}{|c|c|c|c|c|c|c|c|c|c|c|c|}
\hline PARAMETER NAME & $\underset{\text { LOCATION }}{\text { ID }}$ & LOG DATE & $\begin{array}{c}\text { SAMPLE } \\
\text { ID }\end{array}$ & $\begin{array}{l}\text { FORM } \\
\text { COMP }\end{array}$ & $\begin{array}{l}\text { FLOW } \\
\text { REL. }\end{array}$ & $\begin{array}{l}\text { UNITS OF } \\
\text { MEASURE }\end{array}$ & PVI & $\begin{array}{l}\text { ARAMETER } \\
\text { VALUE }\end{array}$ & FLAGS & $\begin{array}{l}\text { DETECTION } \\
\text { LIMIT }\end{array}$ & $\begin{array}{l}\text { PARAMETER } \\
\text { UNCERTAINTY }\end{array}$ \\
\hline THORIUM-230 & $\begin{array}{l}0510 \\
0510 \\
0510 \\
0512 \\
0512\end{array}$ & $\begin{array}{l}06 / 30 / 86 \\
08 / 28 / 91 \\
12 / 05 / 91 \\
08 / 08 / 91 \\
12 / 05 / 91\end{array}$ & $\begin{array}{l}0001 \\
0001 \\
0001 \\
0001 \\
0001\end{array}$ & $\begin{array}{l}A L \\
A L \\
A L \\
A L \\
A L\end{array}$ & $\begin{array}{l}0 \\
0 \\
0 \\
0 \\
0\end{array}$ & $\mathrm{PCI} / \mathrm{L}$ & & $\begin{array}{l}0.1 \\
0.3 \\
0.4 \\
0.5 \\
0.1\end{array}$ & & $\begin{array}{l}1 . \\
1 . \\
1 . \\
1 . \\
1 .\end{array}$ & $\begin{array}{l}0.2 \\
0.5 \\
0.6 \\
0.5 \\
0.4\end{array}$ \\
\hline TIN & $\begin{array}{l}0503 \\
0503 \\
0503 \\
0503 \\
0503 \\
0503 \\
0504 \\
0504 \\
0504 \\
0504 \\
0504 \\
0506 \\
0506 \\
0506 \\
0506 \\
0507 \\
0507 \\
0507 \\
0507 \\
0507 \\
0508 \\
0508 \\
0508 \\
0508 \\
0509 \\
0509 \\
0509 \\
0509 \\
0510 \\
0510 \\
0510 \\
0510\end{array}$ & \begin{tabular}{|l|}
$06 / 30 / 86$ \\
$05 / 16 / 90$ \\
$03 / 29 / 91$ \\
$08 / 08 / 91$ \\
$12 / 09 / 91$ \\
$10 / 09 / 92$ \\
$05 / 16 / 90$ \\
$04 / 03 / 91$ \\
$68 / 27 / 91$ \\
$12 / 09 / 91$ \\
$10 / 09 / 92$ \\
$03 / 28 / 91$ \\
$08 / 08 / 91$ \\
$11 / 20 / 91$ \\
$10 / 08 / 92$ \\
$05 / 16 / 90$ \\
$03 / 28 / 91$ \\
$08 / 09 / 91$ \\
$12 / 05 / 91$ \\
$10 / 08 / 92$ \\
$03 / 27 / 91$ \\
$08 / 28 / 91$ \\
$12 / 05 / 91$ \\
$10 / 10 / 92$ \\
$03 / 27 / 91$ \\
$08 / 28 / 91$ \\
$11 / 21 / 91$ \\
$10 / 13 / 92$ \\
$06 / 30 / 86$ \\
$05 / 16 / 90$ \\
$03 / 28 / 91$ \\
$12 / 05 / 91$
\end{tabular} & $\begin{array}{l}0001 \\
0001 \\
0001 \\
0001 \\
0001 \\
0001 \\
0001 \\
0001 \\
0001 \\
0001 \\
0001 \\
0001 \\
0001 \\
0001 \\
0001 \\
0001 \\
0001 \\
0001 \\
0001 \\
0001 \\
0001 \\
0001 \\
0001 \\
0001 \\
0001 \\
0001 \\
0001 \\
0001 \\
0001 \\
0001 \\
0001 \\
0001\end{array}$ & $\begin{array}{l}A L \\
A L \\
A L \\
A L \\
A L \\
A L \\
A L \\
A L \\
A L \\
A L \\
A L \\
A L \\
A L \\
A L \\
A L \\
A L \\
A L \\
A L \\
A L \\
A L \\
A L \\
A L \\
A L \\
A L \\
A L \\
A L \\
A L \\
A L \\
A L \\
A L \\
A L \\
A L\end{array}$ & $\begin{array}{l}0 \\
0 \\
0 \\
0 \\
0 \\
0 \\
D \\
D \\
D \\
D \\
D \\
D \\
D \\
D \\
D \\
D \\
D \\
D \\
D \\
D \\
0 \\
0 \\
0 \\
0 \\
0 \\
0 \\
0 \\
0 \\
0 \\
0 \\
0 \\
0\end{array}$ & $M G / L$ & $\begin{array}{l}< \\
< \\
< \\
< \\
< \\
< \\
< \\
< \\
< \\
< \\
< \\
< \\
< \\
< \\
< \\
< \\
< \\
< \\
< \\
< \\
< \\
< \\
< \\
< \\
< \\
< \\
< \\
< \\
<\end{array}$ & $\begin{array}{l}0.005 \\
0.018 \\
0.005 \\
0.05 \\
0.03 \\
0.05 \\
0.017 \\
0.005 \\
0.05 \\
0.03 \\
0.05 \\
0.005 \\
0.005 \\
0.03 \\
0.05 \\
0.005 \\
0.005 \\
0.005 \\
0.005 \\
0.05 \\
0.005 \\
0.05 \\
0.005 \\
0.05 \\
0.005 \\
0.05 \\
0.03 \\
0.005 \\
0.005 \\
0.005 \\
0.005 \\
0.005\end{array}$ & $\begin{array}{l}\text { I } \\
1 \\
1 \\
J \\
1 \\
1 \\
1 \\
1 \\
1\end{array}$ & $\begin{array}{l}0.005 \\
0.005 \\
0.005 \\
0.05 \\
0.03 \\
0.05 \\
0.005 \\
0.005 \\
0.05 \\
0.03 \\
0.05 \\
0.005 \\
0.005 \\
0.03 \\
0.05 \\
0.005 \\
0.005 \\
0.005 \\
0.005 \\
0.05 \\
0.005 \\
0.05 \\
0.005 \\
0.05 \\
0.005 \\
0.05 \\
0.03 \\
0.005 \\
0.005 \\
0.005 \\
0.005 \\
0.005\end{array}$ & $\begin{array}{l}- \\
- \\
- \\
- \\
- \\
\vdots \\
\vdots \\
- \\
\vdots \\
- \\
- \\
- \\
- \\
- \\
- \\
- \\
- \\
- \\
- \\
- \\
- \\
-\end{array}$ \\
\hline
\end{tabular}

FORMATION OF COMPLETION CODE:

AL - ALLUVIUM

PARAMETER VALUE INDICATOR (PVI): < - LESS THAN DETECTION LIMIT
FLOW RELATIONSHIP CODE:

O - ON-SITE

D - DOWN GRADIENT

0001 - FILTERED SAMPLE (.45 MICRONS)

OTHER PARAMETER VALUE FLAGS:

1 - INCREASED DETECTION LIMIT DUE TO REQUIRED DILUTION $\mathrm{j}$ - ESTIMATED VALUE 
TABLE 3.27 BASELINE GROUWDWATER QUALITY DATA BY PARAMETER FOR THE ALLUVIUM NC AND UC PROCESSING SITES, SLICK ROCK, COLORADO

SITE: SRKO1 SLICK ROCK (BOTH SITES)

$06 / 30 / 86$ TO $10 / 13 / 92$

REPORT DATE: $07 / 26 / 93$

\begin{tabular}{|c|c|c|c|c|c|c|c|c|c|c|c|c|}
\hline & PARAMETER NAME & $\underset{\text { ID }}{\text { LOCATION }}$ & LOG DATE & $\underset{\text { SAMPLE }}{\text { ID }}$ & $\begin{array}{l}\text { FORM } \\
\text { COMP }\end{array}$ & $\begin{array}{l}\text { FLOW } \\
\text { REL. }\end{array}$ & $\begin{array}{l}\text { UNITS OF } \\
\text { MEASURE }\end{array}$ & PVI & $\begin{array}{l}\text { PARAMETER } \\
\text { VALUE }\end{array}$ & FLAGS & $\begin{array}{l}\text { DETECTIOW } \\
\text { LIMIT }\end{array}$ & $\begin{array}{l}\text { PARAMETER } \\
\text { UNCERTAINTY }\end{array}$ \\
\hline & TIN & $\begin{array}{l}0510 \\
0512 \\
0512 \\
0512 \\
0512\end{array}$ & $\begin{array}{l}10 / 08 / 92 \\
04 / 05 / 91 \\
08 / 08 / 91 \\
12 / 10 / 91 \\
10 / 09 / 92\end{array}$ & $\begin{array}{l}0001 \\
0001 \\
0001 \\
0001 \\
0001\end{array}$ & $\begin{array}{l}A L \\
A L \\
A L \\
A L \\
A L\end{array}$ & $\begin{array}{l}0 \\
0 \\
0 \\
0 \\
0\end{array}$ & MG/L & $\mid \begin{array}{l}< \\
< \\
< \\
<\end{array}$ & $\begin{array}{l}0.05 \\
0.005 \\
0.05 \\
0.005 \\
0.005\end{array}$ & $\begin{array}{l}1 \\
1\end{array}$ & $\begin{array}{l}0.05 \\
0.005 \\
0.05 \\
0.005 \\
0.005\end{array}$ & : \\
\hline$\underset{\sim}{\sim}$ & TOTAL DISSOLVED SOLIDS & $\begin{array}{l}0503 \\
0503 \\
0503 \\
0503 \\
0503 \\
0503 \\
0503 \\
0503 \\
0504 \\
0504 \\
0504 \\
0504 \\
0504 \\
0504 \\
0504 \\
0504 \\
0506 \\
0506 \\
0506 \\
0506 \\
0506 \\
0506 \\
0506 \\
0507 \\
0507 \\
0507 \\
0507 \\
0507 \\
0507 \\
0507 \\
0507 \\
0508\end{array}$ & $\begin{array}{l}06 / 30 / 86 \\
10 / 14 / 87 \\
02 / 22 / 88 \\
05 / 16 / 90 \\
03 / 29 / 91 \\
08 / 08 / 91 \\
12 / 09 / 91 \\
10 / 09 / 92 \\
07 / 01 / 86 \\
10 / 14 / 87 \\
02 / 22 / 88 \\
05 / 16 / 90 \\
04 / 03 / 91 \\
08 / 27 / 91 \\
12 / 09 / 91 \\
10 / 09 / 92 \\
07 / 01 / 86 \\
10 / 14 / 87 \\
02 / 22 / 88 \\
03 / 28 / 91 \\
08 / 08 / 91 \\
11 / 20 / 91 \\
10 / 08 / 92 \\
06 / 30 / 86 \\
10 / 14 / 87 \\
02 / 22 / 88 \\
05 / 16 / 90 \\
03 / 28 / 91 \\
08 / 09 / 91 \\
12 / 05 / 91 \\
10 / 08 / 92 \\
06 / 30 / 86\end{array}$ & $\begin{array}{l}0001 \\
0001 \\
0001 \\
0001 \\
0001 \\
0001 \\
0001 \\
0001 \\
0001 \\
0001 \\
0001 \\
0001 \\
0001 \\
0001 \\
0001 \\
0001 \\
0001 \\
0001 \\
0001 \\
0001 \\
0001 \\
0001 \\
0001 \\
0001 \\
0001 \\
0001 \\
0001 \\
0001 \\
0001 \\
0001 \\
0001 \\
0001\end{array}$ & $\begin{array}{l}A L \\
A L \\
A L \\
A L \\
A L \\
A L \\
A L \\
A L \\
A L \\
A L \\
A L \\
A L \\
A L \\
A L \\
A L \\
A L \\
A L \\
A L \\
A L \\
A L \\
A L \\
A L \\
A L \\
A L \\
A L \\
A L \\
A L \\
A L \\
A L \\
A L \\
A L \\
A L\end{array}$ & $\begin{array}{l}0 \\
0 \\
0 \\
0 \\
0 \\
0 \\
0 \\
0 \\
D \\
D \\
D \\
D \\
D \\
D \\
D \\
D \\
D \\
D \\
D \\
D \\
D \\
D \\
D \\
D \\
D \\
D \\
D \\
D \\
D \\
D \\
D \\
D\end{array}$ & $M G / L$ & & $\begin{array}{l}3400 . \\
3130 . \\
3130 . \\
2770 . \\
2830 . \\
1060 . \\
2640 . \\
2520 . \\
3950 . \\
4300 . \\
4080 . \\
2470 . \\
2350 . \\
2160 . \\
1970 . \\
1670 . \\
5370 . \\
5220 . \\
5170 . \\
9560 . \\
2780 . \\
5840 . \\
7560 . \\
1520 . \\
1413 . \\
1260 . \\
892 . \\
259 . \\
863 . \\
911 . \\
928 . \\
4420 .\end{array}$ & $\mathbf{J}$ & $\begin{array}{l}10 . \\
10 . \\
10 . \\
10 . \\
10 . \\
10 . \\
10 . \\
10 . \\
10 . \\
10 . \\
10 . \\
10 . \\
10 . \\
10 . \\
10 . \\
10 . \\
10 . \\
10 . \\
10 . \\
10 . \\
10 . \\
10 . \\
10 . \\
10 . \\
10 . \\
10 . \\
10 . \\
10 . \\
10 . \\
10 . \\
10 . \\
10 .\end{array}$ & $\begin{array}{l}- \\
- \\
- \\
- \\
- \\
- \\
- \\
- \\
- \\
- \\
- \\
- \\
- \\
- \\
- \\
- \\
- \\
- \\
- \\
- \\
- \\
- \\
-\end{array}$ \\
\hline
\end{tabular}

FORMATION OF COMPLETION COOE:

AL - ALLUVIUM
FLOW RELATIONSHIP COOE:

D - DOUN GRADIENT

PARAMETER VALUE INDICATOR (PVI): < - LESS THAN DETECTION LIMIT

SAMPLE ID CODES:

0001 - FILTERED SAMPLE (.45 MICRONS)

OTHER PARAMETER VALUE FLAGS:

I - INCREASED DETECTION LIMIT DUE TO REQUIRED DILUTION

J - ESTIMATED VALUE 
TABLE 3.27 BASELINE GROUNDWATER OUALITY DATA BY PARAMETER FOR THE ALLUVIUM NC AND UC PROCESSING SITES, SLICK ROCK, COLORADO

SITE: SRKO1 SLICK ROCK (BOTH SITES)

06/30/86 TO $10 / 13 / 92$

REPORT DATE: $07 / 26 / 93$

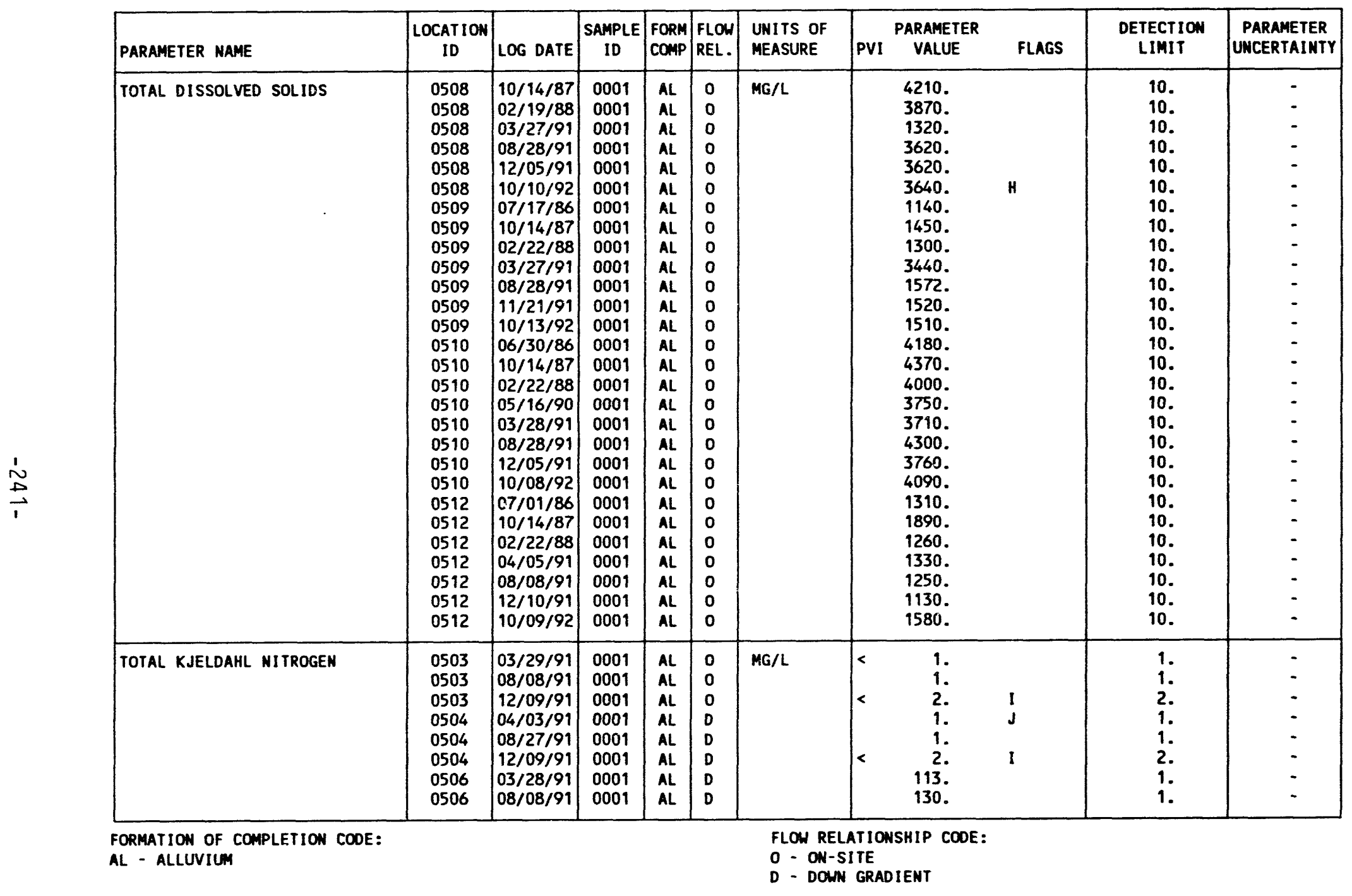

PARAMETER VALUE INDICATOR (PVI): < - LESS THAN DETECTION LIMIT SAMPLE ID CODES:

OTHER PARAMETER VALUE FLAGS:
H - HOLD TIME EXPIRED, VALUE SUSPECT

0001 - FILTERED SAMPLE (.45 MICROWS)

1 - INCREASED DETECTION LIMIT DUE TO REQUIRED DILUTION

j - estimated VALLE 
TABLE 3.27 BASELINE GROUNDHATER QUALITY DATA BY PARAMETER FOR THE ALLUVIUM

NC AND UC PROCESSING SITES, SLICK ROCK, COLORADO

SITE: SRKOI SLICK ROCK (BOTH SITES)

06/30/86 TO 10/13/92

REPORT DATE: $07 / 26 / 93$

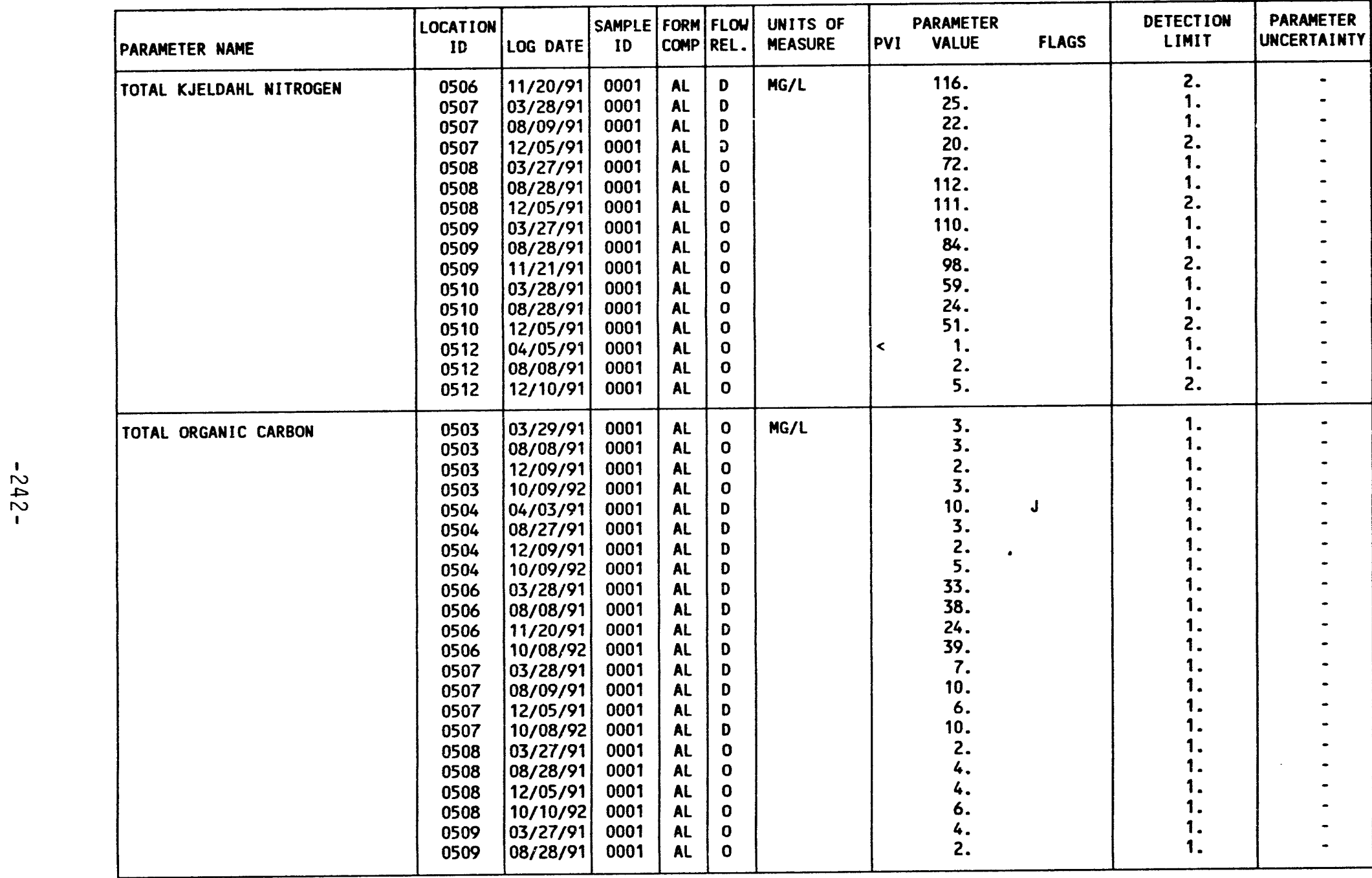

FORMATION OF COMPLETION CODE:

AL - ALLUVIUM

FLOW RELATIONSHIP CODE:

D - DOWN GRADIENT

O - ON-SITE

PARAMETER VALUE IMDICATOR (PVI): < - LESS THAN DETECTION LIMIT

0001 - FILTERED SAMPLE (.45 MICRONS)

OTHER PARAMETER VALUE fLAGS:

$J$ - ESTIMATED VALUE 
TABLE 3.27 BASELINE GROUNDWATER QUALITY DATA BY PARAMETER FOR THE ALLUVIUM NC AND UC PROCESSING SITES, SLICK ROCK, COLORADO

NC AND UC PROCESSING SITES, SLICK ROCK,
SITE: SRKO1 SLICK ROCK (BOTH SITES)

SITE: SRKO1 SLICK ROCK

REPORT DATE: $07 / 26 / 93$

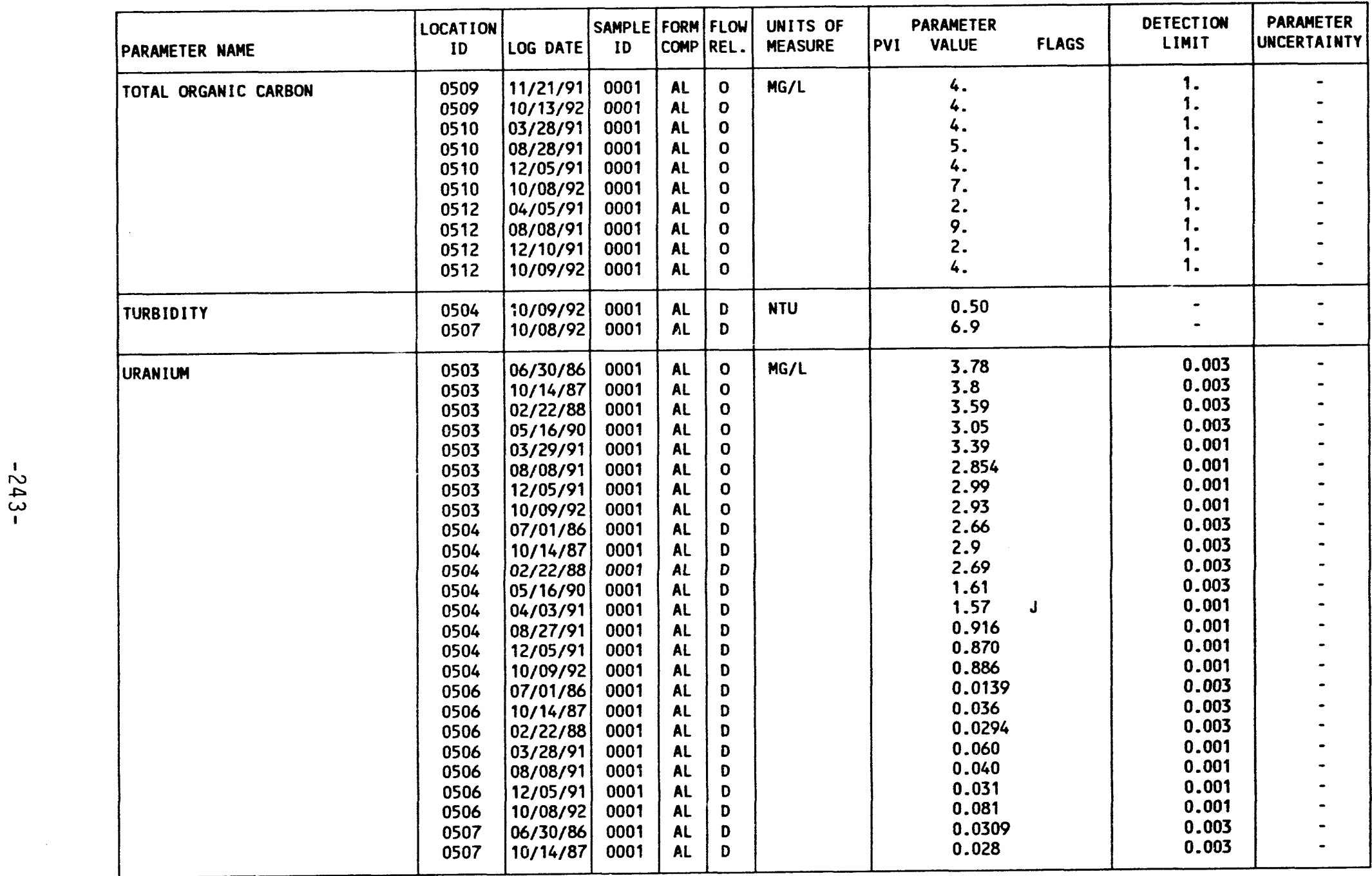

FORMATION OF COMPLETION CODE:

AL - ALLUVIUM
FLON RELATIONSHIP CODE:

ON-SITE

- DOWN GRADIENT

PARAMETER VALUE INDICATOR (PVI): < - LESS THAN DETECTION LIMIT

0001 - FILTERED SAMPLE (.45 MICRONS)

OTHER PARAMETER VALUE fLAGS:

$J$ - ESTIMATED VALUE 
TABLE 3.27 BASELINE GROUNDHATER QUALITY DATA BY PARAMETER FOR THE ALLUVIUM

NC AND UC PROCESSING SITES, SLICK ROCK, COLORADO

SITE: SRK01 SLICK ROCK (BOTH SITES)

$06 / 30 / 86$ TO $10 / 13 / 92$

REPORT DATE: $07 / 26 / 93$

\begin{tabular}{|c|c|c|c|c|c|c|c|c|c|c|c|}
\hline & PARAMETER NAME & $\begin{array}{c}\text { LOCATION } \\
\text { ID }\end{array}$ & LOG DATE & $\begin{array}{c}\text { SAMPLE } \\
\text { ID }\end{array}$ & $\begin{array}{l}\text { FORM } \\
\text { COMP }\end{array}$ & $\begin{array}{l}\text { FLOW } \\
\text { REL. }\end{array}$ & $\begin{array}{l}\text { UNITS OF } \\
\text { MEASURE }\end{array}$ & PVI & $\begin{array}{l}\text { ARAMETER } \\
\text { VALUE }\end{array}$ & $\begin{array}{l}\text { DETECTION } \\
\text { LIMIT }\end{array}$ & $\begin{array}{l}\text { PARAMETER } \\
\text { UNCERTAINTY }\end{array}$ \\
\hline 1 & URANIUM & $\begin{array}{l}0507 \\
0507 \\
0507 \\
0507 \\
0507 \\
0507 \\
0508 \\
0508 \\
0508 \\
0508 \\
0508 \\
0508 \\
0508 \\
0509 \\
0509 \\
0509 \\
0509 \\
0509 \\
0509 \\
0509 \\
0510 \\
0510 \\
0510 \\
0510 \\
0510 \\
0510 \\
0510 \\
0510 \\
0512 \\
0512 \\
0512 \\
0512 \\
0512 \\
0512 \\
0512\end{array}$ & $\begin{array}{l}02 / 22 / 88 \\
05 / 16 / 90 \\
03 / 28 / 91 \\
08 / 09 / 91 \\
12 / 05 / 91 \\
10 / 08 / 92 \\
06 / 30 / 86 \\
10 / 14 / 87 \\
02 / 19 / 88 \\
03 / 27 / 91 \\
08 / 28 / 91 \\
12 / 05 / 91 \\
10 / 10 / 92 \\
07 / 17 / 86 \\
10 / 14 / 87 \\
02 / 22 / 88 \\
03 / 27 / 91 \\
08 / 28 / 91 \\
12 / 05 / 91 \\
10 / 13 / 92 \\
06 / 30 / 86 \\
10 / 14 / 87 \\
02 / 22 / 88 \\
05 / 16 / 90 \\
03 / 28 / 91 \\
08 / 28 / 91 \\
12 / 05 / 91 \\
10 / 08 / 92 \\
07 / 01 / 86 \\
10 / 14 / 87 \\
02 / 22 / 88 \\
04 / 05 / 91 \\
08 / 08 / 91 \\
12 / 05 / 91 \\
10 / 09 / 92\end{array}$ & $\begin{array}{l}0001 \\
0001 \\
0001 \\
0001 \\
0001 \\
0001 \\
0001 \\
0001 \\
0001 \\
0001 \\
0001 \\
0001 \\
0001 \\
0001 \\
0001 \\
0001 \\
0001 \\
0001 \\
0001 \\
0001 \\
0001 \\
0001 \\
0001 \\
0001 \\
0001 \\
0001 \\
0001 \\
0001 \\
0001 \\
0001 \\
0001 \\
0001 \\
0001 \\
0001 \\
0001\end{array}$ & $\begin{array}{l}A L \\
A L \\
A L \\
A L \\
A L \\
A L \\
A L \\
A L \\
A L \\
A L \\
A L \\
A L \\
A L \\
A L \\
A L \\
A L \\
A L \\
A L \\
A L \\
A L \\
A L \\
A L \\
A L \\
A L \\
A L \\
A L \\
A L \\
A L \\
A L \\
A L \\
A L \\
A L \\
A L \\
A L \\
A L\end{array}$ & $\begin{array}{l}D \\
D \\
D \\
D \\
D \\
D \\
0 \\
0 \\
0 \\
0 \\
0 \\
0 \\
0 \\
0 \\
0 \\
0 \\
0 \\
0 \\
0 \\
0 \\
0 \\
0 \\
0 \\
0 \\
0 \\
0 \\
0 \\
0 \\
0 \\
0 \\
0 \\
0 \\
0 \\
0 \\
0\end{array}$ & $M G / L$ & & $\begin{array}{l}0.0237 \\
0.023 \\
0.029 \\
0.034 \\
0.027 \\
0.028 \\
0.115 \\
0.127 \\
0.126 \\
0.021 \\
0.073 \\
0.103 \\
0.104 \\
0.0287 \\
0.029 \\
0.0254 \\
0.078 \\
0.027 \\
0.022 \\
0.024 \\
0.195 \\
0.178 \\
0.126 \\
0 \\
0.110 \\
0.092 \\
0.112 \\
0.132 \\
0.151 \\
0\end{array}$ & $\begin{array}{l}0.003 \\
0.003 \\
0.001 \\
0.001 \\
0.001 \\
0.001 \\
0.003 \\
0.003 \\
0.003 \\
0.001 \\
0.001 \\
0.001 \\
0.001 \\
0.003 \\
0.003 \\
0.003 \\
0.001 \\
0.001 \\
0.001 \\
0.001 \\
0.003 \\
0.003 \\
0.003 \\
0.003 \\
0.001 \\
0.001 \\
0.001 \\
0.001 \\
0.003 \\
0.003 \\
0.003 \\
0.001 \\
0.001 \\
0.001 \\
0.001\end{array}$ & $\begin{array}{l}- \\
- \\
- \\
- \\
- \\
- \\
- \\
- \\
- \\
- \\
- \\
- \\
- \\
- \\
- \\
- \\
- \\
- \\
- \\
- \\
- \\
- \\
- \\
- \\
- \\
- \\
-\end{array}$ \\
\hline & VANADIUM & $\begin{array}{l}0503 \\
0503 \\
0503 \\
0503\end{array}$ & $\begin{array}{l}06 / 30 / 86 \\
10 / 14 / 87 \\
05 / 16 / 90 \\
03 / 29 / 91\end{array}$ & $\begin{array}{l}0001 \\
0001 \\
0001 \\
0001\end{array}$ & $\begin{array}{l}A L \\
A L \\
A L \\
A L\end{array}$ & $\begin{array}{l}0 \\
0 \\
0 \\
0\end{array}$ & $M G / L$ & $\mid<$ & $\begin{array}{l}0.53 \\
0.01 \\
0.03 \\
0.01\end{array}$ & $\begin{array}{l}0.01 \\
0.01 \\
0.01 \\
0.01\end{array}$ & : \\
\hline
\end{tabular}

FORMATION OF COMPLETION CODE:

AL - ALLUVIUM

PARAMETER VALUE INDICATOR (PVI): < - LESS THAN DETECTION LIMIT
FLOW RELATIONSHIP CODE:

D - DOWN GRADIENT

O - ON-SITE

SAMPLE ID CODES

0001 - FILTERED SAMPLE (.45 MICRONS) 
TABLE 3.27 BASELINE GROUNDWATER QUALITY DATA BY PARAMETER FOR THE ALLUVIUM NC AND UC PROCESSING SITES, SLICK ROCK, COLORADO

SITE: SRKO1 SLICK ROCK (BOTH SITES)

06/30/86 TO $10 / 13 / 92$

REPORT DATE : $07 / 26 / 93$

\begin{tabular}{|c|c|c|c|c|c|c|c|c|c|c|c|c|}
\hline & PARAMETER NAME & $\begin{array}{l}\text { LOCATION } \\
\text { ID }\end{array}$ & LOG DATE & $\begin{array}{c}\text { SAMPLE } \\
\text { ID }\end{array}$ & $\begin{array}{l}\text { FORM } \\
\text { COMP }\end{array}$ & $\begin{array}{l}\text { FLOW } \\
\text { REL. }\end{array}$ & $\begin{array}{l}\text { UNITS OF } \\
\text { MEASURE }\end{array}$ & PVI & $\begin{array}{l}\text { PARAMETER } \\
\text { VALUE }\end{array}$ & FLAGS & $\begin{array}{l}\text { DETECTION } \\
\text { LIMIT }\end{array}$ & $\begin{array}{l}\text { PARAMETER } \\
\text { UNCERTAINTY }\end{array}$ \\
\hline & VANADIUM & $\begin{array}{l}0503 \\
0503 \\
0503 \\
0504 \\
0504 \\
0504 \\
0504 \\
0504 \\
0504 \\
0504 \\
0506 \\
0506 \\
0506 \\
0506 \\
0506 \\
0506 \\
0507 \\
0507 \\
0507 \\
0507 \\
0507 \\
0507 \\
0507 \\
0508 \\
0508 \\
0508 \\
0508 \\
0508 \\
0508 \\
0509 \\
0509 \\
0509 \\
0509 \\
0509 \\
0509 \\
0510 \\
0510 \\
0510\end{array}$ & $\begin{array}{l}08 / 08 / 91 \\
12 / 09 / 91 \\
10 / 09 / 92 \\
07 / 01 / 86 \\
10 / 14 / 87 \\
05 / 16 / 90 \\
04 / 03 / 91 \\
08 / 27 / 91 \\
12 / 09 / 91 \\
10 / 09 / 92 \\
07 / 01 / 86 \\
10 / 14 / 87 \\
03 / 28 / 91 \\
08 / 08 / 91 \\
11 / 20 / 91 \\
10 / 08 / 92 \\
06 / 30 / 86 \\
10 / 14 / 87 \\
05 / 16 / 90 \\
03 / 28 / 91 \\
08 / 09 / 91 \\
12 / 05 / 91 \\
10 / 08 / 92 \\
06 / 30 / 86 \\
10 / 14 / 87 \\
03 / 27 / 91 \\
08 / 28 / 91 \\
12 / 05 / 91 \\
10 / 10 / 92 \\
07 / 17 / 86 \\
10 / 14 / 87 \\
03 / 27 / 91 \\
08 / 28 / 91 \\
11 / 21 / 91 \\
10 / 13 / 92 \\
06 / 30 / 86 \\
10 / 14 / 87 \\
05 / 16 / 90\end{array}$ & $\begin{array}{l}0001 \\
0001 \\
0001 \\
0001 \\
0001 \\
0001 \\
0001 \\
0001 \\
0001 \\
0001 \\
0001 \\
0001 \\
0001 \\
0001 \\
0001 \\
0001 \\
0001 \\
0001 \\
0001 \\
0001 \\
0001 \\
0001 \\
0001 \\
0001 \\
0001 \\
0001 \\
0001 \\
0001 \\
0001 \\
0001 \\
0001 \\
0001 \\
0001 \\
0001 \\
0001 \\
0001 \\
0001 \\
0001\end{array}$ & $\begin{array}{l}A L \\
A L \\
A L \\
A L \\
A L \\
A L \\
A L \\
A L \\
A L \\
A L \\
A L \\
A L \\
A L \\
A L \\
A L \\
A L \\
A L \\
A L \\
A L \\
A L \\
A L \\
A L \\
A L \\
A L \\
A L \\
A L \\
A L \\
A L \\
A L \\
A L \\
A L \\
A L \\
A L \\
A L \\
A L \\
A L \\
A L \\
A L\end{array}$ & $\begin{array}{l}0 \\
0 \\
0 \\
D \\
D \\
D \\
D \\
D \\
D \\
D \\
D \\
D \\
D \\
D \\
D \\
D \\
D \\
D \\
D \\
D \\
D \\
D \\
D \\
0 \\
0 \\
0 \\
0 \\
0 \\
0 \\
0 \\
0 \\
0 \\
0 \\
0 \\
0 \\
0 \\
0 \\
0\end{array}$ & $M G / L$ & $\begin{array}{l}< \\
< \\
< \\
< \\
< \\
< \\
< \\
< \\
< \\
< \\
< \\
< \\
< \\
< \\
< \\
< \\
< \\
< \\
< \\
< \\
<\end{array}$ & $\begin{array}{l}0.01 \\
0.1 \\
0.05 \\
0.33 \\
0.01 \\
0.02 \\
0.01 \\
0.01 \\
0.01 \\
0.01 \\
0.33 \\
0.01 \\
0.01 \\
0.01 \\
0.01 \\
0.01 \\
0.23 \\
0.01 \\
0.02 \\
0.01 \\
0.01 \\
0.01 \\
0.01 \\
1.04 \\
0.66 \\
0.01 \\
0.62 \\
0.59 \\
0.54 \\
0.43 \\
0.01 \\
0.61 \\
0.01 \\
0.01 \\
0.01 \\
0.36 \\
0.01 \\
0.02\end{array}$ & $\begin{array}{l}\text { I } \\
\mathbf{J}\end{array}$ & $\begin{array}{l}0.01 \\
0.1 \\
0.05 \\
0.01 \\
0.01 \\
0.01 \\
0.01 \\
0.01 \\
0.01 \\
0.01 \\
0.01 \\
0.01 \\
0.01 \\
0.01 \\
0.01 \\
0.01 \\
0.01 \\
0.01 \\
0.01 \\
0.01 \\
0.01 \\
0.01 \\
0.01 \\
0.01 \\
0.01 \\
0.01 \\
0.01 \\
0.01 \\
0.01 \\
0.01 \\
0.01 \\
0.01 \\
0.01 \\
0.01 \\
0.01 \\
0.01 \\
0.01 \\
0.01\end{array}$ & 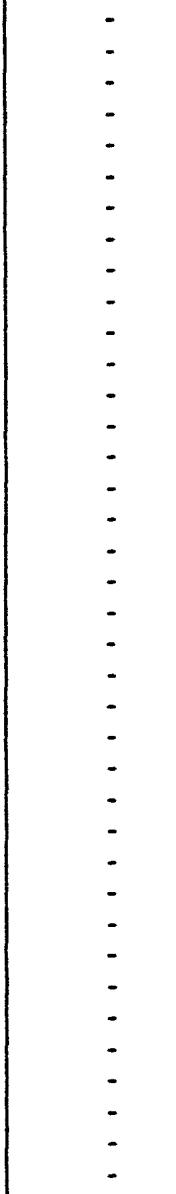 \\
\hline
\end{tabular}

FORMATION OF COMPLETION COOE:

AL - ALLUVIUM

PARAMETER VALUE INDICATOR (PVI): < - LESS than DETECTION LIMIT
FLOW RELATIONSHIP COOE:

O - ON-SITE

D - DOWN GRADIENT

SAMPLE ID COOES:

0001 - FILTERED SAMPLE (.45 MICRONS)

OTHER PARAMETER VALUE FLAGS:

1 - INCREASED DETECTION LIMIT DUE TO REQUIRED DILUTION

J - eSTIMATED VALUE 
TABLE 3.27 BASELINE GROUNDHATER QUALITY DATA BY PARAMETER FOR THE ALLUVIUM MC AND UC PROCESSING SITES, SLICK ROCK, COLORADO

SITE: SRKO1 SLICK ROCK (BOTH SITES)

$06 / 30 / 86$ TO $10 / 13 / 92$

REPORT DATE : 07/26/93

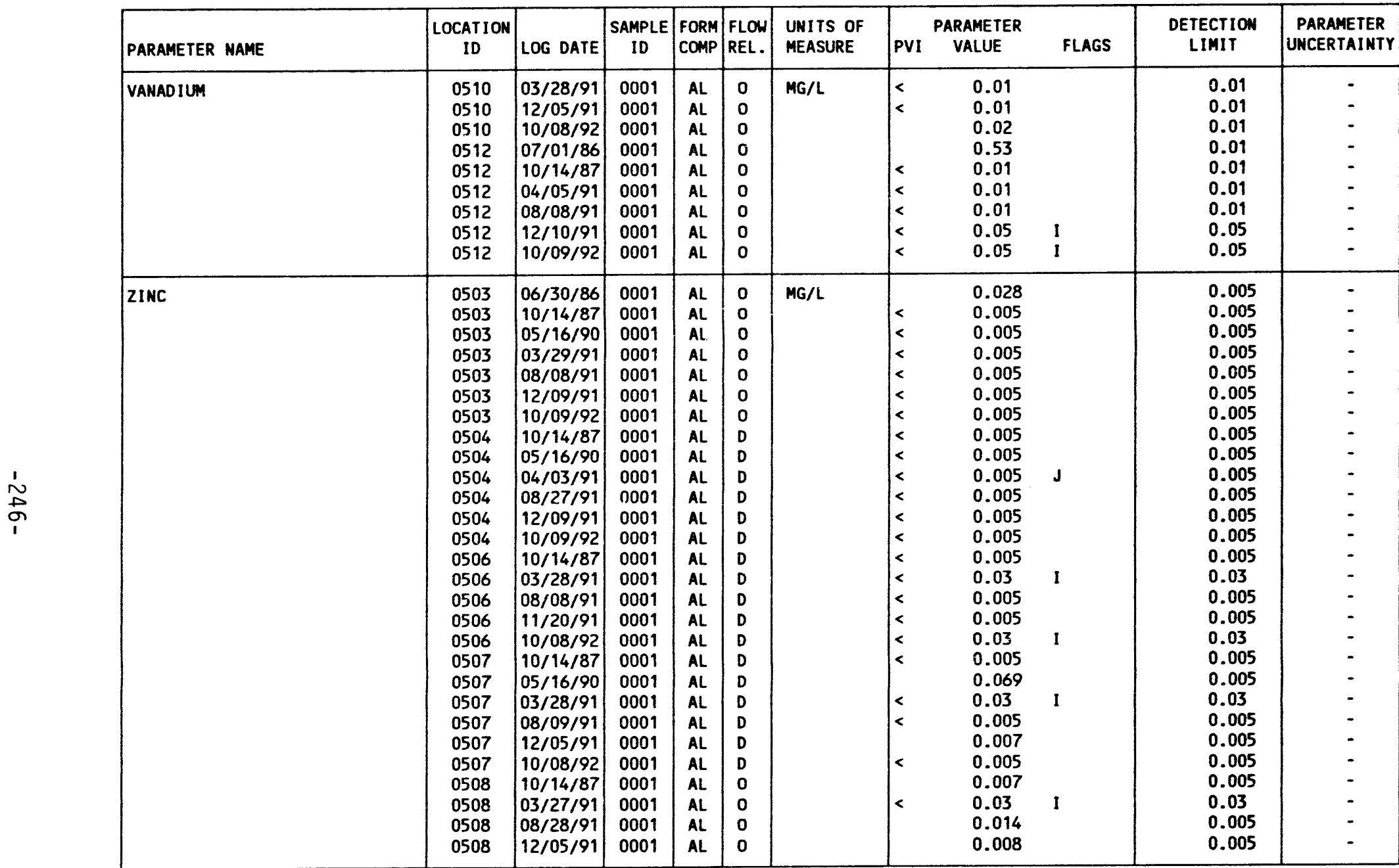

FORMATION OF COMPLETION COOE:

AL - ALLUVIUM

PARAMETER VALUE INDICATOR (PVI): < - LESS THAN DETECTION LIMIT

\section{FLOW RELATIONSHIP COOE:}

O - ON-SITE

D - DOWN GRADIENT

0001 - FILTERED SAMPLE (.45 MICRONS)

OTHER PARAMETER VALUE FLAGS:

I - INCREASED DETECTION LIMIT DUE TO REQUIRED DILUTION

J - ESTIMATED VALUE 
TABLE 3.27 BASELINE GROUNDWATER QUALITY DATA BY PARAMETER FOR THE ALLUVIUM TABLE 3.27 BASELINE GROUNDWATER QUALITY DATA BY PA

SITE: SRKO1 SLICK ROCK (BOTH SITES)

SITE: SRKO1 SLICK ROCK

REPORT DATE: $07 / 26 / 93$

\begin{tabular}{|c|c|c|c|c|c|c|c|c|c|c|c|}
\hline PARAMETER NAME & $\underset{\text { ID }}{\text { LOCATION }}$ & LOG DATE & $\begin{array}{c}\text { SAMPLE } \\
\text { ID }\end{array}$ & $\begin{array}{l}\text { FORM } \\
\text { COMP }\end{array}$ & $\begin{array}{l}\text { FLOW } \\
\text { REL. }\end{array}$ & $\begin{array}{l}\text { UNITS OF } \\
\text { MEASURE }\end{array}$ & PVI & $\begin{array}{l}\text { PARAMETER } \\
\text { VALUE }\end{array}$ & FLAGS & $\begin{array}{l}\text { DETECTION } \\
\text { LIMIT }\end{array}$ & $\begin{array}{l}\text { PARAMETER } \\
\text { UNCERTAINTY }\end{array}$ \\
\hline ZINC & $\begin{array}{l}0508 \\
0509 \\
0509 \\
0509 \\
0509 \\
0509 \\
0510 \\
0510 \\
0510 \\
0510 \\
0510 \\
0510 \\
0512 \\
0512 \\
0512 \\
0512 \\
0512\end{array}$ & \begin{tabular}{|l|}
$10 / 10 / 92$ \\
$10 / 14 / 87$ \\
$03 / 27 / 91$ \\
$08 / 28 / 91$ \\
$11 / 21 / 91$ \\
$10 / 13 / 92$ \\
$06 / 30 / 86$ \\
$10 / 14 / 87$ \\
$05 / 16 / 90$ \\
$03 / 28 / 91$ \\
$12 / 05 / 91$ \\
$10 / 08 / 92$ \\
$10 / 14 / 87$ \\
$04 / 05 / 91$ \\
$08 / 08 / 91$ \\
$12 / 10 / 91$ \\
$10 / 09 / 92$
\end{tabular} & $\begin{array}{l}0001 \\
0001 \\
0001 \\
0001 \\
0001 \\
0001 \\
0001 \\
0001 \\
0001 \\
0001 \\
0001 \\
0001 \\
0001 \\
0001 \\
0001 \\
0001 \\
0001\end{array}$ & $\begin{array}{l}A L \\
A L \\
A L \\
A L \\
A L \\
A L \\
A L \\
A L \\
A L \\
A L \\
A L \\
A L \\
A L \\
A L \\
A L \\
A L \\
A L\end{array}$ & $\begin{array}{l}0 \\
0 \\
0 \\
0 \\
0 \\
0 \\
0 \\
0 \\
0 \\
0 \\
0 \\
0 \\
0 \\
0 \\
0 \\
0 \\
0\end{array}$ & $M G / L$ & $\begin{array}{l}< \\
< \\
< \\
< \\
< \\
< \\
< \\
< \\
< \\
< \\
< \\
<\end{array}$ & $\begin{array}{l}0.005 \\
0.005 \\
0.005 \\
0.005 \\
0.005 \\
0.005 \\
0.06 \\
0.005 \\
0.009 \\
0.03 \\
0.006 \\
0.005 \\
0.005 \\
0.005 \\
0.005 \\
0.005 \\
0.005\end{array}$ & 1 & $\begin{array}{l}0.005 \\
0.005 \\
0.005 \\
0.005 \\
0.005 \\
0.005 \\
0.005 \\
0.005 \\
0.005 \\
0.03 \\
0.005 \\
0.005 \\
0.005 \\
0.005 \\
0.005 \\
0.005 \\
0.005\end{array}$ & $\begin{array}{l}- \\
- \\
- \\
- \\
- \\
- \\
- \\
- \\
- \\
- \\
- \\
-\end{array}$ \\
\hline
\end{tabular}

FORMATION OF COMPLETION CODE:

AL - ALLUVIUM

PARAMETER VALUE INDICATOR (PVI): < - LESS THAN DETECTION LIM!T
FLOW RELATIONSHIP COOE:

O- ON-SITE

SAMPLE ID COOES:

0001 - FILTERED SAMPLE (.45 MICRONS)

OTHER PARAMETER VALUE FLAGS:

I - INCREASED DETECTION LIMIT DUE TO REQUIRED DILUTION

DATA FILE NAME: M: IDARTISRK01\GWD10041.DAT 


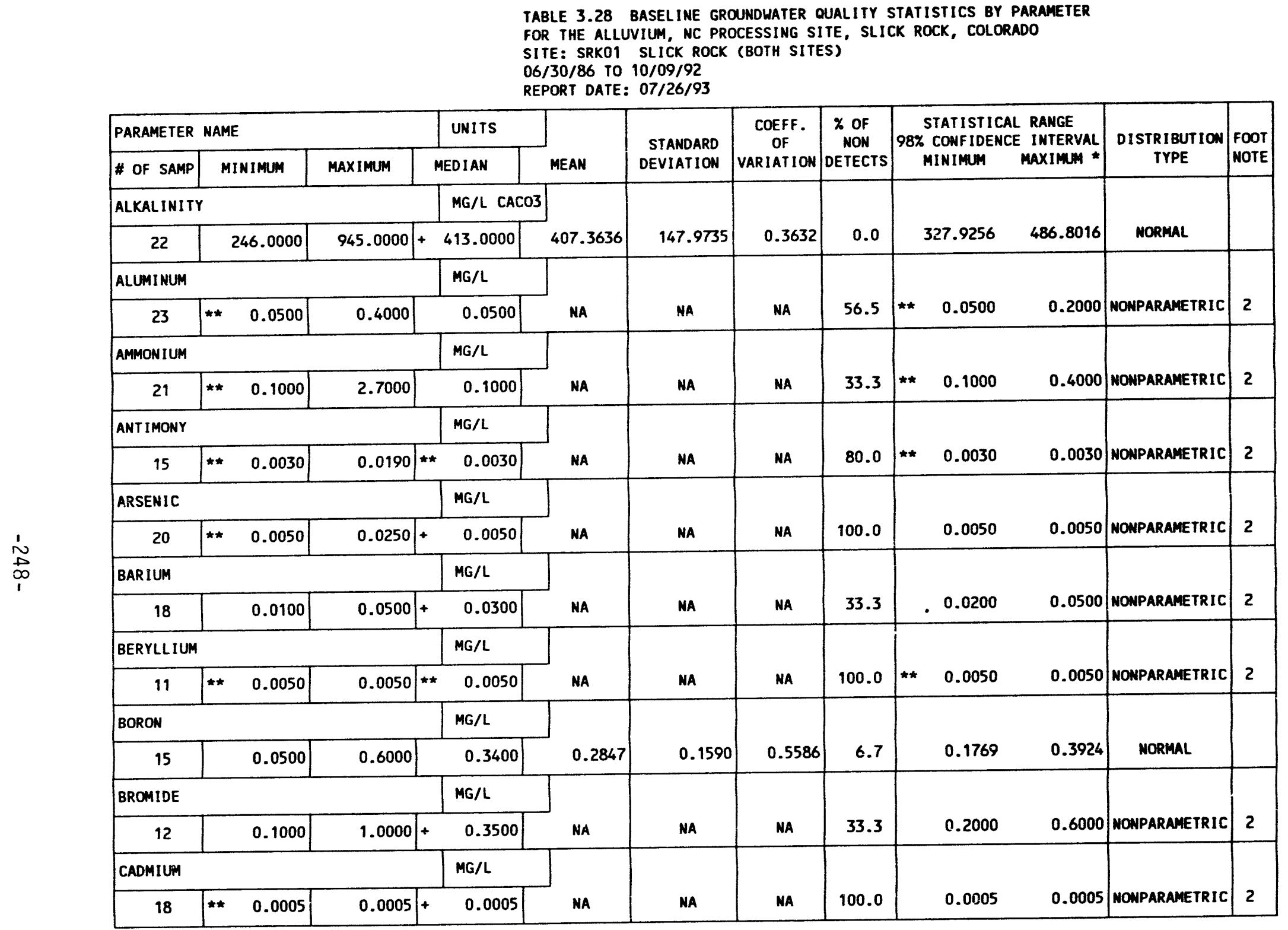

** The reported value is the minimum detection limit of the data set

* The sample size is even, so the median value is the arithidence interval, $\alpha=0.01$

2) The nonparametric distribution was used because the nondetected values comprise more than $15 \%$ of the samples. 
TABLE 3.28 BASELINE GROUNDWATER QUALITY STATISTICS BY PARAMETER

FOR THE ALLUVIUM, NC PROCESSING SITE, SLICK ROCK, COLORADO

SITE: SRKO1 SLICK ROCK (BOTH SITES)

$06 / 30 / 86$ TO $10 / 09 / 92$

REPORT DATE: $07 / 26 / 93$

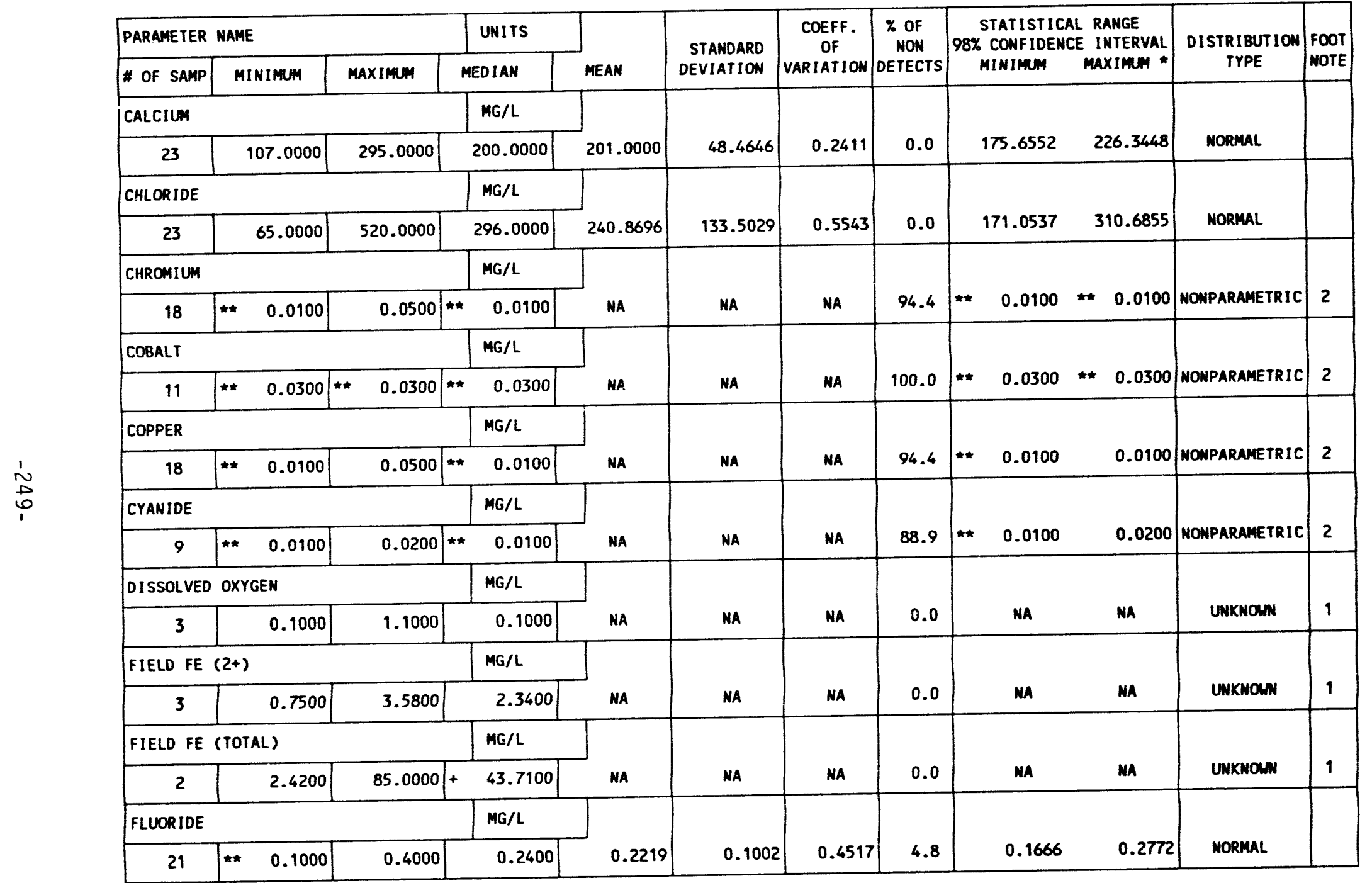

* The reported value is the minimm detection limit of the data set

- The sample size is even, so the median value is the arithmetic average of the two

1) A minimm of 4 samples must be available for the statistical analysis.

2) The nonparametric distribution was used because the nondetected values comprise more than $15 \%$ of the samples. 
TABLE 3.28 BASELINE GROUNDWATER QUALITY STATISTICS BY PARAMETER

FOR THE ALLUVIUM, NC PROCESSING SITE, SLICK ROCK, COLORADO

SITE: SRKO1 SLICK ROCK (BOTH SITES)

06/30/86 TO 10/09/92

REPORT DATE: $07 / 26 / 93$

\begin{tabular}{|c|c|c|c|c|c|c|c|c|c|c|c|}
\hline \multicolumn{3}{|c|}{ PARAMETER MAME } & UNITS & \multirow[b]{2}{*}{ MEAN } & \multirow{2}{*}{$\begin{array}{l}\text { STANDARD } \\
\text { DEVIATION }\end{array}$} & \multirow{2}{*}{$\begin{array}{c}\text { COEFF. } \\
\text { OF } \\
\text { VARIATION }\end{array}$} & \multirow{2}{*}{$\begin{array}{c}x \text { OF } \\
\text { NON } \\
\text { DETECTS }\end{array}$} & \multirow{2}{*}{\multicolumn{2}{|c|}{$\begin{array}{l}\text { STATISTICAL RANGE } \\
\text { 98\% CONFIDENCE INTERVAL } \\
\text { MINIMM MAXIMUM * }\end{array}$}} & \multirow{2}{*}{$\begin{array}{c}\text { DISTRIBUTION } \\
\text { TYPE }\end{array}$} & \multirow{2}{*}{$\begin{array}{l}\text { FOOT } \\
\text { NOTE }\end{array}$} \\
\hline \# OF SAMP & MINIMUM & MAXIMUN & MEDIAN & & & & & & & & \\
\hline \multicolumn{3}{|c|}{ GROSS ALPHA } & $\mathrm{PCl} / \mathrm{L}$ & & \multirow[b]{2}{*}{569.3336} & \multirow[b]{2}{*}{0.4358} & \multirow[b]{2}{*}{0.0} & \multirow[b]{2}{*}{859.7317} & \multirow[b]{2}{*}{1753.1516} & \multirow[b]{2}{*}{ NORMAL } & \\
\hline 12 & 641.0000 & 2299.0000 & +1199.5000 & 1306.4417 & & & & & & & \\
\hline \multicolumn{3}{|l|}{ GROSS BETA } & $\mathrm{PCI} / \mathrm{L}$ & \multirow[b]{2}{*}{535.2500} & \multirow[b]{2}{*}{257.8601} & \multirow[b]{2}{*}{0.4818} & \multirow[b]{2}{*}{0.0} & \multirow[b]{2}{*}{332.9280} & \multirow[b]{2}{*}{737.5720} & \multirow[b]{2}{*}{ MORMAL } & \\
\hline 12 & 188.0000 & 984.0000 & $+\quad 516.5000$ & & & & & & & & \\
\hline \multicolumn{3}{|l|}{ IRON } & $M G / L$ & \multirow[b]{2}{*}{2.8126} & \multirow[b]{2}{*}{2.3208} & \multirow[b]{2}{*}{0.8251} & \multirow[b]{2}{*}{0.0} & \multirow[b]{2}{*}{1.5989} & \multirow[b]{2}{*}{4.0263} & \multirow[b]{2}{*}{ MORMAL } & \\
\hline 23 & 0.0700 & 8.8000 & 2.3900 & & & & & & & & \\
\hline \multicolumn{3}{|l|}{ LEAD } & $M G / L$ & & & & & & & & \\
\hline 18 & $\star \star \quad-0030$ & 0.0100 & $\star \star \quad 0.0030$ & NA & NA & NA & 100.0 & 0.0030 & 0.0050 & MONPARAMETRIC & 2 \\
\hline LEAD-210 & & & $\mathrm{PCI} / \mathrm{L}$ & & & & & & & & \\
\hline 7 & 33.0000 & 216.0000 & 105.0000 & 105.1429 & 65.9866 & 0.6276 & 0.0 & 26.7546 & 183.5311 & NORMAL & \\
\hline MAGNESIUM & & & $\mathrm{MG} / \mathrm{L}$ & & & & & & & & \\
\hline 23 & 36.8000 & 200.0000 & 87.8000 & 92.6739 & 45.2930 & 0.4887 & 0.0 & 68.9878 & 116.3601 & MORMAL & \\
\hline MANGANESE & & & $M G / L$ & & & & & & & & \\
\hline 23 & 0.0900 & 0.8600 & 0.4500 & 0.4683 & 0.1890 & 0.4035 & 0.0 & 0.3694 & 0.5671 & MORMAL & \\
\hline MERCURY & & & $M G / L$ & & & & & & & & \\
\hline 15 & $\star \star \quad 0.0002$ & $\# \quad 0.0002$ & 0.0002 & NA & NA & NA & 100.0 & 0.0002 & $\star \quad 0.0002$ & NONPARAMETRIC & 2 \\
\hline MOLYBDENUY & & & $M G / L$ & & & & & & & & \\
\hline 23 & $\begin{array}{ll}* & 0.0100\end{array}$ & 0.1700 & 0.0200 & NA & NA & NA & 39.1 & ** $\quad 0.0100$ & 0.0400 & NOWPARAMETRIC & 2 \\
\hline NET GROSS & ALPHA $\quad * \star \star$ & & $\mathrm{PCl} / \mathrm{L}$ & & & & & & & & \\
\hline 12 & -622.7000 & 139.9200 & +-81.6900 & NA & NA & NA & 0.0 & -493.0000 & 123.8600 & NONPARAMETRIC & 9 \\
\hline
\end{tabular}

*** NET GROSS ALPHA (GROSS ALPHA - URANIUM) WITH 1 MG URANIUM $=686 \mathrm{PCI}$

** The reported value is the minimm detection limit of the data set

* The reported value is the minime de value is the arithmetic average of the two middle values

+ The sample size is even, so the median value is the arithmetic average $\alpha=0.01$

- The statistical maximum is the 99 percent one sided confidence

2) The nonparametric distribution was used because the nondetected values comprise more than $15 \%$ af the sailed the normal distribution test and inclues values $\leq 0$. 
TABLE 3.28 BASELINE GROUNDHATER QUALITY STATISTICS BY PARAMETER

FOP THE ALLUVIUM, MC PROCESSING SITE, SLICK ROCK, COLORADO

SITE: SRKO1 SLICK ROCK

$06 / 30 / 86$ TO $10 / 09 / 92$

REPORT DATE: $07 / 26 / 93$

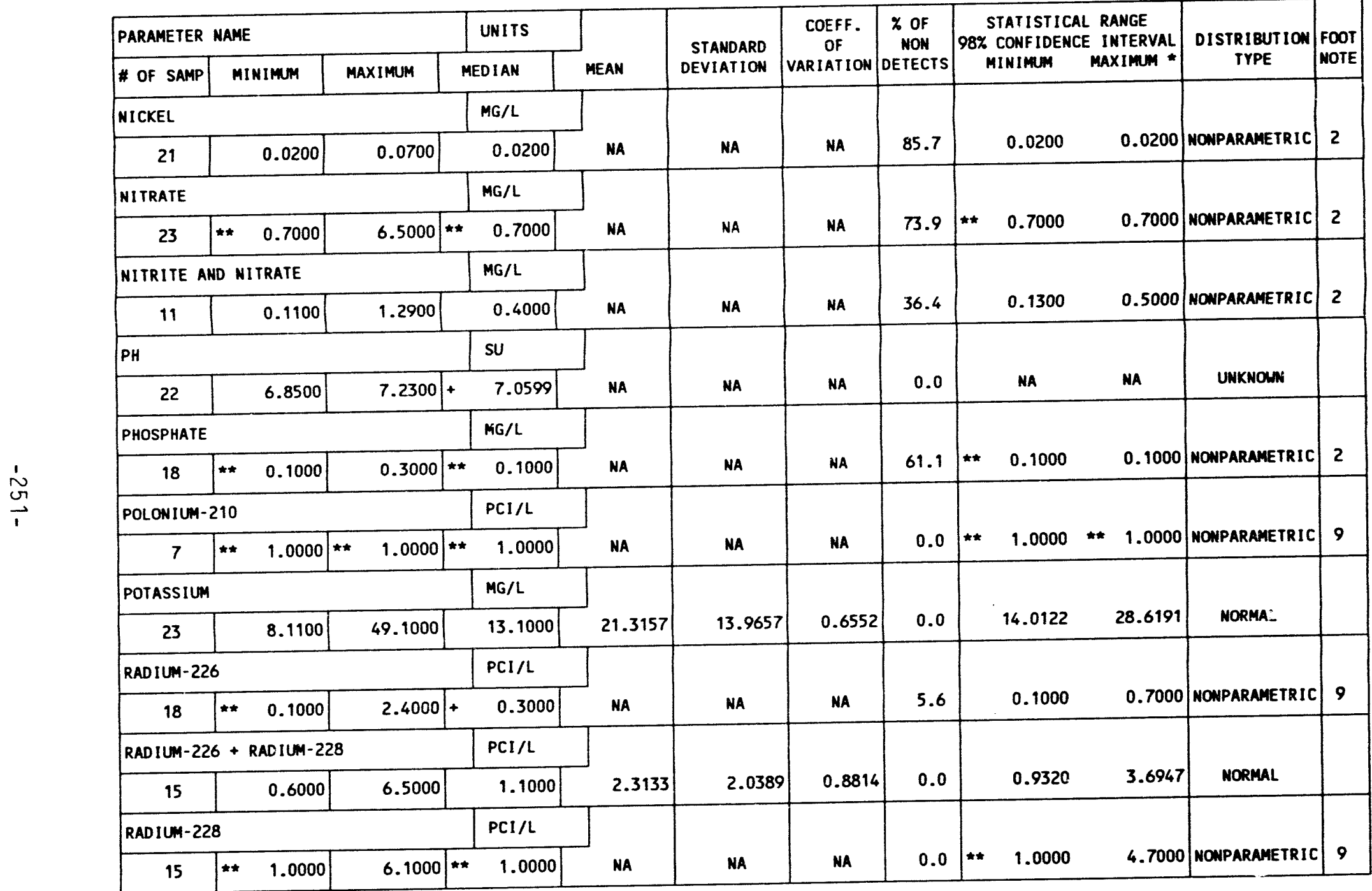

** The reported value is the minimum detection limit of the data set

+ The sample size is even so the median value is the arithmetic average of the two midale values

- The sample size is encent one sided confidence interval, $\alpha=0.01$

1) A inim of 4 samples must be available for the statistical analysis.

1) A minimum of

2) The nonparametric distribution was used because the nondetected values comprise more than $15 \%$ of the samples. 
TABLE 3.28 BASELINE GROUNDWATER QUALITY STATISTICS BY PARAMETER

FOR THE ALLUVIUM, NC PROCESSING SITE, SLICK ROCK, COLORADO

SITE: SRK01 SLICK ROCK (BOTH SITES)

06/30/86 TO 10/09/92

REPORT DATE: 07/26/93

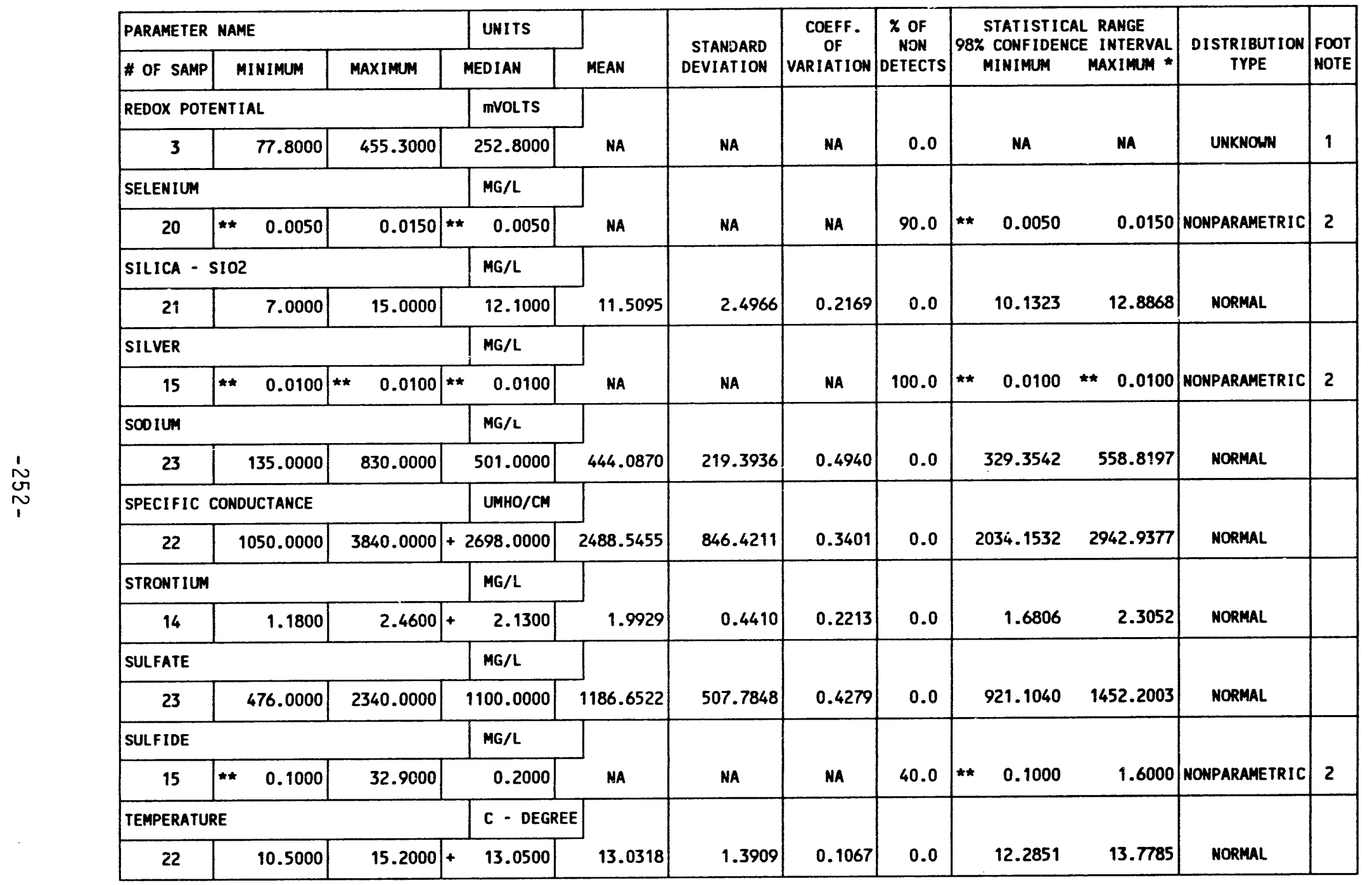

** The reported value is the minimum detection limit of the data set

+ The sample size is even, so the median value is the arithmetic average of the two middle values

* The statistical maximum is the 99 percent one sided confidence interval, $\alpha=0.01$

1) A minimm of 4 samples must be available for the statistical analysis.

2) The nonparamet ic distribution was used because the nondetected values comprise more than $15 \%$ of the samples. 
TABLE 3.28 BASELINE GROUNDUATER OUALITY STATISTICS BY PARAMETER

TABLE 3.28 BASELINE GROUNOWATE SITE, SLICK ROCK, COLORADO

FOR THE ALLUVIUM, NC PROCESSING SITE,
SITE: SRKO1 SLICK ROCK (BOTH SITES)

06/30/86 TO $10 / 09 / 92$

REPORT DATE: $07 / 26 / 93$

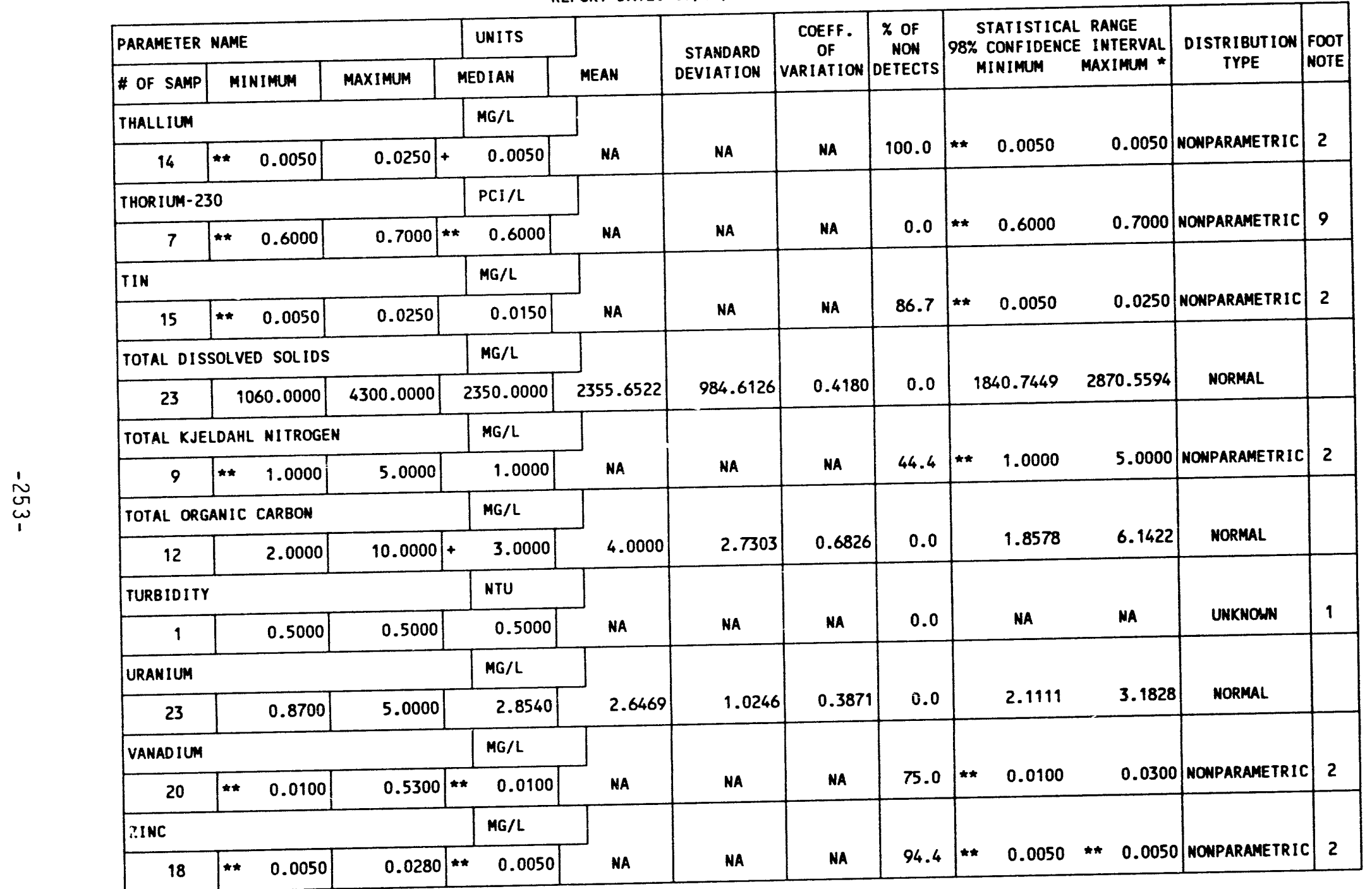

* The reported value is the minimum detection timit of the data set

+ The sample size is even, so the median value is the arithmetic average of the $\alpha=0.01$

- The statistical maximm is the 99 percent one sided confidence interval.

1) A minimm of 4 samples must be available for the statistical analysis. comprise more than $15 \%$ of the samples.

2) The nonparametric distribution was used because the nondetected values comprise more than 
Table 3.29 summary of regulated constituents in alluvial baseline groundwater, NC processing site, slick Rock, Colorado

Constituents with MCLs

\begin{tabular}{llllc}
\hline \multicolumn{1}{c}{ Parameter } & $\begin{array}{c}\text { Baseline } \\
\text { Median }\end{array}$ & $\begin{array}{c}\text { Baseline } \\
\text { Stat Max }\end{array}$ & $\begin{array}{c}\text { Background } \\
\text { Stat Max }\end{array}$ & MCL \\
\hline Arsenic & $0.01^{\mathrm{g}}$ & $0.01^{\mathrm{g}}$ & $0.01^{\mathrm{g}}$ & 0.05 \\
Barium & $0.10^{\mathrm{g}}$ & $0.10^{\mathrm{g}}$ & $0.20^{\mathrm{e}}$ & 1.00 \\
Cadmium & $0.001^{\mathrm{g}}$ & $0.001^{\mathrm{g}}$ & $0.001^{\mathrm{g}}$ & 0.01 \\
Chromium & $0.01^{\mathrm{g}}$ & $0.01^{\mathrm{g}}$ & $0.04^{\mathrm{e}}$ & 0.05 \\
Net gross alpha & $-81.69^{\mathrm{e}}$ & 123.86 & $4.72^{\mathrm{e}}$ & 15.00 \\
Lead & $0.01^{\mathrm{g}}$ & $0.01^{\mathrm{g}}$ & $0.01^{\mathrm{g}}$ & 0.05 \\
Mercury & $0.0002^{\mathrm{g}}$ & $0.0002^{\mathrm{g}}$ & $0.0002^{\mathrm{g}}$ & 0.002 \\
Molybdenum & $0.02^{\mathrm{e}}$ & 0.04 & $0.13^{\mathrm{d}}$ & 0.10 \\
Nitrate & $1.00^{\mathrm{g}}$ & $1.0 \mathrm{~g}$ & $1.6^{\mathrm{e}}$ & 44.0 \\
Radium-226, $-228^{\mathrm{f}}$ & $2.31^{\mathrm{d}}$ & 3.69 & $7.80^{\mathrm{e}}$ & 5.0 \\
Selenium & $0.005^{\mathrm{g}}$ & $0.015^{\mathrm{e}}$ & $0.005^{\mathrm{g}}$ & 0.01 \\
Silver & $0.01^{\mathrm{g}}$ & $0.01^{\mathrm{g}}$ & $0.01^{\mathrm{g}}$ & 0.05 \\
Uranium & $2.647^{\mathrm{d}}$ & 3.183 & $0.048^{\mathrm{d}}$ & 0.044 \\
\hline & & & & \\
\hline
\end{tabular}


Table 3.29 Summary of regulated constituents in alluvial baseline groundwater, NC processing site, slick Rock, Colorado (concluded)

\begin{tabular}{|c|c|c|c|c|}
\hline \multicolumn{5}{|c|}{ Constituents without MCLs } \\
\hline Parameter & $\begin{array}{c}\text { Baseline } \\
\text { Median }\end{array}$ & $\begin{array}{l}\text { Baseline } \\
\text { Stat Max }\end{array}$ & $\begin{array}{l}\text { Background } \\
\text { Stat. Max }\end{array}$ & $\mathrm{MCL}$ \\
\hline Antimony & $0.003^{\mathrm{g}}$ & $0.003^{8}$ & $0.003^{\mathrm{B}}$ & None \\
\hline Beryllium & $0.01^{\mathrm{g}}$ & $0.01^{\mathrm{g}}$ & $0.01^{\mathrm{g}, \mathrm{h}}$ & None \\
\hline Cobalt & $0.05^{\mathrm{g}}$ & $0.05^{\mathrm{g}}$ & $0.05^{g, h}$ & None \\
\hline Copper & $0.02^{\mathrm{g}}$ & $0.02^{\mathrm{g}}$ & $0.05^{\mathrm{e}}$ & None \\
\hline Cyanide & $0.01^{\mathrm{g}}$ & $0.02^{\mathrm{e}}$ & $0.01^{g, h}$ & None \\
\hline Nickel & $0.04^{\mathrm{g}}$ & $0.04^{\mathrm{g}}$ & $0.04^{g}$ & None \\
\hline Sulfide & $0.2^{\mathrm{e}}$ & 1.6 & $1.0^{e}$ & None \\
\hline Thallium & $0.01^{\mathrm{g}}$ & $0.01^{\mathrm{g}}$ & $0.01^{\mathrm{g}}$ & None \\
\hline Tin & $0.015^{\mathrm{e}}$ & 0.025 & $0.005^{g}$ & None \\
\hline Vanadium & $0.01^{\mathrm{g}}$ & $0.03^{\mathrm{e}}$ & $0.39^{e}$ & None \\
\hline Zinc & $0.005^{\mathrm{g}}$ & $0.005^{8}$ & $0.011^{\mathrm{c}}$ & None \\
\hline
\end{tabular}

${ }^{\mathrm{a}} \mathrm{All}$ units are $\mathrm{mg} / \mathrm{l}$ unless otherwise noted.

${ }^{b}$ NC Processing site background groundwater statistical maximum.

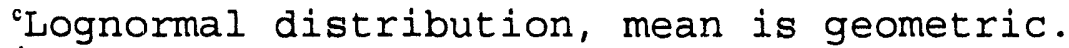

'Normal distribution, mean is arithmetic.

'Nonparametric distribution

Units are $\mathrm{pCi} / \mathrm{l}$.

'Statistical values are below laboratory detection limits in

Table 8.1 of the Technical Approach Document (DOE, 1989).

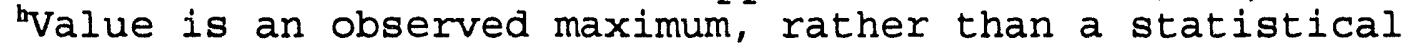
maximum, because less than four samples were available for statistical analysis. 


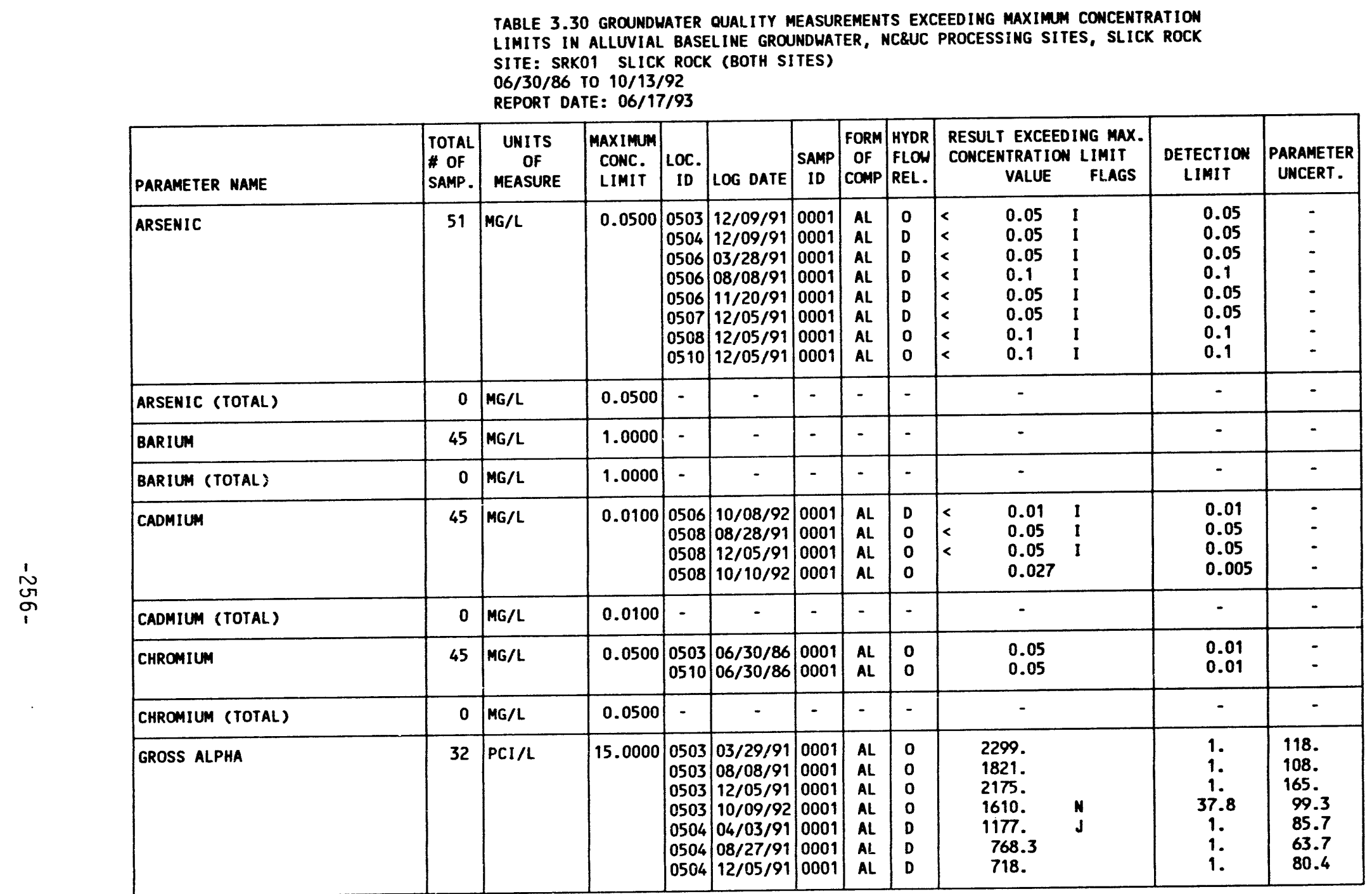

< - the data is flagged as a mon-detect, so the result is an estimated value or the detection limit

FORMATION OF COMPLETION COOE:

AL - ALLUVIUM

OTHER PARAMETER VALUE FLAGS:

I - INCREASED DETECTION LIMIT DUE TO REQUIRED DILUTION

$J$ - ESTIMATED VALUE

N - SPIKE SAMPLE RECOVERY NOT WITHIN CONTROL LIMITS
FLON RELATIONSHIP COOE:

O - ON-SITE

D - DOUN GRADIENT

SAMPLE ID CODES:

0001 - FILTERED SAMPLE (.45 MICRONS) 
TABLE 3.30 GROUNDWATER QUALITY MEASUREMENTS EXCEEDING MAXIMMM CONCENTRATION LIMITS IN ALLUVIAL BASELINE GROUNDHATER, NC\&UC PROCESSING SITES, SLICK ROCK SITE: SRKOI SLICK ROCK (BOTH SITES)

06/30/86 TO $10 / 13 / 92$

REPORT DATE: $06 / 17 / 93$

\begin{tabular}{|c|c|c|c|c|c|c|c|c|c|c|c|c|}
\hline PARAMETER NAME & $\begin{array}{l}\text { TOTAL } \\
\# \text { OF } \\
\text { SAMP. }\end{array}$ & $\begin{array}{c}\text { UNITS } \\
\text { OF } \\
\text { MEASURE }\end{array}$ & $\begin{array}{l}\text { MaXIMUM } \\
\text { CONC. } \\
\text { LIMIT }\end{array}$ & $\underset{10}{L O C .}$ & LOG DATE & $\begin{array}{c}\text { SAMP } \\
\text { ID }\end{array}$ & $\begin{array}{l}\text { FORM } \\
\text { OF } \\
\text { COMP }\end{array}$ & $\begin{array}{l}\text { HYDR } \\
\text { FLOW } \\
\text { REL. }\end{array}$ & $\begin{array}{c}\text { RESULT EXCEE } \\
\text { CONCENTRATIO } \\
\text { VALUE }\end{array}$ & $\begin{array}{l}\text { DING maX. } \\
\text { W LIMIT } \\
\text { FLAGS }\end{array}$ & $\begin{array}{l}\text { DETECTION } \\
\text { LIMIT }\end{array}$ & $\begin{array}{l}\text { PARAMETER } \\
\text { UNCERT. }\end{array}$ \\
\hline GROSS ALPHA & 32 & $\mathrm{PCI} / \mathrm{L}$ & 15.0000 & $\begin{array}{l}0504 \\
0506 \\
0506 \\
0506 \\
0507 \\
0507 \\
0507 \\
0508 \\
0508 \\
0508 \\
0509 \\
0509 \\
0509 \\
0509 \\
0510 \\
0510 \\
0510 \\
0512 \\
0512 \\
0512 \\
0512\end{array}$ & $\begin{array}{l}10 / 09 / 92 \\
03 / 28 / 91 \\
08 / 08 / 91 \\
10 / 08 / 92 \\
03 / 28 / 91 \\
08 / 09 / 91 \\
12 / 05 / 91 \\
03 / 27 / 91 \\
08 / 28 / 91 \\
10 / 10 / 92 \\
03 / 27 / 91 \\
08 / 28 / 91 \\
12 / 05 / 91 \\
10 / 13 / 92 \\
03 / 28 / 91 \\
08 / 28 / 91 \\
10 / 08 / 92 \\
04 / 05 / 91 \\
08 / 08 / 91 \\
12 / 05 / 91 \\
10 / 09 / 92\end{array}$ & $\begin{array}{l}0001 \\
0001 \\
0001 \\
0001 \\
0001 \\
0001 \\
0001 \\
0001 \\
0001 \\
0001 \\
0001 \\
0001 \\
0001 \\
0001 \\
0001 \\
0001 \\
0001 \\
0001 \\
0001 \\
0001 \\
0001\end{array}$ & $\begin{array}{l}A L \\
A L \\
A L \\
A L \\
A L \\
A L \\
A L \\
A L \\
A L \\
A L \\
A L \\
A L \\
A L \\
A L \\
A L \\
A L \\
A L \\
A L \\
A L \\
A L \\
A L\end{array}$ & $\begin{array}{l}D \\
D \\
D \\
D \\
D \\
D \\
D \\
0 \\
0 \\
0 \\
0 \\
0 \\
0 \\
0 \\
0 \\
0 \\
0 \\
0 \\
0 \\
0 \\
0\end{array}$ & $\begin{array}{c}641 . \\
191 . \\
23.0 \\
189 . \\
41.0 \\
30.6 \\
19.3 \\
63.2 \\
67.2 \\
23.1 \\
111 . \\
23.5 \\
19.0 \\
16.1 \\
132 . \\
84.2 \\
118 . \\
1222 . \\
916 . \\
870 . \\
1460 .\end{array}$ & $\begin{array}{l}\mathbf{N} \\
\mathbf{N}\end{array}$ & $\begin{array}{c}25.0 \\
1 . \\
1 . \\
82.4 \\
1 . \\
1 . \\
1 . \\
1 . \\
1 . \\
48.4 \\
1 . \\
1 . \\
1 . \\
20.2 \\
1 . \\
1 . \\
41.2 \\
1 . \\
1 . \\
1 . \\
22.5\end{array}$ & $\begin{array}{c}51.7 \\
140 . \\
71.2 \\
74.3 \\
17.0 \\
13.6 \\
26.0 \\
23.2 \\
34.2 \\
31.6 \\
70.7 \\
12.0 \\
23.8 \\
13.9 \\
73.1 \\
37.6 \\
40.0 \\
58.2 \\
51.1 \\
66.1 \\
72.3\end{array}$ \\
\hline GROSS ALPHA (TOTAL) & 0 & $\mathrm{PCI} / \mathrm{L}$ & 15.0000 & - & - & - & - & - & - & & - & - \\
\hline LEAD & 45 & $M G / L$ & 0.0500 & 13506 & $08 / 08 / 91$ & 0001 & AL & D & 0.05 & I & 0.05 & - \\
\hline LEAD (TOTAL) & 0 & $M G / L$ & 0.0500 & - & - & - & - & - & - & & - & $\cdot$ \\
\hline MERCURY & 37 & $M G / L$ & 0.0020 & - & - & - & - & - & - & & - & - \\
\hline MERCURY (TOTAL) & 0 & $M G / L$ & 0.0020 & - & - & - & - & - & - & & - & - \\
\hline MOLYBDENUMM & 59 & $M G / L$ & 0.1000 & $\begin{array}{l}0503 \\
0504 \\
0506\end{array}$ & $\begin{array}{l}02 / 22 / 88 \\
02 / 22 / 88 \\
07 / 01 / 86\end{array}$ & $\left|\begin{array}{l}0001 \\
0001 \\
0001\end{array}\right|$ & $\begin{array}{l}\hat{A L} \\
\hat{A L} \\
\hat{A L}\end{array}$ & $\begin{array}{l}\text { O } \\
\text { D } \\
\text { D }\end{array}$ & $\begin{array}{l}0.14 \\
0.17 \\
0.17\end{array}$ & & $\begin{array}{l}0.01 \\
0.01 \\
0.01\end{array}$ & - \\
\hline
\end{tabular}

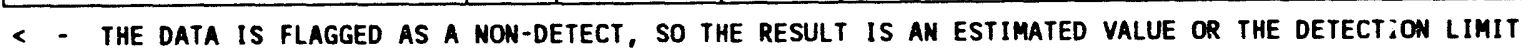

FORMATION OF COMILETION COOE:

AL - ALLUVIUM

OTHER PARAMETER VALUE FLAGS:

I - INCREASED DETECTION LIMIT DUE TO REQUIRED DILUTION

N - SPIKE SAMPLE RECOVERY NOT WITHIN CONTROL LIMITS
FLOW RELATIONSHIP CODE:

D- DOWN GRADIENT

O - ON-SITE

SAMPLE ID CODES:

0001 - FILTERED SAMPLE (.45 MICRONS) 
TABLE 3.30 GROUNDHATER QUALITY MEASUREMENTS EXCEEDING MAXIMUM CONCENTRATIOM LIMITS IN ALLUVIAL BASELINE GROINDWATER, NC\&UC PROCESSING SITES, SLICK ROCK SITE: SRKO1 SLICK ROCK (BOTH SITES)

06/30/86 TO $10 / 13 / 92$

REPORT DATE: $06 / 17 / 93$

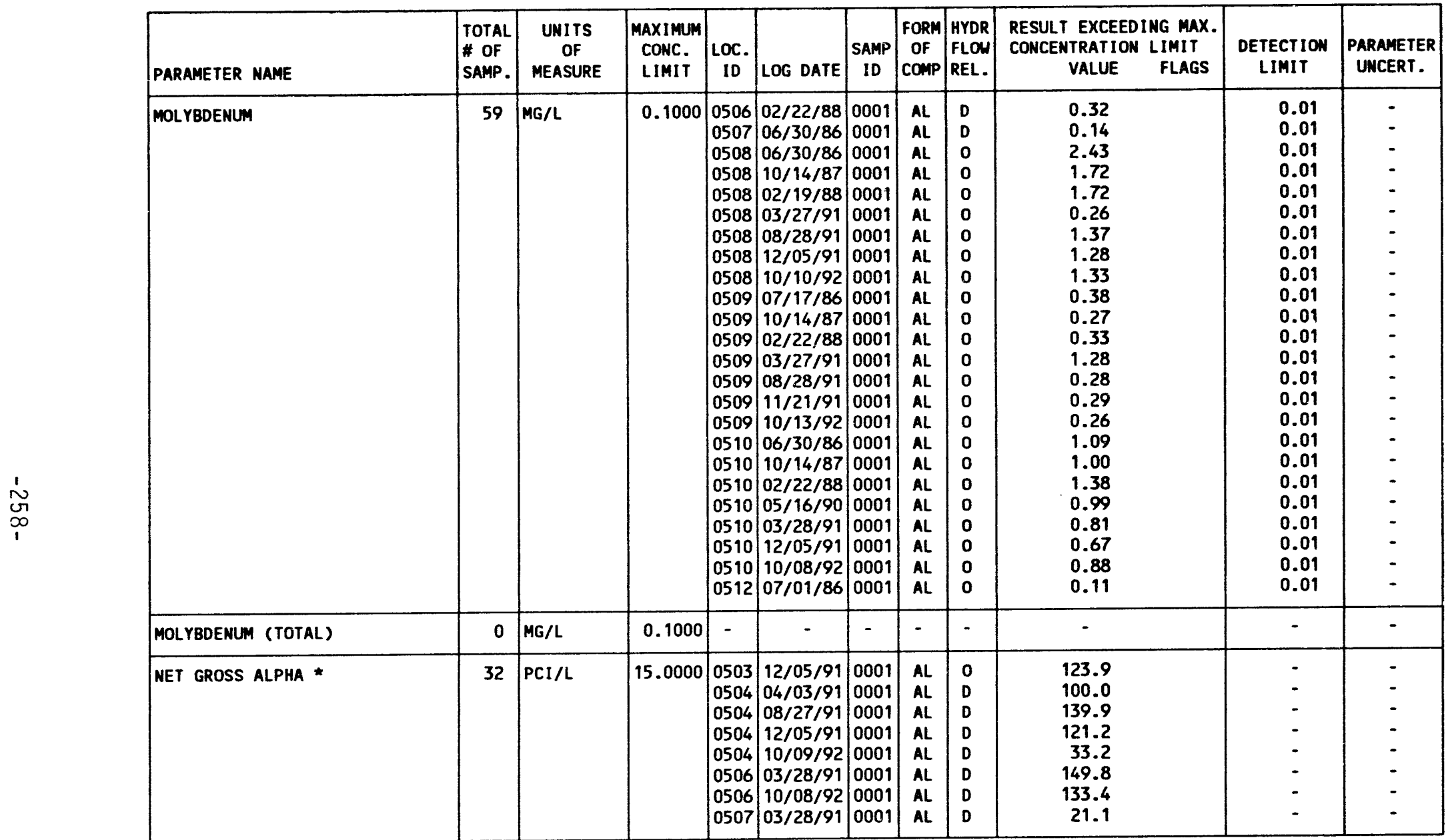

* Net gross alPHa (GROSS alPha - URANIUM) FORMATION OF COMPLETION CODE: AL - ALLUVIUM
WITH 1 MG URANIUM $=686 \mathrm{PCI}$

\section{FLOW RELATIONSHIP COOE:}

D - DOWN GRADIENT

O - ON-SITE

SAMPLE ID CODES:

0001 - FILTERED SAMPLE (.45 MICRONS) 
TABLE 3.30 GROUNDWATER OUALITY MEASUREMENTS EXCEEDING MAXIMU CONCENTRATION LIMITS IN ALLUVIAL BASELINE GROUNDWATER, NC\&UC PROCESSING SITES, SLICK ROCK SITE: SRKO1 SLICK ROCK (BOTH SITES)

06/30/86 TO $10 / 13 / 92$

REPORT DATE: $06 / 17 / 93$

\begin{tabular}{|c|c|c|c|c|c|c|c|c|c|c|c|c|}
\hline & PARAMETER MAME & $\begin{array}{l}\text { TOTAL } \\
\# \text { OF } \\
\text { SAMP. }\end{array}$ & $\begin{array}{l}\text { UNITS } \\
\text { OF } \\
\text { MEASURE }\end{array}$ & \begin{tabular}{|} 
MAXIMMM \\
CONC. \\
LIMIT
\end{tabular} & IOC. & LOG DATE & $\begin{array}{c}\text { SAMP } \\
\text { ID }\end{array}$ & $\begin{array}{c}\text { FORM } \\
\text { OF } \\
\text { COMP }\end{array}$ & $\begin{array}{l}\text { HYDR } \\
\text { FLOW } \\
\text { REL. }\end{array}$ & $\begin{array}{l}\text { RESULT EXCEEDING MAX. } \\
\text { CONCENTRATION LIMIT } \\
\text { VALUE FLAGS }\end{array}$ & $\begin{array}{l}\text { DETECTION } \\
\text { LIMIT }\end{array}$ & $\begin{array}{l}\text { PARAMETER } \\
\text { UNCERT. }\end{array}$ \\
\hline & MET GROSS ALPHA * & 32 & $\mathrm{PCI} / \mathrm{L}$ & 15.0000 & $\begin{array}{l}0508 \\
0508 \\
0509 \\
0510\end{array}$ & $\begin{array}{l}03 / 27 / 91 \\
08 / 28 / 91 \\
03 / 27 / 91 \\
03 / 28 / 91\end{array}$ & $\left|\begin{array}{l}0001 \\
0001 \\
0001 \\
0001\end{array}\right|$ & $\begin{array}{l}A L \\
A L \\
A L \\
A L\end{array}$ & $\begin{array}{l}0 \\
0 \\
0 \\
0\end{array}$ & $\begin{array}{l}48.8 \\
17.1 \\
57.5 \\
68.9\end{array}$ & - & :- \\
\hline & NET GROSS ALPHA (TOTAL) ** & 0 & PCI/L & 15.0000 & - & - & - & - & - & - & - & - \\
\hline & MITRATE & 60 & $M G / L$ & 44.0000 & $\begin{array}{l}0506 \\
0508 \\
0508 \\
0508 \\
0508 \\
0508 \\
0508 \\
0509 \\
0510 \\
0510 \\
0510 \\
0510 \\
0510 \\
0510 \\
0510 \\
0510\end{array}$ & $\begin{array}{l}03 / 28 / 91 \\
06 / 30 / 86 \\
10 / 14 / 87 \\
02 / 19 / 88 \\
08 / 28 / 91 \\
12 / 05 / 91 \\
10 / 10 / 92 \\
03 / 27 / 91 \\
06 / 30 / 86 \\
10 / 14 / 87 \\
02 / 22 / 88 \\
05 / 16 / 90 \\
03 / 28 / 91 \\
08 / 28 / 91 \\
12 / 05 / 91 \\
10 / 08 / 92\end{array}$ & $\left|\begin{array}{l}0001 \\
0001 \\
0001 \\
0001 \\
0001 \\
0001 \\
0001 \\
0001 \\
0001 \\
0001 \\
0001 \\
0001 \\
0001 \\
0001 \\
0001 \\
0001\end{array}\right|$ & $\begin{array}{l}A L \\
A L \\
A L \\
A L \\
A L \\
A L \\
A L \\
A L \\
A L \\
A L \\
A L \\
A L \\
A L \\
A L \\
A L \\
A L\end{array}$ & $\begin{array}{l}0 \\
0 \\
0 \\
0 \\
0 \\
0 \\
0 \\
0 \\
0 \\
0 \\
0 \\
0 \\
0 \\
0 \\
0 \\
0\end{array}$ & $\begin{array}{c}110 . \\
290 . \\
1250 . \\
1220 . \\
1040 . \\
1200 . \\
1360 . \\
1050 . \\
1000 . \\
1620 . \\
1190 . \\
1000 . \\
943 . \\
947 . \\
837 . \\
257 .\end{array}$ & $\begin{array}{r}1 . \\
1 . \\
1 . \\
1 . \\
75 . \\
125 . \\
150 . \\
1 . \\
1 . \\
1 . \\
1 . \\
1 . \\
1 . \\
75 . \\
125 . \\
10 .\end{array}$ & $\begin{array}{l}- \\
- \\
- \\
- \\
- \\
- \\
- \\
- \\
- \\
- \\
-\end{array}$ \\
\hline & NITRATE (TOTAL) & 0 & $M G / L$ & 44.0000 & - & - & - & - & - & - & - & - \\
\hline & $R A-226 \& R A-228$ & 42 & $\mathrm{PCI} / \mathrm{L}$ & 5.0000 & $\begin{array}{l}0506 \\
0508 \\
0509 \\
0512 \\
0512\end{array}$ & $\mid \begin{array}{l}10 / 08 / 92 \\
03 / 27 / 91 \\
03 / 27 / 91 \\
04 / 05 / 91 \\
12 / 05 / 91\end{array}$ & $\begin{array}{l}0001 \\
0001 \\
0001 \\
0001 \\
0001\end{array} \mid$ & $\begin{array}{l}A L \\
A L \\
A L \\
A L \\
A L\end{array}$ & $\begin{array}{l}D \\
0 \\
0 \\
0 \\
0\end{array}$ & $\begin{array}{l}7.3 \\
5.5 \\
8.3 \\
5.7 \\
6.5\end{array}$ & $\begin{array}{l}- \\
- \\
-\end{array}$ & : \\
\hline & RA-226 \& RA-228 (TOTAL) & 0 & $\mathrm{PCI} / \mathrm{L}$ & 5.0000 & - & - & - & - & - & - & - & - \\
\hline
\end{tabular}

* MET GROSS ALPHA (GROSS ALPHA - URANIUM) HITH 1 MG URANIUM = 686 PCI

* total NET GROSS ALPHA (TOTAL GROSS ALPHA - TOTAL URANIUM)

FORMATION OF COMPLETION COOE: AL - ALLUVIUA

\section{FLON RELATIONSHIP COOE:}

O - ON-SITE

D - DON GRADIENT

SAMPLE ID CODES:

0001 - FILTERED SAMPLE (.45 MICRONS) 
TABLE 3.30 GROUNDWATER OUALITY MEASUREMENTS EXCEEDING MAXIMUM CONCENTRATION LIMITS IN ALLUVIAL BASELINE GROUNDWATER, NC\&UC PROCESSING SITES, SLICK ROCK SITE: SRKO1 SLICK ROCK (BOTH SITES)

06/30/86 TO $10 / 13 / 92$

REPORT DATE: $06 / 17 / 93$

\begin{tabular}{|c|c|c|c|c|c|c|c|c|c|c|c|c|}
\hline PARAMETER NAME & $\begin{array}{l}\text { TOTAL } \\
\text { \# OF } \\
\text { SAMP. }\end{array}$ & $\begin{array}{c}\text { UNITS } \\
\text { OF } \\
\text { MEASURE }\end{array}$ & $\begin{array}{l}\text { MAXIMUM } \\
\text { CONC. } \\
\text { LIMIT }\end{array}$ & LOC. & LOG DATE & $\begin{array}{c}\text { SAMP } \\
\text { ID }\end{array}$ & $\begin{array}{c}\text { FORM } \\
\text { OF } \\
\text { COMP }\end{array}$ & $\begin{array}{l}\text { HYDR } \\
\text { FLOW } \\
\text { REL. }\end{array}$ & $\begin{array}{r}\text { RESULT EXCE } \\
\text { CONCENTRATI } \\
\text { VALUE }\end{array}$ & $\begin{array}{l}\text { DING mAX. } \\
\text { N LIMIT } \\
\text { FLAGS }\end{array}$ & $\begin{array}{l}\text { DETECTION } \\
\text { LIMIT }\end{array}$ & $\begin{array}{l}\text { PARAMETER } \\
\text { UNCERT. }\end{array}$ \\
\hline SELENIUM & 51 & $M G / L$ & 0.0100 & $\begin{array}{l}0503 \\
0503 \\
0503 \\
0504 \\
0504 \\
0504 \\
0506 \\
0506 \\
0506 \\
0507 \\
0508 \\
0508 \\
0508 \\
0508 \\
0508 \\
0509 \\
0509 \\
0509 \\
0510 \\
0510 \\
0510 \\
0510 \\
0510 \\
0512\end{array}$ & $\begin{array}{l}05 / 16 / 90 \\
03 / 29 / 91 \\
12 / 09 / 91 \\
05 / 16 / 90 \\
04 / 03 / 91 \\
12 / 09 / 91 \\
08 / 08 / 91 \\
11 / 20 / 91 \\
10 / 08 / 92 \\
12 / 05 / 91 \\
06 / 30 / 86 \\
10 / 14 / 87 \\
08 / 28 / 91 \\
12 / 05 / 91 \\
10 / 10 / 92 \\
03 / 27 / 91 \\
08 / 28 / 91 \\
11 / 21 / 91 \\
10 / 14 / 87 \\
05 / 16 / 90 \\
03 / 28 / 91 \\
12 / 05 / 91 \\
10 / 08 / 92 \\
04 / 05 / 91\end{array}$ & $\begin{array}{l}0001 \\
0001 \\
0001 \\
0001 \\
0001 \\
0001 \\
0001 \\
0001 \\
0001 \\
0001 \\
0001 \\
0001 \\
0001 \\
0001 \\
0001 \\
0001 \\
0001 \\
0001 \\
0001 \\
0001 \\
0001 \\
0001 \\
0001 \\
0001\end{array}$ & $\begin{array}{l}A L \\
A L \\
A L \\
A L \\
A L \\
A L \\
A L \\
A L \\
A L \\
A L \\
A L \\
A L \\
A L \\
A L \\
A L \\
A L \\
A L \\
A L \\
A L \\
A L \\
A L \\
A L \\
A L \\
A L\end{array}$ & $\begin{array}{l}0 \\
0 \\
0 \\
0 \\
0 \\
0 \\
0 \\
0 \\
0 \\
0 \\
0 \\
0 \\
0 \\
0 \\
0 \\
0 \\
0 \\
0 \\
0 \\
0 \\
0 \\
0 \\
0 \\
0\end{array}$ & $\begin{array}{l}0.015 \\
0.03 \\
0.03 \\
0.015 \\
0.03 \\
0.03 \\
0.05 \\
0.03 \\
0.05 \\
0.03 \\
0.035 \\
0.99 \\
0.9 \\
1.0 \\
1.1 \\
0.525 \\
0.014 \\
0.016 \\
0.17 \\
0.016 \\
0.065 \\
0.10 \\
0.2 \\
0.03\end{array}$ & $\begin{array}{l}\text { I } \\
\text { I } \\
\text { IJ } \\
\text { I } \\
\text { I } \\
\text { I }\end{array}$ & $\begin{array}{l}0.005 \\
0.03 \\
0.03 \\
0.005 \\
0.03 \\
0.03 \\
0.05 \\
0.03 \\
0.05 \\
0.03 \\
0.005 \\
0.005 \\
0.1 \\
0.3 \\
0.1 \\
0.005 \\
0.005 \\
0.005 \\
0.005 \\
0.005 \\
0.005 \\
0.05 \\
0.2 \\
0.03\end{array}$ & $\begin{array}{l}- \\
: \\
- \\
- \\
- \\
- \\
- \\
- \\
- \\
- \\
- \\
- \\
- \\
- \\
- \\
- \\
- \\
-\end{array}$ \\
\hline SELENIUM (TOTAL) & 0 & $M G / L$ & 0.0100 & - & - & - & - & - & - & & - & - \\
\hline SILVER & 37 & $M G / L$ & 0.0500 & - & - & - & - & - & - & & - & - \\
\hline SILVER (TOTAL) & 0 & $M G / L$ & 0.0500 & - & - & - & - & - & - & & - & - \\
\hline URANIUM & 60 & MG/L & 0.0440 & $\begin{array}{l}0503 \\
0503 \\
0503 \\
0503\end{array}$ & $\begin{array}{l}06 / 30 / 86 \\
10 / 14 / 87 \\
02 / 22 / 88 \\
05 / 16 / 90\end{array}$ & $\begin{array}{l}0001 \\
0001 \\
0001 \\
0001\end{array}$ & $\begin{array}{l}A L \\
A L \\
A L \\
A L\end{array}$ & $\begin{array}{l}0 \\
0 \\
0 \\
0\end{array}$ & $\begin{array}{l}3.78 \\
3.8 \\
3.59 \\
3.05\end{array}$ & & $\begin{array}{l}0.003 \\
0.003 \\
0.003 \\
0.003\end{array}$ & - \\
\hline
\end{tabular}

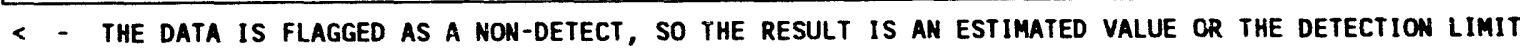

FORMATION OF COMPLETION CODE:

AL - ALLUVIUM

OTHER PARAMETER VALUE FLAGS:

I - INCREASED DETECTION LIMIT DUE TO REQUIRED DILUTION

J - estimated VALUE
FLOW RELATIONSHIP CODE:

O - ON-SITE

D - DOWN GRADIENT

SAMPLE ID CODES:

0001 - FILTERED SAMPLE (.45 MICRONS) 
TABLE 3.30 GROUNDWATER OUALITY MEASUREMENTS EXCEEDING MAXIMM CONCENTRATION LIMITS IN ALLUVIAL BASELINE GROUNDWATER, NC\&UC PROCESSING SITES, SLICK ROCK SITE: SRKO1 SLICK ROCK (BOTH SITES)

REPORT DATE: $06 / 17 / 93$

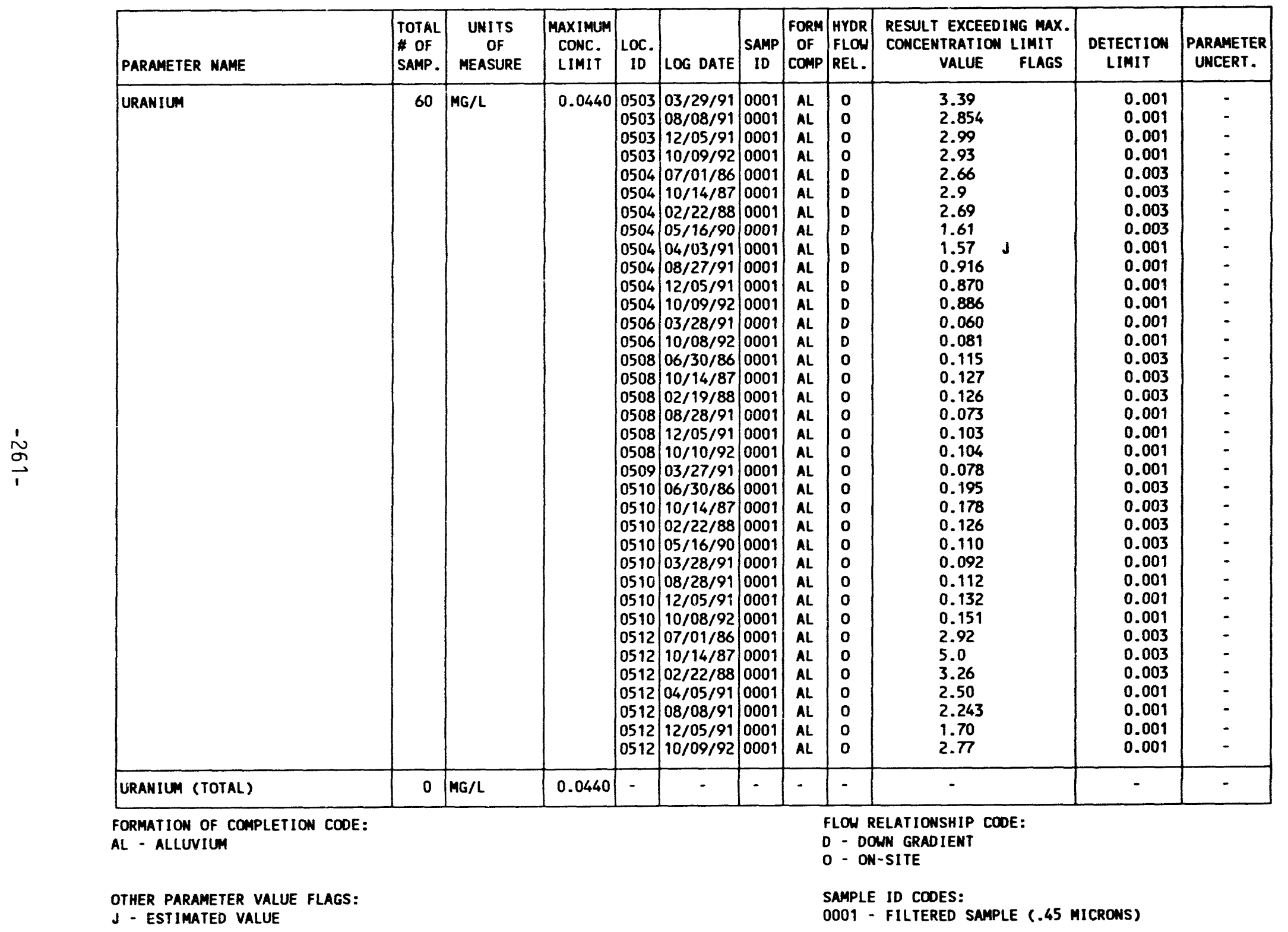

DATA FILE NAME: M: DDARTISRK011GWQ10027.DAT 
TABLE 3.31 BASELINE GROUNDWATER QUALITY STATISTICS BY PARAMETER

FOR THE ALLUVIUM, UC PROCESSING SITE, SLICK ROCK, COLORADO

SITE: SRKO1 SLICK ROCK (BOTH SITES)

$06 / 30 / 86$ TO $10 / 13 / 92$

REPORT DATE: $07 / 26 / 93$

\begin{tabular}{|c|c|c|c|c|c|c|c|c|c|c|c|c|c|}
\hline & PARAMETER & NAME & & UNITS & & STANDARD & $\begin{array}{c}\text { COEFF. } \\
\text { OF }\end{array}$ & $\begin{array}{c}x \text { OF } \\
\text { NOW }\end{array}$ & & $\begin{array}{l}\text { STATISTIC } \\
\text { CONFIDEN }\end{array}$ & $\begin{array}{l}\text { AL RANGE } \\
\text { CE INTERVAL }\end{array}$ & DISTRIBUTION & FOOT \\
\hline & * OF SAMP & MINIMUM & MAXIMUM & MEDIAN & MEAN & DEVIATION & VARIATION & DETECTS & & MINIMUM & MAXIMUM * & TYPE & MOTE \\
\hline & ALKALINIT & & & $M G / L C A C$ & & & & & & & & & \\
\hline & 37 & 249.0000 & 791.0000 & 406.0000 & 458.7297 & 145.4819 & 0.3171 & 0.0 & & 400.5156 & 516.9439 & NORMAL & \\
\hline & ALUMINUM & & & $M G / L$ & & & & & & & & & \\
\hline & 36 & $\star * \quad 0.0500$ & 0.4000 & ** $\quad 0.0500$ & NA & NA & NA & 72.2 & ** & 0.0500 & 0.0500 & MONPARAMETRIC & 2 \\
\hline & AMMONIUM & & & $M G / L$ & & & & & & & & & \\
\hline & 33 & 22.8000 & 190.0000 & 115.0000 & 111.0364 & 51.4043 & 0.4630 & 0.0 & & 89.1308 & 132.9419 & NORMAL & \\
\hline & ANT IMONY & & & $M G / L$ & & & & & & & & & \\
\hline & 22 & $\begin{array}{ll}* \star & 0.0030\end{array}$ & 0.0150 & 0.0030 & NA & NA & NA & 95.5 & $\star \star$ & 0.0030 & $\star \quad 0.0030$ & MONPARAMETRIC & 2 \\
\hline & ARSENIC & & & $\mathrm{MG} / \mathrm{L}$ & & & & & & & & & \\
\hline & 31 & $* \quad 0.0050$ & 0.0500 & 0.0050 & NA & NA & NA & 100.0 & & 0.0050 & 0.0050 & NONPARAMETRIC & 2 \\
\hline & BARIUM & & & MG/L & & & & & & & & & \\
\hline & 27 & 0.0100 & 0.1000 & 0.0300 & NA & NA & NA & 25.9 & & 0.0200 & 0.0500 & NONPARAMETRIC & 2 \\
\hline & BERYLLIUM & & & $M G / L$ & & & & & & & & & \\
\hline & 16 & ** $\quad 0.0050$ & 0.0050 & 0.0050 & NA & NA & NA & 100.0 & $\star \star \star$ & 0.0050 & $\star \quad 0.0050$ & NONPARAMETRIC & 2 \\
\hline & BORON & & & $M G / L$ & & & & & & & & & \\
\hline & 22 & 0.0500 & 0.5000 & 0.4100 & 0.3773 & 0.1312 & 0.3478 & 4.5 & & 0.3068 & 0.4477 & MORMAL & \\
\hline & BROMIDE & & & $M G / L$ & & & & & & & & & \\
\hline & 20 & $\star * \quad 0.1000$ & 9.1000 & 1.4000 & NA & NA & NA & 50.0 & & 0.4000 & 3.9000 & MONPARAMETRIC & 2 \\
\hline & CADMIUM & & & $M G / L$ & & & & & & & & & \\
\hline & 27 & ** $\quad 0.0010$ & 0.0270 & 0.0010 & NA & NA & NA & 70.4 & $\star \star$ & 0.0010 & 0.0012 & MONPARAMETRIC & 2 \\
\hline
\end{tabular}

** The reported value is the minimum detection limit of the data set

+ The sample size is even, so the median value is the arithmetic average of the two middle values

* The statistical maximm is the 99 percent one sided confidence interval, $\alpha=0.01$

2) The nomparametric distribution was used because the nondetected values comprise more than $15 \%$ of the samples. 
TABLE 3.31 BASELINE GROUNDWATER OUALITY STATISTICS BY PARAMETER FOR THE ALLUVIUM, UC PROCESSING SITE, SLICK ROCK, COLORADO

FOR THE ALLUVIUY,

06/30/86 TO $10 / 13 / 92$

REPORT DATE: $07 / 26 / 93$

\begin{tabular}{|c|c|c|c|c|c|c|c|c|c|c|c|}
\hline \multicolumn{3}{|c|}{ PARAMETER NAME } & UNITS & \multirow[b]{2}{*}{ MEAN } & \multirow{2}{*}{$\begin{array}{r}\text { STANDARD } \\
\text { DEVIATION }\end{array}$} & \multirow{2}{*}{$\begin{array}{c}\text { COEFF. } \\
\text { OF } \\
\text { VARIATION }\end{array}$} & \multirow{2}{*}{$\mid \begin{array}{c}X \text { OF } \\
\text { NON } \\
\text { DETECTS }\end{array}$} & \multirow{2}{*}{\multicolumn{2}{|c|}{$\begin{array}{l}\text { STATISTICAL RANGE } \\
98 \% \text { CONFIDENCE INTERVAL } \\
\text { MINIMUM MAXIMUM * }\end{array}$}} & \multirow{2}{*}{$\begin{array}{c}\text { DISTRIBUTION } \\
\text { TYPE }\end{array}$} & \multirow{2}{*}{$\begin{array}{l}\text { FOOT } \\
\text { NOTE }\end{array}$} \\
\hline \# OF SAMP & MINIMUM & MAXIMUM & MEDIAN & & & & & & & & \\
\hline \multicolumn{3}{|l|}{ CALCIUM } & $M G / L$ & \multirow[b]{2}{*}{384.3611} & \multirow[b]{2}{*}{227.6243} & \multirow[b]{2}{*}{0.5922} & \multirow[b]{2}{*}{0.0} & \multirow[b]{2}{*}{291.9077} & \multirow[b]{2}{*}{476.8145} & \multirow[b]{2}{*}{ NORMAL } & \\
\hline 36 & 110.0000 & 970.0000 & +456.0000 & & & & & & & & \\
\hline \multicolumn{3}{|l|}{ CHLOR IDE } & $M G / L$ & \multirow[b]{2}{*}{178.6312} & \multirow[b]{2}{*}{2.8823} & \multirow[b]{2}{*}{ NA } & \multirow[b]{2}{*}{0.0} & \multirow[b]{2}{*}{116.9478} & \multirow[b]{2}{*}{272.8490} & \multirow[b]{2}{*}{ LOGNORMAL } & \multirow[b]{2}{*}{7,8} \\
\hline 37 & 71.0000 & 3400.0000 & 127.0000 & & & & & & & & \\
\hline \multicolumn{3}{|l|}{ CHROMIUM } & $M G / L$ & \multirow[b]{2}{*}{ NA } & \multirow[b]{2}{*}{ NA } & \multirow[b]{2}{*}{ MA } & \multirow[b]{2}{*}{88.9} & \multirow[b]{2}{*}{0.0100} & \multirow[b]{2}{*}{$* 0.0100$} & & \\
\hline 27 & $\star \star \quad 0.0100$ & 0.0500 & 0.0100 & & & & & & & NONPARAMETRIC & 2 \\
\hline COBALT & & & $M G / L$ & & & & & & & & \\
\hline 16 & 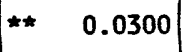 & $\star \star \quad 0.0300$ & 0.0300 & NA & NA & NA & 100.0 & 0.0300 & $\star * \quad 0.0300$ & NONPARAMETRIC & 2 \\
\hline COPPER & & & $M G / L$ & & & & & & & & \\
\hline 27 & $\star \star \quad 0.0100$ & 0.0600 & 0.0100 & NA & NA & Ma & 92.6 & 0.0100 & 0.0100 & MONPARAMETRIC & 2 \\
\hline CYANIDE & & & $M G / L$ & & & & & & & & \\
\hline 15 & $\star \quad * \quad 0.0100$ & $\star \star \quad 0.0100$ & 0.0100 & NA & NA & NA & 100.0 & 0.0100 & $\star * 0.0100$ & NONPARAMETRIC & 2 \\
\hline DISSOLVED & OXYGEN & & $M G / L$ & & & & & & & & \\
\hline 5 & 0.0000 & 0.2000 & 0.0000 & NA & NA & MA & 0.0 & 0.0000 & 0.2000 & MONPARAMETRIC & 9,5 \\
\hline FIELD FE & $(2+)$ & & $M G / L$ & & & & & & & & \\
\hline 4 & 0.0000 & 3.3700 & 1.2200 & NA & NA & NA & 0.0 & 0.0000 & 3.3700 & NOMPARAMETRIC & 9,4 \\
\hline FIELD FE & (TOTAL) & & $M G / L$ & & & & & & & & \\
\hline 2 & 0.1000 & 5.4200 & 2.7600 & NA & NA & MA & 0.0 & MA & MA & UNKNONN & 1 \\
\hline
\end{tabular}

** The reported value is the minimum detection limit of the data set

- The sample size is even, so the median value is the arithmetic average of the two middle values

- The statistical maximum is the 99 percent one sided confidence interval, $a=0.01$

1) A minimum of 4 samples must be available for the statistical analysis.

2) The nonparametric distribution was used because the nondetected values comprise more than $15 \%$ of the samples.

4) The stat, range is the $87.5 \%$ confidence interval due to a sample size of 4 . The maximm is the $93.8 \%$ one sided confidence int.

5) The stat. range is the $87.5 \%$ confidence interval due to a sample size of 5 . The maximm is the $96.9 \%$ one sided confidence int.

7) The lognormal distribution us used because the data failed the normal distribution test.

8) The logne value to divide or multiply with the geometric mean.

8) The mean is geometric. The standard deviation the data failed the normal distribution test and includes values $\leq 0$. 
TABLE 3.31 BASELIME GROUNDWATER OUALITY STATISTICS BY PARAMETER

FOR THE ALLUVIUM, UC PROCESSING SITE, SLICK ROCK, COLORADO

SITE: SRKO1 SLICK ROCK (BOTH SITES)

$06 / 30 / 86$ TO $10 / 13 / 92$

REPORT DATE: $07 / 26 / 93$

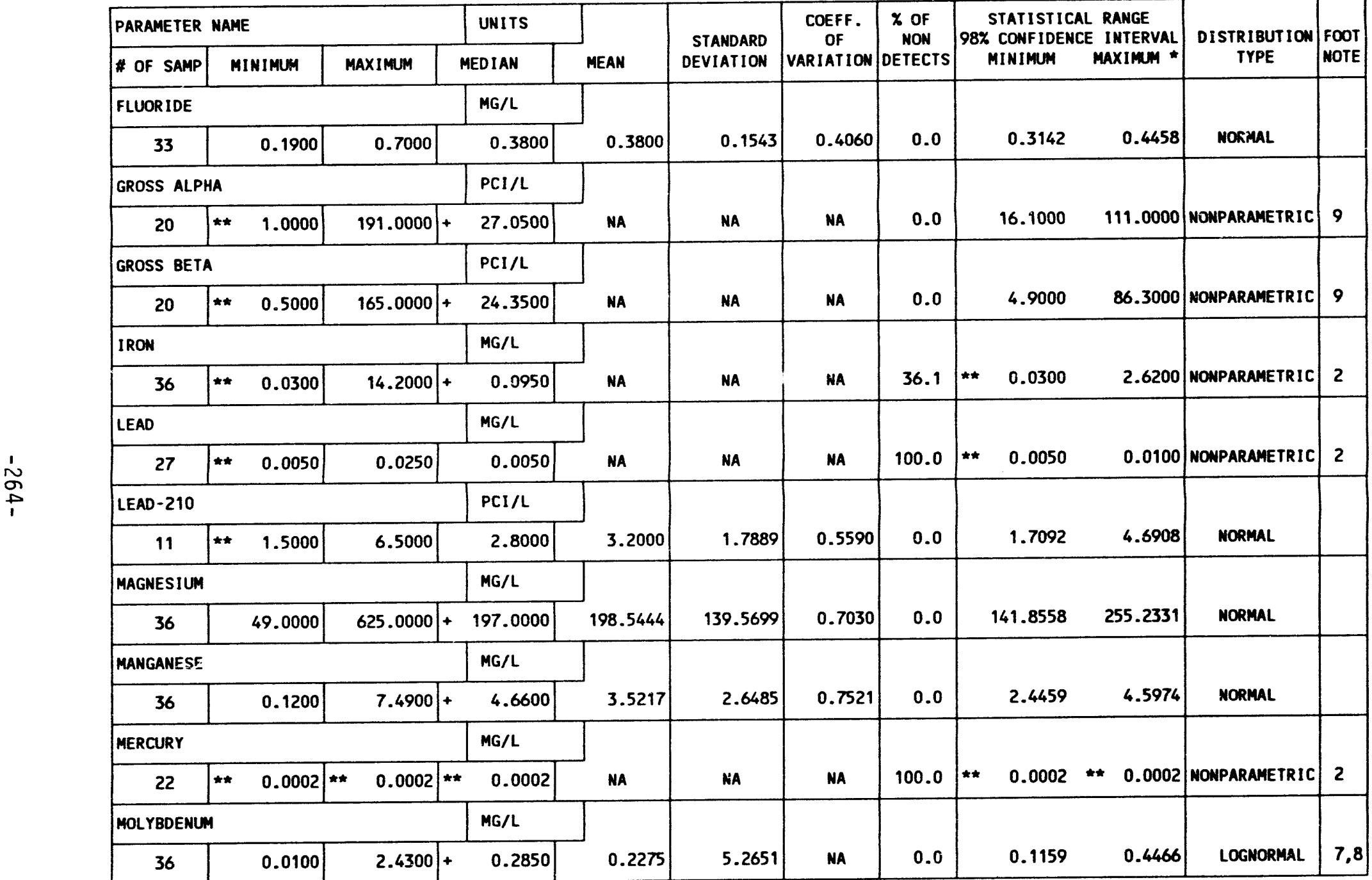

** The reported value is the minimum detection limit of the data set

+ The sample size is even, so the median value is the arithmetic average of the two middle values

* The statistical maximum is the 99 percent one sided confidence interval, $a=0.01$

2) The nonparametric distribution was used because the nondetected values comprise more than $15 \%$ of the samples.

7) The lognormal distribution was used because the data failed the normal distribution test.

8) The

9) The monparametic distribution was used because the data failed the normal distribution test and includes values $\leq 0$. 
TABLE 3.31 BASELINE GROUNDUATER QUALITY STATISTICS BY PARAMETER FOR THE ALLUVIUM, UC PROCESSING SITE, SLICK ROCK, COLORADO

SITE: SRKO1 SLICK ROCK CBOT

06/30/86 TO $10 / 13 / 92$

REPORT DATE: $07 / 26 / 93$

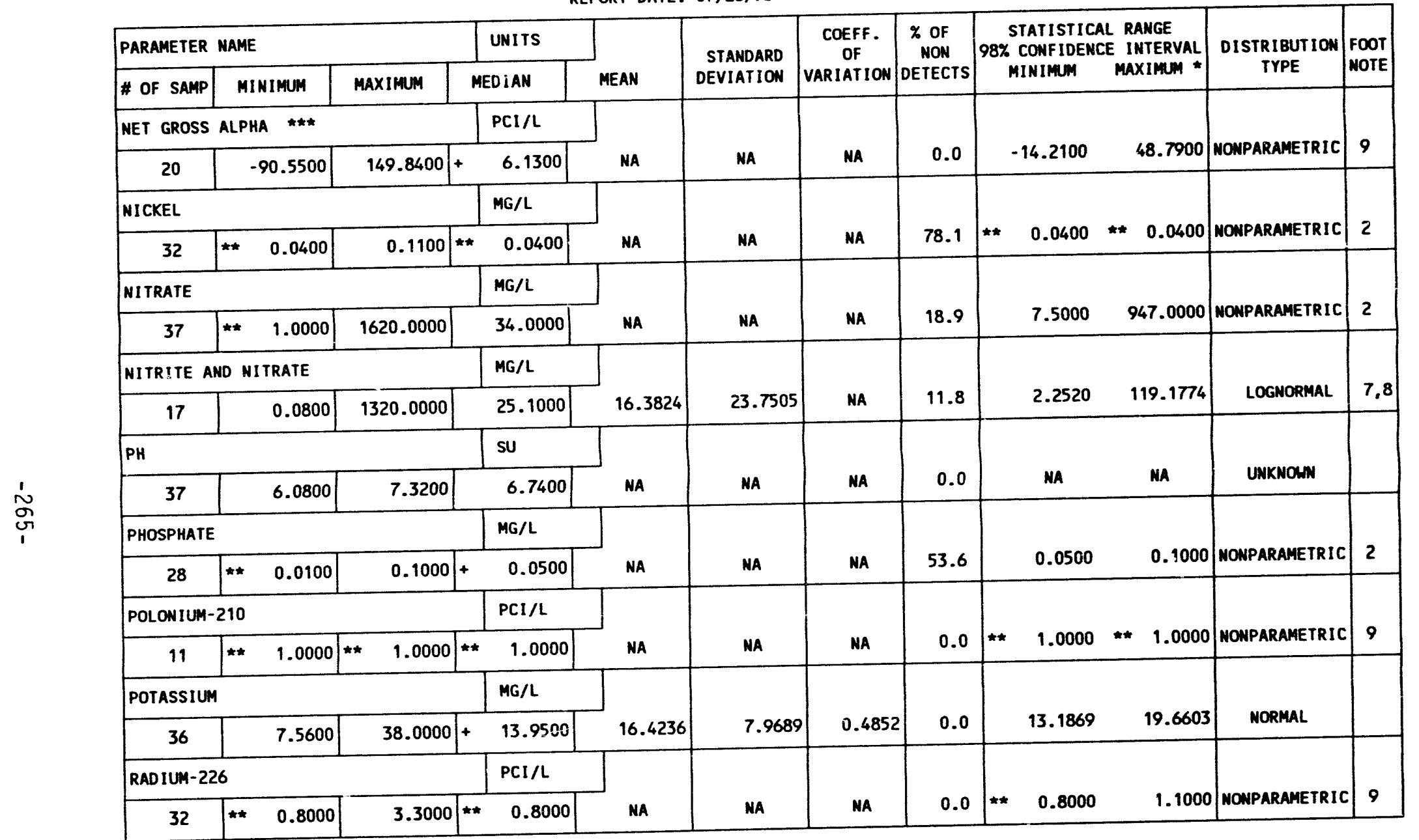

*** MET GROSS ALPHA (GROSS ALPHA - URANIUM) WITH 1 MG URANIUM = 686 PCI

* The reported value is the minimm detection limit of the data set

erage of the two middle values

* The statistical maximm is the 99 percent one sided confidence interval, $\alpha=0.01$

1) A minim of 4 samplestical analysis.

1) A minimm

2) The nonparametric distribution was used because the nondetected value normal distribution test.

7) The lognormal distribution was used because the data failed the noride or multiply with the geometric mean.

8) The mean is geometric. The standard deviation is the value to divide or multiply with the nomparametic distribution was used because the data failed the normal distribution test and includes values $\leq 0$. 
TABLE 3.31 BASELINE GROUNDWATER QUALITY STATISTICS BY PARAMETER

FOR THE ALLUVIUM, UC PROCESSING SITE, SLICK ROCK, CGLORADO

SITE: SRKO1 SLICK ROCK (BOTH SITES)

06/30/86 TO $10 / 13 / 92$

REPORT DATE: $07 / 26 / 93$

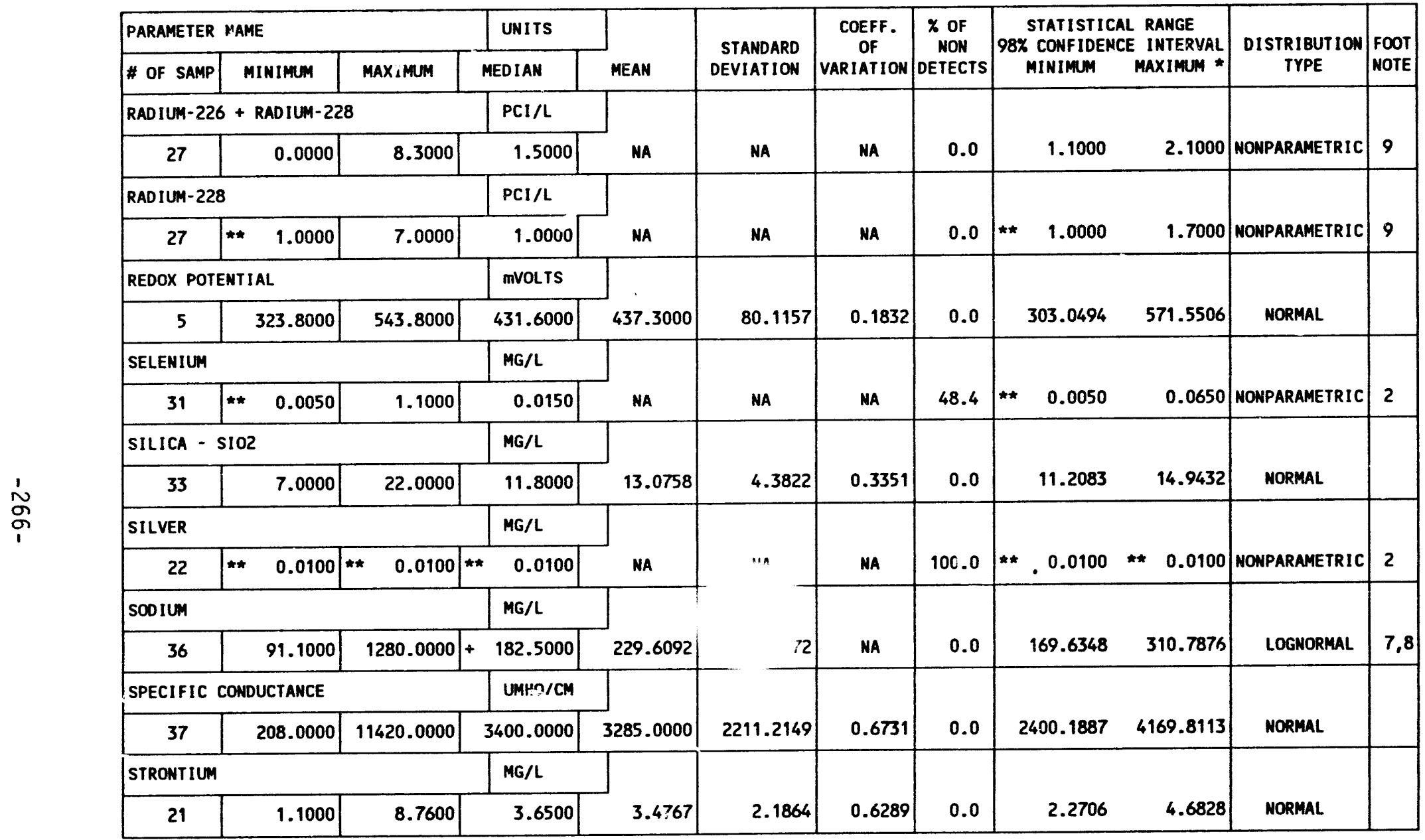

** The reported value is the minimum detection limit of the data set

+ The sample size is even, so the median value is the arithmetic average of the two middle values

* The statistical maximum is the 99 percent one sided confidence interval, $\alpha=0.01$

2) The nonparametric distribution was used because the nondetected values comprise more than $15 \%$ of the samples.

7) The lognormal distribution was used because the data failed the normal distribution test.

7) The lognoris distribution wa the geometric mean.

9) The nonparametic distribution was used because the data failed the normal distribution test and includes values $\leq 0$. 
TABLE 3.31 BASELINE GROUNDWATER QUALITY STATISTICS BY PARAMETER

TABLE 3.31 BASELINE GROCESING SITE, SLICK ROCK, COLORADO

FOR THE ALLUVIUM, UC PROCESSING SITE,
SITE: SRKO1 SLICK ROCK (BOTH SITES)

$06 / 30 / 86$ TO $10 / 13 / 92$

REPORT DATE: 07/26/93

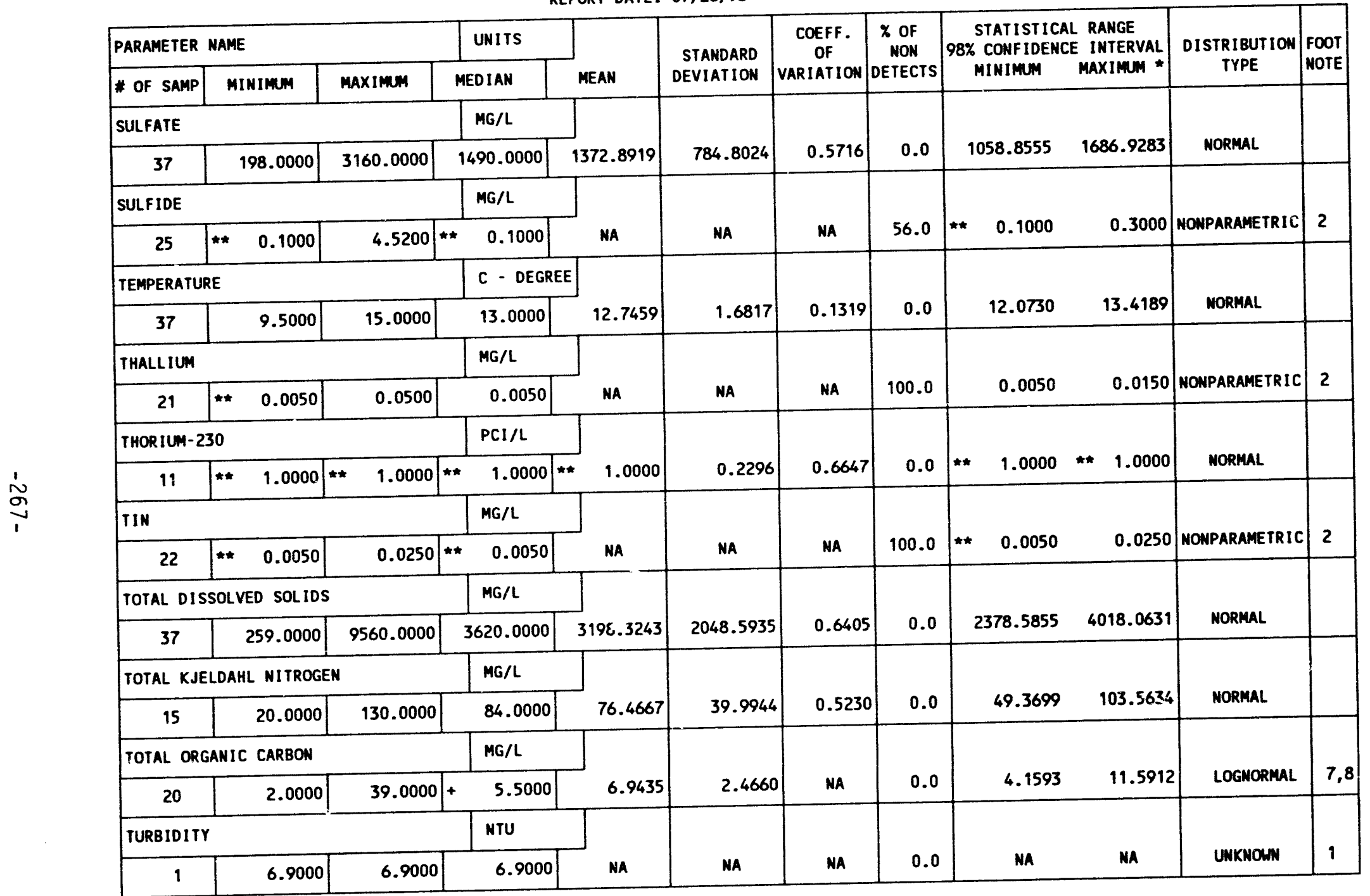

* The reported value is the minimum detection limit of the data set

+ The sample size is even, so the median value is the arithetic average of the two

* The statistical maximum is the 99 percent one sided confidence intervas.

mamples must be available for the stanes

2) The nonparametric distribution was used because the nondetected values conprise mor tion test.

The lognormal distribution was used because the data failed to divide or multiply with the geometric mean. 
TABLE 3.31 GASELINE GROUMDUATER QUALITY STATISTICS BY PARAMETER

FOR THE ALLUVIUM, UC PROCESSING SITE, SLICK ROCK, COLORADO

SITE: SRKO1 SLICK ROCK (BOTH SITES)

$06 / 30 / 86$ TO $10 / 13 / 92$

REPORT DATE: $07 / 26 / 93$

\begin{tabular}{|c|c|c|c|c|c|c|c|c|c|c|c|}
\hline \multicolumn{3}{|c|}{ PARAMETER NAME } & \multirow{2}{*}{$\frac{\text { UNITS }}{\text { MEDIAN }}$} & \multirow[b]{2}{*}{ MEAN } & \multirow{2}{*}{$\begin{array}{r}\text { STANDARD } \\
\text { DEVIATION }\end{array}$} & \multirow{2}{*}{$\begin{array}{c}\text { COEFF. } \\
\text { OF } \\
\text { VARIATION }\end{array}$} & \multirow{2}{*}{$\begin{array}{c}\% \text { OF } \\
\text { NON } \\
\text { DETECTS }\end{array}$} & \multirow{2}{*}{\multicolumn{2}{|c|}{$\begin{array}{l}\text { STATISTICAL RANGE } \\
\text { 98\% CONF IDENCE INTERVAL } \\
\text { MINIMUM MAXIMUM }\end{array}$}} & \multirow{2}{*}{$\begin{array}{l}\text { DISTRIBUTION } \\
\text { TYPE }\end{array}$} & \multirow{2}{*}{$\begin{array}{l}\text { FOOT } \\
\text { NOTE }\end{array}$} \\
\hline \# OF SAMP & MINIMUM & MAXIMUM & & & & & & & & & \\
\hline \multicolumn{3}{|l|}{ URANIUM } & $M G / L$ & \multirow[b]{2}{*}{0.0679} & \multirow[b]{2}{*}{0.0506} & \multirow[b]{2}{*}{0.7445} & \multirow[b]{2}{*}{0.0} & \multirow[b]{2}{*}{0.0477} & \multirow[b]{2}{*}{0.0882} & \multirow[b]{2}{*}{ MORMAL } & \\
\hline 37 & 0.0139 & 0.1950 & 0.0360 & & & & & & & & \\
\hline \multicolumn{3}{|l|}{ VANADIUM } & $M G / L$ & \multirow[b]{2}{*}{ NA } & \multirow[b]{2}{*}{ NA } & \multirow[b]{2}{*}{ NA } & \multirow[b]{2}{*}{45.2} & \multirow[b]{2}{*}{0.0100} & \multirow[b]{2}{*}{0.3300} & \multirow[b]{2}{*}{ NONPARAMETRIC } & \\
\hline 31 & $\star \quad 0.0100$ & 1.0400 & 0.0100 & & & & & & & & 2 \\
\hline \multicolumn{3}{|l|}{ ZINC } & $M G / L$ & & & & & & & & \\
\hline 27 & 0.0050 & 0.0690 & 0.0050 & NA & NA & NA & 63.0 & 0.0050 & 0.0150 & NONPARAMETRIC & 2 \\
\hline
\end{tabular}

* The reported value is the minimum detection limit of the data set

* The statistical maximum is the 99 percent one sided confidence interval, $\alpha=0.01$

2) The nonparametric distribution was used because the nondetected values comprise more than $15 \%$ of the samples.

INPUT DATA FILENAME: M: IDARTISRK01\GWO10042.DAT 
Table 3.32 Summary of regulated constituents in alluvial baseline groundwater, UC processing site, Slick Rock, Colorado

Constituents with MCLs

\begin{tabular}{lcccc}
\hline \multicolumn{1}{c}{ Parameter } & $\begin{array}{c}\text { Baseline } \\
\text { Median }\end{array}$ & $\begin{array}{c}\text { Baseline } \\
\text { Stat Max }\end{array}$ & $\begin{array}{c}\text { Background } \\
\text { Stat Max }\end{array}$ & MCL \\
\hline Arsenic & $0.01^{\mathrm{g}}$ & $0.01^{\mathrm{g}}$ & $0.01^{\mathrm{g}}$ & 0.05 \\
Barium & $0.10^{\mathrm{g}}$ & $0.10^{\mathrm{g}}$ & $0.10^{\mathrm{g}}$ & 1.00 \\
Cadmium & $0.001^{\mathrm{g}}$ & $0.001^{\mathrm{g}}$ & $0.001^{\mathrm{g}}$ & 0.01 \\
Chromium & $0.01^{\mathrm{g}}$ & $0.01^{\mathrm{g}}$ & $0.07^{\mathrm{e}}$ & 0.05 \\
Net gross alpha & $6.13^{\mathrm{e}}$ & 48.79 & $5.08^{\mathrm{b}}$ & 15.00 \\
Lead & $0.01^{\mathrm{g}}$ & $0.01^{\mathrm{g}}$ & $0.01^{\mathrm{g}}$ & 0.05 \\
Mercury & $0.0002^{\mathrm{g}}$ & $0.0002^{\mathrm{g}}$ & $0.0002^{\mathrm{g}}$ & 0.002 \\
Molybdenum & $0.23^{\mathrm{c}}$ & 0.47 & $0.11^{\mathrm{d}}$ & 0.10 \\
Nitrate & $34.0^{\mathrm{e}}$ & 947.0 & $12.0^{\mathrm{e}}$ & 44.0 \\
Radium-226, $-228^{\mathrm{f}}$ & $1.50^{\mathrm{e}}$ & 2.10 & $2.33^{\mathrm{d}}$ & 5.0 \\
Selenium & $0.01^{\mathrm{e}}$ & 0.065 & $0.007^{\mathrm{e}}$ & 0.01 \\
Silver & $0.01^{\mathrm{g}}$ & $0.01^{\mathrm{g}}$ & $0.01^{\mathrm{g}}$ & 0.05 \\
Uranium & $0.068^{\mathrm{d}}$ & 0.088 & $0.033^{\mathrm{d}}$ & 0.044 \\
& & & & \\
\hline
\end{tabular}


Table 3.32 Summary of regulated constituents in alluvial baseline groundwater, UC processing site, Slick Rock, Colorado (concluded)

\begin{tabular}{|c|c|c|c|c|}
\hline \multicolumn{5}{|c|}{ Constituents without MCLs } \\
\hline Parameter & $\begin{array}{l}\text { Baseline } \\
\text { Median }\end{array}$ & $\begin{array}{l}\text { Baseline } \\
\text { Stat Max }\end{array}$ & $\begin{array}{l}\text { Background } \\
\text { Stat. Max }\end{array}$ & MCL \\
\hline Antimony & $0.003^{\mathrm{g}}$ & $0.003^{\mathrm{g}}$ & $0.003^{8}$ & None \\
\hline Beryllium & $0.01^{\mathrm{g}}$ & $0.01^{\mathrm{g}}$ & $0.01^{\mathrm{g}, \mathrm{h}}$ & None \\
\hline Cobalt & $0.05^{\mathrm{g}}$ & $0.05^{\mathrm{g}}$ & $0.05^{\mathrm{g}, \mathrm{h}}$ & None \\
\hline Copper & $0.02^{\mathrm{g}}$ & $0.02^{\mathrm{g}}$ & $0.03^{\mathrm{c}}$ & None \\
\hline Cyanide & $0.01^{\mathrm{B}}$ & $0.01^{\mathrm{g}}$ & $0.01^{\mathrm{g}, \mathrm{h}}$ & None \\
\hline Nickel & $0.04^{\mathrm{g}}$ & $0.04^{8}$ & $0.04^{\mathrm{B}}$ & None \\
\hline Sulfide & $0.1^{\mathrm{g}}$ & $0.3^{e}$ & $0.3^{\mathrm{e}}$ & None \\
\hline Thallium & $0.01^{g}$ & $0.015^{\mathrm{e}}$ & $0.01^{8}$ & None \\
\hline Tin & $0.005^{\mathrm{g}}$ & $0.025^{\mathrm{e}}$ & $0.025^{\mathrm{e}}$ & None \\
\hline Vanadium & $0.01^{8}$ & $0.33^{\mathrm{e}}$ & $0.24^{\mathrm{e}}$ & None \\
\hline Zinc & $0.005^{g}$ & $0.015^{\mathrm{e}}$ & $0.015^{\mathrm{e}}$ & None \\
\hline \multicolumn{5}{|c|}{$\begin{array}{l}\text { "All units are mg/l unless otherwise noted. } \\
\text { bNC Processing site background groundwater statistical } \\
\text { maximum. } \\
\text { "Lognormal distribution, mean is geometric. } \\
\text { dNormal distribution, mean is arithmetic. } \\
\text { 'Nonparametric distribution } \\
\text { 'Units are pCi/l. } \\
\text { 'Statistical values are below laboratory detection limits in } \\
\text { Table } 8.1 \text { of the Technical Approach Document (DOE, 1989). } \\
\text { "Value is an observed maximum, rather than a statistical } \\
\text { maximum, because less than four samples were available for } \\
\text { statistical analysis. }\end{array}$} \\
\hline
\end{tabular}


TABLE 3.33 BASELINE GROUNDWATER QUALITY DATA BY PARAMETER FOR THE ENTRADA FORMATION, UC PROCESSING SITE, SLICK ROCK, COLORADO

SITE: SRKO1 SLICK ROCK (BOTH SITES)

03/29/89 TO $10 / 15 / 92$

REPORT DATE: $06 / 17 / 93$

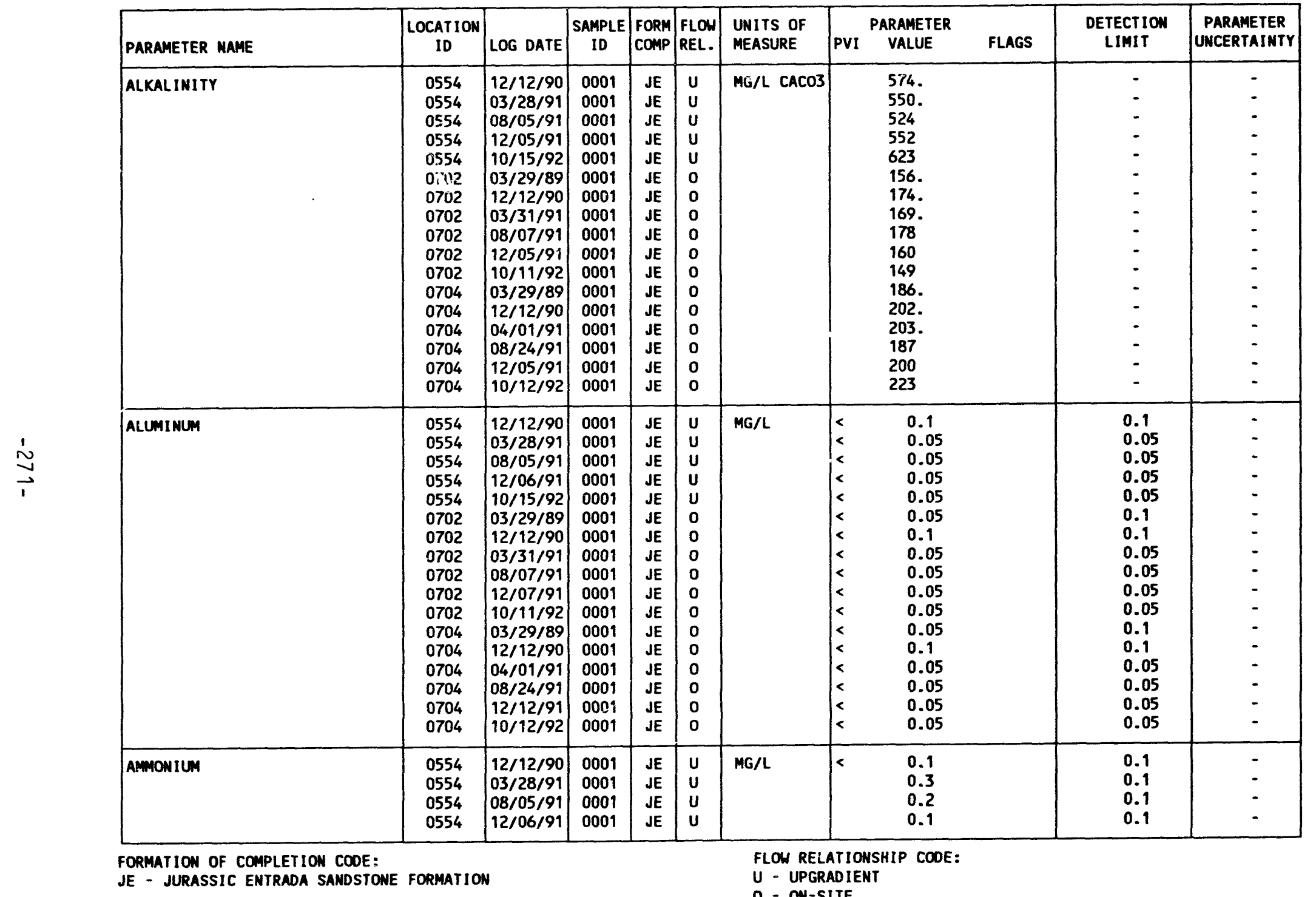

PARAMETER VALUE IMDICATOR (PVI): < - LESS THAN DETECTION LIMIT

SAMPLE ID CODES:

OOO1 - FILTERED SAMPLE (.45 MICRONS) 
TABLE 3.33 BASELINE GROUNDWATER QUALITY DATA BY PARAMETER FOR THE ENTRADA

FORMATIOW, UC PROCESSING SITE, SLICK ROCK, COLORADO

SITE: SRKO 1 SICK ROCK (BOTH SITES)

$03 / 29 / 89$ TO $10 / 15 / 92$

REPORT DATE: $06 / 17 / 93$

\begin{tabular}{|c|c|c|c|c|c|c|c|c|c|c|c|}
\hline PARAMETER NAME & $\begin{array}{c}\text { LOCATION } \\
\text { ID }\end{array}$ & LOG DATE & $\begin{array}{c}\text { SAMPLE } \\
\text { ID }\end{array}$ & $\begin{array}{l}\text { FORM } \\
\text { COMP }\end{array}$ & $\begin{array}{l}\text { FLOW } \\
\text { REL. }\end{array}$ & $\begin{array}{l}\text { UNITS OF } \\
\text { MEASURE }\end{array}$ & PVI & $\begin{array}{l}\text { PARAMETER } \\
\text { VALUE }\end{array}$ & FLAGS & $\begin{array}{l}\text { DETECTION } \\
\text { LIMIT }\end{array}$ & \begin{tabular}{|} 
PARAMETER \\
UNCERTAINTY
\end{tabular} \\
\hline AMMONIUM & $\begin{array}{l}0554 \\
0702 \\
0702 \\
0702 \\
0702 \\
0702 \\
0702 \\
0704 \\
0704 \\
0704 \\
0704 \\
0704 \\
0704\end{array}$ & $\begin{array}{l}10 / 15 / 92 \\
03 / 29 / 89 \\
12 / 12 / 90 \\
03 / 31 / 91 \\
08 / 07 / 91 \\
12 / 07 / 91 \\
10 / 11 / 92 \\
03 / 29 / 89 \\
12 / 12 / 90 \\
04 / 01 / 91 \\
08 / 24 / 91 \\
12 / 12 / 91 \\
10 / 12 / 92\end{array}$ & $\begin{array}{l}0001 \\
0001 \\
0001 \\
0001 \\
0001 \\
0001 \\
0001 \\
0001 \\
0001 \\
0001 \\
0001 \\
0001 \\
0001\end{array}$ & $\begin{array}{l}\mathrm{JE} \\
\mathrm{JE} \\
\mathrm{JE} \\
\mathrm{JE} \\
\mathrm{JE} \\
\mathrm{JE} \\
\mathrm{JE} \\
\mathrm{JE} \\
\mathrm{JE} \\
\mathrm{JE} \\
\mathrm{JE} \\
\mathrm{JE} \\
\mathrm{JE}\end{array}$ & $\begin{array}{l}U \\
0 \\
0 \\
0 \\
0 \\
0 \\
0 \\
0 \\
0 \\
0 \\
0 \\
0 \\
0\end{array}$ & MG/L & $\mid \begin{array}{l}< \\
< \\
<\end{array}$ & $\begin{array}{l}0.4 \\
0.04 \\
0.1 \\
0.1 \\
0.1 \\
0.2 \\
0.1 \\
0.05 \\
0.1 \\
0.1 \\
0.1 \\
0.2 \\
0.6\end{array}$ & c & $\begin{array}{l}0.1 \\
0.04 \\
0.1 \\
0.1 \\
0.1 \\
0.1 \\
0.1 \\
0.05 \\
0.1 \\
0.1 \\
0.1 \\
0.1 \\
0.1\end{array}$ & $\begin{array}{l}- \\
: \\
- \\
- \\
- \\
- \\
- \\
- \\
-\end{array}$ \\
\hline ANT IMONY & $\begin{array}{l}0554 \\
0554 \\
0554 \\
0554 \\
0554 \\
0702 \\
0702 \\
0702 \\
0702 \\
0702 \\
0702 \\
0704 \\
0704 \\
0704 \\
0704 \\
0704 \\
0704\end{array}$ & $\begin{array}{l}12 / 12 / 90 \\
03 / 28 / 91 \\
08 / 05 / 91 \\
12 / 06 / 91 \\
10 / 15 / 92 \\
03 / 29 / 89 \\
12 / 12 / 90 \\
03 / 31 / 91 \\
08 / 07 / 91 \\
12 / 07 / 91 \\
10 / 11 / 92 \\
03 / 29 / 89 \\
12 / 12 / 90 \\
04 / 01 / 91 \\
08 / 24 / 91 \\
12 / 12 / 91 \\
10 / 12 / 92\end{array}$ & $\begin{array}{l}0001 \\
0001 \\
0001 \\
0001 \\
0001 \\
0001 \\
0001 \\
0001 \\
0001 \\
0001 \\
0001 \\
0001 \\
0001 \\
0001 \\
0001 \\
0001 \\
0001\end{array}$ & $\begin{array}{l}\mathrm{JE} \\
\mathrm{JE} \\
\mathrm{JE} \\
\mathrm{JE} \\
\mathrm{JE} \\
\mathrm{JE} \\
\mathrm{JE} \\
\mathrm{JE} \\
\mathrm{JE} \\
\mathrm{JE} \\
\mathrm{JE} \\
\mathrm{JE} \\
\mathrm{JE} \\
\mathrm{JE} \\
\mathrm{JE} \\
\mathrm{JE} \\
\mathrm{JE}\end{array}$ & $\begin{array}{l}U \\
U \\
U \\
U \\
U \\
0 \\
0 \\
0 \\
0 \\
0 \\
0 \\
0 \\
0 \\
0 \\
0 \\
0 \\
0\end{array}$ & $M G / L$ & $\mid \begin{array}{l}< \\
< \\
< \\
< \\
< \\
< \\
< \\
< \\
< \\
< \\
< \\
< \\
< \\
< \\
< \\
< \\
<\end{array}$ & $\begin{array}{l}0.003 \\
0.003 \\
0.003 \\
0.003 \\
0.003 \\
0.001 \\
0.003 \\
0.006 \\
0.003 \\
0.003 \\
0.004 \\
0.001 \\
0.003 \\
0.003 \\
0.003 \\
0.003 \\
0.003\end{array}$ & & $\begin{array}{l}0.003 \\
0.003 \\
0.003 \\
0.003 \\
0.003 \\
0.003 \\
0.003 \\
0.003 \\
0.003 \\
0.003 \\
0.003 \\
0.003 \\
0.003 \\
0.003 \\
0.003 \\
0.003 \\
0.003\end{array}$ & $\begin{array}{l}- \\
- \\
- \\
- \\
- \\
- \\
- \\
- \\
- \\
- \\
- \\
- \\
- \\
-\end{array}$ \\
\hline ARSENIC & $\begin{array}{l}0554 \\
0554 \\
0554 \\
0554 \\
0554 \\
0702 \\
0702\end{array}$ & $\begin{array}{l}12 / 12 / 90 \\
03 / 28 / 91 \\
08 / 05 / 91 \\
12 / 06 / 91 \\
10 / 15 / 92 \\
03 / 29 / 89 \\
12 / 12 / 90\end{array}$ & $\begin{array}{l}0001 \\
0001 \\
0001 \\
0001 \\
0001 \\
0001 \\
0001\end{array}$ & $\begin{array}{l}\mathrm{JE} \\
\mathrm{JE} \\
\mathrm{JE} \\
\mathrm{JE} \\
\mathrm{JE} \\
\mathrm{JE} \\
\mathrm{JE}\end{array}$ & $\begin{array}{l}U \\
U \\
U \\
U \\
U \\
0 \\
0\end{array}$ & $M G / L$ & $\mid<$ & $\begin{array}{l}0.01 \\
0.01 \\
0.01 \\
0.01 \\
0.006 \\
0.001 \\
0.01\end{array}$ & c & $\begin{array}{l}0.01 \\
0.01 \\
0.01 \\
0.01 \\
0.005 \\
0.001 \\
0.01\end{array}$ & $\begin{array}{l}- \\
- \\
- \\
-\end{array}$ \\
\hline
\end{tabular}

FORMATION OF COMPLETION CODE:

JE - JURASSIC ENTRADA SANDSTONE FORMATION
FLON RELATIONSHIP COOE:

- - ON-SITE

SAMPLE ID CODES:

0001 - FILTERED SAMPLE (.45 MICRONS)

PARAMETER VALUE INDICATOR (PVI): < - LESS THAN DETECTION LIMIT

OTHER PARAMETER VALUE FLAGS:

C - CHANGED DETECTION LIMIT 
TABLE 3.33 BASELINE GROUNDWATER QUALITY DATA BY PARAMETER FOR THE ENTRADA

FORMATION, UC PROCESSING SITE, SLICK ROCK, COLORADO

SITE: SRKO1 SLICK ROCK (BOTH SITES)

03/29/89 TO 10/15/92

REPORT DATE: 06/17/93

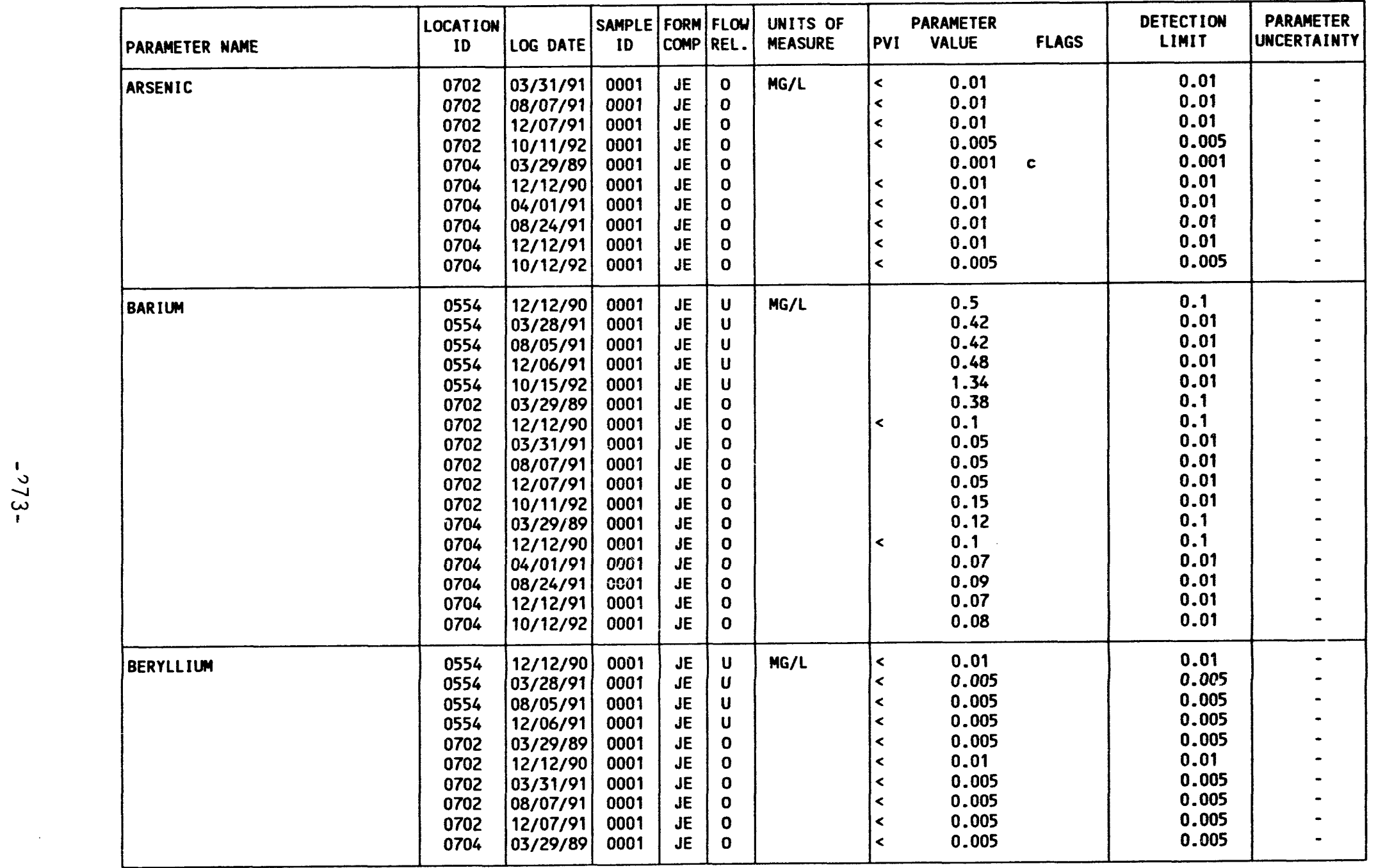

FORMATION OF COMPLETION CODE:

FLOW RELATIONSHIP COOE:

JE - JURASSIC ENTRADA SAMDSTONE FORMATION

O- ON-SITE

$U$ - UPGRADIENT

PARAMETER VALUE INDICATOR (PVI): < - LESS thaN DETECTION LIMIT

TO COOES:

0001 - FILTERED SAMPLE (.45 MICRONS)

OTHER PARAMETER VALUE FLAGS:

c - CHANGED DETECTION LIMIT 
TABLE 3.33 BASELINE GROUNDWATER QUALITY DATA BY PARAMETER FOR THE ENTRADA

FORMATION, UC PROCESSING SITE, SLICK ROCK, COLORADO

SITE: SRKOI SLICK ROCK (BOTH SITES)

03/29/89 TO $10 / 15 / 92$

REPORT DATE: $06 / 17 / 93$

\begin{tabular}{|c|c|c|c|c|c|c|c|c|c|c|c|c|}
\hline & PARAMETER NAME & $\underset{\text { ID }}{\text { LOCATION }}$ & LOG DATE & $\begin{array}{c}\text { SAMPLE } \\
10\end{array}$ & $\begin{array}{l}\text { FORM } \\
\text { COMP }\end{array}$ & $\begin{array}{l}\text { FLOW } \\
\text { REL. }\end{array}$ & $\begin{array}{l}\text { UNITS OF } \\
\text { MEASURE }\end{array}$ & PVI & $\begin{array}{l}\text { ARAMETER } \\
\text { VALUE }\end{array}$ & FLAGS & $\begin{array}{l}\text { DETECTION } \\
\text { LIMIT }\end{array}$ & $\begin{array}{c}\text { PARAMETER } \\
\text { UNCERTAINTY }\end{array}$ \\
\hline & BERYLLIUM & $\begin{array}{l}0704 \\
0704 \\
0704 \\
0704 \\
\end{array}$ & $\begin{array}{l}12 / 12 / 90 \\
04 / 01 / 91 \\
08 / 24 / 91 \\
12 / 12 / 91\end{array}$ & $\begin{array}{l}0001 \\
0001 \\
0001 \\
0001\end{array}$ & $\begin{array}{l}\text { JE } \\
\text { JE } \\
\text { JE } \\
\text { JE }\end{array}$ & $\begin{array}{l}0 \\
0 \\
0 \\
0\end{array}$ & $M G / L$ & $\begin{array}{l}< \\
< \\
< \\
<\end{array}$ & $\begin{array}{l}0.01 \\
0.005 \\
0.005 \\
0.005\end{array}$ & & $\begin{array}{l}0.01 \\
0.005 \\
0.005 \\
0.005\end{array}$ & : \\
\hline \multirow{3}{*}{$\underset{⿱}{N}$} & BORON & $\begin{array}{l}0554 \\
0554 \\
0554 \\
0554 \\
0702 \\
0702 \\
0702 \\
0702 \\
0704 \\
0704 \\
0704 \\
0704\end{array}$ & $\begin{array}{l}12 / 12 / 90 \\
03 / 28 / 91 \\
08 / 05 / 91 \\
12 / 06 / 91 \\
12 / 12 / 90 \\
03 / 31 / 91 \\
08 / 07 / 91 \\
12 / 07 / 91 \\
12 / 12 / 90 \\
04 / 01 / 91 \\
08 / 24 / 91 \\
12 / 12 / 91\end{array}$ & $\begin{array}{l}0001 \\
0001 \\
0001 \\
0001 \\
0001 \\
0001 \\
0001 \\
0001 \\
0001 \\
0001 \\
0001 \\
0001\end{array}$ & $\begin{array}{l}\mathrm{JE} \\
\mathrm{JE} \\
\mathrm{JE} \\
\mathrm{JE} \\
\mathrm{JE} \\
\mathrm{JE} \\
\mathrm{JE} \\
\mathrm{JE} \\
\mathrm{JE} \\
\mathrm{JE} \\
\mathrm{JE} \\
\mathrm{JE}\end{array}$ & $\begin{array}{l}U \\
U \\
U \\
U \\
0 \\
0 \\
0 \\
0 \\
0 \\
0 \\
0 \\
0\end{array}$ & $M G / L$ & $\mid \begin{array}{l}< \\
< \\
< \\
< \\
<\end{array}$ & $\begin{array}{l}0.4 \\
0.29 \\
0.31 \\
0.28 \\
0.1 \\
0.05 \\
0.05 \\
0.05 \\
0.1 \\
0.06 \\
0.10 \\
0.12\end{array}$ & & $\begin{array}{l}0.1 \\
0.05 \\
0.05 \\
0.05 \\
0.1 \\
0.05 \\
0.05 \\
0.05 \\
0.1 \\
0.05 \\
0.05 \\
0.05\end{array}$ & $\begin{array}{l}- \\
- \\
- \\
- \\
- \\
- \\
- \\
- \\
-\end{array}$ \\
\hline & BRTMIDE & $\begin{array}{l}0554 \\
0554 \\
0554 \\
0554 \\
0554 \\
0702 \\
0702 \\
0702 \\
0702 \\
0702 \\
0704 \\
0704 \\
0704 \\
0704 \\
0704\end{array}$ & $\begin{array}{l}12 / 12 / 90 \\
03 / 28 / 91 \\
08 / 05 / 91 \\
12 / 06 / 91 \\
10 / 15 / 92 \\
12 / 12 / 90 \\
03 / 31 / 91 \\
08 / 07 / 91 \\
12 / 07 / 91 \\
10 / 11 / 92 \\
12 / 12 / 90 \\
04 / 01 / 91 \\
08 / 24 / 91 \\
12 / 12 / 91 \\
10 / 12 / 92\end{array}$ & $\begin{array}{l}0001 \\
0001 \\
0001 \\
0001 \\
0001 \\
0001 \\
0001 \\
0001 \\
0001 \\
0001 \\
0001 \\
0001 \\
0001 \\
0001 \\
0001\end{array}$ & $\begin{array}{l}\mathrm{JE} \\
\mathrm{JE} \\
\mathrm{JE} \\
\mathrm{JE} \\
\mathrm{JE} \\
\mathrm{JE} \\
\mathrm{JE} \\
\mathrm{JE} \\
\mathrm{JE} \\
\mathrm{JE} \\
\mathrm{JE} \\
\mathrm{JE} \\
\mathrm{JE} \\
\mathrm{JE} \\
\mathrm{JE}\end{array}$ & $\begin{array}{l}U \\
U \\
U \\
U \\
U \\
0 \\
0 \\
0 \\
0 \\
0 \\
0 \\
0 \\
0 \\
0 \\
0\end{array}$ & $M G / L$ & $\begin{array}{l}< \\
< \\
< \\
< \\
<\end{array}$ & $\begin{array}{c}3.8 \\
3.4 \\
2.9 \\
3.3 \\
10 . \\
0.1 \\
0.9 \\
0.3 \\
0.3 \\
0.5 \\
0.1 \\
0.3 \\
0.1 \\
0.3 \\
0.2\end{array}$ & $\begin{array}{l}1 \\
1 \\
1 \\
c \\
1\end{array}$ & $\begin{array}{c}0.01 \\
0.1 \\
1.5 \\
0.8 \\
10 . \\
0.01 \\
0.1 \\
0.3 \\
0.1 \\
0.5 \\
0.1 \\
0.1 \\
0.1 \\
0.1 \\
0.2\end{array}$ & $\begin{array}{l}- \\
- \\
- \\
- \\
- \\
- \\
- \\
- \\
- \\
- \\
- \\
-\end{array}$ \\
\hline & CADMIUM & $\begin{array}{l}0554 \\
0554 \\
0554 \\
0554\end{array}$ & $\begin{array}{l}12 / 12 / 90 \\
03 / 28 / 91 \\
08 / 05 / 91 \\
12 / 06 / 91\end{array}$ & $\begin{array}{l}0001 \\
0001 \\
0001 \\
0001\end{array}$ & $\begin{array}{l}\mathrm{JE} \\
\mathrm{JE} \\
\mathrm{JE} \\
\mathrm{JE}\end{array}$ & $\begin{array}{l}u \\
u \\
u \\
u\end{array}$ & $M G / L$ & $\begin{array}{l}< \\
< \\
< \\
<\end{array}$ & $\begin{array}{l}0.001 \\
0.001 \\
0.001 \\
0.001\end{array}$ & & $\begin{array}{l}0.001 \\
0.001 \\
0.001 \\
0.001\end{array}$ & : \\
\hline
\end{tabular}

FORMATION OF COMPLETION CODE:

JE - JURASSIC ENTRADA SANDSTONE FORMATION

PARAMETER VALUE INDICATOR (PVI): < - LESS thAN DETECTION LIMIT
FLOW RELATIONSHIP CODE:

O - ON-SITE

SAMPLE ID CODES:

0001 - FILTERED SAMPLE (.45 MICRONS)

OTHER PARAMETER VALUE FLAGS:

I - INCREASED DETECTION LIMIT DUE TO REQUIRED DILUTION

c - CHANGED DETECTION LIMIT 


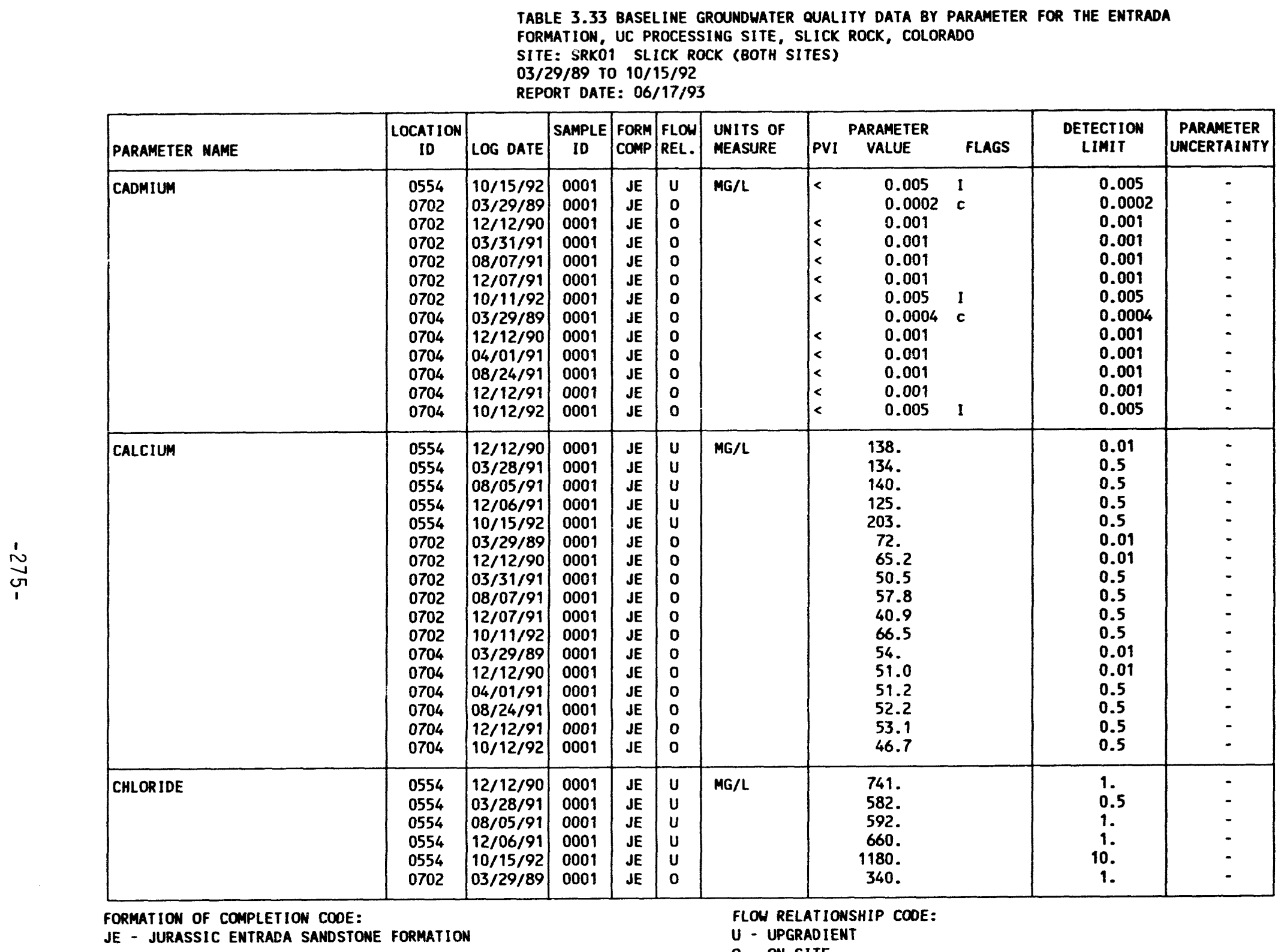

JE - JURASSIC ENTRADA SANDSTONE FORMATION

$U$ - UPGRADIEN

O - ON-SITE

PARAMETER VALUE INDICATOR (PVI): < - LESS THAN DETECTION LIMIT

SAMPLE ID CODES:

0001 - FILTERED SAMPLE (.45 MICRONS)

OTHER PARAMETER YALUE FLAGS:

I - INCREASED DETECTION LIMIT DUE TO REOUIRED DILUTION

c - CHANGED DETECTION LIMIT 
TABLE 3.33 BASELINE GROUNDHATER OUALITY DATA BY PARAMETER FOR THE ENTRADA FORMATION, UC PROCESSING SITE, SLICK ROCK, COLORADO

SITE: SRKDI SLICK ROCK (BOTH SITES)

03/29/89 TO $10 / 15 / 92$

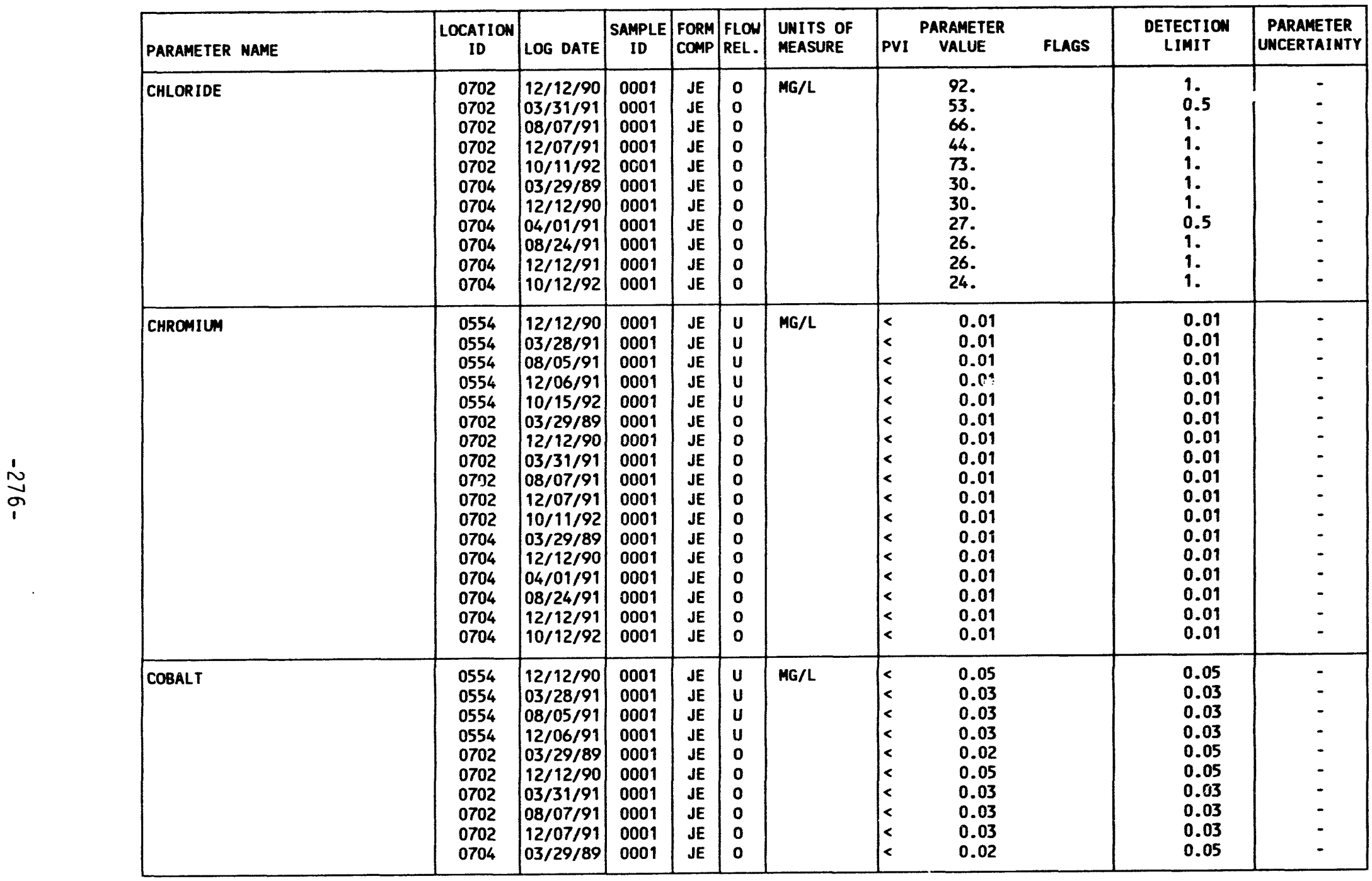

FORMATION OF COMPLETION COOE:

JE - JURASSIC ENTRADA SANDSTONE FORMATION
FLOW RELATIONSHIP CODE:

O - ON-SITE

U - UPGRADIENT

SAMPLE ID CODES

0002 - FILTERED SAMPLE (.45 MICRONS)

PARAMETER VALUE INDICATOR (PVI): < - LESS THAN DETECTION LIMIT 
TABLE 3.33 BASELINE GROUNDWATER QUALITY DATA BY PARAMETER FOR THE ENTRADA FORMATION, UC PROCESSING SITE, SLICK ROCK, COLORADO

SITE: SRKO1 SLICK ROCK (BOTH SITES)

03/29/89 TO 10/15/92

REPORT DATE: 06/17/93

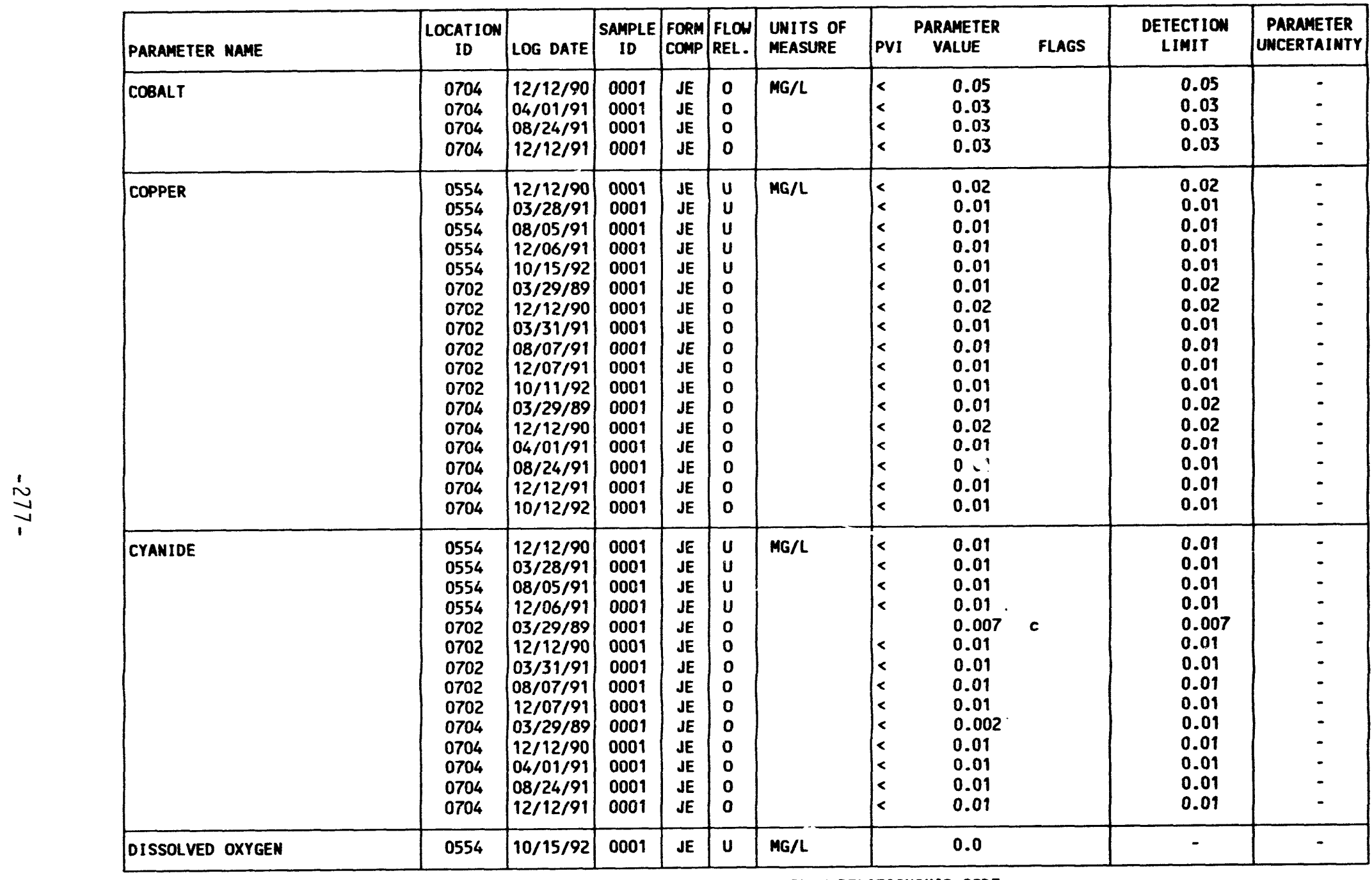

FORMATION OF COMPLETION COOE:

JE - JURASSIC ENTRADA SANDSTONE FORMATION

PARAMETER VALUE INDICATOR (PVI): < - LESS THAN DETECTION LIMIT
FLOW RELATIONSHIP COOE:

O - ON-SITE

SAMPLE ID CODES:

0001 - FILTERED SAMPLE (.45 MICRONS)

OtHer parameter Value flags:

c - CHANGED DETECTION LIMIT 
TABLE 3.33 BASELIME GROUNDUATER QUALITY DATA BY PARAMETER FOR THE ENTRADA

FORMATIOY UC PROCESSIMG SITE, SLICK ROCK, COLORADO

SITE: SRK01 SLICK ROCK (BOTH SITES)

SITE: SRKO1 SLICK ROCK
$03 / 29 / 89$ TO $10 / 15 / 92$

REPORT DATE: 06/17/93

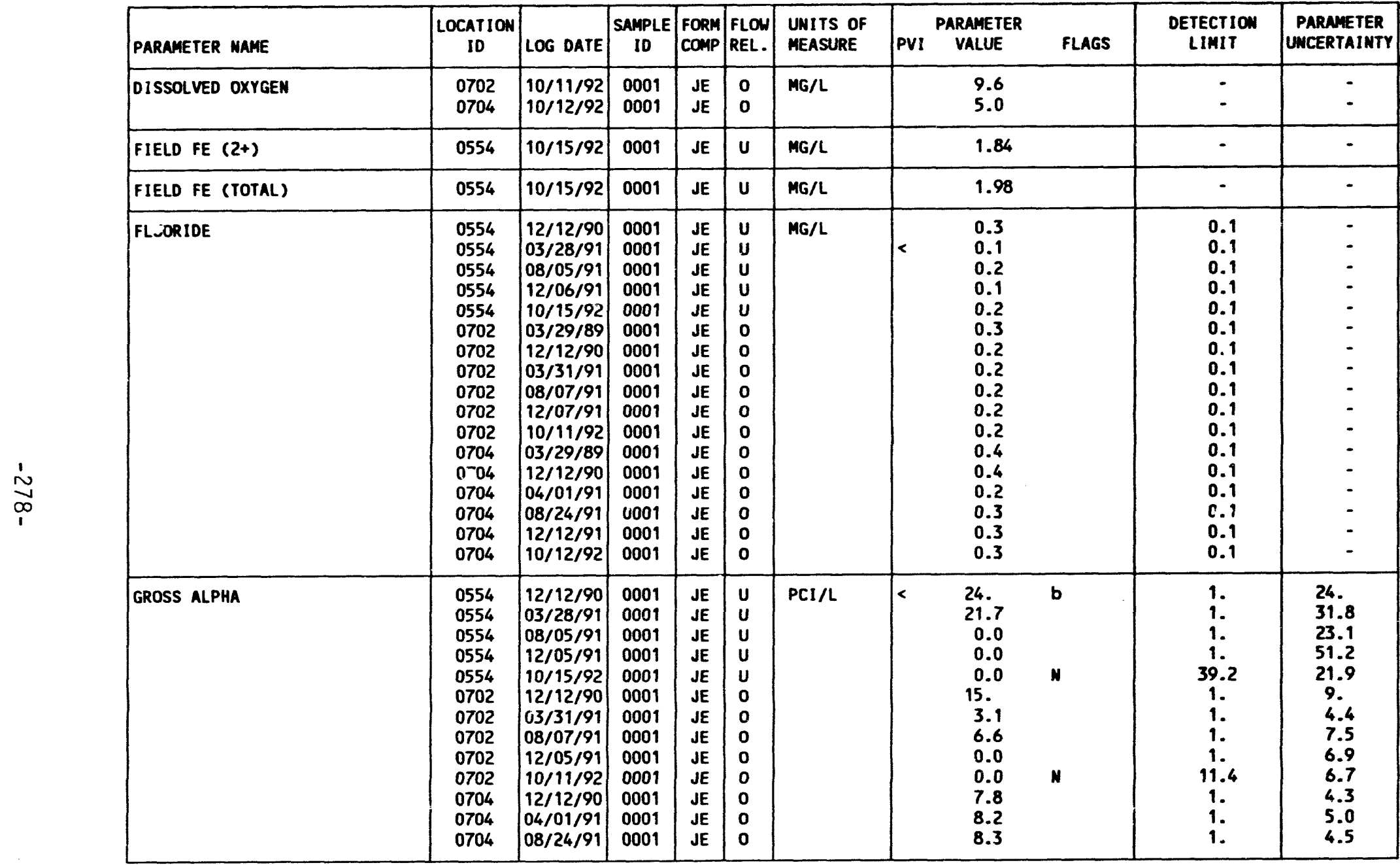

FORMATION OF COMPLETION COOE:

JE - JURASSIC ENTRADA SANDSTONE FORMATION
FLOW RELATIONSHIP COOE:

- ON-SITE

\section{SAMPLE ID COOES:}

0001 - FILTERED SAMPLE (.45 MICRONS)

OTHER PARAMETER VALUE FLAGS:

N - SPIKE SAMPLE RECOVERY NOT HITHIN CONTROL LIMITS

b - CHANGed PARAMETER VAlUe 
TABLE 3.33 BASELINE GROUNDWATER QUALITY DATA BY PARAMETER FOR THE ENTRADA

FORMATION, UC PROCESSING SITE, SLICK ROCK, COLORADO

SITE: SRKO1 SLICK ROCK (BOTH SITES)

03/29/89 TO $10 / 15 / 92$

REPORT DATE: $06 / 17 / 93$

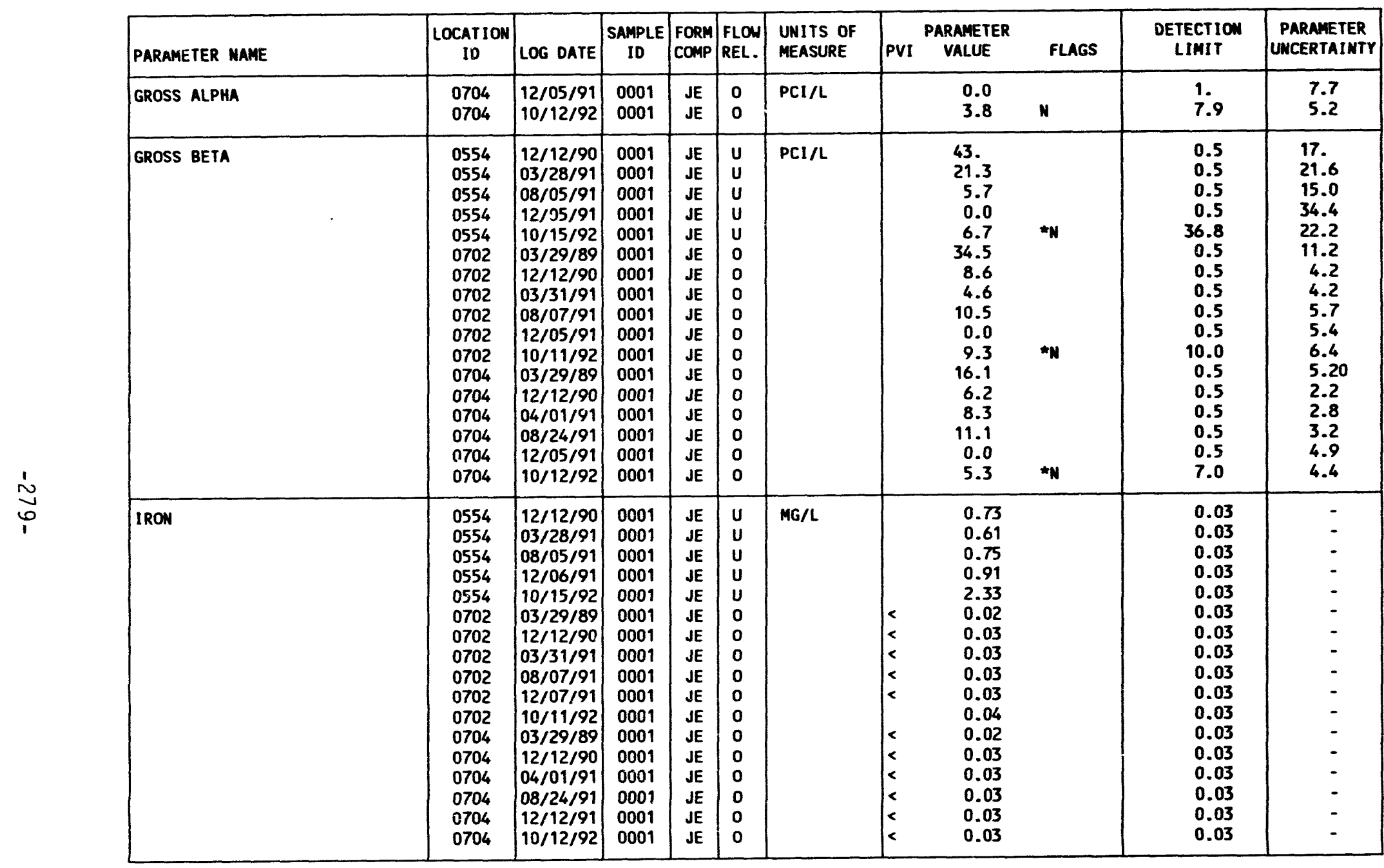

FOYMATION OF COMFIETION COOE:

JE - JURASSIC ENTRADA SANDSTONE FORMATION
FLOW RELATIONSHIP COOE:

U. - OPGRADIENT

PARAMETER VALUE INDICATOR (PVI): < - LESS THAN DETECTION LIMIT

0001 - FILTERED SAMPLE (.45 MICRONS)

OTHER PARAMETER VALUE FLAGS:

* - DUPLicate amalysis not HITHIN CONTROL limits

N - SPIKE SAMPLE RECOVERY NOT WITHIN CONTROL LIMITS 


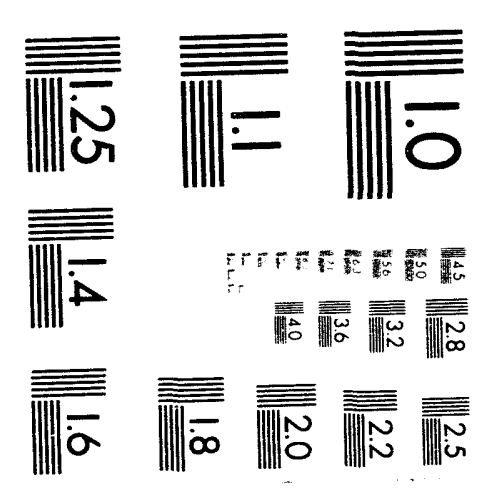



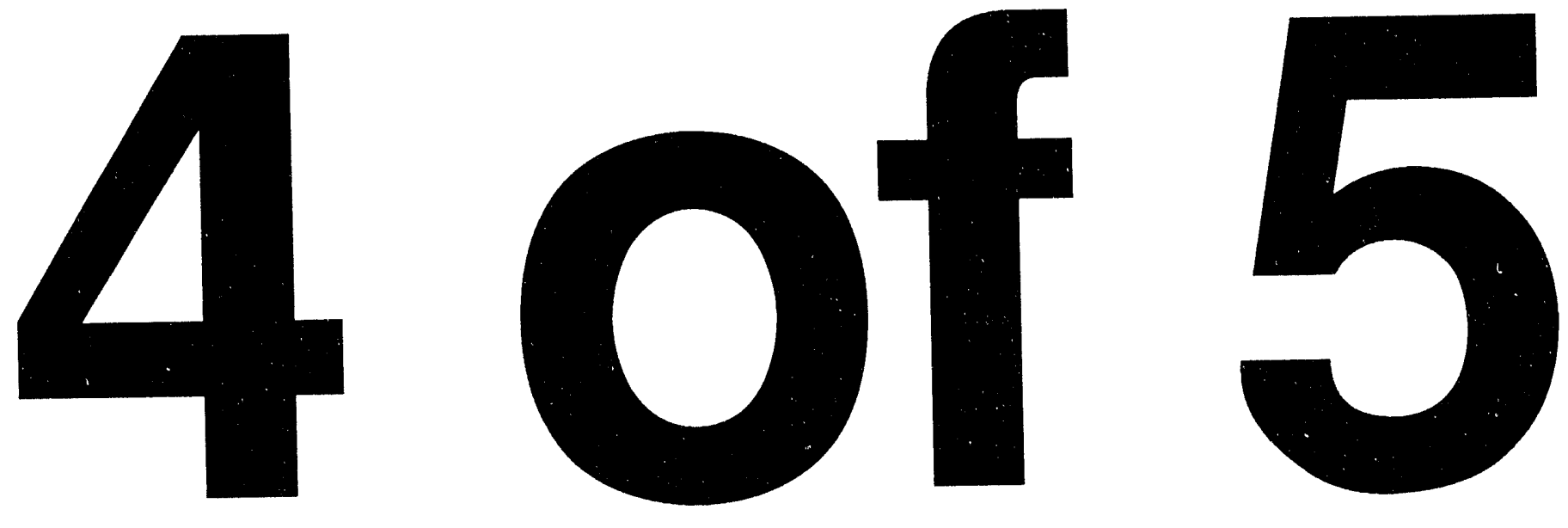
TABLE 3.33 BASELINE GROUNDWATER QUALITY DATA BY PARAMETER FOR THE ENTRADA

FORMATION, UC PROCESSING SITE, SLICK ROCK, COLORADO

SITE: SRKO1 SLICK ROCK (BOTH SITES)

03/29/89 TO 10/15/92

REPORT DATE: $06 / 17 / 93$

\begin{tabular}{|c|c|c|c|c|c|c|c|c|c|c|c|c|}
\hline & PARAMETER NAME & $\begin{array}{c}\text { LOCATION } \\
\text { ID }\end{array}$ & LOG DATE & $\begin{array}{c}\text { SAMPLE } \\
\text { ID }\end{array}$ & $\begin{array}{l}\text { FORM } \\
\text { COMP }\end{array}$ & $\begin{array}{l}\text { FLOW } \\
\text { REL. }\end{array}$ & $\begin{array}{l}\text { UNITS OF } \\
\text { MEASURE }\end{array}$ & PVI & $\begin{array}{l}\text { PARAMETER } \\
\text { VALUE }\end{array}$ & FLAGS & $\begin{array}{l}\text { DETECTION } \\
\text { LIMIT }\end{array}$ & $\begin{array}{l}\text { PARAMETER } \\
\text { UNCERTAINTY }\end{array}$ \\
\hline \multirow{3}{*}{ 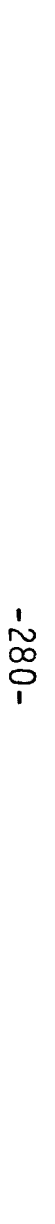 } & LEAD & $\begin{array}{l}0554 \\
0554 \\
0554 \\
0554 \\
0554 \\
0702 \\
0702 \\
0702 \\
0702 \\
0702 \\
0702 \\
0704 \\
0704 \\
0704 \\
0704 \\
0704 \\
0704\end{array}$ & $\begin{array}{l}12 / 12 / 90 \\
03 / 28 / 91 \\
08 / 05 / 91 \\
12 / 06 / 91 \\
10 / 15 / 92 \\
03 / 29 / 89 \\
12 / 12 / 90 \\
03 / 31 / 91 \\
08 / 07 / 91 \\
12 / 07 / 91 \\
10 / 11 / 92 \\
03 / 29 / 89 \\
12 / 12 / 90 \\
04 / 01 / 91 \\
08 / 24 / 91 \\
12 / 12 / 91 \\
10 / 12 / 92\end{array}$ & $\begin{array}{l}0001 \\
0001 \\
0001 \\
0001 \\
0001 \\
0001 \\
0001 \\
0001 \\
0001 \\
0001 \\
0001 \\
0001 \\
0001 \\
0001 \\
0001 \\
0001 \\
0001\end{array}$ & $\begin{array}{l}J E \\
J E \\
J E \\
J E \\
J E \\
J E \\
J E \\
J E \\
J E \\
J E \\
J E \\
J E \\
J E \\
J E \\
J E \\
J E \\
J E\end{array}$ & $\begin{array}{l}U \\
U \\
U \\
U \\
U \\
0 \\
0 \\
0 \\
0 \\
0 \\
0 \\
0 \\
0 \\
0 \\
0 \\
0 \\
0\end{array}$ & $M G / L$ & $\begin{array}{l}< \\
< \\
< \\
< \\
< \\
< \\
< \\
< \\
< \\
k \\
k \\
k \\
< \\
< \\
< \\
< \\
<\end{array}$ & $\begin{array}{l}0.01 \\
0.005 \\
0.005 \\
0.005 \\
0.003 \\
0.001 \\
0.01 \\
0.005 \\
0.005 \\
0.005 \\
0.02 \\
0.001 \\
0.01 \\
0.005 \\
0.005 \\
0.005 \\
0.02\end{array}$ & 1 & $\begin{array}{l}0.01 \\
0.005 \\
0.005 \\
0.005 \\
0.003 \\
0.01 \\
0.01 \\
0.005 \\
0.005 \\
0.005 \\
0.02 \\
0.01 \\
0.01 \\
0.005 \\
0.005 \\
0.005 \\
0.02\end{array}$ & $\begin{array}{l}- \\
- \\
- \\
- \\
- \\
- \\
- \\
- \\
- \\
- \\
- \\
-\end{array}$ \\
\hline & LEAD-210 & $\begin{array}{l}0554 \\
0554 \\
0702 \\
0702 \\
0704 \\
0704\end{array}$ & $\begin{array}{l}08 / 05 / 91 \\
12 / 05 / 91 \\
08 / 07 / 91 \\
12 / 05 / 91 \\
08 / 24 / 91 \\
12 / 05 / 91\end{array}$ & $\begin{array}{l}0001 \\
0001 \\
0001 \\
0001 \\
0001 \\
0001\end{array}$ & $\begin{array}{l}\text { JE } \\
\text { JE } \\
\text { JE } \\
\text { JE } \\
\text { JE } \\
\text { JE }\end{array}$ & $\begin{array}{l}U \\
U \\
0 \\
0 \\
0 \\
0\end{array}$ & $\mathrm{PCI} / \mathrm{L}$ & & $\begin{array}{l}0.2 \\
0.0 \\
1.4 \\
0.0 \\
0.4 \\
0.0\end{array}$ & & $\begin{array}{l}1.5 \\
1.5 \\
1.5 \\
1.5 \\
1.5 \\
1.5\end{array}$ & $\begin{array}{l}0.8 \\
0.8 \\
0.9 \\
0.8 \\
1.0 \\
0.9\end{array}$ \\
\hline & MAGNESIUM & $\begin{array}{l}0554 \\
0554 \\
0554 \\
0554 \\
0554 \\
0702 \\
0702 \\
0702 \\
0702 \\
0702 \\
0702 \\
0704 \\
0704 \\
0704\end{array}$ & \begin{tabular}{|l|}
$12 / 12 / 90$ \\
$03 / 28 / 91$ \\
$08 / 05 / 91$ \\
$12 / 06 / 91$ \\
$10 / 15 / 92$ \\
$03 / 29 / 89$ \\
$12 / 12 / 90$ \\
$03 / 31 / 91$ \\
$08 / 07 / 91$ \\
$12 / 07 / 91$ \\
$10 / 11 / 92$ \\
$03 / 29 / 89$ \\
$12 / 12 / 90$ \\
$04 / 01 / 91$
\end{tabular} & $\begin{array}{l}0001 \\
0001 \\
0001 \\
0001 \\
0001 \\
0001 \\
0001 \\
0001 \\
0001 \\
0001 \\
0001 \\
0001 \\
0001 \\
0001\end{array}$ & 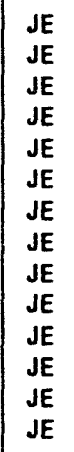 & $\begin{array}{l}U \\
U \\
U \\
U \\
U \\
0 \\
0 \\
0 \\
0 \\
0 \\
0 \\
0 \\
0 \\
0\end{array}$ & $M G / L$ & & $\begin{array}{c}202 . \\
193 . \\
198 . \\
181 . \\
297 . \\
84 . \\
105 . \\
86.0 \\
94.4 \\
64.8 \\
108 . \\
42 . \\
44.3 \\
45.4\end{array}$ & & $\begin{array}{l}0.001 \\
0.5 \\
0.5 \\
0.5 \\
0.5 \\
0.001 \\
0.001 \\
0.5 \\
0.5 \\
0.5 \\
0.5 \\
0.001 \\
0.001 \\
0.1\end{array}$ & $\begin{array}{l}- \\
- \\
- \\
- \\
- \\
- \\
- \\
- \\
-\end{array}$ \\
\hline
\end{tabular}

FORMATION OF COMPLETION CODE:

JE - JURASSIC ENTRADA SANDSTONE FORMATION

PARAMETER VALUE INDICATOR (PVI): < - LESS than DETECTION LIMIT
FLOW RELATIONSHIP COOE

U - UPGRADIENT

O - ON-SITE

SAMPLE ID CODES:

0001 - FILTERED SAMPLE (.45 MICRONS)

OTHER PARAMETER VALUE fLAGS:

1 - INCREASED DETECTION LIMIT DUE TO REQUIRED DILUTION 


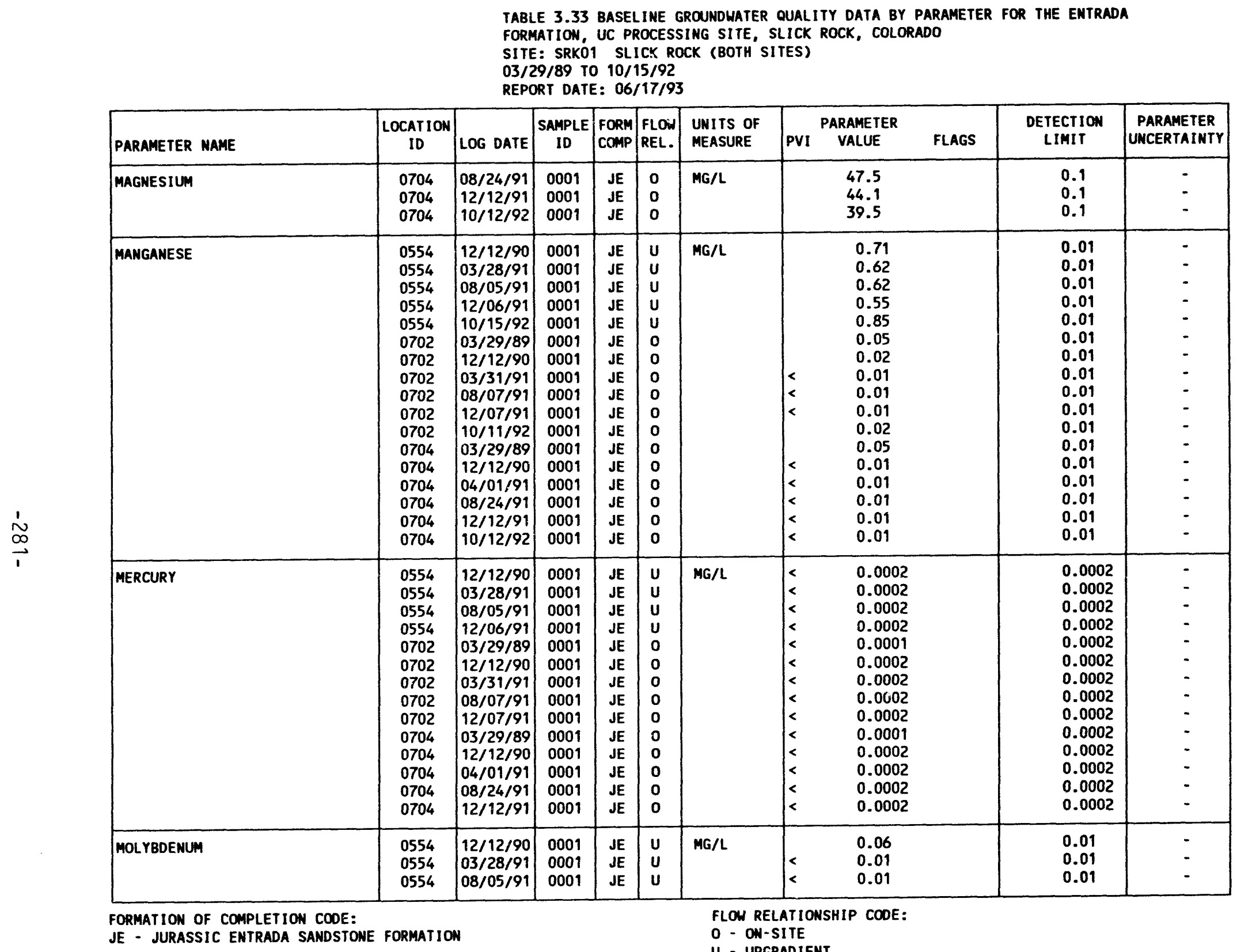

JE - JURASSIC ENTRADA SANDSTONE FORMATION

U - UPGRADIEIT

PARAMETER VALUE INDICATOR (PVI): - - LESS than DETECTION LIMIT SAMPLE ID CODES:

0001 - FILTERED SAMPLE (.45 MICRONS) 
TABLE 3.33 BASELINE GROUNDHATER OUALITY DATA BY PARAMETER FOR THE ENTRADA FORMATION, UC PROCESSING SITE, SLICK ROCK, COLORADO

SITE: SRKO1 SLICK ROCK CBOTH SI

03/29/89 TO 10/15/92

REPORT DATE: $06 / 17 / 93$

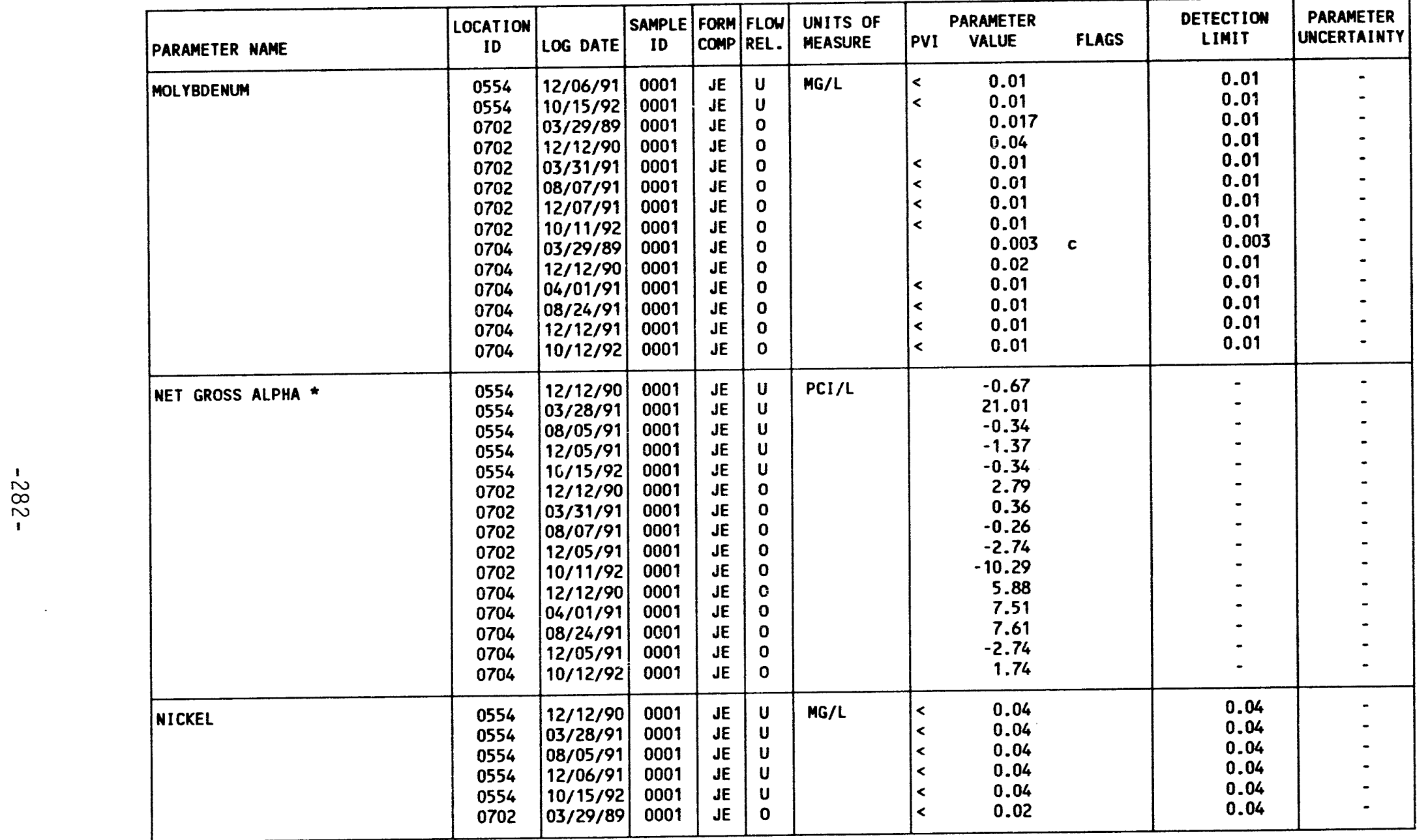

* net gross alPha (Gross ALPHA - URANIUM) WITH 1 Mg URANIUM = 686 PCI

FORMATION OF COMPLETION COOE:

JE - JURASSIC ENTRADA SANDSTONE FORMATION

PARAMETER VALUE INDICATOR (PVI): < - LESS THAN DETECTION LIMIT
FLOW RELATIOUSHIP COOE:

$$
\text { U - UPGRADIENT }
$$

SAMPLE ID CODES:

0001 - FILTERED SAMPLE (.45 MICRONS)

OTHER PARAMETER VALUE FLAGS:

C - CHANGED DETECTION LIMIT 
TABLE 3.33 BASELINE GROUNOWATER QUALITY DATA BY PARAMETER FOR THE ENTRADA FORMATION, UC PROCESSING SITE, SLICK ROCK, COLORADO

SITE: SRKO1 SLICK ROCK (BOTH SITES)

$03 / 29 / 89$ TO $10 / 15 / 92$

REPORT DATE: $06 / 17 / 93$

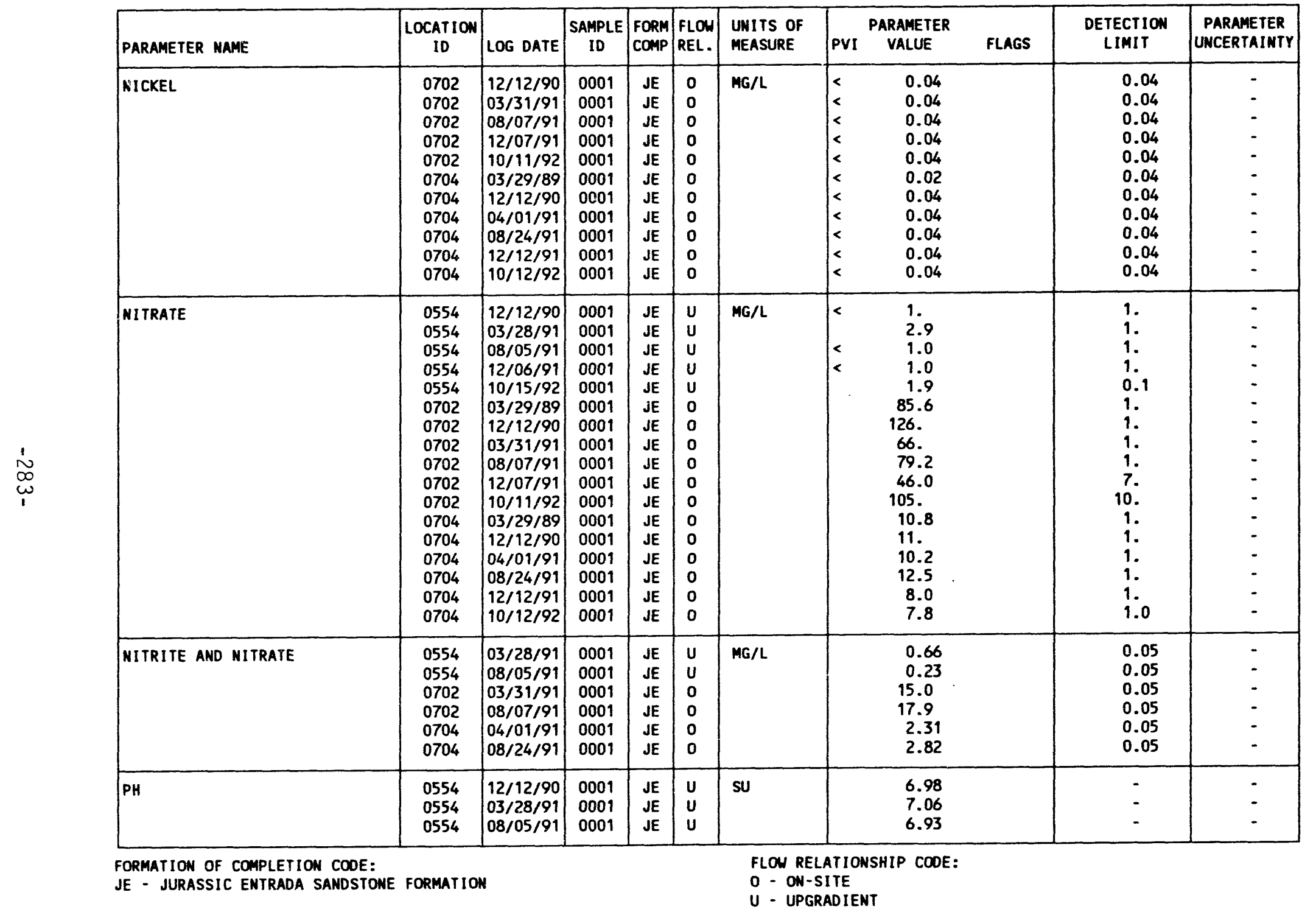

PARAMETER VAlUe INDICATOR (PVI): < - LESS than DETECTION Limit

SAMPLE ID CODES:

0001 - FILTERED SAMPLE (.45 MICRONS) 
TABLE 3.33 BASELINE GROUNDWATER QUALITY DATA BY PARAMETER FOR THE ENTRADA

FORMATION, UC PROCESSING SITE, SLICK ROCK, COLORADO

SITE: SEKO1 SLICK ROCK (BOTH SITES)

$03 / 29 / 89$ TO $10 / 15 / 92$

REPORT DATE: 06/17/93

\begin{tabular}{|c|c|c|c|c|c|c|c|c|c|c|c|}
\hline PARAMETER NAME & $\begin{array}{c}\text { LOCATION } \\
\text { ID }\end{array}$ & LOG DATE & $\begin{array}{c}\text { SAMPLE } \\
\text { ID }\end{array}$ & $\begin{array}{l}\text { FORM } \\
\text { COMP }\end{array}$ & $\begin{array}{l}\text { FLOW } \\
\text { REL. }\end{array}$ & $\begin{array}{l}\text { UNITS OF } \\
\text { MEASURE }\end{array}$ & PVI & $\begin{array}{c}\text { PARAMETE } \\
\text { VALUE }\end{array}$ & FLAGS & $\begin{array}{l}\text { DETECTION } \\
\text { LIMIT }\end{array}$ & $\begin{array}{l}\text { PARAMETER } \\
\text { UNCERTAINTY }\end{array}$ \\
\hline PH & $\begin{array}{l}0554 \\
0554 \\
0702 \\
0702 \\
0702 \\
0702 \\
0702 \\
0702 \\
0704 \\
0704 \\
0704 \\
0704 \\
0704 \\
0704\end{array}$ & $\begin{array}{l}12 / 05 / 91 \\
10 / 15 / 92 \\
03 / 29 / 89 \\
12 / 12 / 90 \\
03 / 31 / 91 \\
08 / 07 / 91 \\
12 / 05 / 91 \\
10 / 11 / 92 \\
03 / 29 / 89 \\
12 / 12 / 90 \\
04 / 01 / 91 \\
08 / 24 / 91 \\
12 / 05 / 91 \\
10 / 12 / 92\end{array}$ & $\begin{array}{l}0001 \\
0001 \\
0001 \\
0001 \\
0001 \\
0001 \\
0001 \\
0001 \\
0001 \\
0001 \\
0001 \\
0001 \\
0001 \\
0001\end{array}$ & 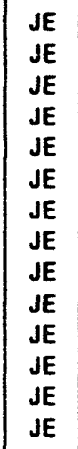 & $\begin{array}{l}U \\
U \\
0 \\
0 \\
0 \\
0 \\
0 \\
0 \\
0 \\
0 \\
0 \\
0 \\
0 \\
0\end{array}$ & su & & $\begin{array}{l}7.09 \\
6.96 \\
7.97 \\
7.79 \\
7.71 \\
7.83 \\
7.79 \\
7.90 \\
7.74 \\
7.51 \\
7.79 \\
7.63 \\
7.84 \\
7.76\end{array}$ & & $\begin{array}{l}- \\
- \\
- \\
- \\
- \\
- \\
- \\
- \\
- \\
-\end{array}$ & $\begin{array}{l}- \\
- \\
- \\
- \\
- \\
- \\
- \\
- \\
-\end{array}$ \\
\hline PHOSPHATE & $\begin{array}{l}0554 \\
0554 \\
0554 \\
0554 \\
0554 \\
0702 \\
0702 \\
0702 \\
0702 \\
0702 \\
0702 \\
0704 \\
0704 \\
0704 \\
0704 \\
0704 \\
0704\end{array}$ & $\begin{array}{l}12 / 12 / 90 \\
03 / 28 / 91 \\
08 / 05 / 91 \\
12 / 06 / 91 \\
10 / 15 / 92 \\
03 / 29 / 89 \\
12 / 12 / 90 \\
03 / 31 / 91 \\
08 / 07 / 91 \\
12 / 07 / 91 \\
10 / 11 / 92 \\
03 / 29 / 89 \\
12 / 12 / 90 \\
04 / 01 / 91 \\
08 / 24 / 91 \\
12 / 12 / 91 \\
10 / 12 / 92\end{array}$ & $\begin{array}{l}0001 \\
0001 \\
0001 \\
0001 \\
0001 \\
0001 \\
0001 \\
0001 \\
0001 \\
0001 \\
0001 \\
0001 \\
0001 \\
0001 \\
0001 \\
0001 \\
0001\end{array}$ & $\begin{array}{l}\mathrm{JE} \\
\mathrm{JE} \\
\mathrm{JE} \\
\mathrm{JE} \\
\mathrm{JE} \\
\mathrm{JE} \\
\mathrm{JE} \\
\mathrm{JE} \\
\mathrm{JE} \\
\mathrm{JE} \\
\mathrm{JE} \\
\mathrm{JE} \\
\mathrm{JE} \\
\mathrm{JE} \\
\mathrm{JE} \\
\mathrm{JE} \\
\mathrm{JE}\end{array}$ & $\begin{array}{l}U \\
U \\
U \\
U \\
U \\
0 \\
0 \\
0 \\
0 \\
0 \\
0 \\
0 \\
0 \\
0 \\
0 \\
0 \\
0\end{array}$ & $M G / L$ & $\begin{array}{l}< \\
< \\
< \\
< \\
< \\
< \\
<\end{array}$ & $\begin{array}{l}0.1 \\
0.2 \\
0.2 \\
0.2 \\
0.1 \\
0.1 \\
0.1 \\
0.1 \\
0.1 \\
0.1 \\
1.2 \\
0.1 \\
0.1 \\
0.1 \\
0.1 \\
0.4 \\
0.3\end{array}$ & $\begin{array}{l}\mathbf{J} \\
\mathbf{J} \\
\mathrm{J}\end{array}$ & $\begin{array}{l}0.1 \\
0.1 \\
0.1 \\
0.01 \\
0.1 \\
0.1 \\
0.1 \\
0.1 \\
0.1 \\
0.1 \\
0.1 \\
0.1 \\
0.1 \\
0.1 \\
0.1 \\
0.1 \\
0.1\end{array}$ & $\begin{array}{l}- \\
- \\
- \\
- \\
- \\
- \\
- \\
- \\
- \\
- \\
- \\
-\end{array}$ \\
\hline POLONIUM-210 & $\begin{array}{l}0554 \\
0554 \\
0702 \\
0702 \\
0704 \\
0704\end{array}$ & $\begin{array}{l}08 / 05 / 91 \\
12 / 05 / 91 \\
08 / 07 / 91 \\
12 / 05 / 91 \\
08 / 24 / 91 \\
12 / 05 / 91\end{array}$ & $\begin{array}{l}0001 \\
0001 \\
0001 \\
0001 \\
0001 \\
0001\end{array}$ & $\begin{array}{l}\mathrm{JE} \\
\mathrm{JE} \\
\mathrm{JE} \\
\mathrm{JE} \\
\mathrm{JE} \\
\mathrm{JE}\end{array}$ & $\begin{array}{l}u \\
U \\
0 \\
0 \\
0 \\
0\end{array}$ & PCI/L & & $\begin{array}{l}0.2 \\
0.0 \\
0.3 \\
0.3 \\
1.4 \\
0.1\end{array}$ & & $\begin{array}{l}1 . \\
1 . \\
1 . \\
1 . \\
1 .\end{array}$ & $\begin{array}{l}0.5 \\
0.2 \\
0.4 \\
0.6 \\
0.9 \\
0.3\end{array}$ \\
\hline
\end{tabular}

FORMATION OF COMPLETION CODE:

JE - JURASSIC ENTRADA SANDSTONE FORMATION

PARAMETER VALUE INDICATOR (PVI): < - LESS THAN DETECTION LIMIT
FLOW RELATIONSHIP COOE:

0. ON-SITE

SAMPLE ID COOES:

0001 - FILTERED SAMPLE (.45 MICRONS)

OTHER PARAMETER VALUE FLAGS:

J - ESTIMATED VALUE 
TABLE 3.33 BASELINE GROUNDHATER QUALITY DATA BY PARAMETER FOR THE ENTRADA

FORMATION, UC PROCESSING SITE, SLICK ROCK, COLORADO

SITE: SRKO1 SLITK ROCK (BOTH SITES)

$03 / 29 / 89$ TO $10 / 13 /$ Y 2

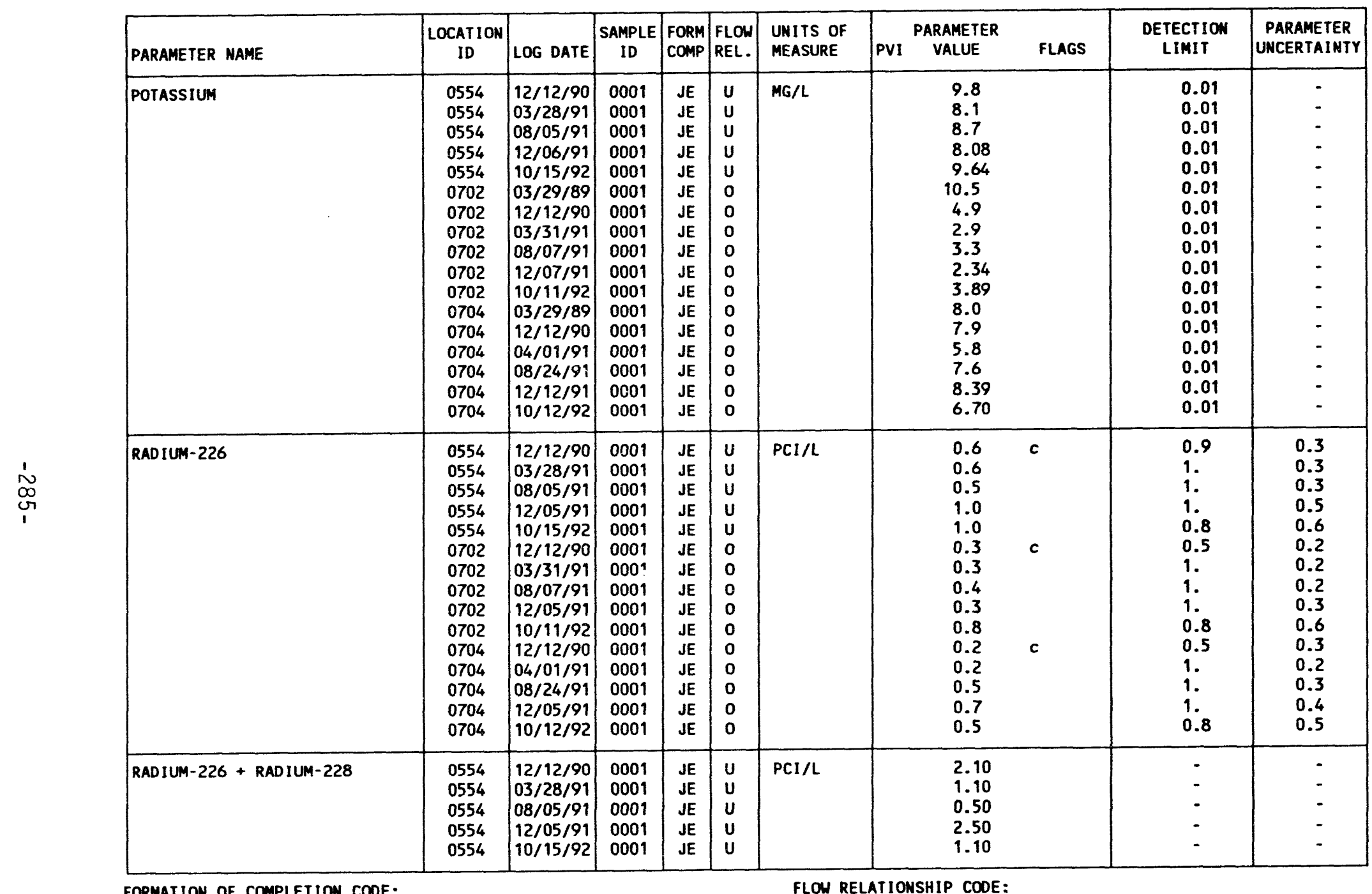

FORMATION OF COMPLETION CODE:

JE - JURASSIC ENTRADA SANDSTONE FORMATION

PARAMETER VALUE INDICATOR (PVI): < - LESS THAN DETECTION LIMIT
FLON RELATIONSHIP CODE:

U - UPGRADIENT

O - ON-SITE

SAMPLE ID CODES:

0001 - FILTERED SAMPLE (.45 MICRONS)

OTHER PARAMETER VALUE FLAGS:

c - CHANGED DETECTION LIK:T 
TABLE 3.33 BASELINE GROUNDHATER QUALITY DATA BY PARAMETER FOR THE ENTRADA FORMATION, UC PROCESSING SITE, SLICK ROCK, COLORADO

SITE: SRKO1 SLICK ROCK (BOTH SITES)

$03 / 29 / 89$ TO $10 / 15 / 92$

REPORT DATE : 06/17/93

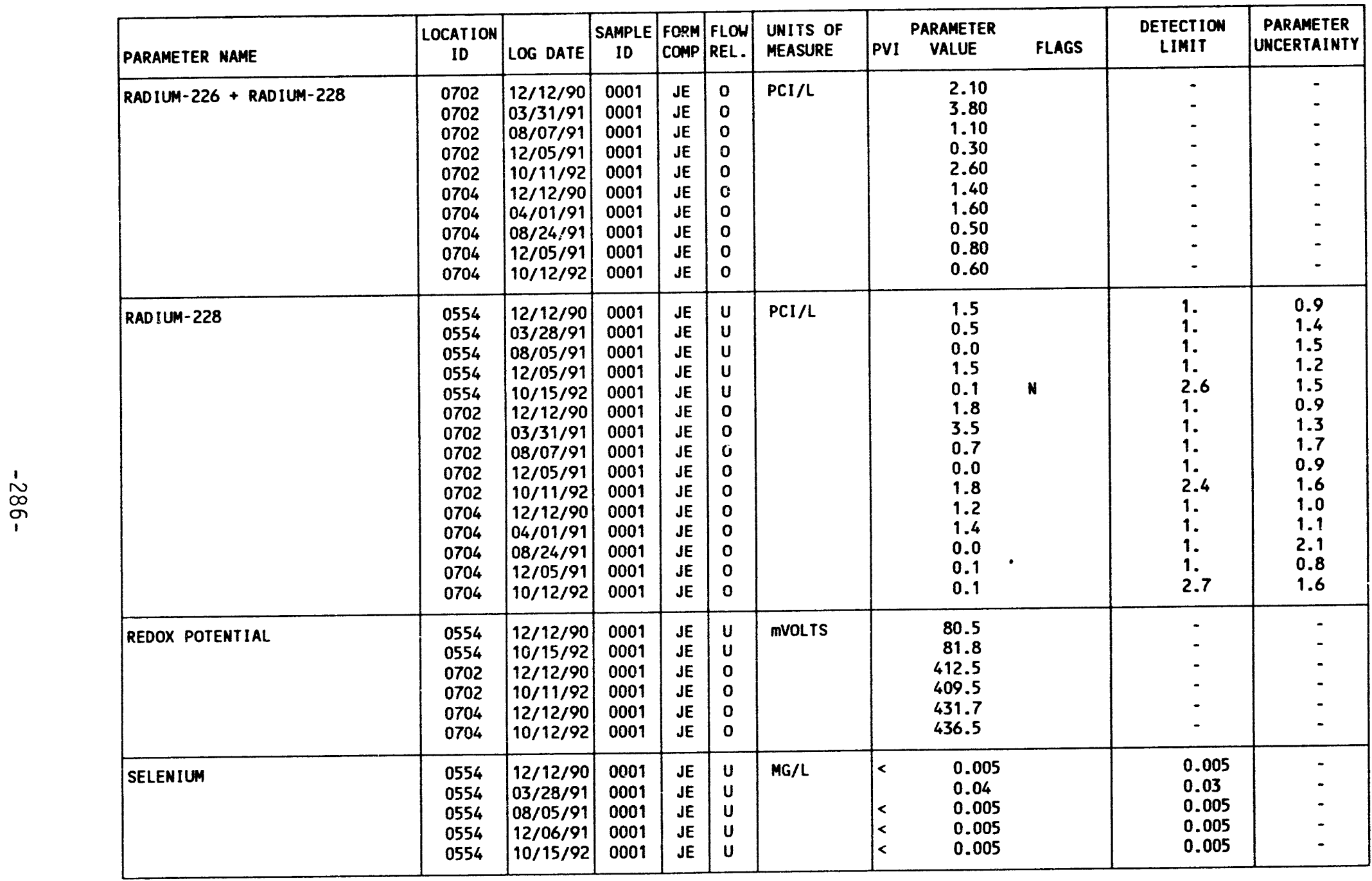

FORMATION OF COMPLETION CODE:

JE - JURASSIC ENTRADA SANDSTONE FORMATION

PARAMETER VALUE indicator (PVI): < - LESS THAN DETECTION LIMIT
FLOW RELATIONSHIP COOE:

O - ON-SITE

U - UPGRADIENT

SAMPLE ID COOES:

0001 - FILTERED SAMPLE (.45 MICRONS)

OTHER PARAMETER VALUE FLAGS:

N - SPIKE SAMPLE RECOVERY NOT WITHIN CONTROL LIMITS 
TABLE 3.33 BASELINE GROUNDWATER QUALITY DATA BY PARAMETER FOR THE ENTRADA

FORMATION, UC PROCESSING SITE, SLICK ROCK, COLORADO

SITE: SRKO1 SLICK ROCK (BOTH SITES)

$03 / 29 / 89$ TO $10 / 15 / 92$

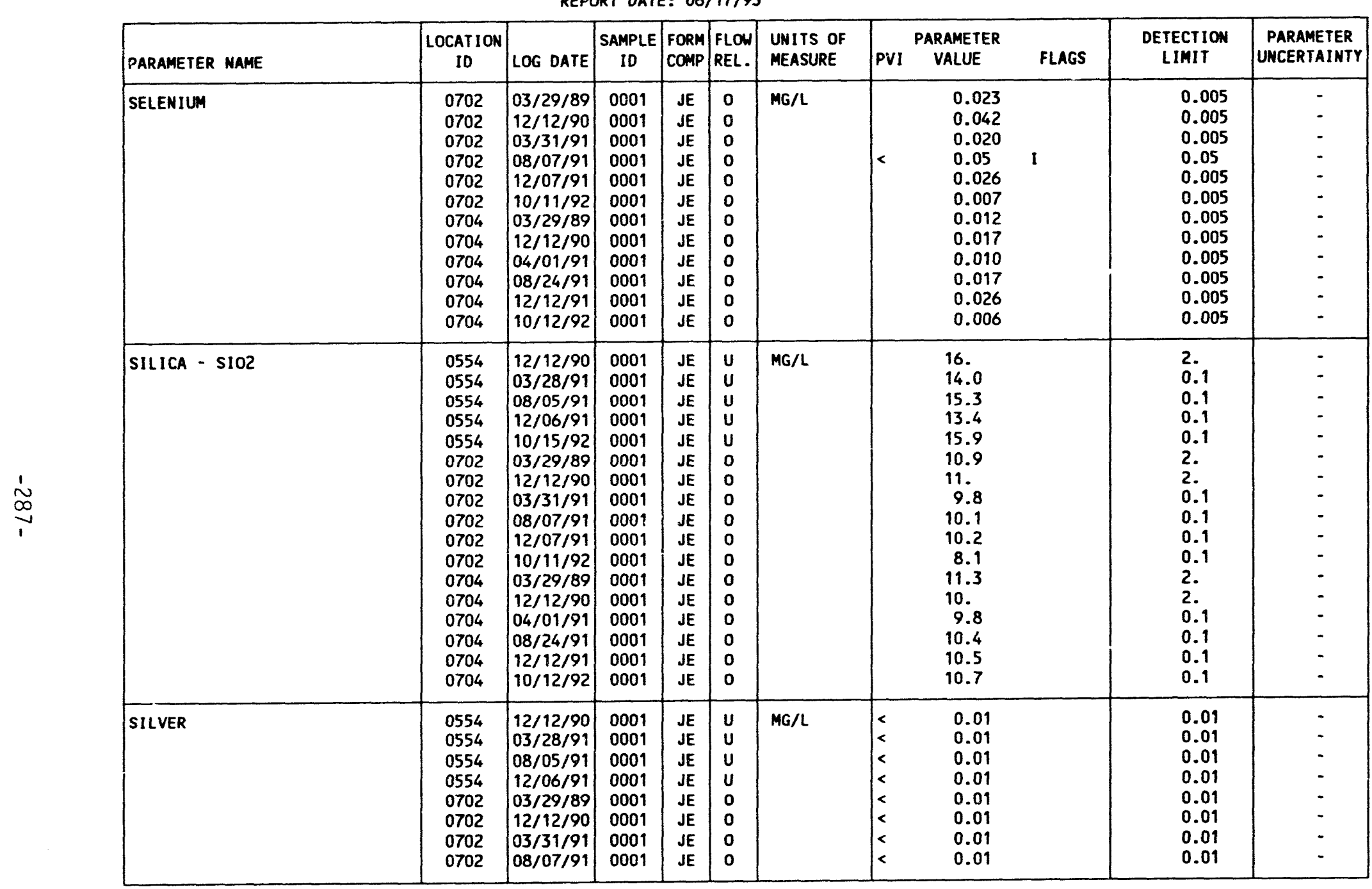

FORMATION OF COMPLETION COOE:

JE - JURASSIC ENTRADA SANDSTONE FORMATION

FLOW RELATIONSHIP CODE:

O - ON-SITE
U - UPGRADIENT

PARAMETER VALUE INDICATOR (PVI): < - LESS THAN DETECTION LIMIT

SAMPLE ID COOES:

0001 - FILTERED SAMPLE (.45 MICRONS)

OTHER PARAMETER VALUE FLAGS:

I - INCREASED DETECTION LIMIT DUE TO REQUIRED DILUTION 
TABLE 3.33 BASELINE GROUNDWATER QUALITY DATA BY PARAMETER FOR THE ENTRADA FORMATION UC PROCESSING SITE SLICK ROCK, COLORADO

SITE: SRKO1 SLICK ROCK (BOTH SITES)

03/29/89 TO $10 / 15 / 92$

REPORT DATE: 06/17/93

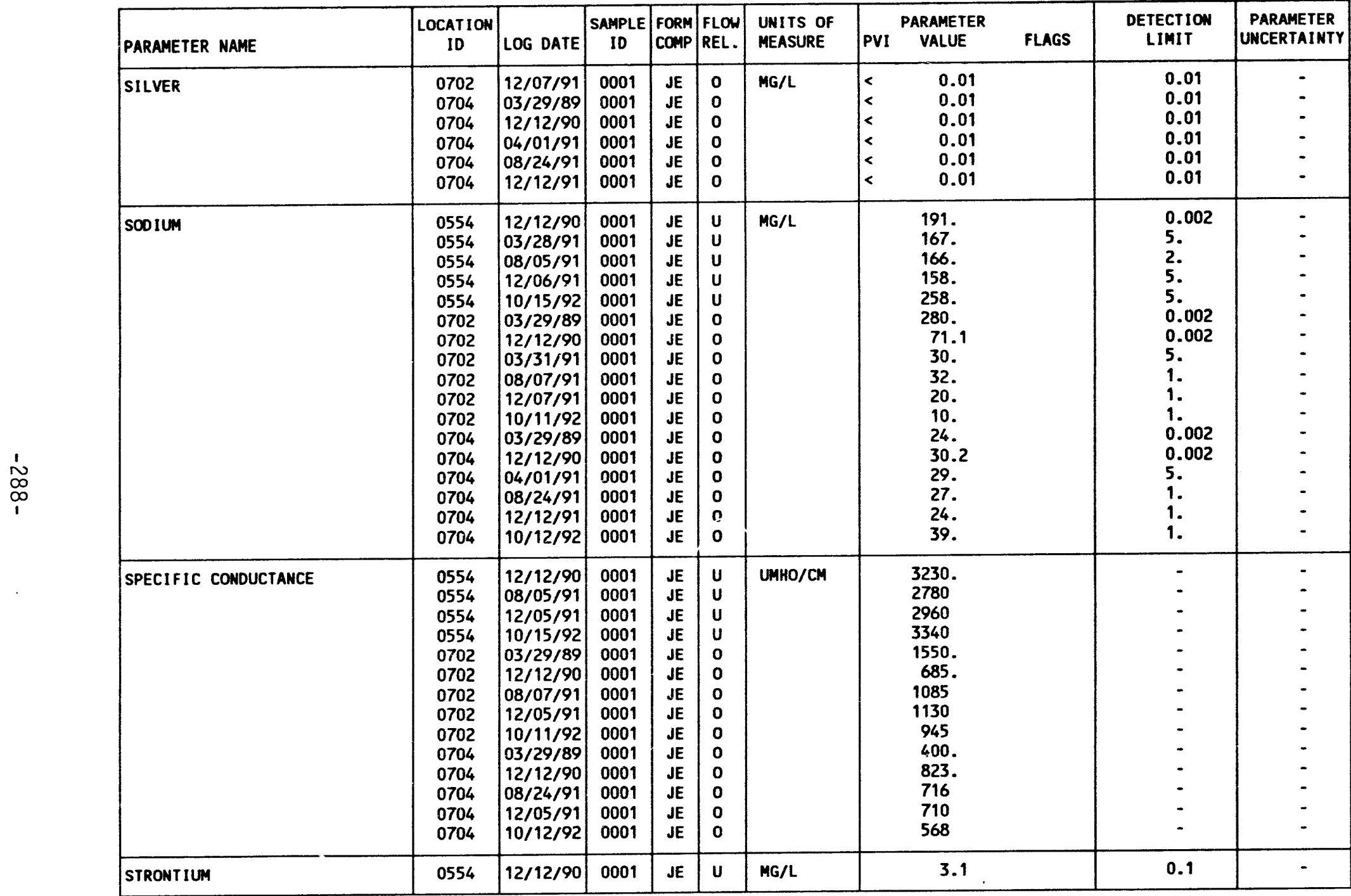

FORMATION OF COMPLETION COOE:

JE - JURASSIC ENTRADA SANDSTONE FORMATION

FLOW RELATIONSHIP COOE:

O - ON-SITE

$U$ - UPGRADIENT

PARAMETER VALUE INDICATOR (PVI): < - LESS THAN DETECTION LIMIT

0001 - FILTERED SAMPLE (.45 MICRONS) 
TABLE 3.33 BASELINE GROUNDHATER QUALITY DATA BY PARAMETER FOR THE ENTRADA

FORMATION, UC PROCESSING SITE, SLICK ROCK, CO! ORADO

SITE: SRKOI SLICK ROCK (BOTH SITES)

03/29/89 TO $10 / 15 / 92$

REPORT DATE: 06/17/93

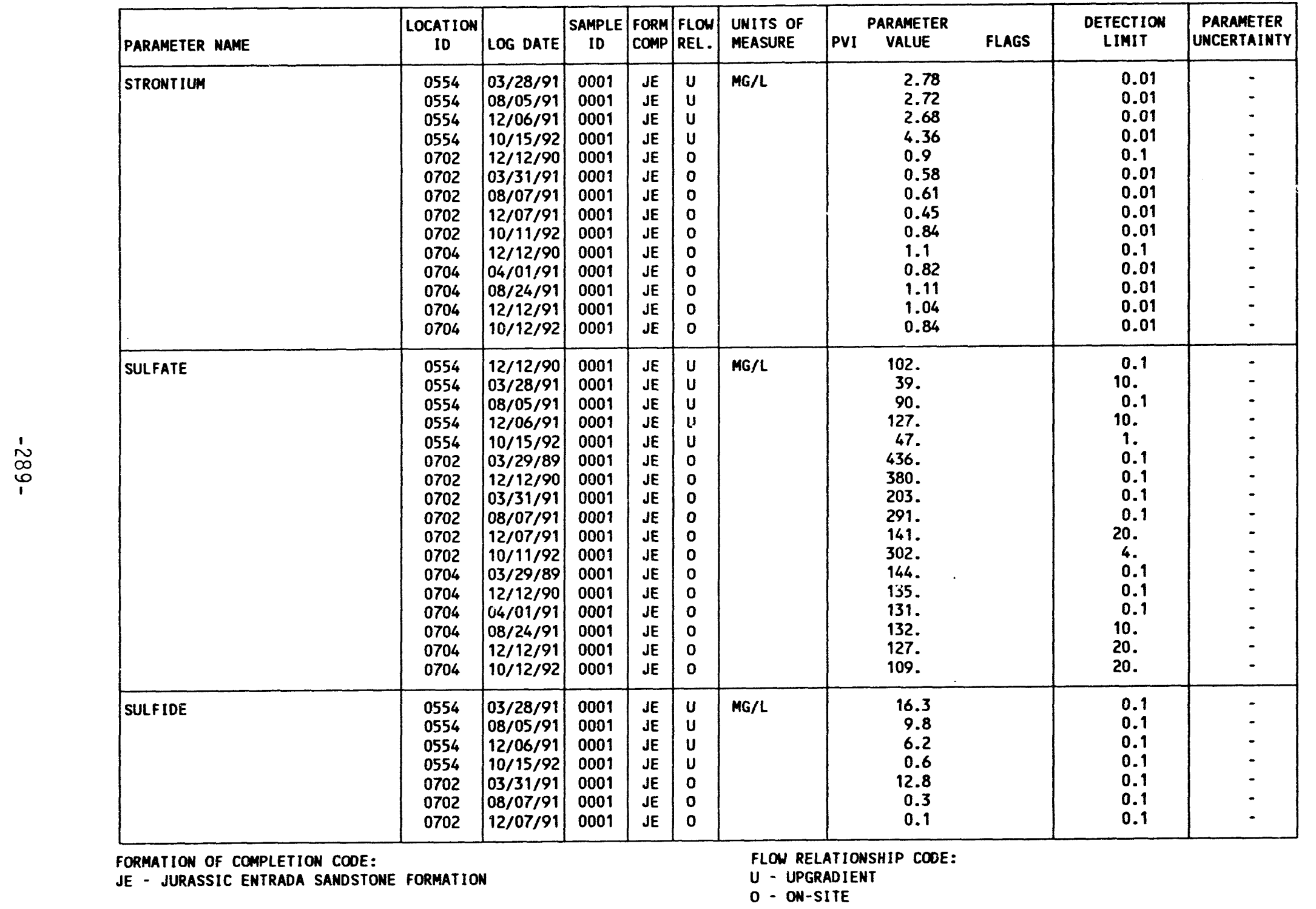

PARAMETER VALUE INDICATOR (PVI): — - LESS than DETECTION LIMIT SAMPLE ID CODES:

0001 - FILTERED SAMPLE (.45. MICRONS) 
TABLE 3.33 BASELINE GROUNDWATER QUALITY DATA BY PARAMETER FOR THE EMTRADA FORMATION, UC PROCESSING SITE, SLICK ROCK, COLORADO

SITE: SRKO1 SLICK ROCK (BOTH SITES)

03/29/89 TO $10 / 15 / 92$

\begin{tabular}{|c|c|c|c|c|c|c|c|c|c|c|c|}
\hline PARAMETER NAME & $\begin{array}{c}\text { LOCATION } \\
10\end{array}$ & LOG DATE & $\begin{array}{c}\text { SAMPLE } \\
\text { ID }\end{array}$ & $\begin{array}{l}\text { FORM } \\
\text { COMP }\end{array}$ & $\begin{array}{l}\text { FLOW } \\
\text { REL. }\end{array}$ & $\begin{array}{l}\text { UNITS OF } \\
\text { MEASURE }\end{array}$ & PVI & $\begin{array}{l}\text { ARAMETER } \\
\text { VALUE }\end{array}$ & FLAGS & $\begin{array}{l}\text { DETECTION } \\
\text { LIMIT }\end{array}$ & $\begin{array}{l}\text { PARAMETER } \\
\text { UMCERTAINTY }\end{array}$ \\
\hline SULFIDE & $\begin{array}{l}0702 \\
0704 \\
0704 \\
0704 \\
0704\end{array}$ & $\mid \begin{array}{l}10 / 11 / 92 \\
04 / 01 / 91 \\
08 / 24 / 91 \\
12 / 12 / 91 \\
10 / 12 / 92\end{array}$ & $\begin{array}{l}0001 \\
0001 \\
0001 \\
0001 \\
0001\end{array}$ & $\begin{array}{l}\mathrm{JE} \\
\mathrm{JE} \\
\mathrm{JE} \\
\mathrm{JE} \\
\mathrm{JE}\end{array}$ & $\begin{array}{l}0 \\
0 \\
0 \\
0 \\
0\end{array}$ & $M G / L$ & & $\begin{array}{r}0.2 \\
42.3 \\
0.6 \\
0.5 \\
0.1\end{array}$ & & $\begin{array}{l}0.1 \\
0.1 \\
0.1 \\
0.1 \\
0.1\end{array}$ & $\begin{array}{l}- \\
- \\
-\end{array}$ \\
\hline TEMPERATURE & $\begin{array}{l}0554 \\
0554 \\
0554 \\
0554 \\
0554 \\
0702 \\
0702 \\
0702 \\
0702 \\
0702 \\
0702 \\
0704 \\
0704 \\
0704 \\
0704 \\
0704 \\
0704\end{array}$ & $\begin{array}{l}12 / 12 / 90 \\
03 / 28 / 91 \\
08 / 05 / 91 \\
12 / 05 / 91 \\
10 / 15 / 92 \\
03 / 29 / 89 \\
12 / 12 / 90 \\
03 / 31 / 91 \\
08 / 07 / 91 \\
12 / 05 / 91 \\
10 / 11 / 92 \\
03 / 29 / 89 \\
12 / 12 / 90 \\
04 / 01 / 91 \\
08 / 24 / 91 \\
12 / 05 / 91 \\
10 / 12 / 92\end{array}$ & $\begin{array}{l}0001 \\
0001 \\
0001 \\
0001 \\
0001 \\
0001 \\
0001 \\
0001 \\
0001 \\
0001 \\
0001 \\
0001 \\
0001 \\
0001 \\
0001 \\
0001 \\
0001\end{array}$ & $\begin{array}{l}\mathrm{JE} \\
\mathrm{JE} \\
\mathrm{JE} \\
\mathrm{JE} \\
\mathrm{JE} \\
\mathrm{JE} \\
\mathrm{JE} \\
\mathrm{JE} \\
\mathrm{JE} \\
\mathrm{JE} \\
\mathrm{JE} \\
\mathrm{JE} \\
\mathrm{JE} \\
\mathrm{JE} \\
\mathrm{JE} \\
\mathrm{JE} \\
\mathrm{JE}\end{array}$ & $\begin{array}{l}u \\
U \\
U \\
U \\
U \\
0 \\
0 \\
0 \\
0 \\
0 \\
0 \\
0 \\
0 \\
0 \\
0 \\
0 \\
0\end{array}$ & C - DEGREE & & $\begin{array}{l}13.6 \\
13.6 \\
14.2 \\
13.9 \\
14.7 \\
14.0 \\
13.4 \\
13.9 \\
14.7 \\
13.5 \\
15.1 \\
13.5 \\
13.1 \\
13.5 \\
14.0 \\
11.9 \\
15.2\end{array}$ & & $\begin{array}{l}- \\
= \\
= \\
: \\
- \\
- \\
- \\
- \\
- \\
- \\
- \\
-\end{array}$ & $\begin{array}{l}- \\
- \\
- \\
- \\
- \\
- \\
- \\
- \\
- \\
- \\
- \\
-\end{array}$ \\
\hline THALLIUM & $\begin{array}{l}0554 \\
0554 \\
0554 \\
0554 \\
0554 \\
0702 \\
0702 \\
0702 \\
0702 \\
0702 \\
0702 \\
0704 \\
0704 \\
0704 \\
0704\end{array}$ & \begin{tabular}{|l|}
$12 / 12 / 90$ \\
$03 / 28 / 91$ \\
$08 / 05 / 91$ \\
$12 / 06 / 91$ \\
$10 / 15 / 92$ \\
$03 / 29 / 89$ \\
$12 / 12 / 90$ \\
$03 / 31 / 91$ \\
$08 / 07 / 91$ \\
$12 / 07 / 91$ \\
$10 / 11 / 92$ \\
$03 / 29 / 89$ \\
$12 / 12 / 90$ \\
$04 / 01 / 91$ \\
$08 / 24 / 91$
\end{tabular} & $\begin{array}{l}0001 \\
0001 \\
0001 \\
0001 \\
0001 \\
0001 \\
0001 \\
0001 \\
0001 \\
0001 \\
0001 \\
0001 \\
0001 \\
0001 \\
0001\end{array}$ & $\begin{array}{l}\text { JE } \\
\text { JE } \\
\text { JE } \\
\text { JE } \\
\text { JE } \\
\text { JE } \\
\text { JE } \\
\text { JE } \\
\text { JE } \\
\text { JE } \\
\text { JE } \\
\text { JE } \\
\text { JE } \\
\text { JE } \\
\text { JE }\end{array}$ & $\begin{array}{l}U \\
U \\
U \\
U \\
U \\
0 \\
0 \\
0 \\
0 \\
0 \\
0 \\
0 \\
0 \\
0 \\
0\end{array}$ & $M G / L$ & $\begin{array}{l}< \\
< \\
< \\
< \\
< \\
< \\
< \\
< \\
< \\
< \\
< \\
< \\
< \\
< \\
<\end{array}$ & $\begin{array}{l}0.01 \\
0.01 \\
0.1 \\
0.05 \\
0.005 \\
0.001 \\
0.01 \\
0.01 \\
0.01 \\
0.01 \\
0.005 \\
0.001 \\
0.01 \\
0.01 \\
0.01\end{array}$ & $\begin{array}{l}1 \\
1\end{array}$ & $\begin{array}{l}0.01 \\
0.01 \\
0.1 \\
0.05 \\
0.005 \\
0.001 \\
0.01 \\
0.01 \\
0.01 \\
0.01 \\
0.005 \\
0.001 \\
0.01 \\
0.01 \\
0.01\end{array}$ & $\begin{array}{l}- \\
- \\
- \\
- \\
- \\
- \\
- \\
- \\
- \\
-\end{array}$ \\
\hline
\end{tabular}

FORMATION OF COMPLETION CODE:

FLOW RELATIONSHIP CODE:

JE - JURASSIC ENTRADA SANDSTONE FORMATION

O - ON-SITE

PARAMETER VALUE INDICATOR (PVI): < - LESS THAN DETECTION LIMIT

SAMPLE ID COOES:

OOO1 - FILTERED SAMPLE (.45 MICRONS)

OTHER PARAMETER VALUE FLAGS:

I - INCREASED DETECTION LIMIT DUE TO REQUIRED DILUTION 
TABLE 3.33 BASELINE GROUNDWATER QUALITY DATA BY PARAMETER FOR THE ENTRAOA FORMATION, UC PROCESSING SITE, SLICK ROCK, COLORADO

SITE: SRKO1 SLICK ROCK (BOTH SITES)

03/29/89 TO $10 / 15 / 92$

REPORT DATE: $06 / 17 / 93$

\begin{tabular}{|c|c|c|c|c|c|c|c|c|c|c|c|c|}
\hline & PARAMETER NAME & $\mid \begin{array}{c}\text { LOCATION } \\
10\end{array}$ & LOG DATE & $\underset{I D}{\text { SAMPLE }}$ & $\begin{array}{l}\text { FORM } \\
\text { COMP }\end{array}$ & $\begin{array}{l}\text { FLOW } \\
\text { REL. }\end{array}$ & $\begin{array}{l}\text { UNITS OF } \\
\text { MEASURE }\end{array}$ & PVI & $\begin{array}{l}\text { PARAMETER } \\
\text { VALUE }\end{array}$ & FLAGS & $\begin{array}{l}\text { DETECTION } \\
\text { LIMIT }\end{array}$ & $\begin{array}{l}\text { PARAMETER } \\
\text { UNCERTAINTY }\end{array}$ \\
\hline & THALLIUM & $\begin{array}{l}0704 \\
0704\end{array}$ & $\left|\begin{array}{l}12 / 12 / 91 \\
10 / 12 / 92\end{array}\right|$ & $\begin{array}{l}0001 \\
0001\end{array}$ & $\begin{array}{l}\text { JE } \\
\text { JE }\end{array}$ & $\begin{array}{l}\mathbf{0} \\
0\end{array}$ & $M G / L$ & $<$ & $\begin{array}{l}0.01 \\
0.005\end{array}$ & & $\begin{array}{l}0.01 \\
0.005\end{array}$ & - \\
\hline & THORIUM-230 & $\begin{array}{l}0554 \\
0554 \\
0702 \\
0702 \\
0704 \\
0704\end{array}$ & $\begin{array}{l}08 / 05 / 91 \\
12 / 05 / 91 \\
08 / 07 / 91 \\
12 / 05 / 91 \\
08 / 24 / 91 \\
12 / 05 / 91\end{array}$ & $\begin{array}{l}0001 \\
0001 \\
0001 \\
0001 \\
0001 \\
0001\end{array}$ & $\begin{array}{l}\text { JE } \\
\text { JE } \\
\text { JE } \\
\text { JE } \\
\text { JE } \\
\text { JE }\end{array}$ & $\begin{array}{l}U \\
U \\
0 \\
0 \\
0 \\
0\end{array}$ & $\mathrm{PCI} / \mathrm{L}$ & & $\begin{array}{l}0.1 \\
0.1 \\
0.5 \\
0.2 \\
0.3 \\
0.3\end{array}$ & & $\begin{array}{l}1 . \\
1 . \\
1 . \\
1 . \\
1 .\end{array}$ & $\begin{array}{l}0.5 \\
0.5 \\
0.4 \\
0.4 \\
0.5 \\
0.5\end{array}$ \\
\hline & TIN & $\begin{array}{l}0554 \\
0554 \\
0554 \\
0554 \\
0554 \\
0702 \\
0702 \\
0702 \\
0702 \\
0702 \\
0702 \\
0704 \\
0704 \\
0704 \\
0704 \\
0704 \\
0704\end{array}$ & $\begin{array}{l}12 / 12 / 90 \\
03 / 28 / 91 \\
08 / 05 / 91 \\
12 / 06 / 91 \\
10 / 15 / 92 \\
03 / 29 / 89 \\
12 / 12 / 90 \\
03 / 31 / 91 \\
08 / 07 / 91 \\
12 / 07 / 91 \\
10 / 11 / 92 \\
03 / 29 / 89 \\
12 / 12 / 90 \\
04 / 01 / 91 \\
08 / 24 / 91 \\
12 / 12 / 91 \\
10 / 12 / 92\end{array}$ & $\begin{array}{l}0001 \\
0001 \\
0001 \\
0001 \\
0001 \\
0001 \\
0001 \\
0001 \\
0001 \\
0001 \\
0001 \\
0001 \\
0001 \\
0001 \\
0001 \\
0001 \\
0001\end{array}$ & 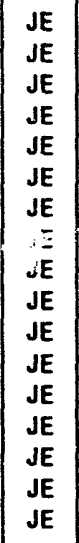 & $\begin{array}{l}U \\
U \\
U \\
U \\
U \\
0 \\
0 \\
0 \\
0 \\
0 \\
0 \\
0 \\
0 \\
0 \\
0 \\
0 \\
0\end{array}$ & $M G / L$ & $\begin{array}{l}< \\
< \\
< \\
< \\
< \\
< \\
< \\
< \\
< \\
< \\
< \\
< \\
< \\
< \\
< \\
< \\
<\end{array}$ & $\begin{array}{l}0.005 \\
0.005 \\
0.05 \\
0.005 \\
0.05 \\
0.001 \\
0.005 \\
0.005 \\
0.05 \\
0.005 \\
0.05 \\
0.001 \\
0.005 \\
0.005 \\
0.005 \\
0.005 \\
0.005\end{array}$ & $\begin{array}{l}1 \\
1 \\
1 \\
1\end{array}$ & $\begin{array}{l}0.005 \\
0.005 \\
0.05 \\
0.005 \\
0.05 \\
0.005 \\
0.005 \\
0.005 \\
0.05 \\
0.005 \\
0.05 \\
0.005 \\
0.005 \\
0.005 \\
0.005 \\
0.005 \\
0.005\end{array}$ & $\begin{array}{l}- \\
- \\
- \\
- \\
- \\
- \\
- \\
- \\
- \\
- \\
-\end{array}$ \\
\hline & TOTAL DISSOLVED SOLIDS & $\begin{array}{l}0554 \\
0554 \\
0554 \\
0554 \\
0554 \\
0702 \\
0702 \\
0702 \\
0702 \\
0702 \\
0702\end{array}$ & $\begin{array}{l}12 / 12 / 90 \\
03 / 28 / 91 \\
08 / 05 / 91 \\
12 / 06 / 91 \\
10 / 15 / 92 \\
03 / 29 / 89 \\
12 / 12 / 90 \\
03 / 31 / 91 \\
08 / 07 / 91 \\
12 / 07 / 91 \\
10 / 11 / 92\end{array}$ & $\begin{array}{l}0001 \\
0001 \\
0001 \\
0001 \\
0001 \\
0001 \\
0001 \\
0001 \\
0001 \\
0001 \\
0001\end{array}$ & $\begin{array}{l}\mathrm{JE} \\
\mathrm{JE} \\
\mathrm{JE} \\
\mathrm{JE} \\
\mathrm{JE} \\
\mathrm{JE} \\
\mathrm{JE} \\
\mathrm{JE} \\
\mathrm{JE} \\
\mathrm{JE} \\
\mathrm{JE}\end{array}$ & $\begin{array}{l}U \\
U \\
U \\
U \\
U \\
0 \\
0 \\
0 \\
0 \\
0 \\
0\end{array}$ & MG/L & & $\begin{array}{c}1980 . \\
1740 . \\
1880 . \\
1740 . \\
2650 . \\
1432 . \\
960 . \\
607 . \\
724 . \\
478 . \\
794 .\end{array}$ & & $\begin{array}{l}10 . \\
10 . \\
10 . \\
10 . \\
10 . \\
10 . \\
10 . \\
10 . \\
10 . \\
10 . \\
10 .\end{array}$ & $\begin{array}{l}. \\
: \\
- \\
- \\
- \\
- \\
-\end{array}$ \\
\hline
\end{tabular}

FORMATION OF COMPLETION COOE:

JE - JURASSIC ENTRADA SANDSTONE FORMATION

PARAMETER VALUE INDICATOR (PVI): < - LESS thAN DETECTION LIMIT
FLOW RELATIONSHIP COOE:

O - ON-SITE

U - UPGRADIENT

SAMPLE ID CODES:

0001 - FILTERED SAAPLE (.45 MICRONS)

OTHER PARAMETER VALUE FLAGS:

I - INCREASED DETECTION LIMIT DUE TO REQUIRED DILUTION 
TABLE 3.33 BASELINE GROUNDUATER OUALITY DATA BY PARAMETER FOR THE EMTRADA

FORMATION UC PROCESSING SITE, SLICK ROCK, COLORADO

SITE: SRKO1 SLICK ROCK (BOTH SITES)

03/29/89 TO $10 / 15 / 92$

REPORT DATE: $06 / 17 / 93$

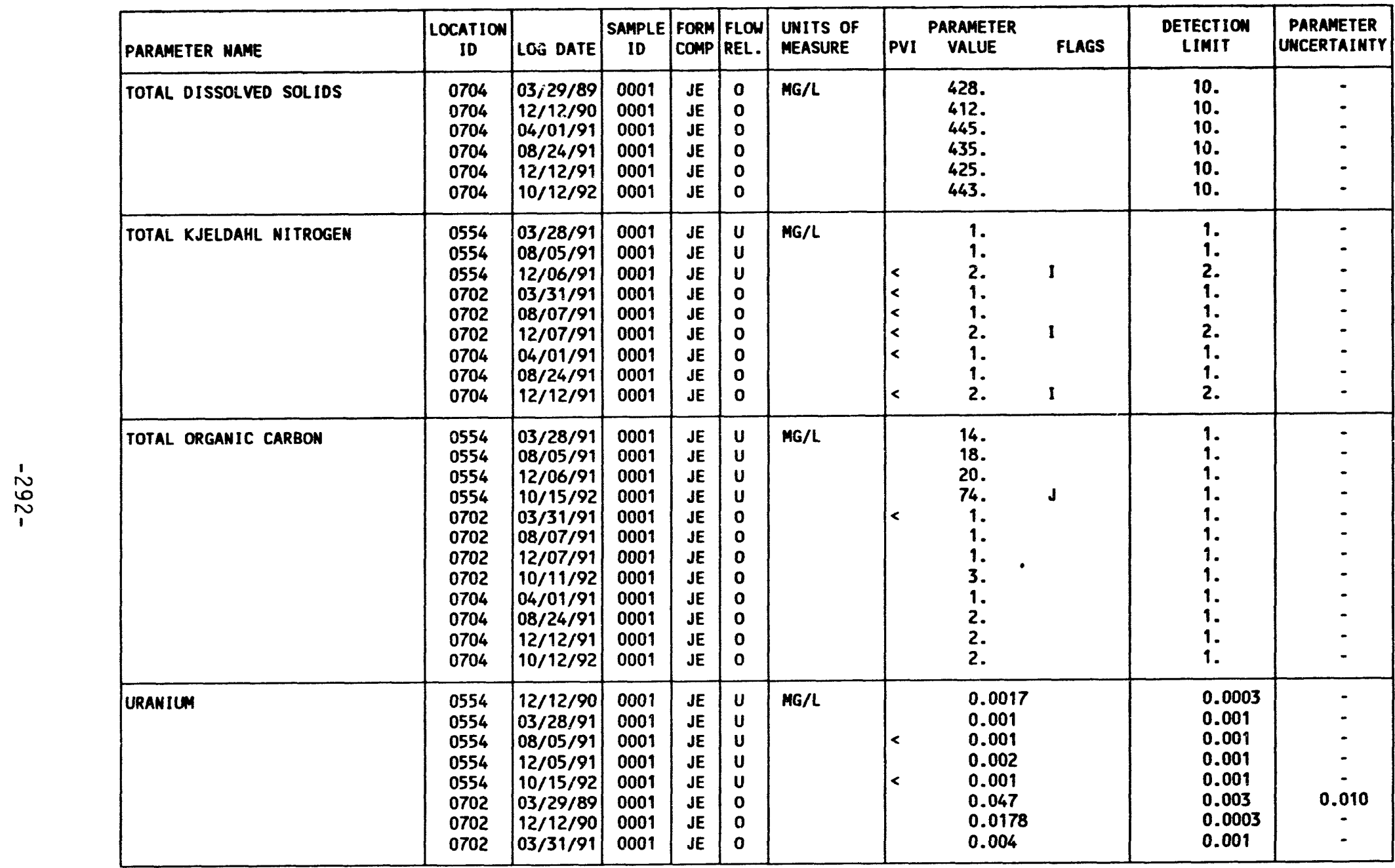

FORMATION OF COMPLETION COOE:

JE - JURASSIC ENTRADA SANDSTONE FORMATION

FLON RELATIONSHIP CODE:

O - ON-SITE

$U$ - UPGRADIENT

PARAMETER VALUE INDICATOR (PVI): < - LESS THAN DETECTION LIMIT

SAMPLE ID CODES:

0001 - FILTERED SAMPLE (.45 MICRONS)

OTHER PARAMETER VALUE FLAGS:

I - INCREASED DETECTION LIMIT DUE TO REQUIRED DILUTION

J - estimated VALUE 
TABLE 3.33 BASELINE GROUNDWATER QUALITY DATA BY PARAMETER FOR THE ENTRADA FORMATION, UC PROCESSING SITE, SLICK ROCK, COLORADO

SITE: SRKO1 SLICK ROCK (BOTH SITES)

03/29/89 TO $10 / 15 / 92$

REPORT DATE: 06/17/93

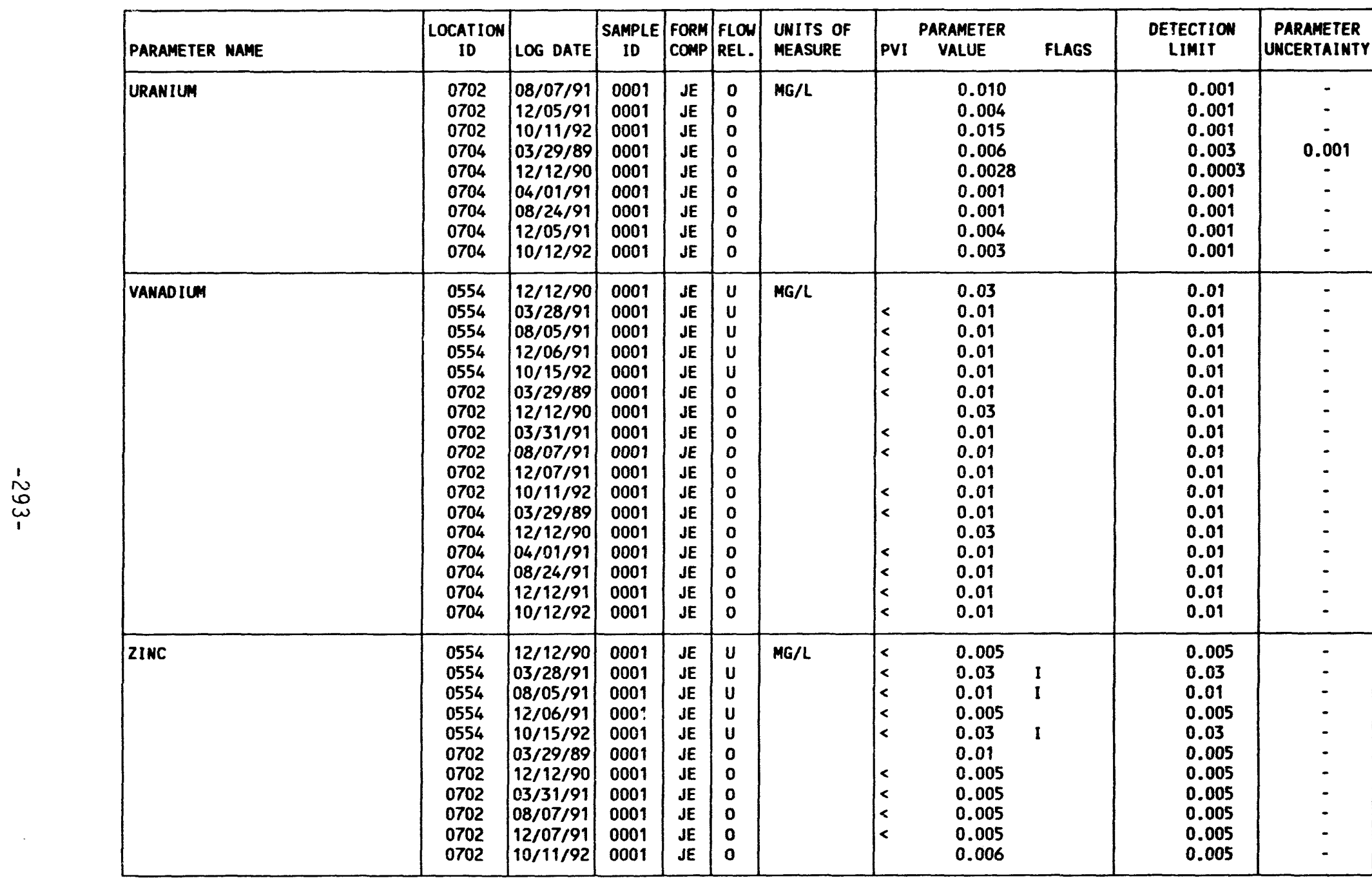

FORMATION OF COMPLETION CODE:

JE - JURASSIC ENTRADA SANDSTONE FORMATION

PARAMETER VALUE IMDICATOR (PVI): < - LeSS than DETECTION LIMIT
FLON RELATIONSHIP CODE:

O- ON-SITE

UPGRADIENT

SAMPLE ID CODES:

0001 - FILTERED SAMPLE (.45 MICRONS)

OTHER PARAMETER VALUE FLAGS:

1 - INCREASED DETECTION LIMIT DUE TO REQUIRED DILUTION 
TABLE 3.33 BASELINE GROUNDUATER OUALITY DATA BY PARAMETER FOR THE ENTRADA FOPMATIOU UC PROCESSING SITE, SLICK ROCK, COLORADO

SITE: SRKOI SLICK ROCK (BOTH SITES)

SITE: SRKO1 SLICK ROCK

REPORT DATE: $06 / 17 / 93$

\begin{tabular}{|c|c|c|c|c|c|c|c|c|c|c|c|}
\hline PARAMETER MAME & $\underset{\text { ID }}{\text { LOCATION }}$ & LOG DATE & $\begin{array}{c}\text { SAMPLE } \\
\text { ID }\end{array}$ & $\begin{array}{l}\text { FORM } \\
\text { COMPP }\end{array}$ & FLOU & $\begin{array}{l}\text { UNITS OF } \\
\text { MEASURE }\end{array}$ & PVI & $\begin{array}{l}\text { ARAMETER } \\
\text { VALUE }\end{array}$ & FLAGS & $\begin{array}{l}\text { DETECTION } \\
\text { LIMIT }\end{array}$ & $\begin{array}{l}\text { PARAMETER } \\
\text { UMCERTAINTY }\end{array}$ \\
\hline ZINC & $\begin{array}{l}0704 \\
0704 \\
0704 \\
0704 \\
0704 \\
0704\end{array}$ & $\begin{array}{l}03 / 29 / 89 \\
12 / 12 / 90 \\
04 / 01 / 91 \\
08 / 24 / 91 \\
12 / 12 / 91 \\
10 / 12 / 92\end{array}$ & $\begin{array}{l}0001 \\
0001 \\
0001 \\
0001 \\
0001 \\
0001\end{array}$ & $\begin{array}{l}\mathrm{JE} \\
\mathrm{JE} \\
\mathrm{JE} \\
\mathrm{JE} \\
\mathrm{JE} \\
\mathrm{JE}\end{array}$ & $\begin{array}{l}0 \\
0 \\
0 \\
0 \\
0 \\
0\end{array}$ & $M G / L$ & $\mid \begin{array}{l}< \\
< \\
< \\
< \\
<\end{array}$ & $\begin{array}{l}0.01 \\
0.005 \\
0.03 \\
0.005 \\
0.005 \\
0.005\end{array}$ & I & $\begin{array}{l}0.005 \\
0.005 \\
0.03 \\
0.005 \\
0.005 \\
0.005\end{array}$ & $\begin{array}{l}- \\
- \\
- \\
-\end{array}$ \\
\hline
\end{tabular}

FORMATION OF COMPLETION COOE:

JE - JURASSIC ENTRADA SANDSTONE FORMATION

PARAMETER VALUE INDICATOR (PVI): < - LESS THAN DETECTION LIMIT
FLOW RELATIONSHIP CODE:

O- ON-SITE

SAMPLE ID CODES:

0001 - FILTERED SAMPLE (.45 MICRONS)

OTHER PARAMETER VALUE FLAGS:

I - INCREASED DETECTION LIMIT DUE TO REQUIRED DILUTION

DATA FILE NAME: M: VDARTISRK01\GWQ10028.DAT 
TABLE 3.34 BASELINE GROUNDHATER OUALITY STATISTICS BY PARAMETER

TAB TE ENTRADA FORMATION, UC PROCESSING SITE, SLICK ROCK, COLORADO

SITE: SRKO1 SLICK ROCK (BOTH SITES)

SITE: SRKO1 SLICK ROCK

REPORT DATE: $07 / 26 / 93$

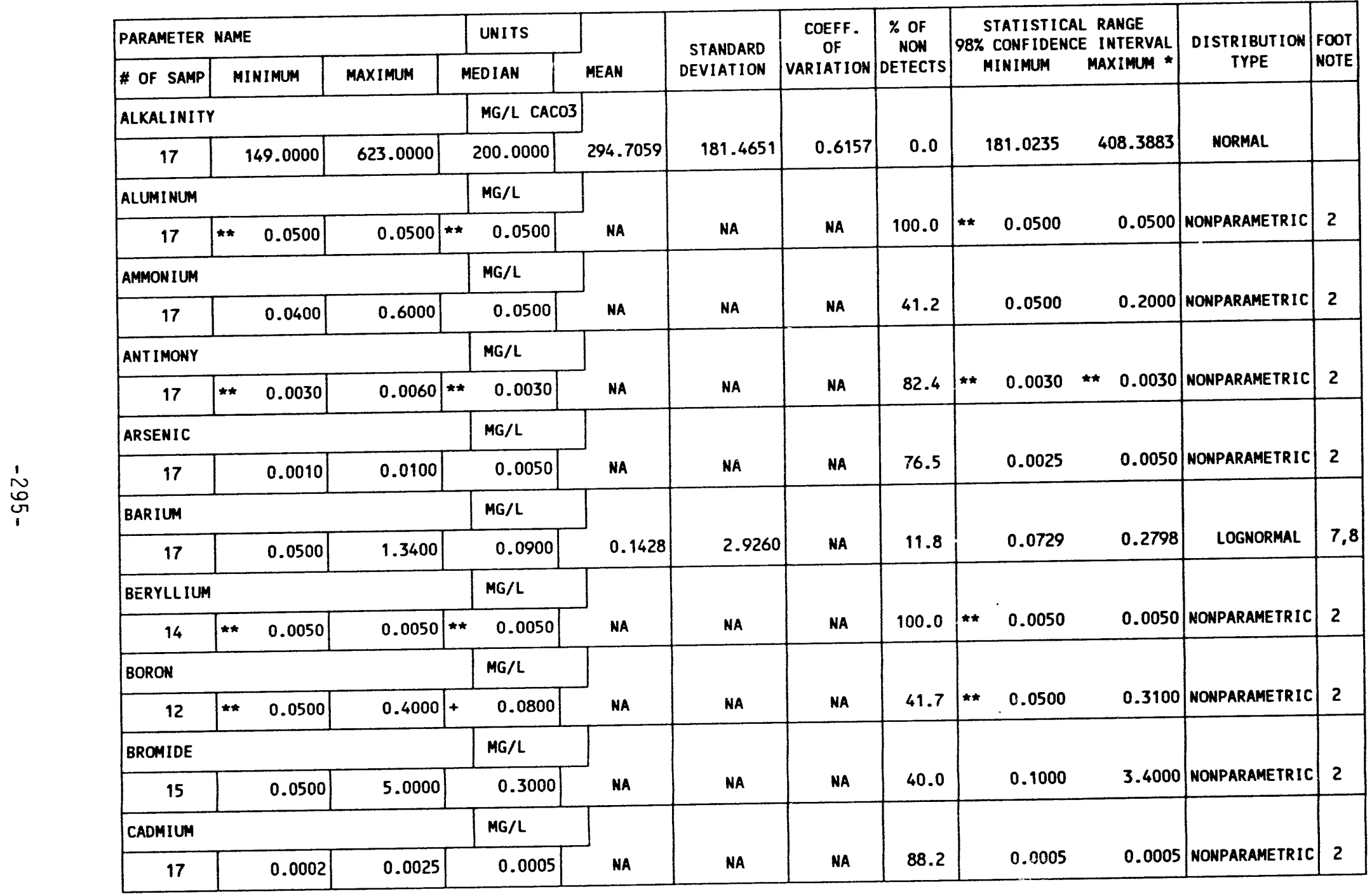

** The reported value is the minimum detection limit of the data set

+ The raportedize values

* The sample size is even, so the 99 percent one sided confidence interval, $\alpha=0.01$

* The statistical maximum

2) The nonparametric distribution was used bailed the normal distribution test.

7) The lognormal distribution was used because the data failue to divide or multiply with the geometric mean.

8) The mean is geometric. The standard deviation is the value to divide or multiply with the geometric mean. 
TABLE 3.34 BASELINE GROUNDHATER QUALITY STATISTICS BY PARAMETER

FOR THE ENTRADA FORMATION, UC PROCESSING SITE, SLICK ROCK, COLORADO

SITE: SRKO1 SLICK ROCK (BOTH SITES)

03/29/89 TO 10/15/92

REPORT DATE: 07/26/93

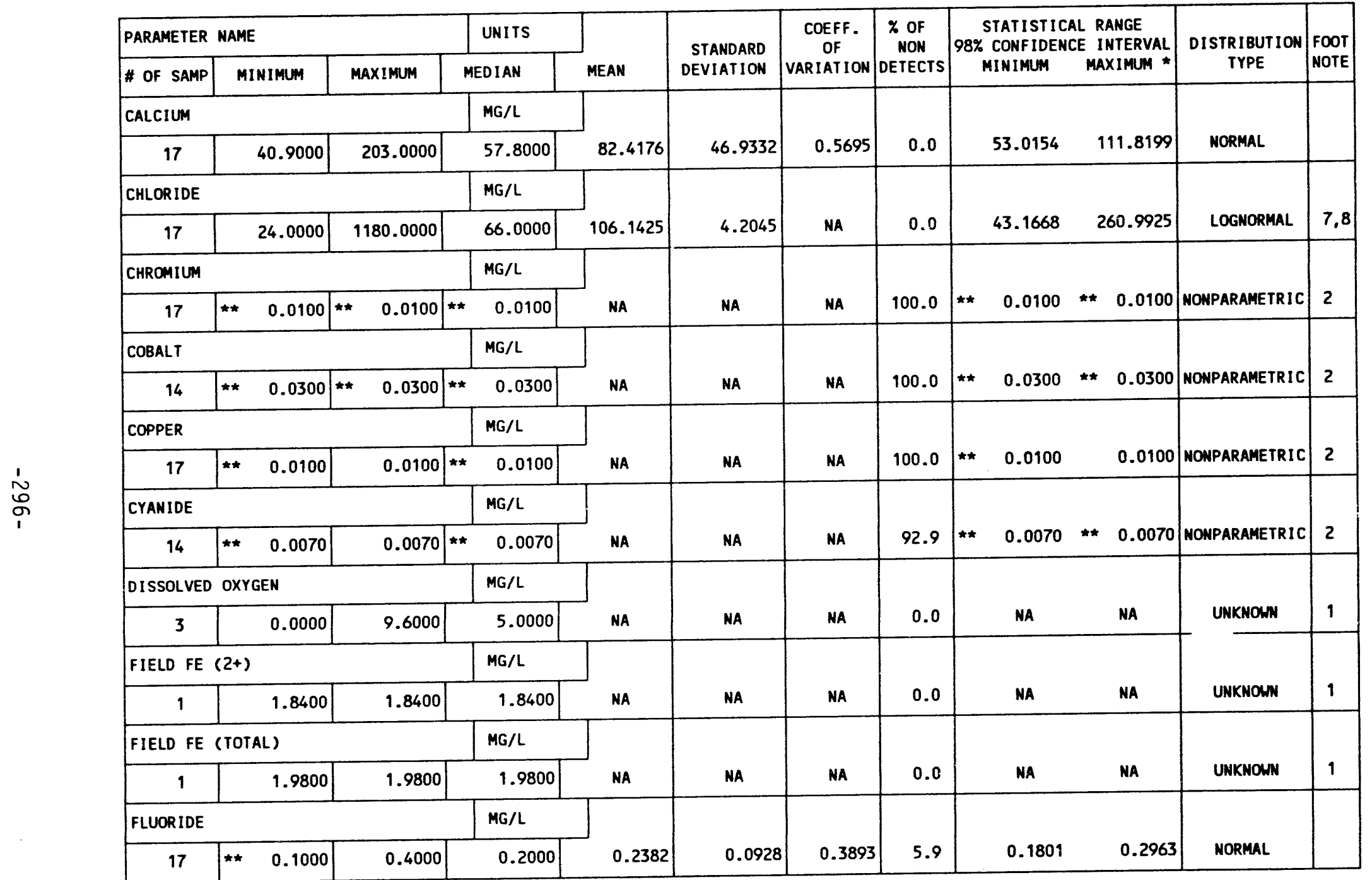

$\star \star$ The reported value is the minimum detection limit of the data set

* The statistical maximum is the 99 percent one sided confidence interval, $\alpha=0.01$

1) A minimum of 4 samples must be available for the statistical analysis.

1) The nomparam $15 \%$ of the samples.

7) The lognormal distribution was used because the data failed the normal distribution test.

8) The mean is geometric. The standard deviation is the value to divide or multiply with the geometric mean. 
TABLE 334 BASELINE GROUMDWATER QUALITY STATISTICS BY PARAMETER TABLE 3. 34 BADE FORMTION UC PROCESSING SITE, SLICK ROCK, COLORADO SITE: SRKO1 SLICK ROCK (BOTH SITES)

SITE: SRKO1 SLICK ROCK

REPORT DATE: $07 / 26 / 93$

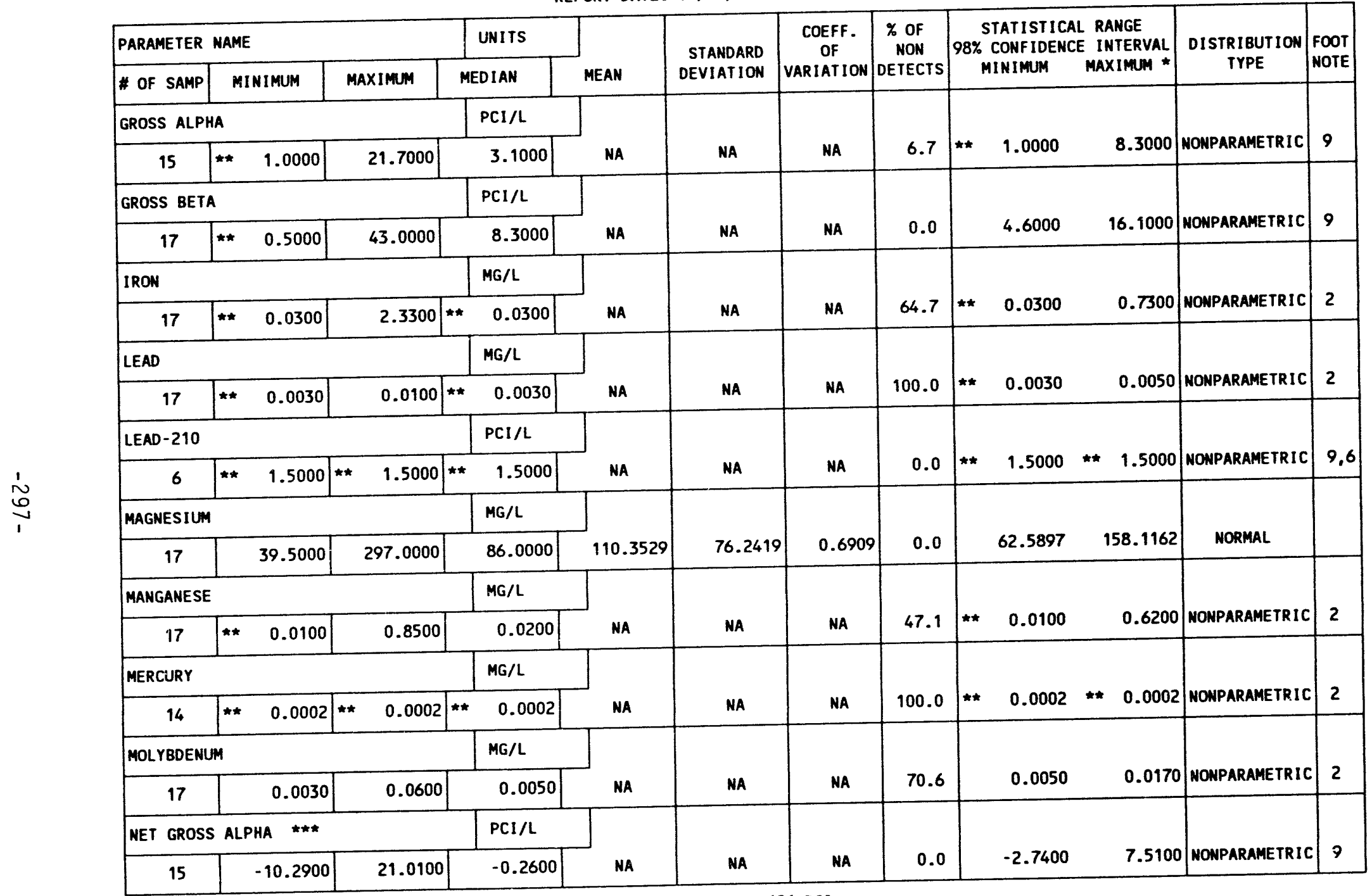

*** NET GROSS ALPHA (GROSS ALPHA - URANIUM) WITH 1 MG URANIUM $=686$ PCI

** The reported value is the minimm detection limit of the data set

* The reported value is the mis 99 percent one sided confidence interval, $\alpha=0.01$

* The statistical maximum is the 99 perces

2) The nonparametric distribution was used because the nondetected

6) The stat. range is the $96.9 \%$ confidence interval due to a sample size of 6 . The maxim thest and includes values $\leq 0$. 
TABLE 3.34 BASELINE GROUNDWATER QUALITY STATISTICS BY PARAMETER

FOR THE ENTRADA FORMATION, UC PROCESSING SITE, SLICK ROCK, COLORADO

SITE: SRKO1 SLICK ROCK (BOTH SITES)

03/29/89 TO $10 / 15 / 92$

REPORT DATE : 07/26/93

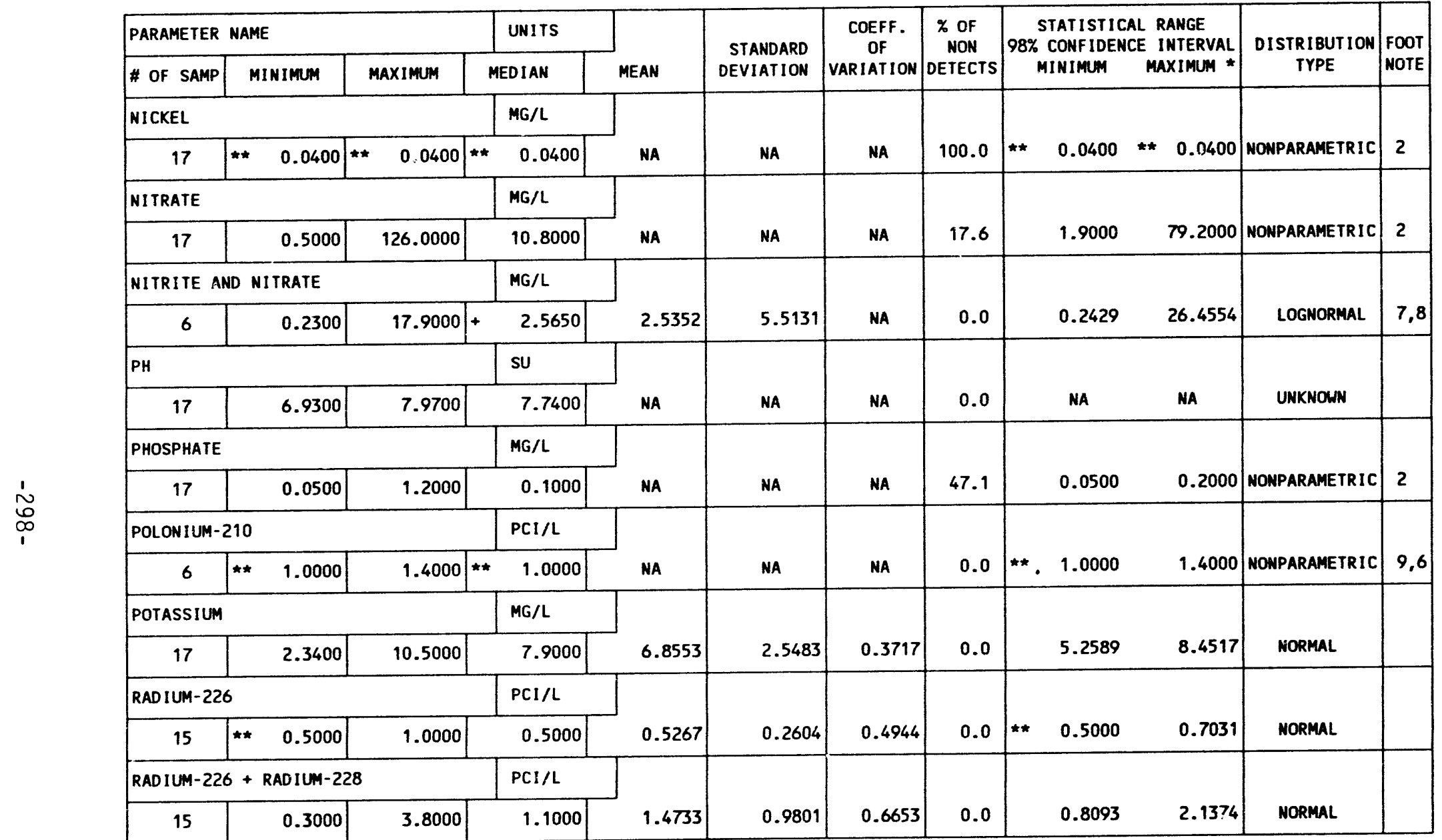

** The reported value is the minimum detection limit of the data set

+ The sample size is even, so the median value is the arithmetic average of the two middle values

* The statistical maximum is the 99 percent one sided confidence interval, $\alpha=0.01$

1) A minimum of 4 samples must be available for the statistical analysis.

2) The nomparametric distribution us used because the nondetected values comprise more than $15 \%$ of the samples.

6) The

6) The stat. range is the $96.9 \%$ confidence interval due to a sample size distribut dion was used because the data failed the normal distrion test.

7) The lognormal distribution was used because the data failed the normal distribution test.

8) The mean is geometric. The standard deviation is the value to the normal distribution test and includes values $\leq 0$. 


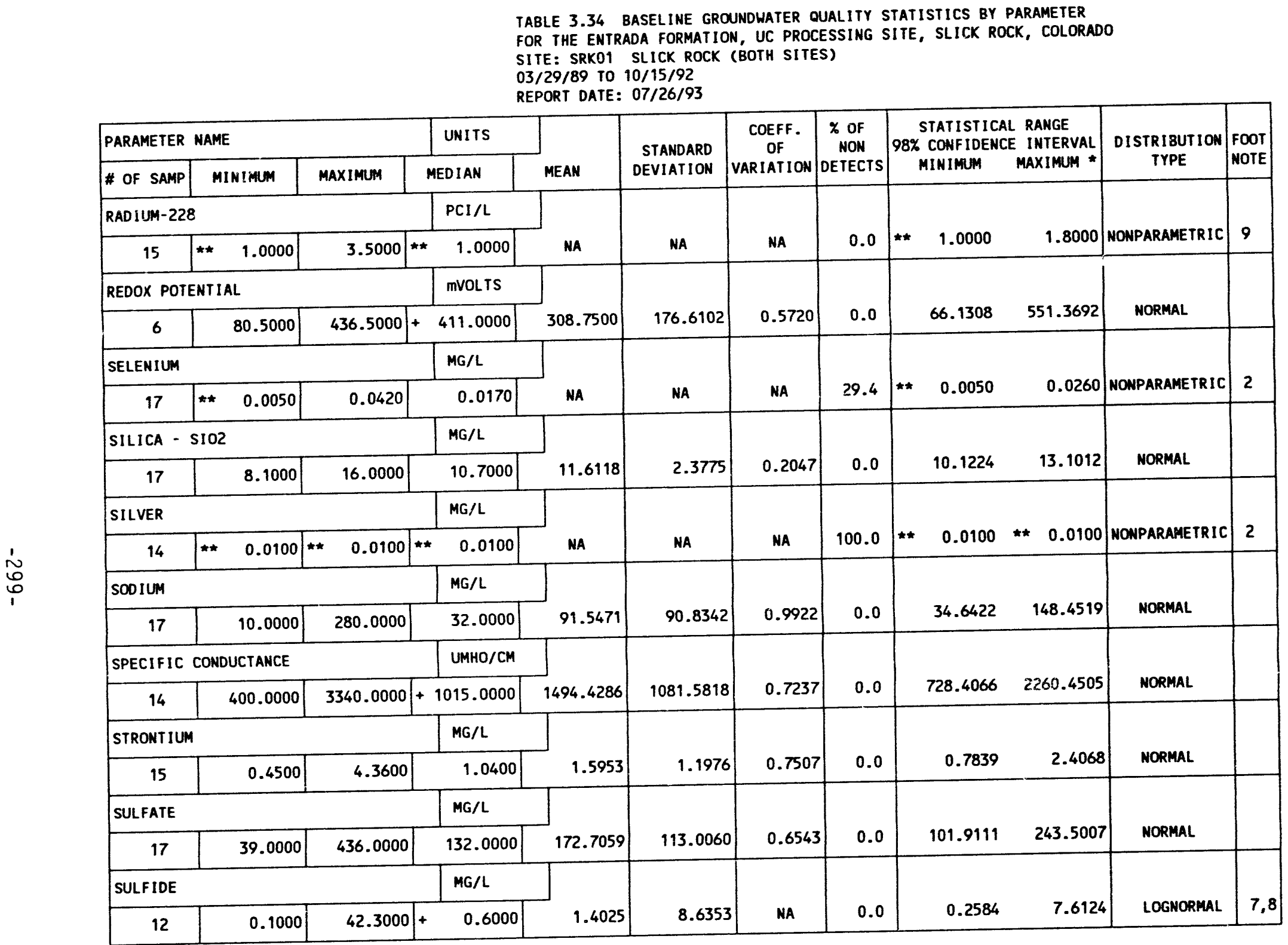

** The reported value is the minimum detection limit of the data set

+ The sample size is even, so the median value is the arithmetic average of the two

* The statistical maximm is the 99 percent one sided confidence interval, $\alpha=0.01$ man $15 \%$ of the samples.

2) The nonparametric distribution was used because the nondetected values comprise more than

7) The lognormal distribution was used because the data failed the normal distribution with the geometric mean.

8) The mean is geometric. The standard deviation is the value to divide or multiply wastribution test and includes values $\leq 0$. 
TABLE 3.34 BASELINE GROUNDWATER QUALITY STATISTICS BY PARAMETER FOR THE ENTRADA FORMATION, UC PROCESSING SITE, SLICK ROCK, COLORADO

SITE: SRKO1 SLICK ROCK (BOTH SITES)

$03 / 29 / 89$ TO $10 / 15 / 92$

REPORT DATE : 07/26/93

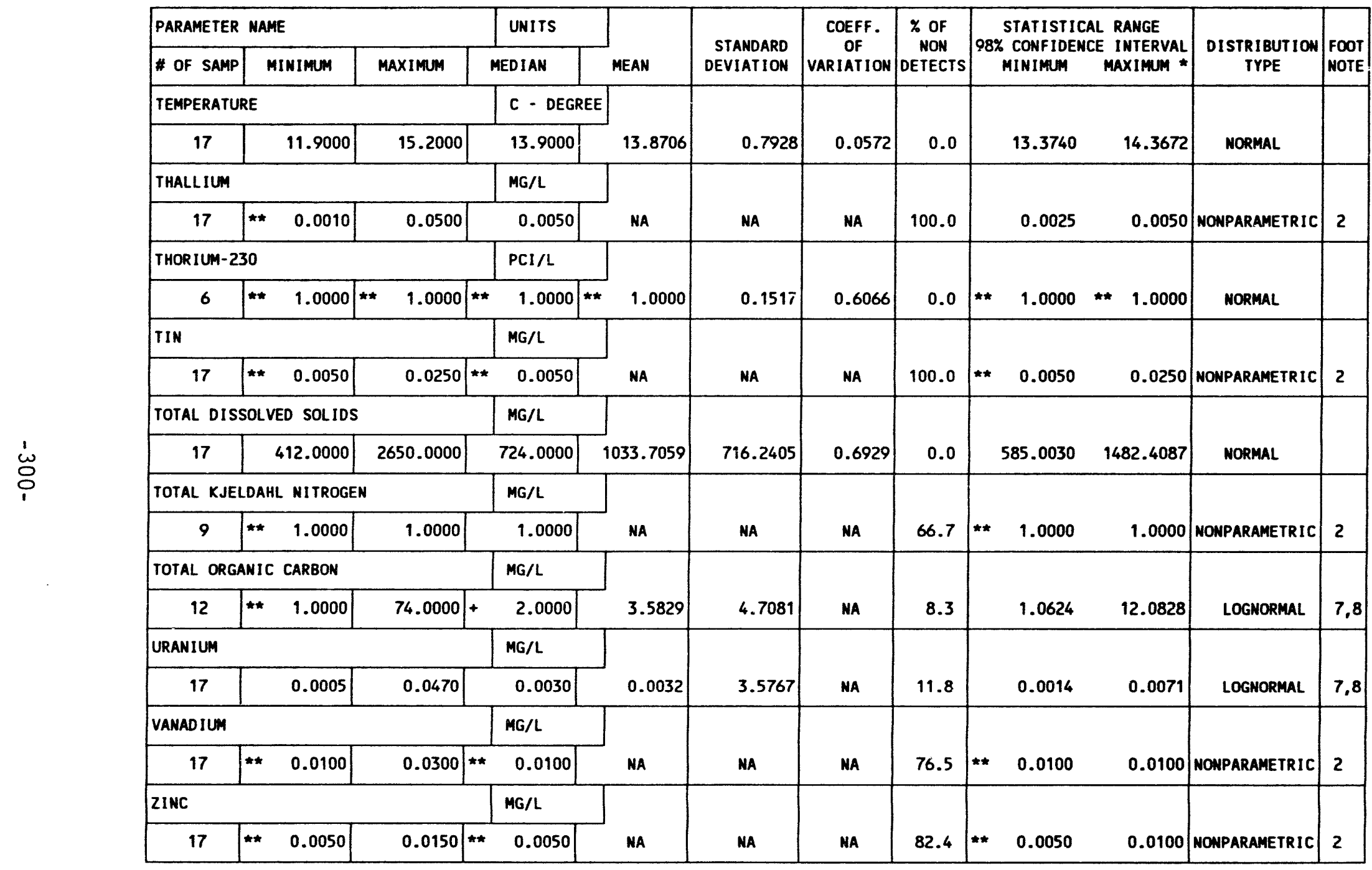

* The reported value is the minimm detection limit of the data set

+ The sample size is even, so the median value is the arithmetic average of the two middle values

* The statistical maximum is the 99 percent one sided confidence interval, $a=0.01$

2) The nonparametric distribution was used because the nondetected values comprise more than $15 \%$ of the samples.

7) The lognormal distribution was used because the data failed the normal distribution test.

8) The mean is geometric. The standard deviation is the value to divide or multiply with the geometric mean. 
Table 3.35 Summary of regulated constituents in the Entrada Formation baseline groundwater, UC processing site, Slick Rock, Colorado

Constituents with MCLs ${ }^{a}$

\begin{tabular}{lcccc}
\hline \multicolumn{1}{c}{ Parameter } & $\begin{array}{c}\text { Baseline } \\
\text { Median }\end{array}$ & $\begin{array}{c}\text { Baseline } \\
\text { Stat Max }\end{array}$ & $\begin{array}{c}\text { Background } \\
\text { Stat Max }\end{array}$ & MCL \\
\hline Arsenic & $0.01^{\mathrm{g}}$ & $0.01^{\mathrm{g}}$ & $0.01^{\mathrm{g}}$ & 0.05 \\
Barium & $0.14^{\mathrm{c}}$ & 0.28 & $0.19^{\mathrm{d}}$ & 1.00 \\
Cadmium & $0.001^{\mathrm{g}}$ & $0.001^{\mathrm{g}}$ & $0.002^{\mathrm{e}}$ & 0.01 \\
Chromium & $0.01^{\mathrm{g}}$ & $0.01^{\mathrm{g}}$ & $0.01^{\mathrm{g}}$ & 0.05 \\
Net gross alphaf & $-0.26^{\mathrm{e}}$ & 7.51 & $4.10^{\mathrm{e}}$ & 15.00 \\
Lead & $0.01^{\mathrm{g}}$ & $0.01^{\mathrm{g}}$ & $0.01^{\mathrm{g}}$ & 0.05 \\
Mercury & $0.0002^{\mathrm{g}}$ & $0.0002^{\mathrm{g}}$ & $0.0002^{\mathrm{g}}$ & 0.002 \\
Molybdenum & $0.01^{\mathrm{g}}$ & 0.02 & $0.03^{\mathrm{e}}$ & 0.10 \\
Nitrate & $10.8^{\mathrm{e}}$ & 79.2 & $7.66^{\mathrm{d}}$ & 44.0 \\
Radium-226, $-228^{\mathrm{f}}$ & $1.47^{\mathrm{d}}$ & 2.14 & $3.17^{\mathrm{c}}$ & 5.0 \\
Selenium & $0.07^{\mathrm{e}}$ & 0.026 & $0.013^{\mathrm{c}}$ & 0.01 \\
Silver & $0.01^{\mathrm{g}}$ & $0.01^{\mathrm{g}}$ & $0.01^{\mathrm{g}}$ & 0.05 \\
Uranium & $0.003^{\mathrm{c}}$ & 0.007 & $0.008^{\mathrm{d}}$ & 0.044 \\
& & & & \\
\hline
\end{tabular}


Table 3.35 Summary of regulated constituents in the Entrada Formation baseline groundwater, UC processing site, Slick Rock, Colorado (concluded)

Constituents without MCLs ${ }^{\mathrm{a}}$

\begin{tabular}{llccc}
\hline \multicolumn{1}{c}{ Parameter } & $\begin{array}{c}\text { Baseline } \\
\text { Median }\end{array}$ & $\begin{array}{c}\text { Baseline } \\
\text { Stat Max }\end{array}$ & $\begin{array}{c}\text { Background } \\
\text { Stat. Max }\end{array}$ & MCL \\
\hline Antimony & $0.003^{\mathrm{g}}$ & $0.003^{\mathrm{g}}$ & $0.003^{\mathrm{g}}$ & None \\
Beryllium & $0.01^{\mathrm{g}}$ & $0.01^{\mathrm{g}}$ & $0.01^{\mathrm{g}}$ & None \\
Cobalt & $0.05^{\mathrm{g}}$ & $0.05^{\mathrm{g}}$ & $0.05^{\mathrm{g}}$ & None \\
Copper & $0.02^{\mathrm{g}}$ & $0.02^{\mathrm{g}}$ & $0.02^{\mathrm{g}}$ & None \\
Cyanide & $0.01^{\mathrm{g}}$ & $0.01^{\mathrm{g}}$ & $0.01^{\mathrm{g}}$ & None \\
Nickel & $0.04^{\mathrm{g}}$ & $0.04^{\mathrm{g}}$ & $0.04^{\mathrm{g}}$ & None \\
Sulfide & $1.4^{\mathrm{c}}$ & $7.6^{\mathrm{c}}$ & $3.00^{\mathrm{c}}$ & None \\
Thallium & $0.01^{\mathrm{g}}$ & $0.01^{\mathrm{g}}$ & $0.01^{\mathrm{g}}$ & None \\
Tin & $0.005^{\mathrm{g}}$ & $0.025^{\mathrm{e}}$ & $0.005^{\mathrm{g}}$ & None \\
Vanadium & $0.01^{\mathrm{g}}$ & $0.01^{\mathrm{g}}$ & $0.02^{\mathrm{e}}$ & None \\
Zinc & $0.005^{\mathrm{g}}$ & $0.01^{\mathrm{c}}$ & $0.005^{\mathrm{e}}$ & None \\
\hline
\end{tabular}

"All units are $\mathrm{mg} / \mathrm{l}$ unless otherwise noted.

'NC Processing site background groundwater statistical maximum.

'Lognormal distribution, mean is geometric.

dNormal distribution, mean is arithmetic.

"Nonparametric distribution

Units are pCi/l.

SStatistical values are below laboratory detection limits in

Table 8.1 of the Technical Approach Document (DOE, 1989). 
TABLE 3.36 GROUNDWATER QUALITY MEASUREMENTS EXCEEDING MCLS IN

TABLE 3.36 GROUN BASELINE GROUNDWATER, UC PROCESSING SITE, SLICK ROCK, CO

SITE: SRKO1 SLICK ROCK (BOTH SITES)

03/29/89 TO $10 / 15 / 92$

REPORT DATE: $07 / 26 / 93$

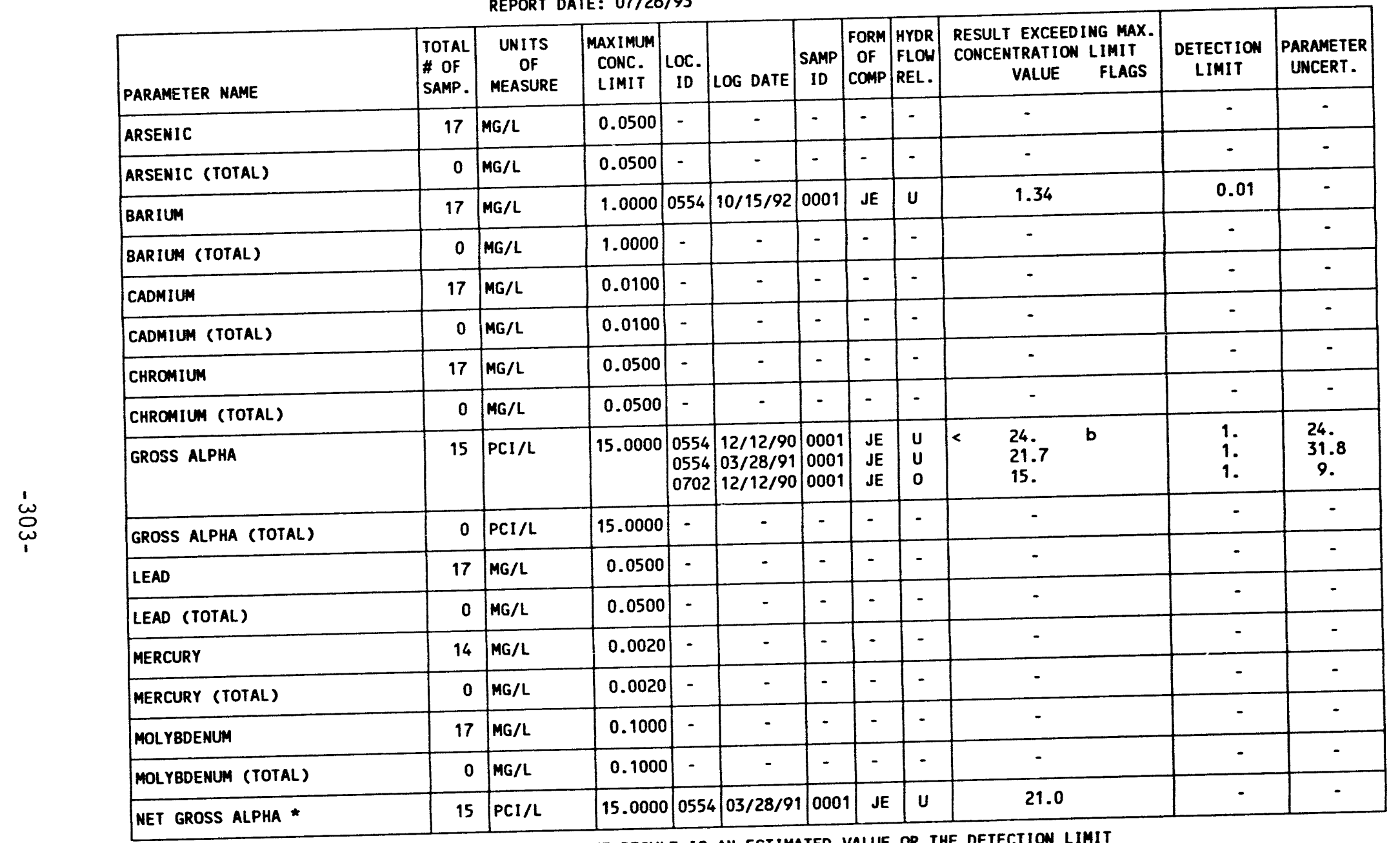

< - the data is flagged as a nON-detect, so the result is an estimated value or the detection limit

* Net GROSS ALPHA (GROSS ALPHA - URANIUN) WITH 1 MG URANIUM = 686 PCI

FORMATION OF COMPLETION CODE:

JE - JURASSIC ENTRADA SANDSTONE FORMATION

FLOW RELATIONSHIP CODE:

$U$ - UPGRADIENT

O - ON-SITE

OTHER PARAMETER VALUE FLAGS
b - CHANGED PARAMETER VALUE

SAMPLE ID COOES:

0001 - FILTERED SAMPLE (.45 MICRONS) 
TABLE 3.36 GROUNDWATER OUALITY MEASUREMENTS EXCEEDING MCLS IM

ENTRADA FORMATION BASELINE GROUNDHATER, UC PROCESSING SITE, SLICK ROCK, CO

SITE: SRKO1 SLICK ROCK (BOTH SITES)

\begin{tabular}{|c|c|c|c|c|c|c|c|c|c|c|c|}
\hline PARAMETER NAME & $\begin{array}{l}\text { TOTAL } \\
\# \text { OF } \\
\text { SAMP. }\end{array}$ & $\begin{array}{l}\text { UNITS } \\
\text { OF } \\
\text { MEASURE }\end{array}$ & $\begin{array}{l}\text { MAXIMUM } \\
\text { CONC. } \\
\text { LIMIT }\end{array}$ & $\begin{array}{c}\text { LOC. } \\
\text { ID }\end{array}$ & LOG DATE & $\mid \begin{array}{c}\text { SAMP } \\
10\end{array}$ & $\begin{array}{c}\text { FORM } \\
\text { OF } \\
\text { COMP }\end{array}$ & $\begin{array}{l}\text { HYDR } \\
\text { FLOW } \\
\text { REL. }\end{array}$ & $\begin{array}{c}\text { RESULT EXCEEDING MAX. } \\
\text { CONCENTRATION LIMIT } \\
\text { VALUE } \\
\text { FLAGS }\end{array}$ & $\begin{array}{l}\text { DETECTION } \\
\text { LIMIT }\end{array}$ & $\begin{array}{l}\text { PARAMETER } \\
\text { UNCERT. }\end{array}$ \\
\hline NET GROSS ALPHA (TOTAL) $\star \star$ & 0 & PCI/L & 15.0000 & - & - & - & - & - & - & - & - \\
\hline NITRATE & 17 & $M G / L$ & 44.0000 & $\left|\begin{array}{l}0702 \\
0702 \\
0702 \\
0702 \\
0702 \\
0702\end{array}\right|$ & $\begin{array}{l}03 / 29 / 89 \\
12 / 12 / 90 \\
03 / 31 / 91 \\
08 / 07 / 91 \\
12 / 07 / 91 \\
10 / 11 / 92\end{array}$ & $\left|\begin{array}{l}0001 \\
0001 \\
0001 \\
0001 \\
0001 \\
0001\end{array}\right|$ & $\begin{array}{l}\mathrm{JE} \\
\mathrm{JE} \\
\mathrm{JE} \\
\mathrm{JE} \\
\mathrm{JE} \\
\mathrm{JE}\end{array}$ & $\begin{array}{l}0 \\
0 \\
0 \\
0 \\
0 \\
0\end{array}$ & $\begin{array}{c}85.6 \\
126 . \\
66 . \\
79.2 \\
46.0 \\
105 .\end{array}$ & $\begin{array}{l}1 . \\
1 . \\
1 . \\
1 . \\
7 . \\
10 .\end{array}$ & $\begin{array}{l}- \\
- \\
- \\
-\end{array}$ \\
\hline NITRATE (TOTAL) & 0 & $M G / L$ & 44.0000 & - & $\cdot$ & - & - & - & - & - & - \\
\hline RA-226 \& RA-228 & 15 & $\mathrm{PCI} / \mathrm{L}$ & 5.0000 & - & - & - & - & - & - & - & - \\
\hline RA-226 \& RA-228 (TOTAL) & 0 & $\mathrm{PCI} / \mathrm{L}$ & 5.0000 & - & - & - & - & - & - & - & - \\
\hline SELENIUM & 17 & MG/L & 0.0100 & $\left|\begin{array}{l}0554 \\
0702 \\
0702 \\
0702 \\
0702 \\
0702 \\
0704 \\
0704 \\
0704 \\
0704 \\
0704\end{array}\right|$ & $\begin{array}{l}03 / 28 / 91 \\
03 / 29 / 89 \\
12 / 12 / 90 \\
03 / 31 / 91 \\
08 / 07 / 91 \\
12 / 07 / 91 \\
03 / 29 / 89 \\
12 / 12 / 90 \\
04 / 01 / 91 \\
08 / 24 / 91 \\
12 / 12 / 91\end{array}$ & $\begin{array}{l}0001 \\
0001 \\
0001 \\
0001 \\
0001 \\
0001 \\
0001 \\
0001 \\
0001 \\
0001 \\
0001\end{array} \mid$ & $\begin{array}{l}\mathrm{JE} \\
\mathrm{JE} \\
\mathrm{JE} \\
\mathrm{JE} \\
\mathrm{JE} \\
\mathrm{JE} \\
\mathrm{JE} \\
\mathrm{JE} \\
\mathrm{JE} \\
\mathrm{JE} \\
\mathrm{JE}\end{array}$ & $\begin{array}{l}U \\
0 \\
0 \\
0 \\
0 \\
0 \\
0 \\
0 \\
0 \\
0 \\
0\end{array}$ & $\begin{array}{l}0.04 \\
0.023 \\
0.042 \\
0.020 \\
0.05 \\
0.026 \\
0.012 \\
0.017 \\
0.010 \\
0.017 \\
0.026\end{array}$ & $\begin{array}{l}0.03 \\
0.005 \\
0.005 \\
0.005 \\
0.05 \\
0.005 \\
0.005 \\
0.005 \\
0.005 \\
0.005 \\
0.005\end{array}$ & $\begin{array}{l}- \\
- \\
- \\
- \\
- \\
- \\
- \\
-\end{array}$ \\
\hline SELENIUM (TOTAL) & $\mathbf{0}$ & $M G / L$ & 0.0100 & - & - & - & - & - & - & - & - \\
\hline SILVER & 14 & MG/L & 0.0500 & - & - & - & - & - & - & - & - \\
\hline SILVER (TOTAL) & 0 & $M G / L$ & 0.0500 & - & - & - & - & - & - & - & - \\
\hline
\end{tabular}

< - the data is flagged as a nON-detect, so the RESUlt is an estimated VAlUe or the detection limit

* net gross alpha (GROSS ALPHa - URAMIUm) WITH 1 Mg URANIUM = 686 PCI

** TOTAL NET GROSS ALPHA (TOTAL GROSS ALPHA - TOTAL URANIUM)

FORMATION OF COMPLETION CODE:

JE - JURASSIC ENTRADA SANDSTONE FORMATION

OTHER PARAMETER VALUE FLAGS:

I - INCREASED DETECTION LIMIT DUE TO REQUIRED DILUTION

\section{FLON RELATIONSHIP CODE:}

O - ON-SITE

$\mathrm{U}$ - UPGRADIENT

SAMPLE ID CODES:

0001 - FILTERED SAMPLE (.45 MICRONS) 
TABLE 3.36 GROUNDWATER OUALITY MEASUREMENTS EXCEEDING MCLS IN

ENTRADA FORMATION BASELINE GROUNDWATER, UC PROCESSING SITE, SLICK ROCK, CO

SITE: SRKO1 SLIC

03/29/89 TO $10 / 15 / 92$

\begin{tabular}{|c|c|c|c|c|c|c|c|c|c|c|c|}
\hline PARAMETER NAME & $\begin{array}{l}\text { TOTAL } \\
\text { \# OF } \\
\text { SAMP. }\end{array}$ & $\begin{array}{l}\text { UNITS } \\
\text { OF } \\
\text { MEASURE }\end{array}$ & $\begin{array}{l}\text { MAXIMUM } \\
\text { CONC. } \\
\text { LIMIT }\end{array}$ & $\begin{array}{l}\text { LOC. } \\
\text { ID }\end{array}$ & LOG DATE & $\left|\begin{array}{c}\text { SAMP } \\
\text { ID }\end{array}\right|$ & $\begin{array}{l}\text { FORM } \\
\text { GF } \\
\text { COMP }\end{array}$ & $\begin{array}{l}\text { HYDR } \\
\text { FLOW } \\
\text { REL. }\end{array}$ & $\begin{array}{l}\text { RESULT EXCEED ING MAX. } \\
\text { CONCENTRATION LIMIT } \\
\text { VALUE FLAGS }\end{array}$ & $\begin{array}{c}\text { DETECTION } \\
\text { LIMIT }\end{array}$ & $\begin{array}{l}\text { PARAMETER } \\
\text { UNCERT. }\end{array}$ \\
\hline URANIUM & 17 & $M G / L$ & 0.0440 & 0702 & $03 / 29 / 89$ & 0001 & JE & 0 & 0.047 & 0.003 & 0.010 \\
\hline URANIUM (TOTAL) & o & $M G / L$ & .0440 & - & - & - & - & - & - & - & - \\
\hline
\end{tabular}

FORMATION OF COMPLETION CODE:

JE - JURASSIC ENTRADA SANDSTONE FORMATION

FLOM RELATIONSHIP CODE:

O - ON-SITE

SAMPLE ID CODES:

0001 - FILTERED SAMPLE (.45 MICRONS)

DATA FILE NAME: M: DDARTISRKOIIGLQ10028.DAT 
TABLE 3.37 BASELINE GROUNDWATER QULAITY DATA BY PARAMETER FOR THE NAVAJO SANDSTONE, UC PROCESSING SITE, SLICK ROCK, COLORADO

SITE: SRKOI SLICK ROCK (BOTH SITES)

06/30/86 TO $10 / 14 / 92$

REPORT DATE: 07/26/93

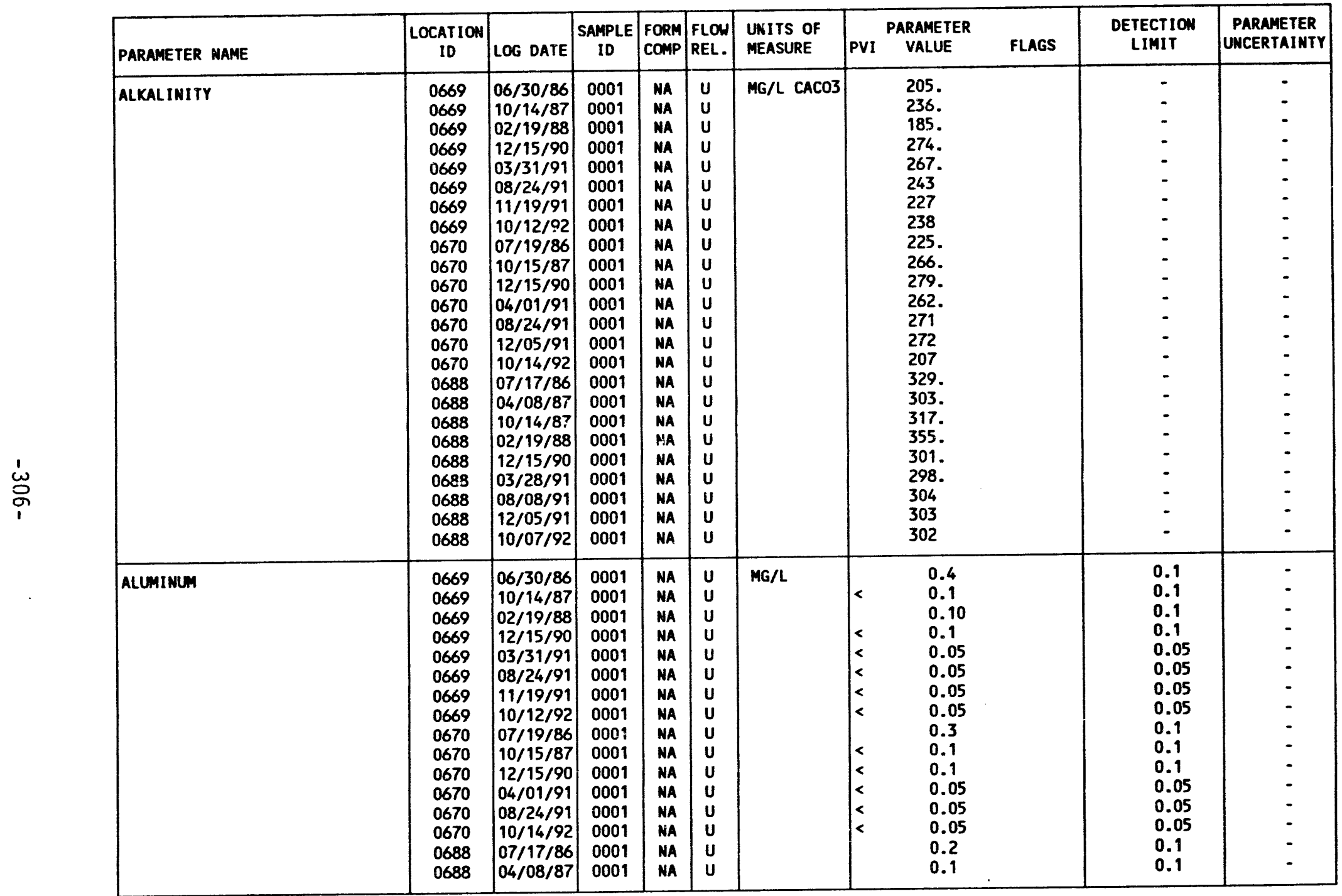

FORMATION OF COMPLETION COOE:

NA - NAVAJO SAMDSTONE

PARAMETER VALUE INDICATOR (PVI): < - LESS than DETECTION LIMIT
FLOU RELATIONSHIP CODE:

$U$ - UPGRADIENT

SAMPLE ID COOES:

0001 - FILTERED SAMPLE (.45 MICRONS) 
TABLE 3.37 BASELINE GROUNDWATER QULAITY DATA BY PARAMETER FOR THE MAVAJO SANDSTONE, UC PROCESSING SITE, SLICK ROCK, COLORADO

SITE: SRKO1 SLICK ROCK (BOTH SITES)

$06 / 30 / 86$ TO $10 / 14 / 92$

REPORT DATE: $07 / 26 / 93$

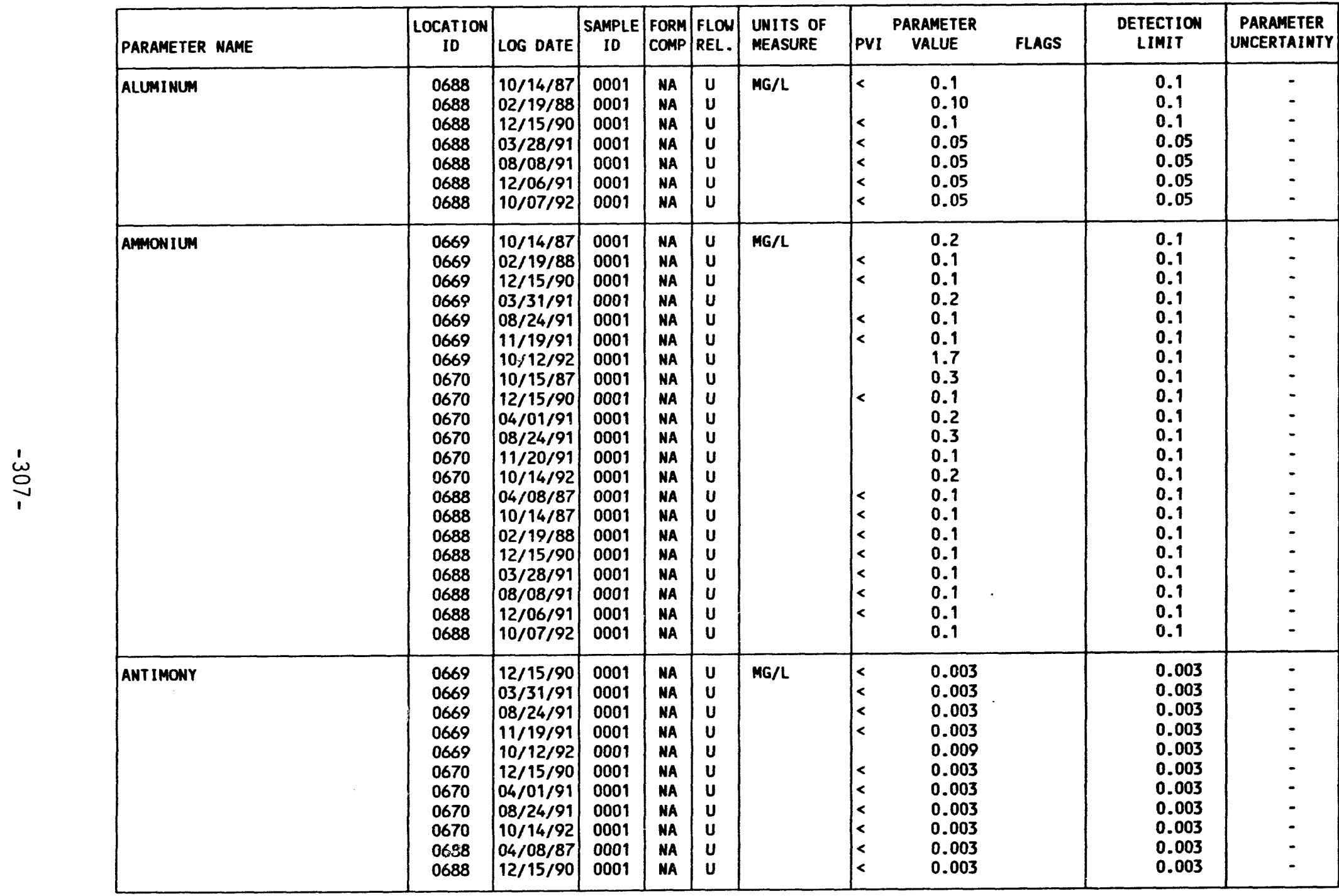

FOPMATION OF COMPLETION COOE:

MA - NAVAJO SAMDSTONE
FLOU RELATIONSHIP CODE:

$U$ - UPGRADIENT

PARAMETER VALUE INDICATOR (PVI): < - LESS THAN DETECTION LIMIT

SAMPLE ID CODES:

0001 - FILTERED SAMPLE (.45 MICRONS) 
TABLE 3.37 BASELIME GROUNDWATER QULAITY DATA BY PARAMETER FOR THE MAVAJO SALOSTONE, UC PROCESSING SITE, SLICK ROCK, COLORADO

SITE: SRKO1 SLICK ROCK (BOTH SITES)

06/30/86 TO 10/14/92

REPORT DATE: 07/26/93

\begin{tabular}{|c|c|c|c|c|c|c|c|c|c|c|c|}
\hline & PARAMETER NAME & $\underset{\text { LOCATION }}{\text { LD }}$ & LOG DATE & $\begin{array}{c}\text { SAMPLE } \\
\text { ID }\end{array}$ & $\begin{array}{l}\text { FORM } \\
\text { COMP }\end{array}$ & $\begin{array}{l}\text { FLOH } \\
\text { REL. }\end{array}$ & $\begin{array}{l}\text { UNITS OF } \\
\text { MEASURE }\end{array}$ & PVI & $\begin{array}{l}\text { PARAMETER } \\
\text { VALUE }\end{array}$ & $\begin{array}{l}\text { DETECTION } \\
\text { LIMIT }\end{array}$ & $\begin{array}{l}\text { PARAMETER } \\
\text { UNCERTAINTY }\end{array}$ \\
\hline & ANT IMONY & $\begin{array}{l}0688 \\
0688 \\
0688 \\
0688\end{array}$ & $\begin{array}{l}03 / 28 / 91 \\
08 / 08 / 91 \\
12 / 06 / 91 \\
10 / 07 / 92\end{array}$ & $\begin{array}{l}0001 \\
0001 \\
0001 \\
0001\end{array}$ & $\begin{array}{l}\text { NA } \\
\text { NA } \\
\text { NA } \\
\text { NA }\end{array}$ & $\begin{array}{l}U \\
U \\
U \\
U\end{array}$ & $M G / L$ & $\begin{array}{l}< \\
< \\
< \\
<\end{array}$ & $\begin{array}{l}0.003 \\
0.003 \\
0.003 \\
0.003\end{array}$ & $\begin{array}{l}0.003 \\
0.003 \\
0.003 \\
0.003\end{array}$ & $\begin{array}{l}- \\
- \\
-\end{array}$ \\
\hline & ARSENIC & $\begin{array}{l}0669 \\
0669 \\
0669 \\
0669 \\
0669 \\
0669 \\
0669 \\
0670 \\
0670 \\
0670 \\
0670 \\
0670 \\
0670 \\
0688 \\
0688 \\
0688 \\
0688 \\
0688 \\
0688 \\
0688 \\
0688\end{array}$ & $\begin{array}{l}06 / 30 / 86 \\
10 / 14 / 87 \\
12 / 15 / 90 \\
03 / 31 / 91 \\
08 / 24 / 91 \\
11 / 19 / 91 \\
10 / 12 / 92 \\
07 / 19 / 86 \\
10 / 15 / 87 \\
12 / 15 / 90 \\
04 / 01 / 91 \\
08 / 24 / 91 \\
10 / 14 / 92 \\
07 / 17 / 86 \\
04 / 08 / 87 \\
10 / 14 / 87 \\
12 / 15 / 90 \\
03 / 28 / 91 \\
08 / 08 / 91 \\
12 / 06 / 91 \\
10 / 07 / 92\end{array}$ & $\begin{array}{l}0001 \\
0001 \\
0001 \\
0001 \\
0001 \\
0001 \\
0001 \\
0001 \\
0001 \\
0001 \\
0001 \\
0001 \\
0001 \\
0001 \\
0001 \\
0001 \\
0001 \\
0001 \\
0001 \\
0001 \\
0001\end{array}$ & $\begin{array}{l}\text { NA } \\
\text { NA } \\
\text { NA } \\
\text { NA } \\
\text { NA } \\
\text { NA } \\
\text { NA } \\
\text { NA } \\
\text { NA } \\
\text { NA } \\
\text { NA } \\
\text { NA } \\
\text { NA } \\
\text { NA } \\
\text { NA } \\
\text { NA } \\
\text { NA } \\
\text { NA } \\
\text { NA } \\
\text { NA } \\
\text { NA }\end{array}$ & $\begin{array}{l}U \\
U \\
U \\
U \\
U \\
U \\
U \\
U \\
U \\
U \\
U \\
U \\
U \\
U \\
U \\
U \\
U \\
U \\
U \\
U \\
U\end{array}$ & $M G / L$ & $\begin{array}{l}< \\
< \\
< \\
< \\
< \\
< \\
< \\
< \\
< \\
< \\
< \\
< \\
< \\
< \\
<\end{array}$ & $\begin{array}{l}0.01 \\
0.02 \\
0.014 \\
0.01 \\
0.01 \\
0.01 \\
0.010 \\
0.01 \\
0.02 \\
0.025 \\
0.01 \\
0.01 \\
0.013 \\
0.01 \\
0.001 \\
0.01 \\
0.001 \\
0.01 \\
0.01 \\
0.01 \\
0.005\end{array}$ & $\begin{array}{l}0.01 \\
0.01 \\
0.01 \\
0.01 \\
0.01 \\
0.01 \\
0.005 \\
0.01 \\
0.01 \\
0.01 \\
0.01 \\
0.01 \\
0.005 \\
0.01 \\
0.01 \\
0.01 \\
0.01 \\
0.01 \\
0.01 \\
0.01 \\
0.005\end{array}$ & $\begin{array}{l}- \\
- \\
- \\
- \\
- \\
- \\
- \\
- \\
- \\
- \\
- \\
- \\
- \\
- \\
- \\
- \\
-\end{array}$ \\
\hline & BARIUM & $\begin{array}{l}0669 \\
0669 \\
0669 \\
0669 \\
0669 \\
0669 \\
0670 \\
0670 \\
0670 \\
0670 \\
0670 \\
0688 \\
0688 \\
0688\end{array}$ & $\begin{array}{l}10 / 14 / 87 \\
12 / 15 / 90 \\
03 / 31 / 91 \\
08 / 24 / 91 \\
11 / 19 / 91 \\
10 / 12 / 92 \\
10 / 15 / 87 \\
12 / 15 / 90 \\
04 / 01 / 91 \\
08 / 24 / 91 \\
10 / 14 / 92 \\
04 / 08 / 87 \\
10 / 14 / 87 \\
12 / 15 / 90\end{array}$ & $\begin{array}{l}0001 \\
0001 \\
0001 \\
0001 \\
0001 \\
0001 \\
0001 \\
0001 \\
0001 \\
0001 \\
0001 \\
0001 \\
0001 \\
0001\end{array}$ & $\begin{array}{l}\text { NA } \\
\text { NA } \\
\text { NA } \\
\text { NA } \\
\text { NA } \\
\text { NA } \\
\text { NA } \\
\text { NA } \\
\text { NA } \\
\text { NA } \\
\text { NA } \\
\text { NA } \\
\text { NA } \\
\text { NA }\end{array}$ & $\begin{array}{l}u \\
U \\
U \\
U \\
U \\
U \\
U \\
U \\
U \\
U \\
U \\
U \\
U \\
U\end{array}$ & $M G / L$ & & $\begin{array}{l}0.2 \\
0.1 \\
0.15 \\
0.12 \\
0.11 \\
0.08 \\
0.1 \\
0.1 \\
0.16 \\
0.15 \\
0.06 \\
0.1 \\
0.2 \\
0.2\end{array}$ & $\begin{array}{l}0.1 \\
0.1 \\
0.01 \\
0.01 \\
0.01 \\
0.01 \\
0.1 \\
0.1 \\
0.01 \\
0.01 \\
0.01 \\
0.1 \\
0.1 \\
0.1\end{array}$ & $\begin{array}{l}- \\
- \\
- \\
- \\
- \\
- \\
- \\
- \\
- \\
-\end{array}$ \\
\hline
\end{tabular}

FORMATION OF COMPLETION COOE:

NA - NAVAJO SANDSTONE

PARAMETER VALUE INDICATOR (PVI): < - LESS THAN DETECTION LIMIT
FLOW RELATIONSHIP CODE:

U - UPGRADIENT

0001 - FILTERED SAMPLE (.45 MICRONS) 
TABLE 3.37 BASELINE GROUNDWATER OULAITY DATA BY PARAMETER FOR THE NAVA DO SAMDSTONE, UC PROCESSING SITE, SLICK ROCK, COLORADO

SITE: SRK01 SLICK ROCK (BOTH SITES)

$06 / 30 / 86$ TO $10 / 14 / 92$

REPORT DATE: $07 / 26 / 93$

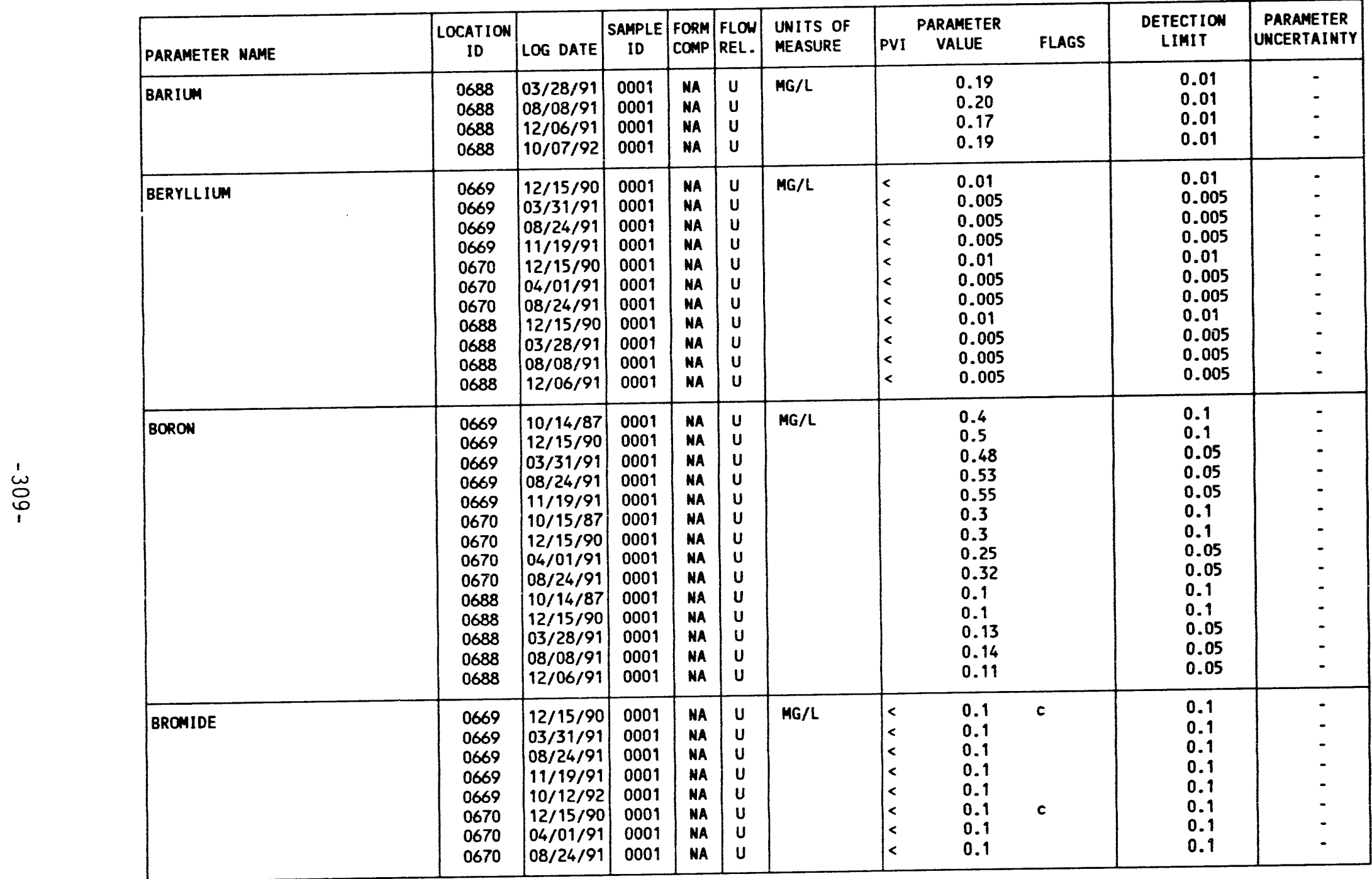

FORMATION OF COMPLETION COOE:

NA - MAVAJO SANDSTONE

PARAMETER VALUE INDICATOR (PVI): < - LESS THAN DETECTION LIMIT
FLOW RELATIONSHIP CODE:

U - UPGRADIENT

SAMPLE ID COOES:

0001 - FILTERED SAMPLE (.45 MICRONS)

OTHER PARAMETER VALUE FLAGS:

c - CHANGED DETECTION LIMIT 
TABLE 3.37 BASELINE GROUNDUATER QULAITY DATA BY PARAMETER FOR THE NAVA JO SAUDSTONE UC PROCESSING SITE, SLICK ROCK, COLORADO

SITE: SRKO1 SLICK ROCK (BOTH SITES)

06/30/86 TO 10/14/92

REPORT DATE: $07 / 26 / 93$

\begin{tabular}{|c|c|c|c|c|c|c|c|c|c|c|c|}
\hline PARAMETER NAME & $\underset{\text { LOCATION }}{\text { ID }}$ & LOG DATE & $\underset{\text { SAMPLE }}{\text { ID }}$ & $\begin{array}{l}\text { FORM } \\
\text { COMP }\end{array}$ & $\begin{array}{l}\text { FLOW } \\
\text { REL. }\end{array}$ & $\begin{array}{l}\text { UNITS OF } \\
\text { MEASURE }\end{array}$ & PVI & $\begin{array}{l}\text { ARAMETER } \\
\text { VALUE }\end{array}$ & FLAGS & $\begin{array}{l}\text { DETECTION } \\
\text { LIMIT }\end{array}$ & $\begin{array}{l}\text { PARAMETER } \\
\text { UNCERTAINTYY }\end{array}$ \\
\hline BROMIDE & $\begin{array}{l}0670 \\
0670 \\
0688 \\
0688 \\
0688 \\
0688 \\
0688\end{array}$ & \begin{tabular}{|l|}
$11 / 20 / 91$ \\
$10 / 14 / 92$ \\
$12 / 15 / 90$ \\
$03 / 28 / 91$ \\
$08 / 08 / 91$ \\
$12 / 06 / 91$ \\
$10 / 07 / 92$
\end{tabular} & $\begin{array}{l}0001 \\
0001 \\
0001 \\
0001 \\
0001 \\
0001 \\
0001\end{array}$ & $\begin{array}{l}\text { NA } \\
\text { NA } \\
\text { NA } \\
\text { NA } \\
\text { NA } \\
\text { NA } \\
\text { NA }\end{array}$ & $\begin{array}{l}u \\
u \\
u \\
u \\
u \\
u \\
U\end{array}$ & $M G / L$ & $\begin{array}{l}< \\
< \\
< \\
<\end{array}$ & $\begin{array}{l}0.1 \\
0.1 \\
0.1 \\
0.1 \\
0.1 \\
3.1 \\
0.2\end{array}$ & $\begin{array}{l}c \\
I\end{array}$ & $\begin{array}{l}0.1 \\
0.1 \\
0.1 \\
0.1 \\
0.1 \\
0.8 \\
0.2\end{array}$ & $\begin{array}{l}- \\
- \\
- \\
-\end{array}$ \\
\hline CADMIUM & $\begin{array}{l}0669 \\
0669 \\
0669 \\
0669 \\
0669 \\
0669 \\
0670 \\
0670 \\
0670 \\
0670 \\
0670 \\
0688 \\
0688 \\
0688 \\
0688 \\
0688 \\
0688 \\
0688 \\
\end{array}$ & \begin{tabular}{|l|}
$10 / 14 / 87$ \\
$12 / 15 / 90$ \\
$03 / 31 / 91$ \\
$08 / 24 / 91$ \\
$11 / 19 / 91$ \\
$10 / 12 / 92$ \\
$10 / 15 / 87$ \\
$12 / 15 / 90$ \\
$04 / 01 / 91$ \\
$08 / 24 / 91$ \\
$10 / 14 / 92$ \\
$04 / 08 / 87$ \\
$10 / 14 / 87$ \\
$12 / 15 / 90$ \\
$03 / 28 / 91$ \\
$08 / 08 / 91$ \\
$12 / 06 / 91$ \\
$10 / 07 / 92$
\end{tabular} & $\begin{array}{l}0001 \\
0001 \\
0001 \\
0001 \\
0001 \\
0001 \\
0001 \\
0001 \\
0001 \\
0001 \\
0001 \\
0001 \\
0001 \\
0001 \\
0001 \\
0001 \\
0001 \\
0001\end{array}$ & $\begin{array}{l}\text { NA } \\
\text { NA } \\
\text { NA } \\
\text { NA } \\
\text { NA } \\
\text { NA } \\
\text { NA } \\
\text { NA } \\
\text { NA } \\
\text { NA } \\
\text { NA } \\
\text { NA } \\
\text { NA } \\
\text { NA } \\
\text { NA } \\
\text { NA } \\
\text { NA } \\
\text { NA }\end{array}$ & $\begin{array}{l}u \\
u \\
u \\
u \\
u \\
u \\
u \\
u \\
u \\
u \\
u \\
u \\
u \\
u \\
u \\
U \\
U \\
U\end{array}$ & $M G / L$ & $\begin{array}{l}< \\
< \\
< \\
< \\
< \\
< \\
< \\
< \\
< \\
< \\
< \\
< \\
< \\
< \\
< \\
< \\
< \\
<\end{array}$ & $\begin{array}{l}0.001 \\
0.001 \\
0.001 \\
0.001 \\
0.001 \\
0.005 \\
0.001 \\
0.001 \\
0.001 \\
0.001 \\
0.001 \\
0.001 \\
0.001 \\
0.001 \\
0.001 \\
0.001 \\
0.001 \\
0.001\end{array}$ & I & $\begin{array}{l}0.001 \\
0.001 \\
0.001 \\
0.001 \\
0.001 \\
0.005 \\
0.001 \\
0.001 \\
0.001 \\
0.001 \\
0.001 \\
0.001 \\
0.001 \\
0.001 \\
0.001 \\
0.001 \\
0.001 \\
0.001\end{array}$ & $\begin{array}{l}- \\
- \\
- \\
- \\
- \\
- \\
- \\
- \\
- \\
- \\
- \\
- \\
- \\
-\end{array}$ \\
\hline CALCIUM & $\begin{array}{l}0669 \\
0669 \\
0669 \\
0669 \\
0669 \\
0669 \\
0669 \\
0669 \\
0670 \\
0670 \\
0670 \\
0670\end{array}$ & \begin{tabular}{|l|}
$06 / 30 / 86$ \\
$10 / 14 / 87$ \\
$02 / 19 / 88$ \\
$12 / 15 / 90$ \\
$03 / 31 / 91$ \\
$08 / 24 / 91$ \\
$11 / 19 / 91$ \\
$10 / 12 / 92$ \\
$07 / 19 / 86$ \\
$10 / 15 / 87$ \\
$12 / 15 / 90$ \\
$04 / 01 / 91$
\end{tabular} & $\begin{array}{l}0001 \\
0001 \\
0001 \\
0001 \\
0001 \\
0001 \\
0001 \\
0001 \\
0001 \\
0001 \\
0001 \\
0001\end{array}$ & $\begin{array}{l}\text { NA } \\
\text { NA } \\
\text { NA } \\
\text { NA } \\
\text { NA } \\
\text { NA } \\
\text { NA } \\
\text { NA } \\
\text { NA } \\
\text { NA } \\
\text { NA } \\
\text { NA }\end{array}$ & $\begin{array}{l}u \\
u \\
u \\
u \\
u \\
u \\
u \\
u \\
u \\
u \\
u \\
u\end{array}$ & $M G / L$ & & $\begin{array}{l}31.9 \\
34 . \\
29.0 \\
24.1 \\
37.0 \\
38.9 \\
39.2 \\
34.5 \\
34.8 \\
42 . \\
44.2 \\
41.9\end{array}$ & & $\begin{array}{l}0.01 \\
0.01 \\
0.01 \\
0.01 \\
0.5 \\
0.5 \\
0.5 \\
0.5 \\
0.01 \\
0.01 \\
0.01 \\
0.5\end{array}$ & $\begin{array}{l}- \\
- \\
- \\
- \\
- \\
- \\
- \\
-\end{array}$ \\
\hline
\end{tabular}

FORMATION OF COMPLETION CODE:

NA - NAVAJO SANDSTONE

PARAMETER VALUE INDICATOR (PVI): < - LESS thaN DETECTION LIMIT
FLOW RELATIONSHIP CODE:

$U$ - UPGRADIENT

OTHER PARAMETER VALUE FLAGS:

I - INCREASED DETECTION LIMIT DUE TO REQUIRED DILUTION

- CHANGED DETECTION LIMIT 
NAVAJO SANDSTONE, UC PROCESSING SITE, SLICK ROCK, COLORADO

SITE: SRKO1 SLICK ROCK (BOTH SITES)

$06 / 30 / 86$ TO $10 / 14 / 92$

REPORT DATE: $07 / 26 / 93$

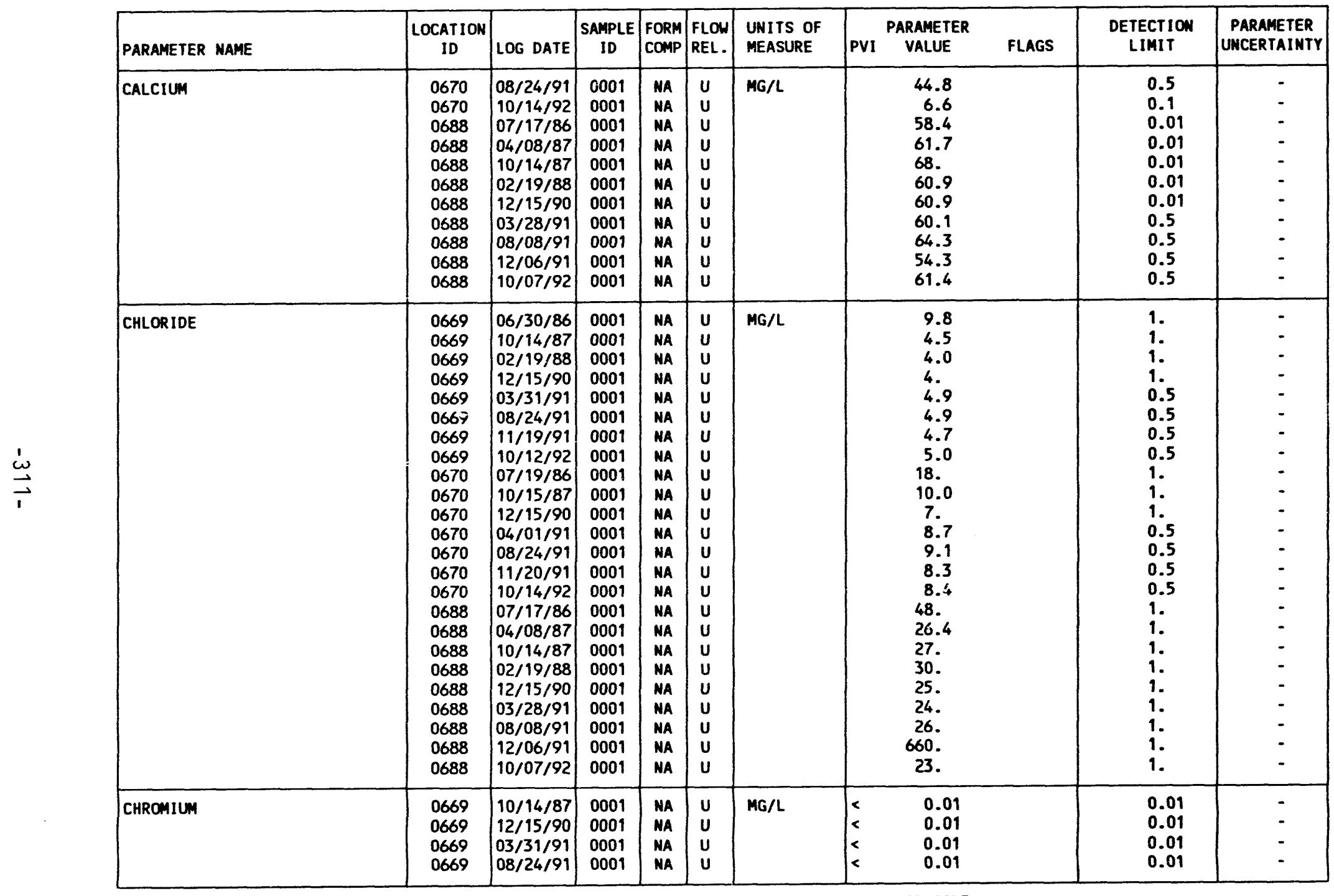

FORMATION OF COMPLETION COOE:

NA - MAVAJO SANDSTONE

PARAMETER VALUE INDICATOR (PVI): < - LESS THAN DETECTION LIMIT
FLOW RELATIONSHIP COOE:

U - UPGRADIENT

0001 - FILTERED SAMPLE (.45 MICRONS) 
TABLE 3.37 3ASELIME GROUNDWATER OULAITY DATA BY PARAMETER FOR THE MAVAJO SANDSTONE, UC PROCESSING SITE, SLICK ROCK, COLORADO

SITE: SRKO1 SLICK ROCK (BOTH SITES)

SITE: SRKO1 SLICK ROCK

RE/30/86 TO $10 / 14 / 92$

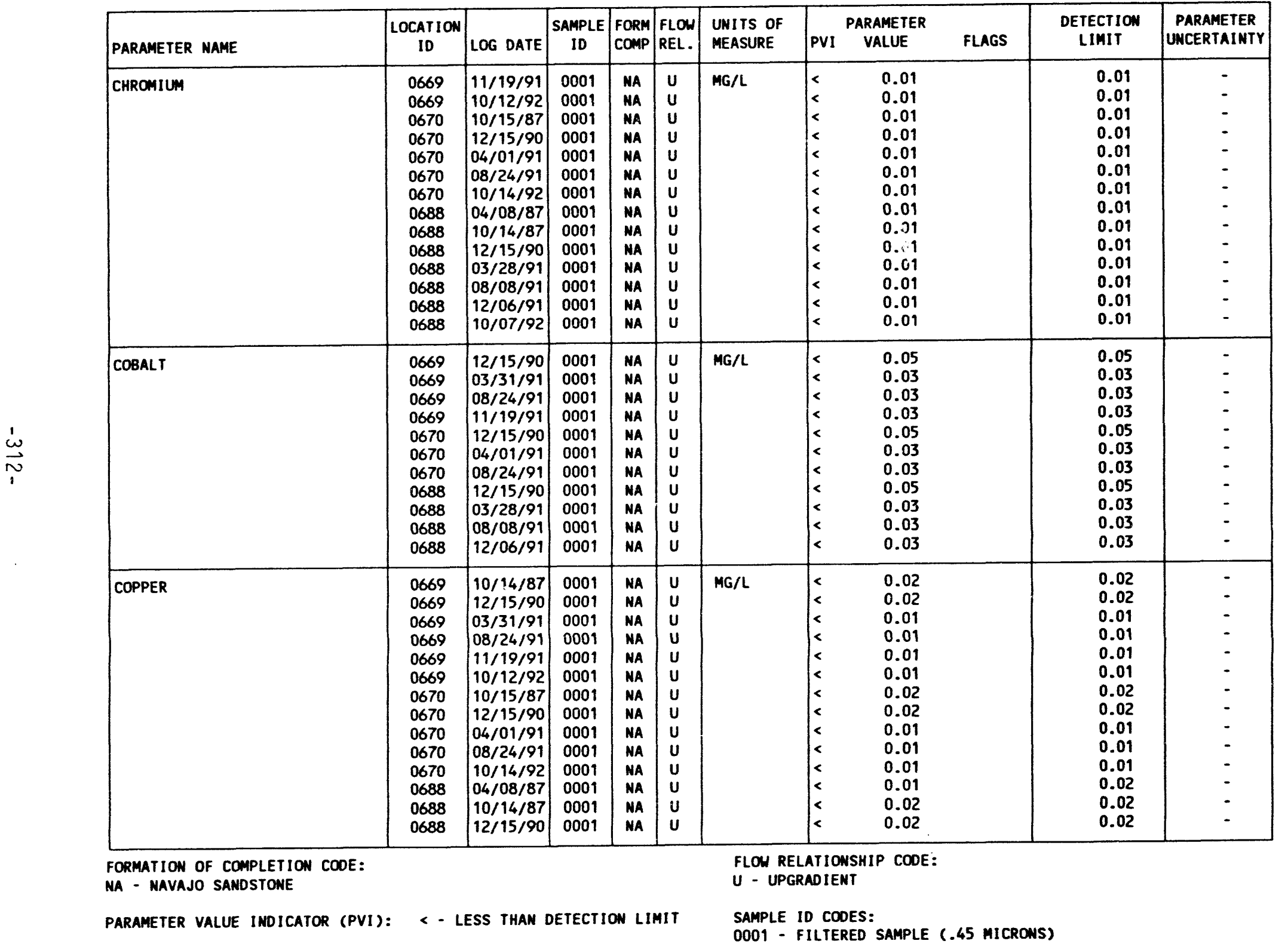


TABLE 337 BASELIME GROUMDUATER OULAITY DATA BY PARAMETER FOR THE

MAVAJO SANDSTONE, UC PROCESSING SITE, SLICK ROCK, COLORADO

SITE. SRKO1 SLICK ROCK (BOTH SITES)

06/30/86 TO $10 / 14 / 92$

REPORT DATE: 07/26/93

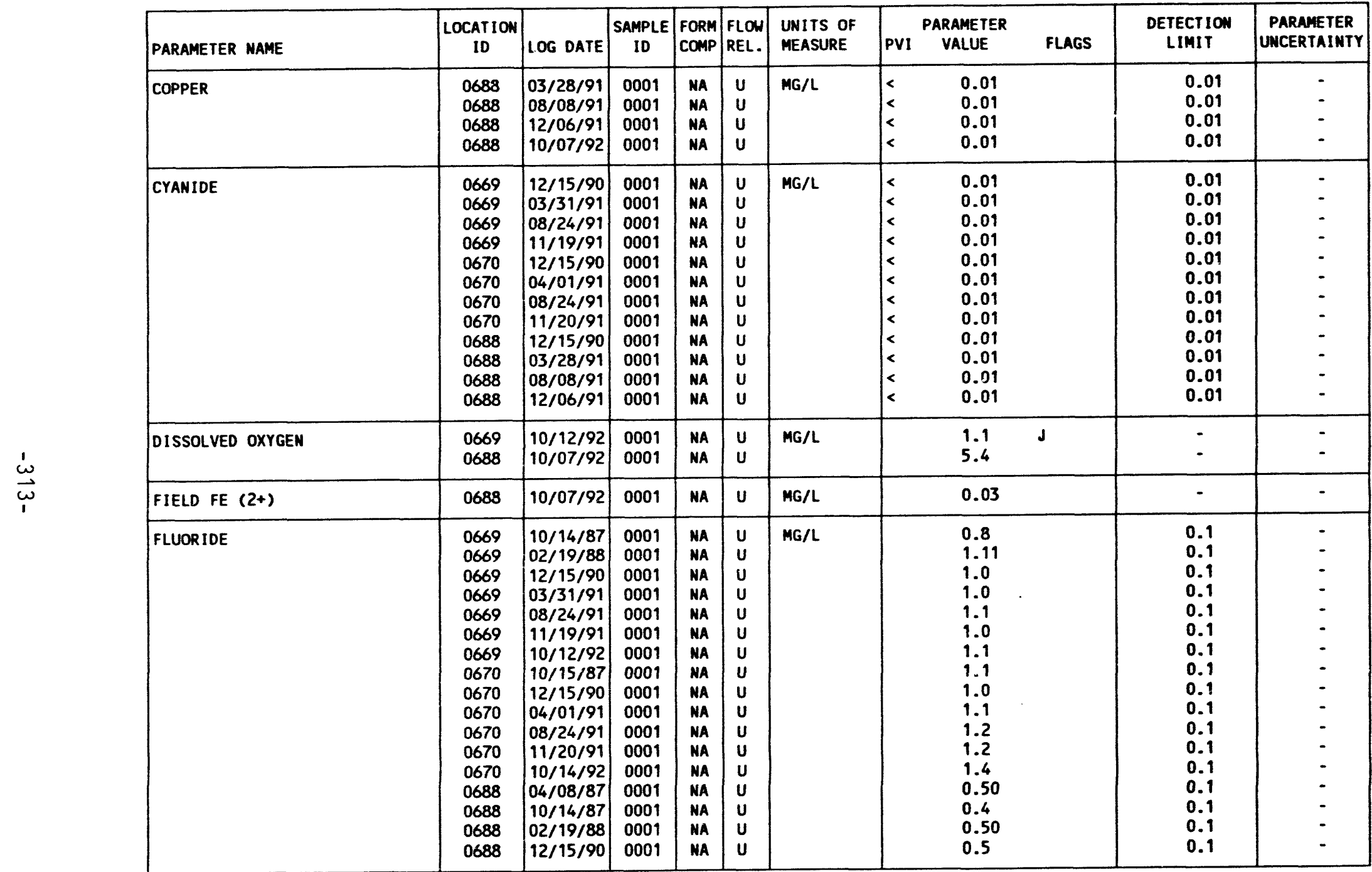

FORMATION OF COMPLETION COOE:

NA - NAVAJO SANDSTONE

PARAMETER VALUE INDICATOR (PVI): < - LESS THAN DETECTION LIMIT
FLOU RELATIONSHIP COOE:

$U$ - UPGRADIENT

OTHER PARAMETER VALUE FLAGS:

$J$ - ESTIMATED VALUE 
TABLE 3.37 BASELINE GROUNDHATER QULAITY DATA BY PARAMETER FOR THE MAVAJO SANDSTONE, UC PROCESSING SITE, SLICK ROCK, COLORADO

SITE: SRKO1 SLICK ROCK (BOTH SITES)

06/30/86 TO $10 / 14 / 92$

REPORT DATE: $07 / 26 / 93$

\begin{tabular}{|c|c|c|c|c|c|c|c|c|c|c|c|c|}
\hline & PARAMETER NAME & $\begin{array}{c}\text { LOCATION } \\
10\end{array}$ & LOG DATE & $\begin{array}{c}\text { SAMPLE } \\
\text { ID }\end{array}$ & $\begin{array}{l}\text { FORM } \\
\text { COMP }\end{array}$ & $\begin{array}{l}\text { FLON } \\
\text { REL. }\end{array}$ & $\begin{array}{l}\text { UNITS OF } \\
\text { MEASURE }\end{array}$ & PVI & $\begin{array}{l}\text { PARAMETER } \\
\text { VALUE }\end{array}$ & FLAGS & $\begin{array}{l}\text { DETECTION } \\
\text { LIMIT }\end{array}$ & $\begin{array}{l}\text { PARAMETER } \\
\text { UNCERTAINTY }\end{array}$ \\
\hline & FLUORIDE & $\begin{array}{l}0688 \\
0688 \\
0688 \\
0688\end{array}$ & $\begin{array}{l}03 / 28 / 91 \\
08 / 08 / 91 \\
12 / 06 / 91 \\
10 / 07 / 92\end{array}$ & $\begin{array}{l}0001 \\
0001 \\
0001 \\
0001\end{array}$ & $\begin{array}{l}\text { MA } \\
\text { KA } \\
\text { NA } \\
\text { MA }\end{array}$ & $\begin{array}{l}u \\
U \\
U \\
U\end{array}$ & $M G / L$ & & $\begin{array}{l}0.5 \\
0.5 \\
0.2 \\
0.5\end{array}$ & & $\begin{array}{l}0.1 \\
0.1 \\
0.1 \\
0.1\end{array}$ & : \\
\hline & GROSS ALPHA & $\begin{array}{l}0669 \\
0669 \\
0669 \\
0669 \\
0669 \\
0670 \\
0670 \\
0670 \\
0670 \\
0670 \\
0688 \\
0688 \\
0688 \\
0688 \\
0688\end{array}$ & $\begin{array}{l}12 / 15 / 90 \\
03 / 31 / 91 \\
08 / 24 / 91 \\
11 / 19 / 91 \\
10 / 12 / 92 \\
12 / 15 / 90 \\
04 / 01 / 91 \\
08 / 24 / 91 \\
12 / 05 / 91 \\
10 / 14 / 92 \\
12 / 15 / 90 \\
03 / 28 / 91 \\
08 / 08 / 91 \\
12 / 05 / 91 \\
10 / 07 / 92\end{array}$ & $\begin{array}{l}0001 \\
0001 \\
0001 \\
0001 \\
0001 \\
0001 \\
0001 \\
0001 \\
0001 \\
0001 \\
0001 \\
0001 \\
0001 \\
0001 \\
0001\end{array}$ & $\begin{array}{l}\text { MA } \\
\text { NA } \\
\text { NA } \\
\text { NA } \\
\text { MA } \\
\text { NA } \\
\text { NA } \\
\text { NA } \\
\text { NA } \\
\text { NA } \\
\text { NA } \\
\text { NA } \\
\text { NA } \\
\text { MA } \\
\text { NA }\end{array}$ & $\begin{array}{l}u \\
U \\
U \\
U \\
U \\
U \\
U \\
U \\
U \\
U \\
U \\
U \\
U \\
U \\
U\end{array}$ & $\mathrm{PCl} / \mathrm{L}$ & $<$ & $\begin{array}{r}4.1 \\
2.3 \\
7.7 \\
425 . \\
0.0 \\
2.6 \\
5.5 \\
5.5 \\
0.0 \\
1.3 \\
4.6 \\
3.2 \\
12.8 \\
0.0 \\
5.8\end{array}$ & $\begin{array}{l}\text { N } \\
\text { b }\end{array}$ & $\begin{array}{l}1 . \\
1 . \\
1 . \\
1 . \\
5.8 \\
1 . \\
1 . \\
1 . \\
1 . \\
5.6 \\
1 . \\
1 . \\
1 . \\
1 . \\
6.6\end{array}$ & $\begin{array}{r}2.7 \\
3.3 \\
3.7 \\
20.2 \\
3.4 \\
3.2 \\
4.0 \\
4.0 \\
6.8 \\
3.5 \\
4.6 \\
3.5 \\
7.0 \\
8.0 \\
4.8\end{array}$ \\
\hline$f$ & GROSS BETA & $\begin{array}{l}0669 \\
0669 \\
0669 \\
0669 \\
0669 \\
0670 \\
0670 \\
0670 \\
0670 \\
0670 \\
0638 \\
0688 \\
0688 \\
0688 \\
0688\end{array}$ & $\begin{array}{l}12 / 15 / 90 \\
03 / 31 / 91 \\
08 / 24 / 91 \\
11 / 19 / 91 \\
10 / 12 / 92 \\
12 / 15 / 90 \\
04 / 01 / 91 \\
08 / 24 / 91 \\
12 / 05 / 91 \\
10 / 14 / 92 \\
12 / 15 / 90 \\
03 / 28 / 91 \\
08 / 08 / 91 \\
12 / 05 / 91 \\
10 / 07 / 92\end{array}$ & $\begin{array}{l}0001 \\
0001 \\
0001 \\
0001 \\
0001 \\
0001 \\
0001 \\
0001 \\
0001 \\
0001 \\
0001 \\
0001 \\
0001 \\
0001 \\
0001\end{array}$ & $\begin{array}{l}\text { MA } \\
\text { NA } \\
\text { NA } \\
\text { NA } \\
\text { NA } \\
\text { NA } \\
\text { NA } \\
\text { NA } \\
\text { NA } \\
\text { NA } \\
\text { NA } \\
\text { NA } \\
\text { MA } \\
\text { NA } \\
\text { NA }\end{array}$ & $\begin{array}{l}u \\
u \\
u \\
u \\
u \\
u \\
u \\
u \\
u \\
u \\
u \\
u \\
u \\
u \\
u\end{array}$ & $\mathrm{PCI} / \mathrm{L}$ & & $\begin{array}{l}12 . \\
11.9 \\
17.0 \\
51.5 \\
14.6 \\
11 . \\
15.1 \\
16.6 \\
5.6 \\
45.4 \\
9.0 \\
7.5 \\
8.6 \\
0.0 \\
4.0\end{array}$ & *N & $\begin{array}{l}0.5 \\
0.5 \\
0.5 \\
0.5 \\
5.3 \\
0.5 \\
0.5 \\
0.5 \\
0.5 \\
5.0 \\
0.5 \\
0.5 \\
0.5 \\
0.5 \\
6.2\end{array}$ & $\begin{array}{l}2.0 \\
2.4 \\
2.6 \\
4.5 \\
3.8 \\
2.8 \\
2.6 \\
2.9 \\
5.2 \\
4.6 \\
2.7 \\
2.2 \\
4.6 \\
5.7 \\
3.9\end{array}$ \\
\hline & IRON & 0669 & $06 / 30 / 86$ & 0001 & NA & $\boldsymbol{U}$ & $M G / L$ & & 0.06 & & 0.03 & - \\
\hline
\end{tabular}

FORMATION OF COMPLETION COOE:

MA - NAVAJO SANDSTONE

FLON RELATIONSHIP COOE

PARAMETER VALUE INDICATOR (PVI): < - LESS thaN DETECTION LIMIT SAMPLE ID CODES:

0001 - FILTERED SAMPLE (.45 MICRONS)

OTHER PARAMETER VALUE FLAGS:

* - DUPLICATE AMALYSIS NOT WITHIN CONTROL LIMITS

N - SPIKE SAMPLE RECOVERY MOT WITHIN CONTROL LIMITS

b - CHANGED PARAMETER VALUE 
TABLE 3.37 BASELINE GROUNDUATER OULAITY DATA BY PARAMETER FOR THE

MAVAJO SAMDSTONE, UC PROCESSING SITE, SLICK ROCK, COLORADO

SITE: SRKO1 SLICK ROCK (BOTH SITES)

$06 / 30 / 86$ TO $10 / 14 / 92$

REPORT DATE: $07 / 26 / 93$

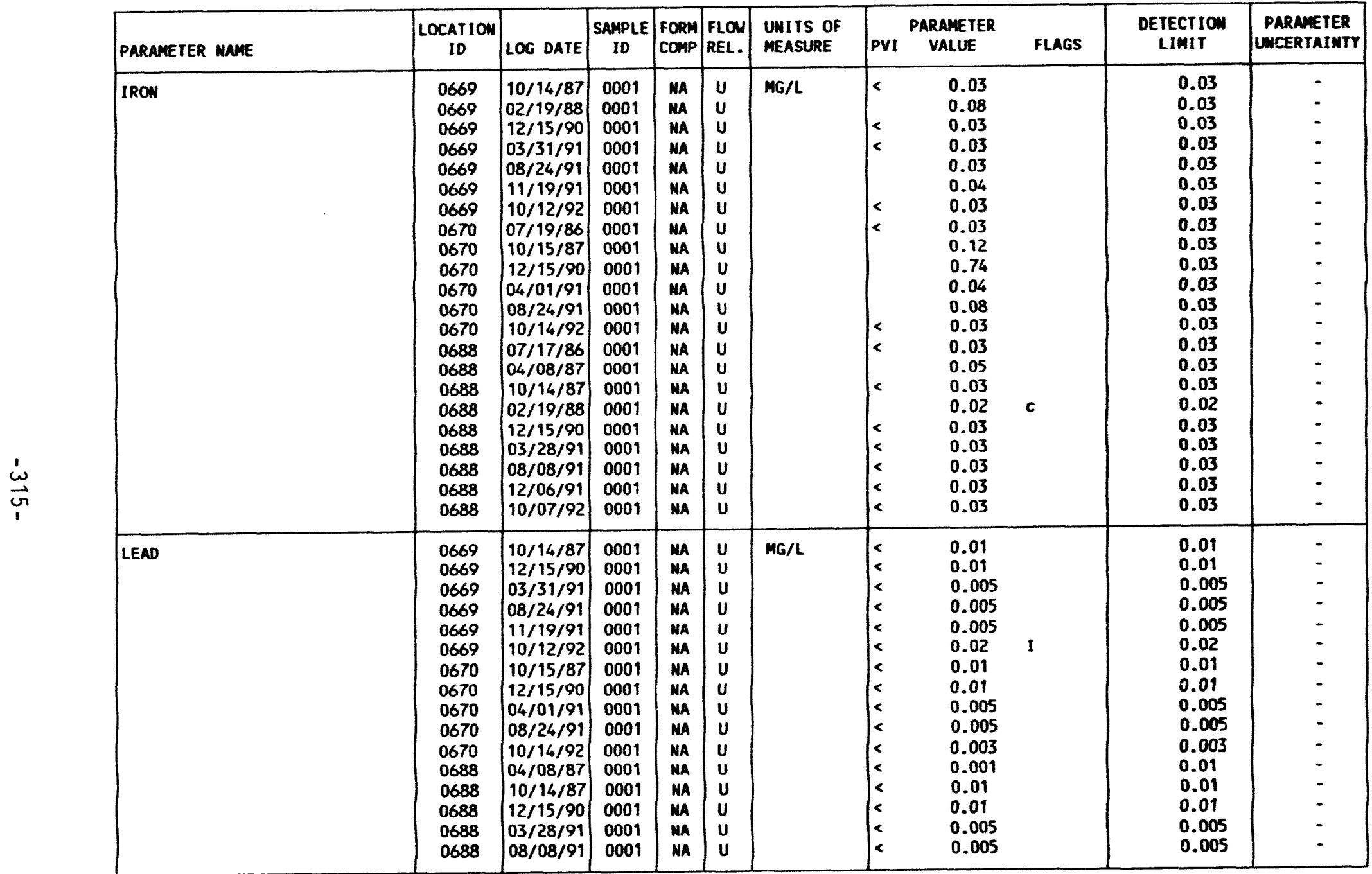

FORMATION OF COMPLETION CODE:

MA - NAVAJO SAMDSTONE

PARAMETER VALUE INDICATOR (PVI): < - LESS THAN DETECTION LIMIT
FLON RELATIONSHIP COOE:

U - UPGRADIENT

SAMPLE ID COOES:

0001 - FILTERED SAMPLE (.45 MICRONS)

OTHER PARAMETER VALUE FLAGS:

I - IMCREASED DETECTION LIMIT DUE TO REOUIRED DILUTION

I - INCREASED DETECTION LIMIT 
TABLE 3.37 BASELINE GROUMDWATER QULAITY DATA BY PARAMETER FOR THE

MAVA JO SAMDSTONE, UC PROCESSING SITE, SLICK ROCK, COLORADO

SITE: SRKO1 SLICK ROCK (BOTH SITES)

O6/30/86 TO $10 / 14 / 92$

REPORT DATE: $07 / 26 / 93$

\begin{tabular}{|c|c|c|c|c|c|c|c|c|c|c|}
\hline PARAMETER NAME & $\begin{array}{c}\text { LOCATION } \\
\text { ID }\end{array}$ & LOG DATE & $\underset{10}{\text { SAMPLE }}$ & $\begin{array}{l}\text { FORM } \\
\text { COMP }\end{array}$ & $\begin{array}{l}\text { FLOW } \\
\text { REL. }\end{array}$ & $\begin{array}{l}\text { UNITS OF } \\
\text { MEASURE }\end{array}$ & PVI & $\begin{array}{l}\text { ARAMETER } \\
\text { VALUE }\end{array}$ & $\begin{array}{l}\text { DETECTION } \\
\text { LIMIT }\end{array}$ & $\begin{array}{l}\text { PARAMETER } \\
\text { UNCERTAINTY }\end{array}$ \\
\hline LEAD & $\begin{array}{l}0688 \\
0688\end{array}$ & $\begin{array}{l}12 / 06 / 91 \\
10 / 07 / 92\end{array}$ & $\begin{array}{l}0001 \\
0001\end{array}$ & $\begin{array}{l}\text { NA } \\
\text { NA }\end{array}$ & $\begin{array}{l}u \\
u\end{array}$ & $M G / L$ & $<$ & $\begin{array}{l}0.005 \\
0.003\end{array}$ & $\begin{array}{l}0.005 \\
0.003\end{array}$ & - \\
\hline LEAD - 210 & $\begin{array}{l}0669 \\
0669 \\
0670 \\
0670 \\
0688 \\
0688\end{array}$ & \begin{tabular}{|l|}
$08 / 24 / 91$ \\
$11 / 19 / 91$ \\
$08 / 24 / 91$ \\
$12 / 05 / 91$ \\
$08 / 08 / 91$ \\
$12 / 05 / 91$
\end{tabular} & $\begin{array}{l}0001 \\
0001 \\
0001 \\
0001 \\
0001 \\
0001\end{array}$ & $\begin{array}{l}\text { MA } \\
\text { NA } \\
\text { NA } \\
\text { NA } \\
\text { NA } \\
\text { NA }\end{array}$ & $\begin{array}{l}u \\
U \\
u \\
u \\
u \\
u\end{array}$ & $\mathrm{PCI} / \mathrm{L}$ & & $\begin{array}{l}0.3 \\
0.3 \\
0.0 \\
0.0 \\
0.6 \\
1.3\end{array}$ & $\begin{array}{l}1.5 \\
1.5 \\
1.5 \\
1.5 \\
1.5 \\
1.5\end{array}$ & $\begin{array}{l}1.0 \\
0.9 \\
1.0 \\
0.9 \\
0.9 \\
0.9\end{array}$ \\
\hline MAGNESIUM & $\begin{array}{l}0669 \\
0669 \\
0669 \\
0669 \\
0669 \\
0669 \\
0669 \\
0669 \\
0670 \\
0670 \\
0670 \\
0670 \\
0670 \\
0670 \\
0688 \\
0688 \\
0688 \\
0688 \\
0688 \\
0688 \\
0688 \\
0688 \\
0688\end{array}$ & $\begin{array}{l}06 / 30 / 86 \\
10 / 14 / 87 \\
02 / 19 / 88 \\
12 / 15 / 90 \\
03 / 31 / 91 \\
08 / 24 / 91 \\
11 / 19 / 91 \\
10 / 12 / 92 \\
07 / 19 / 86 \\
10 / 15 / 87 \\
12 / 15 / 90 \\
04 / 01 / 91 \\
08 / 24 / 91 \\
10 / 14 / 92 \\
07 / 17 / 86 \\
04 / 08 / 87 \\
10 / 14 / 87 \\
02 / 19 / 88 \\
12 / 15 / 90 \\
03 / 28 / 91 \\
08 / 08 / 91 \\
12 / 06 / 91 \\
10 / 07 / 92\end{array}$ & $\begin{array}{l}0001 \\
0001 \\
0001 \\
0001 \\
0001 \\
0001 \\
0001 \\
0001 \\
0001 \\
0001 \\
0001 \\
0001 \\
0001 \\
0001 \\
0001 \\
0001 \\
0001 \\
0001 \\
0001 \\
0001 \\
0001 \\
0001 \\
0001\end{array}$ & $\begin{array}{l}\text { NA } \\
\text { NA } \\
\text { NA } \\
\text { NA } \\
\text { NA } \\
\text { NA } \\
\text { NA } \\
\text { NA } \\
\text { NA } \\
\text { NA } \\
\text { NA } \\
\text { NA } \\
\text { NA } \\
\text { NA } \\
\text { NA } \\
\text { NA } \\
\text { NA } \\
\text { NA } \\
\text { NA } \\
\text { NA } \\
\text { NA } \\
\text { NA } \\
\text { NA }\end{array}$ & $\begin{array}{l}U \\
U \\
U \\
U \\
U \\
U \\
U \\
U \\
U \\
U \\
U \\
U \\
U \\
U \\
U \\
U \\
U \\
U \\
U \\
U \\
U \\
U \\
U\end{array}$ & $M G / L$ & & $\begin{array}{l}22.3 \\
27 . \\
22.2 \\
16.7 \\
29.1 \\
29.7 \\
31.7 \\
27.6 \\
29.7 \\
36 . \\
36.3 \\
35.0 \\
36.6 \\
20.7 \\
38.6 \\
38.3 \\
41 . \\
39.5 \\
39.6 \\
38.6 \\
41.1 \\
35.0 \\
37.6\end{array}$ & $\begin{array}{l}0.001 \\
0.001 \\
0.001 \\
0.001 \\
0.1 \\
0.1 \\
0.1 \\
0.1 \\
0.001 \\
0.001 \\
0.001 \\
0.1 \\
0.1 \\
0.1 \\
0.001 \\
0.001 \\
0.001 \\
0.001 \\
0.001 \\
0.1 \\
0.1 \\
0.1 \\
0.1\end{array}$ & $\begin{array}{l}- \\
- \\
- \\
- \\
- \\
- \\
- \\
- \\
- \\
- \\
- \\
- \\
- \\
- \\
- \\
- \\
-\end{array}$ \\
\hline MANGANESE & $\begin{array}{l}0669 \\
0669 \\
0669 \\
0669 \\
0669 \\
0669 \\
0669\end{array}$ & $\begin{array}{l}06 / 30 / 86 \\
10 / 14 / 87 \\
02 / 19 / 88 \\
12 / 15 / 90 \\
03 / 31 / 91 \\
08 / 24 / 91 \\
11 / 19 / 91\end{array}$ & $\begin{array}{l}0001 \\
0001 \\
0001 \\
0001 \\
0001 \\
0001 \\
0001\end{array}$ & $\begin{array}{l}\text { NA } \\
\text { NA } \\
\text { NA } \\
\text { NA } \\
\text { NA } \\
\text { NA } \\
\text { NA }\end{array}$ & $\begin{array}{l}U \\
U \\
U \\
U \\
U \\
U \\
U\end{array}$ & $M G / L$ & & $\begin{array}{l}0.13 \\
0.06 \\
0.07 \\
0.02 \\
0.03 \\
0.02 \\
0.04\end{array}$ & $\begin{array}{l}0.01 \\
0.01 \\
0.01 \\
0.01 \\
0.01 \\
0.01 \\
0.01\end{array}$ & $\begin{array}{l}- \\
- \\
- \\
-\end{array}$ \\
\hline
\end{tabular}

FORMATION OF COMPLETION COOE:

MA - mavajo SAMDSTOME
FLOW RELATIONSHIP COOE:

PARAMETER VALUE INDICATOR (PVI): < - LESS THAN DETECTION LIMIT

SAMPLE ID COOES:

0001 - FILTERED SAMPLE (.45 MICRONS) 
TABLE 3.37 BASELINE GROUNOHATER QULAITY DATA BY PARAMETER FOR THE MAVAJO SAMDSTOME, UC PROCESSIMG SITE, SLICK ROCK, COLORADO

SITE: SRKOI SLICK ROCK (BOTH SITES)

$06 / 30 / 86$ TO $10 / 14 / 92$

REPORT DATE: $07 / 26 / 93$

\begin{tabular}{|c|c|c|c|c|c|c|c|c|c|c|c|}
\hline & PARAMETER MAME & $\begin{array}{c}\text { LOCATION } \\
\text { ID }\end{array}$ & LOG DATE & $\begin{array}{c}\text { SAMPLE } \\
\text { ID }\end{array}$ & $\begin{array}{l}\text { FORM } \\
\text { COMPP }\end{array}$ & $\begin{array}{l}\text { FLOW } \\
\text { REL. }\end{array}$ & $\begin{array}{l}\text { UNITS OF } \\
\text { MEASURE }\end{array}$ & PVI & $\begin{array}{l}\text { ARAMETER } \\
\text { VALUE }\end{array}$ & $\begin{array}{l}\text { DETECTION } \\
\text { LIMIT }\end{array}$ & $\begin{array}{l}\text { PARAMETER } \\
\text { UNCERTAINTY }\end{array}$ \\
\hline & MANGANESE & $\begin{array}{l}0669 \\
0670 \\
0670 \\
0670 \\
0670 \\
0670 \\
0670 \\
0688 \\
0688 \\
0688 \\
0688 \\
0688 \\
0688 \\
0688 \\
0688 \\
0688\end{array}$ & $\begin{array}{l}10 / 12 / 92 \\
07 / 19 / 86 \\
10 / 15 / 87 \\
12 / 15 / 90 \\
04 / 01 / 91 \\
08 / 24 / 91 \\
10 / 14 / 92 \\
07 / 17 / 86 \\
04 / 08 / 87 \\
10 / 14 / 87 \\
02 / 19 / 88 \\
12 / 15 / 90 \\
03 / 28 / 91 \\
08 / 08 / 91 \\
12 / 06 / 91 \\
10 / 07 / 92\end{array}$ & $\begin{array}{l}0001 \\
0001 \\
0001 \\
0001 \\
0001 \\
0001 \\
0001 \\
0001 \\
0001 \\
0001 \\
0001 \\
0001 \\
0001 \\
0001 \\
0001 \\
0001\end{array}$ & $\begin{array}{l}\text { NA } \\
\text { NA } \\
\text { NA } \\
\text { NA } \\
\text { NA } \\
\text { NA } \\
\text { NA } \\
\text { NA } \\
\text { NA } \\
\text { NA } \\
\text { NA } \\
\text { NA } \\
\text { NA } \\
\text { NA } \\
\text { NA } \\
\text { NA }\end{array}$ & $\begin{array}{l}u \\
U \\
U \\
U \\
U \\
U \\
U \\
U \\
U \\
U \\
U \\
U \\
U \\
U \\
U \\
U\end{array}$ & $M G / L$ & $\begin{array}{l} \\
\\
< \\
< \\
< \\
< \\
< \\
< \\
< \\
< \\
<\end{array}$ & $\begin{array}{l}0.03 \\
0.12 \\
0.18 \\
0.11 \\
0.08 \\
0.07 \\
0.01 \\
0.01 \\
0.01 \\
0.01 \\
0.01 \\
0.01 \\
0.01 \\
0.01 \\
0.01 \\
0.01\end{array}$ & $\begin{array}{l}0.01 \\
0.01 \\
0.01 \\
0.01 \\
0.01 \\
0.01 \\
0.01 \\
0.01 \\
0.01 \\
0.01 \\
0.01 \\
0.01 \\
0.01 \\
0.01 \\
0.01 \\
0.01\end{array}$ & $\begin{array}{l}- \\
- \\
- \\
- \\
- \\
- \\
- \\
- \\
- \\
- \\
- \\
-\end{array}$ \\
\hline$\stackrel{\omega}{\vec{\omega}}$ & MERCURY & $\begin{array}{l}0669 \\
0669 \\
0669 \\
0669 \\
0669 \\
0670 \\
0670 \\
0670 \\
0670 \\
0688 \\
0688 \\
0688 \\
0688 \\
0688 \\
0688\end{array}$ & $\begin{array}{l}10 / 14 / 87 \\
12 / 15 / 90 \\
03 / 31 / 91 \\
08 / 24 / 91 \\
11 / 19 / 91 \\
10 / 15 / 87 \\
12 / 15 / 90 \\
04 / 01 / 91 \\
08 / 24 / 91 \\
04 / 08 / 87 \\
10 / 14 / 87 \\
12 / 15 / 90 \\
03 / 28 / 91 \\
08 / 08 / 91 \\
12 / 06 / 91\end{array}$ & $\begin{array}{l}0001 \\
0001 \\
0001 \\
0001 \\
0001 \\
0001 \\
0001 \\
0001 \\
0001 \\
0001 \\
0001 \\
0001 \\
0001 \\
0001 \\
0001\end{array}$ & $\begin{array}{l}\text { NA } \\
\text { NA } \\
\text { NA } \\
\text { NA } \\
\text { NA } \\
\text { NA } \\
\text { NA } \\
\text { NA } \\
\text { NA } \\
\text { NA } \\
\text { NA } \\
\text { NA } \\
\text { NA } \\
\text { NA } \\
\text { NA }\end{array}$ & $\begin{array}{l}u \\
U \\
U \\
u \\
u \\
U \\
u \\
U \\
U \\
U \\
U \\
U \\
U \\
U \\
U\end{array}$ & $M G / L$ & $\begin{array}{l}< \\
< \\
< \\
< \\
< \\
< \\
< \\
< \\
< \\
< \\
< \\
< \\
< \\
< \\
<\end{array}$ & $\begin{array}{l}0.0002 \\
0.0002 \\
0.0002 \\
0.0002 \\
0.0002 \\
0.0002 \\
0.0002 \\
0.0002 \\
0.0002 \\
0.0002 \\
0.0002 \\
0.0002 \\
0.0002 \\
0.0002 \\
0.0002\end{array}$ & $\begin{array}{l}0.0002 \\
0.0002 \\
0.0002 \\
0.0002 \\
0.0002 \\
0.0002 \\
0.0002 \\
0.0002 \\
0.0002 \\
0.0002 \\
0.0002 \\
0.0002 \\
0.0002 \\
0.0002 \\
0.0002\end{array}$ & $\begin{array}{l}- \\
- \\
- \\
- \\
- \\
- \\
- \\
- \\
- \\
- \\
-\end{array}$ \\
\hline & MOL YBDENUM & $\begin{array}{l}0669 \\
0669 \\
0669 \\
0669 \\
0669 \\
0669 \\
0669 \\
0669\end{array}$ & $\begin{array}{l}06 / 30 / 86 \\
1 n / 14 / 87 \\
02 / 19 / 88 \\
12 / 15 / 90 \\
03 / 31 / 91 \\
08 / 24 / 91 \\
11 / 19 / 91 \\
10 / 12 / 92\end{array}$ & $\begin{array}{l}0001 \\
0001 \\
0001 \\
0001 \\
0001 \\
0001 \\
0001 \\
0001\end{array}$ & $\begin{array}{l}\text { MA } \\
\text { NA } \\
\text { NA } \\
\text { NA } \\
\text { NA } \\
\text { NA } \\
\text { NA } \\
\text { NA }\end{array}$ & $\begin{array}{l}u \\
u \\
u \\
u \\
u \\
u \\
U \\
U\end{array}$ & $M G / L$ & $\begin{array}{l}< \\
< \\
< \\
<\end{array}$ & $\begin{array}{l}0.17 \\
0.01 \\
0.02 \\
0.01 \\
0.01 \\
0.01 \\
0.01 \\
0.01\end{array}$ & $\begin{array}{l}0.01 \\
0.01 \\
0.01 \\
0.01 \\
0.01 \\
0.01 \\
0.01 \\
0.01\end{array}$ & $\begin{array}{l}- \\
- \\
- \\
-\end{array}$ \\
\hline
\end{tabular}

FORMATION OF COMPLETION CODE:

FLON RELATIONSHIP CODE:

NA - NAVAJO SANDSTONE

U - UPGRADIENT

PARAMETER VALUE INDICATOR (PVI): < - LESS THAN DETECTION LIMIT SAMPLE ID CODES:

0001 - FILTERED SAMPLE (.45 MICRONS) 
TABLE 3.37 BASELINE GROUNDWATER OULAITY DATA BY PARAMETER FOR THE

NAVAJO SANDSTONE, UC PROCESSING SITE, SLICK ROCK, COLORADO

SITE: SRKO1 SLICK ROCK (BOTH SITES)

06/30/86 TO 10/14/92

REPORT DATE: $07 / 26 / 93$

\begin{tabular}{|c|c|c|c|c|c|c|c|c|c|c|c|}
\hline PARAMETER NAME & $\underset{\text { ID }}{\text { LOCATION }}$ & LOG DATE & $\begin{array}{c}\text { SAMPLE } \\
\text { ID }\end{array}$ & $\begin{array}{l}\text { FORM } \\
\text { COMP }\end{array}$ & $\begin{array}{l}\text { FLOW } \\
\text { REL. }\end{array}$ & $\begin{array}{l}\text { UNITS OF } \\
\text { MEASURE }\end{array}$ & PVI & $\begin{array}{l}\text { PARAMETER } \\
\text { VALUE }\end{array}$ & FLAGS & $\begin{array}{l}\text { DETECTION } \\
\text { LIMIT }\end{array}$ & $\begin{array}{l}\text { PARAMETER } \\
\text { UNCERTAINTY }\end{array}$ \\
\hline MOL YBDENUM & $\begin{array}{l}0670 \\
0670 \\
0670 \\
0670 \\
0670 \\
0670 \\
0688 \\
0688 \\
0688 \\
0688 \\
0688 \\
0688 \\
0688 \\
0688 \\
0688\end{array}$ & \begin{tabular}{|l|}
$07 / 19 / 86$ \\
$10 / 15 / 87$ \\
$12 / 15 / 90$ \\
$04 / 01 / 91$ \\
$08 / 24 / 91$ \\
$10 / 14 / 92$ \\
$07 / 17 / 86$ \\
$04 / 08 / 87$ \\
$10 / 14 / 87$ \\
$02 / 19 / 88$ \\
$12 / 15 / 90$ \\
$03 / 28 / 91$ \\
$08 / 08 / 91$ \\
$12 / 06 / 91$ \\
$10 / 07 / 92$
\end{tabular} & $\begin{array}{l}0001 \\
0001 \\
0001 \\
0001 \\
0001 \\
0001 \\
0001 \\
0001 \\
0001 \\
0001 \\
0001 \\
0001 \\
0001 \\
0001 \\
0001\end{array}$ & $\begin{array}{l}\text { NA } \\
\text { NA } \\
\text { NA } \\
\text { NA } \\
\text { NA } \\
\text { NA } \\
\text { NA } \\
\text { NA } \\
\text { NA } \\
\text { NA } \\
\text { NA } \\
\text { NA } \\
\text { NA } \\
\text { NA } \\
\text { NA }\end{array}$ & $\begin{array}{l}u \\
U \\
U \\
U \\
U \\
U \\
U \\
U \\
U \\
U \\
U \\
U \\
U \\
U \\
U\end{array}$ & $M G / L$ & $\begin{array}{l}< \\
< \\
< \\
< \\
< \\
< \\
< \\
< \\
< \\
<\end{array}$ & $\begin{array}{l}0.14 \\
0.01 \\
0.02 \\
0.01 \\
0.01 \\
0.01 \\
0.15 \\
0.1 \\
0.01 \\
0.03 \\
0.02 \\
0.01 \\
0.01 \\
0.01 \\
0.01\end{array}$ & c & $\begin{array}{l}0.01 \\
0.01 \\
0.01 \\
0.01 \\
0.01 \\
0.01 \\
0.01 \\
0.1 \\
0.01 \\
0.01 \\
0.01 \\
0.01 \\
0.01 \\
0.01 \\
0.01\end{array}$ & $\begin{array}{l}- \\
- \\
- \\
- \\
- \\
- \\
- \\
- \\
- \\
- \\
-\end{array}$ \\
\hline NET GROSS ALPHA * & $\begin{array}{l}0669 \\
0669 \\
0669 \\
0669 \\
0669 \\
0670 \\
0670 \\
0670 \\
0670 \\
0670 \\
0688 \\
0688 \\
0688 \\
0688 \\
0688\end{array}$ & $\begin{array}{l}12 / 15 / 90 \\
03 / 31 / 91 \\
08 / 24 / 91 \\
11 / 19 / 91 \\
10 / 12 / 92 \\
12 / 15 / 90 \\
04 / 01 / 91 \\
08 / 24 / 91 \\
12 / 05 / 91 \\
10 / 14 / 92 \\
12 / 15 / 90 \\
03 / 28 / 91 \\
08 / 08 / 91 \\
12 / 05 / 91 \\
10 / 07 / 92\end{array}$ & $\begin{array}{l}0001 \\
0001 \\
0001 \\
0001 \\
0001 \\
0001 \\
0001 \\
0001 \\
0001 \\
0001 \\
0001 \\
0001 \\
0001 \\
0001 \\
0001\end{array}$ & $\begin{array}{l}\text { NA } \\
\text { NA } \\
\text { NA } \\
\text { NA } \\
\text { NA } \\
\text { NA } \\
\text { NA } \\
\text { NA } \\
\text { NA } \\
\text { NA } \\
\text { NA } \\
\text { NA } \\
\text { NA } \\
\text { NA } \\
\text { NA }\end{array}$ & $\begin{array}{l}u \\
u \\
u \\
u \\
u \\
u \\
u \\
u \\
u \\
u \\
u \\
u \\
u \\
u \\
u\end{array}$ & $\mathrm{PCI} / \mathrm{L}$ & & $\begin{array}{r}4.00 \\
1.96 \\
7.36 \\
424.66 \\
-1.37 \\
2.12 \\
5.16 \\
5.16 \\
-1.37 \\
0.96 \\
-4.37 \\
-0.92 \\
6.63 \\
-4.80 \\
-1.75\end{array}$ & & $\begin{array}{l}- \\
- \\
- \\
- \\
- \\
- \\
- \\
- \\
- \\
-\end{array}$ & $\begin{array}{l}- \\
- \\
- \\
- \\
- \\
- \\
- \\
- \\
- \\
- \\
-\end{array}$ \\
\hline NICKEL & $\begin{array}{l}0669 \\
0669 \\
0669 \\
0669 \\
0669 \\
0669\end{array}$ & \begin{tabular}{|l|}
$10 / 14 / 87$ \\
$02 / 19 / 88$ \\
$12 / 15 / 90$ \\
$03 / 31 / 91$ \\
$08 / 24 / 91$ \\
$11 / 19 / 91$
\end{tabular} & $\begin{array}{l}0001 \\
0001 \\
0001 \\
0001 \\
0001 \\
0001\end{array}$ & $\begin{array}{l}\text { NA } \\
\text { NA } \\
\text { NA } \\
\text { NA } \\
\text { NA } \\
\text { NA }\end{array}$ & $\begin{array}{l}U \\
U \\
U \\
U \\
U \\
U\end{array}$ & $M G / L$ & $\begin{array}{l}< \\
< \\
< \\
< \\
< \\
<\end{array}$ & $\begin{array}{l}0.04 \\
0.01 \\
0.05 \\
0.04 \\
0.04 \\
0.04\end{array}$ & c & $\begin{array}{l}0.04 \\
0.04 \\
0.05 \\
0.04 \\
0.04 \\
0.04\end{array}$ & $\begin{array}{l}- \\
- \\
- \\
-\end{array}$ \\
\hline
\end{tabular}

* net gross alPha (GROSS alPha - URANIUM) WITH 1 Mg URANIUM = 686 PCI

FORMATION OF COMPLETION COOE:

NA - MAVAJO SANDSTONE

PARAMETER VALUE INDICATOR (PVI): < - LESS THAN DETECTION LIMIT
FLON RELATIONSHIP CODE:

U - UPGRADIENT

SAMPLE ID CODES:

0001 - FILTERED SAMPLE (.45 MICRONS)

OTHER PARAMETER VALUE FLAGS:

C - CHANGED DETECTION LIMIT 
TABLE 3.37 BASELINE GROUNDWATER QULAITY DATA BY PARAMETER FOR THE

NAVAJO SANDSTONE, UC PROCESSING SITE, SLICK ROCK, COLORADO

SITE: SRKOI SLICK ROCK (BOTH SITES)

06/30/86 TO $10 / 14 / 92$

REPORT DATE: 07/26/93

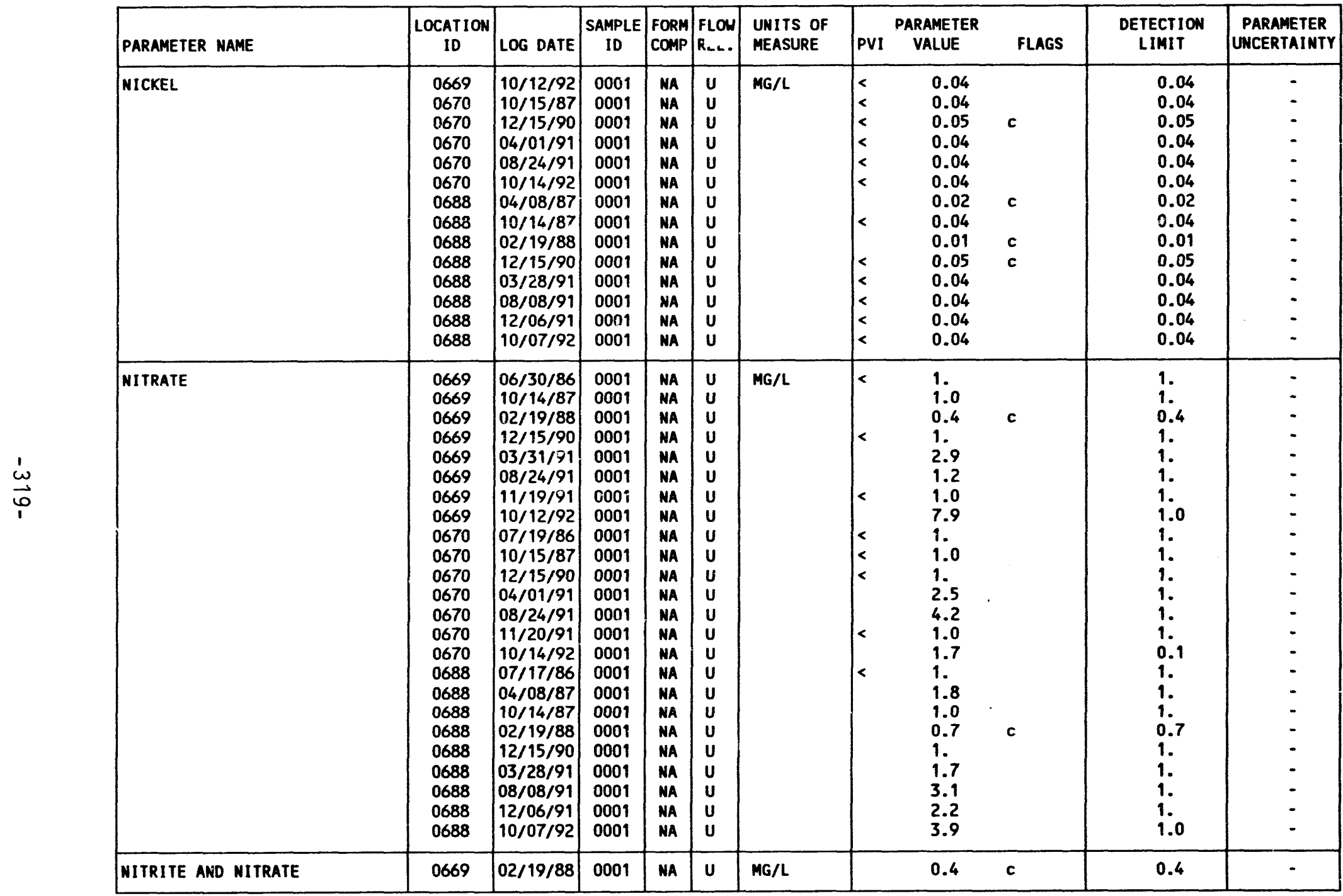

FORMATION OF COMPLETION CODE:

NA - NAVAJO SAMDSTONE

PARAMETER VALUE INDICATOR (PVI): < - LESS THAN DETECTION LIMIT
FLOW RELATIONSHIP COOE:

U - UPGRADIENT

OTHER PARAMETER VALUE FLAGS:

SAPLE ID CODES:

0001 - FILTERED SAMPLE (.45 MICROWS)

C - CHAMGED DETECTION LIMIT 
TABLE 3.37 BASELINE GROUNDWATER QULAITY DATA BY PARAMETER FOR THE

MAVAJO SANDSTONE, UC PROCESSIMG SITE, SLICK ROCK, COLORADO

SITE: SRKO1 SLICK ROCK (BOTH SITES)

06/30/86 TO $10 / 14 / 92$

REPORT DATE: 07/26/93

\begin{tabular}{|c|c|c|c|c|c|c|c|c|c|c|c|}
\hline PARAMETER MAME & $\begin{array}{c}\text { LOCATION } \\
\text { ID }\end{array}$ & LOG DATE & $\underset{\text { ID }}{\text { SAMPLE }}$ & $\begin{array}{l}\text { FORM } \\
\text { COMP }\end{array}$ & $\begin{array}{l}\text { FLOW } \\
\text { REL. }\end{array}$ & $\begin{array}{l}\text { UNITS OF } \\
\text { MEASURE }\end{array}$ & PVI & $\begin{array}{l}\text { PARAMETER } \\
\text { VALUE }\end{array}$ & FLAGS & $\begin{array}{l}\text { DETECTION } \\
\text { LIMIT }\end{array}$ & $\begin{array}{l}\text { PARAMETER } \\
\text { UNCERTAINTY }\end{array}$ \\
\hline NITRITE AND NITRATE & $\begin{array}{l}0669 \\
0669 \\
0669 \\
0670 \\
0670 \\
0670 \\
0688 \\
0688 \\
0688 \\
0688\end{array}$ & $\begin{array}{l}12 / 15 / 90 \\
03 / 31 / 91 \\
08 / 24 / 91 \\
12 / 15 / 90 \\
04 / 01 / 91 \\
08 / 24 / 91 \\
02 / 19 / 88 \\
12 / 15 / 90 \\
03 / 28 / 91 \\
08 / 08 / 91\end{array}$ & $\begin{array}{l}0001 \\
0001 \\
0001 \\
0001 \\
0001 \\
0001 \\
0001 \\
0001 \\
0001 \\
000 !\end{array}$ & $\begin{array}{l}\text { NA } \\
\text { NA } \\
\text { NA } \\
\text { NA } \\
\text { NA } \\
\text { NA } \\
\text { NA } \\
\text { NA } \\
\text { NA } \\
\text { NA }\end{array}$ & $\begin{array}{l}U \\
U \\
U \\
U \\
U \\
U \\
U \\
U \\
U \\
U\end{array}$ & $M G / L$ & $\mid \begin{array}{l}< \\
<\end{array}$ & $\begin{array}{l}1 . \\
0.68 \\
0.27 \\
1 . \\
0.58 \\
0.97 \\
0.7 \\
1 . \\
0.38 \\
0.73\end{array}$ & c & $\begin{array}{l}1 . \\
0.05 \\
0.05 \\
1 . \\
0.05 \\
0.05 \\
0.7 \\
1 . \\
0.05 \\
0.05\end{array}$ & $\begin{array}{l}- \\
- \\
- \\
- \\
- \\
- \\
- \\
-\end{array}$ \\
\hline PH & $\begin{array}{l}0669 \\
0669 \\
0669 \\
0669 \\
0669 \\
0669 \\
0669 \\
0669 \\
0670 \\
0670 \\
0670 \\
0670 \\
0670 \\
0670 \\
0670 \\
0670 \\
0688 \\
0688 \\
0688 \\
0688 \\
0688 \\
0688 \\
0688 \\
0688 \\
0688\end{array}$ & $\begin{array}{l}06 / 30 / 86 \\
10 / 14 / 87 \\
02 / 19 / 88 \\
12 / 15 / 90 \\
03 / 31 / 91 \\
08 / 24 / 91 \\
11 / 19 / 91 \\
10 / 12 / 92 \\
07 / 19 / 86 \\
10 / 15 / 87 \\
02 / 19 / 88 \\
12 / 15 / 90 \\
04 / 01 / 91 \\
08 / 24 / 91 \\
12 / 05 / 91 \\
10 / 14 / 92 \\
07 / 17 / 86 \\
04 / 08 / 87 \\
10 / 14 / 87 \\
02 / 19 / 88 \\
12 / 15 / 90 \\
03 / 28 / 91 \\
08 / 08 / 91 \\
12 / 05 / 91 \\
10 / 07 / 92\end{array}$ & $\begin{array}{l}0001 \\
0001 \\
0001 \\
0001 \\
0001 \\
0001 \\
0001 \\
0001 \\
0001 \\
0001 \\
0001 \\
0001 \\
0001 \\
0001 \\
0001 \\
0001 \\
0001 \\
0001 \\
0001 \\
0001 \\
0001 \\
0001 \\
0001 \\
0001 \\
0001\end{array}$ & $\begin{array}{l}\text { NA } \\
\text { NA } \\
\text { NA } \\
\text { NA } \\
\text { NA } \\
\text { NA } \\
\text { NA } \\
\text { NA } \\
\text { NA } \\
\text { NA } \\
\text { NA } \\
\text { NA } \\
\text { NA } \\
\text { NA } \\
\text { NA } \\
\text { NA } \\
\text { NA } \\
\text { NA } \\
\text { NA } \\
\text { NA } \\
\text { NA } \\
\text { NA } \\
\text { NA } \\
\text { NA } \\
\text { NA }\end{array}$ & $\begin{array}{l}U \\
U \\
U \\
U \\
U \\
U \\
U \\
U \\
U \\
U \\
U \\
U \\
U \\
U \\
U \\
U \\
U \\
U \\
U \\
U \\
U \\
U \\
U \\
U \\
U\end{array}$ & SU & & $\begin{array}{l}8.85 \\
7.80 \\
8.24 \\
8.62 \\
7.68 \\
7.52 \\
7.92 \\
7.86 \\
7.32 \\
7.13 \\
8.19 \\
7.57 \\
7.44 \\
7.41 \\
7.93 \\
8.89 \\
7.1 \\
7.01 \\
6.98 \\
7.20 \\
7.32 \\
7.27 \\
7.37 \\
7.24 \\
7.29\end{array}$ & & $\begin{array}{l}- \\
- \\
- \\
- \\
- \\
- \\
- \\
- \\
- \\
- \\
- \\
- \\
- \\
- \\
- \\
- \\
- \\
- \\
-\end{array}$ & $\begin{array}{l}- \\
- \\
- \\
- \\
- \\
- \\
- \\
- \\
- \\
- \\
- \\
- \\
- \\
- \\
- \\
- \\
- \\
- \\
-\end{array}$ \\
\hline PHOSPHATE & $\begin{array}{l}0669 \\
0669 \\
0669\end{array}$ & $\begin{array}{l}10 / 14 / 87 \\
12 / 15 / 90 \\
03 / 31 / 91\end{array}$ & $\begin{array}{l}0001 \\
0001 \\
0001\end{array}$ & $\begin{array}{l}\text { NA } \\
\text { MA } \\
\text { MA }\end{array}$ & $\begin{array}{l}\mathbf{U} \\
\mathbf{U} \\
\mathbf{U}\end{array}$ & $M G / L$ & $<$ & $\begin{array}{l}0.1 \\
0.1 \\
0.1\end{array}$ & & $\begin{array}{l}0.1 \\
0.1 \\
0.1\end{array}$ & - \\
\hline
\end{tabular}

FORMATION OF COMPLETION COOE:

FLON RELATIONSHIP COOE

MA - NAVAJO SANDSTONE

U - UPGRADIENT

PARAMETER VALUE INDICATOR (PVI): < - LESS THAN DETECTION LIMIT

0001 - FILTERED SAMPLE (.45 MICRONS)

OTHER PARAMETER VALUE FLAGS:

c - CHANGED DETECTION LIMIT 
TABLE 3.37 BASELINE GROUNDHATER QULAITY DATA BY PARAMETER FOR THE NAVAJO SANDSTONE, UC PROCESSING SITE, SLICK ROCK, COLORADO

SITE: SRK01 SLICK ROCK (BOTH SITES)

06/30/86 TO 10/14/92

REPORT DATE: $07 / 26 / 93$

\begin{tabular}{|c|c|c|c|c|c|c|c|c|c|c|c|c|}
\hline & PARAMETER NAME & $\underset{\text { LOCATION }}{\text { LO }}$ & LOG DATE & $\begin{array}{c}\text { SAMPLE } \\
10\end{array}$ & $\begin{array}{l}\text { FORM } \\
\text { COMP }\end{array}$ & $\begin{array}{l}\text { FLOW } \\
\text { REL. }\end{array}$ & $\begin{array}{l}\text { UNI TS OF } \\
\text { MEASURE }\end{array}$ & PVI & $\begin{array}{l}\text { PARAMETER } \\
\text { VALUE }\end{array}$ & FLAGS & $\begin{array}{l}\text { DETECTION } \\
\text { LIMIT }\end{array}$ & $\begin{array}{l}\text { PARAMETER } \\
\text { UNCERTAINTY }\end{array}$ \\
\hline & PHOSPHATE & $\begin{array}{l}0669 \\
0669 \\
0669 \\
0670 \\
0670 \\
0670 \\
0670 \\
0670 \\
0670 \\
0688 \\
0688 \\
0688 \\
0688 \\
0688 \\
0688 \\
0688\end{array}$ & \begin{tabular}{|l|}
$08 / 24 / 91$ \\
$11 / 19 / 91$ \\
$10 / 12 / 92$ \\
$10 / 15 / 87$ \\
$12 / 15 / 90$ \\
$04 / 01 / 91$ \\
$08 / 24 / 91$ \\
$11 / 20 / 91$ \\
$10 / 14 / 92$ \\
$04 / 08 / 87$ \\
$10 / 14 / 87$ \\
$12 / 15 / 90$ \\
$03 / 28 / 91$ \\
$08 / 08 / 91$ \\
$12 / 06 / 91$ \\
$10 / 07 / 92$
\end{tabular} & $\begin{array}{l}0001 \\
0001 \\
0001 \\
0001 \\
0001 \\
0001 \\
0001 \\
0001 \\
0001 \\
0001 \\
0001 \\
0001 \\
0001 \\
0001 \\
0001 \\
0001\end{array}$ & $\begin{array}{l}\text { NA } \\
\text { NA } \\
\text { NA } \\
\text { NA } \\
\text { NA } \\
\text { NA } \\
\text { NA } \\
\text { NA } \\
\text { NA } \\
\text { NA } \\
\text { NA } \\
\text { NA } \\
\text { NA } \\
\text { NA } \\
\text { NA } \\
\text { NA }\end{array}$ & $\begin{array}{l}U \\
U \\
U \\
U \\
U \\
U \\
U \\
U \\
U \\
U \\
U \\
U \\
U \\
U \\
U \\
U\end{array}$ & $M G / L$ & $\mid \begin{array}{l}< \\
< \\
< \\
< \\
< \\
< \\
< \\
< \\
< \\
< \\
< \\
< \\
< \\
<\end{array}$ & $\begin{array}{l}0.1 \\
0.2 \\
0.2 \\
0.1 \\
0.1 \\
0.1 \\
0.1 \\
0.1 \\
0.1 \\
0.1 \\
0.1 \\
0.1 \\
0.1 \\
0.1 \\
0.01 \\
0.1\end{array}$ & $\begin{array}{l}J \\
J\end{array}$ & $\begin{array}{l}0.1 \\
0.1 \\
0.1 \\
0.1 \\
0.1 \\
0.1 \\
0.1 \\
0.1 \\
0.1 \\
0.1 \\
0.1 \\
0.1 \\
0.1 \\
0.1 \\
0.01 \\
0.1\end{array}$ & $\begin{array}{l}- \\
- \\
- \\
- \\
- \\
- \\
- \\
- \\
- \\
- \\
- \\
-\end{array}$ \\
\hline & POLONIUM-210 & $\begin{array}{l}0669 \\
0669 \\
0670 \\
0670 \\
0688 \\
0688\end{array}$ & $\begin{array}{l}08 / 24 / 91 \\
11 / 19 / 91 \\
08 / 24 / 91 \\
12 / 05 / 91 \\
08 / 08 / 91 \\
12 / 05 / 91\end{array}$ & $\begin{array}{l}0001 \\
0001 \\
0001 \\
0001 \\
0001 \\
0001\end{array}$ & $\begin{array}{l}\text { NA } \\
\text { NA } \\
\text { NA } \\
\text { NA } \\
\text { NA } \\
\text { NA }\end{array}$ & $\begin{array}{l}U \\
U \\
U \\
U \\
U \\
U\end{array}$ & $\mathrm{PCI} / \mathrm{L}$ & & $\begin{array}{l}0.1 \\
0.2 \\
0.2 \\
0.0 \\
0.4 \\
0.2\end{array}$ & & $\begin{array}{l}1 . \\
1 . \\
1 . \\
1 . \\
1 . \\
1 .\end{array}$ & $\begin{array}{l}0.5 \\
0.8 \\
0.5 \\
0.3 \\
0.4 \\
0.8\end{array}$ \\
\hline & POTASSIUM & $\begin{array}{l}0669 \\
0669 \\
0669 \\
0669 \\
0669 \\
0669 \\
0669 \\
0669 \\
0670 \\
0670 \\
0670 \\
0670 \\
0670 \\
0670 \\
0688 \\
0688\end{array}$ & $\begin{array}{l}06 / 30 / 86 \\
10 / 14 / 87 \\
02 / 19 / 88 \\
12 / 15 / 90 \\
03 / 31 / 91 \\
08 / 24 / 91 \\
11 / 19 / 91 \\
10 / 12 / 92 \\
07 / 19 / 86 \\
10 / 15 / 87 \\
12 / 15 / 90 \\
04 / 01 / 91 \\
08 / 24 / 91 \\
10 / 14 / 92 \\
07 / 17 / 86 \\
04 / 08 / 87\end{array}$ & $\begin{array}{l}0001 \\
0001 \\
0001 \\
0001 \\
0001 \\
0001 \\
0001 \\
0001 \\
0001 \\
0001 \\
0001 \\
0001 \\
0001 \\
0001 \\
0001 \\
0001\end{array}$ & $\begin{array}{l}\text { NA } \\
\text { NA } \\
\text { NA } \\
\text { NA } \\
\text { NA } \\
\text { NA } \\
\text { NA } \\
\text { NA } \\
\text { NA } \\
\text { NA } \\
\text { NA } \\
\text { NA } \\
\text { NA } \\
\text { NA } \\
\text { NA } \\
\text { NA }\end{array}$ & $\begin{array}{l}U \\
U \\
U \\
U \\
U \\
U \\
U \\
U \\
U \\
U \\
U \\
U \\
U \\
U \\
U \\
U\end{array}$ & $M G / L$ & & $\begin{array}{l}16.3 \\
13.8 \\
14.0 \\
11.2 \\
14 . \\
16 . \\
13 . \\
12 . \\
14.2 \\
21 . \\
13.5 \\
14 . \\
23 . \\
47 . \\
5.65 \\
4.61\end{array}$ & & $\begin{array}{l}0.01 \\
0.01 \\
0.01 \\
0.01 \\
5 . \\
5 . \\
5 . \\
5 . \\
0.01 \\
0.01 \\
0.01 \\
5 . \\
5 . \\
5 . \\
0.01 \\
0.01\end{array}$ & $\begin{array}{l}- \\
: \\
: \\
: \\
- \\
: \\
- \\
- \\
: \\
-\end{array}$ \\
\hline
\end{tabular}

FORMATION OF COMPLETION CODE:

MA - NAVAJO SANDSTONE

PARAMETER VALUE IMDICATOR (PVI): < - LESS than DETECTION LIMIT
FLOW RELATIONSHIP CODE:

U- UPGRADIENT

0001 - FILTERED SAMPLE (.45 MICRONS)

OTHER PARAMETER VALUE FLAGS:

$J$ - ESTIMATED VALUE 
TABLE 3.37 BASELIME GROUNDUATER QULAITY DATA BY PARAMETER FOR THE NAVAJO SANDSTONE, UC PROCESSING SITE, SLICK ROCK, COLORADO SITE: SRKO1 SLICK ROCK (BOTH SITES)

SITE: SRKO1 SLICK ROCK

REPORT DATE: $07 / 26 / 93$

\begin{tabular}{|c|c|c|c|c|c|c|c|c|c|c|c|}
\hline PARAMETER NAME & $\begin{array}{c}\text { LOCATION } \\
\text { ID }\end{array}$ & LOG DATE & $\begin{array}{c}\text { SAMPLE } \\
\text { ID }\end{array}$ & $\begin{array}{l}\text { FORM } \\
\text { COMP }\end{array}$ & $\begin{array}{l}\text { FLOW } \\
\text { REL. }\end{array}$ & $\begin{array}{l}\text { UNITS OF } \\
\text { MEASURE }\end{array}$ & PVI & $\begin{array}{c}\text { PARAMETER } \\
\text { VALUE }\end{array}$ & FLAGS & $\begin{array}{l}\text { DETECTION } \\
\text { LIMIT }\end{array}$ & $\begin{array}{l}\text { PARAMETER } \\
\text { UNCERTAINTY }\end{array}$ \\
\hline POTASSIUM & $\begin{array}{l}0688 \\
0688 \\
0688 \\
0688 \\
0688 \\
0688 \\
0688\end{array}$ & $\begin{array}{l}10 / 14 / 87 \\
02 / 19 / 88 \\
12 / 15 / 90 \\
03 / 28 / 91 \\
08 / 08 / 91 \\
12 / 06 / 91 \\
10 / 07 / 92\end{array}$ & $\begin{array}{l}0001 \\
0001 \\
0001 \\
0001 \\
0001 \\
0001 \\
0001\end{array}$ & $\begin{array}{l}\text { NA } \\
\text { NA } \\
\text { NA } \\
\text { NA } \\
\text { NA } \\
\text { NA } \\
\text { NA }\end{array}$ & $\begin{array}{l}u \\
u \\
u \\
u \\
u \\
u \\
u\end{array}$ & $M G / L$ & & $\begin{array}{l}4.7 \\
4.98 \\
5.9 \\
5.3 \\
5.1 \\
5.20 \\
5.35\end{array}$ & & $\begin{array}{l}0.01 \\
0.01 \\
0.01 \\
0.01 \\
0.01 \\
0.01 \\
0.01\end{array}$ & $\begin{array}{l}: \\
: \\
:\end{array}$ \\
\hline RADIUM-226 & $\begin{array}{l}0669 \\
0669 \\
0669 \\
0669 \\
0669 \\
0669 \\
0669 \\
0670 \\
0670 \\
0670 \\
0670 \\
0670 \\
0670 \\
0688 \\
0688 \\
0688 \\
0688 \\
0688 \\
0688 \\
0688\end{array}$ & $\begin{array}{l}10 / 14 / 87 \\
02 / 19 / 88 \\
12 / 15 / 90 \\
03 / 31 / 91 \\
08 / 24 / 91 \\
11 / 19 / 91 \\
10 / 12 / 92 \\
10 / 15 / 87 \\
12 / 15 / 90 \\
04 / 01 / 91 \\
08 / 24 / 91 \\
12 / 05 / 91 \\
10 / 14 / 92 \\
10 / 14 / 87 \\
02 / 19 / 88 \\
12 / 15 / 90 \\
03 / 28 / 91 \\
08 / 08 / 91 \\
12 / 05 / 91 \\
10 / 07 / 92\end{array}$ & $\begin{array}{l}0001 \\
0001 \\
0001 \\
0001 \\
0001 \\
0001 \\
0001 \\
0001 \\
0001 \\
0001 \\
0001 \\
0001 \\
0001 \\
0001 \\
0001 \\
0001 \\
0001 \\
0001 \\
0001 \\
0001\end{array}$ & $\begin{array}{l}\text { NA } \\
\text { NA } \\
\text { NA } \\
\text { NA } \\
\text { NA } \\
\text { NA } \\
\text { NA } \\
\text { NA } \\
\text { NA } \\
\text { NA } \\
\text { NA } \\
\text { NA } \\
\text { NA } \\
\text { NA } \\
\text { NA } \\
\text { NA } \\
\text { NA } \\
\text { NA } \\
\text { NA } \\
\text { NA }\end{array}$ & 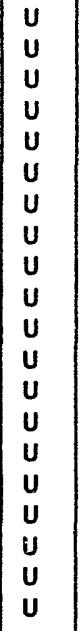 & $\mathrm{PCI} / \mathrm{L}$ & & $\begin{array}{l}0.8 \\
0.5 \\
0.8 \\
0.9 \\
0.6 \\
0.7 \\
0.7 \\
0.9 \\
0.5 \\
0.6 \\
0.7 \\
1.0 \\
0.3 \\
0.2 \\
0.2 \\
0.1 \\
0.0 \\
0.1 \\
0.0 \\
0.0\end{array}$ & $\begin{array}{l}\text { c } \\
\text { c } \\
\\
\text { c } \\
\text { c } \\
\text { c }\end{array}$ & $\begin{array}{l}1 . \\
0.8 \\
1 . \\
1 . \\
1 . \\
1 . \\
0.8 \\
1 . \\
0.8 \\
1 . \\
1 . \\
1 . \\
0.8 \\
0.4 \\
0.4 \\
0.2 \\
1 . \\
1 . \\
1 . \\
2.8\end{array}$ & $\begin{array}{l}0.3 \\
0.3 \\
0.4 \\
0.3 \\
0.3 \\
0.4 \\
0.6 \\
0.2 \\
0.3 \\
0.3 \\
0.3 \\
0.4 \\
0.5 \\
0.2 \\
0.2 \\
0.1 \\
0.1 \\
0.2 \\
0.1 \\
1.3\end{array}$ \\
\hline RADIUM-226 + RADIUM-228 & $\begin{array}{l}0669 \\
0669 \\
0669 \\
0669 \\
0669 \\
0669 \\
0670 \\
0670 \\
0670 \\
0670 \\
0670\end{array}$ & $\begin{array}{l}10 / 14 / 87 \\
12 / 15 / 90 \\
03 / 31 / 91 \\
08 / 24 / 91 \\
11 / 19 / 91 \\
10 / 12 / 92 \\
10 / 15 / 87 \\
12 / 15 / 90 \\
04 / 01 / 91 \\
08 / 24 / 91 \\
12 / 05 / 91\end{array}$ & $\begin{array}{l}0001 \\
0001 \\
0001 \\
0001 \\
0001 \\
0001 \\
0001 \\
0001 \\
0001 \\
0001 \\
0001\end{array}$ & $\begin{array}{l}\text { NA } \\
\text { NA } \\
\text { NA } \\
\text { NA } \\
\text { NA } \\
\text { NA } \\
\text { NA } \\
\text { NA } \\
\text { NA } \\
\text { NA } \\
\text { NA }\end{array}$ & $\begin{array}{l}U \\
U \\
U \\
U \\
U \\
U \\
U \\
U \\
U \\
U \\
U\end{array}$ & $\mathrm{PCI} / \mathrm{L}$ & & $\begin{array}{l}0.90 \\
2.40 \\
8.30 \\
0.60 \\
0.70 \\
1.10 \\
1.70 \\
2.20 \\
4.10 \\
3.10 \\
2.80\end{array}$ & & $\begin{array}{l}- \\
- \\
- \\
- \\
- \\
- \\
-\end{array}$ & $\begin{array}{l}- \\
- \\
- \\
- \\
- \\
- \\
- \\
-\end{array}$ \\
\hline
\end{tabular}

FORMATION OF COMPLETION CODE:

NA - MAVAJO SANDSTONE

PARAMETER VALUE INDICATOR (PVI):

< - LESS THAN DETECTION LIMIT
FLOW RELATIDNSHIP CODE:

U - UPGRADIENT

0001 - FILTERED SAMPLE (.45 MICRONS) 
TABLE 3.37 BASELINE GROUNDWATER QULAITY DATA BY PARAMETER FOR THE

MAVAJO SANDSTONE, UC PROCESSING SITE, SLICK ROCK, COLORADO

SITE: SRKO1 SLICK ROCK (BOTH SITES)

O6/30/86 TO $10 / 14 / 92$

REPORT DATE: $07 / 26 / 93$

\begin{tabular}{|c|c|c|c|c|c|c|c|c|c|c|c|c|}
\hline & PARAMETER NAME & $\begin{array}{c}\text { LOCATION } \\
\text { ID }\end{array}$ & LOG DATE & $\begin{array}{c}\text { SAMPLE } \\
\text { ID }\end{array}$ & $\begin{array}{l}\text { FORM } \\
\text { COMP }\end{array}$ & $\begin{array}{l}\text { FLON } \\
\text { REL. }\end{array}$ & $\begin{array}{l}\text { UNITS OF } \\
\text { MEASURE }\end{array}$ & PVI & $\begin{array}{l}\text { PARAMETER } \\
\text { VALUE }\end{array}$ & FLAGS & $\begin{array}{l}\text { DETECTION } \\
\text { LIMIT }\end{array}$ & $\begin{array}{l}\text { PARAMETER } \\
\text { UNCERTAINTY }\end{array}$ \\
\hline & RADIUM-226 + RADIUM-228 & $\begin{array}{l}0670 \\
0688 \\
0688 \\
0688 \\
0688 \\
0688 \\
0688\end{array}$ & $\begin{array}{l}10 / 14 / 92 \\
10 / 14 / 87 \\
12 / 15 / 90 \\
03 / 28 / 91 \\
08 / 08 / 91 \\
12 / 05 / 91 \\
10 / 07 / 92\end{array}$ & $\begin{array}{l}0001 \\
0001 \\
0001 \\
0001 \\
0001 \\
0001 \\
0001\end{array}$ & $\begin{array}{l}\text { NA } \\
\text { NA } \\
\text { NA } \\
\text { NA } \\
\text { NA } \\
\text { NA } \\
\text { NA }\end{array}$ & $\begin{array}{l}u \\
u \\
u \\
u \\
u \\
u \\
u\end{array}$ & $\mathrm{PCI} / \mathrm{L}$ & & $\begin{array}{l}1.40 \\
1.10 \\
1.00 \\
1.40 \\
3.30 \\
0.00 \\
1.00\end{array}$ & & $\begin{array}{l}: \\
: \\
: \\
-\end{array}$ & $\begin{array}{l}- \\
- \\
- \\
- \\
-\end{array}$ \\
\hline w & RADIUM-228 & $\begin{array}{l}0669 \\
0669 \\
0669 \\
0669 \\
0669 \\
0669 \\
0670 \\
0670 \\
0670 \\
0670 \\
0670 \\
0670 \\
0688 \\
0688 \\
0688 \\
0688 \\
0688 \\
0688\end{array}$ & \begin{tabular}{|l|}
$10 / 14 / 87$ \\
$12 / 15 / 90$ \\
$03 / 31 / 91$ \\
$08 / 24 / 91$ \\
$11 / 19 / 91$ \\
$10 / 12 / 92$ \\
$10 / 15 / 87$ \\
$12 / 15 / 90$ \\
$04 / 01 / 91$ \\
$08 / 24 / 91$ \\
$12 / 05 / 91$ \\
$10 / 14 / 92$ \\
$10 / 14 / 87$ \\
$12 / 15 / 90$ \\
$03 / 28 / 91$ \\
$08 / 08 / 91$ \\
$12 / 05 / 91$ \\
$10 / 07 / 92$
\end{tabular} & $\begin{array}{l}0001 \\
0001 \\
0001 \\
0001 \\
0001 \\
0001 \\
0001 \\
0001 \\
0001 \\
0001 \\
0001 \\
0001 \\
0001 \\
0001 \\
0001 \\
0001 \\
0001 \\
0001\end{array}$ & $\begin{array}{l}\text { NA } \\
\text { NA } \\
\text { NA } \\
\text { NA } \\
\text { NA } \\
\text { NA } \\
\text { NA } \\
\text { NA } \\
\text { NA } \\
\text { NA } \\
\text { NA } \\
\text { NA } \\
\text { NA } \\
\text { NA } \\
\text { NA } \\
\text { NA } \\
\text { NA } \\
\text { NA }\end{array}$ & $\begin{array}{l}u \\
u \\
u \\
U \\
U \\
U \\
U \\
U \\
U \\
U \\
U \\
U \\
U \\
U \\
U \\
U \\
U \\
U\end{array}$ & PCI/L & & $\begin{array}{l}0.1 \\
1.6 \\
7.4 \\
0.0 \\
0.0 \\
0.4 \\
0.8 \\
1.7 \\
3.5 \\
2.4 \\
1.8 \\
1.1 \\
0.9 \\
0.9 \\
1.4 \\
3.2 \\
0.0 \\
1.0\end{array}$ & $\mathbf{N}$ & $\begin{array}{l}1 . \\
1 . \\
1 . \\
1 . \\
1 . \\
2.7 \\
1 . \\
1 . \\
1 . \\
1 . \\
1 . \\
2.6 \\
1 . \\
1 . \\
1 . \\
1 . \\
2.5\end{array}$ & $\begin{array}{l}0.9 \\
0.9 \\
1.5 \\
2.0 \\
1.1 \\
1.6 \\
1.2 \\
0.9 \\
1.3 \\
2.2 \\
1.0 \\
1.6 \\
1.2 \\
0.9 \\
1.3 \\
1.9 \\
1.0 \\
1.6\end{array}$ \\
\hline & REDOX POTENTIAL & $\begin{array}{l}0669 \\
0669 \\
0670 \\
0670 \\
0688 \\
0688\end{array}$ & $\begin{array}{l}12 / 15 / 90 \\
10 / 12 / 92 \\
12 / 15 / 90 \\
10 / 14 / 92 \\
12 / 15 / 90 \\
10 / 07 / 92\end{array}$ & $\begin{array}{l}0001 \\
0001 \\
0001 \\
0001 \\
0001 \\
0001\end{array}$ & $\begin{array}{l}\text { NA } \\
\text { NA } \\
\text { NA } \\
\text { NA } \\
\text { NA } \\
\text { NA }\end{array}$ & $\begin{array}{l}U \\
U \\
U \\
U \\
U \\
U\end{array}$ & mVOLTS & & $\begin{array}{l}285.5 \\
438.5 \\
189 . \\
437.9 \\
400 . \\
431.5\end{array}$ & & $\begin{array}{l}- \\
- \\
- \\
-\end{array}$ & $\begin{array}{l}- \\
- \\
- \\
-\end{array}$ \\
\hline - & SELENIUM & $\begin{array}{l}0669 \\
0669 \\
0669 \\
0669 \\
0669\end{array}$ & $\begin{array}{l}06 / 30 / 86 \\
10 / 14 / 87 \\
12 / 15 / 90 \\
03 / 31 / 91 \\
08 / 24 / 91\end{array}$ & $\begin{array}{l}0001 \\
0001 \\
0001 \\
0001 \\
0001\end{array}$ & $\begin{array}{l}\text { NA } \\
\text { NA } \\
\text { NA } \\
\text { NA } \\
\text { NA }\end{array}$ & $\begin{array}{l}u \\
u \\
u \\
u \\
u\end{array}$ & $M G / L$ & $\begin{array}{l}< \\
< \\
< \\
<\end{array}$ & $\begin{array}{l}0.005 \\
0.005 \\
0.005 \\
0.03 \\
0.005\end{array}$ & 1 & $\begin{array}{l}0.005 \\
0.005 \\
0.005 \\
0.03 \\
0.005\end{array}$ & $\begin{array}{l}- \\
- \\
-\end{array}$ \\
\hline
\end{tabular}

FORMATION OF COMPLETION COOE:

MA - NAVAJO SANDSTONE

PARAMETER VALUE IMDICATOR (PVI): < - LESS THAN DETECTION LIMIT
FLOW RELATIONSHIP CODE:

- UPGRADIENT

0001 - FILTERED SAMPLE (.45 MICRONS)

OTHER PARAMETER VALUE FLAGS:

I - INCREASED DETECTION LIMIT DUE TO REQUIRED DILUTION

N - SPIKE SAMPLE RECOVERY NOT WITHIN CONTROL LIMITS 
TABLE 3.37 BASELINE GROUNDWATER QULAITY DATA BY PARAMETER FOR THE MAVAJO SANDSTONE, UC PROCESSING SITE, SLICK ROCK, COLORADO

SITE: SRKO1 SLICK ROCK (BOTH SITES)

06/30/86 TO $10 / 14 / 92$

REPORT DATE : $07 / 26 / 93$

\begin{tabular}{|c|c|c|c|c|c|c|c|c|c|c|c|}
\hline PARAMETER NAME & $\begin{array}{l}\text { LOCATION } \\
\text { ID }\end{array}$ & LOG DATE & $\begin{array}{c}\text { SAMPLE } \\
\text { ID }\end{array}$ & $\begin{array}{l}\text { FORM } \\
\text { COMP }\end{array}$ & $\begin{array}{l}\text { FLOW } \\
\text { REL. }\end{array}$ & $\begin{array}{l}\text { UNITS OF } \\
\text { MEASURE }\end{array}$ & PVI & $\begin{array}{l}\text { PARAMETER } \\
\text { VALUE }\end{array}$ & FLAGS & $\begin{array}{l}\text { DETECTION } \\
\text { LIMIT }\end{array}$ & $\begin{array}{l}\text { PARAMETER } \\
\text { UNCERTAINTY }\end{array}$ \\
\hline SELENIUM & $\begin{array}{l}0669 \\
0669 \\
0670 \\
0670 \\
0670 \\
0670 \\
0670 \\
0670 \\
0688 \\
0688 \\
0688 \\
0688 \\
0688 \\
0688 \\
0688 \\
0688\end{array}$ & $\begin{array}{l}11 / 19 / 91 \\
10 / 12 / 92 \\
07 / 19 / 86 \\
10 / 15 / 87 \\
12 / 15 / 90 \\
04 / 01 / 91 \\
08 / 24 / 91 \\
10 / 14 / 92 \\
07 / 17 / 86 \\
04 / 08 / 87 \\
10 / 14 / 87 \\
12 / 15 / 90 \\
03 / 28 / 91 \\
08 / 08 / 91 \\
12 / 06 / 91 \\
10 / 07 / 92\end{array}$ & $\begin{array}{l}0001 \\
0001 \\
0001 \\
0001 \\
0001 \\
0001 \\
0001 \\
0001 \\
0001 \\
0001 \\
0001 \\
0001 \\
0001 \\
0001 \\
0001 \\
0001\end{array}$ & $\begin{array}{l}\text { NA } \\
\text { NA } \\
\text { NA } \\
\text { NA } \\
\text { NA } \\
\text { NA } \\
\text { NA } \\
\text { NA } \\
\text { NA } \\
\text { NA } \\
\text { NA } \\
\text { NA } \\
\text { NA } \\
\text { NA } \\
\text { NA } \\
\text { NA }\end{array}$ & $\begin{array}{l}u \\
u \\
u \\
u \\
u \\
u \\
u \\
U \\
U \\
U \\
U \\
u \\
u \\
U \\
U \\
U\end{array}$ & $M G / L$ & $\begin{array}{l}< \\
< \\
< \\
< \\
< \\
< \\
< \\
< \\
< \\
< \\
< \\
< \\
< \\
< \\
<\end{array}$ & $\begin{array}{l}0.005 \\
0.006 \\
0.005 \\
0.005 \\
0.005 \\
0.03 \\
0.005 \\
0.005 \\
0.005 \\
0.002 \\
0.005 \\
0.005 \\
0.005 \\
0.005 \\
0.005 \\
0.005\end{array}$ & 1 & $\begin{array}{l}0.005 \\
0.005 \\
0.005 \\
0.005 \\
0.005 \\
0.03 \\
0.005 \\
0.005 \\
0.005 \\
0.005 \\
0.005 \\
0.005 \\
0.005 \\
0.005 \\
0.005 \\
0.005\end{array}$ & $\begin{array}{l}- \\
- \\
- \\
- \\
- \\
- \\
- \\
- \\
- \\
- \\
- \\
-\end{array}$ \\
\hline SILICA - SIOZ & $\begin{array}{l}0669 \\
0669 \\
0669 \\
0669 \\
0669 \\
0669 \\
0669 \\
0670 \\
0670 \\
0670 \\
0670 \\
0670 \\
0688 \\
0688 \\
0688 \\
0688 \\
0688 \\
0688 \\
0688 \\
0688\end{array}$ & $\begin{array}{l}10 / 14 / 87 \\
02 / 19 / 88 \\
12 / 15 / 90 \\
03 / 31 / 91 \\
08 / 24 / 91 \\
11 / 19 / 91 \\
10 / 12 / 92 \\
10 / 15 / 87 \\
12 / 15 / 90 \\
04 / 01 / 91 \\
08 / 24 / 91 \\
10 / 14 / 92 \\
04 / 08 / 87 \\
10 / 14 / 87 \\
02 / 19 / 88 \\
12 / 15 / 90 \\
03 / 28 / 91 \\
08 / 08 / 91 \\
12 / 06 / 91 \\
10 / 07 / 92\end{array}$ & $\begin{array}{l}0001 \\
0001 \\
0001 \\
0001 \\
0001 \\
0001 \\
0001 \\
0001 \\
0001 \\
0001 \\
0001 \\
0001 \\
0001 \\
0001 \\
0001 \\
0001 \\
0001 \\
0001 \\
0001 \\
0001\end{array}$ & $\begin{array}{l}\text { NA } \\
\text { NA } \\
\text { NA } \\
\text { NA } \\
\text { NA } \\
\text { HA } \\
\text { NA } \\
\text { NA } \\
\text { NA } \\
\text { NA } \\
\text { NA } \\
\text { NA } \\
\text { NA } \\
\text { NA } \\
\text { NA } \\
\text { NA } \\
\text { NA } \\
\text { NA } \\
\text { NA } \\
\text { NA }\end{array}$ & $\begin{array}{l}u \\
U \\
U \\
U \\
u \\
U \\
U \\
U \\
U \\
U \\
U \\
u \\
U \\
U \\
U \\
U \\
U \\
U \\
U \\
U\end{array}$ & $M G / L$ & & $\begin{array}{c}11.8 \\
10.2 \\
13 . \\
11.0 \\
12.2 \\
12.1 \\
14.8 \\
8.9 \\
10 . \\
8.2 \\
9.6 \\
5.9 \\
12.6 \\
11.1 \\
9.3 \\
11 . \\
9.8 \\
10.8 \\
9.6 \\
11.1\end{array}$ & & $\begin{array}{l}2 . \\
2 . \\
2 . \\
0.1 \\
0.1 \\
0.1 \\
0.1 \\
2 . \\
2 . \\
0.1 \\
0.1 \\
0.1 \\
2 . \\
2 . \\
2 . \\
2 . \\
0.1 \\
0.1 \\
0.1 \\
0.1\end{array}$ & $\begin{array}{l}- \\
- \\
- \\
- \\
- \\
- \\
- \\
- \\
- \\
- \\
- \\
- \\
- \\
-\end{array}$ \\
\hline SILVER & $\begin{array}{l}0669 \\
0669\end{array}$ & $\begin{array}{l}10 / 14 / 87 \\
12 / 15 / 90\end{array}$ & $\begin{array}{l}0001 \\
0001\end{array}$ & $\begin{array}{l}\text { NA } \\
\text { NA }\end{array}$ & $\begin{array}{l}u \\
u\end{array}$ & $M G / L$ & $<$ & $\begin{array}{l}0.01 \\
0.01\end{array}$ & & $\begin{array}{l}0.01 \\
0.01\end{array}$ & - \\
\hline
\end{tabular}

FORMATION OF COMPLETION COOE:

MA - NAVAJO SANDSTONE

PARAMETER VALUE INDICATOR (PVI):
FLON RELATIONSHIP CODE:

$U$ - UPGRADIENT

SAMPLE ID CODES:
0001 - FILTERED SAMPLE ( .45 MICRONS)

OTHER PARAMETER VALUE FLAGS:

I - INCREASED DETECTION LIMIT DUE TO REOUIRED DILUTION 
TABLE 3.37 BASELINE GROUNDWATER OULAITY DATA BY PARAMETER FOR THE NAVAJO SANDSTONE, UC PROCESSING SITE, SLICK ROCK, COLORADO NAVAJO SANDSTONE, UC PROCESSING SITE,

SITE: SRKO1 SLICK ROCK

O6/30/86 TO $10 / 14 / 92$

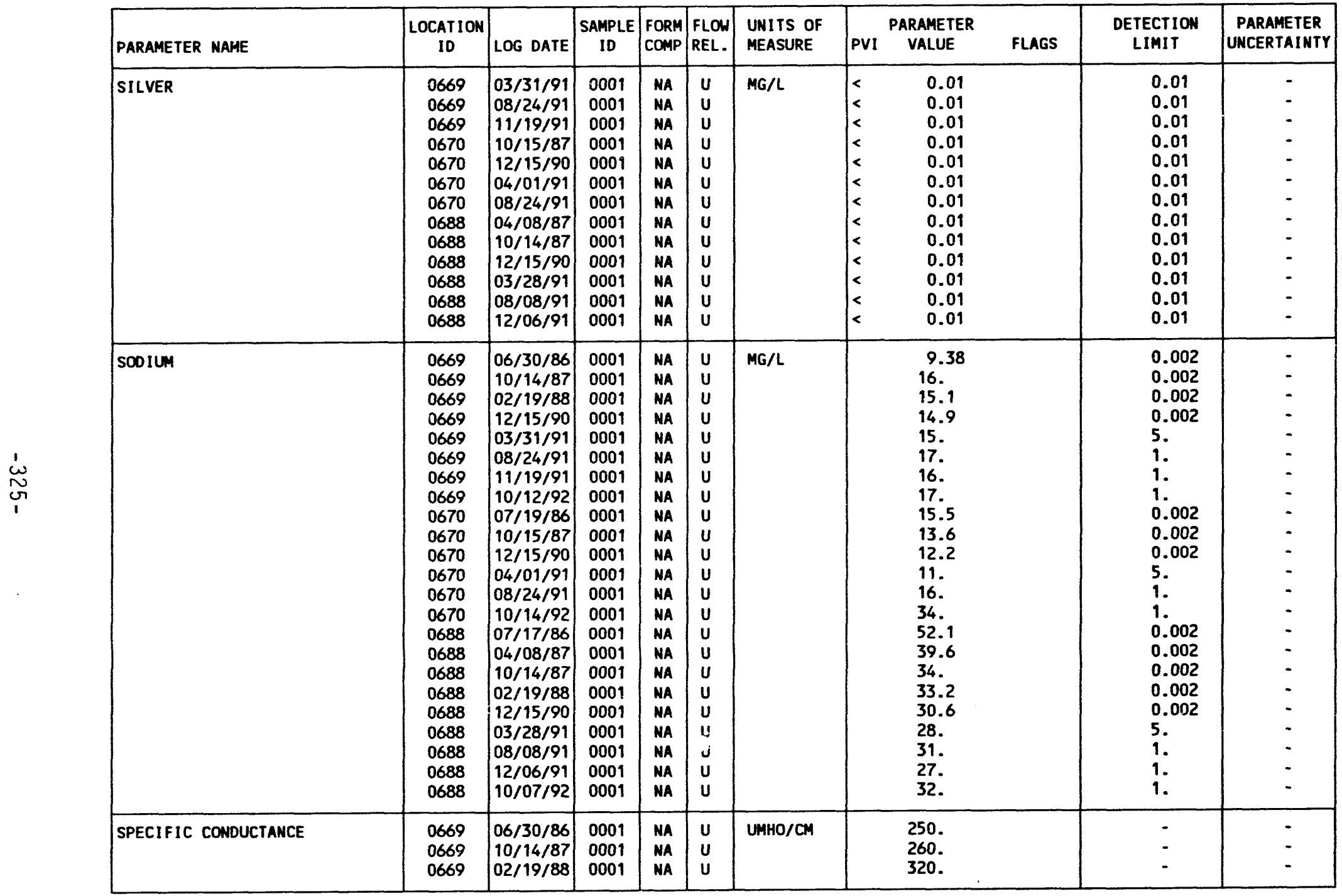

FORMATION OF COMPLETION CODE:

NA - NAVAJO SANDSTONE

PARAMETER VALUE INDICATOR (PVI): < - LESS THAN DETECTION LIMIT
FLON RELATIONSHIP CODE:

U - UPGRADIENT

SAMPLE ID CODES:

0001 - FILTERED SAMPLE (.45 MICRONS) 
TABLE 3.37 BASELINE GROUNDWATER QULAITY DATA BY PARAMETER FOR THE MAVAJO SAMDSTONE, UC PROCESSING SITE SLICK ROCK, COLORADO

SITE: SRKO1 SLICK ROCK (BOTH SITES)

06/30/86 TO $10 / 14 / 92$

REPORT DATE: $07 / 26 / 93$

\begin{tabular}{|c|c|c|c|c|c|c|c|c|c|c|}
\hline PARAMETER NAME & $\begin{array}{c}\text { LOCATION } \\
\text { ID }\end{array}$ & LOG DATE & $\begin{array}{c}\text { SAMPLE } \\
\text { ID }\end{array}$ & $\begin{array}{l}\text { FORM } \\
\text { COMP }\end{array}$ & $\begin{array}{l}\text { FLOW } \\
\text { REL. }\end{array}$ & $\begin{array}{l}\text { UNITS OF } \\
\text { MEASURE }\end{array}$ & PVI & $\begin{array}{l}\text { PARAMETER } \\
\text { VALUE }\end{array}$ & $\begin{array}{l}\text { DETECTION } \\
\text { LIMIT }\end{array}$ & $\begin{array}{l}\text { PARAMETER } \\
\text { UNCERTAINTY }\end{array}$ \\
\hline SPECIFIC CONDUCTANCE & $\begin{array}{l}0669 \\
0669 \\
0669 \\
0669 \\
0670 \\
0670 \\
0670 \\
0670 \\
0670 \\
0670 \\
0670 \\
0688 \\
0688 \\
0688 \\
0688 \\
0688 \\
0688 \\
0688 \\
0688\end{array}$ & $\begin{array}{l}12 / 15 / 90 \\
08 / 24 / 91 \\
11 / 19 / 91 \\
10 / 12 / 92 \\
07 / 19 / 86 \\
10 / 15 / 87 \\
02 / 19 / 88 \\
12 / 15 / 90 \\
08 / 24 / 91 \\
12 / 05 / 91 \\
10 / 14 / 92 \\
07 / 17 / 86 \\
04 / 08 / 87 \\
10 / 14 / 87 \\
02 / 19 / 88 \\
12 / 15 / 90 \\
08 / 08 / 91 \\
12 / 05 / 91 \\
10 / 07 / 92\end{array}$ & $\begin{array}{l}0001 \\
0001 \\
0001 \\
0001 \\
0001 \\
0001 \\
0001 \\
0001 \\
0001 \\
0001 \\
0001 \\
0001 \\
0001 \\
0001 \\
0001 \\
0001 \\
0001 \\
0001 \\
0001\end{array}$ & $\begin{array}{l}\text { NA } \\
\text { NA } \\
\text { NA } \\
\text { NA } \\
\text { NA } \\
\text { NA } \\
\text { NA } \\
\text { NA } \\
\text { NA } \\
\text { NA } \\
\text { NA } \\
\text { NA } \\
\text { NA } \\
\text { NA } \\
\text { NA } \\
\text { NA } \\
\text { NA } \\
\text { NA } \\
\text { NA }\end{array}$ & $\begin{array}{l}u \\
U \\
U \\
u \\
u \\
u \\
u \\
U \\
U \\
u \\
u \\
u \\
u \\
u \\
u \\
U \\
U \\
u \\
u\end{array}$ & UMHO/CM & & $\begin{array}{l}351 . \\
542 \\
510 \\
378 \\
320 . \\
280 . \\
360 . \\
557 . \\
546 \\
560 \\
375 \\
475 . \\
390 . \\
352 . \\
510 . \\
713 . \\
696 \\
699 \\
536\end{array}$ & $\begin{array}{l}- \\
- \\
- \\
- \\
- \\
- \\
- \\
- \\
- \\
- \\
- \\
-\end{array}$ & $\begin{array}{l}- \\
- \\
- \\
- \\
- \\
- \\
- \\
- \\
- \\
- \\
- \\
- \\
-\end{array}$ \\
\hline STRONTIUM & $\begin{array}{l}0669 \\
0669 \\
0669 \\
0669 \\
0639 \\
0670 \\
0670 \\
0670 \\
0670 \\
0688 \\
0688 \\
0688 \\
0688 \\
0688\end{array}$ & $\begin{array}{l}12 / 15 / 90 \\
03 / 31 / 91 \\
08 / 24 / 91 \\
11 / 19 / 91 \\
10 / 12 / 92 \\
12 / 15 / 90 \\
04 / 01 / 91 \\
08 / 24 / 91 \\
10 / 14 / 92 \\
12 / 15 / 90 \\
03 / 28 / 91 \\
08 / 08 / 91 \\
12 / 06 / 91 \\
10 / 07 / 92\end{array}$ & $\begin{array}{l}0001 \\
0001 \\
0001 \\
0001 \\
0001 \\
0001 \\
0001 \\
0001 \\
0001 \\
0001 \\
0001 \\
0001 \\
0001 \\
0001\end{array}$ & $\begin{array}{l}\text { NA } \\
\text { NA } \\
\text { NA } \\
\text { NA } \\
\text { NA } \\
\text { NA } \\
\text { NA } \\
\text { NA } \\
\text { NA } \\
\text { NA } \\
\text { NA } \\
\text { NA } \\
\text { NA } \\
\text { NA }\end{array}$ & $\begin{array}{l}u \\
U \\
u \\
u \\
U \\
U \\
u \\
U \\
U \\
U \\
U \\
U \\
U \\
U\end{array}$ & $M G / L$ & & $\begin{array}{l}0.9 \\
1.40 \\
1.48 \\
1.48 \\
1.13 \\
1.6 \\
1.54 \\
1.77 \\
0.66 \\
0.7 \\
0.72 \\
0.72 \\
0.65 \\
0.70\end{array}$ & $\begin{array}{l}0.1 \\
0.01 \\
0.01 \\
0.01 \\
0.01 \\
0.1 \\
0.01 \\
0.01 \\
0.01 \\
0.1 \\
0.01 \\
0.01 \\
0.01 \\
0.01\end{array}$ & $\begin{array}{l}- \\
- \\
- \\
- \\
- \\
- \\
- \\
- \\
- \\
-\end{array}$ \\
\hline SULFATE & $\begin{array}{l}0669 \\
0669 \\
0669 \\
0669 \\
0669 \\
0669\end{array}$ & $\begin{array}{l}06 / 30 / 86 \\
10 / 14 / 87 \\
02 / 19 / 88 \\
12 / 15 / 90 \\
03 / 31 / 91 \\
08 / 24 / 91\end{array}$ & $\begin{array}{l}0001 \\
0001 \\
0001 \\
0001 \\
0001 \\
0001\end{array}$ & $\begin{array}{l}\text { NA } \\
\text { NA } \\
\text { NA } \\
\text { NA } \\
\text { NA } \\
\text { NA }\end{array}$ & $\begin{array}{l}u \\
u \\
u \\
u \\
u \\
u\end{array}$ & $M G / L$ & & $\begin{array}{l}19.3 \\
23 . \\
29 . \\
20.2 \\
24.4 \\
33 .\end{array}$ & $\begin{array}{c}0.1 \\
0.1 \\
0.1 \\
0.1 \\
0.1 \\
10 .\end{array}$ & $\begin{array}{l}- \\
- \\
-\end{array}$ \\
\hline
\end{tabular}

FORMATION OF COMPLETION CODE:

NA - MAVAJO SANDSTONE

PARAMETER VALUE INDICATOR (PVI): < - LESS THAN DETECTION LIMIT
FLOW RELATIONSHIP CODE:

U - UPGRADIENT

0001 - FILTERED SAMPLE (.45 MICRONS) 
TABLE 3.37 BASELINE GROUNDWATER OULAITY DATA BY PARAMETER FOR THE TAVAE SANDSTONE, UC PROCESSING SITE, SLICK ROCK, COLORADO

SITE: SRKO1 SLICK ROCK (BOTH SITES)

$06 / 30 / 86$ TO $10 / 14 / 92$

REPORT DATE: $07 / 26 / 93$

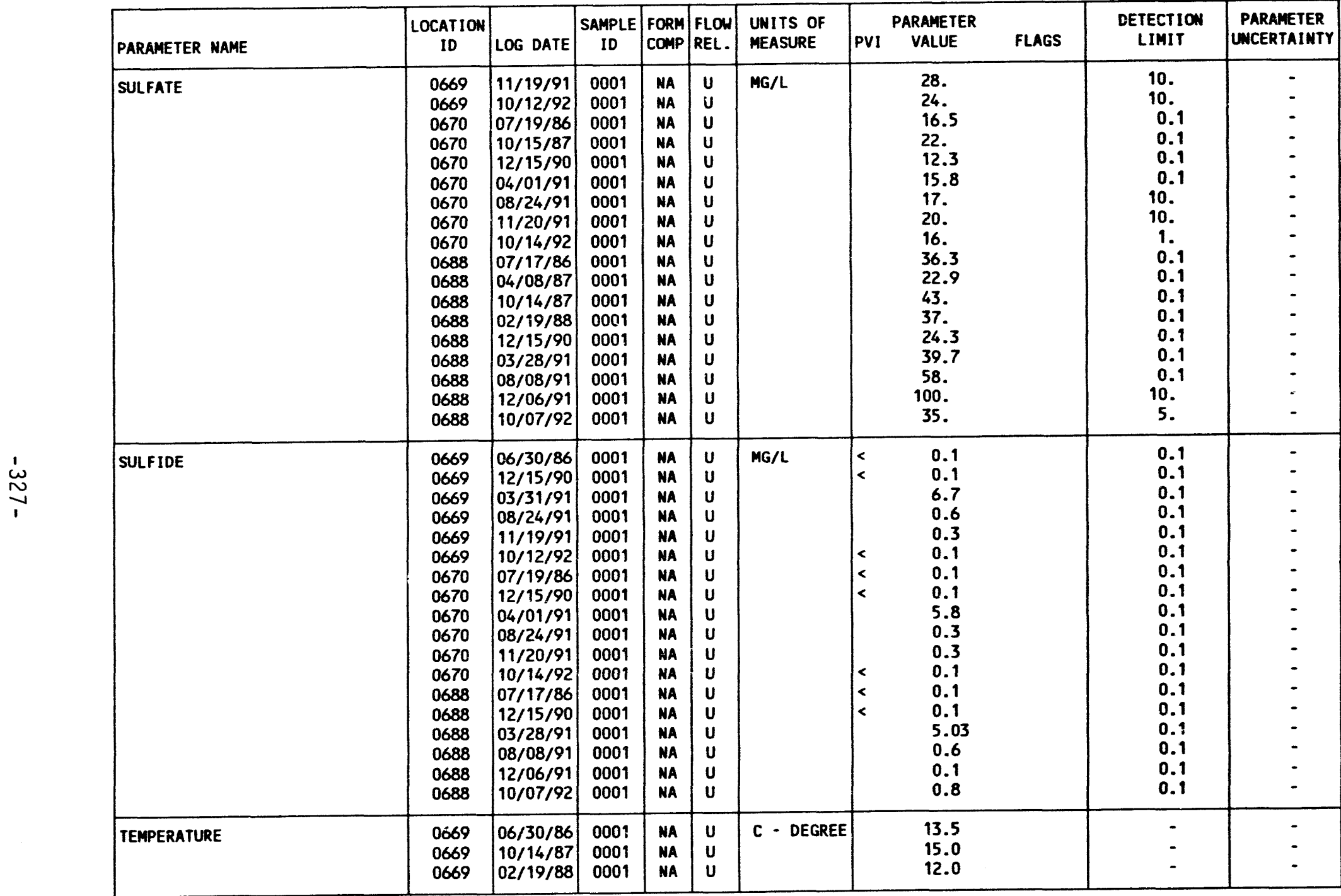

FORMATION OF COMPLETION COOE:

NA - MAVAJO SANDSTONE

PARAMETER VALUE IMDICATOR (PVI): < - LESS THAN DETECTION LIMIT
FLOW RELATIONSHIP COOE:

U - UPGRADIENT

SAMPLE ID COOES:

0001 - FILTERED SAMPLE (.45 MICRONS) 
TABLE 3.37 BASELINE GROUNDHATER OULAITY DATA BY PARAMETER FOR THE NAVA SA SANDSTOYE, UC PROCESSIMG SITE, SLICK ROCK, COLORADO

SITE: SRK01 SLICK ROCK (BOTH SITES)

$06 / 30 / 86$ TO $10 / 14 / 92$

PEPORT DATE: 07/26/93

\begin{tabular}{|c|c|c|c|c|c|c|c|c|c|c|c|}
\hline & PARAMETER MAME & ${ }_{\text {LOCATION }}^{\text {ID }}$ & LOG DATE & $\begin{array}{c}\text { SAMPLE } \\
\text { ID }\end{array}$ & $\begin{array}{l}\text { FORM } \\
\text { COMP }\end{array}$ & $\begin{array}{l}\text { FLOW } \\
\text { REL. }\end{array}$ & $\begin{array}{l}\text { UNITS OF } \\
\text { MEASURE }\end{array}$ & PVI & $\begin{array}{l}\text { PARAMETER } \\
\text { VALUE }\end{array}$ & $\begin{array}{l}\text { DETECTIION } \\
\text { LIMIT }\end{array}$ & $\begin{array}{c}\text { PARAMETER } \\
\text { UWCERTAINTY }\end{array}$ \\
\hline${ }^{\prime}$ & TEMPERATURE & $\begin{array}{l}0669 \\
0669 \\
0669 \\
0669 \\
0669 \\
0670 \\
0670 \\
0670 \\
0670 \\
0670 \\
0670 \\
0670 \\
0670 \\
0688 \\
0688 \\
0688 \\
0688 \\
0688 \\
0688 \\
0688 \\
0688 \\
0688 \\
\end{array}$ & $\begin{array}{l}12 / 15 / 90 \\
03 / 31 / 91 \\
08 / 24 / 91 \\
11 / 19 / 91 \\
10 / 12 / 92 \\
07 / 19 / 86 \\
10 / 15 / 87 \\
02 / 19 / 88 \\
12 / 15 / 90 \\
04 / 01 / 91 \\
08 / 24 / 91 \\
12 / 05 / 91 \\
10 / 14 / 92 \\
07 / 17 / 86 \\
04 / 08 / 87 \\
10 / 14 / 87 \\
02 / 19 / 88 \\
12 / 15 / 90 \\
03 / 28 / 91 \\
08 / 08 / 91 \\
12 / 05 / 91 \\
10 / 07 / 92\end{array}$ & $\begin{array}{l}0001 \\
0001 \\
0001 \\
0001 \\
0001 \\
0001 \\
0001 \\
0001 \\
0001 \\
0001 \\
0001 \\
0001 \\
0001 \\
0001 \\
0001 \\
0001 \\
0001 \\
0001 \\
0001 \\
0001 \\
0001 \\
0001\end{array}$ & $\begin{array}{l}\text { NA } \\
\text { NA } \\
\text { NA } \\
\text { NA } \\
\text { NA } \\
\text { NA } \\
\text { NA } \\
\text { NA } \\
\text { NA } \\
\text { NA } \\
\text { NA } \\
\text { NA } \\
\text { NA } \\
\text { NA } \\
\text { NA } \\
\text { NA } \\
\text { NA } \\
\text { NA } \\
\text { NA } \\
\text { NA } \\
\text { NA } \\
\text { NA }\end{array}$ & $\begin{array}{l}u \\
U \\
U \\
U \\
U \\
u \\
U \\
U \\
U \\
U \\
U \\
U \\
U \\
U \\
U \\
U \\
U \\
U \\
U \\
U \\
U \\
U\end{array}$ & C - DEGREE & & $\begin{array}{l}11.5 \\
12.3 \\
14.2 \\
11.9 \\
14.5 \\
13 . \\
13.0 \\
12.0 \\
10.6 \\
12.3 \\
13.7 \\
10.7 \\
14.5 \\
14 . \\
13.0 \\
14.2 \\
13 . \\
12.5 \\
13.1 \\
13.7 \\
12.9 \\
13.4\end{array}$ & $\begin{array}{l}- \\
- \\
- \\
- \\
- \\
- \\
- \\
- \\
- \\
- \\
- \\
- \\
- \\
- \\
- \\
-\end{array}$ & $\begin{array}{l}- \\
- \\
- \\
- \\
- \\
- \\
- \\
- \\
- \\
- \\
- \\
- \\
- \\
- \\
- \\
-\end{array}$ \\
\hline & THALLIUM & $\begin{array}{l}0669 \\
0669 \\
0669 \\
0669 \\
0669 \\
0670 \\
0670 \\
0670 \\
0670 \\
0688 \\
0688 \\
0688 \\
0688 \\
0688\end{array}$ & $\begin{array}{l}12 / 15 / 90 \\
03 / 31 / 91 \\
08 / 24 / 91 \\
11 / 19 / 91 \\
10 / 12 / 92 \\
12 / 15 / 90 \\
04 / 01 / 91 \\
08 / 24 / 91 \\
10 / 14 / 92 \\
12 / 15 / 90 \\
03 / 28 / 91 \\
08 / 08 / 91 \\
12 / 06 / 91 \\
10 / 07 / 92\end{array}$ & $\begin{array}{l}0001 \\
0001 \\
0001 \\
0001 \\
0001 \\
0001 \\
0001 \\
0001 \\
0001 \\
0001 \\
0001 \\
0001 \\
0001 \\
0001\end{array}$ & $\begin{array}{l}\text { NA } \\
\text { NA } \\
\text { NA } \\
\text { NA } \\
\text { NA } \\
\text { NA } \\
\text { NA } \\
\text { NA } \\
\text { NA } \\
\text { NA } \\
\text { NA } \\
\text { NA } \\
\text { NA } \\
\text { NA }\end{array}$ & $\begin{array}{l}U \\
U \\
U \\
U \\
U \\
U \\
U \\
U \\
U \\
U \\
U \\
U \\
U \\
U\end{array}$ & $M G / L$ & $\begin{array}{l}< \\
< \\
< \\
< \\
< \\
< \\
< \\
< \\
< \\
< \\
< \\
< \\
< \\
<\end{array}$ & $\begin{array}{l}0.01 \\
0.01 \\
0.01 \\
0.01 \\
0.005 \\
0.01 \\
0.01 \\
0.01 \\
0.005 \\
0.01 \\
0.01 \\
0.01 \\
0.01 \\
0.005\end{array}$ & $\begin{array}{l}0.01 \\
0.01 \\
0.01 \\
0.01 \\
0.005 \\
0.01 \\
0.01 \\
0.01 \\
0.005 \\
0.01 \\
0.01 \\
0.01 \\
0.01 \\
0.005\end{array}$ & $\begin{array}{l}- \\
- \\
- \\
- \\
- \\
- \\
- \\
- \\
-\end{array}$ \\
\hline & THORIUM-230 & $\begin{array}{l}0669 \\
0669 \\
0670\end{array}$ & $\begin{array}{l}08 / 24 / 91 \\
11 / 19 / 91 \\
08 / 24 / 91\end{array}$ & $\begin{array}{l}0001 \\
0001 \\
0001\end{array}$ & $\begin{array}{l}\text { NA } \\
\text { NA } \\
\text { NA }\end{array}$ & $\begin{array}{l}\mathbf{U} \\
\mathbf{U} \\
\mathbf{U}\end{array}$ & $\mathrm{PCI} / \mathrm{L}$ & & $\begin{array}{l}0.8 \\
0.4 \\
0.0\end{array}$ & $\begin{array}{l}1 . \\
1 . \\
1 .\end{array}$ & $\begin{array}{l}0.9 \\
0.5 \\
0.4\end{array}$ \\
\hline
\end{tabular}

FORMATION OF COMPLETION COOE:

FLOW RELATIONSHIP COOE

NA - MAVAJO SANDSTONE

U - UPGRADIENT

PARAMETER VALUE INDICATOR (PVI): < - LESS THAN DETECTION LIMIT SAMPLE ID CODES:

0001 - FILTERED SAMPLE (.45 MICRONS) 
TABLE 3.37 BASELINE GROUWDHATER OULAITY DATA BY PARAMETER FOR THE NAVAJO SANDSTONE, UC PROCESSING SITE, SLICK ROCK, COLORADO

SITE: SRK01 SLICK ROCK (BOTH SITES)

06/30/86 TO $10 / 14 / 92$

REPORT DATE : 07/26/93

\begin{tabular}{|c|c|c|c|c|c|c|c|c|c|c|}
\hline PARAMETER MAME & $\begin{array}{l}\text { LOCATION } \\
\text { ID }\end{array}$ & LOG DATE & $\begin{array}{c}\text { SAMPLE } \\
\text { ID }\end{array}$ & $\begin{array}{l}\text { FORM } \\
\text { COMP }\end{array}$ & $\begin{array}{l}\text { FLOW } \\
\text { REL. }\end{array}$ & $\begin{array}{l}\text { UNITS OF } \\
\text { MEASURE }\end{array}$ & PVI & $\begin{array}{l}\text { ARAMETER } \\
\text { VALUE }\end{array}$ & $\begin{array}{l}\text { DETECTION } \\
\text { LIMIT }\end{array}$ & $\begin{array}{l}\text { PARAMETER } \\
\text { UNCERTAINTY }\end{array}$ \\
\hline THORIUN-230 & $\begin{array}{l}0670 \\
0688 \\
0688\end{array}$ & $\begin{array}{l}12 / 05 / 91 \\
08 / 08 / 91 \\
12 / 05 / 91\end{array}$ & $\begin{array}{l}0001 \\
0001 \\
0001\end{array}$ & $\begin{array}{l}\text { MA } \\
\text { NA } \\
\text { NA }\end{array}$ & $\begin{array}{l}u \\
U \\
U\end{array}$ & $\mathrm{PCI} / \mathrm{L}$ & & $\begin{array}{l}0.3 \\
0.5 \\
0.7\end{array}$ & $\begin{array}{l}1 . \\
1 .\end{array}$ & $\begin{array}{l}0.5 \\
0.4 \\
0.5\end{array}$ \\
\hline TIN & $\begin{array}{l}0669 \\
0669 \\
0669 \\
0669 \\
0669 \\
0670 \\
0670 \\
0670 \\
0670 \\
0688 \\
0688 \\
0688 \\
0688 \\
0688\end{array}$ & \begin{tabular}{|l|}
$12 / 15 / 90$ \\
$0 \geq / 31 / 91$ \\
$08 / 24 / 91$ \\
$11 / 19 / 91$ \\
$10 / 12 / 92$ \\
$12 / 15 / 90$ \\
$04 / 01 / 91$ \\
$08 / 24 / 91$ \\
$10 / 14 / 92$ \\
$12 / 15 / 90$ \\
$03 / 28 / 91$ \\
$08 / 08 / 91$ \\
$12 / 06 / 91$ \\
$10 / 07 / 92$
\end{tabular} & $\begin{array}{l}0001 \\
0001 \\
0001 \\
0001 \\
0001 \\
0001 \\
0001 \\
0001 \\
0001 \\
0001 \\
0001 \\
0001 \\
0001 \\
0001\end{array}$ & $\begin{array}{l}\text { MA } \\
\text { NA } \\
\text { NA } \\
\text { NA } \\
\text { NA } \\
\text { NA } \\
\text { HA } \\
\text { NA } \\
\text { NA } \\
\text { NA } \\
\text { MA } \\
\text { HA } \\
\text { NA } \\
\text { NA }\end{array}$ & $\begin{array}{l}u \\
u \\
u \\
U \\
u \\
u \\
u \\
U \\
U \\
U \\
U \\
u \\
U \\
U\end{array}$ & $M G / L$ & $\begin{array}{l}< \\
< \\
< \\
< \\
< \\
< \\
< \\
< \\
< \\
< \\
< \\
< \\
< \\
< \\
<\end{array}$ & $\begin{array}{l}0.005 \\
0.005 \\
0.005 \\
0.005 \\
0.005 \\
0.005 \\
0.005 \\
0.005 \\
0.005 \\
0.005 \\
0.005 \\
0.005 \\
0.005 \\
0.005\end{array}$ & $\begin{array}{l}0.005 \\
0.005 \\
0.005 \\
0.005 \\
0.005 \\
0.005 \\
0.005 \\
0.005 \\
0.005 \\
0.005 \\
0.005 \\
0.005 \\
0.005 \\
0.005\end{array}$ & $\begin{array}{l}- \\
- \\
- \\
- \\
- \\
- \\
- \\
- \\
-\end{array}$ \\
\hline TOTAL DISSOLVED SOLIDS & $\begin{array}{l}0669 \\
0669 \\
0669 \\
0669 \\
0669 \\
0669 \\
0669 \\
0669 \\
0670 \\
0670 \\
0670 \\
0670 \\
0670 \\
0670 \\
0670 \\
0688 \\
0688 \\
0688 \\
0688 \\
0688 \\
0688 \\
0688\end{array}$ & \begin{tabular}{|l|}
$06 / 30 / 86$ \\
$10 / 14 / 87$ \\
$02 / 19 / 88$ \\
$12 / 15 / 90$ \\
$03 / 31 / 91$ \\
$08 / 24 / 91$ \\
$11 / 19 / 91$ \\
$10 / 12 / 92$ \\
$07 / 19 / 86$ \\
$10 / 15 / 87$ \\
$12 / 15 / 90$ \\
$04 / 01 / 91$ \\
$08 / 24 / 91$ \\
$11 / 20 / 91$ \\
$10 / 14 / 92$ \\
$07 / 17 / 86$ \\
$04 / 08 / 87$ \\
$10 / 14 / 87$ \\
$02 / 19 / 88$ \\
$12 / 15 / 90$ \\
$03 / 28 / 91$ \\
$08 / 08 / 91$
\end{tabular} & $\begin{array}{l}0001 \\
0001 \\
0001 \\
0001 \\
0001 \\
0001 \\
0001 \\
0001 \\
0001 \\
0001 \\
0001 \\
0001 \\
0001 \\
0001 \\
0001 \\
0001 \\
0001 \\
0001 \\
0001 \\
0001 \\
0001 \\
0001\end{array}$ & $\begin{array}{l}\text { NA } \\
\text { NA } \\
\text { NA } \\
\text { NA } \\
\text { NA } \\
\text { NA } \\
\text { NA } \\
\text { NA } \\
\text { NA } \\
\text { NA } \\
\text { NA } \\
\text { HA } \\
\text { NA } \\
\text { NA } \\
\text { NA } \\
\text { NA } \\
\text { NA } \\
\text { NA } \\
\text { NA } \\
\text { NA } \\
\text { NA } \\
\text { NA }\end{array}$ & $\begin{array}{l}u \\
u \\
u \\
u \\
u \\
u \\
u \\
u \\
u \\
u \\
u \\
u \\
u \\
u \\
u \\
u \\
u \\
u \\
u \\
u \\
U \\
U\end{array}$ & $M G / L$ & & $\begin{array}{l}288 . \\
273 . \\
222 . \\
280 . \\
273 . \\
291 . \\
288 . \\
243 . \\
322 . \\
313 . \\
296 . \\
293 . \\
318 . \\
307 . \\
262 . \\
409 . \\
377 . \\
421 . \\
377 . \\
396 . \\
389 . \\
389 .\end{array}$ & $\begin{array}{l}10 . \\
10 . \\
10 . \\
10 . \\
10 . \\
10 . \\
10 . \\
10 . \\
10 . \\
10 . \\
10 . \\
10 . \\
10 . \\
10 . \\
10 . \\
10 . \\
10 . \\
10 . \\
10 . \\
10 . \\
10 . \\
10 .\end{array}$ & $\begin{array}{l}- \\
- \\
: \\
: \\
- \\
- \\
- \\
- \\
- \\
- \\
- \\
- \\
- \\
- \\
- \\
-\end{array}$ \\
\hline
\end{tabular}

FORMATION OF COMPLETION CODE: NA - NAVAJO SANDSTONE

PARAMETER VALUE INDICATOR (PVI): < - LESS THAN DETECTION LIMIT
FLOW RELATIOHSHIP COOE:

0001 - FILTERED SAMPLE (.45 MICROWS) 
TABLE 3.37 BASELINE GROUMDUATER QULAITY DATA BY PARAMETER FOR THE MAVAJO SANDSTONE, UC PROCESSING SITE, SLICK ROCK, COLORADO

SITE: SRKO1 SLICK ROCK (BOTH SITES)

06/30/86 TO $10 / 14 / 92$

REPORT DATE: 07/26/93

\begin{tabular}{|c|c|c|c|c|c|c|c|c|c|c|c|c|}
\hline & PARAMETER NAME & $\underset{\text { ID }}{\text { LOCATION }}$ & LOG DATE & $\begin{array}{c}\text { SAMPLE } \\
\text { I0 }\end{array}$ & $\begin{array}{l}\text { FORM } \\
\text { COMP }\end{array}$ & $\begin{array}{l}\text { FLOW } \\
\text { REL. }\end{array}$ & $\begin{array}{l}\text { UAITS OF } \\
\text { MEASURE }\end{array}$ & PVI & $\begin{array}{l}\text { PARAMETER } \\
\text { VALUE }\end{array}$ & FLAGS & $\begin{array}{l}\text { DETECTION } \\
\text { LIMIT }\end{array}$ & $\begin{array}{l}\text { PARAMETER } \\
\text { UACERTAIMTY }\end{array}$ \\
\hline & TOTAL DISSOLVED SOLIDS & $\begin{array}{l}0688 \\
0688\end{array}$ & $\begin{array}{l}12 / 06 / 91 \\
10 / 07 / 92\end{array}$ & $\begin{array}{l}0001 \\
0001\end{array}$ & $\begin{array}{l}\text { MA } \\
\text { NA }\end{array}$ & $\begin{array}{l}u \\
u\end{array}$ & $M G / L$ & & $\begin{array}{l}1760 . \\
379 .\end{array}$ & & $\begin{array}{l}10 . \\
10 .\end{array}$ & $\dot{-}$ \\
\hline & TOTAL KJELDAHL NITROGEN & $\begin{array}{l}0669 \\
0669 \\
0669 \\
0669 \\
0670 \\
0670 \\
0670 \\
0670 \\
0688 \\
0688 \\
0688 \\
0688\end{array}$ & $\begin{array}{l}12 / 15 / 90 \\
03 / 31 / 91 \\
08 / 24 / 91 \\
11 / 19 / 91 \\
12 / 15 / 90 \\
04 / 01 / 91 \\
08 / 24 / 91 \\
11 / 20 / 91 \\
12 / 15 / 90 \\
03 / 28 / 91 \\
08 / 08 / 91 \\
12 / 06 / 91\end{array}$ & $\begin{array}{l}0001 \\
0001 \\
0001 \\
0001 \\
0001 \\
0001 \\
0001 \\
0001 \\
0001 \\
0001 \\
0001 \\
0001\end{array}$ & $\begin{array}{l}\text { NA } \\
\text { NA } \\
\text { NA } \\
\text { NA } \\
\text { NA } \\
\text { NA } \\
\text { NA } \\
\text { NA } \\
\text { NA } \\
\text { NA } \\
\text { NA } \\
\text { NA }\end{array}$ & $\begin{array}{l}U \\
U \\
U \\
U \\
U \\
U \\
U \\
U \\
U \\
U \\
U \\
U\end{array}$ & MG/L & $\begin{array}{l}< \\
< \\
< \\
< \\
< \\
< \\
<\end{array}$ & $\begin{array}{l}1 . \\
1 . \\
1 . \\
2 . \\
1 . \\
1 . \\
1 . \\
2 . \\
1 . \\
1 . \\
1 . \\
2 .\end{array}$ & I & $\begin{array}{l}1 . \\
1 . \\
1 . \\
2 . \\
1 . \\
1 . \\
1 . \\
2 . \\
1 . \\
1 . \\
1 . \\
2 .\end{array}$ & $\begin{array}{l}- \\
- \\
- \\
- \\
- \\
- \\
- \\
- \\
-\end{array}$ \\
\hline$\stackrel{\dot{\omega}}{\omega}$ & TOTAL ORGANIC CARBON & $\begin{array}{l}0669 \\
0669 \\
0669 \\
0669 \\
0669 \\
0670 \\
0670 \\
0670 \\
0670 \\
0670 \\
0688 \\
0688 \\
0688 \\
0688 \\
0688\end{array}$ & $\begin{array}{l}12 / 15 / 90 \\
03 / 31 / 91 \\
08 / 24 / 91 \\
11 / 19 / 91 \\
10 / 12 / 92 \\
12 / 15 / 90 \\
04 / 01 / 91 \\
08 / 24 / 91 \\
11 / 20 / 91 \\
10 / 14 / 92 \\
12 / 15 / 90 \\
03 / 28 / 91 \\
08 / 08 / 91 \\
12 / 06 / 91 \\
10 / 07 / 92\end{array}$ & $\begin{array}{l}0001 \\
0001 \\
0001 \\
0001 \\
0001 \\
0001 \\
0001 \\
0001 \\
0001 \\
0001 \\
0001 \\
0001 \\
0001 \\
0001 \\
0001\end{array}$ & $\begin{array}{l}\text { NA } \\
\text { NA } \\
\text { NA } \\
\text { NA } \\
\text { NA } \\
\text { NA } \\
\text { NA } \\
\text { NA } \\
\text { NA } \\
\text { NA } \\
\text { NA } \\
\text { NA } \\
\text { NA } \\
\text { NA } \\
\text { NA }\end{array}$ & $\begin{array}{l}U \\
U \\
U \\
U \\
U \\
U \\
U \\
U \\
U \\
U \\
U \\
U \\
U \\
U \\
U\end{array}$ & $M G / L$ & $\mid \begin{array}{l}< \\
< \\
< \\
< \\
< \\
< \\
< \\
< \\
<\end{array}$ & $\begin{array}{c}59 . \\
1 . \\
1 . \\
1 . \\
2 . \\
42 . \\
1 . \\
1 . \\
1 . \\
7 . \\
66 . \\
1 . \\
1 . \\
1 . \\
1 .\end{array}$ & $\mathbf{J}$ & $\begin{array}{l}1 . \\
1 . \\
1 . \\
1 . \\
1 . \\
1 . \\
1 . \\
1 . \\
1 . \\
1 .\end{array}$ & $\begin{array}{l}- \\
- \\
- \\
- \\
- \\
- \\
- \\
- \\
- \\
- \\
-\end{array}$ \\
\hline & URANIUM & $\begin{array}{l}0669 \\
0669 \\
0669 \\
0669 \\
0669 \\
0669\end{array}$ & $\begin{array}{l}06 / 30 / 86 \\
10 / 14 / 87 \\
02 / 19 / 88 \\
12 / 15 / 90 \\
03 / 31 / 91 \\
08 / 24 / 91\end{array}$ & $\begin{array}{l}0001 \\
0001 \\
0001 \\
0001 \\
0001 \\
0001\end{array}$ & $\begin{array}{l}\text { MA } \\
\text { NA } \\
\text { NA } \\
\text { NA } \\
\text { NA } \\
\text { NA }\end{array}$ & $\begin{array}{l}u \\
u \\
u \\
u \\
u \\
u\end{array}$ & $M G / L$ & $<$ & $\begin{array}{l}0.002 \\
0.003 \\
0.0010 \\
0.0003 \\
0.001 \\
0.001\end{array}$ & $\begin{array}{l}c \\
c\end{array}$ & $\begin{array}{l}0.002 \\
0.003 \\
0.001 \\
0.0003 \\
0.001 \\
0.001\end{array}$ & $\begin{array}{l}- \\
- \\
- \\
-\end{array}$ \\
\hline
\end{tabular}

FORMATION OF COMPLETION CODE:

NA - MAVAJO SANDSTONE

FLOW RELATIONSHIP COOE:

PARAMETER VALUE IMDICATOR (PVI): < - LESS than DETECTION LIMIT U - UPGRADIENT

SAMPLE ID CODES:

0001 - FILTERED SAMPLE (.45 MICRONS)

OTHER PARAMETER VALUE FLAGS:

1 - INCREASED DETECTION LIMIT DUE TO REQUIRED DILUTION

J. ESTIMATED VALUE

c - CHANGED DETECTION LIMIT 
TABLE 3.37 BASELINE GROUNDHATER QULAITY DATA BY PARAMETER FOR THE

MAVAJO SANDSTONE, UC PROCESSING SITE, SLICK ROCK, COLORADO

SITE: SRKO1 SLICK ROCK (BOTH SITES)

$06 / 30 / 86$ TO $10 / 14 / 92$

REPORT DATE: $07 / 26 / 93$

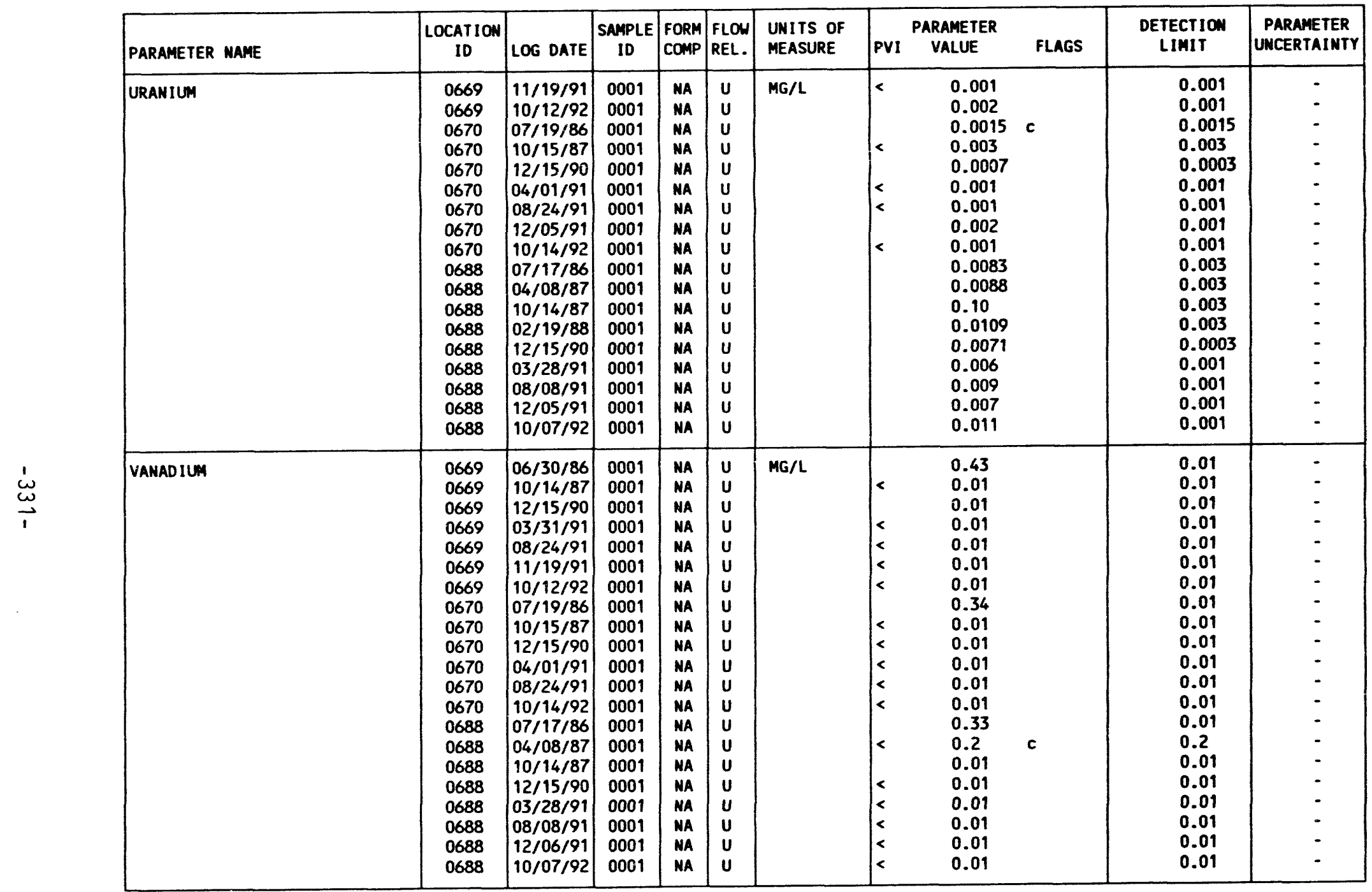

FORMATION OF COMPLETION COOE:

FLOW RELATIONSHIP CODE:

NA - NAVAJO SANDSTONE

$U$ - UPGRADIENT

PARAMETER VALUE IMDICATOR (PVI): < - LESS THAN DETECTION LIMIT

SAMPLE ID CODES:

0001 - FILTERED SAMPLE (.45 MICRONS)

OTHER PARAMETER VALUE FLAGS

C - CHANGED DETECTION LIMIT 
TABLE 3.37 BASELINE GROUNDWATER QULAITY DATA BY PARAMETER FOR THE

NAVAJO SANDSTONE, UC PROCESSING SITE, SLICK ROCK, COLORADO

SITE: SRKO1 SLICK ROCK (BOTH SITES)

06/30/86 TO 10/14/92

REPORT DATE: $07 / 26 / 93$

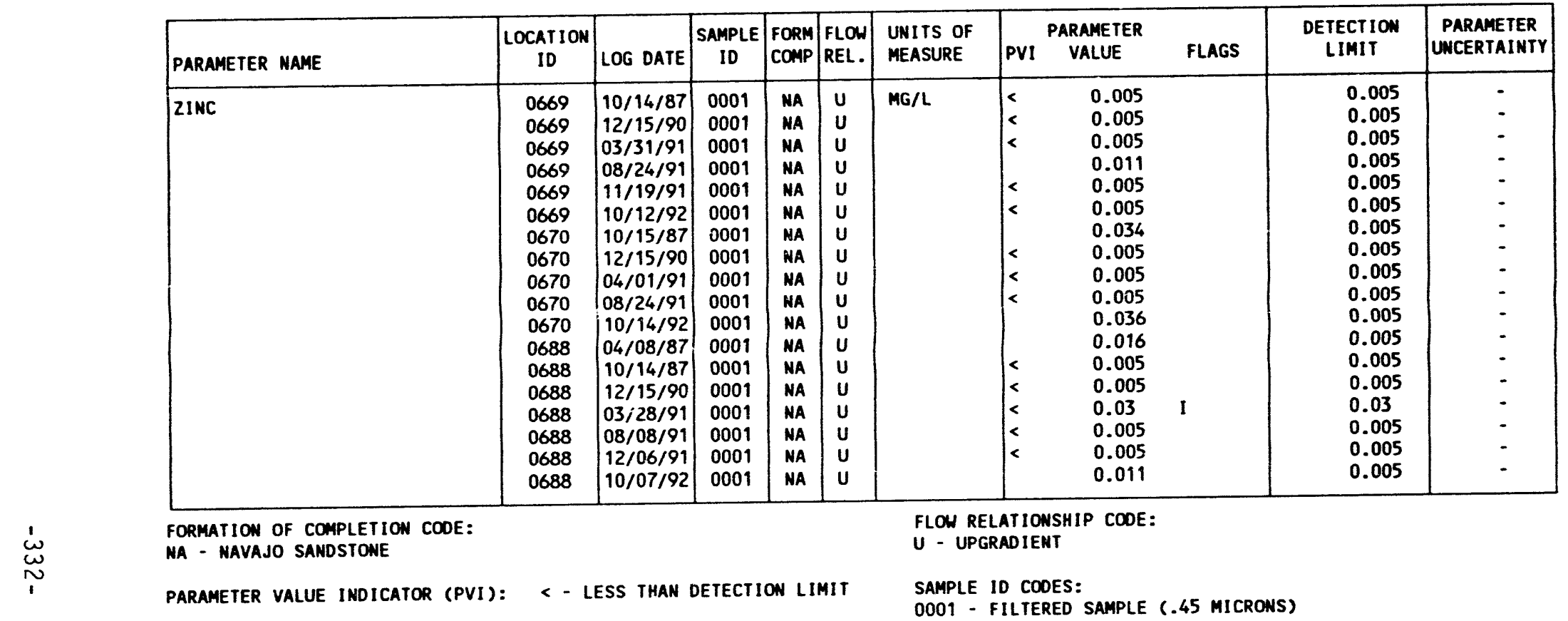

OTHER PARAMETER VALUE FLAGS:

I - INCREASED DETECTION LIMIT DUE TO REQUIRED DILUTION

DATA FILE HAME: M: IOARTISRKO1\GWO10029.DAT 
TABLE 338 BASELIME GROUMDHATER QUALITY STATISTICS BY PARAMETER

TAB THE MAVA SANDSTONE, UC PROCESSING SITE, SLICK ROCK, COLORADO

FOR THE NAVAJO SANOSTONE, (BOTH SITES)

SITE: SRKO1 SLICK ROCK

REPORT DATE: $07 / 26 / 93$

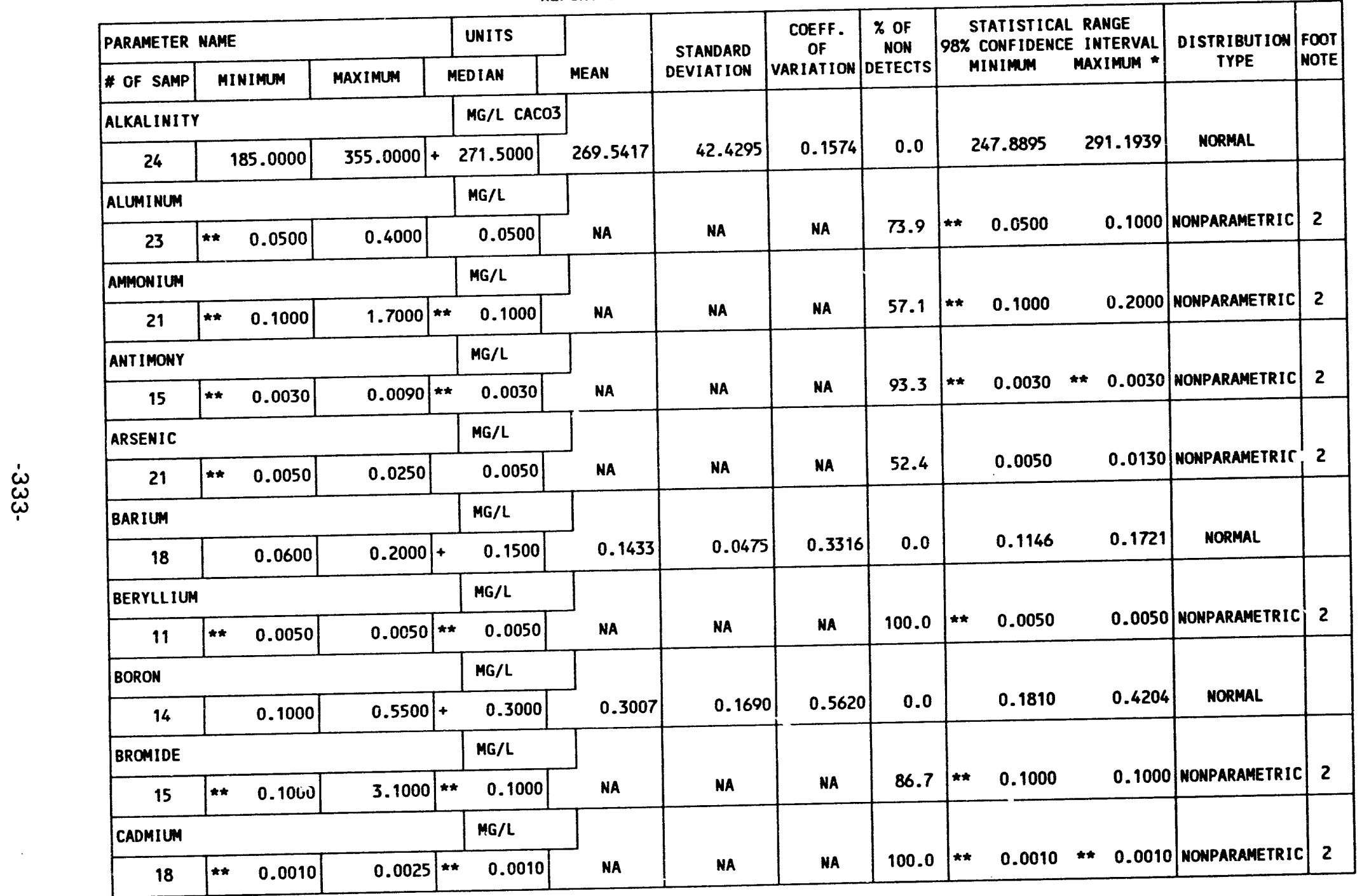

** The reported value is the minimum detection limit of the data set

the minime dwo middle values

* The sample size is even, so the median value sided confidence interval, $\alpha=0.01$

* The statistical maximum is the 99 percent one sided confidence interval, $\alpha=0.01$ more than $15 \%$ of the samples. 
TABLE 3.38 BASELINE GROUNDWATER QUALITY STATISTICS BY PARAMETER

FOR THE NAVAJO SANDSTONE, UC PROCESSING SITE, SLICK ROCK, COLORADO

SITE: SRKO1 SLICK ROCK (BOTH SITES)

$06 / 30 / 36$ TO $10 / 14 / 92$

REPORT DATE : 07/26/93

\begin{tabular}{|c|c|c|c|c|c|c|c|c|c|c|c|}
\hline \multicolumn{3}{|c|}{ PARAMETER NAME } & UNITS & \multirow[b]{2}{*}{ MEAN } & \multirow{2}{*}{$\begin{array}{r}\text { STANDARD } \\
\text { DEVIATION }\end{array}$} & \multirow{2}{*}{$\begin{array}{c}\text { COEFF. } \\
\text { OF } \\
\text { VARIATION }\end{array}$} & \multirow{2}{*}{$\begin{array}{c}\% \text { OF } \\
\text { NON } \\
\text { DETECTS }\end{array}$} & \multicolumn{2}{|c|}{$\begin{array}{c}\text { STATISTICAL RANGE } \\
98 \% \text { CONFIDENCE INTERVAL }\end{array}$} & \multirow{2}{*}{$\begin{array}{c}\text { DISTRIBUTION } \\
\text { TYPE }\end{array}$} & \multirow{2}{*}{ FOT } \\
\hline \# OF SAMP & MINIMUM & MAXIMUM & MEDIAN & & & & & MINIMUM & MAXIMUM * & & \\
\hline \multicolumn{3}{|l|}{ CALCIUM } & MG/L & \multirow[b]{2}{*}{44.9087} & \multirow[b]{2}{*}{15.4879} & \multirow[b]{2}{*}{0.3449} & \multirow[b]{2}{*}{0.0} & \multirow[b]{2}{*}{36.8092} & \multirow[b]{2}{*}{53.0081} & \multirow[b]{2}{*}{ NORMAL } & \\
\hline 23 & 6.6000 & 68.0000 & 42.0000 & & & & & & & & \\
\hline \multicolumn{3}{|l|}{ CHLORIDE } & $M G / L$ & \multirow[b]{2}{*}{13.1170} & \multirow[b]{2}{*}{3.1063} & \multirow[b]{2}{*}{ NA } & \multirow[b]{2}{*}{0.0} & \multirow[b]{2}{*}{7.3559} & \multirow[b]{2}{*}{23.3900} & \multirow[b]{2}{*}{ LOGNORMAL } & \multirow[b]{2}{*}{7,8} \\
\hline 24 & 4.0000 & 660.0000 & 9.4500 & & & & & & & & \\
\hline \multicolumn{3}{|l|}{ CHROMIUM } & $\mathrm{MG} / \mathrm{L}$ & \multirow[b]{2}{*}{ NA } & \multirow[b]{2}{*}{ NA } & \multirow[b]{2}{*}{ NA } & \multirow[b]{2}{*}{100.0} & \multirow[b]{2}{*}{0.0100} & \multirow[b]{2}{*}{$\star \star \quad 0.0100$} & & \\
\hline 18 & 0.0100 & ** $\quad 0.0100$ & ** $\quad 0.0100$ & & & & & & & MONPARAMETRIC & 2 \\
\hline COBALT & & & $M G / L$ & & & & & & & & \\
\hline 11 & ** $\quad 0.0300$ & * $\quad 0.0300$ & $\star * \quad 0.0300$ & NA & NA & NA & 100.0 & 0.0300 & $\star * 0.0300$ & NONPARAMETRIC & 2 \\
\hline COPPER & & & $M G / L$ & & & & & & & & \\
\hline 18 & ** $\quad 0.0100$ & 0.0100 & 0.0100 & NA & NA & NA & 100.0 & 0.0100 & 0.0100 & MONPARAMETRIC & 2 \\
\hline CYANIDE & & & $M G / L$ & & & & & & & & \\
\hline 12 & $\star \star \quad 0.0100$ & * $\quad 0.0100$ & 0.0100 & NA & NA & NA & 100.0 & 0.0100 & $\star \quad 0.0100$ & NONPARAMETRIC & 2 \\
\hline DISSOL VED & OXYGEN & & $\mathrm{MG} / \mathrm{L}$ & & & & & & & & \\
\hline 2 & 1.1000 & 5.4000 & 3.2500 & NA & NA & MA & 0.0 & NA & NA & UNKNOWN & 1 \\
\hline FIELD FE & $(2+)$ & & MG/L & & & & & & & & \\
\hline 1 & 0.0300 & 0.0300 & 0.0300 & NA & NA & NA & 0.0 & NA & MA & UNKNOWN & 1 \\
\hline FLUORIDE & & & MG/L & & & & & & & & \\
\hline 21 & 0.2000 & 1.4000 & 1.0000 & 0.8433 & 0.3403 & c. 4036 & 0.0 & 0.6556 & 1.0311 & NORMAL & \\
\hline
\end{tabular}

** The reported value is the minimum detection limit of the data set

+ The sample size is even, so the median value is the arithmetic sverage of the two middle values

- The statistical maximm is the 99 percent one sided confidence interval, $a=0.01$

1) A minimum of 4 samples must be available for the statistical analysis.

2) The nonparametric distribution was used because the nondetected values comprise more than $15 \%$ of the samples.

7) The lognormal distribution was used because the data failed the normal distribution test.

8) The mean is geometric. The standard deviation is the value to divide or multiply with the geometric mean. 


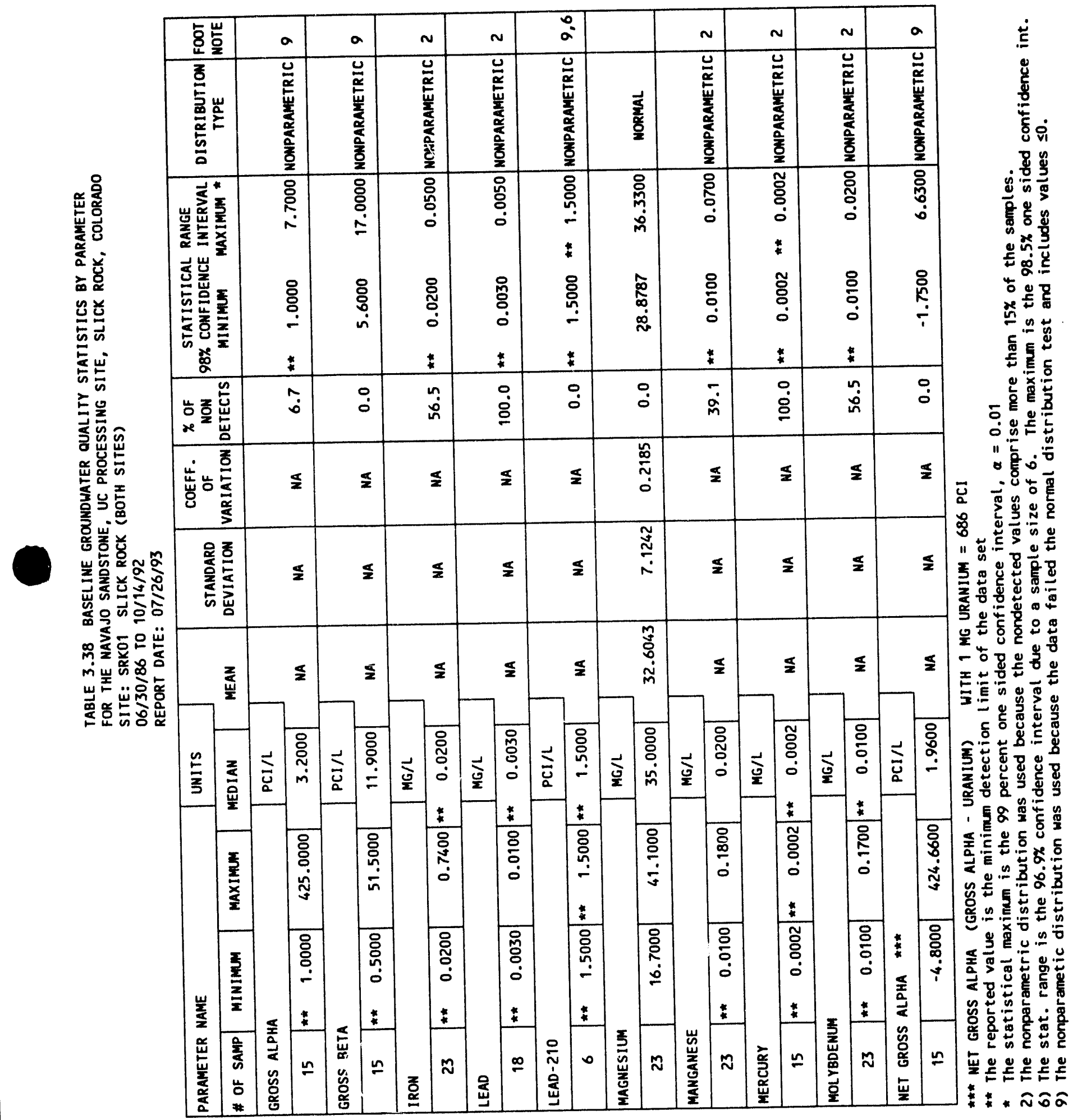


TABLE 3.38 BASELINE GROUNDHATER QUALITY STATISTICS BY PARAMETER FOR THE NAVAJO SAMDSTONE, UC PROCESSING SITE, SLICK ROCK, COLORADO

SITE: SRKO1 SLICK ROCK (BOTH SITES)

SITE: SRK01 SLICK ROCK
$06 / 30 / 86$ TO $10 / 14 / 92$

REPORT DATE: $07 / 26 / 93$

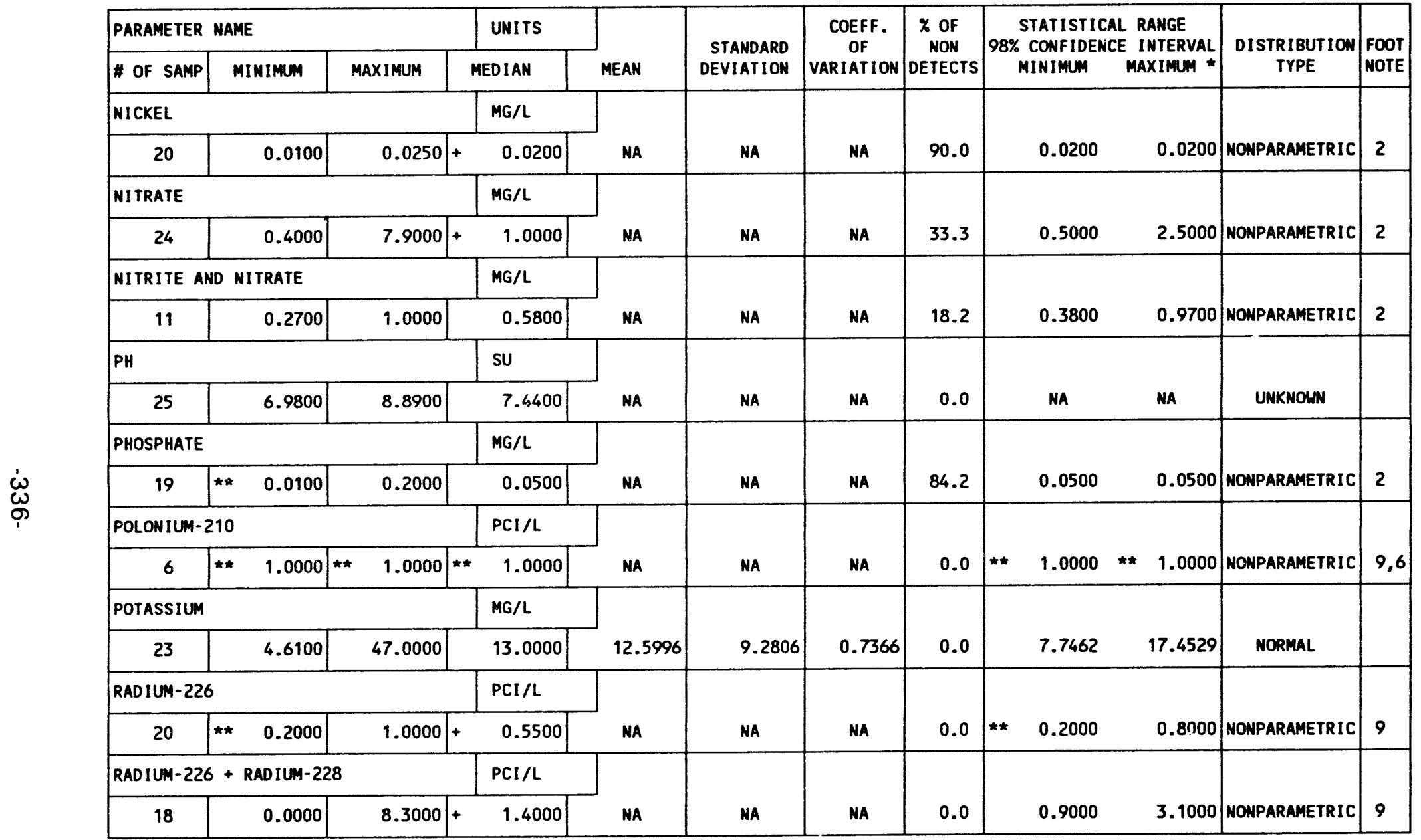

** The reported value is the minimum detection limit of the fata set

+ The sample size is even, so the median value is the arithmeisc averagr of the two middle values

* The statistical maximum is the 99 percent one sided confidence interval, $\alpha=0.01$

1) A minimum of 4 samples must be available for the statistical analysis.

2) The nonparametric distribution was used because the nondetected values comprise more than $15 \%$ of the samples.

6) The stat. range is the $96.9 \%$ confidence interval due to a sample size of 6 . The maximum is the $98.5 \%$ one sided confidence int.

9) The nonparametic distribution was used because the data failed the normal distribution test and includes values $\leq 0$. 
TABLE 3.38 BASELINE GROUMDUATER QUALITY STATISTICS BY PARAMETER FOR THE MAVAJO SANDSTONE, UC PROCESSING SITE, SLICK ROCK, COLORADO SITE: SRKO1 SLICK ROCK

$06 / 30 / 86$ TO $10 / 14 / 92$

REPORT DATE: $07 / 26 / 93$

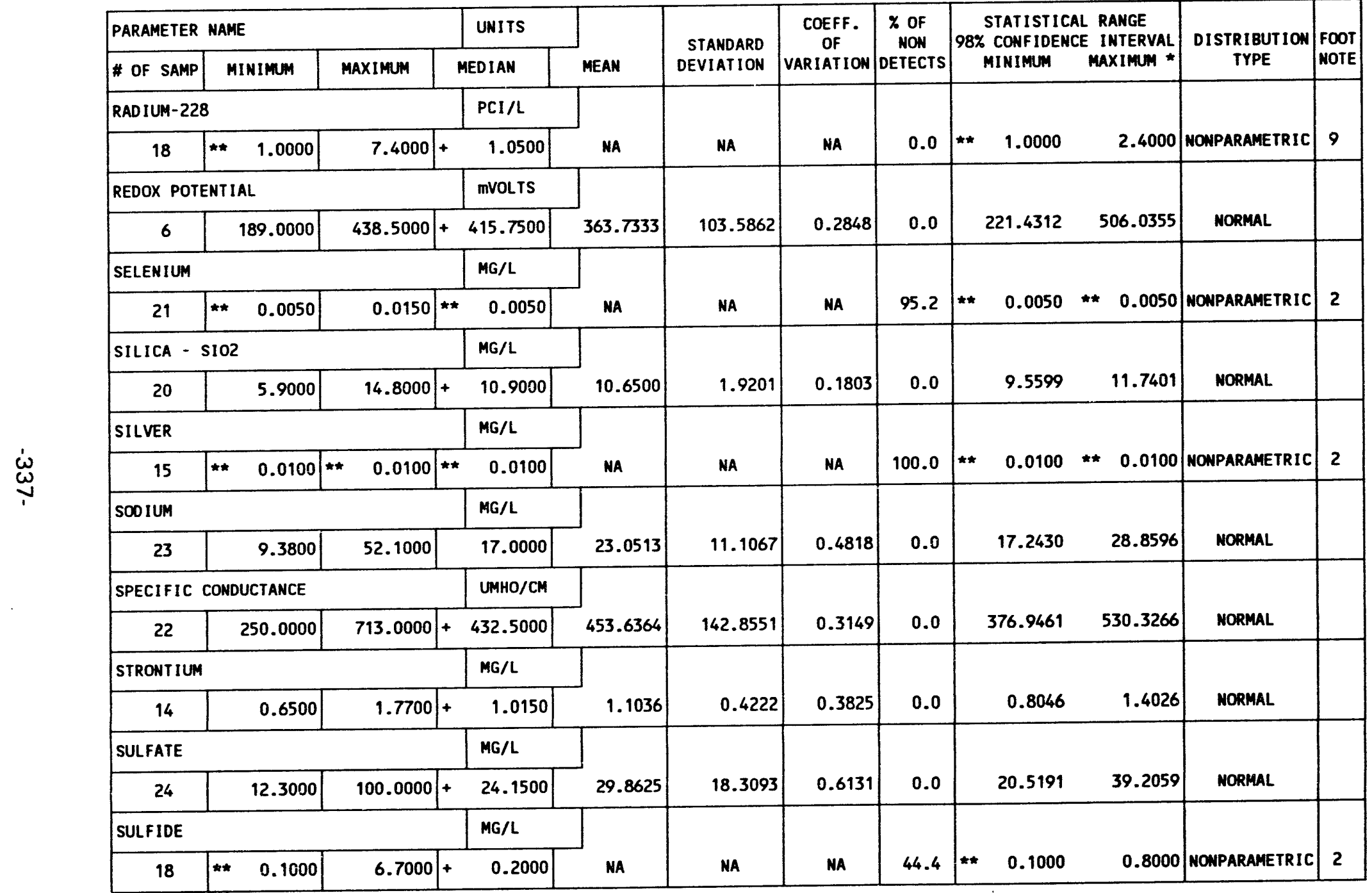

** The reported value is the minimum detection limit of the data set

+ The sample size is even, so the median value is the arithmetic average of the two middle values

* The statistical maximm is the 99 percent one sided confidence interval, $a=0.01$

2) The nomparametric distribution uas used because the nondetected values comprise more than $15 \%$ of the samples.

9) The nonparametic distribution was used because the data failed the normal distribution test and includes values $\leq 0$. 
TABLE 3.38 BASELINE GROUNDWATER QUALITY STATISTICS BY PARAMETER

FOR THE NAVAJO SANDSTONE, UC PROCESSING SITE, SLICK ROCK, COLORADO

SITE: SRK01 SLICK ROCK (BOTH SITES)

$06 / 30 / 86$ TO $10 / 14 / 92$

REPORT DATE: $07 / 26 / 93$

\begin{tabular}{|c|c|c|c|c|c|c|c|c|c|c|c|c|}
\hline \multicolumn{3}{|c|}{ PARAMETER MAME } & UNITS & \multirow[b]{2}{*}{ MEAN } & \multirow{2}{*}{$\begin{array}{l}\text { STANDARD } \\
\text { DEVIATION }\end{array}$} & \multirow{2}{*}{$\begin{array}{c}\text { COEFF. } \\
\text { OF } \\
\text { VARIATION }\end{array}$} & \multirow{2}{*}{$\begin{array}{c}\% \text { OF } \\
\text { NON } \\
\text { DETECTS }\end{array}$} & \multirow{2}{*}{\multicolumn{3}{|c|}{$\begin{array}{c}\text { STATISTICAL RANGE } \\
\text { 98\% CONFIDENCE INTERVAL } \\
\text { MINIMUM } \\
\text { MAXIMUM * }\end{array}$}} & \multirow{2}{*}{$\begin{array}{c}\text { DISTRIBUTION } \\
\text { TYPE }\end{array}$} & \multirow{2}{*}{$\begin{array}{l}\text { FOOT } \\
\text { NOTE }\end{array}$} \\
\hline \# OF SAMP & MINIMUM & MAXIMUM & MEDIAN & & & & & & & & & \\
\hline \multicolumn{3}{|c|}{ TEMPERATURE } & $C$ - DEGR & \multirow[b]{2}{*}{12.9800} & \multirow[b]{2}{*}{1.1460} & \multirow[b]{2}{*}{0.0883} & \multirow[b]{2}{*}{0.0} & \multirow{2}{*}{\multicolumn{2}{|c|}{12.4088}} & \multirow[b]{2}{*}{13.5512} & \multirow[b]{2}{*}{ NORMAL } & \\
\hline 25 & 10.6000 & 15.0000 & 13.0000 & & & & & & & & & \\
\hline \multicolumn{3}{|l|}{ THALLIUM } & $M G / L$ & \multirow[b]{2}{*}{ NA } & \multirow[b]{2}{*}{ NA } & \multirow[b]{2}{*}{ NA } & \multirow[b]{2}{*}{100.0} & \multirow[b]{2}{*}{$\star \star \star$} & \multirow[b]{2}{*}{0.0050} & \multirow[b]{2}{*}{0.0050} & \multirow[b]{2}{*}{ MONPARAMETRIC } & \multirow[b]{2}{*}{2} \\
\hline 14 & $\star \quad 0.0050$ & 0.0050 & 0.0050 & & & & & & & & & \\
\hline \multicolumn{3}{|c|}{ THOR IUM - 230} & $\mathrm{PCI} / \mathrm{L}$ & \multirow[b]{2}{*}{ NA } & \multirow[b]{2}{*}{ NA } & \multirow[b]{2}{*}{ NA } & \multirow[b]{2}{*}{0.0} & \multirow[b]{2}{*}{$\star \star *$} & & & & \\
\hline 6 & ** $\quad 1.0000$ & $\star \star \quad 1.0000$ & $\star \star * \quad 1.0000$ & & & & & & 1.0000 & $\star * \quad 1.0000$ & NONPARAMETRIC & 9,6 \\
\hline TIN & & & $M G / L$ & & & & & & & & & \\
\hline 14 & $\star * \quad 0.0050$ & $\star \quad \quad 0.0050$ & ** $\quad 0.0050$ & NA & NA & NA & 100.0 & $\star \star \star$ & 0.0050 & $\star \quad 0.0050$ & NONPARAMETRIC & 2 \\
\hline TOTAL DISS & SOLVED SOLIDS & & $M G / L$ & & & & & & & & & \\
\hline 24 & 222.0000 & 1760.0000 & +310.0000 & 381.9167 & 298.8620 & 0.7825 & 0.0 & & 229.4043 & 534.4291 & NORMAL & \\
\hline TOTAL KJEL & DAHL NITROGE & & $M G / L$ & & & & & & & & & \\
\hline 12 & ** $\quad 1.0000$ & 1.0000 & 1.0000 & NA & NA & NA & 66.7 & $\star \star \star$ & 1.0000 & 1.0000 & NONPARAMETRIC & 2 \\
\hline TOTAL ORG & ANIC CARBON & & $M G / L$ & & & & & & & & & \\
\hline 15 & $\star \star \quad 1.0000$ & 66.0000 & $\star \star * \quad 1.0000$ & NA & NA & NA & 53.3 & $\star \star$ & 1.0000 & 42.0000 & NONPARAMETRIC & 2 \\
\hline URANIUM & & & $M G / L$ & & & & & & & & & \\
\hline 24 & ** $\quad 0.0003$ & 0.1000 & 0.0018 & NA & NA & NA & 37.5 & & 0.0005 & 0.0083 & MONPARAMETRIC & 2 \\
\hline VANADIUM & & & MG/L & & & & & & & & & \\
\hline 21 & 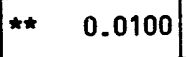 & 0.4300 & 0.0100 & NA & NA & NA & 76.2 & $\star \star *$ & 0.0100 & 0.0100 & NONPARAMETRIC & 2 \\
\hline ZINC & & & $M G / L$ & & & & & & & & & \\
\hline 18 & $\star * \quad 0.0050$ & 0.0360 & 0.0050 & NA & NA & NA & 72.2 & $\star \star$ & 0.0050 & 0.0150 & MONPARAMETRIC & 2 \\
\hline
\end{tabular}

** The reported value is the minimum detection limit of the data set

列

+ The sample size is even, so the median value is the arithice interval, $a=0.01$

* The statistical maximm is the 99 percent one sided confidence interval, comprise more than 15\% of the samples.

2) The nonparametric distribution was used because the nondetected values comprise moximum is the $98.5 \%$ one sided confidence int.

6) The stat. range is the $96.9 \%$ confidence interval due to a sample size of 6 . The maximation test and includes values $\leq 0$. 
Table 3.39 Summary of regulated constituents in the Navajo Sandstone baseline groundwater,

UC processing site, Slick Rock, Colorado

Constituents with MCLs ${ }^{a}$

\begin{tabular}{lllll}
\hline \multicolumn{1}{c}{ Parameter } & $\begin{array}{c}\text { Baseline } \\
\text { Median }\end{array}$ & $\begin{array}{c}\text { Baseline } \\
\text { Stat Max }\end{array}$ & $\begin{array}{c}\text { Background } \\
\text { Stat Max }\end{array}$ & MCL \\
\hline Arsenic & $0.01^{\mathrm{g}}$ & $0.013^{\mathrm{e}}$ & $0.01^{\mathrm{e}}$ & 0.05 \\
Barium & $0.14^{\mathrm{d}}$ & 0.17 & $0.18^{\mathrm{d}}$ & 1.00 \\
Cadmium & $0.001^{\mathrm{g}}$ & $0.001^{\mathrm{g}}$ & $0.001^{\mathrm{g}}$ & 0.01 \\
Chromium & $0.01^{\mathrm{g}}$ & $0.01^{\mathrm{g}}$ & $0.01^{\mathrm{g}}$ & 0.05 \\
Net gross alpha & $1.96^{\mathrm{e}}$ & 6.63 & $3.63^{\mathrm{e}}$ & 15.00 \\
Lead & $0.01^{\mathrm{g}}$ & $0.01^{\mathrm{g}}$ & $0.01^{\mathrm{g}}$ & 0.05 \\
Mercury & $0.0002^{\mathrm{g}}$ & $0.0002^{\mathrm{g}}$ & $0.0002^{\mathrm{g}}$ & 0.002 \\
Molybdenum & $0.01^{\mathrm{c}}$ & 0.02 & $0.06^{\mathrm{c}}$ & 0.10 \\
Nitrate & $1.00^{\mathrm{e}}$ & 2.5 & $5.7^{\mathrm{e}}$ & 44.0 \\
Radium-226,-228 & $1.4^{\mathrm{e}}$ & 3.1 & $5.61^{\mathrm{c}}$ & 5.0 \\
Selenium & $0.005^{\mathrm{g}}$ & $0.005^{\mathrm{g}}$ & $0.025^{\mathrm{c}}$ & 0.01 \\
Silver & $0.01^{\mathrm{g}}$ & $0.01^{\mathrm{g}}$ & $0.30^{\mathrm{e}}$ & 0.05 \\
Uranium & $0.002^{\mathrm{e}}$ & 0.008 & $0.012^{\mathrm{c}}$ & 0.044 \\
& & & & \\
\hline
\end{tabular}


Table 3.39 summary of regulated constituents in the Navajo Sandstone baseline groundwater, UC processing site, Slick Rock, Colorado (concluded)

Constituents without MCLsa

\begin{tabular}{llccc}
\hline \multicolumn{1}{c}{ Parameter } & $\begin{array}{c}\text { Baseline } \\
\text { Median }\end{array}$ & $\begin{array}{c}\text { Baseline } \\
\text { Stat Max }\end{array}$ & $\begin{array}{c}\text { Background } \\
\text { Stat. Max }\end{array}$ & MCL \\
\hline Antimony & $0.003^{\mathrm{g}}$ & $0.003^{\mathrm{g}}$ & $0.003^{\mathrm{g}}$ & None \\
Beryllium & $0.01^{\mathrm{g}}$ & $0.01^{\mathrm{g}}$ & $0.01^{\mathrm{g}}$ & None \\
Cobalt & $0.05^{\mathrm{g}}$ & $0.05^{\mathrm{g}}$ & $0.05^{\mathrm{g}}$ & None \\
Copper & $0.02^{\mathrm{g}}$ & $0.02^{\mathrm{g}}$ & $0.02^{\mathrm{g}}$ & None \\
Cyanide & $0.01^{\mathrm{g}}$ & $0.01^{\mathrm{g}}$ & $0.01^{\mathrm{g}}$ & None \\
Nickel & $0.04^{\mathrm{g}}$ & $0.04^{\mathrm{g}}$ & $0.04^{\mathrm{g}}$ & None \\
Sulfide & $0.2^{\mathrm{e}}$ & $0.8^{\mathrm{e}}$ & $16.6^{\mathrm{e}}$ & None \\
Thallium & $0.01^{\mathrm{g}}$ & $0.01^{\mathrm{g}}$ & $0.01^{\mathrm{g}}$ & None \\
Tin & $0.005^{\mathrm{g}}$ & $0.005^{\mathrm{g}}$ & $0.025^{\mathrm{e}}$ & None \\
Vanadium & $0.01^{\mathrm{g}}$ & $0.01^{\mathrm{g}}$ & $0.01^{\mathrm{g}}$ & None \\
Zinc & $0.005^{\mathrm{g}}$ & $0.015^{\mathrm{e}}$ & $0.007^{\mathrm{e}}$ & None \\
\hline
\end{tabular}

"All units are $\mathrm{mg} / \mathrm{l}$ unless otherwise noted.

'NC Processing site background groundwater statistical maximum.

'Lognormal distribution, mean is geometric.

dNormal distribution, mean is arithmetic.

"Nonparametric distribution

Units are $\mathrm{pCi} / \mathrm{l}$.

'Statistical values are below laboratory detection limits in

Table 8.1 of the Technical Approach Document (DOE, 1989). 
TABLE 3.40 GROUNOWATER QUALITY MEASUREMENTS EXCEEDING MCLS IN NAVAJO SANDSTONE BASELINE GROUNDWATER, UC PROCESSING SITE, SLICK ROCK, CO SITE: SRKO1 SLICK ROCK (BOTH SITES)

$06 / 30 / 86$ TO $10 / 14 / 92$

\begin{tabular}{|c|c|c|c|c|c|c|c|c|c|c|c|}
\hline PARAMETER NAME & $\begin{array}{l}\text { TOTAL } \\
\# \text { OF } \\
\text { SAMP. }\end{array}$ & $\begin{array}{l}\text { UNITS } \\
\text { OF } \\
\text { MEASURE }\end{array}$ & $\begin{array}{c}\text { MAXIMUN } \\
\text { CONC. } \\
\text { LIMIT }\end{array}$ & $\begin{array}{c}\text { LOC. } \\
\text { ID }\end{array}$ & LOG DATE & $\begin{array}{c}\text { SAMAP } \\
\text { ID }\end{array}$ & $\begin{array}{c}\text { FORM } \\
\text { OF } \\
\text { COMP }\end{array}$ & $\begin{array}{l}\text { HYDR } \\
\text { FLOW } \\
\text { REL. }\end{array}$ & $\begin{array}{l}\text { RESULT EXCEEDING MAX. } \\
\text { CONCENTRATION LIMIT } \\
\text { VALUE FLAGS }\end{array}$ & $\begin{array}{l}\text { DETECTION } \\
\text { LIMIT }\end{array}$ & $\begin{array}{l}\text { PARAMETER } \\
\text { UNCERT. }\end{array}$ \\
\hline ARSENIC & 21 & $M G / L$ & 0.0500 & - & $\cdot$ & - & - & - & - & $\cdot$ & - \\
\hline ARSENIC (TOTAL) & 0 & $M G / L$ & 0.0500 & - & - & - & - & - & - & - & - \\
\hline BARIUM & 18 & $M G / L$ & 1.0000 & - & - & - & - & - & $\cdot$ & - & - \\
\hline BARIUM (TOTAL) & 0 & $M G / L$ & 1.0000 & - & - & - & - & - & $\cdot$ & - & - \\
\hline CADMIUM & 18 & $M G / L$ & 0.0100 & $\cdot$ & - & - & - & - & - & - & - \\
\hline CADMIUM (TOTAL) & 0 & $M G / L$ & 0.0100 & - & - & - & - & - & - & - & - \\
\hline CHROMIUM & 18 & $M G / L$ & 0.0500 & - & - & - & - & - & - & - & - \\
\hline CHROMIUM (TOTAL) & 0 & $M G / L$ & 0.0500 & - & - & - & - & - & - & - & - \\
\hline GROSS ALPHA & 15 & $\mathrm{PCI} / \mathrm{L}$ & 15.0000 & 0669 & $11 / 19 / 91$ & 0001 & NA & $u$ & 425. & 1. & 20.2 \\
\hline GROSS ALPHA (TOTAL) & 0 & $\mathrm{PCI} / \mathrm{L}$ & 15.0000 & - & - & - & - & - & - & - & - \\
\hline LEAD & 18 & $M G / L$ & 0.0500 & - & - & - & - & - & - & - & - \\
\hline LEAD (TOTAL) & 0 & $M G / L$ & 0.0500 & $\cdot$ & - & - & - & - & $\therefore$ & - & - \\
\hline MERCURY & 15 & $M G / L$ & 0.0020 & - & - & - & - & - & - & - & - \\
\hline MERCURY (TCTAL) & 0 & MG/L & 0.0020 & - & - & - & - & - & - & - & - \\
\hline MOL YBDENUM & 23 & $M G / L$ & 0.1000 & $\begin{array}{l}0669 \\
0670 \\
0688 \\
0688\end{array} \mid$ & $\begin{array}{l}06 / 30 / 86 \\
07 / 19 / 86 \\
07 / 17 / 86 \\
04 / 08 / 87\end{array}$ & $\left|\begin{array}{l}0001 \\
0001 \\
0001 \\
0001\end{array}\right|$ & $\begin{array}{l}\text { NA } \\
\text { NA } \\
\text { NA } \\
\text { NA }\end{array}$ & $\begin{array}{l}u \\
U \\
u \\
u\end{array}$ & $\begin{array}{l}0.17 \\
0.14 \\
0.15 \\
0.1\end{array}$ & $\begin{array}{l}0.01 \\
0.01 \\
0.01 \\
0.1\end{array}$ & $\begin{array}{l}- \\
-\end{array}$ \\
\hline MOLYBDENUM (TOTAL) & 0 & $M G / L$ & 0.1000 & - & - & - & - & - & - & - & - \\
\hline MET GROSS ALPHA * & 15 & $\mathrm{PCI} / \mathrm{L}$ & 15.0000 & 0669 & $11 / 19 / 91$ & 0001 & NA & U & 424.7 & - & - \\
\hline
\end{tabular}

< - the data is flagged as a nON-DEtect, so the Result is an estimated VAlUe or the detection Limit
* net gross alpha (gross alpha - uranium)
WITH 1 MG URANIUM $=686 \mathrm{PCI}$

FORMATION OF COMPLETION COOE:

MA - MAVAJO SANDSTONE

FLOW RELATIONSHIP COOE:

U - UPGRADIENT

OTHER PARAMETER VALUE FLAGS

C. CHAMGED DETECTION LIMIT

SAMPLE ID CODES:

0001 - FILTERED SAMPLE (.45 MICRONS) 
TABLE 3.40 GROUNDHATER QUALITY MEASUREMEHTS EXCEEDING MCLS IN

MAVAJO SANDSTONE BASELINE GROUNDWATER, UC PROCESSING SITE, SLICK ROCK, CO SITE: SRKO1 SLICK ROCK (BOTH SITES)

SITE: SRKO1 SLICK ROCK

REPORT DATE: $07 / 26 / 93$

\begin{tabular}{|c|c|c|c|c|c|c|c|c|c|c|c|}
\hline PARAMETER NAME & $\begin{array}{l}\text { TOTAL } \\
\text { \# OF } \\
\text { SAMP. }\end{array}$ & $\begin{array}{l}\text { UNITS } \\
\text { OF } \\
\text { MEASURE }\end{array}$ & $\begin{array}{l}\text { MAXIMUM } \\
\text { CONC. } \\
\text { LIMIT }\end{array}$ & LOC. & LOG DATE & $\begin{array}{c}\text { SAMP } \\
\text { ID }\end{array}$ & $\begin{array}{c}\text { FORM } \\
\text { OF } \\
\text { COMP }\end{array}$ & $\begin{array}{l}\text { HYDR } \\
\text { FLOW } \\
\text { REL. }\end{array}$ & $\begin{array}{l}\text { RESULT EXCEEDING MAX. } \\
\text { CONCENTRATION LIMIT } \\
\text { VALUE FLAGS }\end{array}$ & $\begin{array}{l}\text { DETECTION } \\
\text { LIMIT }\end{array}$ & $\begin{array}{l}\text { PARAMETER } \\
\text { UNCERT. }\end{array}$ \\
\hline NET GROSS ALPHA (TOTAL) ** & 0 & $\mathrm{PCI} / \mathrm{L}$ & 15.0000 & - & - & - & - & - & - & - & - \\
\hline NITRATE & 24 & $M G / L$ & 44.0000 & - & - & - & - & - & - & - & - \\
\hline NITRATE (TOTAL) & 0 & MG/L & 44.0000 & - & - & - & - & - & - & $\cdot$ & - \\
\hline RA-226 \& RA- 228 & 18 & $\mathrm{PCI} / \mathrm{L}$ & 5.0000 & 0669 & $03 / 31 / 91$ & 0001 & NA & $u$ & 8.3 & - & - \\
\hline RA-226 \& RA-228 (TOTAL) & 0 & $\mathrm{PCI} / \mathrm{L}$ & 5.0000 & - & - & - & - & - & - & - & - \\
\hline SELENIUM & 21 & $M G / L$ & 0.0100 & $\begin{array}{l}0669 \\
0670\end{array}$ & $\begin{array}{l}03 / 31 / 91 \\
04 / 01 / 91\end{array}$ & $\begin{array}{l}0001 \\
0001\end{array} \mid$ & $\begin{array}{l}\text { NA } \\
\text { NA }\end{array}$ & $\begin{array}{l}u \\
u\end{array}$ & $\begin{array}{ll}0.03 & 1 \\
0.03 & 1\end{array}$ & $\begin{array}{l}0.03 \\
0.03\end{array}$ & - \\
\hline SELENIUM (TOTAL) & 0 & $M G / L$ & 0.0100 & - & - & - & - & $\cdot$ & - & - & - \\
\hline SILVER & 15 & $M G / L$ & 0.0500 & - & - & - & - & - & - & - & - \\
\hline SILVER (TOTAL) & 0 & $M G / L$ & 0.0500 & - & - & - & - & - & - & - & - \\
\hline URANIUM & 24 & $M G / L$ & 0.0440 & 0688 & $10 / 14 / 87$ & 0001 & NA & u & 0.10 & 0.003 & $=$ \\
\hline URANIUM (TOTAL) & 0 & $M G / L$ & 0.0440 & - & - & - & - & - & - & - & - \\
\hline
\end{tabular}

* NET GROSS ALPHA (GROSS ALPHA - URANIUM) WITH 1 MG URANIUM = 686 PCI

* total nEt GROSS alPHa (TOTAL GROSS alPHa - tOtal URANIUM)

FORMATION OF COMPLETION COOE:

NA - NAVAJO SANDSTONE

OTHER PARAMETER VALUE FLAGS:

I - INCREASED DETECTION LIMIT DUE TO REQUIRED DILUTION

DATA FILE NAME: M: IDARTISRK01\GWQ10029.DAT
FLON RELATIONSHIP COOE:

$U$ - UPGRADIENT

SAMPLE ID CODES:

0001 - FILTERED SAMPLE (.45 MICRONS) 
Table 3.41 . Information for Private Wells Located in the Vicinity of the Slick Rock Processing Sites

\begin{tabular}{|c|c|c|c|c|c|c|c|}
\hline $\begin{array}{c}\text { Private } \\
\text { Wells } \\
\text { ID. NOB.' }\end{array}$ & $\begin{array}{l}\text { Permit } \\
\text { No. }\end{array}$ & $\begin{array}{l}\text { TAC } \\
\text { ID }\end{array}$ & $\begin{array}{l}\text { Date (s) } \\
\text { Sampled }\end{array}$ & $\begin{array}{l}\text { Total/Casing } \\
\text { Depth (ft) }\end{array}$ & Aquifer & $\begin{array}{l}\text { Well } \\
\text { Status }\end{array}$ & Water Use' \\
\hline 1 & $25342 \mathrm{~F}$ & 672 & $\begin{array}{l}7 / 86 \\
4 / 91 \\
\end{array}$ & Unknown & Unknown & Active & $\begin{array}{l}\text { Domestic } \\
\text { stock }\end{array}$ \\
\hline 2 & $2135 F$ & 635 & $6 / 86$ & $80 / 20-60$ & Morrison & Inactive & $\begin{array}{l}\text { Industrial } \\
\text { Domestic }\end{array}$ \\
\hline 3 & $15805 \mathrm{~F}$ & 805 & $4 / 91$ & 200/Unknown & Unknown & Active & $\begin{array}{l}\text { Inciustrial } \\
\text { Domestic }\end{array}$ \\
\hline 4 & $4483 F$ & NA & $\mathrm{NA}$ & Unknown & Unknown & Unknown & Industrial \\
\hline 5 & $2164 \mathrm{~F}$ & NA & $\mathrm{NA}$ & $202 / 10-202$ & $\begin{array}{l}\text { Alluvial, } \\
\text { Entrada, } \\
\text { Navajo }\end{array}$ & Inactive & $\begin{array}{l}\text { Industrial } \\
\text { Domestic }\end{array}$ \\
\hline 6 & $2165 \mathrm{~F}$ & $\mathbf{N A}$ & NA & $152 / 10-152$ & $\begin{array}{l}\text { Alluvial, } \\
\text { Entrada }\end{array}$ & Inactive & $\begin{array}{l}\text { Industrial } \\
\text { Dómestic } \\
\end{array}$ \\
\hline 7 & $2166 F$ & NA & NA & $150 / 10-150$ & $\begin{array}{l}\text { Alluvial, } \\
\text { Entrada }\end{array}$ & Inactive & $\begin{array}{l}\text { Industrial } \\
\text { Domestic } \\
\end{array}$ \\
\hline 8 & $2163 \mathrm{~F}$ & $\mathrm{NA}$ & NA & $152 / 12-152$ & $\begin{array}{l}\text { Alluvial, } \\
\text { Entrada }\end{array}$ & Inactive & $\begin{array}{l}\text { Industrial } \\
\text { Domestic } \\
\end{array}$ \\
\hline 9 & $2134 \mathrm{~F}$ & 634 & $\begin{array}{l}6 / 86 \\
10 / 87 \\
2 / 88 \\
\end{array}$ & $125 / 20-125$ & $\begin{array}{l}\text { Alluvial, } \\
\text { Entrada, } \\
\text { Navajo }\end{array}$ & Inactive? & $\begin{array}{l}\text { Industrial } \\
\text { Domestic }\end{array}$ \\
\hline 10 & $2133 \mathrm{~F}$ & NA & NA & $40 / 20-40$ & Entrada & Inactive & $\begin{array}{l}\text { Industrial } \\
\text { Domestic }\end{array}$ \\
\hline 11 & $2167 F$ & NA & NA & $200 / 5-200$ & $\begin{array}{l}\text { Entrada, } \\
\text { Navajo }\end{array}$ & Inactive & $\begin{array}{l}\text { Industrial } \\
\text { Domestic }\end{array}$ \\
\hline 12 & $2168 \mathrm{~F}$ & $N A$ & $N A$ & $106 / 43-106$ & $\begin{array}{l}\text { Entrada, } \\
\text { Navajo }\end{array}$ & sealed? & $\begin{array}{l}\text { Industrial } \\
\text { Domestic }\end{array}$ \\
\hline 13 & $15806 \mathrm{~F}$ & 806 & $\mathrm{NA}$ & $125 /$ Unknown & Unknown & Inactive? & $\begin{array}{l}\text { Industrial } \\
\text { Domestic } \\
\end{array}$ \\
\hline 14 & 142293 & $N A$ & $N A$ & $800 /$ Unknown & Unknown & Unknown & Unknown \\
\hline 15 & $\mathrm{NA}$ & $\mathrm{NA}$ & $\mathrm{NA}$ & Unknown & Unknown & Inactive? & Unknown \\
\hline 16 & $\mathrm{NA}$ & NA & NA & Unknown & Unknown & Sealed? & Unknown \\
\hline 17 & NA & NA & $N A$ & Unknown & Unknown & Sealed? & Unknown \\
\hline 18 & NA & 675 & $6 / 86$ & Unknown & Unknown & Active? & $\begin{array}{l}\text { Domestic } \\
\text { Stock }\end{array}$ \\
\hline $\begin{array}{c}19 \\
\text { Collector } \\
\text { System }\end{array}$ & $N A$ & 807 & $\mathrm{NA}$ & Surface seep & Entrada & Active? & Stock \\
\hline $\begin{array}{l}\text { Locat } \\
\text { Infor }\end{array}$ & $\begin{array}{l}\text { ID } \\
\text { tion }\end{array}$ & $\begin{array}{l}\text { os. } \\
\text { ot a }\end{array}$ & $\begin{array}{l}\text { s shown } \\
\text { ailable }\end{array}$ & in & & & \\
\hline
\end{tabular}


TABLE 3.42. MONITORING WELL INFORMATION FOR THE BURRO CANYON DISPOSAL SITE, SLICK ROCK, COLORADO SITE: SRKO2 BORROW SITE 1 (BURRO CANYON)

REPORT DATE: 03/07/94

\begin{tabular}{|c|c|c|c|c|c|c|c|c|c|c|c|c|}
\hline$\underset{\text { ID }}{\text { LOCAAION }}$ & $\begin{array}{c}\text { NORTH } \\
\text { COORDINATE } \\
\text { (FT) }\end{array}$ & $\begin{array}{c}\text { EAST } \\
\text { COORD INATE } \\
\text { (FT) }\end{array}$ & $\begin{array}{c}\text { GROUND } \\
\text { ELEVATION } \\
\text { (FT MSL) }\end{array}$ & $\begin{array}{l}\text { BOREHOLE } \\
\text { DEPTH } \\
\text { (FT) }\end{array}$ & $\begin{array}{l}\text { BOREHOLE } \\
\text { DIAMETER } \\
\text { (INCHES) }\end{array}$ & $\begin{array}{l}\text { CASING } \\
\text { ELEVATION } \\
\text { (FT MSL) }\end{array}$ & $\begin{array}{l}\text { CASING } \\
\text { DEPTH } \\
\text { (FT) }\end{array}$ & $\begin{array}{l}\text { CASING } \\
\text { DIAMETER } \\
\text { (INCHES) }\end{array}$ & $\begin{array}{c}\text { SCREEN } \\
\text { BEGINNING } \\
\text { DEPTH (FT) }\end{array}$ & $\begin{array}{l}\text { SCREEN } \\
\text { LENGTH } \\
\text { (FT) }\end{array}$ & $\begin{array}{l}\text { FLOW } \\
\text { COOE }\end{array}$ & $\begin{array}{l}\text { FORMATION } \\
\text { OF } \\
\text { COMPLETION }\end{array}$ \\
\hline $\begin{array}{l}0516 \\
0517 \\
0518 \\
0519 \\
0520 \\
0521 \\
0522 \\
0523 \\
0524 \\
0525 \\
0526 \\
0527 \\
0528 \\
0529 \\
0551 \\
0552\end{array}$ & $\begin{array}{l}19099.00 \\
19217.00 \\
19959.00 \\
19960.00 \\
19974.00 \\
19621.00 \\
19670.00 \\
19620.00 \\
19012.06 \\
19023.44 \\
18859.00 \\
18873.00 \\
20137.00 \\
20126.00 \\
18590 \\
18920\end{array}$ & $\begin{array}{l}21931.00 \\
22547.00 \\
21745.00 \\
21758.00 \\
21748.00 \\
22459.00 \\
22470.00 \\
22476.00 \\
21702.85 \\
21712.23 \\
22153.00 \\
22141.00 \\
22121.00 \\
22114.00 \\
22770 \\
22830\end{array}$ & $\begin{array}{l}5862.4 \\
5870.2 \\
5897.0 \\
5897.1 \\
5897.8 \\
5875.0 \\
5874.6 \\
5875.0 \\
5848.9 \\
5849.1 \\
5833.8 \\
5834.6 \\
5896.8 \\
5896.6 \\
5823.0 \\
5843\end{array}$ & $\begin{array}{l}225 . \\
340 . \\
109 . \\
338 . \\
240.5 \\
353 . \\
235 . \\
125 . \\
295.5 \\
203 . \\
207 . \\
81 . \\
223 . \\
119 . \\
112 \\
179\end{array}$ & $\begin{array}{l}6.13 \\
6.13 \\
8 . \\
8 . \\
8 . \\
8 . \\
8 . \\
8 . \\
8 . \\
8 . \\
8 . \\
8 . \\
8 . \\
8 . \\
5.875 \\
7.25\end{array}$ & $\begin{array}{l}5864.36 \\
5871.80 \\
5898.03 \\
5898.12 \\
5899.49 \\
5876.05 \\
5876.50 \\
5876.39 \\
5850.72 \\
5850.89 \\
5835.42 \\
5836.51 \\
5898.37 \\
5898.51 \\
5824.5 \\
5844.5\end{array}$ & $\begin{array}{l}225 . \\
340 . \\
109 . \\
338 . \\
240.5 \\
352 . \\
235 . \\
125 . \\
295.5 \\
203 . \\
207 . \\
81 . \\
223 . \\
119 . \\
112 \\
100.5\end{array}$ & $\begin{array}{l}2 . \\
2 . \\
4 . \\
4 . \\
4 . \\
4 . \\
4 . \\
4 . \\
4 . \\
4 . \\
4 . \\
4 . \\
4 . \\
4 . \\
2 \\
2\end{array}$ & $\begin{array}{l}213 . \\
328 . \\
97 . \\
316 . \\
218.5 \\
330 \\
203 . \\
103 . \\
273.5 \\
171 . \\
175 . \\
59 . \\
201 . \\
107 . \\
90 \\
78.15\end{array}$ & $\begin{array}{l}10 . \\
10 . \\
10 \\
20 . \\
20 . \\
20 \\
30 . \\
20 . \\
20 . \\
30 . \\
30 . \\
20 . \\
20 . \\
10 . \\
20 \\
20\end{array}$ & $\begin{array}{l}0 \\
0 \\
0 \\
0 \\
0 \\
0 \\
0 \\
0 \\
0 \\
0 \\
0 \\
0 \\
0 \\
0 \\
0 \\
0\end{array}$ & $\begin{array}{l}\text { MB } \\
\text { LB } \\
\text { UB } \\
\text { LB } \\
\text { MB } \\
\text { LB } \\
\text { MB } \\
\text { UB } \\
\text { LB } \\
\text { MB } \\
\text { MB } \\
\text { UB } \\
\text { MB } \\
\text { UB } \\
\text { UB } \\
\text { UB }\end{array}$ \\
\hline
\end{tabular}

FORMATION OF COMPLETION CODE:

$\dot{\omega} \quad M B-M I$

FLOW RELATIONSHIP COOE:

LB - LOWER BURRO CANYON

DATA FILE: M: IDARTISRKO2 MMWI 10006.DAT 
TABLE 3.43. STATIC GROUNDHATER LEVELS FOR THE BURRO CANYON DISPOSAL SITE, SLICK ROCK, COLORADO

SITE: SRKOZ BORRON SITE 1 (BURRO CANYON)

REPORT DATE: $03 / 02 / 94$

\begin{tabular}{|c|c|c|c|c|c|c|c|c|c|c|c|}
\hline $\begin{array}{c}\text { LOCATION } \\
\text { ID }\end{array}$ & $\begin{array}{c}\text { NORTH } \\
\text { COORDINATE } \\
\text { (FT) }\end{array}$ & $\begin{array}{c}\text { EAST } \\
\text { COORDINATE } \\
\text { (FT) }\end{array}$ & $\begin{array}{c}\text { FORMATION } \\
\text { OF } \\
\text { COMPLETION }\end{array}$ & $\begin{array}{l}\text { FLOW } \\
\text { CODE }\end{array}$ & $\begin{array}{l}\text { CASING } \\
\text { ELEVATION } \\
\text { (FT MSL) }\end{array}$ & $\begin{array}{l}\text { GROUND } \\
\text { ELEVATION } \\
\text { (FT MSL) }\end{array}$ & LOG DATE & $\begin{array}{l}\text { LOG } \\
\text { TIME }\end{array}$ & $\begin{array}{c}\text { DEPTH FROM } \\
\text { TOP OF } \\
\text { CASING (FT) }\end{array}$ & $\begin{array}{c}\text { DEPTH FROM } \\
\text { GROUND } \\
\text { (FT) }\end{array}$ & $\begin{array}{l}\text { GROUNDWATER } \\
\text { ELEVATION } \\
\text { (FT MSL) }\end{array}$ \\
\hline 0516 & 19099.00 & 21931.00 & MB & 0 & 5864.36 & 5862.4 & $\begin{array}{l}02 / 12 / 90 \\
04 / 13 / 90 \\
05 / 05 / 90 \\
12 / 02 / 90 \\
12 / 07 / 90 \\
04 / 02 / 91 \\
08 / 25 / 91 \\
10 / 14 / 92\end{array}$ & $\begin{array}{l}15: 05 \\
08: 30 \\
09: 05 \\
10: 10 \\
10: 00 \\
15: 21 \\
09: 00 \\
10: 52\end{array}$ & $\begin{array}{l}215 . \\
125.75 \\
124.9 \\
127.01 \\
127.73 \\
127.42 \\
127.64 \\
127.71\end{array}$ & $\begin{array}{l}213.04 \\
123.79 \\
122.94 \\
125.05 \\
125.77 \\
125.46 \\
125.68 \\
125.75\end{array}$ & $\begin{array}{l}5649.36 \\
5738.61 \\
5739.46 \\
5737.35 \\
5736.63 \\
5736.94 \\
5736.72 \\
5736.65\end{array}$ \\
\hline 0517 & 19217.00 & 22547.00 & LB & 0 & 5871.80 & 5870.2 & $\begin{array}{l}04 / 13 / 90 \\
05 / 05 / 90 \\
12 / 02 / 90 \\
12 / 07 / 90 \\
04 / 02 / 91 \\
08 / 25 / 91 \\
10 / 14 / 92\end{array}$ & $\begin{array}{l}08: 40 \\
09: 10 \\
10: 54 \\
14: 30 \\
16: 09 \\
10: 30 \\
15: 11\end{array}$ & $\begin{array}{l}102.6 \\
102.8 \\
103.11 \\
103.15 \\
103.52 \\
103.09 \\
102.64\end{array}$ & $\begin{array}{l}101.00 \\
101.20 \\
101.51 \\
101.55 \\
101.92 \\
101.49 \\
101.04\end{array}$ & $\begin{array}{l}5769.20 \\
5769.00 \\
5768.69 \\
5768.65 \\
5768.28 \\
5768.71 \\
5769.16\end{array}$ \\
\hline 0518 & 19959.00 & 21745.00 & UB & 0 & 5898.03 & 5897.0 & $\begin{array}{l}03 / 31 / 90 \\
04 / 03 / 90 \\
04 / 13 / 90 \\
05 / 05 / 90 \\
12 / 02 / 90 \\
12 / 12 / 90 \\
03 / 31 / 91 \\
08 / 23 / 91 \\
10 / 11 / 92\end{array}$ & $\begin{array}{l}10: 00 \\
08: 00 \\
08: 50 \\
09: 20 \\
10: 24 \\
15: 10 \\
13: 05 \\
14: 25 \\
10: 34\end{array}$ & $\begin{array}{l}103.5 \\
102.5 \\
102.1 \\
101.2 \\
102.70 \\
102.25 \\
103.55 \\
102.78 \\
102.80\end{array}$ & $\begin{array}{l}102.47 \\
101.47 \\
101.07 \\
100.17 \\
101.67 \\
101.22 \\
102.52 \\
101.75 \\
101.77\end{array}$ & $\begin{array}{l}5794.53 \\
5795.53 \\
5795.93 \\
5796.83 \\
5795.33 \\
5795.78 \\
5794.48 \\
5795.25 \\
5795.23\end{array}$ \\
\hline 0519 & 19960.00 & 21758.00 & LB & 0 & 5898.12 & 5897.1 & $\begin{array}{l}03 / 31 / 90 \\
04 / 01 / 90 \\
04 / 03 / 90 \\
64 / 13 / 90 \\
05 / 05 / 90 \\
12 / 02 / 90 \\
12 / 12 / 90 \\
03 / 31 / 91 \\
08 / 22 / 91 \\
10 / 11 / 92\end{array}$ & $\begin{array}{l}07: 50 \\
10: 50 \\
08: 05 \\
09: 00 \\
09: 25 \\
10: 27 \\
11: 00 \\
11: 15 \\
09: 15 \\
08: 58\end{array}$ & $\begin{array}{l}160 . \\
112 . \\
91 . \\
84.75 \\
82.3 \\
81.91 \\
81.75 \\
82.55 \\
81.95 \\
80.63\end{array}$ & $\begin{array}{r}158.98 \\
110.98 \\
89.98 \\
83.73 \\
81.28 \\
80.89 \\
80.73 \\
81.53 \\
80.93 \\
79.61\end{array}$ & $\begin{array}{l}5738.12 \\
5786.12 \\
5807.12 \\
5813.37 \\
5815.82 \\
5816.21 \\
5816.37 \\
5815.57 \\
5816.17 \\
5817.49\end{array}$ \\
\hline 0520 & 19974.00 & 21748.00 & MB & 0 & 5899.49 & 5897.8 & $\begin{array}{l}04 / 03 / 90 \\
04 / 13 / 90\end{array}$ & $\begin{array}{l}08: 10 \\
09: 10\end{array}$ & $\begin{array}{l}151 . \\
150.2\end{array}$ & $\begin{array}{l}149.31 \\
148.51\end{array}$ & $\begin{array}{l}5748.49 \\
5749.29\end{array}$ \\
\hline
\end{tabular}

FORMATION OF COMPLETION COOE:

MB - MIDDLE BURRO CANYON

FLOW RELATIONSHIP COOE:

LB - LOWER BURRO CANYON

O - ON-SITE

UB - UPPER BURRO CAMYON 
TABLE 3.43. STATIC GROUNDHATER LEVELS FOR THE BURRO CANYON DISPOSAL SITE, SLICK ROCK, COLORADO

SITE: SRKO2 BORROH SITE 1 (BURRO CANYON)

REPORT DATE: 03/02/94

\begin{tabular}{|c|c|c|c|c|c|c|c|c|c|c|c|}
\hline $\begin{array}{c}\text { LOCATION } \\
\text { ID }\end{array}$ & $\begin{array}{c}\text { NORTH } \\
\text { COORDINATE } \\
\text { (FT) }\end{array}$ & $\begin{array}{c}\text { EAST } \\
\text { COORDINATE } \\
\text { (FT) }\end{array}$ & $\begin{array}{l}\text { FORMATION } \\
\text { OF } \\
\text { COMPLETION }\end{array}$ & $\begin{array}{l}\text { FLOW } \\
\text { CODE }\end{array}$ & $\begin{array}{l}\text { CASING } \\
\text { ELEVATION } \\
\text { (FT MSL) }\end{array}$ & $\begin{array}{l}\text { GROUND } \\
\text { ELEVATION } \\
\text { (FT MSL) }\end{array}$ & LOG DATE & $\begin{array}{l}\text { LOG } \\
\text { TIME }\end{array}$ & $\begin{array}{l}\text { DEPTH FROM } \\
\text { TOP OF } \\
\text { CASING (FT) }\end{array}$ & $\begin{array}{c}\text { DEPTH FROM } \\
\text { GROUND } \\
\text { (FT) }\end{array}$ & $\begin{array}{l}\text { GROUNDWATER } \\
\text { ELEVATION } \\
\text { (FT MSL) }\end{array}$ \\
\hline 0520 & 19974.00 & 21748.00 & MB & 0 & 5899.49 & 5897.8 & $\begin{array}{l}05 / 05 / 90 \\
12 / 02 / 90 \\
12 / 11 / 90 \\
03 / 31 / 91 \\
08 / 22 / 91 \\
10 / 11 / 92\end{array}$ & $\begin{array}{l}09: 30 \\
10: 22 \\
13: 00 \\
10: 41 \\
10: 47 \\
11: 42\end{array}$ & $\begin{array}{l}149.9 \\
151.15 \\
150.75 \\
151.75 \\
151.85 \\
151.26\end{array}$ & $\begin{array}{l}148.21 \\
149.46 \\
149.06 \\
150.06 \\
150.16 \\
149.57\end{array}$ & $\begin{array}{l}5749.59 \\
5748.34 \\
5748.74 \\
5747.74 \\
5747.64 \\
5748.23\end{array}$ \\
\hline 0521 & 19621.00 & 22459.00 & LB & 0 & 5876.05 & 5875.0 & $\begin{array}{l}04 / 04 / 90 \\
04 / 10 / 90 \\
04 / 13 / 90 \\
05 / 05 / 90 \\
12 / 02 / 90 \\
12 / 05 / 90 \\
03 / 31 / 91 \\
08 / 25 / 91 \\
10 / 12 / 92\end{array}$ & $\begin{array}{l}11: 15 \\
16: 35 \\
09: 20 \\
09: 35 \\
10: 46 \\
09: 30 \\
13: 58 \\
14: 40 \\
11: 16\end{array}$ & $\begin{array}{l}160 . \\
80.5 \\
89.5 \\
82.8 \\
76.94 \\
77.02 \\
77.46 \\
76.74 \\
76.39\end{array}$ & $\begin{array}{r}158.95 \\
79.45 \\
88.45 \\
81.75 \\
75.89 \\
75.97 \\
76.41 \\
75.69 \\
75.34\end{array}$ & $\begin{array}{l}5716.05 \\
5795.55 \\
5786.55 \\
5793.25 \\
5799.11 \\
5799.03 \\
5798.59 \\
5799.31 \\
5799.66\end{array}$ \\
\hline 0522 & 19670.00 & 22470.00 & MB & 0 & 5876.50 & 5874.6 & $\begin{array}{l}04 / 13 / 90 \\
05 / 05 / 90 \\
12 / 02 / 90 \\
12 / 05 / 90 \\
03 / 31 / 91 \\
08 / 22 / 91 \\
10 / 12 / 92\end{array}$ & $\begin{array}{l}09: 30 \\
09: 40 \\
10: 42 \\
14: 20 \\
15: 00 \\
17: 20 \\
08: 46\end{array}$ & $\begin{array}{l}135.0 \\
134.8 \\
136.19 \\
136.26 \\
136.81 \\
137.76 \\
136.36\end{array}$ & $\begin{array}{l}133.10 \\
132.90 \\
134.29 \\
134.36 \\
134.91 \\
135.86 \\
134.46\end{array}$ & $\begin{array}{l}5741.50 \\
5741.70 \\
5740.31 \\
5740.24 \\
5739.69 \\
5738.74 \\
5740.14\end{array}$ \\
\hline 0523 & 19620.00 & 22476.00 & UB & 0 & 5876.39 & 5875.0 & $\begin{array}{l}04 / 13 / 90 \\
05 / 05 / 90 \\
12 / 02 / 90 \\
12 / 11 / 90 \\
03 / 31 / 91 \\
08 / 23 / 91 \\
10 / 12 / 92\end{array}$ & $\begin{array}{l}09: 40 \\
09: 45 \\
10: 40 \\
14: 05 \\
13: 03 \\
12: 15 \\
12: 39\end{array}$ & $\begin{array}{l}111.25 \\
109.6 \\
108.25 \\
107.78 \\
108.53 \\
107.94 \\
108.19\end{array}$ & $\begin{array}{l}109.86 \\
108.21 \\
106.86 \\
106.39 \\
107.14 \\
106.55 \\
106.80\end{array}$ & $\begin{array}{l}5765.14 \\
5766.79 \\
5768.14 \\
5768.61 \\
5767.86 \\
5768.45 \\
5768.20\end{array}$ \\
\hline 0524 & 19012.06 & 21702.85 & LB & 0 & 5850.72 & 5848.9 & $\begin{array}{l}04 / 16 / 90 \\
04 / 18 / 90 \\
05 / 05 / 90 \\
12 / 02 / 90 \\
12 / 06 / 90 \\
03 / 30 / 91 \\
08 / 26 / 91\end{array}$ & $\begin{array}{l}09: 21 \\
09: 15 \\
09: 48 \\
09: 55 \\
09: 00 \\
13: 47 \\
10: 10\end{array}$ & $\begin{array}{l}113.4 \\
97 . \\
89.7 \\
82.58 \\
82.62 \\
83.73 \\
83.53\end{array}$ & $\begin{array}{l}11 . .58 \\
95.18 \\
87.88 \\
80.76 \\
80.80 \\
81.91 \\
81.71\end{array}$ & $\begin{array}{l}5737.32 \\
5753.72 \\
5761.02 \\
5768.14 \\
5768.10 \\
5766.99 \\
5767.19\end{array}$ \\
\hline
\end{tabular}

FORMATION OF COMPLETION COOE:

FLOW RELATIONSHIP CODE:

MB - MIDDLE BURRO CANYON

O - ON-SITE

LB - LONER BURRO CANYON

UB - UPPER BURRO CAMYON 
TABLE 3.43. STATIC GROUNDWATER LEVELS FOR THE BURRO CANYON DISPOSAL SITE,

SLICK ROCK, COLORADO

SITE: SRKO2 BORROW SITE 1 (BURRO CANYON)

REPORT DATE: 03/02/94

\begin{tabular}{|c|c|c|c|c|c|c|c|c|c|c|c|}
\hline$\underset{\text { ID }}{\text { LOCATION }}$ & $\begin{array}{c}\text { NORTH } \\
\text { COORDINATE } \\
\text { (FT) }\end{array}$ & $\begin{array}{c}\text { EAST } \\
\text { COORDINATE } \\
\text { (FI) }\end{array}$ & $\begin{array}{l}\text { FORMATION } \\
\text { OF } \\
\text { COMPLETION }\end{array}$ & $\begin{array}{l}\text { FLOW } \\
\text { CODE }\end{array}$ & $\begin{array}{l}\text { CASING } \\
\text { ELEVATION } \\
\text { (FT MSL) }\end{array}$ & $\begin{array}{l}\text { GROUND } \\
\text { ELEVAIION } \\
\text { (FT MSL) }\end{array}$ & LOG DATE & $\begin{array}{l}\text { LOG } \\
\text { TIME }\end{array}$ & $\begin{array}{l}\text { DEPTH FROM } \\
\text { TOP OF } \\
\text { CASING (FT) }\end{array}$ & $\begin{array}{c}\text { DEPTH FROM } \\
\text { GROUND } \\
\text { (FT) }\end{array}$ & $\begin{array}{l}\text { GROUNDWATER } \\
\text { ELEVATION } \\
\text { (FT MSL) }\end{array}$ \\
\hline 0524 & 19012.06 & 21702.85 & LB & 0 & 5850.72 & 5848.9 & $10 / 13 / 92$ & $15: 23$ & 82.90 & 81.08 & 5767.82 \\
\hline 0525 & 19023.44 & 21712.23 & MB & 0 & 5850.89 & 5849.1 & $\begin{array}{l}04 / 16 / 90 \\
04 / 18 / 90 \\
05 / 05 / 90 \\
12 / 02 / 90 \\
12 / 06 / 90 \\
04 / 02 / 91 \\
08 / 26 / 91 \\
10 / 14 / 92\end{array}$ & $\begin{array}{l}09: 28 \\
09: 30 \\
09: 50 \\
09: 53 \\
12: 00 \\
13: 43 \\
12: 35 \\
08: 30\end{array}$ & $\begin{array}{l}115.0 \\
115.1 \\
112.7 \\
114.47 \\
114.72 \\
115.10 \\
115.08 \\
114.55\end{array}$ & $\begin{array}{l}113.21 \\
113.31 \\
110.91 \\
112.68 \\
112.93 \\
113.31 \\
113.29 \\
112.76\end{array}$ & $\begin{array}{l}5735.89 \\
5735.79 \\
5738.19 \\
5736.42 \\
5736.17 \\
5735.79 \\
5735.81 \\
5736.34\end{array}$ \\
\hline 0526 & 18859.00 & 22153.00 & MB & 0 & 5835.42 & 5833.8 & $\begin{array}{l}04 / 18 / 90 \\
04 / 26 / 90 \\
05 / 05 / 90 \\
12 / 02 / 90 \\
12 / 11 / 90 \\
03 / 30 / 91 \\
08 / 21 / 91 \\
10 / 14 / 92\end{array}$ & $\begin{array}{l}08: 00 \\
16: 30 \\
09: 55 \\
09: 40 \\
10: 00 \\
15: 03 \\
10: 10 \\
12: 32\end{array}$ & $\begin{array}{c}98.0 \\
101.25 \\
100.7 \\
101.85 \\
101.73 \\
102.43 \\
102.58 \\
101.65\end{array}$ & $\begin{array}{r}96.38 \\
99.63 \\
99.08 \\
100.23 \\
100.11 \\
100.81 \\
100.96 \\
100.03\end{array}$ & $\begin{array}{l}5737.42 \\
5734.17 \\
5734.72 \\
5733.57 \\
5733.69 \\
5732.99 \\
5732.84 \\
5733.77\end{array}$ \\
\hline 0527 & 18873.00 & 22141.00 & UB & 0 & 5836.51 & 5834.6 & $\begin{array}{l}04 / 25 / 90 \\
04 / 26 / 90 \\
05 / 05 / 90 \\
12 / 02 / 90 \\
12 / 13 / 90 \\
03 / 30 / 91 \\
08 / 23 / 91 \\
10 / 12 / 92\end{array}$ & $\begin{array}{l}08: 00 \\
16: 40 \\
09: 57 \\
09: 37 \\
13: 00 \\
15: 58 \\
15: 30 \\
15: 22\end{array}$ & $\begin{array}{c}\text { DRY } \\
\text { DRY } \\
\text { DRY } \\
77.22 \\
76.91 \\
77.62 \\
77.39 \\
77.15\end{array}$ & $\begin{array}{c}\text { DRY } \\
\text { DRY } \\
\text { DRY } \\
75.31 \\
75.00 \\
75.71 \\
75.48 \\
75.24\end{array}$ & $\begin{array}{c}- \\
- \\
5759.29 \\
5759.60 \\
5758.89 \\
5759.12 \\
5759.36\end{array}$ \\
\hline 0528 & 20137.00 & 22121.00 & MB & 0 & 5898.37 & 5896.8 & $\begin{array}{l}04 / 27 / 90 \\
05 / 05 / 90 \\
12 / 02 / 90 \\
12 / 13 / 90 \\
03 / 31 / 91 \\
08 / 21 / 91 \\
10 / 13 / 92\end{array}$ & $\begin{array}{l}09: 20 \\
10: 00 \\
11: 04 \\
09: 30 \\
16: 57 \\
15: 00 \\
12: 13\end{array}$ & $\begin{array}{l}146.3 \\
144.5 \\
145.64 \\
145.45 \\
146.25 \\
145.82 \\
146.0\end{array}$ & $\begin{array}{l}144.73 \\
142.93 \\
144.07 \\
143.88 \\
144.68 \\
144.25 \\
144.43\end{array}$ & $\begin{array}{l}5752.07 \\
5753.87 \\
5752.73 \\
5752.92 \\
5752.12 \\
5752.55 \\
5752.37\end{array}$ \\
\hline 0529 & 20126.00 & 22114.00 & UB & 0 & 5898.51 & 5896.6 & $\begin{array}{l}04 / 27 / 90 \\
05 / 05 / 90 \\
12 / 02 / 90\end{array}$ & $\begin{array}{l}09: 10 \\
10: 05 \\
11: 08\end{array}$ & $\begin{array}{l}114.4 \\
106.1 \\
106.39\end{array}$ & $\begin{array}{l}112.49 \\
104.19 \\
104.48\end{array}$ & $\begin{array}{l}5784.11 \\
5792.41 \\
5792.12\end{array}$ \\
\hline
\end{tabular}

FORMATION OF COMPLETION CODE:

FLOW RELATIONSHIP COOE:

LB - LOWER BURRO CANYON

O- ON-SITE

MB - MIDDLE BURRC CANYON

UB - UPPER SURRO CANYON 
TABLE 3.43. STATIC GROUNDHATER LEVELS FOR THE BURRO CANYON DISPOSAL SITE, SLICK ROCK, COLORADO

1 (BURRO CANYON)

REPORT DATE; 03/02/94

\begin{tabular}{|c|c|c|c|c|c|c|c|c|c|c|c|}
\hline $\begin{array}{c}\text { LOCATION } \\
\text { ID }\end{array}$ & $\begin{array}{l}\text { NORTH } \\
\text { COORDINATE } \\
\text { (FT) }\end{array}$ & $\begin{array}{l}\text { EAST } \\
\text { COORDINATE } \\
\text { (FT) }\end{array}$ & $\begin{array}{l}\text { FORMATION } \\
\text { OF } \\
\text { COMPLETION }\end{array}$ & $\begin{array}{l}\text { FLOW } \\
\text { CODE }\end{array}$ & $\begin{array}{l}\text { CASING } \\
\text { ELEVATION } \\
\text { (FT MSL) }\end{array}$ & $\begin{array}{l}\text { GROUND } \\
\text { ELEVATION } \\
\text { (FT MSL) }\end{array}$ & LOG DATE & $\begin{array}{l}\text { LOG } \\
\text { TIME }\end{array}$ & $\begin{array}{l}\text { DEPTH FROM } \\
\text { TOP OF } \\
\text { CASING (FT) }\end{array}$ & $\begin{array}{c}\text { DEPTH FROM } \\
\text { GROUND } \\
\text { (FT) }\end{array}$ & $\begin{array}{l}\text { GROUNDHATER } \\
\text { ELEVATION } \\
\text { (FT MSL) }\end{array}$ \\
\hline 0529 & 20126.00 & 22114.00 & UB & 0 & 5898.51 & 5896.6 & $\begin{array}{l}12 / 06 / 90 \\
03 / 31 / 91 \\
08 / 23 / 91 \\
10 / 12 / 92\end{array}$ & $\begin{array}{l}15: 15 \\
16: 10 \\
10: 45 \\
13: 59\end{array}$ & $\begin{array}{l}106.65 \\
107.15 \\
106.78 \\
106.99\end{array}$ & $\begin{array}{l}104.74 \\
105.24 \\
104.87 \\
105.08\end{array}$ & $\begin{array}{l}5791.86 \\
5791.36 \\
5791.73 \\
5791.52\end{array}$ \\
\hline
\end{tabular}

FORMATION OF COMPLETION CODE:

UB - UPPER BURRO CANYCN

FLON RELATIONSHIP COOE:

DATA FILE: M: IDARTISRK02\GWL10005.DAT

FIELDS DISPLAYED WITH A DASH INDICATE THE DATA IS UNAVAILABLE 
Table 3.44 Hydraulic parameters for the Burro Canyon disposal site, Slick Rock, Colorado

\begin{tabular}{|c|c|c|c|c|c|}
\hline & & & Burro Canyon & Formation & sandstone units \\
\hline $\begin{array}{l}\text { Hydraulic } \\
\text { property }\end{array}$ & $\begin{array}{c}\text { Dakota } \\
\text { sandstone }\end{array}$ & $\begin{array}{c}\text { Burro } \\
\text { Canyon } \\
\text { mudstone }\end{array}$ & Upper & Middle & Lower \\
\hline $\begin{array}{c}\text { Average } \\
\text { hydraulic } \\
\text { cond. }\end{array}$ & $\begin{array}{l}4 \times 10^{-1} \mathrm{ft} / \mathrm{d} \\
1 \times 10^{-4} \mathrm{~cm} / \mathrm{s}\end{array}$ & $\begin{array}{l}6 \times 10^{-3} \mathrm{ft} / \mathrm{d} \\
2 \times 10^{-6} \mathrm{~cm} / \mathrm{s}\end{array}$ & $\begin{array}{l}4 \times 10^{.2} \mathrm{ft} / \mathrm{d} \\
1 \times 10^{.5} \mathrm{~cm} / \mathrm{s}\end{array}$ & $\begin{array}{l}9 \times 10^{-2} \mathrm{ft} / \mathrm{d} \\
3 \times 10^{-5} \mathrm{~cm} / \mathrm{s}\end{array}$ & $\begin{array}{l}5 \times 10^{-3} \mathrm{ft} / \mathrm{d} \\
2 \times 10^{-6} \mathrm{~cm} / \mathrm{s}\end{array}$ \\
\hline $\begin{array}{c}\text { Average } \\
\text { hydraulic } \\
\text { gradient }\end{array}$ & NA & NA & 0.04 & 0.02 & 0.06 \\
\hline $\begin{array}{c}\text { Average } \\
\text { linear } \\
\text { groundwater } \\
\text { velocity }\end{array}$ & $\mathrm{NA}$ & NA & $\begin{array}{c}6 \mathrm{ft} / \mathrm{yr} \\
6 \times 10^{-6} \mathrm{~cm} / \mathrm{s}\end{array}$ & $\begin{array}{c}2 \mathrm{ft} / \mathrm{yr} \\
2 \times 10^{-6} \mathrm{~cm} / \mathrm{s}\end{array}$ & $\begin{array}{c}1 \mathrm{ft} / \mathrm{yr} \\
1 \times 10^{-6} \mathrm{~cm} / \mathrm{s}\end{array}$ \\
\hline
\end{tabular}


TABLE 3.45 BACKGROUND GROUMDHATER QUALITY DATA BY PARAMETER FOR THE UPPER SABDSTONE UNIT, BURRO CANYON DISPOSAL SITE, SLICK ROCK, COLORADO SITE: SRKO2 BORROW SITE 1 (BURRO CANYON)

06/04/90 TO 10/12/92

DEPORT DATE: $03 / 01 / 94$

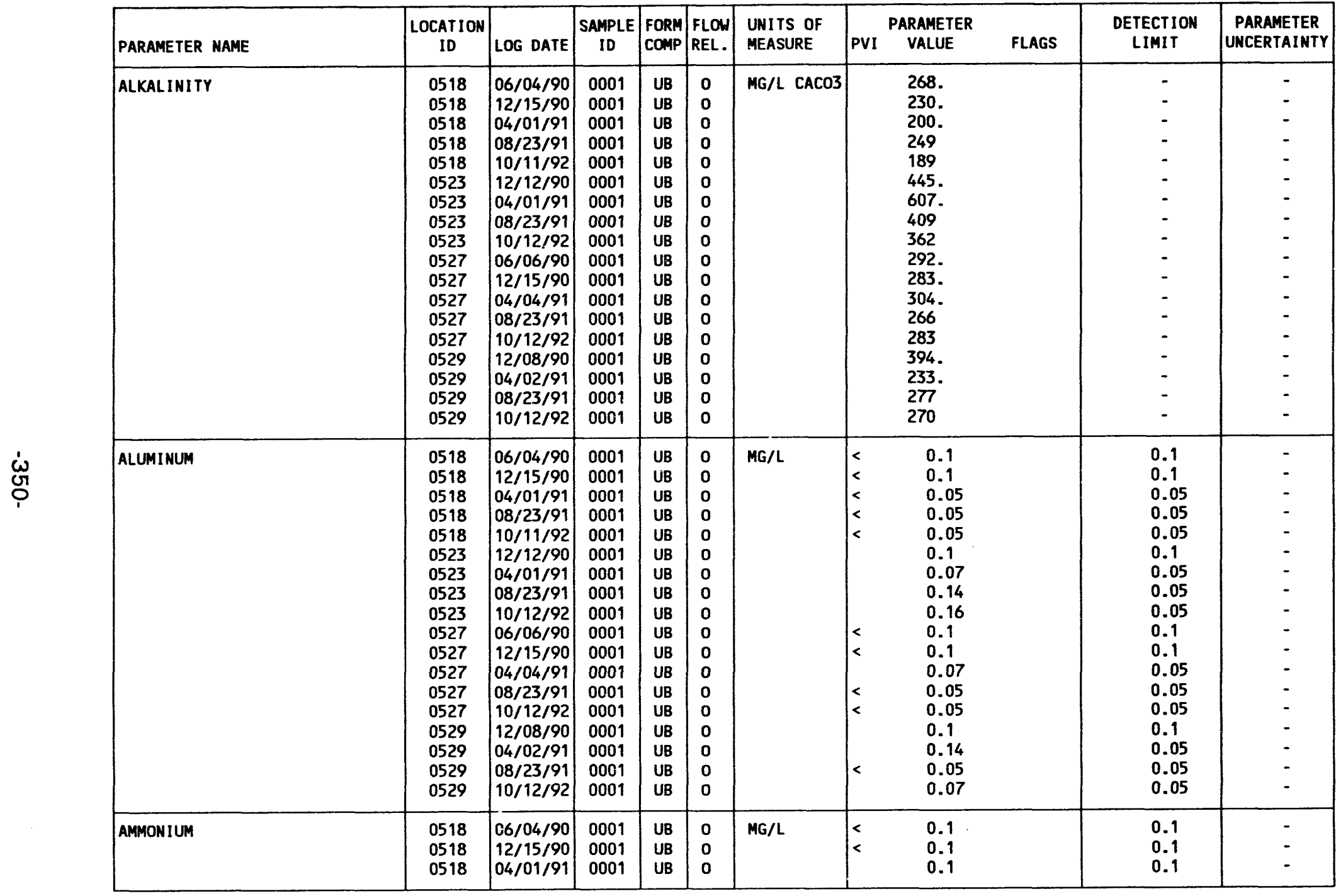

FORMATION OF COMPLETION CODE:

UB - UPPER BURRO CANYON

PARAMETER VALUE INDICATOR (PVI): < - LESS THAN DETECTION LIMIT
FLOW RELATIONSHIP COOE:

0001 - FILTERED SAMPLE (.45 MICRONS) 
TABLE 3.45. BACKGROUND GROUNDHATER QUALITY DATA BY PARAMETER FOR THE UPPER SANDSTONE UNIT, BURRO CANYON DISPOSAL SITE, SLICK ROCK, COLORADO SITE: SRK02 BORROW SITE 1 (BURRO CANYON)

$06 / 04 / 90$ TO $10 / 12 / 92$

REPORT DATE: 03/01/94

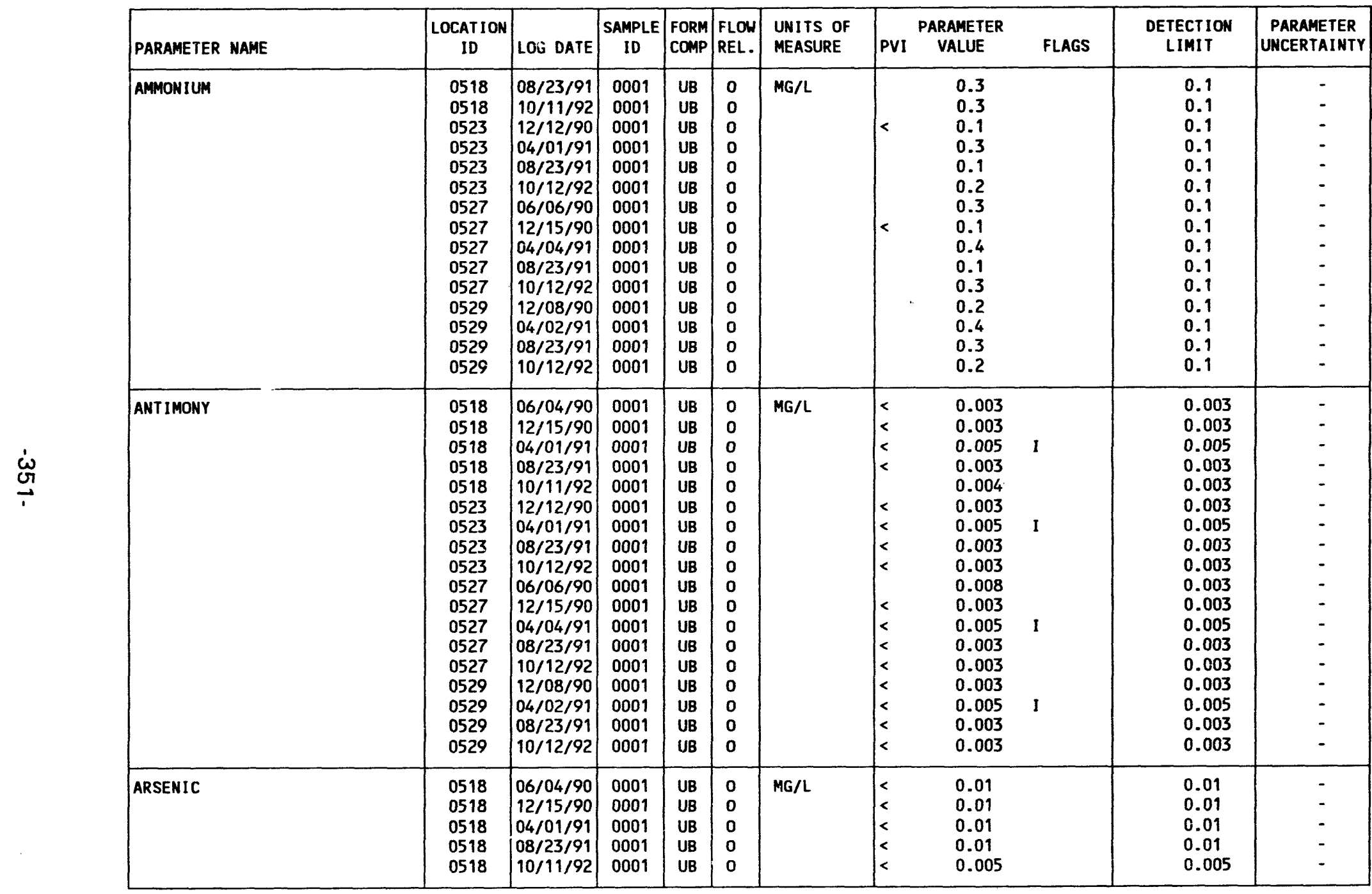

FORMATION OF COMPLETION COOE:

UB - UPPER BURRO CANYON

PARAMETER VALUE INDICATOR (PVI): < - LESS THAN DETECTION LIM!T
FLOW RELATIONSHIP CODE:

O- ON-SITE

0001 - FILTERED SAMPLE (.45 MICRONS)

OTHER PARAMETER VALUE FLAGS

I - INCREASED DETECTION LIMIT DUE TO REQUIRED DILUTION 
TABLE 3.45. BACKGROUND GROUNDWATER QUALITY DATA BY PARAMETER FOR THE UPPER SANDSTONE UNIT, BURRO CANYON DISPOSAL SITE, SLICK ROCK, COLORADO

SITE: SRKO2 BORROW SITE 1 (BURRO CANYON)

06/04/90 TO $10 / 12 / 92$

\begin{tabular}{|c|c|c|c|c|c|c|c|c|c|c|c|}
\hline PARAMETER NAME & $\begin{array}{c}\text { LOCATION } \\
\text { ID }\end{array}$ & LOG DATE & $\begin{array}{c}\text { SAMPLE } \\
\text { ID }\end{array}$ & $\begin{array}{l}\text { FORM } \\
\text { COMP }\end{array}$ & $\begin{array}{l}\text { FLOW } \\
\text { REL. }\end{array}$ & $\begin{array}{l}\text { UNITS OF } \\
\text { MEASURE }\end{array}$ & PVI & $\begin{array}{l}\text { ARAMETER } \\
\text { VALUE }\end{array}$ & FLAGS & $\begin{array}{l}\text { DETECTION } \\
\text { LIMIT }\end{array}$ & \begin{tabular}{|} 
PARAMETER \\
UNCERTAINTY
\end{tabular} \\
\hline ARSENIC & $\begin{array}{l}0523 \\
0523 \\
0523 \\
0523 \\
0527 \\
0527 \\
0527 \\
0527 \\
0527 \\
0529 \\
0529 \\
0529 \\
0529\end{array}$ & \begin{tabular}{|l|}
$12 / 12 / 90$ \\
$04 / 01 / 91$ \\
$08 / 23 / 91$ \\
$10 / 12 / 92$ \\
$06 / 06 / 90$ \\
$12 / 15 / 90$ \\
$04 / 04 / 91$ \\
$08 / 23 / 91$ \\
$10 / 12 / 92$ \\
$12 / 08 / 90$ \\
$04 / 02 / 91$ \\
$08 / 23 / 91$ \\
$10 / 12 / 92$
\end{tabular} & $\begin{array}{l}0001 \\
0001 \\
0001 \\
0001 \\
0001 \\
0001 \\
0001 \\
0001 \\
0001 \\
0001 \\
0001 \\
0001 \\
0001\end{array}$ & $\begin{array}{l}\text { UB } \\
\text { UB } \\
\text { UB } \\
\text { UB } \\
\text { UB } \\
\text { UB } \\
\text { UB } \\
\text { UB } \\
\text { UB } \\
\text { UB } \\
\text { UB } \\
\text { UB } \\
\text { UB }\end{array}$ & $\begin{array}{l}0 \\
0 \\
0 \\
0 \\
0 \\
0 \\
0 \\
0 \\
0 \\
0 \\
0 \\
0 \\
0\end{array}$ & $M G / L$ & $\begin{array}{l}< \\
< \\
< \\
< \\
< \\
< \\
< \\
< \\
< \\
< \\
< \\
< \\
< \\
< \\
<\end{array}$ & $\begin{array}{l}0.01 \\
0.01 \\
0.01 \\
0.005 \\
0.01 \\
0.01 \\
0.01 \\
0.05 \\
0.005 \\
0.01 \\
0.01 \\
0.05 \\
0.005\end{array}$ & $\begin{array}{l}\text { I } \\
\text { I }\end{array}$ & $\begin{array}{l}0.01 \\
0.01 \\
0.01 \\
0.005 \\
0.01 \\
0.01 \\
0.01 \\
0.05 \\
0.005 \\
0.01 \\
0.01 \\
0.05 \\
0.005\end{array}$ & $\begin{array}{l}- \\
- \\
- \\
- \\
- \\
- \\
- \\
- \\
- \\
-\end{array}$ \\
\hline BARIUM & $\begin{array}{l}0518 \\
0518 \\
0518 \\
0518 \\
0518 \\
0523 \\
0523 \\
0523 \\
0523 \\
0527 \\
0527 \\
0527 \\
0527 \\
0527 \\
0529 \\
0529 \\
0529 \\
0529\end{array}$ & $\begin{array}{l}06 / 04 / 90 \\
12 / 15 / 90 \\
04 / 01 / 91 \\
08 / 23 / 91 \\
10 / 11 / 92 \\
12 / 12 / 90 \\
04 / 01 / 91 \\
08 / 23 / 91 \\
10 / 12 / 92 \\
06 / 06 / 90 \\
12 / 15 / 90 \\
04 / 04 / 91 \\
08 / 23 / 91 \\
10 / 12 / 92 \\
12 / 08 / 90 \\
04 / 02 / 91 \\
08 / 23 / 91 \\
10 / 12 / 92\end{array}$ & $\begin{array}{l}0001 \\
0001 \\
0001 \\
0001 \\
0001 \\
0001 \\
0001 \\
0001 \\
0001 \\
0001 \\
0001 \\
0001 \\
0001 \\
0001 \\
0001 \\
0001 \\
0001 \\
0001\end{array}$ & $\begin{array}{l}\text { UB } \\
\text { UB } \\
\text { UB } \\
\text { UB } \\
\text { UB } \\
\text { UB } \\
\text { UB } \\
\text { UB } \\
\text { UB } \\
\text { UB } \\
\text { UB } \\
\text { JB } \\
\text { UB } \\
\text { UB } \\
\text { UB } \\
\text { UB } \\
\text { UB } \\
\text { UB }\end{array}$ & $\begin{array}{l}0 \\
0 \\
0 \\
0 \\
0 \\
0 \\
0 \\
0 \\
0 \\
0 \\
0 \\
0 \\
0 \\
0 \\
0 \\
0 \\
0 \\
0\end{array}$ & $M G / L$ & $<$ & $\begin{array}{l}0.1 \\
0.1 \\
0.03 \\
0.03 \\
0.03 \\
0.1 \\
0.03 \\
0.02 \\
0.02 \\
0.1 \\
0.1 \\
0.04 \\
0.03 \\
0.04 \\
0.1 \\
0.02 \\
0.02 \\
0.02\end{array}$ & & $\begin{array}{l}0.1 \\
0.1 \\
0.01 \\
0.01 \\
0.01 \\
0.1 \\
0.01 \\
0.01 \\
0.01 \\
0.1 \\
0.1 \\
0.01 \\
0.01 \\
0.01 \\
0.1 \\
0.01 \\
0.01 \\
0.01\end{array}$ & $\begin{array}{l}- \\
- \\
- \\
- \\
- \\
- \\
- \\
- \\
- \\
- \\
- \\
- \\
- \\
- \\
-\end{array}$ \\
\hline BERYLLIUM & $\begin{array}{l}0518 \\
0518 \\
0518 \\
0518 \\
0523 \\
0523 \\
0523\end{array}$ & $\begin{array}{l}06 / 04 / 90 \\
12 / 15 / 90 \\
04 / 01 / 91 \\
08 / 23 / 91 \\
12 / 12 / 90 \\
04 / 01 / 91 \\
08 / 23 / 91\end{array}$ & $\begin{array}{l}0001 \\
0001 \\
0001 \\
0001 \\
0001 \\
0001 \\
0001\end{array}$ & $\begin{array}{l}\text { UB } \\
\text { UB } \\
\text { UB } \\
\text { UB } \\
\text { UB } \\
\text { UB } \\
\text { UB }\end{array}$ & $\begin{array}{l}0 \\
0 \\
0 \\
0 \\
0 \\
0 \\
0\end{array}$ & $M G / L$ & $\begin{array}{l}< \\
< \\
< \\
< \\
< \\
< \\
<\end{array}$ & $\begin{array}{l}0.01 \\
0.01 \\
0.005 \\
0.005 \\
0.01 \\
0.005 \\
0.005\end{array}$ & & $\begin{array}{l}0.01 \\
0.01 \\
0.005 \\
0.005 \\
0.01 \\
0.005 \\
0.005\end{array}$ & $\begin{array}{l}- \\
- \\
- \\
- \\
-\end{array}$ \\
\hline
\end{tabular}

FORMATION OF COMPLETION CODE:

UB - UPPER BURRO CANYON

FLOW RELATIONSHIP CODE:

O - ON-SITE

PARAMETER VALUE INDICATOR (PVI): < - LESS THAN DETECTION LIMIT

SAMPLE ID CODES:

0001 - FILTERED SAMPLE (.45 MICRONS)

OTHER PARAMETER VALUE FLAGS:

I - INCREASED DETECTION LIMIT DUE TO REQUIRED DILUTION 
TABLE 3.45. BACKGROUND GROUNDWATER QUALITY DATA BY PARAMETER FOR THE UPPER TABLE 3.45. BACKGROUND GRONDWATE DISPOSAL SITE, SLICK ROCK, COLORADO

SANDSTONE UNIT,

SITE: SRKO2 BORROW SITE 1 (BURRO CANYON)

06/04/90 TO $10 / 12 / 92$

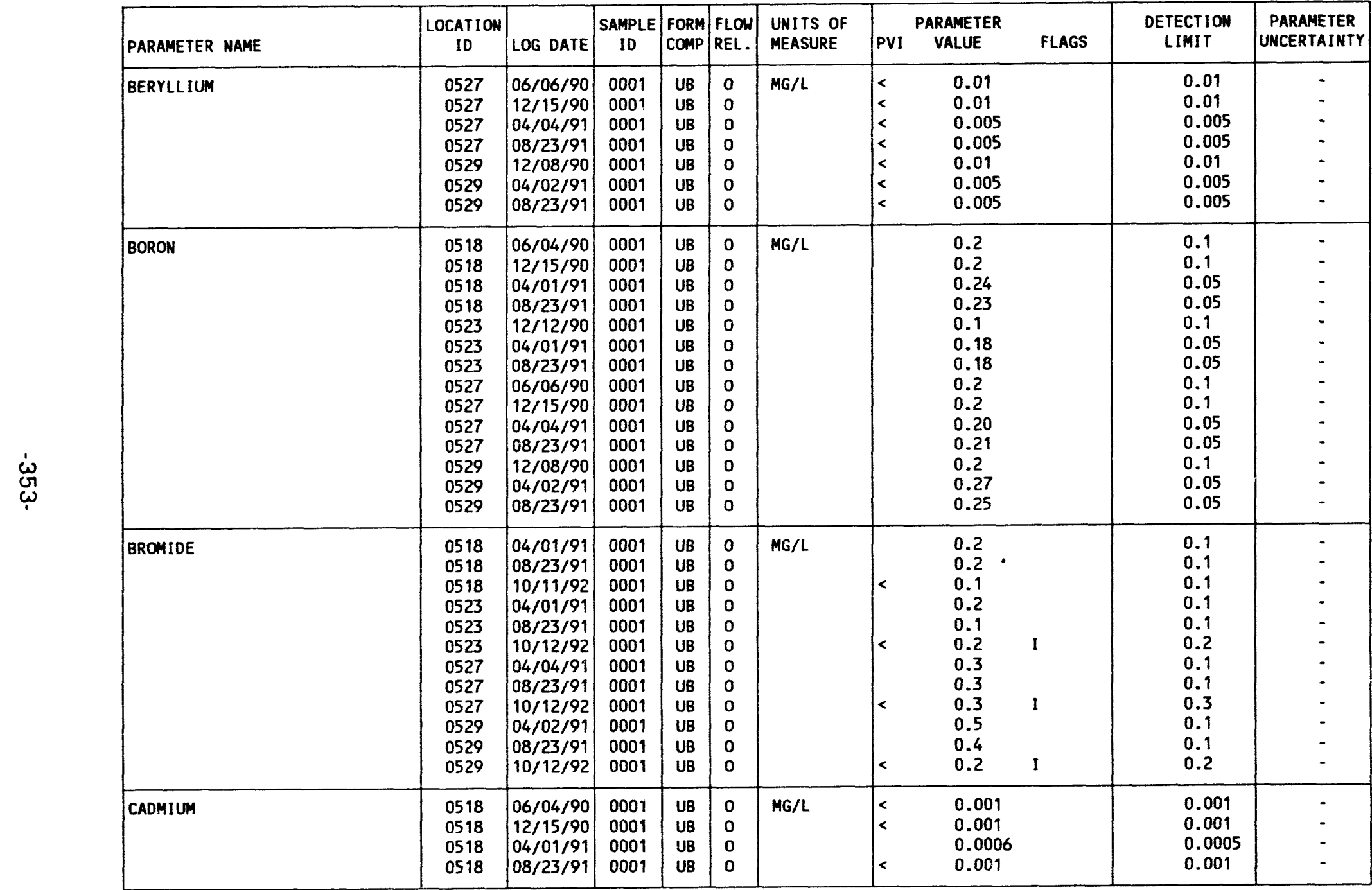

FORMATION OF COMPLETION CODE:

UB - UPPER BURRO CANYON

PARAMETER VALUE INDICATOR (PVI): < - LESS thaN DETECTION LIMIT

OTHER PARAMETER VALUE FLAGS:

I - INCREASED DETECTION LIMIT DUE TO REOUIRED DILUTION
FLOW RELATIONSHIP CODE:

SAMPLE ID CODES:

0001 - FILTERED SAMPLE (.45 MICRONS) 
TABLE 3.45. BACKGROUND GROUNDHATER OUALITY DATA BY PARAMETER FOR THE UPPER SANDSTONE UNIT, BURRO CANYON DISPOSAL SITE, SLICK ROCK, COLORADO

SITE: SRK02 BORROW SITE I (BURRO CAMYON)

$06 / 04 / 90$ iO $10 / 12 / 92$

\begin{tabular}{|c|c|c|c|c|c|c|c|c|c|c|}
\hline PARAMETER NAME & $\begin{array}{c}\text { LOCATION } \\
\text { ID }\end{array}$ & LOG DATE & $\begin{array}{c}\text { SAMPLE } \\
\text { ID }\end{array}$ & $\begin{array}{l}\text { FORM } \\
\text { COMP }\end{array}$ & $\begin{array}{l}\text { FLOW } \\
\text { REL. }\end{array}$ & $\begin{array}{l}\text { UNITS OF } \\
\text { MEASURE }\end{array}$ & PVI & $\begin{array}{l}\text { 'ARAMETER } \\
\text { VALUE }\end{array}$ & $\begin{array}{l}\text { DETECTION } \\
\text { LIMIT }\end{array}$ & $\begin{array}{l}\text { PARAMETER } \\
\text { UNCERTAINTY }\end{array}$ \\
\hline CADMIUM & $\begin{array}{l}0518 \\
0523 \\
0523 \\
0523 \\
0523 \\
0527 \\
0527 \\
0527 \\
0527 \\
0527 \\
0529 \\
0529 \\
0529 \\
0529\end{array}$ & $\begin{array}{l}10 / 11 / 92 \\
12 / 12 / 90 \\
04 / 01 / 91 \\
08 / 23 / 91 \\
10 / 12 / 92 \\
06 / 06 / 90 \\
12 / 15 / 90 \\
04 / 04 / 91 \\
08 / 23 / 91 \\
10 / 12 / 92 \\
12 / 08 / 90 \\
04 / 02 / 91 \\
08 / 23 / 91 \\
10 / 12 / 92\end{array}$ & $\begin{array}{l}0001 \\
0001 \\
0001 \\
0001 \\
0001 \\
0001 \\
0001 \\
0001 \\
0001 \\
0001 \\
0001 \\
0001 \\
0001 \\
0001\end{array}$ & $\begin{array}{l}\text { UB } \\
\text { UB } \\
\text { UB } \\
\text { UB } \\
\text { UB } \\
\text { UB } \\
\text { UB } \\
\text { UB } \\
\text { UB } \\
\text { UB } \\
\text { UB } \\
\text { UB } \\
\text { UB } \\
\text { UB }\end{array}$ & $\begin{array}{l}0 \\
0 \\
0 \\
0 \\
0 \\
0 \\
0 \\
0 \\
0 \\
0 \\
0 \\
0 \\
0 \\
0\end{array}$ & $\mathrm{MG} / \mathrm{L}$ & $\begin{array}{l}< \\
< \\
< \\
< \\
< \\
< \\
< \\
< \\
< \\
< \\
< \\
< \\
< \\
<\end{array}$ & $\begin{array}{ll}0.02 & 1 \\
0.001 & \\
0.0005 & \\
0.001 & \\
0.001 \\
0.001 \\
0.001 \\
0.0005 \\
0.001 \\
0.001 \\
0.001 \\
0.0005 \\
0.001 \\
0.001\end{array}$ & $\begin{array}{l}0.02 \\
0.001 \\
0.0005 \\
0.001 \\
0.001 \\
0.001 \\
0.001 \\
0.0005 \\
0.001 \\
0.001 \\
0.001 \\
0.0005 \\
0.001 \\
0.001\end{array}$ & $\begin{array}{l}- \\
- \\
- \\
- \\
- \\
- \\
- \\
- \\
- \\
- \\
-\end{array}$ \\
\hline CALCIUM & $\begin{array}{l}0518 \\
0518 \\
0518 \\
0518 \\
0518 \\
0523 \\
0523 \\
0523 \\
0523 \\
0527 \\
0527 \\
0527 \\
0527 \\
0527 \\
0529 \\
0529 \\
0529 \\
0529\end{array}$ & $\begin{array}{l}06 / 04 / 90 \\
12 / 15 / 90 \\
04 / 01 / 91 \\
08 / 23 / 91 \\
10 / 11 / 92 \\
12 / 12 / 90 \\
04 / 01 / 91 \\
08 / 23 / 91 \\
10 / 12 / 92 \\
06 / 06 / 90 \\
12 / 15 / 90 \\
04 / 04 / 91 \\
08 / 23 / 91 \\
10 / 12 / 92 \\
12 / 08 / 90 \\
04 / 02 / 91 \\
08 / 23 / 91 \\
10 / 12 / 92\end{array}$ & $\begin{array}{l}0001 \\
0001 \\
0001 \\
0001 \\
0001 \\
0001 \\
0001 \\
0001 \\
0001 \\
0001 \\
0001 \\
0001 \\
0001 \\
0001 \\
0001 \\
0001 \\
0001 \\
0001\end{array}$ & $\begin{array}{l}\text { UB } \\
\text { UB } \\
\text { UB } \\
\text { UB } \\
\text { UB } \\
\text { UB } \\
\text { UB } \\
\text { UB } \\
\text { UB } \\
\text { UB } \\
\text { UB } \\
\text { UB } \\
\text { UB } \\
\text { UB } \\
\text { UB } \\
\text { UB } \\
\text { UB } \\
\text { UB }\end{array}$ & $\begin{array}{l}0 \\
0 \\
0 \\
0 \\
0 \\
0 \\
0 \\
0 \\
0 \\
0 \\
0 \\
0 \\
0 \\
0 \\
0 \\
0 \\
0 \\
0\end{array}$ & $M G / L$ & & $\begin{array}{c}118 . \\
105 . \\
112 . \\
108 . \\
105 . \\
4.54 \\
5.1 \\
3.7 \\
4.8 \\
18.7 \\
17.7 \\
20.1 \\
18.5 \\
15.9 \\
6.96 \\
7.5 \\
7.3 \\
6.8\end{array}$ & $\begin{array}{l}0.01 \\
0.01 \\
0.5 \\
0.5 \\
0.5 \\
0.01 \\
0.1 \\
0.1 \\
0.1 \\
0.01 \\
0.01 \\
0.5 \\
0.1 \\
0.1 \\
0.01 \\
0.1 \\
0.1 \\
0.1\end{array}$ & $\begin{array}{l}- \\
- \\
- \\
- \\
- \\
- \\
- \\
- \\
- \\
- \\
- \\
- \\
- \\
-\end{array}$ \\
\hline CHLORIDE & $\begin{array}{l}0518 \\
0518 \\
0518 \\
0518 \\
0518 \\
0523\end{array}$ & $\begin{array}{l}06 / 04 / 90 \\
12 / 15 / 90 \\
04 / 01 / 91 \\
08 / 23 / 91 \\
10 / 11 / 92 \\
12 / 12 / 90\end{array}$ & $\begin{array}{l}0001 \\
0001 \\
0001 \\
0001 \\
0001 \\
0001\end{array}$ & $\begin{array}{l}\text { UB } \\
\text { UB } \\
\text { UB } \\
\text { UB } \\
\text { UB } \\
\text { UB }\end{array}$ & $\begin{array}{l}0 \\
0 \\
0 \\
0 \\
0 \\
0\end{array}$ & $M G / L$ & & $\begin{array}{l}13 . \\
14 . \\
15.7 \\
15.6 \\
16.3 \\
19 .\end{array}$ & $\begin{array}{l}1 . \\
1 . \\
0.5 \\
0.5 \\
0.5 \\
1 .\end{array}$ & $\begin{array}{l}- \\
- \\
- \\
-\end{array}$ \\
\hline
\end{tabular}

FORMATION OF COMPLETION CODE:

UB - UPPER BURRO CANYON

FLOW RELATIONSHIP CODE:

PARAMETER VALUE INDICATOR (PVI): < - LESS THAN DETECTION LIMIT

SAMPLE ID CODES:

0001 - FILTERED SAMPLE (.45 MICRONS)

OTHER PARAMETER VALUE FLAGS:

I - INCREASED DETECTION LIMIT DUE TO REQUIRED DILUTION 
TABLE 3.45. BACKGROUND GROUHDWATER QUALITY DATA BY PARAMETER FOR THE UPPER SAMDSTONE UNIT, BURRO CAMYON DISPOSAL SITE, SLICK ROCK, COLORADO SITE: SRKO2 BORROH SITE

06/04/90 TO $10 / 12 / 92$

REPORT DATE: 03/01/94

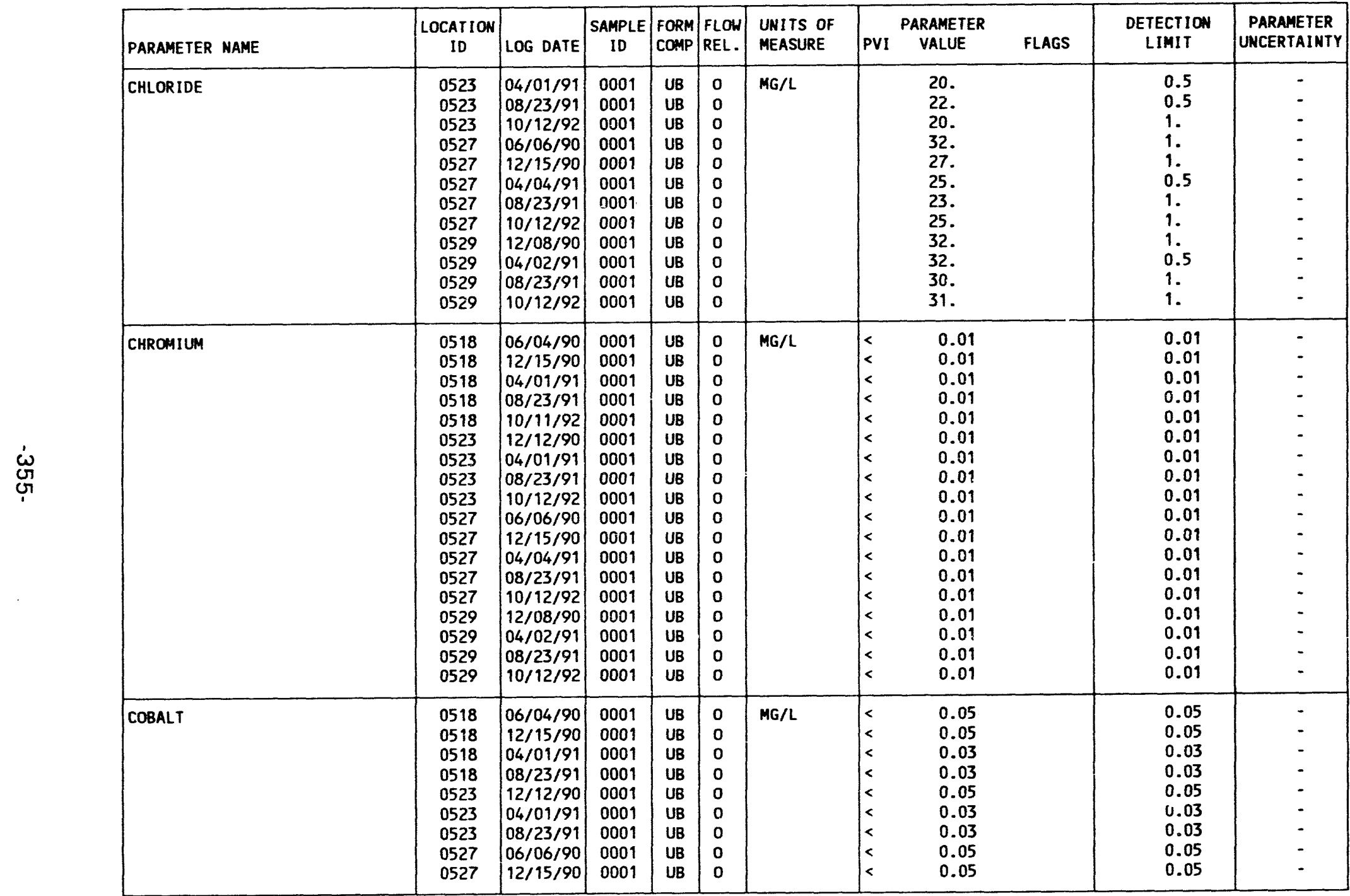

FORMATION OF COMPLETION CODE:

UB - UPPER BURRO CANYON

PARAMETER VALUE INDICATOR (PVI): < - LESS THAN DETECTION LIMIT
FLOU RELATIONSHIP COOE:

O - ON-SITE

SAMPLE ID COOES:

0001 - FILTERED SAMPLE (.45 MICRONS) 
TABLE 3.45. BACKGPOUANO GROU!HDWATER QUALITY DATA BY PARAMETER FOR THE UPPER SANDSTONE UNIT, BURRO CANYON DISPOSAL SITE, SLICK ROCK, COLORADO

SITE: SRKO2 BORROW SITE 1 (BURRO CANYON)

06/04/90 TO $10 / 12 / 92$

REPORT DATE: 03/01/94

\begin{tabular}{|c|c|c|c|c|c|c|c|c|c|c|}
\hline PARAMETER NAME & $\begin{array}{c}\text { LOCATION } \\
\text { ID }\end{array}$ & LOG DATE & $\begin{array}{c}\text { SAMPLE } \\
\text { ID }\end{array}$ & $\begin{array}{l}\text { FORM } \\
\text { COMP }\end{array}$ & $\begin{array}{l}\text { FLOW } \\
\text { REL. }\end{array}$ & $\begin{array}{l}\text { UNITS OF } \\
\text { MEASURE }\end{array}$ & PVI & $\begin{array}{l}\text { ARAMETER } \\
\text { VALUE }\end{array}$ & $\begin{array}{l}\text { DETECTION } \\
\text { LIMIT }\end{array}$ & $\begin{array}{l}\text { PARAMETER } \\
\text { UNCERTAINTY }\end{array}$ \\
\hline COBALT & $\begin{array}{l}0527 \\
0527 \\
0529 \\
0529 \\
0529\end{array}$ & $\begin{array}{l}04 / 04 / 91 \\
08 / 23 / 91 \\
12 / 08 / 90 \\
04 / 02 / 91 \\
08 / 23 / 91\end{array}$ & $\begin{array}{l}0001 \\
0001 \\
0001 \\
0001 \\
0001\end{array}$ & $\begin{array}{l}\text { UB } \\
\text { UB } \\
\text { UB } \\
\text { UB } \\
\text { UB }\end{array}$ & $\begin{array}{l}0 \\
0 \\
0 \\
0 \\
0\end{array}$ & $M G / L$ & $\begin{array}{l}< \\
< \\
< \\
< \\
<\end{array}$ & $\begin{array}{l}0.03 \\
0.03 \\
0.05 \\
0.03 \\
0.03\end{array}$ & $\begin{array}{l}0.03 \\
0.03 \\
0.05 \\
0.03 \\
0.03\end{array}$ & $\begin{array}{l}- \\
- \\
-\end{array}$ \\
\hline COPPER & $\begin{array}{l}0518 \\
0518 \\
0518 \\
0518 \\
0518 \\
0523 \\
0523 \\
0523 \\
0523 \\
0527 \\
0527 \\
0527 \\
0527 \\
0527 \\
0529 \\
0529 \\
0529 \\
0529\end{array}$ & $\begin{array}{l}06 / 04 / 90 \\
12 / 15 / 90 \\
04 / 01 / 91 \\
08 / 23 / 91 \\
10 / 11 / 92 \\
12 / 12 / 90 \\
04 / 01 / 91 \\
08 / 23 / 91 \\
10 / 12 / 92 \\
06 / 06 / 90 \\
12 / 15 / 90 \\
04 / 04 / 91 \\
08 / 23 / 91 \\
10 / 12 / 92 \\
12 / 08 / 90 \\
04 / 02 / 91 \\
08 / 23 / 91 \\
10 / 12 / 92\end{array}$ & $\begin{array}{l}0001 \\
0001 \\
0001 \\
0001 \\
0001 \\
0001 \\
0001 \\
0001 \\
0001 \\
0001 \\
0001 \\
0001 \\
0001 \\
0001 \\
0001 \\
0001 \\
0001 \\
0001\end{array}$ & $\begin{array}{l}\text { UB } \\
\text { UB } \\
\text { UB } \\
\text { UB } \\
\text { UB } \\
\text { UB } \\
\text { UB } \\
\text { UB } \\
\text { UB } \\
\text { UB } \\
\text { UB } \\
\text { UB } \\
\text { UB } \\
\text { UB } \\
\text { UB } \\
\text { UB } \\
\text { UB } \\
\text { UB }\end{array}$ & $\begin{array}{l}0 \\
0 \\
0 \\
0 \\
0 \\
0 \\
0 \\
0 \\
0 \\
0 \\
0 \\
0 \\
0 \\
0 \\
0 \\
0 \\
0 \\
0\end{array}$ & $M G / L$ & $\begin{array}{l}< \\
< \\
< \\
< \\
< \\
< \\
< \\
< \\
< \\
< \\
< \\
< \\
< \\
< \\
< \\
< \\
< \\
< \\
< \\
<\end{array}$ & $\begin{array}{l}0.02 \\
0.02 \\
0.01 \\
0.01 \\
0.01 \\
0.02 \\
0.01 \\
0.01 \\
0.01 \\
0.02 \\
0.02 \\
0.01 \\
0.01 \\
0.01 \\
0.02 \\
0.01 \\
0.01 \\
0.01\end{array}$ & $\begin{array}{l}0.02 \\
0.02 \\
0.01 \\
0.01 \\
0.01 \\
0.02 \\
0.01 \\
0.01 \\
0.01 \\
0.02 \\
0.02 \\
0.01 \\
0.01 \\
0.01 \\
0.02 \\
0.01 \\
0.01 \\
0.01\end{array}$ & $\begin{array}{l}- \\
- \\
- \\
- \\
- \\
- \\
- \\
- \\
- \\
- \\
- \\
- \\
- \\
- \\
-\end{array}$ \\
\hline CYANIDE & $\begin{array}{l}0518 \\
0518 \\
0518 \\
0523 \\
0523 \\
0523 \\
0527 \\
0527 \\
0527 \\
0529 \\
0529 \\
0529\end{array}$ & \begin{tabular}{|l|}
$12 / 15 / 90$ \\
$04 / 01 / 91$ \\
$08 / 23 / 91$ \\
$12 / 12 / 90$ \\
$04 / 01 / 91$ \\
$08 / 23 / 91$ \\
$12 / 15 / 90$ \\
$04 / 04 / 91$ \\
$08 / 23 / 91$ \\
$12 / 08 / 90$ \\
$04 / 02 / 91$ \\
$08 / 23 / 91$
\end{tabular} & $\begin{array}{l}0001 \\
0001 \\
0001 \\
0001 \\
0001 \\
0001 \\
0001 \\
0001 \\
0001 \\
0001 \\
0001 \\
0001\end{array}$ & $\begin{array}{l}\text { UB } \\
\text { UB } \\
\text { UB } \\
\text { UB } \\
\text { UB } \\
\text { UB } \\
\text { UB } \\
\text { UB } \\
\text { UB } \\
\text { UB } \\
\text { UB } \\
\text { UB }\end{array}$ & $\begin{array}{l}0 \\
0 \\
0 \\
0 \\
0 \\
0 \\
0 \\
0 \\
0 \\
0 \\
0 \\
0\end{array}$ & $M G / L$ & $\begin{array}{l}< \\
< \\
< \\
< \\
< \\
< \\
< \\
< \\
< \\
< \\
< \\
< \\
<\end{array}$ & $\begin{array}{l}0.01 \\
0.01 \\
0.01 \\
0.01 \\
0.01 \\
0.01 \\
0.01 \\
0.01 \\
0.01 \\
0.01 \\
0.01 \\
0.01\end{array}$ & $\begin{array}{l}0.01 \\
0.01 \\
0.01 \\
0.01 \\
0.01 \\
0.01 \\
0.01 \\
0.01 \\
0.01 \\
0.01 \\
0.01 \\
0.01\end{array}$ & $\begin{array}{l}- \\
- \\
- \\
- \\
- \\
- \\
- \\
- \\
-\end{array}$ \\
\hline FLUORIDE & $\begin{array}{l}0518 \\
0518 \\
0518\end{array}$ & $\begin{array}{l}06 / 04 / 90 \\
12 / 15 / 90 \\
04 / 01 / 91\end{array}$ & $\begin{array}{l}0001 \\
0001 \\
0001\end{array}$ & $\begin{array}{l}\text { UB } \\
\text { UB } \\
\text { UB }\end{array}$ & $\begin{array}{l}0 \\
0 \\
0\end{array}$ & $M G / L$ & & $\begin{array}{l}0.7 \\
0.8 \\
0.6\end{array}$ & $\begin{array}{l}0.1 \\
0.1 \\
0.1\end{array}$ & - \\
\hline
\end{tabular}

FORMATION OF COMPLETION CODE:

UB - UPPER BURRO CANYON

PARAMETER VALUE INDICATOR (PVI): < - LESS THAN DETECTION LIMIT
FLOW RELATIONSHIP CODE:

O - ON-SITE

SAMPLE ID CODES:

0001 - FILTERED SAMPLE (.45 MICRONS) 
TABLE 3.45. BACKGROUND GROUNDWATER QUALITY DATA BY PARAMETER FOR THE UPPER SANDSTONE UNIT, BURRO CANYON DISPOSAL SITE, SLICK ROCK, COLORADO

SITE: SRKO2 BORROW SITE 1 (BURRO CANYON)

O6/04/90 TO $10 / 12 / 92$

\begin{tabular}{|c|c|c|c|c|c|c|c|c|c|c|c|}
\hline PARAMETER NAME & $\begin{array}{c}\text { LOCATION } \\
\text { ID }\end{array}$ & LOG DATE & $\begin{array}{c}\text { SAMPLE } \\
\text { ID }\end{array}$ & $\begin{array}{l}\text { FORM } \\
\text { COMP }\end{array}$ & $\begin{array}{l}\text { FLOW } \\
\text { REL. }\end{array}$ & $\begin{array}{l}\text { UNITS OF } \\
\text { MEASURE }\end{array}$ & PVI & $\begin{array}{l}\text { ARAMETE } \\
\text { VALUE }\end{array}$ & FLAGS & $\begin{array}{l}\text { DETECTION } \\
\text { LIMIT }\end{array}$ & $\begin{array}{l}\text { PARAMETER } \\
\text { UNCERTAINTY }\end{array}$ \\
\hline FLUOR IDE & $\begin{array}{l}0518 \\
0518 \\
0523 \\
0523 \\
0523 \\
0523 \\
0527 \\
0527 \\
0527 \\
0527 \\
0527 \\
0529 \\
0529 \\
0529 \\
0529\end{array}$ & $\begin{array}{l}08 / 23 / 91 \\
10 / 11 / 92 \\
12 / 12 / 90 \\
04 / 01 / 91 \\
08 / 23 / 91 \\
10 / 12 / 92 \\
06 / 06 / 90 \\
12 / 15 / 90 \\
04 / 04 / 91 \\
08 / 23 / 91 \\
10 / 12 / 92 \\
12 / 08 / 90 \\
04 / 02 / 91 \\
08 / 23 / 91 \\
10 / 12 / 92\end{array}$ & $\begin{array}{l}0001 \\
0001 \\
0001 \\
0001 \\
0001 \\
0001 \\
0001 \\
0001 \\
0001 \\
0001 \\
0001 \\
0001 \\
0001 \\
0001 \\
0001\end{array}$ & $\begin{array}{l}\text { UB } \\
\text { UB } \\
\text { UB } \\
\text { UB } \\
\text { UB } \\
\text { UB } \\
\text { UB } \\
\text { UB } \\
\text { UB } \\
\text { UB } \\
\text { UB } \\
\text { UB } \\
\text { UB } \\
\text { UB } \\
\text { UB }\end{array}$ & $\begin{array}{l}0 \\
0 \\
0 \\
0 \\
0 \\
0 \\
0 \\
0 \\
0 \\
0 \\
0 \\
0 \\
0 \\
0 \\
0\end{array}$ & $M G / L$ & & $\begin{array}{l}0.7 \\
0.8 \\
1.1 \\
0.9 \\
0.9 \\
1.1 \\
0.8 \\
0.8 \\
0.7 \\
0.7 \\
0.8 \\
0.8 \\
0.7 \\
0.6 \\
0.8\end{array}$ & & $\begin{array}{l}0.1 \\
0.1 \\
0.1 \\
0.1 \\
0.1 \\
0.1 \\
0.1 \\
0.1 \\
0.1 \\
0.1 \\
0.1 \\
0.1 \\
0.1 \\
0.1 \\
0.1\end{array}$ & $\begin{array}{l}- \\
- \\
- \\
- \\
- \\
- \\
- \\
- \\
- \\
- \\
-\end{array}$ \\
\hline GROSS ALPHA & $\begin{array}{l}0518 \\
0518 \\
0518 \\
0518 \\
0523 \\
0523 \\
0523 \\
0523 \\
0527 \\
0527 \\
0527 \\
0527 \\
0529 \\
0529 \\
0529 \\
0529\end{array}$ & $\begin{array}{l}12 / 15 / 90 \\
04 / 01 / 91 \\
08 / 23 / 91 \\
10 / 11 / 92 \\
12 / 12 / 90 \\
04 / 01 / 91 \\
08 / 23 / 91 \\
10 / 12 / 92 \\
12 / 15 / 90 \\
04 / 04 / 91 \\
08 / 23 / 91 \\
10 / 12 / 92 \\
12 / 08 / 90 \\
04 / 02 / 91 \\
08 / 23 / 91 \\
10 / 12 / 92\end{array}$ & $\begin{array}{l}0001 \\
0001 \\
0001 \\
0001 \\
0001 \\
0001 \\
0001 \\
0001 \\
0001 \\
0001 \\
0001 \\
0001 \\
0001 \\
0001 \\
0001 \\
0001\end{array}$ & $\begin{array}{l}\text { UB } \\
\text { UB } \\
\text { UB } \\
\text { UB } \\
\text { UB } \\
\text { UB } \\
\text { UB } \\
\text { UB } \\
\text { UB } \\
\text { UB } \\
\text { UB } \\
\text { UB } \\
\text { UB } \\
\text { UB } \\
\text { UB } \\
\text { UB }\end{array}$ & $\begin{array}{l}0 \\
0 \\
0 \\
0 \\
0 \\
0 \\
0 \\
0 \\
0 \\
0 \\
0 \\
0 \\
0 \\
0 \\
0 \\
0\end{array}$ & $\mathrm{PCI} / \mathrm{L}$ & & $\begin{array}{c}18 . \\
12.6 \\
12.6 \\
11.9 \\
1.3 \\
0.0 \\
0.0 \\
0.0 \\
10 . \\
2.4 \\
7.3 \\
0.0 \\
1.7 \\
1.6 \\
10.2 \\
0.0\end{array}$ & $\begin{array}{l}\text { N } \\
\text { N } \\
\text { N } \\
\text { N }\end{array}$ & $\begin{array}{c}1 . \\
1 . \\
1 . \\
11.5 \\
1 . \\
1 . \\
1.9 \\
11.9 \\
1 . \\
1 . \\
1 . \\
14.3 \\
1 . \\
1 . \\
1 . \\
11.1\end{array}$ & $\begin{array}{r}7 . \\
8.9 \\
14.0 \\
8.2 \\
4.3 \\
5.0 \\
8.2 \\
6.3 \\
7 . \\
7.3 \\
12.6 \\
7.6 \\
4.0 \\
4.8 \\
10.5 \\
5.7\end{array}$ \\
\hline GROSS BETA & $\begin{array}{l}0518 \\
0518 \\
0518 \\
0518 \\
0523 \\
0523\end{array}$ & $\begin{array}{l}12 / 15 / 90 \\
04 / 01 / 91 \\
08 / 23 / 91 \\
10 / 11 / 92 \\
12 / 12 / 90 \\
04 / 01 / 91\end{array}$ & $\begin{array}{l}0001 \\
0001 \\
0001 \\
0001 \\
0001 \\
0001\end{array}$ & $\begin{array}{l}\text { UR } \\
\text { UB } \\
\text { UB } \\
\text { UB } \\
\text { UB } \\
\text { UB }\end{array}$ & $\begin{array}{l}0 \\
0 \\
0 \\
0 \\
0 \\
0\end{array}$ & PCI/L & & $\begin{array}{r}11 . \\
7.3 \\
3.8 \\
39.2 \\
9.7 \\
0.0\end{array}$ & $*_{N}$ & $\begin{array}{r}0.5 \\
0.5 \\
0.5 \\
10.2 \\
0.5 \\
0.5\end{array}$ & $\begin{array}{l}4 . \\
4.9 \\
9.3 \\
7.7 \\
3.4 \\
3.2\end{array}$ \\
\hline
\end{tabular}

FORMATION OF COMPLETION COOE:

UB - UPPER BURRO CANYON

FLOW RELATIONSHIP COOE:

PARAMETER VALUE INDICATOR (PVI): - - LESS THAN DETECTION LIMIT SAMPLE ID COOES:

0001 - FILTERED SAMPLE (.45 MICRONS)

OTHER PARAMETER VALUE FLAGS:

* - DUPLICATE ANALYSIS NOT WITHIN CONTROL LIMITS

N - SPIKE SAMPLE RECOVERY NOT WITHIN CONTROL LIMITS 
TABLE 3.45. BACKGROUND GROUNDWATER QUALITY DATA BY PARAMETER FOR THE UPPER SANDSTONE UNIT, BURRO CANYON DISPOSAL SITE, SLICK ROCK, COLORADO

SITE: SRK02 BORROW SITE 1 (BURRO CANYON)

$06 / 04 / 90$ TO $10 / 12 / 92$

REPORT DATE: 03/01/94

\begin{tabular}{|c|c|c|c|c|c|c|c|c|c|c|c|}
\hline PARAMETER NAME & $\underset{\text { ID }}{\text { LOCATION }}$ & LOG DATE & $\begin{array}{c}\text { SAMPLE } \\
\text { ID }\end{array}$ & $\begin{array}{l}\text { FORM } \\
\text { COMP }\end{array}$ & $\begin{array}{l}\text { FLOW } \\
\text { REL. }\end{array}$ & $\begin{array}{l}\text { UNITS OF } \\
\text { MEASURE }\end{array}$ & PVI & $\begin{array}{l}\text { ARAMETER } \\
\text { VALUE }\end{array}$ & FLAGS & $\begin{array}{l}\text { DETECTION } \\
\text { LIMIT }\end{array}$ & $\begin{array}{l}\text { PARAMETER } \\
\text { UNCERTAINTY }\end{array}$ \\
\hline GROSS BETA & $\begin{array}{l}0523 \\
0523 \\
0527 \\
0527 \\
0527 \\
0527 \\
0529 \\
0529 \\
0529 \\
0529\end{array}$ & $\begin{array}{l}08 / 23 / 91 \\
10 / 12 / 92 \\
12 / 15 / 90 \\
04 / 04 / 91 \\
08 / 23 / 91 \\
10 / 12 / 92 \\
12 / 08 / 90 \\
04 / 02 / 91 \\
08 / 23 / 91 \\
10 / 12 / 92\end{array}$ & $\begin{array}{l}0001 \\
0001 \\
0001 \\
0001 \\
0001 \\
0001 \\
0001 \\
0001 \\
0001 \\
0001\end{array}$ & $\begin{array}{l}\text { UB } \\
\text { UB } \\
\text { UB } \\
\text { UB } \\
\text { UB } \\
\text { UB } \\
\text { UB } \\
\text { UB } \\
\text { UB } \\
\text { UB }\end{array}$ & $\begin{array}{l}0 \\
0 \\
0 \\
0 \\
0 \\
0 \\
0 \\
0 \\
0 \\
0\end{array}$ & $\mathrm{PCI} / \mathrm{L}$ & & $\begin{array}{l}4.6 \\
0.7 \\
5.5 \\
0.2 \\
0.0 \\
6.1 \\
3.9 \\
0.4 \\
3.1 \\
0.0\end{array}$ & $\begin{array}{l}*_{N} \\
*_{N} \\
*_{N}\end{array}$ & $\begin{array}{r}0.5 \\
10.2 \\
0.5 \\
0.5 \\
0.5 \\
12.2 \\
0.5 \\
0.5 \\
0.5 \\
9.7\end{array}$ & $\begin{array}{l}7.0 \\
6.1 \\
4.1 \\
4.4 \\
8.0 \\
7.5 \\
2.8 \\
2.9 \\
6.9 \\
5.6\end{array}$ \\
\hline IRON & $\begin{array}{l}0518 \\
0518 \\
0518 \\
0518 \\
0518 \\
0523 \\
0523 \\
0523 \\
0523 \\
0527 \\
0527 \\
0527 \\
0527 \\
0527 \\
0529 \\
0529 \\
0529 \\
0529\end{array}$ & $\begin{array}{l}06 / 04 / 90 \\
12 / 15 / 90 \\
04 / 01 / 91 \\
08 / 23 / 91 \\
10 / 11 / 92 \\
12 / 12 / 90 \\
04 / 01 / 91 \\
08 / 23 / 91 \\
10 / 12 / 92 \\
06 / 06 / 90 \\
12 / 15 / 90 \\
04 / 04 / 91 \\
08 / 23 / 91 \\
10 / 12 / 92 \\
12 / 08 / 90 \\
04 / 02 / 91 \\
08 / 23 / 91 \\
10 / 12 / 92\end{array}$ & $\begin{array}{l}0001 \\
0001 \\
0001 \\
0001 \\
0001 \\
0001 \\
0001 \\
0001 \\
0001 \\
0001 \\
0001 \\
0001 \\
0001 \\
0001 \\
0001 \\
0001 \\
0001 \\
0001\end{array}$ & $\begin{array}{l}\text { UB } \\
\text { UB } \\
\text { UB } \\
\text { UB } \\
\text { UB } \\
\text { UB } \\
\text { UB } \\
\text { UB } \\
\text { UB } \\
\text { UB } \\
\text { UB } \\
\text { UB } \\
\text { UB } \\
\text { UB } \\
\text { UB } \\
\text { UB } \\
\text { UB } \\
\text { UB }\end{array}$ & $\begin{array}{l}0 \\
0 \\
0 \\
0 \\
0 \\
0 \\
0 \\
0 \\
0 \\
0 \\
0 \\
0 \\
0 \\
0 \\
0 \\
0 \\
0 \\
0\end{array}$ & MG/L & $\begin{array}{l}< \\
< \\
< \\
< \\
< \\
< \\
< \\
< \\
< \\
< \\
< \\
< \\
<\end{array}$ & $\begin{array}{l}0.04 \\
0.03 \\
0.03 \\
0.03 \\
0.03 \\
0.03 \\
0.03 \\
0.06 \\
0.07 \\
0.03 \\
0.03 \\
0.03 \\
0.03 \\
0.03 \\
0.03 \\
0.05 \\
0.03 \\
0.03\end{array}$ & & $\begin{array}{l}0.03 \\
0.03 \\
0.03 \\
0.03 \\
0.03 \\
0.03 \\
0.03 \\
0.03 \\
0.03 \\
0.03 \\
0.03 \\
0.03 \\
0.03 \\
0.03 \\
0.03 \\
0.03 \\
0.03 \\
0.03\end{array}$ & $\begin{array}{l}- \\
- \\
- \\
- \\
- \\
- \\
- \\
- \\
- \\
- \\
- \\
- \\
- \\
- \\
-\end{array}$ \\
\hline LEAD & $\begin{array}{l}0518 \\
0518 \\
0518 \\
0518 \\
0518 \\
0523 \\
0523 \\
0523 \\
0523\end{array}$ & $\begin{array}{l}06 / 04 / 90 \\
12 / 15 / 90 \\
04 / 01 / 91 \\
08 / 23 / 91 \\
10 / 11 / 92 \\
12 / 12 / 90 \\
04 / 01 / 91 \\
08 / 23 / 91 \\
10 / 12 / 92\end{array}$ & $\begin{array}{l}0001 \\
0001 \\
0001 \\
0001 \\
0001 \\
0001 \\
0001 \\
0001 \\
0001\end{array}$ & $\begin{array}{l}\text { UB } \\
\text { UB } \\
\text { UB } \\
\text { UB } \\
\text { UB } \\
\text { UB } \\
\text { UB } \\
\text { UB } \\
\text { UB }\end{array}$ & $\begin{array}{l}0 \\
0 \\
0 \\
0 \\
0 \\
0 \\
0 \\
0 \\
0\end{array}$ & $M G / L$ & $\begin{array}{l}< \\
< \\
< \\
< \\
< \\
< \\
< \\
< \\
<\end{array}$ & $\begin{array}{l}0.01 \\
0.01 \\
0.005 \\
0.03 \\
0.02 \\
0.01 \\
0.005 \\
0.005 \\
0.02\end{array}$ & 1 & $\begin{array}{l}0.01 \\
0.01 \\
0.005 \\
0.03 \\
0.02 \\
0.01 \\
0.005 \\
0.005 \\
0.02\end{array}$ & $\begin{array}{l}- \\
- \\
- \\
- \\
- \\
-\end{array}$ \\
\hline
\end{tabular}

TORMATION OF COMPLETION CODE:

UB - UPPER BURRO CANYON

PARAMETER VALUE INDICATOR (PVI): < - LESS THAN DETECTION LIMIT
FLOW RELATIONSHIP CODE:

O- ON-SITE

SAMPLE ID CODES:

0001 - FILTERED SAMPLE (.45 MICRONS)

OTHER PARAMETER VALUE FLAGS:

* - DUPLICATE ANALYSIS NOT WITHIN CONTROL LIMITS

- INCREASED DETECTION LIMIT DUE TO REQUIRED DILUTION

N - SPIKE SAMPLE RECOVERY NOT WITHIN CONTROL LIMITS 
TABLE 3.45. BACKGROUND GROUNDWATER QUALITY DATA BY PARAMETER FOR THE UPPER SANDSTONE UNIT, BURRO CANYON DISPOSAL SITE, SLICK ROCK, COLORADO

SITE: SRKO2 BORROW SITE 1 (BURRO CANYON)

06/04/90 TO $10 / 12 / 92$

REPORT DATE: $03 / 01 / 94$

\begin{tabular}{|c|c|c|c|c|c|c|c|c|c|c|c|c|}
\hline & PARAMETER NAME & $\begin{array}{l}\text { LOCATION } \\
\text { ID }\end{array}$ & LOG DATE & $\begin{array}{l}\text { SAMPLE } \\
\text { ID }\end{array}$ & $\begin{array}{l}\text { FORM } \\
\text { COMP }\end{array}$ & $\begin{array}{l}\text { FLOW } \\
\text { REL. }\end{array}$ & $\begin{array}{l}\text { UNITS OF } \\
\text { MEASURE }\end{array}$ & PVI & $\begin{array}{l}\text { ARAMETER } \\
\text { VALUE }\end{array}$ & FLAGS & $\begin{array}{l}\text { DETECTION } \\
\text { LIMIT }\end{array}$ & $\begin{array}{l}\text { PARAMETER } \\
\text { UNCERTAINTY }\end{array}$ \\
\hline & LEAD & $\begin{array}{l}0527 \\
0527 \\
0527 \\
0527 \\
0527 \\
0529 \\
0529 \\
0529 \\
0529\end{array}$ & $\begin{array}{l}06 / 06 / 90 \\
12 / 15 / 90 \\
04 / 04 / 91 \\
08 / 23 / 91 \\
10 / 12 / 92 \\
12 / 08 / 90 \\
04 / 02 / 91 \\
08 / 23 / 91 \\
10 / 12 / 92\end{array}$ & $\begin{array}{l}0001 \\
0001 \\
0001 \\
0001 \\
0001 \\
0001 \\
0001 \\
0001 \\
0001\end{array}$ & $\begin{array}{l}\text { UB } \\
\text { UB } \\
\text { UB } \\
\text { UB } \\
\text { UB } \\
\text { UB } \\
\text { UB } \\
\text { UB } \\
\text { UB }\end{array}$ & $\begin{array}{l}0 \\
0 \\
0 \\
0 \\
0 \\
0 \\
0 \\
0 \\
0\end{array}$ & MG/L & $\begin{array}{l}< \\
< \\
< \\
< \\
< \\
< \\
< \\
< \\
<\end{array}$ & $\begin{array}{l}0.01 \\
0.01 \\
0.005 \\
0.005 \\
0.02 \\
0.01 \\
0.005 \\
0.005 \\
0.02\end{array}$ & I & $\begin{array}{l}0.01 \\
0.01 \\
0.005 \\
0.005 \\
0.02 \\
0.01 \\
0.005 \\
0.005 \\
0.02\end{array}$ & $\begin{array}{l}- \\
- \\
- \\
- \\
- \\
-\end{array}$ \\
\hline & LEAD-210 & $\begin{array}{l}0518 \\
0518 \\
0518 \\
0523 \\
0523 \\
0523 \\
0527 \\
0527 \\
0527 \\
0529 \\
0529 \\
0529\end{array}$ & \begin{tabular}{|l|}
$12 / 15 / 90$ \\
$04 / 01 / 91$ \\
$08 / 23 / 91$ \\
$12 / 12 / 90$ \\
$04 / 01 / 91$ \\
$08 / 23 / 91$ \\
$12 / 15 / 90$ \\
$04 / 04 / 91$ \\
$08 / 23 / 91$ \\
$12 / 08 / 90$ \\
$04 / 02 / 91$ \\
$08 / 23 / 91$
\end{tabular} & $\begin{array}{l}0001 \\
0001 \\
0001 \\
0001 \\
0001 \\
0001 \\
0001 \\
0001 \\
0001 \\
0001 \\
0001 \\
0001\end{array}$ & $\begin{array}{l}\text { UB } \\
\text { UB } \\
\text { UB } \\
\text { UB } \\
\text { UB } \\
\text { UB } \\
\text { UB } \\
\text { UB } \\
\text { UB } \\
\text { UB } \\
\text { UB } \\
\text { UB }\end{array}$ & $\begin{array}{l}0 \\
0 \\
0 \\
0 \\
0 \\
0 \\
0 \\
0 \\
0 \\
0 \\
0 \\
0\end{array}$ & $\mathrm{PCI} / \mathrm{L}$ & $\mid<$ & $\begin{array}{l}0.2 \\
0.3 \\
0.9 \\
0.7 \\
0.0 \\
0.0 \\
0.9 \\
0.0 \\
0.0 \\
0.9 \\
0.0 \\
0.0\end{array}$ & $\begin{array}{l}\text { c } \\
\text { b } \\
\text { b }\end{array}$ & $\begin{array}{l}1.4 \\
1.5 \\
1.5 \\
1.5 \\
1.5 \\
1.5 \\
1.5 \\
1.5 \\
1.5 \\
1.5 \\
1.5 \\
1.5\end{array}$ & $\begin{array}{l}1.2 \\
1.4 \\
1.0 \\
0.9 \\
1.3 \\
0.9 \\
0.9 \\
1.3 \\
0.9 \\
0.9 \\
1.3 \\
0.9\end{array}$ \\
\hline & MAGNESIUM & $\begin{array}{l}0518 \\
0518 \\
0518 \\
0518 \\
0518 \\
0523 \\
0523 \\
0523 \\
0523 \\
0527 \\
0527 \\
0527 \\
0527 \\
0527 \\
0529\end{array}$ & $\begin{array}{l}06 / 04 / 90 \\
12 / 15 / 90 \\
04 / 01 / 91 \\
08 / 23 / 91 \\
10 / 11 / 92 \\
12 / 12 / 90 \\
04 / 01 / 91 \\
08 / 23 / 91 \\
10 / 12 / 92 \\
06 / 06 / 90 \\
12 / 15 / 90 \\
04 / 04 / 91 \\
08 / 23 / 91 \\
10 / 12 / 92 \\
12 / 08 / 90\end{array}$ & $\begin{array}{l}0001 \\
0001 \\
0001 \\
0001 \\
0001 \\
0001 \\
0001 \\
0001 \\
0001 \\
0001 \\
0001 \\
0001 \\
0001 \\
0001 \\
0001\end{array}$ & $\begin{array}{l}\text { UB } \\
\text { UB } \\
\text { UB } \\
\text { UB } \\
\text { UB } \\
\text { UB } \\
\text { UB } \\
\text { UB } \\
\text { UB } \\
\text { UB } \\
\text { UB } \\
\text { UB } \\
\text { UB } \\
\text { UB } \\
\text { UB }\end{array}$ & $\begin{array}{l}0 \\
0 \\
0 \\
0 \\
0 \\
0 \\
0 \\
0 \\
0 \\
0 \\
0 \\
0 \\
0 \\
0 \\
0\end{array}$ & MG/L & & $\begin{array}{l}32.2 \\
30.9 \\
32.5 \\
30.3 \\
28.7 \\
0.58 \\
0.6 \\
0.3 \\
0.7 \\
4.9 \\
4.86 \\
5.8 \\
5.2 \\
4.1 \\
2.05\end{array}$ & & $\begin{array}{l}0.001 \\
0.001 \\
0.1 \\
0.1 \\
0.1 \\
0.001 \\
0.1 \\
0.1 \\
0.1 \\
0.001 \\
0.001 \\
0.1 \\
0.1 \\
0.1 \\
0.001\end{array}$ & $\begin{array}{l}- \\
- \\
- \\
- \\
- \\
- \\
- \\
- \\
- \\
-\end{array}$ \\
\hline
\end{tabular}

FORMATION OF COMPLETION CODE:

UB - UPPER BURRO CANYON

PARAMETER VALUE INDICATOR (PVI): < - LESS THAN DETECTION LIMIT
FLOW RELATIONSHIP COOE:

O - ON-SITE

SAMPLE ID COOES:

0001 - FILTERED SAMPLE (.45 MICRONS)

OTHER PARAMETER VALUE FLAGS:

1 - INCREASED DETECTION IIIMIT DUE TO REQUIRED DILUTION

b - CHANGED PaRAMETER VALUE

c - CHANGED DETECTION LIMIT 
TABLE 3.45. BACKGROUND GROUNDWATER QUALITY DATA BY PARAMETER FOR THE UPPER SANDSTONE UNIT, BURRO CANYON DISPOSAL SITE, SLICK ROCK, COLORADO SITE: SRKO2 BORROW SITE 1 (BURRO CANYON)

06/04/90 TO $10 / 12 / 92$

REPORT DATE: $03 / 01 / 94$

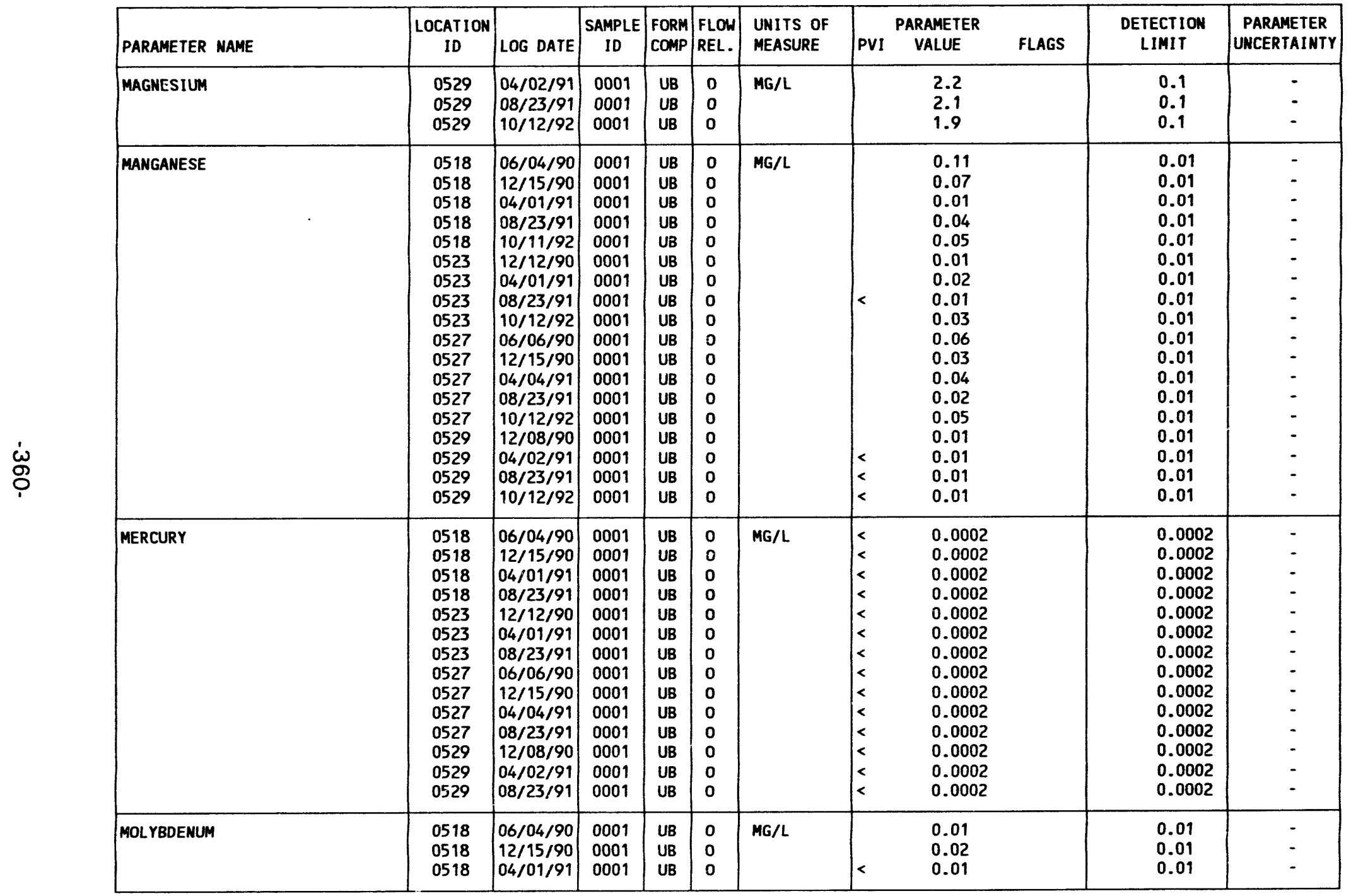

FORMATION OF COMPLETION CODE:

UB - UPPER BURRO CANYON

PARAMETER VALUE INDICATOR (PVI): < - LESS thAN DETECTION LIMIT
FLOW RELATIONSHIP CODE:

O - ON-SITE

SAMPLE ID CODES:

0001 - FILTERED SAMPLE (.45 MICRONS) 
TABLE 3.45. BACKGROUND GROUNDWATER QUALITY DATA BY PARAMETER FOR THE UPPER SANDSTONE UNIT, BURRO CANYON DISPOSAL SITE, SLICK ROCK, COLORADO

SITE: SRKO2 BORROW SITE 1 (BURRO CANYON)

O6/04/90 TO $10 / 12 / 92$

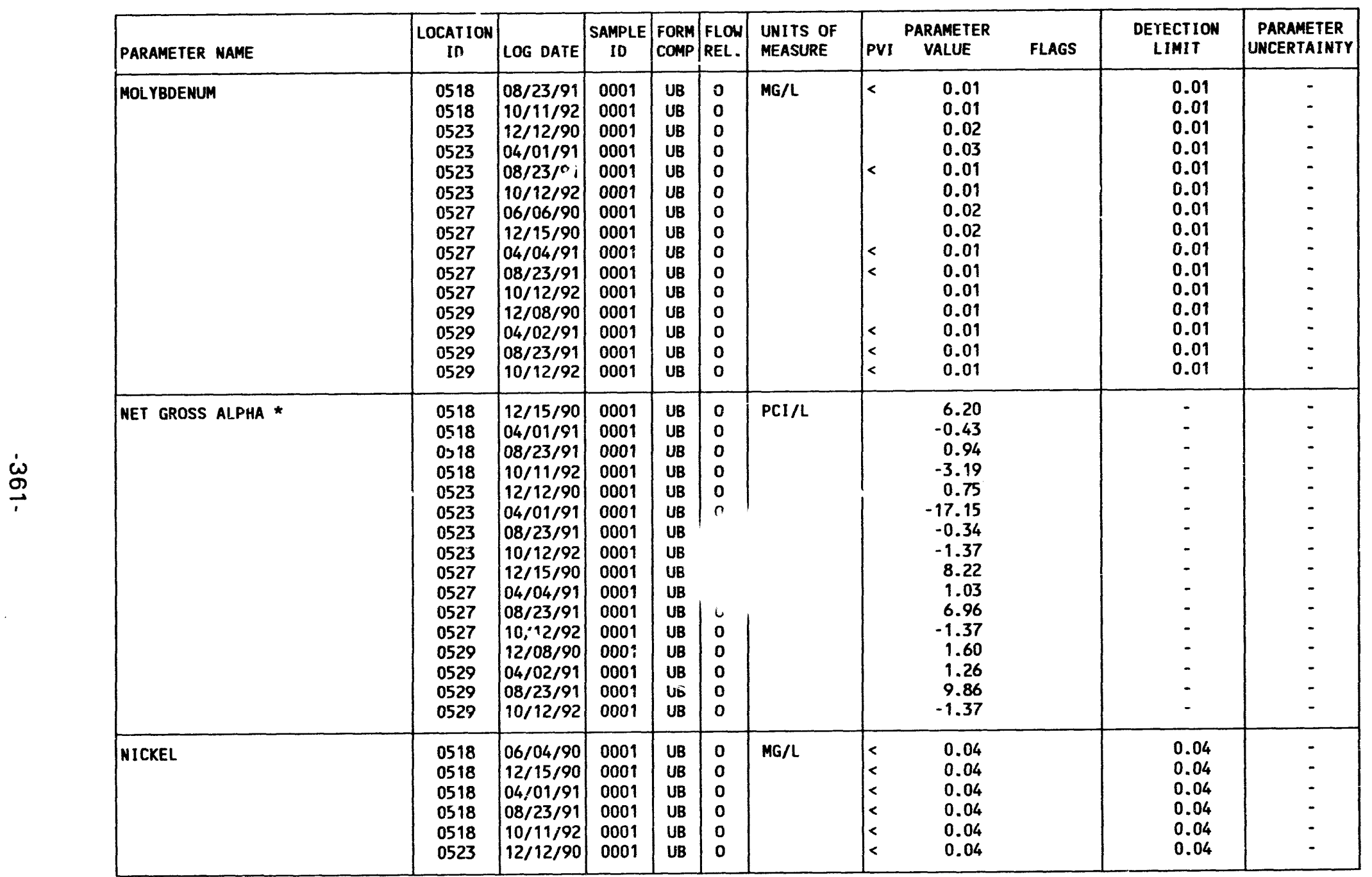

* NET GROSS ALPHA (GROSS ALPHA - URANIUM) WITH 1 MG URANIUM $=686$ PCI

FORMATION OF COMPLETION COOE:

UB - UPPER BURRO CANYON

PARAMETER VALUE INDICATOR (PVI): < - LESS THAN DETECTION LIMIT
FLOW RELATIONSHIP CODE:

O - ON-SITE

SAMPLE :D CODES:

0001 - FILTERED SAMPLE (.45 MICRONS) 
TABLE 3.45 BACKGROUND GROUNDWATER QUALITY DATA BY PARAMETER FOR THE UPPER SAMDSTONE UNIT, BURRO CANYON DISPOSAL SITE, SLICK ROCK, COLORADO

SITE: SRKO2 BORROU SITE 1 (BURRO CANYON)

06/04/90 TO $10 / 12 / 92$

REPORT DATE: 03/01/94

\begin{tabular}{|c|c|c|c|c|c|c|c|c|c|c|c|c|}
\hline & PARAMETER NAME & $\begin{array}{c}\text { LOCATION } \\
\text { ID }\end{array}$ & LOG DATE & $\begin{array}{c}\text { SAMPLE } \\
\text { ID }\end{array}$ & $\begin{array}{l}\text { FORM } \\
\text { COMP }\end{array}$ & $\begin{array}{l}\text { FLOW } \\
\text { REL. }\end{array}$ & $\begin{array}{l}\text { UNITS OF } \\
\text { MEASURE }\end{array}$ & PVI & $\begin{array}{l}\text { ARAMETEE } \\
\text { VALUE }\end{array}$ & FLAGS & $\begin{array}{l}\text { DETECTION } \\
\text { LIMIT }\end{array}$ & $\begin{array}{l}\text { PARAMETER } \\
\text { UNCERTAINTY }\end{array}$ \\
\hline & NICKEL & $\begin{array}{l}0523 \\
0523 \\
0523 \\
0527 \\
0527 \\
0527 \\
0527 \\
0527 \\
0529 \\
0529 \\
0529 \\
0529\end{array}$ & $\begin{array}{l}04 / 01 / 91 \\
08 / 23 / 91 \\
10 / 12 / 92 \\
06 / 06 / 90 \\
12 / 15 / 90 \\
04 / 04 / 91 \\
08 / 23 / 91 \\
10 / 12 / 92 \\
12 / 08 / 90 \\
04 / 02 / 91 \\
08 / 23 / 91 \\
10 / 12 / 92\end{array}$ & $\begin{array}{l}0001 \\
0001 \\
0001 \\
0001 \\
0001 \\
0001 \\
0001 \\
0001 \\
0001 \\
0001 \\
0001 \\
0001\end{array}$ & $\begin{array}{l}\text { UB } \\
\text { UB } \\
\text { UB } \\
\text { UB } \\
\text { UB } \\
\text { UB } \\
\text { UB } \\
\text { UB } \\
\text { UB } \\
\text { UB } \\
\text { UB } \\
\text { UB }\end{array}$ & $\begin{array}{l}0 \\
0 \\
0 \\
0 \\
0 \\
0 \\
0 \\
0 \\
0 \\
0 \\
0 \\
0\end{array}$ & $M G / L$ & $\begin{array}{l}< \\
< \\
< \\
< \\
< \\
< \\
< \\
< \\
< \\
< \\
< \\
<\end{array}$ & $\begin{array}{l}0.04 \\
0.04 \\
0.04 \\
0.04 \\
0.04 \\
0.04 \\
0.04 \\
0.04 \\
0.04 \\
0.04 \\
0.04 \\
0.04\end{array}$ & & $\begin{array}{l}0.04 \\
0.04 \\
0.04 \\
0.04 \\
0.04 \\
0.04 \\
0.04 \\
0.04 \\
0.04 \\
0.04 \\
0.04 \\
0.04\end{array}$ & $\begin{array}{l}- \\
- \\
- \\
- \\
- \\
- \\
- \\
- \\
-\end{array}$ \\
\hline & NITRATE & $\begin{array}{l}0518 \\
0518 \\
0518 \\
0518 \\
0523 \\
0523 \\
0523 \\
0527 \\
0527 \\
0527 \\
0527 \\
0529 \\
0529 \\
0529\end{array}$ & $\begin{array}{l}06 / 04 / 90 \\
04 / 01 / 91 \\
08 / 23 / 91 \\
10 / 11 / 92 \\
04 / 01 / 91 \\
08 / 23 / 91 \\
10 / 12 / 92 \\
06 / 06 / 90 \\
04 / 04 / 91 \\
08 / 23 / 91 \\
10 / 12 / 92 \\
04 / 02 / 91 \\
08 / 23 / 91 \\
10 / 12 / 92\end{array}$ & \begin{tabular}{|l|}
0001 \\
0001 \\
0001 \\
0001 \\
0001 \\
0001 \\
0001 \\
0001 \\
0001 \\
0001 \\
0001 \\
0001 \\
0001 \\
0001
\end{tabular} & $\begin{array}{l}\text { UB } \\
\text { UB } \\
\text { UB } \\
\text { UB } \\
\text { UB } \\
\text { UB } \\
\text { UB } \\
\text { UB } \\
\text { UB } \\
\text { UB } \\
\text { UA } \\
\text { U'S } \\
\text { UB } \\
\text { UB }\end{array}$ & $\begin{array}{l}0 \\
0 \\
0 \\
0 \\
0 \\
0 \\
0 \\
0 \\
0 \\
0 \\
0 \\
0 \\
0 \\
0\end{array}$ & $M G / L$ & $<$ & $\begin{array}{l}1 . \\
2 . \\
4.4 \\
1.6 \\
1.0 \\
5.8 \\
1.0 \\
1 . \\
3 . \\
4.4 \\
1.4 \\
1.0 \\
24.3 \\
1.6\end{array}$ & & $\begin{array}{l}1 . \\
1 . \\
1.0 \\
1.0 \\
1 . \\
1.0 \\
1.0 \\
1 . \\
1 . \\
1 . \\
1.0 \\
1.0 \\
1.0 \\
1.0\end{array}$ & $\begin{array}{l}- \\
- \\
- \\
- \\
- \\
- \\
- \\
- \\
- \\
-\end{array}$ \\
\hline & NITRITE AND NITRATE & $\begin{array}{l}0518 \\
0518 \\
0518 \\
0523 \\
0523 \\
0527 \\
0527 \\
0527 \\
0529 \\
0529\end{array}$ & \begin{tabular}{|l|}
$06 / 04 / 90$ \\
$04 / 01 / 91$ \\
$08 / 23 / 91$ \\
$04 / 01 / 91$ \\
$08 / 2-91$ \\
$06 / 06 / 90$ \\
$04 / 04 / 91$ \\
$08 / 23 / 91$ \\
$04 / 02 / 91$ \\
$08 / 23 / 91$
\end{tabular} & $\begin{array}{l}0001 \\
0001 \\
0001 \\
0001 \\
0001 \\
0001 \\
0001 \\
0001 \\
0001 \\
0301\end{array}$ & $\begin{array}{l}\text { UB } \\
\text { UB } \\
\text { UB } \\
\text { UB } \\
\text { UB } \\
\text { UB } \\
\text { UB } \\
\text { UB } \\
\text { UB } \\
\text { UB }\end{array}$ & $\begin{array}{l}0 \\
0 \\
0 \\
0 \\
0 \\
0 \\
0 \\
0 \\
0 \\
0\end{array}$ & $M G / L$ & $<$ & $\begin{array}{l}1 . \\
0.39 \\
0.98 \\
0.12 \\
1.31 \\
1 . \\
0.70 \\
1.08 \\
0.26 \\
5.54\end{array}$ & & $\begin{array}{l}1 . \\
0.05 \\
0.05 \\
0.05 \\
0.05 \\
1 . \\
0.05 \\
0.05 \\
0.05 \\
0.05\end{array}$ & $\begin{array}{l}- \\
- \\
- \\
- \\
- \\
- \\
- \\
-\end{array}$ \\
\hline & PH & $\begin{array}{l}0518 \\
0518\end{array}$ & $\begin{array}{l}06 / 04 / 90 \\
12 / 15 / 90\end{array}$ & $\begin{array}{l}0001 \\
0001\end{array}$ & $\begin{array}{l}\text { UB } \\
\text { UB }\end{array}$ & $\begin{array}{l}0 \\
0\end{array}$ & su & & $\begin{array}{l}7.58 \\
7.69\end{array}$ & & - & - \\
\hline
\end{tabular}

FORMATION OF COMPLETION CODE:

UB - UPPER BURRO CANYON

PARAMETER VALUE INDICATOR (PVI): < - LESS THAN DETECTION LIMIT
FLOW RELATIONSHIP CODE:

0001 - FILTERED SAMPLE (.45 MICRONS) 
TABLE 3.45. BACKGROUND GROUNDWATER QUALITY DATA BY PARAMETER FOR THE UPPER SAMDSTONE UMIT BURRO CAHYON DISPOSAL SITE, SLICK ROCK, COLORADO SITE: SRK02 BORROW SITE 1 (BURRO CANYON)

06/04/90 TO $10 / 12 / 92$

REPORT DATE: 03/01/94

\begin{tabular}{|c|c|c|c|c|c|c|c|c|c|c|c|}
\hline PARAMETER NAME & $\underset{\text { LOCATION }}{\text { ID }}$ & LOG DATE & $\begin{array}{c}\text { SAMPLE } \\
\text { ID }\end{array}$ & $\begin{array}{l}\text { FORM } \\
\text { COMP }\end{array}$ & $\begin{array}{l}\text { FLOW } \\
\text { REL. }\end{array}$ & $\begin{array}{l}\text { UNITS +" } \\
\text { MEASURE }\end{array}$ & PVI & $\begin{array}{l}\text { ARAMETER } \\
\text { VALUE }\end{array}$ & FLAGS & $\begin{array}{l}\text { DETECTION } \\
\text { LIMIT }\end{array}$ & $\begin{array}{l}\text { PARAMETER } \\
\text { UNCERTAINTY }\end{array}$ \\
\hline PH & $\begin{array}{l}0518 \\
0518 \\
0518 \\
0523 \\
0523 \\
0523 \\
0523 \\
0523 \\
0527 \\
0527 \\
0527 \\
0527 \\
0527 \\
0529 \\
0529 \\
0529 \\
0529 \\
0529\end{array}$ & $\begin{array}{l}04 / 01 / 91 \\
08 / 23 / 91 \\
10 / 11 / 92 \\
06 / 04 / 90 \\
12 / 12 / 90 \\
04 / 01 / 91 \\
08 / 23 / 91 \\
10 / 12 / 92 \\
06 / 06 / 90 \\
12 / 15 / 90 \\
04 / 04 / 91 \\
08 / 23 / 91 \\
10 / 12 / 92 \\
06 / 06 / 90 \\
12 / 08 / 90 \\
04 / 02 / 91 \\
08 / 23 / 91 \\
10 / 12 / 92\end{array}$ & $\begin{array}{l}0001 \\
0001 \\
0001 \\
0001 \\
0001 \\
0001 \\
0001 \\
0001 \\
0001 \\
0001 \\
0001 \\
0001 \\
0001 \\
0001 \\
0001 \\
0001 \\
0001 \\
0001\end{array}$ & $\begin{array}{l}\text { UB } \\
\text { UB } \\
\text { UB } \\
\text { UB } \\
\text { UB } \\
\text { UB } \\
\text { UB } \\
\text { UB } \\
\text { UB } \\
\text { UB } \\
\text { UB } \\
\text { UB } \\
\text { UB } \\
\text { UB } \\
\text { UB } \\
\text { UB } \\
\text { UB } \\
\text { UB }\end{array}$ & $\begin{array}{l}0 \\
0 \\
0 \\
0 \\
0 \\
0 \\
0 \\
0 \\
0 \\
0 \\
0 \\
0 \\
0 \\
0 \\
0 \\
0 \\
0 \\
0\end{array}$ & SU & & $\begin{array}{l}7.58 \\
7.56 \\
7.46 \\
8.72 \\
8.28 \\
8.25 \\
8.27 \\
8.22 \\
8.19 \\
8.00 \\
7.98 \\
7.94 \\
7.96 \\
9.09 \\
8.86 \\
8.94 \\
8.93 \\
8.90\end{array}$ & & $\begin{array}{l}- \\
- \\
- \\
- \\
- \\
- \\
- \\
- \\
- \\
- \\
- \\
- \\
- \\
-\end{array}$ & $\begin{array}{l}- \\
- \\
- \\
- \\
- \\
- \\
- \\
- \\
- \\
- \\
- \\
- \\
-\end{array}$ \\
\hline PHOSPHATE & $\begin{array}{l}0518 \\
0518 \\
0518 \\
0518 \\
0523 \\
0523 \\
0523 \\
0527 \\
0527 \\
0527 \\
0527 \\
0529 \\
0529 \\
0529\end{array}$ & $\begin{array}{l}06 / 04 / 90 \\
04 / 01 / 91 \\
08 / 23 / 91 \\
10 / 11 / 92 \\
04 / 01 / 91 \\
08 / 23 / 91 \\
10 / 12 / 92 \\
06 / 06 / 90 \\
04 / 04 / 91 \\
08 / 23 / 91 \\
10 / 12 / 92 \\
04 / 02 / 91 \\
08 / 23 / 91 \\
10 / 12 / 92\end{array}$ & $\begin{array}{l}0001 \\
0001 \\
0001 \\
0001 \\
0001 \\
0001 \\
0001 \\
0001 \\
0001 \\
0001 \\
0001 \\
0001 \\
0001 \\
0001\end{array}$ & $\begin{array}{l}\text { UB } \\
\text { UB } \\
\text { UB } \\
\text { UB } \\
\text { UB } \\
\text { UB } \\
\text { UB } \\
\text { UB } \\
\text { UB } \\
\text { UB } \\
\text { UB } \\
\text { UB } \\
\text { UB } \\
\text { UB }\end{array}$ & $\begin{array}{l}0 \\
0 \\
0 \\
0 \\
0 \\
0 \\
0 \\
0 \\
0 \\
0 \\
0 \\
0 \\
0 \\
0\end{array}$ & $M G / L$ & $<$ & $\begin{array}{l}0.1 \\
0.1 \\
0.1 \\
0.4 \\
0.1 \\
0.1 \\
1.6 \\
0.1 \\
0.1 \\
0.2 \\
0.5 \\
0.1 \\
0.1 \\
0.6\end{array}$ & $\begin{array}{l}\text { J } \\
\text { J } \\
\text { J }\end{array}$ & $\begin{array}{l}0.1 \\
0.1 \\
0.1 \\
0.1 \\
0.1 \\
0.1 \\
0.1 \\
0.1 \\
0.1 \\
0.1 \\
0.1 \\
0.1 \\
0.1 \\
0.1\end{array}$ & $\begin{array}{l}- \\
- \\
- \\
- \\
- \\
- \\
- \\
- \\
- \\
-\end{array}$ \\
\hline POLONIUM-210 & $\begin{array}{l}0518 \\
0518 \\
0518 \\
0523 \\
0523\end{array}$ & $\begin{array}{l}12 / 15 / 90 \\
04 / 01 / 91 \\
08 / 23 / 91 \\
12 / 12 / 90 \\
04 / 01 / 91\end{array}$ & $\begin{array}{l}0001 \\
0001 \\
0001 \\
0001 \\
0001\end{array}$ & $\begin{array}{l}\text { UB } \\
\text { UB } \\
\text { UB } \\
\text { UB } \\
\text { UB }\end{array}$ & $\begin{array}{l}0 \\
0 \\
0 \\
0 \\
0\end{array}$ & $\mathrm{PCI} / \mathrm{L}$ & & $\begin{array}{l}0.1 \\
0.0 \\
0.1 \\
0.5 \\
0.0\end{array}$ & c & $\begin{array}{l}0.5 \\
1 . \\
1 . \\
0.9 \\
1 .\end{array}$ & $\begin{array}{l}0.4 \\
0.1 \\
0.3 \\
0.4 \\
0.1\end{array}$ \\
\hline
\end{tabular}

FORMATION OF COMPLETION COOE:

UB - UPPER BURRO CANYON

PARAMETER VALUE INDICATOR (PVI): < - LESS THAN DETECTION LIMIT
FLOW RELATIONSHIP CODE:

O - ON-SITE

SAMPLE ID COOES:

0001 - FILTERED SAMPLE (.45 MICRONS)

OTHER PARAMETER VALUE FLAGS:

$J$ - ESTIMATED VALUE

c - CHANGED DETECTION LIMIT 
TABLE 3.45 BACKGROUND GROUNDWATER OUALITY DATA BY PARAMETER FOR THE UPPER SAMDSTONE UNIT BURRO CANYON DISPOSAL SITE, SLICK ROCK, COLORADO

SITE: SRKO2 BORROW SITE 1 (BURRO CANYON)

06/04/90 TO $10 / 12 / 92$

REPORT DATE: $03 / 01 / 94$

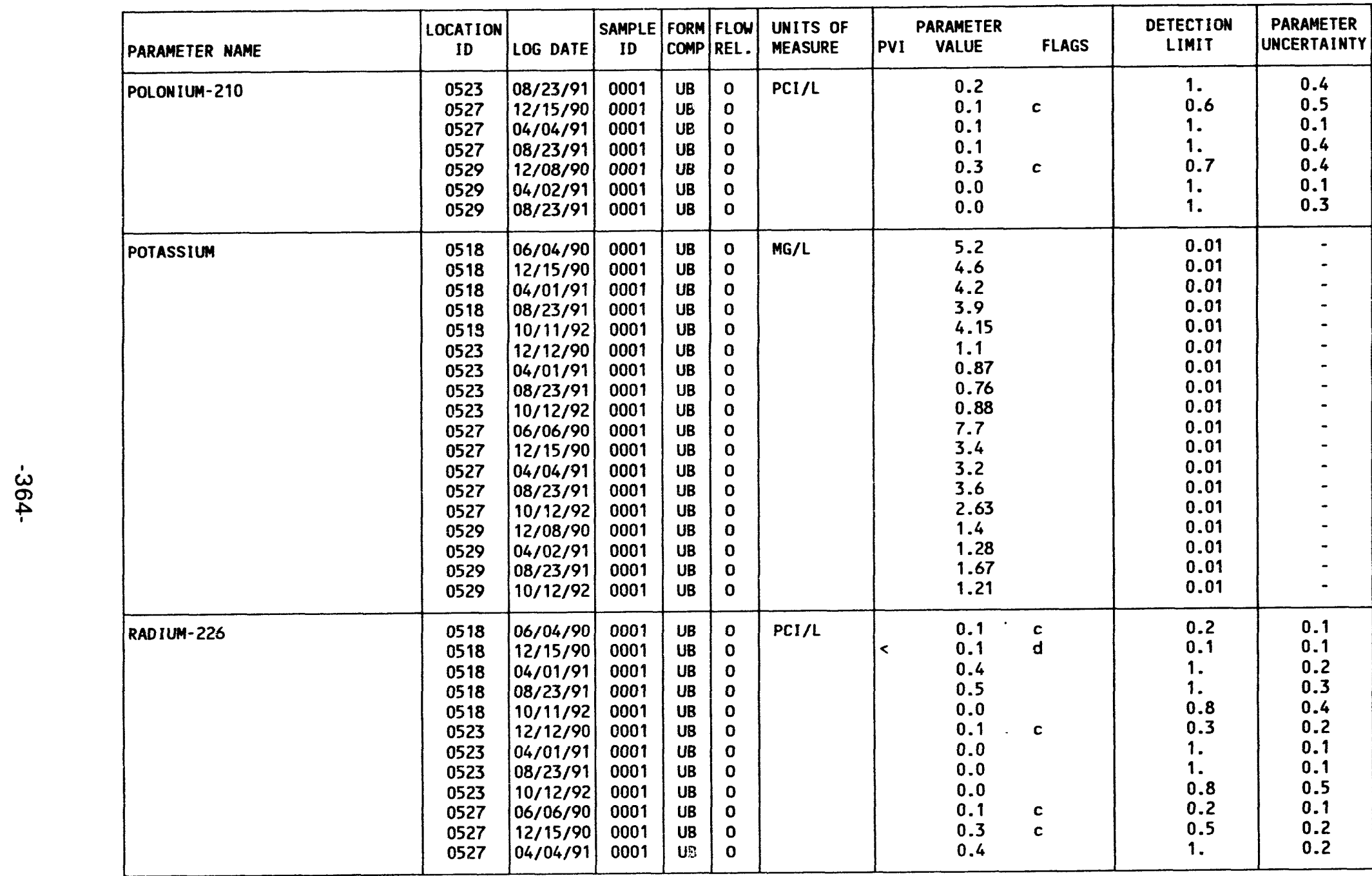

FORMATION OF COMPLETION CODE:

UB - UPPER BURRO CANYOH

PARAMETER VALUE INDICATOR (PVI): < - LESS THAN DETECTION LIMIT
FLOW RELATIONSHIP CODE:

O - ON-SITE

SAMPLE ID CODES:

0001 - FILTERED SAMPLE (.45 MICRONS)

OTHER PARAMETER VALUE FLAGS:

c - CHANGED DETECTION LIMIT

d - CHANGED DETECTION LIMIT AND PARAMETER VALUE 
TABLE 3.45. BACKGROUND GROUNDWATER QUALITY DATA BY PARAMETER FOR THE UPPER SANDSTONE UNIT, BURRO CANYON DISPOSAL SITE, SLICK ROCK, COLORADO

SITE: SRKO2 BORROW SITE 1 (BURRO CANYON)

$06 / 04 / 90$ TO $10 / 12 / 92$

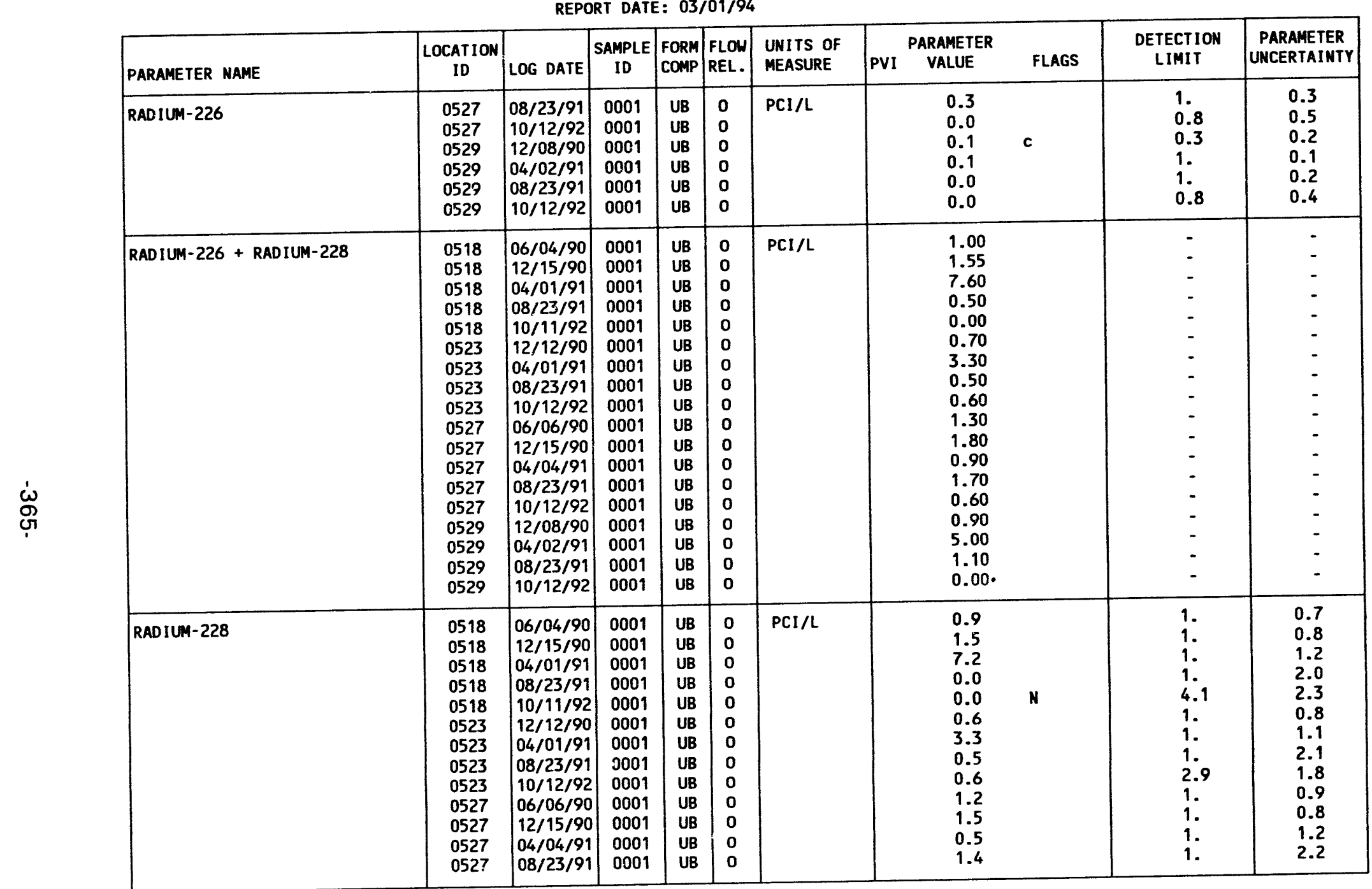

FORMATION OF COMPLETION CODE:

UB - UPPER BURRO CANYON

PARAMETER VALUE INDICATOR (PVI): < - LESS THAN DETECTION LIMIT
FLOW RELATIONSHIP CODE:

O - ON-SITE

SAMPLE ID CODES:

0001 - FILTERED SAMPLE (.45 MICRONS)

OTHER PARAMETER VALUE FLAGS:

N - SPIKE SAMPLE RECOVERY NOT WITHIN CONTROL LIMITS

c - CHANGED DETECTION LIMIT 
TABLE 3.45. BACKGROUND GROUNDHATER QUALITY DATA BY PARAMETER FOR THE UPPER SANDSTONE UNIT, BURRO CANYON DISPOSAL SITE, SLICK ROCK, COLORADO SITE: SRKO2 BORROW SITE 1 (BURRO CANYON)

06/04/90 TO 10/12/92

REPORT DATE : 03/01/94

\begin{tabular}{|c|c|c|c|c|c|c|c|c|c|c|c|}
\hline PARAMETER NAME & $\begin{array}{c}\text { LOCATION } \\
\text { ID }\end{array}$ & LOG DATE & $\begin{array}{c}\text { SAMPLE } \\
\text { ID }\end{array}$ & $\begin{array}{l}\text { FORM } \\
\text { COMP }\end{array}$ & $\begin{array}{l}\text { FLOW } \\
\text { REL. }\end{array}$ & $\begin{array}{l}\text { UNITS OF } \\
\text { MEASURE }\end{array}$ & PVI & $\begin{array}{l}\text { ARAMETER } \\
\text { VALUE }\end{array}$ & FLAGS & $\begin{array}{l}\text { DETECTION } \\
\text { LIMIT }\end{array}$ & $\begin{array}{l}\text { PARAMETER } \\
\text { UNCERTAINTY }\end{array}$ \\
\hline RADIUM-228 & $\begin{array}{l}0527 \\
0529 \\
0529 \\
0529 \\
05: 29\end{array}$ & $\begin{array}{l}10 / 12 / 92 \\
12 / 08 / 90 \\
04 / 02 / 91 \\
08 / 23 / 91 \\
10 / 12 / 92\end{array}$ & $\begin{array}{l}0001 \\
0001 \\
0001 \\
0001 \\
0001\end{array}$ & $\begin{array}{l}\text { UB } \\
\text { UB } \\
\text { UB } \\
\text { UB } \\
\text { UB }\end{array}$ & $\begin{array}{l}0 \\
0 \\
0 \\
0 \\
0\end{array}$ & $\mathrm{PCI} / \mathrm{L}$ & & $\begin{array}{l}0.6 \\
0.8 \\
4.9 \\
1.1 \\
0.0\end{array}$ & & $\begin{array}{l}2.9 \\
1 . \\
1 . \\
1 . \\
2.9\end{array}$ & $\begin{array}{l}1.8 \\
0.7 \\
1.4 \\
2.2 \\
1.7\end{array}$ \\
\hline REDOX POTENTIAL & $\begin{array}{l}0518 \\
0523 \\
0527 \\
0529\end{array}$ & $\begin{array}{l}12 / 15 / 90 \\
12 / 12 / 90 \\
12 / 15 / 90 \\
12 / 08 / 90\end{array}$ & $\begin{array}{l}0001 \\
0001 \\
0001 \\
0001\end{array}$ & $\begin{array}{l}\text { UB } \\
\text { UB } \\
\text { UB } \\
\text { UB }\end{array}$ & $\begin{array}{l}0 \\
0 \\
0 \\
0\end{array}$ & mVOLTS & & $\begin{array}{l}264 . \\
276.7 \\
368.7 \\
194.1\end{array}$ & & $\begin{array}{l}- \\
-\end{array}$ & $\begin{array}{l}- \\
- \\
-\end{array}$ \\
\hline SELENIUM & $\begin{array}{l}0518 \\
0518 \\
0518 \\
0518 \\
0518 \\
0523 \\
0523 \\
0523 \\
0523 \\
0527 \\
0527 \\
0527 \\
0527 \\
0527 \\
0529 \\
0529 \\
0529 \\
0529\end{array}$ & $\begin{array}{l}06 / 04 / 90 \\
12 / 15 / 90 \\
04 / 01 / 91 \\
08 / 23 / 91 \\
10 / 11 / 92 \\
12 / 12 / 90 \\
04 / 01 / 91 \\
08 / 23 / 91 \\
10 / 12 / 92 \\
06 / 06 / 90 \\
12 / 15 / 90 \\
04 / 04 / 91 \\
08 / 23 / 91 \\
10 / 12 / 92 \\
12 / 08 / 90 \\
04 / 02 / 91 \\
08 / 23 / 91 \\
10 / 12 / 92\end{array}$ & $\begin{array}{l}0001 \\
0001 \\
0001 \\
0001 \\
0001 \\
0001 \\
0001 \\
0001 \\
0001 \\
0001 \\
0001 \\
0001 \\
0001 \\
0001 \\
0001 \\
0001 \\
0001 \\
0001\end{array}$ & $\begin{array}{l}\text { UB } \\
\text { UB } \\
\text { UB } \\
\text { UB } \\
\text { UB } \\
\text { UB } \\
\text { UB } \\
\text { UB } \\
\text { UB } \\
\text { UB } \\
\text { UB } \\
\text { UB } \\
\text { UB } \\
\text { UB } \\
\text { UB } \\
\text { UB } \\
\text { UB } \\
\text { UB }\end{array}$ & $\begin{array}{l}0 \\
0 \\
0 \\
0 \\
0 \\
0 \\
0 \\
0 \\
0 \\
0 \\
0 \\
0 \\
0 \\
0 \\
0 \\
0 \\
0 \\
0\end{array}$ & $M G / L$ & $\begin{array}{l}< \\
< \\
< \\
< \\
< \\
< \\
< \\
< \\
< \\
< \\
< \\
< \\
< \\
<\end{array}$ & $\begin{array}{l}0.012 \\
0.015 \\
0.011 \\
0.04 \\
0.02 \\
0.005 \\
0.005 \\
0.005 \\
0.02 \\
0.005 \\
0.005 \\
0.005 \\
0.005 \\
0.007 \\
0.005 \\
0.005 \\
0.005 \\
0.006\end{array}$ & 1 & $\begin{array}{l}0.005 \\
0.005 \\
0.005 \\
0.03 \\
0.02 \\
0.005 \\
0.005 \\
0.005 \\
0.02 \\
0.005 \\
0.005 \\
0.005 \\
0.005 \\
0.005 \\
0.005 \\
0.005 \\
0.005 \\
0.005\end{array}$ & $\begin{array}{l}- \\
- \\
- \\
- \\
- \\
- \\
- \\
- \\
- \\
- \\
- \\
- \\
- \\
- \\
-\end{array}$ \\
\hline SILICA - SIOZ & $\begin{array}{l}0518 \\
0518 \\
0518 \\
0518 \\
0518 \\
0523 \\
0523 \\
0523 \\
0523 \\
0527\end{array}$ & $\begin{array}{l}06 / 04 / 90 \\
12 / 15 / 90 \\
04 / 01 / 91 \\
08 / 23 / 91 \\
10 / 11 / 92 \\
12 / 12 / 90 \\
04 / 01 / 91 \\
08 / 23 / 91 \\
10 / 12 / 92 \\
06 / 06 / 90\end{array}$ & $\begin{array}{l}0001 \\
0001 \\
0001 \\
0001 \\
0001 \\
0001 \\
0001 \\
0001 \\
0001 \\
0001\end{array}$ & $\begin{array}{l}\text { UB } \\
\text { UB } \\
\text { UB } \\
\text { UB } \\
\text { UB } \\
\text { UB } \\
\text { UB } \\
\text { UB } \\
\text { UB } \\
\text { UB }\end{array}$ & $\begin{array}{l}0 \\
0 \\
0 \\
0 \\
0 \\
0 \\
0 \\
0 \\
0 \\
0\end{array}$ & $\mathrm{MG} / \mathrm{L}$ & & $\begin{array}{c}12 . \\
11 . \\
10.8 \\
11.2 \\
11.6 \\
10 . \\
9.8 \\
10.6 \\
9.9 \\
13 .\end{array}$ & & $\begin{array}{l}2 . \\
2 . \\
0.1 \\
0.1 \\
0.1 \\
2 . \\
0.1 \\
0.1 \\
0.1 \\
2 .\end{array}$ & $\begin{array}{l}- \\
- \\
- \\
- \\
- \\
- \\
-\end{array}$ \\
\hline
\end{tabular}

FORMATION OF COMPLETION CODE:

UB - UPPER BURRO CANYON

PARAMETER VALUE INDICATOR (PYI): < - LESS THAN DETECTION LIMIT
FLOH RELATIONSHIP CODE:

O - ON-SITE

\section{SAMPLE ID CODES:}

OOO1 - FILTERED SAMPLE ( .45 MICRONS)

OTHER PARAMETER VALUE FLAGS

I - INCREASED DETECTION LIMIT DUE TO REQUIRED DILUTION 
1)

TABLE 3.45. BACKGROUND GROUNDHATER QUALITY DATA BY PARAMETER FOR THE UPPER SANDSTONE UNIT, BURRO CANYON DISPOSAL SITE, SLICK ROCK, COLORADO

SITE: SRKO2 BORROW SITE 1 (BURRO CAMYON)

06/04/90 TO $10 / 12 / 92$

REPORT DATE: $03 / 01 / 94$

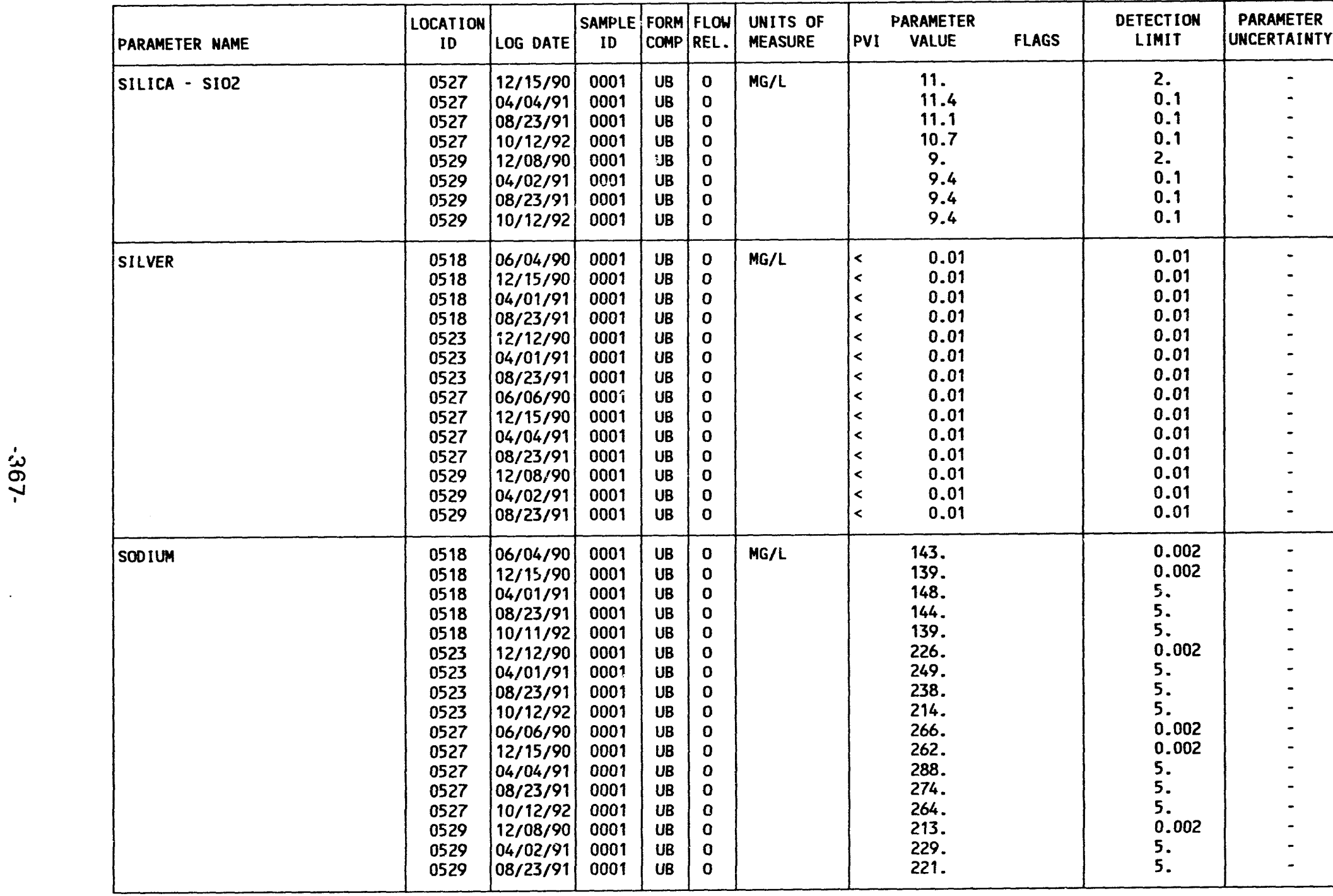

FORMATION OF COMPLETION CODE:

UB - UPPER BURRO CANYON

PARAMETER VALUE INDICATOR (PVI): < - LESS THAN DETECTION LIMIT
FLOW RELATIONSHIP CODE:

O - ON-SITE

SAMPLE ID CODES:

0001 - FILTERED SAMPLE ( .45 MICRONS) 
TABLE 3.45. BACKGROUND GROUNDWATER QUALITY DATA BY PARAMETER FOR THE UPPER SANDSTONE UNIT, BURRO CANYON DISPOSAL SITE, SLICK ROCK, COLORADO

SITE: SRKO2 BORROW SITE 1 (BURRO CANYON)

06/04/90 TO $10 / 12 / 92$

REPORT DATE: 03/01/94

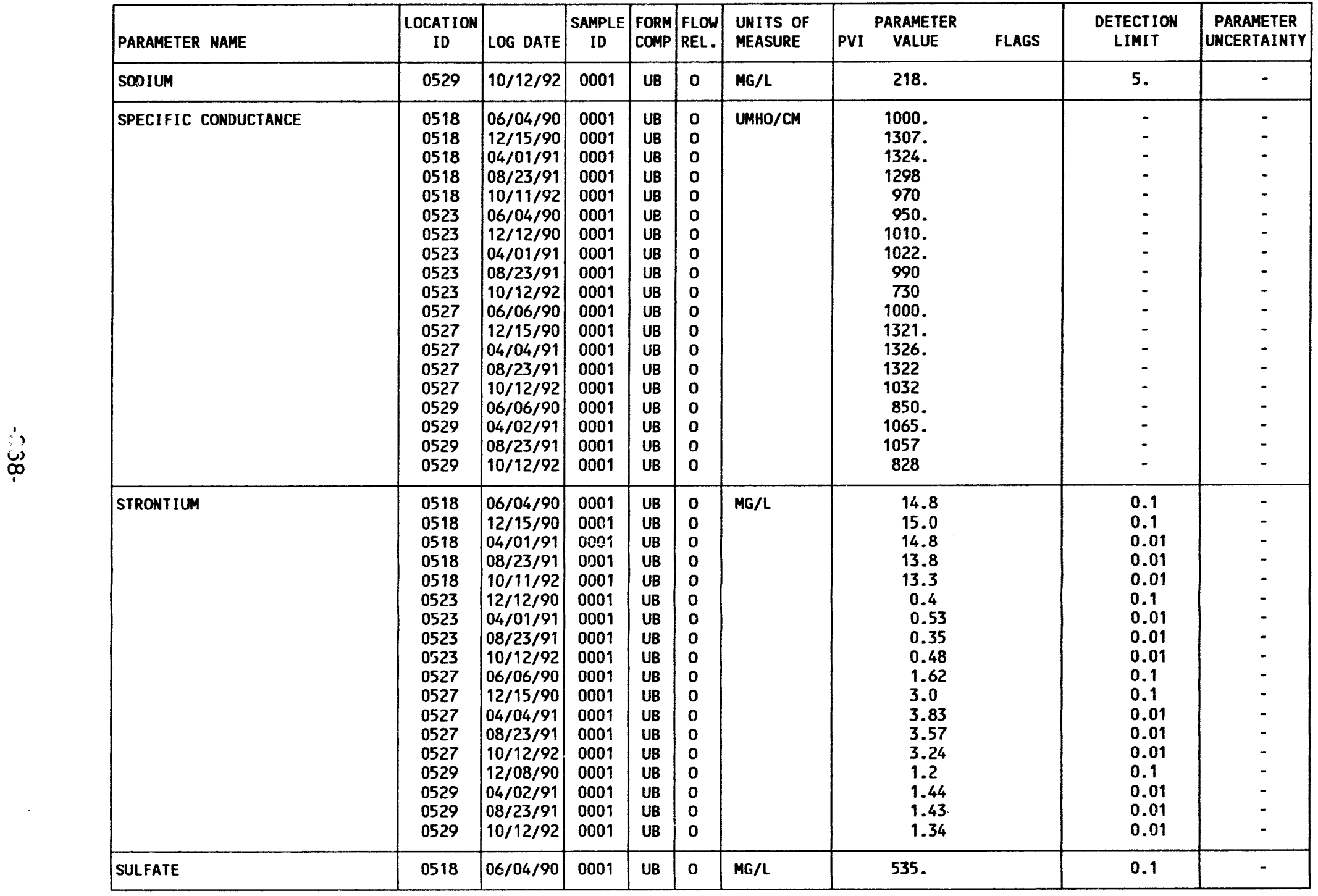

FORMATION OF COMPLETION COOE:

UB - UPPER BURRO CAMYON

PARAMETER VALUE INDICATOR (PVI): < - LESS THAN DETECTION LIMIT
FLOH RELATIONSHIP CODE:

O - ON-SITE

SAMPLE ID CODES:

0001 - FILTERED SAMPLE (.45 MICRONS) 
TABLE 3.45 BACKGROUND GROUNDWATER QUALITY DATA BY PARAMETER FOR THE UPPER SANDSTONE UNIT, BURRO CANYON DISPOSAL SITE, SLICK ROCK, COLORADO SANDSTONE UNIT, BURRO CANYON DISPOSAL SITE,

SITE: SRKO2 BORROW

REPORT DATE: $03 / 01 / 94$

\begin{tabular}{|c|c|c|c|c|c|c|c|c|c|c|}
\hline PARAMETER NAME & $\underset{\text { LOCATION }}{\text { ID }}$ & LOG DATE & $\begin{array}{c}\text { SAMPLE } \\
\text { ID }\end{array}$ & $\begin{array}{l}\text { FORM } \\
\text { COMP }\end{array}$ & $\begin{array}{l}\text { FLOW } \\
\text { REL. }\end{array}$ & $\begin{array}{l}\text { UNITS OF } \\
\text { MEASURE }\end{array}$ & PVI & $\begin{array}{l}\text { ARAMETER } \\
\text { VALUE }\end{array}$ & $\begin{array}{l}\text { DETECTION } \\
\text { LIMIT }\end{array}$ & $\begin{array}{l}\text { PARAMETER } \\
\text { UNCERTAINTY }\end{array}$ \\
\hline SULFATE & $\begin{array}{l}0518 \\
0518 \\
0518 \\
0523 \\
0523 \\
0523 \\
0527 \\
0527 \\
0527 \\
0527 \\
0529 \\
0529 \\
0529\end{array}$ & $\begin{array}{l}04 / 01 / 91 \\
08 / 23 / 91 \\
10 / 11 / 92 \\
04 / 01 / 91 \\
08 / 23 / 91 \\
10 / 12 / 92 \\
06 / 06 / 90 \\
04 / 04 / 91 \\
08 / 23 / 91 \\
10 / 12 / 92 \\
04 / 02 / 91 \\
08 / 23 / 91 \\
10 / 12 / 92\end{array}$ & $\begin{array}{l}0001 \\
0001 \\
0001 \\
0001 \\
0001 \\
0001 \\
0001 \\
0001 \\
0001 \\
0001 \\
0001 \\
0001 \\
0001\end{array}$ & $\begin{array}{l}\text { UB } \\
\text { UB } \\
\text { UB } \\
\text { UB } \\
\text { UB } \\
\text { UB } \\
\text { UB } \\
\text { UB } \\
\text { UB } \\
\text { UB } \\
\text { UB } \\
\text { UB } \\
\text { UB }\end{array}$ & $\begin{array}{l}0 \\
0 \\
0 \\
0 \\
0 \\
0 \\
0 \\
0 \\
0 \\
0 \\
0 \\
0 \\
0\end{array}$ & $M G / L$ & & $\begin{array}{l}498 . \\
468 . \\
477 . \\
150 . \\
129 . \\
138 . \\
364 . \\
360 . \\
351 . \\
431 . \\
315 . \\
303 . \\
324 .\end{array}$ & $\begin{array}{c}10 . \\
10 . \\
6 . \\
0.1 \\
10 . \\
10 . \\
0.1 \\
10 . \\
10 . \\
6 . \\
10 . \\
10 . \\
6 .\end{array}$ & $\begin{array}{l}- \\
- \\
- \\
- \\
- \\
- \\
- \\
- \\
-\end{array}$ \\
\hline SULFIDE & $\begin{array}{l}0518 \\
0518 \\
0518 \\
0518 \\
0523 \\
0523 \\
0523 \\
0523 \\
0527 \\
0527 \\
0527 \\
0529 \\
0529 \\
0529 \\
0529\end{array}$ & \begin{tabular}{|l|}
$12 / 15 / 90$ \\
$04 / 01 / 91$ \\
$08 / 23 / 91$ \\
$10 / 11 / 92$ \\
$12 / 12 / 90$ \\
$04 / 01 / 91$ \\
$08 / 23 / 91$ \\
$10 / 12 / 92$ \\
$12 / 15 / 90$ \\
$04 / 04 / 91$ \\
$10 / 12 / 92$ \\
$12 / 08 / 90$ \\
$04 / 02 / 91$ \\
$08 / 23 / 91$ \\
$10 / 12 / 92$
\end{tabular} & $\begin{array}{l}0001 \\
0001 \\
0001 \\
0001 \\
0001 \\
0001 \\
0001 \\
0001 \\
0001 \\
0001 \\
0001 \\
0001 \\
0001 \\
0001 \\
0001\end{array}$ & $\begin{array}{l}\text { UB } \\
\text { UB } \\
\text { UB } \\
\text { UB } \\
\text { UB } \\
\text { UB } \\
\text { UB } \\
\text { UB } \\
\text { UB } \\
\text { UB } \\
\text { UB } \\
\text { UB } \\
\text { UB } \\
\text { UB } \\
\text { UB }\end{array}$ & $\begin{array}{l}0 \\
0 \\
0 \\
0 \\
0 \\
0 \\
0 \\
0 \\
0 \\
0 \\
0 \\
0 \\
0 \\
0 \\
0\end{array}$ & MG/L & $\begin{array}{l}< \\
< \\
< \\
<\end{array}$ & $\begin{array}{l}0.1 \\
0.3 \\
0.6 \\
0.2 \\
0.1 \\
5.04 \\
2.0 \\
1.0 \\
0.1 \\
0.3 \\
0.6 \\
0.1 \\
0.6 \\
0.8 \\
0.4\end{array}$ & $\begin{array}{l}0.1 \\
0.1 \\
0.1 \\
0.1 \\
0.1 \\
0.1 \\
0.1 \\
0.1 \\
0.1 \\
0.1 \\
0.1 \\
0.1 \\
0.1 \\
0.1 \\
0.1\end{array}$ & $\begin{array}{l}- \\
- \\
- \\
- \\
- \\
- \\
- \\
- \\
- \\
- \\
- \\
-\end{array}$ \\
\hline TEMPERATURE & $\begin{array}{l}0518 \\
0518 \\
0518 \\
0518 \\
0518 \\
0523 \\
0523 \\
0523 \\
0523 \\
0523 \\
0527\end{array}$ & $\begin{array}{l}06 / 04 / 90 \\
12 / 15 / 90 \\
04 / 01 / 91 \\
08 / 23 / 91 \\
10 / 11 / 92 \\
06 / 04 / 90 \\
12 / 12 / 90 \\
04 / 01 / 91 \\
08 / 23 / 91 \\
10 / 12 / 92 \\
06 / 06 / 90\end{array}$ & $\begin{array}{l}0001 \\
0001 \\
0001 \\
0001 \\
0001 \\
0001 \\
0001 \\
0001 \\
0001 \\
0001 \\
0001\end{array}$ & $\begin{array}{l}\text { UB } \\
\text { UB } \\
\text { UB } \\
\text { UB } \\
\text { UB } \\
\text { UB } \\
\text { UB } \\
\text { UB } \\
\text { UB } \\
\text { UB } \\
\text { UB }\end{array}$ & $\begin{array}{l}0 \\
0 \\
0 \\
0 \\
0 \\
0 \\
0 \\
0 \\
0 \\
0 \\
0\end{array}$ & C - DEGREE & & $\begin{array}{l}13.5 \\
12.5 \\
13.0 \\
13.9 \\
12.8 \\
23.5 \\
12.9 \\
13.0 \\
13.0 \\
13.4 \\
15.0\end{array}$ & $\begin{array}{l}- \\
- \\
- \\
- \\
- \\
- \\
-\end{array}$ & $\begin{array}{l}- \\
- \\
- \\
- \\
- \\
- \\
- \\
-\end{array}$ \\
\hline
\end{tabular}

FORMATION OF COMPLETION CODE:

UB - UPPER BURRO CANYON

PARAMETER VALUE INDICATOR (PVI): < - LESS THAN DETECTION LIMIT
FLOW RELATIONSHIP CODE:

SAMPLE ID CODES:

0001 - FILTERED SAMPLE (.45 MICRONS) 
TABLE 3.45 BACKGROUND GROUNDWATER QUALITY DATA BY PARAMETER FOR THE UPPER SAMDSTOME UNIT, BURRO CANYON DISPOSAL SITE, SLICK ROCK, COLORADO SITE: SRKO2 BORROW SITE 1 (BURRO CANYON)

$06 / 04 / 90$ TO $10 / 12 / 92$

REPORT DATE: $03 / 01 / 94$

\begin{tabular}{|c|c|c|c|c|c|c|c|c|c|c|c|}
\hline PARAMETER NAME & $\underset{\text { ID }}{\text { LOCATION }}$ & LOG DATE & $\underset{\text { ID }}{\text { SAMPLE }}$ & $\begin{array}{l}\text { FORM } \\
\text { COMP }\end{array}$ & $\begin{array}{l}\text { FLOW } \\
\text { REL. }\end{array}$ & $\begin{array}{l}\text { UNI TS OF } \\
\text { MEASURE }\end{array}$ & PVI & $\begin{array}{l}\text { ARAMETER } \\
\text { VALUE }\end{array}$ & FLAGS & $\begin{array}{l}\text { DETECTION } \\
\text { LIMIT }\end{array}$ & $\begin{array}{l}\text { PARAMETER } \\
\text { UNCERTAINTY }\end{array}$ \\
\hline TEMPERATURE & $\begin{array}{l}0527 \\
0527 \\
0527 \\
0527 \\
0529 \\
0529 \\
0529 \\
0529 \\
0529\end{array}$ & \begin{tabular}{|l|}
$12 / 15 / 90$ \\
$04 / 04 / 91$ \\
$08 / 23 / 91$ \\
$10 / 12 / 92$ \\
$06 / 06 / 90$ \\
$12 / 08 / 90$ \\
$04 / 02 / 91$ \\
$08 / 23 / 91$ \\
$10 / 12 / 92$
\end{tabular} & $\begin{array}{l}0001 \\
0001 \\
0001 \\
0001 \\
0001 \\
0001 \\
0001 \\
0001 \\
0001\end{array}$ & $\begin{array}{l}\text { UB } \\
\text { UB } \\
\text { UB } \\
\text { UB } \\
\text { UB } \\
\text { UB } \\
\text { UB } \\
\text { UB } \\
\text { UB }\end{array}$ & $\begin{array}{l}0 \\
0 \\
0 \\
0 \\
0 \\
0 \\
0 \\
0 \\
0\end{array}$ & C - DEGREE & & $\begin{array}{l}12.8 \\
13.4 \\
14.2 \\
13.8 \\
14.0 \\
13.0 \\
13.4 \\
13.5 \\
13.4\end{array}$ & & $\begin{array}{l}- \\
- \\
- \\
- \\
- \\
- \\
-\end{array}$ & $\begin{array}{l}- \\
- \\
- \\
- \\
- \\
-\end{array}$ \\
\hline THALLIUM & $\begin{array}{l}0518 \\
0518 \\
0518 \\
0518 \\
0518 \\
0523 \\
0523 \\
0523 \\
0523 \\
0527 \\
0527 \\
0527 \\
0527 \\
0527 \\
0529 \\
0529 \\
0529 \\
0529\end{array}$ & $\begin{array}{l}06 / 04 / 90 \\
12 / 15 / 90 \\
04 / 01 / 91 \\
08 / 23 / 91 \\
10 / 11 / 92 \\
12 / 12 / 90 \\
04 / 01 / 91 \\
08 / 23 / 91 \\
10 / 12 / 92 \\
06 / 06 / 90 \\
12 / 15 / 90 \\
04 / 04 / 91 \\
08 / 23 / 91 \\
10 / 12 / 92 \\
12 / 08 / 90 \\
04 / 02 / 91 \\
08 / 23 / 91 \\
10 / 12 / 92\end{array}$ & $\begin{array}{l}0001 \\
0001 \\
0001 \\
0001 \\
0001 \\
0001 \\
0001 \\
0001 \\
0001 \\
0001 \\
0001 \\
0001 \\
0001 \\
0001 \\
0001 \\
0001 \\
0001 \\
0001\end{array}$ & $\begin{array}{l}\text { UB } \\
\text { UB } \\
\text { UB } \\
\text { UB } \\
\text { UB } \\
\text { UB } \\
\text { UB } \\
\text { UB } \\
\text { UB } \\
\text { UB } \\
\text { UB } \\
\text { UB } \\
\text { UB } \\
\text { UB } \\
\text { UB } \\
\text { UB } \\
\text { UB } \\
\text { UB }\end{array}$ & $\begin{array}{l}0 \\
0 \\
0 \\
0 \\
0 \\
0 \\
0 \\
0 \\
0 \\
0 \\
0 \\
0 \\
0 \\
0 \\
0 \\
0 \\
0 \\
0\end{array}$ & $M G / L$ & $\begin{array}{l}< \\
< \\
< \\
< \\
< \\
< \\
< \\
< \\
< \\
< \\
< \\
< \\
< \\
< \\
< \\
< \\
< \\
<\end{array}$ & $\begin{array}{l}0.01 \\
0.01 \\
0.01 \\
0.01 \\
0.005 \\
0.01 \\
0.01 \\
0.01 \\
0.005 \\
0.01 \\
0.01 \\
0.01 \\
0.01 \\
0.005 \\
0.01 \\
0.01 \\
0.01 \\
0.005\end{array}$ & & $\begin{array}{l}0.01 \\
0.01 \\
0.01 \\
0.01 \\
0.005 \\
0.01 \\
0.01 \\
0.01 \\
0.005 \\
0.01 \\
0.01 \\
0.01 \\
0.01 \\
0.005 \\
0.01 \\
0.01 \\
0.01 \\
0.005\end{array}$ & $\begin{array}{l}- \\
- \\
- \\
- \\
- \\
- \\
- \\
- \\
- \\
- \\
- \\
- \\
-\end{array}$ \\
\hline THOR IUM-230 & $\begin{array}{l}0518 \\
0518 \\
0518 \\
0523 \\
0523 \\
0523 \\
0527 \\
0527 \\
0527 \\
0529 \\
0529\end{array}$ & $\begin{array}{l}12 / 15 / 90 \\
04 / 01 / 91 \\
08 / 23 / 91 \\
12 / 12 / 90 \\
04 / 01 / 91 \\
08 / 23 / 91 \\
12 / 15 / 90 \\
04 / 04 / 91 \\
08 / 23 / 91 \\
12 / 08 / 90 \\
04 / 02 / 91\end{array}$ & $\begin{array}{l}0001 \\
0001 \\
0001 \\
0001 \\
0001 \\
0001 \\
0001 \\
0001 \\
0001 \\
0001 \\
0001\end{array}$ & $\begin{array}{l}\text { UB } \\
\text { UB } \\
\text { UB } \\
\text { UB } \\
\text { UB } \\
\text { UB } \\
\text { UB } \\
\text { UB } \\
\text { UB } \\
\text { UB } \\
\text { UB }\end{array}$ & $\begin{array}{l}0 \\
0 \\
0 \\
0 \\
0 \\
0 \\
0 \\
0 \\
0 \\
0 \\
0\end{array}$ & $\mathrm{PCI} / \mathrm{L}$ & $<$ & $\begin{array}{l}0.3 \\
0.1 \\
0.2 \\
0.3 \\
0.0 \\
0.4 \\
0.4 \\
0.0 \\
0.1 \\
0.3 \\
0.3\end{array}$ & $\begin{array}{l}\text { d } \\
\text { d } \\
\text { d } \\
\text { d }\end{array}$ & $\begin{array}{l}0.1 \\
1 . \\
1 . \\
0.1 \\
1 . \\
1 . \\
0.1 \\
1 . \\
1 . \\
0.1 \\
1 .\end{array}$ & $\begin{array}{l}0.3 \\
0.4 \\
0.5 \\
0.3 \\
0.2 \\
0.4 \\
0.4 \\
0.3 \\
0.2 \\
0.3 \\
0.5\end{array}$ \\
\hline
\end{tabular}

FORMATION OF COMPLETION CODE:

UB - UPPER BURRO CANYON

FLOW RELATIONSHIP CODE:

PARAMETER VALUE INDICATOR (PVI): < - LESS THAN DETECTION LIMIT

SAMPLE ID CODES:

0001 - FILTERED SAMPLE (.45 MICRONS)

OTHER PARAMETER VALUE FLAGS:

d - CHANGED DETECTION LIMIT AND PARAMETER VALUE 
TABLE 3.45. BACKGROUND GROUNDWATER QUALITY DATA BY PARAMETER FOR THE UPPER SANDSTONE UNIT, BURRO CANYON DISPOSAL SITE, SLICK ROCK, COLORADO

SITE: SRKO2 BORROW SITE 1 (BURRO CANYON)

SITE: SRKO2 TO $10 / 12 / 92$

\begin{tabular}{|c|c|c|c|c|c|c|c|c|c|c|c|}
\hline PARAMETER NAME & $\begin{array}{l}\text { LOCATION } \\
\text { ID }\end{array}$ & LOG DATE & $\begin{array}{c}\text { SAMPLE } \\
\text { ID }\end{array}$ & $\begin{array}{l}\text { FORM } \\
\text { COMP }\end{array}$ & $\begin{array}{l}\text { FLOW } \\
\text { REL. }\end{array}$ & $\begin{array}{l}\text { UNITS OF } \\
\text { MEASURE }\end{array}$ & PVI & $\begin{array}{l}\text { ARAMETER } \\
\text { VALUE }\end{array}$ & FLAGS & $\begin{array}{l}\text { DETECTION } \\
\text { LIMIT }\end{array}$ & $\begin{array}{l}\text { PARAMETER } \\
\text { UNCERTAINTY }\end{array}$ \\
\hline THOR IUM-230 & 0529 & $08 / 23 / 91$ & 0001 & UB & 0 & $\mathrm{PCI} / \mathrm{L}$ & \multicolumn{3}{|c|}{0.7} & 1. & 0.6 \\
\hline TIN & $\begin{array}{l}0518 \\
0518 \\
0518 \\
0518 \\
0518 \\
0523 \\
0523 \\
0523 \\
0523 \\
0527 \\
0527 \\
0527 \\
0527 \\
0527 \\
0529 \\
0529 \\
0529 \\
0529\end{array}$ & $\begin{array}{l}06 / 04 / 90 \\
12 / 15 / 90 \\
04 / 01 / 91 \\
08 / 23 / 91 \\
10 / 11 / 92 \\
12 / 12 / 90 \\
04 / 01 / 91 \\
08 / 23 / 91 \\
10 / 12 / 92 \\
06 / 06 / 90 \\
12 / 15 / 90 \\
04 / 04 / 91 \\
08 / 23 / 91 \\
10 / 12 / 92 \\
12 / 08 / 90 \\
04 / 02 / 91 \\
08 / 23 / 91 \\
10 / 12 / 92\end{array}$ & $\begin{array}{l}0001 \\
0001 \\
0001 \\
0001 \\
0001 \\
0001 \\
0001 \\
0001 \\
0001 \\
0001 \\
0001 \\
0001 \\
0001 \\
0001 \\
0001 \\
0001 \\
0001 \\
0001\end{array}$ & $\begin{array}{l}\text { UB } \\
\text { UB } \\
\text { UB } \\
\text { UB } \\
\text { UB } \\
\text { UB } \\
\text { UB } \\
\text { UB } \\
\text { UB } \\
\text { UB } \\
\text { UB } \\
\text { UB } \\
\text { UB } \\
\text { UB } \\
\text { UB } \\
\text { UB } \\
\text { UB } \\
\text { UB }\end{array}$ & $\begin{array}{l}0 \\
0 \\
0 \\
0 \\
0 \\
0 \\
0 \\
0 \\
0 \\
0 \\
0 \\
0 \\
0 \\
0 \\
0 \\
0 \\
0 \\
0\end{array}$ & MG/L & $\begin{array}{l}< \\
< \\
< \\
< \\
< \\
< \\
< \\
< \\
< \\
< \\
< \\
< \\
< \\
< \\
< \\
< \\
< \\
<\end{array}$ & \multicolumn{2}{|c|}{$\begin{array}{l}0.005 \\
0.005 \\
0.005 \\
0.005 \\
0.005 \\
0.005 \\
0.005 \\
0.005 \\
0.005 \\
0.005 \\
0.005 \\
0.005 \\
0.005 \\
0.005 \\
0.005 \\
0.005 \\
0.005 \\
0.05\end{array}$} & $\begin{array}{l}0.005 \\
0.005 \\
0.005 \\
0.005 \\
0.005 \\
0.005 \\
0.005 \\
0.005 \\
0.005 \\
0.005 \\
0.005 \\
0.005 \\
0.005 \\
0.005 \\
0.005 \\
0.005 \\
0.005 \\
0.05\end{array}$ & $\begin{array}{l}- \\
- \\
- \\
- \\
- \\
- \\
- \\
- \\
- \\
- \\
- \\
- \\
- \\
-\end{array}$ \\
\hline TOTAL DISSOLVED SOLIDS & $\begin{array}{l}0518 \\
0518 \\
0518 \\
0518 \\
0518 \\
0523 \\
0523 \\
0523 \\
0523 \\
0527 \\
0527 \\
0527 \\
0527 \\
0527 \\
0529 \\
0529 \\
0529 \\
0529\end{array}$ & $\begin{array}{l}06 / 04 / 90 \\
12 / 15 / 90 \\
04 / 01 / 91 \\
08 / 23 / 91 \\
10 / 11 / 92 \\
12 / 12 / 90 \\
04 / 01 / 91 \\
08 / 23 / 91 \\
10 / 12 / 92 \\
06 / 06 / 90 \\
12 / 15 / 90 \\
04 / 04 / 91 \\
08 / 23 / 91 \\
10 / 12 / 92 \\
12 / 08 / 90 \\
04 / 02 / 91 \\
08 / 23 / 91 \\
10 / 12 / 92\end{array}$ & $\begin{array}{l}0001 \\
0001 \\
0001 \\
0001 \\
0001 \\
0001 \\
0001 \\
0001 \\
0001 \\
0001 \\
0001 \\
0001 \\
0001 \\
0001 \\
0001 \\
0001 \\
0001 \\
0001\end{array}$ & $\begin{array}{l}\text { UB } \\
\text { UB } \\
\text { UB } \\
\text { UB } \\
\text { UB } \\
\text { UB } \\
\text { UB } \\
\text { UB } \\
\text { UB } \\
\text { UB } \\
\text { UB } \\
\text { UB } \\
\text { UB } \\
\text { UB } \\
\text { UB } \\
\text { UB } \\
\text { UB } \\
\text { UB }\end{array}$ & $\begin{array}{l}0 \\
0 \\
0 \\
0 \\
0 \\
0 \\
0 \\
0 \\
0 \\
0 \\
0 \\
0 \\
0 \\
0 \\
0 \\
0 \\
0 \\
0\end{array}$ & $M G / L$ & \multicolumn{3}{|c|}{$\begin{array}{l}966 . \\
928 . \\
973 . \\
951 . \\
906 . \\
556 . \\
636 . \\
615 . \\
587 . \\
762 . \\
760 . \\
854 . \\
843 . \\
840 . \\
600 . \\
664 . \\
662 . \\
676 .\end{array}$} & $\begin{array}{l}10 . \\
10 . \\
10 . \\
10 . \\
10 . \\
10 . \\
10 . \\
10 . \\
10 . \\
10 . \\
10 . \\
10 . \\
10 . \\
10 . \\
10 . \\
10 . \\
10 . \\
10 .\end{array}$ & $\begin{array}{l}- \\
- \\
- \\
- \\
- \\
- \\
- \\
- \\
- \\
- \\
- \\
- \\
- \\
- \\
- \\
- \\
-\end{array}$ \\
\hline TOTAL KJELDAHL NITROGEN & 0518 & $12 / 15 / 90$ & 0001 & UB & 0 & $M G / L$ & \multicolumn{3}{|c|}{1.} & 1. & - \\
\hline
\end{tabular}

FORMATION OF COMPLETION CODE:

FLOW RELATIONSHIP CODE:

UB - UPPER BURRO CANYON

O - ON-SITE

PARAMETER VALUE INDICATOR (PVI): < - LESS THAN DETECTION LIMIT

SAMPLE ID CODES:

0001 - FILTERED SAMPLE (.45 MICRONS)

OTHER PARAMETER VALUE FLAGS

I - INCREASED DETECTION LIMIT DUE TO REQUIRED DILUTION 
TABLE 3.45 BACKGROUND GROUNDWATER QUALITY DATA BY PARAMETER FOR THE UPPER SANDSTONE UNIT, BURRO CANYON DISPOSAL SITE, SLICK ROCK, COLORADO

SITE: SRKO2 BORROW SITE 1 (BURRO CANYON)

O6/04/90 TO $10 / 20$

REPORT DATE: 03/01/94

\begin{tabular}{|c|c|c|c|c|c|c|c|c|c|c|}
\hline PARAMETER NAME & $\begin{array}{c}\text { LOCATION } \\
\text { ID }\end{array}$ & LOG DATE & $\begin{array}{c}\text { SAMPLE } \\
\text { ID }\end{array}$ & $\begin{array}{l}\text { FORM } \\
\text { COMP }\end{array}$ & $\begin{array}{l}\text { FLOW } \\
\text { REL. }\end{array}$ & $\begin{array}{l}\text { UNITS OF } \\
\text { MEASURE }\end{array}$ & PVI & $\begin{array}{l}\text { ARAMETER } \\
\text { VALUE }\end{array}$ & $\begin{array}{l}\text { DETECTION } \\
\text { LIMIT }\end{array}$ & $\begin{array}{l}\text { PARAMETER } \\
\text { UNCERTAINTY }\end{array}$ \\
\hline $\begin{array}{l}\text { TOTAL KJELDAHL NITROGEN } \\
\text {. }\end{array}$ & $\begin{array}{l}0518 \\
0518 \\
0523 \\
0523 \\
0523 \\
0527 \\
0527 \\
0527 \\
0529 \\
0529 \\
0529\end{array}$ & $\begin{array}{l}04 / 01 / 91 \\
08 / 23 / 91 \\
12 / 12 / 90 \\
04 / 01 / 91 \\
08 / 23 / 91 \\
12 / 15 / 90 \\
04 / 04 / 91 \\
08 / 23 / 91 \\
12 / 08 / 90 \\
04 / 02 / 91 \\
08 / 23 / 91\end{array}$ & $\begin{array}{l}0001 \\
0001 \\
0001 \\
0001 \\
0001 \\
0001 \\
0001 \\
0001 \\
0001 \\
0001 \\
0001\end{array}$ & $\begin{array}{l}\text { UB } \\
\text { UB } \\
\text { UB } \\
\text { UB } \\
\text { UB } \\
\text { UB } \\
\text { UB } \\
\text { UB } \\
\text { UB } \\
\text { UB } \\
\text { UB }\end{array}$ & $\begin{array}{l}0 \\
0 \\
0 \\
0 \\
0 \\
0 \\
0 \\
0 \\
0 \\
0 \\
0\end{array}$ & $\mathrm{MG} / \mathrm{L}$ & $\begin{array}{l}< \\
< \\
< \\
<\end{array}$ & $\begin{array}{l}1 . \\
1 . \\
1 . \\
1 . \\
1 . \\
1 . \\
2 . \\
1 . \\
1 . \\
1 . \\
1 .\end{array}$ & $\begin{array}{l}1 . \\
1 . \\
1 . \\
1 . \\
1 . \\
1 . \\
1 . \\
1 . \\
1 .\end{array}$ & $\begin{array}{l}- \\
- \\
- \\
- \\
- \\
- \\
-\end{array}$ \\
\hline TOTAL ORGANIC CARBON & $\begin{array}{l}0518 \\
0518 \\
0518 \\
0523 \\
0523 \\
0523 \\
0527 \\
0527 \\
0527 \\
0529 \\
0529 \\
0529\end{array}$ & $\begin{array}{l}04 / 01 / 91 \\
08 / 23 / 91 \\
10 / 11 / 92 \\
04 / 01 / 91 \\
08 / 23 / 91 \\
10 / 12 / 92 \\
04 / 04 / 91 \\
08 / 23 / 91 \\
10 / 12 / 92 \\
04 / 02 / 91 \\
08 / 23 / 91 \\
10 / 12 / 92\end{array}$ & $\begin{array}{l}0001 \\
0001 \\
0001 \\
0001 \\
0001 \\
0001 \\
0001 \\
0001 \\
0001 \\
0001 \\
0001 \\
0001\end{array}$ & $\begin{array}{l}\text { UB } \\
\text { UB } \\
\text { UB } \\
\text { UB } \\
\text { UB } \\
\text { UB } \\
\text { UB } \\
\text { UB } \\
\text { UB } \\
\text { UB } \\
\text { UB } \\
\text { UB }\end{array}$ & $\begin{array}{l}0 \\
0 \\
0 \\
0 \\
0 \\
0 \\
0 \\
0 \\
0 \\
0 \\
0 \\
0\end{array}$ & $M G / L$ & $<$ & $\begin{array}{l}1 . \\
2 . \\
2 . \\
1 . \\
2 . \\
3 . \\
1 . \\
4 . \\
3 . \\
1 . \\
3 . \\
3 .\end{array}$ & $\begin{array}{l}1 . \\
1 . \\
1 . \\
1 . \\
1 . \\
1 . \\
1 . \\
1 . \\
1 . \\
1 . \\
1 . \\
1 .\end{array}$ & $\begin{array}{l}- \\
- \\
- \\
- \\
- \\
- \\
- \\
- \\
-\end{array}$ \\
\hline URANIUM & $\begin{array}{l}0518 \\
0518 \\
0518 \\
0518 \\
0518 \\
0523 \\
0523 \\
0523 \\
0523 \\
0527 \\
0527 \\
0527 \\
0527 \\
0527 \\
0529 \\
0529\end{array}$ & $\begin{array}{l}06 / 04 / 90 \\
12 / 15 / 90 \\
04 / 01 / 91 \\
08 / 23 / 91 \\
10 / 11 / 92 \\
12 / 12 / 90 \\
04 / 01 / 91 \\
08 / 23 / 91 \\
10 / 12 / 92 \\
06 / 06 / 90 \\
12 / 15 / 90 \\
04 / 04 / 91 \\
08 / 23 / 91 \\
10 / 12 / 92 \\
12 / 08 / 90 \\
04 / 02 / 91\end{array}$ & $\begin{array}{l}0001 \\
0001 \\
0001 \\
0001 \\
0001 \\
0001 \\
0001 \\
0001 \\
0001 \\
0001 \\
0001 \\
0001 \\
0001 \\
0001 \\
0001 \\
0001\end{array}$ & $\begin{array}{l}\text { UB } \\
\text { UB } \\
\text { UB } \\
\text { UB } \\
\text { UB } \\
\text { UB } \\
\text { UB } \\
\text { UB } \\
\text { UB } \\
\text { UB } \\
\text { UB } \\
\text { UB } \\
\text { UB } \\
\text { UB } \\
\text { UB } \\
\text { UB }\end{array}$ & $\begin{array}{l}0 \\
0 \\
0 \\
0 \\
0 \\
0 \\
0 \\
0 \\
0 \\
0 \\
0 \\
0 \\
0 \\
0 \\
0 \\
0\end{array}$ & MG/L & $\mid<$ & $\begin{array}{l}0.020 \\
0.0172 \\
0.019 \\
0.017 \\
0.022 \\
0.0008 \\
0.025 \\
0.001 \\
0.002 \\
0.0066 \\
0.0026 \\
0.002 \\
0.001 \\
0.002 \\
0.0003 \\
0.001\end{array}$ & $\begin{array}{l}0.003 \\
0.0003 \\
0.001 \\
0.001 \\
0.001 \\
0.0003 \\
0.001 \\
0.001 \\
0.001 \\
0.003 \\
0.0003 \\
0.001 \\
0.001 \\
0.001 \\
0.0003 \\
0.001\end{array}$ & $\begin{array}{l}- \\
- \\
- \\
- \\
- \\
- \\
- \\
- \\
- \\
- \\
- \\
-\end{array}$ \\
\hline
\end{tabular}

FORMATION OF COMPLETION COOE:

UB - UPPER BURRO CANYON

FLOW RELATIONSHIP COOE:

PARAMETER VALUE INDICATOR (PVI): < - LESS THAN DETECTION LIMIT

SAMPLE ID CODES:

0001 - FILTERED SAMPLE (.45 MICRONS) 
TABLE 3.45. BACKGROUND GROUNDWATER QUALITY DATA BY PARAMETER FOR THE UPPER SANDSTONE UNIT, BURRO CANYON DISPOSAL SITE, SLICK ROCK, COLORADO

SITE: SRKO2 BORROU SITE 1 (BURRO CANYON)

$06 / 04 / 90$ TO $10 / 12 / 92$

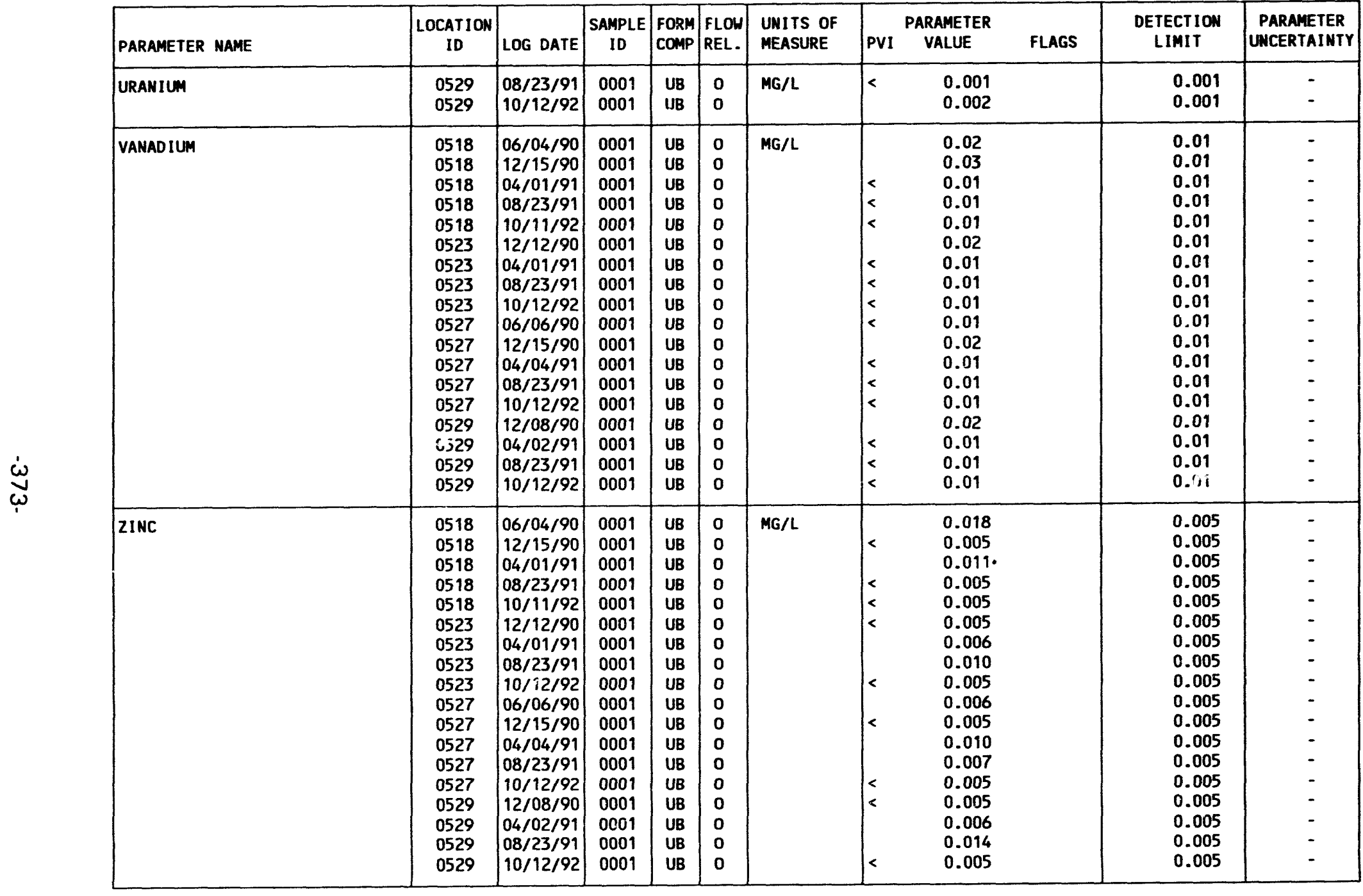

FORMATION OF COMPLETION CODE:

UB - UPPER BURRO CANYON

PARAMETER VALUE INDICATOR (PVI): < - LESS THAN DETECTION LIMIT
FLOW RELATIONSHIP COOE:

O - ON-SITE

SAMPLE ID CODES:

O001 - FILTERED SAMPLE (.45 MICRONS)

DATA FILE NAME: M: \DART \SRK02\IGW10013.DAT 
TABLE 3.46. BACKGROUND GROUNDWATER QUALITY STATISTICS BY PARAMETER FOR THE UPPER SANDSTONE UNIT, BURRO CANYON DISPOSAL SITE, SLICK ROCK, COLORADO

SITE: SRKO2 BORROW SITE 1 (BURRO CANYON)

$06 / 04 / 90$ TO $10 / 12 / 92$

REPORT DATE : 03/02/94

\begin{tabular}{|c|c|c|c|c|c|c|c|c|c|c|c|}
\hline \multicolumn{3}{|c|}{ PARAMETER NAME } & UNITS & \multirow[b]{2}{*}{ MEAN } & \multirow{2}{*}{$\begin{array}{l}\text { STANDARD } \\
\text { DEVIATION }\end{array}$} & \multirow{2}{*}{$\begin{array}{c}\text { COEFF. } \\
\text { OF } \\
\text { VARIATIOH }\end{array}$} & \multirow{2}{*}{$\begin{array}{c}\% \text { OF } \\
\text { NON } \\
\text { DETECTS }\end{array}$} & \multirow{2}{*}{\multicolumn{2}{|c|}{$\begin{array}{l}\text { STATISTICAL RANGE } \\
\text { 98\% CONFIDENCE INTERVAL } \\
\text { MINIMUM MAXIMUM * }\end{array}$}} & \multirow{2}{*}{$\begin{array}{c}\text { DISTRIBUT ION } \\
\text { TYPE }\end{array}$} & \multirow{2}{*}{$\begin{array}{l}\text { FOO } \\
\text { NOT }\end{array}$} \\
\hline \# OF SAMP & MINIMUM & MAXIMUM & MEDIAN & & & & & & & & \\
\hline \multicolumn{3}{|c|}{ ALKALINITY } & $\mathrm{MG} / \mathrm{L} \mathrm{CACO}$ & \multirow[b]{2}{*}{308.9444} & \multirow[b]{2}{*}{102.0303} & \multirow[b]{2}{*}{0.3303} & \multirow[b]{2}{*}{0.0} & \multirow[b]{2}{*}{247.2113} & \multirow[b]{2}{*}{370.6776} & \multirow[b]{2}{*}{ MORMAL } & \\
\hline 18 & 189.0000 & 607.0000 & +280.0000 & & & & & & & & \\
\hline \multicolumn{3}{|l|}{ ALUMINUM } & $M G / L$ & \multirow[b]{2}{*}{ NA } & \multirow[b]{2}{*}{ NA } & \multirow[b]{2}{*}{ NA } & \multirow[b]{2}{*}{55.6} & \multirow[b]{2}{*}{0.0500} & \multirow[b]{2}{*}{0.1000} & \multirow[b]{2}{*}{ MONPARAMETRIC } & \multirow[b]{2}{*}{2} \\
\hline 18 & 0.0500 & 0.1600 & 0.0500 & & & & & & & & \\
\hline \multicolumn{3}{|l|}{ AMMON IUM } & $M G / L$ & \multirow[b]{2}{*}{ NA } & \multirow[b]{2}{*}{ NA } & \multirow[b]{2}{*}{ NA } & \multirow[b]{2}{*}{22.2} & & & & \\
\hline 18 & ** $\quad 0.1000$ & 0.4000 & 0.2000 & & & & & 0.1000 & 0.3000 & MOMPARAMETRIC & 2 \\
\hline ANT IMONY & & & $M G / L$ & & & & & & & & \\
\hline 18 & ** 0.1030 & 0.0080 & 0.0030 & NA & NA & NA & 88.9 & 0.0030 & $\star \star \quad 0.0030$ & NONPARAMETRIC & 2 \\
\hline ARSENIC & & & $M G / L$ & & & & & & & & \\
\hline 18 & ** $\quad 0.0050$ & 0.0250 & 0.0050 & NA & NA & NA & 100.0 & 0.0050 & 0.0050 & NONPARAMETRIC & 2 \\
\hline BARIUM & & & $M G / L$ & & & & & & & & \\
\hline 18 & c.0200 & 0.0500 & 0.0300 & NA & NA & NA & 33.3 & 0.0200 & 0.0500 & NONPARAMETRIC & 2 \\
\hline BERYLLIUM & & & $M G / L$ & & & & & & & & \\
\hline 14 & ** $\quad 0.0050$ & 0.0050 & 0.0050 & NA & NA & NA & 100.0 & 0.0050 & 0.0050 & NONPARAMETRIC & 2 \\
\hline BORON & & & $M G / L$ & & & & & & & & \\
\hline 14 & 0.1000 & 0.2700 & 0.2000 & 0.2043 & 0.0398 & 0.1946 & 0.0 & 0.1761 & 0.2324 & NORMAL & \\
\hline BRONIDE & & & $M G / L$ & & & & & & & & \\
\hline 12 & 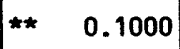 & 0.5000 & 0.2000 & NA & NA & NA & 33.3 & 0.1000 & 0.4000 & NONPARAMETRIC & 2 \\
\hline CADMIUM & & & $M G / L$ & & & & & & & & \\
\hline 18 & ** $\quad 0.0005$ & 0.0100 & 0.0005 & NA & NA & NA & 94.4 & 0.0005 & 0.0005 & NONPARAMETRIC & 2 \\
\hline
\end{tabular}

** The reported value is the minimum detection limit of the data set

+ The sample size is even, so the median value is the arithmetic average of the two middle values

* The statistical maximum is the 99 percent one sided confidence interval, $a=0.01$

2) The nonparametric distribution was used because the nondetected values comprise more than $15 \%$ of the samples. 


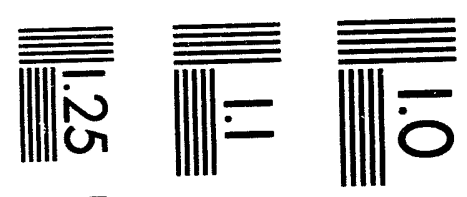

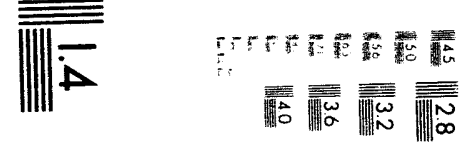

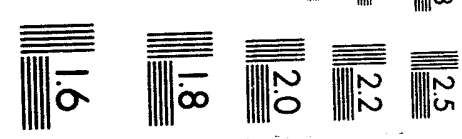



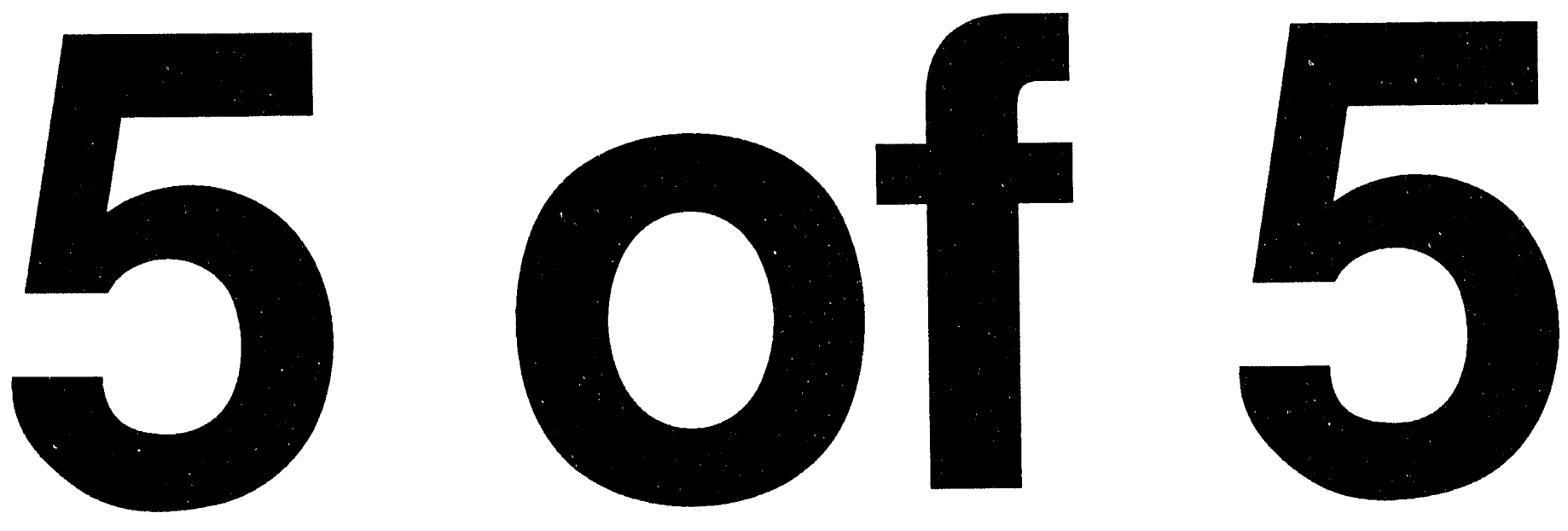
TABLE 3.46. BACKGROUND GROUNDWATER QUALITY STATISTICS BY PARAMETER FOR THE UPPER SANDSTONE UNIT, BURRO CANYON DISPOSAL SITE, SLICK ROCK, COLORADO SITE: SRKO2 BORROW SITE 1 (BURRO CANYON)

06/04/90 TO $10 / 12 / 92$

REPORT DATE : 03/02/94

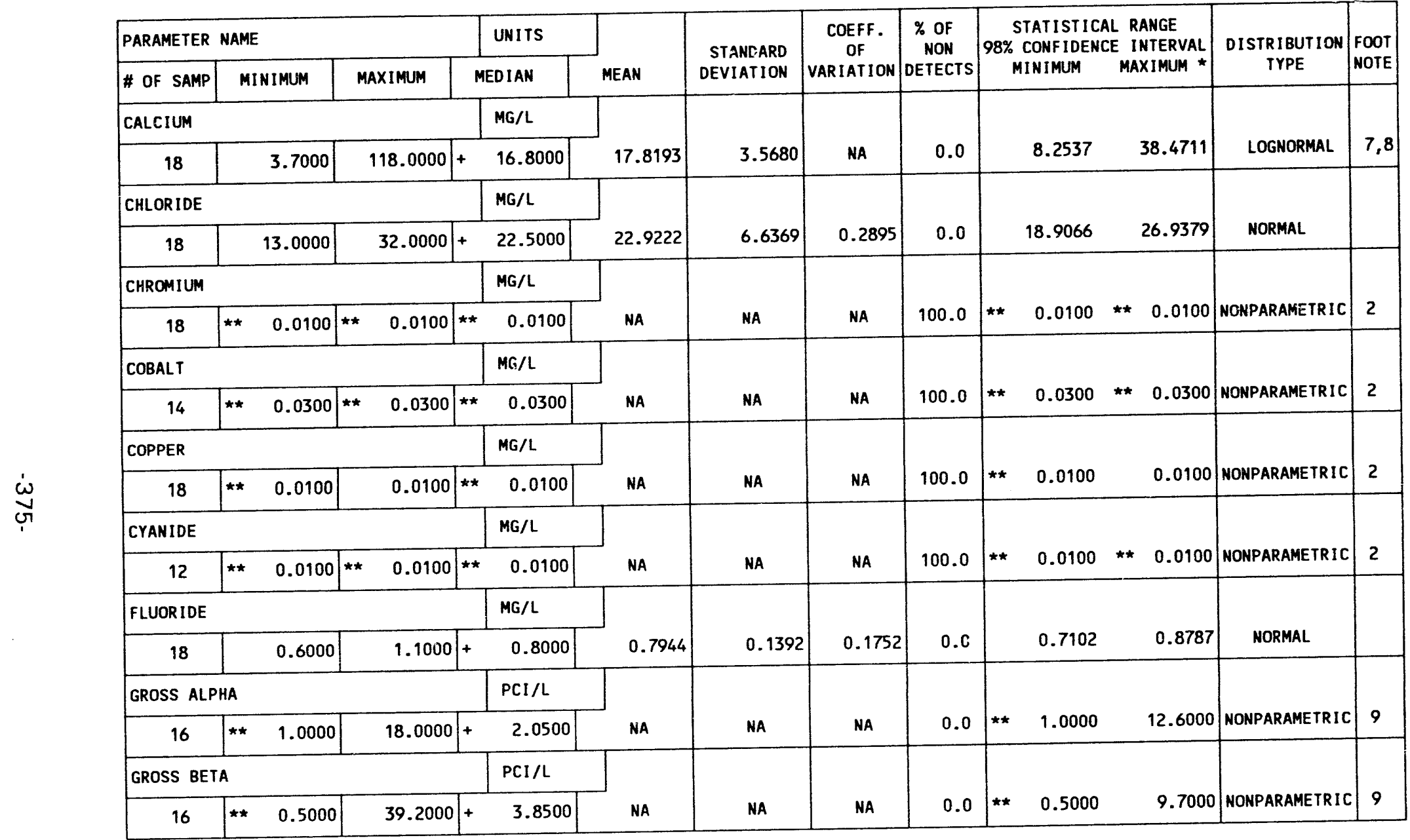

** The reported value is the minimum detection limit of the data set

* The sample size is even, so the median value is the arithidence interval, $\alpha=0.01$

* The statistical maxis

2) The nonparametric distribution was used because the nondetected values comprise dationtion test.

7) The lognormal distribution was used because the data failed the nivide or multiply with the geometric mean.

8) The mean is geometric. The standard deviation is the value to divide or multiply withed the normal distribution test and includes values $\leq 0$. 
TABLE 3.46. BACKGROUND GROUNDWATER QUALITY STATISTICS BY PARAMETER FOR THE UPPER SANDSTONE UNIT, BURRO CANYON DISPOSAL SITE, SLICK ROCK, COLORADO SITE: SRKO2 BORROW SITE 1 (BURRO CANYON)

06/04/90 TO $10 / 12 / 92$

REPORT DATE: $03 / 02 / 9$

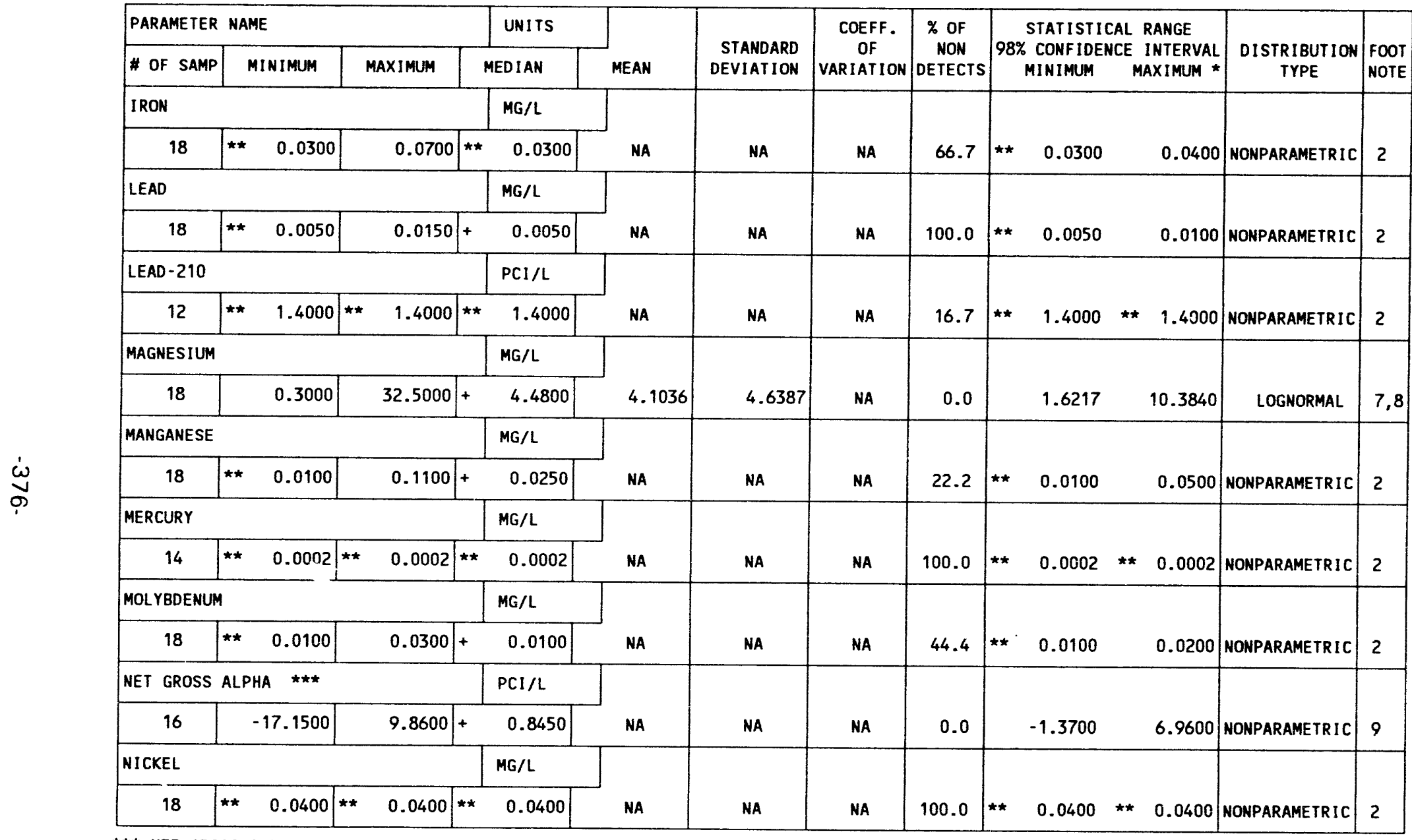

*** NET GROSS ALPHA (GROSS ALPHA - URANIUM) WITH 1 MG URANIUM $=686 \mathrm{PCI}$

$\star$ The reported value is the minimum detection limit of the data set

+ The sample size is even, so the median value is the arithmetic average of the two middle values

* The statistical maximum is the 99 percent one sided confidence interval, $a=0.01$

2) The nonparametric distribution was used because the nondetected values comprise more than $15 \%$ of the samples.

7) The lognormal distribution was used because the data failed the normal distribution test.

8) The mean is geometric. The standard deviation is the value to divide or multiply with the geometric mean.

9) The nonparametic distribution was used because the data failed the normal distribution test and includes values $\leq 0$. 
TABLE 3.46. BACKGROUND GROUNDWATER QUALITY STATISTICS BY PARAMETER FOR THE

UPPER SANDSTONE UNIT, BURRO CAMYON DISPOSAL SITE, SLICK ROCK, COLORADO

SITE: SRKO2 BORROW SITE 1 (BURRO CANYON)

06/04/90 TO 10/12/92

REPORT DATE : $03 / 02 / 94$

\begin{tabular}{|c|c|c|c|c|c|c|c|c|c|c|c|c|}
\hline \multicolumn{3}{|c|}{ PARAMETER NAME } & UNITS & \multirow[b]{2}{*}{ MEAN } & \multirow{2}{*}{$\begin{array}{l}\text { STANDARD } \\
\text { DEVIATION }\end{array}$} & \multirow{2}{*}{$\begin{array}{l}\text { COEFF. } \\
\text { OF } \\
\text { VARIATION }\end{array}$} & \multirow{2}{*}{$\begin{array}{c}\% \text { OF } \\
\text { NON } \\
\text { DETECTS }\end{array}$} & \multirow{2}{*}{\multicolumn{3}{|c|}{$\begin{array}{l}\text { STATISTICAL RANGE } \\
98 \% \text { CONFIDENCE INTERVAL } \\
\text { MINIMUM MAXIMUM * }\end{array}$}} & \multirow{2}{*}{$\begin{array}{c}\text { DISTRIBUTION } \\
\text { TYPE }\end{array}$} & \multirow{2}{*}{$\begin{array}{l}\text { FOOT } \\
\text { NOTE }\end{array}$} \\
\hline \# OF SAMP & MINIMUM & MAXIMUM & MEDIAN & & & & & & & & & \\
\hline NITRATE & & & MG/L & \multirow[b]{2}{*}{ NA } & \multirow[b]{2}{*}{ NA } & \multirow[b]{2}{*}{ NA } & \multirow[b]{2}{*}{35.7} & \multirow[b]{2}{*}{ \#夫 } & \multirow[b]{2}{*}{1.0000} & \multirow[b]{2}{*}{4.4000} & \multirow[b]{2}{*}{ NONPARAMETRIC } & \multirow[b]{2}{*}{2} \\
\hline 14 & $\star \star \quad 1.0000$ & 24.3000 & 1.6000 & & & & & & & & & \\
\hline \multicolumn{3}{|c|}{ NITRITE AND NITRATE } & $M G / L$ & \multirow[b]{2}{*}{ NA } & \multirow[b]{2}{*}{ NA } & \multirow[b]{2}{*}{ NA } & \multirow[b]{2}{*}{20.0} & \multirow{2}{*}{\multicolumn{2}{|c|}{0.2600}} & \multirow[b]{2}{*}{1.3100} & \multirow[b]{2}{*}{ NONPARAMETRIC } & \multirow[b]{2}{*}{2} \\
\hline 10 & 0.1200 & 5.5400 & 0.6000 & & & & & & & & & \\
\hline \multicolumn{3}{|l|}{$\mathrm{PH}$} & su & \multirow[b]{2}{*}{ NA } & \multirow[b]{2}{*}{ NA } & \multirow[b]{2}{*}{ NA } & \multirow[b]{2}{*}{0.0} & & & & & \\
\hline 20 & 7.4600 & 9.0900 & 8.2047 & & & & & & NA & NA & UNKNOWN & \\
\hline PHOSPHATE & & & $M G / L$ & & & & & & & & & \\
\hline 14 & $\star \star * \quad 0.1000$ & 1.6000 & 0.1000 & NA & NA & NA & 35.7 & $\star \star$ & 0.1000 & 0.5000 & NONPARAMETRIC & 2 \\
\hline POLONIUM- & 210 & & $\mathrm{PCI} / \mathrm{L}$ & & & & & & & & & \\
\hline 12 & 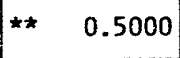 & 0.5000 & 0.5000 & NA & NA & NA & 0.0 & ** & 0.5000 & ** 0.5000 & NONPARAMETRIC & 9 \\
\hline POTASSIUM & & & $M G / L$ & & & & & & & & & \\
\hline 18 & 0.7600 & 7.7000 & 2.9150 & 2.8750 & 1.9040 & 0.6623 & 0.0 & & 1.7230 & 4.0270 & NORMAL & \\
\hline RADIUM-22 & & & $\mathrm{PCl} / \mathrm{L}$ & & & & & & & & & \\
\hline 18 & $\star * \quad 0.1000$ & 0.5000 & 0.1000 & NA & NA & NA & 5.6 & ** & 0.1000 & 0.3000 & NONPARAMETRIC & 9 \\
\hline RADIUM-22 & $5+$ RADIUM- 22 & & $\mathrm{PCI} / \mathrm{L}$ & & & & & & & & & \\
\hline 18 & 0.0000 & 7.6000 & 0.9500 & NA & NA & NA & 0.0 & & 0.5000 & 1.8000 & NONPARAMETRIC & 9 \\
\hline RADIUM-22 & & & $\mathrm{PCI} / \mathrm{L}$ & & & & & & & & & \\
\hline 18 & $\star \star \star \quad 1.0000$ & 7.2000 & 1.0000 & NA & NA & NA & 0.0 & $\star \star \star$ & 1.0000 & 1.5000 & NONPARAMETRIC & 9 \\
\hline REDOX POT & ENTIAL & & mVOLTS & & & & & & & & & \\
\hline 4 & 194.1000 & 368.7000 & $+\quad 270.3500$ & 275.8750 & 71.7526 & 0.2601 & 0.0 & & 112.9606 & 438.7894 & NORMAL & \\
\hline
\end{tabular}

** The reported value is the minimum detection limit of the data set

+ The sample size is even, so the median value is the arithmetic average of the two middle values

* The sample size is even, so the 99 percent one sided confidence interval, $a=0.01$

1) A minimum of 4 samples must be available for the statistical analysis.

1) A minimum of 4 samples must be available for the statistical analysis.

9) The nonparametic distribution was used because the data failed the normal distribution test and includes values $\leq 0$. 
TABLE 3.46. BACKGROUND GROUNDWATER QUALITY STATISTICS BY PARAMETER FOR THE UPPER SANDSTONE UNIT, BURRO CANYON DISPOSAL SITE, SLICK ROCK, COLORADO SITE: SRKO2 BORROW SITE 1 (BURRO CANYON)

06/04/90 TO $10 / 12 / 92$

REPORT DATE: 03/02/94

\begin{tabular}{|c|c|c|c|c|c|c|c|c|c|c|c|}
\hline \multicolumn{3}{|c|}{ PARAMETER NAME } & UNITS & \multirow[b]{2}{*}{ MEAN } & \multirow{2}{*}{$\begin{array}{r}\text { STANDARD } \\
\text { DEVIATION }\end{array}$} & \multirow{2}{*}{$\begin{array}{c}\text { COEFF. } \\
\text { OF } \\
\text { VARIATION }\end{array}$} & \multirow{2}{*}{$\left|\begin{array}{c}\% \text { OF } \\
\text { NON } \\
\text { DETECTS }\end{array}\right|$} & \multirow{2}{*}{\multicolumn{2}{|c|}{ 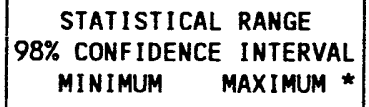 }} & \multirow[b]{2}{*}{$\begin{array}{c}\text { DISTRIBUTION } \\
\text { TYPE }\end{array}$} & \multirow[b]{2}{*}{$\begin{array}{l}\text { FOOT } \\
\text { NOTE }\end{array}$} \\
\hline \# OF SAMP & MINIMUM & MAXIMUM & MEDIAN & & & & & & & & \\
\hline \multicolumn{3}{|l|}{ SELENIUM } & $\mathrm{MG} / \mathrm{L}$ & \multirow[b]{2}{*}{ NA } & \multirow[b]{2}{*}{ NA } & \multirow[b]{2}{*}{ NA } & \multirow[b]{2}{*}{61.1} & \multirow[b]{2}{*}{0.0050} & \multirow[b]{2}{*}{0.0120} & \multirow[b]{2}{*}{ NONPARAMETRIC } & \multirow[b]{2}{*}{2} \\
\hline 18 & $\begin{array}{ll}* & 0.0050\end{array}$ & 0.0400 & $\star \star * \quad 0.0050$ & & & & & & & & \\
\hline \multicolumn{3}{|c|}{ SILICA - SIO2 } & $M G / L$ & \multirow[b]{2}{*}{10.6278} & \multirow[b]{2}{*}{1.0487} & \multirow[b]{2}{*}{0.0987} & \multirow[b]{2}{*}{0.0} & \multirow[b]{2}{*}{9.9933} & \multirow[b]{2}{*}{11.2623} & \multirow[b]{2}{*}{ NORMAL } & \multirow[b]{4}{*}{2} \\
\hline 18 & 9.0000 & 13.0000 & $+\quad 10.7500$ & & & & & & & & \\
\hline \multicolumn{3}{|l|}{ SILVER } & $M G / L$ & \multirow[b]{2}{*}{ NA } & \multirow[b]{2}{*}{ NA } & \multirow[b]{2}{*}{ NA } & \multirow[b]{2}{*}{100.0} & & & & \\
\hline 14 & $\star \star \quad 0.0100$ & $\begin{array}{ll}* & 0.0100\end{array}$ & $\star \star \quad 0.0100$ & & & & & 0.0100 & $\star \star \quad 0.0100$ & NONPARAMETRIC & \\
\hline SODIUM & & & MG/L & & & & & & & & \\
\hline 18 & 139.0000 & 288.0000 & $+\quad 223.5000$ & 215.2778 & 51.0695 & 0.2372 & 0.0 & 184.3783 & 246.1773 & NORMAL & \\
\hline SPECIFIC $C$ & CONDUCTANCE & & UMHO/CM & & & & & & & & \\
\hline 19 & 730.0000 & 1326.0000 & 1022.0000 & 1073.7895 & 187.8450 & 0.1749 & 0.0 & 963.8121 & 1183.7669 & NORMAL & \\
\hline STRONTIUM & & & $M G / L$ & & & & & & & & \\
\hline 18 & 0.3500 & 15.0000 & 2.3100 & 2.5071 & 3.7536 & NA & 0.0 & 1.1262 & 5.5813 & LOGNORMAL & 7,8 \\
\hline SULFATE & & & $M G / L$ & & & & & & & & \\
\hline 14 & 129.0000 & 535.0000 & +355.5000 & 345.9286 & 133.2155 & 0.3851 & 0.0 & 251.5797 & 440.2774 & NORMAL & \\
\hline SULFIDE & & & $M G / L$ & & & & & & & & \\
\hline 15 & ** $\quad 0.1000$ & 5.0400 & 0.4000 & NA & NA & NA & 26.7 & 0.1000 & 1.0000 & NONPARAMETRIC & 2 \\
\hline TEMPERATUR & & & $C$ - DEGR & & & & & & & & \\
\hline 20 & 12.5000 & 23.5000 & 13.4000 & 13.9350 & 2.3241 & 0.1668 & 0.0 & 12.6155 & 15.2545 & NORMAL & \\
\hline THALLIUM & & & $M G / L$ & & & & & & & & \\
\hline 18 & $\begin{array}{ll}* & 0.0050\end{array}$ & 0.0050 & 0.0050 & NA & NA & NA & 100.0 & 0.0050 & 0.0050 & NONPARAMETRIC & 2 \\
\hline
\end{tabular}

** The reported value is the minimum detection limit of the data set

+ The sample size is even, so the median value is the arithmetic average of the two middle values

* The statistical maximum is the 99 percent one sided confidence interval $\alpha=0.01$

2) The nonparametric distribution was used because the nondetected values comprise more than $15 \%$ of the samples.

7) The lognormal distribution was used because the data failed the normal distribution test.

8) The mean is geometric. The standard deviation is the value to divide or multiply with the geometric mean. 
TABLE 3.46. BACKGROUND GROUNDWATER QUALITY STATISTICS BY PARAMETER FOR THE UPPER SANDSTONE UNIT, BURRO CANYON DISPOSAL SITE, SLICK ROCK, COLORADO UPPER SANDSTONE UNIT, BURRO CANYON DISPOSAL

SITE: SRKO2 BORROW

REPORT DATE: $03 / 02 / 9$

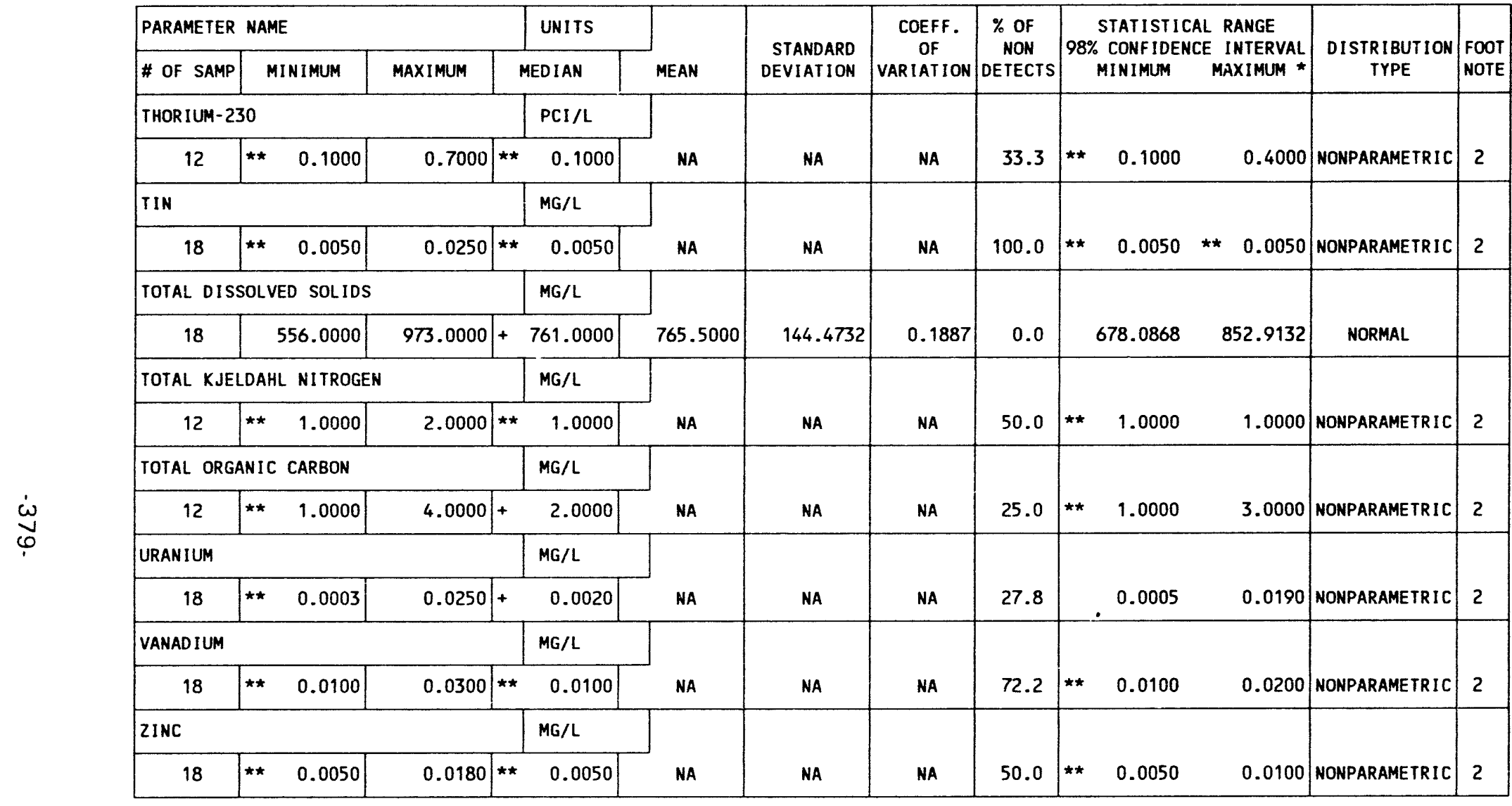

** The reported value is the minimum detection limit of the data set

+ The sample size is even, so the median value is the arithmetic average of the two middle values

* The statistical maximm is the 99 percent one sided confidence interval, $a=0.01$

2) The nonparametric distribution was used because the nondetected values comprise more than $15 \%$ of the samples.

INPUT DATA FILENAME: M: IDARTISRKO2IGWQ10013.DAT 
Table 3.47 Summary of regulated constituents in the upper sandstone unit, Burro Canyon disposal sitea, Slick Rock, Colorado

Constituents with MCLs

\begin{tabular}{|c|c|c|c|c|}
\hline \multirow{2}{*}{ Parameter } & \multirow{2}{*}{ MCL } & \multicolumn{3}{|c|}{ Background } \\
\hline & & Average & stat. & Max. \\
\hline Arsenic & 0.05 & $0.01^{B}$ & & $0.01^{8}$ \\
\hline Barium & 1.0 & $0.1^{8}$ & & $0.10^{8}$ \\
\hline Cadmium & 0.01 & $0.001^{8}$ & & $0.001^{8}$ \\
\hline Chromium & 0.05 & $0.01^{8}$ & & $0.01^{B}$ \\
\hline Net gross alphaf & 15.0 & $0.845^{\mathrm{e}}$ & & $6.96^{\circ}$ \\
\hline Lead & 0.05 & $0.01^{8}$ & & $0.01^{8}$ \\
\hline Mercury & 0.002 & $0.0002^{8}$ & & $0.0002^{8}$ \\
\hline Molybdenum & 0.1 & $0.01^{8}$ & & $0.02^{\circ}$ \\
\hline Nitrate & 44.0 & $1.60^{c}$ & & $4.4^{\mathrm{e}}$ \\
\hline Radium-226, $-228^{\prime}$ & 5.0 & $0.95^{\circ}$ & & $1.80^{c}$ \\
\hline Selenium & 0.01 & $0.005^{B}$ & & $0.012^{\mathrm{c}}$ \\
\hline Silver & 0.05 & $0.01^{d}$ & & $0.01^{8}$ \\
\hline Uri zium & 0.044 & $0.003^{8}$ & & $0.019^{e}$ \\
\hline
\end{tabular}

${ }^{2}$ All units are $\mathrm{mg} / \mathrm{l}$ unless otherwise noted.

bupermost aquifer.

'Lognormal distribution, mean is geometric.

Normal distribution, mean is arithmetic.

Nonparametric distribution

Units are pCi/l.

Statistical values are below laboratory detection limits in Table 8.1 of the Technical Approach Document (DOE, 1989). 
Table 3.47 Summary of regulated constituents in the upper sandstone unit, Burro Canyon disposal sitea, Slick Rock, Colorado (concluded)

Constituents without MCLs

\begin{tabular}{lcc}
\hline \multirow{2}{*}{ Parameter } & \multicolumn{2}{c}{ Background } \\
& Average & Stat. Max. \\
\hline Antimony & $0.003^{\mathrm{B}}$ & $0.003^{\mathrm{B}}$ \\
Beryllium & $0.01^{\mathrm{B}}$ & $0.01^{\mathrm{B}}$ \\
Cobalt & $0.05^{\mathrm{B}}$ & $0.05^{\mathrm{B}}$ \\
Copper & $0.02^{\mathrm{B}}$ & $0.02^{\mathrm{B}}$ \\
Cyanide & $0.01^{\mathrm{B}}$ & $0.01^{\mathrm{B}}$ \\
Nickel & $0.04^{\mathrm{B}}$ & $0.04^{\mathrm{B}}$ \\
Sulfide & $0.4^{\mathrm{C}}$ & $1.00^{\mathrm{C}}$ \\
Thallium & $0.01^{\mathrm{B}}$ & $0.01^{\mathrm{B}}$ \\
Tin & $0.005^{\mathrm{B}}$ & $0.005^{\mathrm{B}}$ \\
Vanadium & $0.01^{\mathrm{B}}$ & $0.02^{\mathrm{C}}$ \\
Zinc & $0.005^{\mathrm{B}}$ & $0.010^{\mathrm{C}}$ \\
\hline
\end{tabular}

${ }^{2} \mathrm{All}$ units are $\mathrm{mg} / \mathrm{l}$ unless otherwise noted.

uppermost aquifer.

${ }^{c}$ Lognormal distribution, mean is geometric.

'Normal distribution, mean is arithmetic.

'Nonparametric distribution

Units are pCi/l.

SStatistical values are below laboratory detection limits in Table 8.1 of the Technical Approach Document (DOE, 1989). 
TABLE 3.48. GROUNDWATER QUALITY MEASUREMENTS EXCEEDING MCLS IN THE UPPER

SANDSTONE UNIT, BURRO CANYON DISPOSAL SITE, SLICK ROCK, COLORADO

SITE: SRKO2 BORROW SITE 1 (BURRO CANYON)

$06 / 04 / 90$ TO $10 / 12 / 92$

REPORT DATE: 03/02/94

\begin{tabular}{|c|c|c|c|c|c|c|c|c|c|c|c|c|}
\hline PARAMETER NAME & $\begin{array}{l}\text { TOTAL } \\
\text { \# OF } \\
\text { SAMP. }\end{array}$ & $\begin{array}{c}\text { UNITS } \\
\text { OF } \\
\text { MEASURE }\end{array}$ & $\begin{array}{l}\text { MAXIMUM } \\
\text { CONC. } \\
\text { LIMIT }\end{array}$ & LOC. & LOG DATE & $\begin{array}{c}\text { SAMP } \\
\text { ID }\end{array}$ & $\begin{array}{l}\text { FORM } \\
\text { OF } \\
\text { COMP }\end{array}$ & $\begin{array}{l}\text { HYDR } \\
\text { FLOW } \\
\text { REL. }\end{array}$ & $\begin{array}{c}\text { RESULT EXCEE } \\
\text { CONCENTRATIU } \\
\text { VALUE }\end{array}$ & $\begin{array}{l}\text { DING MAX. } \\
\text { N LIMIT } \\
\text { FLAGS }\end{array}$ & $\begin{array}{l}\text { DETECTION } \\
\text { LIMIT }\end{array}$ & $\begin{array}{l}\text { PARAMETER } \\
\text { UNCERT. }\end{array}$ \\
\hline ARSENIC & 18 & MG $/ L$ & 0.0500 & $\begin{array}{l}0527 \\
0529\end{array}$ & $\begin{array}{l}08 / 23 / 91 \\
08 / 23 / 91\end{array}$ & $\begin{array}{l}0001 \\
0001\end{array}$ & $\begin{array}{l}\text { UB } \\
\text { UB }\end{array}$ & $\begin{array}{l}0 \\
0\end{array}$ & $\begin{array}{l}0.05 \\
0.05\end{array}$ & 1 & $\begin{array}{l}0.05 \\
0.05\end{array}$ & - \\
\hline ARSENIC (TOTAL) & 0 & $M G / L$ & 0.0500 & - & - & - & - & - & - & & - & - \\
\hline BARIUM & 18 & $M G / L$ & 1.0000 & - & - & - & - & - & - & & - & - \\
\hline BARIUM (TOTAL) & 0 & MG/L & 1.0000 & - & - & - & - & - & - & & - & - \\
\hline CADMIUM & 18 & $M G / L$ & 0.0100 & 0518 & $10 / 11 / 92$ & 0001 & UB & 0 & 0.02 & 1 & 0.02 & - \\
\hline CADMIUM (TOTAL) & 0 & $M G / L$ & 0.0100 & - & - & - & - & - & - & & - & - \\
\hline CHROMIUM & 18 & $M G / L$ & 0.0500 & - & - & - & - & - & - & & - & - \\
\hline CHROMIUM (TOTAL) & 0 & $M G / L$ & 0.0500 & - & - & - & - & - & - & & - & - \\
\hline GROSS ALPHA & 16 & $\mathrm{PCI} / \mathrm{L}$ & 15.0000 & 0518 & $12 / 15 / 90$ & 0001 & UB & 0 & 18. & & 1. & 7. \\
\hline GROSS ALPHA (TOTAL) & 0 & PCI/L & 15.0000 & - & - & - & - & - & - & & - & - \\
\hline LEAD & 18 & $M G / L$ & 0.0500 & - & - & - & - & - & - & & - & - \\
\hline LEAD (TOTAL) & 0 & $M G / L$ & 0.0500 & - & - & - & - & - & - & & - & - \\
\hline MERCURY & 14 & $M G / L$ & 0.0020 & - & - & - & - & - & - & & - & - \\
\hline MERCURY (TOTAL) & 0 & $M G / L$ & 0.0020 & - & - & - & - & - & - & & - & - \\
\hline MOL YBOENUM & 18 & $M G / L$ & 0.1000 & - & - & - & - & - & - & & - & - \\
\hline MOLYBDENUM (TOTAL) & 0 & $M G / L$ & 0.1000 & - & - & - & - & - &.- & & - & - \\
\hline NET GROSS ALPHA * & 16 & $\mathrm{PCI} / \mathrm{L}$ & 15.0000 & - & - & - & - & - & - & & - & - \\
\hline 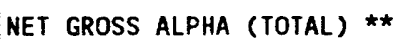 & 0 & $\mathrm{PCI} / \mathrm{L}$ & 15.0000 & - & - & - & - & - & - & & - & - \\
\hline
\end{tabular}

< - the data is flagged as a nON-DEteCt, SO the RESUlt is an EStimated VALUe or the detection Limit

* Net gRoss alPHa (GROSS ALPHA - URANIUM) WITH 1 Mg URANIUM = 686 PCI

** tOTAL NET GROSS ALPHA (TOTAL GROSS ALPHA - tOTAL URANIUM)

FORMATION OF COMPLETION CODE:

UB - UPPER BURRO CANYON

OTHER PARAMETER VALUE FLAGS:

I - INCREASED DETECTION LIMIT DUE TO REQUIRED DILUTION
FLOW RELATIONSHIP CODE:

O - ON-SITE

SAMPLE ID CODES:

0001 - FILTERED SAMPLE (.45 MICRONS) 
TABLE 3.48. GROUNDWATER QUALITY MEASUREMENTS EXCEEDING MCLS IN THE UPPER

SANDSTONE UNIT BURRO CANYON DISPOSAL SITE, SLICK ROCK, COLORADO

SANDSTONE UNIT, BURRO CANYON DISPOSAL SITE,
SITE: SRKO2 BORROW SITE 1 (BURRO CANYON)

06/04/90 TO $10 / 12 / 92$

REPORT DATE: $03 / 02 / 94$

\begin{tabular}{|c|c|c|c|c|c|c|c|c|c|c|c|}
\hline PARAMETER NAME & $\begin{array}{l}\text { TOTAL } \\
\# \text { OF } \\
\text { SAMP. }\end{array}$ & $\begin{array}{c}\text { UNITS } \\
\text { OF } \\
\text { MEASURE }\end{array}$ & $\begin{array}{l}\text { MAXIMUM } \\
\text { CONC. } \\
\text { LIMIT }\end{array}$ & LOC. & LOG DATE & $\begin{array}{c}\text { SAMP } \\
10\end{array}$ & $\begin{array}{c}\text { FORM } \\
\text { OF } \\
\text { COMP }\end{array}$ & $\begin{array}{l}\text { HYDR } \\
\text { FLOW } \\
\text { REL. }\end{array}$ & $\begin{array}{l}\text { RESULT EXCEEDING MAX. } \\
\text { CONCENTRATION LIMIT } \\
\text { VALUE FLAGS }\end{array}$ & $\begin{array}{l}\text { DETECTION } \\
\text { LIMIT }\end{array}$ & $\begin{array}{l}\text { PARAMETER } \\
\text { UNCERT. }\end{array}$ \\
\hline NITRATE & 14 & $M G / L$ & 44.0000 & - & - & - & - & - & - & - & - \\
\hline NITRATE (TOTAL) & 0 & $M G / L$ & 44.0000 & - & - & - & - & - & - & - & - \\
\hline$R A-226 \& R A-228$ & 18 & $\mathrm{PCI} / \mathrm{L}$ & 5.0000 & $\begin{array}{l}0518 \\
0529\end{array}$ & $\begin{array}{l}04 / 01 / 91 \\
04 / 02 / 91\end{array}$ & $\begin{array}{l}0001 \\
0001\end{array} \mid$ & $\begin{array}{l}\text { UB } \\
\text { UB }\end{array}$ & $\begin{array}{l}0 \\
0\end{array}$ & $\begin{array}{l}7.6 \\
5.0\end{array}$ & - & - \\
\hline RA-226 \& RA-228 (TOTAL) & 0 & $\mathrm{PCl} / \mathrm{L}$ & 5.0000 & - & - & - & - & - & - & - & - \\
\hline SELENIUM & 18 & $M G / L$ & 0.0100 & $\mid \begin{array}{l}0518 \\
0518 \\
0518 \\
0518 \\
0518 \\
0523\end{array}$ & $\begin{array}{l}06 / 04 / 90 \\
12 / 15 / 90 \\
04 / 01 / 91 \\
08 / 23 / 91 \\
10 / 11 / 92 \\
10 / 12 / 92\end{array}$ & $\left|\begin{array}{l}0001 \\
0001 \\
0001 \\
0001 \\
0001 \\
0001\end{array}\right|$ & $\begin{array}{l}\text { UB } \\
\text { UB } \\
\text { UB } \\
\text { UB } \\
\text { UB } \\
\text { UB }\end{array}$ & $\begin{array}{l}0 \\
0 \\
0 \\
0 \\
0 \\
0\end{array}$ & $\begin{array}{l}0.012 \\
0.015 \\
0.011 \\
0.04 \\
0.02 \\
0.02 \quad 1\end{array}$ & $\begin{array}{l}0.005 \\
0.005 \\
0.005 \\
0.03 \\
0.02 \\
0.02\end{array}$ & $\begin{array}{l}- \\
- \\
- \\
-\end{array}$ \\
\hline SELENIUM (TOTAL) & 0 & $M G / L$ & 0.0100 & - & - & - & - & - & - & - & - \\
\hline SILVER & 14 & $M G / L$ & 0.0500 & - & - & - & - & - & - & - & - \\
\hline SILVER (TOTAL) & 0 & $M G / L$ & 0.0500 & - & - & - & - & - & - & - & - \\
\hline URANIUM & 18 & $M G / L$ & 0.0440 & - & - & - & - & - & - & - & - \\
\hline URANIUM (TOTAL) & 0 & MG/L & 0.0440 & - & - & - & - & - & - & - & - \\
\hline
\end{tabular}

FORMATION OF COMPLETION CODE:

UB - UPPER BURRO CANYON

OTHER PARAMETER VALUE FLAGS:

1 - INCREASED DETECTION LIMIT DUE TO REQUIRED DILUTION

DATA FILE NAME: M: IDARTISRKO2\GWQ10013.DAT
FLOW RELATIONSHIP CODE:

O - ON-SITE

SAMPLE ID COOES:

0001 - FILTERED SAMPLE (.45 MICRONS) 
TABLE 3.49. BACKGROUND GROUNDWATER QUALITY DATE BY PARAMETER FOR THE MIDDLE SANDSTONE UNIT, BURRO CANYON DISPOSAL SITE, SLICK ROCK, COLORADO SITE: SRKO2 BORROW SITE 1 (BURRO CANYON)

06/04/90 TO $10 / 14 / 92$

REPORT DATE: 03/02/94

\begin{tabular}{|c|c|c|c|c|c|c|c|c|c|c|c|}
\hline PARAMETER NAME & $\begin{array}{c}\text { LOCATION } \\
\text { ID }\end{array}$ & LOG DATE & $\begin{array}{c}\text { SAMPLE } \\
\text { ID }\end{array}$ & $\begin{array}{l}\text { FORM } \\
\text { COMP }\end{array}$ & $\begin{array}{l}\text { FLOW } \\
\text { REL. }\end{array}$ & $\begin{array}{l}\text { UNITS OF } \\
\text { MEASURE }\end{array}$ & PVI & $\begin{array}{l}\text { ARAMETER } \\
\text { VALUE }\end{array}$ & FLAGS & $\begin{array}{l}\text { DETECTION } \\
\text { LIMIT }\end{array}$ & $\begin{array}{l}\text { PARAMETER } \\
\text { UNCERTAINTY }\end{array}$ \\
\hline ALKALINITY & $\begin{array}{l}0516 \\
0516 \\
0516 \\
0516 \\
0516 \\
0520 \\
0520 \\
0520 \\
0520 \\
0520 \\
0522 \\
0522 \\
0522 \\
0522 \\
0522 \\
0525 \\
0525 \\
0525 \\
0525 \\
0526 \\
0526 \\
0526 \\
0526 \\
0526 \\
0528 \\
0528 \\
0528 \\
0528 \\
0528\end{array}$ & $\begin{array}{l}06 / 06 / 90 \\
12 / 08 / 90 \\
04 / 04 / 91 \\
08 / 26 / 91 \\
10 / 14 / 92 \\
06 / 04 / 90 \\
12 / 12 / 90 \\
04 / 01 / 91 \\
08 / 22 / 91 \\
10 / 11 / 92 \\
06 / 04 / 90 \\
12 / 08 / 90 \\
04 / 02 / 91 \\
08 / 22 / 91 \\
10 / 12 / 92 \\
12 / 08 / 90 \\
04 / 03 / 91 \\
08 / 26 / 91 \\
10 / 14 / 92 \\
06 / 06 / 90 \\
12 / 12 / 90 \\
04 / 04 / 91 \\
08 / 21 / 91 \\
10 / 14 / 92 \\
06 / 06 / 90 \\
12 / 15 / 90 \\
04 / 02 / 91 \\
08 / 21 / 91 \\
10 / 13 / 92\end{array}$ & $\begin{array}{l}0001 \\
0001 \\
0001 \\
0001 \\
0001 \\
0001 \\
0001 \\
0001 \\
0001 \\
0001 \\
0001 \\
0001 \\
0001 \\
0001 \\
0001 \\
0001 \\
0001 \\
0001 \\
0001 \\
0001 \\
0001 \\
0001 \\
0001 \\
0001 \\
0001 \\
0001 \\
0001 \\
0001 \\
0001\end{array}$ & $\begin{array}{l}\text { MB } \\
\text { MB } \\
\text { MB } \\
\text { MB } \\
\text { MB } \\
\text { MB } \\
\text { MB } \\
\text { MB } \\
\text { MB } \\
\text { MB } \\
\text { MB } \\
\text { MB } \\
\text { MB } \\
\text { MB } \\
\text { MB } \\
\text { MB } \\
\text { MB } \\
\text { MB } \\
\text { MB } \\
\text { MB } \\
\text { MB } \\
\text { MB } \\
\text { MB } \\
\text { MB } \\
\text { MB } \\
\text { MB } \\
\text { MB } \\
\text { MB } \\
\text { MB }\end{array}$ & $\begin{array}{l}0 \\
0 \\
0 \\
0 \\
0 \\
0 \\
0 \\
0 \\
0 \\
0 \\
0 \\
0 \\
0 \\
0 \\
0 \\
0 \\
0 \\
0 \\
0 \\
0 \\
0 \\
0 \\
0 \\
0 \\
0 \\
0 \\
0 \\
0 \\
0\end{array}$ & $\mathrm{MG} / \mathrm{L} \quad \mathrm{CACO} 3$ & & $\begin{array}{l}263 . \\
265 . \\
248 . \\
234 \\
253 \\
257 . \\
258 . \\
252 . \\
244 \\
266 \\
217 . \\
201 . \\
219 . \\
224 \\
212 \\
264 . \\
266 . \\
276 \\
268 \\
243 . \\
233 . \\
222 . \\
232 \\
234 \\
230 . \\
207 . \\
209 . \\
212 \\
219\end{array}$ & & $\begin{array}{l}- \\
- \\
- \\
- \\
- \\
- \\
- \\
- \\
- \\
- \\
- \\
- \\
- \\
- \\
- \\
- \\
- \\
- \\
- \\
- \\
- \\
- \\
-\end{array}$ & $\begin{array}{l}- \\
- \\
- \\
- \\
- \\
- \\
- \\
- \\
- \\
- \\
- \\
- \\
- \\
- \\
- \\
- \\
- \\
- \\
- \\
- \\
- \\
-\end{array}$ \\
\hline ALUMINUM & $\begin{array}{l}0516 \\
0516 \\
0516 \\
0516 \\
0516 \\
0520 \\
0520 \\
0520 \\
0520 \\
0520 \\
0522\end{array}$ & $\begin{array}{l}06 / 06 / 90 \\
12 / 08 / 90 \\
04 / 04 / 91 \\
08 / 26 / 91 \\
10 / 14 / 92 \\
06 / 04 / 90 \\
12 / 12 / 90 \\
04 / 01 / 91 \\
08 / 22 / 91 \\
10 / 11 / 92 \\
06 / 04 / 90\end{array}$ & $\begin{array}{l}0001 \\
0001 \\
0001 \\
0001 \\
0001 \\
0001 \\
0001 \\
0001 \\
0001 \\
0001 \\
0001\end{array}$ & $\begin{array}{l}\text { MB } \\
\text { MB } \\
\text { MB } \\
\text { MB } \\
\text { MB } \\
\text { MB } \\
\text { MB } \\
\text { MB } \\
\text { MB } \\
\text { MB } \\
\text { MB }\end{array}$ & $\begin{array}{l}0 \\
0 \\
0 \\
0 \\
0 \\
0 \\
0 \\
0 \\
0 \\
0 \\
0\end{array}$ & $M G / L$ & $\begin{array}{l}< \\
< \\
< \\
< \\
< \\
< \\
< \\
< \\
< \\
< \\
< \\
<\end{array}$ & $\begin{array}{l}0.1 \\
0.1 \\
0.05 \\
0.05 \\
0.05 \\
0.1 \\
0.1 \\
0.05 \\
0.05 \\
0.05 \\
0.1\end{array}$ & & $\begin{array}{l}0.1 \\
0.1 \\
0.05 \\
0.05 \\
0.05 \\
0.1 \\
0.1 \\
0.05 \\
0.05 \\
0.05 \\
0.1\end{array}$ & $\begin{array}{l}- \\
- \\
- \\
- \\
- \\
- \\
- \\
-\end{array}$ \\
\hline
\end{tabular}

FORMATION OF COMPLETION COOE:

MB - MIDDLE BURRO CANYON

PARAMETER VALUE INDICATOR (PVI): < - LESS THAN DETECTION LIMIT
FLOW RELATIONSHIP CODE:

O - ON-SITE

SAMPLE ID CODES:

0001 - FILTERED SAMPLE (.45 MICRONS) 
TABLE 3.49. BACKGROUND GROUNDWATER QUALITY DATE BY PARAMETER FOR THE MIDDLE SANDSTONE UNIT, BURRO CANYON DISPOSAL SITE, SLICK ROCK, COLORADO MIDDLE SANDSTONE UNIT, BURRO CANYON DISPOSAL

SITE: SRK02 BORROW SIT

REPORT DATE: $03 / 02 / 94$

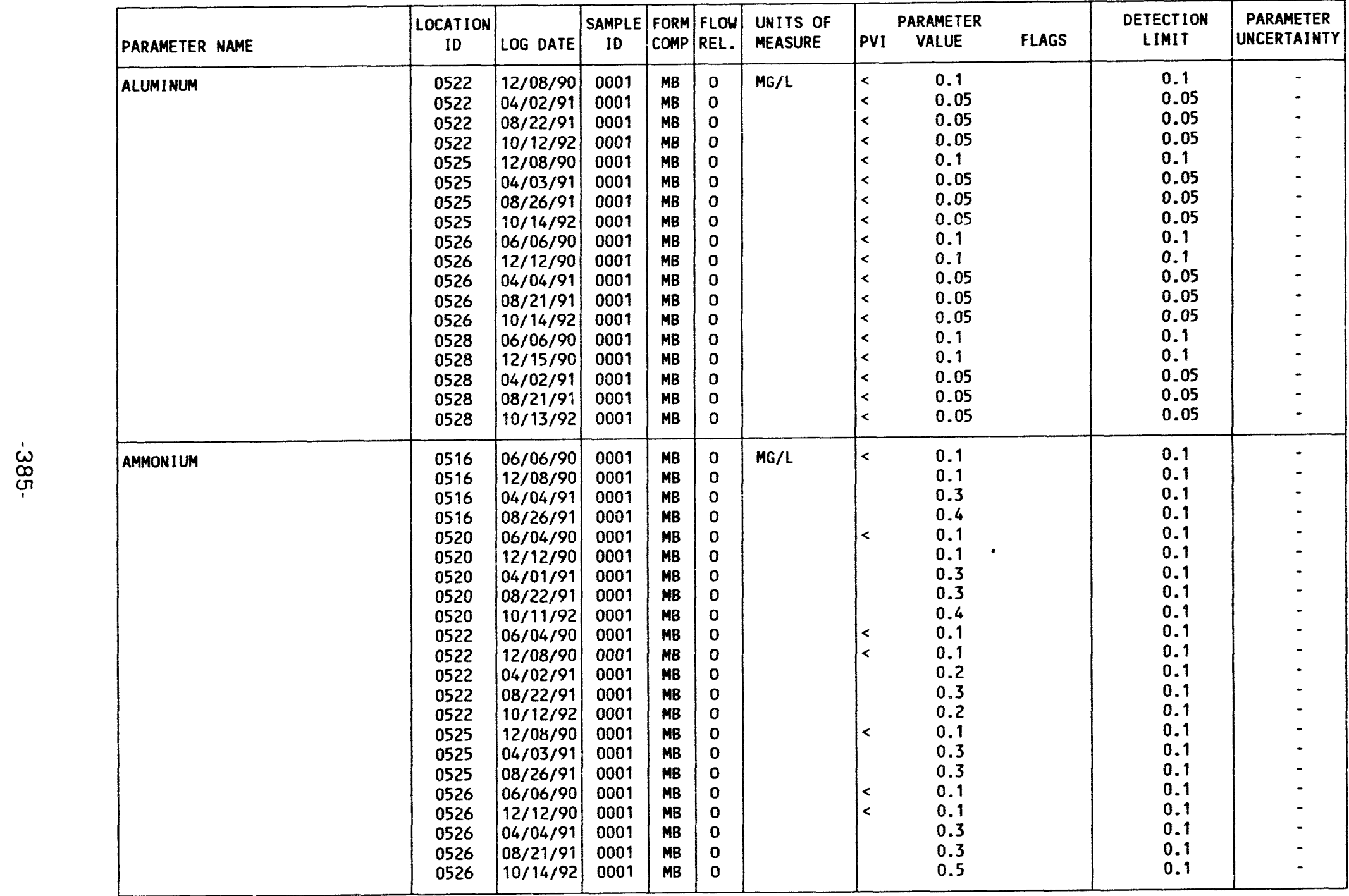

FORMATION OF COMPLETION CODE:

MB - MIDDLE BURRO CANYON

PARAMETER VALUE INDICATOR (PVI): < - LESS THAN DETECTION LIMIT
FLOW RELATIONSHIP CODE:

O - ON-SITE

SAMPLE ID CODES:

0001 - FILTERED SAMPLE (.45 MICRONS) 
TABLE 3.49. BACKGROUND GROUNDWATER QUALITY DATE BY PARAMETER FOR THE MIDDLE SANDSTONE UNIT, BURRO CANYON DISPOSAL SITE, SLICK ROCK, COLORADO SITE: SRKO2 BORROW SITE 1 (BURRO CANYON)

06/04/90 TO $10 / 14 / 92$

REPORT DATE : 03/02/94

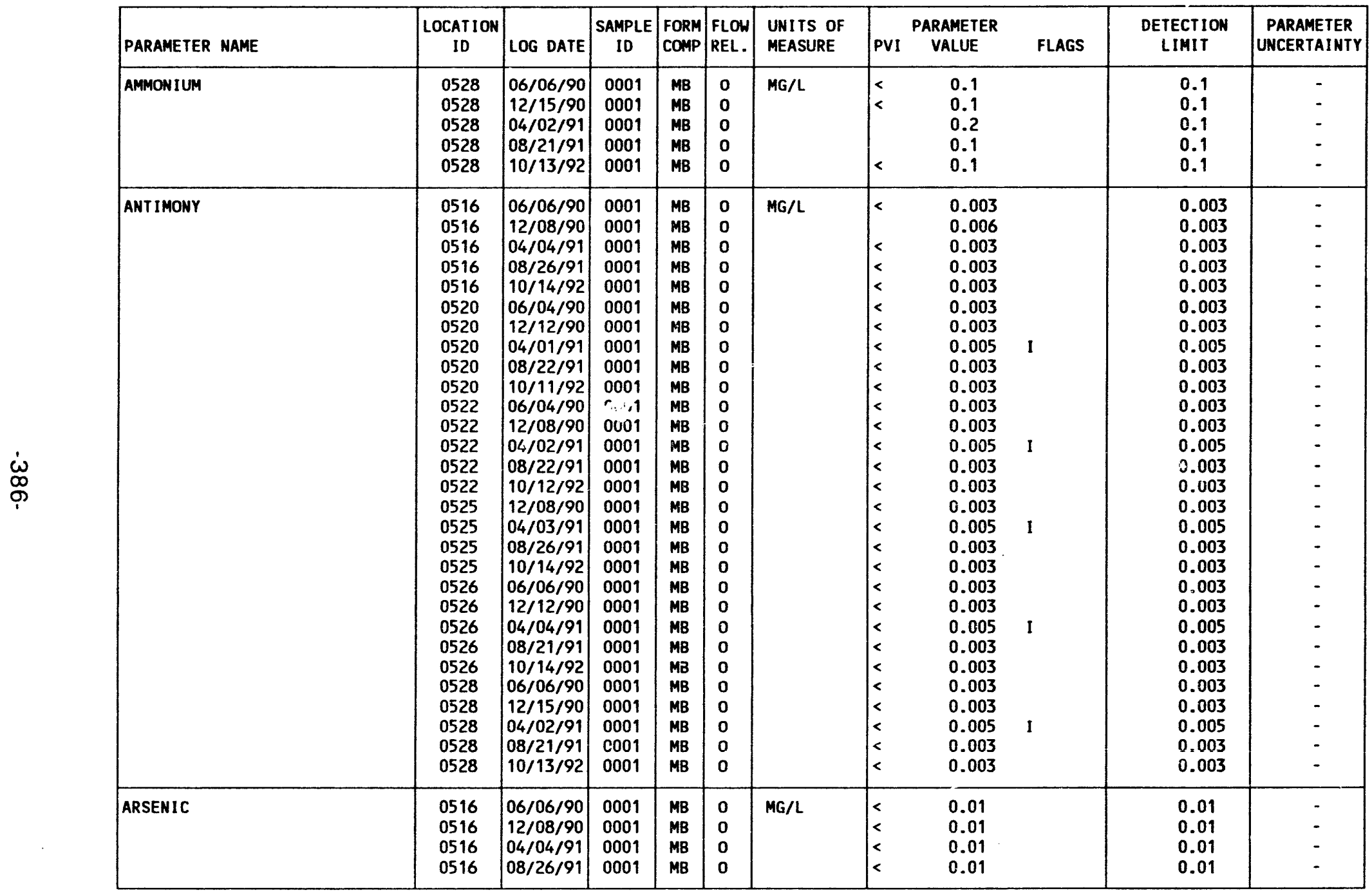

FORMATION OF COMPLETION CODE:

MB - MIDDLE BURRO CANYON

PARAMETER VALUE INDICATOR (PVI): < - LESS THAN DETECTION LIMIT
FLOW PELATIONSHIP CODE:

O - ON-SITE

SAMPLE ID CODES:

0001 - FILTERED SAMPLE (.45 MICRONS)

OTHER PARAMETER VALUE FLAGS:

I - INCREASED DETECTION LIMIT DUE TO REQUIRED DILUTION 
TABLE 3.49. BACKGROUND GROUNDWATER QUALITY DATE BY PARAMETER FOR THE

MIDDLE SANDSTONE UNIT, BURRO CANYON DISPOSAL SITE, SLICK ROCK, COLORADO

SITE: SRKO2 BORROW SITE 1 (BURRO CANYON)

O6/04/90 TO $10 / 14 / 92$

REPORT DATE : $03 / 02 / 94$

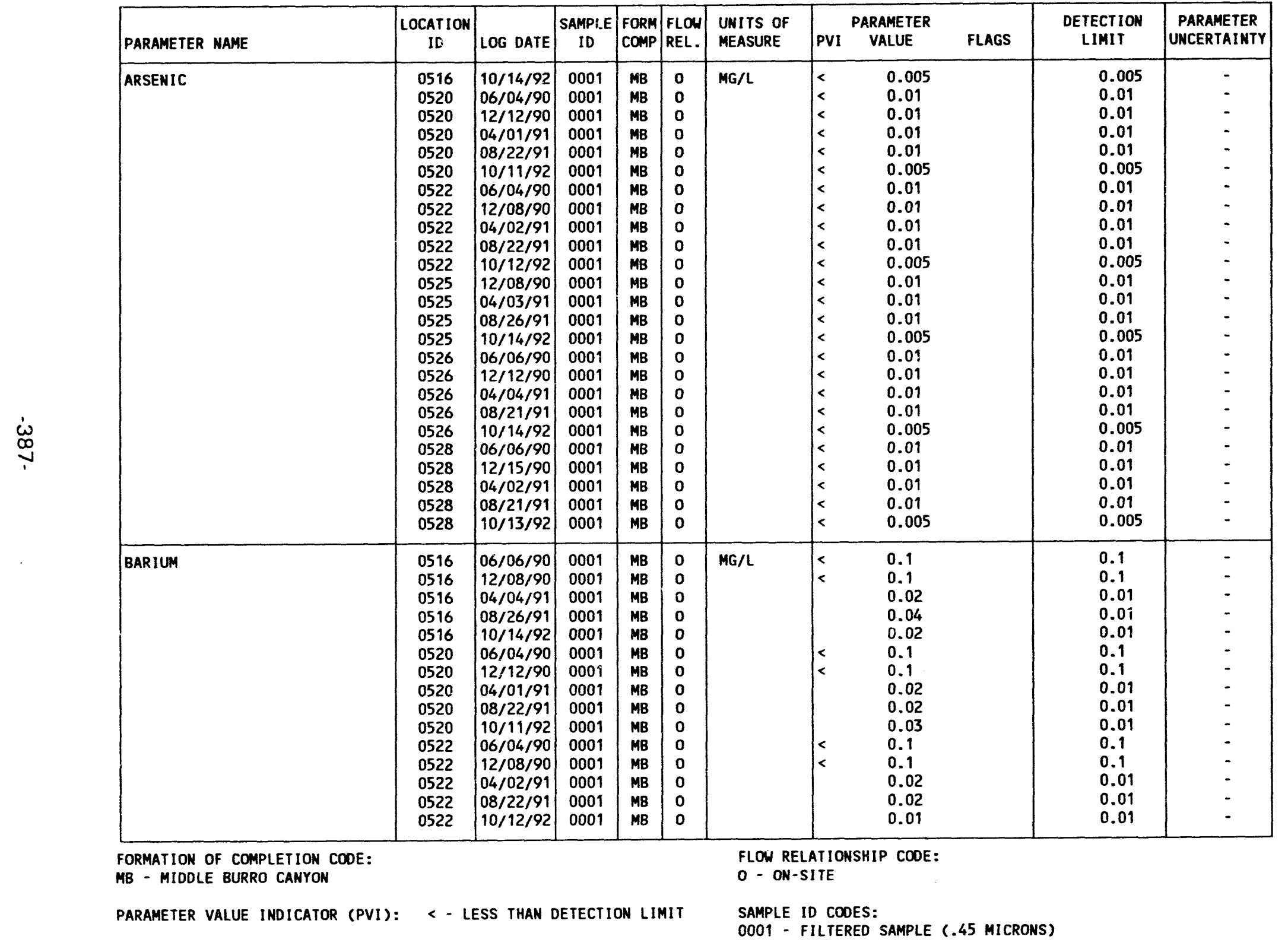


TABLE 3.49. BACKGROUND GROUNDWATER QUALITY DATE BY PARAMETER FOR THE MIDDLE SANDSTONE UNIT, BURRO CANYON DISPOSAL SITE, SLICK ROCK, COLORADO SITE: SRK02 BORROW SITE 1 (BURRO CANYON)

$06 / 04 / 90$ TO $10 / 14 / 92$

REPORT DATE: 03/02/94

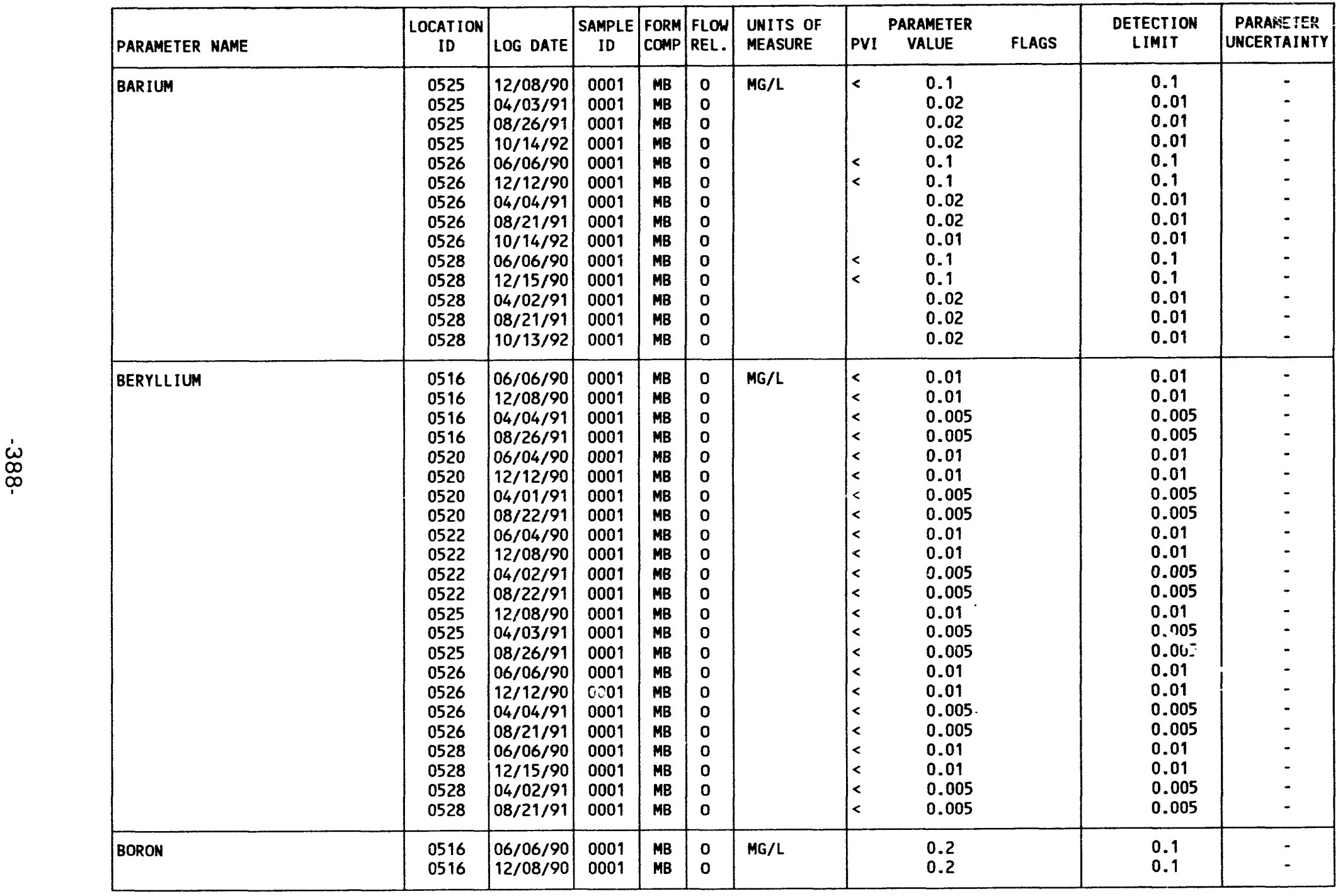

FORMATION OF COMPLETION COOE:

MB - MIDDLE BURRO CANYON

FLOW RELATIONSHIP CODE:

O - ON-SITE

PARAMETER VALUE INDICATOR (PVI): < - LESS THAN DETECTION LIMIT

SAMPLE 10 COOES:

0001 - FILTERED SAMPLE (.45 MICRONS) 
TABLE 3.49. BACKGROUND GROUNDWATER QUALITY DATE BY PARAMETER FOR THE

MIDDLE SANDSTONE UNIT, BURRO CANYON DISPOSAL SITE, SLICK ROCK, COLORADO SITE: SRKO2 BORROW SITE 1 (BURRO CANYON)

06/04/90 TO $10 / 14 / 92$

REPORT DATE: $03 / 02 / 94$

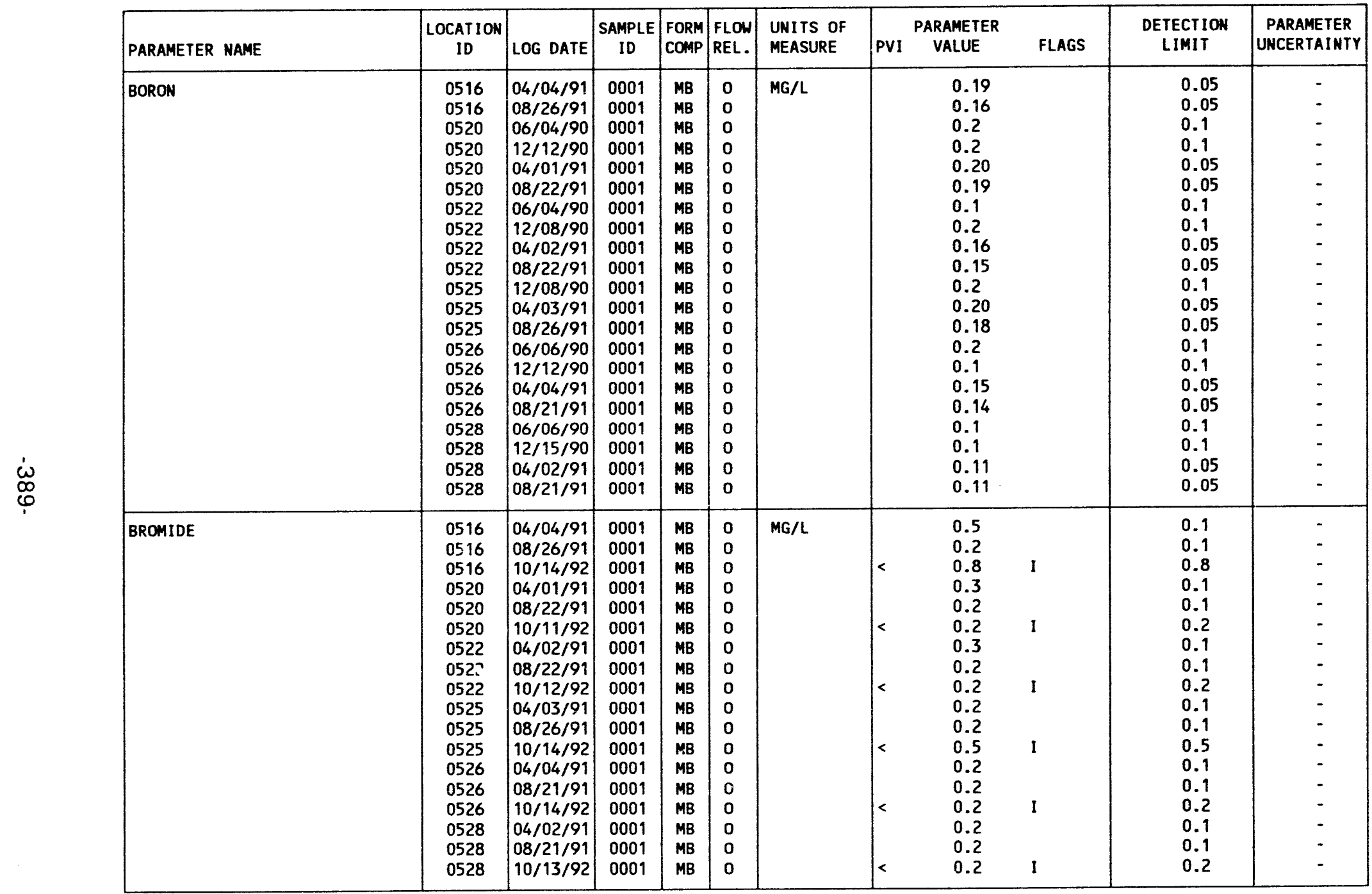

FORMATION OF COMPLETION COOE:

MB - MIDDLE BURRO CANYON
FLOW RELATIONSHIP CODE:

O - ON-SITE

SAMPLE ID CODES:

0001 - FILTERED SAMPLE (.45 MICRONS)

OTHER PARAMETER VALUE FLAGS:

I - INCREASED DETECTION LIMIT DUE TO REQUIRED DILUTION 
TABLE 3.49. BACKGROUND GROUNDWATER QUALITY DATE BY PARAMETER FOR THE MIDDLE SANDSTONE UNIT, BURRO CANYON DISPOSAL SITE, SLICK ROCK, COLORADO SITE: SRKO2 BORROW SITE 1 (BURRO CANYON)

06/04/90 TO $10 / 14 / 92$

REPORT DATE: 03/02/94

\begin{tabular}{|c|c|c|c|c|c|c|c|c|c|c|}
\hline PARAMETER NAME & $\underset{\text { ID }}{\text { LOCAT ION }}$ & LOG DATE & $\begin{array}{c}\text { SAMPLE } \\
\text { ID }\end{array}$ & $\begin{array}{l}\text { FORM } \\
\text { COMP }\end{array}$ & $\begin{array}{l}\text { FLOW } \\
\text { REL. }\end{array}$ & $\begin{array}{l}\text { UNITS OF } \\
\text { MEASURE }\end{array}$ & PVI & $\begin{array}{l}\text { ARAMETER } \\
\text { VALUE }\end{array}$ & $\begin{array}{l}\text { DETECTION } \\
\text { LIMIT }\end{array}$ & $\begin{array}{l}\text { PARAMETER } \\
\text { UNCERTAINTY }\end{array}$ \\
\hline CADMIUM & $\begin{array}{l}0516 \\
0516 \\
0516 \\
0516 \\
0516 \\
0520 \\
0520 \\
0520 \\
0520 \\
0520 \\
0522 \\
0522 \\
0522 \\
0522 \\
0522 \\
0525 \\
0525 \\
0525 \\
0525 \\
0526 \\
0526 \\
0526 \\
0526 \\
0526 \\
0528 \\
0528 \\
0528 \\
0528 \\
0528\end{array}$ & $\begin{array}{l}06 / 06 / 90 \\
12 / 08 / 90 \\
04 / 04 / 91 \\
08 / 26 / 91 \\
10 / 14 / 92 \\
06 / 04 / 90 \\
12 / 12 / 90 \\
04 / 01 / 91 \\
08 / 22 / 91 \\
10 / 11 / 92 \\
06 / 04 / 90 \\
12 / 08 / 90 \\
04 / 02 / 91 \\
08 / 22 / 91 \\
10 / 12 / 92 \\
12 / 08 / 90 \\
04 / 03 / 91 \\
08 / 26 / 91 \\
10 / 14 / 92 \\
06 / 06 / 90 \\
12 / 12 / 90 \\
04 / 04 / 91 \\
08 / 21 / 91 \\
10 / 14 / 92 \\
06 / 06 / 90 \\
12 / 15 / 90 \\
04 / 02 / 91 \\
08 / 21 / 91 \\
10 / 13 / 92\end{array}$ & $\begin{array}{l}0001 \\
0001 \\
0001 \\
0001 \\
0001 \\
0001 \\
0001 \\
0001 \\
0001 \\
0001 \\
0001 \\
0001 \\
0001 \\
0001 \\
0001 \\
0001 \\
0001 \\
0001 \\
0001 \\
0001 \\
0001 \\
0001 \\
0001 \\
0001 \\
0001 \\
0001 \\
0001 \\
0001 \\
0001\end{array}$ & 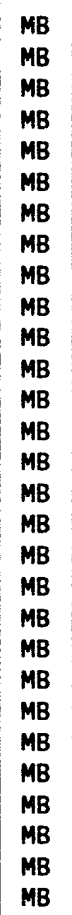 & $\begin{array}{l}0 \\
0 \\
0 \\
0 \\
0 \\
0 \\
0 \\
0 \\
0 \\
0 \\
0 \\
0 \\
0 \\
0 \\
0 \\
0 \\
0 \\
0 \\
0 \\
0 \\
0 \\
0 \\
0 \\
0 \\
0 \\
0 \\
0 \\
0 \\
0\end{array}$ & $M G / L$ & $\begin{array}{l}< \\
< \\
< \\
< \\
< \\
< \\
< \\
< \\
< \\
< \\
< \\
< \\
< \\
< \\
< \\
< \\
< \\
< \\
< \\
< \\
< \\
< \\
< \\
< \\
< \\
< \\
< \\
< \\
< \\
< \\
<\end{array}$ & $\begin{array}{l}0.001 \\
0.001 \\
0.0005 \\
0.001 \\
0.005 \\
0.001 \\
0.001 \\
0.0005 \\
0.001 \\
0.001 \\
0.001 \\
0.001 \\
0.0005 \\
0.001 \\
0.001 \\
0.001 \\
0.0005 \\
0.001 \\
0.001 \\
0.001 \\
0.001 \\
0.0005 \\
0.001 \\
0.001 \\
0.001 \\
0.001 \\
0.0005 \\
0.001 \\
0.001\end{array}$ & $\begin{array}{l}0.001 \\
0.001 \\
0.0005 \\
0.001 \\
0.005 \\
0.001 \\
0.001 \\
0.0005 \\
0.001 \\
0.001 \\
0.001 \\
0.001 \\
0.0005 \\
0.001 \\
0.001 \\
0.001 \\
0.0005 \\
0.001 \\
0.001 \\
0.001 \\
0.001 \\
0.0005 \\
0.001 \\
0.001 \\
0.001 \\
0.001 \\
0.0005 \\
0.001 \\
0.001\end{array}$ & $\begin{array}{l}- \\
- \\
- \\
\\
- \\
- \\
- \\
- \\
- \\
- \\
- \\
- \\
- \\
- \\
- \\
- \\
- \\
- \\
- \\
- \\
- \\
- \\
- \\
- \\
-\end{array}$ \\
\hline CALCIUM & $\begin{array}{l}0516 \\
0516 \\
0516 \\
0516 \\
0516 \\
0520 \\
0520 \\
0520 \\
0520 \\
0520\end{array}$ & \begin{tabular}{|l|}
$06 / 06 / 90$ \\
$12 / 08 / 90$ \\
$04 / 04 / 91$ \\
$08 / 26 / 91$ \\
$10 / 14 / 92$ \\
$06 / 04 / 90$ \\
$12 / 12 / 90$ \\
$04 / 01 / 91$ \\
$08 / 22 / 91$ \\
$10 / 11 / 92$
\end{tabular} & $\begin{array}{l}0001 \\
0001 \\
0001 \\
0001 \\
0001 \\
0001 \\
0001 \\
0001 \\
0001 \\
0001\end{array}$ & $\begin{array}{l}\text { MB } \\
\text { MB } \\
\text { MB } \\
\text { MB } \\
\text { MB } \\
\text { MB } \\
\text { MB } \\
\text { MB } \\
\text { MB } \\
\text { MB }\end{array}$ & $\begin{array}{l}0 \\
0 \\
0 \\
0 \\
0 \\
0 \\
0 \\
0 \\
0 \\
0\end{array}$ & $M G / L$ & & $\begin{array}{l}47.7 \\
45.2 \\
45.7 \\
49.1 \\
44.5 \\
82.5 \\
80.5 \\
85.5 \\
84.6 \\
73.1\end{array}$ & $\begin{array}{l}0.01 \\
0.01 \\
0.5 \\
0.5 \\
0.5 \\
0.01 \\
0.01 \\
0.5 \\
0.5 \\
0.5\end{array}$ & $\begin{array}{l}- \\
- \\
- \\
- \\
- \\
- \\
- \\
- \\
-\end{array}$ \\
\hline
\end{tabular}

FORMATION OF COMPLETION CODE:

MB - MIDDLE BURRO CANYON

PARAMETER VALUE INDICATOR (PVI): < - LESS THAN DETECTION LIMIT
FLOW RELATIONSHIP CODE:

O - ON-SITE

SAMPLE ID CODES:

0001 - FILTERED SAMPLE (.45 MICRONS)

OTHER PARAMETER VALUE FLAGS:

I - INCREASED DETECTION LIMIT DUE TO REQUIRED DILUTION 
TABLE 3.49 BACKGROUND GROUNDWATER QUALITY DATE BY PARAMETER FOR THE MIDDLE SANDSTONE UNIT, BURRO CANYON DISPOSAL SITE, SLICK ROCK, COLORADO SITE: SRKO2 BORROW SITE 1 (BURRO CANYON)

06/04/90 TO $10 / 14 / 92$

REPORT DATE: $03 / 02 / 94$

\begin{tabular}{|c|c|c|c|c|c|c|c|c|c|c|c|}
\hline PARAMETER NAME & $\begin{array}{c}\text { LOCATION } \\
\text { ID }\end{array}$ & LOG DATE & $\begin{array}{c}\text { SAMHLE } \\
\text { ID }\end{array}$ & $\begin{array}{l}\text { FORM } \\
\text { COMP }\end{array}$ & $\begin{array}{l}\text { FLOW } \\
\text { REL. }\end{array}$ & $\begin{array}{l}\text { UNITS OF } \\
\text { MEASURE }\end{array}$ & PVI & $\begin{array}{l}\text { ARAMETE } \\
\text { VALUE }\end{array}$ & FLAGS & $\begin{array}{l}\text { DETECTION } \\
\text { LIMIT }\end{array}$ & $\begin{array}{l}\text { PARAMETER } \\
\text { UNCERTAINTY }\end{array}$ \\
\hline CALCIUM & $\begin{array}{l}0522 \\
0522 \\
0522 \\
0522 \\
0522 \\
0525 \\
0525 \\
0525 \\
0525 \\
0526 \\
0526 \\
0526 \\
0526 \\
0526 \\
0528 \\
0528 \\
0528 \\
0528 \\
0528\end{array}$ & $\begin{array}{l}06 / 04 / 90 \\
12 / 08 / 90 \\
04 / 02 / 91 \\
08 / 22 / 91 \\
10 / 12 / 92 \\
12 / 08 / 90 \\
04 / 03 / 91 \\
08 / 26 / 91 \\
10 / 14 / 92 \\
06 / 06 / 90 \\
12 / 12 / 90 \\
04 / 04 / 91 \\
08 / 21 / 91 \\
10 / 14 / 92 \\
06 / 06 / 90 \\
12 / 15 / 90 \\
04 / 02 / 91 \\
08 / 21 / 91 \\
10 / 13 / 92\end{array}$ & $\begin{array}{l}0001 \\
0001 \\
0001 \\
0001 \\
0001 \\
0001 \\
0001 \\
0001 \\
0001 \\
0001 \\
0001 \\
0001 \\
0001 \\
0001 \\
0001 \\
0001 \\
0001 \\
0001 \\
0001\end{array}$ & $\begin{array}{l}\text { MB } \\
M B \\
M B \\
M B \\
M B \\
M B \\
M B \\
M B \\
M B \\
M B \\
M B \\
M B \\
M B \\
M B \\
M B \\
M B \\
M B \\
M B \\
M B\end{array}$ & $\begin{array}{l}0 \\
0 \\
0 \\
0 \\
0 \\
0 \\
0 \\
0 \\
0 \\
0 \\
0 \\
0 \\
0 \\
0 \\
0 \\
0 \\
0 \\
0 \\
0\end{array}$ & MG/L & & $\begin{array}{l}63.8 \\
60.4 \\
65.2 \\
62.9 \\
60.7 \\
53.4 \\
57.4 \\
56.1 \\
48.4 \\
53.2 \\
51.6 \\
57.2 \\
54.1 \\
53.4 \\
59.6 \\
58.3 \\
61.0 \\
61.2 \\
59.1\end{array}$ & & $\begin{array}{l}0.01 \\
0.01 \\
0.5 \\
0.5 \\
0.5 \\
0.01 \\
0.5 \\
0.5 \\
0.5 \\
0.01 \\
0.01 \\
0.5 \\
0.5 \\
0.5 \\
0.01 \\
0.01 \\
0.5 \\
0.5 \\
0.5\end{array}$ & $\begin{array}{l}- \\
- \\
- \\
- \\
- \\
- \\
- \\
- \\
- \\
- \\
- \\
- \\
- \\
- \\
-\end{array}$ \\
\hline CHLORIDE & $\begin{array}{l}0516 \\
0516 \\
0516 \\
0516 \\
0516 \\
0520 \\
0520 \\
0520 \\
0520 \\
0520 \\
0522 \\
0522 \\
0522 \\
0522 \\
0522 \\
0525 \\
0525 \\
0525 \\
0525 \\
0526 \\
0526\end{array}$ & $\begin{array}{l}06 / 06 / 90 \\
12 / 08 / 90 \\
04 / 04 / 91 \\
08 / 26 / 91 \\
10 / 14 / 92 \\
06 / 04 / 90 \\
12 / 12 / 90 \\
04 / 01 / 91 \\
08 / 22 / 91 \\
10 / 11 / 92 \\
06 / 04 / 90 \\
12 / 08 / 90 \\
04 / 02 / 91 \\
08 / 22 / 91 \\
10 / 12 / 92 \\
12 / 08 / 90 \\
04 / 03 / 91 \\
08 / 26 / 91 \\
10 / 14 / 92 \\
06 / 06 / 90 \\
12 / 12 / 90\end{array}$ & $\begin{array}{l}0001 \\
0001 \\
0001 \\
0001 \\
0001 \\
0001 \\
0001 \\
0001 \\
0001 \\
0001 \\
0001 \\
0001 \\
0001 \\
0001 \\
0001 \\
0001 \\
0001 \\
0001 \\
0001 \\
0001 \\
0001\end{array}$ & $\begin{array}{l}\text { MB } \\
M B \\
M B \\
M B \\
M B \\
M B \\
M B \\
M B \\
M B \\
M B \\
M B \\
M B \\
M B \\
M B \\
M B \\
M B \\
M B \\
M B \\
M B \\
M B \\
M B\end{array}$ & $\begin{array}{l}0 \\
0 \\
0 \\
0 \\
0 \\
0 \\
0 \\
0 \\
0 \\
0 \\
0 \\
0 \\
0 \\
0 \\
0 \\
0 \\
0 \\
0 \\
0 \\
0 \\
0\end{array}$ & $M G / L$ & & $\begin{array}{l}27 . \\
28 . \\
28 . \\
21 . \\
25 . \\
27 . \\
30 . \\
31 . \\
29 . \\
31 . \\
20 . \\
25 . \\
23 . \\
22 . \\
23 . \\
44 . \\
40 . \\
40 . \\
59 . \\
24 . \\
23 .\end{array}$ & & $\begin{array}{l}1 . \\
1 . \\
0.5 \\
1 . \\
1 . \\
1 . \\
\text { u.s } \\
1 . \\
1 . \\
1 . \\
1 . \\
0.5 \\
1 . \\
1 . \\
1 . \\
0.5 \\
1 . \\
1 . \\
1 . \\
1 .\end{array}$ & $\begin{array}{l}- \\
- \\
- \\
- \\
- \\
- \\
- \\
- \\
- \\
- \\
- \\
- \\
- \\
- \\
-\end{array}$ \\
\hline
\end{tabular}

FORMATION OF COMPLETION COOE:

MB - MIDDLE BURRO CANYON

FLOW RELATIONSHIP CODE:

O- ON-SITE

SAMPLE ID CODES:

0001 - FILTERED SAMPLE (.45 MICRONS) 
TABLE 3.49. BACKGROUND GROUNDHATER QUALITY DATE BY PARAMETER FOR THE MIDDLE SANDSTONE UNIT, BURRO CANYON DISPOSAL SITE, SLICK ROCK, COLORADO SITE: SRKO2 BORROW SITE 1 (BURRO CANYON)

06/04/90 TO $10 / 14 / 92$

REPORT DATE: $03 / 02 / 94$

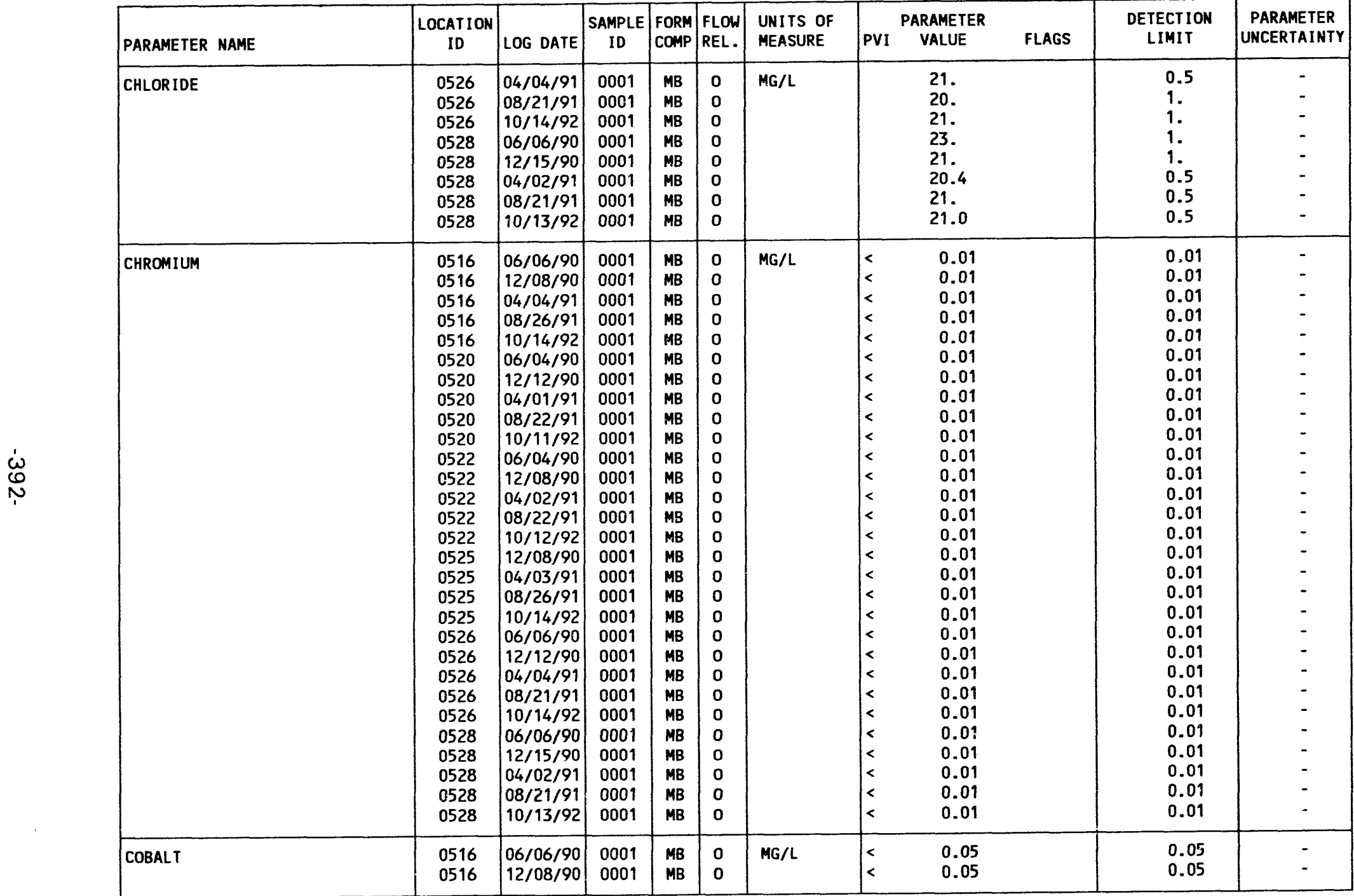

FORMATION OF COMPLETION CODE:

MB - MIDDLE BURRO CANYON

PARAMETER VALUE INDICATOR (PVI): < - LESS THAN DETECTION LIMIT
FLOW RELATIONSHIP CODE:

O - ON-SITE

SAMPLE ID CODES:

0001 - FILTERED SAMPLE (.45 MICRONS) 
TABLE 3.49. BACKGROUND GROUNDHATER QUALITY DATE BY PARAMETER FOR THE MIDDLE SANDSTONE UNIT, BURRO CANYON DISPOSAL SITE, SLICK ROCK, COLORADO SITE: SRKO2 BORROW SITE 1 (BURRO CANYON)

SITE: SRKO2 BORROW

REPORT DATE: 03/02/94

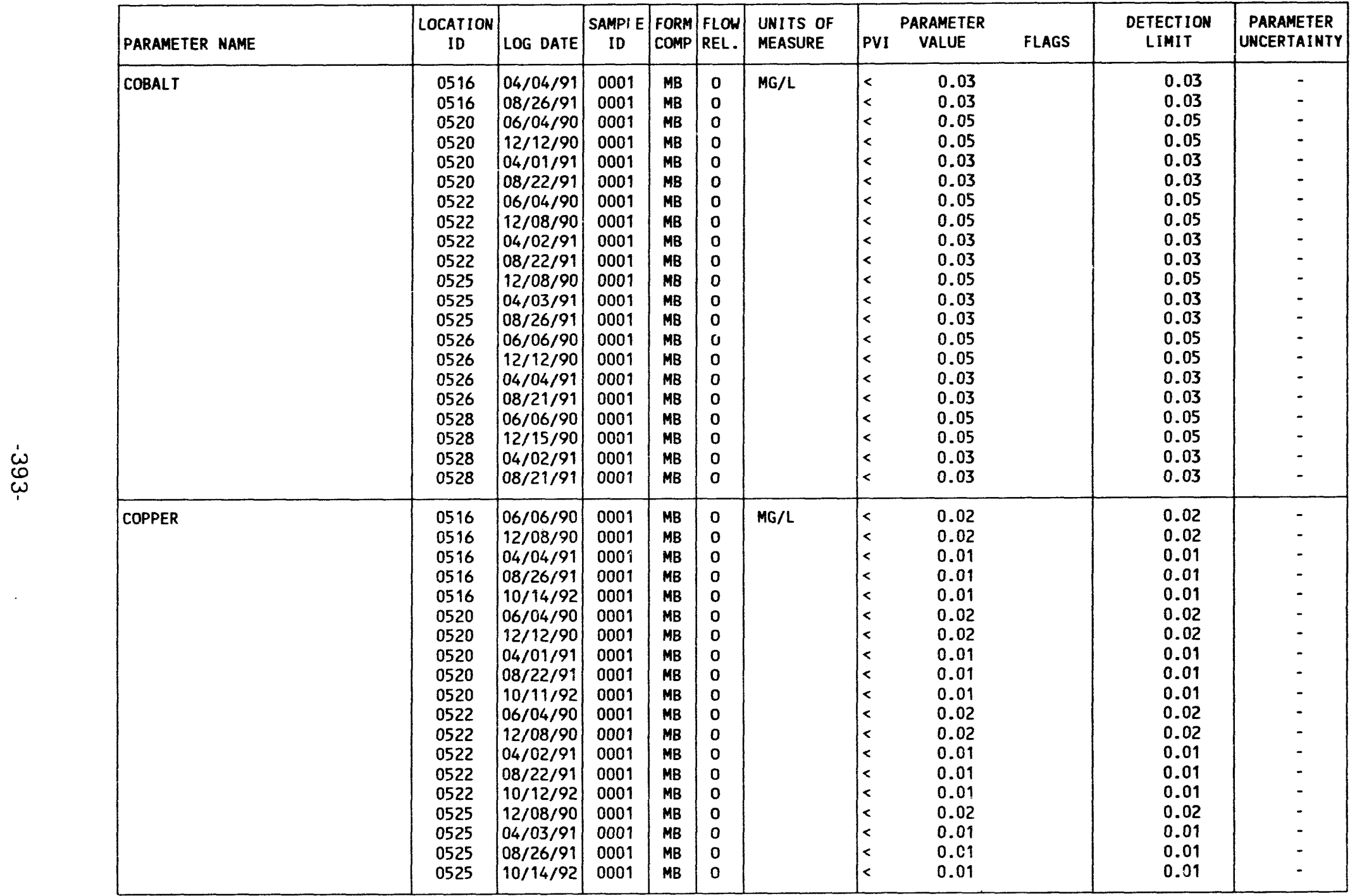

FORMATION OF COMPLETION COOE:

MB - MIDDLE BURRO CANYON

PARAMETER VALUE INDICATOR (PVI): < - LESS THAN DETECTION LIMIT
FLOW RELATIONSHIP CODE:

O - ON-SITE

SAMPLE IO CODES:

0001 - FILTERED SAMPLE (.45 MICRONS) 
TABLE 3.49. BACKGROUND GROUNDWATER QUALITY DATE BY PARAMETER FOR THE MIDDLE SANDSTONE UNIT, BURRO CANYON DISPOSAL SITE, SLICK ROCK, COLORADO SITE: SRKO2 BORROW SITE 1 (BURRO CANYON)

SITE: SRKO2 BORROW SITE

PEPORT DATE: $03 / 02 / 94$

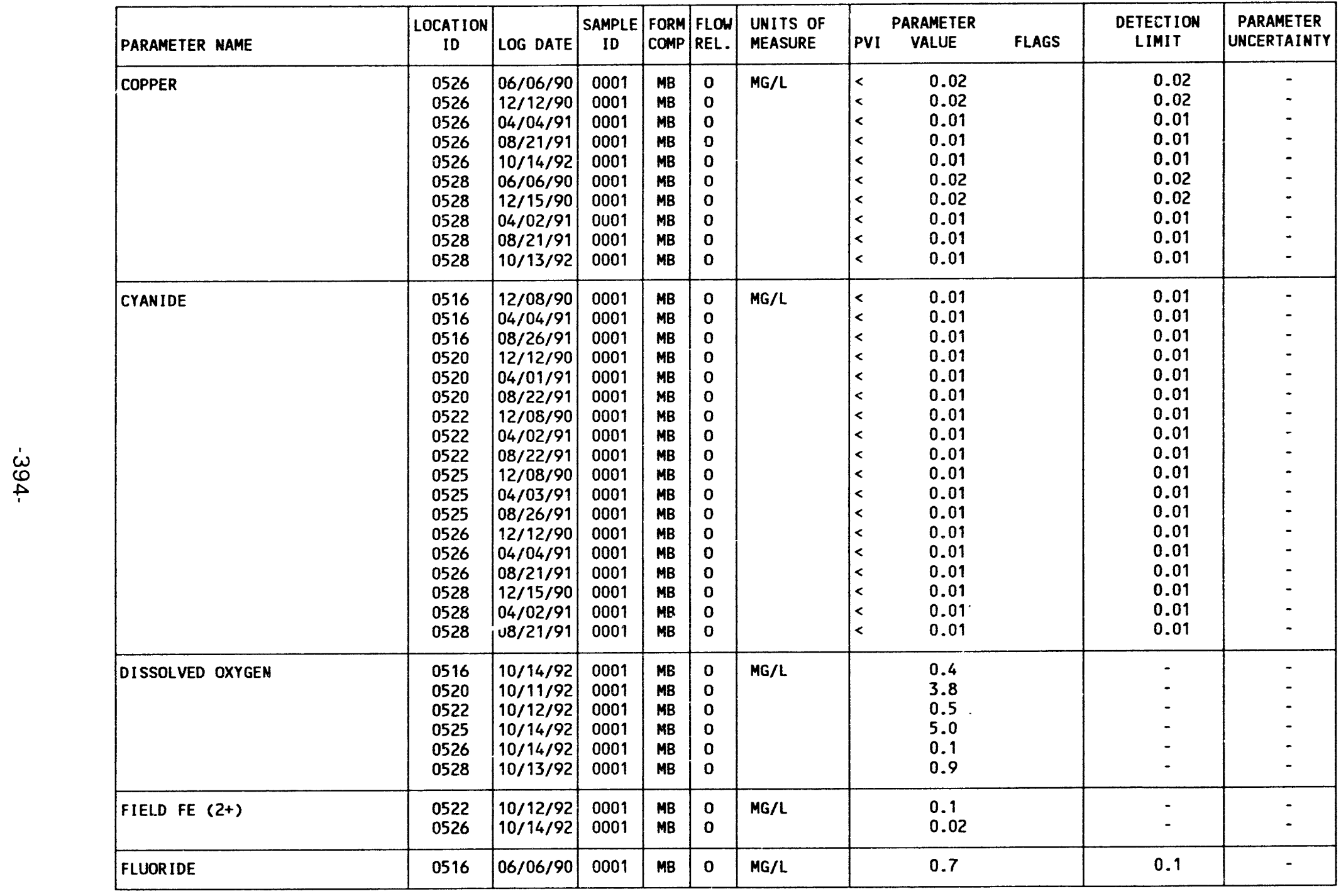

FORMATION OF COMPLETION CODE:

MB - MIDDLE BURRO CANYON

PARAMETER VALUE INDICATOR (PVI): < - LESS THAN DETECTION LIMIT
FLOW RELATIONSHIP CODE:

O - ON-SITE

SAMPLE ID CODES:

0001 - FILTERED SAMPLE (.45 MICRONS) 
TABLE 3.49. BACKGROUND GROUNDWATER QUALITY DATE BY PARAMETER FOR THE MIDDLE SANDSTONE UNIT, BURRO CANYON DISPOSAL SITE, SLICK ROCK, COLORADO SITE: SRK02 BORRC

06/04/90 TO 10/14/92

REPORT DATE: $03 / 02 / 94$

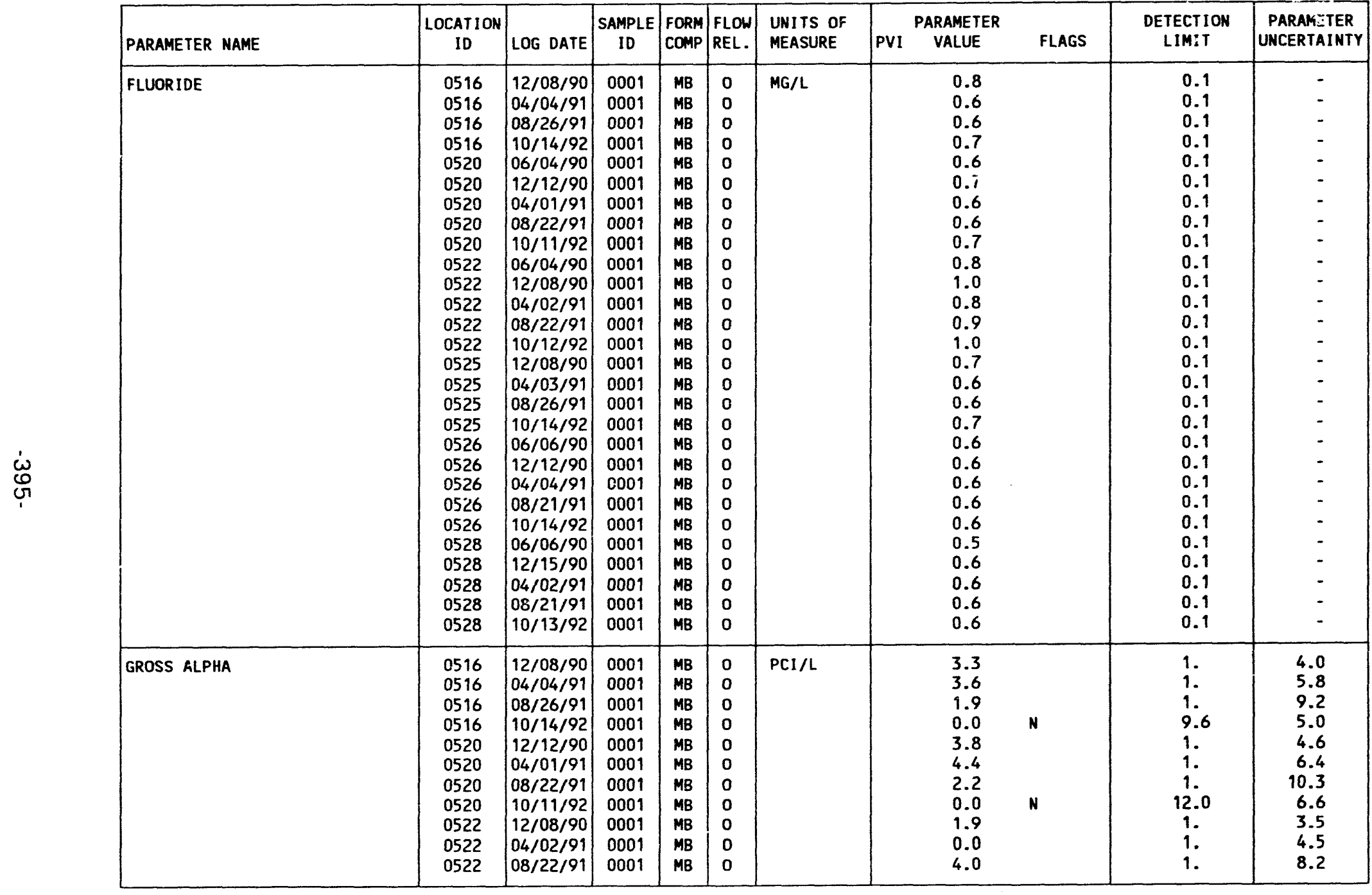

FORMATION OF COMPLETION CODE:

MB - MIDDLE BURRO CANYON

PARAMETER VALUE INDICATOR (PVI): < - LESS THAN DETECTION LIMIT
FLOW RELATIONSHIP CODE:

O - ON-SITE

SAMPLE ID CODES:

0001 - FILTERED SAMPLE (.45 MICRONS)

OTHER PARAMETER VALUE FLAGS:

N - SPIKE SAMPLE RECOVERY NOT WITHIN CONTROL LIMITS 
TABLE 3.49. BACKGROUND GROUNDWATER QUALITY DATE BY PARAMETER FOR THE MIDDLE SANDSTONE UNIT, BURRO CANYON DISPOSAL SITE, SLICK ROCK, COLORADO SITE: SRKO2 BORROW SITE 1 (BURRO CANYON)

06/04/90 TO $10 / 14 / 92$

REPORT DATE: 03/02/94

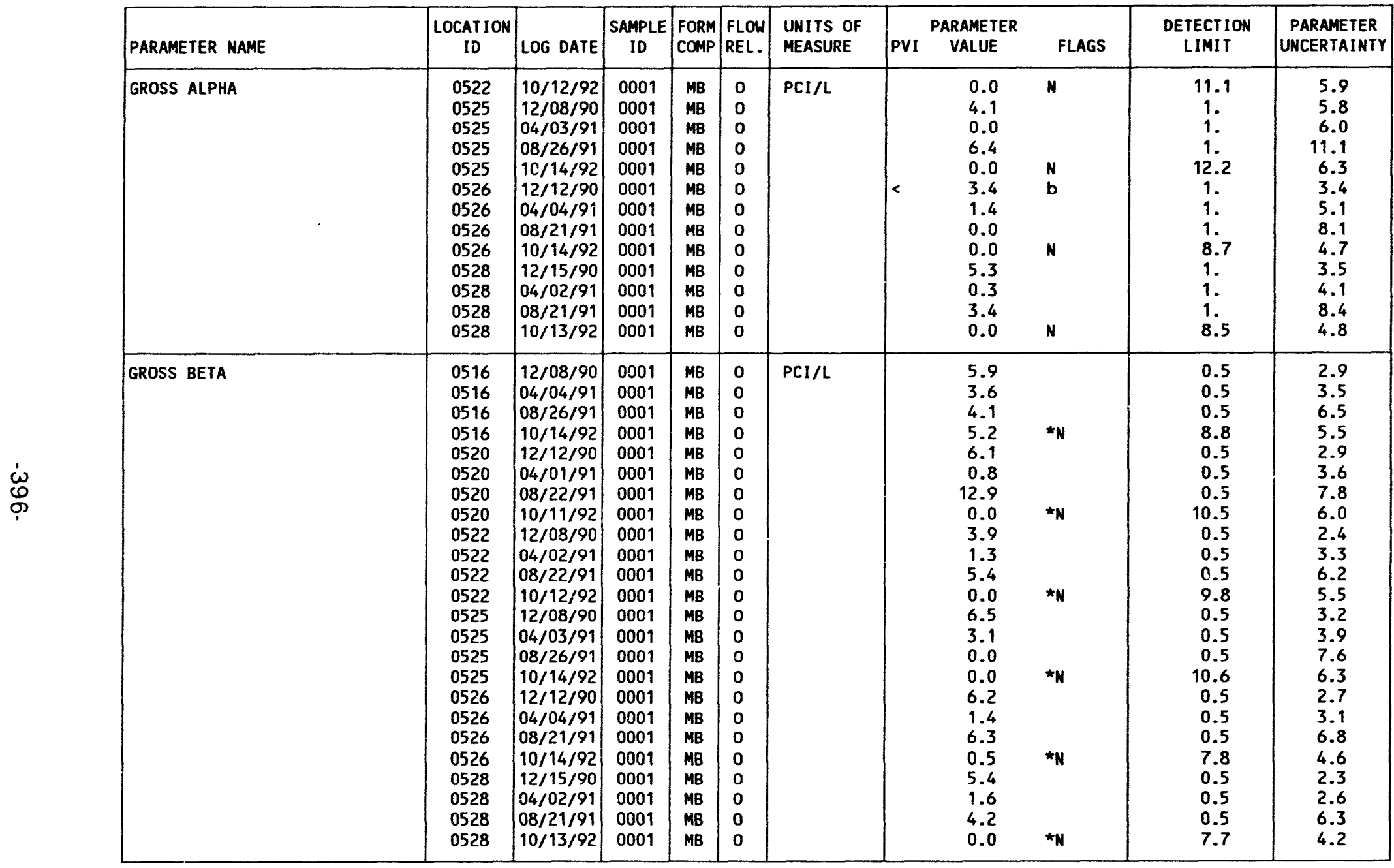

FORMATION OF COMPLETION CODE:

MB - MIDDLE BURRO CANYON

PARAMETER VALUE INDICATOR (PVI): < - LESS THAN DETECTION LIMIT
FLOW RELATIONSHIP CODE:

O - ON-SITE

SAMPLE ID CODES:

0001 - FILTERED SAMPLE ( .45 MICRONS)

OTHER PARAMETER VALUE FLAGS:

* - DUPLICATE ANALYSIS NOT WITHIN CONTROL LIMITS

N - SPIKE SAMPLE RECOVERY NOT WITHIN CONTROL LIMITS

b - CHANGED PARAMETER VALUE 
TABLE 3.49. BACKGROUND GROUNDWATER QUALITY DATE BY PARAMETER FOR THE MIDDLE SANDSTONE UNIT, BURRO CANYON DISPOSAL SITE, SLICK ROCK, COLORADO SITE: SRKO2 BORROW SITE 1 (BURRO CANYOW)

06/04/90 TO $10 / 14 / 92$

REPORT DATE: $03 / 02 / 94$

\begin{tabular}{|c|c|c|c|c|c|c|c|c|c|c|c|}
\hline PARAMETER NAME & $\int_{\text {ID }}^{\text {LOCATION }}$ & LOG DATE & $\begin{array}{c}\text { SAMPLE } \\
\text { ID }\end{array}$ & $\begin{array}{l}\text { FORM } \\
\text { COMP }\end{array}$ & $\begin{array}{l}\text { FLOW } \\
\text { REL. }\end{array}$ & $\begin{array}{l}\text { UNITS OF } \\
\text { MEASURE }\end{array}$ & PVI & $\begin{array}{l}\text { PARAMETER } \\
\text { VALUE }\end{array}$ & FLAGS & $\begin{array}{l}\text { DETECTION } \\
\text { LIMIT }\end{array}$ & \begin{tabular}{|} 
PARAMETER \\
UNCERTAINTY
\end{tabular} \\
\hline IRON & $\begin{array}{l}0516 \\
0516 \\
0516 \\
0516 \\
0516 \\
0520 \\
0520 \\
0520 \\
0520 \\
0520 \\
0522 \\
0522 \\
0522 \\
0522 \\
0522 \\
0525 \\
0525 \\
0525 \\
0525 \\
0526 \\
0526 \\
0526 \\
0526 \\
0526 \\
0528 \\
0528 \\
0528 \\
0528 \\
0528\end{array}$ & $\begin{array}{l}06 / 06 / 90 \\
12 / 08 / 90 \\
04 / 04 / 91 \\
08 / 26 / 91 \\
10 / 14 / 92 \\
06 / 04 / 90 \\
12 / 12 / 90 \\
04 / 01 / 91 \\
08 / 22 / 91 \\
10 / 11 / 92 \\
06 / 04 / 90 \\
12 / 08 / 90 \\
04 / 02 / 91 \\
08 / 22 / 91 \\
10 / 12 / 92 \\
12 / 08 / 90 \\
04 / 03 / 91 \\
08 / 26 / 91 \\
10 / 14 / 92 \\
06 / 06 / 90 \\
12 / 12 / 90 \\
04 / 04 / 91 \\
08 / 21 / 91 \\
10 / 14 / 92 \\
06 / 06 / 90 \\
12 / 15 / 90 \\
04 / 02 / 91 \\
08 / 21 / 91 \\
10 / 13 / 92\end{array}$ & $\begin{array}{l}0001 \\
0001 \\
0001 \\
0001 \\
0001 \\
0001 \\
0001 \\
0001 \\
0001 \\
0001 \\
0001 \\
0001 \\
0001 \\
0001 \\
0001 \\
0001 \\
0001 \\
0001 \\
0001 \\
0001 \\
0001 \\
0001 \\
0001 \\
0001 \\
0001 \\
0001 \\
0001 \\
0001 \\
0001\end{array}$ & $\begin{array}{l}M B \\
M B \\
M B \\
M B \\
M B \\
M B \\
M B \\
M B \\
M B \\
M B \\
M B \\
M B \\
M B \\
M B \\
M B \\
M B \\
M B \\
M B \\
M B \\
M B \\
M B \\
M B \\
M B \\
M B \\
M B \\
M B \\
M B \\
M B \\
M B\end{array}$ & $\begin{array}{l}0 \\
0 \\
0 \\
0 \\
0 \\
0 \\
0 \\
0 \\
0 \\
0 \\
0 \\
0 \\
0 \\
0 \\
0 \\
0 \\
0 \\
0 \\
0 \\
0 \\
0 \\
0 \\
0 \\
0 \\
0 \\
0 \\
0 \\
0 \\
0\end{array}$ & $M G / L$ & $\mid \begin{array}{l}< \\
< \\
< \\
< \\
< \\
< \\
<\end{array}$ & $\begin{array}{l}0.03 \\
0.03 \\
0.05 \\
0.03 \\
0.03 \\
0.05 \\
0.03 \\
0.03 \\
0.03 \\
0.03 \\
0.05 \\
0.06 \\
0.06 \\
0.05 \\
0.11 \\
0.03 \\
0.03 \\
0.03 \\
0.03 \\
0.03 \\
0.03 \\
0.03 \\
0.08 \\
0.03 \\
0.06 \\
0.09 \\
0.11 \\
0.12 \\
0.09\end{array}$ & & $\begin{array}{l}0.03 \\
0.03 \\
0.03 \\
0.03 \\
0.03 \\
0.03 \\
0.03 \\
0.03 \\
0.03 \\
0.03 \\
0.03 \\
0.03 \\
0.03 \\
0.03 \\
0.03 \\
0.03 \\
0.03 \\
0.03 \\
0.03 \\
0.03 \\
0.03 \\
0.03 \\
0.03 \\
0.03 \\
0.03 \\
0.03 \\
0.03 \\
0.03 \\
0.03\end{array}$ & $\begin{array}{l}- \\
- \\
- \\
- \\
- \\
- \\
- \\
- \\
- \\
- \\
- \\
- \\
- \\
- \\
- \\
- \\
- \\
- \\
- \\
- \\
- \\
- \\
-\end{array}$ \\
\hline LEAD & $\begin{array}{l}0516 \\
0516 \\
0516 \\
0516 \\
0516 \\
0520 \\
0520 \\
0520 \\
0520 \\
0520\end{array}$ & $\begin{array}{l}06 / 06 / 90 \\
12 / 08 / 90 \\
04 / 04 / 91 \\
08 / 26 / 91 \\
10 / 14 / 92 \\
06 / 04 / 90 \\
12 / 12 / 90 \\
04 / 01 / 91 \\
08 / 22 / 91 \\
10 / 11 / 92\end{array}$ & $\begin{array}{l}0001 \\
0001 \\
0001 \\
0001 \\
0001 \\
0001 \\
0001 \\
0001 \\
0001 \\
0001\end{array}$ & $\begin{array}{l}\text { MB } \\
\text { MB } \\
\text { MB } \\
\text { MB } \\
\text { MB } \\
\text { MB } \\
\text { MB } \\
\text { MB } \\
\text { MB } \\
\text { MB }\end{array}$ & $\begin{array}{l}0 \\
0 \\
0 \\
0 \\
0 \\
0 \\
0 \\
0 \\
0 \\
0\end{array}$ & $M G / L$ & $\begin{array}{l}< \\
< \\
< \\
< \\
< \\
< \\
< \\
< \\
< \\
<\end{array}$ & $\begin{array}{l}0.01 \\
0.01 \\
0.005 \\
0.005 \\
0.02 \\
0.01 \\
0.01 \\
0.005 \\
0.005 \\
0.003\end{array}$ & 1 & $\begin{array}{l}0.01 \\
0.01 \\
0.005 \\
0.005 \\
0.02 \\
0.01 \\
0.01 \\
0.005 \\
0.005 \\
0.003\end{array}$ & $\begin{array}{l}- \\
- \\
- \\
- \\
- \\
- \\
-\end{array}$ \\
\hline
\end{tabular}

FORMATION OF COMPLETION CODE:

MB - MIDDLE BURRO CANYON

FLOW RELATIONSHIP CODE:

PARAMETER VALUE INDICATOR (PVI): < - LESS THAN DETECTION LIMIT

SAMPLE ID CODES:

SAMPLE ID CODES:
0001 - FILTERED SAMPLE ( 45 MICRONS $)$

OTHER PARAMETER VALUE FLAGS:

I - INCREASED DETECTION LIMIT DUE TO REQUIRED DILUTION 
TABLE 3.49. BACKGROUND GROUNDWATER QUALITY DATE BY PARAMETER FOR THE MIDDLE SANDSTONE UNIT, BURRO CANYON DISPOSAL SITE, SLICK ROCK, COLORADO SITE: SRKO2 BORROW SITE 1 (BURRO CANYON)

06/04/90 TO $10 / 14 / 92$

REPORT DATE: 03/02/94

\begin{tabular}{|c|c|c|c|c|c|c|c|c|c|c|c|}
\hline PARAMETER NAME & $\begin{array}{c}\text { LOCATION } \\
\text { ID }\end{array}$ & LOG DATE & $\begin{array}{c}\text { SAMPLE } \\
\text { ID }\end{array}$ & $\begin{array}{l}\text { FORM } \\
\text { COMP }\end{array}$ & $\begin{array}{l}\text { FLOW } \\
\text { REL. }\end{array}$ & $\begin{array}{l}\text { UNITS OF } \\
\text { MEASURE }\end{array}$ & PVI & $\begin{array}{l}\text { ARAMETER } \\
\text { VALUE }\end{array}$ & FLAGS & $\begin{array}{l}\text { DETECTION } \\
\text { LIMIT }\end{array}$ & $\begin{array}{l}\text { PARAMETER } \\
\text { UNCERTAINTY }\end{array}$ \\
\hline LEAD & $\begin{array}{l}0522 \\
0522 \\
0522 \\
0522 \\
0522 \\
0525 \\
0525 \\
0525 \\
0525 \\
0526 \\
0526 \\
0526 \\
0526 \\
0526 \\
0528 \\
0528 \\
0528 \\
0528 \\
0528\end{array}$ & $\begin{array}{l}06 / 04 / 90 \\
12 / 08 / 90 \\
04 / 02 / 91 \\
08 / 22 / 91 \\
10 / 12 / 92 \\
12 / 08 / 90 \\
04 / 03 / 91 \\
08 / 26 / 91 \\
10 / 14 / 92 \\
06 / 06 / 90 \\
12 / 12 / 90 \\
04 / 04 / 91 \\
08 / 21 / 91 \\
10 / 14 / 92 \\
06 ; 06 / 90 \\
12 / 15 / 90 \\
04 / 02 / 91 \\
08 / 21 / 91 \\
10 / 13 / 92\end{array}$ & $\begin{array}{l}0001 \\
0001 \\
0001 \\
0001 \\
0001 \\
0001 \\
0001 \\
0001 \\
0001 \\
0001 \\
0001 \\
0001 \\
0001 \\
0001 \\
0001 \\
0001 \\
0001 \\
0001 \\
0001\end{array}$ & $\begin{array}{l}\text { MB } \\
\text { MB } \\
\text { MB } \\
\text { MB } \\
\text { MB } \\
\text { MB } \\
\text { MB } \\
\text { MS } \\
\text { MB } \\
\text { MB } \\
\text { MB } \\
\text { MB } \\
\text { MB } \\
\text { MB } \\
\text { MB } \\
\text { MB } \\
\text { MB } \\
\text { MB } \\
\text { MB }\end{array}$ & $\begin{array}{l}0 \\
0 \\
0 \\
0 \\
0 \\
0 \\
0 \\
0 \\
0 \\
0 \\
0 \\
0 \\
0 \\
0 \\
0 \\
0 \\
0 \\
0 \\
0\end{array}$ & $M G / L$ & $\begin{array}{l}< \\
< \\
< \\
< \\
< \\
< \\
< \\
< \\
< \\
< \\
< \\
< \\
< \\
< \\
< \\
< \\
< \\
< \\
< \\
<\end{array}$ & $\begin{array}{l}0.01 \\
0.01 \\
0.005 \\
0.005 \\
0.003 \\
0.01 \\
0.005 \\
0.005 \\
0.003 \\
0.01 \\
0.01 \\
0.005 \\
0.005 \\
0.003 \\
0.01 \\
0.01 \\
0.005 \\
0.005 \\
0.003\end{array}$ & & $\begin{array}{l}0.01 \\
0.01 \\
0.005 \\
0.005 \\
0.003 \\
0.01 \\
0.005 \\
0.005 \\
0.003 \\
0.01 \\
0.01 \\
0.005 \\
0.005 \\
0.003 \\
0.01 \\
0.01 \\
0.005 \\
0.005 \\
0.003\end{array}$ & $\begin{array}{l}- \\
- \\
- \\
- \\
- \\
- \\
- \\
- \\
- \\
- \\
- \\
- \\
- \\
- \\
- \\
-\end{array}$ \\
\hline LEAD-210 & $\begin{array}{l}0516 \\
0516 \\
0516 \\
0520 \\
0520 \\
0520 \\
0522 \\
0522 \\
0522 \\
0525 \\
0525 \\
0525 \\
0526 \\
0526 \\
0526 \\
0528 \\
0528 \\
0528\end{array}$ & $\begin{array}{l}12 / 08 / 90 \\
04 / 04 / 91 \\
08 / 26 / 91 \\
12 / 12 / 90 \\
04 / 01 / 91 \\
08 / 22 / 91 \\
12 / 08 / 90 \\
04 / 02 / 91 \\
08 / 22 / 91 \\
12 / 08 / 90 \\
04 / 03 / 91 \\
08 / 26 / 91 \\
12 / 12 / 90 \\
04 / 04 / 91 \\
08 / 21 / 91 \\
12 / 15 / 90 \\
04 / 02 / 91 \\
08 / 21 / 91\end{array}$ & $\begin{array}{l}0001 \\
0001 \\
0001 \\
0001 \\
0001 \\
0001 \\
0001 \\
0001 \\
0001 \\
0001 \\
0001 \\
0001 \\
0001 \\
0001 \\
0001 \\
0001 \\
0001 \\
0001\end{array}$ & $\begin{array}{l}\text { MB } \\
M B \\
M B \\
M B \\
M B \\
M B \\
M B \\
M B \\
M B \\
M B \\
M B \\
M B \\
M B \\
M B \\
M B \\
M B \\
M B \\
M B\end{array}$ & $\begin{array}{l}0 \\
0 \\
0 \\
0 \\
0 \\
0 \\
0 \\
0 \\
0 \\
0 \\
0 \\
0 \\
0 \\
0 \\
0 \\
0 \\
0 \\
0\end{array}$ & $\mathrm{PCI} / \mathrm{L}$ & $\begin{array}{l}< \\
< \\
< \\
<\end{array}$ & $\begin{array}{l}0.9 \\
0.9 \\
0.0 \\
0.3 \\
0.0 \\
0.0 \\
0.9 \\
0.0 \\
0.0 \\
0.8 \\
1.4 \\
0.0 \\
0.9 \\
0.5 \\
0.0 \\
0.9 \\
0.4 \\
0.0\end{array}$ & $\begin{array}{l}c \\
b \\
b \\
b \\
\text { b }\end{array}$ & $\begin{array}{l}1.5 \\
1.5 \\
1.5 \\
1.2 \\
1.5 \\
1.5 \\
1.5 \\
1.5 \\
1.5 \\
1.5 \\
1.5 \\
1.5 \\
1.5 \\
1.5 \\
1.5 \\
1.5 \\
1.5 \\
1.5\end{array}$ & $\begin{array}{l}0.9 \\
2.8 \\
1.0 \\
0.9 \\
1.4 \\
0.9 \\
0.9 \\
1.3 \\
0.9 \\
0.8 \\
1.4 \\
1.0 \\
0.9 \\
1.4 \\
0.9 \\
0.9 \\
1.4 \\
0.9\end{array}$ \\
\hline MAGNESIUM & 0516 & $06 / 06 / 90$ & 0001 & MB & 0 & $M G / L$ & & 18.1 & & 0.001 & - \\
\hline
\end{tabular}

FORMATION OF COMPLETION COOE:

MB - MIDDLE BURRO CANYON

FLOW RELATIONSHIP COOE:

PARAMETER VALUE INDICATOR (PVI): < - LESS THAN DETECTION LIMIT

SAMPLE ID CODES:

0001 - FILTERED SAMPLE (.45 MICRONS)

OTHER PARAMETER VALUE FLAGS:

b - CHANGED PARAMETER VALUE

c - CHANGED DETECTION LIMIT 
TABLE 3.49. BACKGROUND GROUNDWATER QUALITY DATE BY PARAMETER FOR THE MIDDLE SANDSTONE UNIT, BURRO CANYON DISPOSAL SITE, SLICK ROCK, COLORADO SITE: SRKO2 BORROW SITE 1 (BURRO CANYON)

SITE: SRKO2 BORROW S

REPORT DATE: $03 / 02 / 94$

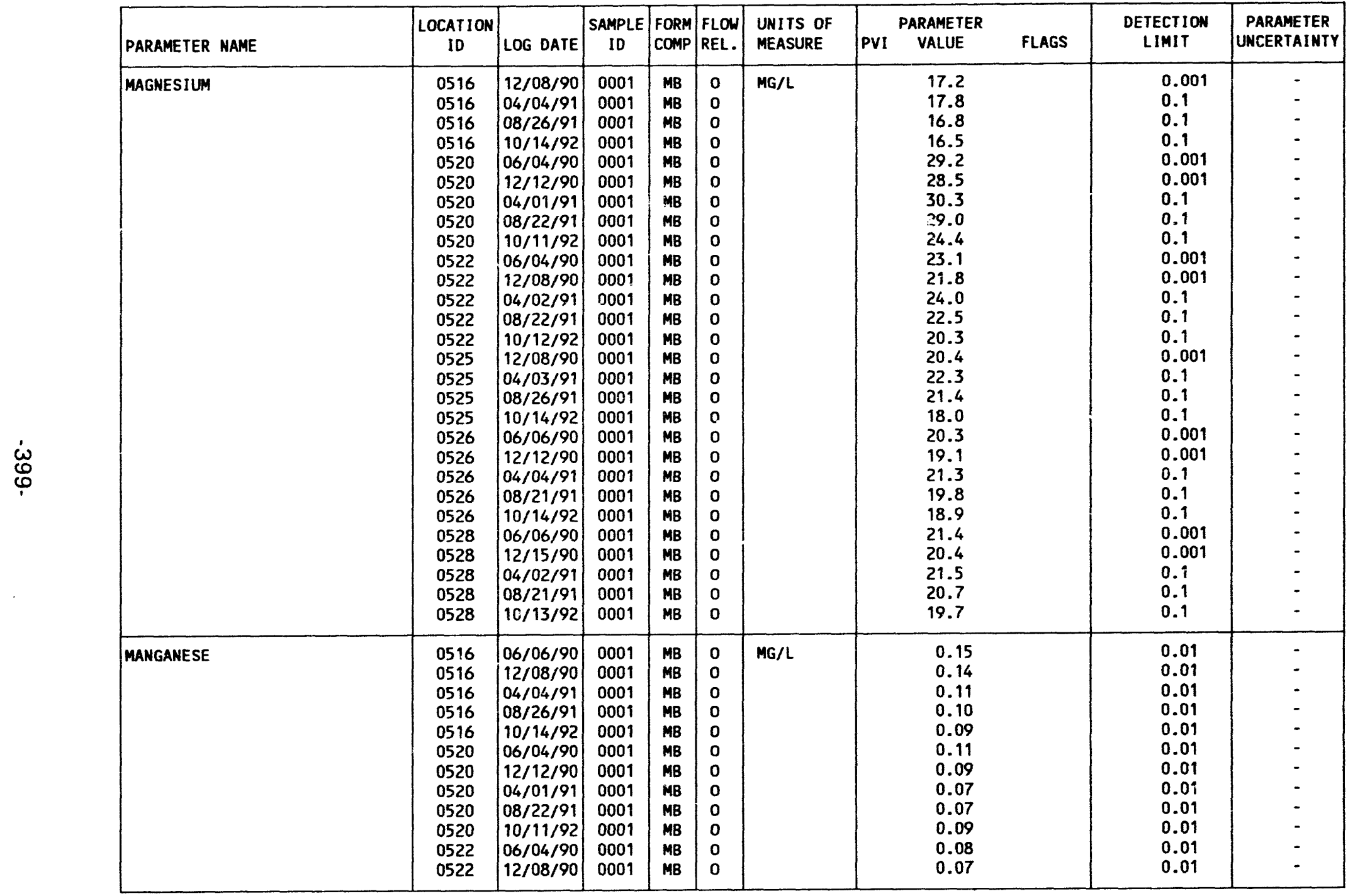

FORMATION OF COMPLETION COOE:

MB - MIDDLE BURRO CANYON

FLOW RELATIONSHIP COOE:

PARAMETER VALUE INDICATOR (PVI): - - LESS THAN DETECTION LIMIT SAMPLE ID COOES:

0001 - FILTERED SAMPLE (.45 MICRONS) 
TABLE 3.49. BACKGROUND GROUNDHATER QUALITY DATE BY PARAMETER FOR THE MIDDLE SANDSTONE UNIT, BURRO CANYON DISPOSAL SITE, SLICK ROCK, COLORADO SITE: SRK02

06/04/90 TO $10 / 14 / 92$

REPORT DATE: $03 / 02 / 94$

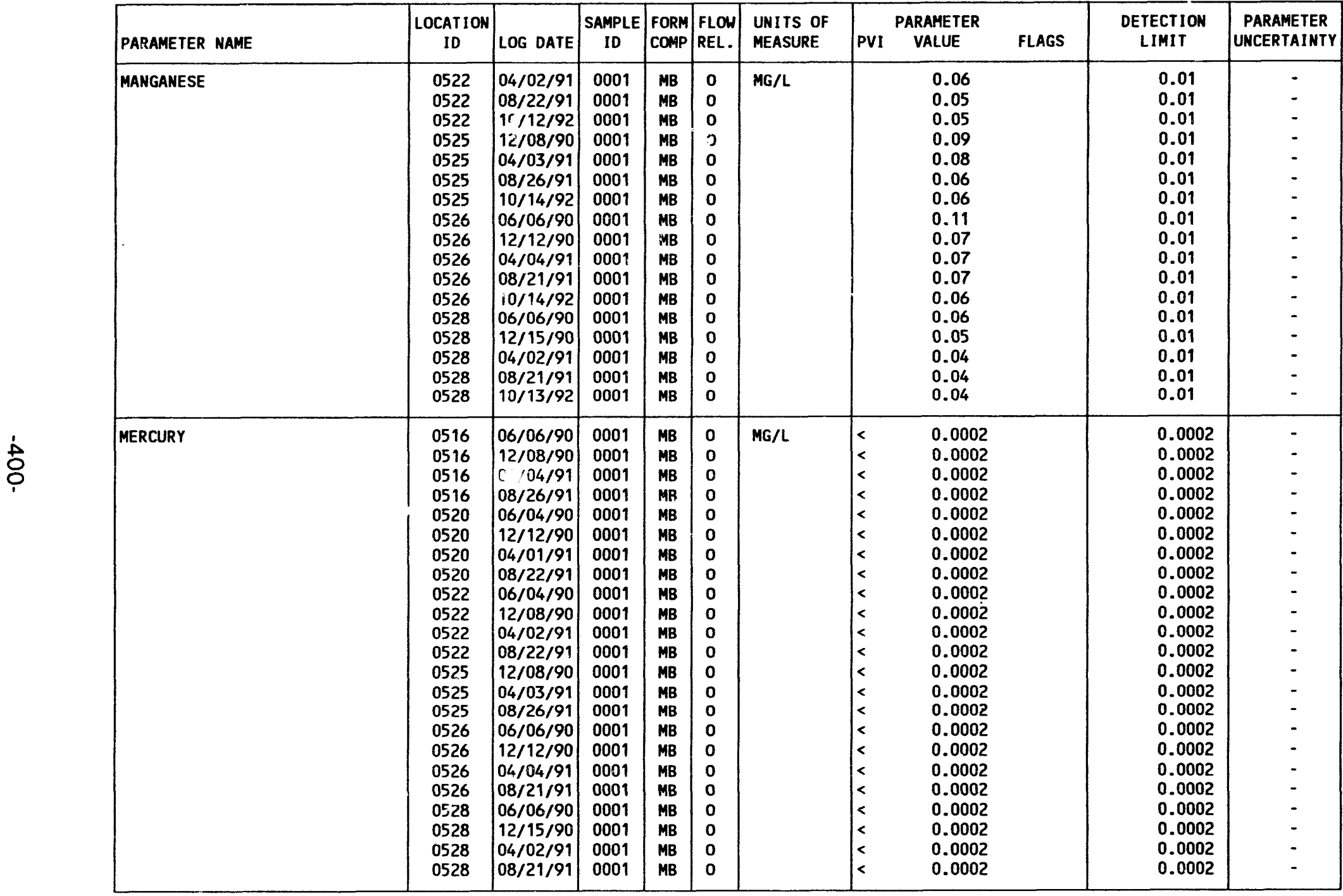

FORMATION OF COHPLETION CODE:

MB - MIDDLE BURRO CANYON

PARAMETER VALUE INDICATOR (PVI): < - LESS THAN DETECTION LIMIT
FLON RELATIONSHIP CODE:

O - ON-SITE

SAMPLE ID CODES:

0001 - FILTERED SAMPLE (.45 MICRONS) 
TABLE 3.49. BACXGROUND GROUNDHATER QUALITY DATE BY PARAMETER FOR THE

MIDDLE SANDSTONE UNIT, BURRO CANYON D'SPOSAL SITE, SLICK ROCK, COLORADO

SITE: SRKO2 BORROW SITE 1 (BURRO CANYON)

SITE: SRKO2 BORROW SITE

REPORT DATE: 03/02/94

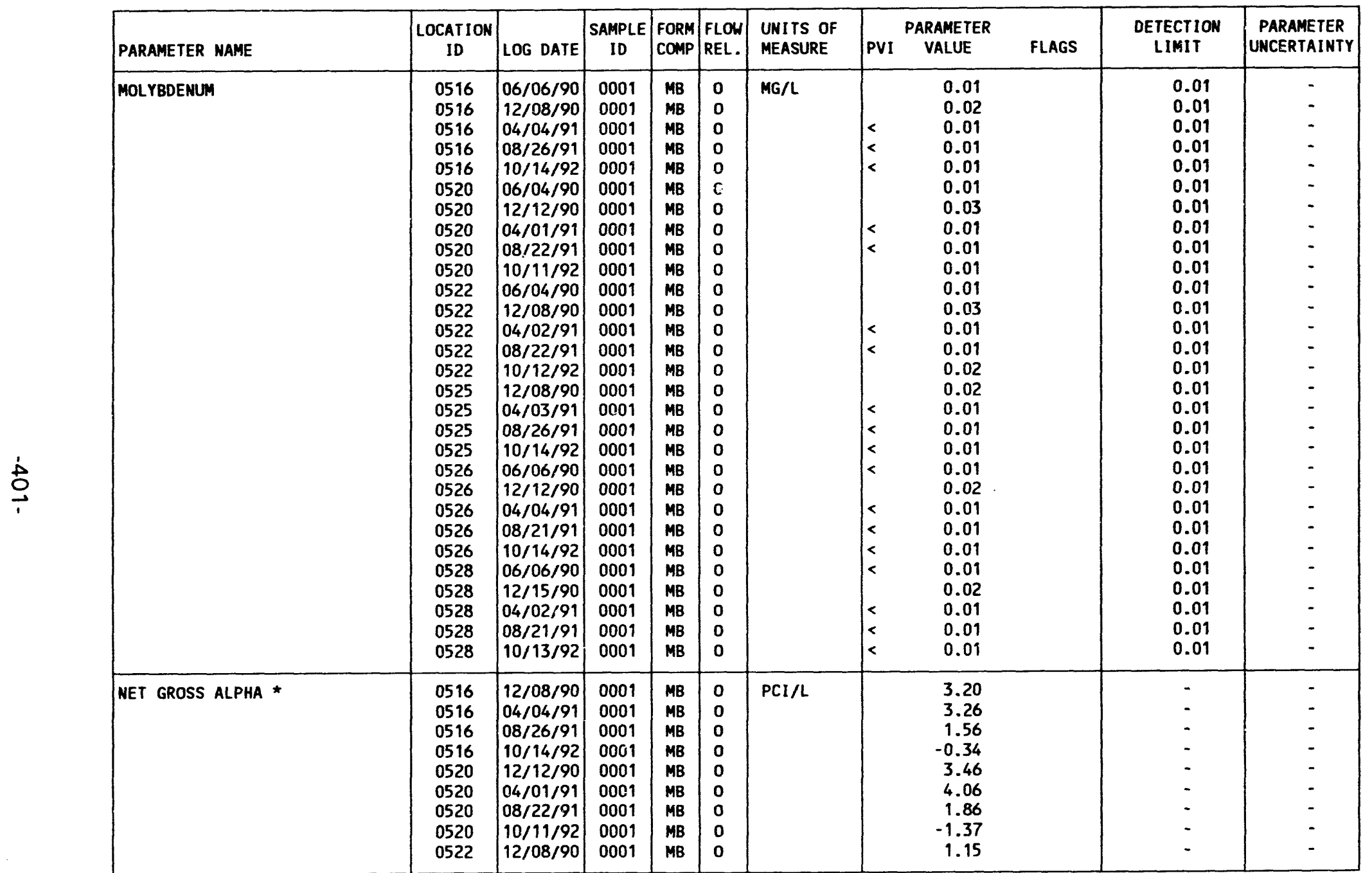

* NET GROSS ALPHA (GROSS ALPHA - URANIUM) WITH 1 MG URANIUM = 686 PCI

FORMATION OF COMPLETION CODE:

MB - MIDDLE BURRO CANYON

PARAMETER VALUE INDICATOR (PVI): < - LESS THAN DETECTION LIMIT
FLOW RELATIONSHIP COOE:

O- ON-SITE

SAMPLE ID COOES:

0001 - FILTERED SAMPLE (.45 MICRONS) 
TABLE 3.49. BACKGROUND GROUNDWATER QUALITY DATE BY PARAMETER FOR THE TABDE 3 SANDSTONE UNIT, BURRO CANYON DISPOSAL SITE, SLICK ROCK, COLORADO SITE: SRKO2 BORROW SITE 1 (BURRO CANYON) 06/04/90 TO $10 / 14 / 92$

REPORT DATE: $03 / 02 / 94$

\begin{tabular}{|c|c|c|c|c|c|c|c|c|c|c|}
\hline PARAMETER NAME & $\begin{array}{l}\text { LOCATION } \\
\text { ID }\end{array}$ & LOG DATE & $\begin{array}{c}\text { SAMPLE } \\
\text { ID }\end{array}$ & $\begin{array}{l}\text { FORM } \\
\text { COMP }\end{array}$ & $\begin{array}{l}\text { FLOW } \\
\text { REL. }\end{array}$ & $\begin{array}{l}\text { UNITS OF } \\
\text { MEASURE }\end{array}$ & PVI & $\begin{array}{l}\text { PARAMETER } \\
\text { VALUE }\end{array}$ & $\begin{array}{l}\text { DETECTION } \\
\text { LIMIT }\end{array}$ & $\begin{array}{l}\text { PARAMETER } \\
\text { UNCERTAINTY }\end{array}$ \\
\hline NET GROSS ALPHA * & $\begin{array}{l}0522 \\
0522 \\
0522 \\
0525 \\
0525 \\
0525 \\
0525 \\
0526 \\
0526 \\
0526 \\
0526 \\
0528 \\
0528 \\
0528 \\
0528\end{array}$ & $\begin{array}{l}04 / 02 / 91 \\
08 / 22 / 91 \\
10 / 12 / 92 \\
12 / 08 / 90 \\
04 / 03 / 91 \\
08 / 26 / 91 \\
10 / 14 / 92 \\
12 / 12 / 90 \\
04 / 04 / 91 \\
08 / 21 / 91 \\
10 / 14 / 92 \\
12 / 15 / 90 \\
04 / 02 / 91 \\
08 / 21 / 91 \\
10 / 13 / 92\end{array}$ & $\begin{array}{l}0001 \\
0001 \\
0001 \\
0001 \\
0001 \\
0001 \\
0001 \\
0001 \\
0001 \\
0001 \\
0001 \\
0001 \\
0001 \\
0001 \\
0001\end{array}$ & $\begin{array}{l}\text { MB } \\
\text { MB } \\
\text { MB } \\
\text { MB } \\
\text { MB } \\
\text { MB } \\
\text { MB } \\
\text { MB } \\
\text { MB } \\
\text { MB } \\
\text { MB } \\
\text { MB } \\
\text { MB } \\
\text { MB } \\
\text { MB }\end{array}$ & $\begin{array}{l}0 \\
0 \\
0 \\
0 \\
0 \\
0 \\
0 \\
0 \\
0 \\
0 \\
0 \\
0 \\
0 \\
0 \\
0\end{array}$ & $\mathrm{PCI} / \mathrm{L}$ & & $\begin{array}{r}-0.34 \\
-0.12 \\
-1.37 \\
4.00 \\
-0.34 \\
6.06 \\
-0.34 \\
0.23 \\
-4.09 \\
-0.34 \\
-0.34 \\
4.61 \\
-1.07 \\
3.06 \\
-0.34\end{array}$ & $\begin{array}{l}- \\
- \\
- \\
- \\
- \\
- \\
- \\
- \\
- \\
- \\
-\end{array}$ & $\begin{array}{l}- \\
- \\
- \\
- \\
- \\
- \\
- \\
- \\
- \\
- \\
- \\
-\end{array}$ \\
\hline NICKEL & $\begin{array}{l}0516 \\
0516 \\
0516 \\
0516 \\
0516 \\
0520 \\
0520 \\
0520 \\
0520 \\
0520 \\
0522 \\
0522 \\
0522 \\
0522 \\
0522 \\
0525 \\
0525 \\
0525 \\
0525 \\
0526 \\
0526 \\
0526 \\
0526\end{array}$ & $\begin{array}{l}06 / 06 / 90 \\
12 / 08 / 90 \\
04 / 04 / 91 \\
08 / 26 / 91 \\
10 / 14 / 92 \\
06 / 04 / 90 \\
12 / 12 / 90 \\
04 / 01 / 91 \\
08 / 22 / 91 \\
10 / 11 / 92 \\
06 / 04 / 90 \\
12 / 08 / 90 \\
04 / 02 / 91 \\
08 / 22 / 91 \\
10 / 12 / 92 \\
12 / 08 / 90 \\
04 / 03 / 91 \\
08 / 26 / 91 \\
10 / 14 / 92 \\
06 / 06 / 90 \\
12 / 12 / 90 \\
04 / 04 / 91 \\
08 / 21 / 91\end{array}$ & $\begin{array}{l}0001 \\
0001 \\
0001 \\
0001 \\
0001 \\
0001 \\
0001 \\
0001 \\
0001 \\
0001 \\
0001 \\
0001 \\
0001 \\
0001 \\
0001 \\
0001 \\
0001 \\
0001 \\
0001 \\
0001 \\
0001 \\
0001 \\
0001\end{array}$ & $\begin{array}{l}\text { MB } \\
\text { MB } \\
\text { MB } \\
\text { MB } \\
\text { MB } \\
\text { MB } \\
\text { MB } \\
\text { MB } \\
\text { MB } \\
\text { MB } \\
\text { MB } \\
\text { MB } \\
\text { MB } \\
\text { MB } \\
\text { MB } \\
\text { MB } \\
\text { MB } \\
\text { MB } \\
\text { MB } \\
\text { MB } \\
\text { MB } \\
\text { MB } \\
\text { MB }\end{array}$ & $\begin{array}{l}0 \\
0 \\
0 \\
0 \\
0 \\
0 \\
0 \\
0 \\
0 \\
0 \\
0 \\
0 \\
0 \\
0 \\
0 \\
0 \\
0 \\
0 \\
0 \\
0 \\
0 \\
0 \\
0\end{array}$ & $M G / L$ & $\begin{array}{l}< \\
< \\
< \\
< \\
< \\
< \\
< \\
< \\
< \\
< \\
< \\
< \\
< \\
< \\
< \\
< \\
< \\
< \\
< \\
< \\
< \\
< \\
< \\
< \\
< \\
< \\
<\end{array}$ & $\begin{array}{l}0.04 \\
0.04 \\
0.04 \\
0.04 \\
0.04 \\
0.04 \\
0.04 \\
0.04 \\
0.04 \\
0.04 \\
0.04 \\
0.04 \\
0.04 \\
0.04 \\
0.04 \\
0.04 \\
0.04 \\
0.04 \\
0.04 \\
0.04 \\
0.04 \\
0.04 \\
0.04\end{array}$ & $\begin{array}{l}0.04 \\
0.04 \\
0.04 \\
0.04 \\
0.04 \\
0.04 \\
0.04 \\
0.04 \\
0.04 \\
0.04 \\
0.04 \\
0.04 \\
0.04 \\
0.04 \\
0.04 \\
0.04 \\
0.04 \\
0.04 \\
0.04 \\
0.04 \\
0.04 \\
0.04 \\
0.04\end{array}$ & $\begin{array}{l}- \\
- \\
- \\
- \\
- \\
- \\
- \\
- \\
- \\
- \\
- \\
- \\
- \\
- \\
- \\
- \\
- \\
- \\
- \\
-\end{array}$ \\
\hline
\end{tabular}

* Net GROSS ALPHA (GROSS ALPHA - URANIUM) WITH 1 MG URANIUM = $686 \mathrm{PCI}$

FORMATION OF COMPLETION CODE: MB - MIDDLE BURRO CANYON

PARAMETER VALUE INDICATOR (PVI): < - LESS THAN DETECTION LIMIT
FLOW RELATIONSHIP CODE:

O - ON-SITE

SAMPLE ID CODES:

0001 - FILTERED SAMPLE (.45 MICRONS) 
TABLE 3.49. BACKGROUND GROUNDWATER QUALITY DATE BY PARAMETER FOR THE MIDDLE SANDSTONE UNIT, BURRO CANYON DISPOSAL SITE, SLICK ROCK, COLORADO SITE: SRKO2 BORROW SITE 1 (BURRO CANYON)

06/04/90 TO $10 / 14 / 92$

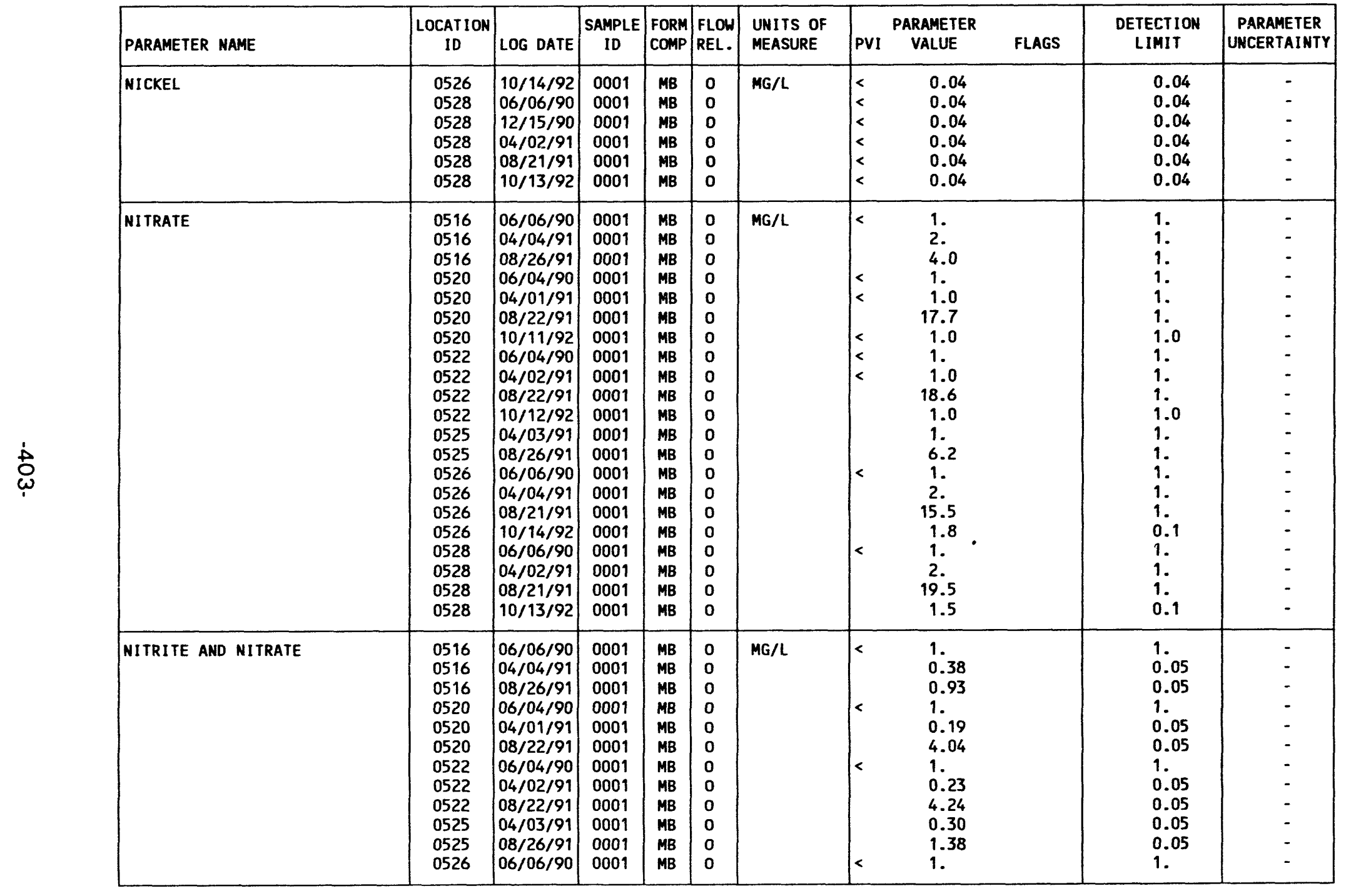

FORMATION OF COMPLETION CODE:

MB - MIDDLE BURRO CANYON

PARAMETER VALUE INDICATOR (PVI): < - LESS THAN DETECTION LIMIT
FLOW RELATIONSHIP CODE:

0001 - FILTERED SAMPLE (.45 MICRONS) 
TABLE 3.49. BACKGROUND GROUNDWATER QUALITY DATE BY PARAMETER FOR THE MIDDLE SANDSTONE UNIT, BURRO CANYGN DISPOSAL SITE, SLICK ROCK, COLORADO SITE: SRKO2 BORROW SITE 1 (BURRO CANYON)

06/04/90 TO $10 / 14 / 92$

REPORT DATE : $03 / 02 / 94$

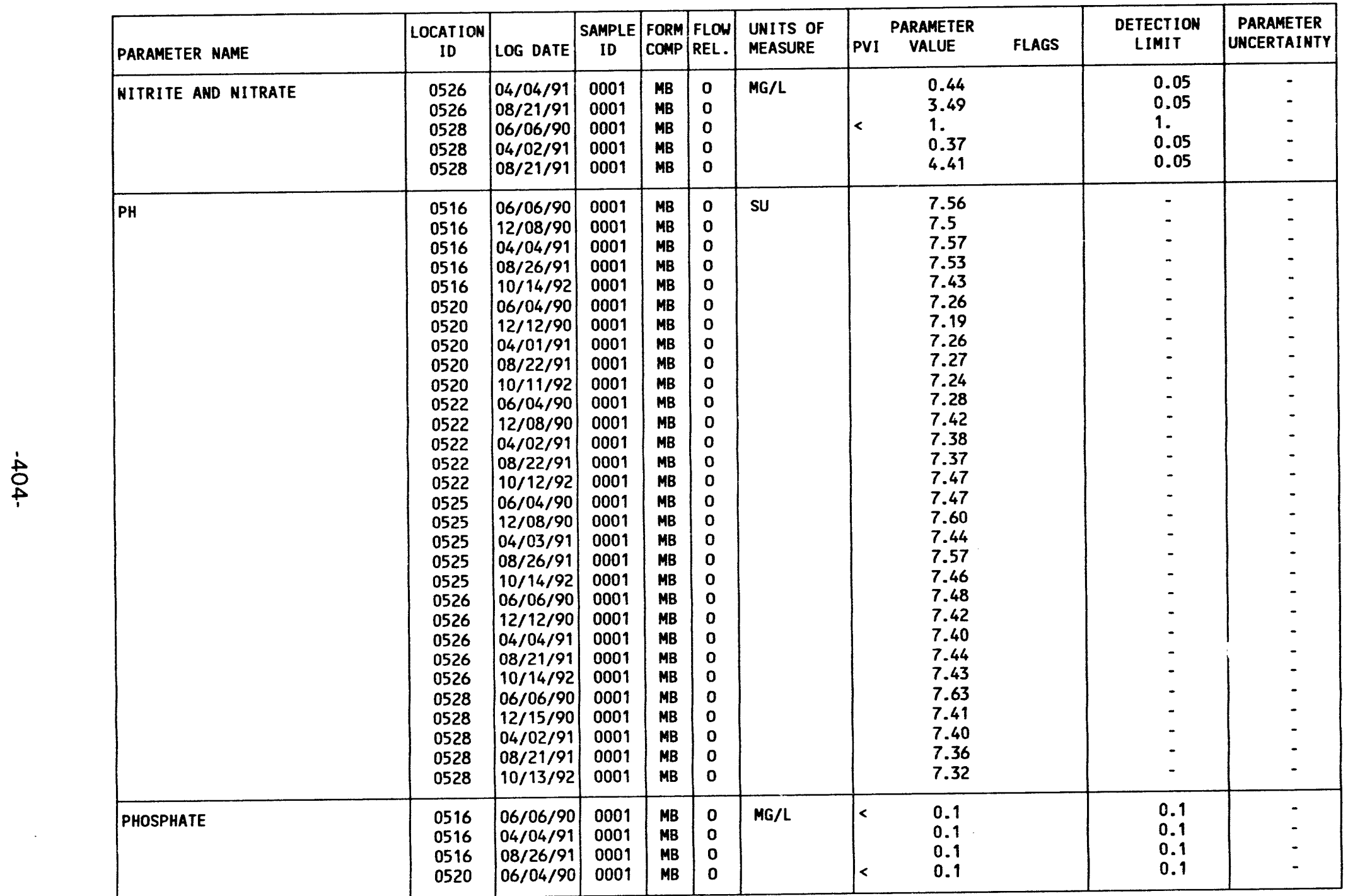

FORMATION OF COMPLETION COOE:

MB - MIDDLE BURRO CANYON

FLOW RELATIONSHIP CODE:

PARAMETER VALUE INDICATOR (PVI): - - LESS THAN DETECTION LIMIT SAMPLE ID CODES:

SAMPLE ID CODES:
0001 - FILTERED SAMPLE (.45 MICRONS) 
TABLE 3.49. BACKGROUND GROUNDWATER QUALITY DATE BY PARAMETER FOR THE MIDDLE SANDSTONE UNIT, BURRO CANYON DISPOSAL SITE, SLICK ROCK, COLORADO MIDDLE SANDSTONE UNIT, BURRO CANYO DANYON)

SITE: SRK02 BORROW SIT

REPORT DATE: $03 / 02 / 94$

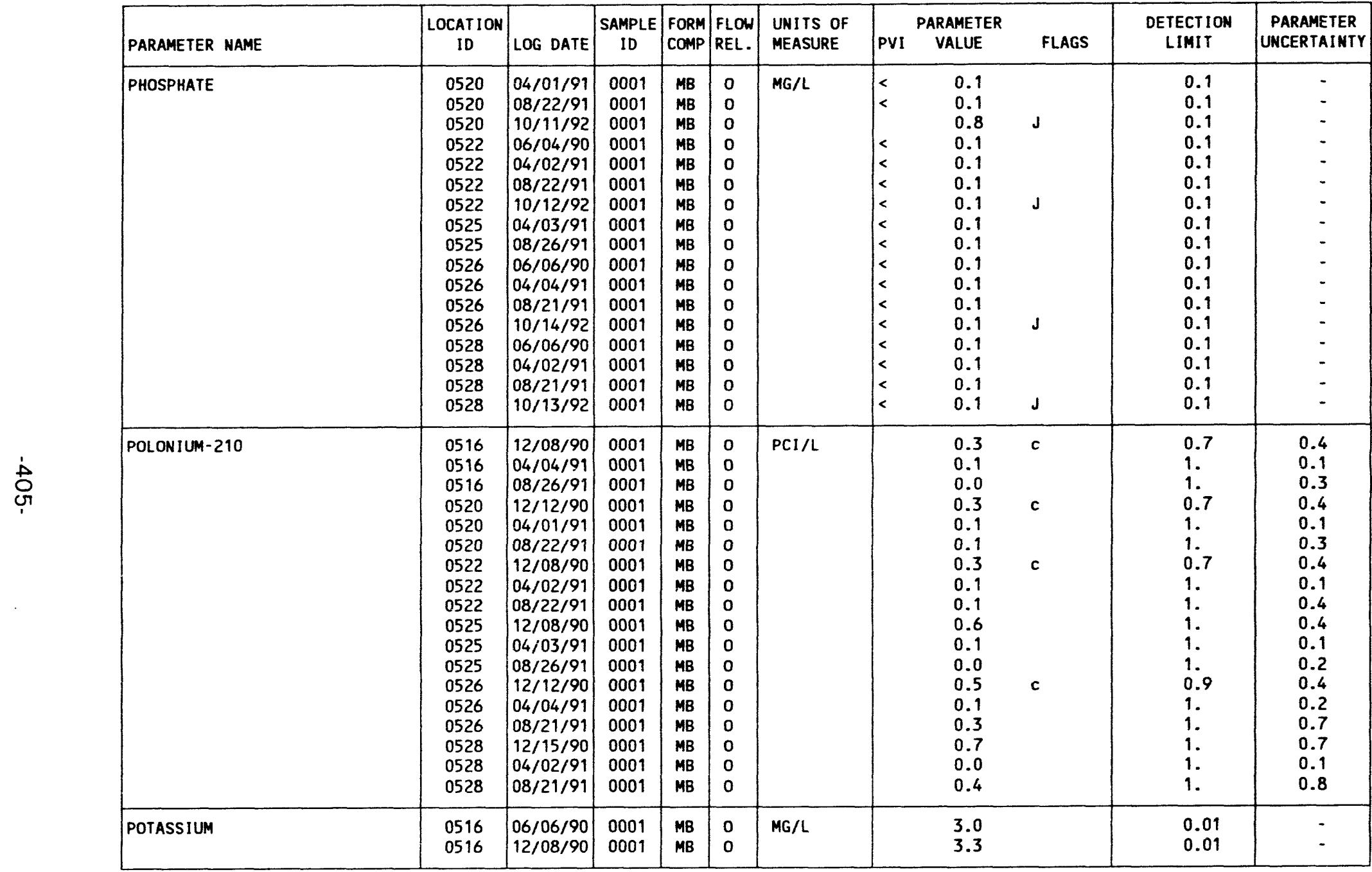

FORMATION OF COMPLETION COOE:

MB - MIDDLE BURRO CANYON

PARAMETER VALUE INDICATOR (PVI): < - LESS THAN DETECTION LIMIT

OTHER PARAMETER VALUE FLAGS:

$J$ - ESTIMATED VALUE

c - CHANGED DETECTION LIMIT
FLOW RELATIONSHIP CODE:

O- ON-SITE

SAMPLE ID CODES:

0001 - FILTERED SAMPLE (.45 MICRONS) 
TABLE 3.49. BACKGROUND GROUNDHATER QUALITY DATE BY PARAMETER FOR THE MIDDLE SANDSTONE UNIT, BURRO CANYON DISPOSAL SITE, SLICK ROCK, COLORADO SITE: SRK02 BORROW SITE 1 (BURRO CANYON)

06/04/90 TO $10 / 14 / 92$

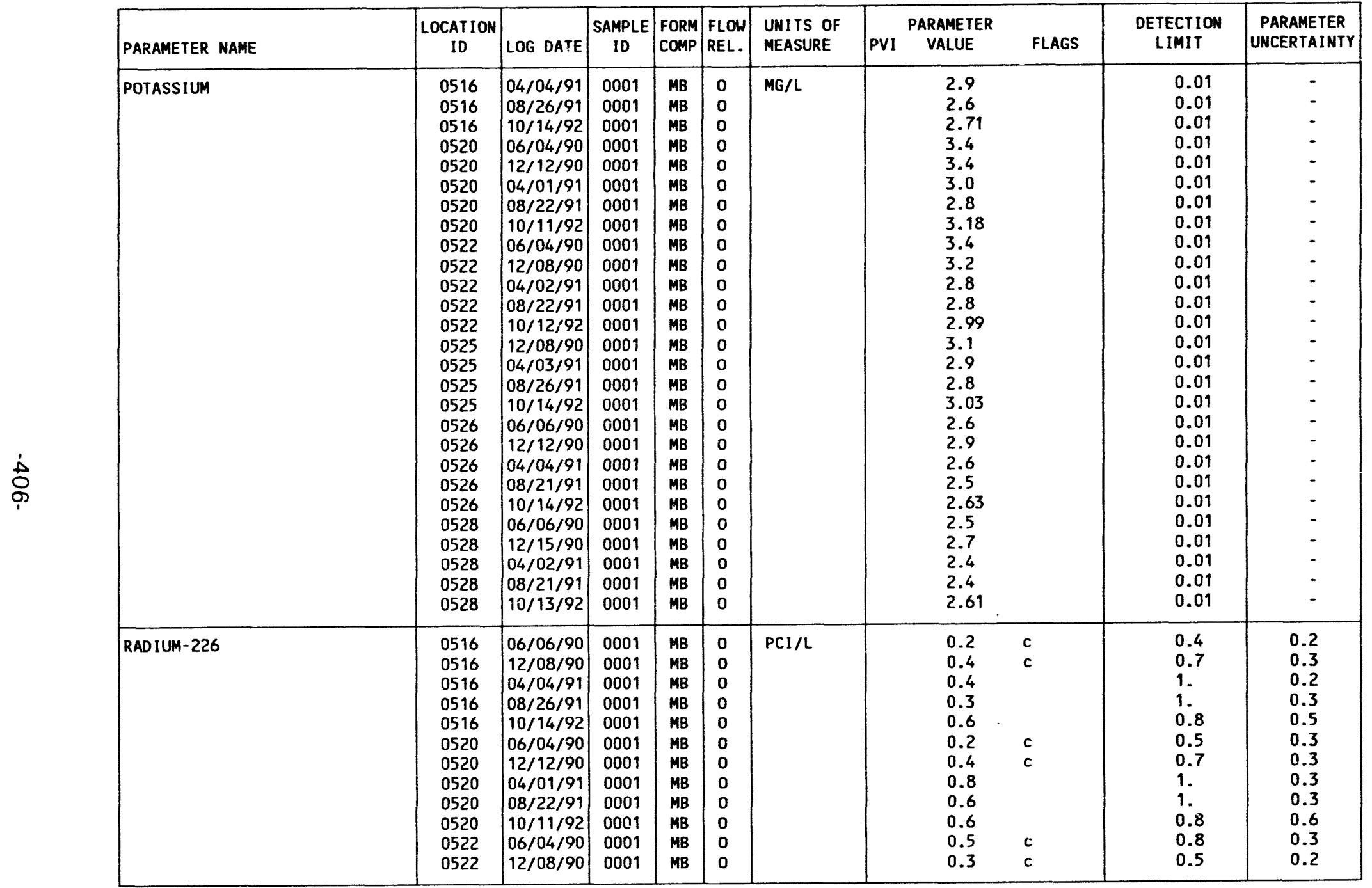

FORMATION OF COMPLETION CODE:

MB - MIDDLE BURRO CANYON

PARAMETER VALUE INDICATOR (PVI): < - LESS THAN DETECTION LIMIT
FLOW RELATIONSHIP CODE:

O - ON-SITE

SAMPLE ID CODES:

0001 - FILTERED SAMPLE (.45 MICRONS)

OTHER PARAMETER VALUE FLAGS :

C - CHANGED DETECTION LIMIT 
TABLE 3.49. BACKGROUND GROUHDWATER QUALITY DATE BY PARAMETER FOR THE

MIDDLE SANDSTONE UNIT, BURRO CANYON DISPOSAL SITE, SLICK ROCK, COLORADO SITE: SRKO2 BORROW SITE 1 (BURRO CANYON)

06/04/90 TO $10 / 14 / 92$

REPORT DATE : 03/02/94

\begin{tabular}{|c|c|c|c|c|c|c|c|c|c|c|c|}
\hline PARAMETER NAME & $\begin{array}{l}\text { LOCATION } \\
\text { ID }\end{array}$ & LOG DATE & $\begin{array}{c}\text { SAMPLE } \\
\text { ID }\end{array}$ & $\begin{array}{l}\text { FORM } \\
\text { COMP }\end{array}$ & $\begin{array}{l}\text { FLOW } \\
\text { REL. }\end{array}$ & $\begin{array}{l}\text { UNITS OF } \\
\text { MEASURE }\end{array}$ & PVI & $\begin{array}{l}\text { ARAMETE } \\
\text { VALUE }\end{array}$ & FLAG & $\begin{array}{l}\text { DETECTION } \\
\text { LIMIT }\end{array}$ & $\begin{array}{l}\text { PARAMETER } \\
\text { UNCERTAINTY }\end{array}$ \\
\hline RADIUM-226 & $\begin{array}{l}0522 \\
0522 \\
0522 \\
0525 \\
0525 \\
0525 \\
0525 \\
0526 \\
0526 \\
0526 \\
0526 \\
0526 \\
0528 \\
0528 \\
0528 \\
0528 \\
0528\end{array}$ & $\begin{array}{l}04 / 02 / 91 \\
08 / 22 / 91 \\
10 / 12 / 92 \\
12 / 08 / 90 \\
04 / 03 / 91 \\
08 / 26 / 91 \\
10 / 14 / 92 \\
06 / 06 / 90 \\
12 / 12 / 90 \\
04 / 04 / 91 \\
08 / 21 / 91 \\
10 / 14 / 92 \\
06 / 06 / 90 \\
12 / 15 / 90 \\
04 / 02 / 91 \\
08 / 21 / 91 \\
10 / 13 / 92\end{array}$ & $\begin{array}{l}0001 \\
0001 \\
0001 \\
0001 \\
0001 \\
0001 \\
0001 \\
0001 \\
0001 \\
0001 \\
0001 \\
0001 \\
0001 \\
0001 \\
0001 \\
0001 \\
0001\end{array}$ & $\begin{array}{l}\text { MB } \\
\text { MB } \\
M B \\
M B \\
M B \\
M B \\
M B \\
M B \\
M B \\
M B \\
M B \\
M B \\
M B \\
M B \\
M B \\
M B \\
M B\end{array}$ & $\begin{array}{l}0 \\
0 \\
0 \\
0 \\
0 \\
0 \\
0 \\
0 \\
0 \\
0 \\
0 \\
0 \\
0 \\
0 \\
0 \\
0 \\
0\end{array}$ & $\mathrm{PCI} / \mathrm{L}$ & & $\begin{array}{l}0.6 \\
0.3 \\
0.9 \\
0.3 \\
0.4 \\
0.6 \\
0.0 \\
0.1 \\
0.2 \\
0.8 \\
0.9 \\
0.5 \\
0.2 \\
0.7 \\
0.8 \\
0.8 \\
1.0\end{array}$ & $\begin{array}{l}\text { C } \\
\text { c } \\
\text { c } \\
\text { c }\end{array}$ & $\begin{array}{l}1 . \\
1 . \\
0.8 \\
0.5 \\
1 . \\
1 . \\
0.8 \\
0.3 \\
0.4 \\
1 . \\
1 . \\
0.8 \\
0.4 \\
1 . \\
1 . \\
1 . \\
0.8\end{array}$ & $\begin{array}{l}0.2 \\
0.3 \\
0.6 \\
0.2 \\
0.2 \\
0.3 \\
0.5 \\
0.2 \\
0.2 \\
0.3 \\
0.4 \\
0.5 \\
0.2 \\
0.3 \\
0.3 \\
0.4 \\
0.6\end{array}$ \\
\hline RADIUM- 226 + RADIUM-228 & $\begin{array}{l}0516 \\
0516 \\
0516 \\
0516 \\
0516 \\
0520 \\
0520 \\
0520 \\
0520 \\
0520 \\
0522 \\
0522 \\
0522 \\
0522 \\
0522 \\
0525 \\
0525 \\
0525 \\
0525 \\
0526 \\
0526 \\
0526\end{array}$ & $\begin{array}{l}06 / 06 / 90 \\
12 / 08 / 90 \\
04 / 04 / 91 \\
08 / 26 / 91 \\
10 / 14 / 92 \\
06 / 04 / 90 \\
12 / 12 / 90 \\
04 / 01 / 91 \\
08 / 22 / 91 \\
10 / 11 / 92 \\
06 / 04 / 90 \\
12 / 08 / 90 \\
04 / 02 / 91 \\
08 / 22 / 91 \\
10 / 12 / 92 \\
12 / 08 / 90 \\
04 / 03 / 91 \\
08 / 26 / 91 \\
10 / 14 / 92 \\
06 / 06 / 90 \\
12 / 12 / 90 \\
04 / 04 / 91\end{array}$ & $\begin{array}{l}0001 \\
0001 \\
0001 \\
0001 \\
0001 \\
0001 \\
0001 \\
0001 \\
0001 \\
0001 \\
0001 \\
0001 \\
0001 \\
0001 \\
0001 \\
0001 \\
0001 \\
0001 \\
0001 \\
0001 \\
0001 \\
0001\end{array}$ & 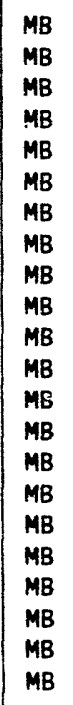 & $\begin{array}{l}0 \\
0 \\
0 \\
0 \\
0 \\
0 \\
0 \\
0 \\
0 \\
0 \\
0 \\
0 \\
0 \\
0 \\
0 \\
0 \\
0 \\
0 \\
0 \\
0 \\
0 \\
0\end{array}$ & $\mathrm{PCI} / \mathrm{L}$ & & $\begin{array}{l}2.40 \\
2.00 \\
8.20 \\
0.30 \\
0.60 \\
0.70 \\
2.50 \\
2.70 \\
0.60 \\
1.30 \\
1.60 \\
2.60 \\
3.30 \\
0.30 \\
1.80 \\
1.90 \\
0.40 \\
0.90 \\
4.80 \\
1.80 \\
3.00 \\
1.90\end{array}$ & & $\begin{array}{l}- \\
- \\
- \\
- \\
- \\
- \\
- \\
- \\
- \\
- \\
- \\
- \\
- \\
- \\
- \\
- \\
- \\
-\end{array}$ & $\begin{array}{l}- \\
- \\
- \\
- \\
- \\
- \\
- \\
- \\
- \\
- \\
- \\
- \\
- \\
- \\
- \\
- \\
-\end{array}$ \\
\hline
\end{tabular}

FORMATION OF COMPLETION COOE:

MB - MIDDLE BURRO CANYON

PARAMETER VALUE INDICATOR (PVI): < - LESS THAN DETECTION LIMIT
FLOW RELATIONSHIP CODE:

O- ON-SITE

0001 - FILTERED SAMPLE (.45 MICRONS)

OTHER PARAMETER VALUE FLAGS:

C - CHANGED DETECTION LIMIT 
TABLE 3.49. BACKGROUND GROUNDWATER QUALITY DATE BY PARAMETER FOR THE MIDDLE SANDSTONE UNIT BURRO CANYON DISPOSAL SITE, SLICK ROCK, COLORADO SITE: SRKO2 BORROH SITE 1 (BURRO CANYON)

06/04/90 TO $10 / 14 / 92$

$102 / 94$

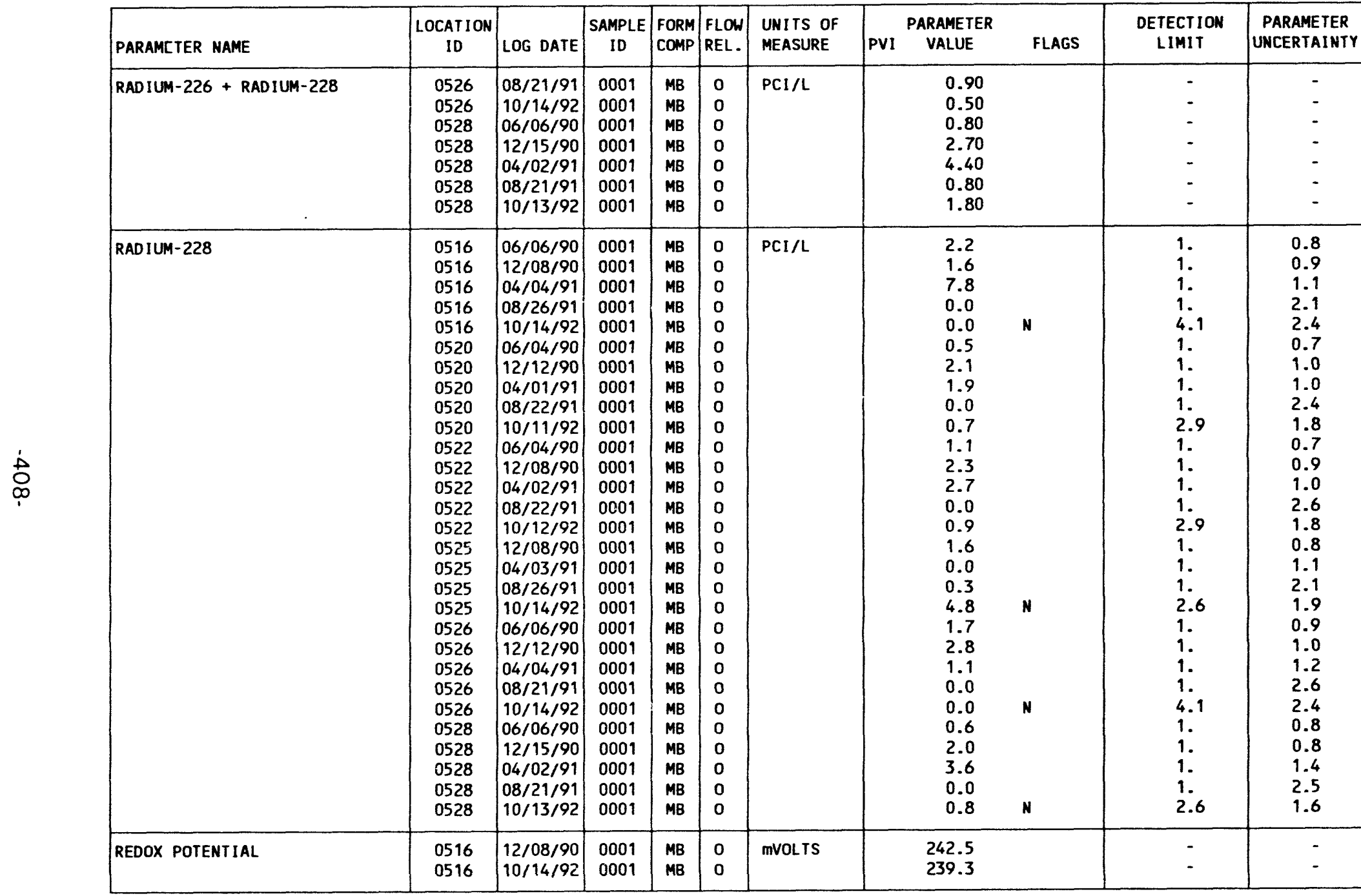

FORMATION OF COMPLETION CODE:

MB - MIDDLE BURRO CANYON

PARAMETER VALUE INDICATOR (PVI): < - LESS THAN DETECTION LIMIT
FLOW RELATIONSHIP COOE:

O - ON-SITE

SAMPLE ID CODES:

0001 - FILTERED SAMPLE (.45 MICRONS)

OTHER PARAMETER VALUE FLAGS:

N - SPIKE SAMPLE RECOVERY NOT WITHIN CONTROL LIMITS 
TABLE 3.49. BACKGROUND GROUNDWATER OUALITY DATE BY PARAMETER FOR THE

MABLE 3.49. BACKGROUND GROUNDWATER OUALITY DATE BY PARAMETER FOR THE MIDDLE SAMDSTONE UNIT, BURRO CANYON DISPOSAL
SITE: SRKO2 BORROU SITE 1 (BURRO CANYON)

SITE: SRKO2 BORROW SIT

REPORT DATE: 03/02/94

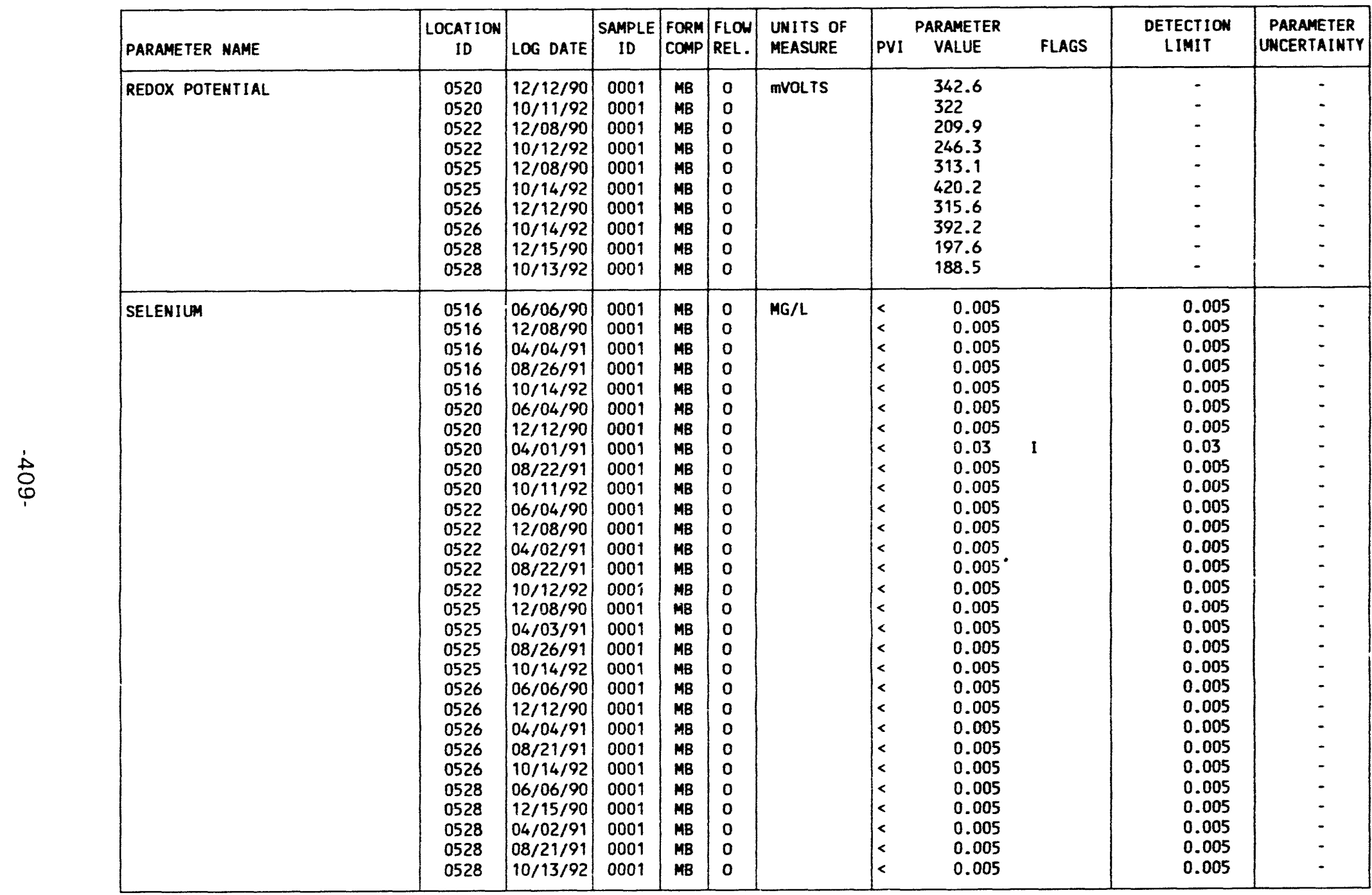

FORMATION OF COMPLETION COOE:

MB - MIDDLE BURRO CANYON

PARAMETER VALUE INDICATOR (PVI): < - LESS THAN DETECTION LIMIT

OTHER PARAMETER VALUE FLAGS:

I - INCREASED DETECTICN LIMIT DUE TO REQUIRED DILUTION
FLON RELATIONSHIP CODE:

O- ON-SITE

SAMPLE ID CODES:

0001 - FILTERED SAMPLE (.45 MICROWS) 
TABLE 3.49. BACKGROUND GROUNJWATER QUALITY DATE BY PARAMETER FOR THE MIDDLE SANDSTONE UNIT, BURRO CANYON DISPOSAL SITE, SLICK ROCK, COLORADO SIIE: SRKO2 BORROW SITE 1 (BURRO CANYON)

06/04/90 TO $10 / 14 / 92$

REPORT DATE: $03 / 02 / 94$

\begin{tabular}{|c|c|c|c|c|c|c|c|c|c|c|}
\hline PARAMETER NAME & $\begin{array}{c}\text { LOCATION } \\
\text { ID }\end{array}$ & LOG DATE & $\begin{array}{c}\text { SAMPLE } \\
\text { ID }\end{array}$ & $\begin{array}{l}\text { FORM } \\
\text { COMP }\end{array}$ & $\begin{array}{l}\text { FLOW } \\
\text { REL. }\end{array}$ & $\begin{array}{l}\text { UNITS OF } \\
\text { MEASURE }\end{array}$ & PVI & $\begin{array}{l}\text { PARAMETER } \\
\text { VALUE }\end{array}$ & $\begin{array}{l}\text { DETECTION } \\
\text { LIMIT }\end{array}$ & $\begin{array}{l}\text { PARAMETER } \\
\text { UNCERTAINTY }\end{array}$ \\
\hline SILICA - SI02 & $\begin{array}{l}0516 \\
0516 \\
0516 \\
0516 \\
0516 \\
0520 \\
0520 \\
0520 \\
0520 \\
0520 \\
0522 \\
0522 \\
0522 \\
0522 \\
0522 \\
0525 \\
0525 \\
0525 \\
0525 \\
0526 \\
0526 \\
0526 \\
0526 \\
0526 \\
0528 \\
0528 \\
0528 \\
0528 \\
0528\end{array}$ & $\begin{array}{l}06 / 06 / 90 \\
12 / 08 / 90 \\
04 / 04 / 91 \\
08 / 26 / 91 \\
10 / 14 / 92 \\
06 / 04 / 90 \\
12 / 12 / 90 \\
04 / 01 / 91 \\
08 / 22 / 91 \\
10 / 11 / 92 \\
06 / 04 / 90 \\
12 / 08 / 90 \\
04 / 02 / 91 \\
08 / 22 / 91 \\
10 / 12 / 92 \\
12 / 08 / 90 \\
04 / 03 / 91 \\
08 / 26 / 91 \\
10 / 14 / 92 \\
06 / 06 / 90 \\
12 / 12 / 90 \\
04 / 04 / 91 \\
08 / 21 / 91 \\
10 / 14 / 92 \\
06 / 06 / 90 \\
12 / 15 / 90 \\
04 / 02 / 91 \\
08 / 21 / 91 \\
10 / 13 / 92\end{array}$ & $\begin{array}{l}0001 \\
0001 \\
0001 \\
0001 \\
0001 \\
0001 \\
0001 \\
0001 \\
0001 \\
0001 \\
0001 \\
0001 \\
0001 \\
0001 \\
0001 \\
0001 \\
0001 \\
0001 \\
0001 \\
0001 \\
0001 \\
0001 \\
0001 \\
0001 \\
0001 \\
0001 \\
0001 \\
0001 \\
0001\end{array}$ & $\begin{array}{l}\text { MB } \\
\text { MB } \\
\text { MB } \\
\text { MB } \\
\text { MB } \\
\text { MB } \\
\text { MB } \\
\text { MB } \\
\text { MB } \\
\text { MB } \\
\text { MB } \\
\text { MB } \\
\text { MB } \\
\text { MB } \\
\text { MB } \\
\text { MB } \\
\text { MB } \\
\text { MB } \\
\text { MB } \\
\text { MB } \\
\text { MB } \\
\text { MB } \\
\text { MB } \\
\text { MB } \\
\text { MB } \\
\text { MB } \\
\text { MB } \\
\text { MB } \\
\text { MB }\end{array}$ & $\begin{array}{l}0 \\
0 \\
0 \\
0 \\
0 \\
0 \\
0 \\
0 \\
0 \\
0 \\
0 \\
0 \\
0 \\
0 \\
0 \\
0 \\
0 \\
0 \\
0 \\
0 \\
0 \\
0 \\
0 \\
0 \\
0 \\
0 \\
0 \\
0 \\
0\end{array}$ & $M G / L$ & & $\begin{array}{l}14 . \\
14 . \\
12.6 \\
12.6 \\
13.3 \\
14 . \\
14 . \\
13.5 \\
14.0 \\
14.2 \\
13 . \\
13 . \\
13.3 \\
13.4 \\
13.3 \\
13 . \\
12.5 \\
12.8 \\
13.0 \\
14 . \\
13 . \\
13.2 \\
13.5 \\
13.6 \\
14 . \\
14 . \\
13.4 \\
13.7 \\
13.8\end{array}$ & $\begin{array}{l}2 . \\
2 . \\
0.1 \\
0.1 \\
0.1 \\
2 . \\
2 . \\
0.1 \\
0.1 \\
0.1 \\
2.1 \\
2.1 \\
0.1 \\
0.1 \\
0.1 \\
2 . \\
0.1 \\
0.1 \\
0.1 \\
2 . \\
2 . \\
0.1 \\
0.1 \\
0.1 \\
2 . \\
2 . \\
0.1 \\
0.1 \\
0.1\end{array}$ & $\begin{array}{l}- \\
- \\
- \\
- \\
- \\
- \\
- \\
- \\
- \\
- \\
- \\
- \\
- \\
- \\
- \\
- \\
- \\
- \\
- \\
- \\
- \\
-\end{array}$ \\
\hline SILVER & $\begin{array}{l}0516 \\
0516 \\
0516 \\
0516 \\
0520 \\
0520 \\
0520 \\
0520 \\
0522 \\
0522 \\
0522\end{array}$ & $\begin{array}{l}06 / 06 / 90 \\
12 / 08 / 90 \\
04 / 04 / 91 \\
08 / 26 / 91 \\
06 / 04 / 90 \\
12 / 12 / 90 \\
04 / 01 / 91 \\
08 / 22 / 91 \\
06 / 04 / 90 \\
12 / 08 / 90 \\
04 / 02 / 91\end{array}$ & $\begin{array}{l}0001 \\
0001 \\
0001 \\
0001 \\
0001 \\
0001 \\
0001 \\
0001 \\
0001 \\
0001 \\
0001\end{array}$ & $\begin{array}{l}\text { MB } \\
\text { MB } \\
\text { MB } \\
\text { MB } \\
\text { MB } \\
\text { MB } \\
\text { MB } \\
\text { MB } \\
\text { MB } \\
\text { MB } \\
\text { MB }\end{array}$ & $\begin{array}{l}0 \\
0 \\
0 \\
0 \\
0 \\
0 \\
0 \\
0 \\
0 \\
0 \\
0\end{array}$ & $M G / L$ & $\begin{array}{l}< \\
< \\
< \\
< \\
< \\
< \\
< \\
< \\
< \\
< \\
<\end{array}$ & $\begin{array}{l}0.01 \\
0.01 \\
0.01 \\
0.01 \\
0.01 \\
0.01 \\
0.01 \\
0.01 \\
0.01 \\
0.01 \\
0.01\end{array}$ & $\begin{array}{l}0.01 \\
0.01 \\
0.01 \\
0.01 \\
0.01 \\
0.01 \\
0.01 \\
0.01 \\
0.01 \\
0.01 \\
0.01\end{array}$ & $\begin{array}{l}- \\
- \\
- \\
- \\
- \\
- \\
- \\
-\end{array}$ \\
\hline
\end{tabular}

FORMATION OF LOMPLETION CODE:

MB - MIDDIE BURRO CANYON

FLOW RELATIONSHIP CODE:

PARAMETER VALUE INDICATOR (PVI): < - LESS THAN DETECTION LIMIT SAMPLE ID CODES:

0001 - FILTERED SAMPLE (.45 MICRONS) 
TABLE 3.49. BACKGROUND GROUNDUATER QUALITY DATE BY PARAMETER FOR THE

MIDDLE SANDSTONE UNIT, BURRO CANYON DISPOSAL SITE, SLICK ROCK, COLORADO

SITE: SRKO2 BORROA SITE 1 (BURRO CANYON)

06/04/90 TO 10/14/92

REPORT DATE : 03/02/94

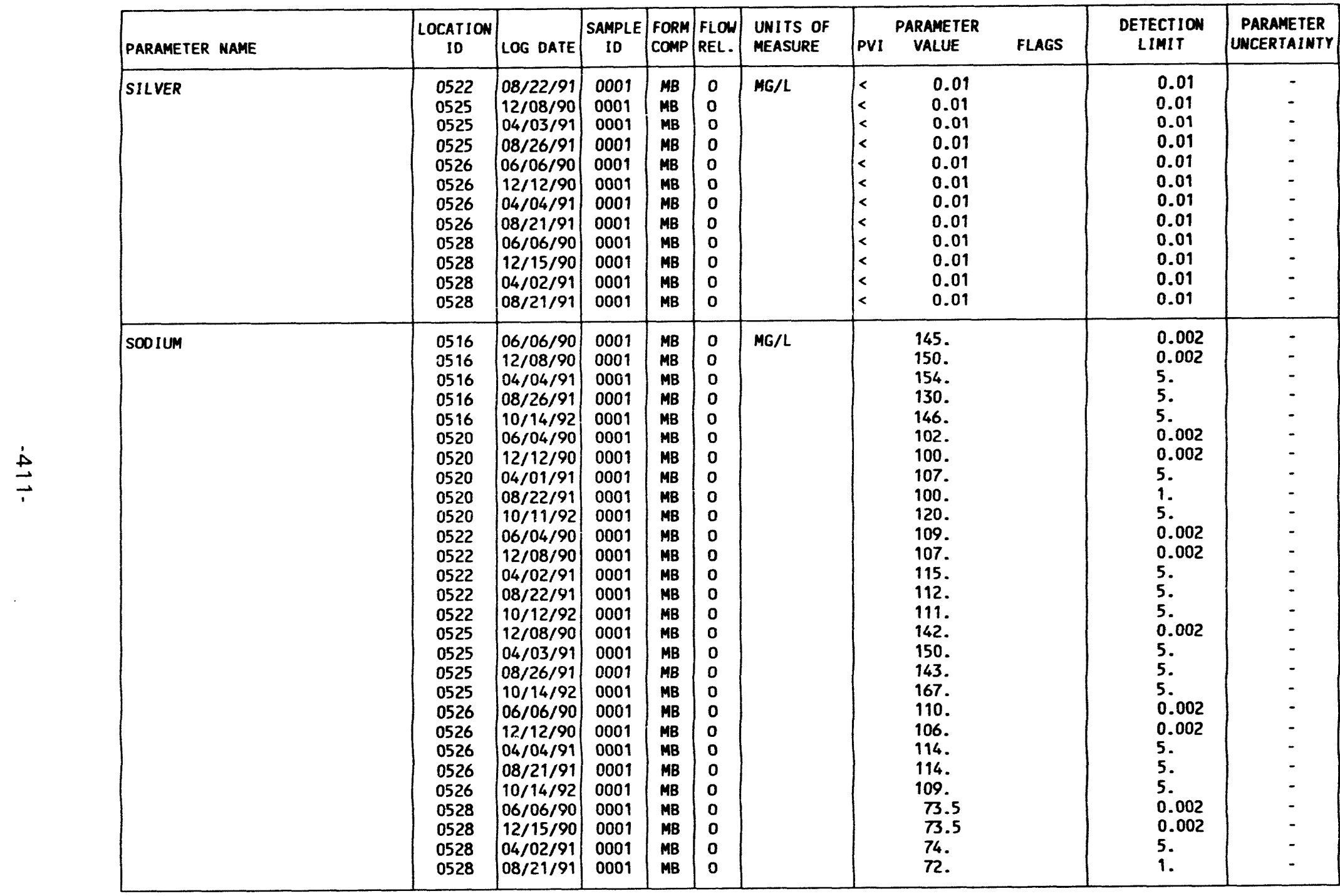

FOPMATION OF COMPLETION CODE:

MB - MIDDLE BURRO CANYON

FLOW RELATIONSHIP COOE:

PARAMETER VALUE INDICATOR (PVI): < - LESS THAN DETECTION LIMIT

O - ON-SITE

SAMPLE ID CODES

0001 - FILTERED SAMPLE (.45 MICRONS) 
TABLE 3.49. BACKGROUND GROUNDWATER QUALITY DATE BY PARAMETER FOR THE MIDDLE SANDSTONE UNIT, BURRO CANYON DISPOSAL SITE, SLICK ROCK, COLORADO SITE: SRK02 BORROW SITE 1 (BURRO CANYON)

06/04/90 TO $10 / 14 / 92$

REPORT DATE: $03 / 02 / 94$

\begin{tabular}{|c|c|c|c|c|c|c|c|c|c|c|}
\hline PARAMETER NAME & $\begin{array}{c}\text { LOCATION } \\
\text { ID }\end{array}$ & LOG DATE & $\begin{array}{c}\text { SAMPLE } \\
\text { ID }\end{array}$ & $\begin{array}{l}\text { FORM } \\
\text { COMP }\end{array}$ & $\begin{array}{l}\text { FLOW } \\
\text { REL. }\end{array}$ & $\begin{array}{l}\text { UNITS OF } \\
\text { MEASURE }\end{array}$ & $\begin{array}{ll} & \text { PARAMETER } \\
\text { PVI } & \text { VALUE }\end{array}$ & FLAGS & $\begin{array}{l}\text { DETECTION } \\
\text { LIMIT }\end{array}$ & $\begin{array}{l}\text { PARAMETER } \\
\text { UNCERTAINTY }\end{array}$ \\
\hline SOOIUM & 0528 & $10 / 13 / 92$ & 0001 & MB & 0 & $M G / L$ & 75. & & 1. & - \\
\hline SPECIFIC CONDUCTANCE & $\begin{array}{l}0516 \\
0516 \\
0516 \\
0516 \\
0520 \\
0520 \\
0520 \\
0520 \\
0520 \\
0522 \\
0522 \\
0522 \\
0522 \\
0525 \\
0525 \\
0525 \\
0525 \\
0526 \\
0526 \\
0526 \\
0526 \\
0526 \\
0528 \\
0528 \\
0528 \\
0528 \\
0528\end{array}$ & $\begin{array}{l}06 / 06 / 90 \\
04 / 04 / 91 \\
08 / 26 / 91 \\
10 / 14 / 92 \\
06 / 04 / 90 \\
12 / 12 / 90 \\
04 / 01 / 91 \\
08 / 22 / 91 \\
10 / 11 / 92 \\
06 / 04 / 90 \\
04 / 02 / 91 \\
08 / 22 / 91 \\
10 / 12 / 92 \\
06 / 04 / 90 \\
04 / 03 / 91 \\
08 / 26 / 91 \\
10 / 14 / 92 \\
06 / 06 / 90 \\
12 / 12 / 90 \\
04 / 04 / 91 \\
08 / 21 / 91 \\
10 / 14 / 92 \\
06 / 06 / 90 \\
12 / 15 / 90 \\
04 / 02 / 91 \\
08 / 21 / 91 \\
10 / 13 / 92\end{array}$ & $\begin{array}{l}0001 \\
0001 \\
0001 \\
0001 \\
0001 \\
0001 \\
0001 \\
0001 \\
0001 \\
0001 \\
0001 \\
0001 \\
0001 \\
0001 \\
0001 \\
0001 \\
0001 \\
0001 \\
0001 \\
0001 \\
0001 \\
0001 \\
0001 \\
0001 \\
0001 \\
0001 \\
0001\end{array}$ & $\begin{array}{l}\text { MB } \\
M B \\
M B \\
M B \\
M B \\
M B \\
M B \\
M B \\
M B \\
M B \\
M B \\
M B \\
M B \\
M B \\
M B \\
M B \\
M B \\
M B \\
\text { MB } \\
M B \\
M B \\
M B \\
M B \\
M B \\
M B \\
M B \\
M B\end{array}$ & $\begin{array}{l}0 \\
0 \\
0 \\
0 \\
0 \\
0 \\
0 \\
0 \\
0 \\
0 \\
0 \\
0 \\
0 \\
0 \\
0 \\
0 \\
0 \\
0 \\
0 \\
0 \\
0 \\
0 \\
0 \\
0 \\
0 \\
0 \\
0\end{array}$ & UMHO/CM & $\begin{array}{c}780 . \\
984 . \\
977 \\
820 \\
900 . \\
944 . \\
1036 . \\
1034 \\
848 \\
700 . \\
925 . \\
935 \\
748 \\
780 . \\
1052 . \\
1038 \\
930 \\
550 . \\
850 . \\
874 . \\
860 \\
708 \\
620 . \\
756 . \\
766 . \\
588 \\
536\end{array}$ & & $\begin{array}{l}- \\
- \\
- \\
- \\
- \\
- \\
- \\
- \\
- \\
- \\
- \\
- \\
- \\
- \\
- \\
- \\
- \\
- \\
- \\
- \\
-\end{array}$ & $\begin{array}{l}- \\
- \\
- \\
- \\
- \\
- \\
- \\
- \\
- \\
- \\
- \\
- \\
- \\
- \\
- \\
- \\
- \\
- \\
- \\
- \\
- \\
- \\
-\end{array}$ \\
\hline STRONT IUM & $\begin{array}{l}0516 \\
0516 \\
0516 \\
0516 \\
0516 \\
0520 \\
0520 \\
0520 \\
0520 \\
0520 \\
0522\end{array}$ & $\begin{array}{l}06 / 06 / 90 \\
12 / 08 / 90 \\
04 / 04 / 91 \\
08 / 26 / 91 \\
; 0 / 14 / 92 \\
06 / 04 / 90 \\
12 / 12 / 90 \\
04 / 01 / 91 \\
08 / 22 / 91 \\
10 / 11 / 92 \\
06 / 04 / 90\end{array}$ & $\begin{array}{l}0001 \\
0001 \\
0001 \\
0001 \\
0001 \\
0001 \\
0001 \\
0001 \\
0001 \\
0001 \\
0001\end{array}$ & $\begin{array}{l}\text { MB } \\
\text { MB } \\
\text { MB } \\
\text { MB } \\
\text { MB } \\
\text { MB } \\
\text { MB } \\
\text { MB } \\
\text { MB } \\
\text { MB } \\
\text { MB }\end{array}$ & $\begin{array}{l}0 \\
0 \\
0 \\
0 \\
0 \\
0 \\
0 \\
0 \\
0 \\
0 \\
0\end{array}$ & $M G / L$ & $\begin{array}{l}3.81 \\
3.8 \\
3.98 \\
3.43 \\
3.74 \\
5.83 \\
5.7 \\
6.12 \\
5.81 \\
5.44 \\
3.12\end{array}$ & & $\begin{array}{l}0.1 \\
0.1 \\
0.01 \\
0.01 \\
0.01 \\
0.1 \\
0.1 \\
0.01 \\
0.01 \\
0.01 \\
0.1\end{array}$ & $\begin{array}{l}- \\
- \\
- \\
- \\
- \\
- \\
- \\
-\end{array}$ \\
\hline
\end{tabular}

FORMATION OF COMPLETION CODE:

MB - MIDDLE BURRO CANYON

PARAMETER VALUE INDICATOR (PVI): < - LESS tHAN DETECTION LIMIT
FLOW RELATIONSHIP CODE:

SAMPLE ID CODES:

0001 - FILTERED SAMPLE (.45 MICRONS) 
TABLE 3.49. BACKGROUND GROUNDWATER QUALITY DATE BY PARAMETER FOR THE MIDDLE SANDSTONE UNIT, BURRO CANYON DISPOSAL SITE, SLICK ROCK, COLORADO MIDDLE SANDSTONE UNIT, BURRO CANYON DISPOSAI

SITE: SRKO2 BORROW SIT

06/04/90 TO $10 / 14 / 92$

\begin{tabular}{|c|c|c|c|c|c|c|c|c|c|c|}
\hline PARAMETER NAME & $\begin{array}{c}\text { LOCATION } \\
\text { ID }\end{array}$ & LOG DATE & $\begin{array}{c}\text { SAMPLE } \\
\text { ID }\end{array}$ & $\begin{array}{l}\text { FORM } \\
\text { COMP }\end{array}$ & $\begin{array}{l}\text { FLOW } \\
\text { REL. }\end{array}$ & $\begin{array}{l}\text { UNITS OF } \\
\text { MEASURE }\end{array}$ & PVI & $\begin{array}{l}\text { ARAMETER } \\
\text { VALUE }\end{array}$ & $\begin{array}{l}\text { DETECTION } \\
\text { LIMIT }\end{array}$ & $\begin{array}{l}\text { PARAMETER } \\
\text { UNCERTAINTY }\end{array}$ \\
\hline STRONTIUM & $\begin{array}{l}0522 \\
0522 \\
0522 \\
0522 \\
0525 \\
0525 \\
0525 \\
0525 \\
0526 \\
0526 \\
0526 \\
0526 \\
0526 \\
0528 \\
0528 \\
0528 \\
0528 \\
0528\end{array}$ & $\begin{array}{l}12 / 08 / 90 \\
04 / 02 / 91 \\
08 / 22 / 91 \\
10 / 12 / 92 \\
12 / 08 / 90 \\
04 / 03 / 91 \\
08 / 26 / 91 \\
10 / 14 / 92 \\
06 / 06 / 90 \\
12 / 12 / 90 \\
04 / 04 / 91 \\
08 / 21 / 91 \\
10 / 14 / 92 \\
06 / 06 / 90 \\
12 / 15 / 90 \\
04 / 02 / 91 \\
08 / 21 / 91 \\
10 / 13 / 92\end{array}$ & $\begin{array}{l}0001 \\
0001 \\
0001 \\
0001 \\
0001 \\
0001 \\
0001 \\
0001 \\
0001 \\
0001 \\
0001 \\
0001 \\
0001 \\
0001 \\
0001 \\
0001 \\
0001 \\
0001\end{array}$ & $\begin{array}{l}\text { MB } \\
\text { MB } \\
\text { MB } \\
\text { MB } \\
\text { MB } \\
\text { MB } \\
\text { MB } \\
\text { MB } \\
\text { MB } \\
\text { MB } \\
\text { MB } \\
\text { MB } \\
\text { MB } \\
\text { MB } \\
\text { MB } \\
\text { MB } \\
M B \\
M B\end{array}$ & $\begin{array}{l}0 \\
0 \\
0 \\
0 \\
0 \\
0 \\
0 \\
0 \\
0 \\
0 \\
0 \\
0 \\
0 \\
0 \\
0 \\
0 \\
0 \\
0\end{array}$ & $M G / L$ & & $\begin{array}{l}3.1 \\
3.49 \\
3.22 \\
2.98 \\
4.4 \\
4.95 \\
4.60 \\
5.41 \\
3.85 \\
3.4 \\
3.94 \\
3.68 \\
3.51 \\
3.11 \\
2.9 \\
3.16 \\
3.03 \\
2.94\end{array}$ & $\begin{array}{l}0.1 \\
0.01 \\
0.01 \\
0.01 \\
0.1 \\
0.01 \\
0.01 \\
0.01 \\
0.1 \\
0.1 \\
0.01 \\
0.01 \\
0.01 \\
0.1 \\
0.1 \\
0.01 \\
0.01 \\
0.01\end{array}$ & $\begin{array}{l}- \\
- \\
- \\
- \\
- \\
- \\
- \\
- \\
- \\
- \\
- \\
- \\
- \\
-\end{array}$ \\
\hline SULFATE & $\begin{array}{l}0516 \\
0516 \\
0516 \\
0516 \\
0520 \\
0520 \\
0520 \\
0520 \\
0522 \\
0522 \\
0522 \\
0522 \\
0525 \\
0525 \\
0525 \\
0526 \\
0526 \\
0526 \\
0526 \\
0528 \\
0528 \\
0528\end{array}$ & $\begin{array}{l}06 / 06 / 90 \\
04 / 04 / 91 \\
08 / 26 / 91 \\
10 / 14 / 92 \\
06 / 04 / 90 \\
04 / 01 / 91 \\
08 / 22 / 91 \\
10 / 11 / 92 \\
06 / 04 / 90 \\
04 / 02 / 91 \\
08 / 22 / 91 \\
10 / 12 / 92 \\
04 / 03 / 91 \\
08 / 26 / 91 \\
10 / 14 / 92 \\
05 / 06 / 90 \\
04 / 04 / 91 \\
08 / 21 / 91 \\
10 / 14 / 92 \\
06 / 06 / 90 \\
04 / 02 / 91 \\
08 / 21 / 91\end{array}$ & $\begin{array}{l}0001 \\
0001 \\
0001 \\
0001 \\
0001 \\
0001 \\
0001 \\
0001 \\
0001 \\
0001 \\
0001 \\
0001 \\
0001 \\
0001 \\
0001 \\
0001 \\
0001 \\
0001 \\
0001 \\
0001 \\
0001 \\
0001\end{array}$ & $\begin{array}{l}\text { MB } \\
\text { MB } \\
\text { MB } \\
\text { MB } \\
\text { MB } \\
\text { MB } \\
\text { MB } \\
\text { MB } \\
\text { MB } \\
\text { MB } \\
\text { MB } \\
\text { MB } \\
\text { MB } \\
\text { MB } \\
\text { MB } \\
\text { MB } \\
\text { MB } \\
\text { MB } \\
\text { MB } \\
\text { MB } \\
\text { MB } \\
\text { MB }\end{array}$ & $\begin{array}{l}0 \\
0 \\
0 \\
0 \\
0 \\
0 \\
0 \\
0 \\
0 \\
0 \\
0 \\
0 \\
0 \\
0 \\
0 \\
0 \\
0 \\
0 \\
0 \\
0 \\
0 \\
0\end{array}$ & $M G / L$ & & $\begin{array}{l}214 . \\
209 . \\
195 . \\
210 . \\
254 . \\
251 . \\
251 . \\
253 . \\
244 . \\
223 . \\
220 . \\
216 . \\
212 . \\
223 . \\
227 . \\
194 . \\
185 . \\
164 . \\
189 . \\
146 . \\
148 . \\
144 .\end{array}$ & $\begin{array}{c}0.1 \\
0.1 \\
10 . \\
4 . \\
0.1 \\
0.1 \\
10 . \\
3 . \\
0.1 \\
0.1 \\
10 . \\
20 . \\
10 . \\
10 . \\
3 . \\
0.1 \\
0.1 \\
10 . \\
3 . \\
0.1 \\
0.1 \\
10 .\end{array}$ & $\begin{array}{l}- \\
- \\
- \\
- \\
- \\
- \\
- \\
- \\
- \\
- \\
- \\
- \\
- \\
- \\
-\end{array}$ \\
\hline
\end{tabular}

FORMATION OF COMPLETION CODE:

MB - MIDDLE BURRO CANYON

PARAMETER VALUE IHDICATOR (PVI):
FLOW RELATIONSHIP COOE:

O - ON-SITE

SAMPLE ID CODES:

0001 - FILTERED SAMPLE (.45 MICRONS) 
TABLE 3.49. BACKGROUND GROUNDWATER QUALITY DATE BY PARAMETER FOR THE MIDDLE SANDSTONE UNIT, BURRO CANYON DISPOSAL SITE, SLICK ROCK, COLORADO SITE: SRKO2 EORROW SITE 1 (BURRO CANYON)

SITE: SRKO2 EORROW

PEPORT DATE: $03 / 02 / 94$

\begin{tabular}{|c|c|c|c|c|c|c|c|c|c|c|}
\hline PARAMETER NAME & $\begin{array}{c}\text { LOCATION } \\
\text { ID }\end{array}$ & LOG DATE & $\begin{array}{c}\text { SAMPLE } \\
\text { ID }\end{array}$ & $\begin{array}{l}\text { FORM } \\
\text { COMP }\end{array}$ & $\begin{array}{l}\text { FLOW } \\
\text { REL. }\end{array}$ & $\begin{array}{l}\text { UNITS OF } \\
\text { MEASURE }\end{array}$ & PVI & $\begin{array}{l}\text { PARAMETER } \\
\text { VALUE }\end{array}$ & $\begin{array}{l}\text { DETECTION } \\
\text { LIMIT }\end{array}$ & $\begin{array}{l}\text { PARAMETER } \\
\text { UNCERTAINTY }\end{array}$ \\
\hline SULFATE & 0528 & $10 / 13 / 52$ & 0001 & MB & 0 & $M G / L$ & & 145. & 4. & - \\
\hline$\therefore$ LFIDE & $\begin{array}{l}0516 \\
0516 \\
0516 \\
0520 \\
0520 \\
0520 \\
0520 \\
0522 \\
0522 \\
0522 \\
0522 \\
0525 \\
0525 \\
0525 \\
0526 \\
0526 \\
0526 \\
0526 \\
0528 \\
0528 \\
0528 \\
0528\end{array}$ & $\begin{array}{l}12 / 08 / 90 \\
04 / 04 / 91 \\
08 / 26 / 91 \\
12 / 12 / 90 \\
64 / 01 / 91 \\
08 / 22 / 91 \\
10 / 11 / 92 \\
12 / 08 / 90 \\
04 / 02 / 91 \\
08 / 22 / 91 \\
10 / 12 / 92 \\
12 / 08 / 90 \\
04 / 03 / 91 \\
08 / 26 / 91 \\
12 / 12 / 90 \\
04 / 04 / 91 \\
08 / 21 / 91 \\
10 / 14 / 92 \\
12 / 15 / 90 \\
04 / 02 / 91 \\
08 / 21 / 91 \\
10 / 13 / 92\end{array}$ & $\begin{array}{l}0001 \\
0001 \\
0001 \\
0001 \\
0001 \\
0001 \\
0001 \\
0001 \\
0001 \\
0001 \\
0001 \\
0001 \\
0001 \\
0001 \\
0001 \\
0001 \\
0001 \\
0001 \\
0001 \\
0001 \\
0001 \\
0001\end{array}$ & $\begin{array}{l}\text { MB } \\
\text { MB } \\
\text { MB } \\
\text { MB } \\
\text { MB } \\
\text { MB } \\
\text { MB } \\
\text { MB } \\
\text { MB } \\
\text { MB } \\
\text { MB } \\
\text { MB } \\
\text { MB } \\
\text { MB } \\
\text { MB } \\
\text { MB } \\
\text { MB } \\
\text { MB } \\
\text { MB } \\
\text { MB } \\
\text { MB } \\
\text { MB }\end{array}$ & $\begin{array}{l}0 \\
0 \\
0 \\
0 \\
0 \\
0 \\
0 \\
0 \\
0 \\
0 \\
0 \\
0 \\
0 \\
0 \\
0 \\
0 \\
0 \\
0 \\
0 \\
0 \\
0 \\
0\end{array}$ & $M G / L$ & < & $\begin{array}{r}0.1 \\
3.3 \\
0.3 \\
0.1 \\
0.3 \\
1.6 \\
1.2 \\
0.1 \\
17.9 \\
2.9 \\
0.4 \\
0.1 \\
0.5 \\
0.3 \\
0.1 \\
0.3 \\
0.1 \\
0.1 \\
0.1 \\
0.3 \\
0.6 \\
0.1\end{array}$ & $\begin{array}{l}0.1 \\
0.1 \\
0.1 \\
0.1 \\
0.1 \\
0.1 \\
0.1 \\
0.1 \\
0.1 \\
0.1 \\
0.1 \\
0.1 \\
0.1 \\
0.1 \\
0.1 \\
0.1 \\
0.1 \\
0.1 \\
0.1 \\
0.1 \\
0.1 \\
0.1\end{array}$ & $\begin{array}{l}- \\
- \\
- \\
- \\
- \\
- \\
- \\
- \\
- \\
- \\
- \\
- \\
- \\
- \\
- \\
- \\
-\end{array}$ \\
\hline TEMPERATURE & $\begin{array}{l}0516 \\
0516 \\
0516 \\
0516 \\
0516 \\
0520 \\
0520 \\
0520 \\
0520 \\
0520 \\
0522 \\
0522 \\
0522 \\
0522 \\
0522 \\
0525\end{array}$ & $\begin{array}{l}06 / 06 / 90 \\
12 / 08 / 90 \\
04 / 04 / 91 \\
08 / 26 / 91 \\
10 / 14 / 92 \\
06 / 04 / 90 \\
12 / 12 / 90 \\
04 / 01 / 91 \\
08 / 22 / 91 \\
10 / 11 / 92 \\
06 / 04 / 90 \\
12 / 08 / 90 \\
04 / 02 / 91 \\
08 / 22 / 91 \\
10 / 12 / 92 \\
06 / 04 / 90\end{array}$ & $\begin{array}{l}0001 \\
0001 \\
0001 \\
0001 \\
0001 \\
0001 \\
0001 \\
0001 \\
0001 \\
0001 \\
0001 \\
0001 \\
0001 \\
0001 \\
0001 \\
0001\end{array}$ & $\begin{array}{l}\text { MB } \\
\text { MB } \\
\text { MB } \\
\text { MB } \\
M B \\
\text { MB } \\
\text { MB } \\
\text { MB } \\
\text { MB } \\
\text { MB } \\
\text { MB } \\
\text { MB } \\
\text { MB } \\
M B \\
\text { MB } \\
\text { MB }\end{array}$ & $\begin{array}{l}0 \\
0 \\
0 \\
0 \\
0 \\
0 \\
0 \\
0 \\
0 \\
0 \\
0 \\
0 \\
0 \\
0 \\
0 \\
0\end{array}$ & C - DEGREE & & $\begin{array}{l}16.0 \\
14.0 \\
13.9 \\
16.9 \\
17.1 \\
17.5 \\
18.6 \\
16.2 \\
15.5 \\
16.0 \\
17.6 \\
16.0 \\
15.7 \\
15.3 \\
15.5 \\
16.5\end{array}$ & $\begin{array}{l}- \\
- \\
- \\
- \\
- \\
- \\
- \\
- \\
- \\
- \\
- \\
- \\
-\end{array}$ & $\begin{array}{l}- \\
- \\
- \\
- \\
- \\
- \\
- \\
- \\
- \\
- \\
- \\
-\end{array}$ \\
\hline
\end{tabular}

FORMATION OF COMPLETION CODE:

MB - MIDDLE BURRO CANYON

PARAMETER VALUE INDICATOR (PVI): < - LESS THAN DEIECTION LIMIT
FLOW RELATIONSHIP COOE:

O - ON-SITE

SAMPLE ID CODES:

0001 - FILTERED SAMPLE (.45 MICRONS) 
TABLE 3.49. BACKGROUND GROUNDWATER QUALITY DATE BY PARAMETER FOR THE MIDDLE SANDSTOME UNIT, BURRO CANYON DISPOSAL SITE, SLICK ROCK, COLORADO MIDDLE SANDSTON

06/04/90 TO $10 / 14 / 92$

REPORT DATE: $03 / 02 / 94$

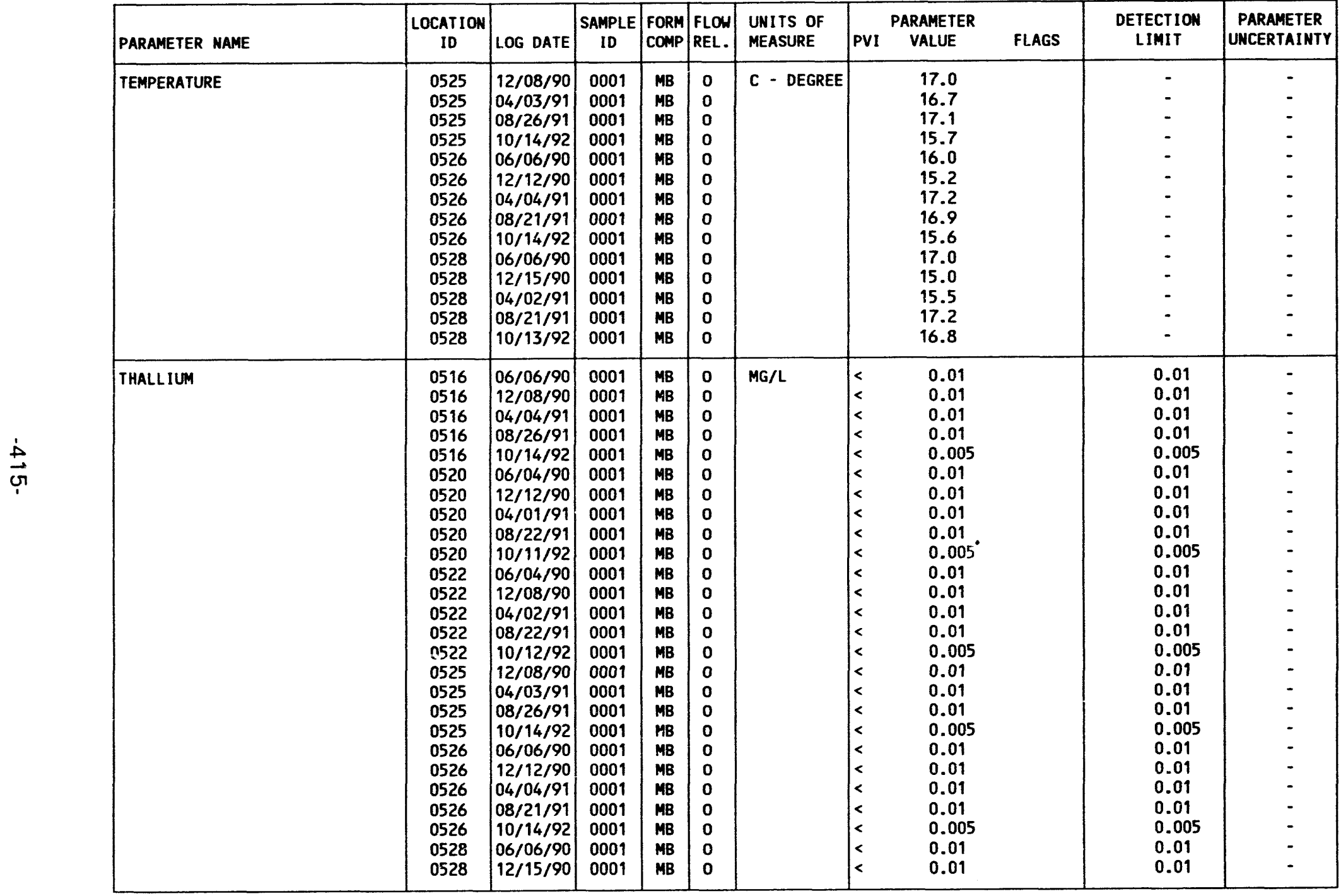

FORMATION OF COAPLETION COOE:

MB - MIDDLE BURRO CANYON

PARAMETER VALUE INDICATOR (PVI): < - LESS THAN DETECTION LIMIT
FLOW RELATIONSHIP CODE:

O - ON-SITE 
TABLE 3.49. BACKGROUND GROUNDWATER QUALITY DATE BY PARAMETER FOR THE

MIDDLE SANDSTONE UNIT, BURRO CANYON DISPOSAL SITE, SLICK ROCK, COLORADO

SITE: SRKO2 BORROW SITE 1 (BURRO CANYON)

06/04/90 TO 10/14/92

REPORT DATE: $03 / 02 / 94$

\begin{tabular}{|c|c|c|c|c|c|c|c|c|c|c|c|}
\hline PARAMETER NAME & $\begin{array}{c}\text { LOCATION } \\
\text { ID }\end{array}$ & LOG DATE & $\begin{array}{c}\text { SAMPLE } \\
\text { ID }\end{array}$ & $\begin{array}{l}\text { FORM } \\
\text { COMP }\end{array}$ & $\begin{array}{l}\text { FLOW } \\
\text { REL. }\end{array}$ & $\begin{array}{l}\text { UNITS OF } \\
\text { MEASURE }\end{array}$ & PVI & $\begin{array}{l}\text { RAMETER } \\
\text { VALUE }\end{array}$ & FLAGS & $\begin{array}{l}\text { DETECTION } \\
\text { LIMIT }\end{array}$ & $\begin{array}{l}\text { PARAMETER } \\
\text { UNCERTAINTY }\end{array}$ \\
\hline THALLIUM & $\begin{array}{l}0528 \\
0528 \\
0528\end{array}$ & $\begin{array}{l}04 / 02 / 91 \\
08 / 21 / 91 \\
10 / 13 / 92\end{array} \mid$ & $\begin{array}{l}0001 \\
0001 \\
0001\end{array}$ & $\begin{array}{l}\text { MB } \\
\text { MB } \\
\text { MB }\end{array}$ & $\begin{array}{l}0 \\
0 \\
0\end{array}$ & $M G / L$ & $<$ & $\begin{array}{l}0.01 \\
0.01 \\
0.005\end{array}$ & & $\begin{array}{l}0.01 \\
0.01 \\
0.005\end{array}$ & - \\
\hline THOR IUM-230 & $\begin{array}{l}0516 \\
0516 \\
0516 \\
0520 \\
0520 \\
0520 \\
0522 \\
0522 \\
0522 \\
0525 \\
0525 \\
0525 \\
0526 \\
0526 \\
0526 \\
0528 \\
0528 \\
0528\end{array}$ & $\begin{array}{l}12 / 08 / 90 \\
04 / 04 / 91 \\
08 / 26 / 91 \\
12 / 12 / 90 \\
04 / 01 / 91 \\
08 / 22 / 91 \\
12 / 08 / 90 \\
04 / 02 / 91 \\
08 / 22 / 91 \\
12 / 08 / 90 \\
04 / 03 / 91 \\
08 / 26 / 91 \\
12 / 12 / 90 \\
04 / 04 / 91 \\
08 / 21 / 91 \\
12 / 15 / 90 \\
04 / 02 / 91 \\
08 / 21 / 91\end{array}$ & $\begin{array}{l}0001 \\
0001 \\
0001 \\
0001 \\
0001 \\
0001 \\
0001 \\
0001 \\
0001 \\
0001 \\
0001 \\
0001 \\
0001 \\
0001 \\
0001 \\
0001 \\
0001 \\
0001\end{array}$ & $\begin{array}{l}\text { MB } \\
\text { MB } \\
\text { MB } \\
\text { MB } \\
\text { MB } \\
\text { MB } \\
\text { MB } \\
\text { MB } \\
\text { MB } \\
\text { MB } \\
\text { MB } \\
\text { MB } \\
\text { MB } \\
\text { MB } \\
\text { MB } \\
\text { MB } \\
\text { MB } \\
\text { MB }\end{array}$ & $\begin{array}{l}0 \\
0 \\
0 \\
0 \\
0 \\
0 \\
0 \\
0 \\
0 \\
0 \\
0 \\
0 \\
0 \\
0 \\
0 \\
0 \\
0 \\
0\end{array}$ & $\mathrm{PCI} / \mathrm{L}$ & < & $\begin{array}{l}0.3 \\
0.2 \\
0.4 \\
0.3 \\
0.1 \\
0.7 \\
0.4 \\
1.3 \\
0.1 \\
0.4 \\
0.5 \\
0.3 \\
0.3 \\
0.2 \\
0.3 \\
0.4 \\
0.1 \\
0.7\end{array}$ & $\begin{array}{l}d \\
d \\
d \\
d \\
d \\
d\end{array}$ & $\begin{array}{l}0.1 \\
1 . \\
1 . \\
0.1 \\
1 . \\
1 . \\
0.1 \\
1 . \\
1 . \\
0.1 \\
1 . \\
1 . \\
0.1 \\
1 . \\
1 . \\
0.1 \\
1 . \\
1 .\end{array}$ & $\begin{array}{l}0.3 \\
0.3 \\
0.4 \\
0.3 \\
0.3 \\
0.7 \\
0.4 \\
0.8 \\
0.2 \\
0.4 \\
0.4 \\
0.4 \\
0.3 \\
0.3 \\
0.4 \\
0.4 \\
0.3 \\
0.5\end{array}$ \\
\hline TIN & $\begin{array}{l}0516 \\
0516 \\
0516 \\
0516 \\
0516 \\
0520 \\
0520 \\
0520 \\
0520 \\
0520 \\
0522 \\
0522 \\
0522 \\
0522 \\
0522 \\
0525\end{array}$ & $\begin{array}{l}06 / 06 / 90 \\
12 / 08 / 90 \\
04 / 04 / 91 \\
08 / 26 / 91 \\
10 / 14 / 92 \\
06 / 04 / 90 \\
12 / 12 / 90 \\
04 / 01 / 91 \\
08 / 22 / 91 \\
10 / 11 / 92 \\
06 / 04 / 90 \\
12 / 08 / 90 \\
04 / 02 / 91 \\
08 / 22 / 91 \\
10 / 12 / 92 \\
12 / 08 / 90\end{array}$ & $\begin{array}{l}0001 \\
0001 \\
0001 \\
0001 \\
0001 \\
0001 \\
0001 \\
0001 \\
0001 \\
0001 \\
0001 \\
0001 \\
0001 \\
0001 \\
0001 \\
0001\end{array}$ & $\begin{array}{l}\text { MB } \\
\text { MB } \\
\text { MB } \\
\text { MB } \\
\text { MB } \\
\text { MB } \\
\text { MB } \\
\text { MB } \\
\text { MB } \\
\text { MB } \\
\text { MB } \\
\text { MB } \\
\text { MB } \\
\text { MB } \\
\text { MB } \\
\text { MB }\end{array}$ & $\begin{array}{l}0 \\
0 \\
0 \\
0 \\
0 \\
0 \\
0 \\
0 \\
0 \\
0 \\
0 \\
0 \\
0 \\
0 \\
0 \\
0\end{array}$ & $\mathrm{MG} / \mathrm{L}$ & $\begin{array}{l}< \\
< \\
< \\
< \\
< \\
< \\
< \\
< \\
< \\
< \\
< \\
< \\
< \\
< \\
< \\
< \\
< \\
<\end{array}$ & $\begin{array}{l}0.005 \\
0.005 \\
0.01 \\
0.005 \\
0.005 \\
0.005 \\
0.005 \\
0.005 \\
0.005 \\
0.005 \\
0.005 \\
0.005 \\
0.005 \\
0.005 \\
0.005 \\
0.005\end{array}$ & I & $\begin{array}{l}0.005 \\
0.005 \\
0.01 \\
0.005 \\
0.005 \\
0.005 \\
0.005 \\
0.005 \\
0.005 \\
0.005 \\
0.005 \\
0.005 \\
0.005 \\
0.005 \\
0.005 \\
0.005\end{array}$ & $\begin{array}{l}- \\
- \\
- \\
- \\
- \\
- \\
- \\
- \\
- \\
- \\
- \\
- \\
-\end{array}$ \\
\hline
\end{tabular}

FORMATION OF COMPLETION CODE:

MB - MIDDLE BURRO CANYON

PARAMETER VALUE INDICATOR (PVI): < - LESS THAN DETECTION LIMIT
FLOW RELATIONSHIP CODE:

0001 - FILTERED SAMPLE (.45 MICRONS)

OTHER PARAMETER VALUE FLAGS:

I - INCREASED DETECTION LIMIT DUE TO REQUIRED DILUTION

d - CHANGED DETECTION LIMIT AND PARAMETER VALUE 
TABLE 3.49. BACKGROUND GROUNDWATER OUALITY DATE BY PARAMETER FOR THE

MIDDLE SANDSTONE UNIT, BURRO CANYON DISPOSAL SITE, SLICK ROCK, COLORADO SITE: SRKO2 BORROW SITE 1 (BURRO CANYON)

$06 / 04 / 90$ TO $10 / 14 / 92$

REPORT DATE : 03/02/94

\begin{tabular}{|c|c|c|c|c|c|c|c|c|c|c|c|}
\hline PARAMETER NAME & $\begin{array}{c}\text { LOCATION } \\
\text { ID }\end{array}$ & LOG DATE & $\begin{array}{c}\text { SAMPLE } \\
10\end{array}$ & $\begin{array}{l}\text { FORM } \\
\text { COMP }\end{array}$ & $\begin{array}{l}\text { FLOW } \\
\text { REL. }\end{array}$ & $\begin{array}{l}\text { UNITS OF } \\
\text { MEASURE }\end{array}$ & PVI & $\begin{array}{l}\text { PARAMETEF } \\
\text { VALUE }\end{array}$ & FLAGS & $\begin{array}{l}\text { DETECTION } \\
\text { LIMIT }\end{array}$ & $\begin{array}{l}\text { PARAMETER } \\
\text { UNCERTAINTY }\end{array}$ \\
\hline TIN & $\begin{array}{l}0525 \\
0525 \\
0525 \\
0526 \\
0526 \\
0526 \\
0526 \\
0526 \\
0528 \\
0528 \\
0528 \\
0528 \\
0528\end{array}$ & $\begin{array}{l}04 / 03 / 91 \\
08 / 26 / 91 \\
10 / 14 / 92 \\
06 / 06 / 90 \\
12 / 12 / 90 \\
04 / 04 / 91 \\
08 / 21 / 91 \\
10 / 14 / 92 \\
06 / 06 / 90 \\
12 / 15 / 90 \\
04 / 02 / 91 \\
08 / 21 / 91 \\
10 / 13 / 92\end{array}$ & $\begin{array}{l}0001 \\
0001 \\
0001 \\
0001 \\
0001 \\
0001 \\
0001 \\
0001 \\
0001 \\
0001 \\
0001 \\
0001 \\
0001\end{array}$ & $\begin{array}{l}\text { MB } \\
\text { MB } \\
\text { MB } \\
\text { MB } \\
\text { MB } \\
\text { MB } \\
\text { MB } \\
\text { MB } \\
\text { MB } \\
\text { MB } \\
\text { MB } \\
\text { MB } \\
\text { MB }\end{array}$ & $\begin{array}{l}0 \\
0 \\
0 \\
0 \\
0 \\
0 \\
0 \\
0 \\
0 \\
0 \\
0 \\
0 \\
0\end{array}$ & MG/L & $\begin{array}{l}< \\
< \\
< \\
< \\
< \\
< \\
< \\
< \\
< \\
k \\
k \\
k \\
k \\
k\end{array}$ & $\begin{array}{l}0.005 \\
0.005 \\
0.005 \\
0.005 \\
0.005 \\
0.005 \\
0.005 \\
0.005 \\
0.005 \\
0.005 \\
0.005 \\
0.005 \\
0.005\end{array}$ & & $\begin{array}{l}0.005 \\
0.005 \\
0.005 \\
0.005 \\
0.005 \\
0.005 \\
0.005 \\
0.005 \\
0.005 \\
0.005 \\
0.005 \\
0.005 \\
0.005\end{array}$ & $\begin{array}{l}- \\
- \\
- \\
- \\
- \\
- \\
- \\
- \\
- \\
-\end{array}$ \\
\hline TOTAL DISSOLVED SOLIDS & $\begin{array}{l}0516 \\
0516 \\
0516 \\
0516 \\
0516 \\
0520 \\
0520 \\
0520 \\
0520 \\
0520 \\
0522 \\
0522 \\
0522 \\
0522 \\
0522 \\
0525 \\
0525 \\
0525 \\
0525 \\
0526 \\
0526 \\
0526 \\
0526 \\
0526 \\
0528 \\
0528 \\
0528\end{array}$ & $\begin{array}{l}06 / 06 / 90 \\
12 / 08 / 90 \\
04 / 04 / 91 \\
08 / 26 / 91 \\
10 / 14 / 92 \\
06 / 04 / 90 \\
12 / 12 / 90 \\
04 / 01 / 91 \\
08 / 22 / 91 \\
10 / 11 / 92 \\
06 / 04 / 90 \\
12 / 08 / 90 \\
04 / 02 / 91 \\
08 / 22 / 91 \\
10 / 12 / 92 \\
12 / 08 / 90 \\
04 / 03 / 91 \\
08 / 26 / 91 \\
10 / 14 / 92 \\
06 / 06 / 90 \\
12 / 12 / 90 \\
04 / 04 / 91 \\
08 / 21 / 91 \\
10 / 14 / 92 \\
06 / 06 / 90 \\
12 / 15 / 90 \\
04 / 02 / 91\end{array}$ & $\begin{array}{l}0001 \\
0001 \\
0001 \\
0001 \\
0001 \\
0001 \\
0001 \\
0001 \\
0001 \\
0001 \\
0001 \\
0001 \\
0001 \\
0001 \\
0001 \\
0001 \\
0001 \\
0001 \\
0001 \\
0001 \\
0001 \\
0001 \\
0001 \\
0001 \\
0001 \\
0001 \\
0001\end{array}$ & $\begin{array}{l}\text { MB } \\
\text { MB } \\
\text { MB } \\
\text { MB } \\
\text { MB } \\
\text { MB } \\
\text { MB } \\
\text { MB } \\
\text { MB } \\
\text { MB } \\
\text { MB } \\
\text { MB } \\
\text { MB } \\
\text { MB } \\
\text { MB } \\
\text { MB } \\
\text { MB } \\
\text { MB } \\
\text { MB } \\
\text { MB } \\
\text { MB } \\
\text { MB } \\
\text { MB } \\
\text { MB } \\
\text { MB } \\
\text { MB }\end{array}$ & $\begin{array}{l}0 \\
0 \\
0 \\
0 \\
0 \\
0 \\
0 \\
0 \\
0 \\
0 \\
0 \\
0 \\
0 \\
0 \\
0 \\
0 \\
0 \\
0 \\
0 \\
0 \\
0 \\
0 \\
0 \\
0 \\
0 \\
0 \\
0\end{array}$ & MG/L & & $\begin{array}{l}568 . \\
584 . \\
641 . \\
576 . \\
621 . \\
642 . \\
636 . \\
669 . \\
667 . \\
677 . \\
586 . \\
536 . \\
598 . \\
585 . \\
587 . \\
596 . \\
600 . \\
651 . \\
696 . \\
498 . \\
508 . \\
551 . \\
550 . \\
558 . \\
422 . \\
444 . \\
486 .\end{array}$ & & $\begin{array}{l}10 . \\
10 . \\
10 . \\
10 . \\
10 . \\
10 . \\
10 . \\
10 . \\
10 . \\
10 . \\
10 . \\
10 . \\
10 . \\
10 . \\
10 . \\
10 . \\
10 . \\
10 . \\
10 . \\
10 . \\
10 . \\
10 . \\
10 . \\
10 . \\
10 . \\
10 . \\
10 .\end{array}$ & $\begin{array}{l}- \\
- \\
- \\
- \\
- \\
- \\
- \\
- \\
- \\
- \\
- \\
- \\
- \\
- \\
- \\
- \\
- \\
- \\
- \\
- \\
-\end{array}$ \\
\hline
\end{tabular}

FORMATION OF COMPLETION CODE:

MB - MIDDLE BURRO CANYON

PARAMETER VALUE INDICATOR (PVI): < - LESS THAN DETECTION LIMIT
FLOW RELATIONSHIP CODE:

O - ON-SITE

SAMPLE ID CODES:

0001 - FILTERED SAMPLE (.45 MICRONS) 
TABLE 3.49. BACKGROUND GROUNDWATER QUALITY DATE BY PARAMETER FOR THE MIDDLE SANDSTOHE UNIT BURRO CANYON DISPOSAL SITE, SLICK RGCK, COLORADO SITE: SRKO2 BORROW SITE 1 (BURRO CANYON)

SITE: SRKO2 BORROW

REPORT DATE: 03/02/94

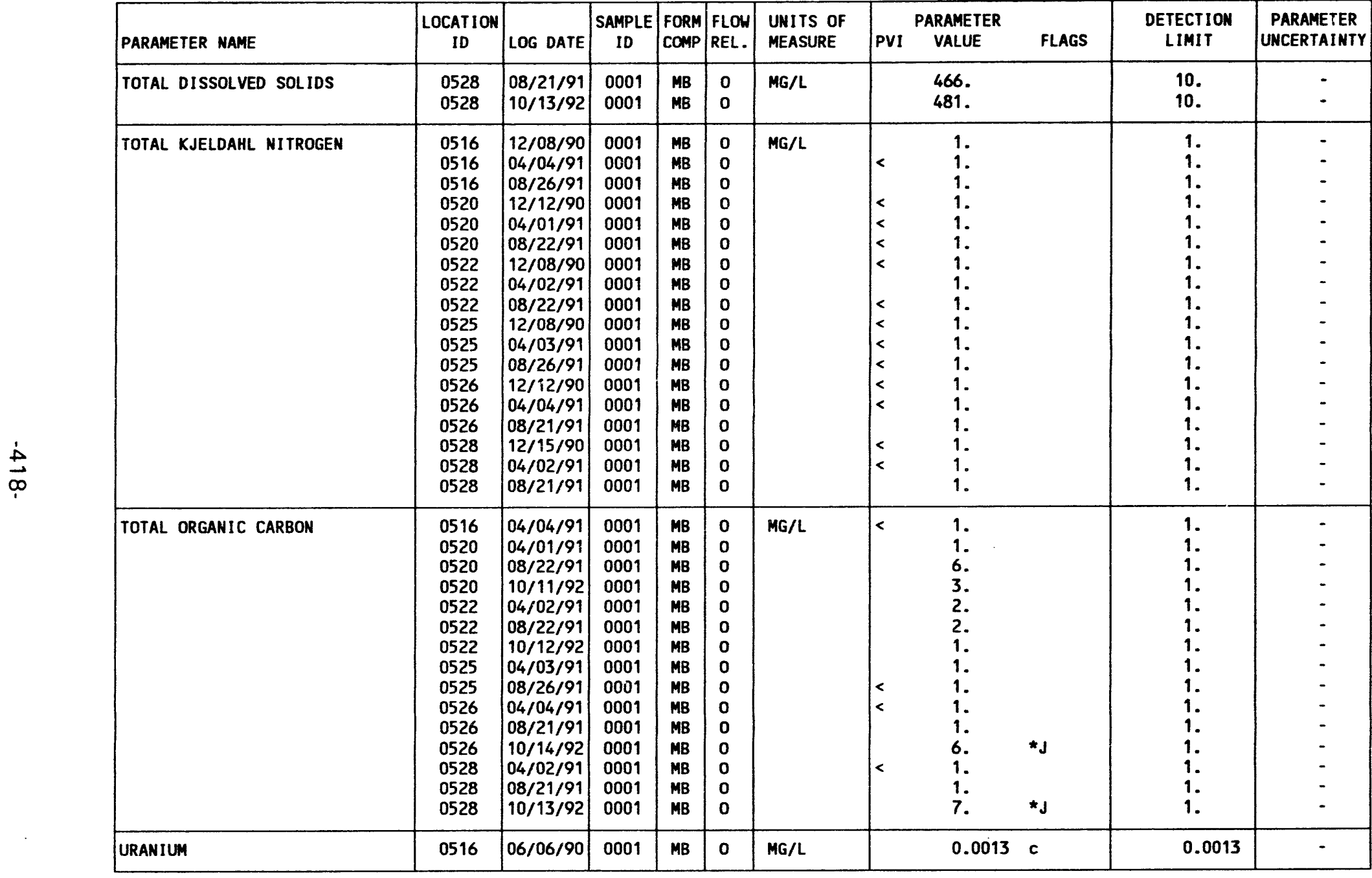

FORMATION OF COMPLETION CODE:

MB - MIDDLE BURRO CANYON

FLOW RELATIONSHIP CODE:

PARAMETER VALUE INDICATOR (PVI): < - LESS THAN DETECYION LIMIT

SAMPLE ID CODES:

0001 - FILTERED SAMPLE (.45 MICRONS)

OTHER PARAMETER VALUE FLAGS:

* - DUPLICATE ANALYSIS NOT HITHIN CONTROL LIMITS

J - estimated value

c - CHANGED DETECTION LIMIT 
TABLE 3.49. BACKGROUND GROUNDWATER QUALITY DATE BY PARAMETER FOR THE MIDDLE SANDSTONE UNIT, BURRO CANYON DISPOSAL SITE, SLICK ROCK, COLORADO SITE: SRKO2 BORROW SITE 1 (BURRO CANYON)

06/04/90 TO $10 / 14 / 92$

REPORT DATE: $03 / 02 / 94$

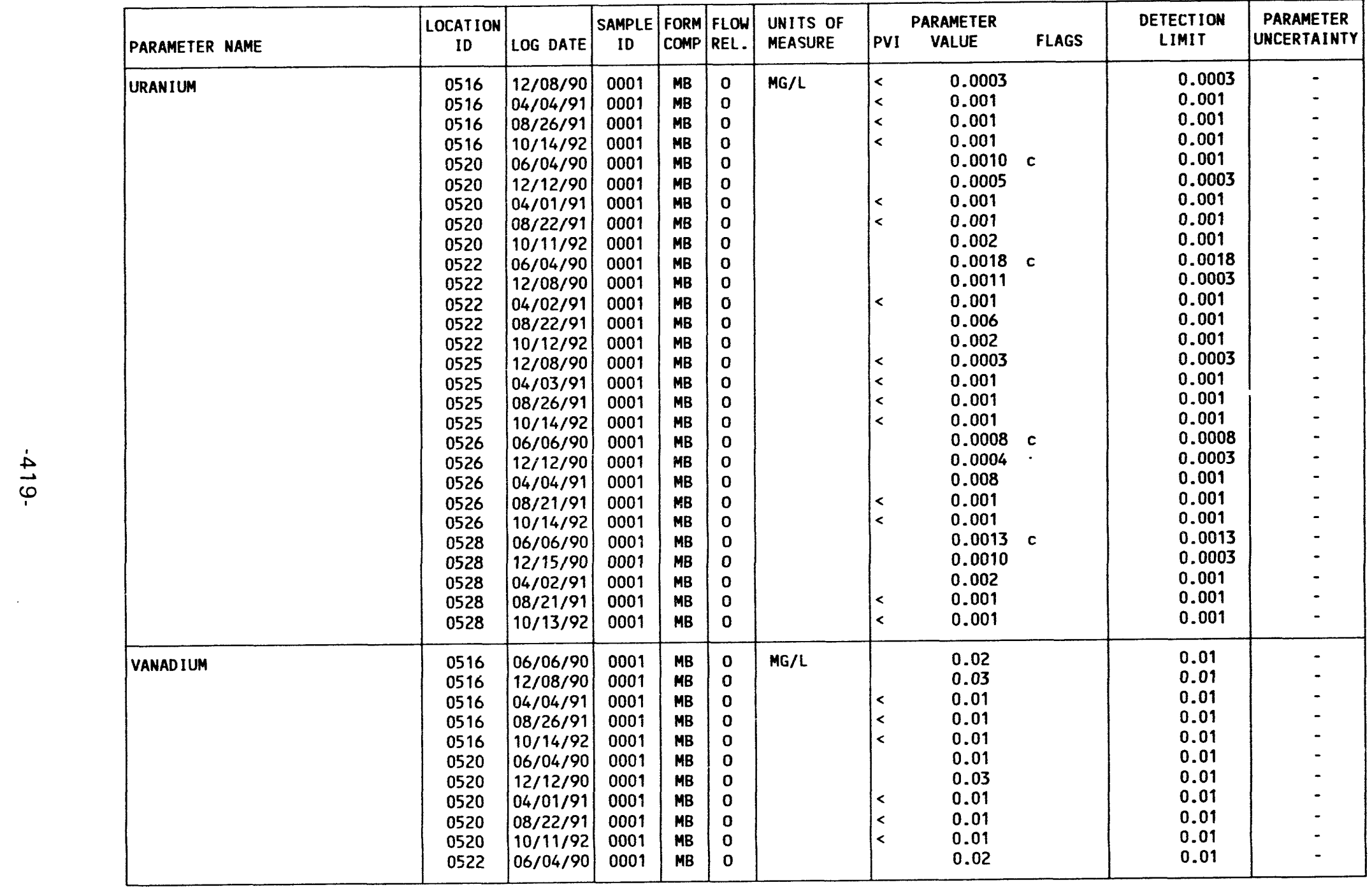

FORMATION OF COMPLETION CODE:

MB - MIDDLE BURRO CANYON

PARAMETER VALUE INDICATOR (PVI): < - LESS THAN DETECTION LIMIT
FLOW RELATIONSHIP CODE:

O - ON-SITE

0001 - FILTERED SAMPLE (.45 MICRONS)

OTHER PARAMETER VALUE FLAGS:

c - CHANGED DETECTION LIMIT 
TABLE 3.49. BACKGROUND GROUNDWATER QUALITY DATE BY PARAMETER FOR THE

MIDDLE SANDSTONE UNIT, BURRO CANYON DISPOSAL SITE, SLICK ROCK, COLORADO

SITE: SRKO2 BORROW SITE 1 (BURRO CANYON)

06/04/90 TO $10 / 14 / 92$

REPORT DATE : 03/02/94

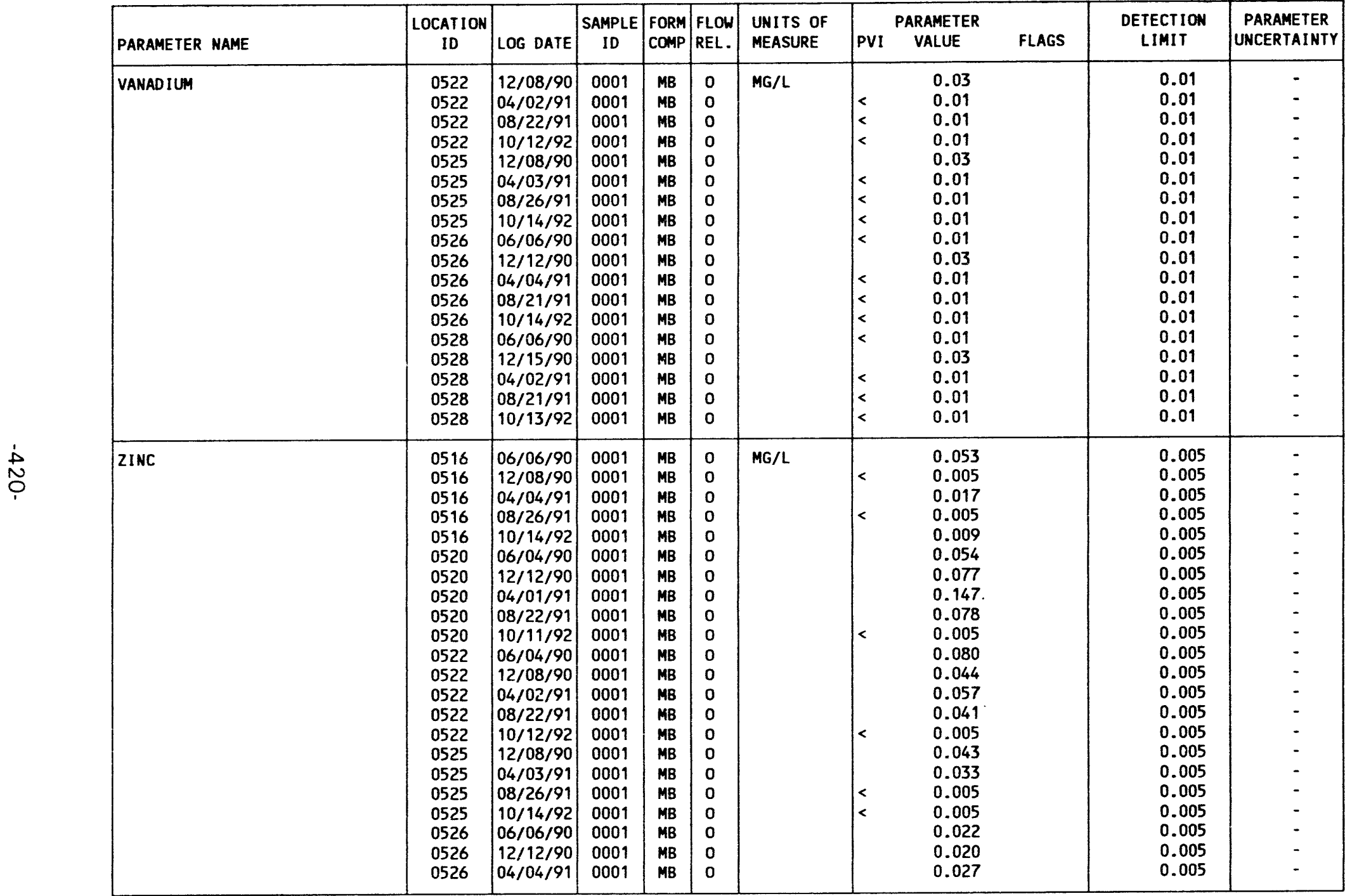

FORMATION OF COMPLETION CODE:

MB - MIDDLE BURRO CANYON

PARAMETER VALUE INDICATOR (PVI): < - LESS THAN DETECTION LIMIT
FLOW RELATIONSHIP COOE:

O - ON-SITE

SAMPLE ID CODES:

0001 - FILTERED SAMPLE (.45 MICRONS) 
TABLE 3.49. BACKGROUND GROUNDWATER QUALITY DATE BY PARAMETER FOR THE

MIDDLE SANDSTOME UNIT, BURRO CANYON DISPOSAL SITE, SLICK ROCK, COLORADO

SITE: SRK02 BORROW SITE 1 (BURRO CANYON)

06/04/90 TO $10 / 14 / 92$

REPORT DATE : $03 / 02 / 94$

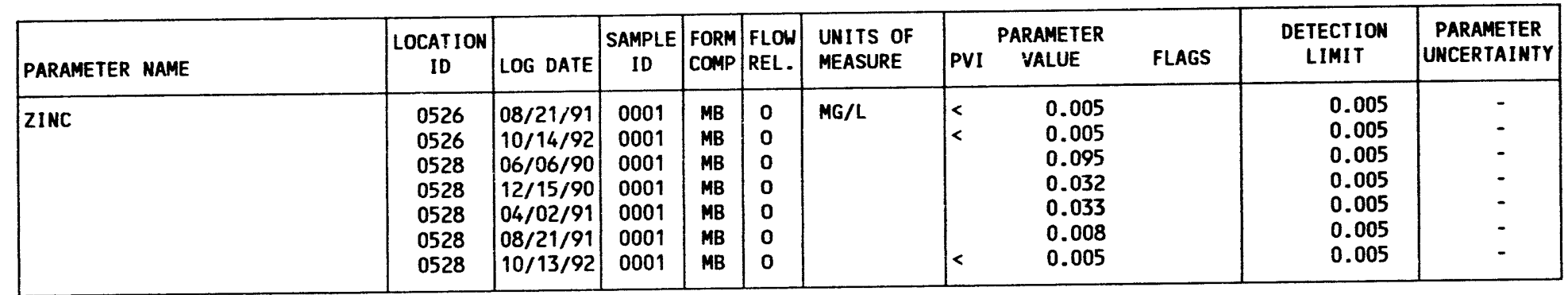

FORMATION OF COMPLETION COOE:

MB - MIDDLE BURRO CANYON

FLOW RELATIONSHIP CODE:

o - ON-SITE

PARAMETER VALUE INDICATOR (PVI): < - LESS THAN DETECTION LIMIT

SAMPLE ID CODES:

0001 - FILTERED SAMPLE (.45 MICRONS)

DATA FILE NAME: M: IDARTISRKO2\GWQ10011.DAT 
TABLE 3.50. BACKGROUND GROUNDWATER QUALITY STATISTICS BY PARAMETER FOR THE MIDDLE SANDSTONE UNIT, BURRO CANYON DISPOSAL SITE, SLICK ROCK, COLORADO

SITE: SRKO2 BORROW SITE 1 (BURRO CANYON)

06/04/90 TO $10 / 14 / 92$

REPORT DATE: 03/02/94

\begin{tabular}{|c|c|c|c|c|c|c|c|c|c|c|c|}
\hline \multicolumn{3}{|c|}{ PARAMETER NAME } & UNITS & \multirow[b]{2}{*}{ MEAN } & \multirow{2}{*}{$\begin{array}{l}\text { STANDARD } \\
\text { DEVIATION }\end{array}$} & \multirow{2}{*}{$\begin{array}{c}\text { COEFF. } \\
\text { OF } \\
\text { VARIATION }\end{array}$} & \multirow{2}{*}{$\begin{array}{c}\% \text { OF } \\
\text { NON } \\
\text { DETECTS }\end{array}$} & \multirow{2}{*}{\multicolumn{2}{|c|}{$\begin{array}{l}\text { STATISTICAL RANGE } \\
\text { 98\% CONFIDENCE INTERVAL } \\
\text { MINIMUM MAXIMUM * }\end{array}$}} & \multirow{2}{*}{$\begin{array}{c}\text { DISTRIBUTION } \\
\text { TYPE }\end{array}$} & \multirow{2}{*}{$\begin{array}{l}\text { FOOT } \\
\text { NOTE }\end{array}$} \\
\hline$\#$ OF SAMP & MINIMUM & MAXIMUM & MEDIAN & & & & & & & & \\
\hline \multicolumn{3}{|l|}{ ALKALINITY } & MG/L CACO3 & \multirow[b]{2}{*}{238.8966} & \multirow[b]{2}{*}{22.0038} & \multirow[b]{2}{*}{0.0921} & \multirow[b]{2}{*}{0.0} & \multirow[b]{2}{*}{228.8164} & \multirow[b]{2}{*}{248.9767} & \multirow[b]{2}{*}{ NORMAL } & \\
\hline 29 & 201.0000 & 276.0000 & 234.0000 & & & & & & & & \\
\hline \multicolumn{3}{|l|}{ ALUMINUM } & $M G / L$ & \multirow[b]{2}{*}{ NA } & \multirow[b]{2}{*}{ NA } & \multirow[b]{2}{*}{ NA } & \multirow[b]{2}{*}{100.0} & \multirow[b]{2}{*}{0.0500} & \multirow[b]{2}{*}{0.0500} & \multirow[b]{2}{*}{ NONPARAMETRIC } & \multirow[b]{2}{*}{2} \\
\hline 29 & ** $\quad 0.0500$ & 0.0500 & $\begin{array}{ll}* \star & 0.0500\end{array}$ & & & & & & & & \\
\hline \multicolumn{3}{|l|}{ AMMON IUM } & $M G / L$ & \multirow[b]{2}{*}{ NA } & \multirow[b]{2}{*}{ NA } & \multirow[b]{2}{*}{ NA } & \multirow[b]{2}{*}{37.0} & & & & \\
\hline 27 & ** $\quad 0.1000$ & 0.5000 & 0.2000 & & & & & 0.1000 & 0.3000 & NONPARAMETRIC & 2 \\
\hline ANT IMONY & & & MG/L & & & & & & & & \\
\hline 29 & $\begin{array}{ll}\star \star & 0.0030\end{array}$ & 0.0060 & $\begin{array}{ll}* & 0.0030\end{array}$ & NA & NA & NA & 96.6 & 0.0030 & $\star \star \quad 0.0030$ & NONPARAMETRIC & 2 \\
\hline ARSENIC & & & $M G / L$ & & & & & & & & \\
\hline 29 & $\begin{array}{ll}* * & 0.0050\end{array}$ & 0.0050 & 0.0050 & NA & NA & NA & 100.0 & 0.0050 & 0.0050 & NONPARAMETRIC & 2 \\
\hline BARIUM & & & $M G / L$ & & & & & & & & \\
\hline 29 & 0.0100 & c. 2500 & 0.0200 & NA & NA & NA & 37.9 & 0.0200 & 0.0500 & NONPARAMETRIC & 2 \\
\hline BERYLLIUM & & & $M G / L$ & & & & & & & & \\
\hline 23 & ** $\quad 0.0050$ & 0.0050 & 0.0050 & NA & NA & NA & 100.0 & 0.0050 & 0.0050 & NONPARAMETRIC & 2 \\
\hline BORON & & & $M G / L$ & & & & & & & & \\
\hline 23 & 0.1000 & 0.2000 & 0.1800 & 0.1626 & 0.0407 & 0.2503 & 0.0 & 0.1413 & 0.1839 & NORMAL & \\
\hline BROMIDE & & & $\mathrm{MG} / \mathrm{L}$ & & & & & & & & \\
\hline 18 & 0.1000 & 0.5000 & 0.2000 & NA & NA & NA & 33.3 & 0.1000 & 0.3000 & NONPARAMETRIC & 2 \\
\hline CADMILM & & & $M G / L$ & & & & & & & & \\
\hline 29 & $\begin{array}{ll}\text { ** } & 0.0005 \\
\end{array}$ & 0.0025 & 0.0005 & NA & NA & NA & 100.0 & 0.0005 & 0.0005 & NONPARAMETRIC & 2 \\
\hline
\end{tabular}

** The reported value is the minimum detection limit of the data set

* The sample size is even, so the median value is the arithmetic average of the two middle values

* The statistical maximum is the 99 percent one sided confidence interval, $a=0.01$

2) The nonparametric distribution was used because the nondetected values comprise more than $15 \%$ of the samples. 
TABLE 3.50. BACKGROUND GROUNDWATER OUALITY STATISTICS BY PARAMETER FOR THE

MIDDLE SANDSTONE UNIT, BURRO CANYON DISPOSAL SITE, SLICK ROCK, COLORADO

SITE: SRKO2 BORROW SITE 1 (BURRO CANYON)

$06 / 04 / 90$ TO $10 / 14 / 92$

REPORT DATE: $03 / 02 / 94$

\begin{tabular}{|c|c|c|c|c|c|c|c|c|c|c|c|}
\hline \multicolumn{3}{|c|}{ PARAMETER NAME } & UNITS & \multirow[b]{2}{*}{ MEAN } & \multirow{2}{*}{$\begin{array}{l}\text { STANDARD } \\
\text { DEVIATION }\end{array}$} & \multirow{2}{*}{$\begin{array}{c}\text { COEFF. } \\
\text { OF } \\
\text { VARIATION }\end{array}$} & \multirow{2}{*}{$\begin{array}{c}\% \text { OF } \\
\text { NON } \\
\text { DETECTS }\end{array}$} & \multirow{2}{*}{\multicolumn{2}{|c|}{$\begin{array}{l}\text { STATISTICAL RANGE } \\
\text { 98\% CONFIDENCE INTERVAL } \\
\text { MINIMUM MAXIMUM * }\end{array}$}} & \multirow{2}{*}{$\begin{array}{c}\text { DISTRIBUTION } \\
\text { TYPE }\end{array}$} & \multirow{2}{*}{$\begin{array}{l}\text { FOOT } \\
\text { NOTE }\end{array}$} \\
\hline \# OF SAMP & MINIAUM & MAXIMUM & MEDIAN & & & & & & & & \\
\hline \multicolumn{3}{|l|}{ CALCIUM } & $M G / L$ & \multirow[b]{2}{*}{59.8414} & \multirow[b]{2}{*}{11.5675} & \multirow[b]{2}{*}{0.1933} & \multirow[b]{2}{*}{0.0} & \multirow[b]{2}{*}{54.5422} & \multirow[b]{2}{*}{65.1406} & \multirow[b]{2}{*}{ NORMAL } & \\
\hline 29 & 44.5000 & 85.5000 & 58.3000 & & & & & & & & \\
\hline \multicolumn{3}{|l|}{ CHLORIDE } & $M G / L$ & \multirow[b]{2}{*}{27.1862} & \multirow[b]{2}{*}{8.7842} & \multirow[b]{2}{*}{0.3231} & \multirow[b]{2}{*}{0.0} & \multirow[b]{2}{*}{23.1621} & \multirow[b]{2}{*}{31.2104} & \multirow[b]{2}{*}{ NORMAL } & \\
\hline 29 & 20.0000 & 59.0000 & 24.0000 & & & & & & & & \\
\hline \multicolumn{3}{|l|}{ CHROMIUM } & $M G / L$ & \multirow[b]{2}{*}{ NA } & \multirow[b]{2}{*}{ NA } & \multirow[b]{2}{*}{ NA } & \multirow[b]{2}{*}{100.0} & \multirow[b]{2}{*}{0.0100} & \multirow[b]{2}{*}{0.0100} & & \\
\hline 29 & $\star \star \quad 0.0100$ & $\begin{array}{ll}* & 0.0100\end{array}$ & ** $\quad 0.0100$ & & & & & & & NONPARAMETRIC & 2 \\
\hline COBALT & & & $M G / L$ & & & & & & & & \\
\hline 23 & $\begin{array}{ll}* & 0.0300\end{array}$ & ** $\quad 0.0300$ & 0.0300 & NA & NA & NA & 100.0 & 0.0300 & $\star \star \quad 0.0300$ & NONPARAMETRIC & 2 \\
\hline COPPER & & & MG/L & & & & & & & & \\
\hline 29 & $\begin{array}{ll}* & 0.0100\end{array}$ & 0.0100 & 0.0100 & NA & NA & NA & 100.0 & 0.0100 & 0.0100 & NONPARAMETRIC & 2 \\
\hline CYANIDE & & & $M G / L$ & & & & & & & & \\
\hline 18 & $\star \star \quad 0.0100$ & 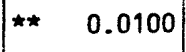 & 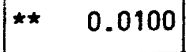 & NA & NA & NA & 100.0 & $\star * \quad 0.0100$ & ** 0.0100 & NONPARAMETRIC & 2 \\
\hline DISSOLVED & OXYGEN & & $M G / L$ & & & & & & & & \\
\hline 6 & 0.1000 & 5.0000 & 0.7000 & 0.8363 & 4.3520 & NA & 0.0 & 0.1109 & 6.3057 & LOGNORMAL & 7,8 \\
\hline FIELD FE & $(2+)$ & & $M G / L$ & & & & & & & & \\
\hline 2 & 0.0200 & 0.1000 & 0.0600 & NA & NA & NA & 0.0 & NA & NA & UNKNOWN & 1 \\
\hline FLUORIDE & & & $M G / L$ & & & & & & & & \\
\hline 29 & 0.5000 & 1.0000 & 0.6000 & 0.6759 & 0.1244 & 0.1840 & 0.0 & 0.6189 & 0.7328 & NORMAL & \\
\hline
\end{tabular}

** The reported value is the minimum detection limit of the data set

* The reported value is the minime detection is the arithmetic average of the two

* The sample size is even, so the median value is the aridence interval, $a=0.01$

1) A minimum of 4 samples must be available for the statistical analysis.

1) A minimum of 4 samples must be available for the statistical analysis. comprise more than $15 \%$ of the samples.

2) The nonparametric distribution was used because the nondetected natues distribution test.

8) The mean is geometric. The standard deviation is the value to divide or multiply with the geometric mean. 
TABLE 3.50. BACKGROUND GROUNDWATER QUALITY STATISTICS BY PARAMETER FOR THE

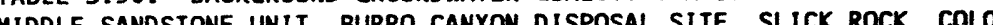

SITE: SRKO2 BORROW SITE 1 (BURRO CANYON)

$06 / 04 / 90$ TO $10 / 14 / 92$

REPORT DATE: $03 / 02 / 9$

\begin{tabular}{|c|c|c|c|c|c|c|c|c|c|c|c|c|}
\hline \multicolumn{3}{|c|}{ PARAMETER MAME } & UNITS & \multirow[b]{2}{*}{ MEAN } & \multirow{2}{*}{$\begin{array}{l}\text { STANDARD } \\
\text { DEVIATION }\end{array}$} & \multirow{2}{*}{$\begin{array}{l}\text { COEFF. } \\
\text { OF } \\
\text { VARIATION }\end{array}$} & \multirow{2}{*}{$\begin{array}{l}\text { \% OF } \\
\text { NON } \\
\text { DETECTS }\end{array}$} & \multirow{2}{*}{\multicolumn{3}{|c|}{$\begin{array}{l}\text { STATISTICAL RANGE } \\
98 \% \text { CONFIDENCE INTERVAL } \\
\text { MINIMUM MAXIMUM * }\end{array}$}} & \multirow{2}{*}{$\begin{array}{c}\text { DISTRIBUTION } \\
\text { TYPE }\end{array}$} & \multirow{2}{*}{$\begin{array}{l}\text { FOOT } \\
\text { NOTE }\end{array}$} \\
\hline \# OF SAMP & MINIMUM & MAXIMUM & MEDIAN & & & & & & & & & \\
\hline GROSS ALPI & & & $\mathrm{PCI} / \mathrm{L}$ & \multirow[b]{2}{*}{ NA } & \multirow[b]{2}{*}{ NA } & \multirow[b]{2}{*}{ NA } & \multirow[b]{2}{*}{4.2} & \multirow[b]{2}{*}{$\star \star$} & \multirow[b]{2}{*}{1.0000} & \multirow[b]{2}{*}{3.8000} & \multirow[b]{2}{*}{ MONPARAMETRIC } & \multirow[b]{2}{*}{9} \\
\hline 24 & $* \quad 1.0000$ & 6.4000 & 1.6500 & & & & & & & & & \\
\hline \multicolumn{3}{|c|}{ GROSS BETA } & $\mathrm{PCI} / \mathrm{L}$ & \multirow[b]{2}{*}{ NA } & \multirow[b]{2}{*}{ NA } & \multirow[b]{2}{*}{ NA } & \multirow[b]{2}{*}{0.0} & \multirow{2}{*}{\multicolumn{2}{|c|}{0.5000}} & \multirow[b]{2}{*}{5.9000} & \multirow[b]{2}{*}{ NONPARAMETRIC } & \multirow[b]{2}{*}{9} \\
\hline 24 & $\star \star \quad 0.5000$ & 12.9000 & 3.7500 & & & & & & & & & \\
\hline \multicolumn{3}{|l|}{ IRON } & $M G / L$ & \multirow[b]{2}{*}{ NA } & \multirow[b]{2}{*}{ NA } & \multirow[b]{2}{*}{ NA } & \multirow[b]{2}{*}{44.8} & & & & & \\
\hline 29 & $\star * \quad 0.0300$ & 0.1200 & 0.0300 & & & & & $\star \star \star$ & 0.0300 & 0.0600 & MONPARAMETRIC & 2 \\
\hline LEAD & & & MG/L & & & & & & & & & \\
\hline 29 & $\star \star \quad 0.0030$ & 0.0100 & 0.0030 & NA & NA & NA & 100.0 & $\star \star$ & 0.0030 & 0.0050 & MONPARAMETRIC & 2 \\
\hline LEAD-210 & & & $\mathrm{PCI} / \mathrm{L}$ & & & & & & & & & \\
\hline 18 & ** 1.2000 & 1.4000 & $\star \star \quad 1.2000$ & NA & NA & NA & 22.2 & $\star \star \star$ & 1.2000 & $\star \quad 1.2000$ & MONPARAMETRIC & 2 \\
\hline MAGNESIUM & & & $\mathrm{MG} / \mathrm{L}$ & & & & & & & & & \\
\hline 29 & 16.5000 & 30.3000 & 20.7000 & 21.5414 & 3.7254 & 0.1729 & 0.0 & & 19.8347 & 23.2480 & NORMAL & \\
\hline MANGANESE & & & $\mathrm{MG} / \mathrm{L}$ & & & & & & & & & \\
\hline 29 & 0.0400 & 0.1500 & 0.0700 & 0.0769 & 0.0279 & 0.3630 & 0.0 & & 0.0641 & 0.0897 & MORMAL & \\
\hline MERCURY & & & $M G / L$ & & & & & & & & & \\
\hline 23 & $\star * \quad 0.0002$ & 0.0002 & 0.0002 & NA & NA & NA & 100.0 & $* *$ & 0.0002 & $\star \quad 0.0002$ & NONPARAMETRIC & 2 \\
\hline MOLYBDENU & & & $M G / L$ & & & & & & & & & \\
\hline 29 & 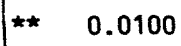 & 0.0300 & $\begin{array}{ll}* & 0.0100\end{array}$ & NA & NA & NA & 62.1 & $\star \star *$ & 0.0100 & 0.0100 & NONPARAMETRIC & 2 \\
\hline NET GROSS & ALPHA $\quad \star \star \star$ & & $\mathrm{PCI} / \mathrm{L}$ & & & & & & & & & \\
\hline 24 & -4.0900 & 6.0600 & 0.0550 & NA & NA & NA & 0.0 & & -0.3400 & 3.2600 & NONPARAMETRIC & 9 \\
\hline
\end{tabular}

*** NET GROSS ALPHA (GROSS ALPHA - URANIUM) WITH 1 MG URANIUM = 686 PCI

** The reported value is the minimum detection limit of the data set

+ The sample size is even, so the median value is the arithmetic average of the two middle values

* The statistical maximm is the 99 percent one sided confidence interval, $\alpha=0.01$

2) The nonparametric distribution was used because the nondetected values comprise more than $15 \%$ of the samples.

9) The nonparametic distribution was used because the data failed the normal distribution test and includes values $\leq 0$. 
TABLE 3.50 BACKGROUND GROUNDHATER QUALITY STATISTICS BY PARAMETER FOR THE MABLE 3.5O. BACKTIONE UNIT, BURRO CANYON DISPOSAL SITE, SLICK ROCK, COLORADO

MIDDE: SRKO2 BORROH SITE 1 (BURRO CANYON)

SITE: SRKO2 BORROW

REPORT DATE: 03/02/94

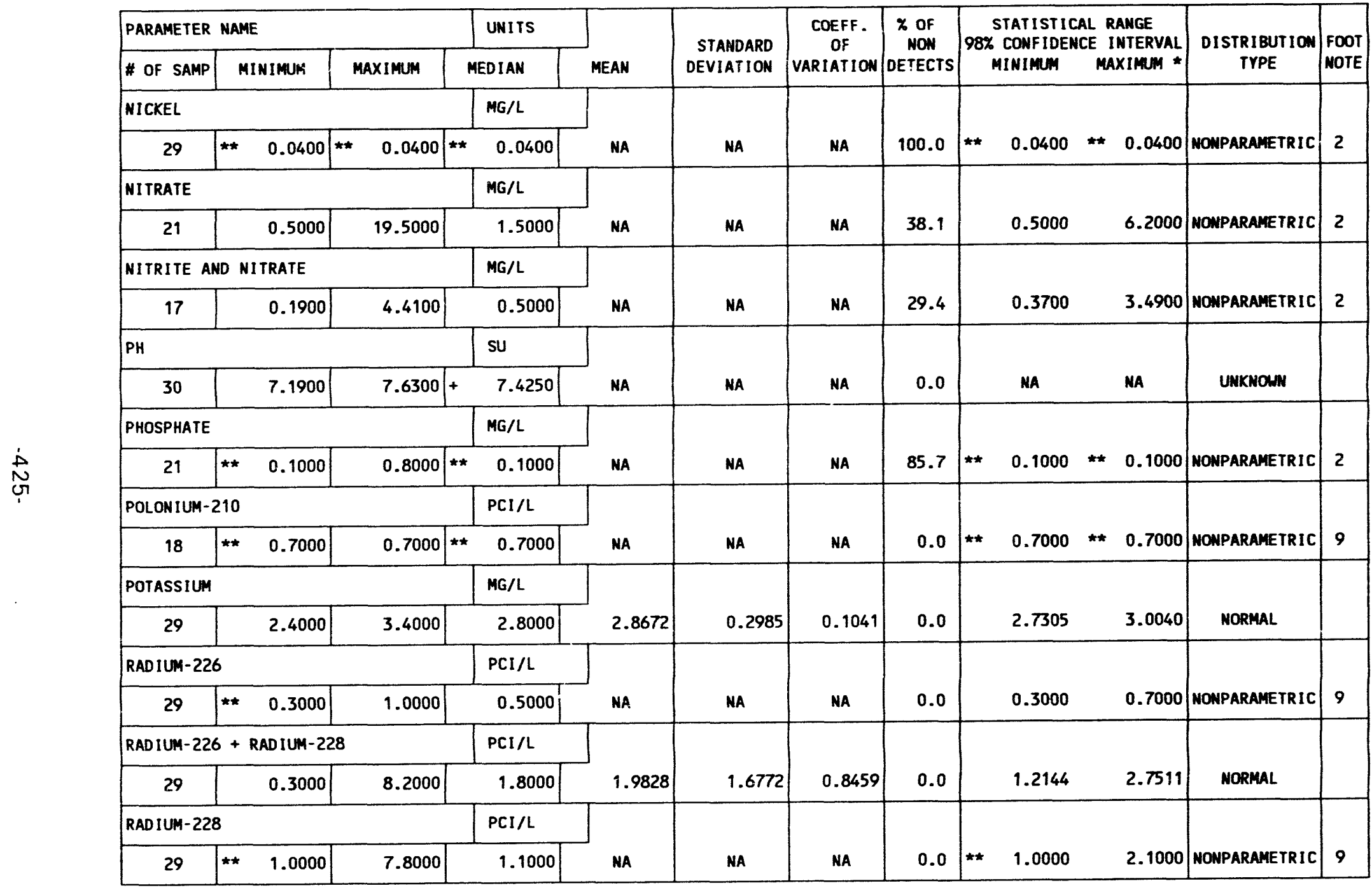

** The reported value is the minimum detection limit of the data set

+ The sample size is even, so the median value is the arithmetic average of the two middle values

* The statistical maximum is the 99 percent one sided confidence interval, $\alpha=0.01$

1) A minimum of 4 samples must be available for the statistical analysis.

2) The nonparametric distribution was used because the nondetected values comprise more than $15 \%$ of the samples.

9) The nonparametic distribution was used because the data failed the normal distribution test and includes values $\leq 0$. 
TABLE 3.50 BACKGROUND GROUNDWATER OUALITY STATISTICS BY PARAMETER FOR THE MIDDLE SANDSTONE UNIT, BURRO CANYON DISPOSAL SITE, SLICK ROCK, COLORADO

SITE: SRKO2 BORRON SITE 1 (BURRO CANYON)

06/04/90 TO $10 / 14 / 92$

REPORT DATE : 03/02/94

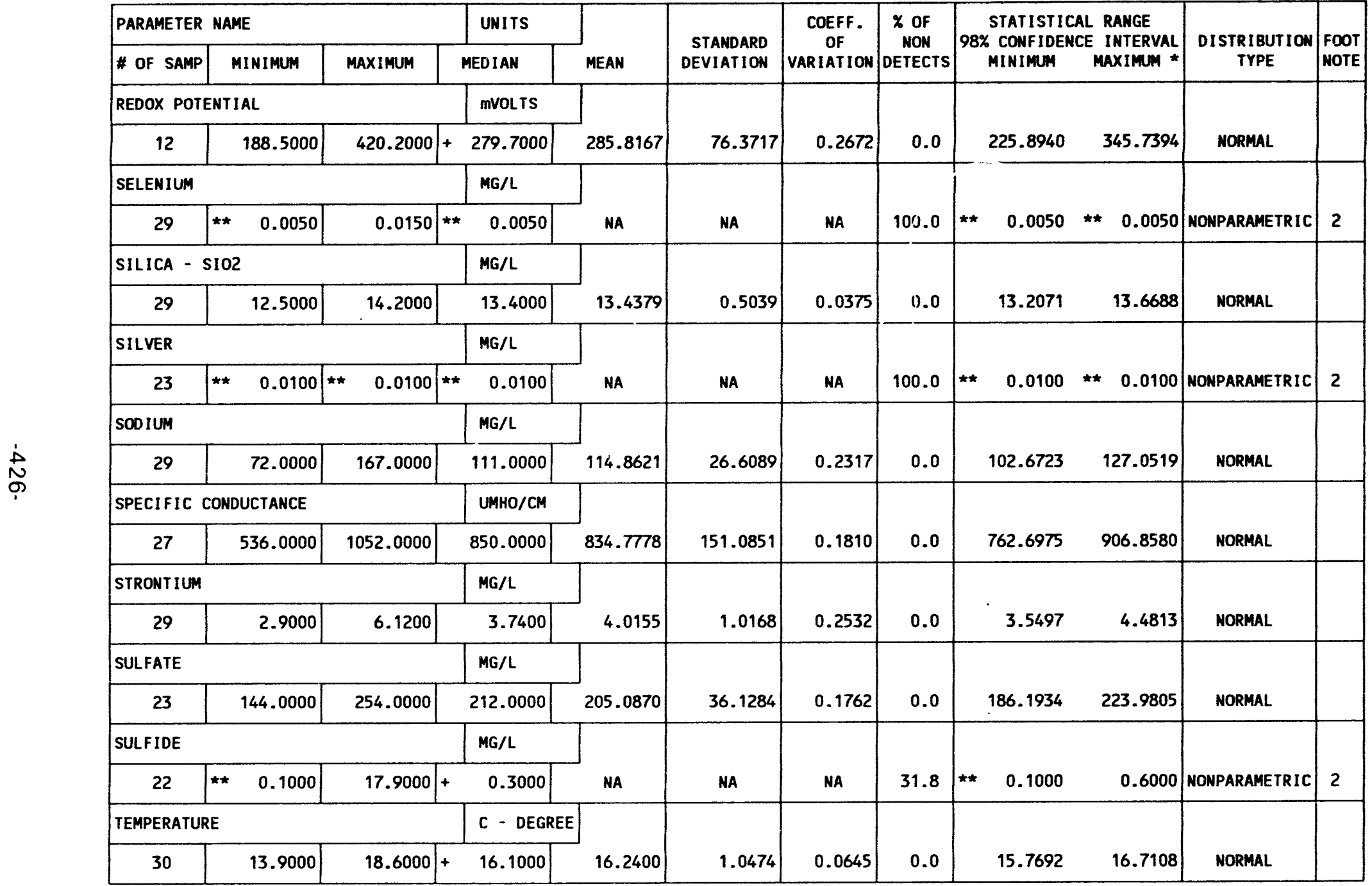

** The reported value is the minimum detection limit of the data set

+ The sample size is even, so the median value is the arithmetic average of the two middle values

* The statistical maximum is the 99 percent one sided confidence interval, $\alpha=0.01$

2) The nonparametric distribution was used because the nondetected values comprise more than $15 \%$ of the samples. 
TABLE 3.50. BACKGROUND GROUNDWATER QUALITY STATISTICS BY PARAMETER FOR THE MIDDLE SAMDSTONE UNIT, BURRO CANYON DISPOSAL SITE, SLICK ROCK, COLORADO

SITE: SRKO2 BORROW SITE 1 (BURRO CANYON)

STIE: SRKO2 BORROW S1

REPORT DATE: $03 / 02 / 94$

\begin{tabular}{|c|c|c|c|c|c|c|c|c|c|c|c|c|}
\hline \multicolumn{3}{|c|}{ PARAMETER NAME } & UNITS & \multirow[b]{2}{*}{ MEAN } & \multirow{2}{*}{$\begin{array}{l}\text { STANDARD } \\
\text { DEVIATION }\end{array}$} & \multirow{2}{*}{$\begin{array}{c}\text { COEFF. } \\
\text { OF } \\
\text { VARIATION }\end{array}$} & \multirow{2}{*}{$\begin{array}{c}\% \text { OF } \\
\text { NON } \\
\text { DETECTS }\end{array}$} & \multirow{2}{*}{\multicolumn{3}{|c|}{$\begin{array}{l}\text { STATISTICAL RANGE } \\
\text { 98\% CONFIDENCE INTERVAL } \\
\text { MINIMUM MAXIMUM * }\end{array}$}} & \multirow{2}{*}{$\begin{array}{c}\text { DISTRIBUTION } \\
\text { TYPE }\end{array}$} & \multirow{2}{*}{$\begin{array}{l}\text { FOOT } \\
\text { NOTE }\end{array}$} \\
\hline \# OF SAMP & MINIMUM & MAXIMUM & MEDIAN & & & & & & & & & \\
\hline \multicolumn{3}{|l|}{ THALLIUM } & MG/L & \multirow[b]{2}{*}{ NA } & \multirow[b]{2}{*}{ NA } & \multirow[b]{2}{*}{ NA } & \multirow[b]{2}{*}{100.0} & \multirow{2}{*}{\multicolumn{2}{|c|}{0.0050}} & \multirow[b]{2}{*}{0.0050} & \multirow[b]{2}{*}{ NONPARAMETRIC } & \multirow[b]{2}{*}{2} \\
\hline 29 & $\star \quad 0.0050$ & 0.0050 & 0.0050 & & & & & & & & & \\
\hline \multicolumn{3}{|c|}{ THORIUM-230 } & $\mathrm{PCI} / \mathrm{L}$ & \multirow[b]{2}{*}{ NA } & \multirow[b]{2}{*}{ NA } & \multirow[b]{2}{*}{ HA } & \multirow[b]{2}{*}{33.3} & \multirow[b]{2}{*}{$\star \star$} & \multirow[b]{2}{*}{0.1000} & \multirow[b]{2}{*}{0.5000} & \multirow[b]{2}{*}{ NONPARAMETRIC } & \multirow[b]{2}{*}{2} \\
\hline 18 & $\star \quad 0.1000$ & 1.3000 & 0.1500 & & & & & & & & & \\
\hline \multicolumn{3}{|l|}{ TIN } & $M G / L$ & \multirow[b]{2}{*}{ NA } & \multirow[b]{2}{*}{ NA } & \multirow[b]{2}{*}{ NA } & \multirow[b]{2}{*}{100.0} & \multirow[b]{2}{*}{$\star \star$} & & & & \\
\hline 29 & $\star \star \quad 0.0050$ & 0.0050 & $\star * \quad 0.0050$ & & & & & & 0.0050 & $\star * 0.0050$ & NOMPARAMETRIC & 2 \\
\hline TOTAL DISS & SOLVED SOLIDS & & MG/L & & & & & & & & & \\
\hline 29 & 422.0000 & 696.0000 & 585.0000 & 575.1724 & 72.5874 & 0.1262 & 0.0 & & $\$ 41.9194$ & 608.4255 & NORMAL & \\
\hline TOTAL KJEL & DAHL NITROGE & & $M G / L$ & & & & & & & & & \\
\hline 18 & $* * \quad 1.0000$ & 1.0000 & $\star * \quad 1.0000$ & NA & NA & NA & 72.2 & $\star \star$ & 1.0000 & 1.0000 & NONPARAMETRIC & 2 \\
\hline TOTAL ORGA & ANIC CARBON & & $M G / L$ & & & & & & & & & \\
\hline 15 & ** $\quad 1.0000$ & 7.0000 & 1.0000 & NA & NA & NA & 26.7 & $\star \star \star$ & 1.0000 & 6.0000 & MONPARAMETRIC & 2 \\
\hline URANIUM & & & $M G / L$ & & & & & & & & & \\
\hline 29 & ** $\quad 0.0003$ & 0.0080 & 0.0005 & NA & NA & NA & 51.7 & & 0.0005 & 0.0013 & NOMPARAMETRIC & 2 \\
\hline VANADIUM & & & $M G / L$ & & & & & & & & & \\
\hline 29 & ** $\quad 0.0100$ & 0.0300 & $\star \star \quad 0.0100$ & NA & NA & NA & 69.0 & $\star \star$ & 0.0100 & 0.0200 & NONPARAMETRIC & 2 \\
\hline ZINC & & & $M G / L$ & & & & & & & & & \\
\hline 29 & $\star \star \quad 0.0050$ & 0.1470 & 0.0270 & NA & NA & NA & 31.0 & $\star \star$ & 0.0050 & 0.0530 & NONPARAMETRIC & 2 \\
\hline
\end{tabular}

** The reported value is the minimum detection limit of the data set

* The reported value is the minimun detection limit of the data set

* The sample size is even, so the median value is the arithidence interval, $\alpha=0.01$

2) The statistical maximum is the 99 percent one sided confidence values comprise more than $15 \%$ of the samples.

INPUT DATA FILENAME: M: IDARTISRKO2\GWO10011.DAT 
TABLE 3.51. GROUNDWATER QUALITY MEASUREMENTS EXCEEDING MCLS IH THE

MIDDLE SANDSTONE UNIT, BURRO CANYON DISPOSAL SITE, SLICK ROCK, COLORADO

SITE: SRKO2 BORROW SITE 1 (BURRO CANYON)

06/04/90 TO $10 / 14 / 92$

REPORT DATE: 03/02/9

\begin{tabular}{|c|c|c|c|c|c|c|c|c|c|c|c|}
\hline PARAMETER NAME & $\begin{array}{l}\text { TOTAL } \\
\text { \# OF } \\
\text { SAMP. }\end{array}$ & $\begin{array}{l}\text { UNITS } \\
\text { OF } \\
\text { MEASURE }\end{array}$ & $\begin{array}{l}\text { MAXIMUM } \\
\text { CONC. } \\
\text { LIMIT }\end{array}$ & LOC. & LOG DATE & $\begin{array}{c}\text { SAMP } \\
\text { ID }\end{array}$ & $\begin{array}{c}\text { FORM } \\
\text { OF } \\
\text { COMP }\end{array}$ & $\begin{array}{l}\text { HYDR } \\
\text { FLOW } \\
\text { REL. }\end{array}$ & $\begin{array}{c}\text { RESULT EXCEEDING MAX. } \\
\text { CONCENTRATION LIMIT } \\
\text { VALUE FLAGS }\end{array}$ & $\begin{array}{l}\text { DETECTION } \\
\text { LIMIT }\end{array}$ & $\begin{array}{l}\text { PARAMETER } \\
\text { UNCERT. }\end{array}$ \\
\hline ARSENIC & 29 & $\mathrm{MG} / \mathrm{L}$ & 0.0500 & - & - & $\cdot$ & $\cdot$ & - & $\cdot$ & - & $\cdot$ \\
\hline ARSENIC (TOTAL) & 0 & $M G / L$ & 0.0500 & - & - & - & - & - & - & - & - \\
\hline BARIUM & 29 & $M G / L$ & 1.0000 & - & - & - & $=$ & - & - & $\cdot$ & - \\
\hline BARIUM (TOTAL) & 0 & $M G / L$ & 1.0000 & - & - & - & - & - & $\cdot$ & - & - \\
\hline CADMIUM & 29 & $M G / L$ & 0.0100 & - & - & - & - & - & - & - & - \\
\hline CADMIUM (TOTAL) & 0 & MG/L & 0.0100 & - & - & - & - & - & - & - & - \\
\hline CHROMIUM & 29 & $M G / L$ & 0.0500 & - & - & - & - & - & - & - & - \\
\hline CHROMIUM (TOTAL) & 0 & $M G / L$ & 0.0500 & - & - & - & - & - & - & - & - \\
\hline GROSS ALPHA & 24 & $\mathrm{PCI} / \mathrm{L}$ & 15.0000 & - & - & - & $\cdot$ & - & - & - & - \\
\hline GROSS ALPHA (TOTAL) & 0 & $\mathrm{PCI} / \mathrm{L}$ & 15.0000 & - & - & - & - & - & - & - & - \\
\hline LEAD & 29 & $M G / L$ & 0.0500 & - & - & - & - & - & - & - & - \\
\hline LEAD (TOTAL) & 0 & $M G / L$ & 0.0500 & - & - & - & - & - & - & - & - \\
\hline MERCURY & 23 & $M G / L$ & 0.0020 & - & - & - & - & - & - & - & - \\
\hline MERCURY (TOTAL) & $\mathbf{0}$ & $M G / L$ & 0.0020 & - & - & - & - & - & - & - & - \\
\hline MOLYBDENUM & 29 & $M G / L$ & 0.1000 & - & - & - & - & - & - & - & - \\
\hline MOLYBDENUM (TOTAL) & 0 & $M G / L$ & 0.1000 & - & $=$ & - & - & - & - & - & - \\
\hline NET GROSS ALPHA * & 24 & $\mathrm{PCI} / \mathrm{L}$ & 15.0000 & - & - & - & - & - & - & - & - \\
\hline NET GROSS ALPHA (TOTAL) ** & $\mathbf{0}$ & $\mathrm{PCI} / \mathrm{L}$ & 15.0000 & - & - & - & - & - & - & - & - \\
\hline NITRATE & 21 & $M G / L$ & 44.0000 & - & - & - & - & - & - & - & - \\
\hline
\end{tabular}

* NET GROSS ALPHA (GROSS ALPHA - URANIUM) WITH 1 MG URANIUM $=686$ PCI

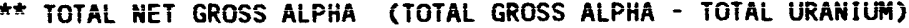




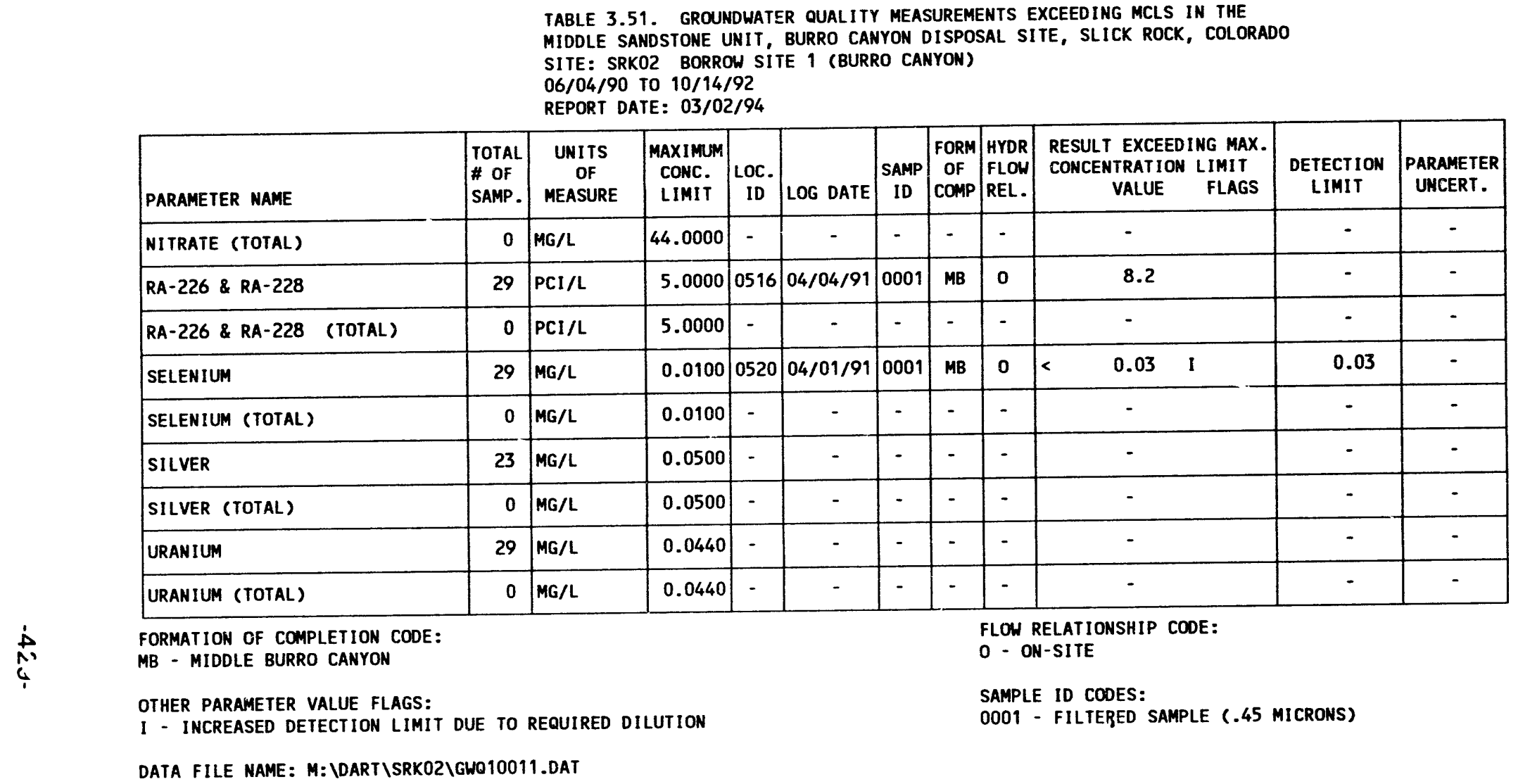


TABLE 3.52. BACKGROUND GROUNDWATER QUALITY DATA BY PARAMETER FOR THE LOWER SAMDSTONE UNIT, BURRO CANYON DISPOSAL SITE, SLICK ROCK, COLORADO SITE: SRKO2 BORROH SITE 1 (BURRO CAUYON)

06/04/90 TO 10/14/92

REPORT DATE: $03 / 02 / 94$

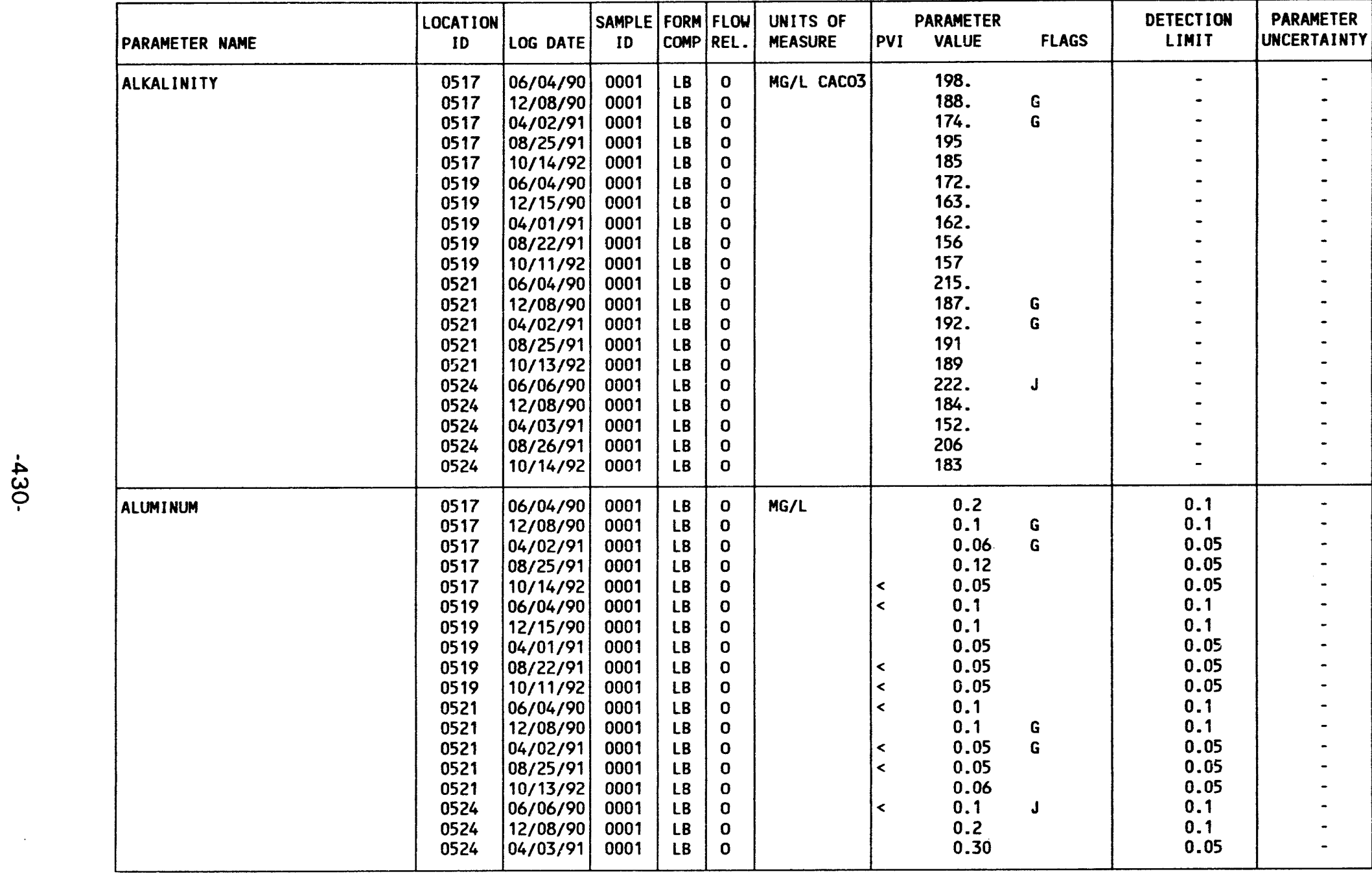

FORMATION OF COMPLETION CODE:

LB - LOWER BURRO CANYON

PARAMETER VALUE INDICATOR (PVI): < - LESS THAN DETECTION LIMIT
FLOW RELATIONSHIP CODE:

$$
\text { O - ON-SITE }
$$

SAMPLE ID CODES:

0001 - FILTERED SAMPLE (.45 MICRONS)

OTHER PARAMETER VALUE FLAGS:

G - PH > 9, POSSIBLE GROUT CONTAMINATION

J. ESTIMATED VALUE 
TABLE 3.52. BACKGROUND GROUNDWATER QUALITY DATA BY PARAMETER FOR THE

TOUER SANDSTONE UNIT, BURRO CANYON DISPOSAL SITE, SLICK ROCK, COLORADO

SITE: SRKO2 BORROW SITE 1 (BURRO CANYON)

06/04/90 TO $10 / 14 / 92$

REPORT DATE: $03 / 02 / 94$

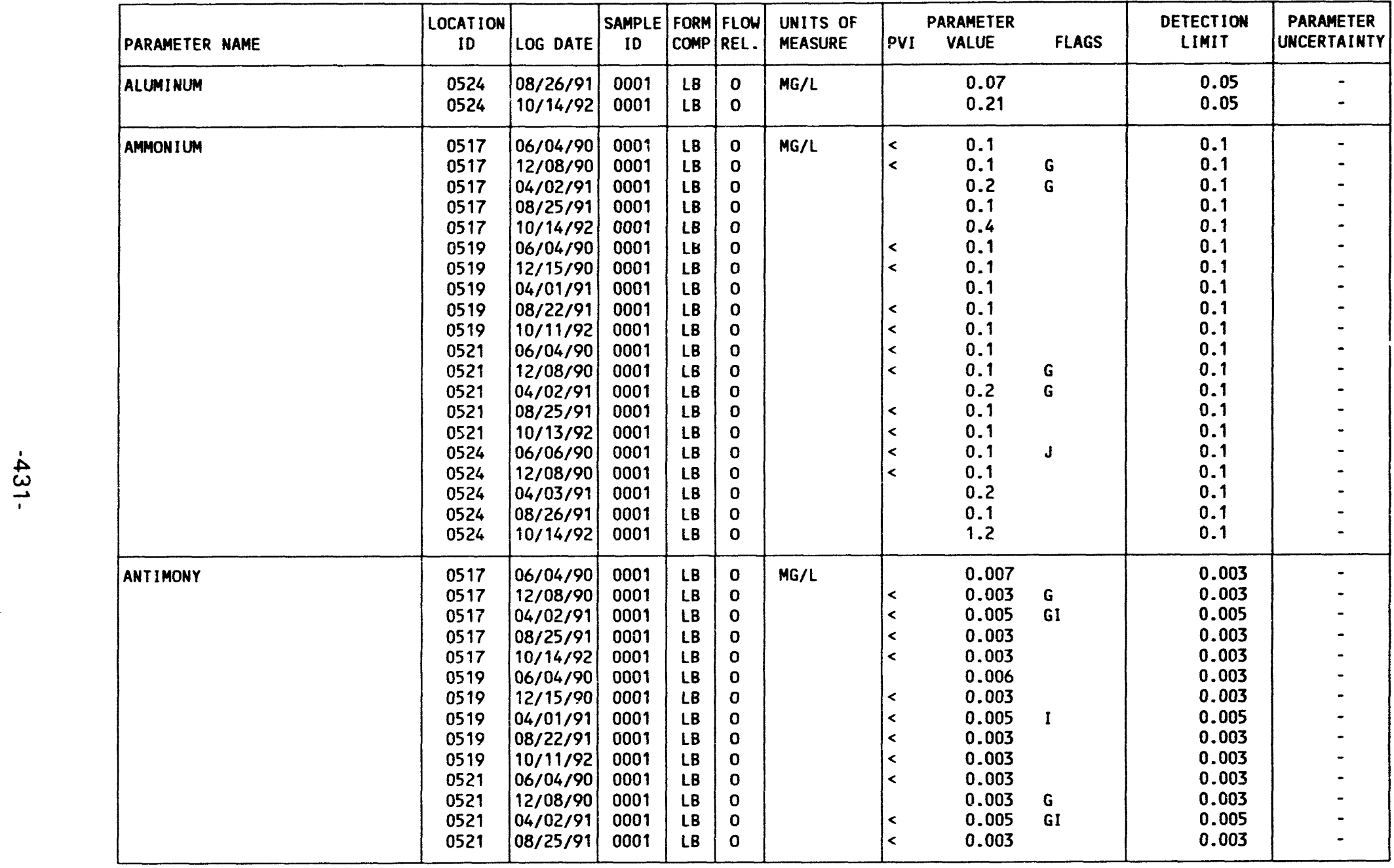

FORMATION OF COMPLETION CODE:

FLOW RELATIONSHIP CODE:

LB - LOWER BURRO CANYON

O - ON-SITE

PARAMETER VALUE INDICATOR (PVI): < - LESS THAN DETECTION LIMIT

SAMPLE ID CODES:

0001 - FILTERED SAMPLE (.45 MICRONS)

OTHER PARAMETER VALUE FLAGS:

G - PH > 9, POSSIBLE GROUT CONTAMINATION

1 - INCREASED DETECTION LIMIT DUE TO REQUIRED DILUTION

$J$ - ESTIMATED VALUE 
TABLE 3.52. BACKGROUND GROUNDWATER OUALITY DATA BY PARAMETER FOR THE LOWER SANDSTONE UNIT, BURRO CANYON DISPOSAL SITE, SLICK ROCK, COLORADO SITE: SRKO2 BORROW SITE 1 (BURRO CANYON)

06/04/90 TO $10 / 14 / 92$

REPORT DATE: $03 / 02 / 94$

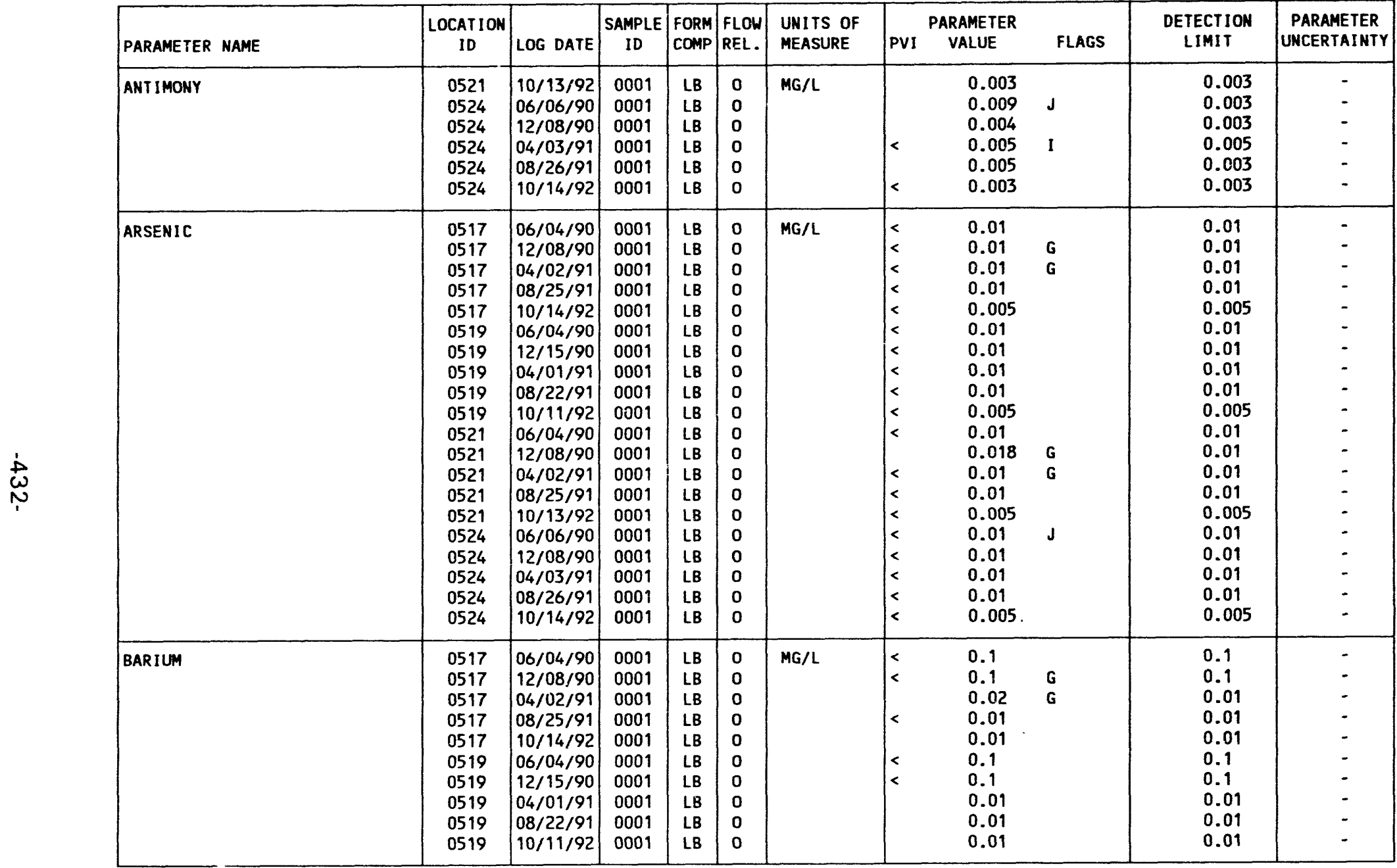

FOPMATION OF COMPLETION COOE:

LB - LOWER BURRO CANYON
FLOW RELATIONSHIP CODE:

O - ON-SITE

SAMPLE IO CODES:

0001 - FILTERED SAMPLE (.45 MICRONS)

OTHER PARAMETER VALUE FLAGS:

G - PH > 9, POSSIBLE GROUT CONTAMINATION

I - INCREASED DETECTION LIMIT DUE TO REQUIRED DILUTION

- ESTIMATED VALUE 
TABLE 3.52. BACKGROUND GROUNDWATER QUALITY DATA BY PARAMETER FOR THE LOWER SANDSTONE UNIT, BURRO CANYON DISPOSAL SITE, SLICK ROCK, COLORADO

SITE: SRKO2 BORROW SITE 1 (BURRO CAMYON)

06/04/90 TO $10 / 14 / 92$

REPORT DATE: $03 / 02 / 94$

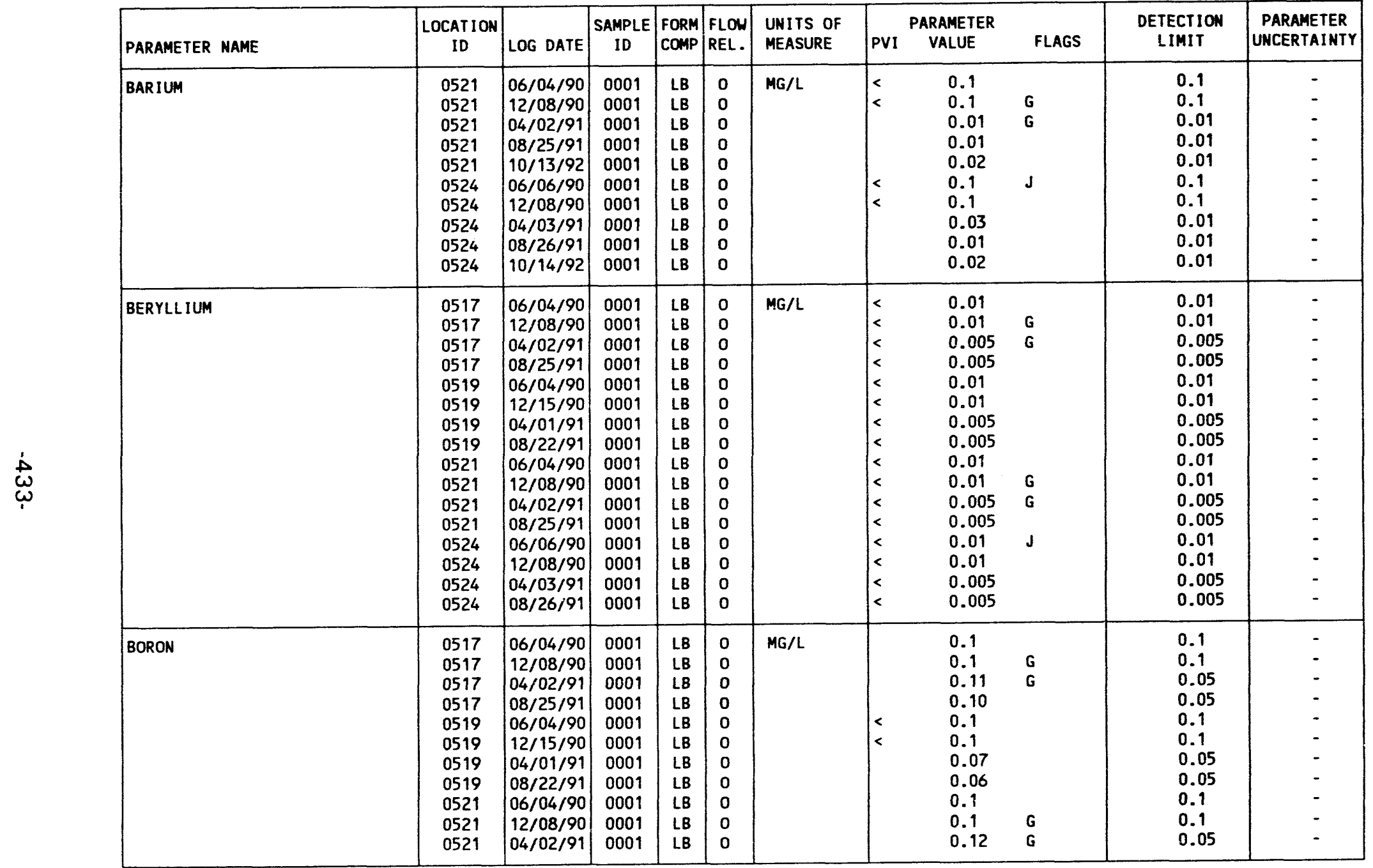

FORMATION OF COMPLETION CODE:

LB - LOWER BURRO CANYON

PARAMETER VALUE INDICATOR (PVI): < - LESS THAN DETECTION LIMIT

OTHER PARAMETER VALUE FLAGS:

G - PH > 9, POSSIBLE GROUT CONTAMINATION

$J$ - eStIMATED VALUE
FLOW RELATIONSHIP COOE:

O - ON-SITE

SAMPLE ID CODES:

OO01 - FILTERED SAMPLE (.45 MICRONS) 
TABLE 3.52. BACKGROUND GROUNDWATER QUALITY DATA BY PARAMETER FOR THE LOWER SANDSTOME UNIT, BURRO CANYON DISPOSAL SITE, SLICK ROCK, COLORADO SITE: SRKO2 BORROW SITE 1 (BURRO CANYON)

06/04/90 TO $10 / 14 / 92$

REPORT DATE: $03 / 02 / 94$

\begin{tabular}{|c|c|c|c|c|c|c|c|c|c|c|c|}
\hline PARAMETER NAME & $\begin{array}{c}\text { LOCATION } \\
\text { ID }\end{array}$ & LOG DATE & $\underset{\text { ID }}{\text { SAMPLE }}$ & $\begin{array}{l}\text { FORM } \\
\text { COMP }\end{array}$ & $\begin{array}{l}\text { FLOW } \\
\text { REL. }\end{array}$ & $\begin{array}{l}\text { UNITS OF } \\
\text { MEASURE }\end{array}$ & PVI & $\begin{array}{l}\text { ARAMETER } \\
\text { VALUE }\end{array}$ & FLAGS & $\begin{array}{l}\text { DETECTION } \\
\text { LIMIT }\end{array}$ & $\begin{array}{l}\text { PARAMETER } \\
\text { UNCERTAINTY }\end{array}$ \\
\hline BORON & $\begin{array}{l}0521 \\
0524 \\
0524 \\
0524 \\
0524\end{array}$ & $\begin{array}{l}08 / 25 / 91 \\
06 / 06 / 90 \\
12 / 08 / 90 \\
04 / 03 / 91 \\
08 / 26 / 91\end{array}$ & $\begin{array}{l}0001 \\
0001 \\
0001 \\
0001 \\
0001\end{array}$ & $\begin{array}{l}\text { LB } \\
\text { LB } \\
\text { LB } \\
\text { LB } \\
\text { LB }\end{array}$ & $\begin{array}{l}0 \\
0 \\
0 \\
0 \\
0\end{array}$ & $M G / L$ & $<$ & $\begin{array}{l}0.10 \\
0.1 \\
0.1 \\
0.08 \\
0.08\end{array}$ & $J$ & $\begin{array}{l}0.05 \\
0.1 \\
0.1 \\
0.05 \\
0.05\end{array}$ & $\begin{array}{l}- \\
- \\
-\end{array}$ \\
\hline BROMIDE & $\begin{array}{l}0517 \\
0517 \\
0517 \\
0517 \\
0519 \\
0519 \\
0519 \\
0519 \\
0521 \\
0521 \\
0521 \\
0521 \\
0524 \\
0524 \\
0524 \\
0524\end{array}$ & \begin{tabular}{|l|}
$12 / 08 / 90$ \\
$04 / 02 / 91$ \\
$08 / 25 / 91$ \\
$10 / 14 / 92$ \\
$12 / 15 / 90$ \\
$04 / 01 / 91$ \\
$08 / 22 / 91$ \\
$10 / 11 / 92$ \\
$12 / 08 / 90$ \\
$04 / 02 / 91$ \\
$08 / 25 / 91$ \\
$10 / 13 / 92$ \\
$12 / 08 / 90$ \\
$04 / 03 / 91$ \\
$08 / 26 / 91$ \\
$10 / 14 / 92$
\end{tabular} & $\begin{array}{l}0001 \\
0001 \\
0001 \\
0001 \\
0001 \\
0001 \\
0001 \\
0001 \\
0001 \\
0001 \\
0001 \\
0001 \\
0001 \\
0001 \\
0001 \\
0001\end{array}$ & $\begin{array}{l}\text { LB } \\
\text { LB } \\
\text { LB } \\
\text { LB } \\
\text { LB } \\
\text { LB } \\
\text { LB } \\
\text { LB } \\
\text { LB } \\
\text { LB } \\
\text { LB } \\
\text { LB } \\
\text { LB } \\
\text { LB } \\
\text { LB } \\
\text { LB }\end{array}$ & $\begin{array}{l}0 \\
0 \\
0 \\
0 \\
0 \\
0 \\
0 \\
0 \\
0 \\
0 \\
0 \\
0 \\
0 \\
0 \\
0 \\
0\end{array}$ & $\mathrm{MG} / \mathrm{L}$ & $\begin{array}{l}< \\
< \\
< \\
< \\
< \\
< \\
< \\
< \\
< \\
< \\
<\end{array}$ & $\begin{array}{l}0.1 \\
0.1 \\
0.1 \\
0.2 \\
0.1 \\
0.2 \\
0.1 \\
0.1 \\
0.1 \\
0.1 \\
0.1 \\
0.5 \\
0.1 \\
0.2 \\
0.1 \\
0.5\end{array}$ & $\begin{array}{l}G J \\
G \\
1 \\
J \\
G J \\
G \\
I \\
J \\
I\end{array}$ & $\begin{array}{l}0.1 \\
0.1 \\
0.1 \\
0.2 \\
0.1 \\
0.1 \\
0.1 \\
0.1 \\
0.1 \\
0.1 \\
0.1 \\
0.5 \\
0.1 \\
0.1 \\
0.1 \\
0.5\end{array}$ & $\begin{array}{l}- \\
- \\
- \\
- \\
- \\
- \\
- \\
- \\
- \\
- \\
- \\
- \\
-\end{array}$ \\
\hline CADMIUM & $\begin{array}{l}0517 \\
0517 \\
0517 \\
0517 \\
0517 \\
0519 \\
0519 \\
0519 \\
0519 \\
0519 \\
0521 \\
0521 \\
0521 \\
0521 \\
0521\end{array}$ & $\begin{array}{l}06 / 04 / 90 \\
12 / 08 / 90 \\
04 / 02 / 91 \\
08 / 25 / 91 \\
10 / 14 / 92 \\
06 / 04 / 90 \\
12 / 15 / 90 \\
04 / 01 / 91 \\
08 / 22 / 91 \\
10 / 11 / 92 \\
06 / 04 / 90 \\
12 / 08 / 90 \\
04 / 02 / 91 \\
08 / 25 / 91 \\
10 / 13 / 92\end{array}$ & $\begin{array}{l}0001 \\
0001 \\
0001 \\
0001 \\
0001 \\
0001 \\
0001 \\
0001 \\
0001 \\
0001 \\
0001 \\
0001 \\
0001 \\
0001 \\
0001\end{array}$ & $\begin{array}{l}\text { LB } \\
\text { LB } \\
\text { LB } \\
\text { LB } \\
\text { LB } \\
\text { LB } \\
\text { LB } \\
\text { LB } \\
\text { LB } \\
\text { LB } \\
\text { LB } \\
\text { LB } \\
\text { LB } \\
\text { LB } \\
\text { LB }\end{array}$ & $\begin{array}{l}0 \\
0 \\
0 \\
0 \\
0 \\
0 \\
0 \\
0 \\
0 \\
0 \\
0 \\
0 \\
0 \\
0 \\
0\end{array}$ & MG/L & $\begin{array}{l}< \\
< \\
< \\
< \\
< \\
< \\
< \\
< \\
< \\
< \\
< \\
< \\
< \\
< \\
< \\
<\end{array}$ & $\begin{array}{l}0.001 \\
0.001 \\
0.0005 \\
0.001 \\
0.005 \\
0.001 \\
0.001 \\
0.0005 \\
0.001 \\
0.001 \\
0.001 \\
0.001 \\
0.0005 \\
0.001 \\
0.005\end{array}$ & $\begin{array}{l}G \\
G \\
I\end{array}$ & $\begin{array}{l}0.001 \\
0.001 \\
0.0005 \\
0.001 \\
0.005 \\
0.001 \\
0.001 \\
0.0005 \\
0.001 \\
0.001 \\
0.001 \\
0.001 \\
0.0005 \\
0.001 \\
0.005\end{array}$ & $\begin{array}{l}- \\
- \\
- \\
- \\
- \\
- \\
- \\
- \\
- \\
- \\
- \\
- \\
- \\
-\end{array}$ \\
\hline
\end{tabular}

FORMATION OF COMPLETION CODE:

LB - LONER BURRO CANYON

PARAMETER VALUE INDICATOR (PVI): < - LESS THAN DETECTION LIMIT
FLOW RELATIONSHIP CODE:

O - ON-SITE

SAMPLE ID CODES:

O001 - FILTERED SAMPLE (.45 MICRONS)

OTHER PARAMETER VALUE FLAGS:

G - PH > 9, POSSIBLE GROUT CONTAMINATION

I - INCREASED DETECTION LIMIT DUE TO REQUIRED DILUTION

J - ESTIMATED VALUE 
TABLE 3.52. BACKGROUND GROUNDWATER QUALITY DATA BY PARAMETER FOR THE

LONER SANDSTONE UNIT, BURRO CANYON DISPOSAL SITE, SLICK ROCK, COLORADO

SITE: SRKO2 BORROU SITE 1 (BURRO CANYON)

06/04/90 TO $10 / 14 / 92$

REPORT DATE: $03 / 02 / 94$

\begin{tabular}{|c|c|c|c|c|c|c|c|c|c|c|c|}
\hline PARAMETER NAME & $\underset{\text { ID }}{\text { LOCAT ION }}$ & LOG DATE & $\underset{\text { ID }}{\text { SAMPLE }}$ & $\begin{array}{l}\text { FORM } \\
\text { COMP }\end{array}$ & $\begin{array}{l}\text { FLOW } \\
\text { REL. }\end{array}$ & $\begin{array}{l}\text { UNITS OF } \\
\text { MEASURE }\end{array}$ & PVI & $\begin{array}{l}\text { ARAMETER } \\
\text { VALUE }\end{array}$ & FLAGS & $\begin{array}{l}\text { DETECTION } \\
\text { LIMIT }\end{array}$ & $\begin{array}{l}\text { PARAMETER } \\
\text { UNCERTAINTY }\end{array}$ \\
\hline CADMIUM & $\begin{array}{l}0524 \\
0524 \\
0524 \\
0524 \\
0524\end{array}$ & $\begin{array}{l}06 / 06 / 90 \\
12 / 08 / 90 \\
04 / 03 / 91 \\
08 / 26 / 91 \\
10 / 14 / 92\end{array}$ & $\begin{array}{l}0001 \\
0001 \\
0001 \\
0001 \\
0001\end{array}$ & $\begin{array}{l}\text { LB } \\
\text { LB } \\
\text { LB } \\
\text { LB } \\
\text { LB }\end{array}$ & $\begin{array}{l}0 \\
0 \\
0 \\
0 \\
0\end{array}$ & $M G / L$ & $<<$ & $\begin{array}{l}0.0001 \\
0.001 \\
0.0005 \\
0.001 \\
0.001\end{array}$ & J & $\begin{array}{l}0.001 \\
0.001 \\
0.0005 \\
0.001 \\
0.001\end{array}$ & $\begin{array}{l}- \\
- \\
- \\
-\end{array}$ \\
\hline CALCIUM & $\begin{array}{l}0517 \\
0517 \\
0517 \\
0517 \\
0517 \\
0519 \\
0519 \\
0519 \\
0519 \\
0519 \\
0521 \\
0521 \\
0521 \\
0521 \\
0521 \\
0524 \\
0524 \\
0524 \\
0524 \\
0524\end{array}$ & $\begin{array}{l}06 / 04 / 90 \\
12 / 08 / 90 \\
04 / 02 / 91 \\
08 / 25 / 91 \\
10 / 14 / 92 \\
06 / 04 / 90 \\
12 / 15 / 90 \\
04 / 01 / 91 \\
08 / 22 / 91 \\
10 / 11 / 92 \\
06 / 04 / 90 \\
12 / 08 / 90 \\
04 / 02 / 91 \\
08 / 25 / 91 \\
10 / 13 / 92 \\
06 / 06 / 90 \\
12 / 08 / 90 \\
04 / 03 / 91 \\
08 / 26 / 91 \\
10 / 14 / 92\end{array}$ & $\begin{array}{l}0001 \\
0001 \\
0001 \\
0001 \\
0001 \\
0001 \\
0001 \\
0001 \\
0001 \\
0001 \\
0001 \\
0001 \\
0001 \\
0001 \\
0001 \\
0001 \\
0001 \\
0001 \\
0001 \\
0001\end{array}$ & $\begin{array}{l}\text { LB } \\
\text { LB } \\
\text { LB } \\
\text { LB } \\
\text { LB } \\
\text { LB } \\
\text { LB } \\
\text { LB } \\
\text { LB } \\
\text { LB } \\
\text { LB } \\
\text { LB } \\
\text { LB } \\
\text { LB } \\
\text { LB } \\
\text { LB } \\
\text { LB } \\
\text { LB } \\
\text { LB } \\
\text { LB }\end{array}$ & $\begin{array}{l}0 \\
0 \\
0 \\
0 \\
0 \\
0 \\
0 \\
0 \\
0 \\
0 \\
0 \\
0 \\
0 \\
0 \\
0 \\
0 \\
0 \\
0 \\
0 \\
0\end{array}$ & $M G / L$ & & $\begin{array}{l}0.94 \\
1.17 \\
1.0 \\
0.5 \\
0.5 \\
2.51 \\
2.64 \\
2.5 \\
1.9 \\
2.1 \\
2.34 \\
1.59 \\
1.7 \\
1.5 \\
1.2 \\
1.07 \\
2.16 \\
2.1 \\
1.8 \\
1.1\end{array}$ & $\begin{array}{l}\text { G } \\
\text { G } \\
\text { J }\end{array}$ & $\begin{array}{l}0.01 \\
0.01 \\
0.1 \\
0.1 \\
0.1 \\
0.01 \\
0.01 \\
0.1 \\
0.1 \\
0.1 \\
0.01 \\
0.01 \\
0.1 \\
0.1 \\
0.1 \\
0.01 \\
0.01 \\
0.1 \\
0.1 \\
0.1\end{array}$ & $\begin{array}{l}- \\
- \\
- \\
- \\
- \\
- \\
- \\
- \\
- \\
- \\
- \\
- \\
- \\
- \\
- \\
- \\
- \\
-\end{array}$ \\
\hline CHLORIDE & $\begin{array}{l}0517 \\
0517 \\
0517 \\
0517 \\
0517 \\
0519 \\
0519 \\
0519 \\
0519 \\
0519 \\
0521 \\
0521\end{array}$ & $\begin{array}{l}06 / 04 / 90 \\
12 / 08 / 90 \\
04 / 02 / 91 \\
08 / 25 / 91 \\
10 / 14 / 92 \\
06 / 04 / 90 \\
12 / 15 / 90 \\
04 / 01 / 91 \\
08 / 22 / 91 \\
10 / 11 / 92 \\
06 / 04 / 90 \\
12 / 08 / 90\end{array}$ & $\begin{array}{l}0001 \\
0001 \\
0001 \\
0001 \\
0001 \\
0001 \\
0001 \\
0001 \\
0001 \\
0001 \\
0001 \\
0001\end{array}$ & $\begin{array}{l}\text { LB } \\
\text { LB } \\
\text { LB } \\
\text { LB } \\
\text { LB } \\
\text { LB } \\
\text { LB } \\
\text { LB } \\
\text { LB } \\
\text { LB } \\
\text { LB } \\
\text { LB }\end{array}$ & $\begin{array}{l}0 \\
0 \\
0 \\
0 \\
0 \\
0 \\
0 \\
0 \\
0 \\
0 \\
0 \\
0\end{array}$ & $M G / L$ & & $\begin{array}{l}15 . \\
14 . \\
15.8 \\
14.9 \\
15.0 \\
8 . \\
11 . \\
13.3 \\
13.0 \\
13.2 \\
12 . \\
16 .\end{array}$ & $\begin{array}{l}\text { G } \\
\text { G }\end{array}$ & $\begin{array}{l}1 . \\
1 . \\
0.5 \\
0.5 \\
0.5 \\
1 . \\
1 . \\
0.5 \\
0.5 \\
0.5 \\
1 . \\
1 .\end{array}$ & $\begin{array}{l}- \\
- \\
- \\
- \\
- \\
- \\
- \\
- \\
-\end{array}$ \\
\hline
\end{tabular}

FORMATION OF COMPLETION CODE:

LB - LOWER BURRO CANYON

PARAMETER VALUE INDICATOR (PVI): < - LESS THAN DETECTION LIMIT
FLOW RELATIONSHIP COOE:

o - ON-SITE

SAMPLE ID CODES:

0001 - FILTERED SAMPLE (.45 MICRONS)

OTHER PARAMETER VALUE FLAGS:

$G$ - PH > 9, POSSIBLE GROUT CONTAMINATION

J - eSTIMATED VALUE 
TABLE 3.52. BACKGROUND GROUNDWATER QUALITY DATA BY PARAMETER FOR THE LOWER SANDSTONE UNIT, BURRO CANYON DISPOSAL SITE, SLICK ROCK, COLORADO

SITE: SRK02 BORROW SITE 1 (BURRO CANYON)

06/04/90 TO $10 / 14 / 92$

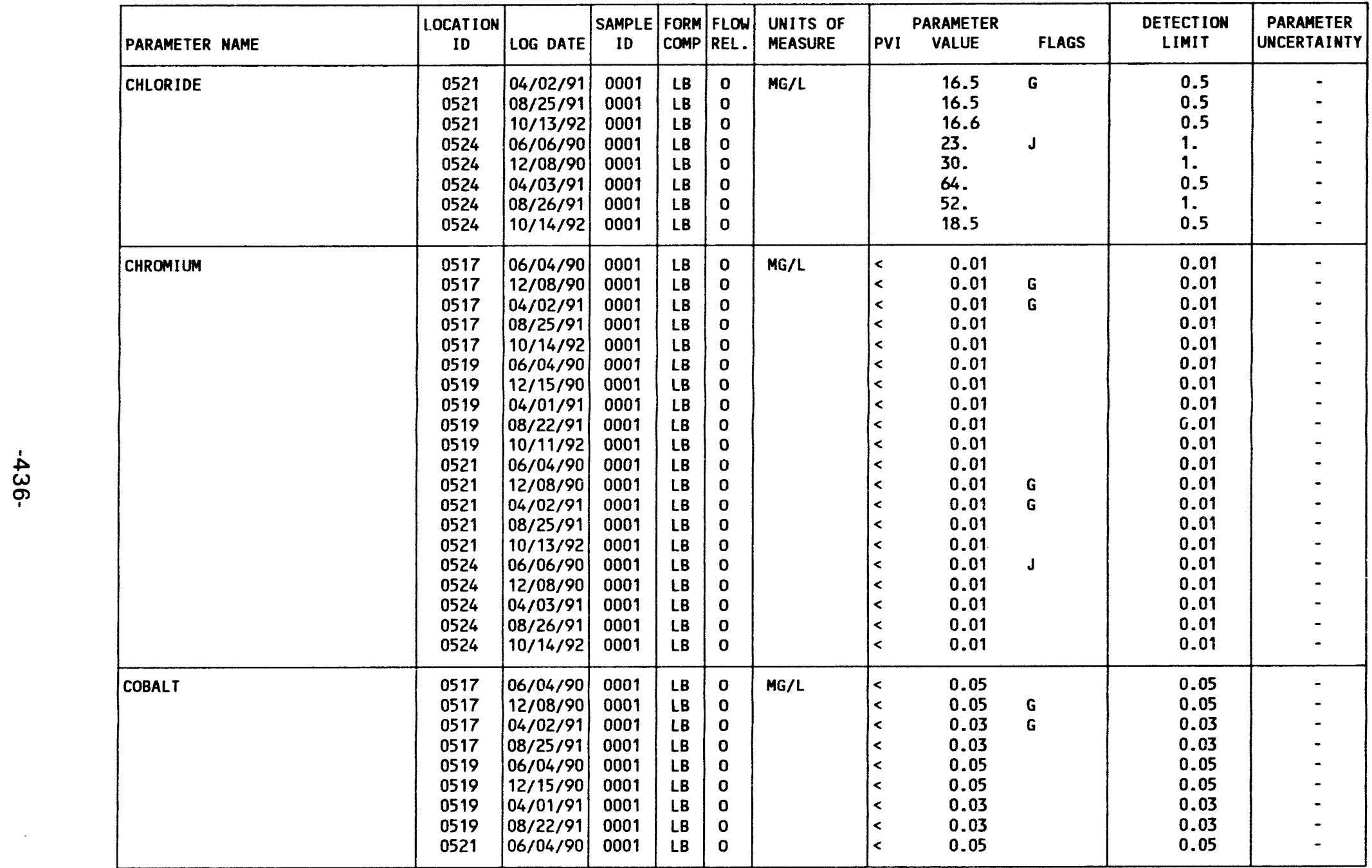

FORMATION OF COMPLETION CODE:

LB - LOWER BURRO CANYON

FLOW RELATIONSHIP COOE:

PARAMETER VALUE INDICATOR (PVI): < - LESS THAN DETECTION LIMIT

SAMPLE ID COOES:

0001 - FILTERED SAMPLE (.45 MICRONS)

OTHER PARAMETER VALUE FLAGS:

G - PH > 9, POSSIBLE GROUT CONTAMINATION

J - ESTIMATED VALUE 
TABLE 3.52. BACKGROUND GROUNDHATER QUALITY DATA BY PARAMETER FOR THE

LOWER SANDSTONE UNIT, BURRO CANYON DISPOSAL SITE, SLICK ROCK, COLON.DO

SITE: SRKO2 BORROW SITE 1 (BURRO CANYOH)

06/04/90 TO $10 / 14 / 92$

REPORT DATE: 03/02/94

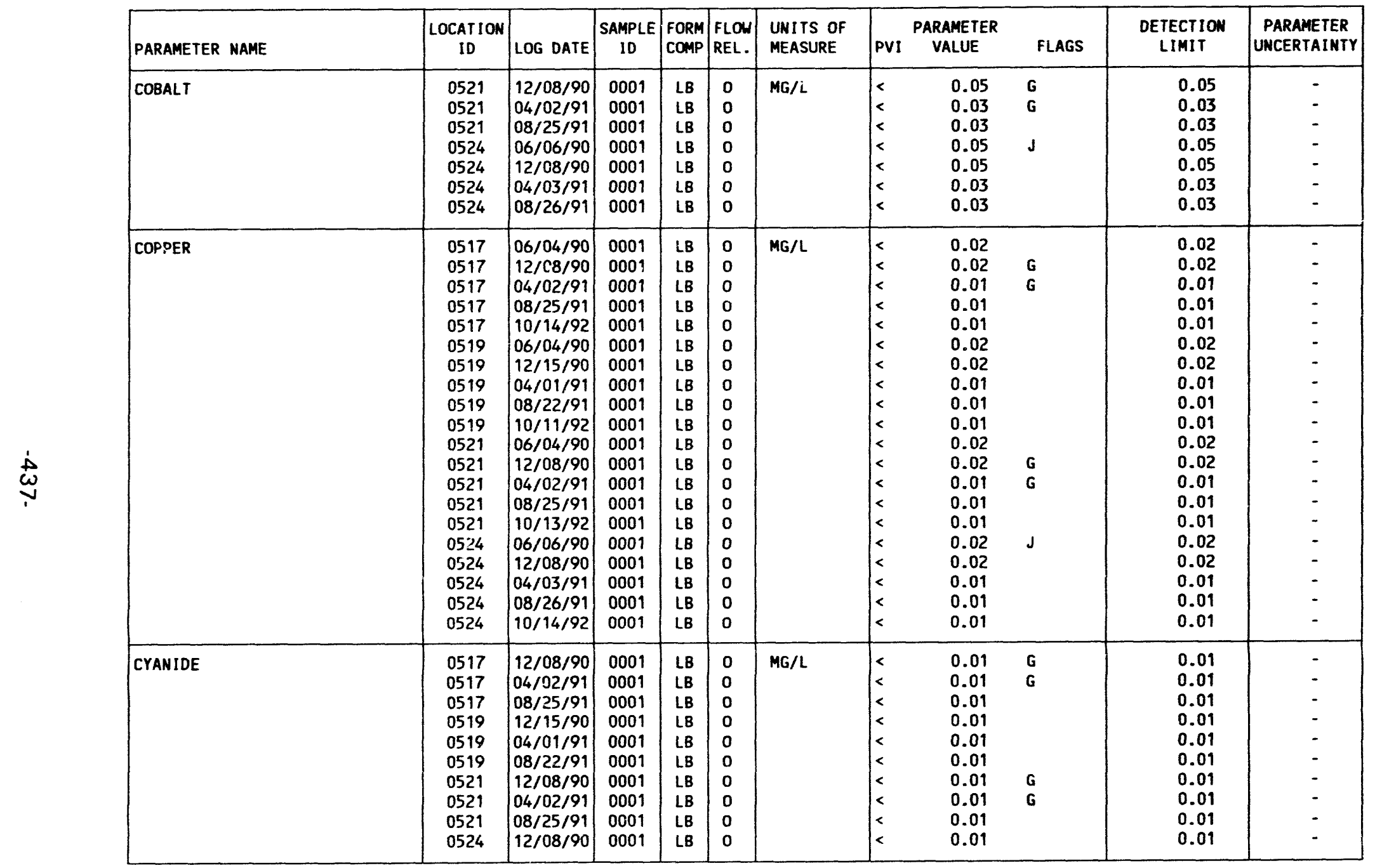

FORMATION OF COMPLETION COOE:

LB - LONER BURRO CANYON

FLOW RELATIONSHIP COOE:

PARAMETER VALUE INDICATOR (PVI): < - LESS THAN DETECTION LIMIT

SAMPLE ID CODES:

0001 - FILTERED SAMPLE (.45 MICRONS)

OTHER PARAMETER VALUE FLAGS:

G - PH > 9, POSSIBLE GROUT CONTAMINATION

J - ESTIMATED VALUE 
TABLE 3.52. BACKGROUND GROUNDWATER QUALITY DATA BY PARAMETER FOR THE LONER SANDSTONE UNIT, BURRO CANYON DISPOSAL SITE, SLICK ROCK, COLORADO SITE: SRKO2 BORROW SITE 1 (BURRO CANYON)

$06 / 04 / 90$ TO $10 / 14 / 92$

REPORT DATE: 03/02/94

\begin{tabular}{|c|c|c|c|c|c|c|c|c|c|c|c|}
\hline PARAMETER NAME & $\underset{\text { ID }}{\text { LOCATION }}$ & LOG DATE & $\begin{array}{c}\text { SAMPLE } \\
\text { ID }\end{array}$ & $\begin{array}{l}\text { FORM } \\
\text { COMP }\end{array}$ & $\begin{array}{l}\text { FLOW } \\
\text { REL. }\end{array}$ & $\begin{array}{l}\text { UNITS OF } \\
\text { MEASURE }\end{array}$ & PVI & $\begin{array}{l}\text { ARAMET } \\
\text { VALUE }\end{array}$ & FLAGS & $\begin{array}{l}\text { DETECTION } \\
\text { LIMIT }\end{array}$ & $\begin{array}{l}\text { PARAMETER } \\
\text { UNCERTAINTY }\end{array}$ \\
\hline CYANIDE & $\begin{array}{l}0524 \\
0524\end{array}$ & $\begin{array}{l}04 / 03 / 91 \\
08 / 26 / 91\end{array}$ & $\begin{array}{l}0001 \\
0001\end{array}$ & $\begin{array}{l}\text { LB } \\
\text { LB }\end{array}$ & $\begin{array}{l}0 \\
0\end{array}$ & $M G / L$ & $<$ & $\begin{array}{l}0.0 \\
0.0\end{array}$ & & $\begin{array}{l}0.01 \\
0.01\end{array}$ & - \\
\hline DISSOLVED OXYGEN & $\begin{array}{l}0517 \\
0519 \\
0521 \\
0524\end{array}$ & $\begin{array}{l}10 / 14 / 92 \\
10 / 11 / 92 \\
10 / 13 / 92 \\
10 / 14 / 92\end{array}$ & $\begin{array}{l}0001 \\
0001 \\
0001 \\
0001\end{array}$ & $\begin{array}{l}\text { LB } \\
\text { LB } \\
\text { LB } \\
\text { LB }\end{array}$ & $\begin{array}{l}0 \\
0 \\
0 \\
0\end{array}$ & $M G / L$ & & $\begin{array}{l}0.9 \\
3.6 \\
1.1 \\
1.2\end{array}$ & & $\begin{array}{l}- \\
- \\
-\end{array}$ & $\begin{array}{l}- \\
-\end{array}$ \\
\hline FLUORIDE & $\begin{array}{l}0517 \\
0517 \\
0517 \\
0517 \\
0517 \\
0519 \\
0519 \\
0519 \\
0519 \\
0519 \\
0521 \\
0521 \\
0521 \\
0521 \\
0521 \\
0524 \\
0524 \\
0524 \\
0524 \\
0524\end{array}$ & $\begin{array}{l}06 / 04 / 90 \\
12 / 08 / 90 \\
04 / 02 / 91 \\
08 / 25 / 91 \\
10 / 14 / 92 \\
06 / 04 / 90 \\
12 / 15 / 90 \\
04 / 01 / 91 \\
08 / 22 / 91 \\
10 / 11 / 92 \\
06 / 04 / 90 \\
12 / 08 / 90 \\
04 / 02 / 91 \\
08 / 25 / 91 \\
10 / 13 / 92 \\
06 / 06 / 90 \\
12 / 08 / 90 \\
04 / 03 / 91 \\
08 / 26 / 91 \\
10 / 14 / 92\end{array}$ & $\begin{array}{l}0001 \\
0001 \\
0001 \\
0001 \\
0001 \\
0001 \\
0001 \\
0001 \\
0001 \\
0001 \\
0001 \\
0001 \\
0001 \\
0001 \\
0001 \\
0001 \\
0001 \\
0001 \\
0001 \\
0001\end{array}$ & $\begin{array}{l}\text { LB } \\
\text { LB } \\
\text { LB } \\
\text { LB } \\
\text { LB } \\
\text { LB } \\
\text { LB } \\
\text { LB } \\
\text { LB } \\
\text { LB } \\
\text { LB } \\
\text { LB } \\
\text { LB } \\
\text { LB } \\
\text { LB } \\
\text { LB } \\
\text { LB } \\
\text { LB } \\
\text { LB } \\
\text { LB }\end{array}$ & $\begin{array}{l}0 \\
0 \\
0 \\
0 \\
0 \\
0 \\
0 \\
0 \\
0 \\
0 \\
0 \\
0 \\
0 \\
0 \\
0 \\
0 \\
0 \\
0 \\
0 \\
0\end{array}$ & $M G / L$ & & $\begin{array}{l}0.7 \\
0.7 \\
0.6 \\
0.5 \\
0.6 \\
0.4 \\
0.5 \\
0.3 \\
0.4 \\
0.4 \\
0.6 \\
0.9 \\
0.6 \\
0.6 \\
0.7 \\
0.5 \\
0.6 \\
0.6 \\
0.5 \\
0.5\end{array}$ & $\begin{array}{l}\mathbf{G} \\
\mathbf{G} \\
\mathbf{J}\end{array}$ & $\begin{array}{l}0.1 \\
0.1 \\
0.1 \\
0.1 \\
0.1 \\
0.1 \\
0.1 \\
0.1 \\
0.1 \\
0.1 \\
0.1 \\
0.1 \\
0.1 \\
0.1 \\
0.1 \\
0.1 \\
0.1 \\
0.1 \\
0.1 \\
0.1\end{array}$ & $\begin{array}{l}- \\
- \\
- \\
- \\
- \\
- \\
- \\
- \\
- \\
- \\
- \\
- \\
- \\
- \\
- \\
-\end{array}$ \\
\hline GROSS ALPHA & $\begin{array}{l}0517 \\
0517 \\
0517 \\
0517 \\
0519 \\
0519 \\
0519 \\
0519 \\
0521\end{array}$ & $\begin{array}{l}12 / 08 / 90 \\
04 / 02 / 91 \\
08 / 25 / 91 \\
10 / 14 / 92 \\
12 / 15 / 90 \\
04 / 01 / 91 \\
08 / 22 / 91 \\
10 / 11 / 92 \\
12 / 08 / 90\end{array}$ & $\begin{array}{l}0001 \\
0001 \\
0001 \\
0001 \\
0001 \\
0001 \\
0001 \\
000 ? \\
0001\end{array}$ & $\begin{array}{l}\text { LB } \\
\text { LB } \\
\text { LB } \\
\text { LB } \\
\text { LB } \\
\text { LB } \\
\text { LB } \\
\text { LB } \\
\text { LB }\end{array}$ & $\begin{array}{l}0 \\
0 \\
0 \\
0 \\
0 \\
0 \\
0 \\
0 \\
0\end{array}$ & $\mathrm{PCI} / \mathrm{L}$ & & $\begin{array}{l}2.1 \\
0.0 \\
0.0 \\
0.0 \\
0.0 \\
0.0 \\
1.5 \\
0.0 \\
8.1\end{array}$ & $\begin{array}{l}\mathbf{G} \\
\mathbf{G} \\
\mathbf{N}\end{array}$ & $\begin{array}{l}1 . \\
1 . \\
1 . \\
5.8 \\
1 . \\
1 . \\
1 . \\
6.5 \\
1 .\end{array}$ & $\begin{array}{l}2.6 \\
3.2 \\
4.7 \\
3.3 \\
2.6 \\
2.8 \\
5.0 \\
3.2 \\
3.7\end{array}$ \\
\hline
\end{tabular}

FORMATION OF COMPLETION CODE:

LB - LOWER BURRO CANYON

PAIAMETER VALUE IMDICATOR (PVI): < - LESS THAN DETECTION LIMIT
FLOW RELATIONSHIP COOE:

O - ON-SITE

\section{SAMPLE ID CODES:}

0001 - FILTERED SAMPLE (.45 MICRONS)

OTHER PARAMETER VALUE FLAGS:

G - PH > 9, POSSIBLE GROUT CONTAMINATION

$J$ - ESTIMATED VALUE

N - SPIKE SAMPLE RECOVERY NOT WITHIN CONTROL LIMITS 
TABLE 3.52. BACKGROUND GROUNDHATER QUALITY DATA BY PARAMETER FOR THE LOWER SANDSTONE UNIT, BURRO CANYON DISPOSAL SITE, SLICK ROCK, COLORADO SITE: SRKO2 BORROW SITE 1 (BURRO CANYON)

06/04/90 TO $10 / 14 / 92$

REPORT DATE : 03/02/94

\begin{tabular}{|c|c|c|c|c|c|c|c|c|c|c|c|}
\hline PARAMETER MAME & $\begin{array}{l}\text { LOCATION } \\
\text { ID }\end{array}$ & LOG DATE & $\begin{array}{l}\text { SAMPLE } \\
\text { ID }\end{array}$ & $\begin{array}{l}\text { FORM } \\
\text { COMP }\end{array}$ & $\begin{array}{l}\text { FLOW } \\
\text { REL. }\end{array}$ & $\begin{array}{l}\text { UNITS OF } \\
\text { MEASURE }\end{array}$ & PVI & $\begin{array}{l}\text { ARAMETER } \\
\text { VALUE }\end{array}$ & FLAGS & $\begin{array}{l}\text { DETECTION } \\
\text { LIMIT }\end{array}$ & $\begin{array}{l}\text { PARAMETER } \\
\text { UNCERTAINTY }\end{array}$ \\
\hline GROSS ALPHA & $\begin{array}{l}0521 \\
0521 \\
0521 \\
0524 \\
0524 \\
0524 \\
0524\end{array}$ & $\begin{array}{l}04 / 02 / 91 \\
08 / 25 / 91 \\
10 / 13 / 92 \\
12 / 08 / 90 \\
04 / 03 / 91 \\
08 / 26 / 91 \\
10 / 14 / 92\end{array}$ & $\begin{array}{l}0001 \\
0001 \\
0001 \\
0001 \\
0001 \\
0001 \\
0001\end{array}$ & $\begin{array}{l}\text { LB } \\
\text { LB } \\
\text { LB } \\
\text { LB } \\
\text { LB } \\
\text { LB } \\
\text { LB }\end{array}$ & $\begin{array}{l}0 \\
0 \\
0 \\
0 \\
0 \\
0 \\
0\end{array}$ & $\mathrm{PCl} / \mathrm{L}$ & & $\begin{array}{l}4.3 \\
7.1 \\
0.0 \\
0.2 \\
0.0 \\
3.6 \\
1.0\end{array}$ & $\begin{array}{l}\text { G } \\
\text { N } \\
\text { N }\end{array}$ & $\begin{array}{l}1 . \\
1 . \\
7.2 \\
1 . \\
1 . \\
1 . \\
6.1\end{array}$ & $\begin{array}{l}4.0 \\
5.9 \\
3.6 \\
3.1 \\
4.1 \\
7.2 \\
3.7\end{array}$ \\
\hline GROSS BETA & $\begin{array}{l}0517 \\
0517 \\
0517 \\
0517 \\
0519 \\
0519 \\
0519 \\
0519 \\
0521 \\
0521 \\
0521 \\
0521 \\
0524 \\
0524 \\
0524 \\
0524\end{array}$ & $\begin{array}{l}12 / 08 / 90 \\
04 / 02 / 91 \\
08 / 25 / 91 \\
10 / 14 / 92 \\
12 / 15 / 90 \\
04 / 01 / 91 \\
08 / 22 / 91 \\
10 / 11 / 92 \\
12 / 08 / 90 \\
04 / 02 / 91 \\
08 / 25 / 91 \\
10 / 13 / 92 \\
12 / 08 / 90 \\
04 / 03 / 91 \\
08 / 26 / 91 \\
10 / 14 / 92\end{array}$ & $\begin{array}{l}0001 \\
0001 \\
0001 \\
0001 \\
0001 \\
0001 \\
0001 \\
0001 \\
0001 \\
0001 \\
0001 \\
0001 \\
0001 \\
0001 \\
0001 \\
0001\end{array}$ & $\begin{array}{l}\text { LB } \\
\text { LB } \\
\text { LB } \\
\text { LB } \\
\text { LB } \\
\text { LB } \\
\text { LB } \\
\text { LB } \\
\text { LB } \\
\text { LB } \\
\text { LB } \\
\text { LB } \\
\text { LB } \\
\text { LB } \\
\text { LB } \\
\text { LB }\end{array}$ & $\begin{array}{l}0 \\
0 \\
0 \\
0 \\
0 \\
0 \\
0 \\
0 \\
0 \\
0 \\
0 \\
0 \\
0 \\
0 \\
0 \\
0\end{array}$ & $\mathrm{PCI} / \mathrm{L}$ & & $\begin{array}{l}1.9 \\
6.1 \\
0.0 \\
0.0 \\
0.6 \\
0.0 \\
1.6 \\
0.0 \\
4.0 \\
1.5 \\
1.6 \\
1.6 \\
1.9 \\
0.0 \\
2.6 \\
0.0\end{array}$ & $\begin{array}{l}G \\
G \\
\star_{N} \\
\star_{N} \\
G \\
G \\
*_{N} \\
\star_{N}\end{array}$ & $\begin{array}{l}0.5 \\
0.5 \\
0.5 \\
5.2 \\
0.5 \\
0.5 \\
0.5 \\
6.3 \\
0.5 \\
0.5 \\
0.5 \\
6.2 \\
0.5 \\
0.5 \\
0.5 \\
5.1\end{array}$ & $\begin{array}{l}1.8 \\
2.3 \\
4.1 \\
3.0 \\
1.6 \\
2.2 \\
3.4 \\
3.7 \\
1.9 \\
2.2 \\
3.9 \\
3.8 \\
1.8 \\
2.6 \\
4.6 \\
3.0\end{array}$ \\
\hline IRON & $\begin{array}{l}0517 \\
0517 \\
0517 \\
0517 \\
0517 \\
0519 \\
0519 \\
0519 \\
0519 \\
0519 \\
0521 \\
0521 \\
0521\end{array}$ & $\begin{array}{l}06 / 04 / 90 \\
12 / 08 / 90 \\
04 / 02 / 91 \\
08 / 25 / 91 \\
10 / 14 / 92 \\
06 / 04 / 90 \\
12 / 15 / 90 \\
04 / 01 / 91 \\
08 / 22 / 91 \\
10 / 11 / 92 \\
06 / 04 / 90 \\
12 / 08 / 90 \\
04 / 02 / 91\end{array}$ & $\begin{array}{l}0001 \\
0001 \\
0001 \\
0001 \\
0001 \\
0001 \\
0001 \\
0001 \\
0001 \\
0001 \\
0001 \\
0001 \\
0001\end{array}$ & $\begin{array}{l}\text { LB } \\
\text { LB } \\
\text { LB } \\
\text { LB } \\
\text { LB } \\
\text { LB } \\
\text { LB } \\
\text { LB } \\
\text { LB } \\
\text { LB } \\
\text { LB } \\
\text { LB } \\
\text { LB }\end{array}$ & $\begin{array}{l}0 \\
0 \\
0 \\
0 \\
0 \\
0 \\
0 \\
0 \\
0 \\
0 \\
0 \\
0 \\
0\end{array}$ & $M G / L$ & $\begin{array}{l}< \\
< \\
< \\
< \\
< \\
< \\
< \\
< \\
<\end{array}$ & $\begin{array}{l}0.06 \\
0.03 \\
0.03 \\
0.04 \\
0.03 \\
0.03 \\
0.03 \\
0.03 \\
0.03 \\
0.03 \\
0.05 \\
0.03 \\
0.03\end{array}$ & $\begin{array}{l}\mathbf{G} \\
\mathbf{G}\end{array}$ & $\begin{array}{l}0.03 \\
0.03 \\
0.03 \\
0.03 \\
0.03 \\
0.03 \\
0.03 \\
0.03 \\
0.03 \\
0.03 \\
0.03 \\
0.03 \\
0.03\end{array}$ & $\begin{array}{l}- \\
- \\
- \\
- \\
- \\
- \\
- \\
- \\
-\end{array}$ \\
\hline
\end{tabular}

FORMATION OF COMPLETION CODE:

LB - LOWER BURRO CANYON

PARAMETER VALUE INDICATOR (PVI): < - LESS THAN DETECTION LIMIT
FLOW RELATIONSHIP CODE:

O - ON-SITE

OTHER PARAMETER VALUE FLAGS:

$\star$ - DUPLICATE ANALYSIS NOT HITHIN CONTROL LIMITS

G - PH $>$ 9, POSSIBLE GROUT CONTAMINATION

N - SPIKE SAMPLE RECOVERY NOT WITHIN CONTROL LIMITS 
TABLE 3.52. BACKGROUND GROUNDHATER OUALITY DATA BY PARAMETER FOR THE TABLE 3.52. BACKGROUND GROUDUATER OUALITY DATA BY PARAMETER FOR THE SITE: SRKO2 BORROW SITE 1 (BURRO CANYON)

O6/04/90 TO 10/14/92

O6/O4/90 TO $10 / 14 / 92$

\begin{tabular}{|c|c|c|c|c|c|c|c|c|c|c|c|}
\hline PARAMETER NAME & $\underbrace{\text { LON }}_{\text {LOCATION }}$ & LOG DATE & $\begin{array}{c}\text { SAMPLE } \\
\text { ID }\end{array}$ & $\begin{array}{l}\text { FORM } \\
\text { COMP }\end{array}$ & $\begin{array}{l}\text { FLOW } \\
\text { REL. }\end{array}$ & $\begin{array}{l}\text { UNITS OF } \\
\text { MEASURE }\end{array}$ & PVI & $\begin{array}{l}\text { PARAMETER } \\
\text { VALUE }\end{array}$ & FLAGS & $\begin{array}{l}\text { DETECTION } \\
\text { LIMIT }\end{array}$ & $\begin{array}{l}\text { PARAMETER } \\
\text { UNCERTAINTY }\end{array}$ \\
\hline IRON & $\begin{array}{l}0521 \\
0521 \\
0524 \\
0524 \\
0524 \\
0524 \\
0524\end{array}$ & $\begin{array}{l}08 / 25 / 91 \\
10 / 13 / 92 \\
06 / 06 / 90 \\
12 / 08 / 90 \\
04 / 03 / 91 \\
08 / 26 / 91 \\
10 / 14 / 92\end{array}$ & $\begin{array}{l}0001 \\
0001 \\
0001 \\
0001 \\
0001 \\
0001 \\
0001\end{array}$ & $\begin{array}{l}\text { LB } \\
\text { LB } \\
\text { LB } \\
\text { LB } \\
\text { LB } \\
\text { LB } \\
\text { LB }\end{array}$ & $\begin{array}{l}0 \\
0 \\
0 \\
0 \\
0 \\
0 \\
0\end{array}$ & $M G / L$ & $<$ & $\begin{array}{l}0.03 \\
0.03 \\
0.03 \\
0.03 \\
0.23 \\
0.03 \\
0.05\end{array}$ & $J$ & $\begin{array}{l}0.03 \\
0.03 \\
0.03 \\
0.03 \\
0.03 \\
0.03 \\
0.03\end{array}$ & $\begin{array}{l}- \\
- \\
- \\
- \\
-\end{array}$ \\
\hline LEAD & $\begin{array}{l}0517 \\
0517 \\
0517 \\
0517 \\
0517 \\
0519 \\
0519 \\
0519 \\
0519 \\
0519 \\
0521 \\
0521 \\
0521 \\
0521 \\
0521 \\
0524 \\
0524 \\
0524 \\
0524 \\
0524\end{array}$ & $\begin{array}{l}06 / 04 / 90 \\
12 / 08 / 90 \\
04 / 02 / 91 \\
08 / 25 / 91 \\
10 / 14 / 92 \\
06 / 04 / 90 \\
12 / 15 / 90 \\
04 / 01 / 91 \\
08 / 22 / 91 \\
10 / 11 / 92 \\
06 / 04 / 90 \\
12 / 08 / 90 \\
04 / 02 / 91 \\
08 / 25 / 91 \\
10 / 13 / 92 \\
06 / 06 / 90 \\
12 / 08 / 90 \\
04 / 03 / 91 \\
08 / 26 / 91 \\
10 / 14 / 92\end{array}$ & $\begin{array}{l}0001 \\
0001 \\
0001 \\
0001 \\
0001 \\
0001 \\
0001 \\
0001 \\
0001 \\
0001 \\
0001 \\
0001 \\
0001 \\
0001 \\
0001 \\
0001 \\
0001 \\
0001 \\
0001 \\
0001\end{array}$ & $\begin{array}{l}\text { LB } \\
\text { LB } \\
\text { LB } \\
\text { LB } \\
\text { LB } \\
\text { LB } \\
\text { LB } \\
\text { LB } \\
\text { LB } \\
\text { LB } \\
\text { LB } \\
\text { LB } \\
\text { LB } \\
\text { LB } \\
\text { LB } \\
\text { LB } \\
\text { LB } \\
\text { LB } \\
\text { LB } \\
\text { LB }\end{array}$ & $\begin{array}{l}0 \\
0 \\
0 \\
0 \\
0 \\
0 \\
0 \\
0 \\
0 \\
0 \\
0 \\
0 \\
0 \\
0 \\
0 \\
0 \\
0 \\
0 \\
0 \\
0\end{array}$ & $M G / L$ & $\begin{array}{l}< \\
< \\
< \\
< \\
< \\
< \\
< \\
< \\
< \\
< \\
< \\
< \\
< \\
< \\
< \\
< \\
< \\
< \\
< \\
< \\
< \\
<\end{array}$ & $\begin{array}{l}0.01 \\
0.01 \\
0.005 \\
0.005 \\
0.02 \\
0.01 \\
0.01 \\
0.005 \\
0.005 \\
0.003 \\
0.01 \\
0.01 \\
0.005 \\
0.005 \\
0.02 \\
0.01 \\
0.01 \\
0.705 \\
0.005 \\
0.003\end{array}$ & $\begin{array}{l}\mathbf{G} \\
\mathbf{G} \\
\mathbf{I} \\
\mathbf{J}\end{array}$ & $\begin{array}{l}0.01 \\
0.01 \\
0.005 \\
0.005 \\
0.02 \\
0.01 \\
0.01 \\
0.005 \\
0.005 \\
0.003 \\
0.01 \\
0.01 \\
0.005 \\
0.005 \\
0.02 \\
0.01 \\
0.01 \\
0.005 \\
0.005 \\
0.003\end{array}$ & $\begin{array}{l}- \\
- \\
- \\
- \\
- \\
- \\
- \\
- \\
- \\
- \\
- \\
- \\
- \\
- \\
- \\
-\end{array}$ \\
\hline LEAD-210 & $\begin{array}{l}0517 \\
0517 \\
0517 \\
0519 \\
0519 \\
0519 \\
0521 \\
0521 \\
0521\end{array}$ & \begin{tabular}{|l|}
$12 / 08 / 90$ \\
$04 / 02 / 91$ \\
$08 / 25 / 91$ \\
$12 / 15 / 90$ \\
$04 / 01 / 91$ \\
$08 / 22 / 91$ \\
$12 / 08 / 90$ \\
$04 / 02 / 91$ \\
$08 / 25 / 91$
\end{tabular} & $\begin{array}{l}0001 \\
0001 \\
0001 \\
0001 \\
0001 \\
0001 \\
0001 \\
0001 \\
0001\end{array}$ & $\begin{array}{l}\text { LB } \\
\text { LB } \\
\text { LB } \\
\text { LB } \\
\text { LB } \\
\text { LB } \\
\text { LB } \\
\text { LB } \\
\text { LB }\end{array}$ & $\begin{array}{l}0 \\
0 \\
0 \\
0 \\
0 \\
0 \\
0 \\
0 \\
0\end{array}$ & $\mathrm{PCI} / \mathrm{L}$ & & $\begin{array}{l}0.0 \\
0.4 \\
0.0 \\
0.0 \\
0.9 \\
0.0 \\
0.0 \\
0.5 \\
0.5\end{array}$ & $\begin{array}{l}G \\
G\end{array}$ & $\begin{array}{l}1.5 \\
1.5 \\
1.5 \\
1.5 \\
1.5 \\
1.5 \\
1.5 \\
1.5 \\
1.5\end{array}$ & $\begin{array}{l}0.8 \\
1.4 \\
1.0 \\
0.9 \\
1.4 \\
0.9 \\
1.0 \\
1.4 \\
1.0\end{array}$ \\
\hline
\end{tabular}

FORMATION OF COMPLETION CODE:

LB - LOWER BURRO CANYON

PARAMETER VALUE INDICATOR (PVI): < - LESS THAN DETECTION LIMIT
FLOW RELATIONSHIP CODE:

$$
\text { O - ON-SITE }
$$

SAMPLE ID CODES:

0001 - FILTERED SAMPLE (.45 MICRONS)

OTHER PARAMETER VALUE FLAGS:

$G$ - PH $>9$, POSSIBLE GROUT CONTAMINATION

I - INCREASED DETECTION LIMIT DUE TO REQUIRED DILUTION

J - ESTIMATED VALUE 
TABLE 3.52. BACKGROUND GROUNDWATER OUALITY DATA BY PARAMETER FOR THE TABL SAMDSTONE UNIT, BURRO CANYON DISPOSAL SITE, SLICK ROCK, COLORADO SITE: SRKO2 BORROU SITE 1 (BURRO CAMYON)

SITE: SRKO2 BORROW SIT

REPORT DATE: 03/02/94

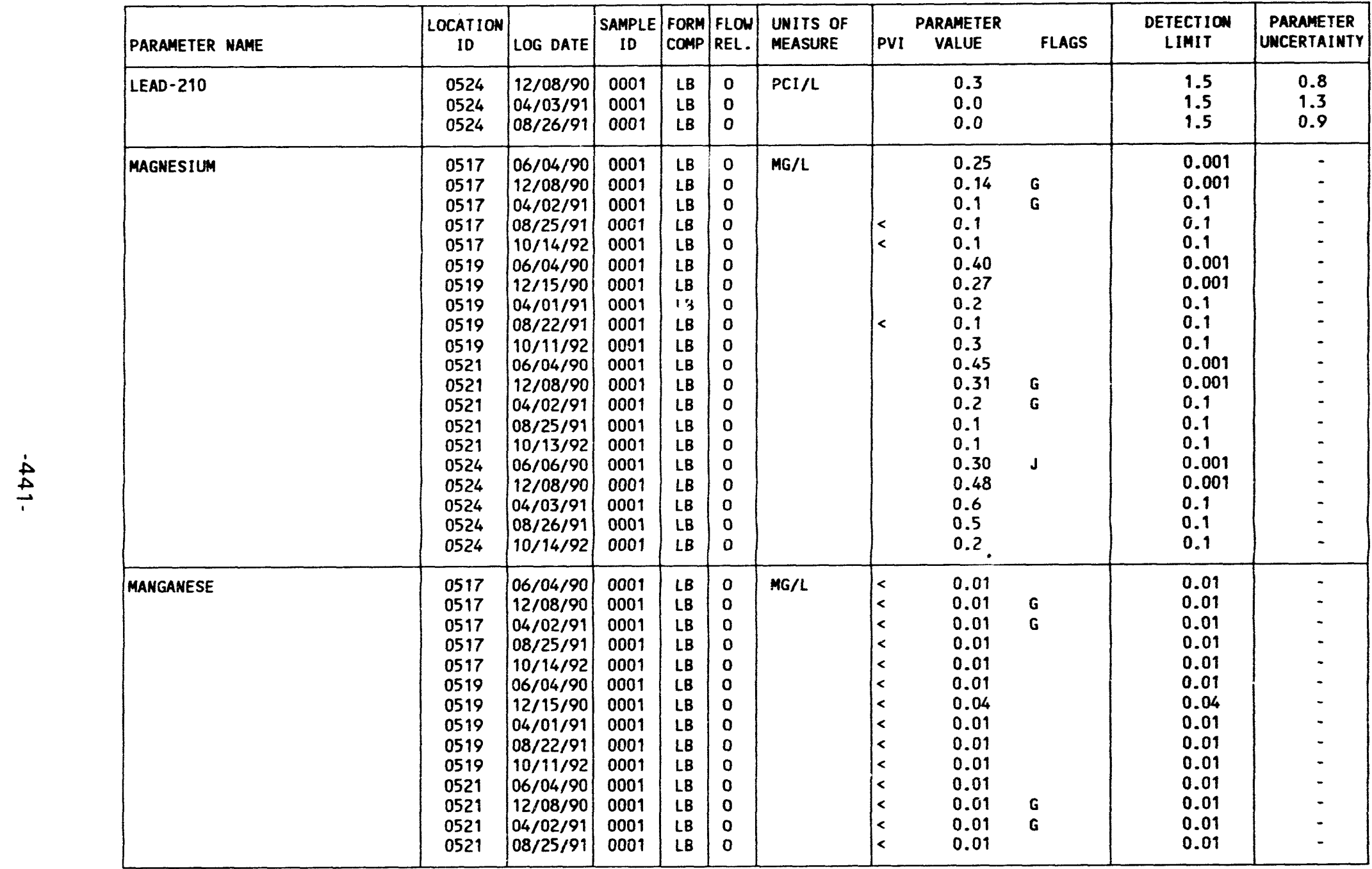

FOPMATION OF COMPLETION CODE:

LB - LONER BURRO CANYON

PARAMETER VALUE INDICATOR (PVI): < - LESS THAN DETECTION LIMIT
FLOU RELATIONSHIP COOE:

O - ON-SITE

SAMPLE ID COOES

0001 - FILTERED SAMPLE (.45 MICRONS)

OTHER PARAMETER VALUE FLAGS:

G - PH > 9, POSSIBLE GROUT CONTAMINATION

$J$ - ESTIMATED VALUE 
TABLE 3.52. BACKGROUN, GROUNDWATER QUALITY DATA BY PARAMETER FOR THE

LOWER SANDSTONE UNIT, BURRO CANYON DISPOSAL SITE, SLICK ROCK, COLORADO

SITE: SRKO2 BORROW SITE 1 (BURRO CANYON)

06/04/90 TO $10 / 14 / 92$

REPORT DATE : 03/02/9

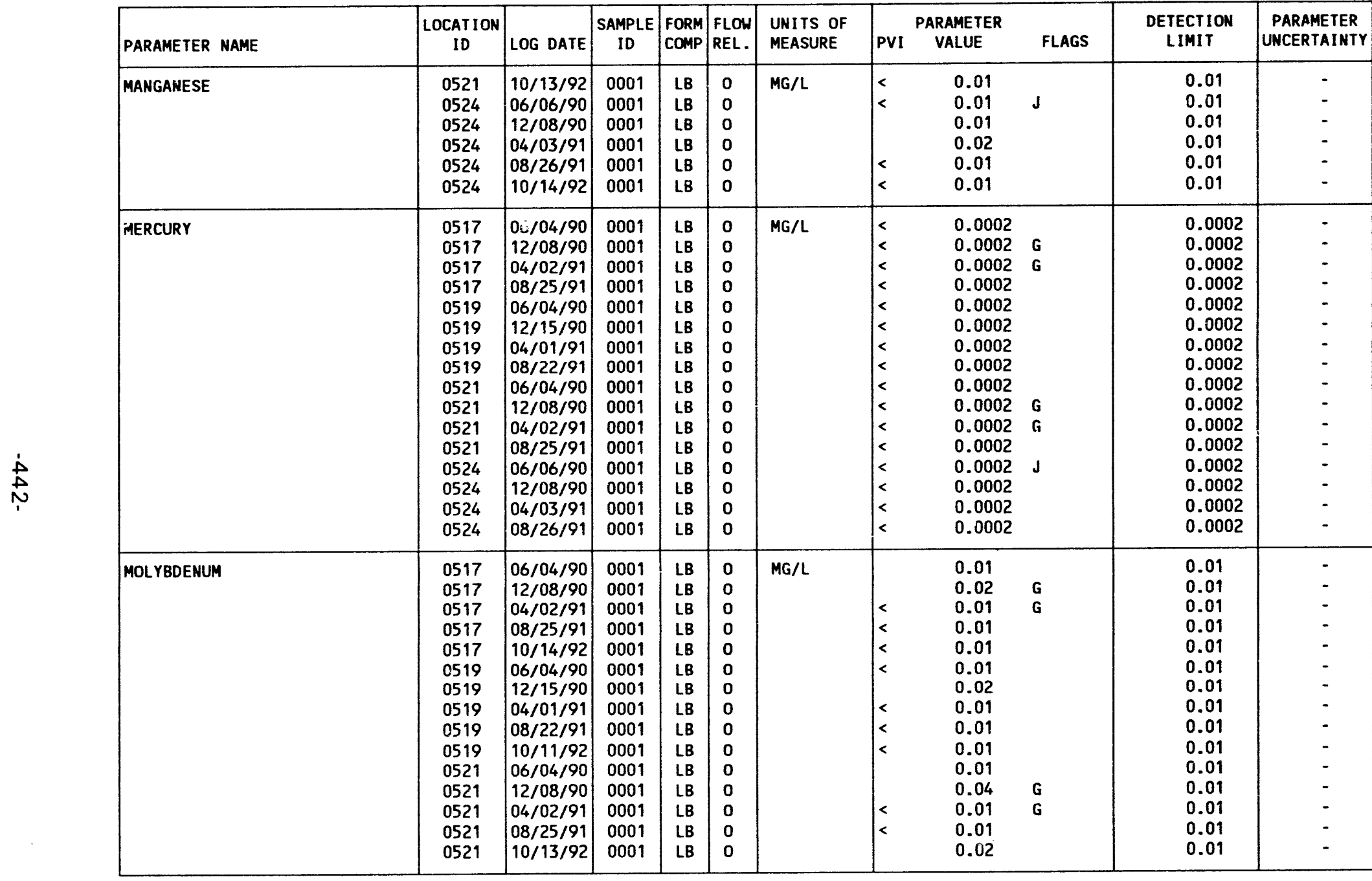

FORMATION OF COMPLETION CODE:

LB - LOWER BURRO CANYON

PARAMETER VALUE INDICATOR (PVI): < - LESS THAN DETECTION LIMIT
FLOW RELATIONSHIP COOE:

D - ON-SITE

0001 - FILTERED SAMPLE (.45 MICRONS)

OTHER PARAMETER VALUE FLAGS:

$G$ - PH > 9, POSSIBLE GROUT CONTAMINATION

J - estimated VALUE 
TABLE 3.52. BACKGROUND GROUNDWATER QUALITY DATA BY PARAMETER FOR THE LOWER SANDSTONE UNIT, BURRO CANYON DISPOSAL SITE, SLICK ROCK, COLORADO SITE: SRKO2 BORROW SITE 1 (BURRO CANYON)

SITE: SRKO2 BORROW
$06 / 04 / 90$ TO $10 / 14 / 92$

REPORT DATE : $03 / 02 / 94$

\begin{tabular}{|c|c|c|c|c|c|c|c|c|c|c|c|}
\hline PARAMETER NAME & $\begin{array}{c}\text { LOCATION } \\
\text { ID }\end{array}$ & LOG DATE & $\begin{array}{c}\text { SAMPLE } \\
10\end{array}$ & $\begin{array}{l}\text { FORM } \\
\text { COMP }\end{array}$ & $\begin{array}{l}\text { FLOW } \\
\text { REL. }\end{array}$ & $\begin{array}{l}\text { UNITS OF } \\
\text { MEASURE }\end{array}$ & PVI & $\begin{array}{l}\text { PARAMETER } \\
\text { VALUE }\end{array}$ & FLAGS & $\begin{array}{l}\text { DETECTION } \\
\text { LIMIT }\end{array}$ & $\begin{array}{l}\text { PARAMETER } \\
\text { UNCERTAINTY }\end{array}$ \\
\hline MOLYBDENUM & $\begin{array}{l}0524 \\
0524 \\
0524 \\
0524 \\
0524\end{array}$ & $\begin{array}{l}06 / 06 / 90 \\
12 / 08 / 90 \\
04 / 03 / 91 \\
08 / 26 / 91 \\
10 / 14 / 92\end{array}$ & $\begin{array}{l}0001 \\
0001 \\
0001 \\
0001 \\
0001\end{array}$ & $\begin{array}{l}\text { LB } \\
\text { LB } \\
\text { LB } \\
\text { LB } \\
\text { LB }\end{array}$ & $\begin{array}{l}0 \\
0 \\
0 \\
0 \\
0\end{array}$ & $M G / L$ & $\begin{array}{l}< \\
< \\
<\end{array}$ & $\begin{array}{l}0.01 \\
0.02 \\
0.01 \\
0.01 \\
0.01\end{array}$ & 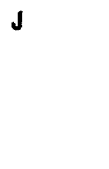 & $\begin{array}{l}0.01 \\
0.01 \\
0.01 \\
0.01 \\
0.01\end{array}$ & : \\
\hline NET GROSS ALPHA * & $\begin{array}{l}0517 \\
0517 \\
0517 \\
0517 \\
0519 \\
0519 \\
0519 \\
0519 \\
0521 \\
0521 \\
0521 \\
0521 \\
0524 \\
0524 \\
0524 \\
0524\end{array}$ & $\begin{array}{l}12 / 08 / 90 \\
04 / 02 / 91 \\
08 / 25 / 91 \\
10 / 14 / 92 \\
12 / 15 / 90 \\
04 / 01 / 91 \\
08 / 22 / 91 \\
10 / 11 / 92 \\
12 / 08 / 90 \\
04 / 02 / 91 \\
08 / 25 / 91 \\
10 / 13 / 92 \\
12 / 08 / 90 \\
04 / 03 / 91 \\
08 / 26 / 91 \\
10 / 14 / 92\end{array}$ & $\begin{array}{l}0001 \\
0001 \\
0001 \\
0001 \\
0001 \\
0001 \\
0001 \\
0001 \\
0001 \\
0001 \\
0001 \\
0001 \\
0001 \\
0001 \\
0001 \\
0001\end{array}$ & $\begin{array}{l}\text { LB } \\
\text { LB } \\
\text { LB } \\
\text { LB } \\
\text { LB } \\
\text { LB } \\
\text { LB } \\
\text { LB } \\
\text { LB } \\
\text { LB } \\
\text { LB } \\
\text { LB } \\
\text { LB } \\
\text { LB } \\
\text { LB } \\
\text { LB }\end{array}$ & $\begin{array}{l}0 \\
0 \\
0 \\
0 \\
0 \\
0 \\
0 \\
0 \\
0 \\
0 \\
0 \\
0 \\
0 \\
0 \\
0 \\
0\end{array}$ & $\mathrm{PCI} / \mathrm{L}$ & & $\begin{array}{r}2.00 \\
-0.34 \\
-5.49 \\
-0.34 \\
-0.10 \\
-0.34 \\
0.13 \\
-1.37 \\
5.77 \\
2.93 \\
6.76 \\
-0.34 \\
-0.07 \\
-0.34 \\
3.26 \\
0.66\end{array}$ & & $\begin{array}{l}- \\
- \\
- \\
- \\
- \\
- \\
- \\
- \\
- \\
- \\
- \\
- \\
-\end{array}$ & $\begin{array}{l}- \\
- \\
- \\
- \\
- \\
- \\
- \\
- \\
- \\
- \\
- \\
-\end{array}$ \\
\hline NICKEL & $\begin{array}{l}0517 \\
0517 \\
0517 \\
0517 \\
0517 \\
0519 \\
0519 \\
0519 \\
0519 \\
0519 \\
0521 \\
0521 \\
0521 \\
0521\end{array}$ & $\begin{array}{l}06 / 04 / 90 \\
12 / 08 / 90 \\
04 / 02 / 91 \\
08 / 25 / 91 \\
10 / 14 / 92 \\
06 / 04 / 90 \\
12 / 15 / 90 \\
04 / 01 / 91 \\
08 / 22 / 91 \\
10 / 11 / 92 \\
06 / 04 / 90 \\
12 / 08 / 90 \\
04 / 02 / 91 \\
08 / 25 / 91\end{array}$ & $\begin{array}{l}0001 \\
0001 \\
0001 \\
0001 \\
0001 \\
0001 \\
0001 \\
0001 \\
0001 \\
0001 \\
0001 \\
0001 \\
0001 \\
0001\end{array}$ & $\begin{array}{l}\text { LB } \\
\text { LB } \\
\text { LB } \\
\text { LB } \\
\text { LB } \\
\text { LB } \\
\text { LB } \\
\text { LB } \\
\text { LB } \\
\text { LB } \\
\text { LB } \\
\text { LB } \\
\text { LB } \\
\text { LB }\end{array}$ & $\begin{array}{l}0 \\
0 \\
0 \\
0 \\
0 \\
0 \\
0 \\
0 \\
0 \\
0 \\
0 \\
0 \\
0 \\
0\end{array}$ & $M G / L$ & $\begin{array}{l}5 \\
< \\
< \\
< \\
< \\
< \\
< \\
< \\
< \\
< \\
< \\
< \\
< \\
< \\
<\end{array}$ & $\begin{array}{l}0.04 \\
0.04 \\
0.04 \\
0.04 \\
0.04 \\
0.04 \\
0.04 \\
0.04 \\
0.04 \\
0.04 \\
0.04 \\
0.04 \\
0.04 \\
0.04\end{array}$ & $\begin{array}{l}\text { G } \\
\text { G }\end{array}$ & $\begin{array}{l}0.04 \\
0.04 \\
0.04 \\
0.04 \\
0.04 \\
0.04 \\
0.04 \\
0.04 \\
0.04 \\
0.04 \\
0.04 \\
0.04 \\
0.04 \\
0.04\end{array}$ & $\begin{array}{l}- \\
- \\
- \\
- \\
- \\
- \\
- \\
- \\
- \\
- \\
- \\
-\end{array}$ \\
\hline
\end{tabular}

* NET GROSS ALPHA (GROSS ALPHA - URANIUM) WITH 1 MG URANIUM = 686 PCI

FORMATION OF COMPLETION COOE:

LB - LOWER BURRO CANYON

PARAMETER VALUE INDICATOR (PVI): \& - LESS THAN DETECTION LIMIT

OTHER PARAMETER VALUE FLAGS:

$G$ - PH > 9, POSSIBLE GROUT CONTAMINATION

J - ESTIMATEd VALUE
FLOW RELATIONSHIP CODE:

O - ON-SITE

SAMPLE ID CCOES:

0001 - FILTERED SAMPLE (.45 MICRONS) 
TABLE 3.52. BACKGROUND GROUNDWATER QUALITY DATA BY PARAMETER FOR THE LOWER SANDSTONE UNIT, BURRO CANYON DISPOSAL SITE, SLICK ROCK, COLORADO SITE: SRKO2 BORROW SITE 1 (BURRO CANYON)

06/04/90 TO $10 / 14 / 92$

REPORT DATE: $03 / 02 / 94$

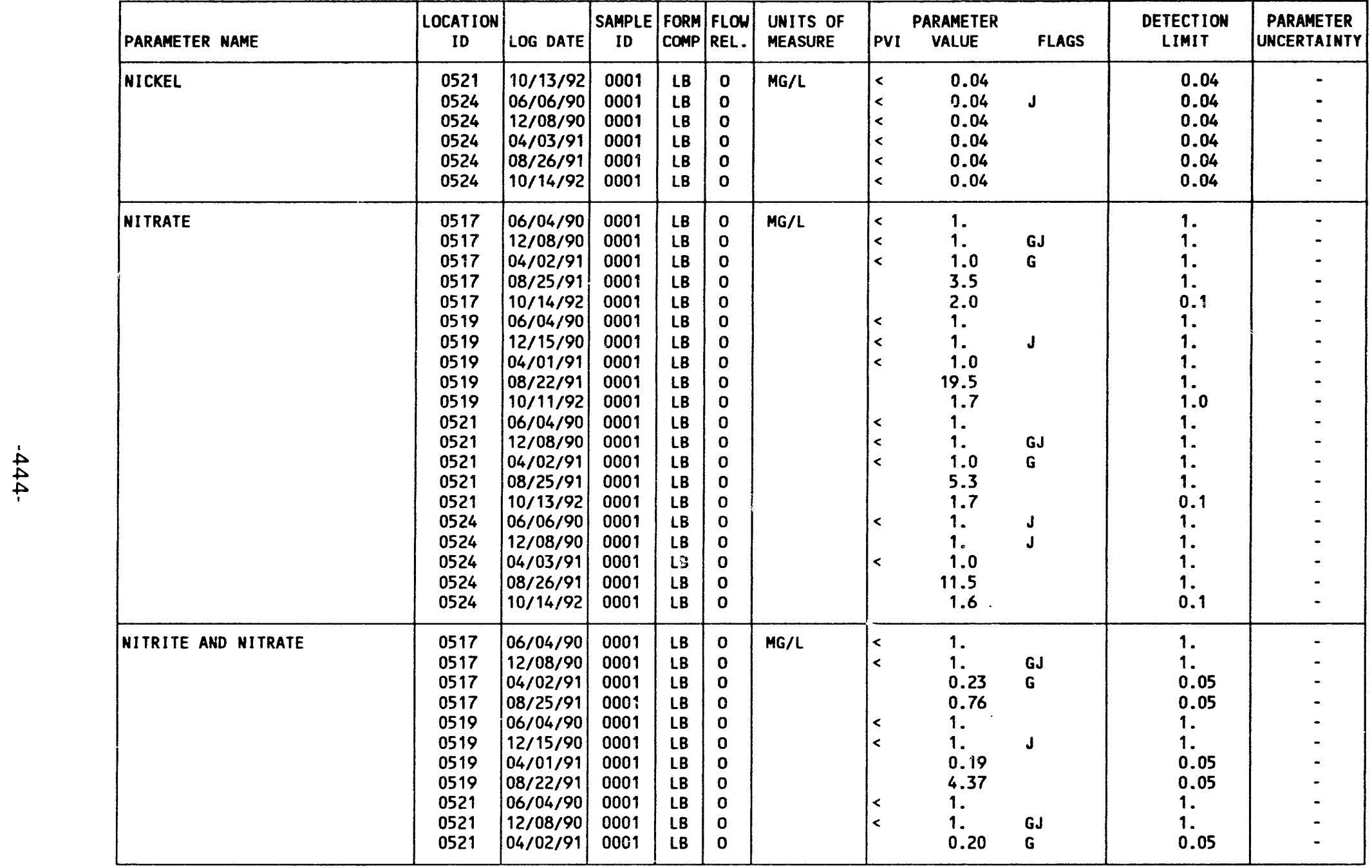

FORMATION OF COMPLETION CODE:

LB - LOWER BURRO CANYON

PARAMETER VALUE INDICATOR (PVI): < - LESS THAN DETECTION LIMIT
FLOW RELATIONSHIP CODE:

O - ON-SITE

SAMPLE ID COOES:

0001 - FILTERED SAMPLE (.45 MICRONS)

OTHER PARAMETER VALUE FLAGS:

G - PH > 9, POSSIBLE GROUT CONTAMINATION

J - ESTIMATED VALUE 
TABLE 3.52. BACKGROUND GROUNDWATER QUALITY DATA BY PARAMETER FOR THE

LOWER SANDSTONE UNIT, BURRO CANYON DISPOSAL SITE, SLICK ROCK, COLORADO SITE: SRKO2 BORROW SITE 1 (BURRO CANYON)

06/04/90 TO $10 / 14 / 92$

REPORT DATE: $03 / 02 / 94$

\begin{tabular}{|c|c|c|c|c|c|c|c|c|c|c|c|}
\hline PARAMETER NAME & $\begin{array}{c}\text { LOCATION } \\
\text { ID }\end{array}$ & LOG DATE & $\begin{array}{c}\text { SAMPLE } \\
10\end{array}$ & $\begin{array}{l}\text { FORM } \\
\text { COMP }\end{array}$ & $\begin{array}{l}\text { FLOW } \\
\text { REL. }\end{array}$ & $\begin{array}{l}\text { UNITS OF } \\
\text { MEASURE }\end{array}$ & PVI & $\begin{array}{l}\text { ARAMETER } \\
\text { VALUE }\end{array}$ & FLAGS & $\begin{array}{l}\text { DETECTION } \\
\text { LIMIT }\end{array}$ & $\begin{array}{l}\text { PARAMETER } \\
\text { UNCERTAINTY }\end{array}$ \\
\hline NITRITE AND NITRATE & $\begin{array}{l}0521 \\
0524 \\
0524 \\
0524 \\
0524\end{array}$ & $\begin{array}{l}08 / 25 / 91 \\
06 / 06 / 90 \\
12 / 08 / 90 \\
04 / 03 / 91 \\
08 / 26 / 91\end{array}$ & $\begin{array}{l}0001 \\
0001 \\
0001 \\
0001 \\
0001\end{array}$ & $\begin{array}{l}\text { LB } \\
\text { LB } \\
\text { LB } \\
\text { LB } \\
\text { LB }\end{array}$ & $\begin{array}{l}0 \\
0 \\
0 \\
0 \\
0\end{array}$ & $M G / L$ & $<$ & $\begin{array}{l}1.23 \\
1.0 \\
1 . \\
0.22 \\
2.62\end{array}$ & $\vec{J}$ & $\begin{array}{l}0.05 \\
1 . \\
1 . \\
0.05 \\
0.05\end{array}$ & $\begin{array}{l}- \\
- \\
- \\
-\end{array}$ \\
\hline PH & $\begin{array}{l}0517 \\
0517 \\
0517 \\
0517 \\
0517 \\
0519 \\
0519 \\
0519 \\
0519 \\
0519 \\
0521 \\
0521 \\
0521 \\
0521 \\
0521 \\
0524 \\
0524 \\
0524 \\
0524 \\
0524\end{array}$ & $\begin{array}{l}06 / 04 / 90 \\
12 / 08 / 90 \\
04 / 02 / 91 \\
08 / 25 / 91 \\
10 / 14 / 92 \\
06 / 04 / 90 \\
12 / 15 / 90 \\
04 / 01 / 91 \\
08 / 22 / 91 \\
10 / 11 / 92 \\
06 / 04 / 90 \\
12 / 08 / 90 \\
04 / 02 / 91 \\
08 / 25 / 91 \\
10 / 13 / 92 \\
06 / 06 / 90 \\
12 / 08 / 90 \\
04 / 03 / 91 \\
08 / 26 / 91 \\
10 / 14 / 92\end{array}$ & $\begin{array}{l}0001 \\
0001 \\
0001 \\
0001 \\
0001 \\
0001 \\
0001 \\
0001 \\
0001 \\
0001 \\
0001 \\
0001 \\
0001 \\
0001 \\
0001 \\
0001 \\
0001 \\
0001 \\
0001 \\
0001\end{array}$ & $\begin{array}{l}\text { LB } \\
\text { LB } \\
\text { LB } \\
\text { LB } \\
\text { LB } \\
\text { LB } \\
\text { LB } \\
\text { LB } \\
\text { LB } \\
\text { LB } \\
\text { LB } \\
\text { LB } \\
\text { LB } \\
\text { LB } \\
\text { LB } \\
\text { LB } \\
\text { LB } \\
\text { LB } \\
\text { LB } \\
\text { LB }\end{array}$ & $\begin{array}{l}0 \\
0 \\
0 \\
0 \\
0 \\
0 \\
0 \\
0 \\
0 \\
0 \\
0 \\
0 \\
0 \\
0 \\
0 \\
0 \\
0 \\
0 \\
0 \\
0\end{array}$ & SU & & $\begin{array}{l}9.13 \\
9.14 \\
9.22 \\
9.21 \\
9.24 \\
8.68 \\
8.57 \\
8.65 \\
8.76 \\
8.77 \\
9.55 \\
9.05 \\
9.09 \\
9.15 \\
9.15 \\
9.05 \\
8.82 \\
8.75 \\
8.85 \\
9.07\end{array}$ & $\begin{array}{l}\mathbf{G} \\
\mathbf{G}\end{array}$ & $\begin{array}{l}- \\
- \\
- \\
- \\
- \\
- \\
- \\
- \\
- \\
- \\
- \\
- \\
- \\
- \\
- \\
-\end{array}$ & $\begin{array}{l}- \\
- \\
- \\
- \\
- \\
- \\
- \\
- \\
- \\
- \\
- \\
- \\
- \\
- \\
- \\
-\end{array}$ \\
\hline PHOSPHATE & $\begin{array}{l}0517 \\
0517 \\
0517 \\
0517 \\
0517 \\
0519 \\
0519 \\
0519 \\
0519 \\
0519 \\
0521 \\
0521\end{array}$ & $\begin{array}{l}06 / 04 / 90 \\
12 / 08 / 90 \\
04 / 02 / 91 \\
08 / 25 / 91 \\
10 / 14 / 92 \\
06 / 04 / 90 \\
12 / 15 / 90 \\
04 / 01 / 91 \\
08 / 22 / 91 \\
10 / 11 / 92 \\
06 / 04 / 90 \\
12 / 08 / 90\end{array}$ & $\begin{array}{l}0001 \\
0001 \\
0001 \\
0001 \\
0001 \\
0001 \\
0001 \\
0001 \\
0001 \\
0001 \\
0001 \\
0001\end{array}$ & $\begin{array}{l}\text { LB } \\
\text { LB } \\
\text { LB } \\
\text { LB } \\
\text { LB } \\
\text { LB } \\
\text { LB } \\
\text { LB } \\
\text { LB } \\
\text { LB } \\
\text { LB } \\
\text { LB }\end{array}$ & $\begin{array}{l}0 \\
0 \\
0 \\
0 \\
0 \\
0 \\
0 \\
0 \\
0 \\
0 \\
0 \\
0\end{array}$ & MG/L & & $\begin{array}{l}0.9 \\
0.9 \\
0.7 \\
0.7 \\
0.6 \\
0.7 \\
0.9 \\
0.7 \\
0.6 \\
0.6 \\
0.8 \\
0.9\end{array}$ & $\begin{array}{l}\text { GJ } \\
\text { G } \\
\text { J } \\
\text { J } \\
\text { J } \\
\text { GJ }\end{array}$ & $\begin{array}{l}0.1 \\
0.1 \\
0.1 \\
0.1 \\
0.1 \\
0.1 \\
0.1 \\
0.1 \\
0.1 \\
0.1 \\
0.1 \\
0.1\end{array}$ & $\begin{array}{l}- \\
- \\
- \\
- \\
- \\
- \\
- \\
-\end{array}$ \\
\hline
\end{tabular}

FORMATION OF COMPLETION COOE:

LB - LOWER BURRO CANYON

PARAMETER VALUE INDICATOR (PVI): < - LESS THAN DETECTION LIMIT
FLOW RELATIONSHIP COOE:

0001 - FILTERED SAMPLE (.45 MICRONS)

OTHER PARAMETER VAL:

G - PH > 9, POSSIBLE GROUT CONTAMINATION

$J$ - ESTIMATED VALUE 
TABLE 3.52. BACKGROUND GROUNDWATER QUALITY DATA BY PARAMETER FOR THE LOUER SANDSTONE UNIT, BURRO CANYON DISPOSAL SITE, SLICK ROCK, COLORADO SITE: SRKO2 BORROW SITE 1 (BURRO CANYON)

S6/04/90 TO $10 / 14 / 92$

REPORT DATE: $03 / 02 / 94$

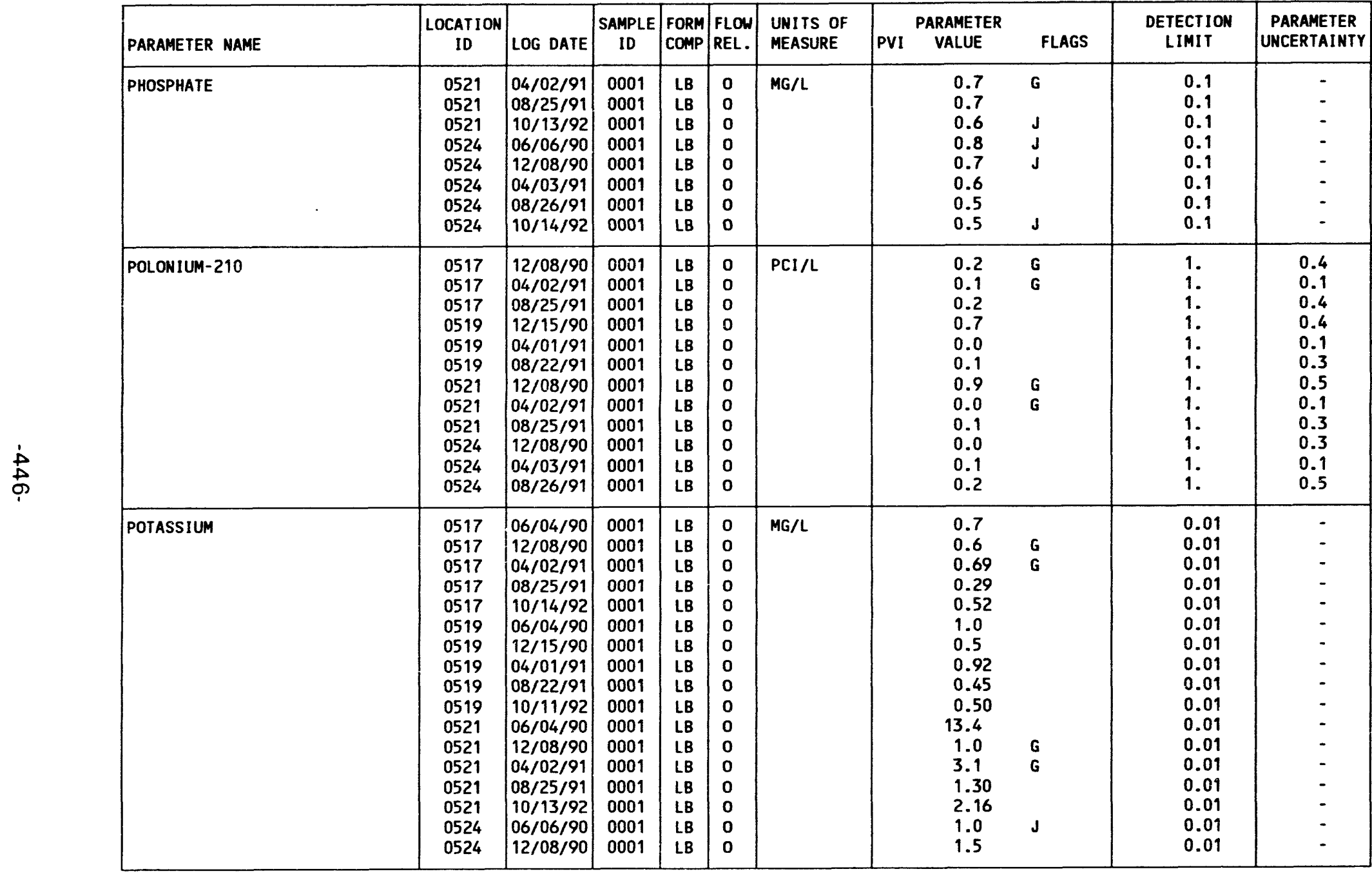

FORMATION OF COMPLETION CODE:

LB - LOWER BURRO CANYON

PARAMETER VALUE INDICATOR (PVI): < - LESS THAN DETECTION LIMIT
FLOW RELATIONSHIP CODE:

O - ON-SITE

0001 - FILTERED SAMPLE (.45 MICRONS)

OTHER PARAMETER VALUE FLAGS:

$G$ - PH > 9, POSSIBLE GROUT CONTAMINATION

J - estimated VALUE 
TABLE 3.52. BACKGROUND GROUNDHATER QUALITY DATA BY PARAMETER FOR THE

AOLE SANDSTONE UNIT, BURRO CANYON DISPOSAL SITE, SLICK ROCK, COLORADO

SITE: SRKO2 BORROW SITE 1 (BURRO CANYON)

SITE: SRKO2 BORROW SIT

REPORT DATE: $03 / 02 / 94$

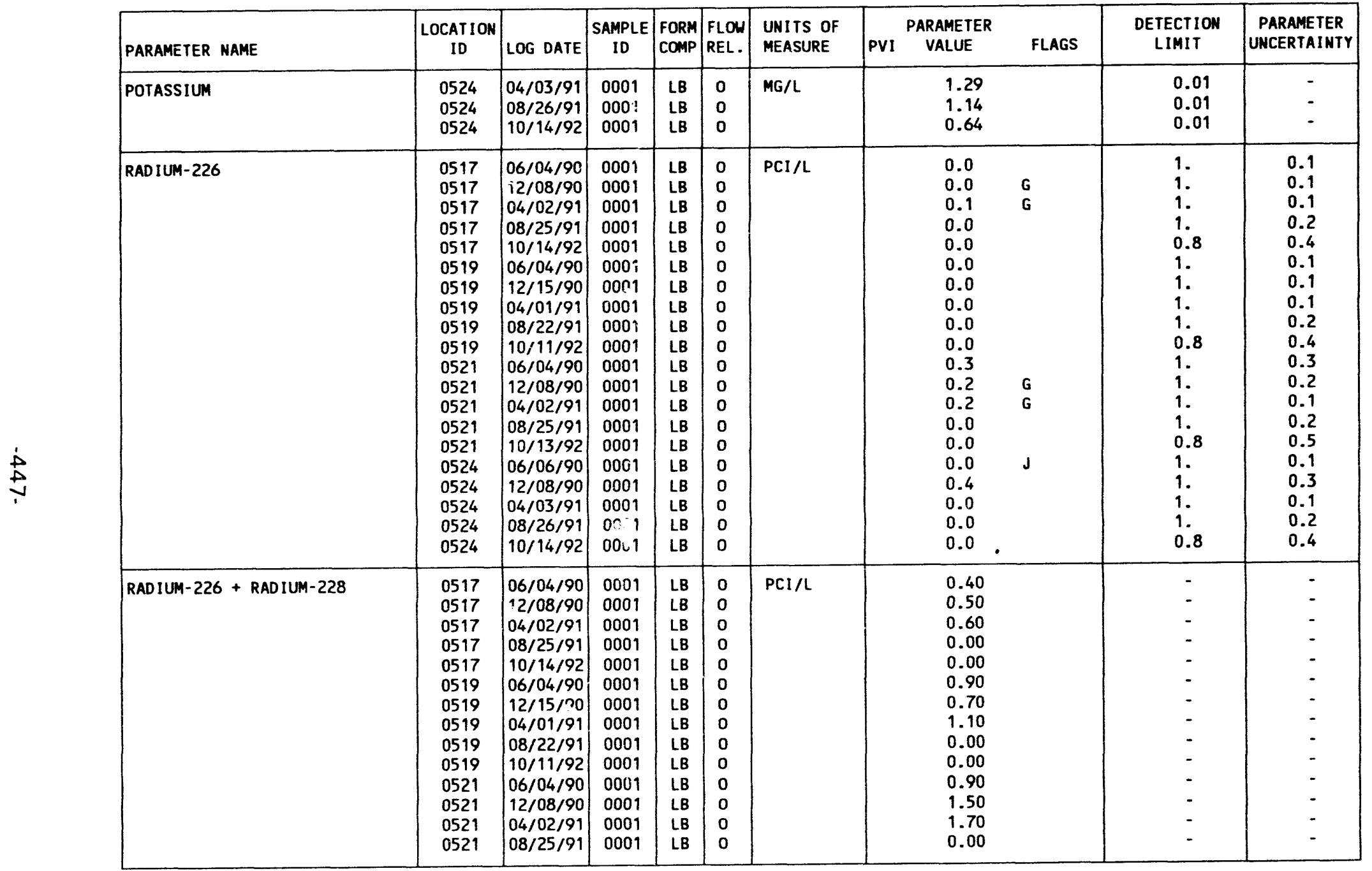

FORMATION OF COMPLETION CODE:

LB - LOWER BURRO CANYON

PARAMETER VALUE INDICATOR (PVI): < - LESS THAN DETECTION LIMIT
FLOW RELATIONSHIP COOE:

O - ON-SITE

SAMPLE ID COOES:

0001 - FILTERED SAMPLE (.45 MICRONS)

OTHER PARAMETER VALUE FLAGS:

$G$ - PH $>9$, POSSIBLE GROUT CONTAMINATION

$J$ - ESTIMATED VALUE 
TABLE 3.52. BACKGROUND GROUNDWATER OUALITY DATA BY PARAMETER FOR THE LONER SANDSTONE UNIT, BURRO CANYON DISPOSAL SITE, SLICK ROCK, COLORADO SITE: SRKO2 BORROW SITE 1 (BURRO CANYON)

06/04/90 TO 10/14/92

REPORT DATE: $03 / 02 / 94$

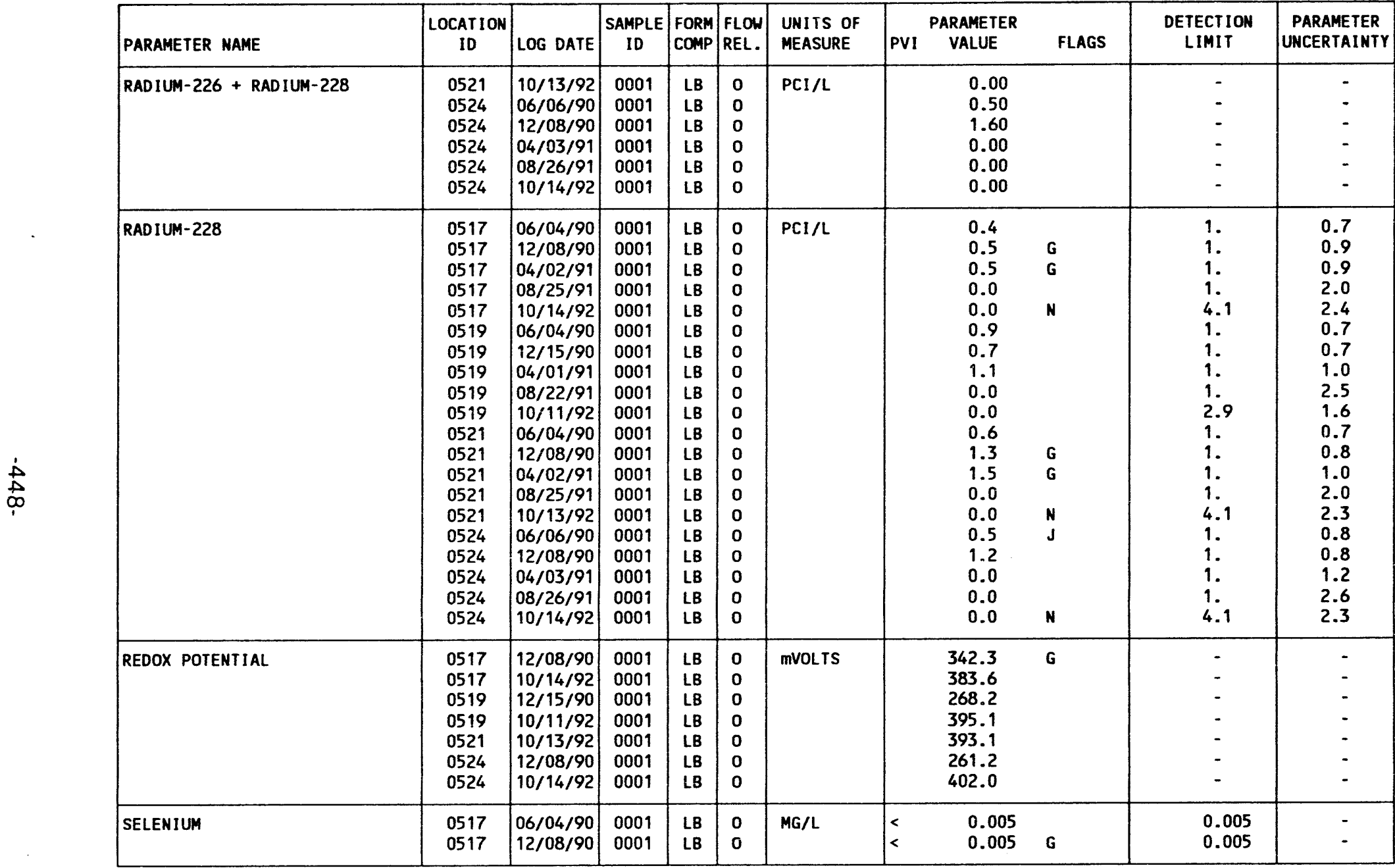

FORMATION OF COMPLETION COOE:

LB - LOWER BURRO CANYON

PARAMETER VALUE INDICATOR (PVI): < - LESS THAN DETECTION LIMIT
FLOW RELATIONSHIP CODE:

O - ON-SITE

SAMPLE ID CODES:

0001 - FILTERED SAMPLE (.45 MICRONS)

OTHER PARAMETER VALUE FLAGS:

G - PH > 9, POSSIBLE GROUT CONTAMINATION

J - ESTIMATED VALUE

- SPIKE SAMPLE RECOVERY NOT WITHIN CONTROL LIMITS 
TABLE 3.52. BACKGROUND GROUNDHATER QUALITY DATA BY PARAMETER FOR THE TOUER SANDSTONE UNIT BURRO CANYON DISPOSAL SITE, SLICK ROCK, COLORADO SITE: SRKO2 BORROW SITE 1 (BURRO CANYON)

SITE: SRKOL BORROW

REPORT DATE: 03/02/94

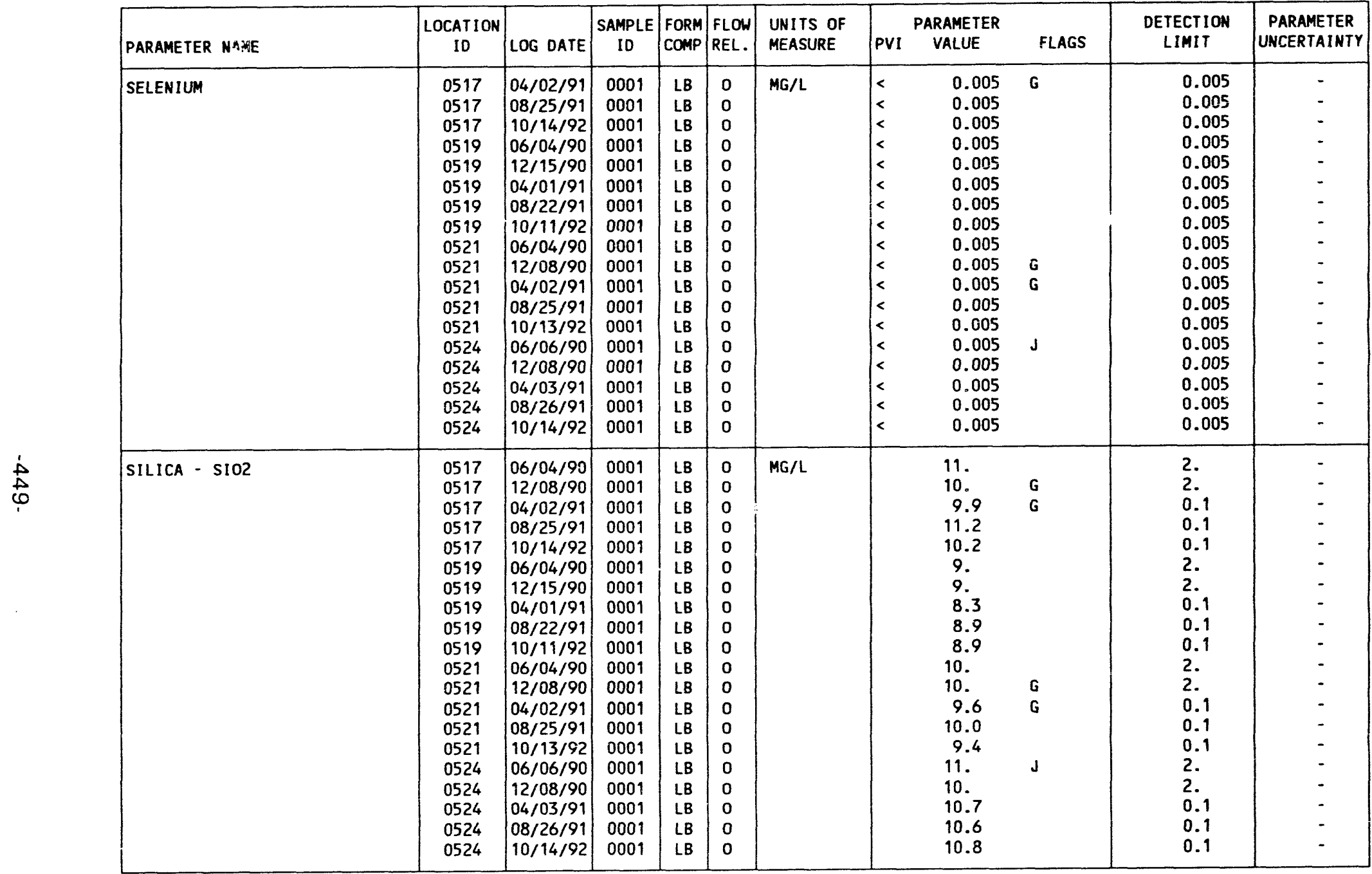

FOPMATION OF COMPLETION COOE:

LB - LOWER BURRO CANYON

PARAMETER VALUE INDICATOR (PVI): < - LESS THAN DETECTION LIMIT
FLOU RELATIONSHIP CODE: 0 - ON-SITE

0001 - FILTERED SAMPLE (.45 MICRONS)

OTHER PARAMETER VALUE FLAGS:

G - PH > 9, POSSIBLE GROUT CONTAMINATION

J - ESTIMATED VALUE 
TABLE 3.52. BACKGROUND GROUNDWATER QUALITY DATA BY PARAMETER FOR THE LOUER SANDSTONE UNIT, BURRO CANYON DISPOSAL SITE, SLICK ROCK, COLORADO SITE: SRKO2 BORROW SITE 1 (BURRO CANYON)

SITE: SRK02 BORROW

REPORT DATE: $03 / 02 / 94$

\begin{tabular}{|c|c|c|c|c|c|c|c|c|c|c|c|}
\hline PARAMETER NAME & $\begin{array}{c}\text { LOCATION } \\
\text { ID }\end{array}$ & LOG DATE & $\begin{array}{c}\text { SAMPLE } \\
\text { ID }\end{array}$ & $\begin{array}{l}\text { FORM } \\
\text { COMP }\end{array}$ & $\begin{array}{l}\text { FLOW } \\
\text { REL. }\end{array}$ & $\begin{array}{l}\text { UNITS OF } \\
\text { MEASURE }\end{array}$ & PVI & $\begin{array}{l}\text { ARAMETE } \\
\text { VALUE }\end{array}$ & FLAGS & $\begin{array}{l}\text { DETECTION } \\
\text { LIMIT }\end{array}$ & $\begin{array}{l}\text { PARAMETER } \\
\text { UNCERTAINTY }\end{array}$ \\
\hline SILVER & $\begin{array}{l}0517 \\
0517 \\
0517 \\
0517 \\
0519 \\
0519 \\
0519 \\
0519 \\
0521 \\
0521 \\
0521 \\
0521 \\
0524 \\
0524 \\
0524 \\
0524\end{array}$ & $\begin{array}{l}06 / 04 / 90 \\
12 / 08 / 90 \\
04 / 02 / 91 \\
08 / 25 / 91 \\
06 / 04 / 90 \\
12 / 15 / 90 \\
04 / 01 / 91 \\
08 / 22 / 91 \\
06 / 04 / 90 \\
12 / 08 / 90 \\
04 / 02 / 91 \\
08 / 25 / 91 \\
06 / 06 / 90 \\
12 / 08 / 90 \\
04 / 03 / 91 \\
08 / 26 / 91\end{array}$ & $\begin{array}{l}0001 \\
0001 \\
0001 \\
0001 \\
0001 \\
0001 \\
0001 \\
0001 \\
0001 \\
0001 \\
0001 \\
0001 \\
0001 \\
0001 \\
0001 \\
0001\end{array}$ & $\begin{array}{l}\text { LB } \\
\text { LB } \\
\text { LB } \\
\text { LB } \\
\text { LB } \\
\text { LB } \\
\text { LB } \\
\text { LB } \\
\text { LB } \\
\text { LB } \\
\text { LB } \\
\text { LB } \\
\text { LB } \\
\text { LB } \\
\text { LB } \\
\text { LB }\end{array}$ & $\begin{array}{l}0 \\
0 \\
0 \\
0 \\
0 \\
0 \\
0 \\
0 \\
0 \\
0 \\
0 \\
0 \\
0 \\
0 \\
0 \\
0\end{array}$ & MG/L & $\begin{array}{l}< \\
< \\
< \\
< \\
< \\
< \\
< \\
< \\
< \\
< \\
< \\
< \\
< \\
< \\
< \\
< \\
<\end{array}$ & $\begin{array}{l}0.01 \\
0.01 \\
0.01 \\
0.01 \\
0.01 \\
0.01 \\
0.01 \\
0.01 \\
0.01 \\
0.01 \\
0.01 \\
0.01 \\
0.01 \\
0.01 \\
0.01 \\
0.01\end{array}$ & $\begin{array}{l}G \\
G \\
J\end{array}$ & $\begin{array}{l}0.01 \\
0.01 \\
0.01 \\
0.01 \\
0.01 \\
0.01 \\
0.01 \\
0.01 \\
0.01 \\
0.01 \\
0.01 \\
0.01 \\
0.01 \\
0.01 \\
0.01 \\
0.01\end{array}$ & $\begin{array}{l}- \\
- \\
- \\
- \\
- \\
- \\
- \\
- \\
- \\
- \\
- \\
- \\
-\end{array}$ \\
\hline SODIUM & $\begin{array}{l}0517 \\
0517 \\
0517 \\
0517 \\
0517 \\
0519 \\
0519 \\
0519 \\
0519 \\
0519 \\
0521 \\
0521 \\
0521 \\
0521 \\
0521 \\
0524 \\
0524 \\
0524 \\
0524 \\
0524\end{array}$ & $\begin{array}{l}06 / 04 / 90 \\
12 / 08 / 90 \\
04 / 02 / 91 \\
08 / 25 / 91 \\
10 / 14 / 92 \\
06 / 04 / 90 \\
12 / 15 / 90 \\
04 / 01 / 91 \\
08 / 22 / 91 \\
10 / 11 / 92 \\
06 / 04 / 90 \\
12 / 08 / 90 \\
04 / 02 / 91 \\
08 / 25 / 91 \\
10 / 13 / 92 \\
06 / 06 / 90 \\
12 / 08 / 90 \\
04 / 03 / 91 \\
08 / 26 / 91 \\
10 / 14 / 92\end{array}$ & $\begin{array}{l}0001 \\
0001 \\
0001 \\
0001 \\
0001 \\
0001 \\
0001 \\
0001 \\
0001 \\
0001 \\
0001 \\
0001 \\
0001 \\
0001 \\
0001 \\
0001 \\
0001 \\
0001 \\
0001 \\
0001\end{array}$ & $\begin{array}{l}\text { LB } \\
\text { LB } \\
\text { LB } \\
\text { LB } \\
\text { LB } \\
\text { LB } \\
\text { LB } \\
\text { LB } \\
\text { LB } \\
\text { LB } \\
\text { LB } \\
\text { LB } \\
\text { LB } \\
\text { LB } \\
\text { LB } \\
\text { LB } \\
\text { LB } \\
\text { LB } \\
\text { LB } \\
\text { LB }\end{array}$ & $\begin{array}{l}0 \\
0 \\
0 \\
0 \\
0 \\
0 \\
0 \\
0 \\
0 \\
0 \\
0 \\
0 \\
0 \\
0 \\
0 \\
0 \\
0 \\
0 \\
0 \\
0\end{array}$ & $M G / L$ & & $\begin{array}{l}139 . \\
132 . \\
136 . \\
136 . \\
132 . \\
112 . \\
108 . \\
115 . \\
112 . \\
110 . \\
142 . \\
161 . \\
148 . \\
140 . \\
129 . \\
130 . \\
133 . \\
182 . \\
158 . \\
124 .\end{array}$ & $\begin{array}{l}\mathbf{G} \\
\mathbf{G} \\
\mathbf{J}\end{array}$ & $\begin{array}{l}0.002 \\
0.002 \\
5 . \\
5 . \\
5 . \\
0.002 \\
0.002 \\
5 . \\
5 . \\
5 . \\
0.002 \\
0.002 \\
5 . \\
5 . \\
5 . \\
0.002 \\
0.002 \\
5 . \\
5 . \\
5 .\end{array}$ & $\begin{array}{l}- \\
- \\
- \\
- \\
- \\
- \\
- \\
- \\
- \\
- \\
- \\
- \\
- \\
- \\
- \\
- \\
- \\
-\end{array}$ \\
\hline SPECIFIC CONDUCTANCE & 0517 & $06 / 04 / 90$ & 0001 & LB & 0 & UMHO/CM & & 465. & & - & - \\
\hline
\end{tabular}

FORMATION OF COMPLETION CODE:

LB - LOWER BURRO CANYON

PARAMETER VALUE INDICATOR (PVI): < - LESS THAN DETECTION LIMIT
FLOW RELATIONSHIP CODE:

0001 - FILTERED SAMPLE (.45 MICRONS)

OTHER PARAMETER VALUE FLAGS:

G - PH > 9, POSSIBLE GROUT CONTAMINATION

J - estimated value 
TABLE 3.52. BACKGROUND GROUNDWATER QUALITY DATA BY PARAMETER FOR THE LONER SANDSTONE UNIT, BURRO CANYON DISPOSAL SITE, SLICK ROCK, COLORADO SITE: SRKO2 BORROW SITE 1 (BURRO CANYON)

SITE: SRK02 BORROW SIT

REPORT DATE: $03 / 02 / 94$

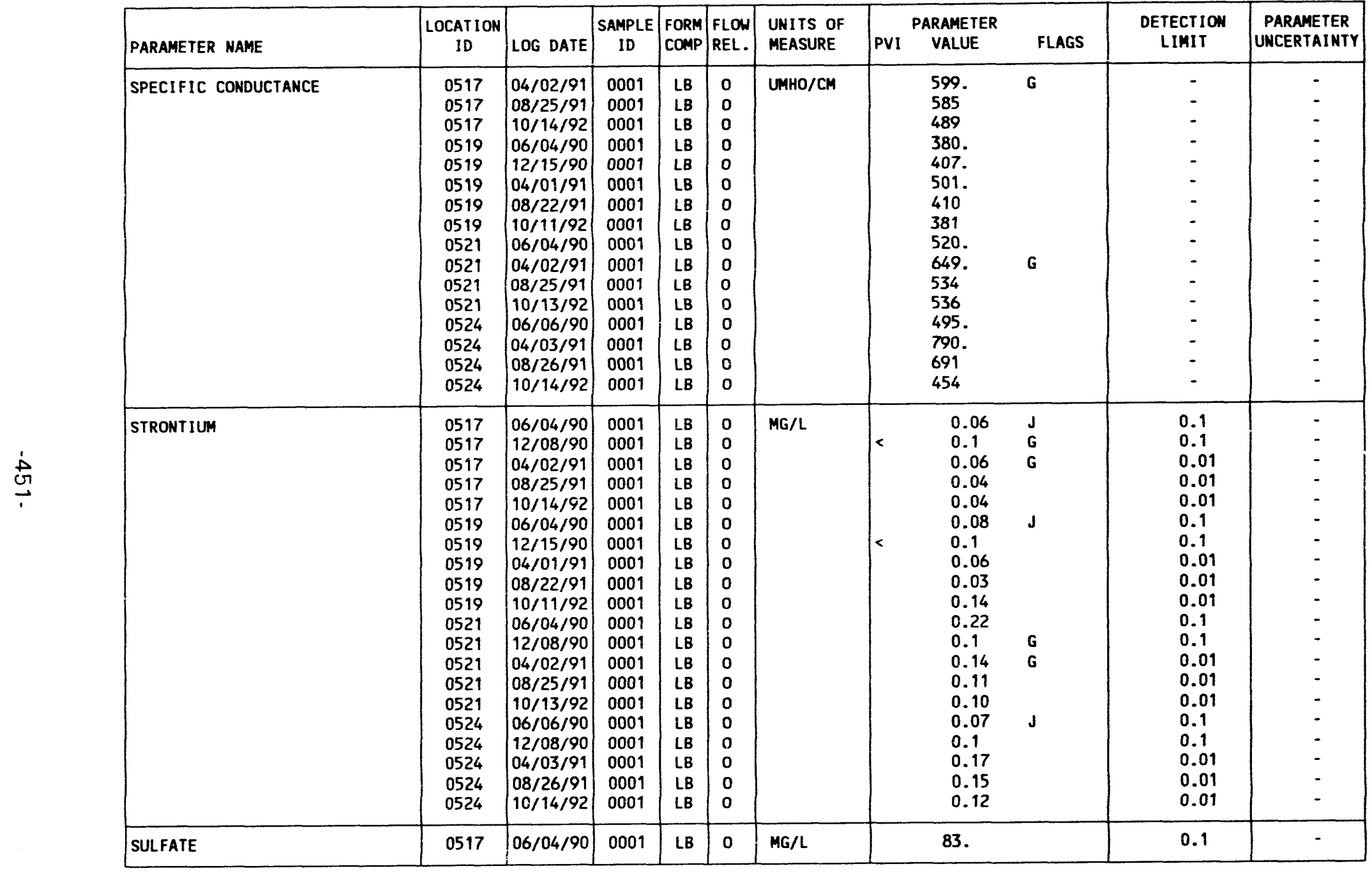

FGRMATION OF COMPLETION CODE:

FLOW RELATIONSHIP COOE:

LB - LONER BURRO CANYON

O - ON-SITE

PARAMETER VALUE INDICATOR (PVI): < - LESS THAN DETECTION LIMIT

PLE ID COOES:

0001 - FILTERED SAMPLE (.45 MICRONS)

OTHER PARAMETER VALUE FLAGS:

$G$ - PH $>9$, POSSIBLE GROUT CONTAMINATION

$J$ - ESTIMATED VALUE 
TABLE 3.52. BACKGROUND GROUNDWATER QUALITY DATA BY PARAMETER FOR THE LOUER SANDSTONE UNIT BURRO CANYOM DISPOSAL SITE SLICK ROCK, COLORADO SITE: SRKO2 BORROU SITE 1 (BURRO CANYON)

06/04/90 TO $10 / 14 / 92$

REPORT DATE : 03/02/94

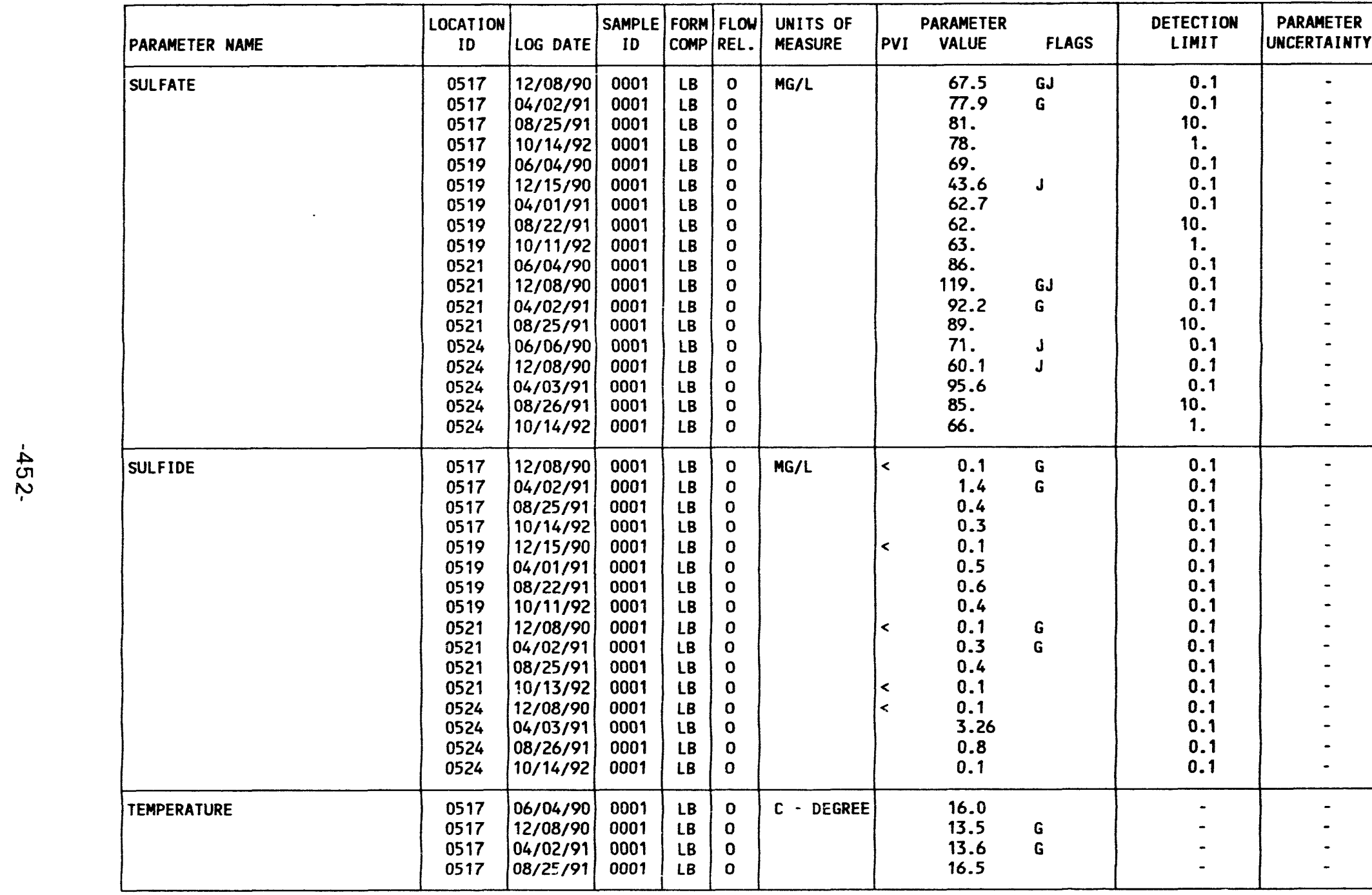

FORMATION OF COMPLETION CODE:

LB - LOWER BURRO CANYON

PARAMETER VALUE INDICATOR (PVI): < - LESS THAN DETECTION LIMIT
FLOW RELATIONSHIP COOE:

O- ON-SITE

SAMPLE ID CODES:

0001 - FILTERED SAMPLE (.45 MICRONS)

OTHER PARAMETER VALUE FLAGS:

G - PH > 9, POSSIBLE GROUT CONTAMINATION

J. ESTIMATED VALUE 
TABLE 3.52. BACKGROUND GROUNDWATER QUALITY DATA BY PARAMETER FOR THE

LONER SANDSTONE UNIT, BURRO CANYON DISPOSAL SITE, SLICK ROCK, COLORADO

SITE: SRKO2 BORROW SITE 1 (BURRO CANYOW)

$06 / 04 / 90$ TO $10 / 14 / 92$

REPORT DATE: $03 / 02 / 94$

\begin{tabular}{|c|c|c|c|c|c|c|c|c|c|c|c|}
\hline PARAMETER NAME & $\underset{\text { LOCATION }}{\text { ID }}$ & LOG DATE & $\begin{array}{c}\text { SAMPLE } \\
\text { ID }\end{array}$ & $\begin{array}{l}\text { FORM } \\
\text { COMP }\end{array}$ & $\begin{array}{l}\text { FLOW } \\
\text { REL. }\end{array}$ & $\begin{array}{l}\text { UNITS OF } \\
\text { MEASURE }\end{array}$ & PVI & $\begin{array}{l}\text { ARAMETER } \\
\text { VALUE }\end{array}$ & FLAGS & $\begin{array}{l}\text { DETECTION } \\
\text { LIMIT }\end{array}$ & $\begin{array}{l}\text { PARAMETER } \\
\text { UWCERTAINTY }\end{array}$ \\
\hline TEMPERATURE & $\begin{array}{l}0517 \\
0519 \\
0519 \\
0519 \\
0519 \\
0519 \\
0521 \\
0521 \\
0521 \\
0521 \\
0521 \\
0524 \\
0524 \\
0524 \\
0524 \\
0524\end{array}$ & $\begin{array}{l}10 / 14 / 92 \\
06 / 04 / 90 \\
12 / 15 / 90 \\
04 / 01 / 91 \\
08 / 22 / 91 \\
10 / 11 / 92 \\
06 / 04 / 90 \\
12 / 08 / 90 \\
04 / 02 / 91 \\
08 / 25 / 91 \\
10 / 13 / 92 \\
06 / 06 / 90 \\
12 / 08 / 90 \\
04 / 03 / 91 \\
08 / 26 / 91 \\
10 / 14 / 92\end{array}$ & $\begin{array}{l}0001 \\
0001 \\
0001 \\
0001 \\
0001 \\
0001 \\
0001 \\
0001 \\
0001 \\
0001 \\
0001 \\
0001 \\
0001 \\
0001 \\
0001 \\
0001\end{array}$ & $\begin{array}{l}\text { LB } \\
\text { LB } \\
\text { LB } \\
\text { LB } \\
\text { LB } \\
\text { LB } \\
\text { LB } \\
\text { LB } \\
\text { LB } \\
\text { LB } \\
\text { LB } \\
\text { LB } \\
\text { LB } \\
\text { LB } \\
\text { LB } \\
\text { LB }\end{array}$ & $\begin{array}{l}0 \\
0 \\
0 \\
0 \\
0 \\
0 \\
0 \\
0 \\
0 \\
0 \\
0 \\
0 \\
0 \\
0 \\
0 \\
0\end{array}$ & C - DEGREE & & $\begin{array}{l}18.3 \\
17.0 \\
14.0 \\
14.4 \\
22.3 \\
14.2 \\
16.5 \\
17.5 \\
14.4 \\
17.4 \\
19.1 \\
19.0 \\
17.0 \\
15.5 \\
19.1 \\
16.0\end{array}$ & $\begin{array}{l}\text { G } \\
\text { G }\end{array}$ & $\begin{array}{l}- \\
- \\
- \\
- \\
- \\
- \\
- \\
- \\
- \\
- \\
- \\
- \\
-\end{array}$ & $\begin{array}{l}- \\
- \\
- \\
- \\
- \\
- \\
- \\
- \\
- \\
- \\
-\end{array}$ \\
\hline THALLIUM & $\begin{array}{l}0517 \\
0517 \\
0517 \\
0517 \\
0517 \\
0519 \\
0519 \\
0519 \\
0519 \\
0519 \\
0521 \\
0521 \\
0521 \\
0521 \\
0521 \\
0524 \\
0524 \\
0524 \\
0524 \\
0524\end{array}$ & $\begin{array}{l}06 / 04 / 90 \\
12 / 08 / 90 \\
04 / 02 / 91 \\
08 / 25 / 91 \\
10 / 14 / 92 \\
06 / 04 / 90 \\
12 / 15 / 90 \\
04 / 01 / 91 \\
08 / 22 / 91 \\
10 / 11 / 92 \\
06 / 04 / 90 \\
12 / 08 / 90 \\
04 / 02 / 91 \\
08 / 25 / 91 \\
10 / 13 / 92 \\
06 / 06 / 90 \\
12 / 08 / 90 \\
04 / 03 / 91 \\
08 / 26 / 91 \\
10 / 14 / 92\end{array}$ & $\begin{array}{l}0001 \\
0001 \\
0001 \\
0001 \\
0001 \\
0001 \\
0001 \\
0001 \\
0001 \\
0001 \\
0001 \\
0001 \\
0001 \\
0001 \\
0001 \\
0001 \\
0001 \\
0001 \\
0001 \\
0001\end{array}$ & $\begin{array}{l}\text { LB } \\
\text { LB } \\
\text { LB } \\
\text { LB } \\
\text { LB } \\
\text { LB } \\
\text { LB } \\
\text { LB } \\
\text { LB } \\
\text { LB } \\
\text { LB } \\
\text { LB } \\
\text { LB } \\
\text { LB } \\
\text { LB } \\
\text { LB } \\
\text { LB } \\
\text { LB } \\
\text { LB } \\
\text { LB }\end{array}$ & $\begin{array}{l}0 \\
0 \\
0 \\
0 \\
0 \\
0 \\
0 \\
0 \\
0 \\
0 \\
0 \\
0 \\
0 \\
0 \\
0 \\
0 \\
0 \\
0 \\
0 \\
0\end{array}$ & MG/L & $\begin{array}{l}< \\
< \\
< \\
< \\
< \\
< \\
< \\
< \\
< \\
< \\
< \\
< \\
< \\
< \\
< \\
< \\
< \\
< \\
< \\
< \\
<\end{array}$ & $\begin{array}{l}0.01 \\
0.01 \\
0.01 \\
0.01 \\
0.005 \\
0.01 \\
0.01 \\
0.01 \\
0.01 \\
0.005 \\
0.01 \\
0.01 \\
0.01 \\
0.01 \\
0.005 \\
0.01 \\
0.01 \\
0.01 \\
0.01 \\
0.005\end{array}$ & $\begin{array}{l}\mathbf{G} \\
\mathbf{G}\end{array}$ & $\begin{array}{l}0.01 \\
0.01 \\
0.01 \\
0.01 \\
0.005 \\
0.01 \\
0.01 \\
0.01 \\
0.01 \\
0.005 \\
0.01 \\
0.01 \\
0.01 \\
0.01 \\
0.005 \\
0.01 \\
0.01 \\
0.01 \\
0.01 \\
0.005\end{array}$ & $\begin{array}{l}- \\
- \\
- \\
- \\
- \\
- \\
- \\
- \\
- \\
- \\
- \\
- \\
- \\
- \\
- \\
-\end{array}$ \\
\hline THORIUM-230 & 0517 & $12 / 08 / 90$ & 0001 & LB & 0 & $\mathrm{PCI} / \mathrm{L}$ & & 0.0 & G & 1. & 0.4 \\
\hline
\end{tabular}

FORMATION OF COMPLETION CODE:

LB - LONER BURRO CANYON

PARAMETER VALUE INDICATOR (PVI): < - LESS THAN DETECTION LIMIT
FLOW RELATIONSHIP COOE:

O - ON-SITE

\section{SAMPLE ID COOES:}

O001 - FILTERED SAMPLE (.45 MICRONS)

OTHER PARAMETER VALUE FLAGS:

G - PH > 9, POSSIBLE GROUT CONTAMIMATION

J - estimated VAlUE 
TABLE 3.52. BACKGROUND GROUNDWATER QUAL ITY DATA BY PARAMETER FOR THE LOWER SANDSTONE UNIT, BURRO CANYON DISPOSAL SITE, SLICK ROCK, COLORADO

06/04/90 TO $10 / 14 / 92$

REPORT DATE: $03 / 02 / 94$

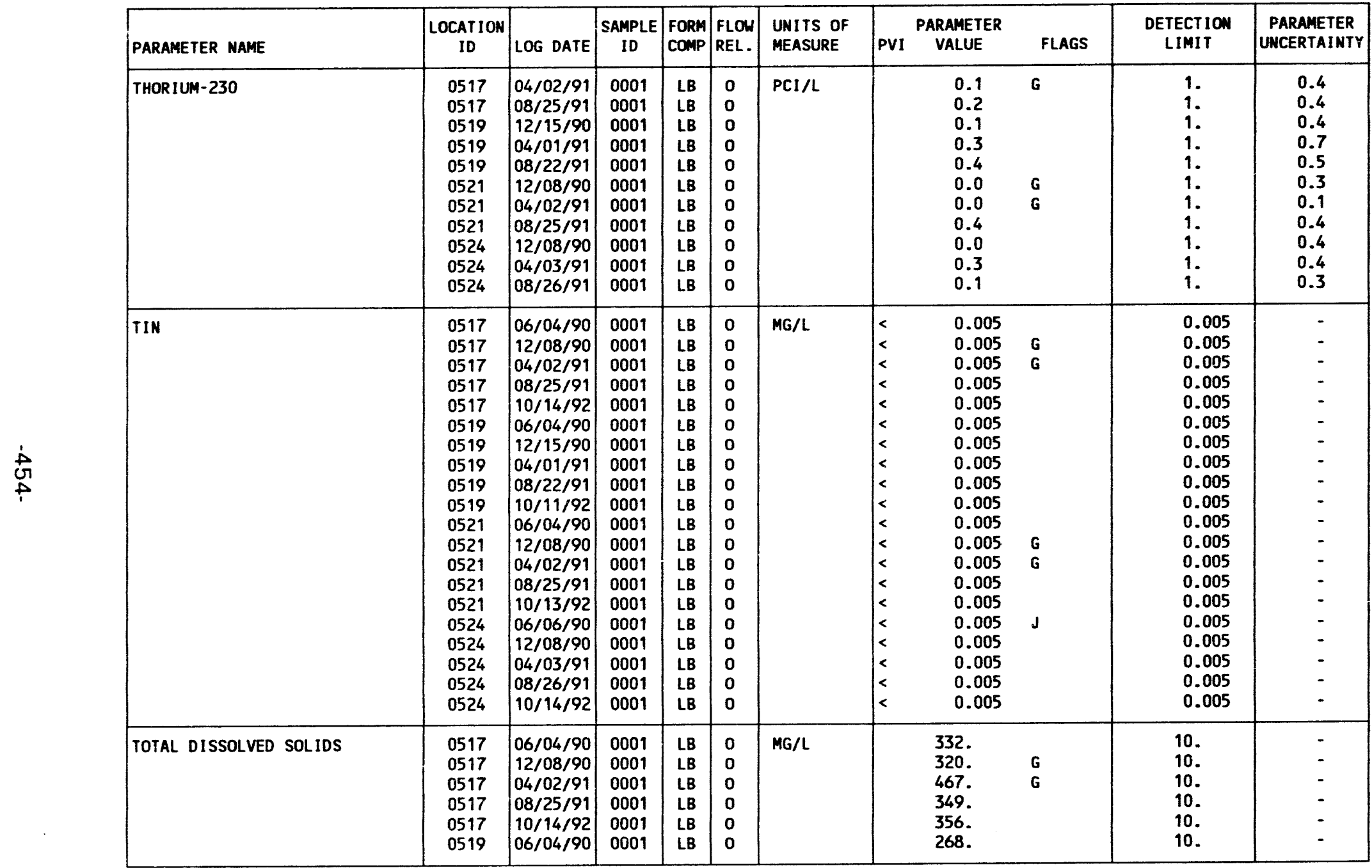

FORMATION OF COMPLETION CODE:

LB - LOWER BURRO CANYON

FLOW RELATIONSHIP CODE:

PARAMETER VALUE INDICATOR (PVI): < - LESS THAN DETECTION LIMIT

SAMPLE ID COOES:

0001 - FILTERED SAMPLE (.45 MICRONS)

OTHER PARAMETER VALUE FLAGS:

G - PH > 9, POSSIBLE GROUT CONTAMINATION $J$ - estimated VALUE 
TABLE 3.52. BACKGROUND GROUNDWATER QUALITY DATA BY PARAMETER FOR THE

LOWER SANDSTONE UNIT, BURRO CANYON DISPOSAL SITE, SLICK ROCK, COLORADO

SITE: SRKO2 BORROW SITE 1 (BURRO CANYON)

06/04/90 TO $10 / 14 / 92$

REPORT DATE: 03/02/94

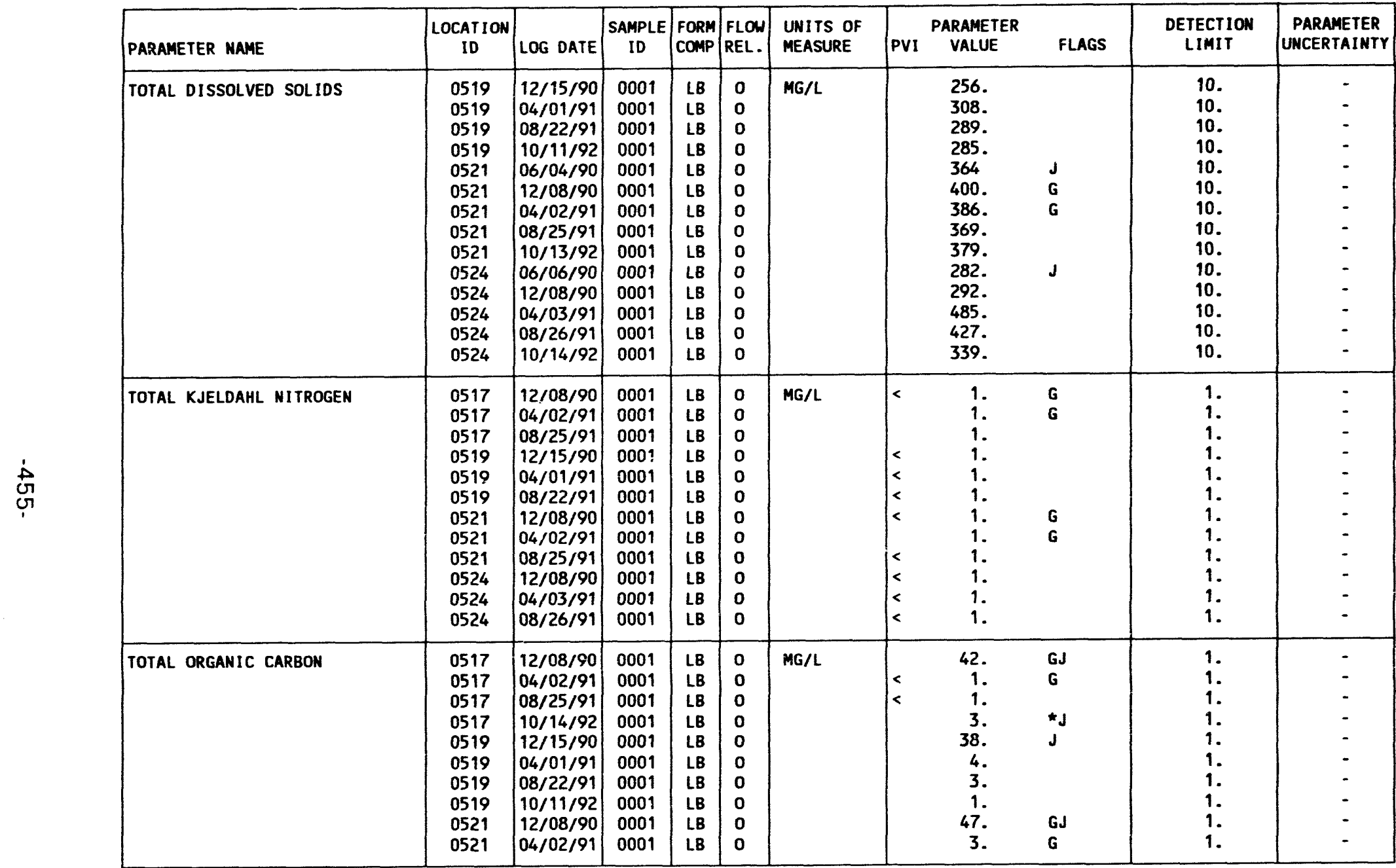

FORMATION OF COMPLETION COOE:

L3 - LOWER BURRO CANYON

PARAMETER VALUE INDICATOR (PVI): < - LESS THAN DETECTION LIMIT

OTHER PARAMETER VALUE FLAGS:

* DUPLICATE ANALYSIS NOT HITHIN CONTROL LIMITS

G - PI! > 9, POSSIBLE GROUT CONTAMINATION

$J$ - ÉsTIMATED VALUE
FLOW RELATIONSHIP CODE:

SAMPLE ID CODES:

0001 - FILTERED SAMPLE (.45 MICRONS) 
TABLE 3.52 BACKGROUND GROUNDUATER QUALITY DATA BY PARAMETER FOR THE LOWER SANDSTONE UNIT, BURRO CANYON DISPOSAL SITE, SLICK ROCK, COLORADO SITE: SRKO2 BORROW SITE 1 (BURRO CANYON)

O6/04/90 TO $10 / 14 / 92$

PEPORT DATE: 03/02/94

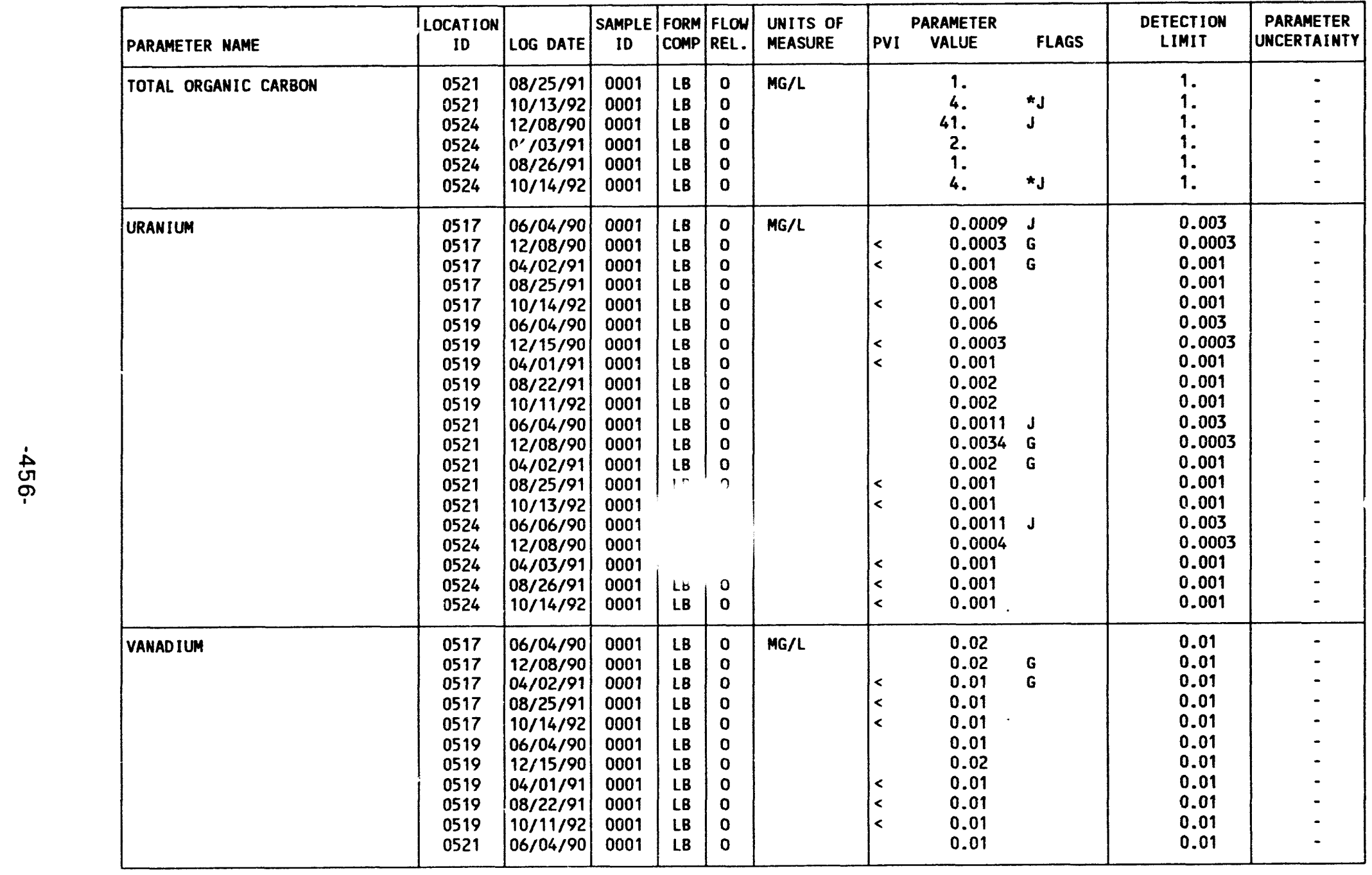

FORMATION OF COMPLETION CODE:

LB - LOWER BURRO CANYON

PARAMETER VALUE INDICATOR (PVI):
FLOW RELATIONSHIP CODE:

O - ON-SITE

OOC, - FILTERED SAMPLE (.45 MICRONS)

OTHER PARAMETER VALUE FLAGS:

* - DUPLICATE analysis NOT WITHIN CONTROL limits

$G$ - PH > 9, POSSIBLE GROUT CONTAMINATION

J - eSTIMATED VALUE 
TABLE 3.52. BACKGROUND GROUNDWATER QUALITY DATA BY PARAMETER FOR THE LOWER SANDSTONE UNIT, BURRO CANYON DISPOSAL SITE, SLICK ROCK, COLORADO SITE: SRKO2 BORROW SITE 1 (BURRO CANYON)

06/04/90 TO 10/14/92

REPORT DATE: $03 / 02 / 94$

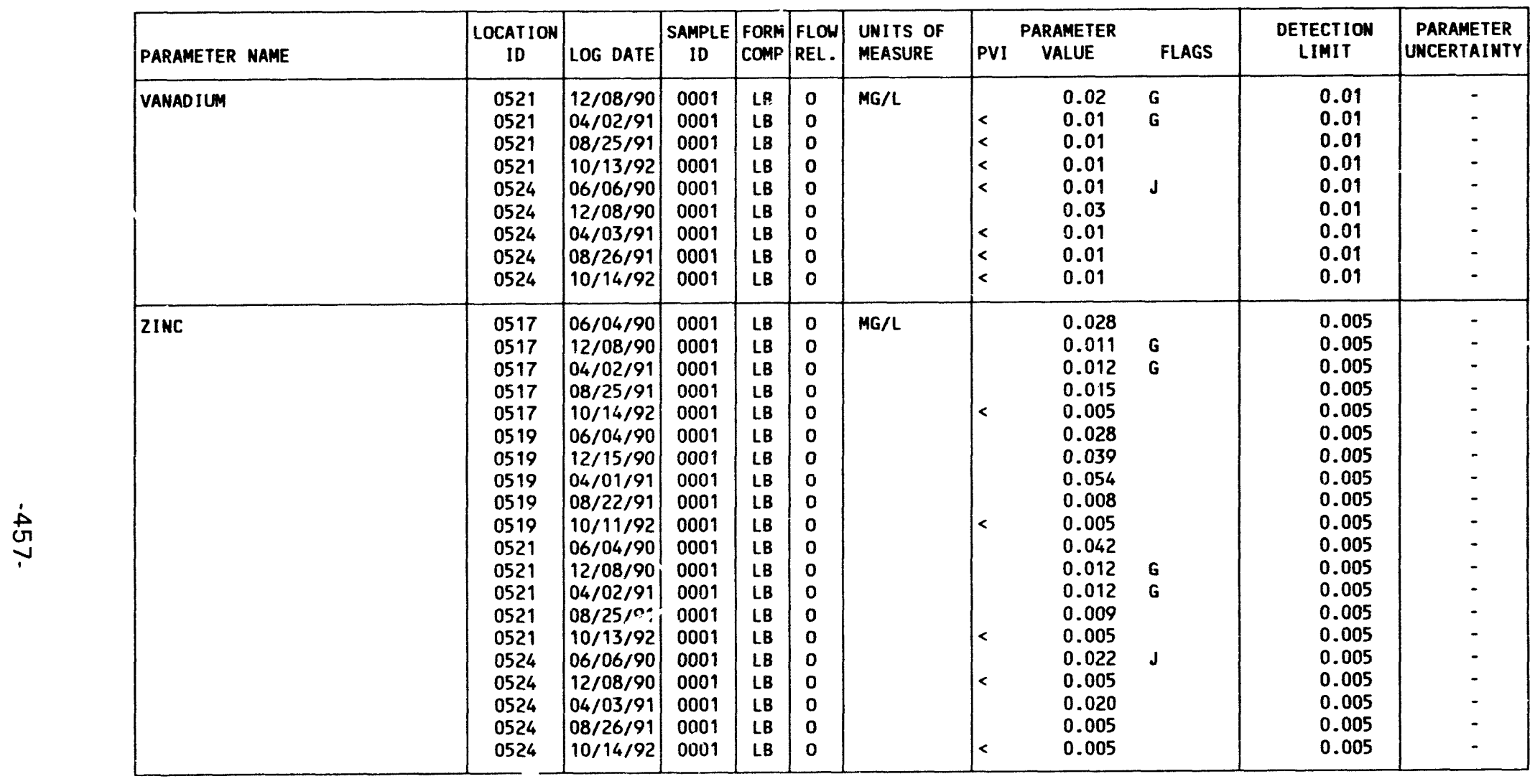

FORMATION OF COMPLETION CODE:

LB - LOWER BURRO CANYON

PARAMETER VALUE INDICATOR (PVI): < - LESS THAN DETECTION LIMIT
FLOW RELATIONSHIP COOE:

O - ON-SITE

0001 - FILTERED SAMPLE (.45 MICRONS)

OTHER PARAMETER VALUE FLAGS:

$G$ - $P H>9$ POSSIBLE GROUT CONTAMINATIGN

J - estimated value

DATA FILE NAME: M: IDARTISRKO2\GWO10014.DAT 
TABLE 3.53. BACKGROUND GROUNDHATER QUALITY STATISTICS BY PARAMETER FOR THE TABLE 3.53

SITE: SRKO2 BORROW SITE 1 (BURRO CANYON)

SITE: SRKO2 BORROW SI

REPORT DATE : 03/02/94

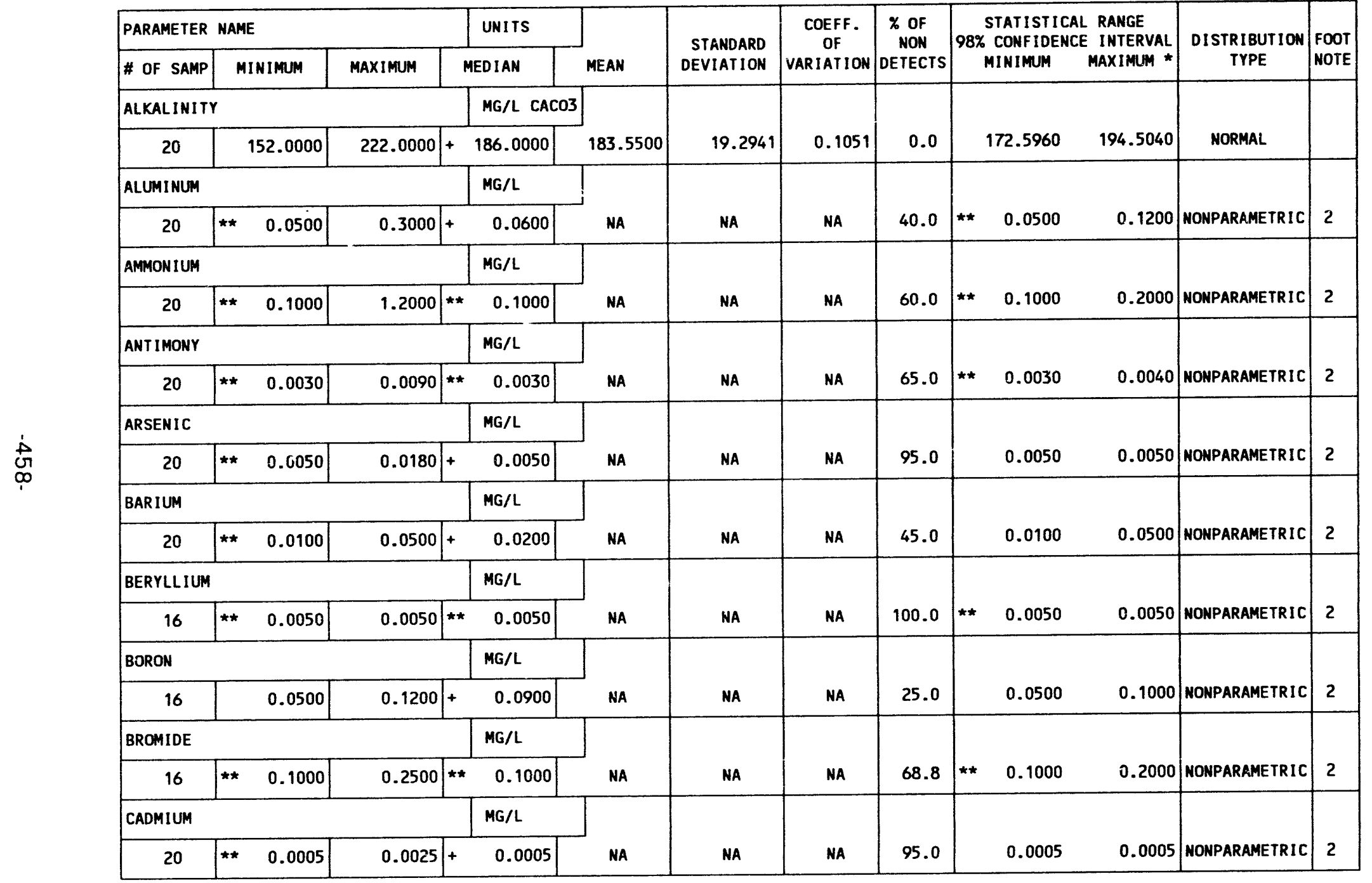

** The reported value is the minimum detection limit of the data set

+ The sample size is even, so the median value is the arithmetic average of the two middle values

* The statistical maximum is the 99 percent one sided confidence interval, $a=0.01$

2) The nonparametric distribution was used because the nondetected values comprise more than $15 \%$ of the samples. 
TABLE 3.53. BACKGROUND GROUNDWATER QUALITY STATISTICS BY PARAMETER FOR THE LOWER SANDSTONE UNIT, BURRO CANYON DISPOSAL SITE, SLICK ROCK, COLORADO

SITE: SRKO2 BORROW SITE 1 (BURRO CANYON)

SITE: SRKO2 BORROW SIT

REPORT DATE : $03 / 02 / 94$

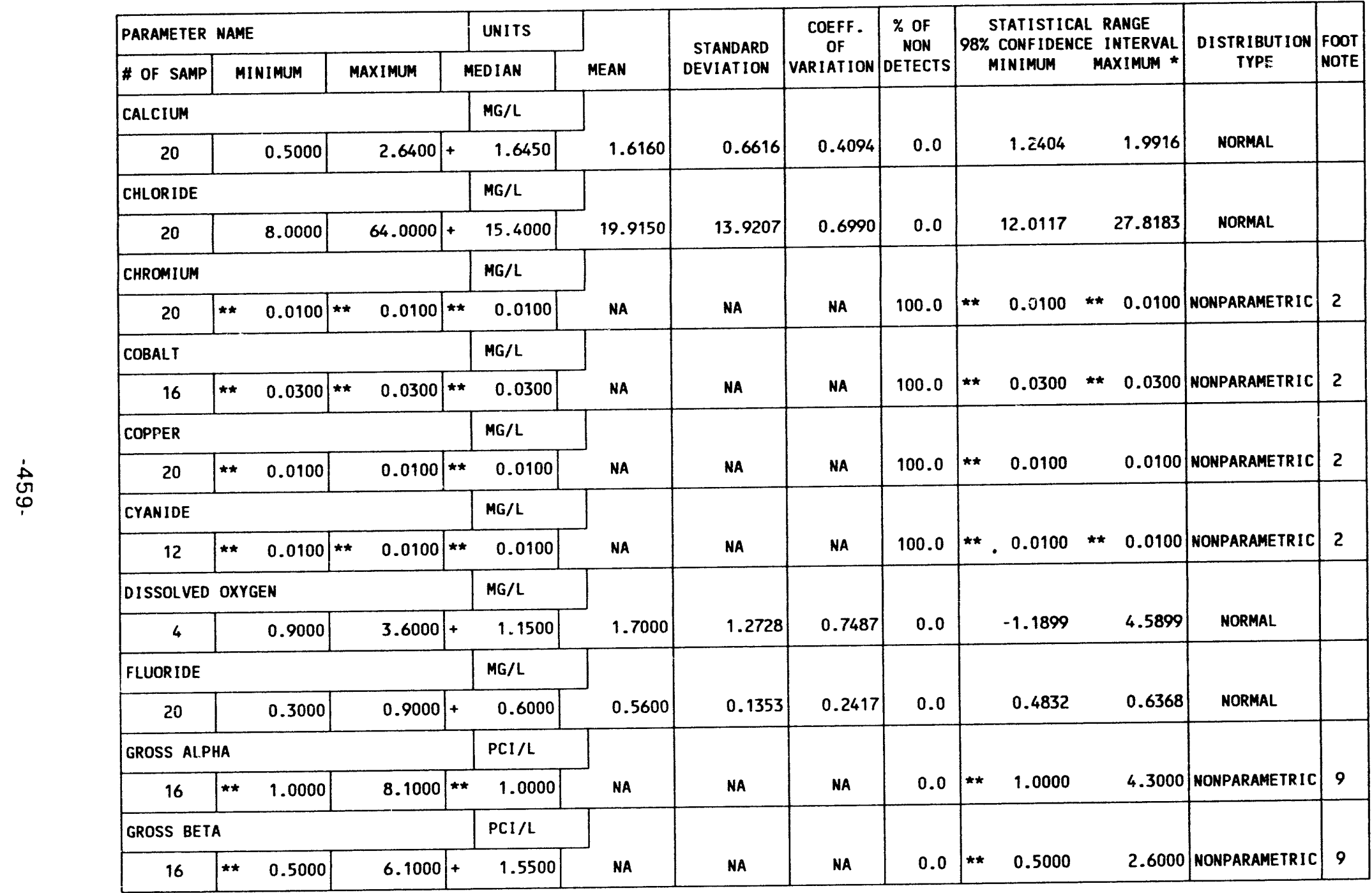

** The reported value is the minimum detection Limit of the data set

+ The samle size is even so the median value is the arithmetic average of the two middle values

* The statistical maximum is the 99 percent one sided confidence interval, $\alpha=0.01$

2) The nomparametric distribution uas used because the nondetected values comprise more than $15 \%$ of the samples.

9) The nonparametic distribution was used because the data failed the normal distribution test and includes values $\leq 0$. 
TABLE 3.53. BACKGROUND GROUNDWATER QUALITY STATISTICS BY PARAMETER FOR THE TOUER SAMDSTONE UNIT, BURRO CANYON DISPOSAL SITE, SLICK ROCK, COLORADO SITE: SRKO2 BORROW SITE 1 (BURRO CANYON)

O6/04/90 TO $10 / 14 / 92$

REPORT DATE: $03 / 02 / 94$

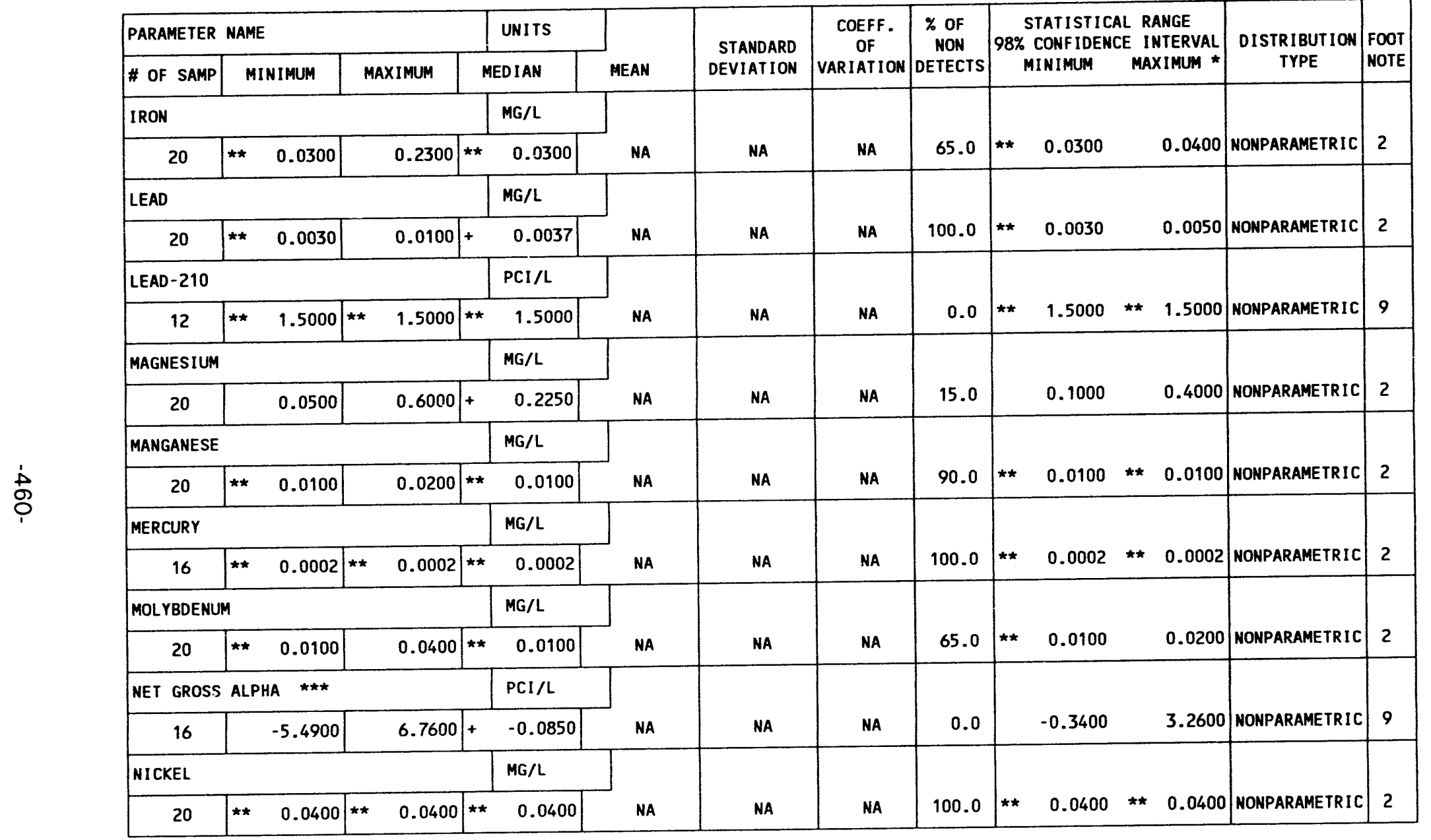

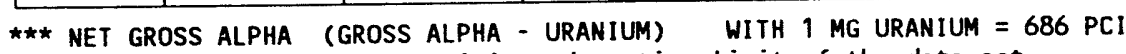

** The reported value is the minimum detection limit of the data set

* The sample size is even, so the median value is the arithmetic average of the two middle values

* The statistical maximum is the 99 percent one sided confidence interval, $\alpha=0.01$

2) The ronparamtric distribution was used because the nondetected values comprise more than $15 \%$ of the samples.

2) The honparametric distribution was used because the data failed the normal distribution test and includes values $\leq 0$. 
TABLE 3.53. BACKGROUND GROUNDWATER QUALITY STATISTICS BY PARAMETER FOR THE

LOWER SANDSTONE UNIT, BURRO CANYON DISPOSAL SITE, SLICK ROCK, COLORADO

SITE: SRKO2 BORROW SITE 1 (BURRO CANYON)

06/04/90 TO $10 / 14 / 92$

REPORT DATE : 03/02/94

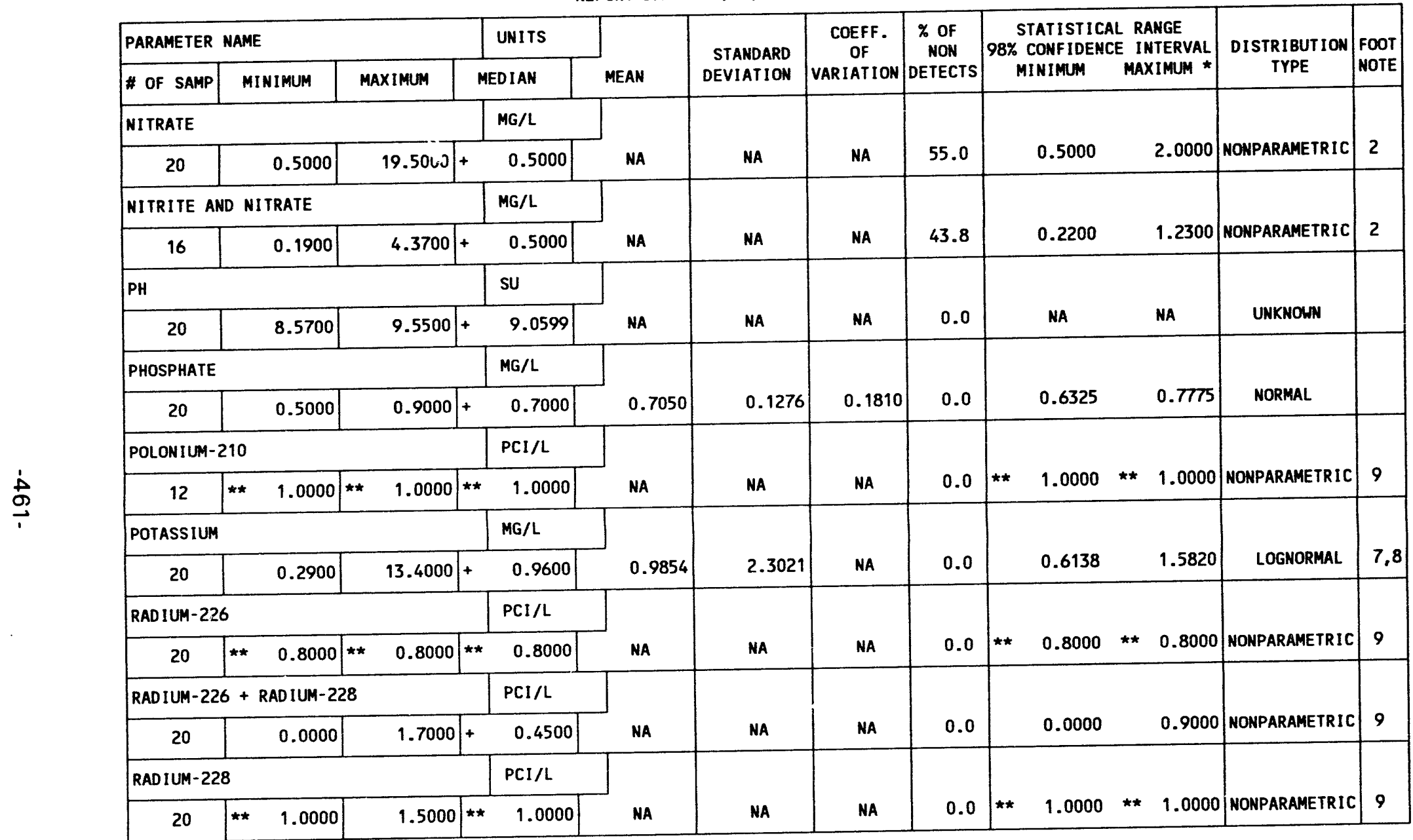

** The reported value is the minimum detection limit of the data set

* The reported value is the minimum

+ The sample size is even, so the median value ide confidence interval, $a=0.01$

1) A minimum of 4 samples must be available for the statistical analysis.

2) The nonparametric distribution available for the statistical

7) The lognormal distribution was used because the data failed the normal distribution test:

8) The mean is geometric. The standard deviation is the value to divide or multiply with the geometric mean.

9) The nonparametic distribution was used because the data failed the normal distribution test and includes values $\leq 0$. 
TABLE 3.53. BACKGROUND GROUNGWATER QUALITY STATISTICS BY PARAMETER FOR THE

LOWER SANDSTONE UNIT, BURRO CANYON DISPOSAL SITE, SLICK ROCK, COLORADO

SITE: SRKO2 BORROW SITE 1 (BURRO CANYON)

06/04/90 TO $10 / 14 / 92$

REPORT DATE : 03/02/94

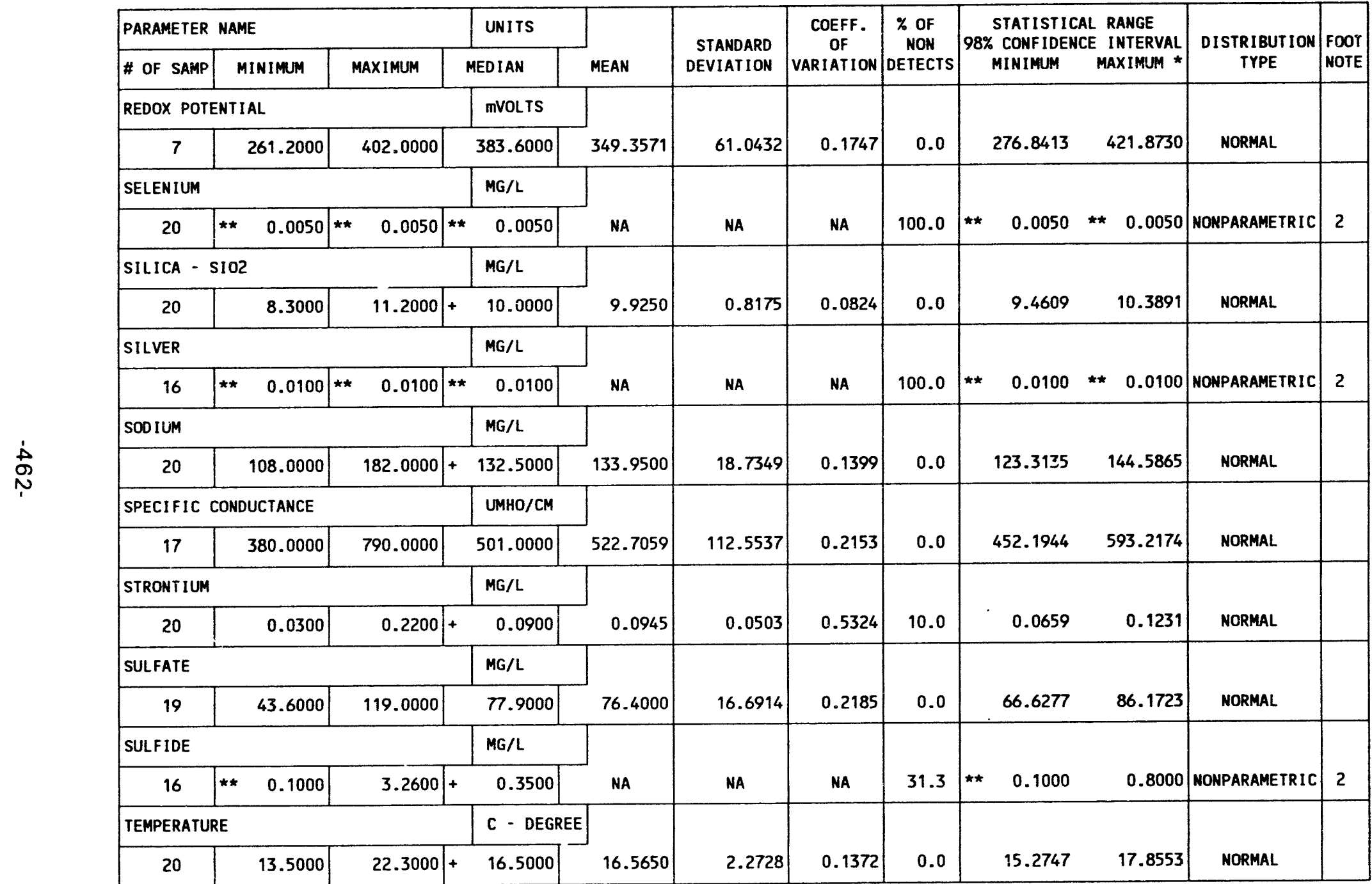

** The reported value is the minimum detection limit of the data set

+ The sample size is even, so the median value is the arithmetic average of the two middle values

* The statistical maximum is the 99 percent one sided confidence interval, $\alpha=0.01$

2) The nonparametric distribution was used because the nondetected values comprise more than $15 \%$ of the samples. 
TABLE 3.53. BACKGROUND GROUNDWATER QUALITY STATISTICS BY PARAMETER FOR THE LOWER SANDSTONE UNIT, BURRO CANYON DISPOSAL SITE, SLICK ROCK, COLORADO

SITE: SRKO2 BORROW SITE 1 (BURRO CAMYON)

$06 / 04 / 90$ TO $10 / 14 / 92$

REPORT DATE: $03 / 02 / 94$

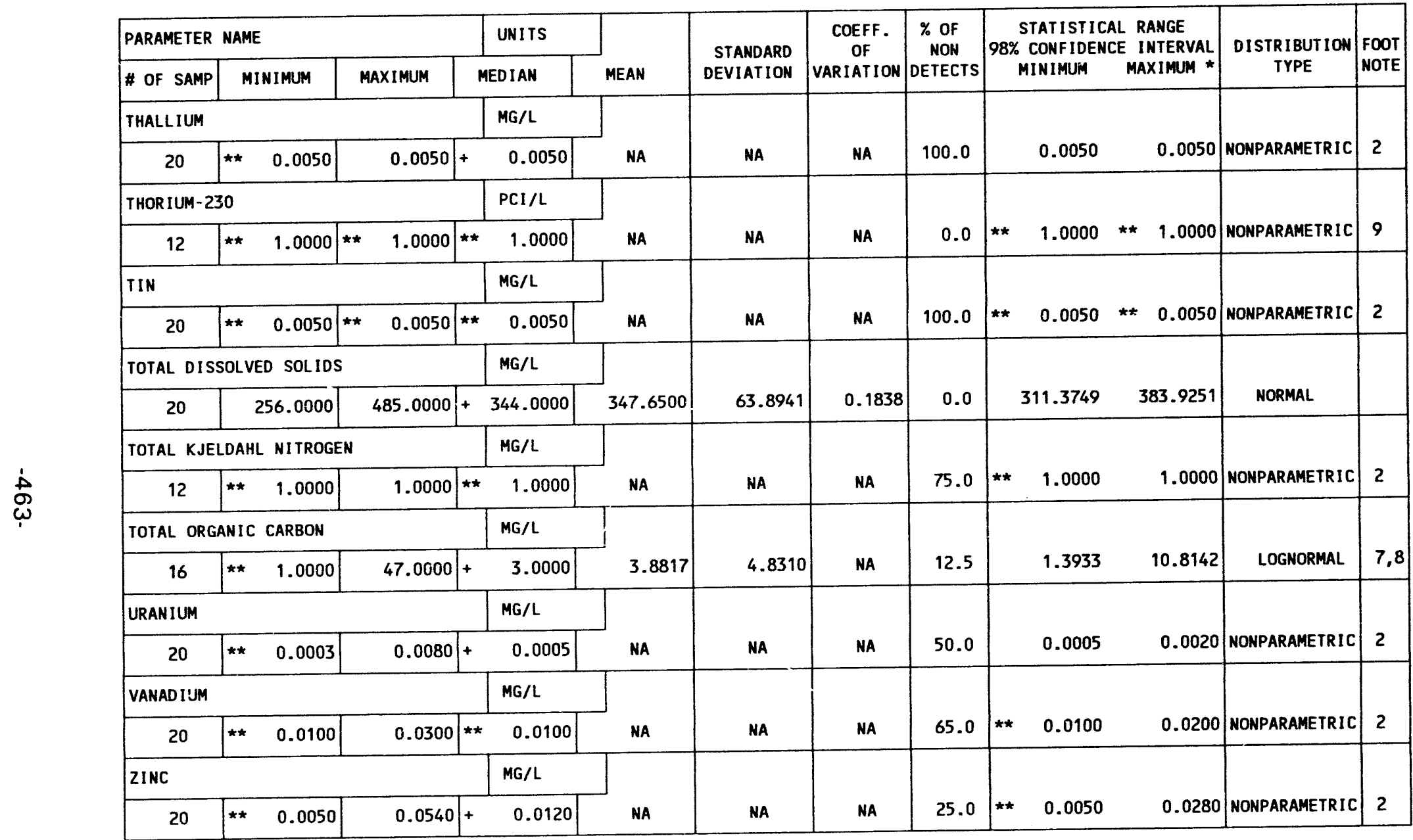

** The reported value is the minimum detection limit of the data set

the ralues

* The sample size is even, so the median value is the arificice interval, $\alpha=0.01$

* The statistical maximum is the 99 percent one sided confidence interval, $\alpha=0.01$ more than $15 \%$ of the samples.

2) The nonparametric distribution was used because the nondetected values comprise mol distribution test.

8) The mean is geometric. The standard deviation is the value to divide or multiply with the geometric mean.

9) The nonparametic distribution was used because the data failed the normal distribution test and includes values $\leq 0$. 


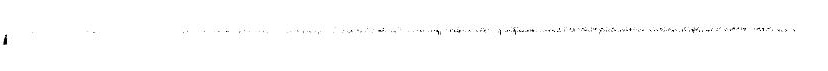

